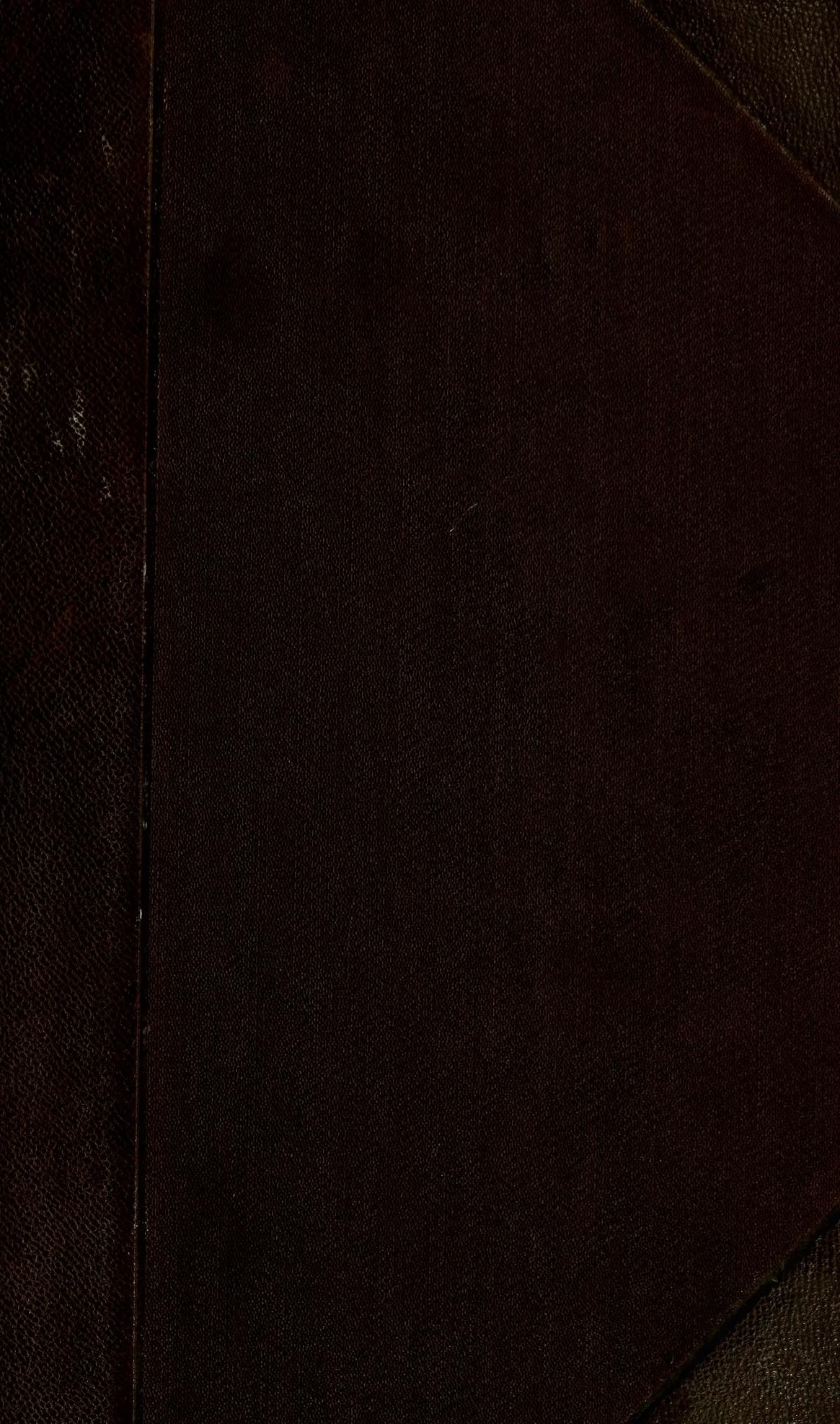




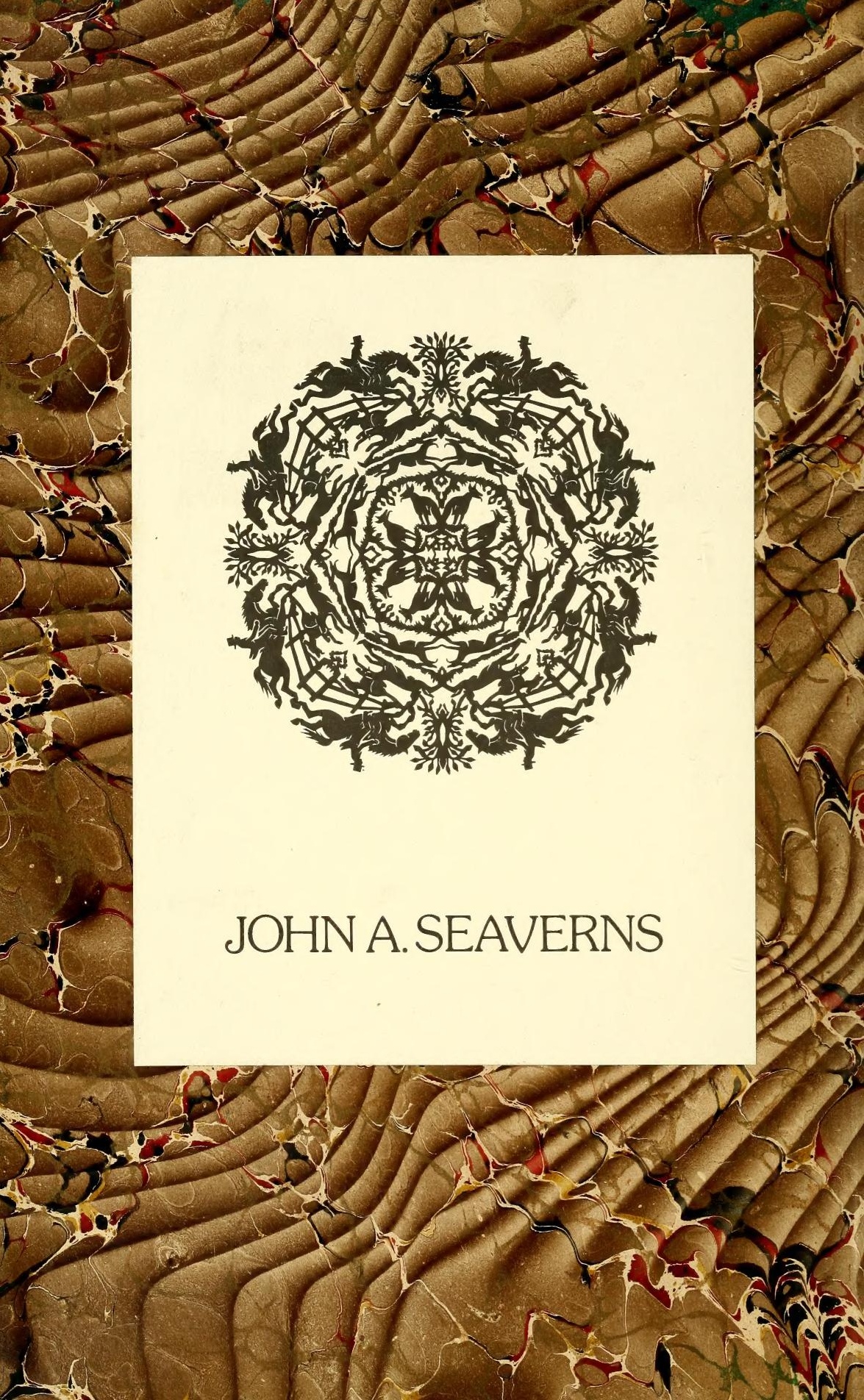




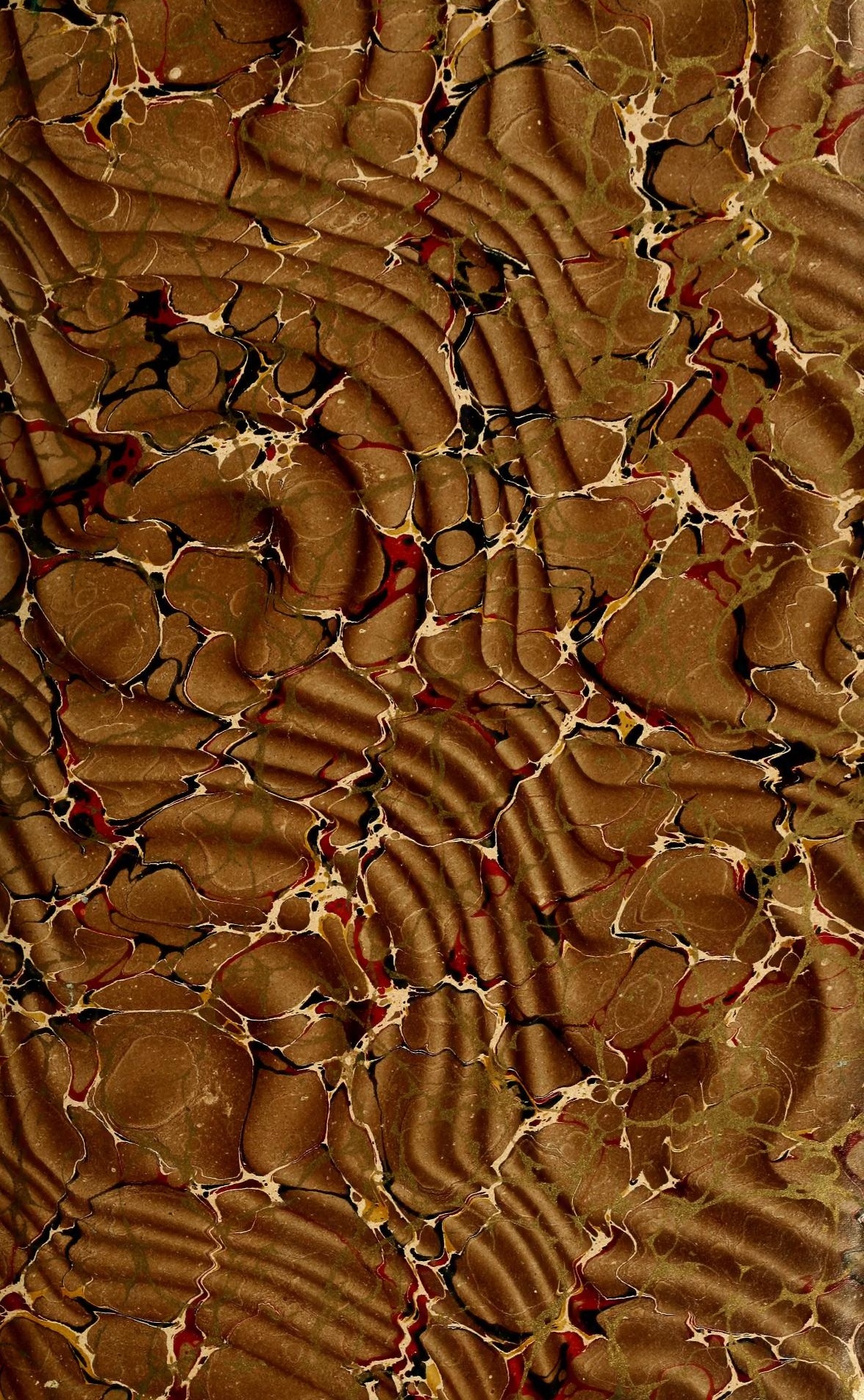



(1) 

Digitized by the Internet Archive in 2009 with funding from

Boston Library Consortium Member Libraries

http://www.archive.org/details/americanstallion02batt 


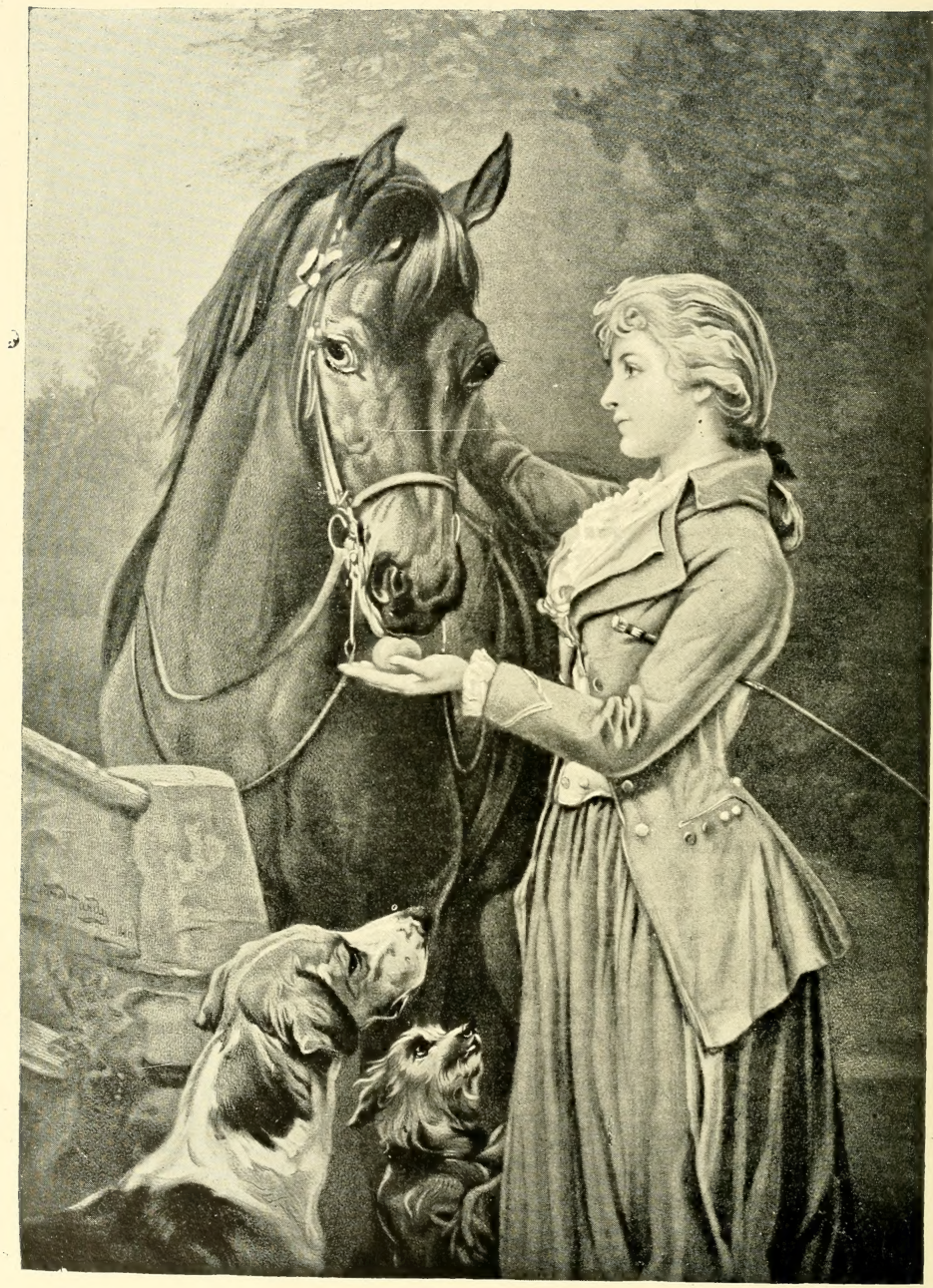




\section{AMERICAN STALLION REGISTER}

INCLUDING ALL STALLIONS PROMINENT IN THE BREEDING OF THE AMERICAN

ROADSTER, TROTTER AND PACER, FROM THE EARLIEST RECORDS TO I9O3.

AND THIS INCLUDES NEARLY ALL IMPORTED ENGLISH THOROUGHBREDS,

AND THEIR MORE DISTINGUISHED GET, TOGETHER WITH MANY OF

THE STALLIONS FROM WHICH THEY ARE DESCENDED; AND

ALL SIRES OF $2: 30$ TROTTERS OR $2: 25$ PACERS TO I9O3.

ALSO THE RATING OF MORGAN BLOOD IN ALL OF

THESE STALLIONS SO FAR AS KNOWN

\section{COMPILED FROM ORIGINAL SOURCES}

WITH

MANY PEDIGREES, HITHERTO INCORRECTLY RECORDED, CORRECTED (IN ALL CASES THE EVIDENCE UPON

WHICH THIS IS DONE BEING GIVEN), AND

MANY MORE PEDIGREES EXTENDED

\section{ILLUSTRATED}

BY JOSEPH BATTELL

AUTHOR OF THE MORGAN HORSE AND REGISTER

"I did for the horse what I would neither do for earl or baron, doffed my hat; yes! I doffed my hat to the wondrous horse, the fast trotter, the best in mother England."-George Borrow in "Lavengro."

\section{VOLUME II.}

AMERICAN PUBLISHING COMPANY

MIDDLEBURY, VT.

I9II. 
Copyright, i9ir, by Joseph Battell. 


\section{PREFACE}

$\mathrm{T}$

HIS Volume of the American Stallion Register comprises D, E, F, and

$\mathrm{G}$, together with a short Introduction followed by a History of the Early Importation of Horses, mainly thoroughbreds, into America. Succeeding this is a brief history of the New England States, with the more valuable families of horses bred in them, to be followed in Vol. III., by a similar history of other States.

We have given the tracing of several quite prominent horses, especially that of Ethan Allen, very completely in the body of this volume; in part because of the interest that connects directly with the horse himself, and in part because of the introduction of other noted horses bred in the same locality and referred to in the various interviews. The same will be true of the more prominent stallions that appear in other volumes.

We also give special prominence to the tracing of the dam of George Wilkes. We did the same in Vol. I., especially with American Star, Black Hawk, and Blue Bull. We shall give in Vol. III., a very complete history of Hambletonian, his dam by imported Bellfounder, and the stallions of Orange County, N. Y., at the time he was bred. And we shall also give an unusually thorough history of the excellent Messenger horse, Bishop's Hamiltonian, and his sons the Judson, Andrus, and Harris' Hamiltonian, the last three born, and for the larger part of their lives, living in Vermont. This is followed by an equally thorough history of the celebrated stallion Henry Clay, from which the Clay family of trotters and roadsters are descended.

Under Engineer, we give a very interesting account of the early life of Lady Suffolk, obtained by interviews with her breeder, Mr. L. W. Lawrence, and his wife, and the veteran horseman, Carl Burr, Sr., all residents of Long Island. It is quite possible that the noted pacer Hero, $2: 20 \mathrm{~T} / 2$ ( 1853 ), foaled in Vermont, and taken to New York in $185 \mathrm{I}$, was got by a greatgrandson of Engineer, grandsire of Lady Suffolk. See Hero, Vol. III. 
In the Introduction of this volume will be found also quite a complete account of the Government Morgan Horse Farm at Weybridge, Vt., followed by brief notice of the famous early trotters, Fanny Jenks, Flora Temple, Mac, Tacony, Edwin Forrest, Ripton, Americus, Lady Sutton, and the fastest Vermont roadster Dariel or Lady Wonder, $2: 00 \mathrm{I} / 4$; together with some interesting information regarding the Casol breed of horses, Vermont Boy (French Charley), and Columbus.

At the end of this volume will be found an index of Breeders and Owners of horses which appear in this book, succeeded by indexes of articles appearing in the Introduction of Vol. I., and also of this Volume, largely taken from the files of the earlier horse journals.

In the histories of the different States, we have been assisted by Judge Wm. H. Bliss of Middlebury, Vt.

The next volume, the material of which is entirely completed and the type setting about half done, will include the five letters, H, I, J, K, and L.

\section{EXPLANATORY.}

In stating pedigrees we generally set down whatever information we have, and stop; not deeming it necessary to add explanatory words, such as "untraced," or "breeding unknown."

We also generally follow back the line at least two generations, and if known, often more, or until we strike the name of some well known horse. In the case of the following noted horses, however, we frequently give the name only, and whenever the name is used alone it refers to the horse mentioned in this table:

\begin{tabular}{|c|c|c|c|c|c|}
\hline American Star, & means & that & son & of & Coburn's Americar \\
\hline by $\mathrm{Coc}$ & $\mathrm{k}$ of the $\mathrm{I}$ & Rock, & son & of & Sherman Morgan. \\
\hline Black Hawk, & means & that & son & of & Sherman Morgan. \\
\hline Bulrush Morgan, & " & “ & " & “" & Justin Morgan. \\
\hline Daniel Lambert, & “ & " & “ & " & Ethan Allen. \\
\hline Copperbottom, & " & " & " & “ & Justin Morgan. \\
\hline Electioneer, & “ & " & “ & “ & Hambletonian. \\
\hline Ethan Allen, & “ & “ & “ & “ & Black Hawk. \\
\hline Fearnaught, & " & " & " & " & Young Morrill. \\
\hline General Knox, & " & " & " & “ & Vermont Hero. \\
\hline Golddust, & " & " & " & " & Vermont Morgan. \\
\hline George Wilkes, & " & " & “ & " & Hambletonian. \\
\hline Gifford Morgan, & " & " & " & " & Woodbury Morgan. \\
\hline Green Mountain 1 & Morgan, & “ & “ & “ & Gifford Morgan. \\
\hline Hambletonian, & " & " & “ & " & Abdallah. \\
\hline Henry Clay, & " & " & “ & " & Andrew Jackson, \\
\hline by Young & Bashaw, s & son of & impor & ted & Grand Bashaw. \\
\hline Magna Charta, & means & that & son & of & Morgan Eagle. \\
\hline Morrill, & “ & & “ & " & Jennison Colt. \\
\hline Sherman Morgan, & “ & “ & " & “ & Justin Morgan. \\
\hline Woodbury Morgan & “ & $" 6$ & “ & " & \\
\hline
\end{tabular}




\section{ILLUSTRATIONS}

FRONTISPIECE,

United States Morgan Horse Farm,

Untted States Morgan Horse Farm,

Sunset Rock, The Kattskills, New York,

Mr. Ethan Allen, Vermont, No. I,

New England County Fair,

Arabian Horses,

Duroc, BY IMPORTED Diomed,

American Eclipse, by Duroc,

The Bowery, New York City,

General Gates,

White Mountains, -

Ellen's Mountain, near the Summit,

Addison County, Vt., Scenes,

Mountain Road, Vermont, -

Country Life,

Near Bread Loaf InN, · -

RANDOLPH, VT.,

Old Oaken Bucket, Scituate, Mass.,

New England School Life,

New England School Life,

Washington County, Vermont,

Residence of Hon. Robbins Battell, Norfolk, Conn.,

Pennsvlvania Avenue, Washington, D. C.,

Washington, D. C., from Department of Agriculture,

Daniel Lambert,

DiCTATOR,

Acropolis, Athens, 
Green Mountains, Vermont,

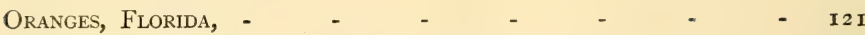

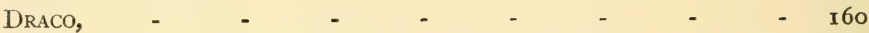

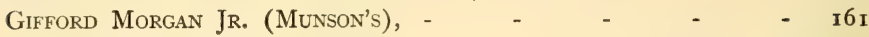

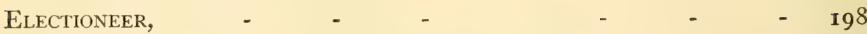

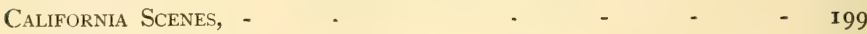

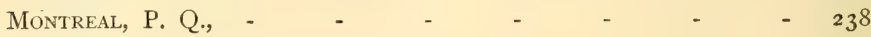

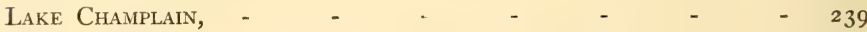

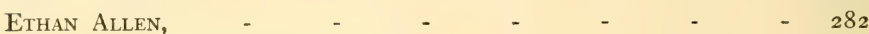

Adirondacks and Lake Champlain, - $\quad$ - $\quad$ - $\quad 283$

Grand Isle County, and Lake Champlain, No. I, - - 324

Grand Isle County, and Lake Champlain, No. 2, - $\quad 325$

Draco, by Young Morrill and Tornado, by Fearnaught, - 364

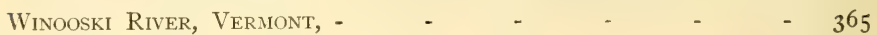

Fort Marion, St. Augustine, Florida, - - $\quad$ - $\quad$ - 400

Havana, Cuba, -

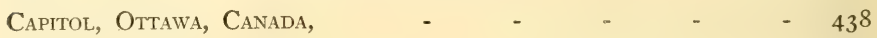

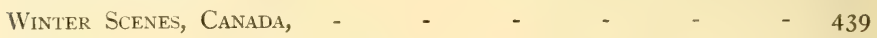

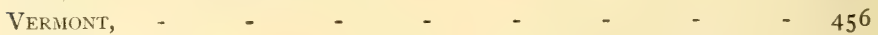

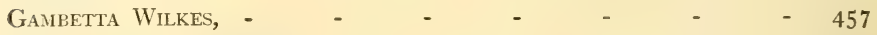

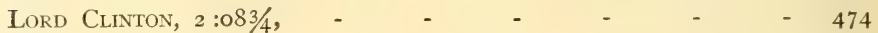

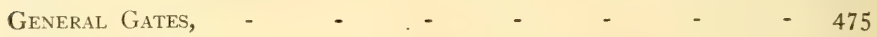

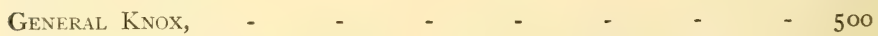

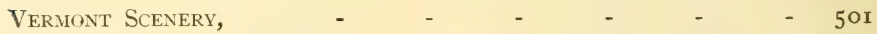

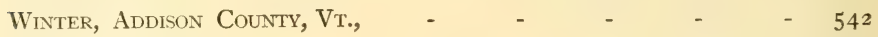

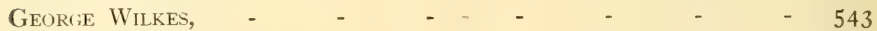

Green Mountain Morgan, - $\quad$ - $\quad$ - $\quad$ - $\quad$ - $\quad 572$

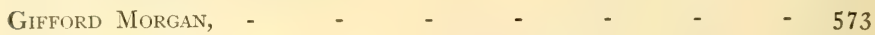

ERICSSON, - $\quad$ - $\quad$ - $\quad$ - $\quad$ - $\quad$ -

Pelican Island, Florida, - $\quad$ - $\quad$ - $\quad$ - $\quad$ - $\quad$ - $60 \mathrm{I}$

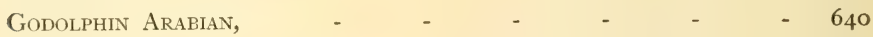

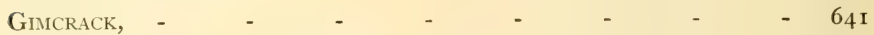

Otter River, Vermont, - $\quad$ - $\quad$ - $\quad$ - $\quad$ - $\quad$ - 694

Mount Ethan Allen, Veriont, No. 2, - - - - $\quad 695$ 


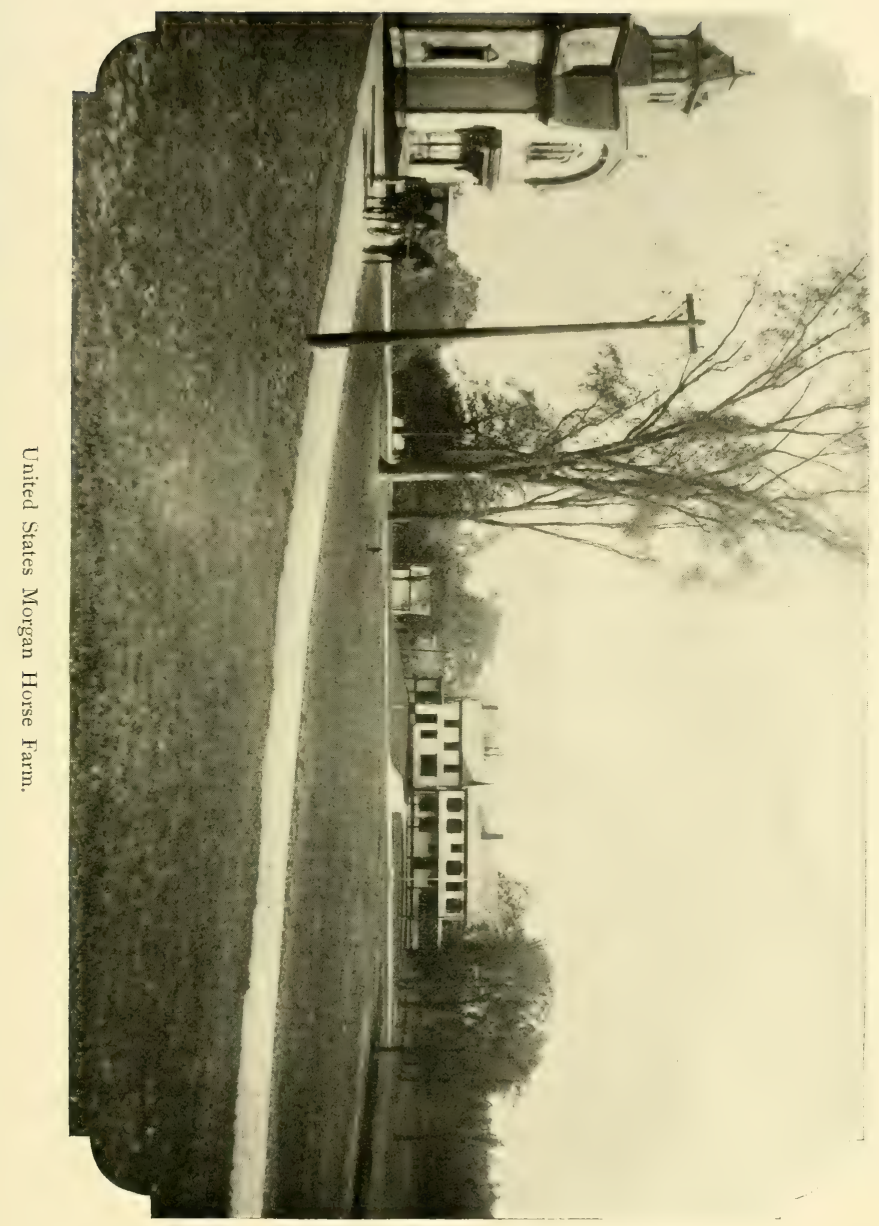




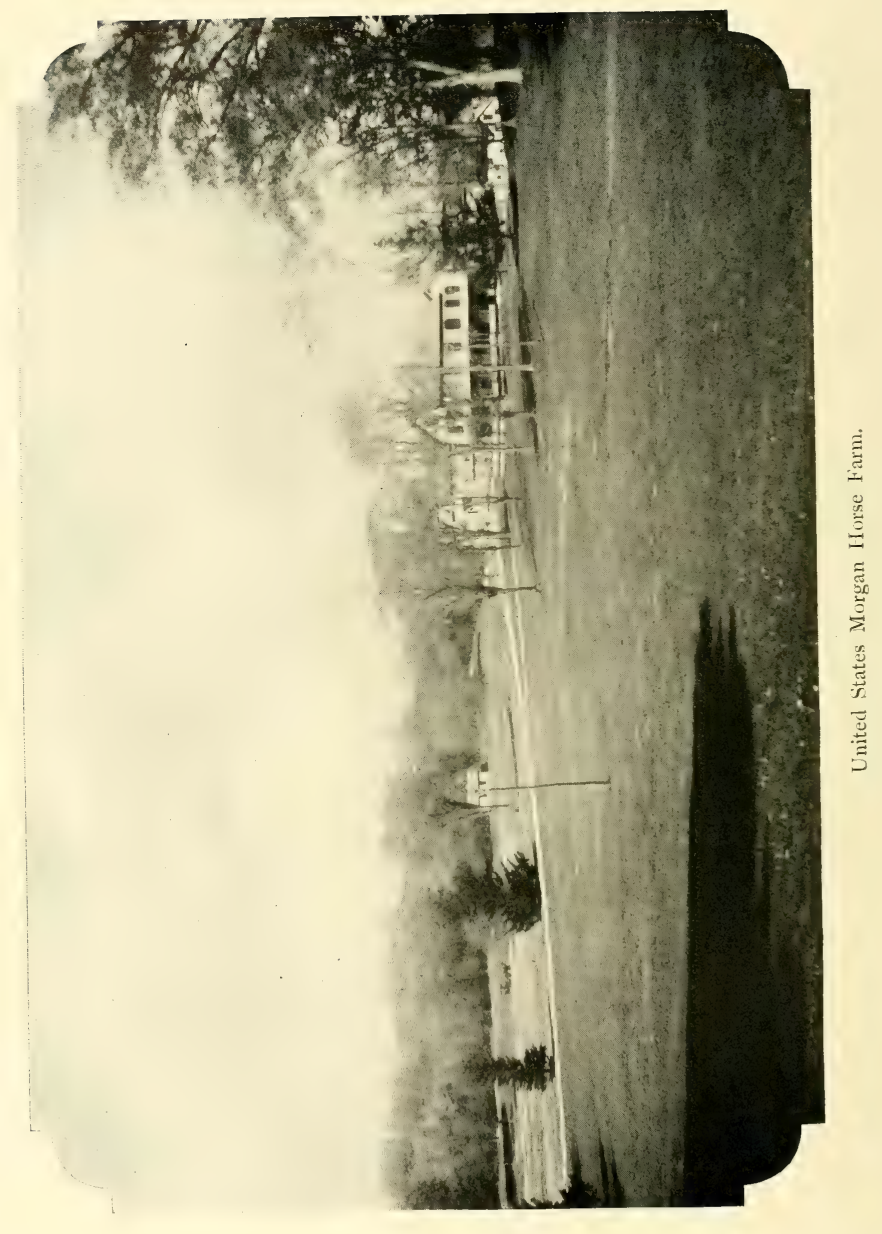




\section{INTRODUCTION.}

\section{GOVERNMENT MORGAN HORSE FARM.}

\section{Editor of the The Horseman and Spirit of the Times :}

Dear Sir :-Your letter of Nov. I 2 th received making inquires in regard to the Morgan Horse interests of Vermont, and especially information concerning the Government Morgan Horse Farm, and the progress made at that farm during the past year.

As I understand there was a very fine show of Morgan horses this year at the Vermont State Fair, including some 250 from Vermont and other States, quite a number especially good ones from Pennsylvania. I did not myself get time to attend this Fair, but recently had the pleasure of driving to the Government Stock Farm at Weybridge in company with a Forestry representative of the Government. I had not visited the farm for something more than a year, and was most agreeably surprised in finding that much progress had been made during the present season in perfecting its general appearance and efficiency.

As we believe is reasonably well understood throughout the country, the Government came into possession of this farm, by gift, in the fall of 1906 . The farm itself consists of about 500 acres, divided into meadow, pasture, and woodland in about equal proportions. The forest upon it is not only remarkably picturesque but also valuable, much of it being a hundred years old. The farm is also very handsomely situated on both sides of the old turnpike leading from Middlebury to Vergennes, with the Otter River bounding it on the east, from which it rises gradually at the west to a hill that commands one of the finest views in the State, including Middlebury with its college buildings and other public edifices, distant about two miles, also the Green Mountain Range to the east, and glimpses of the Adirondacks toward the west.

This farm formerly consisted of four farms, including three of the older farm houses of Vermont, two of one story and a half, and one of two stories. These have been thoroughly repaired, together with the barns connected with them; the whole farm newly fenced with the best woven wire and cedar 
posts; and the grounds connecting with the house occupied by the Superintendent, handsomely graded, including very fine circular macadamized driveways.

There has also been constructed a complete system of water works, including an artesian well 488 feet deep, having a flow of fifty gallons per minute. Pipes have been laid to the different houses and barns as well as the pastures. The water is forced to the different points by an automatic pump, driven by electric power. There are also hydrants for fire protection. The various watering troughs and tubs are all made of grouting, and everything done in the most thorough manner.

After dinner we visited the stables where the stallions are kept and saw General Gates, whose picture I forward you. This is a fine horse and he impresses most strikingly his characteristics upon his stock, including both form and action.

Gen. Gates is full brother to Lord Clinton, trotting race record in $\mathbf{I} \$ 94$, $2: 083 / 4$. At the time Lord Clinton's record was $2: 101 / 4$, I was in Kentucky and was told that he could be bought for $\$ 3,000$. He was then owned by a lumber dealer in Memphis, Tenn. Thinking I might buy him I went to Memphis; the horse was at the time in training, and after examining him and being much pleased with him, I called upon his owner, whom I found at his office, and introducing myself said: "I have understood you wished to sell Lord Clinton at three thousand dollars, and I have called to say, if so, I will take him." He took from his pocket several letters, and handing me one said read that, and added, if it was not for that letter you would get the horse, which I took on a debt, for I do not want any race horse; but I think now I will get more for him.

The letter was from Budd Doble stating that he had a party who wished to buy Lord Clinton and asking price.

Seeing that the horse would probably be sold I made inquiries about his sire and learned that he together with dam of Lord Clinton was owned at Little Rock, Ark. I immediately took the train for that point, saw the horses and bought them. The mare was quite old but the stallion looked exceedingly well, being well shaped, of good size, and in good condition. They were shipped at once to Vermont, where the mare was bred to Denning Allen and the next year foaled Gen. Gates, a very promising colt when he came, in all respects, and especially so in his trotting action; but he has never been given any chance whatever to show what he could do in that line.

In the next few years I exhibited Denning Allen at quite a number of fairs, including the World's Fair at Chicago, one of the principal New York City Fairs with large competition, and a Provincial Fair in Canada, besides several County Fairs; in all of which he was awarded first premium.

$\mathrm{He}$ also received the very high compliment of being one of the eight horses selected by Max Lansberg, the noted sculptor, sent out by the German Government to take models of such American horses at the World's Fair as he thought desirable for use in the Agricultural Schools of Germany. 
Denning Allen was fully $151 / 2$ hands with good weight, bred in Kentucky, got by Honest Allen, son of Ethan Allen : dam also bred in Kentucky and got by Ward's Flying Cloud (dam by Hackett Horse, son of Gifford Morgan), son of Black Hawk, by Sherman Morgan.

Gen. Gates we consider phenomenally well bred. Sire Denning Allen: dam Fanny Scott, bred by E. W. Hughes, Todd, Ky.; got by Revenue Jr., son of Revenue, by Imported Trustee; these last two horses being especially noted among thoroughbreds. Revenue Jr., we understand from those who knew him in Kentucky, where he was taken from Virginia, was a horse of great beauty and substance. His dam was by Imported Glencoe. Revenue Jr. is recorded in Bruce's Thoroughbred Stud Book.

The second dam of Gen. Gates was said to have been by a Copperbottom horse.

And this introduces an episode in pedigree hunting, that was not only extremely entertaining in its surroundings, but also yielded information of very valuable character that couldn't possibly be got to-day, and had never been before. We refer to our investigation into the early horse history of the Province of Quebec.

At this time we will only mention the information which we got of the original Copperbottom. The first knowledge which we had of this horse came from Kentucky, where he was taken from Canada in r8r6. This we obtained from two advertisements in the Lexington (Ky.) Gazette, of June Ioth, I816, and April 4th, I832.

The first is :

\section{"COPPERBOTTOM.}

"The celebrated fast pacing Canadian stallion Copperbottom will stan' the following season at the farm of Capt. Jowitt, about two miles from Lexington, on the Georgetown road. He is a full blooded Canadian pacer, imported by Capt. Jowitt ; is a beautiful copper sorrel, rising seven years old, and for bone, sinew, and performance, is equal to any horse in the United States.

May 8th, i 8 i $6 . "$

William Allex.

The second is an advertisement of Fenwick's Copperbottom, by Brutus, son of Jowitt's Copperbottom. In which it is stated that Jowitt's Copperbottom was from Bolton, Canada.

With this information to point the way we made two trips to Bolton, Can., which complemented by several letters from different parties that we had been referred to, enabled us to secure the whole history of Copperbottom. He was bred by David Blunt, then of Danville, Vt., foaled I 809 ; got by the original Justin Morgan horse, which was kept at the residence of David Goss, St. Johnsbury, Vt., close to the Danville line, I805-6 and I $80 \$-9-10$.

In i 8 i I Mr. Blunt moved to Bolton, Can., where for many years he kept a tavern. By correspondence and from members of Mr. Blunt's family, seen at Bolton, I learned that Mr. Blunt, when he went to Bolton from Danville, took a stallion and brood mare with him, afterwards selling the 
stallion to parties who took him first to Montreal, and thence to a southern State. One of the witnesses whom I saw remembered the stallion when owned by Mr. Blunt, saying that he was a chestnut of fair size and a very fine horse. Others told me that he was the best stallion that had ever been kept in that locality. Afterwards Mr. Blunt in 1823 bought the Hawkins Horse, another son of the original Morgan horse. This Hawkins Horse was foaled in I 806 or 'o7, the property of Mr. Melvin of St. Johnsbury, Vt. When three years old Mr. Melvin sold him to Olney Hawkins, a neighbor. He sold to his brother Stephen, who took the horse to Stanstead, Can.

Mr. Olney Hawkins advertised this horse in $18{ }_{17}$ in the Danville (Vt.) North Star. He was advertised in 1820 in the same paper to be kept at Stanstead and in I823 was advertised in the Stanstead Journal, to be kept at Stanstead, where probably Mr. Blunt bought him. About 1828 he was purchased by David and Alonzo Wood of Shefford, P. Q., Can.

Mr. Wallace says, of Jowitt's Copperbottom :

"He was the original of his name, being perhaps the first horse of his type taken to the Blue Grass region. He left a race of very valuable descendants going all gaits."

And again in his magazine he says :

"We have been trying for years to find out something about Copperbottom, old Pacing Pilot, or Blackburn's Davy Crockett, coming from Canada, as well as many others, but we have never succeeded in getting the slightest clue to the importations of any of them.

"There is another fact connected with the appearance of these pacers, whether Canadian or not, that has a very significant meaning. There is $\boldsymbol{a}$ strong family resemblance among them and the further you get away from outside or modifying crosses, the stronger that resemblance apfears."

To return to the Weybridge Farm; there was also at the same barn the bay colt Red Oak, by Gen. Gates from an inbred Morgan mare by White River Morgan, a stallion owned by L. D. Ely, Rochester, N. Y., who has been breeding excellent Morgan stock for a number of years. Second and third dams of Red Oak were by a grandson and son of Black Hawk. Red Oak is a fine three-year-old colt of good size and very handsomely turned. He took the first premium at the Addison County Fair when a yearling, with twenty competitors. I am told by those who have seen him exercised on the Middlebury track that he shows fine trotting action.

I have myself a four-year-old gelding by Gen. Gates, dam by Motion, son of Daniel Lambert, that we believe here to be a world-beater, and I am searching now for one of the best trainers to give him a chance to prove this another season. Our horsemen think he is able to lower the race record of Lord Clinton, $2: 083 / 4$.

There was also at these barns a very handsome yearling stallion by Gen. Gates: dam bred in Kentucky, got by Harrison Chief; second dam by Cabell's Lexington. 
Harrison Chief was by Clark Chief, son of Mambrino Chief, and his dam by Joe Downing, son of Edwin Forrest, by One-eyed Kentucky Hunter. The dam of Clark Chief was by Downing's Bay Messenger, son of Harpinus, by Bishop's Hamiltonian; second dam Mrs. Caudle (dam of Ericsson 「Morgan Chief], $2: 30 \mathrm{x} / 2$ ), a Morgan mare sent 1830 by William J. Porter, then editor of The Spirit of the Times, to Henry Mangin, of Savannah, Cia., after whose death she was sold to I. C. Plant, of Macon, Ga. Mrs. Caudle trotted several races at Augusta Ga., in 1846 , an account of which appeared in The Spirit of the Times.

Of Edwin Forrest, Hart Boswell, Lexington, Ky., breeder of Nancy Hanks, 2 :04, in an interview, said :

"Edwin Forrest was a great horse, but had no opportunities. He was the right horse to breed to, for a show horse. He was a splendid looking horse, with a great deal of style. Bay, $15 \frac{1}{2}$ to 16 hands and could trot in three minutes. Stout enough. A model horse. One of the finest horses to look at ever brought to this country."

Cabell's Lexington was by Gist's Black Hawk (dam said to be by Copperbottom), son of Blood's Black Hawk, an exceedingly stylish son of the renowned Black Hawk, by Sherman Morgan. The following letter which we received from a noted Kentucky breeder, and which may be found in Vol. I., of the American Stallion Register, shows the favor with which he was regarded in Kentucky :

Joseph Battell, EsQ., July $20, \mathbf{1} 886$.

DEAR SIR:-Your inquiry for history and description of Blood's Black Hawk after he came to Kentucky, addressed to B. F. \& A. Van Meter, is just received; and here I would say that Mr. A. Van Meter removed to Texas eight or ten years since.

Blood's Black Hawk was obtained in the North (I think in Orange County, Vt.), by Mr. Blood of Lexington, Ky., and brought to that city and owned and stood by him in the city for several years. The horse was finally purchased by Maj. H. T. Dunkin, of Fayette County, Ky., who removed him two or three miles from the city and kept him till the horse died.

I will try to make the description of the horse plain but short.. He was a very rich brown color, two white ankles and a stripe in his face, scant $\mathrm{I}_{5}$ hands high, when standing quiet and out of harness, but when hitched up and driven, appeared full $\mathrm{I} 6$ hands high and was the finest show horse that I ever saw a line pulled on. Belle Sheridan was his exact color and was as fine a mare as he was a horse. They both received premiums at the fairs of Kentucky, until they could show no more.

\section{Yours respectfully, $\quad$ B. F. VAN METER.}

The dam of the noted speed sire Hamlin's Almont Jr. was by Blood's Black Hawk.

There are besides these stallions, at the Government Farm, $2 \mathrm{x}$ brood mares, and quite a number of young stock. Twelve of these mares 
were purchased in Vermont, and are descendants of Ethan Allen, the first stallion to trot under $2: 30$; two were purchased in Kentucky, and are by Harrison Chief, son of Clark Chief, by Mambrino Chief. The dam of one, by Cabell's Lexington, has already been mentioned. The dam of the other was by Coleman's Eureka, son of Young's Morgan, a grandson of Butler's Eureka, by Green Mountain Morgan.

This Butler's Eureka was purchased of Lorenzo Pratt of Woodstock, Vt., in the fall of 1854 , by Dr. Russ Butler of Woodford County, Ky., who took the horse to his home, in Kentucky, and kept him there for several years. This horse has often been erroneously credited to Long Island Black Hawk. Our information of the purchase of the horse, and his pedigree, is from the wife of Dr. Russ Butler, who copied it for us from her deceased husband's diary; and also from Allen W. Thompson, still living at Woodstock, Vt., who remembers that the horse was sold to Dr. Butler and taken to Kentucky.

The other seven brood mares are very good size and well appearing mares, brought from the West this summer and bred to Gen. Gates. They were bred by the Government at the Experiment farm of the State Agricultural College, Fort Collins, Col., and are by Carmon, son of Carnagie, by Robert McGregor, son of Major Edsall, by Alexander's Abclallah, son of Hambletonian. In the pedigree of Carmon are several excellent Morgan strains. First the dam of Kobert McGregor was by Seeley's American Star, an inbred great-grandson of Sherman Morgan by the original Morgan horse. A second strain is from Pilot Jr., that got the dam of Carnagie; a third from Vermont Boy, supposed to be by a son of Billy Root by Sherman Morgan; a fourth from Trojan (sire of the dam of Carmon), by Jackson's Flying Cloud, son of Black Hawk; and a fifth from Seth Warner (sire of second dam of Carmon), by Ethan Allen, son of Black Hawk. There is also a very strong probability that the dam of Major Edsall was a Morgan mare. She was one of a pair of mares taken from Vermont to New York City, and most pronouncedly, as we were told by one of her owners, resembled the Morgans.

This experiment, by the Government, of breeding these mares by Carmon to General Gates we think will be satisfactory. Always when we bred him to a mare of good size he has produced a well appearing and very serviceable animal.

In addition to the horses, the Government have purchased in Canada a fine flock of southdown sheep. These are kept on the farm formerly known as the "Cotton Farm," with a fine meadow for hay, and a very good pasture near by. The old Cotton house is very pleasantly situated upon a road which bounds the farm on the west, and is about half a mile west of and parallel to the highway on which the various horse barns and Superintendent's house are situated. Two barns are connected with the Cotton place, a small horse barn, and a quite commodius sheep barn roo feet in length by 30 in width. All these buildings, and indeed all buildings on the different farms, are now in thorough repair, and handsomely pairted. The third farm, known as the "Willard Farm," adjoins those already described on the north. Here is quite 
a good sized old fashion two story farm house, with comfortable barn adjoining. This house standing upon ground rising from the highway, gives an extensive view of the Green Mountains, which extend through the State north and south, and at this point are about six miles east. The Willard house is - used as a boarding house for the help. It is about a quarter of a mile north of the superintendent's house upon the same highway. Directly north of this farm is a cross-road leading from the Middlebury and Vergennes turnpike to Weybridge Monument, where is located a Congregational Church, and a monument erected to the memory of Silas Wright, who in his early life lived in this town.**

Secretary Wilson, although we do not think he has yet visited the farm, has guided the management of it with excellent results. Mr. Geo. MI. Rommel and Mr. Bell of the Bureau of Animal Industry at Washington, under secretary Wilson, and Mr. Cassius M. Peck of the State Agricultural College, Burlington, Vt., have been active in purchasing the stock, and overseeing the repairs.

Mr. W. F. Hammond, a grandson of Edwin Hammond of Middlebury, Vt., formerly the most successfnl breeder of Merino sheep in the world, from the start has been the Superintendent, and to his efficient management of men is largely due the present excellent condition of the grounds and buildings. There is still a little more to do to make them perfect, but not very much, and can be easily accomplished another year.

We should have mentioned perhaps before, that on the grounds near the Superintendent's house, is a neat flag-staff from which we have frequently noticed,- - for it can be seen from Middlebury village,-a very handsome United States flag. This is a welcome to visitors, especially American citizens, all of whom can truthfully feel that they have an equal interest in the farm.

Visitors to the farm should stop at Middlebury, where are excellent hotel and livery accommodations. It is, too, in itself, a town worth visiting, with its very flourishing college and beautiful surrounding country.

Very truly yours, JOSEPH BATTELL.

- From the Christmas number of The Horseman and Spirit of the Times, Chicago, I9Io.

* Silas Wright was born at Amherst, Mass, I795; removed with his parents to Weybridge, Vt.; fitted for college in Addison County Grammar School; graduated at Middlebury College, I815; was member of the New York State Senate, I823-27; Nember of Congress, I827-29; Comptroller of State of New York, 1829-32; Member of United States Senate, 1832-44; Governor of New York, 1845-47; died at Canton, N. Y., Aug. 27, 1847. 


\title{
PEDIGREE MANUFACTURING.
}

\author{
AS ILLUSTRATED BY THE ENGINEERS.
}

IN Vol. I, page I25, American Trotting Register, appears:

"Engineer, gr. h., foaled I8-; got by imported Messenger, I562; dam unknown, but believed to have been well bred. For a number of years this horse was represented to have been imported into Canada by a British officer, and to have found his way, by surreptitious means into the State of New York, about $\mathrm{r} 8 \mathrm{r} 4$. His advertisements of that period conveyed this impression. Thomas Jackson and George Tappen owned the horse, and in after years the latter, who was an unusually candid man for one of his business and pursuits, gave David W. Jones of Cold Harbor, L. I., the true history of the horse. His former owner, in order to save him from the attachment of a creditor, ran him off from Pennsylvania, where he was bred, and sold him to Jackson and Tappan, at a very low price for so fine an animal; subsequent investigation clearly established the fact that he was got by Messenger, probably in I802, the year he stood at Cooper's Ferry. He was sixteen hands and an inch high, and of most perfect proportions. He stood two or three years about Jericho, and was taken to Suffolk County."

Underneath this, same volume and page, is :

"Engineer 2d, gr. h., foaled about I 820 ; got by Engineer, son of Messenger, 1562 : dam a bay mare that ran well, by Plato, son of Messenger, 1562 ; grandam by Rainbow, son of imported Wildair, $275_{2}$; bred by Alexander Lewis, afterwards owned by Smith Burr, Suffolk County, L. I.; stood some seasons across the sound in Connecticut."

We add pedigree of Lady Suffolk, page 203, same volume, as being the probable end for which these pedigrees were manufactured:

"Lady Suffolk, gr. m., foaled $\mathbf{1} \$ 33$; got by Engineer $2 \mathrm{~d}$ : dam bred by John Floyd, Long Island, got by Don Quixote, son of imported Messenger, 1562 ; grandam by Rainbow, son of imported Wildair, $275_{2}$; bred by Leonard W. Lawrence, Smithstown, L. I. ; sold at weaning time to Charles Little for $\$ 60.00$ from whom Richard F. Blydenburgh bought her and sold her at four years old to David Bryan for $\$$ II $2.5^{\circ}$, whose property she remained until she died, $\mathrm{x} 855$. This pedigree may be taken as conclusive. For her wonderful performances see calendar."

Same volume, page i 16 , is :

"Don Quixote, br. h., foaled I 80-, got by imported Messenger, I562: dam not known. Owned by Mr. Kissam, L. I."

We now look to Vol. II. to see what alterations Mr. Wallace makes in his "conclusive" pedigree, and are surprised to find that it still remains intact. But in Vol. III, page I 72, we find: 
"Don Quixote, br. h., foaled I $\delta$ I-, got by Potomac, son of imported Messenger: dam by imported Messenger. The late David W. Jones of L. I. was present when this daughter was bred to Potomac. (Corrected from Vol. I.)"

It would occur to an ordinary compiler of pedigrees that if $\mathrm{Mr}$. David W. Jones saw this mare bred to Potomac, and knew that she was a daughter of Messenger, he ought also to have known by whom she was owned when the transaction occurred; and if he knew that Don Quixote was the result of that union, he must also have known the year when it took place.

Looking for Potomac in Vol. I. we find:

“Potomac (Young), b. h., foaled I8I7; got by Duroc, 791 : dam by Potomac, I916, son of Messenger, 1562; grandam by Bashaw, I8o. Stood at Fishkill, Dutchess County, N. Y., I $823 . "$

In Mr. Wallace's American Stud Book, page 306, occurs :

“i916, Potomac (Van Rantz's), b.h., foaled x 796 ; got by imported Messenger, 1562: dam by imported Figure, 903; grandam by Bashaw, 180 . Bred by Samuel Young of New York."

Whether a pedigree giving name of breeder with no available address is any better than one giving no name at all, would seem to be an open question. This is the only pedigree of this horse, Potomac, given in any of Mr. Wallace's registers.

In Vol. V., Trotting Register, page 330, Mr. Wallace has :

“Engineer (Burdick's), ch. h., foaled about i 8r9, got by Engineer, son of imported Messenger : dam not traced. Bred on Long Island and purchased there by Henry Newland when three years old and taken to Stillwater, N. Y. ; passed through several hands to Nathan Burdick of Warrensburg, N. Y., who kept him many years. He then gave him to his brother and he died at a great age in the neighborhood of Sandy Hill or Fort Miller, Washington County, N. Y."

In Vol. IX., page 376 , of his Monthly, Mr. Wallace informs us that "it appears to be known by everybody about Warrensburg that the Isaiah Wilcox mare, that was traded off in I 839 to Nathaniel Clift and then to L. B. Adams, the breeder of Princess, was got by Nathan Burdick's Engineer; and thus another direct and short line to the fountain head is added to the inheritance of Happy Medium and his progeny."

Further on we quote the valuable lessons which are drawn from these alleged facts.

Possibly no better illustration could be given than this of the manner in which Mr. Wallace is accustomed to build up and bring into common acceptance a wholly conjectural pedigree. This method is an invention of his own, but is as simple when understood as was Columbus' feat of making the egg stand on end. As he has no "copyright" on it, perhaps it will be lawful to explain briefly how it works. Its foundation is a formula like this :

All horses that trot have Messenger blood. This horse trots; therefore, this horse has Messenger blood. But as the country was known to be broad and trotters were seen to be springing up in all quarters, it became necessary to have an unlimited supply of Messenger stallions, and as the genuine 
ones were few, the next best way appeared to be to seize upon any stallion that happened to be well spoken of and lacked a pedigree, and supply him with the desired Messenger strains, making him either a son or a grandson usually, and then attribute all the trotters that sprung up within a day's journey of his locality, either directly or indirectly, to him. The plan has worked so charmingly that a large majority of all turf performers are supplied with the requisite Messenger strains to entitle them to trot, and thus the theory provided the facts, and the facts in turn supported the theory.

Let us apply these principles to the case under consideration, which is a representative case, and see if it has not proceeded strictly in accordance with the formula.

We first call attention to the fact that, although some of these pedigrees are ancient, the compiling of them is a very modern work, the American Stud Book having been published in $1 \$ 67$, and the first volume of the Trotting Register in $I S_{71}$. The whole vast field of horse breeding in America was unexplored and there were no records by which the honest explorer could be guided or the dishonest refuted. It was a noble field for an honest, careful and unpartisan worker, but furnished every facility for fraud by the dishonest and error by the careless or prejudiced operator. In this field appeared John H. Wallace.

We will judge of the value of this line of pedigrees by Mr. Wallace's own oft-reiterated standard, viz.: A pedigree is of no value unless the breeder is given. This rule is obviously sound, and indispensable, as it is clearly impossible for any man to know that an animal is by a given sire and not to know by whom such animal was bred. It will afford a test practically sure when the service books of the horse are accessible, whereby the statement of the alleged breeder can be proven or disproven. But it is as necessary for the public to know the address of the breeder as his name; otherwise it is the statement of the editor of the register only on which reliance must be placed. "Bred by Gen. W. T. Withers, Lexington, Ky.", is a vastly different statement from "bred by John Smith, N. Y." Therefore, when we say the breeder is given, we mean that he is so given that any intelligent man can find where he was at the time of such breeding.

Beginning, then, with the pedigree of Lady Suffolk, which was compiled throughout after she had passed to an honorable grave, the most famous trotter of her day, we find that her breeder is given, and are thus reasonably assured that she was got by the horse called Engineer $2 \mathrm{~d}$. The name of the alleged breeder of her dam is given- "John Floyd, L. I.", but to find his abode you must search the length and breadth of Long Island. It may, therefore, be said that her dam was possibly, but not certainly, got by a horse called Don Quixote. The breeder of her second dam is not given, and the statement that she was got by Rainbow goes for nothing.

Admitting for sake of the argument, that the dam was by Don Quixote, we now have three-fourths of the blood of this famous mare accounted for; she was half Engineer 2 d, and one-fourth Don Quixote; and if we can learn 
the blood of these horses we shall have the benefit of knowing where to go to get similar blood; otherwise we shall know nothing about it, unless we can find other descendants of these same sires. Applying the test to Don Quixote, he is found nowhere; he has "vanished in the viewless air." All that is alleged to be known of him is that he was "owned by Mr. Kissam, L. I." It is asserted that he was "by imp. Messenger," and also that he was "by Potomac, son of imp. Messenger," and it seems that a man, dead before this last statement was published, was present at the breeding. If Wallace is to be believed, this same Jones was commonly sent for as a witness when any mare of Messenger blood was to be bred to any near relation of her's, and he always attended; but in this case, as Mr. Jones in his lifetime forgot to name the breeder or given place, time or circumstance, or how he knew it was a daughter of Messenger or anything else whereby his alleged statement could be proved or disproved, it goes for nothing and Don Quixote must stand, as he is, unknown. The great apostle of Messengerism himself would be the first to scout such nonsense and lash the utterer of it, if it came from any other person and concerned a horse of any other blood.

We now come to Engineer 2d, sire of Lady Suffolk, and again apply the test. The name, not the residence, of his breeder is given; and we will therefore say that he was probably, but not certainly got by a horse called Engineer. Breeder of dam not given, and we will, therefore under the rule, lay aside the "Plato, son of Messenger" pedigree that has been gractiously donated to this "bay mare that ran well," and under the rule stated her blood is also unknown.

Nothing is left now but the original Engineer, and the only pedigree given to him is the inevitable "got by imp. Messenger." Again we apply the test, and, as his breeder is wanting, his alleged pedigree also seems about to disappear-but hold, says the pedigree manufacturer; there are circumstances which account for his breeder's not being known, and they are sufficient to establish that he was a son of Messenger. It is fair to give these circumstances a candid examination; possibly they might be such as to afford a reasonable presumption that his sire was the horse designated.

Allowing, then, that in those rare cases wherein the breeder is unavoidably lost sight of, other evidence must be resorted to, to afford a reasonable "said to be" to the horse's breeding; what evidence is most pertinent and satisfactory? Experience and reason alike tell us that contemporaneous advertisements of the horse by his owners, if they then claimed to have any knowledge of his pedigree and history, would afford the best evidence ; contemporaneous declarations of his owners, fairly made and carefully proven the next; and next to these, probably, the build, quality and characteristics of the horse might assist in forming some uncertain conjecture as to his blood. Among the things that would not be considered evidence should clearly be classed, in case of a fine animal, the declarations of those not connected with the horse, but interested in a given family, to the effect that 
such excellent animal belonged to their special family. Assuming that these propositions are reasonable, and are generally accepted, we will apply them to Engineer.

We have not seen any advertisement of Engineer, but Mr. Wallace has. Was it of a character to show that the horse was a son of Messenger? Let us see what we can glean from what Mr. Wallace is graciously pleased to say it contains, for he deals out evidence in such kind and quantity as he thinks will not hurt his weaker constituents. In Volume I. of the Register he says :

"For a number of years this horse was represented to have been imported into Canada by a British officer, and to have found his way by surreptitious means into the State of New York, about I8I4. His advertisement of that period conveyed this impression."

This volume was published in $187 \mathrm{r}$. In the May number of his Monthly, $1876, \mathrm{Mr}$. Wallace, in an editorial, gives us another nibble of these advertisements, saying :

"The advertisement contains the following very unsatisfactory paragraph relating to his pedigree, viz.: "The manner he came into this country is such that I cannot give an account of his pedigree, but his courage and activity show the purity of his blood which is better than the empty sound of a long pedigree.' It is here intimated that the horse was imported, and the story which Jackson (one of his owners) told was 'that he was brought from England to Canada by a British officer and by some surreptitious means found his way from Canada to Long Island.' "

And in an editorial in the Monthly for June, $188_{3}, \mathrm{Mr}$. Wallace in an unguarded moment of honesty says :

"When we struck the advertisement of this horse for the year I $8 \mathrm{I} 6$ in the Long Island Star, and there found him represented as an imported horse, we were taken all aback."

This is all that he tells us about the advertisements. It was not, then, either from the breeder or from advertisements of the horse or the contemporaneous declarations of his owners that Mr. Wallace learned that he was a son of Messenger. The breeder was unknown; the owner said he was imported; and the advertisements so flatly contradicted the Messenger theory as to take the mortal mouth-piece of the dead Messenger "all aback." It would seem that he could not longer honestly hold to the Messenger theory, even though he should find that in build, character and quality Engineer was the exact counterpart of the old horse. But it appears that the two horses were as essentially unlike as two light gray horses of similar size could well be. Probably before John H. Wallace, Messenger had no more ardent worshiper than this same David W. Jones, of blessed memory; a description of the horse by Mr. Jones might therefore be expected to be complimentary, and doubtless is so; but he never ventures to give him any touch of elegance. In a description of him recorded on page 29, Vol. I., American Trotting Register, Mr. Jones says he had a large bony head, rather short neck, with windpipe and nostrils nearly twice as large as ordinary, low withers, shoulders somewhat upright, hocks and knees unusually large. We 
submit that no great fineness, beauty or elegance went with that description. If we can judge of his appearance by the varying degrees of hideousness which mark his descendants through Mambrino at the present day, he surely was not a handsome horse.

On the other hand, Engineer is described in the first volume of the Register as a gray horse "sixteen hands and an inch high, and of the most perfect proportions." Again in Vol. I. of the Monthly, page 743, Mr. Wallace says he was "very elegant in his form, style and proportions," and that "his fine appearance was so captivating that he was a dangerous competitor" and the same David W. Jones says his buyers were "impressed with his fine appearance."

Considering Messenger's own plainness, it surely could not have been argued with a grave face that he must from similarity of form and characteristics have been the sire of this other animal so distinguished for fineness, elegance and beauty. It was not then from any such similarity that $\mathrm{Mr}$. Wallace selected Messenger as the sire of Engineer.

And now, the ordinary ways of proving, or even guessing, out a pedigree having all failed, or tended to prove the contrary, probably no man in the United States except John H. Wallace would have shown such a degree of infatuation, not to say of idiocy, as to claim that such was the pedigree. Yet he does so, and practically without qualification, and shields himself behind the veriest "cock and bull" story out of the mouth of a man whom he himself first proves a liar and would-be taker of stolen goods, coming not direct to him, but stored up for half a century in the versatile and prolific brain of this same Jones before it is given to the public. The value of space forbids our copying this precious piece of lunacy in full. It may be found in Volume I., Wallace's Monthly, page 43, and consists of an extract of a letter dated February $28, \mathbf{1} 870$. It is to the effect that Thomas Jackson and George Tappan, owners and keepers of stallions in Long Island and in Orange and Dutchess Counties, purchased Engineer of a stranger who "represented him as having been imported from England into Canada and ridden in the army by Gen. Brock, who in an engagement with our troops was shot and killed. The horse escaping into our lines, was secured by our soldiers and brought to the State of New York." Mr. Jones afterwards occasionally rendered Mr. Tappen a favor by preparing his horse bills. On one of these occasions Mr. Tappen made a statement to Mr. Jones, of which the latter says: "Some of the details have escaped me, but the essential facts are distinctly recollected. The owner, with Engineer in his possession, was met at some public place, and the purchase was soon completed," and this statement then made "that he had become involved in debt, and that his creditors had begun a prosecution, with a view to levy on the horse, the only property he possessed, and he was determined not to lose it all." This was certainly enough to arouse their suspicion in regard to his history. He declared the horse was bred and raised in Pennsylvania, and that he was got by imported Messenger. Whether any further pedigree was given is not 
recollected. He was at this time, $\mathrm{I} 8 \mathrm{I} 4$, a horse considerably advanced in years and perfectly white. Mr. Tappen also told me that they had afterwards traced the horse, and was entirely satisfied of the former owner's veracity.

This was a great compliment to the former owner and one that he could not conscientiously have returned; for the above statements, if correctly reported, establish but one fact, and that is that Mr. Tappen was a liar. It will be borne in mind, however, that this Jones, who, after so long a silence, finally lets this remarkable story escape him, long after the witnesses are all dead, was an enthusiastic admirer of Messenger and always largely interested in his stock. Yet it is upon this unaided story that Mr. Wallace (honest, they say, but prejudiced) makes, in the American Trotting Register, the unqualified statement that "subsequent investigation clearly established the fact that he was got by Messenger," and thus completed the rascally work of manufacturing this pedigree.

- Judge W. H. Bliss in Middlebury (Vt.) Register, Dec. $18,1885$.

\section{FANNY JENKS.}

THE GREAT LONG-DISTANCE TROTTER.

W were very fortunate in securing from Dr. Norman D. Ross, of Middlebury, Vt., an intelligent horseman, the following facts regarding the birth and early life of Fanny Jenks. Dr. Ross, said :

"Fanny Jenks was bred by a Mr. Hatch, a farmer, who sold to Mr. Jenks of Exchange Hotel, West Troy.

"Hatch bred three colts from same mare. I drove Fanny Jenks often when Jenks owned her; bay, 900 pounds, two little white lines on feet. A beauty, mane and tail wavy, square as a brick. She had two colts at Whitewater, Wis., where she died. I drove out to see her. Gen. Dunham made a bet, won $\$ 20,000$. He took her to Wisconsin.

"She was Morgan all over; Morgan mane and tail. A perfect picture of old Gifford, except he was chestnut and she bay. I lived at Cohoes and kept drug store. I think she was bred a little north of Saratoga. Jenks said he bought her of Jerry Hatch, a farmer, who raised her. Owned her two years or more before she made a race."

Chester has: "Fanny Jenks, b. m. (3:05 3-5), George Ferguson, Centreville, L. I., Nov. I4, I 844, Troy, 30:56. Ten miles. Gen. Dunham, Albany, N. Y., May 5, I845, $9: 42: 57$. To beat ro hours; one hundred and one miles."

It has been frequently suggested that Fanny Jenks was by Gifford Morgan. If so, she was doubtless bred the year that he was owned and kept near Fort Ann, N. Y., which was about $18{ }_{3} 6$, and agrees with above dates. See Gifford Morgan in this volume. 


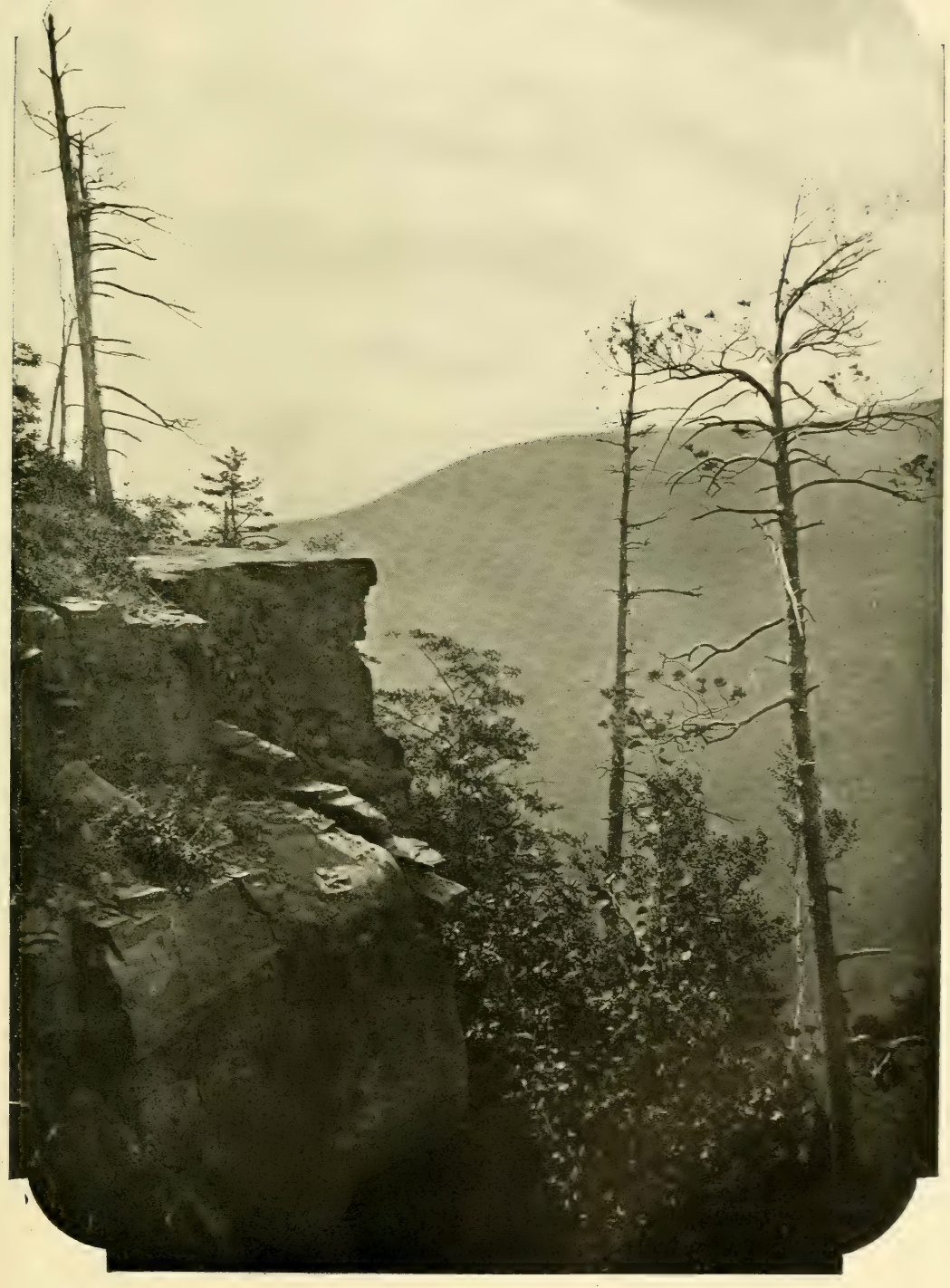

Sunset Rock, Kattskill M untains. 


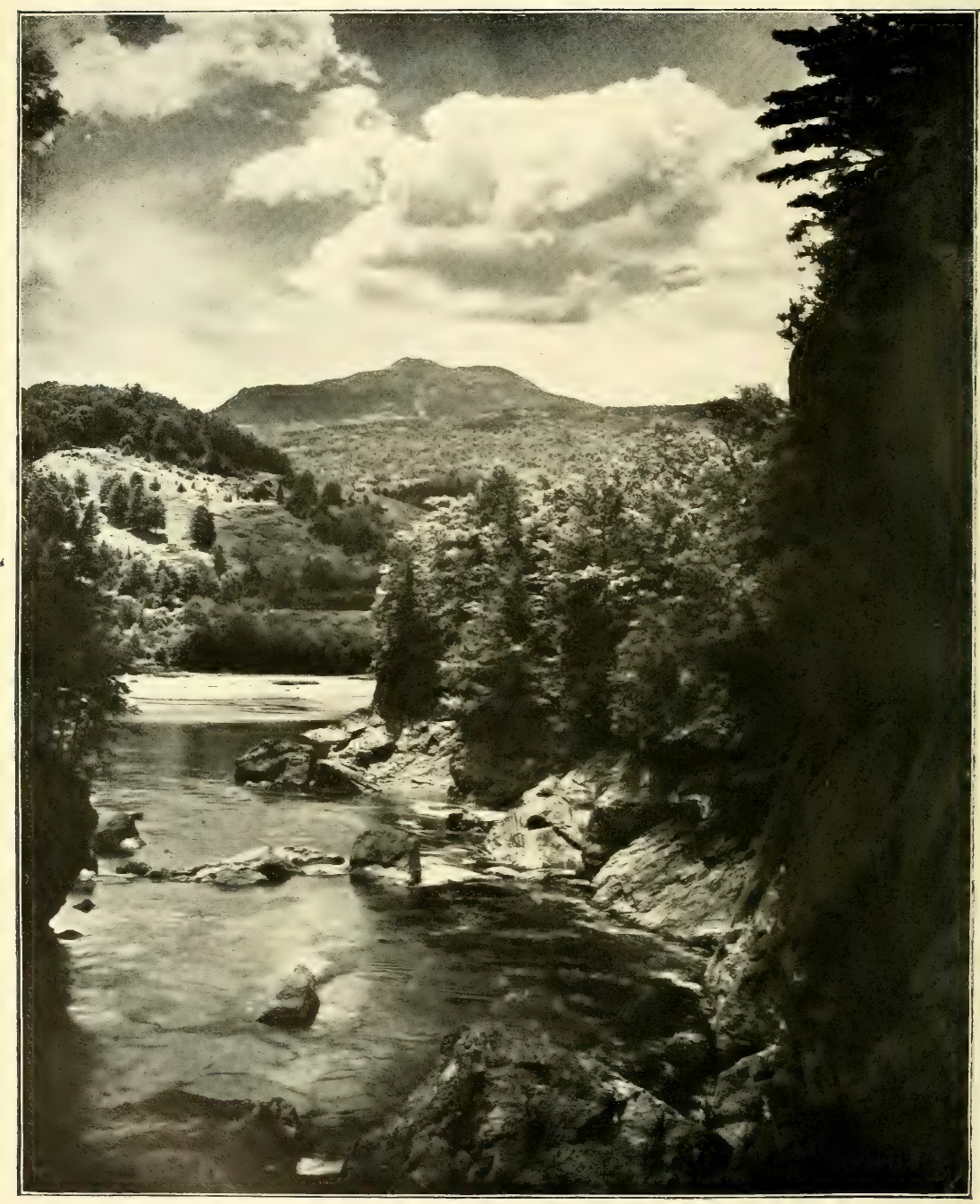

Mount Ethan Allen, Washington and Chittenden Counties, Vermont, from the East, No. I. 
INTERVIEIV WITH GEN. I. T. WILDER, U. S. A.

$\mathrm{B}$ RIG. GEN. G. T. WILDER, born in New Hampshire, now of Tennessee, and whom we met at Washington, D. C., said :

"I left my home in New Hampshire when a hoy and went to New York State, in the vicinity of the Catskills, where I remained some years. Horse dealers of Kingston, N. Y., and farmers, about $\mathbf{x} 843-5$, used to go to Montreal and buy horses. Most all pacers, go like the wind, splendid travelers. Generally brown, some black and bay; very heavy manes and tails. A horse of splendid courage; some of them stallions great big necks. Good looking horses, substantial sturdy stock, heavy bodied for height, strong limbed and wonderful courage. A generous stock of horses in war. I had some 3000 in my command; served in the country and excellent for cavalry, short backed, big in belly, strong boned, very high withers, narrow between fore legs, admirable saddle horses, running or walk. Narrow between legs, don't jolt you like a cat. The most enduring horses I ever saw for their size, save mustangs.

"I remember seeing Morgans in Ohio in $\mathbf{1} 845-52$. They were very fine trotters; three-quarter Morgans. That Morgan stock were all generous horses, very energetic. I don't remember the French in Ohio or Indiana. One man went to Montreal and brought in 50 of them; buy low; sold for $\$$ roo. Brought into Montreal in the fall. They looked quite a good deal like the Morgans ; only have one idea in their head at once."

\section{KERSAUL, KASAUL, OR CASOL HORSES.}

Q UITE a number of times in tracing pedigrees in southern Vermont, the name Kersaul, Kasaul, or Casol was introduced, which seemed to refer to horses of more or less pronounced cream color, with black list down back. From the first we were interested, but this interest was much enhanced when we learned that this blood entered into the pedigree of Flora Temple, one of the most enduring of all trotters, and the first to trot under $2: 20$; and possibly may also connect with the Blue Bulls.

In letter Dr. Warren B. Sargent, Pawlet, Vt., born I803, a gentleman from whom we got much information of early Vermont horses, said :

"Sixty years or more since, I used to hear a stud horse talked about called Old Consol, or Consul. He was said to be a horse of uncommon energy and bottom. I think he was owned east of here, but by whom I do not know. I think he was an imported horse. If I ever saw him his color was cream."

The following letter from Dorson Eastman, another gentlemen from whom we got much valuable information of the horses in south-western Vermont, dated East Rupert, Vt., Aug. 21, I889, throws more light upon this breed of horses.

Joseph Battell, EsQ.,

Dear Sir:-Yours of June 27 th came duly to hand. About forty years 
ago I saw a cream-colored stallion at a Washington County Fair held at Salem, N. Y. He was a magnificent looking animal while standing, but when he moved faster than a walk I lost interest in him. He was of massive build, as I viewed him then. I judged him to weigh I 300 pounds. $\mathrm{He}$ was free from marks, except his mane and tail, which were brown. He was said, by those apparently best acquainted with him, to be of the Casol breed, and an excellent stock getter but my own opinion is that he was of Hanoverian descent.

About thirty-seven or thirty-eight years ago Mr. Philetus Hulett brought to Pawlet a beautiful cream-colored mare. I think he bought her in Weston, Vt. I often used to see her on the road in harness, and every time I saw her my admiration increased; which led me to inquire after her pedigree, for I thought there was a fortune in her. I contemplated buying her to breed from, and consulted the late James Biggart and Ephraim Jones, neighbors of said Hulett.

When I asked of what breed she was, they answered Casol. Further interrogations convinced me,--though they were positive in their opinions,- that their knowledge of the breed was hearsay, borrowed from others equally as ignorant as themselves.

The mare proved by her breeding all that I anticipated. There was another horse in Rupert, the very counterpart of the one aforesaid, except a size smaller. She was celebrated as a breeder of fine stock and was owned by Jonathan Ransom, at the time the Judson Hamiltonian was born. The exact year I cannot call to mind. It is my opinion that these horses had a common origin at some remote period of the past. They were of the same shade of color from their noses to their hoofs, except manes and tails being brown. Counting the Hulett mare for the first generation, we count three more generations of them, bearing the same color as the first. Those that own them speak very highly of them.

I am acquainted with two geldings of the third generation. They retain the color of their grandmother, but lack her finish. They rank No. I in the "all powerful class." They are perfect farm horses - no great style in them when on the road, yet they are high-spirited, with great ambition.

There is a fine mare in this district that was bred in Weston, as I understand-a fair sample of the Hulett mare. I think she is of the same strain of blood. I think her a beauty. I wish you could see her.

Wishing you much success, I remain,

$$
\text { Yours truly, Dorson Eastman. }
$$

Daniel Kelly of Wheaton, Ill., formerly of Rutland County, Vt., writes :

"The third dam of Vermont Chief, by Black Hawk, was bred by Barton Brown, Danby, Vt., foaled I8ı6, got by Kersaul."

D. C. Linsley, author of "Morgan Horses," gives this third dam as by imported Yellow Bird.

From a grandson of Barton Brown, living on the old farm in Danby, we learned that the origin of the cream-colored stock in that section, was a cream-colored horse owned by a peddler who stopped over night with his grandfather about I8I5. This stallion was turned into a pasture over night, and got with a fine young mare of Mr. Brown's, part English, and begot a cream-colored filly from which this stock has sprung. The young man showed us in his stable a handsome cream-colored mare of this stock, which has ever 
since been kept in the family. The peddler is thought to have come from Connecticut. His horse was the original Kersaul Horse, and old gentlemen in Danby and vicinity, including Dr. Sargent, thought the name came from that of the peddler. Dr. Sargent said the stock resembled the Morgans.

E. Kelley, Clarendon, Vt., born about 1802 , said :

"Barton Brown of Pawlet raised his cream-colored mare from a Casol horse that came along, and from this mare quite a race of horses sprung. They were good horses and good size. Cole had one of the mares from Brown's old mare; his colts were all cream colored. Father bought the last colt of the Brown mare, which she had when very old. I came from Danby when twelve and this colt was five years old when we moved. It was sixtyeight years when father bought the colt, and Brown's inare was from twenty to twenty-five years when this colt was foaled. Father said the Casol or Kasaul horse was a large, square, chunked kind of a cream-colored horse. I think they called him imported. Brown came from Connecticut, and I think a man acquainted with him stopped with him a year or two and had this horse."

Amos Brown, Pawlet, Vt., in interview, 1890, said :

"My grandfather owned a fine gray mare. A peddler stopped over night with him, having a stallion which was turned into the lot; got with the mare and she had a cream-colored filly. The peddler stayed but one night. Father remembered the peddler and his horse and has often told me about it. My father and uncle kept these cream-colored horses."

Silas Hulett, Rutland County, Vt., born I 807 , said (189o) :

"The Brown horses were ambitious kind of horses; tough little fellows; generally little smallish arm; 900 to Iooo pounds; they did not generally have a black list on back. There were a good many Morgans here fifty or sixty years ago."

Joshua Hulett, born I $\mathrm{S}_{14}$, said :

"The Barton Brown horses were cream, not very large."

Mr. Bromley of Pawlet said :

"Mr. Train, a relative of the Browns, told me that the sire of the Brown mare came from Rhode Island or Connecticut."

Dr. IV. B. Sargent, Pawlet, further said:

"The peddler's horse that got the Brown mare was a little smart French horse, small, similar to the Morgan. On an average these Brown horses were not large. I got this information of stud from Barton Brown. The peddler came from Connecticut."

Dr. Albert Barrows of Newark, O., formerly of Dorset, Vt., in interview Oct. I 2, r 889 , said :

"I owned old Gray Eagle bred in Kentucky, and his sire Red Eagle. Gray Eagle died mine. Daniel the Prophet I raised. He was by Red Eagle : dam Napoleon, a horse raised in Albany, of Maine blood. I own now a son of Woodford Mambrino, from a daughter of Red Eagle. 
"Leonard Hodges, Wallingford, Vt., brought at first a pair of Green Mountain stallions, to Newark. Later he brought another by Vermont Morgan, to Newark; later he brought three more Morgans to State of Ohio, and another to Perry County.

"The next man, by name of Pease, brought in a son of Black Hawk to Utica, Licking County, a black horse, fine manner and was called Pease's Black Hawk Morgan.

"Then a man named Bailey brought a Black Hawk Morgan, and took him to Granville, O., a big horse fine manner. Pease's Black Hawk got the dam of George A., $2: 211 / 2$.

"A Casol horse, when I was at school at Granville 64 or 65 years ago ( I 824 ) was kept at Pawlet, Vt. Was a cream colored stallion, very attractive. I think, was called Casol, after a man who owned him. My father raised some 30 colts from Judson's Hamiltonian; I tried to have him breed to the Casol horse but he did not.

"I went to Ohio in $\mathrm{I} 846$, and there were quite a number of Morgan stallions about Dorset, Vt., before I left there. The Morgans were the speediest horses we had; but we bred more to the Hamiltonians on account of size.

"Old Gurney was dark brown, regular Canadian pony, never saw him pace. Gurney bought wood for Geo. Smith, and Smith let him have care of a pair of Canadian ponies; both stallions that he drove from Cleveland. He called them Canadian. He used every spring to bring down some Canadian ponies.

"Think Gurney about I 3 hands, stout built, heavy mane and tail, weight about 800 or 900 . He was bred to Bertrand, Sir Charles and Eclipse mares in that region, which accounts in a great measure for his getting speed. I never saw him pace. Got one pacer kept entire until four years old-got a few colts ; one of which beat $2: 30$. Dam of the sire was by a son of American Eclipse. Gurney left no sons to my knowledge that were kept older than four years.

"Smith is dead and Gurney is dead. I saw him the day that Smith brought him in. Think he bought in Canada or some one for him. He brought in two pairs of this same stamp of stud colts. Gurney owned the horse till he died. He used to drive him buying wool.

"I think the first Morgan I ever saw was Gifford Morgan; he was driven at Arlington as early as I830. Think Smith got Gurney across the lake.

"William Pierce bought one pair of these ponies.

"I knew James Wilson of Rushville well. He was all at sea about the origin of Blue Bull. I suggested to him that I knew a horse of that color and description, was bid off at auction at Cherry Valley, Newark Township, O., by Abraham Flary, at N. B. Hogg's auction, then of Newark,-a two year old colt that spring. It was right date for the Wilson's Blue Bull, so he and I both made.

"This colt was a very dark brown pacer. Flary had this same Geo. Smith take him to Cincinnati at five years old, and he said he sold him to a man from Kentucky.

"This colt was got by a son of Cheshire Morgan that was owned by Hogg.

"Cheshire Morgan was bought by Hogg near Walpole, N. H. Think he was a son of Gifford. Wilson believed this to be the same colt."

Whilst we were at Warrensburgh, N. Y. tracing the dam of Happy Medium, Mr. Hammond, a prominent citizen, suddenly remarked: 
"The prettiest horse, the prettiest colored horse, dark cream with dark spots all over, I think the neatest horse all over I ever saw, white mane and tail, called Morgan Tiger, was from Rutland way, kept at (iranville, N. Y. about 1850. Father bred two mares to him; a thick set Morgan shaped horse, about 15-2 or 15-3 hands, 1050 pounds."

For Morgan Tiger, see American Morgan Register, Vol. II., page 24 I.

John Moore, Fleetwood Park, N. Y., born I823, said :

"Kersaul was a chestnut or dun that stood west of Chenango Falls, a good many of them had a list on the back. They were all good trotters and road horses. We had two Highlanders, nearly a mouse color with list, straight hips. A. Cook, a lawyer in New York, owned one in $184 \mathrm{I}$. Kersaul was a well-bred horse. I think English.

"Yellow Bird was in Sherburne, Chenango County ; had black list ; a good business horse. He was a dun color, with strip on his back. I cannot tell where he went. They were good horses, but a little ugly. We had a pair of them and they were matched close, but rather too high strung to suit me."

Dr. McCarthy, a very intelligent horseman, born in New York State about $\mathrm{I}_{2} 6$, moving to Wisconsin $\mathrm{I} 8_{3} 6$, and to Tennessee ${ } 8_{7} 6$, and whom we met in Tennessee, said:

"Copperbottom used to be the stock horse of the country as far as pacers were concerned. Came here early. Went to Wisconsin $18_{3} 6$.

"A breed of horses called Indian pony breed sprang from French horses introduced during the French war at time the French came in at Green Bay, Wis."

"Dominix that went to California, was owned by Carson Newman, Fon du Lac, Wis. I handled him. He bought him of parties at Green Bay; of the Six-Penny breed, I5 hands, dapple gray, full mane and tail. Wonderful horse; fully developed in quarters, very strong at all points, showing great substance. A grand piece of machinery; pacer, about I 852 .

"The Six-Penny, when I went there, were crossed up from stallions brought in during the French war, and bred to Indian ponies. Many of this breed could pace faster than any horse could run.

"The French horse is not a pacer. There were in the family a distinct race of pacers, every one of them. The horses they crossed to Indian ponies were not pacers. Color generally chestnut or red roan (the Six Penny). Indian ponies from $\mathrm{I}_{3}-2$ to 14 hands; 700 to 800 pounds. All small; some of beautiful form; have seen some perfect horses.

"I have seen the Mustang horses twice in California. They are larger, will average $I 4$ to $I 4 \% 2$ hands, occasionally one $I 5$ hands. I am 65 .

"The Messenger stock recognized good in New York. Another breed of horses called Magnum Bonum, and the Consol breed of horses, a class of horses that had a black list running down their back. They were considered of the very best family of horses when I was a boy, and I have often heard my father speak of them. I think it was spelled Consall. Mlost of them a clay bank. I saw plenty of them. Owned in West Martinsburgh. Consall stallion, I think, owned by some one of the Curtis family; I5-3 hands ; very blocky horse, that was the character of the whole family whenever you saw them; with black list, good style, not a coarse horse, all good shape, well cut in throat latch, with nice ear set well, fine eyes well set, showing a good deal of breeding. I think the original Consall was an imported horse. 
$\mathrm{He}$ indicated too much breeding for the family of Morgans. If from Vermont they must have been Morgans. Many Morgans show uniformly flashy, powerful built horses, very large arm, not like the Magnum Bonums; they more rangy and coarser bone.

"Magnum Bonum not like Messenger; coarser boned than Messenger; Messenger all style; Magnum Bonum not so much; never seen any horses out style, some of the present blood of Messenger horses. Recollect Gen. Ruggles' Messenger. Never saw horse with more style; gray; 16 hands; full I roo pounds; big enough for a stallion.

"Ruggles lived in West Martinsburgh, Lewis County, N. Y. I think he shipped that horse to Fon du Lac, Wis.; took him to Wisconsin as late as I850."

Another gentleman present said: "In I857 I lived near Fon du Lac, Wis., and Black Hawks were all the rage there."

The Doctor, continuing, said: "The Ruggles Horse was the first Messenger horse taken to Wisconsin at this point. My father owned a Messenger stallion, steel gray, perfect picture. A few Mlorgan horses had come into New York before I left, I 836 .

"The Messenger horse in New York not coarse; as fine as Hambletonian horses of today, with more thoroughbred. They showed life, sparkle and spirit when lead out, seemed to know they were handsome.

"Consall horse's eye stuck out just as a thoroughbred, always full over the eye. Could stand behind him and shoot his eye out, a feature of the thoroughbred. Another horse was brought to Wisconsin from Canada. A very remarkable horse, a stallion, pacer, from Three Rivers. My brother and self owned him at one time; called Jack; very blocky, red roan in the type of Morgans. Up headed, very stylish; a horse of the greatest of endurance; about $15^{1 / 2}$ hands; strong 1050 pounds; a most powerful horse to pull; very rapid pacer.

"Sol. Pier brought the horse and a mare, not a French mare, but Canadian, I think; brought in about I $847-8$. We owned him about I 854 . Mr. Pier had him. He kept him several seasons. We gave him to Fisher (Andrew) in 1855 . I was married in $185-$; brought in before; left good stock, part pacers. He was about eight or ten years old when he was brought in from Three Rivers, where he paced a race.

"The Black Hawk Morgan was the first horse that could trot in three minutes in Wisconsin.

"Dandy Jack, got by Black Hawk Tiger, son of Sherman Black Hawk, died 1876 , then 25 years old. Bred in Stanstead, Canada West, by Bigelow : dam a Morrill, bay, I $51 / 2$ hands, looked larger. Bought of Miller, Colerain, Mass.; brought to Hawkins County, Tenn., I 869 . I paid $\$$ Iooo for him. Stock distributed here quite a good deal; best son, chestnut, taken to Atlanta, Ga. Used as a driver by Mr. Price. Foaled I $87 \mathrm{I}$. Went to Atlanta 1878 .

"I am satisfied the Six-Penny horse was introduced into Wisconsin about I 765. 'Too much finish, I think, for common running blood; a great deal of breeding in them; Kentucky pacer slimmer and taller, not so blocky. The Six-Penny red roan or chestnut, some gray, some bay, not a single black. 'The Melendy horse was owned in Tennessee when I came in 1876 , a Morgan. [IVe suppose this to have been Morgan Bulrush, got by Bulrush Morgan, son of the original Morgan horse ; bred by Jack Melendy, Bennington County, Vt.] King, a Frenchman, brought a trotter to Fon du Lac from Montreal, light bay, white marks. I left Wisconsin in 1855 . Thor- 
oughbred stock in Tennessee when I came here seventeen years ago, except the Melendy horse, I 6 hands, I roo pounds.

"The Copperbottoms were quite compact horses, remarkable for their staying qualities. A blocky horse, $15 \frac{1}{2}$ hands, rather fine; shoulders and neck of the finest. Morgans naturally up-headed, prompt. Copperbottom more straight neck. Tom Hal like Copperbottom, blocky; Hal Pointer an exception, a big styled horse. Hobkirk's Sir Henry had a mean disposition. The Copperbottoms are remarkably prepotent."

When visiting central New York in spring of 1889 , especially to look up the pedigree of Flora Temple and that of Pilot, we learned that a son of Geo. W. W. Loomis of Sangerfield, who owned the sire of Flora Temple at the time she was bred, was living at Higginsville, N. Y., some 60 miles distant, and visited him. Mr. Loomis said :

"One-eyed Kentucky Hunter was bred by Geo. W. W. Loomis, Sangerfield, N. Y.; and got by old Kentucky Hunter called the Sherrill Horse, of New Hartford, N. Y., dam also bred by my father, sire, I think, a Messenger horse owned west of Hamilton village. The Casol breed of horses were here, her dam [ $2 \mathrm{~d}$ dam of Kentucky Hunter] that breed. I think they came from Vermont; brought here 60 years ago. Rodney Ackley, Hamilton, would know [Mr. Loomis at first thought the dam Casol, but changed it as above]. "Bogus was got by Old Lame Bogus, what we used to call the Ellis Bogus Horse; bred by Geo. W. W. Loomis of Sangerfield, from a Casol mare. It was another Casol mare that was $2 \mathrm{~d}$ dam of One-eyed Hunter. We sold the grandam of One-eyed Hunter to Horace Fox of Morrisville, a great big fine mare, nicest parade mare you ever saw, I 6 hands, I 50 pounds, dun with black holsters. The dam of One-eyed Hunter was bay with star, I050 pounds, $15 \frac{1}{2}$ hands, a fine built chunked mare.

"The dain of Bogus was dun, black legs, the one we let Fox have. This mare was foaled from a mare that father drove cattle with. I was about Io years old, now 69. I think I was about 20 when Bogus was foaled. Bogus extra good horse for stock. Hamilton and Eaton sold a pair from him for $\$ 800$. We took Bogus to Canada near Belleville before the war. $\mathrm{He}$ was dapple chestnut with white stripe in face, two white hind and one white fore foot, I $61 / 2$ hands, 1200 pounds. We called him the nicest appearing horse you ever saw. Hind parts not so good as front, little peaked. Very fine stepper, I think the finest appearing horse ever brought out of a barn, so everybody said; feet right under him. The Tippoo horse was by the Scott horse at Bridgwater; got very good colts; dam Messenger. This within 30 years; sold to Stephen Cotton; to a Mr. Mills, and went to Oneida. He got one colt that sold at 3 years for $\$ 800$.

"We had a Black Hawk from Canada, a very good horse, black, no white, I6-2, I 200 pounds, seven years old when we bought him; kept him five years; he was burned up.

"The first Messenger I remember was a big bay, when I was a little boy, at Hubbard's Corners, Hamilton, N. Y.

"The Morgan horses and Kentucky Hunters were very much alike.

The Morgan horses a little more chunked, thicker set.

"The Bogus horses had great durability; nothing could beat them; good to work or for the road."

We have received the following letter from Mr. Hiram Ackley, Hamilton, N. Y.: 
"There was a Casaul horse here that was brought from Vermont. $\mathrm{He}$ was a dun color with black stripe on his back. I cannot tell where he went. They were good horses, a little ugly. We had a pair of them and they were matched close, but rather too high strung to suit me."

For further suggestion regarding the Casol horses in New York State at about this time, see Bolivar (Pintler's) Vol. I., p. 342, of this work.

\section{FLORA TEMPLE.}

$\mathrm{T}^{\mathrm{H}}$

HIS Casol breed of horses, which are introduced several times in the preceding interviews, seem to have been quite a remarkable breed in their day and to have originated in Vermont. As we have mentioned, the dam of Bogus, sire of Flora Temple, was by a Casol horse, which, the son of the breeder, who remembered the horses well, says was by a Casol horse that was brought from Vermont.

Flora Temple has to her credit 106 recorded races, at the time more than any other trotter. She was, too, the first to trot below $2: 20$. Her pedigree is given correctly in the "Breeders' Stud Book" by J. H. Sanders, but we have never seen it so anywhere else. She is generally said to be by Bogus Hunter, son of Kentucky Hunter; but there never was a horse called Bogus Hunter, nor any called Bogus, got by any horse named Kentucky Hunter. One-eyed Kentucky Hunter, and Bogus, by Lame Bogus, were bred by G. W. W. Loomis, Sangerfield, Oneida County, N. Y., and both owned by the Loomises when Flora was bred. The following letter received by us from her breeder Samuel Welch, whom we found to be universally regarded as an intelligent and very truthful man, is decisive as to which horse got Flora. Mr. Welch allows himself to use the name "Bogus Hunter" for Bogus, which we and others used in writing to him, though in closing the letter he says the horse's name was Bogus, and this is what we found it was when later we visited Oneida County, and interviewed the son of his breeder. The name of the horse was Bogus, after his sire, and he was known as Loomis' Bogus :

Reedsburg, Wis., March i 8 , i887.

Dear Sir :-Yours making further inquiries in relation to Flora Temple is at hand. Cannot say that Bogus Hunter was any relation to One-eyed Kentucky Hunter. They did not look alike. One-eyed Hunter was a small chestnut horse, and Bogus Hunter was a large sorrel horse with three white feet and a white stripe in his face. Both horses were there when I bred the mare. I bred her to Bogus Hunter. The mare was not taken to the horse but once and I took her myself and saw her covered.

I cannot tell whether the two horses were in any way related or not. I don't know. The horses did not look at all alike. Bogus Hunter was a large, rangy horse, high-headed. One-eyed Hunter was not so large and the mare was small; would weigh only eight or nine hundred; so I bred to the largest horse. Bogus is what they called the horse I bred the mare to. I knew the horse for a number of years. I only lived a mile and a half from where the horse was kept and knew him well. 
LETTER FROM THE SPIRIT OF THE TIMES, FEB. $\mathbf{8} 8$, 1857 , CONCERNING FLORA TEMPLE AND HER BREEDINC:

Dear Sir:-I notice with pleasure, in several of the recent issues of your paper, a flattering sketch of the life and exploits of "Flora Temple." Having once been the owner of Flora's dam, and having therefore been quite familiar with the various changes that have attended her career, I have thought a brief notice of her early history might not be uninteresting to your readers.

Madame Temple, the dam of Flora, was foaled the property of Elisha Peck, Esq., of Waterville, Oneida County, N. Y., in the spring of 1840 . Her dam was a small but fleet bay mare. Madame Temple was by a spotted Arabian stallion, owned by Horace Terry, Esq.

Mr. Peck disposed of Madame Temple when four months old for a mere trifle, to William Johnson, Esq., of the same place, who always had a keen eye for good points in a horse. This latter gentleman kept her till she was three years old, when he sold her to Sam Welch.

In the month of May, I845, Mr. Welch transferred "Madame," and her colt afterwards Flora Temple, then five weeks old, to Archer Hughes of the same place. The colt was the picture of her dam in all respects but nothing extraordinary was predicted of her. To all appearances, she was simply a very pretty and rather promising colt. Sometime in the fall after she was foaled, Mr. Hughes sold her to Nathan Tracy of Hamilton, Madison County, N. Y., for the insignificant sum of \$13. Mr. Tracy, it seems, had not the slightest idea of her really extraordinary parts, for after keeping her about two years and a half, he in turn, disposed of her to Mr. Congden of Smyrna, Chenango County, N. Y. How long she was the property of Mr. Congden is not precisely known. He did not however understand her worth, for on the first good opportunity he sold her to Messrs. Richardson and Kellogg of Eaton, Madison County, N. Y. These gentlemen kept a livery and on their property she was kept at pretty hard service as a livery horse. It was here, however, that she began for the first time to develop those wonderful powers of speed and bottom which have since rendered her so famous. As a horse in the livery, she speedily became a favorite with the public and was universally regarded as a remarkably free and sharp traveler. But she was not considered a first rate animal and no predictions were made concerning her at all, commensurate with the triumphs she has since achieved. Still Mr. Richardson considered her altogether too brave and spirited an animal to be ingloriously worn out as a livery horse, accordingly he took her with a drove of cattle to Washington Hollow, Dutchess County, N. Y., and without any conception of her matchless speed and bottom, he relinquished all right and title to her for $\$ 175$. From that time to the present Flora has been the heroine of a brilliant history, which has been so capitally told in "Porter's Spirit of the Times," that I shall not undertake to enlarge upon it.

The sire of Madame Temple was a spotted Arabian horse brought from Dutchess County, N. Y., to Waterville, N. Y., by Horace Terry, Esq., and kept at that place a number of years. He was a remarkably strong, restless, fast trotting horse; and is said to have been got by a full-blood Arabian stallion on Long Island. He was a great favorite in this section and his stock, for general use, possessed probably more excellent qualities than that of any other horse ever known in this vicinity; they were uniformly strong with race speed and bottom.

The general high repute in which his stock was held here may be judged 
from the fact that George W. Crowingshield of Boston owned a pacing gray mare of his get, so fast and enduring that he sold her for $\$ I, 500$.

Madame Temple has always been regarded as a remarkable roadster. Mr. Hughes sold her in 1846 to J. B. Cleveland of Waterville, who soon parted with her to N. W. Moon of the same place, but now of Osage, Ia. By him she was kept as a horse of all work for several years, from whom she was purchased by James M. Tower in the Spring of 1854 , and by him subsequently sold to H. L. Barker of Clinton, N. Y., in January, 1855, who now owns her.

Flora was her first colt. Her second a horse colt was killed by lightning when three months old. Her third a horse colt was foaled in the spring of I 855 and purchased by J. WV. Taylor of East Bloomfield, N. Y., for R. A. Alexander of Kentucky for $\$ 500$. This colt was got by H. L. Barker's Edwin Forrest (a Kentucky Hunter colt), now owned by J. Downing of Lexington, Ky. Edwin Forrest trotted when three years old at the United States Horse Fair at Springfield, Mass., in 1854 , half a mile in one minute and thirty seconds and received a premium.

The fourth also a horse colt was foaled ${ }^{2} 856$ and is now owned by Mr. Barker and by the same horse, Edwin Forrest.

Madame Temple now in her $17^{\text {th }}$ year is looking finely at the residence of H. L. Barker, Clinton, N. Y., and is with foal by his horse Norman.

JAS. M. TOWER.

The foregoing is true according to the best of my knowledge and belief.

Subscribed and sworn before me, Feb. 24, I $857 \cdot\left\{\begin{array}{l}\text { Elisha Peck, } \\ \text { Wh. Johnson, } \\ \text { Horace Terry, } \\ \text { Archer Hughes, } \\ \text { G. B. Cleveland, } \\ \text { GAs. M. Tower, } \\ \text { H. L. Barker, } \\ \text { Chas. Webster. }\end{array}\right.$

FROM THE SPIRIT OF THE TIMES, MAY 20, 1854.

"The celebrated trotting mare, Flora Temple, is offered for sale. She is well known in American sporting circles as one of the best mares that ever appeared on the turf. She is nine years old, a bay roan in color, $14 \frac{1}{2}$ hands high and perfectly sound. She has trotted in $2: 28$ in a wagon race-the fastest on record. Also in $2: 27$ twice in harness. She is perfectly kind in single or double harness or under the saddle. Apply to the editor of 'Spirit of The Times,' 3 Park Place. Price, $\$ 7500$.

"Flora can be seen at the stables of B. B. Boram at the 'Old Homestead.' New York, May 9, I854."

\section{INFORMATION OF SECOND AND THIRD DAMS.}

Mr. Joseph Battell, Middlebury, Vt.,

Bloomington, Ill., Feb. 8, I892.

Yours of January 28 received. In reply will say my father owned the $2 \mathrm{~d}$ dam of Flora Temple; also the Ist dam was foaled his. My father bought her of a man by the name of Randal, who lived then in the town of Paris, Oneida County. We lived in Marshall, but I cannot tell what Mr. Randall's 
first name was. Neither can I refer you to any one who can. It must have been about the year I $\$ 40$ when father got the mare. He owned her a number of years. I remember her very well; she was blocky built, bay, without mark, mealy nose, weight about 1000 or 1050 , free, good driver and fine looking.

Respectfully yours,

J)HN L. PECK.

Mr. Joseph Battell, Middlebury, Vt.,

Bloomingion, Ill., Feb. 8 , i 892.

Dolly, the dam of Madam Temple, was five or six years old when my father bought her of MIr. Randall, and I think that was about I 840 -not more than a year either way from that. I was a small boy at that time, but I remember the mare well, as she was the first horse I rode. I was born April $2 \mathrm{~d}, \mathrm{I}_{32}$. Mr. Randall was a tall, rather slim man, ahout 40 years old at that time.

Respectfully yours,

JoHN L. PECK.

\section{MAC.}

One of the greatest of the early trotters was Mac, $2: 28, \mathrm{I}_{5}^{\mathrm{I}} / 2$ hands; foaled I 843 ; bred by Thomas Record, Canton, Me.; got by Morgan Caesar (Morgan Post Boy), son of Woodbury Morgan by the original Justin Morgan : dam bay, with dark points, breeding unknown. Mac trotted Io races with Lady Suffolk, winning seven, and losing three when lame.

Mr. Wallace gives the breeding of his dam, by Bush Messenger, no breeder given.

We have received a letter from John Record of Livermore Falls, Me., son of Thomas Record, breeder of Mac, who writes :

"Mac's dam was a bay mare, dark points, breeding unknown. Fathebought her of Dr. Coolege, of Canton, Me. She was fourteen years old when father bought her. He owned her two years before she had Mac. She was a good mare and one of the best road mares of her day."

This makes the mare foaled in 1827 . Bush Messenger was foaled in I833, or six years after the mare. This is another of the many Messenger pedigrees for important animals inserted in the Trotting Register, while under the management of Mr. Wallace, which are not correct, and which have not since been corrected.

A very full history of Mac, who was kept as a stallion till three years old and got fifteen colts, will be found in Vol. III. of this work.

\section{THE TROTTING HORSE TACONY.}

“ On Thursday morning, 2oth April, I 854, at I I o'clock, at the stable, Cherry Street above Fifth, in rear of 189 Arch Street, Philadelphia, will be sold to the highest bidder, the well known trotting horse Tacony, believed to be the fastest young trotting horse in the world. Tacony is a strawberry 
roan, about I 5 hands 2 inches high, and only nine years old, is perfectly sound and kind, has been well wintered, and is now in first rate condition. Tacony's performances are too well known to require enumerating. He may be seen previous to sale, and any further information obtained by applying to or addressing the auctioneer at Philadelphia.

AlfRed M. HaRkness, Auctioneer.

April I, I 854."-Spirit of The Times, April 15, 1854.

\section{BLACK HAWK STALLIONS.}

"Col. S. C. Hall \& Co., of Manchester, N. H., have just arrived in this city with three beautiful Black Hawk studs, one ten-year-old horse and two four-year-old colts of this sire. They are all of a jet black color, and are the best specimens of horse flesh ever seen in this part of the country. They are on the way to Kentucky.

Boston, March 29, I854."-Spirit of The Times, April 15, 1854.

\section{EDWIN FORREST (NED FORREST).}

The following article regarding another of the very fast early trotters we take from Porter's Spirit of The Times of Nov. 6, I858:

Antique House, Palier, Mass., Oct. 23, I 858.

Dear Spirit:-I have observed in the New York Times of this date an obituary notice headed: "Death of the Bashaw Trotting Horse, Ned Forrest," in which his wonderful performances are honorably mentioned, and he is represented as a son of Grand Bashaw, which is surely a mistake. $\mathrm{He}$ was raised in South Hadley, Mass., from there sold to a gentleman in Amherst, and bought from him by Mr. Goodrich of Springfield, Mass., and sent to New Haven by him with a drove of shippers, but, as $\$ 8 \mathbf{5}$ could not be obtained for him, was brought back. It being soon after discovered that he possessed a great turn of speed, he began to attract notice and was sold to General Cadwallader. From this time forward his performances are well known to the public. He was a Morgan horse, and possessed a greater share of Morgan blood than any living horse of the Bashaw blood does, having been born thirty years ago; while the Bashaws and Morgans of the present date are at least two generations of crosses further removed from their respective blood.

SINDA.

It will be seen that this history of the horse, so far as given, agrees with that given on page I 86 of this volume, excepting that this correspondent of The Times states that the horse was Morgan, which both his description and the locality where he was raised will sustain.

\section{FRENCH CHARLEY AND COLUMBUS.}

As both of these horses have aided materially in the production of the American trotter and roadster, and but comparatively little is known of either of them, we add the following notes which we took in our return in I887 from a trip to Canada. A. W. Goff of Richford, Vt., said : 
"The Stone Horse was a medium-sized dark bay horse and a stepper; cross in stable; I 100 fat, 1025 lean; $151 / 2$ hands. Owned by Frank Stone, East Berkshire; he took horse to New York and sold him, I think, to go to Pennsylvania, for $\$ 600$. Sold, I think, 1850 or '5 1 . See Dan Moran or Adolphus Paul. Horse came from Canada, I think St. Hyacinthe.

"We traded our Morgan mares in Canada, old mares. They would trade to get our mares; Stone Horse pony built; fine, likely built horse; heavy front, heavy breasted, lightish behind; built for a goer. I think called French Charley. He was the first stepper I really saw. He had the sand in him. I think he came here about 1850 .

"Ten Eyck Horse died at Dunham, claimed to be by old Black Hawk, kept by Ten Eyck, large, black, nice style; 16 hands; kept there till he died; I think foaled $\mathrm{s} 853$ or '54. Comet Horse a Swanton horse.

"Farmer's Beauty handsomest horse I ever saw, never saw anything that could begin with him, Morgan horse. Joe Wheeler, Richford, owned him about 1865 , chestnut, rooo pounds, $\mathrm{I}_{5}$ hands. Died here $1875-8$.

"He raised two stallions; Anthony Wheeler bred one; Frenchman from Canada, John Lahue, bred one in Dunham; a good one, dam by Royce Horse; Lahue Horse dark bay, I roo pounds, $15^{1} / 2$ hands, black points; foaled 1875 ; good looking horse.

"Gov. Royce Horse was got by Black Hawk, I think. Dam bred by Gov. Royce, got by Nimrod. A great many trotters from Nimrod.

"The Page Horse was by Columbus. See Stillman Page, Bakersfield. Nimrod stock, smooth, heavy built, good size; Hamilton of Montgomery bought a Gifford Morgan. Black Diamond was at Newport. Ira Allen and he in race at St. Armand's. Ira Allen a very fine horse.

"Wiers Horse at Sheldon by Nimrod; heavy horse, good stepper. Root went through here first with Comet, by Billy Root, afterwards with Root Horse, by Streeter Horse, a small black horse; went to Swanton; both steppers, and stopped here.

"Old Steele Horse raised in Barton, and a'young Streeter Horse, got by old Streeter Horse, blood bay, black points, prompt, IO5O pounds, I 5 hands.

"Bulrush Morgan, blood bay; George F. Dunkley of Burke owned him. Dunkley bred a mare to old Willoughby Lake Tiger, I Ioo pounds; four white feet, white stripe ; sold to Lyon, Westmore, Io years old, 900 pounds, very pretty horse ; got awful good colts. Pettis of Sutton traded in Massachusetts and got Dictator."

\section{J. P. Goddard, Richford, Vt., said :}

"Goddard Horse got by old Steele Horse (Royal Morgan, by Sherman Morgan), bred by Reuben Goddard, Farnham, Can.; chestnut, low, black horse, 15 hands."

Mr. Boutelle, Bakersville, Vt., in interview, 1887 , said :

"Forty-two years ago the Lothrop Horse (Columbus) was brought here

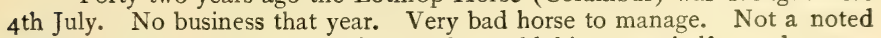
horse in Canada. Man an old man that sold him; one-half way between Chambly and Longuille, I think in direct route.

"About I 5 or I 6 years old when brought out. That is, we supposed he was. Lothrop bought him; paid in buggies; gave three or four buggies for him. Think not a great sight of stock there.

"Frank Stone's horse left splendid stock here, and Stone lived at East

Berkshire. They brought out this colt, about five years old, about 1850 . Horse raised in neighborhood of man that sold him; 1847 I saw him; 
had peculiar white mark up and down on nose, white stripe across belly two inches wide, six inches long; natural mark; chestnut; rooo pounds; one white near hind foot; natural pacer, could trot fastest.

"I saw St. Lawrence at four, when Bachaud owned him. Blood bay; 950 pounds at four or five years old, I 5 hands; don't think a Morgan, think a Canadian French horse.

"Columbus, steep rump, very round hip; small ear, good as ever saw on horse; very heavy mane and tail; well cut up; clean limb as you ever saw. The horse that was his sire was kept near by; I saw the dam, brown, a little white on nose; I 000 lbs., low frame. [See Columbus Vol. I., p. 554.]

"Harrison Chadwick was with Lothrop when he brought Columbus out, worked for Lothrop.

"Tecumseh, I think, was owned in Upper Canada.

"The Stone Horse was claimed to be a Morgan horse; always called him a Morgan."

Mr M. B. Walker, of Whiting, Vt., now (I910) 77, of whom we have obtained much valuable information of old-time Vermont horses, has just visited the office of the American Publishing Company, and, to questions, says :

"I saw French Charley at the Vermont State Fair, Rutland, I852 I think, but anyway the year that Black Hawk and Green Mountain Morgan were both exhibited there. Mr. Stone claimed this horse to be related to Columbus. His color was similar to that of Columbus. A sort of sorrel chestnut, white stripe in face, one white leg (nigh I think), most to gambrel."

In the Mark Field Monthly of July, I885, in a long article of several columns concerning this horse (known in the west as Vermont Boy), taken from a poster of the horse, advertising him at Long Ridge, Marshall County, Iowa, the following statement is given:

"Napoleon Bonaparte, Emperor of France, procured three stallions and four mares from the government of Barbary, which he bred through successive generations that he might produce superior animals for the French cavalry service. By a law none of this stock could be sold for exportation. Though probably purchased, this law was indirectly evaded by Vermont Boy being presented, when one year old, in $\mathbf{I} 85_{2}$, to John A. Trask and Louis Barboo, celebrated French sheep importers, of Chambly, Canada East, with a lot of imported sheep. When three years old he was presented or sold to G. V. Gadcomb and Sanderson, of St. Albans, Vermont, also importers of fine stock. He was kept by them one year and sold to Frank Stone of the same place, who in turn sold him to E. K. Conklin, proprietor of the Hunting Park course, Philadelphia, in whose hands and Stone's he was first trained and trotted in races. Conklin next sold him to one Joseph Brown, a silk merchant in Philadelphia, who presented him to his brother, M. B. Brown, of Pittsburg, Penn., from whom he was purchased by his present owner, James Torrence, then of Allegheny County, Pennsylvania.

"This printed handbill gives in detail the record of the races in which Vermont Boy trotted and the premiums he won and places where he trotted. Two samples of these are, one trotted over the Hunting Park course, a tenmile heat race, against Sagarro, Cotton Tail and Gen. Scott, for $\$ 500$ each, and won by Vermont Boy in $26: 50$; the other at the Pennsylvania State Fair at Pittsburg in 1858 , a twelve-mile heat exhibition in $32: 12 . "$

See French Charley, page 448, also The Morgan Horse and Register, Vol. I., page 762 . 


\section{RIPTON, $2: 33$,}

AND WINNER OF 19 RECORDEI RACES.

Another of the early trotters, and one of the best, was Ripton, bay gelding with blaze and four white legs, 15 hands, foaled about 1829 ; bred by Burr Meeker, Westport, Conn.; got by Heron Horse, said to be running bred: and dam Morgan.

We have received the following interesting letter dated Westport, Conn., November 27, I889:

Joseph Battell, EsQ.,

Dear Sir:-Ripton was bred by the late Burr Meeker, Sr.; the year I cannot state. He was got by a horse called the Heron Horse. All I can state about the origin and history of the Heron Horse is that the late Morris Ketchum, the New York banker, whose country residence was at Westport, bought a mare with a colt by her side somewhere on Long Island. He sent a man up to this place with the mare and the colt. The man rode the mare and the colt followed by her side. 'This journey gave the colt what are called sand heels, from which he never recovered. He always had bunches on his heels, but they never made him lame. The colt grew up an entire colt and when old enough got Ripton. The dam of Ripton was a good-sized, brown mare, no white on her, low headed and not fast. I can not now ascertain where Meeker, Sr., got her. She was quite old when she foaled Ripton. The sire of Ripton grew up and became a mature horse, and was traded about from place to place; was owned at one time by the old Heron family of Redding Ridge, Conn., and then by the late Nathaniel Lyon of Dodgingtown, a few miles north of Redding Ridge. Then he was returned to Westport and an Irish carman by the name of Welch owned him and used him as a cart-horse. While he was thus owned by Welch he covered a number of mares at a nominal price. Welch used to run him short distances over our common roads for small wagers and he was always the winner. When the colt Ripton grew up William Meeker, son of Burr Meeker, Sr., used to ride him, and a man by the name of Henry Nichols of Weston, Conn., owned a horse that could trot then a mile in about three minutes. Ripton was about a match for him. Sometimes one would win and sometimes the other. It very soon became noised about that Ripton was a trotter and Samuel H. Blackman, then of Norwalk, Conn., bought him of Burr Meeker, Sr., for $\$ 250$ and then sold him to a man by the name of Hutchinson of New York, and he then went into the hands of the late Hiram Woodruff of New York. I am aware that this letter falls far short of a definite and exact pedigree of the horse Ripton, but it is the best I can do, aided by a gentleman of this place by the name of IV. J. Finch, who is personally cognizant of all the above facts.

Burr Meeker, Sr., died March 20, 1860, aged 75 years. Morris Ketchum is also dead. Any other information possible will be cheerfully furnished you on request.

Yours respectfully,

MOSES W. WILSON.

\section{AMERICUS.}

CTLL another of the famous early trotters was Americus (I-I6), $2: 33 \frac{\pi}{4}$, and winner of fifteen recorded races; bay gelding, foaled 1832 ; bred by John Tunnacliff; got by Blind Duroc (owned by Henry S. Orendorff, 
Columbia Center, N. Y.), son of Utica Duroc: dam said to be by a Morgan horse owned by Leonard Brown, Columbia, N. Y. Trotted I 839-46.

\section{LADY SUTTON.}

I ADY SUTTON (3-16) $2: 30$, was foaled 1839 ; bred by Peter Nichols, Larre, Vt. ; got by Morgan Eagle, son of Woodbury Morgan : dam said to be a large, brown or black mare of high mettle.

Sold to George Colamer for $\$ 1$ roo, who showed her on the road one-half in $I: 30$, in those days called very fast, and he sold to Mr. Fisk a peddler for $\$ 400$. Mr. Chester in his "Complete Trotting and Pacing Record," says her dam was a Morgan mare. He credits Lady Sutton with winning two races against Lady Suffolk, the last two-mile heats.

Her sire, Morgan Eagle, is described as a horse of great beauty and power. He was also sire of the famous Michigan stallion, Magna Charta. Information from John Grow, Barre, Vt.

\section{DARIEL (LADY WONDER).}

T HE fastest harness horse bred in Vermont, to date, is Dariel (Lady Wonder) (I-I6), pacer, $2: 00 \frac{1}{4}$, bay, little white in face and one white ankle, I5 I/4 hands; foaled May 30, I 893 ; bred by Whitcomb Bros., Essex Junction, Vt. ; got by Alcander, son of Alcantara: dam Topsy, bay, bred by L. D. Whitcomb, Essex Junction, Vt., got by Holabird's Ethan Allen, son of Ethan Allen; 2d dam Fanny, bay, bred by M. Griffith, Colchester, Vt., got by McCullif Horse, son of Flying Morgan. Sold to Potter Bros., Greenfield, Mass. ; to Mr. Hobinger of Connecticut ; to Mr. Chapin, Rochester, N. Y. Pedigree from breeders. This mare carries a good percentage of Morgan blood, as sires of first and second dams are inbred Morgans.

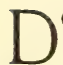

ORA J. Letter from R. S. Dora :

Mr. Joseph Battell, Middlebury, Vt.,

Charleston, Ill., March 26, 1906.

My Dear Sir :- In the interests of the breeding of the Morgan horse I may be able to give you some information which may be of some value and interest to you, considering the Morgans. If I mistake not, a few years ago you wrote to my father (now deceased), John F. Dora, for some information concerning the great brood mare Dora J., got by Dr. Herr, son of Mambrino Patchen : dam Black Belle, the intensely inbred Morgan mare, who was got by Frank Hinds' (of Hindsboro, Ill.) Green Mountain, son of Dorsey's Green Mountain of Kentucky (L. L. Dorsey of Anchorage, Ky., is the man referred to, I believe). Black Belle's first and second dams were also by Hinds' Green Mountain. Dora J. is now the dam of Argonaut, 2 years, $2: 15 \frac{1}{4}, 4$ years, $2: 093 / 4$; Gus Waible, $2:$ II $1 / 4$; A. J. Glick, 3 years, 
$2: 103 / 4$; Ronald Crews, $2: 15^{\mathrm{T}} / 4$; Paris, $2: 19 \frac{1}{4}$, and Argolet, $2: 29 \frac{1}{4}$. Paris (dam Dora J.) is a great sire, having produced the great pacer, John M., $2: 023 / 4$, the best class pacer on the Grand Circuit in 1904 , and a number of others, including Sweet Bay, $2: 10 \mathrm{~T} / 4$, Oakland Boy, $2: \mathrm{I} 21 / 2$, etc. A. J. Glick (dam also Dora J.) got the good three-year-old Central G., $2: 161 / 2$, a trotter of considerable class in 1905 , having won a five-heat race at Springfield at the State Fair and others. Gus Waible is the sire of the good pacer Fanny Waible, $2: 14 \frac{1}{4}$. Another good brood mare is Cora, who is a full sister to Dora J. Cora is the dam of Argue, $2: 17 \frac{1}{2}$ ( $I$ think this is the correct record; I know Argue has a record better than 2:20); Arguenot, $2: 103 / 4$, and Alfalfa, $2: 1 \mathrm{I} / 4$, the great class pacer of last season, who was second in $2: 05 \frac{1}{4}$ and $2: 06 \frac{1}{4}$ at Columbus, Ohio, in 1905.

Dora A. also from Black Belle is the dam of Alma B., 3 years, $2: 15 \frac{1}{4}$, 4 years, $2: 103 / 4$. Now, I think this is no mean showing for one brood mare (Black Belle), being the dam of three mares who have produced nine performers in the $2: 20$ list, ten in the $2: 30$ list, one in the $2: 10$ list, five in the 2 :I I list, and six in the $2: \mathrm{I} 2$ list. Dora J. and Cora were got by Dr. Herr and bred by John F. Dora of Charleston, Ill., while Dora A., dam of Alma B., $2: 103 / 4$, was got by Dr. Herr Jr. and bred by myself (R. S. Dora).

Among the Morgan bred horses of this vicinity is the good pacer, Beth D., $2: 14 \frac{1}{4}$, record taken in 1904 . Beth D. was got by Paris, $2: 191 / 4$, and from a daughter of Black Hawk Messenger, sire of Larry C, $2: 193 / 4$, son of Morgan Messenger. I believe Beth D, $2: 14 \mathrm{~T} / 4$, was bred by C. C. Ashmere, of Oakland, Ill., owner of Paris, $2: 19 \frac{1}{4}$. By the way, Paris was bred by John P. Dora, of Charleston, Ill. Paris, $2: 19 \frac{1}{4} / 4$, was got by Edgar Wilkes, $2: 22$, son of Ethan Wilkes. The other performers I enumerated from Dora J., Cora and Dora A. are by Argot Wilkes, $2: 14 \frac{1}{4}$, son of Tennessee Wilkes. The Wilkes, Dr. Herr and Morgan blood combined has proven a good nick and almost certain of good results in the production of extreme speed, as is evidenced by the list I have given you.

Hoping that this information may prove of interest to you, and admiring the blood of the Morgan horse as I do, I shall be glad to furnish you any further information concerning Morgans that I may observe that I feel is worthy of mention, if you so desire. I remain,

Very sincerely yours,

R. S. DORA.

\section{MAN'S DEBT TO THE HORSE.}

"No Animal on the face of the earth works like the horse; no animal anywhere is his equal in usefulness to man. $\mathrm{He}$ is the one real slave of humanity; for never lived a human slave in any age or in any land who went about his task and his crushing labors more uncomplainingly, more steadily and more faithfully than does the horse. He brings help when the home is aflame; he drags in the harvest that feeds millions; he scurries over the ground to bring the physician to the bedside when we come into the world; he paces solemnly onward as he drags us to the grave. He carries the joyous children upon his broad back, and he thunders to the hospital with the clanging ambulance. Through the streets he drags the mighty iron supports for giant skyscrapers, and over the boulevards of the park he sweeps with fashion and beauty at his hoofs. In the midst of plenty he carries food in abundance to countless homes, and in the midst of starvation he yields up his own body to keep life in the human frame. 
"And for this sublime devotion, this lifelong labor, this noble martyrdom, how often is the faithful animal repaid with atrocious cruelty and vile and inhuman neglect! The treatment of horses by some people is immeasureably base; and it is all the more hideous and scoundrelly because the poor animal has no means of defense, no chance for aid, no voice to demand help.

" $\mathrm{He}$ is driven at terrific speed for immense distances; he is forced to wear rough and heavy harness over a sore and lacerated body, dragging after him heavily laden wagons, all the while suffering silently the most awful torture. He is compelled to drag overloaded wagons up steep hills, often cruelly lashed with the whip, and then after a long day of dreadful slavery he is poorly housed, often with insufficient food.

"There are men into whose hardened soul no appreciation of the value and devotion of the horse is allowed to penetrate. They misuse the animal to an atrocious degree, and are impervious to his appealing look, when he is racked by pain or worn down with toil, as though the poor beast were but a senseless rock. Such men as these know no pity, and because they know no pity, they know no horse.

"There is nothing overdrawn in this recital of man's inhumanity to his one best and most constant friend. Happily, though, it is not a recital of the usual treatment of the horse. Turning from the consideration of ill-treatment, it is pleasant to know that in the hearts of the vast majority of men, women and children there is genuine love for this fine and good friend in the animal kingdom. And assuredly he deserves that love.

"When you love a horse, you love man's best, truest, and most useful friend in all the range of the world of animals." - Our Dumb Animals. 


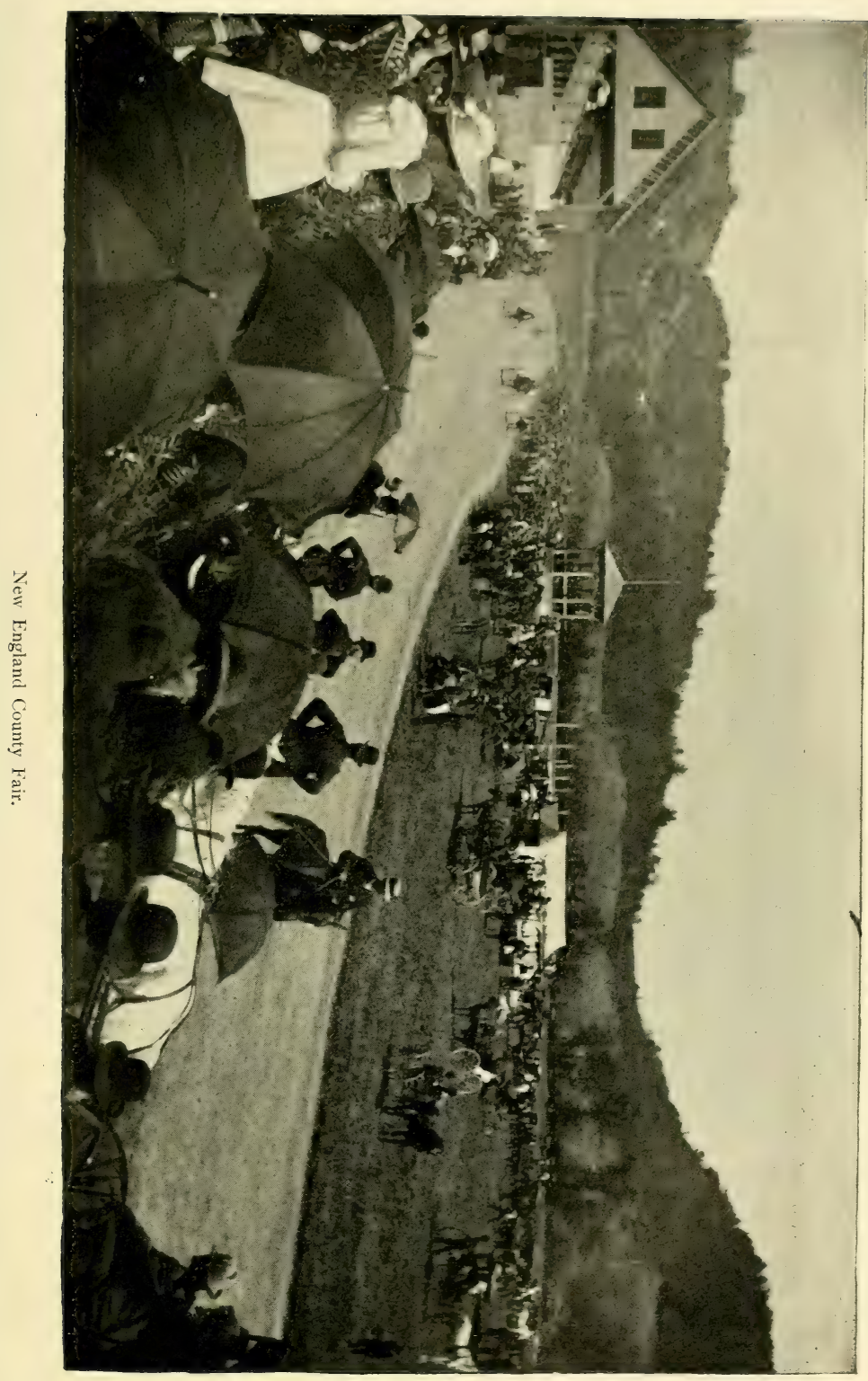




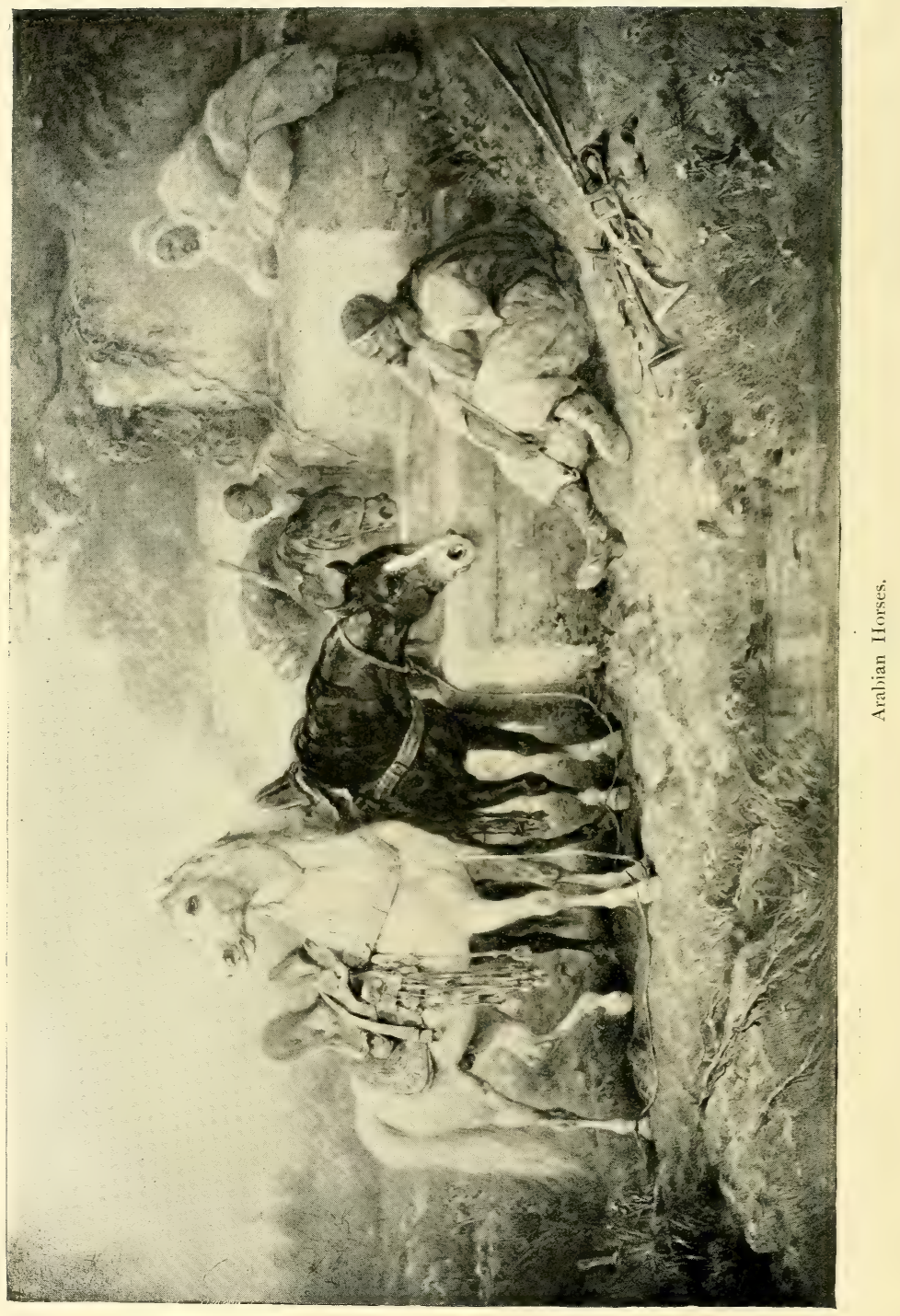




\section{THE HORSES OF AMERICA.}

Our country! 'tis a glorious land,

With broad arms stretched from shore to shore;

The proud Pacific chafes her strand-

She hears the dark Atlantic roar.

WHEN America was discovered by Europeans, the natives of both the northern and southern continents were strangely lacking in those things, in both the vegetable and the animal world, that are now classed among the necessaries of life. There was little beyond one cereal, Indian corn; one esculent, the potato ; one species of dog elsewhere unknown, and one feeble beast of burden, the llama, limited to the uplands of the southern Cordilleras, in Peru, Chili and that vicinity. In North America there was no domesticated animal except the dog. The llamas, the only hoofed domestic animals of the western world, were kept not only for their value as beasts of burden, but also for their flesh, hides and wool-supplying, in fact, the place of the horse, the ox, the goat and the sheep of the Old World. The llama was a small animal, standing little more than three feet high at the shoulder, with straight back, short tail, neck and head like a doe, large ears, legs like a sheep, deer-like hoofs with peculiar bosses or cushions on the under side; body deep at the breast, but smaller at the loins, covered with long, soft and very fine hair, usually white or spotted with brown or black, and sometimes altogether black. He was spoken of as a sheep by the early Spanish adventurers, though he possessed rather the characteristics of the camel and the goat. The earliest account of this animal is by Augustin de Zarate, treasurer-general of Peru, in I 544, giving a summary of the general character and uses to which the llama was put by the Peruvians at the time of the Spanish conquest; as follows:

"In places where there is no snow, the natives want water, and to supply this they fill the skins of sheep with water and make other living sheep carry them; for these sheep of Peru are large enough to serve as beasts of burden. They can carry roo pounds or more, and the Spaniards used to ride them and they would go four or five ieagues a day. When they are weary they lie down upon the 
ground, and as there are no means of making them get up, either by beating or assisting them, the load must of necessity be taken off. When there is a man on one of them, if the beast is tired and urged to go on, he turns his head round and discharges his saliva, which has an offensive odor, into the rider's face. These animals are of great use and profit to their masters, for their wool is very good and fine, particularly that of the species called pacas, which have very long fleeces; and the expense of their food is trifling, as a handful of maize suffices them, and they can go four or five days without water. Their flesh is as good as that of the fat sheep of Castile. There are now public shambles for the sale of their flesh in all parts of Peru, which was not the case when the Spaniards first came; for when one Indian had killed a sheep his neighbors came and took what they wanted, and then another Indian killed a sheep in his turn."

Gregory de Bolivar estimated that in his day as many as 300,000 llamas were employed in transporting from the mountains to the coast the produce of the mines of Potosi alone.

Leaving now this solitary and feeble predecessor of the horse in the New World, let us return to the horse himself. Columbus brought the first horses from Spain, in his second voyage to the West Indies islands in I493. They were largely of the Andalusian breed. They multiplied on these islands and the Spaniards took them to use as cavalry in their expeditions to North and South America. In I 528, Pamphilo Narva sailed from Xagua, Cuba, for Florida with 400 foot and 40 horse. These are the first horses known to have been introduced into the United States, and they are supposed to have all perished, as did all the men of the expedition except Cabeca de Vaca and three others who made their way to Mexico, after great hardships.

The next expedition to Florida was by Ferdinando de Soto, in I 539. He sailed from Havana, Cuba, and took with him 900 foot soldiers and 350 horse. Florida at this time was of undefined limits and included the Mississippi River, which De Soto discovered and on whose banks he died of a fever. After his death the remnant of his force, reduced more than half by exposure, famine, disease and nearly three years constant warfare with the Indians, built boats, sailed down the river and returned to Cuba.

Nearly all of their horses, to which the Spaniards owed many a victory over the Indians, perished. But it is stated in "A Relation of the Expedition of Don Ferdinando de Soto to Florida in I 539-40," preserved in Force's Historical Tracts, that in leaving Florida the 
Spanish soldiers killed most of their horses, but left five or six alive. La Vega states that the number of horses was reduced to less than fifty before the embarkation on the Mississippi. On the whole it seems probable that several horses were left, perhaps of both sexes, and it is possible that some of the horses later owned by the Indian tribe of this locality were descended from these abandoned war horses of Spain; but of this there is no proof.

Garcelossa de la Vega, in his history of the conquest of Florida by De Soto, says of these horses: "There were also some ships in which sailed a quantity of horses of all colors and sizes, the most beautiful in the world." Illustrations in this book, published in the seventeenth century, represent these horses as of Arab type and decidedly handsome.

In 1565 St. Augustine, Florida, was settled by the Spaniards. John Bartram, of Philadelphia, describing East Florida in a book published in London in I 769, says :

"The horses are of the Spanish breed, of great spirit, but little strength. They are seldom over I 4 hands high. The Indians here, by mixing the Spanish breed with the Carolina, have excellent horses, both for service and beauty." And William Roberts, in a book entitled "Florida," published in London in 1763 , says: "Horses are also bred here, very good both for the saddle and draft, and so cheap that one of them may be purchased for any trifle that is brought from Europe."

From the Spanish horses are descended all the native or wild horses of South America, Mexico, Texas and California, and a part, at least, of the blood that exists in the Louisiana purchase, and along the coast of the Gulf of Mexico to Florida; and undoubtedly they were mixed more or less with the horses of the Carolinas and Georgia.

A large majority of this native breed of horses at the present day are small, and not very valuable; but I have seen in the streets of Mexico horses of great beauty and symmetry, weighing perhaps 900 pounds, resembling much in finish and form some of our Morgan stock. In California, too, I have seen some of the native or wild stock, of great excellence, though not large. I remember especially a bay stallion that I used to notice going through the streets of Santa Barbara, in 1876 , ridden by a Spaniard. I priced this horse one day at one hundred dollars, and would quickly have bought him, but learned that no one but this Spaniard had ever been able to ride him. I insisted on mounting him, and got well on, 
xlvi

but when I went to take the reins from the Spaniard he saw that I was unused to the Spanish bit, and refused to let them go; so I got off, and undoubtedly thereby saved being thrown, for a few days after I bought a gray half-breed, somewhat larger and a very fine horse, far more manageable, but the first time I rode him, annoyed by my handling of the bit, he became so restive that I gave him the rein and let him run for a mile; after which we became the best of friends. And this being before the Southern Pacific Railroad was built, I started to ride him from Santa Barbara to New Orleans, but was stopped at the border of Arizona by sickness.

Both these horses, the one full-bred Spanish and the other from a Spanish dam and said to be by a Morgan sire, were superb animals of great vigor, power, speed and beauty.

Of the horses brought over by the Spaniards and their distribution, perhaps the most interesting and reliable account is given in the "Commentaries of Peru," by Garcelossa de la Vega, who was born toward the middle of the sixteenth century, at Cresco, in Peru, and went to Spain in I560. These Commentaries were written about I600 and translated in London in 1788 . They have the merit of almost contemporaneous history:

"Of the mares and horses and how they were bred in the beginning, and of the great price and value of them.

"For the better information and satisfaction, as well of the present as of future ages, it will be necessary to know what things were not in Peru at the time when the Spaniards first entered into Peru, and therefore I have thought fit to make a satisfactory chapter thereof, to enumerate how many things these people wanted, which we esteem necessary for the welfare and convenient living of mankind, and yet, notwithstanding, they lived happily and contented without them. In the first place we must know that they had neither horses nor mares, cows, oxen, nor sheep. *** As to the Horses and Mares the Spaniards brought them over with themselves, having been very serviceable and useful to them in making their conquests in the New World, of which the Indians had no great necessity, for they were unusually hardy and nimble of foot. All those horses and mares which are in the kingdoms and provinces of those Indies which have been discovered by the Spaniards since the year I 492 until this time, are of the race of those which were brought from Spain, and particularly from Andalusia. The first were landed on the Isle of Cuba and St. Domingo, and the other islands of Barrotento, as they were discovered and subdued; where they increased 
and multiplied abundantly, and thence they were transported to Mexico and Peru for their services and use in those conquests. At first for want of care in the masters, who put their horses out to pasture into places without fences, they could not easily be catched again, and so roving in the mountains they became wild, flying like deer at the sight of a man and not being seized or preyed upon by any fierce creature, they increased and multiplicd in great abundance.

"The Spaniards who inhabited the islands, observing how necessary horses were for the conquests, and their countrics producing such as were very good, enhanced the prices of them to a considerable rate. There were certain men who kept thirty, forty and fifty horses in their stables, as we have mentioned in our history of the Florida.

"After all parts of the West Indies were subdued, there was no such occasion for horses as before, nor encouragement given for breeding and managing them as formerly, so that the inhabitants of those islands turned their traffic another way, and began to trade and deal in hides. Considering often with myself at how great a price horses are held in Spain, and what an excellent race these islands yield, both for their size, shape and color, I have much wondered at the reason why they have not been transported thence into Spain, though it were only in acknowledgment of those which Spain did first send thither and which were the sires and dams of that new race, especially since they may be transported with so much facility and ease from the island of Cuba, which is one great part of the way, and many ships come empty thus far. The horses of Peru are much more forward than those in Spain; for the first time I started on horseback in Cozco was upon a horse newly broken, and which had scarce arrived at three years of age."

(As the author speaks of seeing things in 1550 and 1590 , this must have been written about I600).

The works of Samuel Purcheas, "Purcheas, His Pilgrimes; In Five Bookes: London, I625," contain English voyages to the East, West, and South parts of America by Right Honorable George, Earl of Cumberland, who, writing from Puerto Rico, I 596, says:

"About their horses, none of which I have seene by much so tall and goodly as ordinarily they are in England: They are well made and well mettled, and good store there are of them, but methinks there are many things wanting in them which are ordinary in our English light horses. They are all trotters; nor do I remember that I have seen above one ambler, and that a very little fiddling 
nag. But it may be if there were better breeders they would have better and more useful increase, yet they are good enough for hackneys, to which use only almost they are employed."

In a work entitled "Natural History of Man," by Dr. James Cowles Pritchard (3d ed., London, I848), the horses of Peru are thus referred to:

"Two other very important observations made by M. Roulin in South America, were pointed out by M. Geoffrey St. Hilaire in his report to the Academy of Sciences. They refer to the fact of the hereditary transmission of habits originally impressed with care and art upon the ancestors. Of this fact I shall adduce other examples in the sequel; at present I only advert to M. Roulin's observations. The horses bred on the grazing farms on the table lands of the Cordillera are carefully taught a peculiar pace, which is a sort of running. amble. This is not their natural mode of progression, but they are inured to it very early, and the greatest pains are taken to prevent them from moving in any other gait; in this way the acquired habit becomes a second nature. It happens, occasionally, that such horses, becoming lame, are no longer fit for use; it is then customary to let them loose, if they happen to be well-grown stallions, into the pasture grounds. It is constantly observed that these horses become the sires of a race to which the ambling pace is natural, and which require no teaching. The fact is so well known that such colts have received a particular name ; they are termed aguilillas."

We do not know when these observations of M. Roulin were made, only that they were referred to in Berenger's work on Horsemanship, published in $177 \mathrm{I}$.

The following sketch was written by Mr. J. Sharples, a gentleman who had spent twenty years, ending in 1875 , in various parts of South America. It is preserved in Sidney's Book of the Horse, and is somewhat abridged as given here:

\section{HORSES OF THE RIVER PLATTE STATES.}

"The horse was introduced into the southern continent of America in the sixteenth century, by the Spanish 'Conquistadores.' During the frequent commotions and 'guerillas' which distracted their early settlements, some of their horses (both stallions and mares) escaped into the immense plains (pampas), and there formed themselves into herds, which were sub-divided by the natural instinct of the animals into families, called by the Spaniards 'Manadas.' These herds, being left in peaceful possession of the plains, 
multiplied in the course of time to such an extent that they now form an essential part of the national wealth of the Argentine Republic.

"The number of horses pasturing on the plains of the Argentine Republic at the present day $(1876)$ has been roughly computed at two and a half millions, not including the east coast of the river Uruguay, which probably contains an additional half-million. The annual net increase may be set down as 300,000, the residue finding their way to the slaughter-houses (saladeros), or perishing in the long droughts from want of pasture and water.

"The provinces of Buenos Ayres, Entre Rios, Santa Fe, Corrientes and Cordova are the chief horse producers; the remaining provinces, indeed, are insignificant contributors towards the grand total.

"The breed is undersized, averaging about I 4.I or I 4.2 hands, and are of every conceivable color. Piebalds and skewbalds, when curiously marked, were much sought after some twenty-five years ago and brought more than average prices. A very beautiful color, now unfortunately almost extinct, is the 'plateado'-a white horse with black skin, magnificent black eye and bluish black muzzle. There are also some beautiful shades of dun, with black stripe along the back and across the shoulders, and black bands on the legs. Horses of this color are supposed by the natives to be descended indirectly from the donkey, probably on account of the black cross on the back. An exception as to size is to be found in the southern districts of Buenos Ayres, notably in the Montes Grandes, where horses of $\mathrm{I} 5$ hands and $\mathrm{I} 5$ hands 2 inches are frequently to be met with. The difference in size is owing to the richness and abundance of the herbage, also to the shelter which the woods afford from the heats of summer and the cold of winter. On account of their size they command far above average prices in the city of Buenos Ayres as hacks and carriage horses; but for work on a cattle farm or for a long journey, they are quite inferior to their smaller brethren. Plenty of large, roomy mares might be selected from these districts for crossing, with imported sires, and would give what is at present the great desideratum-size.

"The breed of horses in the Argentine and Oriental republics is extremely hardy and enduring and exempt from nearly every ailment that afflicts horseflesh. Hence I consider the breed as constituting a good foundation for the building up of a superior class of horses; and to my mind there is no doubt but that the liberal intro- 
duction of thoroughbreds from England and elsewhere, combined with a judicious selection of mares, will in a short time so improve the existing breed that exportations from those countries will become an extensive branch of business.

"During the last thirty years many attempts have been made in the right direction by the introduction of European sires, and with the best results, as far as the production of useful, shapely and good-sized horses is concerned.

"As far as I can learn, the first thoroughbred sire introduced into the province of Buenos Ayres since the conquest was in the year 1850 , and in the following year a second was sent out from this country. Since then numbers of European stallions have been introduced, and, notably during the past year (1875), scarcely a steamer leaves for the river Platte without having on board one or more thoroughbreds or heavy cart stallions. The latter, however, is totally unfit for the small 'South American mares. After the thoroughbred, what is most required is an active, clean-legged, smart-looking horse, about I 5.2 hands, such as I have often seen in the tradesmen's goods carts in the streets of London.

"Breeding horses in the River Platte States, so much favored by pastures and climate, and with an unlimited quantity of mares from which to select, cannot but prove lucrative if carried on by men of intelligence and with a fair knowledge of their business. But they must be prepared to expend time and money in the introduction of thoroughbred stock and be content to await the result. The day will come when the southern continent will be a formidable rival of the northern in the exportation of horses, and it depends upon the exertions of the breeders whether that day be remote or otherwise.

HORSE-BREEDING IN THE RIVER PLATTE STATES.

"The common system of breeding in the settled districts at the present day differs very little from the natural system which the horse had re-established for himself on the open plains some 300 years ago. The herds are divided into families called Manadas, which pasture all the year round in the open, exposed to all the vicissitudes of weather and seasons, and are, as occasion requires, driven up to the homesteads and enclosed in the 'corral' for the branding of the foals, denuding the mares of their manes and tails for the sake of the hair, and the domestication of the colts. Newly formed Manadas are frequently enclosed during the night as a precaution against straying; also when horse-stealers are about and 
mosquitoes are prevalent, the annoyances from these being such that horses will stray long distances up wind during the night. Each of these Manadas has a stallion at its head, and consists usually of twenty or thirty mares, with a sprinkling of colts and fillies. Over these the stallion keeps most jealous watch, pursuing and bringing back, in no gentle manner, any mare which attempts to wander. By instinct the stallion does not allow full grown fillies, his own progeny, to remain in his harem, and he suffers them to be appropriated by his rivals without opposition. He will also appropriate any stray mare which may come his way, and occasionally he will make a raid on a neighboring Manadas and attempt to steal away a mare or two, when right royal fights take place between the rival stallions, and the prize is carried off by the victor. These fights are very frequent in the plains and occasionally are to be witnessed between horse and stallion donkey, often ending with the victory of the latter; indeed, the horse as a rule does not seem to care much about attacking the donkey, having a wholesome dread of his teath, which he uses in fight with the same tenacity which distinguishes the bulldog.

"The selection and occasional changing of stallions for their Manadas is the only improvement or modification of the system established by the horse himself at the time of the conquest, at least as far as concerns the great majority of native breeders; exceptions are to be met with in a few of the native and most of the foreign breeders.

"There is a remarkable exemplification of instinct in horses, which may or may not be peculiar to horses bred in the Pampas, but which I have never seen in print. It is the wonderful manner in which horses, taken away from their birthplace, will return as soon as they regain their liberty. I have known horses return two or three hundred miles, swimming rivers and overcoming every obstacle. It matters not if they be taken away at night or by a circuitous route, they will find their way back-not, indeed, by the circuitous way they may have come, but in a direct line. It always appeared to me a marvellous instinct which could guide them so unerringly over such long distances, over immense open plains with scarcely a land- . mark to assist them. This instinct, though common to all horses that are taken from one breeding ground to another, is, however, much stronger in some than in others. For instance, horses reared on rich pasture have the instinct much stronger, or at least they retain it longer, than those reared on the poorer lands. Those bred in the 
districts of the Montes Grandes, where the grasses are especially luxuriant, scarcely ever lose this home-pining; and though they are the finest-looking horses in the Republic, they are of little value to farmers, as it is next to impossible to keep them from straying. As hacks in the city of Buenos Ayres they soon lose this instinct, probably owing to total change of diet and the comforts of a stable. A very marked exception to this instinct is to be found in the 'Baqual '-strictly speaking, the wild horse of the Pampas, as distinguished from his domesticated or semi-wild brethren of the settled districts. The 'Baqual,' when captured, tamed and taken to the settled districts, seems to lose this instinct entirely. He has also another very singular peculiarity-the transformation from a wild to a domesticated state causes him to lose his gregarious habits. $\mathrm{He}$ will stray away here, there and everywhere, but seldom will he associate with other horses, and never with the same for any length of time. This horse is popularly supposed never to become thoroughly confidential for riding, being, it is said, apt to buck-jump and plunge when least expected. I, however, had one for five or six years. He was very quiet and steady, and a good useful horse for general purposes.

\section{HORSES OF THE BANDA ORIENTAL.}

"Or east coast of the river Uruguay, are much the same in general characteristics as those of the Argentine Republic. In size they are a trifle smaller than those bred in the southern districts of Buenos Ayres, but they stand almost unrivalled in powers of endurance, frequently compassing journeys of one hundred miles in the day. Owing to civil wars, revolutions and petty broils, few attempts have been made to improve the existing breed by the introduction of European sires.

\section{HORSES OF THE WEST COAST (CHILI).}

"The republic of Chili, on the west coast of the southern continent, produces a breed of horses superior in size, quality and shapeliness to those of the River Platte States. Bays, blacks and browns are the prevailing and most esteemed colors. The origin of this breed is identical with that of the Argentine horses, and their superiority may be traced to more careful selection and breeding. In height they vary from 14.3 to I 5.2, but their chief superiority consists in their fine action and perfect education.

"As far as my experience goes, no pleasanter or more perfect hack exists; for what better qualities are to be looked for in a hack 
than an exquisite mouth, easy paces, good up action that renders stumbling almost an impossibility, fine courage, high mettle and extraordinary tractability? I speak here of the superior and not general class of horses in Chili. The Chilian horses have usually high action, but the trotting pace is two-fold, some being trained to throw their feet outwards their arms. These are called 'brazeadores,' from 'brazas,' Anglice 'arms'; others have straight, high action (much preferable to the former), and are called 'pisadores,' steppers. Their high action is partly natural, inherent to the breed, according to some, and the result, according to others, of the nature of the land on which they have been reared, which is strong, rugged and intersected by numerous watercourses. Their natural high action is increased and improved during the process of breaking by means of bolitos, (wooden balls about an inch and a half in diameter, loosely beaded into a string and tied around the pasterns of the forelegs, which have the effect of causing them to throw their legs high). The high action towards the arms (brazradores) is produced by tying strong strips of rawhide round the pastern, and which are allowed to trail on the ground to the length of six or seven inches. To avoid treading on them the horse throws his legs outwards, and in process of time this becomes a second nature and clings to him through life. A Chilian horsebreaker is a breaker in the best acceptation of the word; he is a perfect master of his art, and quite at the top of the tree as an educator. The Argentine, on the other hand, is a breaker in the worst meaning of the word, and the best among them cannot turn out a horse with perfect manners. The Chilian requires a much longer time to educate a horse, but the delay is amply compensated for by the accomplished manner in which he does his work.

"I have ridden hacks by the score, both in England and South America, and the pleasantest one I ever crossed was a Chileno. He had extraordinary mettle, but was so gentle and tractable that a girl seven years of age has frequently ridden him; his mouth, paces and manners were perfection, and I never remember him to have committed a fault either in the stable or in the saddle. He would have been an invaluable horse for a timid lady to ride in the Row; I don't think he would have gone wrong in a crowd with the reins thrown loose over his neck.

"The bit in use in Chili is, I believe, similar to the Moorish bit introduced by the Spaniards 300 years ago. It is very severe, and requires good hands, especially with young horses." 
IMPORTATIONS TO SOUTH AMERICA FROM THE UNITED STATES.

We have found no record of importations to South America of horses from the United States until very recent times, although there may have been horses so taken there. But recently, from I 886 to I 889 , there was quite a large transportation of horses from western Vermont to Buenos Ayres in the Argentine Republic and of some to Montevideo in Uruguay. Some of these were entire horses, used for stock purposes after their arrival. Probably the pioneer in this enterprise was Charles R. Witherell of Cornwall, Vermont, who took horses to Buenos Ayres as early as I887. The horses transported from Vermont to South America during this period, from I 887 to I 889 inclusive, were mostly of Morgan or Hambletonian lineage or a mixture of the two. In 1887 Page G. Potter of Middlebury, Vermont, took to Montevideo the entire horses Coleraine by Addison Lambert (2:27), son of Daniel Lambert, and Limber Dick, by Broken Leg, son of Rysdyk's Hambletonian. In I 888 Addison Lambert himself was taken by Page G. Potter to Buenos Ayres, where he made a season in the stud, being bred to thirty-three mares before his return to Vermont in $\mathbf{I} 89 \mathrm{I}$.

Also in I888, Mr. Potter took to Buenos Ayres the stallion General Grant, by Vermont Boy, son of Benedict Morrill. Another son of Addison Lambert was taken there the same year by E. C. Eells, then of Middlebury, now of Buenos Ayres. About the same time the stallion Gen. Knox, son of Eastern Boy, by the famous Vermont bred horse, Gen. Knox, was taken to Buenos Ayres by Gen. E. H. Ripley of Mendon, Vermont.

The beautiful horse Harvester, an entire son of Daniel Lambert, was taken to Buenos Ayres by J. E. Wright of Middlebury in I 889. The above-named horses were all of Morgan blood (except Limber Dick) and were extensively patronized. Among the horses of Hambletonian lineage taken to Buenos Ayres during this period were General Arthur and Middletown Jr., by Middletown, son of Hambletonian, taken by H. C. Potter and George Hammond of Middlebury; and Blackstone Jr., son of Blackstone, by Hambletonian, taken by Dr. E. O. Porter of Cornwall.

We understand that most of these Vermont horses were successful as sires in their new homes.

THE INDIAN PONY,

When the red Indian of North America first began to ride on horseback there is no evidence to show; but Captain Butler, in his 
"Great Lone Land," states that the Indian word for horse also means "big dog."

The following account of the animals on which, Tartar like, the Indians have for centuries carried out their border raids against the settlers of the border is from "Hunting Grounds of the Great West," by Lieut.-Col. Dodge of the U. S. army, who commanded a force employed to keep them in check:

"The pony used by the red Indians of America is scarcely fourteen hands in height, rather light than heavy in build, with good legs, straight shoulders (like all uncultivated horses?) short, strong back, full barrel; he has no appearance of 'blood,' except sharp, nervous ears and bright, intelligent eyes; but his endurance is incredible. He is never stalled, nor washed, nor dressed, nor blanketed, nor shod, nor fed. When not under saddle he is picketed or turned loose to shift for himself.

"In winter he is a terrible object-an animated skeleton. His pasture being buried beneath the snow, he would perish if the squaws did not cut branches of the cotton-wood tree for him to browse on. But when the spring brings out the tender grass he sheds his coat, scours his protuberant belly and moves with head erect, ears and eyes full of intelligence. He will climb steep rocks like a mule, plunge down a perpendicular precipice like a buffalo, only the elk can more successfully cross swamps, and he will go at speed through sand-hills and ground perforated with holes where an American horse would fall in the first fifty yards of a gallop. The work he can do is astonishing; no mercy is shown.

"The Indian pony is the same animal as the mustang, or wild horse of Texas. He is sufficiently tractable to the rough-riding Indian, but when stabled and fed on corn and oats, he becomes either a vicious, dangerous brute or a fat, lazy cob.

"An Indian will ride a horse from the back of which every particle of skin and much flesh has been torn by the ill-fitting saddle, ride him at speed until he drops, then force him to his feet and ride him again.

"There is a 'plain' saying that a white will abandon a horse as broken down; a Mexican will then mount and ride him fifty miles further; an Indian will then mount and ride him for a week. Riding is second nature to the Indian, strapped astride of a horse as soon as he can walk.

"The bit is the Mexican bit; the bar bent in the centre, from two to four inches long, extends backwards to the horse's throat. 
To the upper end is attached the bar with reins of horsehair or rawhide. The head-stall is of horse-hair, elaborately ornamented with silver or plated buckles. With his bridle the horse can be turned on its haunches with one turn of the wrist.

"The saddle is a light frame of wood, the side pieces shaped to fit a horse's back. The seat is almost straight and nearly forms a right angle with the pommel and cantle; these are about eight inches above the seat. The pommel ends with a knob. The cantle, rather wide at top and bottom, is cut away in the middle to fit the leg or heel of the rider and form his support when he throws himself (out of sight) on one side of the horse, right or off-side, leaving the left hand free to grasp the reins, while the right grasps the mane or pommel. When riding under ordinary circumstances his seat and carriage are very ungraceful; the short stirrups force him to sit almost on the small of his back; his head pokes forwards as far as his neck will let him; his left hand holds the reins, his right is armed with a short stick with a lash of rawhide. With a light blow of this he marks every slip of his horse. He has no spurs, but his heels are constantly drumming his horse's ribs with a nervous motion. He scarcely ever turns his head, and when most watchful appears to see nothing. Looking stiff, constrained, uncomfortable on horseback, he yet will, with his horse at full speed, pick a small coin from the ground and throw himself on the side of the horse in such a position that only a small portion of his leg or foot can be seen on the other side.

"The ponies are as carefully trained as the riders. Colonel Dodge relates (but does not say that he was present) how a Comanche pony in Texas, 'a miserable sheep of a pony, with legs like churns, three inches of rough hair all over the body, with a general expression of neglect and helplessness and patient suffering, which struck pity into the hearts of all beholders,' ridden by a stalwart Comanche of one hundred and seventy pounds ( 12 st. 2 lbs.) armed with a club, first won a race of five hundred yards from the third best horse of the garrison by a neck; then another race against the second-best horse. 'The officers, thoroughly disgusted, proposed a third race and brought to the ground a magnificent Kentucky mare of the true Lexington blood, which could beat the other two at least forty yards in four hundred. The Indians accepted the challenge, and not only doubled the bets, but piled everything they could raise on it. The riders mounted, the word was given. The Indian threw away his club, gave a whoop, and the sheep pony 
pricked his ears and went away two feet to the mare's one. The - last fifty yards of the course was run with the rider sitting with his face to the tail of the pony, grimacing horribly, and beckoning the rider of the mare to come on!'

"The woodwork of the saddle is covered with green hide, which, drying, binds all the parts together and makes the saddle almost as strong as iron. The girth is a broad band of plaited hair, terminating in iron rings, which are attached to the saddle on the principle of the Mexican cinche, by which a man of ordinary strength can almost crush a horse's ribs. The stirrup is of thin wood, fastened to the saddle with rawhide. The skin of a wolf or calf, or a pair of old blankets, is used as padding between the horse and saddle. The stirrups are extremely short and of little use, except to mount or rest the feet."

Either different people see with different eyes, or the wild horse of the prairies contained finer specimens early in the century than at present, and were less uniform. A writer in the American Turf Register in I 833 says:

"I was once in a village of the Comanches in the valley where the Colorado rises. There are probably three thousand horses in that valley, and I never saw any finer horses than some of them. At the same time a large proportion were the poorest horses in existence. If fine, delicate heads, wide nostrils, slim and tapering and clean limbs, small and hard hoofs and an Arabian symmetry of form will make a fine horse, there are fine horses in abundance on the prairie. I have seen one leader of a herd, while the whole body was coming at full speed, circle round and round the body like a hawk, driving up the laggards in the rear, and then returning to the front, seemingly with great ease."

Colonel Dodge's story of the beating of the thoroughbreds by the little mustang many will be inclined to take with a grain of allowance; yet it is the universal testimony that almost any Indian pony can beat a thoroughbred for a short distance, but that when the distance is a mile or more the tables are turned. Col. Theodore Ayrault Dodge, in "Some American Riders," expressly so states. Berenger, in his "Art of Horsemanship," (I77I), Vol. I, p. 208, speaking of the South American horses, says: "One sort of these horses, called Aguilillas, not only excel in the amble, a pace universally practiced here, but are so superior in their gallop that no other horse can contend with them." And Ulloa writes, in his "Voyage to South America": "The boasted swiftness of European horses 
is dullness when compared with those of South America.

I possessed one of the Aguilillas which often carried me from Callao to Lima, two measured leagues and a half, over a very bad and stony road, in twenty-nine minutes. The species is not handsome, but easy to the rider, very gentle and docile, yet full of spirit and intrepidity."

\section{THE CHICKASAW HORSE.}

In "Smyth's Tour in the United States," published in London in 1784 , the author, speaking of a town in North Carolina, says:

"Whilst I remained at this place I purchased a beautiful Chickasaw horse-named so from a nation of Indians, who are very careful in preserving a fine breed of Spanish horses they have long possessed unmixed with any other."

From North Carolina Mr. Smyth passed to Kentucky, where he joined two Virginians in a trip by boat down the Mississippi to New Orleans, and in this trip they stopped on shore two days at the mouth of the Yazoo River, where they met a party of Chickasaw Indians, of whom he thus speaks:

"The Chickasaws are a very brave and respectable nation, not for their numbers, for they are few, but for their virtue and unconquerable spirit. They are also remarkably handsome, and what is very singular, have a beautiful breed of horses amongst them, which they carefully preserve unmixed. The Chickasaws, it is said, and I make no doubt of the fact, came originally from South America, having traveled across the continent for upwards of 2000 miles, and brought these horses along with them, which are of the breed of that much admired kind called Spanish gennets, having long since taken them from the Spaniards.

"There is no Indian nation on the continent of North America near so handsome as the Chickasaws. The Hurons come next to them in beauty. * * * Another singularity that seems to be peculiar to this nation is their frequently going out to meet their enemies on horseback, which with their very fine horses that they take such delight in, renders them, in fact, a nation of cavalry."

Later he describes meeting at New Orleans a gentleman who, with a large number of British sailors and French emigrants, landing in Mexico, were made prisoners by the Spaniards and carried to a town in New Mexico, inland, no less than 86 days' journey. Here a priest interested himself to procure their liberty and furnished them every day with a fat bullock.

"But," the account says, "so numerous were his flocks of 
cattle, as well as of horses, that although they received above one hundred oxen from him, yet they could not be missed out of the whole flock. And Mr. Ford assures me that he possessed more than I 5,000 horned cattle and near 10,000 horses and colts, which were kept fat the whole year around by the luxuriant pasture which that country affords."

Returning by boat, he stops at Florida, where he says horses are from $£_{4}$ to $£_{5}$ each; cow with calf, $£_{2}$.

\section{HORSES OF GENERAL WASHINGTON.}

From "Travels in North America," by the Marquis de Chastellux in I780, I78 I and I782, we get a glimpse of the horses of Gen. Washington and those about him, as noted by a very keeneyed observer:

"Whilst we were at breakfast horses were brought and Gen. Washington gave orders for the army to get under arms at the head of the camp. The horses brought were a present from the state of Connecticut; he mounted one himself and gave me the other. Mr. Lynch and M. de Montesquieu had each of them also a very handsome blood horse, such as we could not find at Newport (whence his journey began) at any money. * * * I distinguished with pleasure among the colonels, who were extremely well mounted, M. de Guinot. This whole vanguard consisted of six battalions, forming two brigades; but there was only one piquet of dragoons, or light cavalry, the remainder having marched to the southward with Col. Lee. These dragoons are perfectly well mounted and do not fear meeting the English dragoons anywhere. They have gained several advantages."

And again he speaks of Gen. Washington's horses as follows:

"The weather being fair on the 26 th, I got on horseback after breakfasting with the general. $\mathrm{He}$ was so attentive as to give me the horse he rode on the day of my arrival, which I had greatly commended. I found him as good as he is handsome; but above all perfectly well broke and well trained, having a good mouth easy in hand, and stopping short in a gallop without bearing on the bit. I mention these matters particularly because it is the General himself who breaks all his own horses: and he is a very excellent and bold horseman, leaping the highest fences and going extremely quick."

In "Washington's Letters to John Sinclair, Bart., M. P.," dated Philadelphia, July 20, I 794, Gen. Washington himself says : 
"Our domestic animals (as well as our agriculture) are inferior to yours in point of size, but this does not proceed from any defect in the stamina of them, but to deficient care in providing for their support, experience having abundantly evinced that where our pastures are as well improved as the soil and climate will admit; when a competent share of wholesome produce is laid up and proper care used in issuing it, that our horses, black cattle, sheep, are not inferior to the best of their respective kinds which have been imported from England."

\section{PONIES IN MARILAND.}

"The little nag I bestrode was barely fourteen hands, and although I rode thirteen stone and a half and had come twenty miles over very bad roads, she was just as fresh and anxious to push on as if she had just left the stable. All I saw would have been regarded as extraordinary little creatures for their inches. More lasting, more valuable, not so high but stouter, are the Beach ponies, brought from the island of Chincolique, a long, comparatively waste on the Atlantic sea-board, where they roam about in large herds, wild as the mustangs on the prairies of Northern Mexico. Since their capacity for work, high courage and sure-footedness have become known they have become expensive. Ten of the the Beach ponies which I saw at Baltimore reminded me much of the admirable ponies which are found in Morocco. The outline, topping shape of head and setting on of both were the same. Their origin is unknown. Probably they are of Spanish breed, bred originally in Mexico." (Parker Gilmore.)

\section{IMPORTATIONS TO CANADA.}

The next known importation to America after the Spanish was by M. L'Escarbot, a French lawyer, in I604, who brought horses with other domestic animals to Acadia. Herbert says that in 1608 the French extended their colonization into Canada and introduced horses into that country "where the present race, though it has somewhat degenerated in size, owing probably to the inclemency of the climate, still shows the blood, sufficiently distinct, of the Norman and Breton breeds." We have found no other authority that they were thus early taken to Canada. On the contrary, Charlevoix, in his history of New France, published at Paris in I 764 (Histoire de la Nouvelle France, par le P. De Charlevoix de la Compagnie de Jesus, Paris, I764) says (Vol. I, p. 38I) that the first horses were brought to Canada in $166_{5}$ : 
("Le reste du Regiment de Caregnan arriva avec M. de Salieres sur une Escadre, que portait aussi un grand nombre de familles. * * * Les premiers cheveaux, qu on ait vas en Canada; des boeufs, des moutons, en un mot une Colonie plus considerable qui celles, qu'on renait renforcer.")

This statement of this early historian has becn usually accepted as correct, though why Canada should have gone so long without horses does not well appear. The history of the horses of Canada will be considered in a future chapter.

\section{IMPORTATIONS TO VIRGINIA.}

In I609 the English ships landing at Jamestown, Va,, brought besides swine, sheep and cattle, six mares and a horse. This is the second importation of horses to the United States, and the first made by the English, so far as known. But these animals all perished the next winter, in the "starvation time," as fully shown in the article on Virginia within; and as late as I649 it would appear that there had been no considerable increase, as it is stated in "A Perfect Description of Virginia," London, I649: “That there are in Virginia about I5,000 English and of Negroes 300, good servants. That of kine, oxen, bulls, calves, 20,000 large and good; and they make plenty of butter and very good cheese. That there are, of an excellent race, about 200 horses and mares. That of asses for burthen and use there are 50, but daily increased. That for sheep they have about 3,000, good wool. That for goats their number is 5,000; thrive well. That for swine, both tame and wilde (in the woods) innumerable; the flesh pure and good, and bacon none better. That for poultry, hens, turkeys, ducks, geese, without number," etc. (See Virginia.)

\section{IMPORTATIONS TO MASSACHUSETTS.}

In 1629 horses and mares were brought into the plantation of Massachusetts Bay by Francis Higginson, formerly of Leicestershire, from which county many of the animals are said to have been imported. The same year seven mares and one stallion were landed at Salem, together with 40 cows and forty goats. And in 1635 two Dutch ships arrived at Salem with 27 mares valued at $£ 34$ each, and three stallions.

These are the first and principal importations of horses to America that history records, and from these the principal part of the original stock descended. It will be seen that the Spanish, 
the French, the Dutch and the English horses were equally drawn upon. Probably of these the Spanish was the best blood. The French and the Dutch made serviceable and enduring stock. And from the English, improved by Narragansett blood, came the pacer or New England and Virginia pony, afterwards exported in large numbers to the West Indies. 


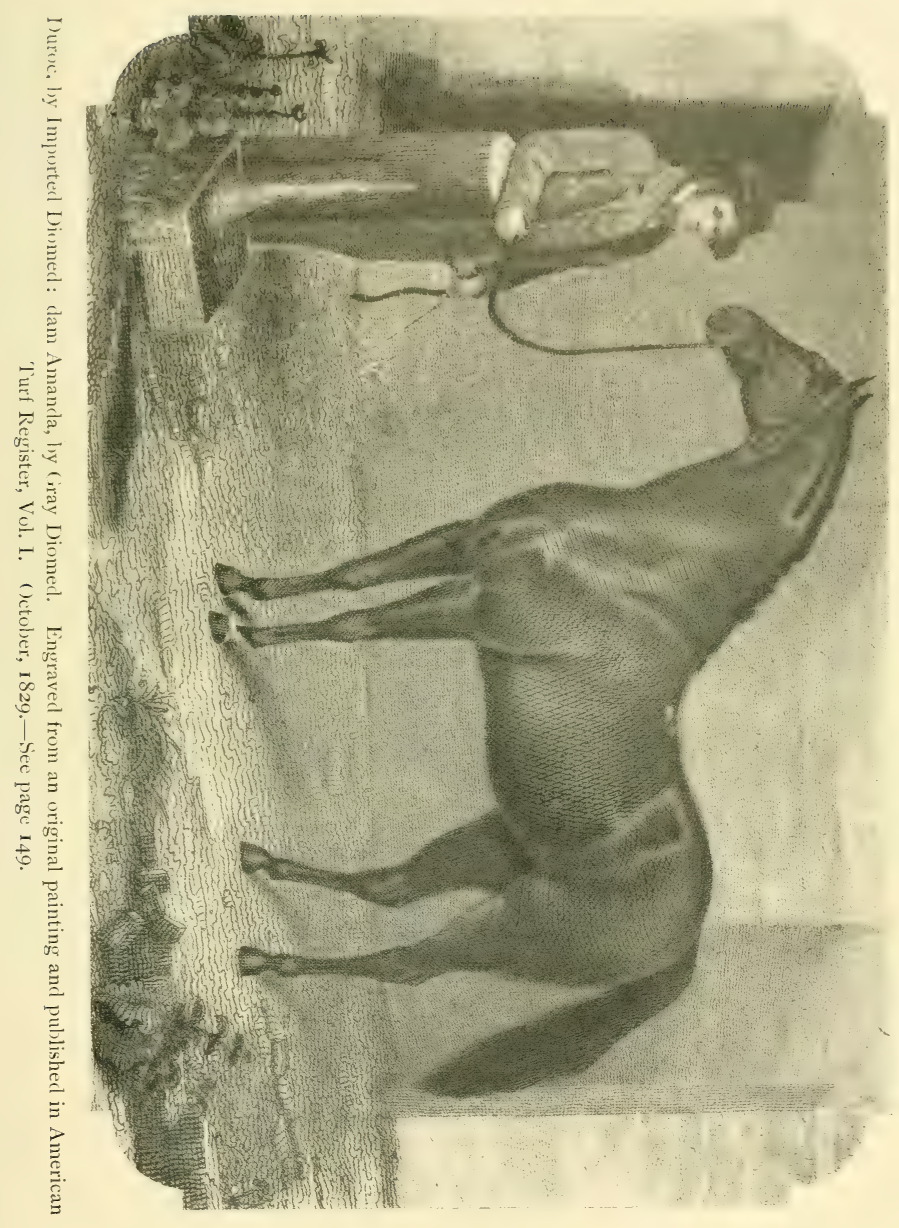




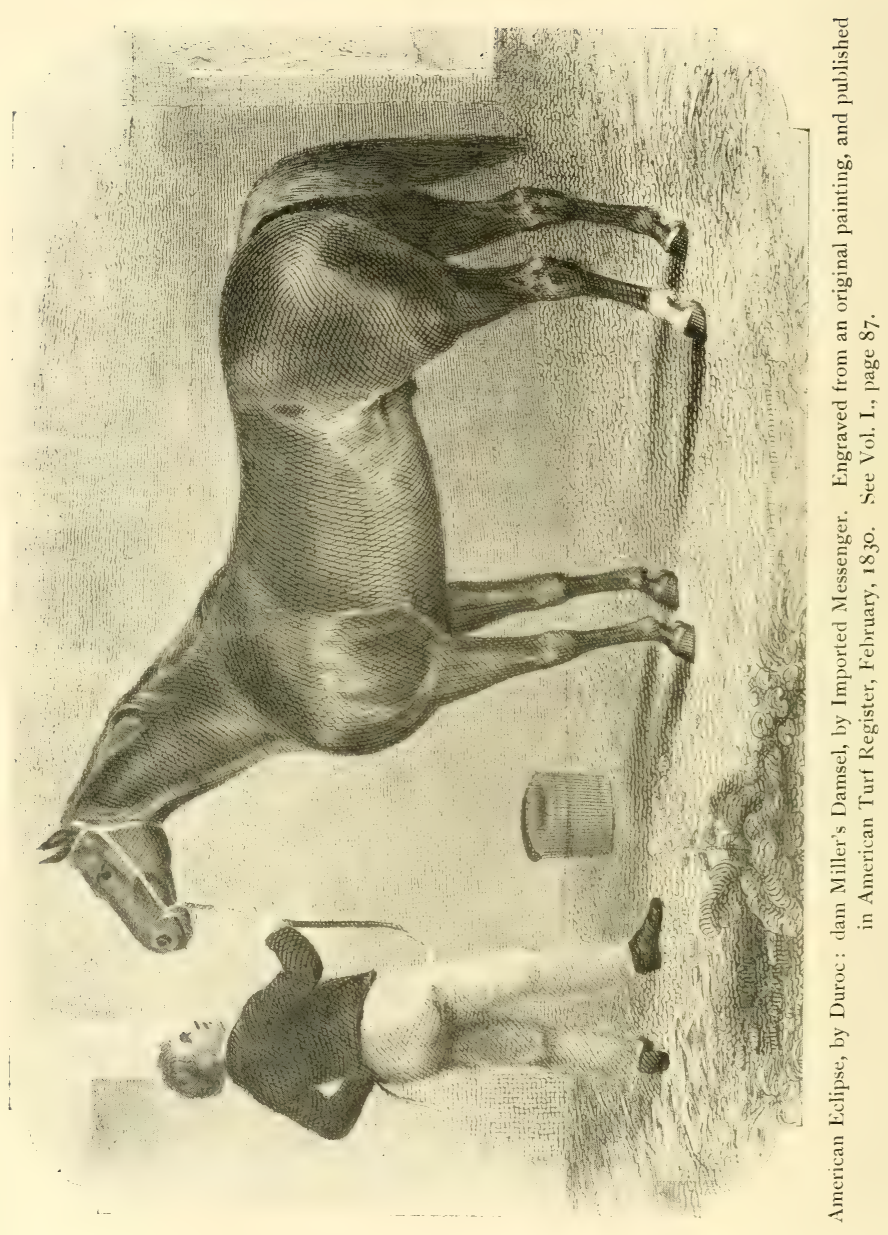




\section{II. THE THOROUGHBRED.}

"Choose with like care the courser's generous breed, And from his birth prepare the parent steed.

As yet a colt he stalks with lofty pace, And balances his limbs with flexile grace:

First leads the way, the threatening torrent braves;

And dares the unknown arch that spans the waves.

Light on his airy crest his slender head,

His belly short, his loins luxuriant spread:

Muscle on muscle knots his brawny breast,

No fear alarms him, nor vain shouts molest.

But at the clash of arms, his ear afar

Drinks the deep sound, and vibrates to the war:

Flames from each nostril roll in gather'd stream,

His quivering limbs with restless motion gleam."-Virgil.

BY referring to Chapter IX. of Volume I. of this work, giving a history of the horses of England and the British Isles, it will be seen that Great Britain, when invaded by the Romans, possessed many horses, and from that time on they were more or less carefully bred, the blood being reinforced occasionally by foreign importations, including that of Europe as well as the East, large as well as small. It also appears that racing and hunting had always been in vogue in the British Isles, and that therefore many of their horses must have been bred for such purposes, thus combining and perpetuating in long line the blood of winners.

In the early part of the sixteenth century additional importations of Eastern horses and mares were made and a systematic effort inaugurated to improve the running stock. To these importations the English thoroughbred horse, from which the American is descended, is credited. That the English thoroughbred is largely descended from these later Eastern importations is unquestionably true, but undoubtedly with more or less admixture of the native English blood, as evidenced by the increased size, and in the incomplete pedigrees, especially of the dams, of nearly or quite all of the foundation stock. It is very possible, 
too, indeed almost certain, that some of the pedigrees as given are incorrect. Judicious selection in breeding, with liberal feeding and care as more generally practiced in later years, undoubtedly had more or less to do with the increase in size.

In 1616 the Markham Arabian was purchased by James I. He is usually spoken of as the first Arabian horse brought to England, but this is unquestionably an error. Previous to this time, however, Eastern blood does not appear to have been a dominant or even an important factor in English runners. Mr. Gervase Markham, in a book on the horse, published 1606 , says:

"For swiftness, what nation has brought forth the horse which excelled the English? When the best Barbaries that ever were in their prime, I saw them overcome by a black Hobbie, of Salisbury, and yet this black Hobbie was overcome by a horse called Valentine, which Valentine neither in hunting nor running was ever equalled, yet was a plain English horse, both by sire and dam."

And in a description of the city of London by William Fitzstephen, I I 74, he says that in a certain " plane field without one of the gates every Friday, unless it be one of the more solemn festivals, is a noted show of well-bred horses exposed for sale. The earls, barons and knights, who are resident in the city, as well as a multitude of citizens, flock thither either to look on or buy." After describing the different varieties of horses brought into the market, especially the more valuabie chargers, he says: "When a race is to be run by such horses as these, and perhaps by others which, in like manner, according to their breed are strong for carriage and vigorous for the course, the people raise a shout and order the common horses to be withdrawn to another part of the field. The jockeys, who are boys expert in the management of horses, which they regulate by means of curb bridles, sometimes by threes and sometimes by twos, as the match is made, prepare themselves for the contest. Their chief aim is to prevent a competitor from getting before them. The horses, too, after their manner, are eager for the race; their limbs tremble, and impatient of delay they cannot stand still; upon the signal being given they stretch out their limbs, hurry on the course, and are borne along with unremitting speed. The riders, inspired with the love of praise and the hope of victory, clap spurs to their flying horses, lashing them with whips, and inciting them by their shouts."

Of all the early English importations two horses-the Godolphin Arabian and Darley Arabian-stand pre-eminent as contributors to 
the foundation upon which was builded the famous English and American race horse; and while both are called Arabians, and probably were descended from that blood, it is not certainly known where or how they were bred. The Darley Arabian, a bay, about 15 hands, powerfully built and of elegant carriage, was brought from Aleppo, in Asia Minor. He was taken to England in I 703, twenty-five years before the arrival of the Godolphin Arabian. The latter, described as a brown bay, about I 5 hands, was brought to England from France.

Many of the most famous English race horses trace in direct male line to one or both of these stallions; a number of others in the maternal line, and a large majority of successful race horses and progenitors of race horses, both in England and America, carry more or less of their blood. Nor did any Eastern horse imported after them become prominent in the English thoroughbred.

The first mention of English thoroughbreds brought to America that we have account of, was the stallion Tamerlane and several mares said to have been imported into Pennsylvania by William Penn about I697. Nothing further appears concerning these horses and the statement of their importation may be a mistake. The first of English thoroughbreds brought to America whose blood appears in American pedigrees, was the stallion Bulle Rock, foaled about I 7 I 8 , got by the Darley Arabian: dam by Byerly Turk; $2 \mathrm{~d}$ dam by Lister Turk; 3d dam Arabian mare. Imported into Virginia in 1730.

Among the more important thoroughbred stallions imported into America since Bulle Rock, are the following, given in the order of their importation:

\section{INTO VIRGINIA.}

Dabster, sorrel, blaze in face, white legs, flaxen mane and tail, glass eyes; said to be foaled I 735 and imported I74I ; got by Hobgoblin, son of Aleppo: dam by Spanker; $2 \mathrm{~d}$ dam by Hautboy. Edgar says he get, in general, very good stock.

Crab (Routh's), by old Crab, dam Coneyskins mare by Counsellor, 2d dam by Hutton's Gray Barb-Hutton's Royal Colt-Byerly Turk-Bustler (Son of the Helmsly Turk). Said to have been imported into Virginia about I 745. See Othello.

Monkey, foaled I 725 , bred by Lord Lonsdale, imported I 747 ; got by the Lonsdale Bay Arabian: dam bred by Mr. Curwen, got by Curwen's Bay Barb-Viola Turk-Arabian mare. He is said 
to have got about two hundred and fifty colts in America and to have died in I 754. Kept in Virginia and North Carolina. His stock were excellent.-Pedigree from General Stud Book.

Jolly Roger, chestnut; foaled I74I ; bred by Mr. Craddock, England; imported about I 748 and died in Greenville County, Va., 1772. Under the name of Roger of the Vale he won a number of rich stakes in England, his name being changed to Jolly Roger after landing in America. He was got by Roundhead, son of Flying Childers, by Darley Arabian; Roundhead's dam the famous plate winner Roxana (dam of Lath and Cade, by Godolphin Arabian), by the Bald Galloway; the dam of Jolly Roger by Craft's Partner, son of Jigg, by the Byerly Turk; 2d dam by Woodcock-Croft's Bay Barb - Makeless - Brimmer, etc. Jolly Roger got many fine racers, stallions and brood mares. Skinner's "American Turf Journal” says he was the first horse that gave distinction to running stock in Virginia.

Janus, foaled I746, imported into Virginia about 1752 by Mordecai Booth, and was one of the most famous of imported horses, his stock being greatly noted for their individuality and speed at short distances. He was advertised at Goodbridge, Chesterfield County, Va., in the "Virginia Gazette," I 775, by John Goode, Sr. Janus came nearer to being the founder of a family than any other horse owned in the Southern States, and crosses to him were long and highly valued. Janus was got by Old Janus (son of Godolphin Arabian, out of the little Hartley mare); dam by Fox, son of Clumsey, by Hautboy, son of Darcy White Turk; 2 d dam by the Bald Galloway. Janus died in I779, the property of J. Atherton, Northampton, N. C. His best son was Celer, bred by Mr. Mead of Virginia, foaled I 774: dam by Imported Aristotle, son of the Cullen Arabian. Celer died I 802. A correspondent writes to the "American Turf Register," I 829: "I have heard Revolutionary officers say that the imported Janus had a blaze in his face, and both hind legs about half up white, and he was about 15 hands high, of singular strength and roundness of form; and that he died in Northumberland County, N. C., at about thirty-four years old. The "Sporting Magazine," Vol. 3, in a list of the stallions of North Carolina, says: "Janus was a small but beautiful horse. He was a chestnut; speckled on the rump as he grew old; a small blaze in the face and hind foot white. His stock were celebrated for beauty, great speed in short distance, hardy constitution and long life."

Morton's Traveler, foaled 1748 , imported to Virginia and kept 
at Richmond from 1754. Morton's Traveler was one of the best of the early importations. Skinner in his "Turf Magazine" writes: "Not until the get of imported Traveler and Fearnaught ran, were Virginia horses able to compete with those of Maryland in races of four-mile heats."

Traveler was bred at Raby in Yorkshire, Eng., by Mr. Crofts, foaled I 747 ; got by Crofts' Partner, son of Jigg, by the Bycrly Turk, dam Bay Bloody Buttocks, foaled 1729, bred byMr. Crofts, got by Bloody Buttocks, Arabian; $2 \mathrm{~d}$ dam foaled 1722 , bred by $\mathrm{Mr}$. Crofts, got by Grayhound, Arabian; 3d dam Brown Farewell, foaled I 7 IO, bred by Mr. Crofts, got by Makeless, son of the Oglethorpe Arabian; 4th dam thought to have been bred at Hampton Court, got by Brimmer, son of Yellow Turk; 5th dam said to be by Place's White Turk; 6th dam by Dodsworth, Arabian; and 7 th dam the Layton Barb mare.

Partner was chestnut; foaled I7I8; bred by Mr. Pelham and got by Jigg, son of Byerly Turk: dam by Curwen's Bay Barb; 2d dam by Curwen's Old Spot; 3d dam by the Chestnut White-Legged Lowther Barb.

Jigg was owned by Sir R. Mostyn. He was a common country stallion in Lincolnshire, till Partner, a capital horse, was six years old.

The Byerly Turk was Captain Byerly's charger in Ireland, in King William's wars ( I689, etc.).

Bloody Buttocks was a gray Arabian, with a red mark on his hip, whence his name. He was owned by Mr. Crofts.

Grayhound was bred in Barbary, where his dam (in foal with him), and sire, Chillaby, were purchased and brought to England by Mr. Marshall.

The breeder of Makeless is unknown. He was by the Oglethorpe Arabian: dam unknown.

Brimmer was bred by the D'Arcy family; got by D'Arcy Yellow Turk: dam a Barb.

Place's White Turk was the property of Mr. Place, stud-master to Oliver Cromwell.

Dodsworth was bred in Barbary about I674, and, with his dam, a natural Barb, afterward called a Royal mare, imported into England.

Very little is known of Morton's Traveler. He was imported into Virginia by James Morton. Edgar states that he stood at Richmond Court House in I 754. His blood enters very largely into the American thoroughbred horse, especially through his sons, Lloyd's Traveler from imported Jenny Cameron; Yorick and Tyrall from 
imported Betty Blazella, a daughter of Jenny Cameron; and Partner and Ariel from Tasker's imported Selima. The last of his get that we have record of were foaled in 1769 , and he probably died about that time. No description of him has been handed down, but of his get, that appear in Edgar, two are bay, two brown, three gray, three chestnut, one sorrel and two black. Of these, one is fourteen and three-quarters hands, one fifteen hands, two fifteen and a quarter hands, two fifteen and a half hands, two fifteen and three quarters hands, and three sixteen hands.

The famous Widdrington mare, dam of Shepherd's Crab and other capital racers, was full sister to Traveler.

The sire of the original Morgan horse was a horse called True Briton, or Beautiful Bay, which was captured from Col. James De Lancey of the English army near King's Bridge, N. Y., in I 780 by several American scouts, who sold him to parties at Hartford, Conn., where he passed into the possession of Selah Norton, who kept him for stock purposes and repeatedly advertised him. In these advertisements he is described as a full blooded English horse, bay, I 5 hands, got by imported Traveler that stood in New Jersey, dam De Lancey's imported racer.

As advertisements of the sale of stock by Capt. James De Lancey in 1775 showed that he had bred his racing mare, Betty Leedes, to Lloyd's Traveler, son of Morton's imported Traveler, and which is supposed to have stood in New Jersey, it seemed most probable that this Traveler was the sire of Beautiful Bay, or True Briton, and this probability is suggested in Volume I. of the American Morgan Register. But further information in regard to True Briton preserved in the De Lancey family, is to the effect that he was imported from England by Capt. James De Lancey, importer of Wildair and the Cub Mare. This account furnished by Mr. Edward F. De Lancey, now residing at New York and a grand nephew of Governor James De Lancey, for Volume II. of the Morgan Register, appears in this chapter under the importations of stallions to New York.

Fearnaught, bay, I 5 hands $21 / 2$ inches high; foaled I 755 ; bred by Mr. Warren; got by Regulus, son of Godolphin Arabian: dam Silvertail by Heneage's Whitenose, foaled I722, son of Hall's Arabian-Rattle, son of Sir J. Harper's Barb-Darley ArabianOld Child Mare by Sir T. Gresley's Bay Arabian-Mr. Cook's Vixen by the Helmsley Turk-Dodsworth's dam. See General Stud Book, Vol. I., page I83. Fearnaught was a successful race horse.

Edgar says: "He was imported by John Baylor, of Virginia 
and brought into that Statc in March, I 764. His first cost, including freight, insurance, provender, commissions, etc., was $£ 289,5$ s., 9 d., sterling.

"Fearnaught afterwards became the property of Mr. William Edwards at Hick's Ford, Greenesville County, Va. He covered at that place in the spring of 1775 and 1776 and died in the fall of the latter year. His service fee was $£ 6$, Virginia currency, the season, equal to nearly $£ \mathrm{I} 5$ at the present time, comparing the value of the property and the price of the country produce during these periods.

"Fearnaught was one of the most distinguished stallions ever in America. Very many deservedly celebrated horses sprang from him and his distinguished name is to be found in almost any thoroughbred horse's pedigree, in Virginia, which traces back to this time. He left behind him a most brilliant and lasting race."

The most noted of the sons of Fearnaught, on the turf and in the stud, were Nonpariel, dam by Janus; Nimrod, dam by Partner; America, dam by Jolly Roger; Fitzhugh's Regulus, dam imported Jenny Dismal; Godolphin, full brother to Regulus; Specimen, another full brother and sire of the noted racer Paul Jones; Shakespeare, dam by Cub; Shakespeare, dam by Shakespeare; General Spottswood's Apollo; Harris' Eclipse; Matchless; King Herod, dam by Othello; Whynot, dam by Othello; Dandrick's Fearnaught and Symmes' Wildair, the last two probably the best of the descendants of old Fearnaught.

Aristotle, brown ; foaled I 755 ; bred by Mr. Bladen, England ; got by Cullen Arabian: dam by Crab-Hobgoblin-Godolphin Arabian, -out of the famous mare called White Cheeks. This pedigree is certified to by his breeder. Imported about I 764. Advertised I 773 by Benjamin Harrison, at Berkeley, Va.; died I776. Ran three times in England, winning twice. Not in General Stud Book.

Shadow, bred by the Duke of Northumberland and got by Babraham, son of Godolphin Arabian: dam by Starling, son of old Starling by Bay Bolton, son of Gray Hautboy by Hautboy, son of White Darcy Turk; 2d dam Coughing Polly, by Bartlet's Childers, full brother to Flying Childers; 3d dam by Counsellor, son of Lonsdale Counsellor, by the Shaftsbury Turk-Snake-Luggs-Davill's old Woodcock. Shadow was imported to Virginia in 1767 , and kept in Mecklenburg County; soon after went to South Carolina. He was quite a race horse and left a valuable progeny from which have descended many first-class horses of the present day. 
Merry Tom, said to have been an exceedingly beautiful bay horse, I $43 / 4$ hands; foaled I759; bred by William Parker, Newcastle, England; got by Regulus, son of the Godolphin Arabian: dam by Locust, son of Crab. Imported previous to I767. He ran several successful races in England in 1762-64. Advertised in Prince George County, Va., by John Baird in I767-68, I $773-76$ and kept in that county up to 1784 . He left some very good stock.

Medley, gray; foaled I776; got by Gimcrack, a gray, and from his low stature called the "little gray horse Gimcrack," foaled I 760 , son of Cripple, by the Godolphin Arabian. Gimcrack was said to be one of the best bottomed horses that ever ran in England. Though small, his ability to carry weight was very great, as he frequently gave the odds as high as 28 pounds; he continued on the turf until I I years old. The dam of Medley was Arminda by Snap; 2nd dam Miss Cleveland, by Regulus; 3d dam Midge, by a son of Bay Bolton; 4th dam by Bartlet's Childers; 5 th dam by Honeywood's Arabian; 6th dam the dam of the two True Blues. Medley was imported 1784 by Malcomb Hart of Hanover County, Va., who paid £IOO, I5s. IId., for him and in I792 sold a half interest to John and James Wilkinson of Southampton County, Va., for 29,000 pounds of tobacco. Medley died that fall.

Col. John Tayloe, one of the most extensive importers and breeders of thoroughbreds in Virginia, writes of Medley: "He was one of the most beautiful horses I ever saw. I cannot at this remote period pretend to describe him further than to say he was a gray horse of the finest proportions, and not more than $14 \frac{1}{2}$ to 15 hands high. I have always esteemed him one of the best horses ever imported into the United States, and concur with you in the opinion that his stock is decidedly the best we have had. His colts were the best racers of their day, although generally small, but their limbs were remarkably strong and fine, and they were distinguished for their ability to carry weight."

The blood of imported Medley has proved not only a most important factor in the production of our greatest runners, but is found in many of the speediest light harness horses of the present day. The dam of the Morgan stallion Black Jack was by a son of imported Medley. Black Jack got the grandam of Lady Yeiser, who produced Lottie Loraine, 2:053/4, Don Pizarro, 3 years old, $2: 143 / 4$, Mistake, $2: 291 / 4$, Don Lorenzo ( 3 years ), $2: 173 / 4$, Chastine $2: 29 \frac{1}{2}$, Galena, $2: 281 / 2$, Griselda, $2: 291 / 2$, and Chief $2: 32 \frac{1}{2}$. 
Shark, considered in Iingland the best horse of his time, beating nearly all his contemporaries at every distance, clcarly demonstrating his superiority both for speed and bottom. He was brown, I $51 / 2$ hands; foaled I77I; bred by Mr. Pigot; got by Marske, son of Squirt, by Bartlet's Childers: dam by Snap; 2nd dam by Marlborough, son of Godolphin Arabian; 3d dam a Natural Barb Mare.

Imported to Virginia in I 786 by Benjamin Hyde of Fredericksburg. He proved a successful sire of running stock, and his name frequently appears in trotting pedigrees. His son Camden got Simpson's Blackbird, a fast runner and long-distance trotter, and he in turn begot speedy trotters and producers, such as California Blackbird, $2: 22$, and Alf Richmond, sire of the dams of Anteeo, 2:16, Antevolo, 2:19; and these, together with their full brother Anteros, have furnished nearly a hundred members of the $2: 30$ list. Shark died in the stud of General Washington about I 796.

Dare Devil, bay; foaled I787; bred by the Duke of Grafton; got by Magnet, son of King Herod: dam Hebe, by Chrysolite, son of Blank, by Godolphin Arabian. Imported by Col. Hoomes of Virginia, I 795, and sold to Mr. Starke. Kept at Warrenton in I800. Dare Devil was a successful racer in England and got in this country some excellent stock.

Bedford, bay; foaled I 792; bred by Lord Grosvenor; got by Dungannon, son of Eclipse: dam Fairy, by Highflyer, son of King Herod; 2d dam Fairy Queen (2d dam of imported Citizen), by Young Cade, son of Cade, by Godolphin Arabian; 3d dam Routh's Black Eyes, by Routh's Crab, son of Crab, by Alcock Arabian.

Imported by John Hoomes and advertised at Bowling Green, Va., I 796, at four guineas. Sold to Wade Hampton, October, I 803. In his three-year-old form Bedford ran some good races, though badly managed. His progeny proved first class performers. Fairy, the first of his get in this country, won thirteen races out of fifteen. Fairy's full brother, Gallatin, when three years old, won a three-mile heat in 5 minutes 43 seconds, the best time on record up to that day. Dungannon, a son, was a consistent performer at all distances and many of the best race horses of early days, such as Kosciusko, Crusader, American Eclipse, Bertrand, Gohanna, Kate Kearney, Sussex, Giles Scroggins, Caswell, Trifle, and others, trace to Bedford mares, and in the pedigrees of many of our fastest and gamiest harness horses of the present day are found their names, or those of their descendants. 
Diomed, chestnut; foaled 1777 ; bred by Richard Vernon, of Newmarket; got by Florizel, son of Herod: dam by SpectatorBlank-Childers-Miss Belvoir by Gray Grantham-Paget (or Pigot) Turk-Betty Percival by Leedes Arabian-Spanker. Diomed was imported into Virginia by John Hoomes, in I798. He was a successful racer in England and proved a very successful sire in this country. Herbert says of him: "Diomed is probably the greatest sire of the greatest winner getters ever brought into this country, and again one of the best horses ever imported, and who has told the longest tale on American stock." A note in Weatherbee's English Stud Book says of him: "Sire in America of Sir Archie, Duroc, Florizel, Dinwiddie, Gracken and Hampton, and many other first-class runners, and themselves sires of runners. Indeed, his get were among the best ever sired in the United States, being large and powerful." Diomed was not only the begetter of speed at the run, but his blood enters very largely in the pedigrees of American trotters and pacers. $\mathrm{He}$ was sold to Goode, Selden \& Co. Died I 808 .

The blood of Diomed has also been very widely distributed over the country. In the South many of his sons, grandsons and great-grandsons were kept as stalliors and became very noted, so that there is hardly a pedigree of note in that whole region including Tennessee, Virginia and Kentucky, whether of runners, trotters or pacers, in which this blood does not appear. His descendants were also numerous throughout the West; and in New York and New England the blood became prominent through his son, Duroc, and his grandson, the very celebrated American Eclipse, as well as from other sources.

The well known and brilliant turf writer, S. W. Parlin, editor-inchief of the "American Horse Breeder," Boston, Mass., gives the following history of this remarkable horse and his ancestors:

\section{THE HISTORY OF DIOMED.}

"The following account is given by an English writer, briefly outlining the career of this truly celebrated horse before he came to this country:

" Diomed, the first winner of the Derby stakes at Epsom, a chestnut horse, foaled in I 777, bred by the Hon. Richard Vernon of Newmarket, and sold to Sir C. Bunbury, Bart. Diomed was got by Florizel, out of the Spectator mare, dam of Pastorella, Fame, etc.

"At Newmarket second spring meeting, I 780 , Diomed won a 
sweepstakes of 600 gs. each, six subscribers. At Epsom, May 4, he won the Derby stakes of 50 gs. each, 36 subscribers, the last mile of the course, beating Mr. Kelley's Boudrow, Mr. Waller's Spitfirc, Sir C. Colinson's Wooton, Mr. Panton's Drone, Duke of Cumberland's Polydore, Lord Grosvenor's Diadem, Duke of Bolton's Bay Bolton and Mr. Delme's gray colt, by Gimcrack, from Woolscy's dam; six to four against Diomed, four to one against Boudrow, and seven to one against Spitfire. At Newmarket July meeting, he walked over a swecpstake of 100 gs. each, seven subscribers across the flat.

" On Tuesday, in the first October meeting, a sweepstakes of 100 guineas each. Next day he won the Perram purse of $£ 30$, with $£ 50$ added. On Friday he received forfeit from Catalpha, by Turf, R. M. IOO guineas. In the second October meeting, I $78 \mathrm{I}$, Diomed received forfeit from Susannah, b. c. 500 guineas $h$. ft. In the Spring meeting, he won the claret stakes of 200 guineas each, $h$. ft. and a hogshead of claret each, p. p. fourteen subscribers.

" "At Nottingham, he was beat for the first time by Fortitude, and at Newmarket in October by Boudrow. In I 782 he did not start, but paid a forfeit to Crop.

“"Diomed was beat six times in 1783 , viz. : at Newmarket for the Craven stakes, won by Arabic, in the first Spring meeting; for the $£_{50}$ purse by Laburnum and Drone, also for the King's purse, won by Drone at Ascot Heath, by Soldier and Oliver Cromwell; at Winchester for the King's purse by Anvil; and at Lewes for the King's purse by Mercury and Diadem. Diomed fell lame in running and was put out of training.

" "He was sold in 1798 , by Sir Charles Bunbury, for fifty guineas to go to America, where he was sold for IOoO guineas. Was alive in I 807 .'

"It will be noted from his pedigree when fully extended that Diomed traces back to the following-named horses, through his sire and dam, viz.: Leedes' Arabian, nine times; Darley's Arabian, seven times; Byerly Turk, five times; Curwen's Bay Barb twice, Bald Galloway once, Godolphin Arabian twice, Flying Childers four times, Fox once, Basto twice, Crab twice, Herod once, Bay Bolton once, and several other Arabians, Barbs and Turks.

"All the above-mentioned horses have a history that is worthy of note, and it is my purpose to give this history as related by this English writer, as it lies at the root of the question as to the powers of what we call thoroughbred horses. 
Ixxiv

"The Leedes Arabian, sire of Ariadne, was first called the Northumberland Arabian, and afterwards being disposed of to Mr. Leedes of North Melford, Yorkshire, was distinguished in his stud by the name of the Leedes' Arabian. He was foaled in 1655 and was purchased in Zamie of the Immanum or King of Sinna, in Arabia Felix, at a very great expense, and brought into England by Mr. Phillips, a gentleman well known for his extensive skill and nice judgment in the peculiar and distinguished points and qualifications necessary in a race horse.

"The following is the account given of this horse by Mr. P. Pick:

"“Mr. Phillips was sent into Arabia by the Earl of Northumberland, purposely to select and purchase for his lordship such Arabian horses and mares as might appear best calculated to improve the breed of horses in this country. The Leedes Arabian was a private stallion in Lord Northumberland's stud until the year I666, when he served mares at Mr. Leedes' at 3 gs. and 5s. the groom; in 1667 , I678, and several years afterwards, at $5 \mathrm{gs}$. and $3 \mathrm{~s}$. He was also sire of his Lordship's Nonesuch, Actaeon and Grizelda, of Mr. Shafto's Mittimus, Mr. Jenning's Ultra-marine, Sir John Douglas' Phillippo, Mr. Morrisson's Dolly-O, etc. He served very few mares, notwithstanding which there was not above two or three of his get but what were winners. The Darley Arabian (sire of Childers) was the property of Mr. Darley of Buttercramp, near York. A brother of that gentleman being an agent in merchandise abroad, became a member of a hunting club, by which means he acquired interest to procure the said Arabian for a moderate sum, and which he sent over to England as a present to his brother. He also got Almanzor, a very fleet horse; the Duke of Somerset's Whitley, own brother to Almanzor, and thought to be as good, but meeting with an accident he never ran in public; Cupid and Briskgood horses; Dædalus, a very fleet horse; Skipjack, Manica, Aleppo, Brisk, Bully, Rook, Whistlejacket and Dart, good plate horses, though out of indifferent mares, and Lord Tracey's Whimsey, a good plate mare. He covered only a few mares besides Mr. Darley's.'

"The Byerly Turk (sire of Basto) was Capt. Byerly's charger in Ireland in King William's wars ( 1689 , etc.), and afterwards proved a most excellent stallion, though he did not cover many well-bred mares.

"He was sire of the Duke of Kingstone's Sprite, who was allowed to be nearly as good as Leedes'; of Sir Roger Moyston's Jigg (sire of Mr. Croft's Partner); of the Duke of Rutland's Archer 
and Black Hearty (sire of Bonny Black); of Iord Bristol's Grasshopper, Lord Godolphin's Bycrly gelding, Mr. Knightley's mare, etc, all in very high forms as racers. He got the dams of Lord Halifax's Farmer Mare (dam of his lordship's Miss Malifax), Sir W. W., Wynn's Looby, Mr. Smales' Childers, etc. The great-grandam of Lord Godolphin's Whitefoot, Wryfoot and Morat, which grandam of the said three was the dam of Grey Ramsden and great-great-grandam of the Bolton Fearnaught.

"The Curwen Bay Barb (sire of the dam of Partner) was a present to Louis XIV. from Muley Ishmael, King of Morocco, and was brought into England by Mr. Curwen of Workington, Cumberland, who being in France when Count Bizham and Count Thoulouse (two natural sons of Louis XIV.) were (the former was master of the horse, and the latter admiral), he procured of them two Barb horses, which he conveyed to England, both of which proved to be most excellent stallions. The Curwen Barb was distinguished for several years, by the bare style of the Bay Barb, and was as well known to sportsmen by that name as he would have been had there never been another Barb horse of his color in the kingdom. He did not cover many mares except Mr. Curwen's and Mr. Preham's.

"The Bald Galloway (sire of Buckhunter) was bred by Capt. Ryder of Whittlebury Forest, Northamptonshire. He was got by a Barb of Monsieur St. Victor, of France, well known to the sportsmen by the name of St. Victor's Barb; his dam was a mare of Captain Rider's, got by Mr. Fenwick's Whynot (son of his Barb); his grandam was a royal mare. The Bald Galloway was also sire of Lord Portmore's Snake and Daffodil, Mr. Elstob's Cartouch, Mr. Duncombe's Dart (that won the King's Plate at York in I722); he also got Mr. Howe's Foxhunter, and Grey Avington, Bald Avington, Roxanna (Cade and Lath's dam), Silverlocks (Brilliant's grandam) and several others that won plates in the north, which brought him into great repute as a stallion. He covered at the Oak-tree, Leeming-lane, Yorkshire, where he died.

"The Godolphin Arabian. - This extraordinary horse was of a brown bay color, with some white on the off heel behind, and supposed to have been foaled in 1724 ; he stood about fifteen hands high. He was long considered an Arabian, although his points resembled more those of the highest breed of Barbs. It is now generally believed that he was imported into France from Barbary, and there is reason to believe was sent as a present from the Emperor of Morocco to Louis XIV. So little was he valued in France, says the 
author of the 'Sportsman's Repository,' that he was actually employed in the drudgery of drawing a cart in Paris. He was brought into England by Mr. Coke, who gave him to Mr. Roger Williams, proprietor of the St. James's Coffee House.

"As we intend giving the performances of the most celebrated of his get, it would be superfluous to do more here than to remark that every superior race horse, since his time up to the present day, partakes of his valuable blood. By Mr. Williams he was presented to the Earl of Godolphin, in whose possession he continued as a private stallion till his death. He was teazer to Hobgoblin in the years I730 and I73I, and on the latter refusing to cover Roxanna, she was put to the Godolphin Arabian, and from that cover produced Lath, the first horse the supposed Arabian got.

"Lath was one of the finest horses of his day, and was pronounced by the most skilled at that time to be the best that had appeared at Newmarket for many years previous to his time, Childers only excepted. The Godolphin Arabian died at Hog-Magog in Cambridgeshire in 1752 , being supposed to have been then in the twenty-ninth year of his age, and is buried in a covered passage leading to the stable, with a flat stone over him without any inscription. At his interment cake and ale were given, as at that afterwards of the celebrated race horse Eclipse.

"There is an original portrait of this remarkable horse, by Seymour, in the collection of the Marquis of Cholmondely, at Houghton Hall, Norfolk, and another picture of him with his favorite cat in the library at Hog-Magog, in Cambridgeshire. He was represented in all the prints of the day with his favorite cat, and such was the regard existing between them, that the cat really pined to death for the loss of the horse.

"The Godolphin Arabian was remarkable also for the almost unnatural curve of his crest. The Duke of Portland, it is well known, once possessed a horse with the same singularity. It is worthy of remark that the production of both colts and fillies produced by this celebrated horse were of a bay color, like himself. This blood has now, however, been so much crossed that his descendants are to be met with of all colors.

"Childers, also called Flying Childers, a chestnut horse with part white on his nose and four white legs, foaled in I7I5. Bred by Leonard Childers, Esq., of Carr-House, near Doncaster, and was purchased when young by the Duke of Devonshire. Childers was got by the Darley Arabian; his dam, called Betty Leedes, by Old 
Careless; his grandam (own sister to Lecdes), by Leedes' Arabian; his great grandam by Spanker, out of the Old Morocco mare that was the dam of Spanker.

"Childers started several times at Newmarket against the best horses of his time and was never beaten. In April, I 721 , he beat the Duke of Bolton's Speedwell, eight stone seven pounds each, four miles, 500 gs., and in October following he received of Specdwell 500 gs. forfeit. In October, 1722 , Childers beat the Earl of Drogheda's Chaunter, ten stone each, six miles for 1000 gs. In April, I 723, received of the Duke of Bridgewater's Lonsdale mare, and Lord Milsintowne's Stripling, fifty gs. forfeit, each, and in November following he received $\mathrm{I} O \mathrm{O}$ gs. from Lord Godolphin's Bobsey.

"About the year I72I Childers ran a trial against Alamanzor and the Duke of Rutland's Brown Betty, carrying nine stone two pounds over the round course at Newmarket, in six minutes and forty seconds; and it was thought he moved $82 \mathrm{I}-2$ feet in one second of time, which is nearly at the rate of one mile in a minute, a degree of velocity which no horse has been known to exceed. He likewise ran over the Beacon course in seven minutes and thirty seconds; and it was supposed that he covered at every bound a space of twenty. five feet. He leaped ten yards on level ground with his rider. He was allowed by Sportsmen to be the fleetest horse that ever ran at Newmarket, or, as generally believed, that was ever bred in the world. He was not only eminent as a racer, but allowed by breeders to be a very valuable stallion, though he covered only a few mares, except the Duke of Devonshire's. He died in his grace's stud in the year I74I, aged twenty-six; and the last of his get that was trained was Velters Cromwell, Esq.'s Nestgul, foaled in the year I 740 .

"Fox, commonly called Old Fox - a bay horse, foaled in I 7 I 4. Bred by Sir Ralph Ashton, Bart., and sold to Mathew Liston, Esq. Sir Ralph Ashton purchased two mares of Mr. Leedes, and had them both covered in one season (I7I3) by Clumsy, son of Mr. Wilke's Hautboy, one of which produced Fox, the other Fox-Cub or Squirrel. The dam of Fox was called Bey Peg, by the same Arabian, sire of Leedes' out of Spanker's dam. At York in I719, Fox won the ladies' plate for five-year-olds, eight stone four miles, beating Lord Londale's Bay Jack, Duke of Ancaster's Blacklegs and others. He was then sold to the Duke of Rutland, in whose possession he beat the Duke of Wharton's Stripling at Newmarket for a considerable sum. He won two King's plates at Newmarket, the King's plate at 
Lewes, and received 250 gs. from the Duke of Wharton's Swallows. Fox then became the property of Mr. Cotton of Sussex, in whose hands he won the 300 gs. stakes at Quainton Meadow; he afterwards beat Lord Hillsborough's Witty, gelding, for 2000 gs., from whom he also received a forfeit of IOO gs.; he likewise beat Lord Drogheda's Snip three matches for considerable sums, and Mr. Frampton's Miss Worksop, for $200 \mathrm{gs}$.

"Fox was a stallion in Lord Portmore's stud, and died in his lordship's possession in the spring of 1738 , aged twenty-three. He was sire of Capt. Appleyard's Cuddy and Conqueror, of the Duke of Bolton's Goliah and Merry Andrew, of Lord Portmore's Victorious and Slipby, of Mr. Witty's Meliora (dam of the famous Tartar, sire of King's Herod), of the dam of the Duke of Cumberland's Crab, Sir William Middleton's Childerkin, Mr. Shafto's Snap, Northumberland, Swiss, Legacy, etc.

"Basto, a brown horse, foaled in I 703, bred by Sir IVilliam Ramsden, Bart., of Byram, near Ferrybridge, Yorkshire, and sold when young to the Duke of Devonshire. He was got by the Byerly Turk; his dam was called Bay Peg, a daughter of Leedes' Arabian, sire of Leedes and of the grandam of Childers. Basto's grandam was out of a daughter of Mr. Leedes' Bald Peg, and got by Old Spanker. Bald Beg, Basto's great-grandam, was bred by Lord General Fairfax, out of a mare of the same name, and got by his lordship's Morocco Barb.

"Basto won several matches at. Newmarket, but the accounts are deficient for several years in mentioning the sums that he, as well as many other horses, ran for at that place. The horses Basto beat are as follows, viz.: In October, I 703 , at eight stone three pounds, he beat the Lord Treasurer's Squirrel, seven stone twelve pounds, four miles; and in November following, at eight stone five pounds, he beat the Lord Treasurer's Billy, eight stone three pounds, five miles. In March, I 709, Basto, at eight stone five pounds, beat Lord Raylstone's Chance, seven stone, four miles; and in October following, at eight stone five pounds, he beat Mr. Pulleine's Tantivy, eight stone five pounds, five miles. In I IIO, Basto, carrying eight stone seven pounds, four miles. He then became a stallion in the Duke of Devonshire's stud, and died about the year 1723 .

"Basto was looked upon, when in keeping at Newmarket, to be a very fine form for running; he had an appearance of pride and spirit, which added greatly to his figure; he was remarkably strong, and was allowed to be one of the most beautiful horses of his color that ever appeared in this kingdom. 
"Basto was sire of the Duke of Devonshire's Old Coquette, Gimcrack, Sorcheels and Little Lear; of the Duke of Rutland's Blackeyed Susan, Dimple and Brown Betty, dam of MIr. Cole's Foxhunter; he also got the dam of Bay Motte, Old Crab, Blacklegs, Hip, Puff, Snit, etc., and the grandam of Vernon's Milliner, the Duke of Grafton's Magnet, Madam, etc. He covered very few mares beside the Duke of Devonshire's and Rutland's."

In addition to the above, Mr. Parlin writes us as follows, dated Boston, Aug. 28, I901 :

"Very few horsemen of the present gencration realize what Diomed accomplished in the way of improving the speed and other valuable racing qualities of the horse stock of America. In Youatt's work on the horse, which was edited by Skinner and published early in 1843 , are four tables. These tables occupy one page each, and begin on page 36 . The first gives the best races at mile heats that had ever been run in America.

"Table No. I contains I 8 names and they were the I 8 best performers at mile heats. By carefully tracing the pedigrees of these I 8 I find that 14 of them are direct descendants in the male line of imported Diomed. Just think of it! A horse that was 22 years old when imported in 1799, and only lived nine years after that beats all the other thoroughbred sires that ever stood in this country I4 to 4 .

"Table No. 2 contains 3 I names of all the best performers at two-mile heats, and $2 \mathrm{I}$ of them trace directly through their sires to old Diomed. In this table he beats all the other thoroughbred sires that had ever stood in this country $2 \mathrm{I}$ to IO.

"Table No. 3 shows 24 of the best performers in races of threemile heats, and 16 of these 24 trace directly in the paternal line to imported Diomed. Here old Diomed beats all the others in the ratio of $\mathrm{I} 6$ to 8 .

"The best races at four-mile heats are shown in table No. 4. This contains 17 names, and 10 of the 17 are direct descendants of old Diomed in the paternal line, showing a ratio of 10 to 7 against all other sires. The simple facts shown in these impartial tables tell the merits of old Diomed as a perpetuator of all the qualities of first class race horses in a more eloquent and convincing manner than the most gifted writer can express in song or story."

Buzzard, chestnut; foaled 1787 ; bred by Mr. Bullock; got by Woodpecker, son of Herod: dam Misfortune by Dux, son of Matchem by Cade, son of Godolphin Arabian; $2 \mathrm{~d}$ dam Curiosity by 
Snap, son of Snip, by Flying Childers; 3d dam by Regulus, son of Godolphin Arabian; 4th dam by Bartlet's Childers, full brother to Flying Childers; 5 th dam by Honeywood's Arabian; 6th dam the dam of the two True Blues. Buzzard was imported to Virginia about I 804 by John Hoomes, and soon after taken to Kentucky by Benjamin Graves, where he was kept until his death in I 8 I I.

Whip, bay, I53/4 hands; foaled I794; bred by Mr. Durand; got by Saltram, son of Eclipse: dam by King Herod, son of Tartar by Partner, son of Fox, by Clumsy, son of Hautboy, by D'Arcy's White Turk-Oroonoko-Cartouch-son of Seabright's Arabian. Whip is said to have been a horse of great strength and beauty, which qualities he impressed to a remarkable degree upon his descendants. He was imported about I8OI to Virginia, and owned at one time, if not imported, by Captain Richard Bland. Died in Kentucky, 1825.

The very noted race horse, Hickory, brown, I 5 I/2 hands, foaled ISO4; dam Dido by imported Dare Devil; 2nd dam by imported Clockfastwas a son of his. Sir Walter, chestnut, $15 \frac{1}{4}$ hands, foaled ISI6; dam Nettletop by imported Diomed, 2nd dam by imported Shark, 3d dam by Lindsay's Arabian; was a son of Hickory. Sir Walter went to the Province of Quebec, Canada, where he ran races and was used as a stock horse, many of his get being kept as stallions. Moscow, the third horse to trot in $2: 30$ ( I 840 ), was by a son of his. Tacony, the ninth horse to trot in $2: 30$, was also by a son of his. And Highland Maid, 2:27, the eleventh horse to trot in $2: 30$, was by a son of Blackburn's Whip: dam by a son of Hickory.

Cook's or Blackburn's Whip, bred in Virginia, which went to Kentucky, was also a son of imported Whip. Of this last a correspondent in Kentucky writes to the American Turf Register:

"Cook's or Blackburn's Whip was the favorite horse in Kentucky for fifteen or twenty years; went to nearly all our best mares; was a uniform winner at one and two miles; of great speed and incomparable beauty. His stock was of the best. He was got by imported Whip: dam Speckleback by Randolph's Celer, son of Mead's Celer; 2d dam by Mead's Celer, son of imported Janus."

\section{INTO MARYLAND.}

The importations into Maryland were among the first and include some of the best imported horses:

Spark said to be by Aleppo, son of the Darley Arabian: dam by Bartlet's Childers; 2d dam by old Spark, son of Honeycomb 
Punch ; 3d dam by Rutland Coneyskins, out of Sweetlips; imported about 1746 by Governor Ogle of Maryland, presented to him by Lord Baltimore, who received him as a gift from Frederick the Prince of Wales.

Othello one of the best stallions of his day in America. Othello is advertised in the "Maryland Gazette," in 1756 , as follows :

"In the hands of John Pearson, at Colonel Tasker's plantation, in Prince George's County, a beautiful black horse, full fifteen hands high, and will cover mares this season at four guineas. The dam of this horse was bred by the Duke of Somerset, and got by the Hampton Court Childers. His sire was my Lord Portmore's Crab, sire of Oronoko, Sloe, Black-and-all-Black, and many other stallions now in great repute."

It will be perceived that the horse in this advertisement has no name, which would indicate that he was young and not then named. The next two seasons he is advertised under the name of Othello, in the same paper, to stand at the same place, in the same hands; but the pedigree is omitted. The statement that Lord Portmore's Crab was the sire of Oronoko, Sloe and Black-and-all-Black, would appear to be a mistake, as it was his sire, Cotton's or Panton's Crab, that got these horses; or it is possible that at some time this last Crab was owned by Lord Portmore.

Othello is advertised again in the "Maryland Gazette," I 766, as follows :

"The horse Othello, that was bred by Colonel Tasker, and by him sold into Virginia, is now at Whitehall, on the north side of the Severn river in Anne Arundel County, and will cover mares this season at four guineas, and five shillings to the groom, the money to be paid before the mares are taken away.

ROBERT GAY."

$\mathrm{He}$ is advertised the next year, by Mr. Gay, to stand near Annapolis at the same terms. The last advertisement that appears of him is in the same paper, I770, as follows:

"The horse Othello, that was bred by Colonel Tasker, will cover this season at Whitehall. Four guineas each mare, and a dollar to groom."

Edgar, Bruce and Wallace all confound Tasker's Othello with English Othello, also called Black-and-all-Black, foaled i 743, bred by Lord Portmore and got by Crab son of Alcock Arabian.

From the above information it would seem quite probable that Colonel Tasker purchased Queen Mab of her breeder, his Majesty's 
groom, Thomas Smith, in England. It would appear, too, that Miss Colville was the dam of Queen Mab and whether imported by Colonel Tasker or not, was owned by him in 1755 . It would also appear that Miss Colville was the dam of Othello, and that Othello was probably foaled in 1752 . As in the first advertisement of Othello when at Colonel Tasker's plantation in 1756, when Colonel Tasker was alive, it is not stated that he was imported, and as later advertisements of him after Colonel Tasker's death state that he was bred by Colonel Tasker, it would seem probable that Othello was bred by Colonel Tasker, possibly in England before importation of his dam, but perhaps more probably in America.

Herbert, in his tabulations, gives Othello by imported Crab, son of Crab. Both Edgar and Herbert mention Routh's Crab, gray, foaled I736, as having been imported about 1746 , and having died in Virginia in 1750 . Herbert says of him: "One of the oldest and finest of the old English thoroughbreds." Possibly he may have been owned at one time by Lord Portmore.

OTHELLO'S DA.I.

It will be noticed that the first advertisement of Tasker's Othello states that his dam was bred by the Duke of Somerset and got by the Hampton Court Childers. In the American Turf Register Vol. VI., pages 207-208, under the heading "Pedigrees of Horses of the Olden Times" the following information is published:

DEAR SIR:- In looking over some old papers of my father's a few days since, I accidentally found the following pedigree, which may perhaps be of some use to the sporting world, as I do not find either of them in your magazine.

John M. Garnet."

Old Spark was got by Aleppo, son of the Darley Arabian (sire of Childers); his dam was full sister to Squire Bathurst's Lookabout-you; she was got by Bartlet's Childers; her dam by old Spark; her grandam by the Rutland Coneyskins, out of Sweetlips.

“Queen Mab was got by Musgrove's Gray Arabian; her dam by the Hampton Court Childers; her grandam by Governor Harrison's Arabian; her great-grandam by the Chestnut Arabian; her great-great-grandam was a Leedes; her great-great-great-grandam was a bay mare brought over by Mr. Marshall, and was the dam of Mr. Croft's Grayhound.

"The above pedigrees of old Spark and Queen Mab I have now by me from under the hands of their breeders.

May 20, 1758.

Benj. TASker, JR. 
"Mille, the filly I sold Mr. Sprigg, was got by Old Spark, and her dam Queen Mab.

BENJ. TASKEK, JR."

"Queen Mab had but two foals after she came to America. The first was Pacolet, that Colonel Tasker ran several times in Virginia; the second was Mille, which my father bought at six months old, on the death of Queen Mab. Coloncl Tasker never was possessed of any of the produce from Mille; he had many from old Spark.

\section{RICHARI) SIRIG(G."}

The following advertisement appears in the "Maryland Gazctte," I 76 I :

"To be sold at public auction, pursuant to the testament of the Hon. Benj. Tasker, deceased, May 2 I, I76I, at Bellaire, near Queen Anne, the noted bay mare called Selima, four of her foals, the breeding mare of the late Governor Ogle, and their increase, in all thirty.

ROBERT CARTER."

From this last advertisement it would appear that Selima imported by Governor Ogle passed to Benjamin Tasker.

It becomes, too, very evident from all of above information that the dam of Othello was the dam of Queen Mab. And it is very probable that she was imported at the same time as Queen Mab and that all after the death of Governor Ogle passed to Colonel Tasker. In several contemporaneous advertisements it is stated that the dam of Queen Mab was Miss Caldwell.

On page II 5 of the General Stud Book a Leedes Mare is recorded, got by Leedes from a Moonah Barb Mare. This mare in I 72 I has a filly by the Hampton Court, Chestnut Arabian and this filly was probably the third dam of Queen Mab.

Edgar records Spark as imported by Governor Ogle; got by Honeycomb Punch: dam Wilkes' old Mare called Miss Colville, also imported into America by the late Col. Colville, of Virginia, and got by old Hautboy: dam by Brimmer. It does not appear in what part of Virginia the Colonel lived.

Bruce, as usual, copies Edgar, but without credit, and adds that the pedigree cannot be authenticated from the English Stud Book. He also says that Miss Colville is said to have been the dam of Spark.

Under this mare (Vol. I., page I09), Bruce enters for produce a filly by imported Spark, and 1756 the colt Young Traveler by Morton's imported Traveler.

The record of this horse Young Traveler is from an advertisement in the Maryland Gazette of April 2, I 761, as follows: 
"Young Traveler is five years old, I6 hands I inch high, to stand at Mr. Rogers' at two guineas. He was bred by Col. Tasker; got by Morton's Traveler, dam Miss Colville." This advertisement shows that Colonel Tasker owned Miss Colville in 1755 .

Lord Portmore's Crab is thus registered in the English "General Stud Book": "Crab (Duke of Cumberland's), gray, foaled I744, bred by Lord Portmore; got by Crab: dam Fox Mare (sister to Slipby), bred by Lord Portmore in 1740 ; her dam Gypsy, black, foaled 1725, (bred by Duke of Bolton), by Bay Bolton-Duke of Newcastle's Turk-Byerley Turk-Taffolet Barb-Place's White Turk-Barb Mare.

Crab was gray; foaled 1722 ; bred by Mr. Cotton and Mr. Panton; got by the Alcock Arabian: dam, sister to Soreheels, by Basto, son of Byerley Turk; second dam, sister to Mixbury, by Curwen's Bay Barb; third dam a daughter of old Spot, by the Sellaby Turk; fourth dam a daughter of the White-legged [Lowther Barb; fifth dam old Vintner Mare. Died Christmas, I750. Basto's dam was Bald Peg, by Leedes' Arabian; second dam Young Bald Peg, also by Leedes' Arabian; third dam, Spanker's dam, the old Morocco Mare, by Morocco Barb; fourth dam old Bald Peg, by an Arabian; fifth dam a Barb Mare. Basto died 1723.

Fox was by Clumsy, son of Hautboy. Hautboy was bred by the D'Arcy family and got by D'Arcy White Turk, out of a Royal Mare, a Barb. Dam of Fox, Bay Peg, given above. Dam of Clumsy, Miss D'Arcy's Pet Mare by Sedbury; second dam, a Royal Mare.

Bay Bolton was foaled I705, got by Gray Hautboy, son of Hautboy: dam by Makeless, son of Oglethorpe's Arabian; second dam by Brimmer, son of the D'Arcy Yellow Turk; third dam by Diamond, out of a sister to the dam of old Merlin. The dams of Gray Hautboy and of Makeless are unknown. The Taffolet Barb stood in England in the time of Charles II. (I660-1685). Place's White Turk was owned by Mr. Place, studmaster to Oliver Cromwell, when Protector (1653-1658). The Byerley Turk was Captain Byerley's charger in Ireland in King William's wars (I689, etc.)

Curwen's Bay Barb was a present to Louis XIV. from Muley Ismael, King of Morocco, and was brought into England by Mr. Curwen, who being in France procured from Count Byram and Count Toulouse, natural sons of Louis XIV., two Barb horses, both of which proved excellent stallions and are well known by the names of Curwen's Bay Barb and the Toulouse Barb. Mixbury was a small horse 
not over thirteen and onc-half hands, but not more than two horses of his time could beat him at light weights. The Marshall or Sellaby Turk was the property of Mr. Marshall's brother, studmaster to King William, Queen Anne and King George I. He was purchased in Barbary and brought to England by Mr. Marshall.*

Hampton Court Childers was bred by the Duke of Devonshire; got by Childers: dam Duchess by the Newcastle Turk; second dam Gray Royal, bred at Hampton Court or Sedbury, got by D'Arcy White Turk; third dam a Royal mare by D'Arcy Yellow Turk.

Childers (also called Flying or Devonshire Childers) was bay with blaze and four white feet; foaled I7I6; bred by Mr. Childers, and got by the Darley Arabian: dam Betty Leedes, by Careless, son of Spanker, by D'Arcy Yellow Turk, and from a Barb Mare; second dam, sister to Leedes, by Leedes' Arabian; third dam a daughter of Spanker; fourth dam, Spanker's dam, a Barb. The General Stud Book says: "Generally supposed to have been the fleetest horse ever trained in this or any other country. He gave Fox twelve pounds over the course and beat him one quarter of a mile, in a trial."

Careless ran at Newmarket in $\mathbf{1 6 9 8}$, then owned by Lord Wharton. He was at one time owned by Mr. Leedes.

The Darley Arabian was brought over by a brother of Mr. Darley, of Yorkshire, who, being an agent in merchandise abroad, became a member of a hunting club, by which means he acquired interest to procure this horse. The Godolphin Arabian was a brown bay, with some white on the off hind heel; about fifteen hands. $\mathrm{He}$ is said to have becn presented to Louis XV in I73I, by the Bey of Tunis together with seven other Barbary steeds, on the consummation of a treaty of commerce. Louis being more interested in large horses was indifferent to these and this one was sold and used as a cart horse in Paris, where he was purchased by Mr. Coke, an Englishman, who brought him to England, and gave him to Lord Godolphin. He died in Cambridgeshire, in the possession of Lord Godolphin, in, I 753, supposed to be in his twenty-ninth year. The General Stud Book says: "It is remarkable that there is not a superior horse now on the turf without a cross of the Godolphin Arabian, neither has there been for many years past." Sidney's Book of the Horse, says: "Of the pedigrees of celebrated race horses, carried back to the commencement of the eighteenth century, one may safely say that nearly all go back to the

* Sidney's Book of the Horse, pp. $5^{\mathrm{I}-2}$. 
Darley Arabian ( I 7 I 5 ), or the Godolphin Barb ( I 724), or both."

It will be seen that Edgar was badly mixed concerning both Spark and Miss Caldwell, or Colville. He records Spark as by Honeycomb Punch, dam Wilkes' old Hautboy Mare, and imported by Governor Ogle. An old Hautboy Mare is recorded on page I I of the General Stud Book, and among her produce a colt foaled in 1707 , and another as late as I7I3. The General Stud Book is quite economical as to dates in speaking of the older horses, but says of Honeycomb Punch that he was got by the Taffolet or Morocco Barb, and won at Newmarket in I 699 as Sir George Warburton's. The whole history of the Taffolet or Morocco Barb in this book is comprised in his two names. But it is evident that Spark by Honeycomb Punch must have been foaled in the early part of the eighteenth century, probably before I710. Not this Spark, but Spark by Aleppo, was imported to America; and not Miss Caldwell or Colville, the dam of Queen Mab was the dam of Spark by Aleppo, but some other mare by Bartlet's Childers. For the second dam of Queen Mab was by the Chestnut Arabian, but the second dam of Spark was by old Spark; and third dam by the Rutland Coneyskins out of Sweetlips.

The Rutland Coneyskins is recorded, page 379, Vol. I. of the General Stud Book, as foaled I 7 I 2; got by Lister Turk: dam by Jigg. The only Sweetlips recorded is by Cade and was foaled I742. Bruce says that both of the Sparks were imported; one by Governor Ogle, the other by Benjamin Tasker, and makes Sweetlips by Cade the fourth dam of Spark by Aleppo (foaled I 79I). That is he gives as the fourth dam of a horse, foaled 1740 or before, a mare foaled I 742 , which is not at all probable.

Indeed Edgar has got all of these earlier Maryland pedigrees badly mixed, but Bruce a good deal worse, and this remark will include that of the very celebrated mare imported Selima, as will be shown hereafter.

As appears in the above certficate of Benjamin Tasker Jr. Spark by Aleppo was imported; nor has the slightest evidence ever been produced to show that any other Spark was ever imported. It is generally understood that this Spark was imported by Governor Ogle to whom he was presented by Lord Baltimore, who received him as a present from Frederick Prince of WVales.

Samuel Ogle was governor of Maryland I737-42, and from I 746 to his death, I75I. He had previously held office in Ireland.

True Briton, bay, got by Othello, was in his day one of the most famous race horses in America, as was also Selim another son of 
Othello. An advertisement of True Briton in the Maryland Gazette of March 26, I76 I, gives further information concerning these pedigrees as follows:

"True Briton, a fine strong horse, four years old, fifteen hands high, belonging to Thomas Garnctt, Jr., in l'rince George's county, groes to mares at two guineas the season; he was got by Colonel Tasker's Othello, and came of Mille, got by old Spark, and full sister to Colonel Hopper's Pacolet; her dam was Queen Mab, got by Musgrove's Gray Arabian, a most beautiful horse, for which he refused 500 guineas, and that stood at ten guineas; her dam by the Ilampton Court Childers; her grandam by Governor Harrison's Arabian; her great-grandam by the chestnnt Arabian; her great-great-grandam by Leedes; her great-great-great-grandam was a Barb, brought over by Mr. Marshall, and was the dam of Mr. Croft's Greyhound.

"The above pedigree Colonel Tasker had from under the hand of Thomas Smith, his late majesty's stud-groom at Hampton Court, who bred Queen Mab."

True Briton was owned in 1763 by Anthony Waters, who that season challenged any horse on the continent to run against him for $£$ Iooo. The challenge was finally accepted, I 765 , by the owners of Selim, also a son of Othello; Selim won the race, True Briton winning the first heat by a neck.

The repute in which these two sons of Othello were held for speed is shown in the following notice in the "Pennsylvania Gazette" of March, I 765.

\section{"Chester Town Races.}

"To be run for on the second Wednesday in May next, near the town, a purse of forty pistoles, free for any number of horses, mares or geldings (Mr. Samuel Galloway's horse, Selim, and Mr. Waters' horse, Briton, only excepted): upon the following terms, etc.

Samuel Galloway lived in Cecil County, Maryland.

Julius PORTER."

Bruce gives under Mille:

Produce - colt, Merry Andrew, by imported Othello.

filly, by imported Othello (grandam of Careless).

bay colt, Liberty, by imported Dove.

filly, Molly Pacolet, by imported Pacolet.

I 754, bay colt, True Briton, by imported Othello.

I76 I, gray filly, Britannia, by imported Othello.

We can add: I 770, chestnut colt, Traveler, by Othello.

( From an advertisement of Traveler in New Jersey I $778-9$. ) 
The date I754 should read I757. Liberty was foaled I 766 .

Nothing appears of Merry Andrew. Edgar says of Liberty: "A fine bay horse fifteen and one-fourth hands, very lengthy and strong, and allowed by all good judges to be as handsome a horse as any in America. He stood at Colts-neck, Monmouth county, New Jersey, at the stables of John Van Mater, at forty-one dollars the season, the money to be paid at the stable door."

There is no description of Molly Pacolet. Bruce says that she produced in 1782 the chestnut colt Whistle Jacket, by imported Badger, and also, years not given, the brown colt Koulikhan, by Bajazet St. Patrick, by imported Granby, and a filly by Galloway's Selim. An advertisement of Koulikhan, in the "New Jersey Gazette," I 784 , describes him as bay with star, fifteen hands, foaled 1776 , bred by Jacob Heiltzheimer, Philadelphia. In this advertisement the dam is called Molly Pitcher; second dam by imported Spark, and third dam Queen Mab.

Dove, gray, I $51 / 4$ hands; foaled 1756 ; bred by Thomas Jackson, Sr., North of England; got by Young Cade, son of Cade, by Godolphin Arabian: dam by Teaser, son of Bolton Starling; 2d dam by Seawing Arabian; 3d dam Gardner Mare, that won six royal plates of 100 guineas each, by Bridgewater's horse-Commoner-Makeless-Wormwood. Dove was imported by Dr. Thomas Hamilton, of Prince George County, Md., November, I76I. Sold to Henry W. Pearce. Ran successfully at Newcastle-on-Tyne, I760. He was started in a few races in 1763 with indifferent success, but his get were quite numerous and many of them very speedy with game and bottom. Among his best were Thistle, Primrose, Regulus, the grandam of Hall's Union, and Nonpareil, the latter a first class four-miler when young and never was beaten until he met Lath at Philadelphia.

Figure, bay, I $5 \frac{1}{2}$ hands; said to be by old Figure, son of Belgrade Turk: dam Mariamne by Partner; $2 \mathrm{~d}$ dam by Bald Galloway. Pedigree as given by owners, and furnished the American Farmer, I 828. Imported 1765 by Dr. Thomas Hamilton, who imported Dove. Sold to Nathaniel Head and went to New Jersey, I77-. He ran several successful races in this country, and is said to have been an exceedingly handsome and well formed horse. He got Gray Figure, Rochester, Brown Figure, Harmony, Mr. Gibson's Cub mare and the dam of Hall's Union, all good runners. A correspondent in the Turf Magazine states that Figure was bred in the north of England; and, like many thoroughbred horses of that locality, does. not appear in the General Stud Book. 
Badger, gray, said to be by Bosphorus, son of Babraham by Godolphin Arabian: dam by Black-and-all-13lack, son of Crab, and 2 dam by Flying Childers. Imported by Governor Eden of Maryland, who began his administration in 1769. Advertised in the Virginia Gazette, I 777, to be kept in Northampton County, N. C.

Cardinal P'uff (Young P'uff), bay, I $53 / 4$ hands; bred by Lord Grosvenor; foaled I 782 ; got by Cardinal I'uff, son of Babraham, by Godolphin Arabian: dam by Bandy; 2d dam by Matchem. Imported 1786, by Samucl Harrison of Anne Arundel County, Md., and advertised in the Maryland Gazette, I 787, with pedigree as above. Cardinal Puff has become a factor in the Amcrican road and trotting horse, through Gifford Morgan, who appears in the pedigrees of such stallions as Golddust, Kentucky Prince, Kirkwood, etc., and whose dam was by Henry Dundas, son of Cardinal Woolsey, by Cardinal Puff.

\section{INTO SOUTH CAROLINA.}

Between I 748 and I768, many importations of thoroughbreds, were made to South Carolina. Cade, a very popular stallion, came in I 762, when five years old. He was by Cade, son of Godolphin Arabian, dam by Wormwood, son of King Herod. In the same year Pharaoh was brought over and kept several seasons at Ashley Ferry. He was bay, of good size and remarkable action ; foaled 1753 ; got by Moses, son of Chedworth's Foxhunter, by Cole's Foxhunter, son of Brisk (probably Brisk foaled I 7 I I by Darley Arabian): dam by Godolphin Arabian. In 767 Abdallah, a horse of repute as a sire of style and beauty but not of race horses, was brought to Beaufort, S. C., from Gibraltar. The next year, I 768, Moro, a well bred horse and progenitor of a family that contributed largely to the improvement of horses in the South, arrived. It was said that the agent who bought and imported Moro came very near securing for America the celebrated Eclipse.

Flimnap, bay, I 4 hands and half an inch high; foaled I $76_{5}$; bred by Sir J. Moore; got by South, son of Regulus, by Godolphin Arabian: dam by Cygnet, son of Godolphin Arabian; was imported to South Carolina about the beginning of the Revolution. He was a very excellent and popular stallion. It is related that when the British cavalry, commanded by Col. Tarlton, had overrun that State, diligent search was made for Flimnap; but his groom, a faithful slave of his owner (Major Isaac Harleston, then in the Continental army under General Green), succeeded in baffling them by secreting 
him in swamps until the search was considered hopeless, and the trusty negro conveyed him to North Carolina, where he remained until South Carolina was rid of the invaders.

\section{INTO NEW YORK.}

Wildair, a famous bay thoroughbred, foaled in 1753 , bred in England by Mr. Swinburne, was imported with the Cub Mare by Capt. James De Lancey of New York, in I 764. He was landed in Baltimore consigned to Mr. Sims, but soon went to New York. Such was his reputation that he was repurchased in 1773 , and sent back to England, where his service fee was 40 guineas. Wildair was got by Cade: dam by Steady, foaled I 720, son of Devonshire Flying Childers; second dam by Partner; third dam by Grayhound; fourth dam Chestnut Layton, by Makeless; fifth dam Bay Layton, by Counselor; sixth dam by Brimmer; seventh dam by Place's White Turk; eighth dam by Dodsworth, and ninth dam, the Layton Barb Mare.

Cade was bred and owned by Lord Godolphin and got by the Godolphin Arabian: dam Roxana, by Bald Galloway; second dam, sister to Chanter, by Ancaster Turk; third dam by Leedes' Arabian, and fourth dam by Spanker, son of the Darcy Yellow Turk.

Steady was gray; foaled I 733; bred by Duke of Devonshire: dam Miss Belvoir, by Gray Grantham, son of the Brownlow Turk; second dam by Paget Turk; third dam Betty Percival, by Leedes' Arabian; fourth dam by Spanker.

Partner (Croft's) was foaled I7I8; bred by Mr. Pelham; got by Jigg, son of the Byerley Turk: dam, sister to Mixbury, by Curwen's Bay Barb.

Grayhound was bred in Barbary, after which both his sire and dam were purchased and brought into England by Mr. Marshall. He was got by King William's White Barb, Chillaby, out of Slugey, a natural Barb mare.

Brimmer was bred by the Darcy Family and got by the Yellow Turk: dam a Royal mare.

Place's White Turk was the property of Mr. Place, stud-master to Oliver Cromwell when Protector, and was sire of Wormwood, Commoner, and the great-grandam of Windham, Gray Ramsden and Cartouch.

Dodsworth, though foaled in England, was a natural Barb. His dam a Barb mare, was imported in the time of Charles the Second (I660-I685), and was called a Royal mare. 


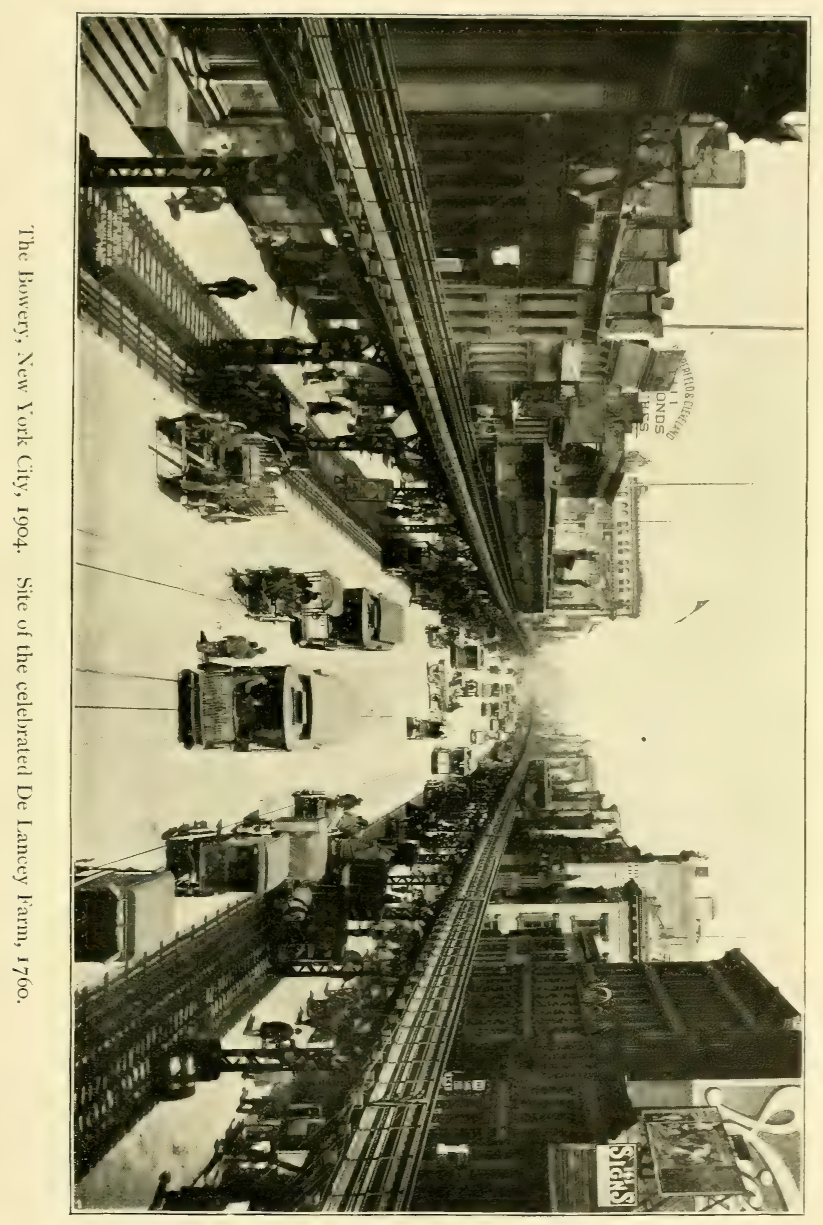




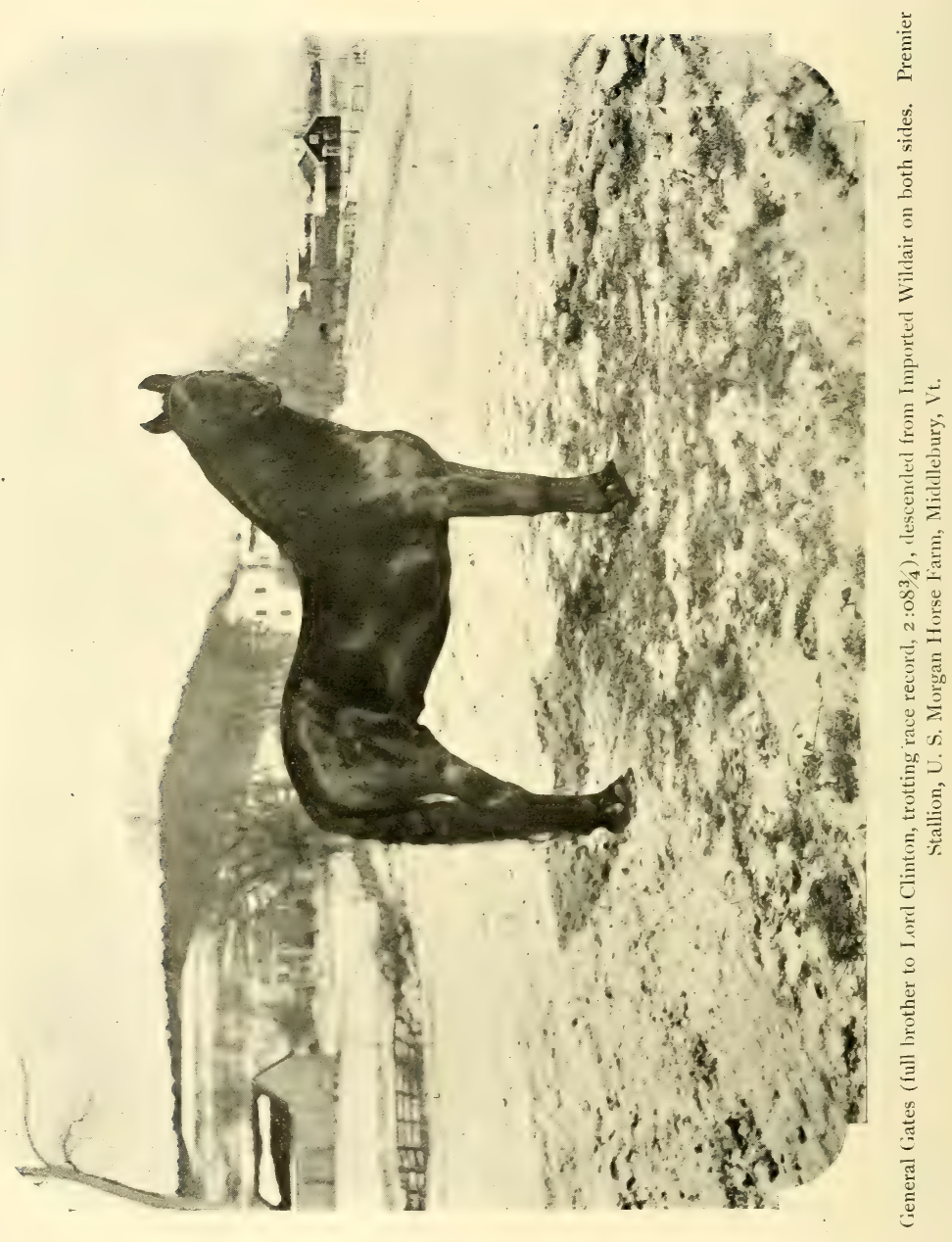


The Godolphin Arabian was a brown bay, about fiftecn hands high with some white on the off hind heel. He was imported from France in 1730 by Mr. Coke, and passed from him to Lord Godolphin. He died at Cambridgeshire in the possession of Lord Godolphin in 1753 , being then supposed to be in his twenty-ninth year.

The General Stud Book says: "It is remarkable that there is not a superior horse now on the turf without a cross of the Godolphin Arabian, neither has there been for many years past."

The General Stud Book records Bald Galloway as bred by Captain Ryder and got by St. Victor Barb: dam by old Whynot son of the Fenwick Barb; second dam a Royal mare.

Spanker was bay, bred by the Duke of Buckingham; got by Darcy Yellow Turk: dam Old Peg, bred by Lord Fairfax, got by his Morocco Barb; 2d dam Old Bald Peg, by an Arabian; 3d dam a Barb mare. He was sometimes called Mr. Pelham's Bay Arabian, and is said to have been an excellent horse.

Jigg, by the Byerly Turk, was a common country stallion in Lincolnshire until Partner was six years old.

Byerly Turk was Captain Byerly's charger in Ireland in King William's wars ( I689, etc.).

From Wildair, the improved New England blood is very largely descended; not only through the Morgan stock, the most renowned of all bred in New England, but from numerous sons and grandsons, as advertisements from old newspaper files abundantly show. (See Wildair advertisements in Vermont, Connecticut and New York chapters; which advertisements serve not only to show the popularity of the Wildair breed, but will also illustrate the very large number of thoroughbred or part-bred stallions that came into use all over this country from shortly before and after the Revolution; and indeed, perhaps especially in the South, through the beginning of the present century, as late as I820 or 1830 ).

Among the very noted get of Wildair, was an inbred son known as Hooker's Wildair, very highly spoken of in the advertisements of the Wildair stock, He got Diamond, bred at East Hartford, Conn., a daughter of which was the dam of the original Justin Morgan. Rainbow, a son of his, is supposed to have got the $2 \mathrm{~d}$ dam of Lady Suffolk, who first trotted in 2:30 (July 4, I843), and is one of the most renowned of all American trotters. Among other of the noted get of Wildair were Slamerkin, dam, the Cub Mare, imported with Wildair; Sim's Wildair, and the racing mare Sultana. This mare Slamerkin figures very extensively in the breeding of the American 
xcii

trotter, as crossed to Whirligig she produced the grandam of Mambrino, grandsire of Rysdyk's Hambletonian.

In 1768 , Lath, a bay horse, $15 \frac{1}{4}$ hands; foaled 1763 ; got by Shepherd's Crab: dam by Lath, son of Godolphin Arabian; 2d dam by Childers; was also imported to New York by Capt. James De Lancey. Lath was a first-class race horse after landing in this country, having won in I 768 the $£ 50$ weight for age plate at New Market on Long Island; in 1769 the Jockey Club purse of $£$ IOO at Philadelphia, beating the then best running horses of that State and from Maryland; in I 770 the $£$ IOO plate at the same place, and in I 77 I the $£$ IOO plate at New Market, and was never beaten but once, when he was out of condition. He was retired to the stud in 1773 by his owner, Mr. De Lancey, and in 1779 he was advertised by Mr. Thomas Goode in Chesterfield County, Va.

The statement in the General Stud Book that Lath was the colt Protector, foaled 1763 , dam Crazy, by Lath, is not true. Protector ran in England in 1770 . Lath ran in America and won in $1768-70-71$, and was beaten in 1772 , after which he was kept for stock. The advertisement of Lath in 1773, when he was owned by De Lancey, and so again his advertisement, by Mr. Goode, in the Virginia Gazette, I 779 , states that his dam was by Lath; 2 d dam by Childers; 3d dam by Makeless; 4th dam a full sister of Honeycomb Punch, by the Taffolet Barb; 5th dam a natural Barb mare. De Lancey gave pedigrees very accurately, and this is undoubtedly correct. It is also stated in this pedigree that the grandam of Lath was the grandam of Weasel and of Colonel Tasker's Selima, which, too, is undoubtedly correct, and refers to the Fox Mare; dam Old Polly, by Flying Childers, that appears on page 88, Vol. I., of the General Stud Book.

True Briton or Beautiful Bay, I 5 to $15 \mathrm{I} / 2$ hands; imported by Captain James De Lancey of New York, importer, as above, of Wildair and Lath, and also importer of the very celebrated Cub Mare. Captain De Lancey gave True Briton to his uncle, General Oliver De Lancey, who gave him to his nephew, James De Lancey, colonel of the Westchester Light Horse in the English army, from whom he was captured in the fall of 1779 by American scouts, who rode him into the American lines at White Plains, and soon afterward sold him to Joseph Ward, a merchant of Hartford, Conn., for $£ 60$. Ward kept him several years as a saddle and carriage horse and then traded him to Selah Norton of East Hartford, who used him in the stud and let him for stud service. 
Advertised 1784 at Landlord Miles Powell, Jr., Lanesboro, Conn.; 1785 by Justin Morgan, at his stable in West Springficld, Mass. ; 1788 and 1789 by John Morgan, at his stable in Springfield, Mass.; 179 I by Selah Norton, at East IIartford, Conn., but on June 6th notice published that he will not do service there; 1793, at stable of Landlord White, South Hadley, Mass. IIc was sire of the original Justin Morgan horse.

Mention of True Briton appears on page 26 of this book under Morton's Traveler, where reference is made to a letter giving his history, written for Volume II. of the American Morgan Register, by Mr. Edward F. De Lancey, now residing in New York, and a grandnephew of Gov. James De Lancey. The letter with introduction is as follows :

The following exceedingly interesting letter from Mr. Edward F. De Lancey, a grand-nephew of James DeLancey, and a gentleman now eightytwo years old, whose memory closely connects him with those living at the time that the events which he relates took place, is by far the best information ever published of the sire of Justin Morgan, Col. James De Lancey's war horse, True Briton; being the history of the horse as handed down in the family most interested, and who had the fullest knowledge of the facts.

$$
20 \text { East Twenty-eighth Street, New York City. }
$$

Joseph Battell, EsQ.,

$$
\text { July 3, I } 899 \text {. }
$$

Dear Sir:-Since my brief note of the 2 ist of June last I have seer the first volume of your "Register of Morgan Horses" at the New York Historical Society, of the executive committee of which I am chairman. and its domestic corresponding secretary.

I regret that I did not know of your "Register, Vol. I." nor or your presence in this city when you were compiling it, for I could have saved you from some of the errors as to the famous horse True Briton and his original New York owners--errors which have appeared in different books and papers before your work, having been generally copied by one writer from another, with or without acknowledgement.

Without attempting to correct those errors seriatim, I shall give you the facts as to the latter, and the ownership of True Briton, and how the horse was stolen from Col. James De Lancey of Westchester.

Mr. J. Fennimore Cooper, the novelist whom you refer to, was my uncle by marriage, whom I knew well from my earliest infancy till his death in September, I $85 \mathbf{I}$, at which time I was a married man of thirty years. His wife, Susan Augusta, was the second daughter, who lived to maturity, of my grandfather, Mr. John Peter De Lancey, of Heathcote Hill, Mamaroneck, Westchester County, New York, and a sister of my father, the late Rt. Rev. William Heathcote De Lancey, the first Bishop of Western New York. Mr. Cooper's letter, reprinted in your first volume of the "Register," which I knew of, contains a few errors, the natural result of his always writing letters to inquirers generally currente calamo, off-hand, as it were, and thus making mistakes without intending to do so. It would make this letter too long now 
to go into their correction, although not many, but I will state the real facts as they were known in the family.

My grandfather, John Peter De Lancey's eldest brother, was James De Lancey, the political leader of the Colony of New York on the Conservative side almost from the death of their father, Chief Justice, and later Governor, James De Lancey, who died at the head of the Province in July, 1760. James, the son, is always named in the Assembly Journals of New York up to the end of the Provincial rule, during all which time he was his party's leader, as "Captain" James De Lancey (a title from having served in his youth as a captain in the Provincial service in the old French war) to distinguish him from his first cousin of the same Christian name, who was one of the sons of his uncle, Peter De Lancey, of West Farms, Westchester County, New York, and his wife, Elizabeth, daughter of Governor Cadwallader Colden. This last named James De Lancey was the Colonel of the Westchester Light Horse during the Revolution, and the officer from whom the famous horse "True Briton," or "Beautiful Bay" was stolen in October, I 7 8o. Captain James De Lancey was a very influential man in his day, and a rich one, having inherited the very large estate of his father, the Governor, who died intestate. His wife and the wife of Governor John Penn of Pennsylvania were sisters, daughters of Chief Justice William Allen of that Province. He it was who imported so many blooded horses from England between 1760 and 1775 , in the old colony days of New York. He was in the habit, having many near relatives there, of going to England on visits every year or two, and he always sent out to New York fine blooded horses, mares, and other kinds of live stock, on these occasions. He possessed the great Bowery Farm of his father, the Governor, on Manhattan Isiand, of about 230 acres, with the fine large house which the latter built, and where he died. On this farm (now far below the heart of New York City) James De Lancey (the Captain) laid out a half-mile track, with the requisite stables, paddocks, and outbuildings, for his own private use solely. Here he kept his horses and mares and had them trained until the time of the Revolution.

In March, I 775, public affairs looking very threatening, he decided to sell a large part of his racing stock, and did so in the spring. In the autumn of the same year he disposed of the remainder, the advertisements of these sales filling large portions of the papers of the day. Later he returned to England, and his name being put in the Confiscation Act of New York in $\mathbf{I 7 7 7}$, and his estate forfeited, and a fine put upon his head, together with those of the fifty or more others named in the Act, he and his wife and children remained in England, where he died at his residence in the city of Bath in $\mathrm{I} 80 \mathrm{I}$, and was buried in Walcot Church in that city, where can be seen his mural monument.

This James l)e Lancey was the original owner of True Briton, a horse which was one of his importations from England. He was a bright bay, about fifteen hands in height, very active, and as gentle as he was active. In 1772 or 1773 Mr. De Lancey presented him to his uncle, his father's youngest brother, Oliver De Lancey, Colonel in Chief, as it was then termed, of the Colony Forces, the then designation of the Provincial Militia of the Colony of New York, for his personal use, being a very fine riding animal. His new owner was a man rising fifty years of age. He had a beautiful place of many acres, called Bloomingdale, on the North River, a name the locality still retains. He used him as a saddle horse, though a large man, rising six feet in height. This was the Oliver De Lancey who upon the outbreak of hostilities was appointed the Senior Brigadier-General of the Provincial forces of New York, of which he had been, for some years preceding, the Colonel-in-Chief, as its 
commander was then styled, and placed in command of I ong Island; a command he retained during the whole war, and who is known in history as lirigadier-General Oliver De Lancey. He was also included in the Confiscation Act of 1777 , and a price put upon his hearl, with those of the others therein named. At the close of the war he went to England with his family, and took up his residence in Yorkshire, at the city of Beverley, where he died in the autumn of 1785 , and lies buried in the north transept of the cathedral at that place, where his monument is to be seen to-day.

Brigadier-General De Lancey gave True Briton to his nephew, the Colonel James De Lancey of Westchester, mentioned in the beginning of the letter, This nephew was a very active and skilled horseman, as well as a man noted for his boldness and determination. For many years he had been "High Sheriff," as the term then was, of Westchester County, and Captain of the County "Troop of Horse" in its militia. When the war broke out a Provincial County Regiment of Cavalry was formed, styled the Westchester County Light Horse, and James De Lancey, Captain of the old County Troop, was made its Colonel, and hence is known in history as Colonel James De Lancey. His uncle, Brigadier-General Oliver De Lancey (who never was in command in Westchester County), then presented to him True Briton as the best horse he knew of for his purpose, he himself being then too old and heavy to engage in cavalry expeditions, or raids, as now termed. This was late in 1775 or early in 1776 .

This Colonel James De Lancey of the Westchester Light Horse owned and used True Briton thenceforward during all his military operations in Westchester (for his regiment never served outside of that county and New York Island) until he was stolen from him in October, 1780 , and carried off to Connecticut.

The real story of the theft is this, though many and different stories have been printed and told with little basis of facts, both at the time and since.

The West Farms estate and house on the Bronx, the larger part of which estate now forms the lately erected Bronx Park and Zoological Gardens in New York City, belonged to Mr. Peter De Lancey, the father of Colonel James De Lancey of Westchester above named, who had died a few years before the Revolution. At that time it was occupied by his widow, Elizabeth, daughter of Governor Colden above mentioned, and was the home of herself, Colonel James and his other unmarried brothers and sisters. There Mrs. De Lancey dwelt till her death soon after the Revolution. At this home, whenever the exigencies of military duty permitted, Colonel James De Lancey was in the habit of visiting his mother, it being a comparatively short ride from any part of the territory under his command. On one of these visits he rode over on True Briton from his camp, then at Kingsbridge, about the middle of October, I78o. "Rosehill," as Mrs. De Lancey's place was called, stood on high ground overlooking the Bronx river, and its valley, and on its left bank. The approach to the house from the right bank was across a bridge over the river below, and up a drive or roadway to the house, which stood a little back in shaded grounds. The Colonel, on his arrival, fastened his horse near the house, for in those war days he always kept him close at hand when away from camp. He had been some time in the house, when the quick sound of hoofs was heard, and looking out of the window he saw a man riding his horse rapidly towards the bridge.

$\mathrm{He}$ and his servants with the horses in the stables tried hard to overtake the thief, but in vain. True Briton's speed and bottom were too great, and the daring rider got off with the horse in safety, carried him into Connecticut, and sold him for his own benefit. Who this man was is not now known, as 
the deed, both at the time and since, has been ascribed to several men. $\mathrm{He}$ undoubtedly was one of those marauders so notorious at that day living between the lines, who robbed either side as they got a chance.

This, Mr. Battell, is the account of True Briton's origin, his owners, and himself before he was stolen as above stated. His history since that time you probably have fully investigated and know much more about it than I do.

It has always been said and believed in my family that this horse "True Briton" was imported from England as above stated. And it is certain that he was not a colt bred by Captain James De Lancey above mentioned, nor by his uncle Brigadier General Oliver De Lancey. I have often heard the horse spoken of, and the story of his theft told by different members of the different branches of my family. The horse and Colonel James De.Lancey of Westchester, his last owner there, were thoroughly well known to the old people of the lower part of the county of all ranks, a few of whom I am old enough to remember. It was always said, as old Andrew Corsa, "the last of the guides" of the American armies, told Mr. Lewis G. Morris that "True Briton" came from England. Mr. Morris, whom I knew well, told me the same story as told him by Corsa, and related in D. G. Linsley's "Morgan Horses," page I 22.

I may state, in closing, that there is little or no credence to be placed in the "Connecticut Courant's" story from Fishkill, N. Y., that one Wright Carpenter and two others stole the horse from Col. De Lancey's "quarters," at Kingsbridge, that he cost the Colonel $\mathcal{E}_{200}$, and "that $\mathcal{E}_{150}$ was offered for the horse as soon as he brought him in." It was only a mere camp story of the times, I suppose, and nothing else, as it had no basis of truth. I am, dear sir, yours very truly,

EDWARD F. DE LANCEy.

In the introduction of a work entitled "New York City During the Revolution," published in I86I, is the following reference to the De Lancey homestead:

"The elegant double brick residence of Mr. De Lancey on the eastern side of the Bowery extended to the present De Lancey street; and with its semi-circular gateway, its dense shade trees, and its fine gardens in the rear of the house, was one of the most attractive features in that part of the island."

Probably no breed of horses has had a greater popularity in so many different parts of the United States than the Morgans, and especially in those parts where they have been best known. They are best adapted to road and family use, but few being trained for track purposes. And yet of the 26 horses previous to 1860 who made a trotting record of $2: 30$ or better, eight certainly, and most probably ten, trace in direct male line to Justin Morgan, and six others had Morgan blood. The list of these early Morgan trotters is as follows :

Beppo, $2: 28$, to saddle, July $4, \mathrm{I} 843$.

Mac, $2: 29 \frac{1}{2}$ " “. . . . . . . June 5, I 849 . 


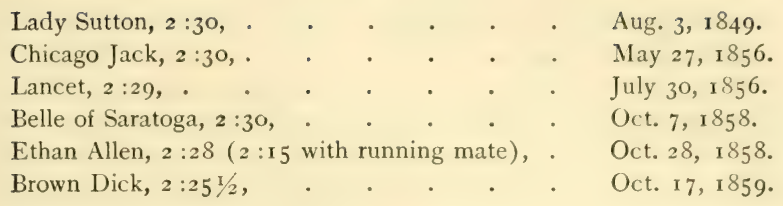

Beppo was the second horse to trot in $2: 30$, his record being made the same day as that of Lady Suffolk, which was the first, and in race with her, she winning the first heat and Beppo the second. For extended history of the Morgans, see The Morgan Horse and Register, Volumes I., II. and III. by author of this work.

Tom Bogus (Old Prisoner), said to have been presented by Lord Sterling to General Burgoyne during the Revolution, from whom he was captured. Kept in Newton, Conn., I788-90, and in Dutchess County, N. Y., I79I-I793, in charge of Job Slocum. A son of this horse, bay very perfect in form, was purchased when two years old in Dutchess County, N. Y., and brought to Marshall, Oneida County, by a Mr. Ellis. His stock noted for courage, with nervous and quick action.

Ellis' Bogus was the sire of Lame Bogus, foaled about 1818, whose shoulder was broken from a kick when he was a foal, resulting in one leg being several inches shorter than the other. Lame Bogus was sire of Loomis' Bogus, bred by G. W. W. Loomis of Sangerfield, N. Y. Loomis' Bogus was the sire of Flora Temple, one of the greatest of American trotters, and the first to trot under $2: 20$. The pedigree of this mare is given correctly in the "Breeder's Stud Book," but not in the "American Trotting Register." She is recorded in this last: "by Bogus Hunter son of Kentucky Hunter"; but there never was a horse called Bogus Hunter, nor any called Bogus, got by any horse called Kentucky Hunter. One-eyed Kentucky Hunter, and Bogus by Lame Bogus, were bred by G. W. W. Loomis, and both owned by Mr. Loomis when Flora Temple was got.

It has been understood that the dam of Flora Temple was by a horse called old Spot owned by Horace Terry, and it has generally been said that old Spot was Arabian and came from Long Island; but we notice that Mr. Wallace says (Wallace's Monthly, Vol. IV., page 74): "We understand Mr. Terry's son says his father got old Spot when a foal in Springfield, Mass.; while others say that Mr. Terry only a few weeks before his death represented that he got him 'on the Island' meaning, as is supposed, on Long Island." 
For fuller particulars in regard to Flora Temple, see the Introduction of this book page xxxii.

The fast old time trotters George Palmer and Damon were got by 'Ames' Bogus, son of Ballard's Bogus by Lame Bogus.

Another family which has been prominent in New York breeding is the Kentucky Hunters. These are descended in male line from Brown Highlander, thoroughbred, imported from England, with several mares and other stallions, to Litchfield, Conn., I797, by Col. Talmage \& Co. A son of this horse, bay, I $5 \frac{1}{4}$ hands, 1000 pounds: dam Nancy Dawson, thoroughbred, imported with the sire; was bred at Litchfield by Col. Talmage, who sold him to Julius Watkins, Torrington, Conn. who took him, I82 I, to Whitestown, Oneida County, N. Y., where he was awarded premiums,as published in the Columbia Gazette,-I 822, '23 and '24.

Watkins' Highlander was sire of the first Kentucky Hunter, afterwards called Old Kentucky Hunter. This horse was bred by Jacob \& Lewis Sherrill, New Hartford, Oneida Co., N. Y. ; foaled I 825 ; dam said to be brought from Kentucky. He was sold about I83 I to Dr. W. H. Kellogg, who sold an interest in him to J. W. Bagg, New Hartford, N. Y.; the horse was soon after sold to Wm. Ferguson, Oriskany Falls, whose property he soon died from effects of a kick.

Other noted horses, which have been credited to this family, but in regard to which there is some doubt, are Bay Kentucky Hunter, sire of Edwin Forrest (which passed to R. A. Alexander in Kentucky); Broken Legged Kentucky Hunter, chestnut, bred by Mr. Brown, Augusta, Oneida County, N. Y., got by Gifford's Kentucky Hunter; and Skenandoah, dark chestnut, bred by J. H. Sykes, Madison County, N. Y.; got by Broken Legged Kentucky Hunter: dam chestnut, bred by J. H. Sykes, got by Morgan Hunter Jr. This pedigree of Skenandoah and sire, is from R. C. Sykes, Canastota, N. Y., son of breeder of Skenandoah.

For further information of this family, see One-eyed Kentucky Hunter and Bay Kentucky Hunter.

Another horse, that through his descendants has become quite prominent in American breeding, is European, a handsome gray horse of Morgan .appearance, to which family he probably belonged, imported to Cambridge, N. Y., from Canada about I829. The horse was quite old at this time and died soon afterward; but left a son, the Morse Horse, bred in WVashington County, from which descended both the Bathgate Norman, and Alexander's Norman; the latter sire of Lula, 2:15, May Queen, 2:20, also sire of four sires of standard 
performers, of which Swigert has to his credit 46 trotters and 2 pacers, besides 39 sires of 65 trotters and 29 pacers, and 35 dams of 32 trotters and I I pacers.

For further information of this family, sec European in this volume.

Engineer, gray; $161 / 4$ hands; and said to have been very elegant in his style, form, and proportions. Advertised May 8, 1816 , in the Long Island Star, as follows:

\section{"THE ELEGANT HORSE FNGINEER}

"Will be kept the present season, at the stable of Daniel Seeley, near the Queens County Court House, on Mondays, Tuesdays and Wednesdays; and at the stable of the subscriber, in Jericho, the remainder of each week, during the season, at five to twelve dollars. Engineer is a gray, sixteen hands and one inch high, lofty carriage, and finely formed; he has a great share of bone and sinew, possesses an excellent temper, and is considered a very superior mover. He was brought into this place last fall, and covered a few mares and proved himself a sure foal getter. The manner he came in to this country is such that I cannot give an account of his pedigree, but his courage and activity show the purity of his blood, which is much better than the empty sound of a long pedigree too often inserted. Those who are desirous of raising good horses are requested to call and see him and judge for themselves."

Mr. Wallace states, in his magazine, Vol. I., page 743 , that the parties who owned the horse on Long Island said that he was imported to Canada from England, and ridden in the war of 1812-14 by an English officer from whom he was captured.

A son of his known as Burdick's Engineer was kept for many years in Warren and neighboring counties in New York. Of this son Wm. Arthur, a prominent citizen and noted horseman, of Ticonderoga, N. Y., in an interview with the writer in I886, said: " A man by the name of Weatherhead had Engineer in West Moriah. They said the horse was twenty years old. I was born in 1822 , and took a mare to this horse in $1836-37$. He was then standing at Crown Point. He was a handsome chestnut horse, sixteen hands high, very round barrel, the roundest I ever saw. He was a little thick headed - short, thick head, not fine. He had a heavy, dark mane and tail. He was a good quarter horse, and could trot in three minutes. He went back to Warrensburg and at last to Glens Falls. I think he lived to be about thirty-five years old. The story they told about his origin was this: That a horse was captured from a British 
officer, which he afterwards ransomed, and they were taking him to his owner, who was then in Canada, when this colt was bred."

To question whether this account of the horse was believed, Mr. Arthur replied: "The Warrensburg folks and Mr. Weatherhead believed this as much as I believe you have got that hat on your head."

A similar story concerning his importation from England to Canada and capture from an English officer in the war of $1812-14$, was told us in connection with the history of the Kasson Horse, another son, kept in Central Vermont for many years.

This statement of the importation of the horse may or not have been true, but it is the only credible history there is of him, and was evidently believed by those who owned his stock. Both the Kasson Horse and Burdick's Engineer were horses of much excellence, and lived to a remarkable old age. But Engineer is best known in the history of American horses through still another son, Engineer 2d, who was the sire of Lady Suffolk, the first trotter to beat $2: 30$, and one of the most famous of all old time trotters.

Zilcaadi, sorrel, four white feet; foaled 1825 ; imported from Constantinople, with Stamboul and two other Arabian stallions, by Charles S. Rhind, United States Consul to Constantinople, to whom they had been presented by Sultan Mohmond. The United States would not permit Mr. Rhind to retain these horses, and had them sold at auction. Zilcaadi was purchased at the sale, or soon after, by the Hon. Joseph Johnson, who took him to Louisiana.

His blood enters into the Great American family of trotters and roadsters through the celebrated Kentucky stallion Golddust, whose dam was by Zilcaadi.

The following letter from Mr. Rhind appears in the "Sporting Magazine" of July, I $8_{32}$ :

New York, May i6, I832.

You request me to give you some account of the Arabian horse Zilcaadi, which you purchased at public sale on the I th inst. This is one of the horses sent me by Sultan Mahmond, a few days before I left Constantinople. I took him from thence to Smyrna, where I embarked for this port. He was pronounced by the best judges, both at Constantinople and Smyrna, to be a genuine and very fine Arab. His colour is sorrel with four white feet-he is of the tribe raised on the borders of Syria; was six years old last grass.

The Arab horse is seldom above I4 hands high, and those I brought were unusually tall - the stallions of this race are considered good for covering until they are twenty-five years old; I am persuaded the colts of this horse will prove the high intrinsic value of 
the animal. Zilcaadi is of the breed most preferred by the Sultan. Very respectfully yours,

(HARLES RHINH.

Hedgeford, dark brown with star, $161 / 2$ hands; foaled 1825 ; bred by Mr. Mytton; got by Filho da I'uta, son of Haphazard by Sir Peter Teazle: dam Miss Craigie by Orville. For extended pedigree, see alphabetical list of imported horses.

Imported, I 832, to New York, by Wm. Jackson. Advertised I 833 near Boydton, Va., by John C. Goode, at $\$ 50$. Afterwards went to Kentucky, probably in I834, where he died in I840.

Hedgeford has become prominent among American horses by his son Denmark, who, crossed to Canadian Morgan stock, produced Gaines' Denmark, foaled I85I, and Rob Roy both noted sires of saddle horses, and admitted as foundation stock in the National Saddle Horse Register. The dam of Denmark was Betty Harrison by Aratus, and her dam the dam of Timoleon.

The National Saddle Horse Register says: "The Denmarks are universally intelligent and add to a graceful movement at all the gates under saddle, a way of going in harness that peculiarly fits them for a place in the all purpose class. They are also tractable, hardy and generally useful where a safe family horse is wanted. The best results have come from mating the Denmark sires with mares from certain strains of Canadian or other pacing blood."

Gaines' Denmark, the most renowned of the Denmark saddle horse progenitors, was black with white hind feet and small star, 15 I/2 hands high, bred by Wm. V. Cromwell near Lexington, Ky., foaled I85I; died I864. Dam brown, owned by Judge John Stephenson of Fayette County, Ky., known as the Stephenson Mare and said to be by Cockspur, which is said to have been the son of a Canadian pacer of same name, foaled about I825, and imported from Canada to Missouri. We notice that Mr. Wallace in his book, "The Horse of America," page 194, says of Denmark, whose grandam was the dam of Timoleon; "I have taken some pains to examine his pedigree; his sire was thoroughbred, his dam and grandam were mongrels, and the remoter crosses were impossible fiction." The remarks made in this work upon the pedigree of Timoleon, although they agree with Mr. Wallace, were made before seeing this criticism.

INTO PENNSYLVANIA.

Whirligig, bay, I5 hands; foaled 1863 ; said to be by Captain, son of Young Cartouche: dam by Devonshire Black Legs-True Blue 
-Lord Oxford's Dun Arabian-D'Arcy's Black Legged Royal Mare; was imported by John Allen to Philadelphia I773, and is advertised I776 at Mr. Hunt's in New Jersey, at which time Miss Slammerkin (owned by Mr. Hunt), by Wildair, was probably bred to him, and produced the mare that was the grandam of Mambrino. The American Turf Register states that he was kept in North Carolina, 1777 .

Messenger.-In I788, the celebrated gray horse Messenger foaled I780, was imported into Pennsylvania, where he was kept near Philadelphia six years, when he was removed to Long Island, where, and in New Jersey and vicinity of New York city, he remained until his death, December, I808. He was $15 \frac{1}{2}$ hands and good weight, descended in direct line through Mambrino that was noted in England for his substance and trotting action, and whose elegant picture by Stubbs we publish, from Sampson, a running horse of unusual size. Nambrino was by Engineer, son of Sampson. Sampson was by Blaze, son of Flying Childers : dam called a Hip mare, unknown, but supposed to be part bred. Third dam of Engineer also unknown. Messenger was more compactly built, and perhaps on that account possessed trotting action more than the majority of running horses. And crossed on to Dutch or common and part-bred mares, which abounded in the locality in which he was kept, he produced many animals that were especially well adapted to road and practical uses, so that the stock then grew very largely in popular favor and were widely distributed over the country. Messenger himself, and probably his ancestors from the time of Sampson, had some coarse qualities which were perpetuated more or less in all, or nearly all, of his stock, and probably because of these the stock in male line eventually largely ran out. Sampson, the progenitor of Messenger, was a very successful race-horse, but Mambrino is described by Weatherbee as "a very moderate race-horse, as was also his son Messenger." The lack of speed was perhaps another reason why the blood of Messenger, in many respects so popular, became in male line so nearly extinguished. Only through his son Mambrino has the family been largely perpetuated in male line. But Mambrino traces directly through his dam to the famous Wildair, a great source of speed; and in trotting lines this strain was further mainly perpetuated where reinforced by cross to the noted trotter Bellfounder, imported from England and a descendant of the famous family of Norfolk trotters, the fastest of their day. The idea, largely sustained by fraudulent and unreliable pedigrees, 
which has been advanced by an enthusiastic admirer of Messenger that he was the principal source of trotting speed in this country, is very absurd. He was undoubtedly a producer of trotting action, also produced from many other sources, but the element of speed, where it appears, would appear to be more properly traced elsewhere. The "American Turf Register," November, I 834, says:

"Desirous of preserving all that at this late day is remembered of an animal which has done so much to improve our stock of horses, we will close this brief account of him with extracts from letters received from Mr. Van Ranst, one of his former owners, who speaks with the enthusiasm of a man who has judgment to distinguish, and a heart to love what is noble, generous and faithful-even though these qualities be found in - a horse.

'In looking over some papers relating to the horses formerly owned by me, I have found a sketch taken by the hand of an artist of my old favorite horse Messenger.

'This draft was taken seven years previous to the death of Messenger, and will enable you, through the medium of your Register to transmit an exact likeness of this noble horsi. Every person who was accustomed to view the strong and powerful form of Messenger, will, I believe, at first view, pronounce this to be a true and faithful likeness.

'Messenger, when landed, was a light dapple gray, but afterwards became white. He had a large full black eye, remarkably brilliant. His movement and action were elegant. His standing, never careless, I never saw him resting himself on three legs, but whether the ground was rough or smooth, he always stood upon it - prompt, erect and lofty; looking apparently beyond this world, "at the clouds beyond it,"- - such was the common and striking attitude of Sir Charles." "

"In a subsequent letter, Mr. Van Ranst observes - Messenger was imported by Mr. Benger, in the year I79I, and landed in this city; where I saw him shortly after, and my mind was fixed on his being much the best horse I had ever seen, and said nothing about a price, as I was confident he was over my mark.

“ 'Mr. Benger shortly after took him to Pennsylvania where he was kept at Shamnay bridge, not far from Bristol, two seasons. After which Mr. Henry Astor, of this city, purchased and kept him two seasons on Long Island, at Philip Platts, "which took with our horsemen "; the next spring I bought one-third, and took him to Pine Plains, Dutchess County-covered IO$_{5}$ mares, very few any pre- 
tensions to blood. After which I bought Mr. Astor out, for which I paid $\$ 2750$. I hired said horse at different stands, the farthest south was Cooper's Ferry, opposite Philadelphia, at $\$ 1600$ per season, free of expense, until the time of his death, January 28 , I 808 , at the farm of Mr. Townsend Cock, L. I., who had hired him three seasons.

Mr. Van Rantz is wrong as to date of importation of Messenger, and probably also as to place of importation. An advertisement in The Pennsylvania Packet of May 27, 1788, states that he was just imported and would cover that season at the sign of the Black Horse in Market street, Philadelphia.

Mambrino, the sire of Messenger, was gray, bred by Lord Grosvenor, foaled i 768, got by Engineer: dam, foaled i 76I, got by Cade son of the Godolphin Arabian; 2nd dam by the Bolton Little John son of Partner by Jigg, son of the Byerly Turk; 3d dam Mr. Durham's Favorite by a son of the Bald Galloway; 4th dam by a foreign horse of Sir T. Gascoigne's.

Engineer was brown; foaled I756; bred by Mr. Fenton; got by Sampson: dam by Young Grayhound; 2nd dam by the Curwen Bay Barb.

Sampson was bay; foaled I 745 ; bred by Mr. Robinson; got by Blaze son of Childers: dam by Hip; 2nd dam by Spark son of Honeycomb Punch-Snake-D'Arcy's Queen by a son of Hautboy -Brimmer-Royal Mare.

Blaze was bay, foaled I 733, bred by Mr. Panton; got by Childers: dam Confederate Filly, by Grantham, son of Brownlow Turk -Duke of Rutland's Black Barb-Bright's Roan, bred by Mr. Leedes said to be got by his Arabian, sire of Leedes.

Childers was bay, with blaze and four white feet; bred by Mr. Childers; foaled I7 I5; got by the Darley Arabian: dam Betty Leedes by Old Careless; 2d dam Leede's Arabian Mare, sister to Leedes, and sometimes called Cream Cheeks-Spanker-Old Morocco Mare.

Darley Arabian was brought from Smyrna by a brother of Mr. Darley of Yorkshire.

The above is as given in the General Stud Book. As is well known Mr. John H. Wallace, was a great admirer of Messenger and his stock. In his book, "The Horse of America," page 208, he makes the following comments upon above pedigrees:

"The pedigree of Childers on the maternal side is one of the oldest in the Stud Book, and we are not aware that any charges have ever been made against its substantial authenticity. 
"Blaze, the son of Childers, was foaled 1733 , and was out of a mare known as 'The Confederate Filly,' by (iray Grantham; her dam was by the Duke of Rutland's Black Barl, anıl her grandam was a mare of unknown breeding called 'Bright's Roan' Here the maternal line runs into the woods, but this is not the only defect in the pedigree, for the dam of Gray (irantham was also unknown.

"Certainly this horse cannot be ranked as thoroughbred under any rule, English or American, that has ever been formulated. Only three generations away we find two animals of hopelessly unknown breeding.

"Sampson, the son of Blaze, was foaled I 745, and he has occupied a very prominent and at the same time unique place in running-horse history. He was not only a great race horse, at heavy weights, but he was considered phenomenal in his size and strength, and in his lack of the appearance of a race horse.

"A number of historians have told us of the merriment among the grooms and jockeys when Sampson made his first appearance on the turf. The question was: 'Has Mr. Robinson brought a coach horse here to run for the plate?' The laugh was on the other side at Malton that day, however, when the 'coach horse,' carrying one hundred and forty pounds, won the plate in three heats. The distance was three miles, and Sampson was then five years old. At long distances and at high weights Sampson was a firstclass race horse for his day. But, notwithstanding all this, we are told that his blood never became fashionable, for there was a widespread conviction that he was not running-bred on the side of his dam. The historians tell us that he transmitted his own coarseness and lack of the true running type in a marked degree, which was very evident in his grandson, Mambrino.

"His pedigree has been questioned from the day of his first appearance to the present time, and we have made a very careful study of all the facts at our command. In the first edition of his Stud Book (I803) Mr. Weatherby gives his dam as by Hip : g. d. by Spark, son of Honeycomb Punch; g. g. d. by Snake and out of Lord D'Arcy's Queen. This has not been materially changed in any of the subsequent editions, and we think it may be taken for granted that the horse was advertised under this pedigree. Mr. Weatherby commenced work on pedigrees in $179 \mathrm{I}$, and avowedly accepted the best information he could get with regard to old pedigrees, regardless of the source. We are not aware that he ever investigated anything outside of his office work, if he did he never gave the public the benefit of the details of his investigations. John Lawrence commenced work on horse history long before Mr. Weatherby commenced as a compiler of pedigrees, and he was altogether the ablest writer of his day, or perhaps we might add, of any other day. He was a clear and independent thinker and a vigorous writer. In his 'History of the Horse in all His Varieties and Uses,' on page $28 \mathrm{I}$, he thus discusses the question of Sampson's pedigree:

" "Nobody yet ever did, or ever could assert positively that Jigg was not thoroughbred, but the case is very different with respect to Sampson: since nobody in the sporting world, 
either of past or present days, ever supposed him so. Nor was the said world at all surprised at Robinson's people furnishing their stallion with a good and true pedigree, a thing so much to their advantage. Having seen a number of Sampson's immediate get, those in the Lord Marquis of Rockingham's stud and others, and all of them, Bay Malton perhaps less than any other, in their heads, size and form, having the appearance of being a degree or two deficient in racing blood, I was convinced that the then universal opinion on that point was well grounded. I was (in 1778 ) an enthusiast, collecting materials for a book on the horse. It happened that I wanted a trusty and steady man for a particular service, and opportunely for the matter now under discussion, a Yorkshire man about threescore years of age was recommended to me, who had recently been employed in certain stablcs. I soon found that his early life had been spent in the running stables of the North, and that he had knowu Sampson, whence he was always afterward named by us "Old Sampson," He was very intelligent on the subject of racing stock and his report was as follows. He took the mare to Blaze, for the cover which produced Sampson, helped to bit and break the colt, rode him in exercise and afterward took him to Malton for his first start, where, before the race, he was ridiculed for bringing a great coach horse to contend against racers. On the sale of Sampson this man left the service of James Preston, Esq., and went with the colt into that of Mr. Robinson. His account of Sampson's dam was that she appeared about three parts bred, a hunting figure and by report a daughter of Hip, which, however, could not be authenticated; and the fact was then notorious and not disputed in the Yorkshire stables. * * * Mr. Tattersall lately showed me a portrait of Sampson in his flesh, in which this defect of blood appears far more obvious than in one which I had of him galloping.'

"Again, in his great quarto work, issued I 809, Mr. Lawrence reiterates his belief that Sampson was not thoroughbred. He says :

" 'I am by no means disposed to retract my opinion concerning Robinson's Sampson Not only did the account of the groom appear to me to be entitled to credit, but the internal evidence of the horse's having had in him a cross of common blood is sufficiently strong by the appearance both of the horse himself and of his stock; an idea in which every sportsman, I believe, who remembers Engineer, Mambrino and others will agree with me.'

"Here then, we have the answer to the whole enquiry reduced to its simplest form. The groom who coupled the mare with Blaze from which came Sampson says the mare was called a Hip mare, but that her pedigree was really unknown. For the intelligence and honesty of this groom Mr. Lawrence does not hesitate to vouch, and he adds the common belief of all the Yorkshire sportsmen of that day, who knew the mare, that she was of unknown breeding. This evidence is further supplemented by the family characteristics of the stock descended from Sampson, to say nothing of the great lack of 'blood' in the appearance of Sampson himself. As against this, we have the dry, unsupported assertion of Mr. Weatherby, forty years after the event, and probably copied from an advertisement of the horse.

"Engineer, son of Sampson, was a brown horse, foaled $\mathbf{1 7 5 5}$, and was out of Miner's dam, by Young Grayhound; grandam by Curwen's Bay Barb, and the next dam unknown. This is all the ppedigree that has ever been claimed for this horse, and falls far short of the rank of thoroughbred. There is a discrepancy of one year between Weatherby and Pick in the age of the horse, and we find Pick is right in giving his date as 1755 .

"Notwithstanding the absence of Eastern blood, Engineer was a race 
horse of above average ability, although not so good as another son of Sampson called Bay Malton. A few of his sons aside from Mambrino ran respectably, and his daughters were at one time, highly prized as brood mares.

"Mambrino, the son of Engineer, was a great strong-boned gray horse, bred by John Atkinson near Leeds in Yorkshire, and was foaled I 768. His dam was by Cade, son of the Godolphin Arabian; grandam by Bolton Little John ; great grandam Favorite by a son of Bald Galloway ; great great grandam (the dam of Lord Portmore's Daffodil) by a foreign horse of Sir 'T'. Gascoigne's. The Cade mare produced Dulcine, a noted performer, and the mare Favorite was a distinguished performer herself. The poverty of this pedigree is all on the side of the sire.

"Mambrino was not put upon the turf till he was five years old, he proved himself a great race horse in the bes: company and for the largest class of stakes. He was on the turf most of the time for five or six years and until

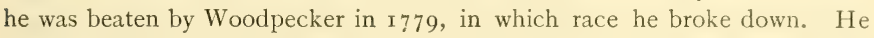
was beaten but four times, and paid four forfeits. He went into the stud in I 777, although he ran after that, at Iogs. Ios. 6d. to cover thirty mares besides those of his owners. In 1779 he was again in the stud, in Cambridgeshire as before, at the same price; $178 \mathrm{I}$ he covered at $50 \mathrm{Ogs}$. IOs. 6d. ; I 785 at 25 gs. Ios. $6 \mathrm{~d}$.; 1776 he dropped back to I5gs. Ios. $6 \mathrm{~d}$.

"We give these prices to show the variations in the estimated value of his services. As a sire of race horses Mambrino was not successful. Some fifteen or twenty of his progeny ran more or less respectably, but none of them was at all comparable with himself."

Four trotters with records of $2: 30$ or better previous to 1860 , trace in male line to Messenger, viz:

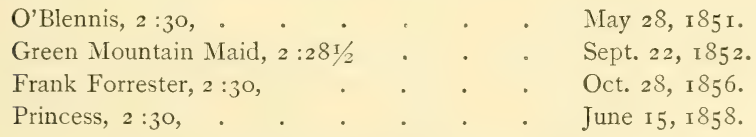

For extended history of Messenger and his sons, see chapter under Pennsylvania.

\section{INTO CONNECTICUT.}

Arabian Ranger, gray, changing to white; I5 hands; foaled I762. The first known advertisement of this horse is in 1776 in the Connecticut Courant to stand near Hartford in charge of James Nicholls, in which he is described, as of "A fine dapple gray color, rising I 5 hands high, and is allowed by competent judges to be the completest horse ever brought to America." The advertisement also states that: "He is a horse of fine strength and beauty, equa] 
perhaps to any in America of the true Barbary breed, bred in England," and says further: "He is the same horse that was in my keeping last season." This advertisement is substantially repeated in 1776 . In 1778 , his advertisement in the same paper states that: "The improved Arabian horse called the Ranger, formerly owned by Colonel Wyllis, of Hartford, is now owned by James Hyde, of Windham." Hyde advertised him again in 1779 , and later in the same year he was advertised by William Lindsay in the Virginia Gazette to be at his farm near Port Royal, Va. Captain Lindsay is said to have paid for the horse 125 hogsheads of tobacco, equal to 605 guineas. His stock was highly valued, and he left many sons kept for stock purposes.

It is said that the uniform elegance, courage, endurance and docility of Arabian Ranger's get in the Connecticut cavalry attracted the attention of Generals Washington and Lee in 1776 , and that they advised Capt. Lindsay to purchase, him.

The Albany Register of April 30, ISI I, says: "More elegant saddle horses were bred from the old Ranger, or Hartford horse, than from any three other horses ever imported to America. The second dam of Justin Morgan, founder of the Morgan family of horses, is said to have been by a son of Arabian Ranger.

For further account of this horse and his progeny, see Chapter under Connecticut.

King IVilliam, bay; foaled I 777 ; bred by A. Smith, England; got by Herod: dam Madcap, foaled I771, got by Snap-Miss Meredith by Cade. Imported to Connecticut by A. Skinner \& Co., of Hartford, in I796, and kept at Stamford, Conn., that season, and at Colonel Orcutt's, Norwich, Vt., I797. Advertised, I804, in the Greenfield Gazette to stand in Deerfield, Mass. Pedigree and history as above. This horse appears under his dam, page 307, Vol. J., General Stud Book.

Henry Watson writes from Connecticut to the New York Spirit of the Times, r 843 :

"King William, Matchem, Guido, Benjamin, and two or three more thoroughbred horses were imported from England to Hartford about $179^{8}$, and some of them were kept there several years. King William left many valuable horses in the country; think he was finally taken to Vermont."

It is very probable that the King William here referred to was the horse of that name, said to be an English thoroughbred, owned about ISOS-I 4 by Joel Doolittle, of Shoreham, Vt., and thought to be 
the sire of Allen Smith's Liberty, of Addison, Vt., which is credited with dams of Sherman Black Hawk and his son Vermont Hero, the sire of General Knox, from which many of the best roadsters and some of the fastest trotters and pacers have descended.

Liberty also got the dam of IVarner's Sir Charles (son of Sir Charles by Duroc), and probably the dam of Young Columbus, one of the early noted Vermont sires of trotters.

Brown Highlander, bred by Thomas Ardelle; got by Paymaster, son of Blank: dam by Herod; $2 \mathrm{~d}$ dam by Eclipse; $3 \mathrm{~d}$ dam by Lancaster Starling; 4th dam by Wildair; was imported fall of 1797 by Colonel Talmage, Litchfield, Conn., who imported, at the same time, Brilliant, Sir Peter Teazle, and Drone, sometimes called Herod, and some mares. Brown Highlander, was kept at Litchfield, several seasons, afterwards in New Jersey and Dutchess County, N. Y., and was advertised ISII and ISI6, at Goshen, Orange County, N. Y.; terms, $\$ 8$ to $\$ 12.00$. A son of this horse, known as Watkins Highlander, I 5 1/t hands, bred by Colonel Talmage, Litchfield, Conn., dam Nancy Dawson a thoroughbred mare imported at same time with Highlander, was sold to Julius Watkins, Torrington, Conn., who took him I 82 I to Whitestown, N. Y., and later to New Hartford, N. Y., where he died I822. This Watkins' Highlander was sire of the original Kentucky Hunter, foaled I 822, and bred by Jacob \& Lewis Sherrill of New Hartford, Oneida County, N. Y.: dam said to be from Kentucky.

\section{INTO MASSACHUSETTS.}

Dey of Algiers, described in the American Turf Resister of I 832 , as a nearly white horse with a few brown spots dashed over his neck and shoulders, fourteen hands, two and a half inches high, of fine figure, great bone and substance, of commanding presence, attractive carriage, and remarkably vigorous and active. $\mathrm{He}$ was procured in Arabia when four years old, by Grand Bailiff Fromm of Prussia, and brought to Fehr Bellen in that kingdom, where he was purchased after the bailiff's death, at the sale of his stud, in I 779, by Lieutenant-General Frederick, Baron of Diemar, by whom he was sold to Colonel Swann of Massachusetts (then in Europe), and by him shipped from Hamburg to Boston, to General Jackson of that city. In I 802 General Jackson sent him to General Mason, of the District of Columbia. He left many descendants in New England, Maryland and District of Columbia; and some of the best horses bred in Maine, New Hampshire and Vermont trace to him, including the famous Morgan stallion Fearnaught, that at one time held the world's 
trotting stallion record. He died in July, I807, near Fredericksburg, Va.

Grand Bashaw, iron gray, I4 $1 / 4$ hands; was foaled 1815 , and imported to Boston, August, I820, from Tripoli, by Joseph C. Morgan. He went from Boston to Lower Merion, Montgomery Co., Penn., and stood there several years. In 1827 he was at Whitemarsh, I 2 miles from Philadelphia. Received first premium at Pennsylvania State Fair, I823; still owned by J. C. Morgan.

The following certificate of his pedigree is copied from Pennsylvania Agricultural Report for 1823 :

“I, John A. Carstemon, his Danish Majesty's consul-general at Tripoli, in the West, do hereby certify that on the 24th of May, I8I9, J. C. Morgan, Esq., of the United States of America, purchased from me an iron gray Arabian horse rising four years old. This horse was begotten by the late Bey's favorite horse, Khasnadger, celebrated in this place for his beauty and other excellent qualities, from a fine mare of the country; is of very best blood to be obtained here. Signed, J. A. Carstemon.

"Tripoli, in the West, May 24, I819."

"I do hereby certify that I am fully acquainted with all the facts stated in the certificate relating to the famous horse called the Grand Bashaw, and that it is entitled to full faith and credit.

$$
\text { " Signed, Richard B. Jones, U. S. Consul." }
$$

The following interesting letter of Richard B. Jones has been published :

"Philadelphia, April 25, I 865.

"Dear Sir:-Still suffering from a neuralgic attack in my head, I comply with your request as far as I can, with perfect reliance on its accuracy.

"In ISIS I loaned to some Danish officers a very valuable Arabian horse; by accident they killed him. On the following morning I found Grand Bashaw in my stable to replace him. I declined, under the circumstances, any compensation, and suggested to Mr. Morgan, residing with me, to purchase, and by virtue of my official influence, would assist him to facilitate his embarkation to America. In I 8 I 9 he took him to Italy, and from there to Marseilles, where he joined me on my way to the United States. We sailed from there to Boston, and arrived the 20th of August, I820. From there he was taken to Lower Merion, Montgomery Co., Penn., and stood there several years. Grand Bashaw was a beautiful black, with a small white star and snip. He was a Barb of the finest quality in every respect, but their pedigrees are not kept with the care of the Arabians. I 
have no personal knowledge of the mares bred to him, but have seen many of his descendants, all showing a resemblance to the original sire.

"Grand Sultan was imported by me at the same time. He stood one, if not two, seasons at Salcm, N. J., under charge of Michael Hackett, Esq, about I822 or I823. He was an iron gray, of the Arabian stock, and had many colts and fillies there.

"Saladin was imported by me at the same time, superior, in my opinion in purity of blood, size and form, to either of the others. I sent him to North Carolina, where he improved the stock, and from thence to Georgia, where he died. Grand Bashaw was about I 4 hands and an inch high.

"In conclusion, I remain respectfully yours,

$$
\text { RICHARD B. JONES. }
$$

The famous Clay and several other trotting families are descended from Grand Bashaw. Three of the early $2: 30$ trotters trace to him in male line.

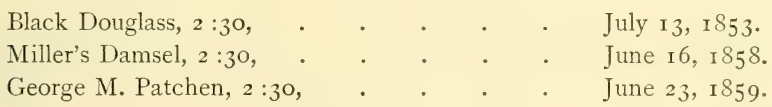

Bellfounder.-Though not thoroughbred, this horse became so important a factor in the production of the American trotter, from being sire of the dam of Hambletonian, that we include him in this chapter. He was bred in England, foaled 1816 , and imported to Boston, Mass., July 22, I 822, by James Boot of that city.

Bellfounder belonged to the English hackney or Norfolk trotting family, whose history appears at length in Volume I. of this work. Besides the dam of Rysdyk's Hambletonian, Bellfounder got the dam of Sayre's Harry Clay, which not many years since disputed with American Star and Mambrino Chief the title of greatest sire of brood mares. He also got the grandam of Green's Bashaw, who died in I880, and was one of the best sires of his day. Bellelupe, by Brown's Bellfounder, produced the very great brood mare Belle by Mambrino Chief, who was the dam of Belmont, the most successful son of Alexander's Abdallah. Several other horses of distinction trace to Bellfounder.

Mr. Boot kept the horse for several years at Charlestown, Mass., and in the spring of 1829 he was leased by Timothy T. Kissam for five years, and stood on Long Island and in Westchester, Jefferson and Orange Counties, N. Y., his last season in the last named county being in 1833 at Washingtonville, and here he was bred to One Eye, 
and got the Charles Kent Mare which became the dam of Hambletonian, and was also the grandam of Green's Bashaw. Later Bellfounder was owned by Henry Van Cott, and died his property, on Long Island, in I 843.

The first advertisement of the horse in this country was as follows:

"BELLFOUNDER.

The Wonderful Norfolk Trotter.

Imported July, I822, from England.

To Cover

This Season 1823

At 20 Dollars and six Shillings the Groom

The Money to be paid to the Groom at Covering.

"This celebrated Horse is a beautiful bright Bay, with black legs, 7 years old, standing I $_{5}$ hands high; his superior blood, symmetry and action excel every other trotting stallion. He is allowed by the best Judges in Norfolk to be the fastest and best bred Horse ever sent out of that county. He has proved himself a sure foal-getter, and his Stock for size and substance are not to be surpassed: they are selling at the highest prices of any Horses in Norfolk.

"Bellfounder was got by that well-known fast and high formed Trotter, Old Bellfounder, out of Velocity, by Haphazard, by Sir Peter, out of Miss Hervy, by Eclipse: grandam was of good North Country blood, but not thoroughbred. Velocity trotted on the Norwich road in I So6 sixteen miles in one hour, and she broke I 5 times into a gallop, and as often turned around, winning her match. In I $80 S$, she trotted twenty-eight miles in one hour and forty-seven minutes, and has also done many other great performances against time.

"Belfounder at five-year-old trotted two miles in six minutes, and in and the following year was matched for 200 guineas to trot nine miles in thirty minutes, which he won easily by twenty-two seconds. His owner shortly after challenged to perform with him seventeen miles and a half in one hour, but it was not accepted. He has since never been saddled or matched.

"Old Bellfounder was a true descendant from the original blood of the Fireaways, which breed of horses stands unrivalled for the saddle, either in this or any other nation.

"Bellfounder is strongly recommended to the public by Mr. S. Gooch of Chelmsford, and by Mr. Woodfield, Moonfields, London."

Several other advertisements of the horse are at our command, but this earliest one covers the ground completely. In considering the speed claimed for these Norfolk trotters it must be taken into account that when the foregoing advertisement was published the 
best record for a trotter in this country was three minutes, by Boston Blue, and the foals of Bellfounder and Velocity appeared phenomenal. Like the Morgans, these Hackney trotters were distinguished for purity of gait, style and endurance, and the great success of Hambletonian as a progenitor of trotters, is due, no doubt, to these characteristics of imported Bellfounder, as much as to any other single source.

\section{INTO RHODE ISLAND.}

Among the most famous of the early American horses were the Narragansetts of Rhode Island. They were especially adapted to the saddle, and noted for their speed at the pacing gait. There is a tradition that they were descended from horses imported from Andalusia in Spain. We have already seen (page 6) that the horses brought to America by Columbus came largely from Andalusia.

Sidney in his "Book on the Horse," says:

"The Spaniards have been famous for their horses from the earliest historical times. The Andalusian horse was acknowledged to be the best in Europe until the English produced the thoroughbred.

"The mares of the Spanish Genet breed (famous since the wars recorded by old Froissart) are kept and much valued as riding horses for long distances by wealthy Spaniards. The Genet, a light, slim, blood-like animal, is the evident descendant of the Barbs brought into the country by the Moors, when they conquered the greater part of Spain."

Mr. Cooper, the novelist, in a foot note to "The Last of the Mohicans," says :

"In the State of Rhode Island there is a bay called Narragansett, so named from a strong tribe of Indians that formerly dwelt on its banks. Acci- dent, or one of those unaccountable freaks which nature sometimes plays in the animal world, gave rise to a breed of horses which were once well known in America, by the name of Narragansetts. They were small, commonly of the color called sorrel in America, and distinguished by their habit of pacing. Horses of this race were, and still are, in much request as saddle horses, on account of their hardiness, and the ease of their movement. As they were also sure of foot, the Narragansetts were much sought for by females who were obliged to travel over the roots and holes in the new countries."

Through different channels the Narragansett has contributed in a marked degree to the production of the American road horse. Thus the dam of Sherman Morgan, one of the most renowned sires 
of road horses that the country has produced, came from Rhode Island and was said to be of the Spanish breed. Unquestionably the Canadian pacer as well as other pacing familes sprang in part from the Narragansett. For extended history of this breed see chapter under Rhode Island.

INTO NEW JERSEY.

Expedition, chestnut; foaled I795; bred by Lord Egremont; got by Pegasus: dam Active, by Woodpecker-Laura by Whistlejacket-Starling-Second-Stanyan's Arabian-King William's NoTongued Barb (Chillaby)_Makeless-Royal Mare. Imported by Mr. Willis in I8OI and was kept in New Jersey. Advertised, by Joshua Humphreys, in Moorestown, N. J., nine miles from Philadelphia, at the stable of Thomas Porter, sign of the Golden Fleece, at $\$$ I 2 to insure a foal.

A line of trotting stock is descended from this horse through his son, Sea Gull. Sea Gull was bred by Joseph Van Mater of New Jersey : dam by imported Sour Kraut ; 2 d dam by imported Slender; 3d dam by Lloyd's Traveler. He was the sire of American Boy, bay, foaled I 822 , bred by Daniel Holmes, New Jersey: dam chestnut, by imported Expedition. American Boy went to Cincinnati or vicinity about $\mathrm{I} 840$, and died there $\mathrm{I}_{4} 7$. He was the sire of American Boy Jr.: dam Matchless by Cincinnatus, son of Shakespeare; $2 \mathrm{~d}$ dam the dam of Brown Highlander.

American Boy was also the sire of Belmont, bay, I 5 hands; foaled I 847 ; bréd by Garrett Williamson at Springdale, O.: dam imported Prunella, thoroughbred. Belmont together with other thoroughbreds, including American Boy Jr., was taken to California in 1853 by $\mathrm{Wm}$. H. and Henry Williamson, where he died in $\mathrm{I} 865$. He was the sire of Venture, chestnut, $2: 27 \mathrm{I} / 4$, and the dams of eight trotters with records of $2: 30$ or better. Belmont also appears in the pedigree of the dams of a number of fast California trotters.

Trustee, by Catton : dam Emma, by Whisker; grandam Gibside Fairy, by Hermes. Imported 1828. Trustee was brought into special prominence through an extraordinary performance of a son and namesake, October 20,1848 , in a match against time over Union course, Long Island, who trotted twenty miles in 59 minutes $35 \mathrm{r} / 2$ seconds without a single break, coming in apparently fresh, and trotting the last mile in $2: 5 \mathrm{I} / 2$, the fastest of the race. This was the first trotting record of twenty miles in an hour, but has since been 
beaten by Capt. Megowen, Controller, John Stewart and Mattie Howard. The dam of George M. Patchen, noted as a trotter and a trotting sire, is said to have been by a thoroughbred son of imported Trustee. And also the dam of Lord Clinton, trotting race record, 2:083/4 in 1894, and full brother to Gen. Gates the premier stallion at the Government Morgan Horse Farm, Wcybridge, Vt., was by Revenue Jr., a grandson of imported Trustee.

The above mentioned horses, Capt. Megowen, Controller, John Stewart and Mattie Howard deserve a passing notice. Very little is known of Captain Megowen, except his, ability to trot long distance races, the second of which, as recorded in Chester, was at Cincinnati, O., Nov. 3 , I $\$ 60$, ten miles for purse of $\$ 2,300$, he winning in 28 minutes, I I $1 / 2$ seconds. Oct. 3 I, I 865 , for purse of $\$ 5,500$ to trot 20 miles in one hour, he won in 58 minutes, 25 seconds. Controller, bay gelding, is said to have been by Gen. Taylor, son of the Morse Horse. He is first recorded by Chester in a five mile race at San Francisco, Dec. 4, 1877. April 20, 1878, for purse $\$ \mathrm{I}, \mathrm{OOO}$, to trot 20 miles in one hour; he won in 58 minutes, 57 seconds.

John Stewart, 2:30, was a bay gelding, by Tom Wonder, son of Tom Crowder: dam bred by Austin Dana, Cornwall, Vt., got by Sherman Black Hawk, son of Black Hawk, by Sherman Morgan; 2 d dam bred by Austin Dana, got by Black Hawk. John Stewart's first race, as recorded in Chester, was one of ten miles for $\$ 2$, , o purse, he winning in 29 minutes, 291/2 seconds. Sept. 22, I868, at Fashion Course, R. I., driven by Hiram Woodruff; purse $\$ 3,000$, to trot 20 miles in one hour, he.won in 59 minutes, 23 seconds. April 4, I874, at Oakland, Cal.; for purse of $\$ 3,000,20$ miles, he won in 58 minutes, 59 seconds. Mattie Howard, chestnut mare, untraced; Dec. 7, I87 I, at San Francisco, to trot 20 miles in one hour on halfmile track, she won in 59 minutes, $30 \mathrm{~T} / 4$ seconds.

INTO ALABAIVA.

Glencoe, chestnut; foaled I83I; bred by Lord Jersey; got by Sultana: dam Trampoline by Tramp-Web by Waxy-Penelope by Trumpator-Prunella by Highflyer-Promise by Snap-Julia by Blank-Spectator's dam by Partner-Bonny Lass by Bay BoltonDarley's Arabian-Byerly Turk - Taffolet Barb-Place's White Turk-Natural Barb Mare. Imported by James Jackson, of Florence, Alabama, in 1836 , having been purchased in England for 2000 guineas. 
cxvi

A number of other Arabian or Barb horses have been imported to this country and many English thoroughbreds not mentioned in this chapter, as well as large numbers of draft horses of different breeds, but we believe that none of these have exerted any great influence in the breeding of the American road and trotting horse.

This concludes our preliminary survey of the Horse in America. The subject here naturally divides still more into localities and will be followed under the different States and regions that have been most prominent in producing valuable horses. It is the origin and early history of horses that are obscure. The immediate ancestry of nearly all notable horses produced within the last forty years is easily accessible. In this preliminary sketch, therefore, we come down in most cases no later than 1860 . The description and history of stallions which have been prominent since that date, and also before, will be found in alphabetical order in the body of this work.

These pages are made up largely of facts ascertained by researches throughout the country from contemporaneous evidence, obtained by personal examinations of libraries, old records, newspaper files, and other sources of information. Although incomplete, as such work must always be, it will be found to furnish many facts entirely new, to shed light on much that was obscure, and to correct many errors. 
EARLY ADVERTISEMENTS OF

NEW ENGLAND STALLIONS. 



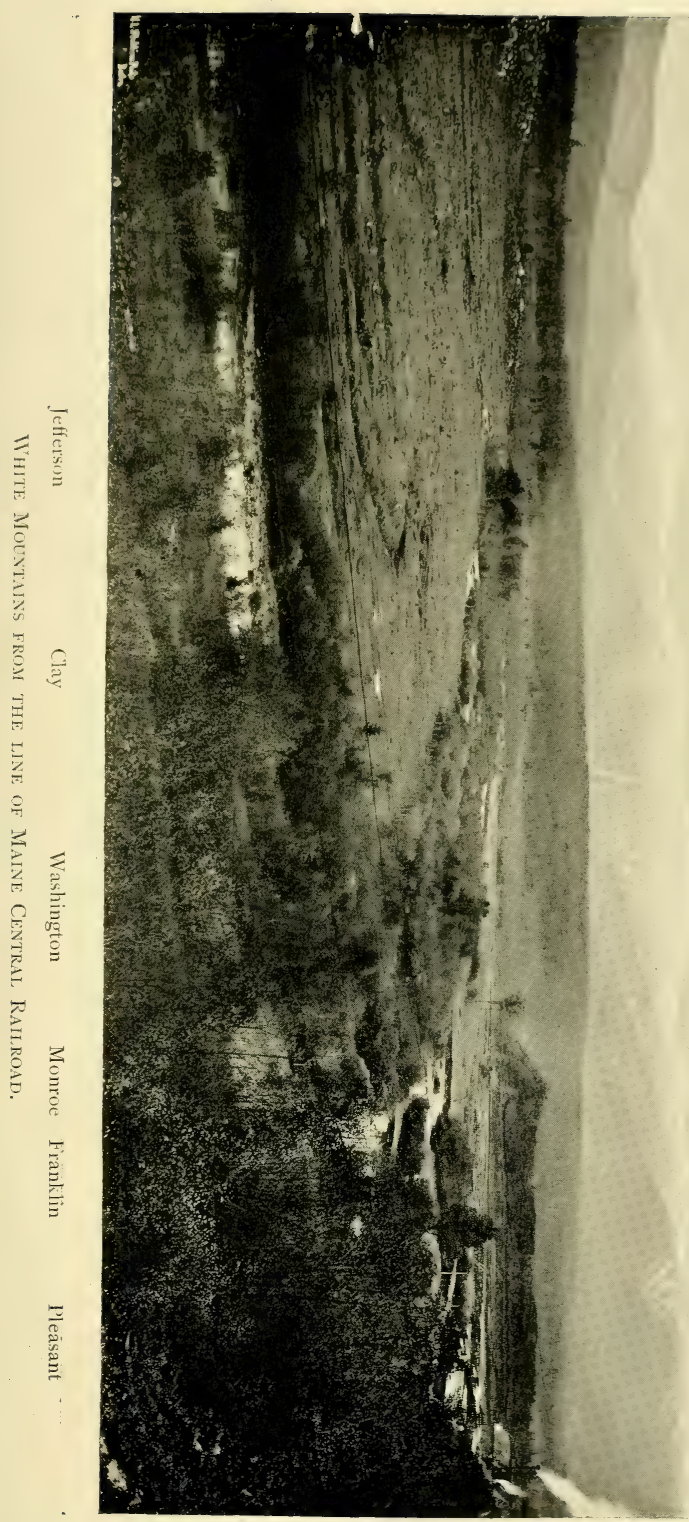




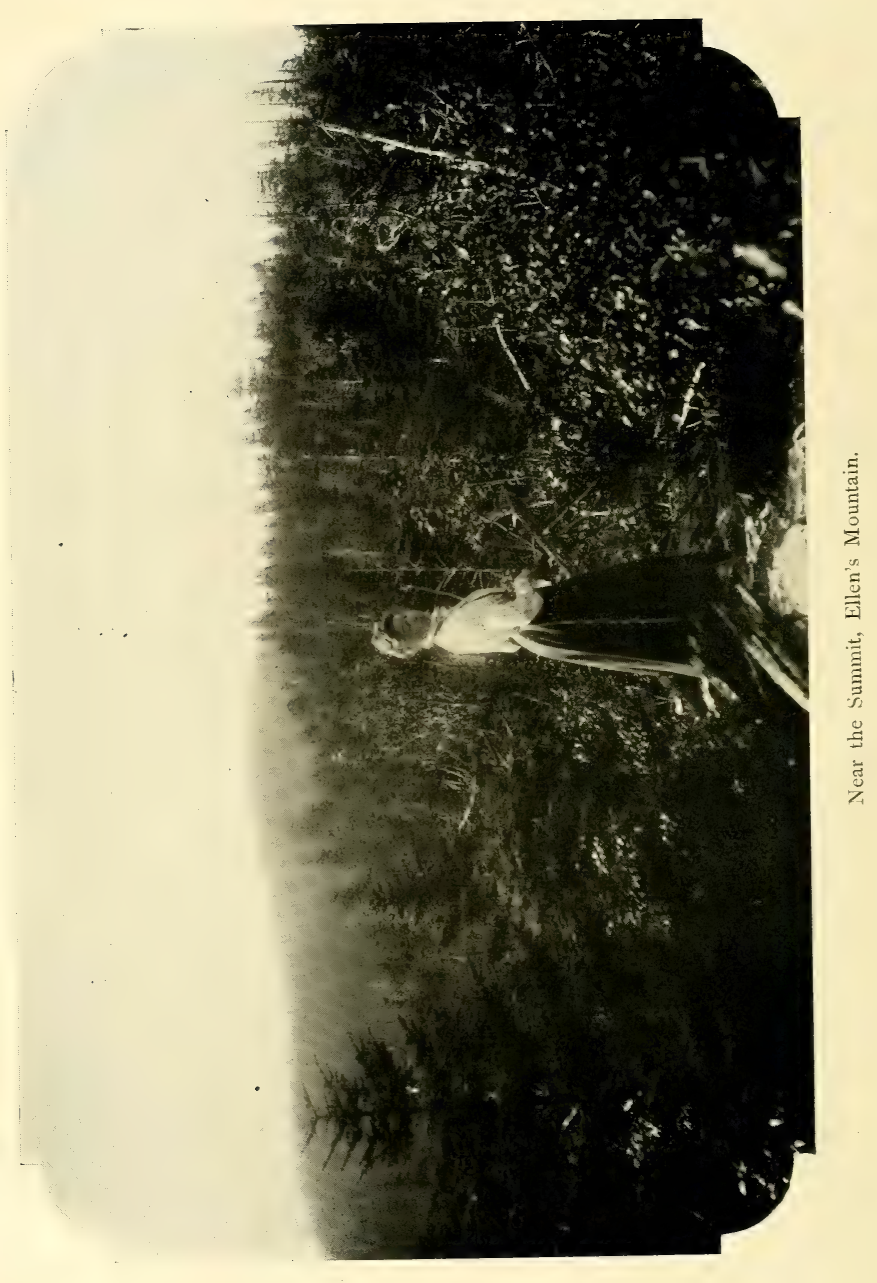




\author{
M A INE. \\ "Our young, wild land, the free, the proud! \\ Uncrushed by power, unawed by fear, \\ Her knee to none but God is bowed, \\ For nature teaches freedom here.
}

AINE was comprised in the mighty grant originally given to
the Plymouth Company. The abundance of fish upon its coast drew attention early to this part of the territory, and as early as 1600 the English were sending to its coast as many as a hundred fishing vessels annually. It is said that the colonies at Plymouth and at Weymuth were both saved from starvation by provisions obtained from this fishing fleet. The first permanent English settiement on the coast of Maine was a fishing station on the island of Monhegan, which continued till the first conflict with the natives. Between the years 1607 and 1622 , 109 ships entered and cleared at Pemaquid, now Bristol in Lincoln County. Soon after the establishment of the Plymouth colony, Robert Gorges, son of Fernando, essayed to plant a colony at the mouth of York River, near the present New Hampshire line, but left it and returned to England in I624, part of the colonists going with him and the rest going southward to the more genial clime of Virginia. When the Plymouth colony surrendered their charter in 1635 , there were four charter claims to the territory of the Maine coast, the three southerly being English, and the northerly one, extending from the Penobscot to the St. Croix, being French. But in 1652 all five of the settlements by leave of Parliament, voluntarily became a province of the Massachusetts Bay Colony.

Cromwell, in 1653 , annulled the cession of Acadia to France.

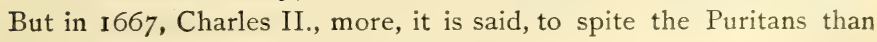
for any other reason, let it be restored to France, by the treaty of Breda, to become a bone of contention, and subsequently to be recovered at great expense, when the inhabitants were carried into exile, an act which forms the subject of one of the darkest pages of English history.

The settlements in Maine were few and feeble at the time of 
King Philip's war (1675-76), and were then nearly all broken up and the people murdered or driven away. For the next fifteen years the colony made no progress, and when, in 1690 , by the abdication of James II., William and Mary came to the English throne, there were only four English settlements in the province-Wells, York, Kittery and Appledore.

Again for a dreary period of seventy years, constantly recurring Indian troubles, and the war between England and France, prevented any settlements, save a few along the coast, until at last, by the fall of the French power in North America in 1760, the province was opened and population flowed in, so that a census in 1764 showed a population of 23,888 . The population even then depended little upon the tilling of the soil. A few cattle and sheep had been introduced, but pasturage was not yet provided. Grain and other provisions were procured from Boston in exchange for lumber and fish. Hay was procured from the extensive salt marshes on the coast, and the fresh water meadows in the interior.

Again in the war of the Revolution the people of this province suffered great hardships, and in the war of 18 I 2 their coasts were ravished by the British. In spite of all discouragements, however, the population increased, so that when Maine was finally admitted to the Union, as a State, she had a population of almost three hundred thousand.

The people immigrating to this province were generally of good character, sober, hardy, intelligent and industrious. They came, not for temporary speculation, but to found and establish homes for themselves and their posterity. They bore with great patience and fortitude the burdens, privations and sufferings of an infant frontier colony, and they transmitted to their descendants these sterling qualities of mind and body.

Maine has long been celebrated for the excellence of its stock of roadsters and trotting horses, but its horse history scarcely begins before the present century. While its territory was a province of the Massachusetts bay colony, its horses were, perhaps, mostly derived from the parent colony, and partook of the general characteristics of the Massachusetts stock. The History of Maine, by James Sullivan (I795), says :

"The cattle, sheep and horses now found in America are brought from Europe, and are as easily raised and multiplied in the district of Maine as in any part of the continent. The horned cattle, with the same attention, are raised to as large a size on the banks of 
the Piścataqua, Kennebec, and Penobscot, as in any part of New England. The sheep are much larger than in Massachusctts. The horses are not so tall, their necks so long, nor their chests so full, as farther to the southward; but they are very hardy, capable o enduring great fatigue, and possess great strength and firmness."

Maine has been fortunate, like Vermont, in having a chronicler of the history of her horses. In $1874, \mathrm{Mr}$. J. W. Thompson of Canton published the first Volume of "Sketches, Historical and I)cscriptive, of Noted Maine Horses," a very creditable work, carrying the horse history of the State back to the advent of Winthrop Messenger in 1816. In I 887 a second volume was issued, bringing the record down to that date.

The earliest animal that is known to have exercised any controlling influence on the road and trotting horses of Maine was Winthrop Messenger, that was brought into the State from Oneida County, N. Y., in ISI6, by Alvin Hayward of Winthrop, Me., and was kept in that State until he died in 1834. He was a large gray or white horse, I 7 hands high, and has usually been called a son of imported Messenger, He was certainly represented as of that blood when taken to Maine, and his description and characteristics were such as to make it extremely probable that such was the fact, although his breeder is unknown, and if his age is correctly given in the following advertisement it is not possible that he was got by imported Messenger, but very likely by a son. This advertisement, the most reliable piece of contemporary evidence that exists, does not state that the horse is a son of imported Messenger, but that he is of Messenger stock; and as it gives his age in 1819 , as eight, and old Messenger died in January, I808, the claim that the horses were sire and son can only be sustained by impeaching the statement of age given by Mr. Hayward, and this has never been done. The advertisement is from the Hallowell Gazette, May i2, I 819.

"The subscriber hereby recommends to the public, and all who feel interested to improve in the breed of good and serviceable horses the good horse, Messenger, that stock so well known and approved of on Long Island, New York and Pennsylvania. Said horse was raised on Long Island and owned by Mr. Rylander, a gentleman who has taken the greatest pains to import the best of horses that came to his knowledge. Said horse is silver gray, eight years old, wellproportioned, of a large size and a good traveler. Gentlemen who are desirous of raising good horses will do well to call and see for themselves. The Messenger will be kept for the most part of the time in the village of Winthrop Mills.

Winthrop, May I, I8I9."

ALVAN HAYWARD. 
Winthrop Messenger left a large family of excellent horses, and doubtless is entitled to a large share of the fame justly due to the State of Maine for the strong and speedy line of animals that she has produced from quite an early period. It is not known that any of the descendants of Winthrop Messenger in direct male line now survive, and it seems that the Morgan stock was the more popular and produced the most trotters.

Among the more noted descendants of Winthrop Messenger, were Bush Messenger, gray, I6 hands, I 300 pounds, foaled I833, bred by William Bradbury, Byron, Me., got by Winthrop Messenger: dam black, said to be inbred Morgan. He died from a kick in 1840 .

Hunton Horse, gray turning to white, I 6 hands, I Ioo pounds; foaled I 440 ; bred by the Widow Lane, Readfield, Me., got by Bush Messenger: dam white, pedigree unknown. He died at Buckfield in 1857 .

Messenger (Witherell's), (3-16), sorrel with white face and white off hind foot, light colored mane and tail, I 5 I/2 hands, I0 50 pounds; foaled June IO, IS34; bred by Rev. S. B. Witherell, Norridgewock, Me., got by Winthrop Messenger: dam, sorrel, bred by Rev. S. B. Witherell, got by a Morgan horse in New Hampshire, understood to have been Sherman Morgan; 2d dam, sorrel. S. B. Witherell, South Norridgewock, Me., nephew of breeder born May 23, I\&I I, writes to Middlebury Register, dated February 20, I 886 :

Editor Register:-Yours of the 15 th is received. The second dam of the Witherell Horse was taken up in dead of winter by Jonathan Bosworth of this town, and my uncle bought her. I well remember her. A nice round plump mare, about 900 pounds had the appearance of the Morgan breed of horses; untraced.

Witherell's Messenger died at Starks, Me., about I859. He was considered the best of the get of Winthrop Messenger and his stock was much sought for by horsemen from out of the State.

Allen horse (Norridegwock Messenger) gray, I6 hands, 1200 pounds; foaled I 844 ; bred by James Moulton, Wayne, Me., got by the Hunton Horse: dam's pedigree unknown. Owned by Lewis Allen Norridgewock, Me., afterwards went to Springfield, Mass.

Kennebec Messenger, gray; foaled I 846 ; bred by Lewis $H$. Blake, Mt. Vernon, Me.; got by Bush Messenger 2d; dam sorrel, called English. Sold when five to Geo. M. Robinson, Augusta, who kept him two years, took him to the first National Horse Fair at Springfield, Mass., and sold him to parties in Baltimore, whence he was taken to New Orleans, where he trotted in the thirties. Bush 
Messenger $2 \mathrm{~d}$ was a gray, son of Bush Messenger from a Canadian dam.

Merrow Horse, (I-8), dark bay, compact build; foaled about 1849 ; bred by Mr. Hight, Athens, Me. ; got by Witherell's Messenger: dam bay, bred by John Woodman, said to be Morgan. Hight sold him to Harford Merrow of Hartland. He was something of a trotter and got Bettie Strickland, $2: 26$.

Winthrop Messenger was also reputed sire of the famous trotting mare Fanny Pullen, dam of Trustee, the first horse to trot twenty-miles inside of an hour.

James Sherman, breeder of Sherman Morgan, the most famous son of the original Morgan, used to drive him in a team from Lyndon, Vt., to Portland, Me., and Mr. Thompson states that the horse left some descendants in Maine. These colts must have been got before I8I9 as Mr. Sherman parted with the horse that year; and they are probably the earliest Morgans introduced into the State. The period may have been anywhere from ISI3 to I8I9, and it is not improbable that Sherman Morgan had foals in Maine before Winthrop Messenger did. Bulrush Morgan, another of the three noted sons of Justin Morgan, was kept in Maine in I83 I and $\mathbf{I} 832$. But before this, Royal Morgan, known in Maine as Morgan Rattler, son of Sherman Morgan, was taken to Maine as a colt and remained there till I 829; he was probably foaled in I824. Morgan Rat, foaled in 1822 , and got by Sherman Morgan was taken to Maine when young, and kept in the vicinity of Norway, Stanwich and Gray. In 1828, Morgan Trotter, son of Bulrush Morgan, was taken to Maine, being then about eight years old; and about 1835, the Enfield Horse, a son of Woodbury Morgan was introduced. Another son of Woodbury called Young Burbank, was taken to Maine about I842, and was owned by a Mr. Farrar of Buckfield. These early scions of this celebrated stock were all good individuals, and their blood is a frequent factor in the fast trotters that later sprung from the Pine Tree State. The earliest of these was the brown gelding, Mac, $2: 28$ ( $2: 27$, saddle) one of the most famous of the early trotters, foaled I 843 , bred in Canton, Me., and got by Morgan Caesar, a son of Woodbury Morgan. Morgan Caesar was owned by Gen. John M. Eustace in Maine, from 1834 to I 842 , and got several other fast ones besides Mac. His dam was by Quicksilver, son of imported Dey of Algiers.

Gen. Knox, son of Vermont Hero, by Sherman Black Hawk: dam by Searcher, son of Barney Henry; 2d dam Morgan; was bred 
in Bridport, Addison County, Vt., foaled I855, and taken to Maine in 1859 . Winthrop Morrill, bred in Barre, Washington County, Vt., got by Young Morrill, from a dam by the Huckins' Horse, son of Royal Morgan, was foaled the same year as Gen. Knox (1855) and was also taken to Maine in 1863. These two sires had a very marked effect in improving the trotters and roadsters of Maine. They were exceedingly popular, and have both a goodly line of descendants in the $2: 30$ list. In fact the compilation of that list for the State, made by J.W. Thompson to the close of I886, shows I23 Maine bred performers in 2:30 and better of which no less than fifty-nine, or almost one-half, trace in direct male line to Justin Morgan, a great majority through Gen. Knox or Winthrop Morrill.

Shortly after the introduction of Winthrop Morrill, the Fearnaught Farm was established at Manchester, Me., by Messrs. Wright and Norcross. Here, under the supervision of Mr. E. L. Norcross, since I 868 , for many years, the blood of Fearnaught, $2: 231 / 4$, son of Young Morrill and one of the handsomest horses of his day, and champion trotting stallion of the world when his record was made, has been bred and developed with much success.

The Canadians have also contributed their share to the horse stock of Maine, the most important of which, the Brandywines of Morgan descent. There were besides the Crawford Horse, Whirlwind and Indian Chief, sketches of which will be found under their several names within. They are spoken of in high terms for their business qualities, and all but Indian Chief have descendants in the 2:30 list.

The Drew Horse, often called old Drew occupies a prominent place among the noted horses of Maine. He was foaled at Exeter, Me., in I 842 , and was largely of thoroughbred blood. He left two in the $2: 30$ list and got the dam of Midnight, 2:181/4. His blood is found also in a large number of stout and successful campaigners.

The Eaton Horse, foaled the same year (1842) at Anson, Me., deserves honorable mention. He was a large sorrel stallion that has left a number of speedy descendants. Rising Sun was another noted Maine horse foaled at Peru in 1843 ; also his son, the Rollins Horse, sire of Emperor, 2:30. All that is known of these horses is given under their names in the body of this work.

In more recent years many descendants of Hambletonian have been introduced, the first of which was Gideon, brought in at four years by Col. T. S. Lang, and kept in Maine throughout his long career. 
Mac was the greatest trotter of his day, beating Lady Suffolk seven in ten times, and when she beat him he was lane. John Record, Livermore Falls, Me., son of Thomas Record, breeder of Mac, writes:

"Mac's dam was a bay mare with dark points, brceding unknown. Father bought her of Dr. Cooledge of Canton, Me. She was fourteen years old when father bought her. He owned her two years before she had Mac. She was a good mare, and one of the best road mares of her day."

Mac was foaled in I 843 . This makes the mare foaled in 1827 . Mr. Thompson says: senger."

"Mac's dam was a large, powerful brown mare by Bush Mes-

This is impossible, as Bush Messenger was foaled in 1833 , six years after the dam of Mac.

$\mathrm{Mr}$. Thompson is led into another mistake by copying $\mathrm{Mr}$. Helm's remarks on the pedigree of Winthrop Morrill into his last book (Noted Maine Horses, I887, p. 35), thus: "He has two crosses of Messenger, one of Duroc; the one to the Vance Horse through old Morrill, and the dam of Morgan Eagle being by Callendar, son of American Eclipse." The Vance Horse had no Messenger blood as we have already shown in The Morgan Horse and Register, Vol. I., p. 20I. His pedigree will also appear in its place in this work. The Morgan Eagle that got the second dam of Winthrop Morrill was by Woodbury Morgan: dam the Cheney mare, said to be by Bulrush Morgan, a very different horse from the Morgan Eagle, said to be by Green Mountain Morgan from a dam by Callender. See The Morgan Horse and Register, Vol. I., pp. 207, 215 and 696, where the pedigrees of Winthrop Morrill and of these two Morgan Eagles are given. Winthrop Morrill had no Messenger or Duroc blood.

\section{(Fenks' Portland Gazette, Vol. VII.)}

I 804-Farmer, full-blooded English, got by the celebrated Wildair; dam of the Hunter breed. Colts famous for being large and beautiful.

E. HathaWAy.

Beautiful full-blooded horse Young Traveler, bred in Pennsylvania, in. Hebron, New Gloster, etc.; I 5 hands, milk white; colts very fine; $\$ 2$ to $\$ 6$.

I 805-Bold Ranger at Gorham, full-blooded English, ten years old, by that noted horse called Traveler, imported by Dr. Craig of Cambridge, Mass. 
cxxvi

\section{(From Travels in North America, by Rochefoucault, 1795-7.)}

"In Northampton, Mass., numbers of horses are seen in the fields, which, however, are not remarkable for beauty.

"Cattle are seen in great abundance and of a very fine breed.

"In Maine, a pair of oxen costs here $\$ 60$, a cow $\$$ I 8 or $\$ 20$. Although no pains are taken to improve the breed of the cattle, they are in general good.

"Present population of Maine, roo,ooo. Common pay of laborers, $\$ 6$ to $\$ 8$ a week.

"One paper published at Portland, Me., twice a week. In New Hampshire a great variety of newspapers are published; Portsmouth has three, Dover two."

\section{BREEDING INTERESTS IN MAINE.}

Editor of American Horse Brecder:

Whalebone Knox is still living, and is as robust as he was ten years ago. He was kept in the town of Palmyra, Somerset County, the years of I $885, I 886$ and I 887 , and left some fifty colts in the three seasons in the towns of Palmyra, Hartland, St. Albans, Pittsfield, Harmony and Ripley. Several of his patrons were by Dirigo, Brown Harry, Winthrop Morrill, Gen. Lightfoot by Knox, Sanborn Horse by Knox, Morrill Horse by Knox, and one other son of Knox.

He got three-fourths of the mares in foal that were bred to him the first two seasons. His get have more finish than the get of any other son of Knox, and are higher toned as a rule. He has more action when trotting, trots with resolution, and is a big-gaited horse. This was handed down from the Clark Horse (Whalebone Morgan) through Pollard Morgan.

Lewiston Boy had the high knee action, but was not so big a gaited horse as Whalebone Knox. He was a horse that would go up to the top speed in going a few rods, and I think he could pull a skeleton wagon at the rate of $2: 30$. Knox horses are somewhat out of fashion just now, but that does not make them any the less valuable. Whalebone Knox has averaged remarkably well as a sire of speedy roadsters that have size and style.

Several hundred of the get of Whalebone Knox and the get of stallions that I have had, and what I have bred outside, are scattered over New England, and a good many are now being traced back to the breeder. 
I have been interested in horses from a mere boy; was born in Skowhegan on the plains where the trotting park now stands. I well remember the mock races thcy had on the plains years ago. They had some fast pacers that came from Canada. Samucl Jacubs owned Highlander, a large Norman stallion, that could trot a threeminute gait. He was a high, pounding-gaited horse. Mr. Crawford also had Norman, a large, yellow-chestnut stallion, that could trot a three-minute gait. He had the same gait as the other. This must have been forty years ago.

B. F. B.

J. W. Thompson in Vol. I. of "Noted Maine Horses," published I874, gives the following table of the early Mainc trotters with records of $2: 30$ or less :

\begin{tabular}{|c|c|c|c|}
\hline aby Bov, & $: 30$ & Iystic Park, Boston, & 3. I 873 \\
\hline Barney Kelley, & $2: 261 / 4$ & Buffalo, N. Y., & Aug. $5, \mathrm{I} 873$ \\
\hline Bay Whalebone, & $2: 261 / 4$ & Mystic Park, Boston, & June $28, \mathbf{I} 87 \mathbf{I}$ \\
\hline Belle of Portland, & $2: 26$ & New City Course, N. Y., & Oct. Io, I 86 I \\
\hline Belle Strickland, & $2: 26$ & Narragansett, R. I., & Oct. 4,1870 \\
\hline Blackstone Belle, & $2: 28 \mathrm{I} / 2$ & Riverside Park, Boston, & July 2, I 866 \\
\hline Camors, & $2: 20^{1 / 2}$ & Buffalo, N. Y., & Aug. I6, I 873 \\
\hline Emperor, & $2: 30$ & Narragansett, R. I., & Oct. 14,1868 \\
\hline Fleetwood, & $2: 29$ & Troy, N. Y., & Sept. 7, I $\delta_{7}$ I \\
\hline Gen. McClellan, & $2: 26$ & Belfast, Me., & Sept. 24, I 864 \\
\hline Geo. B. McClellan (now & & & \\
\hline Dirigo), & $2: 29$ & Belfast, Me., & Sept. $\mathbf{2 4}, \mathbf{1} 864$ \\
\hline Gilbreth Knox, & $2: 263 / 4$ & Narragansett, R. I., & Oct. 7,1869 \\
\hline Independence, & $2: 28$ & Beacon Course, N. J., & July $4, \mathrm{I} 843$ \\
\hline Lady Mead, & $2: 22 \mathrm{~T} / 4$ & Prospect Park, L. I., & Oct. Io, I 872 \\
\hline Lew Pettee, & $2: 29$ & Fashion Park, L. I., & June 29, I 868 \\
\hline License, & $2: 26 \mathrm{I} / 4$ & Fleetwood, N. Y., & Sept. $22, \mathbf{I} 870$ \\
\hline Little Fred, & $2: 263 / 4$ & Prospect, L. I., & May 29, I 869 \\
\hline Mac, & $2: 27$ & Cambridge Course, Mass., & June 14,1849 \\
\hline Madawaska Maid, & $2: 291 / 2$ & Mystic Park, Boston, & Oct. 6, I 868 \\
\hline Nabocklish, & $2: 29 \frac{1 / 4}{4}$ & Cincinnati, Ohio, & Aug. I6, 1864 \\
\hline Pelham, & $2: 28$ & Centreville, N. Y., & July 2, I $\$ 49$ \\
\hline Shepard Knapp Jr., & $2: 29^{1 / 2}$ & Mystic Park, Boston, & June 7, I 869 \\
\hline St. Elmo, & $2: 291 / 4$ & Mystic Park, Boston, & June 21,1872 \\
\hline Stranger, & $2: 30$ & Bangor, Me., & July 4,1855 \\
\hline Tammany, & $2: 27$ & Bangor, Me., & $\longrightarrow, 1871$ \\
\hline Uncle Abe (now Glen- & & & \\
\hline gary), & $2: 27$ & Buffalo, N. Y., & Aug. Io, $187 \mathrm{I}$ \\
\hline William H. Taylor, & $2: 291 / 4$ & Narragansett, R. I., & Oct. I $4, \mathrm{I} 868$ \\
\hline Winthrop Morrill Jr., & $2: 283 / 4$ & Prospect Park, L. I., & Sept. 25,1873 \\
\hline Zac. Taylor, & $2: 29$ & Philadelphia, & Oct. 18,1852 \\
\hline
\end{tabular}


"This list of Maine 2:30 horses I believe to be complete, with perhaps the following exceptions: I am informed, since the body of the work has been in the printer's hands, that the gray gelding, Hopeful, by Godfrey's George M. Patchẹn, which won a race at Prospect Park, September 23, I873, in a field of twelve horses, winning the last three out of five heats, in $2: 26,2: 27,2: 25$, was bred in Maine, near Newport, and kept there until four years old. I am also informed that Elisha won a record of $2: 26$ in California, and although I am unable to find any published account of said race, still I am inclined to place confidence in the statement.

"Shepard F. Knapp, the one that went to England, won a race near Paris, France, trotting two and a half miles in six minutes and fourteen seconds, which is a trifle better than $2: 30$ to the mile. Many believe that Plato, by Gen. Knox, has a record of $2: 27 \mathrm{r} / 2$, and since my list of $2: 30$ horses appeared in the Maine Farmer I have received several letters, asking my reasons for not including Plato. To all such I will say that I am unable to find any such record to his credit. I have been informed, also, that Benjamin McClellan, who won the second heat in a race, at Troy, N. I., July 24, I867, in 2:30, was bred in Maine, and got by the Old Drew Horse, but I have failed entirely to identify him." 
NEW HAMPSHIRE.

The hills were made for freedom; they

Break at a breath the tyrant's rod,

Chains clank in valleys; there the prey

Writhes 'neath Oppression's heel alway:

Hills bow to none but God!

-William Goldsmith Brown.

$\mathrm{T}^{\mathrm{H}}$

HE earliest settlement of white men in the territory now occupied by the State of New Hampshire was made in 1623 , at the places now known as Portsmouth and Dover. The Plymouth Company, whose charter of I 620 from James I., covered this region, granted a sub-charter on the first of August I622, to Sir Fernando Gorges and Captain John Mason, of all land lying between the Merrimac and Kennebec Rivers and a line 60 miles inland. It was parties sent out by Gorges and Mason that made the first settlements above mentioned, but these continued for several years without growth, mere fishing and trading posts; and the next settlements, those at Exeter and Hampton, were not made till 1638 and 1639 . Up to this time the region was known as Maine, or Laconia. In November, I629, Gorges and Mason divided their grant, and Mason obtained from the Plymouth Company a grant of the land between the Merrimac and the Piscataqua for 60 miles inland, which tract he named New Hampshire, from the county in England whence he came. Imigration was discouraged by Indian troubles, as well as by conflicting titles to the land. The four New Hampshire settlements, still weak, petitioned in I64I for union with Massachusetts; they were received and, with some towns on the Merrimac, formed into a county. This union continued till I680, when the claim which Massachusetts had put forward for jurisdiction over New Hampshire, was denied by royal authority, and New Hampshire was declared a separate province with a governor of its own. In $\mathrm{I} 69 \mathrm{I}$, when Massachusetts regained the charter of which it had been deprived, New Hampshire was anxious to unite with it, and did act with it for a time. It did not however cease to be a royal province until the Revolution. Its settlement which had been delayed for many years by Indian invasions and questions of title and jurisdiction, progressed very rapidly 
after these causes ceased to act, about I 764 ; so that, at the breaking out of the Revolution New Hampshire had 80,000 inhabitants.

The early horses of New Hampshire were derived from her sister colonies, notably from Massachusetts, and partook of the characteristics of the pioneer stock of that colony.

In Historical Views of the United States, by W. Winterbottom (New York, I 796), it is said of New Hamphshire (Vol. IV., p. 85) :

"The first neat cattle imported from Europe into New Hampshire were sent by Captain John Mason and his associates about 1633 to stock their plantations and be employed in drawing lumber. These cattle were of a large breed and a yellow color, procured from Denmark. From the upper parts of New Hampshire great herds of fat cattle are drawn to the Boston market, whence the beef is exported.

"At what time and by whom the horse was first imported does not appear. No particular care is taken by the people in general to improve the breed of this majestic and useful animal. The raising of colts is not accounted a profitable part of husbandry as the horse is but little used for draft. The proportion of horses to cattle is not more than one to twenty. Few live and die on the plantation where they are bred; some are exported to the West Indies, but the most are continually shifted from one owner to another by means of a set of contemptible wretches called horse jockeys. Asses have been lately introduced into the country. The raising of mules derives encouragement, as the exportation of them to the West Indies is more profitable than that of horses, and they may be used to advantage in traveling or carrying burdens in the rough or mountainous parts of the wilderness."

It is apparent that the learned author had been trading horses in New Hampshire.

EARLY HORSE ADVERTISEMENTS.

\section{(From New Star at Concord.)}

I 797-Young Shakespeare. T. Drx, JR., Boscawen.

Driver.

J. GibBon, Henniker.

Wildeer and Wildeer Jr.; the last in all respects similar to the first, except in the fashionable gait of pacing.

Young Recovery and Roebuck from Vermont; the latter by Cub of Virginia. Pennsylvania, bay, 15 1/2 hands, from Pennsylvania.

Prince Edward, full-blooded English, imported from England by Prince Edward and kept by him as a favorite parade horse while in Canada. 


\section{(From New Hampshire Scntincl.)}

1797-Phenomenon; lately imported at North Hampton. This from Hampshire Gazette at Portsmouth. Phenomenon, $161 / 2$ hands, chestnut, five years, etc.

I 798-Phenomenon again.

Cantab, 16 hands; brought from Virginia.

I799-Phenomenon and Janus. The noted horse called the Young Traveler will be kept in Plymouth.

I 8 I6-Quick Traveler; by old Quicksilver, six years.

Bay Figure in Keene, etc.; got by the old Quicksilver: dam by imported Kildeer; 16 hands, five years.

Prince Herod, Mercury and Hero.

I 8 I 7-I 8-None.

I 8 I $9-$ Stud Horse Phoenix; $\$$ I to $\$ 4$, in Keene, Young King William.

I $820-$ The Wildeer in Keene

I 82 I-None.

The following are from files of papers in the Keene (N.H.) City Library :

I 799-The Rising Sun, bay; by noted full-blooded horse Eclipse; at Keene.

The Gordan in Keene, at $\$ 4$ to $\$ 6$.

Full-blooded Hero and celebrated Taylor Horse in Winchester, Warwick, etc.; beautiful bay. elegant.

Full-blooded horse Partner, bay, I5 hands, mane light and

The Arab, clear white, kept here several years in Keene.

\section{J. DORR.}

I 800-Brilliant in Keene by J. Grant; said horse has been kept at Newfane and Brattleboro for a number of years past.

The Newmarket, bright bay, 6 years, I $5 \frac{1}{2}$ hands; by the noted Pool Horse; in Keene.

The Gordan in Sullivan.

$1801-N i m r o d$ in Keene. Bay, black mane and tail and star; 16 hands, by full-blooded horse Nimrod; owned by Dr. Dyer, Canterbury, Conn. $\$ 2$ to $\$ 4$.

The Newmarket; Raven, 4 years, 16 hands, star, by Curtis Horse of Windsor, in Keene.

Young Splendor, full-blooded English, in Keene.

Victory in Walpole and Keene. 
A fine Hunter, ch., with star, dark mane and tail, 16 hands, very lengthy and gay; by full-bred horse Washington of Virginia: dam by imported Bulrock.

Defiance in Swanzey; sire, famous Chandler Horse.

D. TWitchell.

I80I-Prince Herod in Sullivan, etc.

I 802 - Red Bird, bred on Long Island, where his reputation as a sire is fully established; beautiful bay, 16 hands, and for smartness none exceed him; in Keene $\$ 2$ to $\$ 3$.

Young President in Keene; got by President kept in Hartford some years: dam, full-blooded mare lately owned by Nathan Nye of Randolph, Vt.

Young Wildair, dark sorrel, in Keene.

Young Paymaster in Swanzey, etc.; bred by Capt. Pratt of Winchester.

1803-Wildeer and Sweet Briar in Keene; Young Splendor, Westmoreland; Camelian, Walpole, etc.

I 804-Spotless, Federal Republican, and imported Sweet Briar, at Keene.

Bajazet, two seasons past in Jeffrey; bay; at Dublin, etc.

Young Janus, six years, dark bay, 16 hands, in Keene.

1805 - Sweet Briar.

1806-Young Eagle in Jeffrey. Young Janus in Keene.

I 807 -Paymaster.

Cincinnatus, black, known as Crombie or Stickney Horse, in Keene, etc.

1808 -Paymaster.

I8I3-Prince Herod in Keene; Young Commodore, 4 years, I 6 hands, in Fitzwilliam.

1814-Sprightly Cub in Chesterfield, Putney, etc. King William, a full-blooded English horse, $15 \mathrm{~T} / 2$ hands, beautiful bay; in Keene; $\$ 4$.

I 8 I 5-Commodore, King Herod, Quicksilver in Keene.

Young Hero.

J. Bellows, JR.

The Traveler at stable of Benoni Shurtleff, Keene, Saturdays; at Capt. Drew's, Walpole, Wednesdays; stable of subscriber, Surry, through the season; $\$ 3$ to $\$ 5$.

William Baxter, Surry.

Magnum Bonum in Ackworth. Gray colt in Marlboro.

I 8 I6-Hero in Nelson, Dublin, etc.

Bay Figure, by Quicksilver: dam by imported Kildeer of 
Hartford, Conn.; 5 years, I6 hands; for speed exceeded by none; in Walpole, etc. ; $\$ 3$ to $\$ 5$.

Mercury in Sullivan Co.

Quick Traveler in Alstead, etc.; got by Quicksilver, six years; $\$ 2$ to $\$ 5$.

FRANCIS HOLBROOK.

Surry, April 17, I 8 I6.

his horse will recommend himself with those who have proved his stock.

I 8 I 7-Bay Figure, 6 years, I 6 hands, in Walpole, Alstead, etc.

I 8 I9-Stud horse Phœnix, at stable of Solon Sumner, $\$$ I to $\$ 4$,

Keene; Nathan Pond. Young King William, Swanzey, etc.

I 820 -The Wildeer in Keene.

I 824 -Diomede.

1827 -Spanish horse and Diomede.

I 828 - Three Spanish horses; Diomede.

I 829-Diomede. Offers $\$ 20$ to $\$ 30$ for colts four weeks old in Keene.

I 83 I-Diomede.

L. PAGE.

American Hero in Keene.

I832-Diomede, known in Massachusetts as Taylor or Northampton Colt, in Keene.

Young Morgan [Woodbury Morgan], in Walpole and Keene. Young Morgan is own brother to the Sherman Morgan that was kept at Charleston, Mass., the last two seasons. \$IO.

JERRE JOHNSON.

I 833-Young Morgan, I6 hands, beautiful chestnut; bred in New York; got by old Duroc.

L. PAGE.

I 834 -Long Island Bellfounder, I $53 / 4$, six years; by old Bellfounder, in Keene.

L. PAGE.

I 835-Long Island Bellfounder.

1836-Young Mikel Raeker in Keene.

I 838-Indian Morgan colt; by old Sherman, in Keene, etc.; trots quick, runs fast, and for beauty and activity is not excelled by any other horse.

James Raymond, Keene.

Prince Raeker in Sullivan.

I 842-The celebrated horse Mikel Raeker [A Canadian horse] in Westmoreland, Putney, Vt.; Dummerston, Vt.; Chesterfield, and Keene, N. H. W. Kingsbury.

The following are from files of papers in the Antiquarian library, Worcester, Mass. : 
cxxxiv

\section{(From Dartmouth, N. H., Centinel.)}

r 794-Regulus in Norwich, dark bay, I 5 I 2 , nine years old; bred by Nathaniel Heard; got by the full-blooded bay horse Wilkes, owned by Col. Grant; Wilkes by Selim, which ran at Philadelphia in 1762 and won $\$ 1000$ against True Briton and was owned by Samuel Galloway, Esq. $\$ 2$ to $\$ 4$.

(Signed)

Roswell Olcott.

The Young Hunter at Concord.

Koulikan, I 5 hands, six years old, light sorrel; got by the noted Geer Horse and advertised at Lyme by Joseph Bellows.

Young Ranger, in Thetford, Vt., I 5 hands, six years old, light roan in color; got by the noted horse Ranger, kept in the State of Connecticut. $\$ 1$ to $\$ 2$. (Signed) Frederick MANN.

I 795 - The Peacock in Rumney and Warren, I 5 I/2, dark bay and elegant gait; advertised by David S. Craig, Warren, N. H. ; $\$$ I and $\$ 2$.

The Prentice Horse in Claremont, by imported Driver.

The Geer Horse in Plainfield and Claremont. WV. DEAN.

I 795-The Pilgrim, Young Ranger.

Young Roebuck and Hyder Alli.

The Young Vergennes, five years, I6 hands, bright bay, in Lyme. JosEPH BELLOWS.

I 796-English Lark by Pool Horse.

Young Vergennes, Recovery or Stiff Shins; black horse Othello, 16 hands, six years; got by Recovery.

American, by Recovery, I 6 hands, bay. Cardinal Woolsey or Hough horse, eight years, bay, $163 / 4$ hands. Hermit by imported Liberty, etc., etc.

The Chandler Horse is also advertised at Hanover, and Recovery, full-blooded English, at Lebanon.

I796-Cardinal Woolsey, known as the Hough Horse, at the stable of Joel Tilden in Lebanon; eight years old, bright bay, I6 hands, full-blooded, etc.

(Signed) Joel Tilden,

Sam. Bingham.

Hermit, dark bay, full-blooded, by old Liberty, imported: dam by the famous Bulrock, grandam by Wildeer, etc. Advertised by Roger Enos, Hartland; $\$ 8$ to $\$$ I 2 .

America by imported Recovery; dam full-blooded mare after old Ranger, bright bay, I 6 hands, six years old.

(Signed) JoHn HATCH, Norwich.

I796-Young Traveler-The famous full-blooded, milk-white 
horse called the Young Traveler, $15 \frac{1}{2}$ hands, from the State of Pennsylvania, will be kept the ensuing scason at the stable of Col. David Webster at 15 to 42 shillings. Said horse was got by the famous imported horse called the Traveler, whose dam was imported from Europe. Advertised by William Webster \& Co., Plymouth.

The same year appears announcement of Golden Britain, well known by the name of the Geer Horse, which is advertised by William Dean of Plainfield.

\section{(From the United States Oracle of the Day, Portsmouth.)}

I 800 -Young Traveler-This beautiful bay horse, $15 \mathrm{I} / 2$, will be kept at Greenland; six years old, nervous, strong-built. He was by the Traveler or noted Craig Horse (so-called).

\section{(Signed) \\ T. G. DEARBORN.}

The owner of Traveler offers him for sale.

Hero is advertised in Rochester; full-blooded young horse called Hero, of a fine changeable bay, four years old, i 6 hands; got by the well-known imported horse called the Traveler, from that full-blooded mare called the Young Duchess, and she was from the old Duchess, imported by Gov. John Wentworth, etc., etc.

Rochester, May 9, I 800.

Samuel Ayers advertised. Golden Eagle in Greenland; three years old, I 5 hands, got by Traveler, an imported English horse.

Bold Hunter, also, is advertised to be kept at Greenland.

\section{(From the Concord Couricr.)}

I 797-Merry Traveler; by Merry Traveler of England. Ranger and Wildeer in Salisbury.

"My horse is neither French nor Dutch, nor never came from Canada; is a Hunter."

This is prefixed with Warwick: "Much hath been said about horses, this and the past year. I shall say but little about mine. This much I will venture to say that my horse is neither French," etc., and signed

John BACHELder, Concord.

I 798-Ranger, Young Shakespeare, Cantab, Pilgrim, Young Fox Hunter, four years old, 15 1/2, seven-eighths blooded; brought last season from Hartford, Conn., to be kept in Moultonboro.

Young Traveler, milk-white; Janus; Young Golden Briton, or Sorrel Horse, in Plymouth. Swan, I 5 hands, three-fourths blooded; formerly kept at Boston. Young Reindeer, four years, I 6 hands. Royal George; Fleetwood, English and Dutch blooded, bright bay, black mane and tail; very few that will equal him in speed. 
I $800-G o d o l p h i n, "$ the famous full-blooded," in Dunbarton; dark bay, $16 \mathrm{I} / 2$. Pedigree: "I certify that I bred said horse; that his dam was by the old Ranger, and he by Washington; bred in Virginia.

ROGER WARDSWORTH."

President, owned by Col. Roswell Orcutt, Norwich, Vt., advertised in Boscawen and Concord by A. Burnham; also Pantaloon by Recovery, etc.

I 801 - Phenomenon appears again.

WANTED - To purchase, 30 elegant horses, none under 15 hands; I 5 of them are wanted to be studs, first rate, black, chestnut or bay.

Sanuel Howe, Portsmouth.

I 802-Young Ranger in Plymouth by S. Wells, described as milk white and lately from the city of Hartford.

"WANTED-A few young handsome horses, in good order, for shipping."

Highlander, bred by Jeremiah Lounsbury, Bedford, Westchester Co., N. Y., is advertised to be at Sandbornton.

Cyrus Finch of Newington advertises Aurelius, owned and kept a few years by John Welch, New London; grandsire, Bucephalus, imported. Aurelius was raised by John Wheeler, Stoningham, Conn.; dark chestnut, 16 hands.

I803-Cardinal Puff is advertised at Henniker.

1803-Traveler-The noted full-blooded milk-white horse, called the Traveler (which has been kept at the stable of Col. David Webster in Plymouth for several seasons past), will be kept the ensuing season at the stable of Mr. Ezra Hutchins in Exeter and in Epping at $\$ 2.50$ to $\$ 4.50$.

Wm. Webster \& Co., Plymouth, April, I803.

Young Rockingham in Dunbarton.

\section{(From the New Hampshire Gasettc.)}

I 800 -Phenomenon, lately imported by Lane, Baesley \& Co., at Northampton; chestnut, $\mathbf{I} 6$ hands, nine years old.

"Will be kept this season in the stable of Mr. George Lane, Wolfboro, the Ranger, from a good-blooded mare, and got by the well-known, full-blooded horse called the Traveler, owned at Cambridge in Massachusetts and esteemed the best horse in New England; Ranger, 16 hands, bay; also Highlander, got by an imported horse called the Highlander; middling size, dapple bay, four years old this spring.

(Signed) NATHANiEl Brown." 
Young Lion in Barrington; dark red, $14 \frac{1}{2}$, and is allowed by good judges to be as handsome a horse as any in this part of the country. The last season he covered 40 mares.

\section{(Signed) DAVID MCDANIEL.}

I 816 - "The noted horse, old Hero. This extraordinary horse is not less remarkable for the uniform excellence of his stock than for his own uncommon qualities. Now forty ycars old, he possesses all the beauty and vigor of youth. That the old Hero is remarkably sure for colts is certain, etc., etc. Terms, $\$ 3$ to $\$ 6$.

\section{Jeremiah Emery, Concord, April 23, i8 i6."}

Noah West advertises same season the Ranger Spy, almost 17 hands; got by that English horse Ranger of lower Canada. "His colts are esteemed higher than either of those wonderful horses, Hero or Bulrock."

I 8 I 3-In the Constitutionalist of Exeter, N. H., there is advertised by Joseph Blake of Epping, Young Herod, five years old, at Sherburne and Raymond.

Rising Sun at Canterbury; 16 hands.

Duke of York at Pémbroke; 16 hands, etc.

There is a very long advertisement of Bulrock; also of Telescope, "Which last year accompanied Bulrock," to be kept, etc., at Salisbury. The above horse is known in Croyden as Young Slender, formerly owned by Mr. Rich of Claremont.

(Signed) B. Thompson, JR., Andover, N. H.

I815-The old Hero was imported and is 39 years old-far superior to the celebrated Bulrock; known by the name of the Plummer Horse, and will be kept at Salisbury; he was got by old Driver, imported by Gov. Wentworth.

In I8I5 Samuel French of Boscawen advertised the Young Charger "that can boast of as good blood as any horse in the country; bright bay," etc.

\section{(From the New Hampshire Patriot, Concord, Vol. I., I809.)}

Young Herod, chestnut with star; got by Bold Hero of Philadelphia: dam owned by N. Brown of Portsmouth.

Shim Wiley.

Hamet Bashaw; by Dey of Algiers; imported by Col. James Swan in 1800 : dam, an Arab mare imported at the same time. At Concord. JOHN ODLIN.

Peacemaker at Hopkinton, full-blooded, 17 hands ; foaled I 799 ; imported from Barbadoes to Pennsylvania. 
I 8 Io-Bold Hunter, Bajazet, imported by Col. Ramsey of Connecticut, in Weare. Also Young Herod, Hamet Bashaw and Young Fearnaught.

Hamet Bashaw.

Young Eagle at Dunbarton and London.

S. Clement.

Young Herod.

A. Messer.

Young Fearnaught; foaled I806; I 6 hands.

M. RiCHARDSON.

Young Bajazet, imported from England by Col. Ramsay of Connecticut, and lately owned by John Prentice of Londonderry; in Weare.

John Melvin.

I 8 I I - Hunter or Mayhew Horse.

Young Eagle. For strength, speed and beauty his colts have not been equalled. To be kept at Canterbury.

Ames \& Messer.

Young Hamlet; by imported Hamlet.

Arabian White.

Ira Cochran, New Boston.

I 8 I 2-Young Fearnaught, I 6 hands, si years, at Pembroke.

Young President, I6 hands, six years old.

E. HACKETT.

I 8 I 3-Hunter, in Deering, Henniker and Hillsboro; bred in New York from the fleet race of horses; 16 hands, bay.

N. JONES.

Bulrock, formerly owned by Shubael and James Converse, Randolph, Vt., in Andover and Salisbury; foaled I SO5.

B. Thompson, JR.

Highly recommended by John French, Joseph Edson of Randolph and others.

ISI4-Hunter, formerly known by the name of the Pattee Horse, $15 \mathrm{I} / 2$ hands. JOHN MOLONEY, Northfield.

Young Quicksilver, dark bay, I6 hands; got by the imported horse, Quicksilver; owned by Gen. Bellows of Walpole.

T. WALLACE, Goffstown.

Young Robin at London, Pittsfield, Pembroke and Canterbury. William St. Clair.

Bulrock and Telescope-the last bay, I 6 hands, star and one white foot.

B. Thompson, Andover.

Mercury.

Stephen Gale, Conway.

I 8 I 5 -The Peeler, English; foaled I $810 ;$ I 6 hands.

D. SPRAGUE, Bedford. 
Black Prince; by Black Prince, imported by Col. Wadsworth, Kilburn and Ramsley in 1797 : dam, the Bissell Mare of Last Windsor, Conn., very noted. Owned since $\mathrm{x} S \mathrm{SO}$ in Walpole by Bellows, etc. hands.

Young Quicksilver; foaled I809; bay, black points, full I 5 Bulrock.

Telescope, known in Croyden as Young Slender and formerly owned by Mr. Rich of Claremont. B. Thompsos, Andover.

"Young Elephant, full-blooded, formerly owned by David S. Eaton of Boston; at Mt. Vernon.

\section{MARK A. Perkins, Mt. Vernon."}

We think this sire of $2 \mathrm{~d}$ dam of Lady Surry, dam of Henry Clay, in accordance with information from Peter W. Jones of Amherst, N. H., who wrote to Mr. Wallace that Lady Surry was a superior saddle mare, owned by Mark D. Perkins, who got her of the Young Muzzy boys, who once owned her dam which was got by an English horse owned or imported by David S. Eaton of Waltham, Mass.

L. M. Hall, city clerk of Waltham, Mass., writes under date of January I3, I904:

"David S. Eaton lived here ISI4; the records show that he had a son born here that year."

In the Patriot of Concord of ISI 5 appears the following advertisement:

That full-blooded horse, formerly owned by David S. Eaton of Boston, will be kept the ensuing season for the use of mares on Mondays and Saturdays at James Ray's tavern in Mount Vernon; on Tuesdays at Peter Woodbury's in Francestown; on Wednesdays at Safford's tavern in New Boston; on Thursdays at James. Wallace's in Milford, and on Fridays at Parley's in Hollis. Said horse is I7 hands high, of bright bay color, with a black mane and tail, and is well proportioned. He is five years old this spring. Terms, two dollars a leap, three dollars the season, and six dollars to insure a foal, Should the owner dispose of a mare, which is warranted, within one year, he will consider himself as liable to be called upon for the price of the warrant.

Mark D. PERkins, Mount Vernon, April I 5 , I 8 i 5.

Duke of York, bay, I6 hands. old.

Prince Edward and Wild Hunter-the last gray and three years 
1816-Peeler, Bulrock; Young Herald, I6 hands, seven years old; formerly owned by Major Cilley.

M. Furber, Nottingham.

Wild Hunter, I6 hands, gray; by old Stargazer, imported from England: dam, a Messenger mare of Florida, N. Y. At Claremont, etc.

W. Dudley.

Young Phenomenon, etc.

Wild Hunter from Florida, N. Y.; got by old Stargazer, which was imported from England, served at \$I 8 the leap and was sent for by his owner two years after his arrival in America, now kept in England and is there much noted.

Bulrock, Young Sweepstakes.

W. Dudley, Newport.

Old Hero; by old Driver; imported by Gov. Wentworth. Hero; foaled I 776 .

J. EMORY, Concord.

Magnum Bonum at Newport, dark bay, 17 hands. His stock may be reviewed at Alstead, where he has been kept last two years.

E. Chellis \& Co., I8I6.

Bulrock, Young Sweepstakes, in Springfield, kept at Strafford, Vt., from I 8 Io to I 8I4. Recommended by Col. Bellows, etc.

Also Wild Hunter in Claremont and Newport; got by old Star Gazer. Not more than three weeks from Florida, N. Y., where or near which he has been kept five seasons: dam, a Messenger mare, dapple gray, eight years.

WilliaM DUdLEY.

Young Quicksilver, Young Phenomenon; got by the Lawrence; Nasby at Hartford, Vt., by imported Nasby of Virginia; brought into State by J. Parkhurst, I 8 I 5.

New York Prince at Chester and Beachwood. Got by noted imported New York Prince.

Young Herald by old Herald at Nottingham.

The Peeler, full-blooded English, at Dunbarton.

Harmonica at Henniker.

Hamet Bashaw at Concord, N. H., dapple gray, full-blooded Arabian, I 5 hands, six years old; got by Dey of Algiers, imported by Col. Swan: dam the gray Arab mare, imported same time.

I 8 I 7 -Black Prince, old Hero, Mercury, Young Nasby; Young Eagle, formerly owned by Thomas Tucker of Henniker.

I 8 I 8-Bulrock, etc.

B. Alcock.

I819-Young Eagle, formerly owned by B. Alcock.

N. HOWARD, Weare. 
Hero Jr. and old IIcro.

Young Quicksilver: dam, full-blooded; raised by Simon Smith, Windsor, bay, $161 / 2$ hands, etc.

E. P'LE, JR.

I820-Young All Fours, Black l'rince, Young Bulrock and Highlander-full-blooded English horse, bay, I 6 hands, at Weare.

I $82 \mathrm{I}$-Young Boxer; raised in Virginia, chestnut, etc.

Black Prince; Young All Fours, ten ycars old, $15 \mathrm{~T} / 2$ hands: dam by White Horse of Plymouth or noted Webster Horse.

I 822-Young Quicksilver.

E. Hutchins, Andover.

I 823 -Young Hero.

I 824-Young Peacock; got by the imported horse Peacock: dam, a beautiful bay called Speed Eagle, got by the noted horse Morgan, the most celebrated horse ever in Vermont. Young Peacock, $161 / 2$ hands, etc.

Ebenezer Pike,

1825-Young Leopard.

R. Huse, Strafford.

Young Herod, red, I6 hands; foaled i 8 I 8.

Young Bulrock.

J. Eastman, Concord.

Royal George.

N. HAynes, Epsom.

Young New York Prince, black. D. LitTLE, Hempstead.

Young Royal George; by the noted Royal George, imported from England: dam, Dutch from New York.

I 826 -Young Hero.

I 827 -Noted horse Shark at Sandwich, Moultonboro and Meredith; got by old Shark, an imported horse.

J. S. Quimby,

Young Hunter.

S. MASON.

I 828 -Verne.

Prince Edward, Wild Hunter, Young Elephant, Bulrock, Telescope, Duke of York. Young Bay Figure, advertised by E. Cressy, Bradford.

Gay Robin, four years.

E. DANFord, Boscawen.

I 829-The Old Morgan, more generally known as the old Morgan Sherman Horse, will be kept at the stable of Mr. Gibbs at Littleton Village, N. H., this season. No history or recommendation is necessary to those who have seen this horse or his stock. He has been kept for many years at Danville, Caledonia County, Vt., by John Buckminster, Esq., and is by far the best sire in the State of Vermont or New Hampshire. Terms, $\$ 6$ the single leap, $\$ 8$ the season, $\$$ Io to warrant.

John Bellows, Lancaster. 
Young Morgan will be kept in New Boston, Francestown, Lyndeboro, Hollis and Amherst Plain. $\mathrm{He}$ is a business horse as firm as any bone or flesh ever put together. He took first premium at the cattle show last fall with good judges. I829.

M. D. PERkins.

1830-Grand Turk, same blood, color, etc., as Eclipse; purchased at Princeton, N. J.

A. Colby, New London.

Dutch Morgan Trotter-A grandson of the old Dutch Morgan Horse and a fair sample of his grandsire. His size is 15 hands and well proportioned; as it respects bone, muscle and speed, he has no rival in this section of country. To be kept at J. Bean's, Holderness; Sam M. Sentor's, Centre Harbor; Josiah Fiske's, Moultonboro; N. Vinton's, Sandwich; J. Wiggins', Somersworth; E. Renwick's, Tamworth, etc.

W. B. Chapin, Moultonboro, I830.

It is quite noticeable that repeatedly the Morgan stallions are recommended for their speed, and very seldom any other.

The noted Dutch Horse, known in Vermont as old Morgan Sherman, at Dover, and So. Berwick, Me.; Wednesdays, Great Falls, Somersworth, Rochester and Concord. Bred by James Sherman, Lyndon, Vt.: dam, an imported Dutch Hungarian mare, etc. His colts take the lead in New England and New York markets, etc. \$IO to \$I4. John Bellows.

Thoroughbred horse Catholic at Concord.

I 83 I-Old Hunter.

Young Morgan Sherman, seven years old, chestnut, I 5 hands; by Sherman Morgan.

IV. Colby, Warren.

I832-A true son of old Sherman Morgan, Cock of the Rock at Plymouth and vicinity. George Bellows, Lancaster.

Young Sherman King in Moultonboro; bred by David Goss \& Son of St. Johnsbury, Vt., and got by Sherman Morgan.

S. C. Gibbs.

Silver Gray at Canterbury and London, I 6 hands.

$$
\text { G. Lovering, I832. }
$$

Hunter, recently from New York.

J. T. COFFIn.

Old Sherman Morgan, accompanied by one of his true sons, will be kept the ensuing May and June at Dover, Durham, Somersworth, So. Berwick and Rochester.

John BeLLows, Lancaster, 1832.

I833-Bucephalus; got by one of old Hunter's colts; gray, six years, etc.

B. B. Scribner, Concord. 
I 834 to 1840 inclusive. None.

I 856 - The Sherman Morgan, a grandson of the original Justin Morgan, and Kent Morgan, a grandson both of old Sherman and old Woodbury, at Lancaster.

I 860-A jax.

A. J. Congidon.

HeNRY H. SiITII.

The Librarian at Concord says: "A two-year-old colt called Shark was sent from England to New Hampshire; owned by Mr. Holton; I 300 pounds, bay, about I835. About 40 years ago a horse called Danvers Boy was taken by George Martin to Danvers, Mass., afterwards, I think, sold for \$IO,Ooo and went to Ohio."

This was a son of Napoleon Morgan, by Flint Morgan, son of Sherman Morgan: dam of Napoleon Morgan, said to be by Cock of the Rock, son of Sherman Morgan.

\section{(From Farmers' Cabinet, Amherst, New Hampshire.)}

I $\mathrm{SO}_{3}$-Merry Momus at Bedford.

The Morning, red, I 6 hands, four years old.

Cardinal Puff, imported, at Henniker.

I So4-Young Comet, bay, I 5 I/2 hands, six years.

A. Gould, Mason.

Wild Roe at Mt. Vernon, Nashua, etc.; red, I 6 hands.

L. W. RAY.

Sivift; Magnum Bonum, bay, I 5 hands, seven years; bred by Gen. Derby, Salem, Mass., from a full-blooded English mare got by the best horse ever imported to New York, that covered at $\$ 40$ the leap.

Sour Crout, I 6 hands, almost black.

Godolphin, bay, I 6 hands, at Dunbarton.

I 805 -Magnum Bonum. Godolphin.

I 8 o6-Bajazet, full-blooded, bay.

I 809-"Take notice. The Young Traveler will be kept coming season at Wm. Parker's in Bedford; Capt. Stark's in Dunbarton; Theophilus Stanley's in Hopkinton; Captain Eaton's in Weare; James Shirley's in Goffstown; J. Goodhue's, New Boston; Esty's, Mount Vernon; R. T. Bass' in Wilton; Dea. Lovejoy's in Milford and James Stanley's in Goffstown; $\$ 4$ to $\$ 6$. The Young Traveler is an elegant bright bay, 16 hands high and 6 years old this spring. This noted horse has for the three last years been kept at Ben. Bassett's stable in Milton, and is known to be one of the finest horses in the county. Constantly attended by the subscriber.

Goffstown, May 4, I 809." 
The Young Paymaster in New Boston, dark ch., I6 hands. JOHN UPTON.

I 813-Young Elephant; Arabian Prince; spotted, I5 hands, seven years.

I. MARsh, Dunstable.

1814-Young Traveler in Wilton, chestnut, four years, owned by Jabez Goldsmith; equalled by few for strength, beauty and activity.

Hunter, bay, 16 hands, brought from New York in the fall of 1812 .

I 8 I 5 -Hunter, etc.

N. JONES.

I 8 I 7 -Bulrush, etc.

1818-Aurum, Dutch, nine years, brought from New York in I816, bay; for strength, beauty and elegance no horse can excel him. At Claremont.

I 8 I 9-'20-None.

182 I-Emperor; by the imported horse Quicksilver, owned by Bellows; bay with black points, I 5 hands, six years old.

R. Wallace, Milford.

1822-Emperor and New York Prince, black.

F. Lovejox, Milford.

1824-New York Prince.

The young horse Washington Gray. He is of the line of Black Prince.

L. Sprague, Bedford.

Financier at Wilton, etc.; got by the famous race horse, Financier, imported: dam, a beautiful Spanish mare now owned on Long Island.

1825-Young Financier.

I826-Comet, I6 hands. Leopard advertised by Mark D. Perkins. Young Farmer advertised by E. Tapley, Wilton.

I 827-Young Morgan at Milford, Hollis, Lyndeboro and New Boston. Mark D. Perkins, Mt. Vernon.

I 830-Young Nondescript; raised by John Muzzey of Peterboro; at Boston, Hollis, etc.; bright bay, six years old, a horse of great power. One of his colts sold for $\$ 500$.

Mark D. Perkins.

I83I-Eclipse at Thomas Muzzey's in Weare, etc., bay, I5 hands, five years old. George W. PARKer, Goffstown.

The Young Lion, dapple gray, I 5 hands, pedigree good.

J. Cochran, Amherst.

Young Morgan, seven years old; a good horse for business.

M. D. Perkins. 
1834-Eclipse, bay, four years old; got by the English horse Hyland.

S. LOVEJOY, Wilton.

Nondescript.

M. D. PERKINS.

Sir Charles at Wilton, Hollis, etc. Sold when five years old for $\$ 1000$; is now eight; was raised in Montpelicr, Vt., and got by Olive Branch; dapple bay, 16 hands, 1600 pounds, pedigree good.

J. Cochran.

Wild Napoleon at New Boston, etc.; eight years old, black, remarkably short back, long hips and low, bone flat, limbs great, cordy and muscular. Got by the Napoleon horse owned by the Agricultural Society of Paris; trotted six leagues in sixty-nine minutes and took a purse of 625 pounds; grandsire owned by Gen. Napoleon Bonaparte and kept by him for a parade horse. His dam was a dapple gray mare and was imported from Paris to the Wild River (near Halifax), where he was foaled; the fall after he was bought at $\$ 100$, and taken up to Three Rivers and from there recently bought by G. E. Cargit of Lancaster and kept by him till 1833, then sold to John Hale of Haverhill.

S. H. Train, Amherst.

I 835-Wild Napoleon; has spirit and energy without end and his speed upon the walk, trot and turf cannot be matched.

Young American Eagle or Wood Horse.

J. BALCH.

1838 -None.

I 839-Sir Edward, a Dutch horse; raised in Dutchess County, N. Y.; has been kept three or four years in Hillsboro.

M. D. Perkins, Mt. Vernon.

$1840-$ Young Nondescript.

M. D. Perkins.

I 84 I-'42-'45-None.

I 845-Young Morgan at Amherst, New Boston and Mt. Vernon.

M. D. PERKINS.

1846-Mikel Raeker or Thayer Horse at Bedford, Mt. Vernon, etc. Can trot or rack a mile in $2: 30$. He is a full-blooded French horse and built for hard service.

M. D. PERkins.

I 847-Mikel Raeker; Easy Traveler; four years old.

M. D. PERKINS.

Wild Indian, ten years old; raised by an Indian in the wilderness of Canada. Sam Vose, Amherst.

1849-Wild Indian.

1852-Mikel Raeker. G. W. BAGLEIGH.

Morgan Tiger or the Bell Horse at New Boston, Wilton, etc.

M. D. Perkins. 
cxlvi

1853-Mr. Perkins advertises again Morgan Tiger or Bell Horse.

1854-Young Green Mountain Morgan at Milford, etc.; by Green Mountain Morgan, owned by Silas Hale. Abel Chase.

Mark D. Perkins appears repeatedly in these advertisements, and generally with a Morgan horse. This is the Mr. Perkins that at one time owned Lady Surry, said to have been by Revenge, son of Justin Morgan, and sold her to Daniel W. Gilmore formerly grocer at City Hall Place and Pearl Street, New York City. Mr. Gilmore rode her to New York City with a young man named Lovejoy, son or relative of the Lovejoy who kept a hotel. She passed to Mr. Platt, a noted builder, then to George M. Patchen, New Jersey, who bred her to Andrew Jackson, son of Young Bashaw, by Grand Bashaw, producing Henry Clay, progenitor of the Clay family of horses.

Gen. Taylor at Milford, etc.; by Green Mountain Morgan: dam, the Patterson Mare, owned by Dr. J. Crombie, Francestown; dark chestnut, seven years old, well built, prompt and spirited, with good action; I IOO pounds. P. M. ROSSITER, Milford.

Black Morgan in Amherst. John L. Poole, Hollis, 1854.

1855-Young Green Mountain Morgan and Young Woodbury Morgan at Milford, etc. : dam of Young Green Mountain by Muzzey Horse; seven years old. Young Woodbury; got by Green Mountain Morgan: dam, a full-blooded Morgan; three years old, dark chestnut, I000 pounds.

Abel Chase.

Gifford Morgan at New Boston, Wilton, Mt. Vernon, etc.

M. D. PERKINS.

I 856-Young Green Mountain Morgan.

H. Prouty, Milford.

Young Woodbury.

A. Chase, Milford.

I857-Telegraph, a fast trotting stallion.

I 858 -Young Green Mountain Morgan.

A. Chase.

1859-None, and none in 1865 to 1869 , inclusive.

(From Oliphant's History of the United States. Edinburgh, I800, page 83.)

"The breed of horses has been neglected, as this animal is little used for draught. The proportion of horses to neat cattle is not more than one to twenty."

"Tables of Exports" for one year (I797) has "Horses, I I37."

also says: "The staple commodities of New Hampshire are ships, lumber, provisions, fish, horses, potash, peainch and flaxseed, all of which compose part of their exports." 

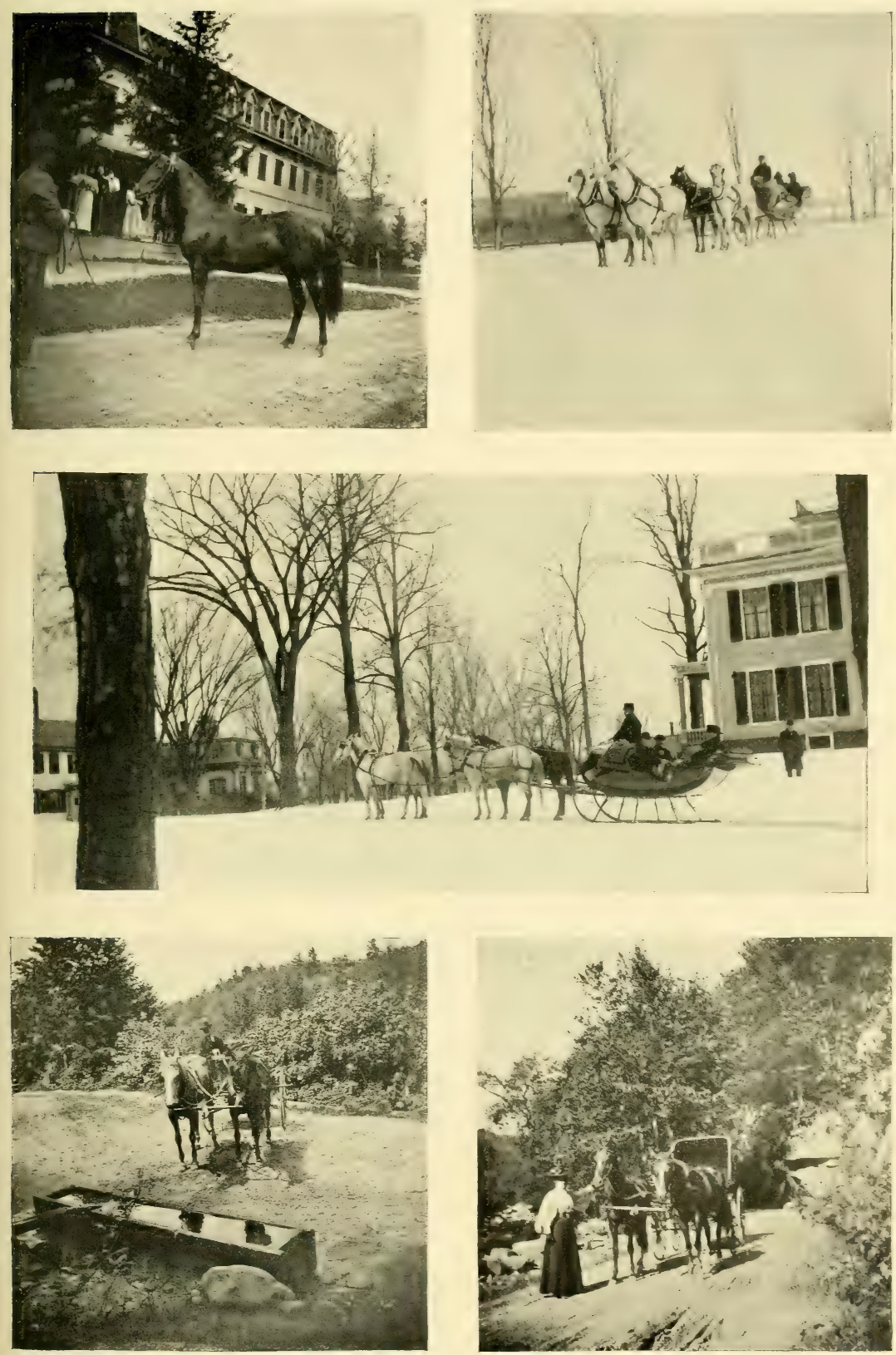


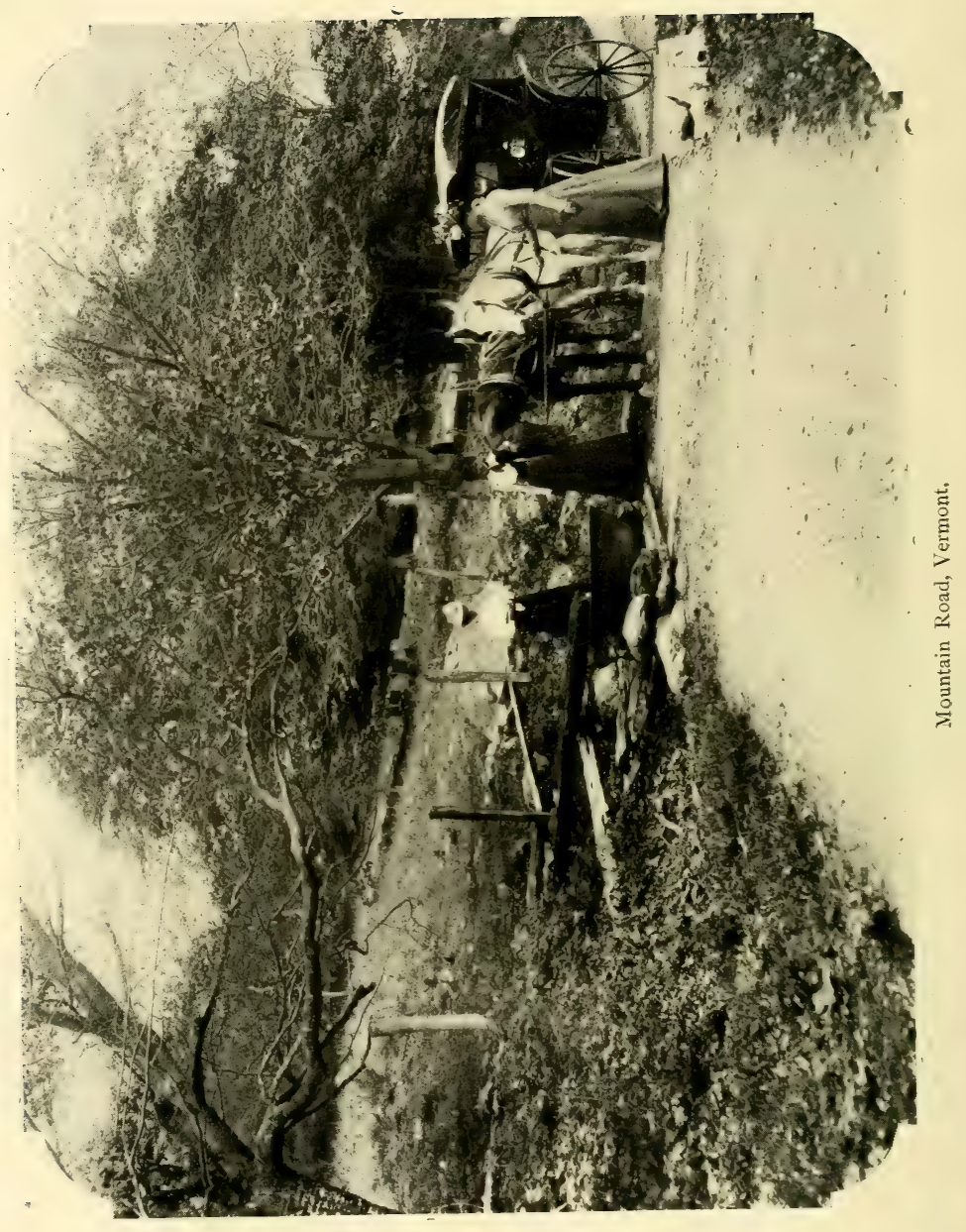




\section{VERMONT.}

Land of the forest and the rock;

Of deep blue lake and noble river :

Of mountains reared aloft to mock

The storm's career, the lightning's shock :-

My own green land, forever !

-Whittier.

$\mathrm{V}$

ERMONT was so named from the color of her mountains, clothed from base to summit in perennial green. The early history of this State is utterly unlike that of any other in the Union. Vermont was never organized as a province under the crown of England; was never recognized by the crown as a separate jurisdiction. She constantly refused, moreover, to submit to any provincial government,-never once recognized the authority either of the province she was nominally placed under, or of any other external power. The inhabitants of the New Hampshire Grants, as Vermont was called before her organization as a State, therefore found themselves from the first a community without a government, bound together only by their common interests and social affections.

“The history of Vermont is hence," says Prof. Zadock Thompson in his history of the State, "that of a people assuming the powers of government and advancing by successive steps from a state of nature to the establishment of a civil compact, and to a regular and efficient organization."

It must not be assumed, however, that Vermont was ever a lawless community. Her pioneers, mostly from Connecticut, New Hampshire, Massachusetts and New York, came within her borders well schooled in the art of local self-government, and with a keen sense of the rights of person, property and opinion. Save in their contests with those who would deprive them of their lands or their liberties, in which they made the name of the Green Mountain Boys a terror to their enemies, there is no record of a more peaceful and law-abiding people.

"The first civilized establishment within the present limits of Vermont," says Professor Thompson, "was made in I 724 by the erection of Fort Dummer in the south-eastern corner of the township 
of Brattleboro. Hitherto the whole of this tract of country had, from time immemorial, been in possession of the native Indians, though it does not appear that, subsequent to the discovery of this country by Champlain in 1609 , the natives had ever resided here in very considerable numbers. The western parts, including Lake Champlain, were claimed by the Indians; the north-eastern parts, including Lake Memphremagog, by the St. Francis and other Canadian tribes; while the south-eastern parts on the Connecticut river were regarded as belonging to the natives in the neighborhood of Massachusetts Bay. Certain establishments were at times made upon the shores of these waters by several tribes; but there is reason to believe that this territory was rather regarded by them as a hunting ground than a permanent residence."

Soon after the erection of Fort Dummer several block-houses were built for the protection of settlers in what is now Vermont and before the year 1754 settlements had been commenced in Vermont as far up the Connecticut as Westminster and Rockingham. This advance was checked by the breaking out of the French war, terminating only with the conquest of Canada in 1760 . During this war these feeble settlements were continually harassed and annoyed by the French and Indians, the inhabitants baing hardly able to cultivate their fields without being exposed to the fire of a lurking foe. Their block-houses were frequently surprised and taken, and the inhabitants either massacred or carried into hopeless captivity. After the conquest of Canada settlements grew with surprising rapidity, especially along the Connecticut. Previous to I 770 there were next to no settlements on the west side of the mountains north of the parent county of Bennington. But during I 77 I several settlements were begun in Rutland County. At the breaking out of the Revolution the population of Vermont is estimated at about 20,000. Nothing can more vividly portray the suddenness of the immigration, and the character of the newly arrived inhabitants, than this extract from a private letter of Gen. Burgoyne to Lord Germain, dated Saratoga, August 20, I 777 :

"The Hampshire Grants in particular, a country unpeopled and almost unknown in the last war, now abounds in the most active and rebellious race on the continent, and hangs like a gathering storm on my left."

Vermont became early noted as a stock-growing State, and her horses were known abroad in the last century. In Oliphant's 
History of the United States (Edinburgh, 1800), in speaking of Vermont, the author says:

"The domestic animals are horses and black cattle, to the breeding of which great attention has been paid of late; jacks, mules and a very fair breed of sheep, which thrive nowhere perhaps better than in Vermont. * * * Some little trade is carried on with the Province of Quebec: The articles of export to Hartford, Boston and New York are horses, beef, pork, butter, cheese, wheat, flour, iron, nails, potash and pearlash."

And Winterbottom in Historical Views of the United States (New York, I 796) says of Vermont:

"Some of the finest beef cattle in the world are driven from this State. Horses also are raised for exportation."

The proportion of early Vermonters that came from Connecticut was very large. The Connecticut River was the first great highway of immigration, and Hartford early became a favorite market for the new comers to the north. This was the region whose horses, especially the descendants of Ranger (Lindsey's Arabian) so strongly and favorably impressed Generals Washington and Lee in 1776 , that they are said to have caused Col. Lindsey to purchase Ranger, and take him to Maryland and Virginia, for the improvement of a stock already famous. It was fortunate for the new settlements that they drew most of their early stock horses from this favored region, where choice strains of thoroughbred blood were very prevalent. The stallion advertisements in the Vermont Journal, published at Windsor, begin in 1784 for the east side of the mountain, and in the same season, for the west side, they appear in the Vermont Gazette, published at Bennington. We note all these advertisements, that give any clue to breeding or origin up to the year 1800 , as being the best accessible index of the blood and character of the horses there bred, during that period.

\section{EARLY HORSE ADVERTISEMENTS.}

(The following are from the Vermont Gazette, Published at Bennington, Vt.)

"Stolen, a light sorrel mare, six years old, I4 hands, with blaze in face; trots single-footed, canters well."

In the same number is: "Taken up a gray mare about I4 hands, about five years old, natural pacer."

I 783- "Strayed or stolen out of the pasture of Cephas Kent, 
innholder in Dorset, dark brown mare about ten years old, about I 4 hands, paces and trots, low carriage.

Amos Fassett, Bennington, July I, i 783 ."

"To be sold, the Young Raven, four years old, of the Wildair breed a horse of size and beauty.

Erastus Sargent, Stockbridge, Mass., April i 7, I 784."

I784-The famous Wildair, in Adams until June 3, after that at Adams and Williamstown; got by the famous horse Wildair: dam full-blooded, by Lath.

I785-At Bennington, the beautiful black horse, Bucephalus, bright black, near I 5 hands, five years old, well built; seven-eighths blooded. $\$ 1$ to $\$ 2$.

David Russell.

At Bennington, the elegant imported dark bay horse, Liberty, nine years old, $14 \frac{1}{2}$ hands high, well made and pedigree equal to any.

At Mapletown (Mass.), imported bay horse, Goliah, bright bay, eleven years old, 15 I/2 hands, full-blooded. Has been kept four years on Long Island.

At Walloomsack (Mass.), beautiful dapple-gray horse, Bajazett, seven-eights blooded, nine years old, I $5 \mathrm{I} / 2$ hands; got by the imported horse Northumberland or Irish Gray, so well known.

I 786-At Bennington, the elegant imported horse, Sampson, bright bay, good size. $\$$ I to $\$ 6$.

At Adams (Mass.), the elegant horse Wildair; got by Lath : dam by Hooker's old Wildair, and is the most elegant and best horse in New England.

Stolen! bay mare, I 4 hands, natural trotter, also two horses, one I 5 hands, the other $14 \mathrm{I} / 2$ hands.

I 787-At Manchester. At the stable of Col. Keyes, Bold Selim, dark brown, near I 6 hands, remarkably strong and well built; bred in New Jersey.

I788-At Clarendon. The famous horse True Briton, seven years old, bright bay, full $15 \mathrm{~T} / 2$ hands, gerieel carriage and step.

I 789-At Sunderland, Tryall, chestnut sorrel, full-blooded, nine years old; got by imported Yorick: dam the imported mare Nancy Bywell, owned by James Lloyd, that ran with DeLancey's noted horse, Lath, at Warwick for $£_{500}$ and distanced him in the second heat. This horse was brought from Maryland by Capt. James Hurd of New Jersey. Figure and appearance elegant. $\$ 2$ to $\$ 5$.

Lemuel BRAdLey. 
At Bennington, the beautiful imported horse, Peacock, black, I 5 hands, equal in spced to any horse in the State. $\$ \mathbf{I}$ to $\$ 3$.

SAMUEL ROBINSON.

At Shaftsbury, Hero, black, I 5 hands. $\$$ I to $\$ 4$.

SETH HUNT.

At Bennington and Pownal. Young Courier, five years old, 16 hands, dark brown, trots and canters; got by Count de Grasse, by Wildair: dam full-blooded.

I 790-At Williamstown and Bennington, Wildair, five years old, I 5 I/4 hands high.

At Williamstown, Mr. Sprague's beautiful horse, Snip, seveneighths blooded, bay, I 5 hands; by Young Wildair: dam by old Minister, a full-blooded horse kept in Philadelphia. $\$ 4$ to $\$ 8$.

I79I-At Sunderland, Janus, full-blooded, about I6 hands, has been kept for several years past in Westchester County, N. Y.

At Pownal, Rainbow, chestnut, seven-eighths blooded, I 5 1 2 hands; got by old Ranger.

At Bennington and Pownal, Young Sampson, bay, three years old, canters and trots; got by Walbridge's Sampson, an imported horse: dam full-blooded.

At Bennington, Young Liberty, six years old, I 5 I 22 hands; bred by Elihu Smith of Clarendon; got by old Liberty.

At Mapletown and Bennington, Young Briton; by Bold Briton; I 5 hands high, eight years old.

At White Creek, N. Y., the full-blooded horse, Antelope; bred in New Jersey; bright chestnut, four years old, I 5 hands; got by Janus, son of Fleetwood, by old Janus of Maryland: dam by Liberty of Maryland, that famous horse, that was sold for 700 pounds; grandam Guinea-water, by True Briton of New Jersey. $\$ 2$ to $\$ 8$.

At Bennington, Sweeper, dark chestnut, I $5 \frac{1}{2}$ hands, fullblooded; got by a colt of old Fearnaught in Virginia, from the imported mare, Miss Leeds, own sister to Nancy Bywell that beat Lath at Warwick, Maryland.

At Shaftsbury, Abimileck, full-blooded.

I 792-At White Creek and Bennington, Fearnaught, I 5 hands, sorrel; got by Young Briton: dam by Jo Miller. $\$$ I to $\$ 4$.

At Vergennes, Junius; got by imported Lath, swiftest horse ever imported to New York: dam by old Wildair, sent back to England from America. Dark bay, I6 hands. $\$ 2$ to $\$ 4$.

It will be noticed that this horse is inbred to De Lancey's celebrated stallions, Wildair and Lath. 
cliv

English Eclipse; Sir Walter's dam, Nettletop, by imported Diomed; foaled i826. (Signed) Silvester Milliman, i 832.

\section{(From The Tablet of The Times, Bennington.)}

I 797 -Bucephalus, bred in Hartford, Conn. ; got by old Bucephalus; bay, I 5 I 2 hands; foaled I 793 ; at Shaftsbury.

\section{Elias Huntington.}

Sweet Briar, bay, i 5 I 2 hands, imported, at Cambridge, Little White Creek and Shaftsbury. Joseph STEWART.

Cincinnatus, full-blooded; by old Cincinnatus; bay, 16 hands. Moses S.tGE, Bennington, I 797.

Bajazet and Venetian in New Hampshire. hands.

At Cambridge and Shaftsbury, Sweetbriar, imported, bay, Is

At Bennington, the full-blooded horse, Cincinnatus, bright bay, I6 hands; got by old Cincinnatus.

Loyal Hunter in Danby, Granville and Manchester, imported by Robert Brown of New York in 1796, full-blooded English Hunter, bright bay, black mane and tail, dark legs, a natural trotter, full I7 hands. \$6 to $\$ 7$.

Sprightly Club at Williamstown.

Herod Tioga, full-blooded, at Bennington, by D. Robinson.

Bold American at Cambridge; by imported Rockingham.

In ISO2 we have the Black Figure at Pawlet and Manchester, by a celebrated horse same name in New Jersey, 15 I/2 hands.

\section{(From I crmont Foumal, published at II"indsor, Vt.)}

I $784-$ Hero at Norwich, Hanover and Lebanon:

"Is a horse equal in beauty to any in this country; full 16 hands high; trots and canters, and his character in Connecticut where he is known is unblemished.

WILLIAM BAXTER."

The noted horse Young Snip, got by the noted horse Snip, which formerly belonged to Gov. Wentworth. \$I and \$2.

\section{EBEN WENTWORTH.}

I 78 - The famous English horse Sampson:

"For beauty, size and going, he is superior to any horse that has ever been brought into this part of the country. He was imported from England since the commencement of the late war. His character in Rhode Island and Connecticut where he is known, is unblemished, and his colts universally esteemed. I 5 and I 8 shillings: JOSEPH HATCH." 

stock :

1786 - The beautiful dapple-gray horse, Moravian, at Wood-

"Moravian is equal in strength, carriage and activity to any horse in this country. His sire was the noted Moravian horse formerly owned by Mr. Chandler of Windham in the State of Connecticut. Well known for getting fine colts. Terms \$r. PAUL TODD."

1787 -An elegant horse from the noted Smiling Ball, is advertised. (Smiling Ball was a Narragansett pacer).

I $78 S$ - Bold Hovey, at Bridgewater. "He is a horse equal for beauty, carriage and activity to any in this country. His sire was the noted English horse of the same name owned in Connecticut. \$I and $\$ 2$.

Elisha Gillett."

Roaring Lion, 17 hands high, trots light and genteel, bright bay, formerly owned by Col. Coggswell of Gilmanton, N. H.

\section{Joseph SiIth.}

I790-The beautiful young horse Peacock, in Hartland and Windsor. He is a colt from the famous English horse of that name, imported by Gov. Wentworth, and is a great likeness of his sire.

Governor Benning Wentworth was born in Portsmouth, New Hampshire, I696; graduated at Harvard in I7 I 5, and died at Portsmouth, I770. He was son of Lieutenant Gov. John Wentworth, born at Portsmouth, I67I, whose father William Wentworth was born in Lincolnshire, England, I6 5 , and died in Dover, N. H., I697. All the Wentworths in the United States are descended from William. Governor Wentworth became a merchant in Portsmouth, and accumulated quite a property. In I 74I when New Hampshire was made a distinct province, he became its governor, and remained so until I 767 . This information is from Appletons' Cyclopædia of American Biography.

In Hartland, the Young Ranger.

I 79 I-In Hanover, the Roving Lion.

I 792-In Hartford, a beautiful horse called Grayhound.

In Strafford, the Young Racer

I793-In Villiamstown, the beautiful full-blooded horse Snip. Also the young horse Weasel:

"Weasel is a bay horse got by IVeasel, a colt of old True Briton an imported horse. His dam is a full-blooded mare, and is the same that brought the Russel Horse, or the Wildair.'

This statement that True Briton was imported, as well also the fact that dam was of the DeLancey stock, is strong evidence that 
clvi

this True Briton was the one imported by Capt. De Lancey, and sire of the original Morgan horse.

Old Racer, dapple-gray, at stable of Col. Asahel Chamberlin in Strafford.

In Woodstock, the Young Weasel lately brought from the State of New York. He is a beautiful chestnut, well proportioned, and his carriage is easy and elegant. SHADRACK DARBI.

I 794-In Reading, the Young Arabian, got by an imported horse, the noted old Arabian. $\mathrm{He}$ is of a beautiful dapple-gray color; his carriage is elegant; his proportions perfect.

Williay N. STONE.

In Plainfield, the Geer horse.

WILLIAM DEAN.

In Jericho, Wildair, the noted bright bay horse, I $5 \mathrm{x} / 2$ hands high and every way well proportioned. Lately from the southward.

MIARTIX CHITTENDEN.

The beautiful full-blooded horse, well known in the county of Worcester and the parts adjacent by the name of Hyder Ally; eight years old, I 6 hands high.

\section{Is.AC CHADDOCK, Randolph.}

The beautiful full-blooded horse, Eclipse, in Westminster and Walpole :

"Eclipse was brought by Gen. Bradley from the Southern States where he was imported, is twelve years old, $151 / 2$ hands, bright bay, completely proportioned, and his movement is as graceful and elegant as the sea in its gentlest motion."

Bay Richmond. At Reuben Blanchard's stable, Peacham, stands that good, delicate and well-bred horse known by the name of Bay Richmond. He is a full-blooded horse, a beautiful bright bay; he was brought from Virginia four years since, has stood at Hartford Conn., and in Massachusetts.

I795- At Norwich, the elegant English hunting horse Rockingham, a beautiful bay, full i 6 hands high, moves well, carries lofty and gay and is six years old this spring. His sire was old Rockinghain, imported from England by Col. Taylor in I786. His dam got by the imported horse Bay Richmond, from Person Nerling's English mare, Flora. Roswell OlcutT.

At IVoodstock, the beautiful horse Foxbury. *** Foxbury is lately from Virginia; is now five years old. His sire was old Cub imported from England. His grandsire was old Belgrade, one of the most noted hunters in the north of England. His color is a beautiful bay; his height is 16 hands 2 inches; his body and 
limbs are well made, completely joined and proportioned. His goings are elegant and easy; he is swift in the race. $\$ 2$ to $\$ 4$.

At Orford, N. H., the beautiful horse, Young Ranger, handsome, gay, young, well built, strong and proves very sure of the likeliest colts in Middletown in Connecticut and in this country. He is of the noted Hartford horse breed, and stood last season in Thetford and Newbury. JOHN MASON, JR.

At Woodstock, that beautiful and noted horse Young Grayhound; 6 to 12 shillings. Thomas Ellis, JR.

At Thetford, The Rainbow, a full-blooded red roan horse, full I 5 hands high; carries loftily and moves beautifully, and is five years old this spring. He was got by the beautiful Selim, formerly owned by Josiah Bond of Conway. Io to 30 shillings.

\section{ADONIRAM SiIALLEY.}

At Royalton, the beautiful horse Macaroni, I 5 1/2 hands high; is a beautiful leopard; is a lofty, beautiful moving horse; was got by old Ranger, or Moravian horse, whose colts were so well known in Connecticut. \$I to $\$ 5$.

Tilley PARKHURST.

At Hartland, the famous horse known by the name of Miltimore.

JOHN S. WILLARD.

At Newbury, that elegant, nervous, full-blooded horse $\mathrm{Hy}$ der Ally, the property of Col. Porter. Hyder Ally is a blood bay, nine years old; about I 6 hands high; well proportioned. For beauty, spirits, strength or speed he is not surpassed by any horse in New England. He was bred by John Phillips, Esq., in New Jersey, and got by the noted full-blooded horse, Liberty, bred by Thomas Grant, Esq., of Maryland. Liberty's dam was Milly, the dam of True Briton; a beautiful thoroughbred mare originally sprung from the Flying Childers in England and got by the imported horse, Dove. The Hyder Ally's dam was Dido, bred by John Schenck, Esq., of New Jersey. She was got by the full-blooded horse, Arabian, got by old Wildair, imported from and afterwards returned to England. Dido's dam was Juniper, from Primrose; her grandam by Othello; her great.grandam by Gen. Ogle’s Barb. \$4 to $\$ 6$.

I 796-At Hartland, the noted horse, Hermit. He was got by old Liberty, a celebrated imported English horse. His dam was got by the famous Bulrock: dam by Wildeer. Sixteen hands; beautiful dark bay; colts have been sold from $\$ 700$ to $\$ 1300$ the past year. Sire of Slippery Whiskey and Cub. \$5 to \$r2.

ROGER ENos. 
clviii

Hermit is advertised in Northampton (Mass.) Gazette, I795, described as $15 \mathrm{I} / 2$ hands; bred in Virginia. Has been kept on Long Island and in Connecticut. Sire of Useful Cub.

At Randolph and Brookfield, the beautiful black horse Arethellow; six years old; $153 / 4$ hands; of great spirit, activity, beauty and strength; got by the noted horse, Recovery, also known as the Pool Horse, now owned by Dr. Jared Dyer, Canterbury, Conn. Terms, $\$ 5$. John HATCH, JR.

At Reading, The Leopard, beautiful dapple gray; of middling size; got by the famous Bulrock: dam by Wildeer. Claimed as sire of Slippery Whiskey and Cub.

\section{George Sturdevant.}

At Windsor, Bucephalus, the beautiful full-blooded horse; also a full-blooded English horse got by the Bucephalus from the best English mare in Connecticut, where he was kept four years. \$5 to $\$ 12$.

At Plainfield, the noted gray horse got by the old Raven Drag, a full-blooded English horse in Philadelphia.

JACOB SMITH.

At Randolph, that full-blooded horse, Herald; beautiful bay; good figure, handsome carriage; about 15 hands; got by the wellknown Russia horse, which was got by the old imported Wildair, from a full-blooded bay mare. Herald's dam by old Liberty. \$2 to $\$ 5$.

Jonathan DuRkeE.

At Norwich, the high-bred horse, America; got by the noted imported horse, Recovery, famed the most of any horse ever on the continent for beauty and as a sire. Dam full-blooded mare after

- old Ranger. America is six years old, bright bay, I6 hands. $\$ 4$ to $\$ 6$.

JoHN HATCH.

At Woodstock, Atlas; by Recovery: dam the noted Putnam Mare.

At Royalton, Young Macaroni again; also the noted horse Fox, by Bedford, by Wildair; also Cardinal Woolsey or Hough Horse at Lebanon.

I797-Young Prince; bred by A. Hatch, Norwich; got by Recovery; chestnut, $151 / 2$ hands.

J. НАтсн, Norwich.

Recovery at Walpole at $\$ 20$; by Tartar, by old Tartar, etc. He was imported from England, is 16 hands and has been kept for four years by Dr. Jared Jones of Canterbury.

Newmarket at the same stable; got by Recovery; also Republican by Recovery.

W. DYer, Walpole. 
The Figure, about fourteen years old, dark bay, $151 / 4$ hands; raised in Virginia and seven-eighths blooded.

Joel TILDEN,

S. Bingham, Lebanon, 1797.

Cardinal Woolsey is advertised by the same parties; dark bay, $161 / 2$ hands.

Young Wildeer at Randolph and Brookfield; by old Wildeer that was kept at Keene six years: dam imported by Timothy Williams of Watertown.

Old Hermit at Pomfret.

Young Nimrod at Montpelier, bay, 16 hands, seven-eighths blooded. DAVID WING.

Old Valiant; by imported Lath at Pomfret.

Beautiful horse, Vulture, bay, $15 \% 2$ hands, brought from the southward last fall, at Hartland.

J. Willard.

Grand Turk in Windsor and Reading; by Recovery: dam, the celebrated Rockwell mare; foaled I792; bay, black points, I 6 hands.

Grayhound in Weathersfield and Windsor; got by the muchfamed horse, Smiling Star: dam, the gray mare Smilax; foaled I793; dapple gray. JOHN FARLEY.

I 797-Cathullon; by Roebuck of Hardwick, Mass.; he by Joe Miller, imported from England by Brigadier Ruggles: dam, Golddust, imported at the same time with Joe Miller, grandam, Nancy Dawson, etc. W. C. ArNold, St. Johnsbury.

Scueball; foaled I790; 15 I /2 hands, chestnut.

Othello, black; by Recovery; in Chelsea.

J. Streeter, Hartford.

JohN Hatch.

Marquis; foaled I794; by Recovery, and Curdon, also by Recovery.

America; by Recovery; at Norwich.

William Dean, Plainfield.

I 798-Mountain Leader, chestnut, I6I/2 hands; kept at Providence, R. I., last season. T. PECK, St. Johnsbury.

At the same place, Pilgrim, nine years old this grass.

Imported horse Figure, 16 hands, at Hartford.

T. IV. Pitkin.

True Figure, bay, I 5 I $/ 2$ hands, at Reading and Woodstock. NATHAN HibBaRd, JR.

Liberty; recommended by parties in Massachusetts; foaled I792; got by imported Liberty: dam by Bulrock.

C. BARDWELL. 
Wildeer; bred in Virginia; $153 / 4$ hands, bay.

J. Streeter, Hartford.

Young Arabian, gray ; foaled I 793 ; in Hartland and Woodstock.

Old Hermit; advertised by O. Hutchinson, Pomfret.

The celebrated horse Pilot in Bradford, bay, I 5 hands.

MICAH BARRON, Bradford.

Also by the same, Venerable, I61/2 hands, bay; foaled I 793.

Young Bajazet.

C. Curtis, Royalton.

Joe Miller in Windsor and Reading.

I 799-At Hartford, the Faithful Champion full-blooded bay, I6 hands; bred in Pennsylvania.

At Windsor, Janus a beautiful, full-blooded horse.

At Windsor, the noted chestnut horse John Miller.

At Hartland, Black and All Black, full-blooded English, nearly I6 hands. One of the swiftest horses in America.

"The beautiful, full-blooded horse called the Zanthus will cover, the ensuing season at the stable of the subscriber at Hartford, at the moderate price of $\$ 4$ the season, and to ensure as the parties may agree. Zanthus is a bright bay, four years old this spring; was got by that noted imported horse called the Figure, but I shall not trouble the public with a long detail of his pedigree; be it sufficient to say that he is out of the most reputed line of horses in all Europe. I shall not give a particular description of the said horse, but wish those who wish to improve their horses to call and see him, and I doubt not they will agree with me in saying that he is equal in beauty, loftiness and activity to any ever kept in the State. Payment made easy, and pay day such as shall be wished for, and every attention paid by JESSE DUTTON."

"The elegant, full-bred, imported horse, Figure, will be kept at the stable of Capt. Lovell in Newbury. $\$ 4$ to $\$ 6$.

Thomas W. Pitkin".

\section{(From the Washingtonian, published at Windsor.)}

I8 I I-Hunting stud horse Young Touchstone, I6-3; bred in New Jersey; by imported Hunter, Touchstone; also Balloon by imported Highflyer. W. JARVIS, Weathersfield.

Punch, lately brought into this country by W. Jarvis-in Chelsea-by old Punch, dam by Eclipse.

The Forester, I6 hands; got by Killdeer of Scotland, at Weathersfield, etc.-advertised by D. JoNES.

I 8 I 2-Touchstone and Sea Gull, full blood. 


\section{(From Windsor Fournal.)}

1822-New Jersey Colt; bred in New Jersey; got by imported Dorchester, etc., $161 / 2$ hands. He has covered 317 marcs in the past two seasons.

Wm. WaLKer, Hartland.

Goldfinder, formerly owned by Clement Chase of Cornish; got by Young Quicksilver, $\$ 2$ and $\$ 3$.

\section{Stephen Cole, Cornish.}

Slow and Easy; bred in Rhode Island; got by Young Traveler; owned by Charles West, Providence; by imported Traveler: Young Traveler's dam a turf mare. Slow and Easy was foaled by a beautiful blood bay, full-blooded Dutch mare, known by the name of Slow and Easy, bred by Judge Vanderloop of Claverack, N. Y., and sold at $\$ 300$. Beautiful blood bay, $\mathbf{1} 6$ hands, short back, short jointed, flat limbs, six years old. To be kept at Plainfield, Lebanon and Hartford. Simon SMith.

Young Magnum Bonum at Hanover and Shrewsbury; by imported Magnum Bonum; 17 hands.

Walpole at Woodstock. G. Dennison, Hartland.

I823-Walpole and Slow and Easy again. to $\$ 6$.

Killdeer at Springfield, Reading, Cavendish and Chester, at $\$ 3$

American Eagle at Woodstock, Weathersfield and Hartland; coal black, $161 / 2$ hands; got by the noted New Jersey Colt from pureblooded English mare. Purchased at $\$ 500$.

I 824-Elegant and active horse Diomede at Hartford and Norwich four years old; got by the full-blooded English horse Diomede.

I 825 -Trinkelow at Windsor, Cavendish, etc., etc.

$$
\text { JAMES TRACY. }
$$
D. HICKs.

(From Spooner's Vermont Fournal, Windsor.)

I 805 -King Herod.

I 806-'07-None.

I 808 -Young Sweepstakes in Hartland.

I 8o9-None.

I 8 Io-Young Black Prince, late from Canada, by imported Black Prince at Hartland.

I $810-Y o u n g$ Black Prince, late from Connecticut, will be kept this season, till the 15 th of July, for covering, in Hartland, at the following stables, viz.: at Mr. Zebulon Lee's on Saturdays and Mondays, at Mr. Lyman Child's Tuesdays, and at Mr. Laban Webster's 
Wednesdays in each week. Said horse was three years old last June and was got by the noted horse Black Prince of old Hartford, Conn., imported by Captain Ramsey from Europe, whose stock has proved to exceed any other breed of horses in the country for the harness and saddle. Those gentlemen who wish to raise horses for business will do well to improve said breed. At $\$ 2$ the leap and $\$ 3$ the season.

Quartus LeE, Hartland, May 22, i8ro.

I 8 I I-Young Touchstone; by an imported horse; Balloon and Don Carlos.

WILLIAM JARVIS, Weathersfield.

I 8 I 2-Touchstone and Sea Gull.

I 8 I 3-Touchstone and Punch.

I 8 I 4 -Touchstone, I6 $\mathrm{I} / 2$ hands. William JARvis.

I814- "The famous stud horse, the Traveler, will be kept Mondays at Capt. N. Duncan's, Weathersfield; Tuesdays at Daniel Brooks', Springfield; Wednesdays in Charleston, (N. H.) ; on Fridays in Chester, North street; on Saturdays at Leonard Walkers', Springfield, and remainder of time at stables of subscriber. The terms are $\$ 2$ the leap; $\$ 3.50$ the season; $\$ 5$ to insure.

Joseph Whitaey, Springfield, May io, i 8 i $4 . "$

1815-The Traveler above mentioned is probably a different horse from Young Traveler. In the same paper for I8I5 in the advertisement of Punch we have the following poetry:

"You may examine the horses, wherever you go,

The Lance, Prince, Arabian and Traveler, also;

With Touchstone and Quicksilver; put them all in a bunch,

They will not compare with the beautiful Punch."

I 8 I6-Nosby in Hartford; by imported Nosby in Virginia.

Touchstone.

WiLliAM JARVis.

I 8 I 7-Young Quicksilver; by the noted Quicksilver of Jonah Bellows; bright bay, I $61 / 2$ hands.

E. Pike, Cornish.

The noted Dutch horse Aurum, known as the Alden Horse, at Daniel Chase tavern, Claremont, and in Unity; said horse was brought from State of New York about one year since.

Joseph Alden, Claremont.

Walpole in Hartford; by old Quicksilver.

(From Spooner's Vermont Fournal, I826.)

Boliver; foaled IS2I ; I 5 hands, black; got by the New Jersey Colt: dam by a son of imported Dey of Algiers.

N. TRASK, Windsor. 
I \$24-Elegant and active horse Diomede at Hartford and Norwich; foaled I820; got by the full-blooded English horse Diomed. JAMES TRACY, Hartford.

American Eagle at Quechee, Woodstock, Weathersficld and Hartland; coal black, $161 / 2$ hands, by the New Jersey Colt, from a full-blooded English mare owned by Aaron Marble, Worcester County, Mass. Purchased by William Dyer at two years old for $\$ 500$.

REUBEN WALKER, WILLIAM WALKER.

I $824-$ Killdeer at Springfield, Reading, Cavendish and Chester; 17 hands; at $\$ 6$. Joseph WhitNey.

New Jersey Colt at Tunbridge, Strafford, Thetford and Sharon

HARRY BAXTER,

SAM BLODGETT.

(From Windsor Republican, May 24, I809.)

I809-The horse Defiance at Josiah Tilden's, Hartford, at Pomfret, and Elisha Taylor's at Woodstock, bright bay; colts have proved very good. $\$ 2$ to $\$ 3$.

Kendall Hallock, Pomfret.

I 8 IO-Victory and Goodspeed Horse.

I 8 I I-Recovery.

That large and elegant horse, full-blooded Yankee, in Bridgewater and Woodstock; between I 7 and I 8 hands and five years old.

Old Sachem, black, 16 hands. Young Touchstone, King Herod.

That noted horse Defiance in Windsor. Said horse is 15 hands and one inch high, of a bright bay, nerves regular, of high carriage and great speed. His stock is remarkably good, and is more highly approved of than that of any other horse in the vicinity.

Ezekiel B. Beckwith, Claremont, May 25, is i i.

This horse is said to have been Morgan.

I 8 I 2-Touchstone and Sea Gull, Recovery, Young Bullrock in Windsor. Bajazet in Pomfret.

In I8I2, Recovery at Woodstock and Hartland; Young Bloodrock, dark chestnut, at Windsor.

I 8 I 3-Rockingham in Hartland. Young Arabian in Cavendish, etc. Bullrock in Windsor.

I 8 I 4-Pennsylvania horse Baronet, I 7 hands, in Hartland, etc.

Young Cranberry by full-blooded Yankee in Windsor; I7 hands, black. Henry Dundas in Randolph and Braintree; got by Woolsey. 
The Black Pope in Sharon, etc.; I 5 hands, well proportioned and good carriage. For beauty and activity he is surpassed by none. He is a remarkable sire and has got some of the best horses in the country. NATHAN Brown, Pomfret, I8I4.

The Black Pope, we think, was a Morgan horse.

The famous stud horse The Traveler will be kept Mondays at Capt. M. Duncan's, Weathersfield; Tuesdays at Daniel Brooks', Springfield; Wednesdays in Charlestown, N. H.; on Fridays in Chester, Vt.; on Saturdays at Leonard Walker's, Springfield, and remainder of time at stables of subscriber. The terms are $\$ 2$ the leap, $\$ 3.50$ the season, $\$ 5$ to insure.

Joseph Whitney, Springfield, May io, i 8 i 4.

Lance, late the property of G. P. Bond, Philadelphia, in Windsor; blood bay, I 5 I/2 hands, by Dragon, etc., etc.

In I8I4, Henry Dundas, got by Woolsey, at Randolph and Braintree.

The Black Pope, I 5 hands, unequaled for beauty, at Sharon, Pomfret and Woodstock.

Lance described as blood bay, I 5 T/2 hands, black mane, tail and legs; brought last fall from Mr. Bond's stud near Philadelphia to Charlestown, Mass.; bred by Col. John Hoomes of Virginia, got by imported Dragon; grandsire, Woodpecker; to stand at Windsor at $\$ 20$.

Same year The Traveler at Weathersfield and Charlestown.

I 8 I 5-Lance again, by Thomas Thomas of Windsor.

I 8 I 6-Touchstone at Claremont and Weathersfield.

I 8 I 7-Young Morley, by old Morley of Virginia, at Lebanon.

The Rover Lyon at Pomfret and Hartford; dark bay, five years old, $16 \mathrm{r} / 2$ hands.

I8I9-Take notice! The Blazing Star at Joel Lull's in Westminster, Foster Taylor's in Woodstock, Simeon Willard's at Hartland and at my stable; $\$ 2.50$ to $\$ 4$.

JAMES MORRISON, Windsor.

I8I9-Young Quicksilver by Bellows' old Quicksilver; I6 1/2 hands, I 300 to I 400 pounds; dam, full-blooded. At Hartland, Windsor and Cornish.

EBenezer Pike.

\section{(From the Washingtonian, Windsor.)}

The following advertisements are from the files of The Washingtonian, published at Windsor, Vt., for I8 I I :

Punch, lately brought into this country by William Jarvis, Esq., 
of Chelsea, at $\$ 4$ to $\$ 6$; by the noted imported horse old Punch: dam by Eclipse. The Forrester, $\$ 2$ to $\$ 6$, at Weathersfield, Clarcmont and Springfield; 16 hands; got by noted race horse Killdecr of Scotland and imported by Col. Benjamin Colt of Philadelphia in I 805 . Darius Jones of Weathersfield hunting stud, advertises Young Touchstone, 163/4 hands, bred in Ncw Jersey, by imported hunter, Touchstone, which see; also Balloon, $15 \frac{1}{4} 4$ hands, bred in Maryland, by High Flyer.

In 18 I 3 Touchstone and Punch are advertised; in I8I2, Touchstone and full-blooded Sea Gull; in ISII, Punch by imported Punch: dam by Eclipse; also: “The Forrester, I 6 hands, got by Killdeer of Scotland and imported by Col. Ben. Colt of Philadelphia in I 805." At Weathersfield and Claremont. His stock very numerous in the State of Pennsylvania.

$$
\text { (Signed) DARIUS JONEs. }
$$

The same appears in 1814 and also this: "Touchstone, the noted Southern-bred horse; $161 / 2$ hands; $\$ 4$ to $\$ 8$, at Weathersfield Bow."

$$
\text { (Signed) WM. JARVis. }
$$

The celebrated high-bred turf horse Lance, late the property of J. B. Bond, Philadelphia, at the stable of Samuel Shuttleworth, Esq., in Windsor, at $\$ 5$ and $\$ 10$; beautiful blood bay, $15-2$; bred by Col. John Hoomes of Virginia.

Thomas Thomas, Windsor, Vt.

The following are from the County Porcupine, Philadelphia, I 798 :

To cover at Wrightstown, Buck Co., the beautiful horse Touchstone, imported from England, $153 / 4$ hands, bay, six years old.

$$
\text { (Signed) JOHN PARKER. }
$$

The noted full-bred horse Flag of Truce in Seventh Street at three guineas; silver gray, 15 I $/ 2$ hands; by imported Goldfinder, etc.

Imported Rodney in Middletown township; dark bay, eight years old; I5-2; got by Paymaster, etc.

(Signed) Jonathan Stackhouse.

\section{(From Windsor Gazette, I803, Vol. III.)}

The well-built horse called The Ranger, $15 \% 2$ hands, at Windsor.

The Granby at Royalton; advertised by Levi Mower.

Sweepstakes in Hartland, advertised by John I. Gallup.

Bold Herod advertised at Weathersfield by Luke Persons, i6 hands, bay, foaled 1798 . 
clxvi

\section{(From The Morning Ray at Windsor.)}

1792-The Young Rover in Hanover, etc. Eclipse, that fullblooded horse, whose beauty and figure are so well known in Europe and the Southern States, as that language can add nothing to his fame, will be kept at Westminster at one guinea the season.

Westminster, May 20, I792.

\section{(From Federal Galaxy.)}

I 797-Soldier, St. Tammany, bay, I 6 hands, six years; and Humbill, I 5 hands, eight years. J. \& E. Houghton, Guilford, Vt.

Sleepy John, bay, seven years, whose greatest glory lies in his speed; at $\$ 2$.

Young Hero in Halifax. Selim, Young Soldier, Paymaster in Deerfield. The Figure at Brattleboro; also Splendor.

I 798-The Sprightly, four years, I 5 hands, bay; got by Eclipse, imported by Hon. Stephen R. Bradley of U. S. Senate, the pedigree of which horse is traced back as far as the time of Alexander the Great; dam of Joe Miller stock. B. BARRETT, Brattleboro.

Fearnaught, dark bay, I 5 1/2 hands, four years.

\section{Z. Goss, Dummerston.}

Wildeer, bright bay, I6 hands, stout built, by imported Warwick Ball; dam by Wildeer; at Brattleboro. Simpson Ellis.

Federal Gray, I 5 hands, five years, dapple gray; at Guilford.

Young Soldier at Dummerston, Young Recovery at Guilford.

I 800-Old Soldier and True American, 16 hands by Hyder Ally, in Brattleboro.

\section{(From the Reporter at Brattleboro, 1807.)}

Red Bird in Whitingham at \$1.50.

King Herod in Guilford.

Elijah Allis, Wilmington.

\section{(From the Woodstock Observer, Vol. I.)}

I $820-Y o u n g$ Patriot; by the noted Pennsylvania horse old Patriot. Well built and well proportioned. At Woodstock, etc.

AMos Warren.

Full-blooded Yankee at Bridgewater and Woodstock; got by the noted Granby. Colts sold at from $\$ 250$ to $\$ 400$.

LUTHER EdSON, Woodstock.

New Jersey Colt at Woodstock, Windsor and Hartland; bred in New York and got by the noted horse Dorchester, a full-blooded 
bay and real hunter, and was foaled by Col. Levi Howell's bloodbay, a real hunter and known by the name of Spread Eagle; coal black, $161 / 2$ hands, etc. One colt sold at $\$ 500$.

\section{Simon Smith, Hartland.}

Advertised in Windsor County, I 804:

Roebuck at Brattleboro. Over 16 hands. At $\$$ I .

A. King.

The Young Soldier will be kept by the subscriber the present season. He is an English horse in the prime of life and not many generations from the famous Childers. He is a dapple gray, and in vigor, activity, beauty and strength seems to possess the spirit of his ancestor. Terms very moderate.

Timothy Knight, Brattleboro, May 7, i804.

Rockingham; never before seen in this part of the country, at Dr. John Campbell's stable in Putney, and in Westminster and Westmoreland; bred in Lebanon, Conn.; got by a full-blooded imported horse. He has been kept seven seasons in the county of Hampshire, Mass. ; dark bay, I 6 hands, carriage lofty and graceful.

\section{John CampBell, Putney.}

\section{(From Bellows Falls Intelligencer.)}

I 8 I 8 -Vol. II. None. File complete.

The Vermont Intelligencer and Bellows Falls Advertiser has none in its first and second volumes (18I6-I7) and Vols. III., IV., V., were not seen. In Vol. VI., Job Fowler advertises Telescope, saying: "The subscriber having brought directly from New York the noted horse Telescope, offers, etc., at Walpole, Putney, Westmoreland." Telescope is described by the advertiser as bright bay; got by Potomac; his grandsire the imported horse old Messenger.

I 822-TELESCOPE. The subscriber having brought directly from New York the noted horse Telescope, etc. At Walpole, Westminster, Putney, Chesterefield and Westmoreland. Bright bay, strong boned, superior produce; bred in Long Island; got by Potomac, by old Messenger. Telescope is half brother to Telescope, bred by Gen. Coles of Long Island; at $\$ 5$. JOB Fowler.

A recommendation follows signed by Jacob L. Field and sixteen other residents of counties of Washington and Rensselaer, New York.

FOR SALE-Hampton Arabian, four years, I 5 hands, dapple gray; a cross of the first blood English Arabian and Narragansett breed of horses.

John Watson, JR., East Windsor, Conn., I822. 
I823-John R. Gibson advertises, under date of Rockingham, May Io, "The noted horse Revenge," at Mr. Harris' stable, Westminster; Mr. Holland's, Walpole; Mr. Lee's, Springfield, and at the stable of the subscriber; terms, \$15 for the season.

This is the son of Justin Morgan of that name, that was bred by Mr. Goss, and foaled the property of Cyrus Moore, Claremont, N. H., I8I5. See The Morgan Horse and Register, Vol. I., page I3I.

The following are from files of Vermont papers in the Antiquarian Library at Worcester, Mass. :

\section{(From North Star, Danville.)}

I 808-Young Mercury, or Bigelow Horse, at Ryegate, Barnet, St. Johnsbury, Lyndon; got by old imported Mercury.

1809-None.

I 8 ro-The Dutch Weasel, a horse four years old, will be kept at the stable of the subscriber one mile north of St. Johnsbury Plains at $\$ \mathrm{I}$ to $\$ 3$. Said horse is I 5 hands high, stoutly built, and was got by the full-blooded Dutch horse that was kept at St. Johnsbury last season.

Richard W. Newton, St. Johnsbury.

Hunter in Littleton and Waterford; same horse that has been kept in New Hampshire a number of seasons.

I8 I I, 'I 2 , 'I 3 not in Library.

I 8 I 4-Rover, also Dutch Prince, at Kirby. Said horse [Dutch Prince] is of as good blood and pedigree as any in country.

William M. CARPENTER.

\section{(From Danville North Star, I809.)}

White horse Hunter, by the noted white horse owned by Col. Webster, at Plymouth, Danville, etc. JOHN HATCH.

Magnum Bonum in Danville; English dray breed; kept at Montpelier. Victory at Windsor.

We give below a series of advertisements from the North Star, published at Danville, Vt. Danville is but a short distance from St. Johnsbury, where the horse Justin Morgan was kept for some time while owned by Mr. Goss. There are very few of these papers in the State Library previous to 1814 , or Vol. VIII., in which year are advertised:

The Lofty at Danville and Wheelock, bay, $162 / 3$ hands.

The Danville North Star of I8I4 has advertisement of Rover at Danville, Peacham and St. Johnsbury, dark bay, 15 1/2 hands; pedigree equal to the best. 
The same year and same paper appears notice of The Dutch Prince at Lyndon, Waterford, Kirby and St. Johnsbury.

Said horse is of as good blood and pedigree as any in the country, of good size, well built and of a dark chestnut color. Come and see. Terms, $\$ 2$ to $\$ 4$.

W. W. Carpenter, Kirby, April 19, 18 I4.

Rover - This famous horse will stand, etc., at Danville, Barnet and St. Johnsbury. Said horse is of a beautiful dark bay, $15 \mathrm{I} / 2$ hands, elegantly built and moves gracefully, and his pedigree is unquestionably equal if not superior to any horse in New England. He need only be seen to be admired; $\$ 2$ to $\$ 3.50$, reduced prices. Samuel Hort, St. Johnsbury, April, I 8 I 4.

I 8 I 5-S. C. Gibbs advertises Bold Phoenix.

The Rover at Danville, Peacham and St. Johnsbury as follows:

"The subscriber declines imposing on the good sense of the public by publishing recommends, as he considers the appearance and age of the horse, together with an exhibition of his stock, to be the best testimony in his favor. His colts may be seen at the several stands. Terms same as last season.

L. DEAN, Danville, I 8 I 5 ."

The next week these terms are raised from $\$ 2.50$ to $\$ 5$.

The same year Roger Enos announces that Telescope will be removed from Burlington to Irasburgh.

The full-blooded and much distinguished turf horse, Honest John, will be kept at the stable of Alpha Warner in Hardwick to be let to mares the present season. Terms, $\$ 3$ to $\$ 6$.

Honest John is esteemed by good judgment to be the finest limbed and best proportioned horse of any that has ever been seen in this part of the country.

Gentlemen who wish to improve their breed of horses are invited to afford their patronage and oblige their humble servants, the subscribers.

Alpha WARNer, SAMUEL French,

Hardwick, May 20, I8I 5. REed PAGe.

I 8 I6-The noted and well-known Young Traveler or Guernsey Horse, will be kept at Bickford's tavern in Wheelock on Thursdays in each week from 5 o'clock to Io o'clock A. M. At Captain Chaffee's in Wheelock Hollow from 12 to 6 o'clock P. M., when he will return again to Bickford's the same day; at Brown's tavern on Danville Green from 2 o'clock P. M. until sunset, and the remainder of the time at the stable of the subscriber in the north part of Danville. 
$\operatorname{clxx}$

Any person wishing to improve his stock in horses may make inquiry of the breed of the Guernsey Horse in Danville, Wheelock or Sutton, where his colts are well known.

Isaac W. Stanton, JR., Danville, June i i, i 8 i 6.

Young Peacock will be kept for service the present season at the stable of the subscriber in Barre excepting each Wednesday and Thursday at the stable of Obadiah Eaton in Montpelier village from the I9th inst. until the 9th of July; $\$ 2.50$ to $\$ 4$.

ENOS TOWN.

I 8 I 8-Mountain Traveler at Concord, Littleton, Barnet, Waterford and St. Johnsbury; lately from the southward; half Dutch and half English; bay, well built.

JOHN BARKER.

Full-blooded Dutch horse Valiant, bred in Ohio.

G. Sinclair.

The fast Dutch horse; formerly owned by Olney Hawkins, at Silas Gorham's in Danville, Wheeler Hollow and St. Johnsbury Plains and at the stable of the subscriber.

Stephen Hawkins, St. Johnsbury, April 23, I 8 I 8.

I 822 -Dutch Horse; by Sinclair Horse, brought from Ohio by Joseph Sinclair in 18 I 7 .

M. WaIT.

Initials are different but we presume this Sinclair Horse is the horse Valiant mentioned above.

In the Star of I 8 I 5 Bold Phoenix is advertised at Col. Warner's, Hardwick; Esquire Farmington's, Walden; John W. Dana's, Cabot, and S. C. Gibbs' on Danville Green; at $\$ 3$ to $\$ 6$.

Appended to the foregoing is the following:

\section{HAVERHILl, May 22, I8I 5.}

We, the undersigned, being well acquainted with the stock of the noted horse Phoenix, recommend it to exceed any in the State of New Hampshire for strength, speed and beauty.

(Signed) REv. MR. MERRII.L and seven others.

The same year The Rover appears again, Leopard and Young Phenomenon.

In 18 I 6 we have Bold Phoenix again; Black Prince at Concord, St. Johnsbury and Ryegate; Rover again; Hamilton in Bartoneight years old, I 6 hands, of Pennsylvania breed; and Young Traveler, or Guernsey Horse, in Wheelock and Danville.

Leopard, Bold Phoenix and Young Phenomenon are advertised and " the elegant stud horse Black Prince" at Concord, St. Johnsbury, Ryegate and Barnet. "Black Prince is six years old, elegantly and 
firmly proportioned, of a good size, fleet in the foot and his colts are admired for their beauty and activity.

Nathan Howe, Barnet, April 25, 1816."

Samuel Hoyt, under date St. Johnsbury, I816, advertises Rover; now owned by L. P. Dana, lately by L. Dean. The same year Hamilton is advertised; also "the noted and well-known Young Traveler or Guernsey Horse" at Wheelock and Danville. "Any person wishing to improve his stock of horses may make inquiries of the breed of the Guernsey Horse in Danville, Wheelock or Sutton, where his colts are well known. Isaac W. Stanton, JR., Danville, June I, i 8 I 6 ."

I 8 I 6 - "The noted and well-known Young Traveler or Guernsey Horse" at Wheelock and Danville. "Any person wishing to improve his stock of horses may make inquiries of the breed of the Guernsey Horse in Danville, Wheelock and Sutton, where his colts are well known.

IsaAC W. Stanton, JR., Danville, June I, I8 I6."

Young Traveler in Danville, Lyndon and St. Johnsbury. "Young Traveler, descended from the old Dutch Goss Horse, and as he is generally known a particular description is deemed unnecessary. It is presumed, however, that those who call will be satisfied with his figure and movements. Terms, $\$ 3$ the season; $\$ 4$ to insure a foal, and $\$ 2$ the single leap.

St. Johnsbury, May I 4, I 8 I $7 . "$

As many of our readers know-but perhaps not all-the Justin Morgan was often in those days called the Goss Horse, as he was owned for many years by Mr. Goss of St. Johnsbury; and, as we have seen, at that time he was often spoken of as Dutch.

Under date Hardwick, April 3, I817, is this:

"TAKE NOTICE-All persons indebted to the company under the public advertisement of the turf horse, Honest John, by Alpha Warner, Samuel French and Reed Paige, for the season 1815; also in 1816 , are hereby notified," etc.

In 18 I 7 Bold Phoenix is advertised at J. W. Dana's in Cabot; Young Phenomenon at Danville and St. Johnsbury, and Young Traveler in Danville, Lyndon and St. Johnsbury. "Young Traveler descended from the old Dutch Goss Horse, and as he is generally known, a particular description is deemed unnecessary. It is presumed, however, that those who call will be satisfied with his figure and movements. Terms, $\$ 3$ the season; $\$ 4$ to ensure a foal, and $\$ 2$ the single leap.

St. Johnsbury, May I4, I817." 
Stephen Hawkins of St. Johnsbury in May, I8 18, advertises " the part Dutch Horse, formerly owned by Clney Hawkins of St. Johnsbury" will be kept, etc., in Danville, Wheelock Hollow and St. Johnsbury at $\$ 2$ to $\$ 4$.

The beautiful horse Mountain Traveler, at Capt. Frye's, Concord; Mr. Warner's store near Littleton; Mr. Park's store; Mr. Henry Stevens' tavern, Barnet; at Mr. Works', Waterford; at Capt. John Barney's tavern, St. Johnsbury Plains. Said horse is lately from the southward-half Dutch and half English; large size, well built, and of a beautiful bay color, and needs only to be seen to be admired.

John Barker, St. Johnsbury, May I4, is I 8.

G. Sinclair, Danville, May I9, I8I8, advertises the full-blooded Dutch horse Valiant Columbian at Danville and Wheelock. He was bred in Ohio; dark bay, elegant carriage, well built, of good size, and celebrated for the beauty and activity of his stock; $\$ 2$ to $\$ 4$.

In I 820 appears notice of Mountain Traveler; "that noted half Dutch horse will be kept, etc., at Barnet and St. Johnsbury;" "said horse is of a beautiful bay color, large size and well proportioned." Terms, $\$ 2$ to $\$ 3$.

The same year is advertised the French Lion at St. Johnsbury, Wheelock, Lyndon and Danville. "Said horse was bred in Montreal and is a dark bay;" \$2 to $\$ 4$.

"Improve your breed of horses! The celebrated Dutch horse, formerly owned by Steven Hawkins, St. Johnsbury, will be at the stable of Robert Rogers every day in the week on Stanstead Plains the coming season; also that beautiful full-blooded horse called Messenger, raised in Dutchess County, N. Y.

Stanstead, May 20, I820.”

The same year "The elegant stud horse Robin" is announced to be at Lyndon, Barton and Wheelock at $\$ 2$ to $\$ 4$; and the full-blooded horse Valiant Columbian at Wheelock and Danville.

In I82 I Leeboo, formerly known by the name of Honest John, is advertised to be at Peacham and Danville at $\$ 3.50$. Leeboo is well known and needs no recommendation. James F. Norris and Alpha Warner are the advertisers, and the notice bears date Hardwick, May 16, I821.

Under date of Danville, May 8, I822, M. Wait advertises the Dutch Horse to be kept at the stable of the subscriber, in Danville, at $\$ 2$ and $\$ 3$. Said horse is the one known by the name of the Sinclair Horse, being the same which Mr. Joseph Sinclair brought from 
the State of Ohio five years ago, and has been kept in this vicinity ever since. His oldest colts are now three years old.

In I 823 The Hunter at Danville; got by the noted Webster horse; 16 hands, dapple gray, Io years old.

The same year M. Wait advertises the noted Dutch Horse, Defiance, in Cabot, Peacham and Danville, at $\$ 3$.

In I 824, under date June 7, M. Wait advertises the Dutch Horse, better known to some by the name of the Sinclair Horse, at Danville.

Strayed OR STOLEN-From the pasture of T. Chamberlain at Peacham Corner, a small chestnut colored horse, stout built, thick black mane and tail, of a Dutch appearance, six years old.

David Haseltine, Newbury, June 23, I 825.

In 1827 it is announced by Joseph Pope of Danville, under date May 30, that the noted dapple gray horse, owned by Sam Ayres of Wheelock, Dutch Prince, will be kept during the present season at the following places, viz.: At Wheelock, Danville and Peacham. "Dutch Prince was got by the noted Sherman Horse, and for size, elegance of proportion and goodness of stock is exceeded by none in this vicinity."

NOTICE-For the information of those who may be gratified therewith, the noted and celebrated Dutch, Morgan or Sherman Horse (which is one and the same), will be kept for the use of mares the ensuing season on St. Johnsbury Plain on Fridays and Saturdays of each week, and the residue of the week at S. West's on Danville Green.

J. Buckminster, May 2, I 828 .

FOR SALE-A pair of five-year-old Dutch horses.

Henry Chamberlin, Danville, May 22, i 829 :

First on the docket. The Young Sherman Horse will be at David Goss' in St. Johnsbury at the stable of Mr. Rice, and at Danville Green.

N. B.-This animal was raised by David Goss \& Son, and warranted to be a true son of the wonderful Sherman Horse. Dam a bright bay, fine blood; sold at \$I40.

S. C. Gibbs, Danville, May 4, I 83 I.

In 1831 , also, John Brown of Lyndon advertises Green Mountain Traveler at Wheelock, Danville, St. Johnsbury and Lyndon. Dark chestnut and as fine figure as can be produced in New England.

In I832 John A. Stanton advertises Bold Morgan; got by a young horse which was got by a Dutch horse from New York: dam by noted Sherman Horse. 
clxxiv

The Young Morgan is advertised at Danville in I833. The same year John H. Moore announces that The Batchelder Horse will be at Danville and Barnet. D. P. Dana \& Co., under date Danville, I833, advertise The Traveler at Danville, Cabot and Marshfield, and describe him as six years old, about is hands. John Buckminster of Danville, the same year, advertises three colts by the noted Sherman Horse; terms $\$ 2$ to $\$ 4$.

Will be kept at the stable of the subscriber at Danville, at Peacham and Cabot, a number of the real Morgan horses selected from a dozen of that blood, from which circumstance it is thought not assuming or arrogant to just suggest that, being thus selected, they are considered superior to any other horses in the State.

J. Buckminster, Danville, May io, I834.

The Traveler is advertised in 1834 .

In 1835 the Batchelder Horse is advertised at Danville Green, Farrington's in Walden, Hardwick Hollow, Hardwick Street, Greensboro and Walden:

"The Batchelder Horse was got by the old Sherman and needs no better recommendation than a reference to his stock, which is universally considered superior to that of any other horse of the Morgan breed in this vicinity. He will be under the care and superintendence of Orange Smith. Danville, May I, I836."

Oh yes, oh yes! the attention of the public is solicited to another little newspaper ditty. Will be keptetc., in Danville, a number of stud horses of the real Morgan blood, among which is that noted horse, in this region of the country, by the name of the Newell Gray. Gentlemen are invited to view said horse, which will supersede the necessity of giving a particular description of his color, height, breadth, length, or of his qualities, such as speed, strength, nerve, beauty, activity on the turf, etc., which, when done on paper, amounts to but little. Suffice it simply to say that he was got by the celebrated and noted Sherman Horse; is six years cld next grass, and is considered the most superior and perfect horse in this section of the country and State.

J. Buckminster, Danville, May 23, I 835 .

In 1836, ' $^{2} 7$ and ' 38 , none.

Morgan Bulrush-H. C. Babcock would inform the public that he has the celebrated Morgan horse called the Morgan Bulrush, or better known by the name of the Randolph Horse. His stock is too well known by all in this vicinity to need any recommendation. Will be at Bliss' Inn, Cabot; Farrington's, Walden ; Warner's, Hardwick.

Danville, May 29, I 839. 
FOR SALE-Beautiful Gray Stud, well known in Dover, N. H., as The Hunter.

P. LAID.

J. I. Babcock advertises the Morgan Bulrush again in 1840 .

In $184 \mathrm{I}$ to 1845 , both inclusive, there is none.

In $1846 \mathrm{~A}$. G. Williams of Cabot informs the public that he has purchased the horse known as the Randolph Horse. "Said horse will be at Cabot, Danville and Peacham."

The same year appears:

The subscriber has purchased of Mr. J. Bellows the Flint Morgan Horse, formerly known in this vicinity as the Bolton Colt. Will be kept at Danville, St. Johnsbury and Lyndon.

From I 847 to ${ }_{1} 8_{5}$ I there are no advertisements.

\section{JONAS FLINT.}

THE MORRILL HORSE-This justly celebrated horse is now eight years old, of a handsome jet-black color, weighs full I 260 pounds, is lofty in his carriage, and is not excelled by any horse for speed, strength or constitution. The horse is of the Morgan blood, got by a colt of the old Weston or Randolph Horse, so called, formerly owned by John Buckminster, late of Danville. At Danville and St. Johnsbury.

French Morrill, Danville, May 27, i 852.

The same year W. B. Stanton of North Danville advertises the American Morgan, six years old, I IOo pounds, about I 5 hands; better kown as the Stanton colt, at Danville, Wheelock and Lyndon.

Moses Clark of Cabot advertises "Clark's Premium Morgan Horse" at Cabot and Peacham, beautiful dapple bay, ten years old, I IOO pounds.

In I 853 there were none. In I 854 "Clark's Premium Morgan Horse" appears again.

\section{(From Standard at Irasburgh, Vt.)}

I864-Honest Abe by the Ford Horse; seven years, I 6 hands, jet black, I I 50 pounds; at Lowell, etc.

Young Ira Allen by Ira Allen, son of Flying Morgan: dam, an English mare, R. P. Orcutt; six years, bay, I5 1/2 hands, 1000 pounds.

\section{(From Caledonian, St. Fohnsbury.)}

1864-Sherman Morgan. Billy Trull by Billy Root: dam, a bay by Steele Horse or Royal Morgan; she was fleet at thirty years of age. Dark chestnut, fourteen years, I $43 / 4$ hands, 966 pounds; can trot in three minutes.

David Trull, West Burke. 
clxxvi

(From The Argus, Putney, Vt., Vol. I.)

I 797-Young Soldier, spotted horse, large, etc. made.

At Dummerston, Young Soldier, spotted, large, heavy and well

This Soldier stock of Windham County was very celebrated in its day, and continues to be spoken of in high terms to the present time. Its origin was not traced until we found the following advertisement in the Granville (Mass.) Gazette of 1795.

"Soldier, gray with star, I 6 hands, got by old Sweeper: dam by Othello; 2d dam imported, by Spot; 3d dam by Cartouche; 4 th dam by Sedbury; 5 th dam by Traveler; 6 th dam by Childers; 7 th dam Barb Mare.

"A true copy from the Racing Calendar in Williamsburgh, Va. Certified by W. Gibson.

To be kept at stables of J. \& E. Houghton at Guilford; $\$ 5$ to $\$ 7 . "$

This Soldier was the Grandsire of King Herod, which see in Vol. III.

True Briton at Pomfret; thirteen years old; dark bay, i 6 hands. He has been broken down running the heats, which causes him to be lame. He was without doubt bred in old England, in the city of London. \$I and \$2. Johnson STREeter, May 24, I 799.

In 1800 there is young Regulus, 15 hands, by old Regulus; and Janus. Under date of Williamstown, April I \&, I 800 , C. Lynde advertises Henry Dundas at Williamstown, Berlin and Montpelier at $\$ 3$ to $\$ 4$.

And again T. W. Pitkin advertises the full-bred imported horse Figure at Hartford and Norwich at $\$ 4$ to $\$ 6$.

Bucephalus advertised, together with Ranger, Badger, Slow and Easy and The Titman by Z. Curtis, Windsor, at $12 \mathrm{I} / 2$ to 34 cents.

The next week Bucephalus is advertised by Ellis \& Smith, Woodstock, at $\$ 5$ to $\$ 8$. The others are still advertised by $\mathrm{Z}$. Curtis, Windsor, at $12 \mathrm{I} / 2$ to 34 cents (to insure).

The next year (ISOI) occurs

A fine opportunity, gentlemen! The subscriber offers for sale two or three elegant stallions and five or six likely breeding mares, which will be sold upon reasonable terms and credit for good security. Having a large number of horses on hand and wishing to bring his business to a close induces him to offer them low.

ZEBina CURTIS, Windsor. 
The same year these are advertised, Jolly at Woodstock, got by Bucephalus; Sweepstakes, a noted horse, in Hartford; Janus, a full-blooded beautiful horse, at Windsor; The Leopard, 16 hands, at Hartford; Black and All Black in Hartland; Young Sorrel in Hartford.

In I 802 appears the advertisement of "Phenomenon, that beautiful full-blooded stallion lately imported from England in Cornish; fine chestnut, $161 / 2$ hands, got by the famous Phenomenon whose grandsire was the great Eclipse: dam Recovery, by Hyder Ally; $2 \mathrm{~d}$ dam, Perdity, by Herod; $3 \mathrm{~d}$ dam by Sampson"; $\$ 5.50$ to $\$ 9.50$.

Weasel is again advertised at Ludlow; Republican at Hartford; the noted horse Silver Heels in Reading and Windsur; Leopard at Hartland; the Trask Horse at Windsor; Sweepstakes at Hartland. Ranger at Woodstock and Bridgewater, appears again as "dark bay, 16 hands, sired by the noted Old Ranger of York at Windsor."

In I 803 Young Prince is advertised at Windsor, got by King William Horse, Old Ranger breed. There are also advertised Silver Heels in Windsor; Sweepstakes in Hartland and Bright Bay in Hartford.

In I 804 Young Prince is advertised at Windsor.

In 1805 Sweepstakes is advertised at Lebanon and Hartland, and King Herod at Hartland and Woodstock.

In 1806 the noted horse Bay Malton is advertised in Montpelier; "dark bay, I6 hands, got by old Bay Malton; grandsire imported old Wild Deer, who was sent home again on account of his fame for stock and has since covered in England for fifty guineas. Dam by imported Regulus. He has stood a number of years past in Hillsboro County, N. H. William Dustin." Above horse for sale at $\$ 400$.

In 1807 there are no horse advertisements.

In I808 Young Sweepstakes is advertised at Hartland.

The following are horse advertisements gleaned from old papers at the Montpelier Library:

The Young Soldier, an English horse descended from Childers. Dapple gray.

T. KNight, Brattleboro.

Buckingham, never before seen in this part of the country, will stand in Putney, Westminster and Westmoreland. Bred at Lebanon, Conn.; sire full-blooded Snip horse. He has stood seven years in County of Hampshire, Mass.; is dark bay, I6 hands. 
The following is from The Farmer's Herald of St. Johnsbury, Vol. II., I830; there are none in Vol. I.:

The Young Morgan Sherman horse, formerly owned by Mr. Flint of St. Johnsbury, will stand at Lyndon, St. Johnsbury and Danville.

GEORGE BELLOWS.

The Vermont Gazette, 1806, has the following; the same appears in 1807 and 1808 , but there is none in 1809 :

The subscriber has on hand the noted horses Moresah, Silver Heels and Tioge to sell or to let.

\section{Daniel Robinson, Bennington.}

In I8I8 Sir Solomon is advertised; in I8I9 Sir Solomon in Bennington by Stephen Hunt of New Jersey. In I 820 appears:

Full-bred running horse Hickory from Virginia, owned by Stephen Hunt, New Jersey, will stand at Pittstown and Hoosick, N. Y.; also Sir Peter Teasle; for pedigree see small bills.

\section{ANDrew RACE, Agent.}

In the "Montpelier Watchman" of I 829 Cyrus Bailey of Berlin advertises The Vermonter at Williamstown, Washington and Barre; five years old; got by Olive Branch; dam by Old Bashaw.

Jonathan Shepherd, in I829, advertises Young Brilliant, four years old, dapple bay; and says "a long list of his ancestors would be entirely superfluous." Mr. Shepherd owned the original Morgan horse and also a son of Sherman Morgan, probably this horse.

Young Hunter and Young Soldier are advertised by R. F. Abbott at Barre, in 1829 . In 1831 are the following, in the same journal:

Improve your breed of horses. The noted Morgan Horse Napoleon will stand at Middlesex, Montpelier and Plainfield; eight years old; dark bay; 15 hands; very fast trotting horse.

\section{LORENZO WiLLARD.}

Union at Middlesex, Moretown and Montpelier; seven years old, bay, good size, formerly known as Robinson or Brooks colt. He claims no Morgan or foreign blood.

I. Riker, Montpelier.

Cripple, by Cock of the Rock (Barnum's), dam by Paymaster.

A. Sмith.

The following are from The Burlington Centinel: In I819 L. Higbee advertises celebrated colts by old Telescope, the oldest, the Beautiful Gray, at St. George. In I820 E. D. Hubbell and William A. Butler advertise "the noted horse Telescope" at Jericho and Essex. The same year James Southard of Burlington advertises 
"the full-blooded French horse First Premicr," at Burlington, and describes him as a beautiful dapple bay, I 5 hands. That year also appears :

The Spanish horse Don Quixote, recently brought into this country, will stand at Painter's stable, Vergennes, at $\$ 5$ to $\$$ I 2 . He has been in America four years; is 15 hands.

A. W. BARNum.

The Centinel for I $82 \mathrm{I}-\mathbf{2} 3$ contains no horse advertisements. In 1824 Cock of the Rock is advertised at Vergennes, also the noted horses Telescope and the Wild Phoenix horse at Westford, Milton, Burlington and Fairfax. "The above horses are too well known to need any recommendation. Their stock has been sold in Boston, Montreal, Quebec and other markets at higher prices than any other.

S. \& I. Calhoun, Westford.”.

E. Thurston of Burlington in 1824 advertises, also in the Centinel, Young Morgan, at R. H. Gould's, Burlington, Ezra Meech's, Shelburne, and Dan Arnold's, Williston; and describes him as "of the well-known Morgan breed crossed by the Quicksilver. In bone, muscle and action he is not exceeded."

In $1836, ' 37$, ' 38, ' 39 and ' 42 there is no horse advertising in the Centinel. M. L. Church in I 844 advertises Morgan Bashaw at Shelburne and Burlington.

In the Windsor Gazette of May 3, I803, is advertisement of "the noted well-built horse called The Ranger" ; in Windsor ; 15 I/2 hands; also the Granby and Bald Head.

The following are further results of examinations of files of papers in the State Library at Montpelier:

In the Vermont Republican for I8I4 (Vol. VI.), G. F. Holmes advertises under date of Randolph, March I 5, Henry Dundas at Randolph aud Braintree; "the same breed as formerly owned by C. Lynde, Williamstown; owned by me last season."

Young Cranberry, got by the full-blooded horse Yankee, is advertised at Windsor.

The Pennsylvania horse Baronet, formerly kept in New York, is advertised to stand at Windsor.

N. Brown of Pomfret advertises The Black Pope, I5 hands and beautiful, to stand at Woodstock.

Lance, and the Fields Horse from New York are also announced.

The Vermont Centinel for 1807 to 18 I 2 contains no advertisements, nor are there any in I8I7 or' 18 . In I 819 the celebrated colts got by the old Telescope are advertised to be at Lewis Higbee's, 
$\operatorname{clxxx}$

St. George, and the oldest, The Beautiful Gray, at Burritt's Inn, Shelburne.

The Vermont Republican and American Seaman, published at Windsor, has, in I8I9, announcement of the Blazing Star at Windsor.

Young Quicksilver is also announced to be at Hartland and Cornish; got by the noted horse Quicksilver, owned by Mr. Jonah Bellows, 2d, of Walpole, and foaled by the full-blooded mare owned by S. Smith of Windsor; bay, I61/2 hands, I300 pounds. E. Pike, Jr., is the advertiser. The same announcement appears again in I 820 ; also notice of New Jersey Colt. $\$ 5$ to $\$ 8$.

In Spooner's Vermont Journal T. W. Pitkin, under date April 23, I 796, advertises the elegant, full-bred imported horse Figure, at Daniel Marsh's, Hartford. "Figure is about I6 hands, well-proportioned; his points, both in carriage, shape and movement, are almost unequaled; color, bright bay." $\$ 4$ to $\$ 6$.

True Figure is announced to be at Woodstock by N. Hibbard; the full-blooded horse Grand Turk at Samuel Morgan's, Windsor; and in I 799, J. Galton advertises the full-blooded horse Zanthus, got by Figure.

In the Montpelier Press of May, I8I I, Black Prince is advertised by Joshua Pitkin of Marshfield at Plainfield, Montpelier and Marshfield; five years old; from noted Black Prince, imported by Capt. Ramsey of Hartford.

James Paddock of Barre advertises The Bold Farmer at $\$ 3$ to $\$ 5$; eleven years old; bred in Pennsylvania by C. Hart; got by old Rockingham.

Figure, known by the name of the Borden Horse, will stand, etc., at Col. Moses Morse's in Montpelier village, Michael Hammitt's in Montpelier, Elisha Coburn's in Cabot and at Gilmore's on Cabot Plains, at $\$ 1.50$ and $\$ 2$.

Vial Allen, Calais, April 27, i 8 i r.

U. Whitney in I8I I advertises Roe Buck at Montpelier and Berlin.

The same year G. F. Holmes of Randolph advertises Henry Dundas, bred and formerly kept by Cornelius Lynde, Esq., of Williamstown, at Randolph.

April I8, I822, Jonathan Shepherd of Montpelier advertises Olive Branch, raised in Petersham, Mass., by Mr. Lewis Mac; near six years old, bay, large; got by the celebrated Virginia horse Diomede, from one of the best brood mares in the County of Worcester. The same notice appears again the next year. 

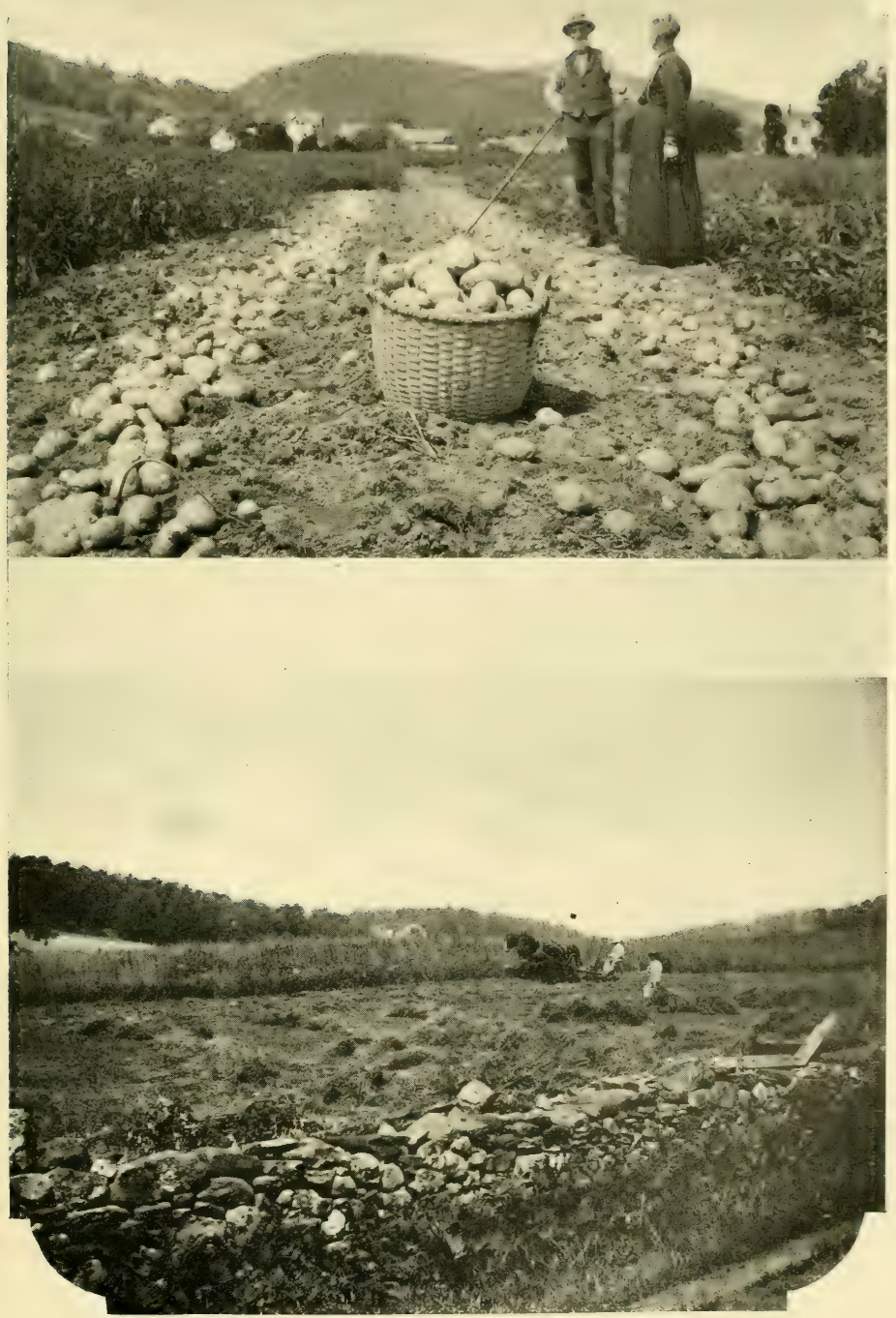

Cuuntry Life, Vermont. 

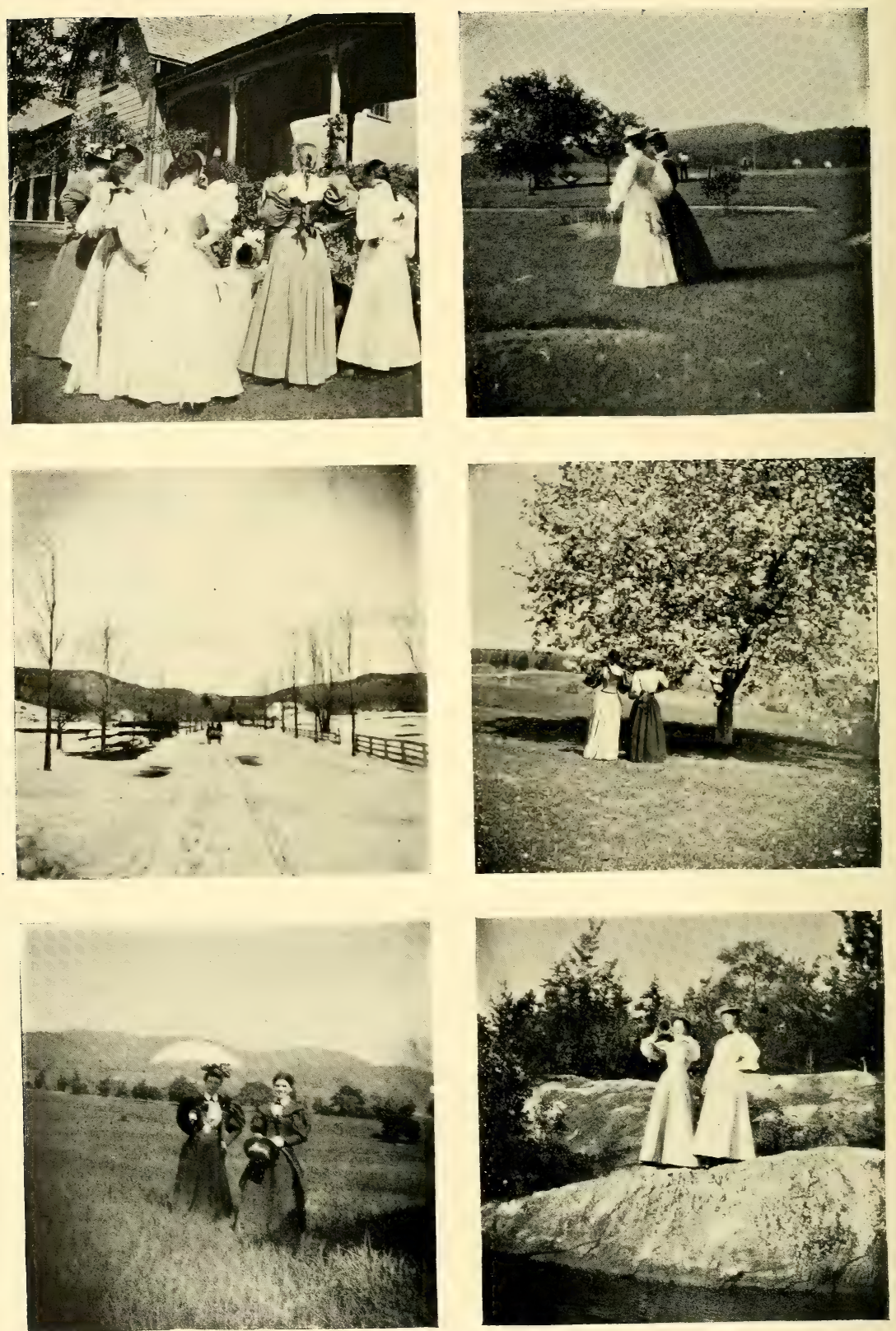

Near Bread Loaf Inn. 
Young Olive Branch is advertised in 1827 at Montpelier, and also Young Figure. "This horse will be kept by the same person and at the same place as last ycar." Morctown, May II, I827.

The following are from the Vermont Couricr, published at Rutland :

In 1796 appear advertisements of Janus, by old Janus, dam by imported True Britain; Slender, in Salem; Bay Figure, by old Ranger, old Ranger imported by Gen. Wyllys, in Tinmouth; and Fosbury, by old Cub of Virginia, at Clarendon.

In I 799 Koulikan, Cardinal Puff, imported by Samuel Harrison of Virginia, and Shakespeare, are also advertised by Asa Graves of Rutland.

The same year Hyder Ally, imported from England, bright bay, I 5 hands, the handsomest horse without exception on the continent, got by the King's horse, Bashaw, is advertised in Pittsford.

The following advertisement appears in the Montpelier Watchman of 1829 :

Young Hunter and Young Soldier, beautiful gray color, good size, to be kept at East Montpelier, Plainfield, Barre and Washington.

$$
\text { (Signed) F. R. Аввотт, Barre, Vt. }
$$

I 842-Jonathan Sheppard gives notice that his well-known Morgan horse will be kept for service at his stable.

June 9,1853 , the editor of the Watchman says concerning an article on the Morgan horse taken from the Albany Cultivator, and which gives the pedigree of Justin Morgan as Linsley gave it four year later:

"It corresponds with the information we received a number of years since from the late Joseph Edson of Randolph in this State, a good judge of that noble animal, the horse, and well versed in the pedigree of the old Justin Morgan. We can therefore vouch for the accuracy of the following in all the material facts."

(From Vermont Patriot and State Gazette, Vol. I., I826, Montpelier.)

Lala Rook; by Young Black Prince, by imported Black Prince: dam by imported Cantab; also a full-blooded French horse raised in Quebec.

Malon CotTrell, Montpelier.

The Young Hero; by Olive Branch, at Barre.

Vermonter; by Olive Branch ; foaled I 824; at Barre, Williamstown and Berlin.

Sir Edward at Brookfield and Randolph; by Don Quixote, son of Potomac, by Messenger: dam by Admiral, son of Allen's Figure, 
by imported Figure; dam of Admiral, by Bashaw, son of Wildair. Sir Edward is 16 hands; foaled I8I5; bay. He took the first premium in 1823 at the Saratoga Fair; owned by George Edson.

\section{James F. Kelley, Brookfield.}

The above pedigree of Don Quixote, "son of Potomac by Messenger," although not suggesting owner, breeder or locality where owned, is clean cut and suggests that this horse called Don Quixote, by Potomac, son of Messenger, was getting stock in 1814 , which was about the time that the dam of Lady Suffolk, said to be by a horse called "Don Quixote" was got.

I829-The Vermonter again at Berlin.

Columbus at Barre; foaled I824, bay, $161 / 2$ hands.

T. Town.

The Young Hunter and Young Soldier at Barre, Plainfield, Montpelier, Orange and Washington; gray and good size.

R. F. Аввотт, Barre, 1829.

Napoleon at the stable of Mr. Wait, Union Hotel, Montpelier; dapple gray; bred by Gen. Ridgeley of Virginia ; got by Virginian: dam by Bay Yankee; grandam by sorrel Diomed, etc.

\section{(From Green Monntain Patriot, at Peacham, l't.)}

I 798-Roe Buck in Peacham, one-half blooded, 15 hands, dark chestnut.

I799, I800, 'OI, 'O2, 'O3, 'O4 not in Library.

I 805-Hunter, I 7 hands; Young Roe Buck. The Ranger.

I 806, '07, 'o8, '09, 'Io not in Library.

I 8 I 4 -Lance, bay, I 5 I $/ 2$ hands, bred by John Hoomes, Virginia ; got by imported Dragon. To be kept in Windsor.

Montpelier Precursor, I807, Vol. I. None.

Montpelier Watchman, Vol. II., iso8. None.

Montpelier Watchman, I809, not in Library.

I 8 IO-Henry Dundas, bred and kept by Cornelius Lynde of Williamstown, in Williamstown and Montpelier; also Roe Buck.

The Young Eclipse in Montpelier at $\$ 5$. Owned by Mr. Sellick of Fayston, better known as Sellick or Eaton Horse. Got by the full-blooded horse old Eclipse, bred upon the Nine Partners, New York. Bay, black legs, seven years, about I6 hands.

Chester W. Houghton, i8 88.

I 855-Green Mountain Morgan, at Mr. Cottrill's stable at $\$ 25$. Took first premium, I853, at Ohio, Michigan and Kentucky State Fairs, and at Brattleboro, N. E. Fair, I 854 . 


\section{(From Northern Sentincl at Burlington, 1827.)}

Urilleas in Shelburne and Burlington; bay trimmed with black, rising 16 hands. He was the sire of the Dixon Horse, sold in Boston last spring for $\$ 700$, now held at $\$ 1500$. Purchased the last season by the owners at great expense.

I 827-Telescope in Ferrisburgh. Olive Branch and Dinwiddie in Westford. Dinwiddie three years old, dapple bay, I6 hands; got by Olive Branch; well known to be superior to any other horse ever raised in the United States, not excepting Cock of the Rock, Mars, Hamiltonian, Urilleas, or any of their posterity.

\section{Samuel Calhoon, Westford.}

I828-Young Hickory, well-known horse, at Meech's, Shelburne, and at Williston, at $\$ 5$.

URIAH DUBOIS.

Urilleas.

I 825 -Olive Branch, by Diomed, etc.

I 8 I 5 -Old Sweepstakes and son Independence in Fairfield.

Danill Barlow.

We found in the Fletcher Library at Burlington complete files of the Free Press from Vol. I., I827. In 1828 is advertisement of auction sale of horses, one sorrel horse, four years old, by Don Quixote; one black horse, three years old; one brood mare, ten years old, by Robin; one mare, five years old, by Robin; one bay mare, four years old, by Bedford. The same year R. H. Gould advertises the Urilleas horse at Burlington at $\$ 5$. The full-blooded horse Napoleon, the same horse that has been kept the last three years at Essex, at Jericho, Fairfax, and Essex; beautiful dapple gray, large size, justly made and moves elegantly, movement easy at ten miles an hour. (Signed)

Roswell Butler, JEHIEL BLOOD.

SiR WALTER-This well-known horse at Mr. Henry Thomas'.

$$
\text { (Signed) Paul Kauntz, i } 828 .
$$

1829-“Horses! Horses! The public's humble servant, Lewis Higbee, would hereby give notice that he has at his stables in St. George three young stud horses, two Telescopes and one Cock of the Rock."

Cock of the Rock and son, Cripple, are advertised at Vergennes in 1829 .

1829-Sir Jed is advertised at R. H. Goulds, Burlington ; chestnut, four years old; by Cock of the Rock: dam, Lady Converse, by the celebrated horse Morgan, at \$IO.

(Signed) W. L. Harrington, Burlington. 
I 829-Urilleas; this elegant and full-blood coach horse, in Shelburne and Charlotte, at $\$ 6$; bay trimmed with black; his colts brought more money in Boston as coach horses than any other breed in this section. It has been thought by many that the delicate, slimlegged, soaring, jumping, flying, kicking horses are the only kind that would bring a price in market; but that point has been settled by the many who have returned wiping their eyes and enquiring where the Urilleas were.

(Signed) E. IRISH.

I 829-The elegant horse Bedford at Shelburn, Charlotte and Monkton; bright bay, seven years old, I 5 hands; got by old Bedford, an imported horse: dam by old Balance; terms $\$ 5$.

\section{(Signed) P. TROWBRIDGE.}

The noted horse, Young Telescope, formerly owned by Dan Arnold of Hinesburgh, at Charlotte and Williston.

\section{(Signed) LEONARD FrEeland.}

I 830 - "Old Telescope is but 24 years old this season and it is and will be acknowledged for years to come that more benefit has come from his use for I6 years than any other horse"; terms $\$ 7$.

$$
\text { (Signed) Roswell Butler, Essex. }
$$

I 830-Sterling at Burlington, Richmond and Jericho: "the same horse has been kept by George Tyler for five years" - at $\$ 5$.
(Signed)
ERAstus TYler, Essex.

I830-Lewis Higbee of St. George advertises Young Cock of the Rock at St. George and Williston; five years old, 16-2, bay; got by Cock of the Rock "and is from my Messenger mare so noted for colts"; terms $\$ 5$.

I 83 I - F. \& B. Nye advertise Hickory at Henry Thomas' stables in Burlington.

\section{(From the Rutland Hcrald.)}

I793-Koulikan; by a son of William Hunt's full-blooded imported Bajazet, from Hiltzmer's full-blooded mare: dam by fullblooded Granby; grandam by Bulrock; dark bay, I $53 / 4$ hands.

AsA Graves, Rutland.

I793-Federal Ranger, bay, very large.

Roger DARBe, Brandon.

I794-Janus, sorrel, got by the full-blooded Janus from Virginia; dam by imported True Briton.

Henry and Silas Mead, Rutland.

All Fours; by Rainbow.

Shakespeare; by Don Carlos, by old Figure; black, I 5 I $/ 2$ hands, etc. 
Bold Hunter; by Figure, etc.

Enterprise; bred by Ephraim Ladlaw of Long Island; got by imported Allen's Figure; foaled I790. Has beaten the famous Messenger. Bay, $15 \mathrm{I} / 2$ hands; to be kept in Charlotte and Vergennes.

Irish Gray.

I 794-Silverheels, bay, I 5 I/2 hands, in Ferrisburgh.

GEORGE FIELD.

Brilliant, from Philadelphia, bay, I6 hands, foaled I 787.

James Seaman, Castleton.

Koulikan and gray horse Macaroni in Rutland. ford.

I 795-Young Rover; foaled I79I ; by Golden Briton, in Pitts-

Bay Figure; by Gen. Heard's Bay Figure.

Bohemian, seven-eighths blooded, I 6 hands, at Brandon.

Young Bold Air in Salisbury; dark bay, rising I 5 hands, eight years old this season; noted for his colts; got by the noted horse Bold Air, which was got by DeLancey's famous horse called the Wild Air, allowed to be equal if not superior to any horse ever imported, and after he had covered two years in the city of New York was purchased by his former owner and exported to England, where he covered at thirty guineas each mare.

LEONARD REED.

Young Ranger, dapple gray, I 5 1/2 hands; foaled I 788 ; by fullblooded Young Wildair, by Hooker's Wildair: dam by old Ranger.

JAMES MEAD, Rutland.

Phoenix; by Air Balloon, at Esquire Callender's in Shoreham and in Orwell.

JEM. BRIDGE.

Young Union, I $53 / 4$ hands, bay with Snip, by imported Union, owned by Major DeLancey of New York.

\section{Frost, Rutland.}

In Rutland Herald of May 9, I 797, are the following advertisements :

Janus, by Janus of Virginia.

Shakespeare, Bold Hunter and Bay Figure, all at Rutland.

Irish Gray will be kept this season at the subscriber's stable in Bridport, about half a mile north of Callender's Inn. Irish Gray is I6 hands and one inch high, stout and elegant built.

Abel PotTer, March 30, 1797.

Dick Bogus will be kept at the stable of the subscriber in Bridport the coming season. Bogus is eight years old this spring; he is 
a beautiful brown bay, I5 $\mathrm{x} / 4$ hands high, moves well and in figure, make and shape is inferior to few. His colts prove good. Dick Bogus was got by the imported horse Tom Bogus: dam by Mr. Delancy's noted horse Lath, who won more prizes by running than any other horse in America; grandam by True Briton; great-grandam by the old Wildeer.

\section{JoHN WARD, Bridport, May 3, I 797.}

This breeding is quite noticeable, introducing three of DeLancy's stallions, Lath, True Briton and Wildeer, suggesting that the True Briton, which got the $2 \mathrm{~d}$ dam, was DeLancy's, and the sire of Justin Morgan.

ENTERPRISE-Enterprise was bred by Mr. Ephraim Ludlam, Long Island, and foaled the 20th of May, I 790, his sire the famous imported horse, Allen's Figure, well known to breeders and sportsmen; his dam got by the imported horse Lath, his grandam by Speedwell, also imported as will appear by the certificate of the breeder; he is a beautiful dark bay, I $5 \mathrm{I} / 2$ hands high, lengthy, bony and stout, of great action and spirit, well calculated to get colts for the turf, saddle or harness. Platt BRush, April 23, I797.

I 798-Janus, sorrel, by Virginia Janus, at Rutland.

RALPH PAIGE.

I 798-Shakespeare; foaled I 783 ; black, I 5 1/2 hands, by Don Carlos, son of Hamilton's old Figure; at Rutland.

ASA GRAvES.

I 8 Io-Eclipse, in West Clarendon; eight years, I6 hands. DAVid PotTer.

The Spy in Clarendon and Wallingford; brown, I6 hands, six years; got by old Chanticleer: dam by the old Tom Bogus; $\$ 3$ to $\$ 5$.

SPENCER BRIGgs.

Hamlet, thirteen years old, imported to Long Island by Capt. Charles Hamlet. He was kept the last season at Middlebury and New Haven.

H. Finney, Brandon.

ISIo-Young Koulikan in Rutland; Jehu in Benson.

I 8 I I - Not in Library.

I 8 I 2 -'i 3 -None.

I 8 I 4-The great and celebrated hunting horse, Leonidas, at stable of Sam Moulton, Castleton ; dark sorrel, elegantly formed, I6 $1 / 2$ hands. For figure, bone, action, carriage and movement he is allowed by good judges to be equal to any other horse. Got by imported hunting horse, Emperor, from a full-bred mare, Miss Leedes. This horse was the property of Col. James Hart of Philadelphia, 
from whom he was purchased one year since, and moved to this stand; $\$ 6$ to $\$ 15$.

Heman Moulton.

I 8 I6-Leonidas at Capt. Samuel Moulton's, Castleton, at \$1o.

I 817 -The elegant horse Duroc at West Rutland at $\$ 8 ; 17$ hands, nine years, bright bay, lofty and elegant, stocky and well built.

Nashan C. Sherman.

I 820-Young Nimrod in Ira and Clarendon; got by old Nimrod that formerly was kept at Castleton; dam a Messenger; bay, I6 hands.

EDWARD CARPENTER.

Young Phoenix, at Rutland; by old Phoenix: dam, one of the first-rate mares from the Matchem; 16 hands, four years old.

DANIEl FORD.

Young Nimrod at Ira and Clarendon at $\$ 2.50$ to $\$ 3.50$. It is unnecessary to give a long pedigree of said horse, as a view of him is sufficient to covince any good judge of horses that he is not excelled by many in this part of the country. Said horse is three years old past; was got by old Nimrod, that was formerly kept in Castleton. His dam was a Messenger. He is 16 hands high, of a bright bay color; a deep breast and a broad stern. His limbs are flat and well furnished with nerves and sinews.

EdWard CaRpenter, Ira, May i, i 820.

Daniel Ford, Rutland, May i6, i 820.

1824-Young Magnum Bonum.

D. MARsh.

Eclipse again by M. Lester.

Old Magnum Bonum and the gray Arabian horse Young Arab at I. Reed's tavern, Rutland, and Pittsford, and the dapple gray horse called the Messenger, at Pittsford.

JoHN DEAN.

I 824-Old Magnum Bonum, Young Arab (gray) and the dapple-gray horse Messenger at Pittsford.

Young Phønix at Rutland at $\$ 2$ to $\$ 2.50$. Said horse was sired by the old Phœnix; his dam one of the first-rate mares from the Matchem. He is I6 hands, bright bay, four years olu this spring, and for saddle or turf is not exceeded by many in this country.

I 827-The celebrated English horse Nimrod at Ira.

Young Magnum Bonum.

I. R. CARPEnter.

Clarendon.

Rob Roy at Clarendon, Ira, etc.

DANIEL MAKSH.

The noted horse Magnum Bonum at Brandon.

Pittsford.

G. Hammond. 
Eclipse, from the old Magnum Bonum: dam by Shakespeare. M. LESTER.

Notice-The celebrated English horse Nimrod, at Rutland and East Rutland, at \$3. I. R. CARPENTER, Ira, April 19, I827.

Rob Roy at A. Mead's in Rutland and at Clarendon.

E. Collins, Ira, May, I827.

Noted horse Farmer, by Durkee; at Pittsford.

$$
\text { E. Brown, April, i } 829 .
$$

Young Magnum Bonum at N. Gould's in Rutland. He is I6 hands high and well proportioned: was bred in Danby, Vt., by Ira Vail; is eight years old this spring; dark brown; small stripe of white on nose; hind feet white. He was got by old Magnum Bonum, that was formerly kept in Cambridge, N. Y., I4 years at the Checquered House, so-called. He is from a beautiful mare that was got by the noted horse Speculator. He was purchased by Bethuel Bromley of the man that bred him and sold by him to Roswell Bromley.

$$
\text { N. Gould, Agent, Rutland, May i I, I } 829 .
$$

I830-Eclipse Fagdown at Hampton, N. Y., near Norton Mills and East Poultney; eight years this spring, gray, $\mathrm{I} 6$ hands. $\mathrm{He}$ is from trotting stock. He was got by the noted traveling horse, Fagdown, of Philadelphia; grandsire, the celebrated Fagdown of New Jersey; great-grandsire, imported Messenger. Dam by imported Eagle, etc.

Daniel Mallory, Hampton, N. Y.

\section{(From Rutland Herald or Vcrmont Mercury, Vol. I., I795.)}

The beautiful horse Bay Figure, from New Jersey, at Rutland; I $53 / 4$ hands, star, snip and two white feet; got by Gen. Heard's full-blooded horse Bay Figure, and from imported mare Britannia, which blood is well known to be the first in America. Dam by imported Lofty, from a three-fourths blooded mare by old Britain. Macaroni will also be kept at same stable. $\$ 4$ to $\$ 6$.

\section{Asa Graves.}

At stable of subscriber in Orwell, and Esq. Calender's, Shoreham, and Lemmon Gray's in Bridport, the beautiful horses Phoenix and Air Balloon. Phoenix is an English horse, late from the southward, bright chestnut color, elegant and genteel made, I 6 hands high. Air Balloon is a full-blooded horse, $15 \frac{1}{2}$ hands, bright bay, formerly owned by James Seaman, Castleton; had last season 153 mares, all but nine in foal. Eight to thirty shillings. 
Young Rover, I5 hands, four ycars past, by son of Golden Britain. Bohemia in Leicester at David Buxton's and Landlord Woodward's stable; seven-eighths blooded, I 6 hands. I 2 to 40 shillings.

D.Avid Buxion, Brandon, i 795.

The Young Bold Air at Lconard Reed's, Salisbury; 10 to 20 shillings. Dark bay, 15 hands, and colts fit for either saddle or harness; by old Bold Air, which was got by DeLancey's famous imported horse called the Wildair, which was allowed, by competent judges, to be equal, if not superior, to any horse ever imported into America, and after he was kept two years in the city of New York was purchased by his former owner and exported to Europe again, where he covered at the rate of thirty guineas each mare. Wheat received in payment.

L. REED.

1795-At Rutland, the beautiful horse Bay Figure, from New Jersey, by Gen. Heard's full-blooded Bay Figure, dam by imported Lofty, from a three-fourths blooded mare by old Benton.

Also at Orwell, Shoreham and Bridport, the beautiful horses, Phoenix and Air Balloon, Phoenix is an English horse late from the southward is bright chestnut color, elegant and genteel made, standing 16 hands. Air Balloon is a full-blooded horse, I $51 / 2$ hands, bright bay.

Also in Leicester, Young Rover, son of Golden Briton. And Bohemia, seven-eights blooded.

Also in Addison, the noted horse Genet, bright sorrel, six years old, well built for saddle or draft; got by Kildare, son of Lath: dam a Jersey bred mare, three-fourths blooded, owned by Colonel Ray.

I 796-At Rutland, the full-biooded horse, Bold Hunter, bred in Virginia, brown bay, I $53 / 4$ hands, by imported Figure, dam imported Selima, etc.

"Bold Hunter is well known as to his speed in the lower counties of Virginia and Maryland. He started for a purse against four capital horses the Slammerkin Mare, Fearnaught, Steel Jacket and Young Lath, and beat them with ease."

Also Janus, by the full-blooded old Janus from Virginia, dam by imported True Briton.

At Salem (N. Y.), Slender, by Herod. Also Bay Figure.

At Clarendon, Foxbury, by old Cub imported from England.

Young Ranger in Rutland; well known for getting excellent colts in this neighborhood; dapple gray, $15 \mathrm{~T} / 2$ hands, seven years; got by Young Wildair, he by the famous horse called Hooker's old Wildair: dam by old Ranger.

JAMES MEAD. 
GEnET-At Gen. Strong's in Addison, the noted horse Genet, a bright sorrel, six years old this season; seven-eighths blooded, well built for the saddle or draught. Genet was got by the elegant horse, the Kildare, whose sire was the imported horse old Lath: his dam was a Jersey-bred mare, three-fourths blooded, owned by Col. Ray; at nine to thirty shillings. JOHN HOWARD, Addison, April 25.

1796-The Bold Hunter and Koulikan at three to forty-four shillings at Rutland. Bold Hunter is full-blooded; bred in Virginia; brown bay, $153 / 4$ hands; by imported Figure: dam imported Selima; grandam by old Dave; great-grandam by Godolphin; great-greatgrandam from Othello; a noted running mare in England. These were all running horses and best stock in England. Bold Hunter is well known as to his speed in the lower counties of Virginia and Maryland. He started for a purse against four capital horses, the Slamerkin Mare, Fearnaught, Steel Jacket and Young Lath, and beat them with ease. He has also won several other races. Koulikan is so well known for getting good colts in this town and county, and almost throughout the State, that it is sufficient to inform, etc.

\section{(Signed) Asa Graves.}

The celebrated horse Janus; bright sorrel, I $5 \frac{3}{4}$ hands, and well made, fit for the saddle or harness; has a star, snip and two white feet; got by the full-blooded old Janus from Virginia: dam by imported True Britain; at twelve to twenty shillings at Rutland.

I 796.

HENRY MEAD,

Silas Mead.

Slender in Salem, at $\$ 6$ to $\$ 20$; got by Duke of Queensbury: dam by Herod, etc., etc., full brother to Highflyer; also Bay Figure.

ANDREW RACE, Salem, I796.

In Tinmouth, Ranger; got by the old Ranger, imported by Gen. Wyllys, and from as fine a mare as any in Connecticut, known by the name of Steele's Free and Easy.

\section{James Benjamin, Tinmouth.}

Foxbury, at Clarendon and Wallingford, lately from Virginia; got by old $\mathrm{Cub}$, imported from England; grandsire old Bellgrade, one of the most noted hunters in the north of England; bay, $161 / 4$ hands.

SHADRACK DARBY.

(From Farmers' Library at Rutland, Vt.)

I793-Koulikan, by imported Bajazet, in Rutland; dark bay, I5 3/4 hands, etc.

Asa Graves.

Brilliant, from Pennsylvania, in Castleton; 16 hands, long built. 
1794-Wildeer brought from Massachusetts to Jericho.

MORTON CHITTENDEN.

Junius, by Lath, in Williston.

(From Vergennes Gasitte of Vermont and Now York Advertiser at lirgonnes, I799, Vol. I.)

The Granby at the stable of Widow Tupper in Ferrisburgh; bay; got by the Morrassar: dam by True Britain horse; six to twenty shillings.

Johnson Walker, Ferrisburgh.

Imported horse Revenge, at Williston and Mr. Read's, Shelburne; $161 / 2$ hands, six years, dapple gray; $\$ 5$ to $\$ 8$.

Charles Mcloud, Williston.

The following advertisements are copied from Volume I. of The Vermont Aurora, published at Vergennes. In No. 48 of that volume, bearing date May 25, I825:

The well-known horse Telescope will stand this season at $\mathrm{T}$. Stevens' Tavern in Vergennes and at stable of the subscriber in Ferrisburgh. Henry Cronk, Ferrisburgh, May II, I 825.

Cock of the Rock will be kept at Vergennes. The terms are $\$ 20$ whether the mare proves in foal or not. To save trouble, travel and disappointment the public are informed that no deduction will be made from that price.

A. W. Barnum, Vergennes, i2th April, I825.

Independence at Addison, Panton and Vergennes. Independence is four years old, of a light bay color and for beauty, size and stock will compare with any horse in the country.

\section{David Jackson, Addison, May io, I 825.}

Cock of the Rock appears in a similar advertisement in 1826 , and also again “The noted horse Telescope," at $\$ 2$ and $\$ 3$. Also:

Post Boy-The subscriber purchased on the $3 \mathrm{~d}$ day of May, I 825, the celebrated and thoroughbred English horse Post Boy, which will be kept the coming season at the stable of Col. Joel Doolittle in Shoreham at the moderate price of $\$ 5$ and $\$ 6$, the same he has always stood at, at the stable of John Earl of Warwick, Worcester, Mass.

Post Boy was bred by said Earl on his own farm; he was got by the noted horse Dinwiddie, the name of the county in Virginia where the Dinwiddie was bred. Said horse was purchased by said Earl and Luther Smith at the price of $\$ 1000$, cash. The dam of Post Boy was purchased by the said Earl in the city of Charleston, S. C., at the price of $\$ 150$. She was a first rate English mare and 
was $15^{1 / 2}$ hands high. Post Boy is 15 hands, of a dark bay roan color, is uncommonly handsome and of great speed. He has run a number of races not exceeding one-mile heats, in the State of Massachusetts, and has never been beaten by any horse. His colts are elegant, some of them 16 hands, valued at from one to six hundred dollars each.

For beauty, bone and activity he is thought by good judges to be the most elegant horse in the State. He had seventy mares last season at the stable of Charles Eager in Bridport.

\section{Joel Doolittle, Shoreham, April 7, i826.}

The elegant horse Superior is a dapple black, $161 / 2$ hands, eight years old next June, said to be by King Herod. Will be kept at Hinesburgh, Monkton and Starksboro.

$$
\text { Jedediah Reed, Monkton, May io, i } 826 .
$$

Young Messenger-The noted horse, Young Messenger, well known by those acquainted in St. Lawrence County, N. Y., by the name of the Freeman Horse, will be kept at George Pease's in Ferrisburgh, at George Sherman's Inn, Charlotte, and stable of subscriber. Young Messenger is seven years old, of a beautiful dapple gray, 16 hands high; for beauty, speed and elegance of movement is exceeded by none. This horse is of a noted breed: his grandsire was by the old imported horse Messenger: his dam a full-blooded English mare, his stock is indisputably good. Twelve of his colts can be seen at Wainwright's stable, Middlebury. $\$ 2$ to $\$ 4$.

\section{Abner Squier, Charlotte, May, 1826.}

The following statement of the pedigree of Young Messenger is given by his former owner:

\section{Mr. Abner Squier,}

$$
\text { "MADRID, April I } 7 \text { th, I } 826 .
$$

Sir :-Agreeably to your request of the $I_{5}$ inst., wishing me to forward you pedigree of Young Messenger, I can say he was got by the Messenger owned by me whose sire was the old Messenger purchased on Long Island by Judge Ogden. Old Messenger was got by the imported Messenger. His dam was Katy Fisher, owned by Dr. Young of Virginia; this mare had run nine heats, and as report says, was never beaten. Old Messenger from his stock ranks first in the estimation of the best judges in the United States and needs no further recommendation. Young Messenger was from Mr. Bass' English mare, which mare was bred in New Hampshire; her stock has proved her blood. Young Messenger is seven this spring; his stock are scattered over this country and in some parts of Canada, which for size, strength and activity has not been surpassed except by Messenger himself. 
Young Messenger is advertised by Abner Squicr again in 1827 , at Charlotte and Vergennes. Also in 1828, at Charlotte, Vergennes and Middlebury, at $\$ 6$.

In 1829 the noted horse Magnum Bonum, at Ferrisburgh, Charlotte, Hinesburgh, Monkton and Vergennes. Dark bay, 15 1/2 hands, I 100 pounds; got by the celebrated horse Magnum Bonum. imported by Mr. Rylander of New York, and has generally been considered by good judges to be as good a horse for stock as was ever imported. His dam was of high blood. He took first premium at the New York Agricultural Fair. This certificate is given:

"We certify that we have been acquainted with the horse Magnum Bonum, lately purchased by Joseph Wells, Vermont, and consider him to be as good a horse for stock as this country ever produced. Given at Cambridge, Washington County, N. Y."

(Signed) Austin Wells and eleven others.

Telescope appears again; Cock of the Rock at \$15; Cripple, by Cock of the Rock, four years old, also.

Young Telescope, by Hiram Spaulding, Panton; and the beautiful horse Young Brutus, got by imported horse old Brutus, well known for speed and bottom; his dam was got by old Enterprise, for many years the most celebrated horse in this part of the country. Young Brutus, dark bay, four years old.

Primus Storms, Panton, May 5, i 829.

Dapple Gray Messenger at S. Hobb's in Waltham, Erick Sprague's, Weybridge, and William Hartshorn's, Vergennes; four years old, by Freeman Horse or old Messenger; bred by Ira Sanford, Canton, N. Y. His dam owned by Ira Sanford, St. Lawrence County, sold for $\$ 150$. Terms, $\$ 4$ to $\$ 6$.

A. M. HobBs, Waltham.

Liberty - The noted horse, at Addison, Hinesburgh, New Haven, Vergennes. Liberty is owned by David G. Jackson, and is from the well known horse old Liberty, formerly kept in this county by Allen Smith of Addison, and from which many of the finest horses in this country descended. Liberty is very large, of a beautiful light bay color, and moves elegantly. His stock is hardly exceeded in beauty by that of any horse in the county and in size, bone and muscle by none. $\$ 3$ to $\$ 5$.

A. W. Bristol, Panton, May i I, i 829.

\section{(From Vergennes Vermonter.)}

I 850-Napoleon Morgan, six years old last June; mahogany bay; at Vergennes, $\$ 6$ to $\$ 10$. Got by Gen. Gifford, owned by 
Moses Ingersoll, Seneca County, N. Y.; grandsire, Gifford Morgan. Among many celebrated foals of Gifford Morgan are the well-known trotting pony of Horatio Sargent, Springfield, Mass., sold to Mr. Wood of Providence for $\$ 1000$; making there a mile in $2: 30$, and for the last three or four years known in New York as the Henry Clay; the chestnut horse of Robert Abel, Pawtucket, going in 2:40; the noted Beppo; the chestnut horse Pizarro, 2:50; the Green Mountain Morgan, the General Gifford; the Major Gifford, owned by Messrs. Mason \& Co., Jordan, N. Y.; the Morgan Hunter and Morgan Chief, both owned by Ackley \& Gilbert of East Hamilton, N. Y., etc.

(Signed) B. A. BRAGG.

The same appears the next year, $185 \mathrm{I}$.

The account of the State Fair at Middlebury, in I85 I, speaks of Old Black Hawk: Black Hawk Jr., owned by Mr. Myrick of Bridport, six years; Bigelow Horse, six years old, from State of New York; a four-year-old stud owned by Col. Foot of Cornwall, another owned by Edrick Adams of Panton; Black Hawk stud, three years old, owned by Ezra Champion of Vergennes. There were a very large number of one and two-year-olds owned by Mr. Moore of Shoreham; a yearling by Dr. Rice of Bridport and another by Col. Howe of Shoreham. The Green Mountain Morgan is mentioned; also Bay Morgan, four years old, from Springfield; a beautiful brown Morgan stud from Pittsford, by the Gifford Morgan; the Richardson Morgan from Waitsfield and the Lyman from Randolph. A superior two-year-old Morgan colt, owned by John Ayres of Grafton, sold for $\$ 800$ on the grounds. There were some forty others, mostly from the East side of the Mountains.

OTHer BReEds.-The Washington Hamiltonian was shown by Noonan and Holmes, North Ferrisburgh. The Searcher, owned by $\mathrm{Mr}$. Andrus of Brandon, is a beautiful bay stud, for which the owner refused $\$ 1800$ on the ground. The Sir Walter from New York made an excellent appearance. Altogether there were probably not less than between 250 and 300 horses present for exhibition.

I 852-Full-blooded Morgan horse, Woodbury 2d; four years old the 2 Ist day of June, I85I; IOI 5 pounds; bred by Luke Havens; got by F. M. Wheeler's full-blooded Morgan: dam by Colonel Hackett's full-blooded Morgan; grandam by old Woodbury. Wheeler Morgan's sire, Hackett Morgan and dam by old Gifford; Hackett Morgan by old Gifford and dam by old Woodbury. 
Middlebury, Dec. IO, I 849.

This may certify that the colt sold Samucl A. Farr of New Haven by Luke Havens, and sold to Van Ness Scott of Vergennes, that the dam of the colt was got by my Morgan horse, and her dam by old Woodbury, both raised by Mr. Clemons of Goshen, Vt.

\section{JOHN HACKETT, Hancock. (Signed) Joshua Scotr.}

Hungarian, three years old this spring; bay, I $4 \frac{1}{2}$ hands; got by Black Hawk: dam by Post Boy; at New Haven.

M. THOMPSON.

Young Sherman Morgan, got by old Black Hawk, will be five years old next June; dark dapple chestnut, IOOO pounds.

G. R. Robinson.

R. M. Satterly.

Vergennes, May 12, I 852.

Fast trotting stallion Flying Morgan, at Burlington; 900 pounds ; trotted on Cambridge course in $2: 45 \mathrm{r} / 2$ last fall.

R. M. ADAMs.

I 852-Black Hawk Jr. at C. C. Evert's stable, Vergennes. Black, I Ioo pounds: dam black, medium size, owned by Edrick Adams; foaled June 3, I 847 ; got by Black Hawk.

Keokuk, Black Hawk colt, at E. S. Champion's in Vergennes.

I 853 -Black Spaniard, I 5 r $/ 2$ hands, 1200 pounds; by Nimrod, son of True American by the celebrated old Quicksilver of Josiah Bellows, Walpole. Quicksilver was bred by Gorham Parsons of Brighton, Mass. Nimrod's dam was a bay mare by old Morgan. Black Spaniard's dam a beautiful black mare bred by A. Bell, Ticonderoga, N. Y., and got by a Morgan horse owned by John Graham of Putnam, N. Y. ; grandam imported mare owned by William Bell. To be kept at East Monkton, etc.

Charles A. Hurlburt.

Black Hawk Keokuk. This ceiebrated Black Hawk stallion, raised and owned by the subscriber, will be kept at Charlotte and Vergennes; was four years old June 4, I 852 , and weighed I050 pounds; dark bay, etc.

EzRA Champion.

Young Mambrino Paymaster at North Ferrisburgh; five years old, by Mambrino Paymaster, etc.

Gideon Fuller.

Woodbury 2d again.

Second advertisement of Keokuk gives pedigree as follows: By Black Hawk, son of Sherman Morgan, by old Morgan horse. The dam of Black Hawk was a three-fourths blood English mare raised in the province of New Brunswick, who could trot a mile in 
less than three minutes and weighed IOI 5 pounds, and was in every respect a most perfect animal. The dam of Keokuk was got by Young Hamiltonian and he by the old Bishop Hamiltonian, which was by the imported Messenger; grandam, by Morgan; dam of Young Hamiltonian by old Leonidas; grandam, by Bellfounder, a mare of great excellence brought from New Hampshire by Dr. Nicenor Needham into Shoreham, Vt., and there used in the practice of his profession.

The pedigree here given of the grandam is impossible because of dates. Young Hamiltonian was bred by Judge Larrabee, Shoreham, Vt. ; foaled I820. See The Morgan Horse and Register, Vol. I., page 350 .

Green Mountain Morgan at Middlebury. Bay State Morgan by Green Mountain Morgan at Vergennes.

Silas HALE.

Young Sherman Morgan by Black Hawk: dam, a black mare, owned by L. D. Stone of Charlotte. Young Sherman, six years old June, I 853 ; dark dapple chestnut, compact and beautiful form, etc. Also Pirate, a colt of Black Hawk from Hamiltonian mare that could travel ten miles an hour. Third and last as good a Mambrino as ever in State.

T. R. Robinson, Ferrisburgh.

English looking stallion Topsy and Woodbury $2 \mathrm{~d}$ again.

I 854-Young Sherman Morgan again by T. R. Robinson.

Robert P. Satterlee advertises a four-year-old Black Hawk at North Ferrisburgh.

Woodbury $2 \mathrm{~d}$ again.

Flying Morgan at Burlington; also Flying Morgan Sprout.

Snake Mountain Black Hawk at Bristol and Lincoln; five years old I 6 th of June, I 854 ; I 5 hands, I 000 pounds; got by Black Hawk Jr., well known as Myrick Horse, now owned by Col. North of Champlain: dam by Magnum Bonum, owned by Mr. Guindon of Ferrisburgh; grandam, owned in Missouri, brought to Addison by C. Foot, and was well known as the Black Nettle.

O. N. WHITFORD.

I855-Morgan Black Hawk, advertised by Robert P. Satterlee.

I 856-Black Hawk Napoleon, four years old May I 3, i 865; jet black, Io8o pounds, I 6 hands, at Charlotte. Combines the blood of the two best races of horses ever improved by the American people, that of the Black Hawk and Messenger.

A. C. PAlmer. 
Account of second Champlain Valley Agricultural Fair at Vergennes says:

"Sherman Black Hawk was present; and Hemenway Horse, ridden by Marshall Grandey. We never saw his superior in style, pride and beauty. G. A. Austin, Orwell, exhibited his pair of royal chestnut stallions, Red Jacket and Osceola, among the last of old Black Hawk's colts. They made a showy and superb appearance as Mr. Austin drove them around the track, and could not probably be bought for many thousand dollars. Another pair of matched Black Hawk stallions owned by Julius Crane of Bridport. Another notable was old Mazeppa, owned by E. C. Eells, of Sudbury. George B. Pease, Port Henry, exhibited his two well-known first-class stallions, Fashion and Lunkhead. B. J. Myrick exhibited a superb black stallion, six years old; a son of the Myrick Horse. Mr. Barbour of Burlington exhibited his well-known fast trotting mare, Flora, who made the greatest time of any one on the track. Hon. H. S. Morse of Shelburne exhibited a superior chestnut stallion. Mr. Champlain, Whiting, presented a splendid and valuable dark bay horse. John Jackson of Brandon showed Black Boy, a son of Black Hawk, five years old, and a three-year-old from Prophet."

I859-Account of the Vergennes Fair speaks of Young Vermont, owned by Joseph Nash, New Haven, Vt. ; six years old, a golden bay. Hemenway horse, nine years old, ridden by Gen. Grandey.

Right Bower, dark bay, $15 \mathrm{I} / 2$ hands, nearly 1000 pounds, five years old June, I862; got by old Black Hawk: dam, trotting mare Gipsey, bred by Albert Lloyd Jones, Long Island; has trotted in $2: 34 \frac{1}{2}$. Gipsey's sire Almack, by Mambrino, son of imported Messenger: dam by imported Arabian horse, Grand Bashaw, from Pearl. Terms, \$IO.

David Hill.

Account of Fair speaks of Black Hawk stallion owned by Charles Tredo of Vergennes; another by S. W. Smith of Addison; a third by Nathan Russell, Bridport.

I 863-Trial of speed at Vergennes Fair between Delong Colt and Holabird and Satterly colts, both by Ethan Allen and both five years old. First heat won by Ethan Allen, $2: 48$; second heat by Delong, 2:48; third heat and race by Ethan (Holabird's) in $2: 59$.

\section{(From National Standard, Middlebury.)}

I809-'I 5 , inclusive, none.

1815-Telescope to be kept in Burlington. A horse of much recent celebrity, both as a racer and as a stallion. 
I 8 I6-Young Dey of Algiers and noted horse, Revenge, Bridport, Middlebury and Ripton. Light bay with dark list on back, full I 6 hands and for blood, bottom, pedigree, bone, size, sinew, activity and loftiness of carriage not to be equaled; got by the short-jointed running horse, Revenge, imported from England I 796; he by Achilles, by Eclipse. Dam of Revenge by old Kildare.

I 8 I 7, 'i 8, 'is not in Library.

HENRY MERRY.

I 820 -Warrior, a full-blooded Canadian stallion.

$$
\text { JAMES SATTERLEE. }
$$

The Spanish horse, Don Quixote, recently brought into this country, at Painter's stables, Vergennes; $\$ 5$ to $\$ 12$. Has been in this country four years; a complete model of perfection.

\section{A. W. BarnhaM, Vergennes.}

It would appear that Mr. Burnham brought Don Quixote from Long Island with Cock of the Rock.

I825-Post Boy, advertised by Joel Doolittle, Shoreham. Green Mountain Farmer at Bennington.

\section{(From The Middlcbury Micrcury.)}

I 802 - The noted horse, Active, at Gamaliel Painter's stable, \$7 to $\$$ Io. Wheat, corn or oats will be received for pay, if delivered by the Ist of January next.

1803-The noted and much-approved horse, President, will be let to mares this season at the stable of the subscriber in Monkton on Mondays and Tuesdays, on Wednesdays at Landlord Pier's near the Mills in New Haven, on Thursdays at Nathaniel Munger's in Middlebury and on Fridays and Saturdays at Landlord Cook's in New Haven, continuing alternating so to stand through the season. $\mathrm{He}$ is I 5-2 hands; got by the full-blooded horse old Cincinnatus: dam by old Lath (which horse, it is well known, is one of the best horses that ever trod the turf). Most produce will be received in payment if delivered before the Ioth of December. Terms, $\$ 4$ the season, $\$ 2$ the leap, $\$ 6$ to insure a foal.

\section{Hinman Hurd, Monkton, April 21, 1803.}

Also in same paper: The thoroughbred horse, old Cincinnatus, will be let to mares, etc., at stable of Samuel Mattock, Esq. in Middlebury, Monday, Tuesday, Wednesday and Thursday, at Landlord Woodward's stable in Leicester on Friday and Saturday of each week through the season. Terms, $\$ 8$ the season, $\$ 16$ to insure. He is 16 hands, strong, elegant, etc.; got by the thoroughbred horse, 
Bay Richmond, well known to sportsmen and breeders. His dam was bred by Col. Mead of Virginia and sold to the late Gen. Baron Steuben for $\$ 1000$. She was got by Gen. Taylor's powerful horse Fearnaught, one of the best colts of Regulus, who was got by the Goldolphin Arabian: dam the celebrated old Galloway Mare. Regulus, his grandsire, won eight royal plates of 100 guineas each, and one fifty-pound purse in the course of 12 months, and was never beaten. Most kinds of grain received in payment.

Hinman Hurd, Monkton, April 21, 1803.

A certificate, appended to above and signed by Josiah Starr and others of New Milford, Conn., is to the effect that they have been for a number of years acquainted with the horse Cincinnatus, which the Messrs. Taylor have this day sold to Hinman Hurd of Monkton, Vt., that his reputation, is excellent, etc. March 25, 1803 .

I 804-President-To cover, the beautiful full-blooded horse President, ten years old, bright bay, I 5-2 hands, strong and bony. The noted horse, Figure, was the sire of President: his dam by Wildair from an imported mare of the most esteemed blood. President will commence the present season the second week of the present month at the stable of the subscriber, the next week at the stable of Azariah Painter in Vergennes; $\$ 4$ the leap, $\$ 8$ the season and $\$ 16$ to insure. Nathaniel Sherill, Middlebury, May I, I804.

President is advertised in May, $\mathbf{1 8 0 7}$, to be kept at A. Stowell's in Vergennes and Joseph Rogers' in Ferrisburgh by Amos W. Barnum of Monkton.

In the Mercury of May I6, I804, is the following-The noted and full-blooded horse Revenge will be kept at the stable of Moses Spencer of Hinesburg at $\$ 5$ the season, $\$ 3$ the single leap and to insure a foal as the parties can agree. He is a beautiful dapple gray, about $\mathrm{I} 7$ hands, justly made, and his stock recommends him sufficiently. Cattle on the Ist of October next or grain by the Ist of January next will be received in payment. Good pasture, etc.

In the same paper Driver is advertised-During the present season the noted imported horse Driver will be kept at the stable of Gamaliel Painter in Middlebury. Said horse has been in Connecticut for six years past. He will be let to mares at $\$ 8$ each. $\mathrm{He}$ is a beautiful bay, I 5-2 hands, bred by the Duke of Queensbury; got by Saltram, son of Eclipse: dam by Woodpecker, son of King Herod, who was the sire of Guido and many of the first studs and mares of England. Driver's grandam was own sister to the celebrated Highflyer. He is as high-bred a horse as any imported into 
America, beautiful in form, carriage, etc. Also will be kept at the same stable the beautiful horse, Young Driver, at the moderate price of $\$ 4$ the season; got by the above-mentioned Driver and dam a full-blooded English mare. Young Driver needs no further recommendation than to say that he is the same horse the subscriber has kept for two seasons past.

JEHIEL STORRS.

In the Middlebury Mercury of May 9, I804, John Brown of Salisbury advertises Active as follows:-The public are informed that the horse Active is now kept at the stable of the subscriber, in Salisbury, where he will be let to mares at the usual price.

The same horse is advertised again, this time at Middlebury, by the same man, in 1805 .

In the Mercury of May 27, I807, is this:-Young Active will cover, etc., at the stable of Gamaliel Painter in Middlebury at $\$ 4$ the season or $\$ 2.50$ the leap, payable in grain on the Ist of January. He was got by old Active: dam by Koulikhan, seven-eighths blooded; he is $15^{-2}$ hands and a beautiful bright bay.

\section{John Smith, Middlebury, May 20, I807.}

I 808 - Active by the noted horse Active, at Judge Painter's stable at i 8 to 24 shillings. Also at the same stable the black horse that has been kept for a considerable time by Freedom Loomis.

Elisha Bentley, Middlebury, April 25, I808.

Young Highflyer at Harvey Bell's in the village. Five years old, dark bay, above ${ }_{5} 5$ hands; got by the noted horse Highflyer, and a sure foal-getter. Terms 9 to I 5 shillings.

I 809-That fine imported horse Hamlet will be kept the ensuing season at the stable of Nathan Phelps in New Haven and at Jesse Hanford's. He is ten years old, was imported by Capt. Charles Hamlet in I802 was sold for $\$ 1000$ to Dr. Heaxt of New York. $\$ 4$ to $\$$ Io.

James B. Spencer,

Abner P. Spencer, New Haven, April 29.

"The Young Dey of Algiers, full-blooded Arabian, I 5 hands, dapple gray now nearly white, eight years old, finely proportioned, etc., like his sire, the noted Dey of Algiers, imported by Col. James Swan in the year $\mathbf{1} 800$. His dam was the gray Arab mare Cappadocia, imported at the same time with the horse. Has just arrived from Boston and is owned by Ep. Jones, and will be kept at the stable of Gamaliel Painter, Esq., at Middlebury, the ensuing season. Any one acquainted with the Ranger breed of horses, so well known in the State of Connecticut, can justly appreciate the stock from the Arabian horses. Terms, \$10 to \$I 5." 
Two years after in I 8 I I, we find this horse in the Albany ( $\mathrm{N} . \mathrm{Y}$.) Register of April 20, I8I I, as follows:

"Young Dey of Algiers.-This far-famed full-blooded Arabian horse was brought to this city yesterday and he may justly be considered the greatest acquisition to our breed of horses which the country has ever gained since the importation of the Ranger or Hartford Horse as he was called. More elegant saddle horses were bred from that horse than from any other three horses ever imported into America. As the breed of Arabian horses has for centuries past been considered superior to any other in Europe it is surprising that so few of them have found their way to the United States. Young Dey is in almost every respect very like the Ranger; he is however, stouter built, has more bone, and I should say (if possible) more nerve. I am not going to attempt a description of Young Dey; it is only my wish (having no possible interest at stake), to call the attention of breeders to this horse at Baker's stable. I have seen Young Dey and shall seek no farther for anything that can be admired in a horse. EQues."

I 810 -In the Mercury: The full-blooded, imported horse, President, at the stables of Nathan Spaulding in Panton on Thursdays, Fridays and Saturdays of each week through the season; at the subscriber's stable, in Vergennes, the remaining part of the week. President has been kept at Vergennes for the four years past. Terms, $\$ 3$ to $\$ 5$.

(Signed) Amasa Stowell, Vergennes, Vt., May I.

\section{(From Vermont Mirror.)}

I 8 I 3-"The full-blooded Arabian horse Young Dey of Algiers, will be kept the ensuing season at stable of Gamaliel Painter, Esq., Middlebury. Terms may be found posted at the stable." * * *

"Old Sweepstakes.-That noted and full-blooded horse, Old Sweepstakes, will be kept at the stable of the subscriber, half a mile west of the town house in Fairfield, the ensuing season, at the very reduced price of $\$ 5$ the season. Payment to be made in grain on the first day of January next at the place of service. Good pasture and punctual attendance by the public's humble servant,

\section{DAvid BARLow, Fairfield, May 3, I813."}

I 8 I 5-Telescope will be kept the ensuing season at the stable of Edward Washburn, in Burlington, at the tavern lately occupied by Abraham Brinsmain. Telescope is a horse of much recent celebrity, both as a racer and stallion; is a beautiful light bay color, is 
only eight years old last grass, is a remarkably sure foal getter, and taken for all in all is equal to any other horse. The public will shortly be gratified with the appearance of his stock, which, it is announced, will furnish, if possible, additional evidence of the superior excellence of this justly admired and truly celebrated horse.

\title{
HEMAN ALLEN \\ JABEZ PENNIMAN, ROGER ENos, \\ EDWARD WASHBURNE.
}

Colchester, May I, I8I 5.

\section{(From Columbian Patriot, Middlebury, I't., r814.)}

Arabian horse, Young Dey of Algiers, stable of Gamaliel Painter.

Paragon, chestnut, I 6 hands; got by the famous imported English dray horse, Matchem, well known in the State for his superior stock of colts.

\author{
JAMES SATTERLEE.
}

Telescope-An anxious desire to improve the breed of horses in this country has induced the subscribers to purchase of Mr. Soper of Boston his highly celebrated horse. Telescope was bred on Long Island and is seven years next grass, beautiful light bay, rising I 5 hands. At Sears' stable in Williston, where he will remain through the season.

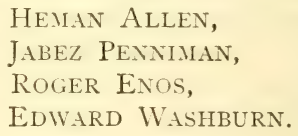

(From Anti-Masonic Republican, Middlibury, I't., April 20, I83I.)

The elegant horse Yankee Boy will be kept, etc., at I. Moody's stable, Cornwall, Mondays and Tuesdays. IVednesdays he will pass through the east part of Addison and west side of Snake Mountain. Thursdays around north end of Snake Mountain to William Sampson's in Weybridge; Fridays and Saturdays at Mr. Chipman's stable in Middlebury. Yankee Boy is seven years old, $15 \mathrm{I} / 2$ hands high, justly proportioned and of a beautiful brown color. Raised by Capt. Amos Willmarth of Addison, from his celebrated Killdeer mare, and got by the noted horse, Liberty, kept for some time in Addison by Allen Smith; $\$ 4$ the season.

\section{Henry Delano, EBENEZER SEVERANCE.}

"Middlebury, April 2, I83I.

We, the subscribers, are acquainted with the brown horse raised and formerly owned by Capt. Amos Willmarth of Addison, and know 
him to be of a good thoroughbred stock of horses, and his stock is as good as can be produced from any other horse in this section of the country.

JOHN HAMILTON, ABEl Richardson,

DAVID WRIGIIT, DAVID A. CRAM, SiLAS WRIGHT, JOSEPH HAYWARD."

(From Middlebury Free Press, May 4, I83I.)

First Consul-Fresh from Long Island. The subscriber, having taken unwearied pains to improve the breed of horses in this section of the country by procuring the most pure-blooded horses from the South that could be had, such as Sir Charles, now owned by David Hill of Shoreham, and the celebrated horse Tippo Saib, which the subscriber has been prevailed upon to be kept in Rutland County the ensuing season, would now present the services of the abovenamed horse to his former customers, as also all others who wish to improve the best blooded horse he has ever offered, and he feels warranted in saying that First Consul is of better and more approved blood upon Long Island than either Sir Charles or Tippo Saib. First Consul will be kept at Shoreham and Bridport; $\$ 7$ the season. He is five years old, good bay, I 6 hands high and having a beautiful head, neck and presence, great depth of chest, length of waist, breadth of loin, with quarters deep and well spread, forearm and thigh strong and well proportioned. First Consul was bred by Mr. Sands on Long Island and was got by the imported horse Dinwiddie. His dam was the Wildair and was got by the Flag of Truce; Flag of Truce by the imported horse First Consul. Wildair's dam by Coriander ; Coriander was from the Figure mare and got by old Messenger; so it will be seen his blood is of first quality. Said horse will be tended by Joseph J. Herriman this season.

Abraham Frost.

\section{(From the Pcople's Press, Middlebury, 1843.)}

Premium horse Eclipse which received at New York State Fair, at Albany, the greatest ever held in that State, first premium from a host of competitors, will stand at Shoreham, Bridport and Addison.

$$
\begin{aligned}
& \text { (Signed) EDWARD LONG, } \\
& \text { DAVID LONG. }
\end{aligned}
$$

(From The Northern Galaxy, Middlebury, Vt., MIay 28, 1845.)

"Notice.-The subscriber would notify all persons who wish to improve their breed of horses that he offers them the services of the 
cciv

noted horse, Morgan Tiger, whose stock is so favorably known in this county. He will pass with the Morgan Tiger through" etc., "Cornwall, Shoreham, Addison and Bridport-each week.

WM. S. LANE."

The following are from papers at Henry L. Sheldon's antiquarian rooms, Middlebury:

In April, I833, John Hurd of Bridport advertises "the celebrated horse Sir John" at Vergennes and Middlebury.

S. H. Baker, for the owners, in the same paper, advertises the Arabian horse Alexander, at Middlebury and Vergennes, at $\$ 7$ to \$IO.

April 28, I834, the horse Duroc Messenger is advertised to be kept at the stable of Elisha R. Pratt in Cornwall, at $\$ 3$ to $\$ 5$. Duroc Messenger is from the best stock in America. He was got by the old Virginia Duroc; his dam is a descendant of old Messenger, one of the best horses ever imported. He is half brother to the celebrated American Eclipse. Duroc Messenger is I 6 hands, admirably proportioned, spirited and graceful. He is thick and strong built, dark chestnut interspersed with gray hairs, and is the fastest trotter and walker in Vermont.

(Signed)

Elisha R. Pratt,

A. W. DANA.

April I0, I834, S. Smith advertises the thoroughbred Young Napoleon at Cornwall, Shoreham and Orwell; dark bay, I 5 I 2 hands, by imported Napoleon: dam a Virginia mare.

In the National Standard of April I 8, I 827, is an announcement of Cock of the Rock. To a long advertisement given before, Mr. Barnham adds: "A word to breeders-colts foaled as early as May or June ought to run with the dam until the following January and after weaning should daily and regularly be fed with wheat bran or oat meal and occasionally with carrots or potatoes, unwashed, and plenty of salt. Bone and strength can only be acquired by good keeping the first year."

In the National Standard, May 8, I827, American Eagle is advertised. "This admirable horse will be kept at Shoreham, and at Col. Smith's, Bridport, and Middlebury. Pedigree-got by the celebrated New Jersey Colt, and foaled by the full-blooded English mare, Miss Portley, Worcester County, Mass. (a beautiful dapple). New Jersey Colt was got by the noted imported horse Dorchester, and foaled by Col. Levi Howell's blood bay mare, Spread Eagle, 
a real hunter. Said horse is of a jet and bluc-black, making a beautiful dapple; I 6 hands, low boned, short back, flat limbs and remarkably well proportioned. Colts have been sold at $\$ 450$. Terms, \$8." (Signed)

Z. LulL,

A. LULL,

WilliaM LULl.

In I 827 D. Hill of Shoreham advertises the thoroughbred horse Sir Charles.

Under date of Middlebury, May I8, I827, Joshua Ballard advertises Bergami, by Cock of the Rock, from full-blooded Morgan mare raised by $\mathrm{J}$. Howard, Burlington, to be kept at the stable of Asa Chapman. Bergami is described as five years old, of beautiful dark bay color and admirably proportioned.

This also appears:

The dapple-gray horse Wild Arab. This horse will stand for mares at stable of subscriber Mondays, at the stable of Asa Chapman Tuesdays, and at stable of Darius Tupper Wednesdays, and at the moderate price of $\$ 5$. The subscriber feels confident that this horse needs no recommendation from his former run of business where he has been known, and those who now own his stock he is confident will still give him their custom. HARVEY YALE.

Middlebury, May 2I, I 827.

This advertisement is nearly 60 years old, but Mr. Yale may still often be seen upon our streets.

Sir Charles appears again in I828: "Seven years old this spring, a bright bay, I5-3, well proportioned; has a remarkable share of bone and sinew; his colts are large and promising."

Signed, D. Hill, Shoreham.

In May, I828, Harvey Yale advertises the noted horse Wild Arab at Bristol, Starksboro and Middlebury. "Wild Arab is six years old. His grandsire was the old Arabian horse Dey of Algiers, and his stock indisputably good."

Harry Moore and Chas. Eager, under date of Shoreham, April 27, I829, advertised: "The full-bred English horse Virginian at Shoreham and Col. Smith's, Bridport, at $\$ 5$. This horse was raised in Madison County, Virginia; got by the noted horse Republican: dam by imported Bedford. Republican by Sir Lumber, by imported Bedford: dam by Mack by imported Shark."

Abram Frost of Shoreham, under date of April 24, I 829, advertises Young Tippoo Saib at Cornwall and Shoreham, at $\$ 5$. "Five years old this spring, of a beautiful bay with black legs, mane and 
tail, I6 hands, with great bone and muscle; by Young Duroc, son of Duroc; Young Duroc's dam, Merry Momus by old Figure; Figure by True Briton, and Young Tippoo Saib's dam by old Mambrino; 2d dam, by Volunteer; 3d dam by old Tippoo Saib."

In 1829 it is announced that Sir Charles, brother to American Eclipse, is " eight this spring."

In May, I829, Wild Arab is advertised at Middlebury, New Haven, East Mills and Bristol.

Byron Murray and George Murray the same year advertise Sir John at Bridport, Middlebury, Addison and Chimney Point, six years old: by Cock of the Rock: dam Gov. Van Ness' favorite Porter mare.

Young Tippoo Saib and Sir Charles appear again in I830, and Sir Charles in 1835 .

\section{EARLY ADDISON COUNTY HORSES.}

The very excellent history of Mambrino that appeared in a recent issue of the Register was written for the New York Sportsman by W. H. Merritt, now manager of the New York department of the Boston Horse Breeder, who writes under the name of Vision. We understand Mr. Merritt to be a very careful and generally accurate writer. We think, however, he is misinformed in some particulars. The statement concerning Harris' Hamiltonian that "in a region where nothing except Morgans were then appreciated, he was perpetuated only through 'his daughters," is incorrect in this, that in that region there were then practically no Morgans, and Harris Hamiltonian, if he can be said to have been perpetuated at all, owes his posthumous fame almost exclusively to a line of mares falsely represented to have been his daughters, and so recorded by John $\mathrm{H}$. Wallace.

The records, as well as the memory of all more elderly people in this region, show that when Black Hawk came to Bridport, in the fall of 1844 , fifteen years later than the Harris Horse, there was only the lightest sprinkling of Morgans in Addison County, where this horse was kept. We recall only Fox and Gifford Morgan, the latter only two or three seasons, as Morgan sires in Addison County west of the mountain, before that time. The leading sires in this county prior to that time had been the Diomed stallions, Hill's Sir Charles, by Duroc; Barnum's Cock of the Rock, by the 
same sire, and Doolittle's Post Boy by Dinwiddie, another son of imported Diomed; the English blood of Doolittle's King William and his supposed son, Smith's Liberty; Enterprise by imported Figure, a number of sires from the line of imported Wildair and Barney Henry by Signal; the Spanish blood of Yale's Alexander; an excellent strain of Arabian from Young Dey of Algiers; the racing blood of Telescope, and the Messenger strain through the Freeman Horse, third in the line of descent from Messenger.

The blending of these excellent strains formed a line of horses so full of merit as to be very hard to displace. Bishop's Hamiltonian, no doubt an excellent son of Messenger, came to Granville, N. Y., in I8I9, with quite a flourish of trumpets, and his fame spread rapidly. Breeders in this county were prepossessed in his favor and were anxious to try his stock, and several of his sons did service here. Allen Smith and Asa Hemenway of Bridport each had one, and Harris' Hamiltonian was here during half of his active life; yet none of these horses made any distinct and lasting impression on the stock of Addison County. They were not superior to the then existing stock, or, if they were so, their superiority was not generally recognized. A horse really superior to all others in his region, whose superiority is known to the public, carries all before him with astonishing quickness. The eleven years service of Black Hawk in Addison County changed the complexion of her horses as if it had been raining ink upon her pastures.

Harris' Hamiltonian, who died two years after Black Hawk came to Bridport, was a good horse, probably the best son of the Bishop Horse that came into this region, but he was by no means the sire that some modern writers would make him. He is credited by Wallace with four 2:30 performers, one of which, Hero, he did not get, and Lady Shannon very doubtful; also with the dams of six $2: 30$ trotters, five of which he certainly did not get, and the other doubtful; also with the dam of the Morse Horse, got by Alexander's Norman, likewise an error; also with Gray Rose, dam of Cuyler and Stillson, which is not true; also with the dam of Young Columbus, like the rest, false. In fact, as we have before shown, of fifteen distinguished animals registered by Wallace as the get of Harris' Hamiltonian ten are certainly spurious, three are doubtful, and only two are ascertained to be genuine. We have already published proof of these statements, but for the accrediting of these animals to this horse no evidence has been given to the public. The fame of Harris' Hamiltonian, such as it is, has no true and ascertained 
foundation save Green Mountain Maid, 2:281/2, Sontag, 2:3 I to wagon, and Paris Hamiltonian, sire of one $2: 30$ trotter.-Middlebury Register, March 27, I89I.

\section{THE JUSTIN MORGAN HORSE.}

In I 887 we visited the town of Danville, Vt., and came to the house and barn where Mr. David Goss lived, who in I804 obtained at Randolph the original Morgan horse and brought him to Danville, where he was kept most of the time until I 8 I I.

A grandson of the David Goss, who lived here in I804-I I, said:

"I have often heard grandfather talk about the old Morgan horse. The horse was kept here in this barn. The house and barn are just the same as when he was brought here." *

It was a two-story house, but of ancient pattern, upon a side hill, the barn across the road; in the immediate vicinity, quite a few Vermont hills are in sight, interspersed with fields green and fresh with the advancing summer. It was a pleasant and home-like spot; and below, through the valley, there was a small stream winding, and a saw mill. The house and barn were built in I 794. The Morgan horse certainly did his part faithfully and well. He shirked no duty whilst he lived, and had no rival. No horse that came in contact with him could equal him whether in pulling, trotting, running or walking. And there was none that was more perfectly formed, or more entirely kind. And there sprung from his loins a family that have pervaded not only valley and hillside of his native State, but, remaining still the favorite horse of New England and Canada, they have also extended into every State and to many climes. And when, in addition to this, it is considered that in nearly every fastest record bearer of trotting or pacing, his blood is coursing in direct line by sire or dam or both, we can perceive how pure and strong must have been its current.

The Morgan Horse was bred by Justin Morgan at West Springfield, Mass., and was foaled in 1789 , possibly late in the season of I 788. Mr. Morgan moved to Randolph, Vt., in the summer of I 788. He made a trip back to West Springfield, on horseback, probably in the latter part of May, I792, when the colt was three years old. During his absence in Vermont the colt was foaled and had been taken to West Hartford, Conn., where, it seems, he was

* A fine picture of this old homestead will be found in Vol. I. of The Morgan Horse and Register, page 108, and in Vol. I., page cxxxvi, of this work. 
named Figure, and we think almost certainly is the animal mentioned in an advertisement in the Hartford (Conn.) Courant, running weckly from May 7 to May 21, I 792, as follows:

"Figure, a beautiful bay horse, I5 hands high, will cover this season at the stable of the subscriber, at twenty shillings the season or two dollars the single leap.

Samuel Whitman, Hartford (West Division) May 5."

As this advertisement is discontinued May $2 \mathrm{I}$, and as Mr. Morgan's grand list for 1792 at Randolph, Vt., tends to show that he had the colt there as early as June 20 , this evidence and other circumstances point to this period as the time when Justin Morgan brought the colt, Figure, later universally known as the Justin Morgan, from Hartford, Conn., to Randolph, Vt.

In the Vermont Journal, published at Windsor, Vt., appeared in $\mathbf{I} 793$ this advertisement:

"Will cover this season at Captain Elias Bissell's stable in Randolph and at Captain Josiah Cleveland's stable in Lebanon, the famous Figure horse from Hartford, Conn., at fifteen shillings for the season, if paid down, or eighteen shillings if paid in the fall, in cash or grain at cash prices. Said horse's beauty, strength and activity, the subscriber flatters himself, the curious will be best satisfied to come and see. Said horse will be in Lebanon the second Monday in May next, there to continue two weeks and then return to Randolph, so to continue at said Cleveland's and Bissell's, two weeks at each place through the season.

Justin Morgan, Randolph, April 8, 1793."

And in 1794 , the following:

"The beautiful horse, Figure, will cover this season at the moderate price of one dollar the single leap, two dollars the season, if paid down, or by the first of September next; if not paid then it will be sixteen shillings. Said horse will be kept at the stable of Ezra Edgerton in Randolph, and Lieut. Durkee or E. Stephen's in Royalton. He will be kept at Randolph till the second Monday of May, when he will be taken to Royalton, there to be kept every Monday, Tuesday and Wednesday; then return to Randolph, where he will continue Thursday, Friday and Saturday, and so alternately during the season. Constant attention will be paid at each of the above places.

Justin Morgan, Randolph, April 21, 1794.

In The Rutland (Vt.) Herald of May, I795, is the last and most complete advertisement of the horse by Mr. Morgan as follows: 
"Figure will cover this season at stable of Samuel Allen in Williston, and at a stable in Hinesburgh, formerly owned by Mr. Munson. $\mathrm{He}$ will be kept at Williston till the eighteenth of May; then to Hinesburgh, where he will be kept one week; then back to Williston, to continue through the season, one week in each place. With regard to said horse's beauty, strength and activity, the subscriber flatters himself that the curious will be best satisfied to come and see.

"Figure sprang from a curious horse owned by Col. De Lancy of New York, but the greatest recommend I can give him is, he is exceedingly sure, and gets curious colts.

\section{Justin Morgan, Williston, April 30, I795."}

Williston adjoins South Burlington, and Hinesburgh touches Williston on the south.

From this horse it is that the extended reputation of Vermont for its fine horses has principally been derived, the qualities in which they excel being beauty of form, superior road speed, and remarkable endurance. 


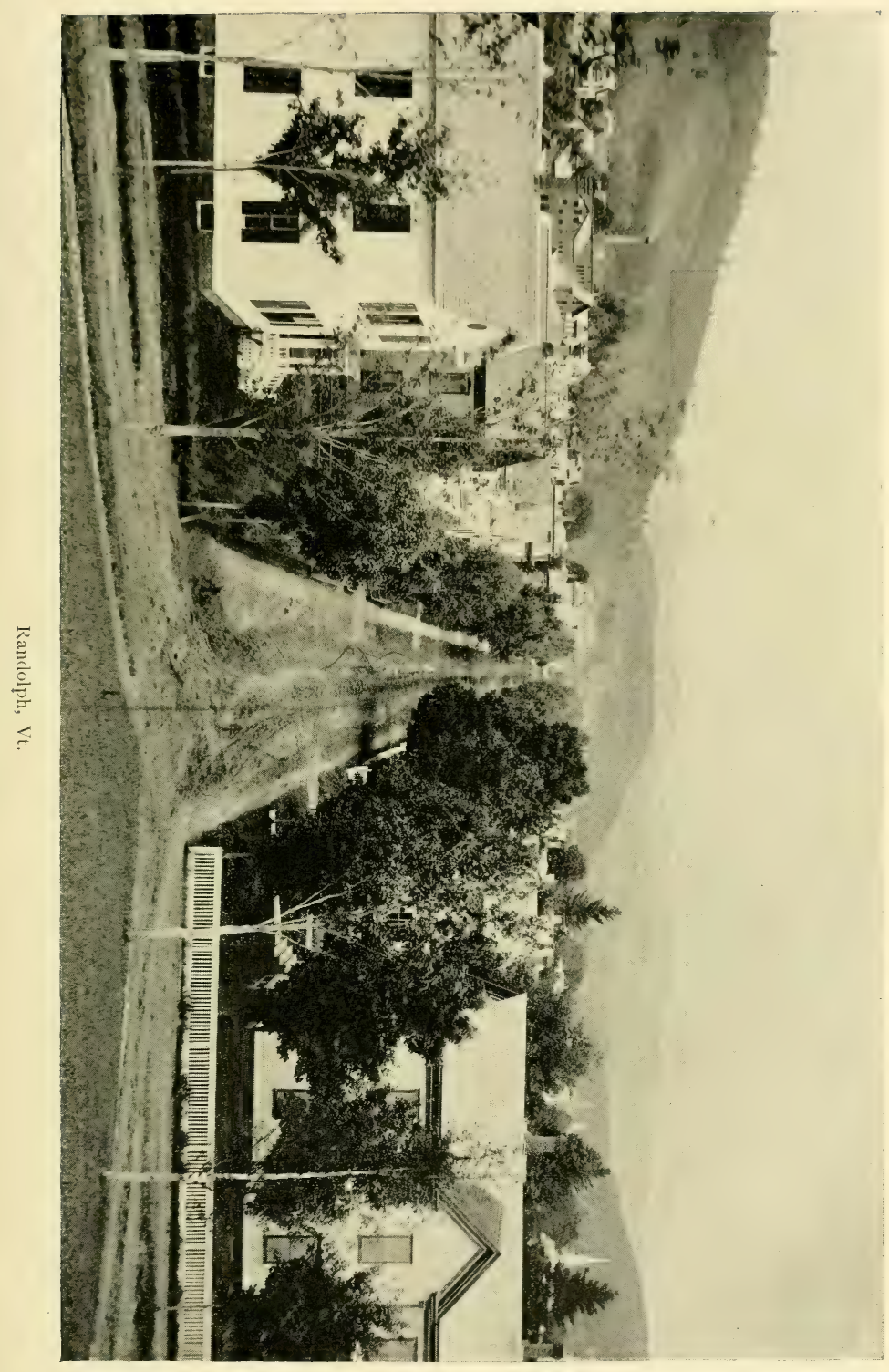



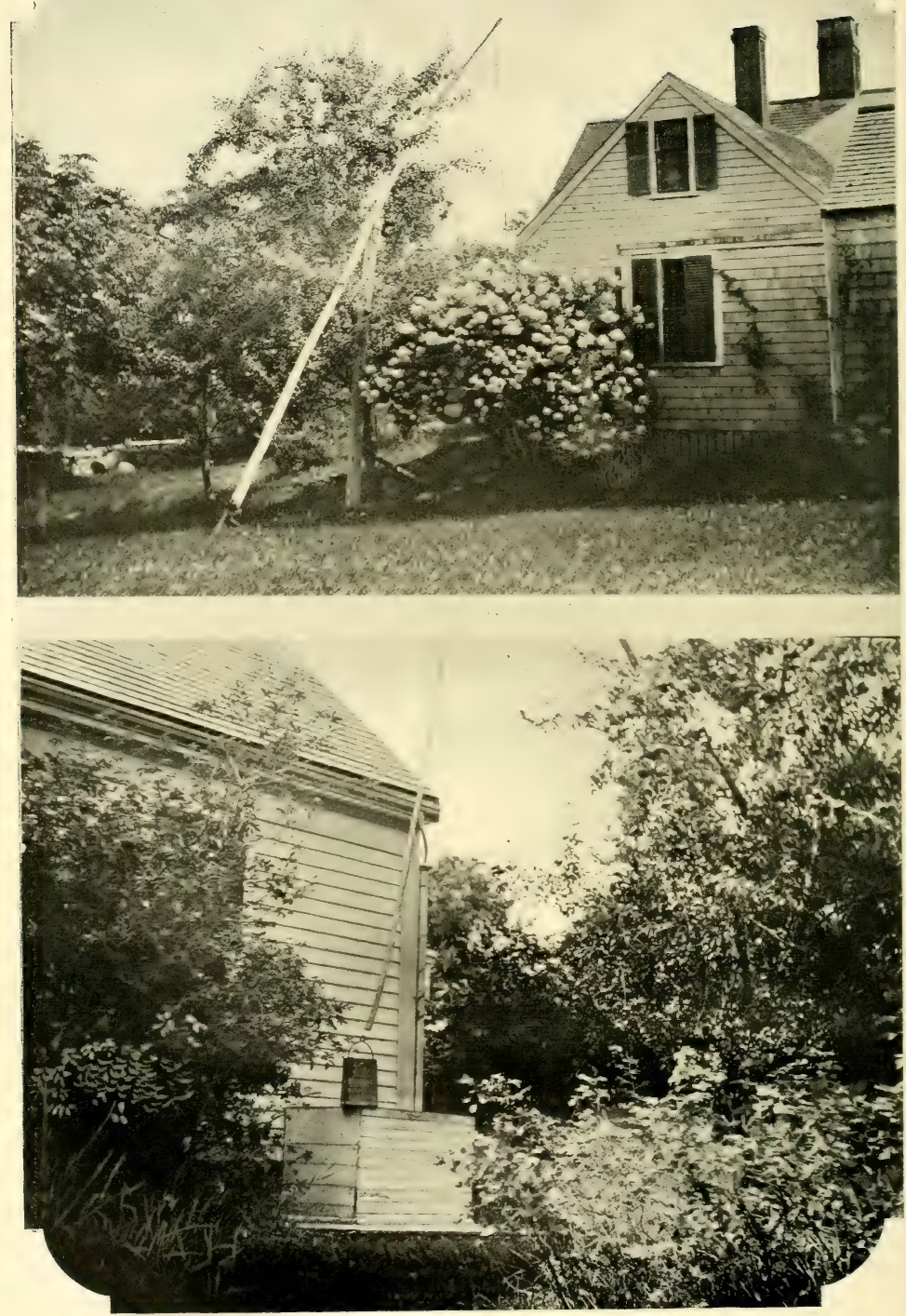

Old Oaken Bucket, Scituate, Mass. 


\section{A S A C H USETTS.}

"Home of my heart! to me more fair

Than gay Versailles or Windsor's halis, The painted, shingly town-house where

The freeman's vote for Freedom falls !

The simple roof where prayer is made,

Than Gothic groin and colonnade;

The living temple of the heart of man,

Than Rome's sky-rocking vault, or many-spired Milan!"

\section{- Whittier.}

$\mathrm{T}$ HE Pilgrim settlement at Plymouth in December, I620, was, as is well known, the first New England settlement. This was followed by the settlement of Salem, then called Naumkeag, in I626. Boston was first settled in I630. The Plymouth colony seems to have been either indifferent to horses, or unfortunate in getting them, as it appears in the History of Plymouth, by James Thrasher, Boston (page I IO) that the first notice of horses on record is in I644, twentythree years after the landing of the Pilgrims, when a mare belonging to the estate of Stephen Hopkins was appraised at six pounds. In I647 a colt in the inventory of the estate of Thomas Bliss was appraised at four pounds, and the same year a mare and year old colt in the inventory of Joseph Holloway's estate were valued at $£$ I 4 .

It does not appear just when the first horses were introduced into the Plymouth colony, nor whence they came. There were none in 1624, as we learn from a History of New England by Jeremiah Morse, D.D. (Charlestown, Mass., I 820) :- “In March, I624, Mr. Winslow, who had been sent to England for the purpose, arrived with clothes and brought a bull and three heifers, which were the first neat cattle imported into New England. . . . . At the close of this year the Plymouth colony consisted of 180 persons who lived in thirty-two dwelling houses. Their stock consisted of the cattle brought over by Mr. Winslow, a few goats and a plenty of swine and poultry."

Charles W. Elliott, in his History of New England, Vol. I., page 86, makes a like statement, saying:- "Edward Winslow who had 
been sent to England upon business with the company, returned in March, I624, bringing with him an important accession to the Pilgrims-three heifers and one bull, the first neat cattle that came into New England. In the year I627 division was made of the cattle (which had increased) into 12 lots, one lot to each party of thirteen. . . . . The first notice of horses occurs in 1644 , when one belonging to the estate of Stephen Hopkins was appraised at six pounds sterling."

Page 43, quoting from Young's Chronicles of the Pilgrims, page 260, says:

"There were 40 cows, as many goats, a horse and six or seven mares, that came over in 1629 to the Massachusetts Colony."

Economic and Social History of New England, Werden, Vol. II., page 523, says:

"Colchester, Conn., sold a black stallion three years old because his height fell below legal requirement."

Page 554-"Six vessels carrying horses, left New London together for West Indies June 16 , I724. I 716 , left Hutton, took forty-five horses to Barbadoes."

Newport, R. I., was active in this trade. It was contended in I 74I, that the trade between New England and Barbadoes or West Indies, amounted to $\$ 500,000$; equal to that with England.

Mr. Arthur Cresfield, Washington, says all pacers in his day in Maryland were generally called of Canadian stock, also horses when chunked built.

Tom Brown, I4 $1 / 2$, very well made, black tipped with silver.

See "Skinner's Essay on the Horse." Youatt, page 20, etc., -it is stated, page 32 , that Bulrock was imported to Virginia in I730.

Page 690 of Werden. "Horses were grown and exported. Bennett noted among the poor kind and common draught horses in Boston that there were good ones for carriage and saddle. Sir Peter Warren sent through Sir William Pepperell to Massachusetts in 1750 , two horses to mend the breed. A committee received and assigned them. Common price at this time in Hampshire County was $£ 7$ to $£ 32$ a few brought $£ 40$. Parson Williams of Hadley owned the best of his region, value, I 754, $£ 663 / 4$.

Page 757-"The West India commerce went in single deck vessels; horses and oxen were tethered on deck. 
Page 828-“Small sloops carricd a surprising number of cattle of all kinds from South shore of New England to West Indies and to the Northern coast of the farther America. One brig took 49 horses but many sloops took 35 in a single cargo. Vesscls in the trade arranged two voyages a year."

Loudon's Encyclopædia of Agriculture, published by John Claudius Loudon, a distinguished writer, born in Lancashire, Eng., I 873 , is a book worth purchasing. The 5 th edition is advertised by Green \& Longman, Paternoster Row. See articles on the horse, and articles 6218 to 6228 inclusive, also page 950. A valuable work.

From History of Ipswich, Mass., by Felt, page 3I, (I 834 ):

"At the first settlement of Ipswich, as horses run scarce, walking on foot was common with all classes, when such animals became plenty the farmers would ride one of them fitted out with a saddle and a pillion. Females also rode singly on side saddles much more commonly than in modern times. About I770 it began to be the practice to trot horses. Previously these animals had paced. It had been common to pay individuals to learn them to go in this manner. The way in which a horse was learned to pace was by fastening his two right and two left feet with leather straps so that the two former might step together, and then the two latter. The first chaise here a sort of chaise body without a top owned in Ipswich was in I730. One of the first chaises, I753. There were a few sleighs in I740."

The Complete Farmer by T. G. Fessenden, editor of The New England Farmer, Boston, I839, Vol. III., page 2.30, says: "A horse's manner of going is a matter of no small importance. The ambling gait or what in this country is vulgarly called pacing is not good either for the horse or the rider. It is tiresome to both.

"The method so much practiced formerly in this country of teaching horses to pace swiftly, and racing in that gait, is highly pernicious. It puts them to a much greater strain than running, and numbers have been ruined. Some colts naturally amble and others trot. But all may be made to trot if care and pains be taken with them when they are young. In a carriage an amble appears highly improper and is disgusting to every one. And I do not see why it is more tolerable in the saddle." 
cexiv

Many have deemed wholly fanciful the quaint picture drawn by Longfellow, the sweet singer of New England, of the wedding journey of the Puritan John Alden:

"Then from a stall near at hand, amid exclamations of wonder, Alden, the thoughtful, the careful, so happy, so proud of Priscilla, Brought out his snow-white bull, obeying the hand of its master, Led by a cord that was tied to an iron ring in its nostrils, Covered with a crimson cloth, and a cushion placed for a saddle. She should not walk, he said, through the dust and heat of the noon-day; Nay, she should ride like a queen, not plod along like a peasant. Somewhat alarmed at first, but reassured by the others, Placing her hand on the cushion, her foot in the hand of her husband, Gayly, with joyous laugh, Priscilla mounted her palfrey."

But here is the story in cold prose, in Elliott's History, following the above quotation.

"It was a country for cattle rather than horses, and it seems to have been a not uncommon thing to ride on bulls. When John Alden went to Cape Cod to marry Priscilla Mullins, he covered his bull with broad cloth and rode on his back. When he returned he placed his wife there and led the bull home by a ring in his nose."

The Plymouth settlement was often referred to as The Old Colony, while the settlement on Massachusetts Bay, forty to fifty miles north, including Boston, Lynn and Salem, was called the Massachusetts, or Massachusetts Bay Colony. It is stated in "The Planter's Plea," published in London in 1630 , that the first settlers of the Massachusetts Bay Colony came with John Endicott from Dorchester, England, in I628, sent out by parties in Lincolnshire and London.

It was to the Massachusetts Bay Colony that the first consignment of horses that reached New England, came. We quote further from The Planter's Plea:- "In I629 about three hundred persons were sent from England to the Massachusetts Colony, together with sixty or seventy cattle, and some mares and horses, of which the kine came safe for the most part; but the greater part of the horses died, so that there remained not over thirteen or fourteen alive." These are the first horses of which there is any record, that ever came to New England.

William Douglass, author of the very excellent work, British Settlements in North America (Boston, 1755), confirms, in that work, the above statement, saying, "In I629 the company sent over 
350 people, I I 5 neat cattle, some horses, sheep and goats (most of the stock died on the passage). They landed at Naumkeag, now Salem, June 24, I629."

Governor Thomas Dudley's letter of March 28, I63I, to the Countess of Lincoln, gives like information of the arrival of animals in I629, and says:- "I should also have remembered how the half of our cows and almost all the mares and goats, sent us out of England, died at sea in their passage hither, and that those intended to be sent us out of Ireland were not sent at all." And Elliott says, (Hist. New Eng. p. 260) quoting from Young's Chronicles of the Pilgrims :- "There were forty cows, as many goats, a horse and six or seven mares, that came over in I629 to the Massachusetts Colony."

From the History of the British Dominion in North America (London, I 773) it appears that the ships which in I 629 brought the first horses to Massachusetts Bay, sailed from the Isle of Wight on the I Ith of May. As the Isle of Wight is just off the southern coast of Hampshire in the English Channel, it seems probable that these pioneers of the equine family in New England sprung from the south of England. Nothing further has been discovered, by an exhaustive search, concerning their origin, nor have any descriptions of these animals been preserved.

It would seem that another consignment of animals, including horses was made to the Massachusetts colony in I629. A letter from the Governor and Deputy of the New England Company for a Plantation in Massachusetts Bay, dated Gravesend, April I 7, I629 (Hazzard's Historical Collections, Philadelphia, I 792), contains the following:

"Such cattle, both horses, mares, cows, bulls and goats, as are shipped by Mr. Craddock, are to be divided into equal halves twixt him and the company."

This work also contains a copy of the record of the "Division of the cattle at New Plymonth" viz. "At a public Court held May 22, 1637 , that the cattle which were the company's, to wit, the cows and the goats should be equally divided, \&c." It does not appear that there were any horses then at Plymouth.

Among the abundance of Historical material preserved in Force's Historical Tracts, there is a work by Rev. Francis Higginson, entitled New England Plantations, and dated in 1630 ; in which he says :- "The fertility of the soil is to be admired at, as appeareth in the abundance of Grape that grows everywhere. . . . . It is scarce to be believed how our Kine and Goats, Horses and Hogs do 
thrive and prosper here, and like well of the Country. . . Here wants as yet the good Company of Heros and Christians to bring with them Horses, Cows and Sheep, to make use of this fruitful land."

A History of New England, from 1628 to 1652 , by Capt. Edward Johnson, (London, I654) says (page 4I):-“Their corn land in tillage in the town is about 1200 acres; their great cattle are about 490 head; sheep, near upon 400 . As for their horses, you shall hear from them, God willing, when we come to speak of their military discipline." We are sorry to say that the writer did not reach this latter subject. He was speaking of Charlestown, Mass., in I631. He did, however, say of Lynn, the same year:- "The people have built many farms remote, their cattle exceedingly multiplied. Goats which were in great esteem at their first coming are now almost quite banished, and now horse, cow and sheep are more in request with them."

The Commissioners for Massachusetts Bay forbade the sale of horses to Indians in $\mathrm{I}_{5} 6$ 6. "And that no horse or mare, young or old be sold to any Indian under the penalty of five for one." (Haz. His. Col.)

John Josselyn, Gent., in his Two Voyages to New England (first in 1638 and second in 1663), published in 1674, describes the different towns of New England, speaks of their cattle and sheep but not of horses, and says that at Charlestown, Mass., "I 200 acres of land belongs to the town, 400 head of cattle and as many sheep." He further tells us (page I72) "July I2, I630, John Winthrop and his assistants arrived with the papers for the Massachusetts Colony. The passage of the people that came along with him in ten vessels came to 95,000 pounds. The Swine, goats, sheep, cattle and horses cost to transport I2,000 pounds, besides the price they cost them."

Werden states that the freight of a horse from England in 1630 was ten pounds.

Josselyn also mentions the first importation of neat cattle into New Plymouth, in I624, and adds- "these thrive and increase exceedingly, but grow less of body than those they bred of, yearly." Speaking evidently of the time of his last voyage (I663) he says:" $\mathrm{H}$ ( rses there are numerous, and here and there a good one; they let them run all the year abroad, and in the winter seldom provide any fodder, for them (except it be Magistrate's, great Master's and Trooper's horses) which brings them very low in flesh till the spring, and so crest-fallen that the crests never rise again." 
The History of the British Dominion in North America, speaking of Massachusetts Bay (page 90) says that in I631 cattle were extremely dear, a great part of what were shipped from England being dead, and that a milch cow was worth from 25 to 30 pounds sterling. These large prices for cattle kept up until 1640 , when, the emigration from England suddenly dropping off because the Puritans were no longer persecuted, the price fell suddenly from 25 to 5 pounds. It was computed at this time that there were 12,000 cattle and 3,000 sheep in the Massachusetts Bay Colony.

In I642 Thomas Lechford published a book called "Plain Dealing, or News from New England," the introduction to which was dated at Clement's Inne, London, Jan. 17, 1641. Mr. Lechford introduces his work in the following quaint language:- "Having been forth of my Native Country almost for the Space of foure Yeeres last past, and now through the Goodness of Almighty God, returned; manie of my Friends desiring to knowe of me the Manner of Governments and state of things in the place from whence I came, New England; I thinke goode to declare my Knowledge in such things as briefly as I may."

On page IOI he says:- "The land is reasonably fruitful, as I think; they have cattle and goats and swine good store, and some horses, store of fish and fowl, venison and corn, both English and Indian."

This is the first direct report of the horses after their arrival in 1629. It does not suggest that they had become very plenty.

John Winthrop, first governor of the colony of Massachusetts, was born in Groton in the county of Suffolk, England, January I2, $\mathbf{I} 588$ and was bred to the law. In 1629 he was elected by the governor and company of Massachusetts Bay to govern their colony. He sold his estate, and sailed from Yarmouth on the 7 th of April, I630, with ten ships, ladened with nine hundred persons and some live stock, a part of which consisted of horses, as appears from the above quotation of Josselyn, as well as from the statement of Gov. Winthrop himself, given below; but the number and description of the horses is nowhere given. John Winthrop continued to be governor of the colony, save in the interval from I 634 to I 637 when he was deputy governor to Sir Harry Vane, and one other short interval, from his first appointment up to his death, in March, I649. He kept a journal of all this period (I630 to I649) two books of which were published in 1790 , and the third, found in the New England Library kept in the tower of the Old South Church in Boston, in 
1816. A revised edition in two volumes was published in Boston in I $825-6$.

Another edition was published in Boston in I853, entitled, "History of New England, I630 to I649, by John Winthrop." From the journal, as given in this edition, the following extracts are taken:

Thursday July I, I630.

"The Mayflower and the Whale arrived safe in Charleston harbor. Their passengers were all in health, but most of their cattle dead (whereof a mare and horse of mine) some stallions came in good plight."

"They sailed from the Cowes near Isle of Wight, March 30."

$$
\text { July 29, I630. }
$$

"The Handmaid arrived at Plymouth having been I 2 weeks at sea and spent all her masts, and of 28 corvs she lost ten."

\section{May 26, 1632.}

"The Whale arrived with about 50 passengers all in health, and of 70 ccws, lost but two. She came from Hampton, April 8."

June 5,1632 .

"The Charles of Barnstable arrived with near So cows and 6 mares and about 20 passengers."

June 12,1632 .

"The James arrived, eight weeks from London, she brought 6 I heifers and lost 40, and brought 12 passengers."

June 15,1633 .

"Mr. Graves in ship Elizabeth arrived from Yarmouth with 95 passengers, 34 Dutch sheep and two mares."

"Arrival of ship Bird with four mares."

Sept. 4, 1633.

Sept. I0, I633.

"Arrival of ship James at Salem from Gravesend, England, bringing some 60 cattle. besides passengers."

Sept. I I, I633.

"The wolves continued to do much hurt among our cattle; and this month by Mr. Grant there came over four Irish grayhounds, sent to the Governor."

Page I 38 speaks of cows selling at $20,24 \& 26$ pounds and a mare at $£ 35$. "And yet many cattle were every year brought out of England and some from Virginia."

I634- "Divers of the ships lost many cattle: but the two which came from Ipswich of more than 20 lost but seven."

I635-“"Here arrived two Dutch ships who brought 27 Flanders 
mares at $£ 34$ a mare, and 3 horses; 63 heifers at $£ 12$ thc beast and 88 sheep at 50 shillings the sheep.

"They came from the Tessell in five weeks three days and lost not one beast or sheep.

"Here arrived also the same day the James with cattle and passengers, which came all safe from Southampton in same time.

"The Lords day there came in seven other ships and one to Salem and four more to the mouth of the bay, with store of passengers and cattle. They came all within six weeks."

Oct. I 5, I635.

"About 60 men, women and children went by land toward Connecticut with their cows, horses and swine and after a tedious and difficult journey arrived there safe."

\section{(From Boston Weckly News Letter.)}

I633-59-Laws are found to impound horses or mares and cattle, breaking into enclosures.

I636-44- "That it shall be lawful for the goverment's assistant to press horses for the country's service paying the owners for them or taking orders for their payment."

In I 647, in Massachusetts Bay Colony, a law was passed to forbid taking other men's horses to ride and in I64.9 forbids the exportation of mares, and in order that this may be enforced provides that the commander of any ship or bark shall not take on board any horse or gelding that is not registered by Edward Bendall of Boston, or the clerk of the writs of other towns, with color, marks, and name of person of whom the horse was bought. Registration fee six pence.

I656-Vol. II., page 349-The Commissioner for Massachusetts Bay forbids sale of horses to Indians. "And that noe horse and mare, younge or old, bee sould to any Indian under penalties."

I657-The Court recommended to the different towns that any one keeping three mares should keep a horse for military service and that those doing so should be freed from military service.

In 1658 it is enacted: "that every town in this government shall have some public brand mark for their horses and also some fit person to take notice of men's public marks for horses, and register them in a book with their day and year, which may be the Town Clerk, and the said person to have four pence a piece for any horse he registers."

That all persons resident in any township who have horses 
growing there, give in to said person from time to time their several marks with their age, so that they may record them.

I659-Towns fined $£_{5}$ if they neglect to procure a brand mark.

Owners fined 5 shillings for neglect.

The marks for horses for distinction of the towns is then given for Plymouth a P. on the near Buttock, for Taunton a $\mathrm{T}$. on the near shoulder, etc.

In I66I law passed to protect from horses from Rhode Island straying into this colony.

In I670 law passed that none shall allow a stallion over two years old to go at large unless I 3 hands high.

"I 728-Lately arrived from Barbadoes a parcel of fine likely negroes. To be sold by T. Richards, two boys, three girls, three women and four men. At the house of N. Jarvis at the North End, Boston."

I 732-To be sold a large bay horse of lofty carriage and a good pacer, at Boston,

Old white horse advertised I732. A great many negroes advertised probably thousands, that had run away or were to be sold.

1753-Strayed large bay horse that can both pace and trot; has been used in a chaise.

I 765 -Wanted two or three saddle horses about i 5 hands.

STRAYED-black mare, small, natural pacer, trots but little.

From Plymouth Colony Records by David Pulsifer, Vol. II., page 236 , we find the following law of 1674 :

"It is enacted by the Court that whatever person shall run a race with a horse kind in any street or common road shall forfeit 5 shillings in money forthwith to be levied by the Constable or sit in the stockes I hour if it be not paid."

From Essays upon Field Husbandry, by Jared Eliott, M.A., Boston, I 760 , we quote page 2.

"We have also increased in our stocks of cattle and improved our Breeds of Horses.

"For some time after the country was settled they had no cattle at all, when some were brought over, what with the bad hay they provided, it being cut upon Bog Meadows, the multitude of wolves and other beasts of prey, for sundry years they were kept so low, and had so few cattle that the common price for a grown Bullock was $£ 20$ sterling equal to $£ 200$ old Tenor.

"I remember when I was a boy I heard a very ancient woman 
of good credit say that she had seen 20 hard pieces paid down for a 2 -year-old heifer, which is now equal to £250 old Tenor."

Same book, page 48-"The historian of those times informs us that bringing over Live Stock, Horses, Neat Cattle, Sheep and Goats to New England cost 20,000 pounds.

The breed of horses in New England, at least as far as related to Massachusetts appears prior to $\mathbf{I} 688$ to have deteriorated; for in that year a stringent law was passed for the purpose of correcting the evil, and in Connecticut as well as Rhode Island much care was given to the raising of good stock.

Palfrey's History of New England, Vol. III., page 54, in note. In estimate of cost in stocking a farm, page 58 , he gives

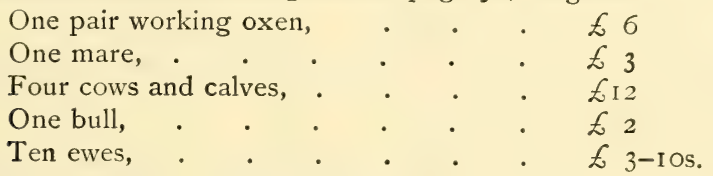

"The above mentioned prices are for goods at first cost in England which in country money be something above one-third higher, viz. : a cow and calf valued in goods at first cost at $£ 3$, is worth in country money $£_{5}$."

From Force's Historical Tracts, "A Brief Relation of the State of New England.” by Increase Mather, I689 says: “The Caribbean Islands have their horses from New England."

From Hildreth's History of the United States we learn that in I634 "Six great ships arrived at the Massachusetts Bay Colony with store of passengers and cattle."

From Trade of Northern Colonies, Philadelphia, I 764, we quote:

"The Colonies of New England export lumber, horses, pork and beef. Of these commodities as much is sold to the English West Indies as they will purchase, the remainder to the French and Dutch for molasses; this molasses is brought into the Colonies and there distilled into rum which is sent to the coast of Africa and there sold for gold, ivory and slaves, the last of which are carried to the English West Indies and sold for money or bills of exchange."

From another similar work published I 748, at London, "The State of Trade in the Northern Colonies," it is stated, page 35 :

"The West Indies Islands are furnished from New England with horses and several kinds of live stock, flour, bread, peas, salted beef, pork, fish, cider and timber."

Same work page 37 , it says: "It will be of great consequence 
to citizens of Nova Scotia that in claims of their land they can produce timber which can be carried to market by vessels that will supply them with horses, cattle, swine and other necessaries to stock their improved lands."

From "Observations on the Culture and Commerce of the British Colonies in America, by an old and experienced trader. London, I769," page 6I :

"Commodities exported from New" England, valued at an average of three years, amounting in all to 370,500 pounds, largely of fish and oil but including of horses and live stock of 12 ,000 pounds. Page 67: giving the same statistics from Connecticut, Rhode Island and New Hampshire in addition, although it states they may be considered a part of New England, there are added for horses and live stock $£ 25$,000."

History of America by C. H. Arnold, I 782, page 53: "European cattle in general multiply in New England, and the horses though small are sound and serviceable."

From "Some Information Respecting America, collected by Thomas Cooper, Dublin, I 794,” page I 2 I :

"In New England as the inhabitants of that part of America trade much with the West Indies for stock cattle and horses, they bring back among other articles a great quantity of molasses, hence the spirit drank in common there is New England rum."

Warden's North America, Vol. I. (Edinburgh I8I9), page 33I, says of the horses of Massachusetts:

"There were originally three distinct races, which by crossing the breed have lost much of their original form and qualities. The Narragansett breed, supposed to be of English origin, is nearly extinct. The others are the English Courser, and the Norman horse, of which the qualities are much deteriorated. The horses of Massachusetts being little employed in works of agriculture, have been neglected, and are inferior to those of Virginia and Pennsylvania."

Public carriages, page 343 :

"The mail stage-coach, common to all the States, is a light carriage drawn by two or four horses, and fitted for the accomodation of nine passengers, whose trunks or luggage are placed behind, by means of a leather strap or fixed upon the seats. The driver is not separated from the passengers, to which no objection is made, as he is often the son of a farmer, proprietor of the stage. In summer this carriage is agreeable in winter uncomfortable, as there is no other protection against the weather than a curtain or leather, often fastened in a negligent manner to the posts which support the root. But some of the stages in this State are nearly as good as those of England." 


\section{(From Boston News Lettcr, Established I707.)}

I706-Strayed or stolen out of Mr. Stcphen Easton's farm, in Rhode Island, the I 3 th of September last, a black gelding about I 4 hands high; he gallops, trots and paces, branded on hip.

In the New England Chronicle, printed at Boston, we find, in I 776: Strayed or stolen, a large mare of a dark red, about i 5 hands high; trots and paces.

In 1777 another strayed or stolen horse is advertised-this one a bay, about $\mathrm{I} 4$ hands, trots all, etc. We notice quite a number of others, at least twenty, advertised in New England, Pennsylvania and elsewhere, none of which were over 15 hands.

One Thousand Dollars Reward! Stolen out of the stable of Mr. Dana, Innholder at Brookline, a brown horse about I4 hands high; also a wagon, etc. Whoever will discover the thief or thieves, so that he or they may be brought to justice, and the horse and goods recovered, shall receive the above reward, or $\$ 500$ for the horse only, by Elijah Wilds of Shirley.

\section{(From the Worcester Spy, I784.)}

The half-blooded black Arabian sire, got by the beautiful black horse imported from Arabia, and formerly owned by Timothy Ruggles, Esq., of Hardwick, and an English mare the property of William Oliver, Esq., of Hardwick.

JOHN GREEN.

I 784-Wanted a number of shipping horses from 4 to 6 years old, natural pacers, and about I 4 hands high, etc.

B. GREEN, Worcester.

I785-Chandler or Taylor Horse in Shrewsbury.

Shipping horses-wanted a number of horses about 15 hands, natural pacers. J. Trumbull, Petersham, March 27, I 786.

TAKEN-A horse about 14 hands high, well framed and thick set, dark red chestnut, dark mane and tail.

Middletown, Essex Co., I 788.

I 788-Pilgrim or Holbrook Horse bred in the groves in Northborough.

H. TAYLOR.

Young Sultan, by Peacock, imported by Gov. Wentworth.

Mower Horse at Worcester.

Young Farmer in Petersham, full blooded, bay, 16 hands; got by Farmer, imported to New York.

A. WILDER.

Young Wildeer, bay, I 5 hands, foaled I 785 , got by noted horse Wildeer: dam by full blooded imported horse. P. WAITE. 
Young Defiance, black, I 6 hands; foaled I778, by old Defiance, Virginia.

Bay Brier, English.

Roebuck, formerly called in New York, Livingston Horse; by Lath: dam by Wildair, I 5 I/2 hands; colts bay.

Fearnaught in Northborough.

Hero, bay; a horse $151 / 2,6$ years old; by a son of Wyllis' Arabian, in Worcester.

Will cover, etc., at Jacob Dyer's, Canterbury, Conn., noted imported horse Nimrod; dark bay, 17 hands; very fast trotter, but four seasons in America: got by Herod and is full blooded. Also Recovery, in Boston. Signed, JACOB Dyer.

Virginia Horse at Hardwick; bay, I6 hands.

JOHN EARLE.

1795-6-9-180I-Hyder Ally by Col. Wyllis' Ranger, at Hardwick; $153 / 4$ hands. He proved very sure, of I 33 mares last year, 120 were in foal. STEPhen Rice.

I796-1800-Roebuck lately owned by Martin Kingsley in Hardwick.

LeNiUEL WiLlis.

I 797-Koulikhan, dark bay, I $53 / 4$ hands, by Koulikhan, son of Badjazet. Has been in Rutland, Vt., two years, and two years before that time at Salem, N. Y.

S. RICE, Hardwick.

I 797-Fearnaught; Weasel by Badjazet, I61/2 hands.

Hunter, bay, at Hardwick.

I798-The Bulrock in New Braintree; a full blooded Dutch horse, his sire was imported from Holland: dam a Dutch mare from New York. He is equal in strength and beauty to any in the State and a good saddle horse and equal for draught to any in Worcester County.

M. Hamilton.

I 799-Paymaster in Westminster.

I799-I 806-Traveler, that has been kept some years back near Boston, in Worcester.

I $800-H e r o d$, by King Herod, in Hardwick, chestnut, $151 / 2$ hands; bred by Sir H. Harper, Derbyshire; full blooded, at $\$ 20$.

Killdare by Lath.

S. Whipple.

Sir Charles, by Young Herod, lately imported and purchased by Sam. Whipple, Hardwick: dam by Marsk, from Cade Mare, $\mathbf{5}$ hands, remarkable beauty, hardy and strong.

Geo. Aldrich, Mendon.

I 800-Paymaster, I $5 \frac{3}{4}$ hands. L. MOORE, Worcester. 

I 80 I-Paymaster, kept by
D. Fisil, Barre.

I80I-Dey of Algiers at Charlestown; 7 years old, remarkably long, healthy and vigorous; and for beauty, figure and blood has not his equal in the United States.

I 806-Young Traveler in Spencer, dark bay, near I 6 hands.

I 807-Wildair in Leicester.

J. BEMIS.

I $808-9-E c l i p s e$, by Traveler, bay, I 5 hands, at Shrewsbury.

I 808 -Quicksilver, 4 years old.

G. Wheeler.

I 808-9-I 3-Sterling or New Jersey Colt, I6 hands.

I809-The Pilot, red roan; foaled I804, I6 hands, in Princeton, and bred in Marlboro.

J. WHEELER.

I 8 IO-I2-I3-Diomede, bred by Dr. Wm. Cutler, Virginia, foaled I 804 ; of uncommon beauty; I $5 \frac{1}{2}$ hands, bay, by imported Diomed: dam full blooded, by imported Wildair.

JOHN EARLE, Hardwick. land.

I812-I3-Hyder Ally and Traveler, black, I3 hands, at Rut-

I 8 I3-The Shark in Northboro, full blooded, much famed for speed and strength, has stood two years near Charlton.

I 8 I4-Sterling at Hardwick.

B. Munroe.

From the Massachusetts Spy or Worcester Gazette, published at Worcester, Mass. (Burlington College Library):

At Hardwick the elegant full-blooded horse, lately from the State of New York, by Lath, dam by Wildair.

(Signed) Martin Kinsley.

The same year Sultan is advertised in Princeton; and "An elegant English horse called the Wildair," at Brookfield; got by the famous imported Wildair; bay, $15 \mathrm{~T} / 2$ hands six years old, terms, eight to twenty shillings. Hero, at Northfield; also Roebuck, 15 I $/ 2$ hands, at Grafton.

In 1785 the Chandler or Taylor Horse is advertised at Shrewsbury at $\$ 4$ to warrant.

In 1788 Pilgrim and Young Sultan are advertised at Rutland; "'got by the celebrated Peacock, imported by the late Gov. Wentworth of New Hampshire, that has been acknowledged the completest horse on every account ever brought to America. Sultan is 15 hands, three years old, moves with great majesty; terms, ten to twenty shillings."

In 1789 is advertised the noted horse Pilgrim at Northboro and Young Sultan at Rutiand, four years old, 15 r 2 hands. 
In I 790 Young Hero, descended from the famous Wildair, dam by Bold Britain, bay, I 5 hands, six years old, is advertised by $\mathrm{H}$. Taylor, Northboro ; and Roebuck, cinnamon color, about I 5 hands, by C. French of Grafton; and Hyder Ally and Traveler at Rutland, Mass. I 8 I 2-I3-Sterling, black, I7 hands, formerly owned by Earle at Charlton.

I8I3--The Shark, full blooded, much famed for speed and strength.

Signed, D. Mosroe.

I 8 I $4-$ Sterling at Hardwick.

I 8 I6-Prince Regent by Diomede, foaled i 8 I 2 .

I8I6-Young Phøenix by old Phœnix in Sutton: dam by Feather, one of the swiftest horses ever brought out of the State of New York; grandam by Light Infantry.

I8I8-Phœnix, ten years old, chestnut bay, is hands: dam Wildair.

I 8 i 8 - Young Diomede, six years old, in Petersham.

I819-Sterling at Charlton.

I 822-Imported Columbus, gray; foaled I I I 5 ; at Charlton.

IS23-Othello, by Olive Branch: dam by Traveler; $2 \mathrm{~d}$ dam by Hyder Ally; dark bay, I61/2 hands, foaled I8I9; bred by D. Home, Petersham.

I 825 -Duroc, full blooded, from New York, in Barre.

I 825 -Young Highlander, sorrel, I 5 hands; foaled I 822 ; got by Connecticut Highlander; in Spencer.

I 826-7-Imported Roman, and Topliff, gray, six years old.

I829-Berghami, Topliff and Sterling, by Sterling; Hampton, gray, $15 \mathrm{~T} / 2$ hands.

I $832-$ Sir Peter Teazle, bay, I6 hands, nine years old; got by old Sir Peter Teazle, the fastest trotter in Maryland. Sir Walter, bay, elegant and fleet. Duroc, five years old, gray, 15 hands; by imported Highlander, son of Highlander: dam by Duroc.

Eclipse, bay, I 6 hands, by Eclipse, whose dam was by imported Dey of Algiers, son of Virginia Eclipse: dam by same, from a Messenger mare.

Signed, E. BRowNELL.

1834-Dey of Algiers.

(From Federal Spy of Springficld.)

1788-Young Granby and Raven, Suffield.

1789-Young Wallie, English, I 5 1 2 hands, advertised by John Morgan, Jr., West Springfield, Mass.; also same year by the same horse Flying Buck, full blood English. 
Phœenix at West Springfield.

Young Lark at Bloomfield.

I 79I-Young Kildeer, from New York, bay, I 6 hands, English bred; in Hebron, Conn.

I794-Roebuck and others.

I 795-President and Splendor at Westfield.

(From Brookficld, Mass., Adicrtiscr.)

I795-Roebuck at Hardwick, Mass, by Lath: dam by Wildair Fearnot, imported, bay, 7 years old, I6 hands.

Young Merry Momus, by old Merry Momus, imported by Lord Cornwallis. Timothy Newell, Stockbridge.

Fox, I 5 hands, red roan, 8 years old.

I 799-Liberty; by old Obscurity; bay, I 6 hands, 5 years old. Hotspur, 15 1 $2 / 2$, hands, 6 years old, by noted Chandler Horse.

\section{T. RICE.}

Creeper, bought in England by that excellent judge of horses, Capt. Abraham Skinner of Hartford; imported I 796.

Traveler, undoubtedly one of the best horses ever seen in New England: dam large breeding mare and her dam by imported Ranger; 16 hands, brown bay, well made. Has been kept in vicinity of Wolfsboro, N. H., seven years, most of time.

A. Adans.

Celebrated Arabian horse Phoenix at Stephen Lee's livery stable, Portland, at $\$ 5$ to $\$ \mathrm{I} O$. " $\mathrm{He}$ is an elegantly formed horse possessing both beauty and strength, full i 5 hands, beautiful chestnut with a few white spots, bought of Joseph Rylander, New York when four years old for $\$ 1700$; got by native Arabian horse Diomed: dam Maid of Oaks, by King Herod; grandam sister to Juno, dam of Dragon and Young Eclipse by Spectator; great-grandam by Regulus -Bartlet's Childers-Honeywoods' Arabian Courser."

\section{JOHN DOWNeR, I 805 .}

(From the Merrimack Intelligencer, Haverhill, Mass., 1815.)

Black Prince in New Salem and Londonderry; "got by Black Prince, imported by Col. Wadsworth, Kilburn and Ramsey, I798: his dam the noted Bissell Mare of East Windsor, Vt., who had such astonishing powers as to render her as noted in the county of Hartford as his sire." There follows a certificate of Joseph Bellows, Ist and $2 \mathrm{~d}$, and ten others that Black Prince had been at Walpole since I 808 with one year excepted, and that his stock were large and well formed and well adapted to the various uses of farmers, etc. 
Young Quicksilver; got by that noted imported horse old Quicksilver, formerly owned by J. Bellows, Esq., Walpole, and from a superior mare; six years old, 16 hands, dark bay; for activity, speed, bone and nerve, perhaps not excelled by any.

(Signed) Thomas Wallace, Goffstown, I815.

Acorn, the Boston correspondent of The Spirit of the Times, Vol. XIX., page I38, writes:

"It is an established fact that many of the fastest trotters that now appear on the turf as well in our own city as New York, Philadelphia and Baltimore were bred in Massachusetts, New Hampshire or Maine, the latter has probably sent out more trotters than any state including Ice Pony, Fanny Pullen, Boston, Tom Thumb, Edwin Forest, D. S. Tompkins and Z. Taylor. Page I26, Mac is the horse that with name of La Prairie beat St. Lawrence twice and also won a match here (Albany) against Doughnuts."

Live Stock Journal Chicago, Ill., page 386, article on Justin Morgan says: "Edwin Forest and Boston Blue were his reputed sons. The claim rests upon tradition, there is no positive testimony to prove it."

From Lindsley's Vermont Stock Journal, Vol. II.: “Green Mountain Boy, by Mazeppa; bred by Dan Kimball, Rutland. Napoleon by Young Mambrino, son of Chancellor, by imported Messenger."

A correspondent writes in New England Farmer, I 826-7, Vol. V.: "It is difficult at the present time to obtain as many horses as are wanted that are serviceable, for our wants, without getting them from Vermont or New York."

I $820-$ Vol. I. Nothing on horses.

I 825 -Columbus a Suffolk cart horse. Imported Roman; Bellfounder; Sir Isaac, Cleveland Bay breed.

I 826-Bellfounder, bright bay, with black legs, I 5 hands, a celebrated trotter and a true descendant of the Fireaways, at Col. Jacques' stable in Charlestown at $\$ 20$. Roman, bay, full blooded in Northboro.

1827-Bellfounder at Charlestown. Roman, imported.

I 827-Top Gallant by Col. Taylor's Top Gallant, son of imported Diomed.

The following are from the files of the New England Farmer, preserved in the library of the Brooklyn Historical Society: 
Roman, imported, purchased of the Earl of Warwick and descended from Childers ; an elegant, full-blooded horse, a light bay, black mane and tail, of high spirit and good temper, is advertised to be kept at the farm of Stephen Williams, Northborough, Mass., at $\$ 20$.

An account of the Brighton Cattle show speaks of Young Bellfounder, by Col. Jacques' famous horse Bellfounder, owned by Samuel Jones, Charlestown.

The report of the cattle show at Hartford, Conn., speaks of the beautiful horse Highlander, owned by Ralph Watson, East Windsor.

Further facts are given about Roman; from Childers through eight generations of highest-bred horses; has beat some of the fleetest horses in England; walks and trots well; $15 \mathrm{~T} / 2$ hands; mares sent to him from all the New England States.

Volume VI., page 93, speaks of a two-year-old colt bred by Edwin Brownell, Little Compton, got by a colt of Eclipse, dam by Lance, called Young Eclipse, awarded premium of $\$ 50$.

A writer, page 273, Vol. V., remarks: "No horse is worth breeding now that cannot trot with ease ten miles an hour."

FOR SALE OR TO LET-The three elegant stud horses Dey of Algiers, Ranger and Young Highlander, all got by the celebrated horse Highlander. RALPH WATSON, East Windsor, Conn.

In this volume Bellfounder is advertised as before by Samuel Jacques, Jr.; and the same pedigree appears.

On page 354 is this letter on "Horses":

\section{MR. FESSENDEN :}

“Boston, May 25, 1828.

I observe in one of your late numbers that three stallions are expected in this port from England. Most of the names in the pedigrees are new names to me as they are written. If I may be allowed to make a remark upon the subject, it is to state that one of them, Barefont, is of a particular blood, and not one of the refuse horses that are sent here to poison our stock, but one of first-rate decided reputation at home. He is unquestionably a horse of the highest reputation in England that has ever been brought young. He is, I believe, only eight years old, of a far superior class to a horse like Messenger. Before reading that communication I had not the slightest knowledge of the circumstances under which they were to come to this country. Truly yours,

\section{J. L. Ellwyn."}

Barefoot and Scrub, sent to this country by Admiral Sir Isaac Coffin, will be kept at Brighton; Barefoot, foaled 1820, by Trump, etc.; Scrub, foaled I82I, by Phantom. 
In Volume VIII., published in 1830 , in a series of articles on "The Horse," is, page 244: "The Canadian is found principally in Canada and the Northern States. $\mathrm{He}$ is supposed to be of French descent, and many of the celebrated American trotters are of this breed." The article goes on to speak of the English horse, the celebrated Shark, and Tally-Ho, a son of the Highflyer, that was very popular in the Jerseys.

\section{(From Hampshire Gazette, Northampton, Mass.)}

I788 - In Conway, Black Dread, also Dapple Gray, the last brought from Canada last winter, said to be part English and part French; is good for the saddle and very excellent for the draught. He is a nervous, fiery, strong, well-built horse.

I792-Rover, descendant of Royal Bay of Connecticut.

\section{(From Columbia.Sentinel, Boston, 1806.)}

Young Dey of Algiers at Milton. Full-blooded Arabian colt, nearly 15 hands, dapple gray, 4 years old; long and well-proportioned; his figure and movements lofty and elegant. His sire was the noted Dey of Algiers, imported by Col. James Swan in the year I 800. His dam the gray Arab mare imported same time with the horse; $\$ 15$ to $\$ 30$.

\section{(From Worcester Gazette.)}

Sterling, chestnut horse, 16 hands.

JOHN EARLE.

Fair American, got by old Traveler, from full-blooded mare; six years old, etc. Joel Nurse, Shrewsbury.

Eclipse, five years old, 16 hands, got by old Traveler, etc.; at Worcester. JosepH LOVELL.

The Pilot, that high bred, red roan horse, five years old, I6 hands, in Princeton; bred in Marlboro and said to be out of a very excellent breed of horses. JACOB WHEELER.

\section{(From Palladium of Liberty, Morristown, I800.)}

Young Nimrod at Troy; bay, 15 $1 / 2$ hands; got by Nimrod, imported by Doc Tate of Philadelphia; he by King Fergus, etc.: dam by Collector.

Henry COBb, Troy.

Sportsman, full-blooded, is advertised to be kept at Worcester, Shrewsbury and Westborough, Mass., in 1830.

In $1832 \mathrm{~J}$. Parkinson advertises Young Barefoot, three years old (first colt got by Barefoot in America), bred by John Prince, Jamaica, from large American mare; at Brighton at \$I 2. 
Conqueror is advertised at Ten Hills Stock Farm, Charlestown, by Samuel Jacques; "bred near Montreal; foaled 1825 ; by a noted Normandy horse, from a blooded mare; rising 15 hands, iron gray. This horse has taken three premiums in Canada. He has probably as much as or more than any other horse now living of the strains of blood so well known in New England by the name of the "Morgan breed.' From the best accounts the original Morgan horse was made up of the same strains of blood as Conqueror. The fullblooded horse Sportsman also is kept as above; for pedigree see late volume of the Farmer. May I6, I832."

Eli M. Richardson of Franklin advertises Young Cleveland, a Cleveland Bay, I 5 r $/ 2$ hands, by Sir Isaac, son of Molineux: dam, a native mare.

Sportsman, foaled the property of Gen. Coles, of Downs, L. I., by the Bussorah Arabian: dam Sportmistress by Hickory; her dam Miller's Damsel by Messenger.

Samuel Jacques.

B. W. Hobart advertises Quicksilver at Brighton at $\$ 15$; bright bay, three years old, by Barefoot: dam by the Cleveland Bay, Sir Isaac.

John Pelton advertises Pioneer at Framingham; I 5 1/2, by imported Debash: dam by Cub.

The index to the American Farmer, Vols. I. and II., I 82 I-22, show no horse matter of interest; index to Vol. III., I 836, of Albany Cultivator, the same.

In Vol. XI., 1833, the issue for March 30 contains an extract from a letter from a gentleman in Talbot County, Md., who says:

"I have long looked over your paper in hopes of seeing some account of the New England trotting horse, and as I have not been gratified, you will now much oblige me by answering the following queries:

"First. Do you know anything of this race of horses?

"Second. In what estimation are they generally held as to speed, bottom and durability on the road either in harness or under the saddle?

"Third. Are they characterized with long life and spirit?

"Fourth. What general color characterizes this family of horses; and what could a stallion of five or six years old be had for, delivered in Philadelphia or Baltimore, at the shortest notice?

"Fifth. What is their general form, whether that of the race, horse or pony?"

"We are not acquainted with the race of horses alluded to, and would be much obliged to any friend to answer through the paper. 


\section{(From the New England Farmer.)}

"The following horses are for sale or to let the coming season; if not parted with will be kept for mares at the farm of A. Dey, Lodi, Bergen Co., New Jersey, seven miles from New York:

" 'Pathkiller, chestnut, six years, $153 / 4$ hands, by Eclipse: dam by Hyacinth. His colts promise to be great trotters.

“'Navarino, bay, five years, I $5 \frac{3}{4}$ hands, sire Delyroot's Sir Harry.

“' Harpinus, blood bay, $161 / 2$ hands, seven years this spring (I833), sire, Hamiltonian: dam, a Messenger mare. A great trotter, and his colts large and fine, well calculated for coach horses. $\$ 400$ offered for one pair two and three years old.

" "King Philip, a sorrel, said to be I 3 years old; a full blood Narragansett, and the only known thoroughbred in this part of the country. He is a descendant of a race of animals that have been in the family of Gen. Jay for many years. His stock, especially those by high-bred mares, are said to be very fine, and will carry a man with great ease 60 miles a day under saddle. As saddle horses they readily sell at from $\$ 300$ to $\$ 500$ at five years old. They rack, trot and canter, and are good for both saddle and harness. The above horse will stand for $\$ 15$ the season."

" "Numidian - The full-blooded Arabian horse Numidian will be kept at Ten Hill Stock farm, two and a half miles from Boston, at $\$ 20$. History: In the winter of $1823-24$ the Dey of Algiers conquered the Arabs, capturing horses, of which this was one. $\mathrm{Mr}$. Shater, our Consul, imported him in 1826 ; since 1827 he has been kept at Mount Holley, N. J.

SAMUEL JACQUes." "

In 1832 there are advertisements of Sportsman, Young Barefoot, Conqueror, Young Cleveland and Barefoot. Page 196 of Vol. VIII., I 829, is gone; it has account of breeds of horses. 


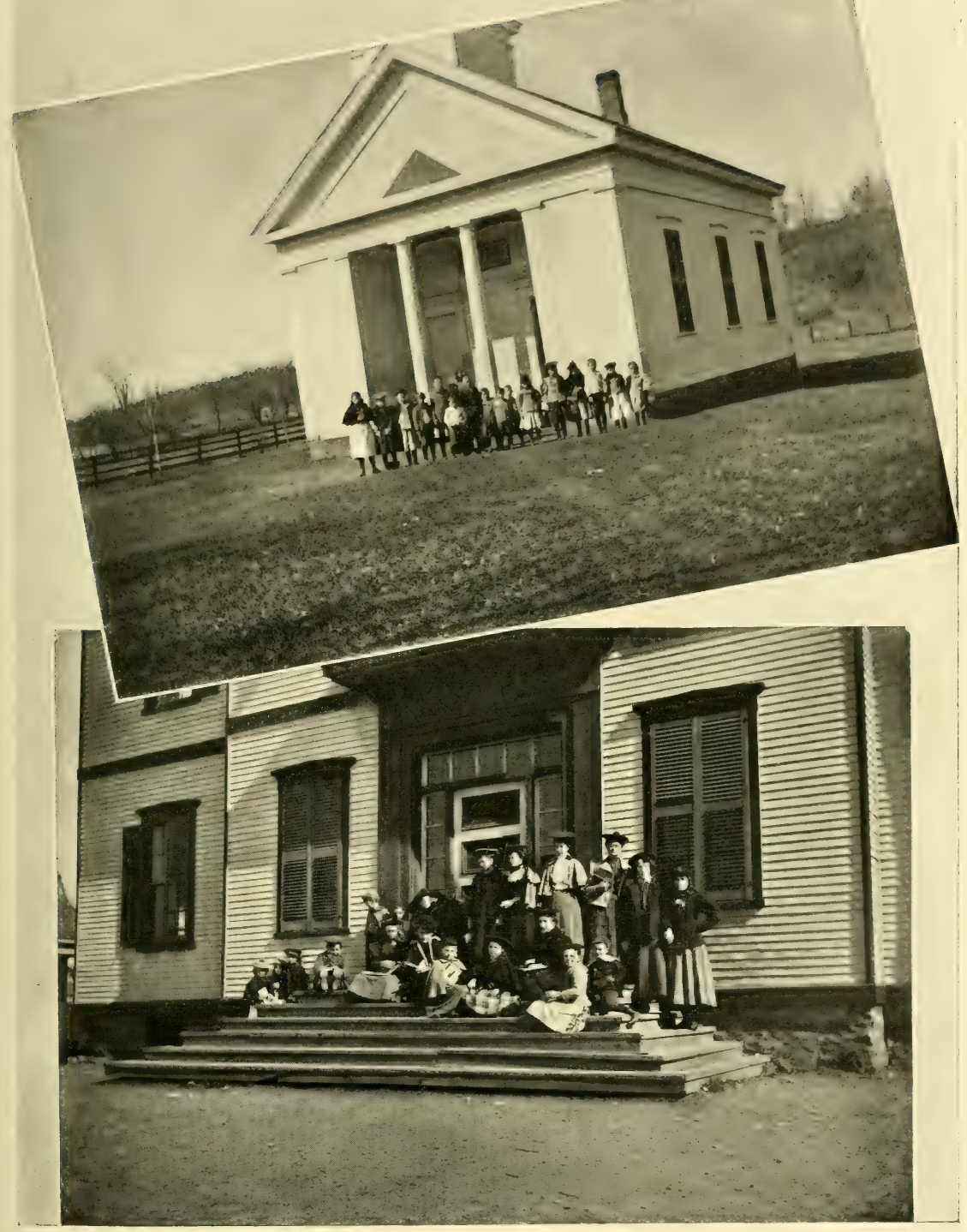

New England School Life. 

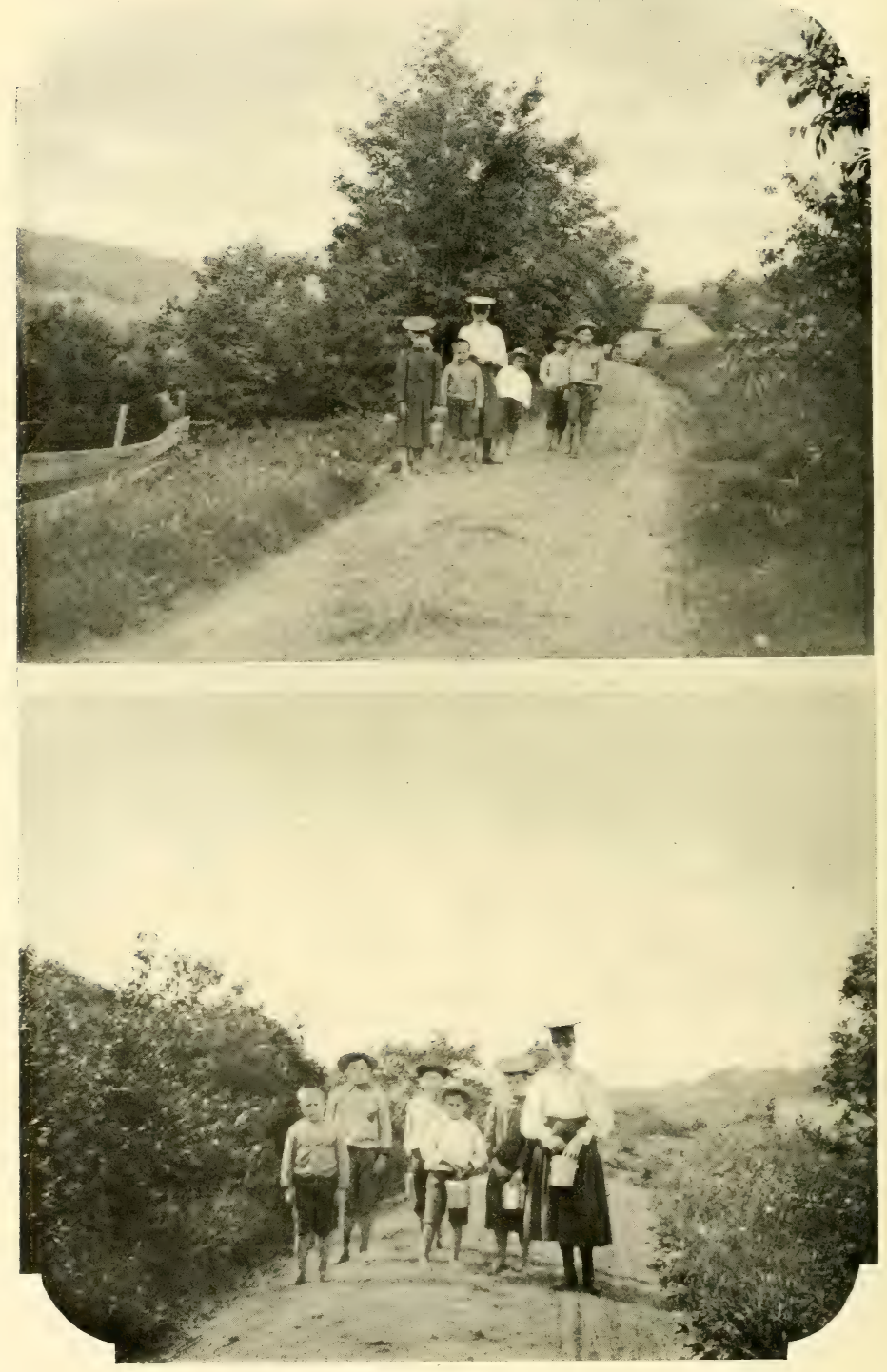

New England School Life. 


\section{RHODE ISLAND.}

"Angel of life! thy glittering wings explore
Earth's loneliest bounds, and Ocean's wildest shore.
Lo! to the wintry winds the pilot yields
His bark careering o'er unfathom'd fields ;
Now on Atlantic waves he rides afar,
Where Andes, giant of the western star,
With meteor-standard to the winds unfurl'd,
Looks from his throne of clouds o'er half the world." - Campbell.

RODE ISLAND, least in area of the States, is the home of
manufactures and commerce. Only about three per cent of its population are engaged in agriculture. The prosperity of its people is evidenced by the fact that the assessed valuation of their property increased from eighty and a half millions of dollars in I 850 , to over four hundred and twenty millions in I880, a gain of over five hundred per cent in thirty years.

The first settlement in Rhode Island was made by Roger Williams at Providence in $\mathrm{I}_{6} 6$. On account of his more liberal and tolerant religious opinions, which he seems to have defended with much zeal and ability, he was driven out of Salem and the Massachusetts Bay Colony in mid-winter, and reached the shores of Narragansett Bay, with a few followers. Williams was a man of great purity of character, and very liberal learning, having in England studied the Hebrew, Greek, Latin, French and Dutch languages, and being there ordained a clergyman in the Church of England, a faith which he soon after recanted for Puritanism. In America he made a study of the Indian dialects of New England, and gained a familiarity with them which was afterwards of great service to him in his negotiations with the tribes about Providence, of whom he purchased large and fertile tracts of land in that region. He held it wrong to take the Indian lands without compensation, and this is said to have been one of the points of bitter and lasting difference between him and the thrifty magistrates of the Massachusetts Bay Colony.

The little company of Roger Williams made the journey to 
Providence in boats, and could not have taken horses with them. Among the early settlers of the Rhode Island colony was William Coddington, afterwards governor, and long distinguished as a leading man in the colony, who went thither from Boston, and in the spring of 1637 , purchased of the Sachems of the Narragansetts the Island of Rhode Island, then called Acquidneck, and founded thereon the town of Portsmouth. The deed of the Island is dated March 24, I637, and the grant is to William Coddington and seven others. The first mention of horses in Rhode Island is in a vote of the proprietors of Portsmouth in 1638 , viz.:- "It is ordered that every one of this body shall have for his present use one acre of meadow for his beast, one acre for his sheep, and one and one-half acres for a horse, to be layd out at the discretion of Mr. Sanford, Mr. Wilbor and John Porter, with what convenient speed may be, upon notice given of every man's several cattle."

(Record of the Colony of Rhode Island and Providence Plantations, Vol. I., page 54.)

It is most probable that the first horses introduced into Rhode Island were young stock from the colony of Massachusetts Bay, sprung from the animals which, as we have seen, had been imported a few years previously. But the pioneers of the new settlements on Narragansett Bay, with its excellent harbor and roadway for ships, soon developed into ambitious merchants, and ere many years their sails were whitening distant seas-" About I642-3 there were two trading houses set up in the Narragansett country; one by Mr. Wilcox and R. Williams, the other by Richard Smith; and some few plantations were made near there on particular grants, or purchases of the Indians, but not very many till 1657 , when several gentlemen on the Island and elsewhere made a considerable purchase called the Pettaquensett Purchase." (Col. of R. I. Hist., Vol. IV., page 92.)

Here is the record of the first Rhode Island horse law suit:

"Court of Commissioners held at Portsmouth, May 22, I656.

"Voted that the petition of William Brenton against Mr. William Coddington, for being about to ship several horses of the said Brenton, shall first be agitated.

"It is ordered upon a petition exhibited to the Court by William Brenton, Merchant, of Boston, touching some horses which Mr. William Coddington is reported to be transporting to Barbadoes, and Mr. William Brenton, Merchant, etc., challengeth and layeth claim unto, as unjustly obtaineth from him. The Court, after full debate and mature consideration, ordereth that a special writ of attachment issue from this Court, to stay said horses upon the Island until a due 
trial of such challenge shall be had, according to the law and order established amongst us: Providing that Mr. Brenton, or his assigns furnish security to make good all damages which may fall to $\mathrm{Mr}$. Coddington by this attachment, in case Mr. Brenton make not good his challenge.

"An attachment granted.

"Memo. Mr. William Brenton and William Dyre do engage in one thousand pounds sterling that Mr. William Brenton shall do and perform the law in all points as concerning attachment granted forth against certain horses, shipped by $\mathrm{Mr}$. Coddington to the Barbadoes; which horse or horses are laid claim to by Mr. Brenton or his assignees."

(Record of the Col. of R. I. etc., Vol. I., page 337.)

Werden, in his History (page 337) speaking of a period about I678, says:- "Horses were an important export from the Narragansett country. Hull, with his associates, began breeding them early on Point Judith Neck."

It appears from the suit of Brenton vs. Coddington that the latter before his title in Rhode Island was yet a score of years of age, had found a market for his horses in the far-off Barbadoes, nearly a thousand leagues away. This little island, lying at the south-easterly corner of the Carribee or Windward group, was a favorite market for the horses of the colonies both of Rhode Island and of Massachusetts. Barbadoes was settled by the English, with negro slaves, in I625, and the production oi sugar and kindred products very soon became its chief industry. Horses were used in their cane crushing mills, as there was no water power in the island, which indeed was but little more than 100,000 acres in its entire extent; these horses were found in New England, and thus a trade was begun, extending to the other islands of the West Indies and the Bahamas, that continued for nearly two hundred years. Werden states (Economic and Social History of N.E., Vol. I., ) that this trade was large from all New England parts and often included Newfoundland in its route: that about 1649 the New England colonists sent letters to England by Barbadoes, so frequent was the intercourse with that quarter. Massachusetts Bay, to prevent depletion of the stock, forbade the exportation of mares. The West India commerce went in single decked vessels; horses and oxen together on deck.

"Small sloops carried a surprising number of cattle of all kinds from the south shores of New England to the West Indies and to the eastern coast of the farther America. One brig took 49 horses, and many sloops took 35 in a single cargo. Vessels in the trade made two voyages a year. Six vessels carrying horses left New London 
together for the West Indies, June 16, I 724. In I 7 I6 Capt. Hutton took 45 horses to Barbadoes. Newport, R. I., was active in the trade. It was estimated in I74I that the trade between New England and Barbadoes, or the West Indies, amounted to five hundred thousand pounds, equal to that with England."

Before considering the Narragansett Pacer, for many years the flower of Rhode Island horses, it may be well briefly to inquire what was the condition and what were the characteristics of the stock thus planted in the new colonies, and so early increasing as to seek a market abroad.

FIRST, then, the horses of New England of the seventeenth century were hardy and enduring. They were sprung chiefly from the English stock imported as we have seen. The heavier stock of Flanders which was introduced seems to have left little trace of its existence after a few years. We have already given Gervase Markham's description of the English horse of the time of James I. (I603I625), from whose stock these early importations were drawn. He was, as we have seen, an animal builded up of many elements upon the original British horse as he existed before the Roman invasion, (B. C. 57). With the legions of the Roman Cæsar came an influx of foreign blood probably from many parts of the world-wide empire that then was subject to the Roman sway. From five or six hundred years later came the Saxons and the Angles, riding to victory on horses bred in the widely separated districts of what is now the German empire, whence they came. They permanently occupied the land, and the blood of their war-horses furnished a new element to the existing stock. In the eleventh century came the Danish irruptions, and the horses of the Danes no doubt left their mark upon the English stock. It was in the same century (A. D. I066) that William the Conqueror overthrew the Saxon Harold at Hastings, and taking his seat on the English throne, established in the land his rule by the prowess of his steel-clad knights, mounted on the excellent chargers bred in Normandy. These were the elements that made up the English horse, from whose stock, nearly six hundred years later, the earliest exports were made to New England. From Markham's graphic description it appears that these horses were of good size, strong, substantial, shapely, swift enough so that their best could outrun the coursers brought from Barbary; and "for infinite labor and long endurance, which is to be desired in our hunting matches, I have not seen any horse to compare with the English. He is of tolerable shape, strong, valiant and durable." (Markham). 
In selecting horses for importation, it is safe to say that only young and sound animals would be chosen, and those supposed to be of such hardiness as to be capable of enduring the hardships of the voyage (fatal to so many) as well as the rigors of the climate and the unavoidable privations and exposures to which they must be subject in that new land whither they were bound. Considering also the cost of transportation (ten pounds then, representing a much larger sum now) no cheap or faulty animals would be selected. On the other hand, fancy qualities would not be sought nor fancy prices paid; the animal that would prove useful, strong and enduring would be the one chosen; so it is safe to assume that the early importations were young and hardy specimens of the most hardy and useful horses of England of that day.

SECONDLY:-The horses of New England, after a few generations, were small. The original importations were probably not tall horses, though substantial. An act of parliament in the time of Henry the seventh, (I $4 \delta_{5-1509}$ ) providing that every brood mare should be at least fourteen hands high, suggests very strongly the comparatively low stature of the English horse. Then the long sea voyage and the lack of proper food and shelter after it was ended, in the long and bitter winters of New England, told upon the pioneer stock, while the same conditions tended to stint the growth of the young colts and fillies. We have seen that Josselyn noted of the cattle that they "grow less of body than those they are bred of, yearly," and also the sorry condition of the horses (I663) in the spring time from running all the year abroad and having no fodder provided for them. Of course it was impossible in the early years to furnish more than the most meagre provender in winter for horses and cattle. As other evidence that the hardy equine youngsters bred on the New England coast, that survived these ordeals, were of small stature at maturity, we have the law of Plymouth colony passed in I670 that, "No one shall allow a stallion over two years old to go at large, under $I_{3}$ hands high." But a still more convincing fact is that in the earliest advertisements of horses "stolen or strayed" it is extremely rare that one is described as tall as fifteen hands, the usual height being fourteen or fourteen and a half hands, some as low as thirteen.

THIRDLY :-The early horses of New England had a variety of gaits, among which the pacing gait was very common. This, also, is shown by the advertisements of estrays, a large proportion of 
which describe the errant animal as one that paces, or one that both trots and paces. In the eighteenth century the advertisements for large lots of pacing horses for shipping to the West Indies, are very common, showing that there must have been a supply; but how far the spread of the popular Narragansett pacer filled this want, or what proportion of the common stock would answer the description, we cannot say. One thing may be taken as certain, however, that in a time when almost all travel with horses was done on horseback, for lack of carriage roads, the pacing gait was taught, and thus became more and more prevalent both from actual teaching and from inheritance of the gait thus taught.

In Howard and Crocker's History of New England, the subject of traveling in the early times is thus spoken of:

"During the colonial period, traveling in New England was principally performed on foot or on horseback; the women being mounted on pillions behind the men. Pedestrians were at first guided through the forest by blazed trees. The earliest roads were mere bridle paths. As late as I69 I the blind husband of Elizabeth Howe, accompanied by his two young daughters, might have been seen journeying on horse-back twice a week, along narrow, difficult, and sometimes dangerous roads, all the way from Topsfield to Boston, to visit the wife and mother confined there as a convicted witch.

"These primitive bridle-paths gave way to cart roads, some of which, having never attained to the dignity of highways, still remain clean-cut through leafy woods, affording us romantic traces of the simplicity of earlier times.

"At the close of the colonial period, or of the seventeenth century, roads, such as they were, radiated in every direction from Boston to the surrounding villages, forming the means of communication with their inhabitants. These roads, ordinarily, were very poorly worked, and travel thereon was accordingly exceedingly laborious and uncomfortable; a trip of only a few miles, amply sufficing to cure even the most inveterate case of dyspepsia. Even yet, however, the more distant hamlets, buried in the depths of the primeval forests, were reached only by tortuous paths indicated by marked trees, fallen timber and ragged rocks, piled in heaps or scattered about in indiscriminate confusion, often impeding the progress of the wayfarer in reaching these settlements.

"Pleasure carriages, save in Boston, were very rarely seen until the middle of the eighteenth century. The chaise, so long the pleasure vehicle of New England, was introduced about that time. The wagons of the farmers were, for the most part, very rude structures, usually bedded solidly on the axles, so that riding on them (they ordinarily served the purpose of conveyance both to mill 
and to meeting) especially over the hidcous highways of the period, rough as yet with unpulled stones and stumps, was far from being voluptuously easy.

"Stage-coaches were not introduced until near the close of the seventeenth century, the very first of which we have any account being that of Lady Andros, wife of the provincial governor."

\section{(Rhode Island Records, Vol. III., p. II7.)}

It appears-page 87, I639-that William Coddington, William Brewster and others were invited to propagate a plantation in the midst of the island or elsewhere. Other names are N. Eaton, J. Coggeshall, J. Clarke, Thomas Hazard, H. Bull and William Dyre.

Records of colony of Rhode Island, vol. III., page 532: Rowland Robinson appears as deputy for Kingston, I 705.

I678- "Voted, whereas there was very lately in the town of Newport in Rhode Island very great hurt done to a small childe by reason of exceeding fast and hard riding of horses in said town this assembly enact, etc . . . . . if any person or persons shall presume to ride a horse a gallop or to run or speed in any of the streets of said towne of Newport, he shall be fined 5 shillings."

"Voted upon petition of severall farmers in townes of Providence and Warwick for liberty to sett up a troop of horse." Granted to the number of thirty-six. Ordered to exercise the same, 1682.

I 7 I 4-Three troops of horse to be raised, one on the Island and two on the Mainland.

I722-Wm. Robinson lived in the Narragansett country. In I 724 he was a member of the legislature from South Kingston; same in 1726 and 1734 , and was chosen deputy governor of Rhode Island in 1745 .

Rip Van Dam born in Albany, N. Y., about I662, died after I 736 .

I 777-An act passed to prevent horse racing.

"A Description of the province of New Albion," I648 says of the Barbadoes:

"Here was no store of land for our Ioo men and their families, here wants the Englishman's grape, and so the Englishman's Beef, Mutton, Milk, Butter, Cheese, and they want rivers to turn their sugar mills, so that New England sendeth Horses and Virginia Oxen, to turn them at excessive rates, and their keeping there is chargeable." 
A letter written from Plymouth, New England, December I 7, I62 I, published in the Massachusetts Historical Collections, Vol. IX., page 63, says: "And if we have but once kine, horses and sheep I make no question but men might live as contented here as in any part of the world."

The first child was born at Providence in 1638 ; in 1637 settlement began at New Haven, Conn., and in 1637 on the Connecticut River from the Massachusetts colony.

This account is from the Providence Gazette of 1765 and states that in 1637 the first war broke out in New England between the English and Indians, and says: "The manner in which they improved their land and took care of their domestic animals, some of which were now in the country, suggested to the Indians that it would cut off their hunting," etc.

It says of William Coddington (page I 79): "He was the father of Rhode Island; was a gentleman of family and competent fortune, came to America in 1630 , settled in Boston and was one of the first and most considerable merchants."

Newport began in 1638 . Rhode Island obtained its charter in I643. In I 643 the Massachusetts colony took prisoners the settlers of Warwick, R. I., and all their cattle, eighty head.

Arnold's History of Rhode Island, Vol. I., page 486, states that thirty wild or unmarked horses were ordered to be caught and the proceeds to be used in building a prison, etc. This was in June, I686.

Page 489-Answer of Rhode Island to the Board of Trade appointed by England- "To the 5 th we answer that as for horses we have but few, but the chief of our militia consists of ten companies of foot, etc."

The Hudson River was colonized by the Dutch in I623 (discovered in I609). New Amsterdam was surrendered to the English in 1664. New York had, in 1656, I20 houses and I000 inhabitants; in 1677,368 houses.

Watson's New York City, page I63, speaks of a Narragansett pacer bought by Rip Van Dam in Rhode Island for \$160 in I7II.

Quebec was founded in 1608 ; conquered by the English in $176 \mathbf{r}$.

From Collections of the Rhode Island Historical Society, Vol. III., page I05:

"In 1685 a number of Protestants from France came to the Narragansett country and pitched their tents in the wilderness at Franktown. Population of Rhode Island in $1730,17,935 . "$ 
From "British Scttlements in North America" by Wm. Douglass, Boston, 1755, Vol. II., page 100 :

"Rhode Island Colony in gencral is a country for pasture, not for grain: their winters are softer and shorter than up inland. It is noted for dairies, hence the best of cheese made in any part of New England is called (abroad) Rhode Island cheese.

"The most considerable farms are in the Narragansett Country. Their largest dairy of one farm milks about I IO cows, cuts about 200 loads of hay, markets about I 3,000 weight of cheese, besides butter and sells off considerable in calves and fatted bullocks."

Nothing is said about horses but under Connecticut we find this:

"Connecticut has scarce any foreign trade; lately they sent some small craft to the West India Islands; they sent their produce in the neighboring continent colonies, viz. wheat, Indian corn, pork, beeves, butter, horses and flax."

In chapter headed "Some remarks relating to the natural history of New England," he says :

"We have natural pacers of horses which at a cow run (a gait which they acquire by pasturing when colts with the cows), will pace three miles in seven minutes."

"History of the British Dominion in North America," London, I773, says of Rhode Island:

" They export for the West India Islands, horses, live stock of several kinds, butter, cheese, lumber and rum, but this trade has been upon the decline."

And an account of Canada says:

"The Indians in this country raise Indian corn and have plenty of horses."

Rochefaucault, "Travels in North America," I795-6-7, says Vol. II., page 297 :

"A considerable number have emigrated from Rhode Island to the newly occupied lands, and in particular to Canada."

"Travels in North America," I759-1760, by Rev. Andrew Barnaby, A. M., London, 1775 , says of Rhode Island, page 70 : "The horses are long and strong and the oxen much the largest in America, several of them weighing from 1600 to I $800 . "$

Werden's History, I640-1662, page I 82 :

"Stiff old Endicott negotiating for Winthrop, with a woman who had been offered $\$ 50$ for her horse writes: 'he is a costly horse and I think $£$ ro will hardly fetch him.'” 
Mavirick writing in I660, page 204 says to an English correspondent:

"This country also is now well stocked with horses, cows, sheep and goats."

Page 25I- "Hull bred horses were on his farm in Boston Neck and Point Judith, R. I., I670."

Page 277-"The commons were open and stallions, many of them inferior, ran at large among the mares. It was found the whole breed of horses would deteriorate. Massachusetts excluded from the commons all stallions under I 4 hands and not of 'comely proportion.'"

In "A Concise Account of North America by Major Robert Rogers," published at London, I765, the author says of Rhode Island ( p. 56):

"They raise cattle, sheep and horses in abundance and the latter the best on the continent. The principal commodities exported are horses, sheep and cheese."

And the writer of the "History of the New World called America," published at Dublin, I775, in treating of New England says :

"Their horned cattle are very numerous and some of them very large, oxen have been killed there of I 800 weight. Hogs likewise are numerous and particularly excellent. They have besides a breed of small horses, which are particularly hardy. They pace naturally though in no very graceful or easy manner but with such swiftness and for so long a continuance as must appear almost incredible, to those who have not experienced it.

"They have a great number of sheep too and of a good kind. The wool is of a staple sufficiently long, but it is not near as fine as that of England. However they manufacture a great deal of it very successfully."

Again in an account of Rhode Island another work called "History and Account of British Colonies, London, I 775," says :

"Their horses are much coveted by the other Colonies."

As neither of these books mentions the horses of any of the other colonies it would show that this preference must have been very marked, and it would also seem that there must have been some cause for it.

"Oliphant's History of the United States" (Edinburgh, I800), says of Rhode Island (p. I 77 ) :

"The tract of land lying between North and South Kingston on the east and Connecticut on the west, called Shannock Country or 
Purchase, is excellent grazing land and is inhabited by a number of large and wealthy farmers, who raise some of the finest neat cattle in New England. They keep large dairies, and make butter and cheese of the best quality and large quantities for market.

"The Narragansett (which includes a strip of land seven or eight miles wide) terminated on the east by the bay of the same name, and extending from Point Judeth on the south to Hunt's River or near it on the north, has been famed for an excellent breed of pacing horses, remarkable for their speed and hardiness in enduring the fatigues of a journey.

"This breed of horses has much depreciated of late, the best mares having been purchased by people from the westward.

"The principal exports from the State are flaxseed, lumber, horses, cattle, etc."

In Watson's “Historic Tales of Olden Times” (Philadelphia, I 833 ), quoting James Read, an aged horseman, who died in I793, appears :

"In old times the horses most valued were pacers, now so odious deemed. To this end the breed was propagated with care and pace races were held in preference. The Narragansett pacers of Rhode Island were in such repute that they were sent for at much trouble and expense, by some few who were choice in their selections."

In Warden's North America (Edinburgh, I819) :

"The Narragansett tract which terminates on the bay of the same name, produces a breed of pacing horses remarkable for their speed and vigor."

\section{GALLOWAYS.}

There was an excellent breed of little horses, varying from thirteen to fourteen hands high, existing in the district of Galloway, on the shore of Solway Frith, in the south of Scotland, which had their name from the district in which they had their origin. But it is now nearly extinct.

"There is a tradition," according to Mr. Youatt, "that the breed is of Spanish extraction, some horses having escaped from one of the Grand Armada, which was wrecked on the neighbouring coast. This district, however, so early as the time of Edward I., supplied that monarch with a great number of horses.

"The pure Galloway was said to be nearly fourteen hands high, and sometimes more, of bright bay or brown, with black legs, and small head and neck, and peculiarly deep clean legs. Its qualities were speed, stoutness, and sure-footedness, over a very rugged and mountainous country." 
Dr. Anderson thus describes the Galloway:

"There was once a breed of small elegant horses in Scotland, similar to those of Iceland and Sweden, which were known by the name of Galloways, the best of which sometimes reached the height of fourteen-and-a-half hands.

"In my own youth, I recollect to have seen two Galloways of the true Scottish blood, as distinct from those, of which I shall presently speak, created by especial breeding, in the vain hope of filling the vacancy.

"They were both, as nearly as possible of the size indicated, fourteen hands to fourteen hands and a half in height; but, unlike what is stated above of their color, they were of a deep, rich, glossy chestnut, almost copper colored in the shadow, with legs not black, but decidedly darker, instead of being lighter than the bodies. All these points were conspicuous in the Galloways of which I speak, and, moreover, they had long thin manes; rather spare than shaggy tails; small, lean, bony heads; one of them with the broad brow and basin face of the Arab; thin necks, particulariy fine towards the throat, and setting on of the head; soft silky coats; large eyes, and all the particular indications of thorough blood.

"Their paces were generally the walk or the canter; and neither of the two was a particularly handsome or fast trotter, going along at a good rate, indeed, but in a shuffling style, neither clearly a trot nor a canter. One of them which I often rode, ambled, as it was called then and there, so fast as to keep up with the hand gallop of a thoroughbred lady's mare, in company with which it was constantly ridden.

"This Galloway, so far as I can remember it, was in fact neither more nor less than a natural pacer, and I am convinced that the other might with ease have been trained to the same pace, and to a good rate of going.

"Whether this was or was not a characteristic of the race, I am unable to say; but I know that the animals seemed to me, then, perfect beaux ideals of Andalusion jennets, and were regarded as such by persons more competent to pronounce than myself."

Taken in consideration with reference to the tradition, as to their origin, and comparing them with the like story in regard to the Narragansett pacers, it is quite probable that these two now nearly extinct races, were of the same descent.

In giving the history of the Narragansett pacer it should be stated that it is impossible to define at all times between this Narragansett and other pacing blood, or to distinguish exactly how much the fast pacing horse of America is indebted to the Narragansett pacer.

We have thought best to include in this account all the more noted families of American pacers, except those originating or 
coming from the Province of Quebec, which last will appear in the chapter upon Canadian horses.

The Tom breed of horses in Maryland, evidently a pacing breed, dates back to the times of the Revolution, or before.

It would seem, too, as though the old Tom breed in Maryland, and those known there the last 50 years under this name might be in part, at least, two different families of horses. There is some reason to think the last may have been Canadian. The first could not have been.

The first distinct reference to this breed which we have met is in an advertisement in the Maryland Gazette, of 1789 , of the stallion Jolly Roger, there described as, "black, I 5 hands, well and stout made, and perhaps as good a draft horse as any in the State. His blood is between the dray and Tom; his dam was a Tom and his sire Sterling (a dray)." In I 790 he is advertised again, dam spoken of as "a remarkably fine Tom mare." He was kept in Anne Arundel County.

The following advertisement appears in The Genessee Advertiser of Easton, Md., April, I 8 I6:

\section{“THE CELEBRATED STALLION OLD TOM}

the property of Sam. Hamilton, Esq., will be kept at Easton, Md.; terms, \$IO the chance.

"Tom is a descendant of the Native American Woods Horse, and is said to be the only horse in this part of the United States through whose veins that valuable blood runs pure and uncontaminated by the least mixture with European breeds; few horses have acquired a greater celebrity as a foal getter, and it is no small compliment to Tom that his high reputation has for several years past drawn to him a number of the finest mares in the country both of the English and Arabian stocks. On the Western shore of this State and on the borders of Pennsylvania and Virginia his colts are highly esteemed as saddle horses; they pace and rack naturally, are well formed, active, strong and hardy, travel remarkably swift and possess the most ardent spirits. The great superiority of the Tom breed for the saddle, consists in their strength and activity; being celebrated for neither stumbling or pulling, consequently uniting the safety with the ease of the rider. Warranted a sure foal getter. Some of his colts will be shown at Easton next month.

Ed. T. Hamilton."

In $189 \mathrm{I}$ we interviewed several of the older horsemen of Maryland concerning the breed.

Gov. Bowie of Baltimore said:

"The Tom breed of horses was a saddle horse breed, with evidently a cross of the thoroughbred. Distinctly saddle horses about 
I $5 \mathrm{~T} / 2$ hands, generally bay, blood like looking horses; did not show Canadian. They were single footers. Archie Tom was of this breed. I think they were Maryland horses. I remember them 50 years back; they were quite common then, an established breed at that time. Alexander's Pilot (Pilot Jr.) did not show Canadian. He was, too, blooded."

S. Taggart Esq. of Baltimore, said:

"I remember the Tom breed was a very noted breed of saddle horses; bays of fine mettle, spirited, well gaited and remarkable for endurance and fine appearance. Had the saddle gaits, rackers not pacers. Medium size, say $\mathrm{I} 5 \mathrm{I} / 2$ hands, round bodied and deep chested. I should think they were entirely distinct from the thoroughbred.'

The Native American Woods Horse referred to in the advertisement of old Tom, appears in several of the older advertisements (see that of Robin in Pennsylvania in I774). The word Wood or Woods probably refers to some animal that wandered or was captured in the woods, though this does not certainly appear. It would seem that it might possibly connect with the legend that the original Naragansett mare swam ashore from some shipwreck. If this is correct the Tom family of Maryland is at once connected with the Narragansett. And indeed the facts are well authenticated that before I 750 racing with Narragansett pacers was common in Rhode Island, and also interchange of racing between Rhode Island and Virginia. (See quotations from "The Horses of America" by Henry William Herbert in Introduction of Vol. I., page xxxvi.)

In the issue of April 25, I8I7, of the Kentucky Gazette, published at Lexington, appears an advertisement by William T. Banton, of two horses called Tom and Sweeper, in which Tom is thus described:

"Tom is one of those much admired Narragansett pacers, and perhaps the best blooded one now living in America. This race of horses was first introduced into this country by a gentleman named Tom, of the State of Maryland, whose name my horse bears. They are thought more highly of than any other horses in the world, being hardy, long lived, very strong, fine goers, and fast travelers, calculated to endure hardship and always command a high price for the saddle. Tom is a fine dark bay, fifteen hands and one inch high, of great muscular power and extraordinary activity."

In the same paper in 1825 is the following advertisement:

"The Maryland Pony, Little Tom, raised by Gen. Ringgold of Maryland and lately presented to Dr. Pindell of this county, will cover at five dollars; beautiful sorrel, light mane and tail, fifteen hands, seven years old this spring. Of Little Tom's pedigree, suffice 
it to say that he is a mixture of the Tom and Narragansett breeds of horses so much admired in Maryland and the Atlantic states, not only as fine hackneys but also for the draught. He is the same strain as those ponies which the Doctor brought with him from Maryland, and which have been so deservedly esteemed. These ponies grow unil they are eight years old, and for longevity, durability, great strength and activity, they are not excelled by any in America. Old Tom was one of the most celebrated horses of his day, remarkable for getting the finest hackneys. The Narragansetts came from the borders of Canada, and are equally esteemed. A filly of the breed sold at Annapolis, Md., for $\$ 350$. Two more are now in town for which $\$ 200$ has been offered. The high price at which the strain sells in Maryland would scarcely be credited here. His grand-sire at twenty-five could take the swingle-tree from any horse he was ever matched with, although he was not as large as Little Tom. Will be kept at Lexington.

T. H. Pindell."

This advertisement places the grand-sire back beyond the beginning of the century.

These advertisements would appear to be conclusive that the original Tom horses, or Tom horse of Maryland was descended from the Narragansett, very probably brought from Rhode Island. It also suggests in introducing the word "Canada" that his sire was one of the Canadian Morgan stock that before this time had been introduced into both Kentucky and Maryland.

The advertisement of Tom Foot which follows still further emphasizes this fact. Copperbottom, by Justin Morgan as we have demonstrated went from Canada to Kentucky in I8I6.

In the Lexington Reporter, of $183 \mathrm{I}$, Tom Foot is advertised as follows :

"The very fast and beautiful pacing pony, Tom Foot, will be kept at my stable in Bourbon County, Kentucky, eight miles west of Paris. He is now rising seven years old, $133 / 4$ hands, and is very heavy and powerfully made, and can perhaps out-pace anything of his inches in Kentucky. It is said that, when in full practice, he paces a mile in three minutes. He rides remarkably easy and strong. I know nothing more of his pedigree than that he is descended from the Canadian and Narragansett stock of horses, a stock very highly valued in their country for their excellency in riding, and their capability to stand hard labour and fatigue. Gentlemen who have large mares would do well to breed them to Tom Foot to improve our stock of riding horses, for they are very scarce and valuable. Four dollars to warrant.

Wm. G. Skillman."

Another family of pacing horses that appear in the early history of the Kentucky pacers, brought there from Virginia, and which still 
continues in direct male line, (though not in Kentucky) with perhaps the longest known genealogy of any of the pacers, is the Hiatoga. This can be definitely traced back to the last century, where it existed in Virginia, and then comes a distinct statement, or tradition, that its origin was a Narragansett pacer brought from the East.

The first of them was called Roodell's Hiatoga or Hiatoga Ist, and was foaled in Virginia about I780. He was a dark sorrel with flaxen mane and tail, and is said to have been taken when old to Kentucky, and died there in I8I4. A pacing grandson of this horse, strawberry roan, flaxen mane and tail, I6 $1 / 4$ hands, foaled I 8 I 5 in Caroline County, Va., and whose dam was said to be by imported Diomed, was taken to Kentucky in I822, by John Polluck, who advertised him that season in Fayette County. For further information of this family see the Hiatogas in Vol. III.

But before the advent of Tom and Little Tom, and this last Hiatoga, into Kentucky there came a more prominent pacer than any of these we have mentioned, a horse individually of great excellence, and whose blood enters into many of the very best horses in Kentucky and adjoining States, - the original Copperbottom. To this horse coming not from Virginia or Maryland, but from the mythical land of Canada, whence after followed a horde of pacers that invaded Kentucky, Tennessee, Ohio, Indiana, Illinois and indeed every Western State, and several of the Eastern ones as well, very much as the Goths and the Vandals came down from an unknown North and overran and finally subdued the Roman Empire. And to these pacers from Canada which came as unheralded as the wind, with never the slightest pretense of pedigree, is largely due the speed of the American trotter as well as pacer of Kentucky and neighboring States. For we think there is very little trotting or pacing speed in Kentucky, Tennessee, Illinois or Indiana stock which does not carry more or less of the blood of this Canadian pacer: Nancy Hanks, Maud S., Jay Eye See, Stamboul, Axtel, Jack, Harry Wilkes, Rosalind Wilkes, Trinket, Johnston, Hal Pointer, Little Brown Jug, Buffalo Girl, Brown Hal, Almont, Nutwood, Onward, Thorndale, King Rene, Egmont, Jaybird, Mambrino Gift, Messenger Chief, Princess, Pilot Jr., Pilot Medium, The Moor, Sultan, Suigert, Blue Ball, all have it. As the old time horseman Charlebois of Montreal well expressed it: "No Commis, no Maud S."

But Copperbottom was bred at Danville, Vt.; foaled I809, and got by the original Morgan horse. See Copperbottom (Jowett's), 
pp. x. and 590, Vol. I. Wallace says of him: "He was the original of the name, being, perhaps, the first horse of his type taken to the Blue Grass region. He left a race of very valuable descendants, going all gaits."

The following copies of advertisements for shipping horses are given as samples of those which appeared in newspapers throughout New England during the seventeenth and beginning of the eighteenth century.

\section{(From Worcester, Mass., Spy.)}

I 784 -Wanted a number of shipping horses from 4 to 6 years old, natural pacers and about I 4 hands high.

B. GREeN, Worcester.

I 7 55 -Shipping Horses. Wanted a number of horses ábout 5 years old, natural pacers.

\section{(From American Mercury, Hartford, Conn.)}

I 785 -Wanted a number of likely pacing horses, 4 to 6 years old, for shipping; bay or gray preferred. Ready pay.

DAvid Bird, Litchfield, Conn.

I 786-Wanted a number of likely young pacing horses for which good payment will be made.

H. VAN DuZEN, Middletown, Conn.

I 787 -Wanted by H. \& I. Hart, a number of handsome pacing horses, 4 to 6 years old, I 4 to I 5 hands, for which good prices will be given.

$$
\text { (From Portsmouth, N. H., Gazette.) }
$$

I $787-\mathrm{N}$. Fulson wants to purchase a few good shipping horses.

(From Windsor, Vt., Foumal and Universal Advertiser, I789.)

Wanted a number of likely young shipping horses, 3 to 6 years old; for which good pay will be made if delivered within 20 days at the store of Benjamin Green, Windsor, March 25, I 789.

WANTED-A number of likely horses for which good pay will be made. Soloman MeErs, Windsor, March 25, I 789.

I 790-Lemuel Storrs, Middletown, Conn., is in want of 20 sprightly pacing horses in good order for which he will pay cash.

$$
\text { (From Portland, Me., Gazettc.) }
$$

I $803-$ Wanted, I 8 or 20 horses natural pacers, mares preferred, for shipping.

I830-Wanted, 30 shipping horses at Middletown, Conn. 
All of these advertisements suggest the commonness of the pacing gait. The demand was for small horses, natural pacers, and the advertisements show that the supply was to be had all over New England.

In "Watson's Annals of Philadelphia," published about I840, page 209-210, the pacer of Rip Van Dam is again referred to, and it is stated that he was sent inland from New York to Philadelphia by the next post after his arrival at New York and the letter says further: "He is no beauty, although so high priced, save in his legs; he always plays and acts; will never stand still ; will take a glass of wine, beer or cider and probably would drink a dram on a cold morning."

If the date given, I7 I I, (page ccxl.) in which Rip Van Dam is said to have purchased his Narragansett pacer, is correct, William Robinson, born I693, could hardly have imported his ancestors. It is however quite possible that the governor's father imported the horses mentioned from Andalusia, and at the time of his doing so he was accompanied by the governor, then a mere boy.

The only other statement that we have met of the origin of this breed is that from the History of the Art of Horsemanship, by Richard Beringer, England, I77 I, and is as follows:

"But it is possible that the importation was by Williams' father, or the horse purchased by Rip Van Dam might have been of the old New England stock of pacers, which, by training, had become noted for speed in Rhode Island, and that the importation of blooded stock from Andalusia followed after this date, very much as the importation of Arab blood took place in England at about the same time to improve their running stock. And as in England the Arab or thoroughbred blood soon superseded the old English blood upon the race course, so in Rhode Island the same thing occurred. Wherever racing takes place and is followed from year to year with interest, improvement of the breed is always sought and, often, at large expense, the best blood for the purpose introduced from wherever it can be had."

Mr. Beringer, in his work on "The Horse," published I 77 I in England, and which we have so largely quoted from, says:

"Vol. I., page 209. The province of New England has a very peculiar sort of horses originally brought from England which are said to amble naturally; this pace they perform with great speed, and with such safety and exactness that, although otherwise valueable, they are chiefly esteemed for possessing this talent which they exert in a degree very superior to all other horses."

In this item of Mr. Beringer it would appear that he con- 
founded the great speed of the Narragansett pacer with that of the ordinary New England pony imported from England. That this ordinary New England pacing pony was derived from English importation is unquestioned, but why at Narragansett alone in all New England, or for that matter in all the American colonics which had introduced the small English pacers, a breed was formed that not only became distinguished from the rest in its name but in every way, as a saddle horse, and especially in speed which was understood and usually admitted to be very much superior, remains unexplained, if it was derived from the same source as all the other New England horses, and those of Virginia.

Undoubtedly the first horses brought to Rhode Island were, as we have said, brought in by the first settlers and came from the Colony of Massachusetts Bay. These were small, and probably many of them pacers. Almost immediately the trade in horses to the West Indies started up which was continued for nearly or quite 200 years. This trade helped to make the breeding of horses profitable, and to supply it was largely the object of their breeding in Rhode Island as well as elsewhere in the American Colonies.

The Narragansett pacer was recognized for a long time as the most speedy progenitor of that breed on this Continent and his blood was sought at many different places and it is in evidence that he was taken to Pennsylvania, Virginia, and States still further south, from one hundred to two hundred years ago. His fame too, was worldwide for we find him mentioned in works on horses published in England in the I8th century.

We presume that this Narragansett blood entered to some degree into the formation of the Canadian pacer in connection with the pacing blood of the old New England stock of horses, but the puzzling question arises that to our knowledge never has been answered, why did the pacing speed or known pacing blood become nearly extinguished in all parts of the United States, and why was it found in such quantity and of such remarkable quality among the snows of Canada?

Climate certainly did not explain this for it is well known that a pacer becomes a trotter in the deep snow. In examining this problem we see first that the pacers from Canada began to appear about the beginning of this century and we see next that they came from the Province of Quebec. They did not come from Ontario unless they were first brought there from Quebec. In looking to Canada to find a source of great speed and a quality that belonged to these 
pacers, which should antedate their origin, we are unable to find it. There was no such known blood there. But right here two things are noticeable, that the Province of Quebec lies along side of the State of Vermont, separated by only an imaginary line, and that a little before the known origin of these fast pacers in Canada a breed of horses originated in Vermont close to this boundary line, of very similar form and equally speedy.

To believe that this blood on one side of the line would assert itself and become the prominent blood through all the States as it did, and that on the other it should not do so would indeed be incredulous. It would instead be natural to expect, that across the line in Canada, simultaneously with the rise of the Morgan family in Vermont, New Hampshire and Maine, there would arise another branch of this family of equal and similar merit. And this was exactly what took place.

In Massachusetts, laws were passed against horse racing, but in Rhode Island as in the South it was permitted and probably encouraged. To this condition of things undoubtedly in part is due the Narragansett pacer. Demand brings supply, and use brings ability. The existence of the Narragansett pacer is in part explained by his development.

The following advertisements of Narragansett stallions are gleaned from files of old American newspapers and form an interesting addition to the history of this noted breed:

I 780-Peacock, bay with white face, black mane and tail, I5 hands. Advertised by Ezekial Smith, in the New Jersey Gazette:

"Peacock is a New England horse, very just in his proportions, paces, trots and canters. Moves with great agility and amazingly easy to his rider, and is esteemed by most competent judges to be one of the best calculated horses for getting colts for either saddle or harness in New Jersey."

A horse of this name is advertised in the Pennsylvania Gazette, I 776, as follows :

"Peacock, that noted Jersey horse, originally from New England; black, well marked, six years old. As to carriage, courage and activity of feet, perhaps inferior to none, and said by good judges to surpass any horse they have seen in swiftness of pacing; to be kept in Kensett Square.

I. Musgrate."

I 787 -This year Ezra Clark of Lisbon, Conn., advertises " the beautiful and substantial horse Young Snip, of the Narragansett Pacer Breed." 
I 789 -Eaton Horse at East Windsor and Enfield, Conn., that has been kept at Tolland for several years past. Got by the Ranger: dam Princess of Beauty by the Chapman Narragansett pacing horse.

I79I-Grand Turk, bay with star and snip; foaled 1785, is advertised by James Gove of Preston, Conn. "He is of the Narragansett pacing breed generally called the best saddle horses, well built, paces and trots."

The same year at New London, Conn., D. French advertises the natural pacing horse, Revival, dark bay, I 6 hands, well proportioned.

Jolly Farmer, dark bay with star, snip and white hind feet; nearly 16 hands, foaled about i 780 .

Advertised in Maryland Journal and Baltimore Advertiser, I792 :

"Jolly Farmer. The subscriber has the care of the noted country horse Jolly Farmer, rising I 2 years old, the property of Col. James Gittings, to be kept in Long Island. He is perhaps the finest country horse now to be found, nearly i 6 hands, strong and well made, dark bay, star and snip and two hind feet white, paces and trots well. Terms, \$3."

The advertisements of fifteen Narragansett stallions will be found in the following chapter under Connecticut, and others elsewhere in this book. Wherever owned they were evidently of high repute, and one of these is advertised as far south as North Carolina.

The assertion in Updike that the pure bloods did not trot at all is noteworthy, for the use of these records imply that they were a distinct breed from the usual horses of the country, and, if this was so, there must have been a mare or mares imported as well as a stallion.

In connection comes the question if they came from Andalusian stock, why were they pacers? Why was it that the pure bloods did not trot at all? If from imported stock, it would seem that this pacing gait must have been developed before they were imported. But of what high blooded stock was this true? The Spanish horse was noted for the manage trot. We have never seen them spoken of as confirmed pacers, although Gervase Markham in his work on "Horsemanship," published in England in I6I6; says of the Spanish jennet that they naturally desired to amble, and Michael Barret, who wrote on horsemanship in 16 I 8 , refers to Blunderville and Markham as authority that "the Spanish Jennet, Irish Hobby and Arabian Courser were the chief for pacing and neat action."

From Rhode Island Genealogy it appears that Rowland Robinson was born in Long Bluff, England, 1654, and died at Kingston, R. I., I 7 I 6 . 
His son, William, was born at South Kingston, R. I., 1693, married, I7 18 , and died, I75 I.

His daughter, Elizabeth Robinson, born 1724, was married to Thomas Hazard, born I 720 at South Kingston and married I 742.

His father was Robert Hazard, born at South Kingston, I689, and died at South Kingston, I 762 .

His father was Thomas, born at South Kingston, I66o, and his father Robert, born 1635 .

I. T. Hazard has been quoted as saying his grandfather, Robert Hazard, exported annually one hundred Narragansett horses, and that his grandfather Robinson brought the first in from Andalusia in Spain. A Robert Hazard appears first in 1645 in list of Portsmouth's inhabitants. In 1662 he appears again one of a committee appointed to consider bills. He also appears, I662, one of the general court of commissioners for the Colony. This may have been the Grandfather Hazard referred to, and he may have imported the Narragansetts.

Edward Robinson appears in the list of Newport, 1655.

In 1640 it was ordered in the Newport decrees that the chief magistrate should be called Governor.

We will close this chapter with two very excellent letters which we have received from Rowland E. Robinson, the well known and talented author, of Ferrisburgh, Vt., and a descendant of the above William Robinson:

\section{Hon. Joseph Battell,}

Ferrisburgh, March i 3 , i 892.

Dear Sir:-Updike's History of the Narragansett Church, published in I847, gives some account of the famous Narragansett pacers, principally in a letter from Isaac P. Hazard of Rhode Island. He says that his grandfather, Gov. William Robinson, who was my great-great-grandfather, introduced the breed from Andalusia in Spain, and that the raising of these horses for the West Indian market was a principal business of the Rhode Island planters, and that this I. P. H.'s paternal grandfather, Robert Hazard, used to raise one hundred of them a year for that market. Pacing was then the only rapid gait, which they were capable of maintaining all day, and covering a distance of one hundred miles without fatigue to horse or rider. It is said of their gait that it differed from all others in that the backbone moved in a straight line through the air. Racing these days was a favorite diversion of the planters in colonial times, and some of the best made therr mile " in a little over two minutes, and much less than three." The demand for them by the Cuban planters, whose agents were instructed to procure the best at any price, made a constant drain on the best stock, and after the Revo- 
lution trotting horses came into more general favor at home. From these causes the breed so rapidly approached extinction that in $\mathbf{1} 800$ there was but one known to exist in Rhode Island. This is about the substance of I. P. Hazard's communication. He does not describe the size nor the color of the breed. I have often heard my grandfather, Thomas R. Robinson, speak of the Narragansett pacers, and have an impression too indistinct to be relied on, that he said their usual color was light sorrel, or often "buckskin," with a dark line along the back. His mother rode one of the mares to Vermont from Newport, R. I., and in some way got impressed with the belicf that an old sorrel pacing mare, who was the first of horse kind in my memory and affections, was a descendant of this mare, but my brother, G. G. Robinson, thinks I am mistaken in this particular, as it is quite probable I am in that of color. Hoping that what I have been able to gather may be of some use to you, I am,

\section{Very truly yours, \\ ROWLAND E. ROBINSON.}

P. S.-William Robinson, who is credited with the introduction of the Narragansett pacers, died in $175 \mathrm{I}$, aged 57 years, and that is the only clue I can discover to the date of their introduction.

HON. J. BATTELL,

FERRISBURGH, March 25, I 892.

Dear Sir:-William Robinson, maternal grandfather of Isaac P. Hazard, and paternal grandfather of Thomas R. Robinson, my grandfather, was deputy governor of Rhode Island in 1745, ' 46 , ' 47 , '48, was born in 1693 , and died in $175 \mathrm{I}$. The inventory of his estate mentions "thirty horse kind." This from Austin's Genealogical Dictionary of Rhode Island. Nothing is said of the kinds of horses. I do not remember that I ever heard my grandfather speak of the origin of the Narragansett pacers, though frequently of their peculiar excellencies. If I had been fonder of horses no doubt I might have learned more of this famous breed than I did.

Isaac P. Hazard was a gentleman of unquestioned veracity, as was his krother, Thomas R. Hazard. The latter took great interest in everything relating to the history of his State, and wrote and published many papers concerning it. He mentions the pacers and their origin, and corroborates his brother's statement. From the character of the man, and from Thomas R. Hazard's intimate acquaintance with the early history of his State, and with that of his and our families, I think there can be little doubt of the fact. I enclose a copy of what he says, which Mrs. Robinson has made.

Very truly yours,

R. E. ROBINSON.

“Recollections of Olden Times,” by Thomas R. Hazard, says :

"Hannah Robinson mounting from the stone horse-block, her splendid Spanish Jennett, or Narragansett pacer (from whose sire 
and dam, imported by her grandfather Robinson from Andalusia, sprang a race of horses unrivaled for the saddle in America), the party rode away."

This Hannah was own cousin to Thomas R. Robinson, R. E. Robinson's grandfather, and both grandchildren of Dep. Gov. William Robinson.

The horse was named Selim.

"I remember that the commander of the Orpheus (a British blockader during the war of I 8 I2), was very desirous of obtaining one of the far-famed Narragansett pacers to present to his wife in England and that agents from Block Island scoured the Narragansett country to find a horse of that breed, but without success. Many years before most of the favorite pacers had been bought up and shipped on account of wealthy Cuban and Jamaica planters, who paid high prices that they might obtain the easiest going and most surefooted saddle beasts in the country for their wives and daughters. After this an agent from Virginia located himself on Tower Hill, who had orders to buy every full-blooded mare he could find, without limit as to cost. Hence the pure breed is now extinct, although I remember when the late James Robinson, grandson of Dep. Gov. Robinson, used to own one of the mixed breed; that on an urgent occasion he rode from New London to the South Ferry, a distance of forty miles, without once stopping for refreshments or rest."

The above was also furnished us by IV. H. Caswell, Esq., Narragansett Pier, R. I.; it appears in Chapter VI. in the book referred to. 


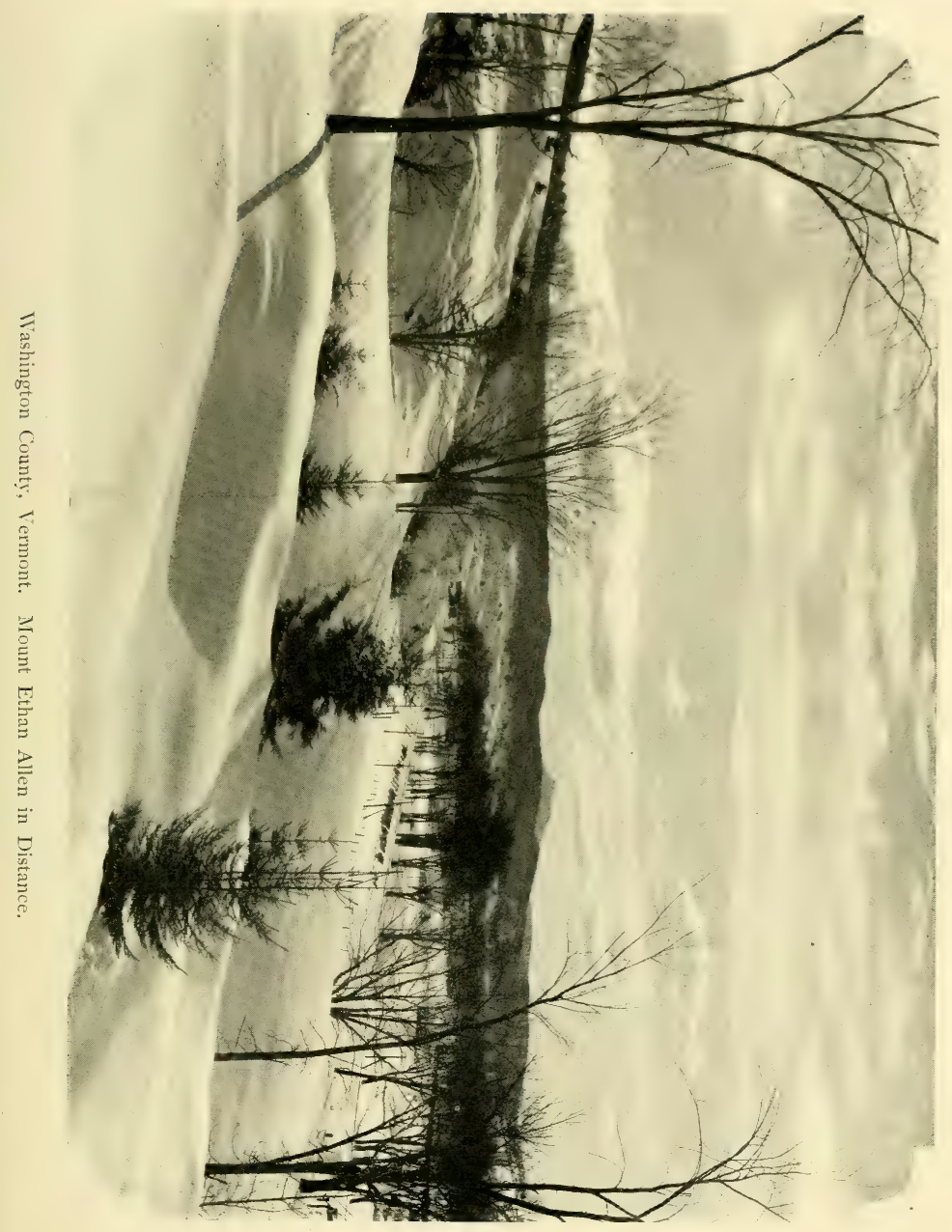




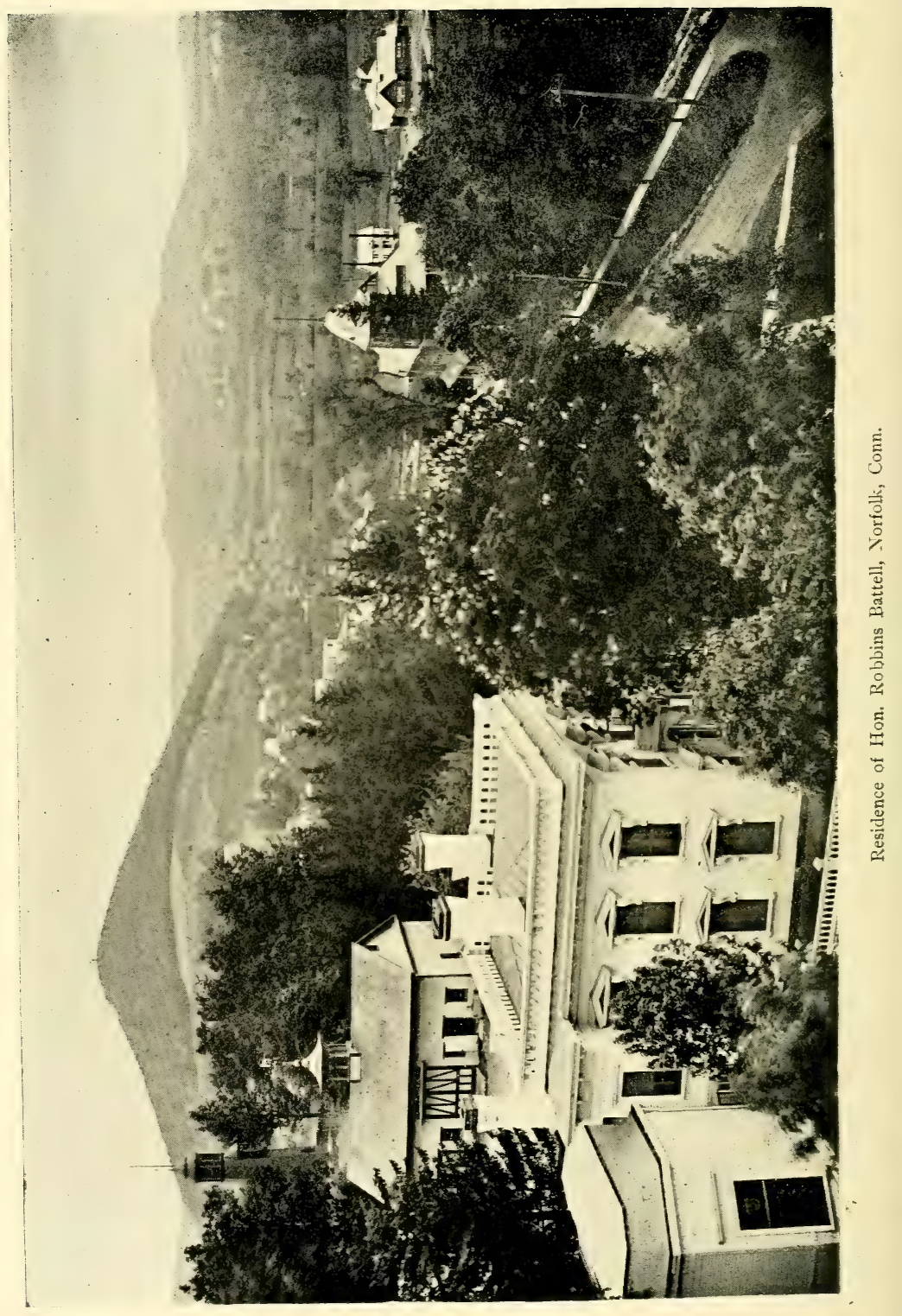




\section{CONNECT I C U T.}

And sweet homes nestle in these dales

And perch along these wooded swells;

And, blest beyond Arcadian vales,

They hear the sound of Sabbath bells !

Here dwells no perfect man sublime,

Nor woman winged before her time, But, with the faults and follies of the race, Old home-bred virtues hold their not unhonored place.

- Whittier.

CONNECTICUT derives its name from its beautiful river, the chief of the streams of New England, whose Indian name was Quinnituck, meaning "The long tidal river." In I6I4 Capt. Adrian Block, commander of one of five vessels sent out from New Netherland (New York) entered Long Island Sound from the east, and sailing along the coast, entered the Connecticut River, and claimed the country for the Dutch. The English afterwards claimed the same land as being included in the New England patent granted by James I. in I6IO; and under the title it was granted in I63I by the Earl of Warwick to Lord Say and Seal, and others. In I633 the rival claimants made their first lodgments on Connecticut soil, the Dutch building a fort at Hartford, and William Holmes of Plymouth colony, a house at Windsor, seven miles north. For a few years there was contention, but soon the Dutch sold out to the English and retired. The Dutch fort was on what is still known as Dutch Point, and was built by Jacob Van Curier, an agent of the Dutch West India Company.

During the summer of 1634 a company from Watertown settled at Weathersfield. In June, I635, the church at Dorchester, of which the Rev. John Wareham was minister, was located at Windsor near the Holmes settlement. After erecting the necessary buildings, the Windsor settlers returned to Massachusetts for their families. A party of sixty started from Dorchester on the I 5 th of October, taking their stock and other property with them, and took their way overland to their new home at Windsor. Winter came on unusually 
early, and before they reached their destination snow fell to a great depth, the Connecticut was covered with thin ice making the crossing very difficult and the party suffered great hardships, a portion of their live stock perishing by the way. They had taken but a limited stock of provisions, their winter's supply and their household goods having been shipped by water. Many of the vessels were wrecked and others forced to turn back to Boston. The settlers were destitute of blankets, and were forced to eke out a subsistence on nuts and acorns. Many, after incredible sufferings, found their way back to Massachusetts. But spring opened early, and with the return of mild weather matters rapidly improved. Those driven away by cold and hunger returned bringing large reinforcements. A fort was erected at the mouth of the river Tunxis (now Farmington) to prevent the encroachments of the Dutch. A third settlement was established at Suckiage, which was named Newton, and there the first court was held, April 26, I636.

During the spring of 1636 , the Rev. Thomas Hooker and his assistant, Rev. Samuel Stone, pastors of the church at Newton, now Cambridge, Mass., headed a party of about ioo persons, including women and children, in an overland journey to the valley of the Connecticut, and laid the foundation of the city of Hartford. At the close of the year 1636 , the total population of the three settlements was about eight hundred.

The next year came the Pequot war, in which Capt. Mason with 90 whites and 70 friendly Indians, annihilated that unhappy tribe. But this summer ( 1637 ) was a critical period for the infant colony. Many of their cattle had perished during the winter; the war called away most of their able-bodied men during planting time; there was also great scarcity of agricultural implements ; all these causes combined to reduce the crops, and had it not been for a supply of corn fortunately obtained from the friendly Indians farther up the river, a famine would have been suffered. The colony, however, by these means, survived this untoward year and entered upon an era of prosperity.

New Haven was settled in 1638 from Boston by English settlers, headed by Theophilus Eaton and Rev. John Davenport. They adopted a constitution of their own without warrant or sanction of England, and, purchasing the land from the Indians, proceeded to lay out the Elm City in regular squares upon a level plain, with a fine harbor opening into the Sound. The site was chosen for its facilities for commerce in which the settlers had been engaged in 
England. New Haven was consolidated with the Connecticut colony in 1665 , by order of the crown.

Lion Gardner was sent out by Lord Say to construct a fort at the mouth of the Connecticut River, about 1633 or ' 4 , and erected the fort at Saybrook, Conn. In I660 Gardiner wrote his Recollections of the Pequot Wars, and begins by saying that he made an agreement for one hundred pounds a year to run the business of the company of patentees, Lord Say and others, for four ycars; and so he came from Holland to London and thence to New England, landing at Boston the last of November. Later he went to the mouth of the Connecticut, just what year does not appear; there a Pequot Indian who had been at Plymouth and spoke English, came, desiring that Stephen Winthrop should go to Pequot with a hundred pounds worth of cloth and wares, and he said: "If he would come he might put off his goods, and the Pequot Sachem would give him two horses that had been there a great while."

Winthrop Gardiner therefore sent a shallop with the goods, and precise orders to the men to stay in the middle of the river, letting but one canoe come at a time to trade, and that with not more than four Indians in it. And if they brought the two horses to take them in at a clear piece of land at the mouth of the river, two of them to go ashore to help the horses in, and the rest to stand ready with their guns to defend themselves if need were. The party went and returned without the horses, escaping with difficulty. In the Pequot war which followed Mr. Gardiner tells of hearing the Indians threatening to go to Connecticut and "Kill women and children and take away the horses, cows and hogs."

In Annals of New England it is stated as a cause of the Pequot war that in 1636 or 37 , nine English were killed at Wethersfield and two young women and some horses were captured by the Indians. What remained of the Pequots after the war some 200 were distributed as slaves to the friendly Indian chiefs. "To Ninigsett 20 where this should satisfy for a mare of Edward Pomeroy's killed by his men."

In the autumn of I639 Mason led another successful expedition against the Indians; and it does not appear that after this Hartford County suffered much from the savages, although for many years the inhabitants dwelt in continual terror and kept a vigilant guard day and night. Having paid them for the land taken, they secured if not the friendship of the local tribes at least their acquiescence in the growth of the colony. During the latter bloody Indian wars, many of the members of the river tribes disappeared, probably allying 
themselves with the various hostile tribes, with whom they perished. The territory east of the Connecticut was not deemed safe from Indians until about 1670 .

In 1639 the people of Connecticut adopted their first constitution, of which Dr. Leonard Bacon has said: "It is the earliest precedent of a written constitution proceeding from a people, and in their name establishing and defining a government. John Haynes was chosen first governor, an office in which he alternated every other year with Edward Hopkins till I 657 when John Winthrop (the younger son of Gov. Winthrop of Massachusetts) was chosen to succeed Gov. Hopkins. Winthrop filled the position with great ability till his death in 1676 .

In I643 Connecticut joined the New England Confederation, a union planned by Haynes and Hooker for the purpose of combining the strength of the colonies against the Indians and the Dutch.

In 1662 Gov. Winthrop visited England and procured from Charles II., the famous charter of Connecticut. This instrument was based upon the colonial constitution of 1639, and proved of great value to the colony, and was highly treasured by them as evidenced by the many unsuccessful attempts to revoke it on the part of the successors of King Charles.

William Knapp in his History of Litchfield County says:

"The cattle were generally small, brindle and brown colors being favorites, and the sheep were long-legged and hardy with thin, coarse wool. The wooden plough, wooden tooth-harrow, and forks too heavy almost for men to lift, were samples of the farming tools of those early times. The early settlers were, for many years, greatly harassed by the depredations of wild beasts ravaging their flocks and crops and putting themselves sometimes in personal peril. Wolves abounded as late as $\mathbf{1 7 8 6}$, and wolf-hunts were very common sports in the Indian summer days. Bears and panthers were common also in those early times, and were frequently shot by the settlers. The activities of agriculture, as well as of every other kind of business, were materially impeded by the serious difficulties in the way of intercourse with the market towns; the roads being generally over steep, and along miry and untrodden bottoms, and where the snow, in winter, lay deep and drifted while the means of communication were of the most primitive and incommodius character. The farmers saw but little money in those days, taking their farm products annually to the trader in the distant village, and being supplied in return with whatever their necessities demanded. 
From Economic and Social History of New England, Werden, Vol. II., page 523- "Colchester, Conn., sold a black horse 3 years old, because his height fell below legal requirement."

From Travels in North America by Rochefaucault, I 795-6-7, page 302- "The exports from New London are sent almost all to the West India Islands. They consist of horses, dried beef and pork, mules, fowls, cattle of all sorts, beans and peas, timber, butter, cheese and salt fish.

"These articles are named here in the order of the quantities in which they are exported. Horses and black cattle are raised in great quantities in this State; but a great proportion of those exported come from the Northern States of New York, Vermont, New Hampshire and Massachusetts.

"It is affirmed that though the cattle be crowded together in the vessels to an incredible number not one out of a hundred dies on the passage. If the captain sells them in the islands he gets 5 per cent."

Page 309- "Horses are not sold until 3 years old."

Page 314-"Black cattle, horses and mules in great numbers are seen feeding upon the meadows around Hartford."

Page 316-"Middletown is the market town to which the farmers of Northern New York, Massachusetts and Vermont, bring for sale those horses, mules and black cattle which they can spa.e, to be exported to the West India Isles. Some small vessels take on board their cargoes at Middletown, but New London as I have already mentioned, is the more usual place for landing. Hartford shares with Middletown in the advantages of this cattle market."

Henry Wansey, in Journal of an excursion to the United States in 1794, page 63, says of stage trip from Hartford to New York: "We had four excellent horses and they took us on at the rate of eight miles an hour; one of them a Danish horse that cost \$IOO."

New Travels in America by Abbè Robin, chaplain of French army under Cœur de Rochambeau, 1781, page 23, in describing Connecticut says:

"The horses are of an excellent breed and it is common for them to go long journeys at the rate of 50 or 60 miles a day. They are very teachable and it is a rare thing to find any of them stubborn or skittish."

This author speaks, too, of often meeting young women traveling alone on horseback or in small chairs, between Boston and Providence. 
From Travels in the United States by J. P. Brissot de Warville, London, I794: "A people without morals may acquire Liberty but without morals they cannot preserve it."

A letter of Aug. 9, I788 page I09, describing a journey from Springfield, Mass., to New Haven, Conn., says :

"On the road you often meet those fair Connecticut girls, either driving a carriage or alone on horseback, galloping boldly; with an elegant hat on the head, a white apron, and a calico gown; usages which prove at once the early cultivation of their reason since they are trusted so young to themselves, the safety of the road, and the general innocence of manners."

\section{NEW HAVEN.}

Colonial Records, I653-1665, page 103; As to order made by General Court in May, I653, concerning the keeping of 12 horses in plantations upon the mains in this jurisdiction, is now ordered to be forthwith put in execution with this added: Two at New Haven and three apiece at the other four towns, constantly in readiness for public service for the more quick despatch of materials, etc.

$$
\text { I689-i 706-None. }
$$

Werden's North America, Vol. II., page 28: "Horses, cattle and sheep are raised in great numbers. The horses are generally slender; with a long switch tail and mane, have a good head and neck, but fall off in the hinder parts, being, in the language of the jockey, goose-rumped and cat-hammed."

\section{EARLY HORSE ADVERTISEMENTS.}

(From American Mercury, at Hartford.)

I 787-Peacock, one.half English, one-half Narragansett, bay, four years, $15 \mathrm{~T} / 2$ hands, well built, trots and paces.

\section{S. WEBSTER.}

1788-Recovery advertised by Thos. Poole, New London, Conn. I790-Partner.

\section{(From Farmors' Fournal, Danby, Conn.)}

I 79I-St. George, bred in Quebec, bay; colts are fine and large. I79I-Young Pontee; dam one of the old-fashioned Narragansett pacers; six years old, at Norwich, Conn.

Young Fox, gray, is hands.

St. George, bay, $15 \frac{1 / 2}{2}$ hands. 
Young Bashaw, bay, I 5 hands; bred on Long Island.

Tom Bogus at Pawling Town; sent from England, by Lord Sterling to Gen. Burgoyne ; I 5 hands, lengthy, strong and bony; 12 to 40 shillings. Has been kept the three last seasons in Newtown, Conn.

I792-“For Sale-Young Janus, I $5 \mathrm{I} / 2$ hands high, natural trotter, by Lansing's Janus in Bedford, by Janus, imported to Virginia: dam by Deermont, son of True Briton, an imported horse."

This True Briton we suppose to be the one imported by Captain De Lancey and sire of Justin Morgan.

I 795-Royal Traveler, a real saddle horse, gray, I6 hands, foaled I 79I, at Lebanon.

I 796-Young Traveler, bay, I6 hands, foaled I 790.

I796-Ranger, gray, I 5 hands, well proportioned.

Signed, E. SANFORD, Belchertown.

I798-Four stallions purchased last fall by Cephas Butler in Litchfield, Eng.; Highlander at Litchfield. Brilliant at Goshen. Sir Peter Teazle at Woodbury. Drone at Greenfield.

\section{(From Litchfield, Conn., Papers.)}

WILD RANGER-Will cover, at the stable of the subscriber in Winchester, at three dollars the season, or nine shillings the single leap, the beautiful gray horse, Wild Ranger, lately owned in Weathersfield; he is recommended to me by different persons to have been one of the most excellent horses for colts of any in this State, when in Weathersfield; said horse is 15 hands high and imitates the old Ranger in movement and spirit. Good attendance and pasturage for mares.

Ozias Brown, April 2o, i 790.

RAIN DEER-The beautiful dark bay horse Rain Deer will cover this season at the stable of Edward Beach, Jr., in Goshen, East Street, at twelve shillings the season or six shillings the single leap. This horse is six years old, his size, shape and movements are good, he was got by the well-known horse, old Liberty, formerly owned by Captain Painter of Salisbury.

April 27, I 790.

CLARICUS-Will cover this season at the stable of William Baldwin in Litchfield, the beautiful gray horse, Claricus. Terms, $\$ 2$ the season, which is much cheaper than any other horse in the county of his blood and figure.

May 29, I 790. 
cclxiv

SyPHAX-Will cover, the approaching season, at the stable of Robert Handah, in Bethlehem and Mr. David Buel in Litchfield, alternately, the noted and much admired, full blooded horse, Syphax, whose agility and superior figure will sufficiently recommend him, without introducing his pedigree, which is noble and respectable. Syphax is a dark bay, I 5 hands high, in prime order and universally approved by all true and judicious connoisseurs of beauty and proportion, is remarkably sure, and produces admirable colts, many of which may be seen in Litchfield and its vicinity. His adventures will commence the Ist of May at Bethlehem, at twelve shillings the season, during which he will be removed once a fortnight to Litchfield, and continue there two days, Fridays and Saturdays, beginning the two first of those days in said month. Those who cannot advance the sum required will be credited till the Ist of October ensuing, on executing a promissory note to the subscriber.

April I 3, I791.

JOLLY RAVEN-A horse famous for strength, style and peauty, will cover this season at the subscriber's stable in Harwinton at the moderate price of nine shillings the single leap or i 8 shillings the season.

Christopher Johnson, April 30, i 787.

HuNTER-Will cover this season at the subscriber's in East Street of Goshen, at twelve shillings the season, the famous horse Hunter. He is a fine dark bay, 7 years old, I5 hands high; his sire was full blooded, and his dam almost pure. His shape, strength and figure are not exceeded but by few.

Edmund BeAch, May 3, I79I.

YOUNG FIGURE-Will cover, the ensuing season, at the stable of the subscriber in Litchfield. Young Figure is seven-eights blood; his dam by the old Figure, full blooded; his sire the old Phœnix; and is the same horse kept at Springfield, Mass., the two last seasons and owned by Major Moses Seymour, in Litchfield.

Were it requisite, an advertisement might be swelled with pedigree and encomium; the superior elegance of the horse will, we presume, recommend him, without minutely tracing his noble ancestry. His limbs and movements exceed any horse ever introduced into this county if not in the State, and his colts are nervous, free, smooth and easy-calculated for pleasure and profit. He is rising I 5 hands high, of a beautiful color (London smoke). For further confirmation come and see. The price for the season is fourteen shillings and pay made easy in country produce; an abatement made for cash. Those inclined to have foals insured may agree at the time and place.

Wm. Baldwin, April 4, i 792. 
Old Pincenix-Will be kept at the subscriber's stable in Litchfleld (south farms) the Old Phœenix. He is a bright bay, 15 hands high and horse of spirit and figure; he has covered in Goshen several seasons and never less than 130 mares. His colts are known to equal any produced in the State. Twelve shillings will be required for the season, six shillings the leap, or fifteen shillings to warrant a foal. Any kind of grain will be received if paid by the I st of November next, an abatement made for cash and ready pay. Good pasturage and good hay may be depended on.

\section{Nathaniel Marsh, April i6, 1792.}

Pegasus-Will be kept at the stable of Edmund Beach, in Hartland, to cover this season at eighteen shillings, or nine shillings the leap. Pegasus is a horse of superior beauty and elegance. He is by Ranger, four years old this spring and is ${ }^{5}$ hands high. He got a few colts the two seasons passed and proved remarkably sure. The colts he got the first season are thought by good judges to be equal to himself.

May 2, I 792.

RANGER-Will be kept for covering the ensuing season, at the stable of Jonathan Beach in Goshen. Ranger is the same horse that stood at Major Timothy Seymour's in Hartford the last season, and two or three seasons before in Gushen. Those who are acquainted with his colts will want no other recommendation of the horse; several of them have been sold for 60 pounds at four years old and are allowed to be the best market horses in the country. Terms, $\$ 3$ the season or nine shillings the leap. Any kind of produce will be received in exchange.

May 2, I 792.

APOLLO-Will De kept this season at the stable of the subscriber, half a mile north of the north meeting house in Cornwall, at the moderate price of $\$ 6$, or $\$ 4$, and $\$ 9$ to insure foal. Apollo is 16 hands high, 8 years old, a beautiful bay and handsomely marked. Apollo's sire was the famous imported horse Badger and from a fullblooded mare. Apollo could undoubtedly, with much more propriety than is usually the case, be praised for his noble pedigree, elegant figure, superior action and the number of purses won by him and his sire ; but admitting every puff of this kind to be just, and however conscious that after all, those who view him would acknowledge that half had not been told of him, yet the subscriber thinks it most proper to submit this to the candid examiner. Good pasturage for mares and constant attendance.

Eliphalet Steele, April 23, I 794. 
HARTSHORN-A horse of uncommon strength and spirits, will be kept the present season at the subscriber's stable; his colts (many of which may be seen in different parts of the town) will sufficiently recommend him. Price only ten shillings.

Ozias Marsh, May 7, I794.

Smiling StaR-This horse, Smiling Star, will be kept at the stable of the subscriber in Salisbury, at the stone house on Town Hill, from Monday morning until Thursday noon; on Friday will be at Landlord Burral's in Canaan at seven o'clock in the morning, where he will continue till five o'clock p.m. ; on Saturday at General Hickock's in Sheffield, the same hours as at Landlord Burral's; from General Hickock's return to the stable of the subscriber. Said horse will continue the same route every week through the season. Smiling Star is about 15 hands high and much might be said in his favor were it requisite; but his appearance will best recommend him. The terms are $\$ 3$ the season or $\$ 2$ the leap.

\section{John Waterhouse, May 7, I794.}

HARMONIS-The horse Harmonis will be kept at my stable at Blue Swamp the present season. He is three-fourths blooded, I 5 hands and one inch high, well made. Those who view him will be pleased with his figure; his colts are likely. Price fifteen shillings or nine shillings. Pasturage if wanted.

Eli Smith, May I4, I794.

MARQUIS-Will be kept the present season at the subscriber's stable. This horse is indisputably much superior to any ever imported in this part of the country. Notwithstanding some illnatured, uncandid busy-bodies have circulated reports to the predjudice of the Marquis as a sire, we challenge an equal number of fine colts to be produced: the average value of which at twenty days old is, at least, thirty dollars. Terms for the Marquis, three or five dollars; insurance, eight. Apply to, WM. BALDWIN, May 21, I794.

Young Hermit-Will be kept the approaching season at the stable of Captain Abijah Pratt in Kent, except Friday and Saturday in each week, when he will be moved to Henry Brainard's stable in New Preston. This horse's sire was old Hermit, which alone is sufficient to recommend him to the public. He is $I 7$ hands high, and nicely proportioned; his movement and beauty are exceeded by no horse in America, and but few, if any, racer in America will outstrip him on the turf. Five dollars required for a foal, or other terms of twelve or twenty shillings. Good pasturage procured reasonably.

David Stone, April 8, i795. 
The Young Cincinnatus-Will be kept the ensuing season at the stable of Josiah Lockwood in New Milford, half a mile north of the meeting-house, except Monday and Friday of each week. On Monday he will be at Stiles Goodsell's, north part of New Medford. This horse's sire is old Cincinnatus, reckoned by competent judges as the completest horse in this State; his dam is seven-eighths blooded; he is five years old, about 17 hands high, and perfectly made, in exact proportion to his height: but a view of the horse and his colts will better recommend him than the most labored advertisement. The terms are seven dollars, four dollars and two dollars.

April 29, '95.

ROMEO-The horse Romeo will cover this season at the stable of the subscriber at Sharon at the very low price of 24 shillings. He will be 5 years old this spring, nearly I $5 \frac{1}{2}$ hands ; his stock is very promising. He was got by the full-blooded horse Roebuck, his dam was bred by Brigadier Ruggles; and from his noted imported Arabian horse, Joe Miller. Romeo is allowed to be a horse of beauty, strength, spirit and speed. Augustus Taylor, April I9, I795.

Young RAVEN-Will be kept at the stable of Thomas Harvey in Harwinton the ensuing season. The horse requires no recommendation. His stock (which may be seen in almost every town in this State) is alone sufficient in his favor, without describing his figure. His sire was old Whirligig, full-blooded, his dam a Narragansett. Three dollars or ten shillings required for his services.

May 6, 1795.

DAUPHIN-Is in high order and will be kept at Jonathan Beach's stable in Goshen. This horse was at Major Lewis' stable in Goshen, two years since, and is so generally known and admired as to save the trouble and expense of much description and pedigree. He is a beautiful blood horse, I $5 \mathrm{r} / 2$ hands high, bony, lengthy, strong and active: his stock in high estimation. His sire was Lloyd's old Traveler, his dam by Figure, his grandam by Dove (all imported by Dr. Hamilton to Calvert County, Va.); his great-grandam by Godolphin Arabian. Price $\$ 4$ or I 5 shillings.

May 3, I795.

SOUTHERLAND-Will be kept this season at my stable in Goshen. He is a fine chestnut, I 5 hands high, four years old. His sire was that noted imported horse Southerland; his grandam a full-blooded Narragansett; was bred in Albany County, State of New York. Terms, six shillings or twelve shillings. Pasturage for mares at usual rates.

Timothy Child, May i3, I795. 
DORCHESTER-Will stand at the stable of the subscriber in Norfolk, at the moderate price of seven dollars, four dollars or two and a half dollars. He is a dark bay, five years old, I $61 / 2$ hands high, well built, in exact proportion to his height; bred in England, travels with ease, is allowed to be a horse of elegance, strength and spirit.

Joseph Ives, May I 3, I 795.

Gray Fox-Will be kept this season at the stable of the subscriber in Salisbury, about four miles north of meeting-house, near colony line, the noted and famous horse Gray Fox, 8 years old, I 5 1/2 hands high. He is an iron gray. His sire the old Irish Gray. He is equal for spirit and movement to any horse in America. Terms, $\$ 3$ and $\$ 4$.

Hezekiah GeER, May i3, i795.

DukE-The famous horse Duke will be kept this season at the subscriber's stable in Litchfield, three miles west of the meeting-house. Said horse is a bright bay color, black mane and tail, I 5 1/2 hands high and every way well proportioned. He is called by good Judges as good a blooded horse as any in these parts. The terms will be I 8 and I 2 shillings.

Solomon Kilborne, May i 3, i 795.

Young Claricus-A splendid dapple gray, i 5 hands high and only 5 years old, will be kept this season at Jacob Kilborn's stable in Litchfield. The color and elegance of this horse cannot fail of pleasing the man of fancy, as well as the spirited and ambitious farmer. Such are invited to call and view him and do themselves justice. Terms, six, twelve and eighteen shillings.

May 2O, I 795 .

HOGARTH-A spirited, noble blooded horse of good figure and excellent for stock, will be kept at Elihu Lewis' stable in Goshen the present season, at the reduced price of nine and eighteen shillings. Hogarth is a fine bay, I 5 hands high, mane and tail black. We should be warranted in saying much more of this horse than is proper for most who advertise. When examined, the judicious farmer will determine for himself.

May 20, I 795.

BRILLIANT-Will stand the present season at the stable of the subscriber in Canaan, at the reduced price of $\$ 3$ the leap, $\$ 4$ the season and $\$ 6$ to insure foal. Brilliant is full I 5 hands 3 inches high and of just proportions; strong without coarseness and fine without weakness, and elegant in movement and carriage. There are a number of his colts in this vicinity, got the last season, which may be seen without trouble. There can likewise be seen one of mature 
age, which he got at Castleton, in Vermont, which shows such a similarity of the horse that no one will doubt the relation. The terms of payment made accommodating, and constant attendance given. -

William Holabird, May 19, 1892.

Young Highlander-Will be kept this season on Mondays, Tuesdays and Wednesdays at O. Seymour's stable in Litchfield, and on Thursdays, Fridays and Saturdays at the subscriber's stable in Milton, where he will cover at the low price of $\$ 2$ the season, eight shillings the single leap and $\$ 3$ to insure a foal. Young Highlander is four years old next June, is of a dark bay color, remarkably round and well built, and is allowed by good judges to be one of the finest horses of his age in the State. His sire is the noted old Highlander imported from England; his dam is three-fourths blooded. The subscriber feels himself warranted in saying that there is no horse equally well made that will be bred to mares at so low a price. He invites those who wish to improve their stock to call and see for themselves.

Samuel Carter, April 20, i 803.

Young KoUliKHAN-Will be kept the ensuing season at the stable of Aaron Bradley, in Litchfield, at the moderate price of eight and ten shillings. Said horse is of a bright bay color, 15 hands high, seven years old; got by old Koulikhan; his dam was by Morwick Ball, an imported horse kept by John Hart at the Rising Sun four miles from Philadelphia on the York road. He can recommend himself for traveling under the saddle or in harness equal, if not superior, to any horse of his size. His foals are known to be good in the county of Luzerne, Penn., where he has been three successive seasons.

May 4, i 803 .

Sir Peter Teazel - That noted horse, Sir Peter Teazel, imported from England by B. Tallmage, E. Starr and B. Norton in the year I 797. His breed and pedigree have been considered to be equal to any horse that could be selected in England. Sir Peter is dark brown, $161 / 2$ hands high; elegantly made. His stock is large and many of his colts very fine. Sir Peter will be kept the ensuing season at the stable of Jonathan Beach in Goshen, and will be bred to mares at the very reduced price of $\$ 5$ the season. Sure foal may be contracted for. Proper attention will be given and pas. turage provided for mares.

Jonathan Beach, May i i, i803.

N. B.-Produce will be received in payment, if delivered to $\mathrm{F}$ Norton by the first of January next. 
CRAB-Will be kept the ensuing season at the old stand, formerly occupied by Col. Elihu Lewis, in Goshen, East Street, and at Capt. Samuel Hulburt's in Winchester, viz.: one-half the time in Goshen, the other half in Winchester, and to be moved regularly once a week during the season, where he will be let to mares at the reduced price of $\$ 3.50$ to $\$ 2$. Sure foals may be contracted for on reasonable terms. Crab is of a beautiful black color, full $\mathrm{I}_{5} \mathrm{I} / 2$ hands high, eleven years old this spring; was bred in Maryland. He was got by Mr. James Pierce's full-blooded horse, Sweeper. Crab's dam was a bay mare called Lady Legs, bred by Gen. John Cadwalader, etc. Long pedigrees at the present day do not make the best colts $\mathrm{He}$ is a sure foal-getter and his stock prove excellent. Every attention necessary will be paid.

\section{Elihu Lewis, May i I, I 803 .}

LA PRISQUE-A full-blcoded Canadian horse, brought from Montreal the winter past, will be kept this season at the stable of the subscriber in Goshen, East Street, at the low price of $\$ 2$ the season. La Prisque is 8 years old this grass; near I 5 hands high; a handsome gray and as active and well proportion as any horse of that breed that can be produced. This is an opportunity for farmers to raise horses which will answer for saddle and harness; as those longlegged, slender-built descendants from England do not generally answer every purpose. $\quad$ ELIHU LEwIS, May 21, 1807.

Young Drone-The property of B. Tallmage and A. Stockholm, will be kept the ensuing season at the stable of Col. R. Hannah in Bethel, where any person disposed to raise good stock may contract on reasonable terms.

May 27, I 807.

SWIfTSURE-This famous young Virginian horse, Swiftsure will be kept the ensuing season, commencing the Ist of May, at the stable of Mr. Geo. Thompson, near Oxford, three days in the week. The other three days of the same week at Woodbury. The week following the first days at Bethlehem at the stable of Sheldon Leavitt, south of the meeting-house; the remainder of the week at Col. Ford's stable in Watertown, changing alternately through the season. Terms $\$ 4 ; \$ 9$ the season; or $\$ 13$ to insure the foal, inclusive of half a dollar to the groom. Swiftsure is a bright bay, handsomely marked, about I 5 hands high and nobly proportioned in body and limbs and for correct movement and activity is excelled by none. His sire was Young Jimcrack, a noted horse for spirit and elegance, whose grandsire was by the famous and much admired 
Goldfinder; his great-grandsire was the old Goldfinder, the most noted and elegant horse in all England; his g. g. grandsire was old Plato, weil known to all the English sportsmen. The dam of Young Jimcrack was the Flying Jib, in high estimation on the Virginia turf; her sire was Young Plato, whose dam was got by the imported Tasker. The dam of Swiftsure was a Fearnaught mare; his grandam was by the noted Partner; his great-grandam by Hannibal; his g. g. g. dam by imported Liberty; his g. g. greatgrandam was from the celebrated Ruth, imported by Dr. Norris; his g. g. g. g. grandam, by Beaumont's famous horse, Paymaster, imported by Mr. Rylander of New York.

\section{Samuel Carmen, May 6, i807.}

ORINOKO-The well-bred horse, Orinoko, will be kept the ensuing season at the stables of Wadhams \& Thompson, in Goshen, and David Huntington \& Co., in Litchfield. He will be at Wadhams \& Thompson's on the first Monday in May, and move from thence to Litchfield, where he will be kept on Wednesday and Thursday of each week, during the season. Terms $\$ 3.50$ and $\$ 5$ the season. Sure foals may be contracted for on reasonable terms. Orinoko is a beautiful iron gray, full I 6 hands high; is six years old this grass, and was got by the noted horse Brilliant; his dam was an excellent blooded mare. A continuance of long pedigrees is so contrary to my feelings that I shall neglect it. Those desirous of that search will find upon inquiry that he is equal, if not superior, to any horse in the State. Those gentlemen who prefer a horse on account of his stock may satisfy themselves by calling at his stand in Goshen, where may be seen some of his colts, which I presume will satisfy the eye of the spectator. $\mathrm{He}$ is unequalled as a sire within many miles.

ISAAC CARRINGTON.

\section{(From Connecticut Fournal, I793.)}

Noted horse Goldfinder, bay, 15 1/2 hands, foaled 1783 , in Newtown, etc.

Cincinnatus, I 6 hands, by imported Bay Richmond: dam by Fearnaught; in New Milford.

Young Rainbow-He is of that excellent breed called the Narragansett, all but one-eighth, which is Arabian. He was got by Col. Wardsworth's Narragansett horse that was sold for a vast sum of money, that there has been such a noise in the world about. His dam was said to be as capital a mare as ever was bred in Bradford. She was about $15 \frac{1}{2}$ hands high and equally officious for the 
cclxxii

dexterious. The Young Rainbow is said to equal his sire in gracefulness, agility and for the dexterious; at $\$$ I I.

I 793-Northford in Bradford.

JAMES LinsLey.

I793-Will cover this season, the full-blooded horse, True Briton, in East Haven and North Bradford at twelve to thirty shillings; about I 5 hands, just and well formed, bright bay with star, moves with great activity; colts prove large and handsome. He was got by old True Briton: dam by Hyder Ally; two imported horses which need no encomium. JOHN SPALDING, JR.

Bold Hunter in Guilford, etc. ; 15 I $/ 2$ hands; foaled 1786.

\section{J. Nichols.}

Wildfire, by Ranger, foaled I 787 , bay, about I5 hands; handsome and active.

Tartar, black, I 5 hands; by Lath: dam by True Briton. (Probably De Lancey's, who owned Lath.)

Peacock in North Haven, etc.

Hyder Ally, directly from Maryland; got by Arabian Ranger: dam, Othella; snow white, I $53 / 4$ hands.

Strayed or stolen, a large black horse about $14 \frac{\mathrm{T}}{2}$ hands high, trots, paces and canters; and another, brown, I5 hands, that also paces, trots and canters.

I794-Demarcus Mercury, gray, I5 hands, foaled I790; got by a son of Arabian Ranger: dam by imported Roebuck.

Young Tartar.

Young Ranger, I 5 hands; by old Ranger.

Hogarth, bay; by Milton, son of imported Wildair.

Highflier, from Long Island, dapple gray, $14 \frac{1}{2}$ hands, threefourths blooded.

Claronet in Guilford, etc., gray, I $5 \frac{1}{2}$ hands; foaled 1787 ; got by Sweeper of Virginia : dam by imported Dove.

Young Wildair; foaled I 790 ; bay, I $5 \frac{3}{4}$ hands; by old Wildair, imported.

Will cover the season at the stable of subscriber, Young Kitt, the full-blooded Narragansett horse. Young Kitt came from an excellent full-blooded Narragansett mare, and his sire is the famous horse which was owned by Colonel Wardsworth of Hartford which wants no further encomiums than was given here the last season by Mr. James Linsley of Northford. Young Kitt is dark sorrel with star, I $4 \frac{1}{2}$ hands, well spread, good limbs, good carriage, high spirits and full of activity. No horse can exceed him in the saddle; 
he is most natural to his trot, which is so easy that it will scarcely stir his rider; but will pace, trot and canter at pleasure of his rider, but no horse can exceed him for swiftness on the pace. Terms, \$I to $\$ 2.50$.

ISAAC FOOT, Northford, April 29, I794.

Cincinnatus again.

Young Rover, by imported old Rover; gray, 16 hands. D. Holt.

Young Syphax, 16 hands, by imported Syphax.

Claronet, by Sweeper: dam by Dove; 15 1 2 hands, etc.

I 80o-Flying Gallop and Matchem, two elegant imported studs from England, kept by Freeman Kilburne at Hartford.

I $80 \mathrm{I}$-None.

I 802-For sale-Two studs, one of Canadian breed.

I $803-1805-N o n e$.

I 806-Black Prince and Young Guido at the stable of the late J. Ramsay.

President. Bashaw.

Sam Whitman.

I807-For Sale-the noted stud Black Prince. Enquire at the late Capt. Jonathan R. Ramsay's.

1808-Auction of Arabian horses in Milton, Mass., of the late Gen. Henry Jackson.

Mammoth, bay, 16 hands, by Black Prince.

J. J. Ramsay, Yorick.

Fifty sprightly pacing horses wanted for shipping.

Sam KellogG.

Also a large number of shipping horses wanted by E. Kilburn. I8IO-The subscriber has purchased the noted stud horse Yorrick, formerly owned by Capt. Samuel Whitman, West Hartford. He will be kept in Chatham.

M. Pelton.

I 8I3-None.

I 8 I4 -Tamerlane in East Hartford, bay, 16 I/4 hands, by Tamerlane, and bred in Pennsylvania.

L. ButLER.

Young Black Prince in Willington, etc.; also Ellcorn from New Jersey.

E. Howe.

I 824-Middlefield, etc.-Magnum Bonum of Lewis county, N. Y., bred by J. A. Halliday, got by imported Magnum Bonum.

I 830-Washington Gray by the noted horse Washington Gray at Windham, Conn.

I 834-Wanted-Thirty shipping horses at Middletown, Conn.

In the Norwich Packet of May 30, I793, is advertised Young Ranger, at Lebanon. 
cclxxiv

\section{(From Hartford Courant, May i3, I767).}

No. 133- Strayed or stolen from the subscriber at Newington a large black mare colt, with star and off hind foot white, a natural pacer, about 14 hands high, branded W on left shoulder and not docked when she went off.

JoHN LUsK. trots.

Strayed from Weathersfield, a dun colored horse colt, paces and

No. I 39-Strayed or stolen from Weathersfield, light gray mare about I 3 hands high, a natural pacer, supposed to be 13 years old. She is ill-tempered and apt to kick.

N. Hurlbut, Aug. 24, I 767.

Strayed, etc., from Hartford, dark roan mare, no white, a natural pacer, about i 8 years old.

\section{J. Sмiтh, Hartford, Sept. 2 I, I 767.}

Stolen at Northampton, iron gray mare, 4 years old, between I 3 and I 4 hands. She trots chiefly.

Selah Wright, Sept. IO, I 767.

No. I 46-Strayed etc., chestnut mare about I 4 hands, 4 years old, both paces and trots, but rather inclined to pace and carries her head very low, of somewhat slender make and a short mare.

\section{JABEZ SWIFT.}

Strayed, etc., in Middletown, brown bay horse, 4 white feet, about 14 hands high, and near white, paces and trots well, about 7 or 8 years old.

Elihu Starr, Oct. 3, I767.

Stolen in Litchfield, black or dark brown mare, about I 4 hands high and about i 4 years old, both paces and trots, but rather inclined to pace, very large ears.

IsAAC Bull, Oct. 26, i 767.

No. I 5 I-Taken up as a stray, gray horse, natural trotter, about I 3 I $/ 2$ hands. MEDAD Webster, Hartford, Oct. 9, I767.

Strayed, etc., in Middletown, a small light bay Dutch mare, about $\mathrm{I} 2$ years old, very fat, never docked.

Benj. Henshaw, Oct. 28, i 767.

Strayed, etc., black mare, with star, about I $43 / 4$ hands, paces.

Caleb Olmsted, Hartford, Feb. i 7, i 768.

No. I68--Strayed, etc., sorrel mare, about 9 years old, I4 hands, natural pacer.

JoHN BENTON.

No. I73-Strayed, etc., black mare colt, 2 years old, about I 3 hands.

THOMAS BARKER.

No. I 83 - Strayed, etc., bay 2 years old mare colt, about I 3 hands, natural pacer.

Elisha Cornish, Simsbury, May 27, 1768. 
No. 184-Broke into common field at Chatham, sorrel mare, about 13 hands, age unknown. June 30,1768 .

No. 184 -Stolen, black mare with stripe in face, left hind foot white, natural pacer, 3 years old.

NOAII IsBELL.

No. 1 84-Strayed, etc., brown horse with star, $14 \frac{1}{2} 2$ hands, natural pacer, about 7 years old.

Azariah Smith, Southington.

No. I87-Taken up as a stray, black mare about 14 hands, 4 years old, star and one white foot, natural pacer.

Benoni Densley, Windsor, July 25, I 768.

Strayed, etc., chestnut bay horse with white stripe in face, about I4 hands high, 7 years old. Natural pacer.

Andrew Culver, Farmington, July i4, i 768.

No. 103-Stolen, etc., yellow sorrel mare, with blaze in face and white hind feet, about 14 hands, 15 years old, natural pacer.

Consider Burt, Hartford.

\section{(From The Hartford (Conn.) Courant.)}

Strayed or stolen from me the subscriber, out of a pasture near Landlord Lewis' in Farmington, on Friday the 7 th day of November last, a dark brown mare with star, saddle gaul on her left shoulder, no brand, about I 4 hands high, shod all around when taken away, three years old. Whoever will take up said mare and convey her to me or give intelligence so as I may find her, shall have a reasonable reward, and all necessary charges paid by me.

\section{Allyn SMith, Dec. I, i 766.}

The distemper among horses which has afflicted New Jersey, Philadelphia and New York, having reached this town and parts adjacent; we think it may be no disservice to our readers, to give a short account of the Naiure of that distemper and the best method of cure, which has been hitherto discovered. It begins with an inflamation in the glands of the throat, which soon fumifies and suppurates, then spreads its effects to the head and eyes; from whence the matter is discharged through the nostrils.

To cure which begin with repeated bleeding, give the horse morning and evening, a ball of brimstone and Saltpetre, from half an ounce to an ounce of each, made up in paste, inject sharp vinegar in his nostrils, and bathe the outside of his throat with vinegar, hog's lard and camphor.

N. B.-The putting tar on the bridle bits of such horses as have hitherto escaped the infection, has proved a good preservative against it.

November 30, I 767 . 
cclxxvi

I 768 -None.

I 769-Handsome Harry, dun color, with list down back and blaze in face, $14 \mathrm{I} / 2$ hands, trots all, three-fourths blooded, a very smart horse, runs a swift race, is five years old, and was bred at Narragansett by one John Easton. NeIl McLean, JR.

Strayed or Stolen-Black horse, $14 \% \frac{1}{2}$ hands, four years old, natural pacer.

C. Phelps, Windsor.

Ditto-Black, I 4 hands, natural pacer.

D. JONES.

Ditto-Bay mare, I 4 hands, pacer, trots. E. Williams.

There are many other similar advertisements, we should judge hundreds of them, horses of all colors, all less than I 5 hands, and nearly all pacers.

Strayed, etc., black mare, small stripe in face and white hind foot, 3 years old, I 4 hands, docked tail and carries head low and trots chiefly. John TRYON, Litchfield, July, I 769.

Strayed, etc., black horse, $14 \frac{1}{2}$ hands, 4 years old, natural pacer, goes narrow behind.

Cornelius Phelps, Windsor, July io, i 769.

Taken up, black horse, with star about $14 \frac{1}{2}$ hands, I 2 or 13 years old.

ABNER PRIOR.

Strayed, etc., large sorrel mare, about I4 years old.

Elijah Keno, Suffield.

Strayed, etc., in Weathersfield, sorrel mare, with white star, about I 3 hands, both paces and trots.

JOSEPH RICHARDS.

Strayed, etc., in Coventry, Conn., dark bay or black horse, about I $4 \frac{1}{2}$ hands high, thick set and well made, very rarely trots, paces square and large, 8 years old.

\section{NATHAN Strony, Sept. 22, I 769.}

Strayed, etc., in Newington, sorrel horse, blaze in face and white feet, about $\mathrm{I} 4$ hands high, 4 years old, both paces and trots.

\section{JOHN GOODRICH.}

Taken up, etc., in Litchfield, gray mare, about $14 \frac{1}{2}$ hands, both paces and trots.

JABEZ FRIESLY, Oct. 30, I 769 .

Strayed, etc., black horse, in Hartford, about I4 hands, natural pacer.

DAVID JONES.

I 770-Samuel Earnsworth, Hartford, has two likely stallionsone the noted horse lately owned by Neil McLean, Jr., and is counted by them that are judges to be the swiftest horse on the continent to take him on the three gaits, pace, trot and run. The other is a very large, thick, heavy horse bred in Canada.

$177 \mathrm{I}-$ Good pasture for mares at a reasonable price. 
Wanted by the subscriber, a few sprightly pacing horses from three to six years old, about $I_{4}$ hands high.

$$
\text { Joseph Bunce, Hartford, June 24, I77I. }
$$

1772-Ranger again in Hartford. JAMES NiCHOLS.

1775-76-Half English horse, Fox; dam, Narragansett, nearly I5 hands, near Salisbury, Conn.; bred in Newport, R. I.

Levi Allen.

Strayed or stolen, mare of dun color, paces and trots.

A. KING, New Lebanon, Conn.

To stand for the season at Mr. Thomas Birds in Salisbury, two miles west of the Furnace. The beautiful horse called the Fox, the property of Levi Allen. I shall only say in recommendation of said horse, it is the same that covered at Mr. Philip Spencer's in the Oblong last season. Two dollars the season. Pasturing provided for mares. Levi Allen, Monday, April i, i776.

At the stable of the subscriber in Litchfield the famous horse called the Leopard, is of the Narragansett breed one-quarter blooded and is equal for beauty, strength and swiftness to any in America, without exception. Terms, $\$ 1$ and $\$ 3$.

\section{Moses Seymour, April 22, i 776.}

Advertised in 1777 and ' 78 at North Killingsworth, by Oliver Parmerle, who says: "A deep sorrel color with blaze in face."

I 776-The famous black English horse Paoli, will cover again this season at the stable of the subscriber in East Windsor, two and four dollars the season.

John Watson, East Windsor, May 6, i 776.

At the stable of Capt. Jacob Bogardus, in Sharon, the beautiful strong, well made bay horse, Yorick. A full blooded Hunter, was bred by Sir Fletcher Norton, and imported by John Foxcraft, Esq., into Virginia, in the year $177 \mathrm{I}$, and is one of the best horses for mending the breed of this country of any one ever imported into these parts. He is fifteen hands and a half high, and since he has been in America, has got some of the best colts for either coach, wagon or saddle, of any horse whatever. He is now the property of Col. Peter R. Livingston, who has purchased him at a very considerable sum.

Sharon, April io, I 776.

At the stable of the subscriber, in Hartford, a four year old horse, called Union (Continental Union). Terms, ten and twentyfour shillings. This horse is truly famous for strength, size and beauty, esteemed by the best judges, inferior to none of the breed; is one of the famous old Ranger's first colts, and by a dam of the 
cclxxviii

same breed, equal to any for beauty and behaviour. Terms, $\$ 6$ and $\$$ IO.

CALEB Bull, Hartford, May 4, I 776.

N. B. - Good stabling and pasturing for mares, if required.

The famous sorrel Narragansett horse, known by the name of Hammon Horse, will be kept this season at the stable of the subscriber, in Hartford. Terms, \$I and $\$ 2$.

Ashbel Steel, Monday, May 27, i 776.

Good pasture for mares at 2 s per week.

In Litchfield, famous horse Wild Boar of the French breed, and is singular for beauty, strength and swiftness; at ninepence to one shilling and sixpence.

Calvin Bissell.

At the stable of the subscriber, the dark gray horse Sportsman. He is one of Ranger's colts, and allowed to be equal to any of his getting in this country. He is an easy canter for the saddle, an excellent trotter for the chaise: The price is nine and eighteen shillings. As I mean to keep him some years for saddle, chaise and troop, don't mean to crowd him with mares or with high keeping this season; would be glad if those brought to him might be good breeders.

\section{Selah Norton, Monday, May i3, i 776.}

At the stable of the subscriber in North Killingsworth, the horse called the Leopard. He is of the Narragansett breed, onequarter blooded and is equal for beauty and strength and swiftness to any in America without exception. The price is $\$ \mathbf{1 . 7 5}$.

Oliver Pariele, Killingsworth, April i 8 , i 777.

The Dolphin, at the stable of the subscriber, in Hartford, at $\$ \mathbf{2}$ and $\$ 6$ the season, he is three-quarters blooded and four years old this spring, and in beauty and strength is such as will meet with appreciation.

DANiel OlcotT, May I2, i 777.

The famous horse called Young Wildair at the stable of Deacon Brown, in Sandisfield. Terms, $\$ 8$. This horse is six years old, rising I 5 hands high, of a bright bay color, seven-eighths of the English breed, got by the famous old Wildair, whose fame is so universaily known, that it wants no recommendation, this horse for beauty, strength and courage none exceeds him on the continent.

Good pasturing for mares.

Jeremiah Whitmore, Sandisfield, April i 2, i 777.

Advertised in 1778 at Josiah Burnham's in Farmington, who says: "The horse is 7 years old, bay; got by Wildair, grandson of the old Godolphin Arabian, the best horse that was ever brought into England." 
Advertised in I 779, at stables of subscriber in Sandisficld, Young Wild Deer, "he is the same horse that was kept in Sandisfield in the year i777." Josian Stillman, Sandisfield, April i6, i 779.

Wild Deer is advertised in I 780 , by Josiah Stillman at Sandisfield.

Young Wild Deer is advertised by J. Stillman at Sandisfield, $\mathrm{I} 78 \mathrm{I}$, and again $\mathrm{I} 782$. "He is a horse of strength and beauty, equal perhaps to any in America."

In 1783 , the famous horse Wildair, at stable of Joseph Stillman, in Sandisfield, "same horse that covered the four last seasons."

At the stable of Capt. Joel Pratt of Spencer Town, the black horse called the Flying Buck. He is a horse of size, strength and beauty, full I 5 hands high, 8 years old, three-quarters blooded. Price $\$ 4$ and $\$ 2$.

JoEL PRATT, Spencer Town, May 23, I 777.

The beautiful horse, Young Ranger, at the stable of the subscriber in Hartford. He was got by the famous horse Ranger, who has been a number of years kept at the same stable, is four years old. The price is 8 shillings and $\$ 3$.

\section{JAMES NiCHOLS, Hartford, June 5, I 777.}

Again in 1778-9-80 by same party who says: "Equal perhaps to any horse in America, and of the true Barbary breed."

Advertised in 1782 by James Nichols at Hartford, and again in I 783 .

Advertised I 784 by Samuel Wolcott, East Windsor, Conn., who says, "this horse belonged to Capt. J. Nichols and was kept by him last season."

The Leopard advertised 1778 as follows: at the stable of the subscriber in Killingsworth, at $\$ 2$ the single leap or $\$ 3$ the season, the Leopard, equal for beauty, strength and swiftness, to any horse in the State; a deep sorrel color, blaze in his forehead, one-quarter blooded and of the Narraganset breed.

Oliver Parmele, April i 8, i 778.

Young Wildeer advertised I 778 as follows: "Will cover this season at Josiah Burnham's stable in Farmington, the famous bay horse Young Wildeer. This horse is seven years old, got by the old Wildeer [Wildair], grandson to the old Godolphin Arabian the best horse that ever was brought into England. This horse is 15 hands high, well proportioned, for beauty, strength and activity none exceeds him, price is $\$ 8$ the season; he is the same horse that was kept at Sandisfield last season." 
$\operatorname{ccl} \operatorname{xxx}$

1778- "Will cover this season, at the stable of the subscriber, price $\$ 3$ or $\$ 5$ the season, the famous horse Young Ranger. He is a horse of size, strength and beauty equal perhaps to any in America, and of the true Barbary breed. JAMES Nichols."

"All gentlemen who wish to improve the breed of horses, may be informed that the famous horse Jolly, will be kept this season by Ebenezer Center, at Hartford, West Division; suffice it to say that the Jolly is a beautiful bay, almost ${ }_{5} 5$ hands high, well bodied, and can boast of as fine limbs as any horse in New England; he is more than three-quarters blooded; he will cover at the subscriber's stable at $\$ 4$ and $\$ 8$. Any who wish to have colts insured may have it done for proportionable advance. EBEN. CENTER, May I 5, I 778."

I 778 -Macaroni, three-fourths blooded, at Killingworth and Fairfield.

Sportsman is advertised 1778 at Justin Morgan's stable, West Springfield. Terms, $\$ 8$ and $\$ 4$; described, dapple gray; "his excellences for beauty, strength, saddle, harness and fine colts, are so well known that there needs no further description.

" N. B.-It is the same horse kept at Colchester last season by the wrong name of Young Ranger."

Advertised I 779 at the stable of Joseph Butler, Weathersfield.

Advertised May 19, I 780 at Samuel Whitman's stable in Hartford, West Division, at a very reasonable price for cash or produce.

"N. B.-The same horse covered last year at Weathersfield, he is much noted for getting fine colts. Hartford, May 19, I780."

Advertised I78I at the stable of William Warner, New Canaan, Conn. "By the famous Barbary horse, Ranger."

Sportsman advertised again 1782 , at the stable of Landlord Asahel Wadsworth in Farmington.

"Will cover this season at the stable of the subscriber in Hartford, the famous horse Ranger. He is a horse of size, strength and beauty, equal perhaps, to any in America, of the true Barbary breed, bred in England. The price is twelve shillings, lawful money, the single leap, and thirty shillings the season. JAMES NichoLS."

N. B.-He is the same horse that was in my keeping last season.

A horse under name of Ranger, a son of Old Ranger, was advertised in 1784 by Samuel Whitman, Hartford, West Division.

In 1778 he was advertised by James Howard of Windsor who says "The imported horse called Ranger, formerly owned by Col. Wyllys of Hartford, will be kept this season at my stable in Windsor. Terms, $\$ 8 . "$ 
The improved $\Lambda$ rabian Ilorse called Ranger, formerly owned by Col. Wyllys of Hartford will be kept by James Iloward at his stable in Windsor. Terms, eight dollars. This horse is too well known to want any further recommendation.

N. B.-Good pasturing for mares. Tuesday, May 5, 1778.

"Will cover this season at the stable of the subscriber in Hartford, the famous horse called the Wildeer, known by the name of the Church Horse. This Horse is judged to be superior to any in New England, and is the same that was in my keeping last season.

\section{William Hooker, Tuesday May 19, I778."}

Advertised in I $78 \mathbf{I}$ at stable of William Hooker, Hartiord. Advertised in 1782 at Mr. Freeman's stable at the farm. "The same horse that covered at Mr. Hooker's stable last year and formerly at Mr. Church's at Springfield. Hartford, May I6, I778."

"Sportsman, the dapple gray horse will cover this season at Justin Morgan's stable in West Springfield, at $\$ 8$ the season and $\$ 4$ the single leap; his excellence for beauty, strength, saddle, harness and fine colts are so well known that there needs no further description.

N. B.-It is the same horse that covered at Colchester last season by the wrong name of Young Ranger."

Will be kept at the stable of the subscriber in Hartford, the horse called Continental, of a silver dapple colour and is the same horse that hath been in his keeping years past. Terms, six and ten dollars.

Caleb Bull.

N. B.-Pasturing for mares if required.

Tuesday May 26, 1778 .

This is to give notice that the Macaroni will be kept this season at Killingsworth, he being three-quarters blooded or English, and allowed by good judges to be very neat, coming five years old, and further recommendation I shall leave him to do. Terms, $\$ 5$.

Will be kept this season, at the stable of Mr. Johathan Lewis in Fairfield, price two dollars and a half and five dollars, the famous horse Salacx. He is a horse of size, strength and beauty, equal perhaps to any in America.

STURGES LEWIS.

Will cover this season at the stable of the subscriber in Coventry old Parish the famous horse called Young Snip, is a horse of beauty and size equal to any in this State, he is a fine pacer and trots well.

John Stanton, Tuesday, June 2, i 778.

Will be kept this season, at the stable of the subscriber in 
Sandisfield the famous horse Young Wild Deer. He is a horse of strength and beauty, equal perhaps to any in America.

\section{Josiah Stillman, Tuesday, April 27, i 779.}

N. B.-He is the same horse that was kept in Sandisfield in the year 1777 .

Sandisfield, April I6, I779, advertised again by J. Stillman in I 780. This is doubtless the horse Wildair advertised, I 777 at Sandisfield by Jeremiah Whittemore.

Full blooded English bay horse Roebuck, will be kept this season at ths stable of Theodore Parmele of Goshen in Litchfield County, at the moderate price of thirty and fifteen dollars. He is $\mathrm{I}_{5}$ hands and one inch high, equal for strength and beauty, to any horse in America. Theodore Parmele, Goshen, April 22, i 779.

The famous horse Young Paoli, will be kept this season at the stable of the subscriber in Somers. He is a horse for strength, beauty and goings equal perhaps to any in America, four years old, and upwards of 15 hands high. Amariah KibBe, May i 8, 1779.

Advertised again 1780 .

To cover, the beautiful black horse Young Wildair, at Nicholson's Mills, at New Milford, in the County of Litchfield, at five hard dollars the season, or ten to insure a colt, or continental currency at the rate of the common exchange. Young Wildair is 14 hands and three-quarters high, is now rising of six years old, strong, lengthy and very handsome; is an excellent grandson of the famous Wildair, allowed to be the best horse that ever was in America. His blood was in so great repute in England that, though nineteen years old, a great price was paid for him and shipped home, where the last accounts we had of him he covered at 25 guineas a mare. This horse is well calculated to get racers, hunters and saddle horses; is a horse of speed, game and temper.

N, B.-His colts prove chiefly black.

May 25, I 779 .

Sportsman-The dapple gray horse covers this season at the stable of Mr. Joseph Butler in Weathersfield. He is allowed to be as fine a horse for colts as any old Ranger has left behind him.

June I 5, I 779 .

The famous horse Wild Deer will cover again this season at the stable of the subscriber in Sandisfield.

$$
\text { Josiah Stillman, Sandisfield, May 9, i } 780 .
$$

N. B.-Good pasturing for mares may be had on reasonable terms. 
Will be kept this season at the stable of the subscriber in Southwick the famous horse Dearing. He is a horse of size, strength, beauty and swiftness, equal perhaps to any in the United States.

$$
\text { James Hugins, April 19, } 1780 .
$$

Will be kept this season at the stable of Danicl Graves in Palmer, the famous and well-bred horse Young Juniper, $141 / 2$ hands high, and is seven years old this spring. His sire was the old Juniper, bred in England and imported from thence to Williamsburg, in Virginia. His dam was the Nancy, whose sire was the Traveler, formerly owned by De Lancey of New York. The Young Juniper is a horse of great beauty, strength and activity.

Young Ranger will cover this season at the stable of the subscriber in Hartford. He is a horse of size, strength and beauty, equal to any in America. No trust. JAMes Nichols, May 23, I 780.

N. B.-Said Nichols has for sale a likely stallion, three years old coming, one of old Ranger's colts.

Will be kept this season at the stable of the subscriber in Somers, the famous horse Young Paoli. He is a horse of strength and beauty and goings equal to any in America, is I 5 hands and one inch high, five years old and half blooded.

Amariah KibBe.

Sportsman-The dapple gray horse (not inferior to any of old Ranger's colts) will cover this season at Samuel Whitman's stable in Hartford, West Division, at a very reasonable price for cash or produce.

N. B. - The same horse covered last year at Wethersfield. He is much noted for getting fine colts. Hartford, May I9, I780.

Sportsman-The dapple gray horse (by the famous Barbary horse Ranger) will cover this season at the stable of Lieut. William Warner, in New Canaan. He is so famous a horse, he needs no description. April I7, I78 I.

Will be kept this season at the stable of Major William Goodrich, in Stockbridge, the famous horse known by the name of Young Figure; till lately owned by Gen. Ethan Allen of Vermont. The horse is the colt of old Figure, the most noted horse that has ever been imported from Europe; he is come of an English mare of equal character, as his colts in Bennington and its vicinity will witness.

William Goodrich, Stockbridge, March 29, I78 I.

N. B.-Pasture will be provided for such as may require it.

Will be kept this season, at the stable of the subscriber, in Middletown, and also every Monday at Esquire John Huff's, miller, in Meriden, for $\$ 3$ or two bushels of wheat the season, a dark gray horse, four 
years old, near I 5 hands high, nc horse of his strength has more activity or better carriage; his sirr was Colonel Wyllys' old Ranger.

A few sides of saddle leather to be sold for paper money.

$$
\text { J. Denny, May 28, I } 78 \text { I. }
$$

The famous horse Wildair will be kept this season at the stable of the subscriber in Hartford. He is so famous a horse that he needs no description. William Hooker, Hartford, May I9, I 78 I.

The beautiful seven-eights blooded horse Hermit, will be kept for mares at the stable of the subscriber, in New Milford, Litchfield County, Conn. Terms, six hard dollars, or six bushels of wheat, the season; three hard dollars, or three bushels of wheat the single leap; twelve hard dollars, or twelve bushels of wheat, to ensure a foal; the money to be paid at the taking away the mares, or the wheat to be delivered at the stable soon after harvest. Hermit is rising seven years old, I 5 hands and an half high, a beautiful bay; his sire Liberty, an imported horse, his dam got by Bulrock, from a half-blooded mare. Hermit's pedigree is so well known that it needs no repetition, $\mathrm{He}$ is, by the most competent judges, without exception, thought to be the best blooded and swiftest running horse in the New England States. Proper attendance will be given.

Nath. Durkee, Jun., May I 5, I78 I.

Young Wildeer will be kept again this season, at the stable of the subscriber, in Sandisfield. He is a horse of strength and beauty, equal perhaps to any in America.

N.B.-Good pasture for mares may be had on reasonable terms. Josiah Stillaian, May 5, i 78 I.

Young Fenocks will be kept this season, at the stable of the subscriber, in Granville. He is a horse of size, strength, beauty and swiftness, equal to any in America; is a bright bay, with good marks and full blooded; he was by the old Fennocks at New York, and gets the best of colts. Good pasturing for mares by the subscriber.

Abel Tillotson, Granville, May i i, i 78 i.

Wildair will be kept this season at Mr. Freeman Kilburn's stable at the Ferry, for four dollars single leap, or eight dollars the season, this beautiful bay horse is the same that covered at Mr. William Hooker's last year, and formerly at Mr. Church's, at Springfield.

N. B.-Pasturing for mares is provided for those that may want. Hartford, April 20, I 782.

Canter, one of old Ranger's colts, and from an excellent mare of the Narraganset breed, six years old, will be kept this season, at the stable of the subscriber in Harwinton, for fifteen shillings the 
season, or nine shillings single leap, pay in hand or a note on interest payable in October next. He is an excellent well made horse and very gay, his colts prove extraordinary good.

William AbERnetir, April 24, i782.

Ranger will be kept this season at Mr. Denny Tanner's, in Middletown. He is a dark gray horse, five years old, near fifteen hands high, his sire was Col. Wyllys' white Arab, well known by the name of old Ranger; this horse is handsome, strong and active, and certain for colts, he is allowed to be the best sire of that breed. The price is fifteen shillings the season, or nine shillings the single leap. Wheat or Indian corn will be received as pay.

The bay horse Liberty will be kept this season, at Mr. Thomas Chapman's, in Salisbury, (except the next week after the Igth of May, inst. and the second week in June) at the moderate price of three dollars, or four bushels of merchantable wheat, the season. It is four years since Liberty was brought off from Long Island, since which he has been kept in the State of New York, the greatest part of the time in the vicinity of Fish Kill.

May i 2, I 782 .

Sterling will be kept this season, at the stable of the subscriber in Sharon, three miles north of the meeting house. Terms, two dollars and a half and four dollars. Sterling is a beautiful bay, fourteen hands and a half high, full blooded and imported. This horse was kept last season at Philadelphia, earning 350 silver dollars.

Moses ReAD, April 26, I 782.

The famous horse Young Wildair, will cover again, this season, for ten shillings the single leap, or three dollars the season, at the stable of Josiah Stillman, in Sandisfield, he is the same horse that was kept the three past years as advertised in this paper.

N. B.-Pasturing for mares may be had on application.

Dolphin and Fearnaught, two beautiful full blooded horses, inferior in blood and figure to no horses on the Continent. Will be kept this season, at the stable of the subscriber in New Milford, County of Litchfield, State of Connecticut. Dolphin from Philadelphia. Terms, forty shillings and twenty shillings; four pounds to insure. Dolphin's sire is the noted bay horse Molton, which is as high a bred horse as any on this Continent: his dam imported from England. Fearnaught from Virginia. Terms, six and twelve dollars. Fearnaught's sire was the noted horse old Fearnaught from England: his dam a full blooded Arabian mare; each horse is upwards of fifteen hands high, five years old this grass.

Nathaniel Durkee, Jun., New Milford, May i I, i 782. 
Advertised I 784 at Woodbury.

"Sportsman, the dapple gray horse, by the famous old Ranger, so much famed for fine colts, will be kept this season, at the stable of Landlord Asahel Wadsworth in Farmington, at a price and upon conditions as reasonable as the times are hard. The excellencies of said horse are so well known he needs no further description.

N. B.-Pasturing for mares may be had very reasonable at the above place."

Flying Bullet, at the stable of the subscriber in Ashford, at twelve shillings the season, he is of a dark bay, full blooded, well built and has a beautiful carriage.

Thomas MaIn, Ashford, May 21, I782.

N. B.-Good pasture for mares.

Ranger will be kept this season at the stable of the subscriber in Hartford. He is one of the famous old Ranger's colts and allowed by good judges to be equal to any horse in the State.

\section{JaMeS Nichols, May 7,1782 .}

N. B.-Said Nichols has one of old Ranger's colts, four years old, for sale.

The beautiful full-blooded bright bay horse Hector. In the care of Mr. Ephraim Stow of Middletown. Terms, one dollar paid down or one bushel and a half of good wheat next fall; four dollars the season. This horse was imported from England by a gentleman of character in a neighboring State, and is known to be equal for colts, beauty and carriage to any horse in this State. Good pasturing for mares. Benj. Henshaw, Middletown, April 24, I782.

Advertised again at Middletown, I 783 .

For Sale-The beautiful bay horse Wildair, so well known for one of the best sires in the State that he needs no description. Cash bills of exchange on France or fine wheat flour will suit for pay. Enquire of Caleb Bull, JR., Hartford, March I, I 782.

To be Sold-A dark gray horse, rising five years old; his sire was Colonel Wyllys' white Barb, known by the name of old Ranger, is near I 5 hands high, is handsome, bony and strong, a known good saddle horse, and no horse has a better carriage, more spirits, or better temper, and is allowed to be as good a sire as any of that breed, and noted for certainty in getting colts. Also a black horse colt, rising three years old, 15 hands high, of the Wildair breed. Enquire of Dennis Tanner, in Middletown, who has for sale a quantity of saddle and other leather all at reasonable rates. 
Will be kept this scason on reasonable terms at the stable of the subscriber in Wintonbury, one of old Ranger's colts, halfblooded; he is of a light iron gray, blackish mane and tail. Pasturing for mares if wanted. Alsel Gillet, JR., May 6, 1783.

The famous horse Paoli will be kept at the stable of the subscriber for this season, in Somers, at the moderate price of nine shillings or eighteen shillings the season. The said horse is $15 \mathrm{I} / 2$ hands high, six years old this spring, is a horse of fine goings, activity and strength; well proportioned in every part as any horse, perhaps, without exception, being half-blooded.

$$
\text { Amariah Kibbe, Somers, May i9, i } 783 .
$$

Will be kept this season at the stable of the subscriber in Harwinton, the Young Britain, from the full-blooded horse called the Bold Britain and a half-blooded mare, and is a horse of strength, life and beauty equal to any. Aвijah Catlin, May 20, I783.

The famous horse Wildair will be kept again this season for ten shillings, or three dollars the season, at the stable of Josiah Stillman in Sandisfield. He is the same horse that was kept the four last years as advertised in this paper. He is a horse of strength and beauty, equal perhaps to any in the States. April 29, I783.

Ranger will stand this season at the stable of the subscriber in Hartford. He is one of the famous old Ranger's colts and allowed by good judges to be equal to any horse in the State.

\section{James Nichols, May 20, I783.}

The beautiful, full-blooded bright bay horse, Hector, at the stable of the subscriber till the 25 th of May inst. when, for the benefit of New Hartford and its vicinity, he will be removed to the subscriber's at West Farm, in the occupation of Mr. William Shattuck, in said New Hartford. Very little need be said in praise of this horse. He is well known; was imported from England when but two years old; finer colts were never got by any sire, and he is remarkably sure as well as handsome. Terms, nine shillings, three and four dollars to insure a colt; the price set thus low to encourage propagating this breed as much as possible, as the horse will go out of this State this summer. Good pasturing for mares.

Benjamin Henshaw, Middletown, May i, 1783.

Pilgrim will be kept this season, at the stable of Samuel Whitman, in Hartford (West Division), at three and five dollars. Pilgrim is a bright bay, fifteen hands high, seven-eights blooded, got by Bay Richmond; his shape is such as will please any that will call and look at him.

West Hartford, June 3, I 783. 
At the stable of Capt. Edmund Beach, at Goshen, in Litchfield County, the noted bay horse Phœnix, who was got by the valuable imported horse Wildair, who in color, figure and pedigree was allowed to be equal to any horse ever imported to America. His dam was blooded and allowed to be exceeding fine. Phœnix is now the property of Platt Smith, in the state of New York, in Dutchess County, where he has been for seven years past at one stable, and is allowed to get as good colts as any horse that was ever in that place, where they raise exceeding fine horses. Terms, five dollars and four dollars. Ediund BEACH, Jun.

Grayhound will be kept this season at the stable of the subscriber in Marlborough, Glastenbury; he is of a dapple gray, lately known by that name, is about fifteen hands high, well proportioned, equal perhaps for beauty and activity to any in the State, and is one of the Arabian breed. Terms, one and two dollars. Good pasturing for mares at a reasonable price.

Abraham Skinner, Jun., Marlborough, April i3, I 784 .

Ranger will stand this season at the stable of the subscriber in East Windsor. He is one of the famous old Ranger's colts, and allowed by good judges to be equal to any horse in the state.

\section{SAMUEL WOLCOTT.}

N. B.-This horse belongs to Capt. J. Nichols, and was kept by him last season.

The elegant and full blooded horse Dolphin will cover the ensuing season, one-half of the time at the stable of Capt. Benjamin Hicock, of Danbury, Bethel Society; the other half at the stable of Mr. Edmond Tomkins in Woodbury, formerly Tousy's Tavern, at the moderate price of four dollars and a half the season or two and a half the single leap. Dolphin is seven years old this grass, dark bay, rising I 5 hands high, and is thought by the best judges to be equal in figure, motion and beauty, to any horse in Connecticut. $\mathrm{He}$ is to continue at Hicock's till Saturday the 8th of May and then to be taken to Tomkins', and after that time to be from stable to stable (as above mentioned) on Saturdays of every week, during the season. Any kind of grain will be taken in payment at cash price. Good pasture may be had for mares at each place.

Woodbury, April I0, I784.

Ranger will be kept this season, at the stable of Samuel Whitman, Hartford, West Division, where any gentlemen may see a horse that makes a figure, either moving or standing, the most like old Ranger of any colt he has left behind him. April 29, I784. 
Bohema will cover this season at the stable of the subscriber in Watertown, North Socicty. Terms, four and two dollars. Bohema is fifteen hands and a half high, full blooded, supposed to be equal to any horse in strength, beauty and activity, his colts are judged to be equal to any. He is the same horse that was kept at Mr. Thomas Hickox, Junior's in this town in $178 \mathrm{I}$.

Samuel Rice, Watertown, April ii , 1784.

"The elegant, full blooded horse, from his shape and color, called Beautiful Bay [True Briton], will be kept this season at Landlord Miles Powell, Junior's stable, in Lanesborough; on account of the difficulty of the times, as low as twenty shillings the season to be paid in Cash or Grain in December next; he needs no further recommendation.

As his name is, so is he,

If you believe not, call and see.

N. B.-Good pasture for Mares and a good allowance for cash in hand. May, I 784."

The above horse was the sire of the original Morgan horse.

The beautiful bright bay, Young Briton, got by old Briton, of Fish Kill, an imported and full blooded Horse, of the best character, and from an excellent half-blooded mare, will stand this season at the stable of the subscriber in Harwinton, where he may be constantly seen, except once or twice a week he may be rode a few miles for the sake of exercise; he is 15 hands and a half high, gay, strong and active, an excellent character for getting Colts, and one of the very best of Saddle Horses.

William Abernethy, Harwinton, April 26, i784.

The Grand Arabian at the stable of the subscriber in New Cambridge, Farmington; he is five years old this spring, of a bright bay, with a biack list upon his back, about I 5 hands high; his Sire was the Young Wildair; is equal for beauty and natural activity perhaps to any in the State; the price will be one dollar, and two dollars the season.

David Newell, New Cambridge, April 29, I 784.

Young Hero will cover this Season at the stable of the Subscriber in Middletown at One and Two dollars. He was got by the famous imported horse Hero, lately owned in New Jersey. He is dark bay, about $\mathrm{I} 5$ hands high, and equal in strength and beauty to any horse in Connecticut.

William Gilbert, Middletown, May 25, 1784.

The noted horse Bohema will be kept the season at the 
stable of Benjamin Hicock in Danbury, Bethel Society at the moderate price of three dollars the season. Bohema is full blooded, I6 hands high, well proportioned, needs no great recommendation; has proved famous and sure for colts.

Danbury, May, I 785.

Ranger will be kept this season at the stable of John Gaylord, East Windsor, where any gentleman may see a horse that makes a figure either moving or standing; the most like old Ranger of any colt he left behind him. May, 1785 .

Will cover the present season at the stable of the subscriber in Wethersfield the beautiful Arabian horse got by the old Arabian called the Ranger. Terms, one and two dollars.

Bezaleel Lattimer, May, i 785.

Black Sloven will cover this season at the stable of the subscriber in New Hartford. Terms, one and two dollars. $\mathrm{He}$ is a horse $15 \mathrm{I} / 4$ hands high, a beautiful coal black, whose activity and strength is not exceeded by any horse in the State.

Stephen Chubb, JR., New Hartford, May i6, I 785.

Partner will cover the season at the stable of the subscriber in Farmington. He was brought from Pennsylvania in the year I 783 , and is a beautiful bright bay, full-blooded; was kept the two last seasons in Woodbury at Mr. Noah Judson's. Any gentleman desirous of seeing the Horse may see him by calling on the subscriber. It is needless to recommend the Horse for he will recommend himself.

John Cooke, Farmington, May i6, I785.

N. B.-Good pasturing for mares.

Now for Saddle Horses.-A Narragansett Horse of the old Snip breed, called the Smiling Ball, just brought I 50 miles from the eastward, will cover this season at the stable of the subscriber in East Hartford, one mile from the ferry. Two Dollars the season and One Dollar the single leap, cash in hand or something equivalent, but no trust. Said horse is a chestnut sorrel, I 5 hands high, paces exceeding fast and easy, trots fast and easy, will travel eighty miles in a day without tiring himself or rider; his colts make excellent easy saddle horses. Good pasturing for mares.

\section{Selah Norton, May 26, I 785.}

N. B.-Said Norton will keep 20 or 30 shipping horses at the best rate, or sell a few tons of the best clover, herds and homelot hay.

Advertised I 786 by Selah Norton of East Hartford. 
Advertised 1787 by Timothy Olmsted at New Hartford.

Will cover at the stable of Samucl Wolcot, in East Windsor, the horse Free and Easy of the true Narragansett breed. One Dollar the single leap and Two Dollars the scason. The proprictor of this horse has procured him at great expense, and assures the public he is of the genuine breed and is put at a low price to encourage those who have likely Mares of the same breed to bring them, that the breed so valuable may not be lost.

Advertised again I 786 at East Windsor.

Advertised 1787 in Hartford, by Col. Wadsworth.

Advertisements on this page are copied literally, showing how much more capital letters were in use at those dates than now.

Now for saddle horses. The subscriber, at the distance of 150 miles to the eastward, has found and purchased a Narragansett horse, of the true genuine Snip breed, called Smiling Ball, I 5 hands High, chestnut colour, is one of the best saddle horses that ever was made, trots single and square and never was beat in pacing as I can learn. I have one of his colts three years which I would not give for any English colt that I know of. Said horse will cover this season at the subscriber's stable in East Hartford, a few rods south of Benjamin's tavern at two dollars the season, cash or produce in hand, or a note of hand for six months, and one dollar the leap for cash only. Those from a distance, who take one leap over night, another in the morning, will be almost sure of a colt for ten shillings, and good pasturing for mares.

Selah Norton, East Hartford, April 8, i 786.

N. B.-Said Norton has two yokes of shipping cattle for sale, for cash only.

Will be kept at the stable of Col. Wadsworth, in Hartford (West Division) the horse Whirligig, of the true Narragansett breed; his movements, spirit and carriage are equal to any horse in America. Terms, one and two dollars the season. Wheat, rye, corn and oats received in payment. No trust. Hartford, May I, I 786.

Advertised again, I 787 .

Will be kept at the stable of Samuel Wolcott, in East Windsor, the Narragansett horse Free and Easy; the same that was there last year. One dollar the single leap, two dollars the season. No Trust. Wheat, rye, oats and corn received in payment.

East Windsor, May, I 786.

To be kept this season, at the stable of Simeon Smith, in Sharon, the beautiful horse Defiance; he is upwards of fifteen hands 
high, five years old, full blooded, equal in speed to any, and allowed to be as good a breed as any in America.

Sharon, May I3, I 783.

Will be kept this season, at the stable of John Taintor, InnHolder in Colchester, the famous horse Grayhound; he is of a beautiful dapple gray, fifteen hands and a half high; he was got by one of the old Ranger's colts, and from a half blooded mare; he is equal if not superior to any horse in the State for beauty and activity. He was owned and kept the last season in the Society of Marlborough. The price is one dollar a leap, or two dollars the season. He will be at or near Dr. Paruvil's every Saturday, at the upper end of East Haddam.

Colchester, May 5, I 786.

The famous horse Molton, will stand this season at the stable of the subscriber, in Torringford. Terms, one and two dollars. Molton is five years old this spring, fifteen hands high, was brought out of the state of New York this spring, and is called as good blooded horse as any in that state. Good pasturing for mares.

Nehemiah Gaylord, Jun., Torringford, April i 8, i 786.

The Painter will be kept this season at the stable of the subscriber in Mansfield. He is the same horse that was there last season; he needs no recommendation for his beauty and activity, and proving a good sire. The Horse will recommend himself to any gentleman.

Oliver Utley, May 22, i 786.

The famous horse Roebuck will be kept the ensuing season at the stable of the subscriber in Farmington. Terms, nine and eighteen shillings the season. This horse was formerly known by the name of Linsley Horse, is rising of 16 hands high; seven-eighths blooded; is equal in strength, activity and beauty to any horse in this State. Good pasturing for mares.

Sol. Cowles, Jun., Farmington, April 6, i 787.

To be kept at the stable of Jonathan Smith in Haddam at two dollars the season and one dollar a single leap, the horse Whirligig, a true Narragansett-the same horse was kept last season at Colonel Wadsworth's stable in Hartford, West Division.

$$
\text { April, I787. }
$$

To be kept at the stable of Elepus Wolcott, the horse Giant, four years old, 16 hands high, a bright bay, of the true hunting breed. Terms, one and two dollars. April, I 787.

To be kept at Colonel Wadsworth's stable in Hartford, West Division, the horse Free and Easy. Terms, one and two dollars. 
Will be kept at the stable of the subscriber in East Hartford, and adjacent to the city of Hartford, the famous dapple gray horse Ranger, I 5 hands high, seven-eighths blooded; as his gait, figure and activity are full recommendations, without tracing a long succession of his pedigree, it is sufficient to say his colts are equal to any. Terms, six shillings and two dollars.

The subscriber has for sale at his store rye, oats, barreled pork and vinegar.

Daniel Pitkin, April 14, 1787.

Will be kept at the stable of the subscriber in Berlin, the famous horse known by the name of Rein-Deer. Terms, one and two dollars. Selah Gridley, Berlin, April 30, 1787.

Advertised, I 788 , by Thomas Gridley in Suffield.

Hero-Will be kept this season at the stable of the subscriber in Glastonbury, Marlborough Society. Terms, twelve and six shillings. Hero is of the English breed. Thursdays and Fridays he will be at Landlord Benjamin's in East Hartford.

Abraham Skinner, Jun., Glastonbury, May i 7, I787.

Advertised again, I79I, at Marlborough.

Will be kept at the stable of Joseph Stillman in Wethersfield, the famous full blooded horse Wildair, being the same horse that has for several seasons been kept at the stable of Josiah Stillman in Sandisfield. The properties of this horse as a sire and the value of his colts, are so well known that they need no description; he will cover at six shillings the leap cash in hand, or seven shillings in onions or other country produce, at the market price, or, double the sum in the same pay for the same.

Wethersfield, May I 5, I 787.

Now for saddle horses. The subscriber informs all gentlemen that would wish to breed fashionable, easy saddle and shipping horses, that the full blooded Narragansett horse, called Smiling Ball, will cover this season at Capt. Gilbert's stable in New Hartford. Terms, one and two dollars, to be paid in cash or grain by the first day of October next, at my house in Hartland, or at Capt. Gilbert's in New Hartford. Said horse never was beat in pacing, trots easy, is I 5 hands high, dark chestnut colour, and one of the best saddle horses in the world. Timothy OLmsted, Hartland, May 22, i 787.

The elegant horse, well known by the name of Granby, will be kept at the stable of the subscriber, in Coventry. Said horse has been kept at the same stable three seasons before this; his colts sufficiently recommend him for a good sire.

Nathan Howard, Coventry, April 28, I 788.

N. B.-Any kind of grain will be received in payment. 
Will be kept this season, at the stable of the subscriber, the famous horse, known by the name of Rein Deer, he is perhaps equal to any one in the State. Terms, twelve and six shillings.

\section{Thomas Gridley, Suffield, May 3, i 788.}

Will be kept this season at the stable of Mr. Joseph Adams in Simsbury, every Monday and Tuesday; and on Wednesday will be on the road to New Hartford, and there will cover at the stable of $\mathrm{Mr}$. Stephen Chubb; on Thursday, Friday and Saturday return to said Adams'; the beautiful Fox, and most famous Bullrock, half English and half Dutch; they are perhaps equal to any horses in the State for size, beauty and strength; Terms, twelve and six shillings. Said horses are in the care of

\section{Joel GRiswold, Jun., Simsbury, April 19, i788.}

N. B.-One of the above will be sold if applied for soon.

Will be at the stable of the subscriber, the present season, in Mansfield, Second Society, the famous noted horse called the Panther. Said horse needs no other recommendation than this, that he is the same horse the subscriber has owned for several seasons past. Oliver Utlei, Mansfield, April 30, I788.

N. B.-Good pasturing for mares at a reasonable price.

Glorious news for owners of mares. Will be kept this season at the stable of Mr. Joseph Utley, at Warehouse Point, in East Windsor, the three first, and at Mr. Amos Alden's in Enfield the three last days of each week, the very noted and much admired horse Young Granby, who has been the two last seasons at said Alden's, and has produced the greatest number of the most beautiful, sprightly, large and gay colts of any sire in Connecticut. He was by the full blooded old Granby of New York, the best horse that ever was imported into America. $H e$ is of a dark bay, $151 / 2$ hands high, proportionably well built, sprightly and active, and moves in the most graceful manner. Terms, twelve and six shillings, payable in produce by the first day of January next.

N. B.-Good pasturing for mares.

Two likely horses, one of the Ranger, the other of the Narragansett breed, will be kept at the stable of subscriber the present season, on reasonable terms. Freeman Kilburn, Hartford, May, i 788.

Gentlemen farmers, put not your strength in Asses, but in that elegant and useful animal the Horse. The young Pilgrim will be kept this season at Col. Seymour's farm house. He is four years old, rising I 6 hands-for beauty and figure equal to any horse. Terms, six and twelve shillings. William Seymour, Hartford, May i 7, i 788. 
Covering horses to let. The subscriber hath on hand, three stallions to let, the ensuing season, on advantageous terms-all sires of approved reputation, known by the names Homer, Laurel and Pink.

I789-Bold Raven at Milford.

Roebuck will cover at the stable of the subscriber the ensuing season, at six shillings the leap, twelve shillings the season and four dollars to warrant with foal; and is equal to any horse in the State as a sire. Solomon Cowles, Farmington, April 4, I789.

To cover this season at the stable of Joseph Utley, at Warehouse Point in East Windsor, and at Amos Alden's in Enfield, the very noted horse known by the name of the Eaton Horse, who has been in Tolland several years past, and has produced the greatest number of likely horses in that and the neighbouring towns of any sire in America. For a sire he needs no recommendation where he is known, and where he is not it may be said with propriety that he is and ever has been the best sire in Connecticut, since the days of his renowned sire, the old Ranger. His dam was the Princess of Beauty, got by the Chapman Narragansett pacing horse. He will be at said Utley's on the third week in May, at said Alden's the fourth week, and shifted from one place to the other every week through the season. Terms, ten and twenty shillings.

Good pasturing for mares at either of said places.

East Windsor, May 4, I789.

Advertised I790, by Joseph Utley and Amos Alden at Warehouse Point, East Windsor and Enfield.

Advertised I79I at same places.

Will be kept this season, at the stable of the subscriber, the famous horse Grayhound, at six shillings and twelve shillings; he is I 5 hands two inches high, of a bright gray colour, black mane and tail, of the true Arabian breed, from a clear English mare; he is the handsomest horse in America without any exception.

\section{Amariah Kibbe, Somers, May I3, I789.}

The noted imported horse Recovery, belonging to Thomas Pool of New London, will be at Mrs. Bigelow's tavern, Middletown, the Ioth of June, and continue there until the I3th; from thence he will go to Hartford where he will continue until the 27 th. On his return to New London he will be at Middletown two days. The particular day when he will be there will be mentioned in the Middletown paper.

May I6, I789.

Advertised again July 6, I789 and I790 at Joseph Pratt's tavern, Hartford. 
I 790-Tartar by Lath.

I 790-Shakespeare by Old Figure at Suffolk, Conn.

The full blooded horse Reindeer will cover this season at the subscriber's stable in Wethersfield, two miles southwest from the Meetinghouse. Terms, nine and fifteen shillings. He is of a dark bay colour, seventeen hands high, equal for beauty and movement to any horse in this State.

Solomon North, Wethersfield, April i9, i 790.

Will cover this season at the stable of the subscriber in Glastenbury, Marlboro parish, the noted Horse Macaroni; he is fifteen and a half hands and well proportioned, is very elegant in his carriage, and of a dapple gray colour; Macaroni was bred by Col. Halsey of Preston, from a very likely dapple gray mare got by Col. Wyllys' old Ranger, and his sire was Mr. Ellsworth's of New Jersey bay horse Macaroni, who was esteemed one of the beautifulest horses in America, of the English breed, whose pedigree, speed and performance are too well known to every lover of the turf, to require any further narrative.

Will be kept this season at the stable of the subscriber, the young Syfax, four years old. Terms, one and two dollars. The pay will be received in any kind of grain by the first day of January next.

Abel Sutliff, Watertown, April 26, I 790.

Advertised May I 7, I 790 by Robert Hannah at Bethlehem.

The Ranger, commonly known by the name of the Eaton Horse, will be kept this season at the stable of Joseph Utley, at Warehouse Point in East Windsor, and at Amos Alden's, innkeeper in Enfield, at twelve shillings the season in specie or grain by the Ist of January next, or six shillings the leap in ready pay. As the progeny of this horse are so numerous, and generally famed for the best breed of horses, the low price of his services must be a sufficient inducement for owners of mares to breed them to him. Ranger will be at said Utley's the week following the Ist Monday in May, and at said Alden's the week following, and changed from the one place to the other every week through the season.

$$
\begin{aligned}
& \text { Joseph Utley, } \\
& \text { Amos Alden, April 27, I790. }
\end{aligned}
$$

N. B.-Good pasturing for mares, and the greatest attention will be given.

The famous full blooded horse, Bucephalus, will cover at the stable of the subscriber in this city. Terms, three and five dollars. $\mathrm{He}$ is equal for beauty, spirit, strength and movement to any horse 
in America; he was bred on James River in Virginia, from the best breed on the Continent; his colts have proved excellent; he is of a dark bay colour, fifteen hands two inches high.

Freeman Kilbourn, Hartford, March, I790.

N. B.-Good attendance, and pasturing for mares.

Advertised again I79I.

The beautiful horse Syphax, will be kept at the stable of the subscriber at Bethlehem, at two dollars the season. Syphax stood at the stable of William Baldwin of Litchfield the season bcfore last, and at the stable of the subscriber the last season. He is so well known, and his colts so unquestionably good, that it would be needless to say anything in their recommendation.

\section{RoBert HANNAH, Bethlehem, May 6, i 790.}

N. B.-Good pasturing, and careful attendance.

The noted horse Partner, formerly called the Judson Horse, will be kept at the stable where he has been for four seasons.

$$
\text { John Cooke, Farmington, May 20, I } 790 .
$$

Grayhound, I 5 hands and a half high, at the stable of Amariah Kibbe, in Somers, I 2 s. the season, 6 s. single leap, and 24 s. to warrant. True Arabian breed. The above horse's colts prove better than the noted imported horses advertised around the country, at least what have been seen in this quarter.

May 25, I 790.

The breed of the old Haden Horse, one-half, the other half of the Smiling Ball, came from the Eastward; five years old, fifteen hands and a half high, will be kept at the stable of Timothy Holton in Ellington. Terms, one and two dollars, to be paid in any produce; the horse will recommend himself.

\section{Timothy Holton, Ellington, May 20, 1790.}

The noted imported stud horse Recovery belonging to Thomas Pool, of New London, will be at Mr. Joseph Pratt's tavern, in the City of Hartford, on the I 2 th day of July and continue there until the 15 th.

I 79I-Young Rainbow, Claricus and Eagle.

July 5 , I 790 .

The famous full blooded horse Bucephalus, will be kept at the stable of the subscriber in this city. Terms, five and three dollars. He is equal for beauty, spirit, strength and movement, to any horse in America; he was bred on James River in Virginia from the best breed on the Continent; his colts have proved excellent; he is of a bay colour, fifteen hands two inches high.

Those mares that failed of having colts by him the last year come this season at half price. 
Also, the full blooded bay horse Bajazet, will be kept at Hartford, He was got by Mr. Westenholm's Tanner, his dam by Bajazet, son to the Godolphin Arabian, his grandam by Babraham, his greatgrandam by Sedbury, and his great-great-grandam by Childers, which was called Lord Portsmouth's Ebony. The colts of Bajazet are all of good size and very handsome-remarkable for their speed, no horses in America are swifter. He has been near Trenton in New Jersey for several years.

Freeman Kilbourn, Hartford, March 25, I 79 I.

The most beautiful horse, Smooth and Easy, will be kept this season at the stable of the subscriber, in Tolland, excepting the $23 \mathrm{~d}$ and $24^{\text {th }}$ days of May, when he will be at the stable of Mr. Abel Holmes, at Willington, and the two last days in May he will be at the stable of Captain John Johnson, in Willington. Terms, one and two dollars. Further particulars may be had of the subscriber. Hope LATHRop, Tolland, April, I79I.

Partner will be kept this season at the stable of the subscriber, Terms, three dollars and nine shillings. He is a fine bay, rising fifteen hands, was bred in New Jersey from an imported horse called Partner and has been kept five seasons past by Mr. John Cook of Farmington, where he has produced as great number of fine colts as any horse in the State.

SaMUEL WhitMan,

Hartford (West Division), April is, I79ı.

That beautiful and well known horse the Young Ranger, will be kept this season at the stable of Timothy Seymour, at West Hartford, at four dollars the season. This horse needs no other recommendation than that he is a colt from the old Ranger, and bred by Capt. James Nichols, late of this town, and his colts are so well known that any further pedigree, description or preamble, as is the late custom, is needless.

\section{Timothy Seymour, Hartford, April 9.}

That well known horse Ranger, formerly known by the name of the Eaton Horse, will be kept this season at the stable of James Warner, in Wilbraham, the last week in April; at Amos Alden's, in Enfield, the first week in May, and Joseph Utley's at Warehouse Point, in East Windsor, the second week in May, and continue in that way through the season. Terms, six and twelve shillings payable the first day of January next. Good pasturing for mares.

Roving Hunter will be kept this season at the subscriber's stable. Terms, six and twelve shillings. Hunter is an imported horse, a 
beautiful bay, with two white feet; he necds no recommendation for such a low price. Good pasturing for mares and the best attention paid by their humble servant.

Elion Deming, Southington, April 28, 1791.

Young Roebuck, will be kept this season at the subscriber's stable. Terms, six and twelve shillings. Roebuck is six years old this spring, and better than 15 hands high; he is of a beautiful black, with a star and three white feet; he was got by a full blooded horse partly of the Scotch breed: his dam from Long Island.

Elion Deming, Southington, April 28, I 79 I.

That beautiful horse the Currimetee will be kept at the stable of Oliver Hubbard, in Wintonbury. Terms, six and ten shillings. This horse needs no other recommendation than only to say he is a colt from the Ranger, he is a bright sorrel, and is fifteen hands and two inches high. Constant attendance and good pasture for mares.

Oliver Hubbard, April 25, i 79i.

Hero will be kept this season at the stable of the subscriber in Glastenbury, Marlborough Parish. A recommendation of said horse where he is known is needless; suffice it to say he is the same horse I kept in 1788 , is of the English breed, of a bright bay; his colts prove very likely; the price only two dollars the season.

Abraham SKinner, Marlborough, May I2, I79i.

Will be kept at the stable of the subscriber in Hebron, Gilead Society, the famous horse Young Ranger. Terms, two dollars the season. He is of a dapple gray and spotted, seven years old, I 5 hands high; he is equal for beauty, spirit and movement to any horse in America; carries his head and tail high; his colts picture the horse as to his shapes, colour and gaits; he needs no further recommendation than to say he is the horse that I have owned for two seasons. I wish that people would be their own judges as to the horse and his colts, which may be seen here. Good pasturing for mares, and good attendance given.

Asaph Tkumbull, Hebron, May 2.

Stolen out of a pasture on the night of the 3oth of April last, a dark bay horse, I $31 / 2$ hands high, natural trotter, shod round, mane natural to the near side, star in his forehead, carries his tail to the right while moving. Whoever will take up said horse and thief, shall receive a reasonable reward and all necessary charges paid, by

SAMuel Hotchkiss, Bristol, May r, I 79 I.

Beautiful Bay, will be kept at my stable (for the benefit of the public) at $15 \mathrm{~s}$. the season, cash or grain next fall, and $9 \mathrm{~s}$. the leap 
pay down; his sire was the imported horse Traveler, owned in New Jersey; his dam DeLancy's imported racer; ten pounds was offered for one of his colts at ten days old, at Lanesborough, and it is affirmed that he got sixteen colts in one day at Springfield; he is in his prime, in fine order, bright bay, 15 hands high, trots and canters very light; the price is low, and so is the price of shipping horses-one thing ought to be in proportion to another.

Selah Norton, East Hartford, April 26, I 79I.

Barbary will be kept at the stable of the subscriber in East Windsor, at six shillings the leap or twelve shillings the season, excepting Thursday, Friday and Saturday in each week, when he will be at the stable of Mr. John Gaylord, Windsor; he was got by the horse late the property of Mr. Samuel Whitman of West Hartford, one of Old Ranger's colts; he is a beautiful figure, either standing or moving, of good size and gets excellent colts.

\section{Asahel Olcott, East Windsor, May 30, I79I.}

Advertised again I 792 .

Will be kept at the stable of the subscriber at one dollar the leap and two dollars the season, the young Free and Easy; he is a horse of size, spirit, beauty and carriage, equal to any of the breed; he is of the true Narragansett breed. All who wish for that kind of saddle horses, are desired to call and see for themselves. Good attention given, and pasturing for mares.

Timothy Elmer, East Windsor, May 2 I.

That well known horse Ranger, formerly known by the name of the Eaton Horse, will be kept this season at the stable of James Warner in Wilbraham, the last week in April; at Amos Alden's, in Enfield, the first week in May, and Joseph Utley's at Ware-house Point, in East Windsor, the second week in May, and continue in that way through the season. Terms, six shillings the single leap, in ready pay, and twelve shillings the season, payable the first day of January next. Good pasturing for mares.

I 792-Young Rover, gray, I6 hands.

July 4, I 79 I

Peacock, the famous half-blooded.

Will be kept this season at the stable of the subscriber in East Windsor, one mile south of Bissel's tavern, the famous young horse called Giant or Dolphin. He is half English and half of the Virginia breed, is a curious bright bay, I $61 / 2$ hands high-yes, sixteen and a half high by the rule, and well proportioned every way, but four years old; for beauty, strength and activity he will recommend 
himself. Cash is scarce, times hard. Terms, twelve and nine shillings, payable by the first of January next.

Natianiel Strong, Jun., East Windsor, March 30, I 792.

That beautiful and well known horse the young Ranger, will be kept this season at the stable of Timothy Seymour, at West Hartford. Terms, four dollars and fifteen shillings. This horse nceds no other recommendation than that he is a colt from the old Ranger, and bred by Capt. James Nichols, late of this town; and his colts are so well known that any further pedigree, description or preamble, as is the late custom is needless.

Timothy Seymour, Hartford, April 9, i 792.

Young Kildeer, lately purchased by the subscriber from the State of New York, will be kept this season at his stable in Glastenbury, Marlborough Parish. Kildeer will be five years old next June, I6 hands high and well proportioned, of a bright bay, black mane and tail, is of the genuine English breed, and is allowed by good judges to be one of the best horses in the state. Terms, nine and eighteen shillings; five dollars to insure.

N. B.-Kildeer will be at Capt. Roger Bulkley's in Colchester on Wednesday, 23d of May, will continue there till 24 th in the afternoon, then return to my stable.

Likewise the well known horse Hero, will be kept at the same place, at six shillings the single leap, twelve the season, twenty to insure with foal. He is the same horse that has been owned by the subscriber a number of seasons past. Gentlemen that wish for a recommendation of said horse, will please to look at his colts. Hero will be at Capt. Cheney's, East Hartford, I 5 th of May, will continue there until the I6th, will then proceed to Land. Benjamin's, East Hartford, continue there till the I8th, then back to my stable, will continue the season through to be kept at Land. Benjamin's every week on Wednesdays, Thursdays and Fridays. Those mares that were served last season and failed, go for half price this season.

Abraham Skinner, Glastenbury, April 2.

The famous full blooded horse Bucephalus, will be kept at the stable of the subscriber in this city, at five dollars the season, or three dollars the single leap. He is equal for beauty, spirit, strength and movement, to any horse in America; he was bred on the James River in Virginia from the best breed on the Continent; his colts have proved excellent; he is of a dark bay colour, I 5 1/2 hands high.

Those mares that failed of having colts by him last year, may come this season at half price. 
cccii

Also, the full blooded bay horse Bajazet, will be kept at the same place and at the same price. He was got by Mr. Westenholme's Tanner, his dam by Bajazet, son of the Godolphin Arabian, and his grandam by Babraham, his great grandam by Sedbury, and his great great grandam by Childers, which was called Lord Portsmouth's Ebony. The colts of Bajazet are all of good size and very handsome, remarkable for their speed, no horses in America are swifter. He has been kept near Trenton in New Jersey for several years; and there are several of his colts in that neighborhood that would add reputation to the first stallion in America. Constant attendance and good pasturing for mares, by

Freeman Kilbourn, Hartford, March i 7, I792.

The famous full blooded horse Polaski, will be kept at the stable of the subscriber in Granville. Terms, two dollars, and four dollars. Polaski is four years old this spring, of a beautiful bay colour, sixteen hands and three inches high, etc. Constant attendance and good pasturing for mares.

John F. Hileman, Granville, April 17, i792.

Barbary will be kept at the stable of the subscriber in East Windsor, at twelve shillings the season, or six shillings the leap, excepting Thursday, Friday and Saturday in each week, when he will be at the stable of Mr. John Gaylord's at Windsor. For beauty, spirit and movement, he is equal to any horse in America; he is of the Ranger breed, his colts prove excellent.

Asahel Olcott, East Hartford, April i9, I792.

Will be kept at the stable of the subscriber in East Windsor, the young Free and Easy. One dollar single leap, two dollars the season; he is a horse of beauty, strength and activity, of the Narragansett breed, fourteen hands three inches high, well proportioned.

Timothy Elmer, East Windsor, April 26.

Good attendance and pasturing for mares.

Partner will be kept at the stable of the subscriber in Ellington, at three dollars the season, or ten shillings the single leap. Partner is a full blooded English horse, was bred in the state of New Jersey, from a mare and horse that were imported; he is of beautiful bay, fifteen hands and one inch high, his colts are exceedingly likely. Those gentlemen that would wish to serve their mares to a likely horse will please call and see him.

Jóseph Аввотt, JR., Ellington, April 30, I792,

"Figure, a beautiful bay horse 15 hands high, will be kept this 
season, at the stable of the subscriber at twenty shillings the scason or two dollars the single leap.

Samuel Wintman, Hartford (West Division), May 5."

This is supposed to be the original Justin Morgan under the name of Figure. See Justin Morgan.

Will be kept at the stable of the subscriber in Kensington, the famous full blooded horse young Driver, $15 \mathrm{l} / 2$ hands high, is of a bright bay, his colts very likely; he is very lofty carriaged, moves very well on the ground. Terms, one, and two dollars.

$$
\text { JABEz Cowles, Berlin, April 26, I } 792 .
$$

The famous five years old horse called Smiling Star, will be kept at the stable of the subscriber, one-half the time, and the other half, beginning on Monday the I 4 th of May, he will be at Landlord Greenslit's in Hampton, at Io o'clock and continue till 3 o'clock, p. m. On Tuesday he will be at Mr. Daniel Payne's in Brooklyne, and continue till Friday night. On Saturday will be at Mr. Greenslit's, the same hours as above mentioned on Monday; from thence return to the stable of subscriber, where he will continue until Monday, the 28 th. Said horse will continue the above mentioned route through the season. He is so completely able to recommend himself, that I shall not attempt it; but only say that he is allowed by gentlemen of the most extensive knowledge and best judgment in horses, to be superior to any horse of his age ever raised in the New England States; he was got by an elegant horse from the State of New York; his dam was a brown mare owned by Mr. Charles Putnam of Coventry; the dam of the Putnam Mare was Sweet Cherry, and the dam of Cherry was the Arnold Mare and her sire was the noted English horse called Smiling Ball; the sire of the Putnam Mare was Spark, a horse imported and a number of years kept by the late Col. Godfrey Malbone of Brooklyne; and the Putnam mare Cherry and the Arnold Mare, were all bred on that gentleman's farm. The terms will be eighteen shillings the season and twelve shillings the single leap, to be paid when the mare is bred. Amaziah Wright, Mansfield, May 7, i 792.

N. B.-Those mares that were bred to the horse last year for the season and failed of being with foal, may be bred to the horse this season at half price.

Will be kept at the stable of the subscriber in Hebron, Gillead Society, the famous horse called the Figure: he is seven-eights blooded. Terms, two dollars and three dollars. He is a curious bright bay, I $5 \mathrm{r} / 2$ hands high, very well proportioned, six years old; for beauty, strength and activity he will recommend himself; he was 
bred in New Jersey, and got by the noted imported horse called the Granby, his dam was got by the horse called the Figure; he is allowed to be from as good a line as any horse upon the continent. He has been kept the two last seasons in Cambridge, and Hoosack, in the State of New York. The colts of the Figure are all of good size, and very handsome; and there are several of his colts in that neighborhood, that would add reputation to the first stallion in America. I wish gentlemen would call on the subscriber, that they might be their own judges, as to the description of the horse.

Asaph Trumbull, Hebron, April 25, 1792.

Will be kept at the stable of the subscriber the well known beautiful bay horse Hero. Terms, six and twelve shillings; he is the same horse advertised in the last paper, by Abraham Skinner of Glastenbury; he will be kept at Benjamin's in East Hartford every Thursday and Friday during the season, beginning the I 7 th of May, and then return to the stable of the subscriber, and so to continue through the season. Good attendance will be given.

Wilks Willialis, Tolland, May io, i792.

Ranger will be kept for service at the stable of Jonathan Beach, in Goshen. Ranger is the same horse that was at Major Timothy Seymour's in Hartford, the two last seasons, and two or three seasons before in Goshen; those that are acquainted with his colts will want no other recommendation of the horse. Several of them have sold for sixty pounds at four years old, and are allowed to be the best market horses of any in the country. Terms, three dollars and nine shillings; any kind of produce will be received in payment.

Pegasus, will be kept at the stable of Edmund Beach, in Hartland, this season, at eighteen shillings or nine shillings. Pegasus is a horse of superior beauty and elegance; he is by the Ranger, four years old this spring, and fifteen hands high. He got a few colts the two seasons past, and proved remarkably sure; the colts he got the first season, are thought by good judges to be equal to himself.

Defiance, a likely young horse, equal in beauty and activity to any horse whatever, will be kept at stable of the subscriber. Terms, twelve and twenty shillings. Abraham Skinner, May i4, I792.

N. B.-The Kildeer will be at Capt. John Gilbert's, Jr., in Hebron the Ioth of May, there to continue one week, then to return to my stable; and Defiance will be at said Gilbert's in Hebron, they are to change weekly through the season.

Valiant, a famous horse, I $53 / 4$ hands high, well proportioned. Will be at the stable of Joseph Utley at Warehouse Point in East 
Windsor, the fourth week in May, and at Amos Alden's in Enfield, the next week following, and will be changed every weck through the season; and for the conveniency of their customers on the west side of the river, he will stand at Mr. Gideon King's in Suffield, every Wednesday in each week. Terms, six, twelve and twenty-four shillings. Valiant was bred in Pomfret, from Doctor Waldo's mare, and got by the Ransom Horse of Uxbridge, in the Commonwealth of Massachusetts. His carriage and movement are equal to any; colts excellent.

Amos Alden, Joseph Utley, East Windsor, May 15, 1792.

1793-Barnaby at East Windsor; of old Ranger breed.

The full-blooded horse Driver is advertised to be kept at Kensington; also Partner in Ellington; Valiant, by Roebuck, in West Suffield; Ranger in East Windsor; Smiling Star, bay, 15-3, at Mansfield; Young Janus in Enfield; and King Philip at the stable of Wm. Knox to receive 30 mares. "This horse is supposed to be the only one in the world of the Narragansett breed unmixed. Nothing need be said in favor of this race of horses, which have been the admiration of foreigners as well as our own countrymen. He was raised by the Hon. Chas. Phelps of Stonington, is fifteen hands high, of a bright bay color with black mane, tail and legs and has been in the highest reputation for foals in the eastern part of the State."

I 793-Goldfinder, chestnut bay, 15 1/2 hands, in Newtown.

I 793-For sale, a large horse of the Narragansett breed, seven years old, 16 hands; paces altogether and very swiftly. He is handsome and a true Narragansett, which are sufficient recommendations, as this breed are so far preferable to any other for shipping or our own country service. Apply to Mr. Butler, innholder, Milford.

Cincinnatus.

Dolphin will be kept this season at the stable of Spencer and Smith in Hartland, East Society. Dolphin is a true full blooded imported horse, a beautiful bay, is $15 \mathrm{~T} / 2$ hands, and is allowed by the best judges to be the completest figure of a horse in America, and has been greatly noted for his extraordinary swiftness; his colts prove universally of the most elegant kind; he was bred last season at Winchester and Hartland to 127 mares, and a much greater number proved with foal than is common from the surest sires. Terms, twenty, and twelve shillings.

Bulrock will be kept at the same stable on Monday and Wednesday in each week, and at Dea. Cosset's, in Granby, every Tuesday, and at the north end of New Hartford, Thursday, Friday and 
Saturday of each week, and so continue through the season. Bulrock is $\mathrm{I} 5$ hands high, coal black, and needs no further recommendation than that he is the same horse lately owned by Mr. Torry of Granville, and the great number of fine colts which he has produced would be the highest recommend to the best horse in America. Terms, twelve and eight shillings. Good pastures for mares.

\section{SPEnCER \& Smith, Hartland, April 8, I793.}

The famous full blooded horse Bucephalus, will be kept for mares at the stable of the subscriber in this city at five and three dollars. He is equal for beauty, spirit, strength and movement, to any horse in America; he was bred on James River in Virginia from the best breed on the continent; his colts have proved excellent; he is of a dark bay colour, fifteen hands two inches high.

Also, the full blooded bay horse Bajazet, at the same place and at the same price. He was got by Mr. Welstenholme's Tanner, his dam by Bajazet, son to the Godolphin Arabian, and his grandam by Babraham, his great-grandam by Sedbury, his great great-grandam by Childers, which was called Lord Portsmouth's Ebony. The colts of Bajazet are all of good size and very handsome, remarkable for their speed, no horses in America are swifter. He has been kept near Trenton in New Jersey for several years; and there are several of his colts in that neighborhood that would give reputation to the first stallion in America.

Also Hermoso, an imported horse from Spain; was a present from the King of Spain to John Jay, Esq., of New York, and now his property; dark bay, of good size, strength and spirit. One of his colts not yet three years old is to be seen at the stable of the subscriber.

Also, the Narragansett horse, Gustavus, at same stable. Terms, $9 \mathrm{~s}$. and $18 \mathrm{~s}$. He is five years old, I5 hands high; his figure and movements equal to any. Constant attendance and good pasturing for mares.

FreEMAN KilboURN.

Wildair will cover this season at the stable of Trumbull and Wells in Hebron (Gilead Society). He is a full blooded horse, dark bay, I $5 \mathrm{I} / 2$ hands, four years old, well proportioned every way, exceeding long neck and thin head, his ears very nigh together and well pricked forward, and moves exceedingly well. He was got by the old Kildeer, which was purchased out of the King's stable in London, and kept several years at Clavarack in the State of New York, and then sold in Virginia for $£_{5} 60$ lawful money. His colts exceeded any in America; his dam was from a full blooded mare, got by the imported horse called the Bulrock. Terms, four dollars, and 
fifteen shillings. Any gentlemen that have a taste for a likely horse, we wish to call and examine him and judge for themselves.

Young Ranger, the spotted horse which I have owned for several seasons will be at the same stables at I $5 \mathrm{~s}$. and $9 \mathrm{~s}$, or four dollars to insure with foal, and he needs no further recommendation only to say that his colts may be seen here.

Trumbull \& Wells, Hebron, April i2, i 793.

N. B.-Said horses will be exchanged from Trumbull's to Well's stable weekly, being about three miles distance.

Janus will cover this season at the stable of the subscriber in Southington, except Wednesday in each week, and at the stable of Mr. John Brownson, in Kensington Blue Hills. Janus is fifteen hands high, a beautiful dark chestnut colour, and is equal in spirit and movement to any horse in America; his colts prove universally of the most elegant kind, which is the greatest recommend to any horse. Terms, six to twelve shillings. Good pasture for mares and constant attendance.

Moses DutTon, Southington, April 25, 1793.

Young Granby will be kept at the stable of the subscriber in Tolland. Terms, 12 and 6 shillings. Said horse was got by old Granby, a noted horse kept at the stable of Dr. Howard, in Coventry, for a number of seasons, and one of the best sires that ever was raised in the State of Connecticut, and Young Granby wants no further recommendation than to say his colour, bigness and activity are as much like his sire as any colt that he has ever left.

Joseph Lillibridge, Tolland, April 25.

Will cover this season at the stable of the subscriber in Hartland, the noted horse Ranger. He needs no other recommendation than to inform that he is the same horse that was bred by Capt. James Nichols of Hartford and was got by the noted imported horse, Ranger, and was kept there and at Goshen several seasons. Ranger is of elegant shape and figure and his colts are fine, and for the saddle the breed has perhaps never been exceeded in this State. Terms, 9 and I 5 shillings. Good pasturing provided and proper care and attendance engaged.

Edmund Beach, Hartland, April 9, I793.

N. B.-Mares sent from out of town for the season will be kept. two weeks gratis.

The famous full-blooded horse, Young Rover, will be kept at Cheshire the 29th and 3oth of April at the stable of Mr. Jonathan Hall, and on Wednesday and Thursday of the same week at the 
stable of Capt. Samuel Judd in Waterbury, and on Friday and Saturday at the stable of Landlord Zachariah Thompson in Bethlehem; and at the stable of Capt. Wadsworth in Litchfield on Monday, Tuesday and Wednesday of the second week in May and on Thursday and Friday of the same week at the stable of Landlord James Thompson in Goshen; and on the third week of May at the stable of the subscriber; and on Monday, Tuesday and Wednesday of the fourth week in May at the stable of Mr. Jonathan Hall in Cheshire, and on Thursday, Friday and Saturday at the stable of Capt. Samuel Judd in Waterbury; and the four last days of May and the first week in June at the stable of the subscriber; and on Monday, Tuesday and Wednesday of the second and fourth week in June at the stable of Mr. Jonathan Hall in Cheshire; and on Monday, Tuesday and Wednesday of the third week in June at the stable of Capt. Samuel Judd in Waterbury. He is equal for beauty, spirit, strength and movement to any horse in America; he was bred at Spencertown in the State of New York from the best breed on the continent; his colts have proved excellent; he is of a beautiful dapple gray, spotted, 16 hands high. Terms, $\$ 2$ and $\$ 4$.

Nathaniel Holt, Meriden, April 19, i793.

N. B.-Those mares that were bred to the horse the last season and failed of having colts may come this season at half price. Good pasturing for mares.

Valiant will cover the present season at the stable of Mr. Gideon King, in West Suffield, except every Saturday in each week he will be at Capt. Lovejoy's in the First Society. Terms, nine and fifteen shillings. He is a horse near 16 hands high; got by the Roebuck, then owned by Mr. Rawson of Uxbridge.

Ranger will be kept at the stable of Joseph Wiley, at Warehouse Point, in East Windsor, the second week in May, beginning Monday, the 6th day; and at Amos Alden's, in Enfield, the third week, and changed every week through the season. Terms, nine and twelve shillings in ready book or fifteen shillings book, and thirty shillings to insure with foal; he is the same horse that we have kept for several years past that got so many fine colts in these and the neighboring towns.

\section{Amos Alden,}

Joseph Utley, East Windsor, April 30, 1793.

N. B-Good pasturing for mares.

The famous horse called Young Killdeer will cover this season at the stable of the subscriber in Glastenbury, Marlborough parish, 
till I $3^{\text {th }}$ of May; he will then be moved to Landlord Alvord's in Bolton, continue there till the $15^{\text {th }}$; he will then be moved to Landlord John Taylor's in New Coventry, continue there till the I 8 th; then back to my stable, continue there till the 28 th; he will then be moved as above mentioned and continue to be moved every other week the season through; will be moved from my stable on Tuesdays, back on Saturdays. Kildeer is of the English breed, is I6 hands high, and every way well proportioned; his colts prove very likely. Terms, $\$ 2$ and $\$ 4$.

Abraham Skinner, Glastenbury, May 4, I 793.

Barbary advertised I 79I-2-3 at East Windsor as follows:

Barbary will cover at the stable of the subscriber in East Windsor. Terms, nine and twelve shillings. For beauty and activity he needs no recommend; he is of the Ranger breed; his colts are well known in this town and its vicinity; he is the same horse I have kept the two last seasons

Asahel Olcott, East Windsor, May I 3, I 793.

Young Janus at the stable of the subscriber in Enfield this season. He is grandson to the noted old Janus that was imported into Virginia and kept there for some years and sold at 23 for 1500 guineas. He was noted for the races. Young Janus was from a Selim mare of as good blood as he, and was raised in Georgia and brought from there by the subscriber last spring, and he is four years old next June. $\mathrm{He}$ is of a bright sorrel and rising is hands high. He is well proportioned and his carriage is equal to any horse in the State. Terms, three dollars and nine shillings or four dollars to warrant a foal.

Eli Bush, Enfield, May 20, 1792.

N. B.-Good pasturing for mares, and good attendance.

The famous imported, full blooded, English horse, Vigour, will be kept the ensuing season, Fridays and Saturdays of each week excepted, at the stable of the subscriber in Somers; Terms, four and two dollars. Said horse is fifteen hands and an half high, is of a beautiful chestnut colour, and for spirit and movement, is inferior to none in New England.

Caivin Pitkin, Somers, May 15, 1793.

N. B.-Constant attendance and good pasturing for mares.

Hyder Ally, will be let to mares this season. Terms, eight and twelve dollars. Will be kept this week at the stable of Mr. John Cook, three miles south of Farmington Meetinghouse, and next week at the stable of Capt. Samuel Whitman, West Hartford, then a 
week alternately, at each stable, through the season. Hyder Ally is directly from Maryland, selected as the best stud horse in that State, was got by the Arabian Ranger, formerly owned in Hartford, by Col. Wyllys. His dam is a large elegant high bred mare, in a line from Othello, Spot, Cartouch, Old Traveler, Sedbury and Childers. He is of a snow-white, $15 \% / 4$ hands high, bony, lengthy, strong and active-in his figure and elegance, like old Ranger.

May 20, I793.

Will be kept at the stable of the subscriber in Kensington this season, the full blooded horse Driver, for two dollars the season or one dollar the single leap. Said horse is of a bright bay, fifteen hands high, active and well built.

\section{Jabez Cowles, Berlin, May i7, I793.}

King Philip, at the stable of William Knox, will be bred to thirty mares. This horse is supposed to be the only one in the world of the Narragansett breed, unmixed. Nothing need be said in favor of this race of horses, which have been the admiration of foreigners, as well as our own countrymen. He was raised by the Hon. Charles Phelps of Stonington, is fifteen hands and three inches high, of a bright bay colour, with black mane, tail and legs, and has been in the highest reputation for foals in the eastern part of this state.

The beautiful full blooded black-bay horse Figure will be kept on Monday and Tuesday every week through the season, at the stable of Bezaleel Latimer in Wethersfield and on Wednesday and Thursday of the fourth week in May, at the stable of Mr. Joseph Galpin in Worthington; and from thence at the stable of Mr. Abel Andrews in Newington, being on Friday and Saturday, and from thence to return at the above stable in Wethersfield. He was bred in Pennsylvania, and got by the noted imported horse True Britain, his dam by Bold Britain, his grandam by the Narragansett horse, Feather. He is five years old in July, 16 hands high, and equal for strength, activity, movements, and for the saddle, to any horse in America. Price for the season, four and two dollars.

Lofty, will be kept at the above stables, every other week through the season, beginning on the fifth week in May. He is four years old this spring, was bred at the eastward. Price, one and two dollars, twenty shillings to insure with foal. He is of a bright sorrel.

Cash paid at the above places, for old gold and silver.

Samuel Latimer, Wethersfield, May i 7, i 793. 
Partner, will be this season at the stable of the subscriber in Ellington, at $18 \mathrm{~s}$. the season, and Ios. the single leap. Ife is a beautiful bay horse, $\mathbf{I} 5$ hands and one inch high, bred from a mare and horse that were both imported, his colts are likcly.

$$
\text { Josiril Abiotr, JR., Ellington, May i 3, I } 793 .
$$

Will be kept this scason at the stable of the subscriber, that well known horse called the Smiling Star; he is of a beautiful bay, fifteen hands three inches high, a finished saddle horse. His colts will recommend him for a sire. Price, $18 \mathrm{~s}$. and $12 \mathrm{~s}$. Constant attendance and good pasturing for mares.

Amaziah Wright, Mansfield, May 8, i 793.

The much reputed, full blooded horse Marquise, will be kept the present season at the subscriber's stables in Litchfield. This noble animal cannot be viewed but with admiration; he is a most brilliant black, $15 \mathrm{I} / 2$ hands high, and a splendid competition with any of the Royal blood in America. His sire was the celebrated imported horse Whirligig, his dam by Bulrock, his grandam by Frederick; and is conspicuously marked with the elegance and action of his pedigree. Marquise having been procured at great expense and exertion, it is presumed the spirited farmer and patriotic gentlemen, ambitious of supporting the increase of a superior breed of horses, will from motives of interest and zeal to the country, give the Marquise a decided preference. Terms, five dollars and three dollars.

William Baldwin, Litchfield, May i 5, i 793.

NoticE-Hyder Ally, as advertised to be kept a week alternately at the stables of Mr. John Cook of Farmington and Capt. Samuel Whitman, West Hartford; will for the remainder of the season be kept at said Whitman's stable.

I 794-Aesopus, gray, at New Fairfield, Conn.

I 794-LaPrisque, a full blooded Canadian horse, brought from Montreal last winter, gray, near I 5 hands, eight years old, active and well proportioned, to be kept at Goshen, Conn. E. LEwis.

I 794-Young Wildair in Woodbridge, four years old, dark bay, I $53 / 4$ hands; got by old Wildair, imported; dam, half-blood, elegant fast runner.

I 795-Rainbow (Narragansett).

J. N. BEECHER.

Smiling Star in Westbury.

Trincalo, imported to Georgetown, Md., in I 793 by Walter Hellen, Esq., seven years old, bay, large and elegant; bred by R. W. Pierce, got by Mr. Willaby's Trincalo.

G. AND A. Wells, Glastonbury. 
I 796-Enterprise at Hamden; six years old, bay.

Cyrus by Samson, bought at three years old by Mr. Posthumus and Mr. Wickoff on Long Island for \$I 500 ; by Wildair, imported, etc.

I 796-Foxhunter, a noted imported stud, I6 $1 / 2$ hands, from Maryland, in Hartford.

D. Hinsdale.

I 796-Nine studs imported from England by the Rhinelanders of New York-Baronet, together with Virtol, Warwick, Nutter, etc.

Fox Hunter, the famous full bred imported hunter, will be kept this season, four days in the week, viz.: Monday, Tuesday, Wednesday and Thursday at the stable late the property of IVilliam Stanley deceased; ten rods north of the bridge in Hartford; Friday and Saturday at Dr. Barnard's, Wethersfield. His size, strength, movement and figure are equal to any imported horse of his kind.

Daniel Hinsdale, Hartford, June 6, I 796.

Young Koulikhan, for sale, a full blooded young stallion, four years old $23 \mathrm{~d}$ of June next. I 5 hands three inches high, a beautiful dark bay, and equal in beauty, strength, activity and movements to any horse of his age in the State of Connecticut. His sire was the noted horse called the Koulikhan (whose stock is equal to any horse on the Continent), any person wishing to purchase will do well by applying soon, as he will not be sold after the Ioth of April, until the season is over.

RichaRd IV. HART, Sapbrook, Feb. I6, I 797.

I 798 - Young Lath.

Four capital full bred stallions, purchased in England, the last fall, by Charles Butler of Litchfield (who went for that sole purpose) and lately arrived at this place, will occupy the following stands the ensuing season, viz.: Highlander, at Litehfield; Brilliant, at Goshen, Sir Peter Teazel, at old Fort Schuyler, Drone, alias Herod, at Hezekiah Bradley's stable in Greenfield. The pedigree and performance of each horse, together with the terms for their services, will be reasonably exhibited in separate bills.

Charles Butler, for the owners,

Litchfield, April 25, I 798.

( $\Im$ Cash paid for oats, by Benjamin Tallmadge, E. Starr, B. Norton and E. Butler.

The noted horse Cincinnatus, owned and kept for several years past by Messrs. Taylor, of Sharon and New Milford, stands this season at the stable of Mr. Andrew Stevens, innholder in Canaan, 
North Society, where good attendance will be given and good pasturing provided.

ERASTUS BAKER,

Sylvester Rowlson, June 20, 1798.

Sportsmen and breeders of fine horscs are hereby informed that the imported full blooded horse Highlander (supposed by good judges to be the finest horse in America) will be kept the ensuing season at the stable of Charles Butler in Litchfield. He will be at Hartford through the election week, where he may be seen, and his terms of service known. April 29, 1799.

Drone, the best blooded horse in America, will cover at the stable of Hezekiah Bradley in Greenfield, in Fairfield County, where the judges of fine horses will do well to turn their attention.

Litchfield, April 29, 1799.

Charles Butler, for the owners.

Stallions.-The subscribers offer for sale, either of their horses, viz: Cincinnatus, Paddy-Whack, Bachelor, or Dictator. Apply to Augustine Taylor in New Milford, February I6, I80I.

Shark.-An elegant and as good a stud horse as ever traveled through America, is for sale or to be let for the season, by Levi Butler.

Weathersfield, March 20, I8OI.

For sale.-Three elegant full-blooded horses. Their pedigrees may be seen with the horses, at the stable of the subscriber. John Watson, JR., East Windsor, March I, iso2.

N. B.-Two of these horses will be let out on reasonable terms the ensuing season, if not sold by the Ist day of April next.

For sale.-Two likely stud horses, one of the Pennsylvania, the other of the Canadian breed.

Solomon Cowles \& SON, Farmington, April i3, iso2.

For sale or to be let by the season. The handsome dark bay stallion Polidore, formerly kept in the State of New York. Inquire of the Printers.

March 9, I 803 .

For sale.-The noted horse Cormorant, he is of a dark bay, sixteen hands high, he was got by the old Obscurity, imported from England, by Mr. Crocket of Baltimore. Said horse is equal to any in the State for strength and beauty, and has produced as good a stock of colts, where he has been kept for three years past, as any horse whatever. If he is not sold by the first of May, he will be let for the season. Inquire of Jonathan Ramsey, Hartford, or Thaddeus Taylor, West Suffield where the horse is kept.

West Suffield, March 26, I804. 
The noted horse Black Prince will be kept at my stable this season.

Joxathax Raisey, Hartford, May 8, iso4.

For sale by the subscriber, a bay stud horse, four years old, got by Guido and from my black mare; also a gray mare, by Benjamin, from a full-blooded mare. They may be seen at my stable.

Williay LORD, Hartford, March 5, I805.

For sale by the subscriber, the young stud horse Guido. Guido is a full-blooded horse, and needs no recommend to good judges. He is a bright bay, six years old.

Williài LoRD, Hartford, March, i 806.

The noted stud horse Black Prince, is offered for sale, he may be seen and the terms known, by applying at the stables of the late Captain Jonathan Ramsey. Should he not be sold, he will be kept for the season at said place.

Hartford, April 2.

Yolig GuIDo.-The beautiful stud horse Young Guido will be at the stable of the late Capt. Jonathan Ramsey in Hartford this season. For terms etc., please call. Hartford, May 9.

The noted stud horse Black Prince will stand for the season at the stable of the late Capt. Jonathan Ramsey. Hartiord, May 7.

The African horse which is now the horse of knowledge, will be exhibited every day, Sundays excepted, at Mr. Stitts' livery stable, a few rods north of the State House This beautiful animal was caught on the coast of Africa, and from the beauty and peculiarity of his colors and shape, was imported into this country and exhibited as a natural curiosity. He is variegated with four very rich and distinct colors, which are formed into beautiful circulars spots, similar to those of the leopard, and his tail resembles that of the elephant. Exclusive of these-peculiarities, he will add, subtract, multiply and divide; tell the hour of the day by a watch; the number of buttons on a gentleman's coat, and the number of persons present, with many other pleasing maneuvers and marks of sagacity, which excite great admiration.

$\mathrm{N}$. B. To gentleman who may wish to propagate the genuine African breed of horses an opportunity is now offered more favorable than perhaps may occur again in the course of an age.

Hartford, May 5, iso6.

The excellent stud horse, Prince William, will be kept this season at the stable of Andrew Brown of North Woodstock and at the stable of Azariah Brown in Sturbridge, every other week at each 
place, beginning on Monday the Igth inst., at Andrew Browns in North Woodstock.

May I9.

For Sale.-The noted stud horse Black Prince. Stock from this horse have proved superior to any other horses. He will be sold at a reasonable price and a credit given, with good security. For terms inquire at the late Capt. Jonathan Ramsey's.

Hartford, March 30, ISO7.

Black Prince. The noted stud horse Black Prince, will stand this season at the stable of the late Mr. Jonathan Ramsey.

Hartford, May 20, I SO7.

For sale or to let. The noted imported horse, Forrester. Said Forrester is a full bred English hunter, full sixteen hands high, his proportion and movements thought to equal any imported. The stock of the Forrester is sufficient to recommend him as one of the best sires, these may be seen at either of the subscribers, or in any of the adjoining towns. The conditions of sale and terms on which he will be let may be known by inquiring of either of the subscribers.

WiLLIAM LEWIS,

David Pattersox, Cornwall, April $\$$, i 808.

A likely bay stud horse, six years old, by the noted horse, Black Prince, sixteen hand high and well spread, will be kept at the stable of J. Utley, in Suffield this season. Those gentlemen who wish to procure this breed of horses, which is the most valuable of any ever brought into this country, will please to call.

Suffield, June 8, isos.

The beautiful stud horse Mammoth will stand this season, at the stable of the subscriber in Hartford. He is a beautiful bay, full sixteen hands, two inches high, was got by the celebrated horse, Black Prince, and has been pronounced by many good judges to be worthy the attention of gentlemen who wish to breed stock, either for profit or use. JoNATHAN RAiser, Hartford, May IO, I809.

For Sale. The elegant full blooded horse, King Villiam, is now offered for sale, on the most advantageous terms to the purchaser, if not sold by the 2oth inst., he will be offered to be let for six months. Apply to

Johx WATSON, JR., East Windsor, March 27, I S Io.

For Sale. Two full blooded stud horses, one called Emperor, the other Yorick, their stock remarkably fine. The property of the late Capt. Samuel Whitman. AuAsa KEYEs, Administrator.

Hartford, April 5, I8IO. 
The subscriber has purchased the noted stud horse Yorick, formerly the property of Capt. Samuel Whitman, West Hartford, deceased. The blood and stock of this horse is of the first-rate; he will be kept in my stable at Chatham, the present season, the price will be reasonable according to the value of the horse, which has been sold for one thousand dollars.

\section{Marshal Pelton, May i6, i 8 io.}

The subscriber has removed his stud horses, Royal Prince and Young Sportsman, the former to Esq. Riley's and the latter to Mr. Elijah Loveland's in Berlin, there to be through the season. These horses were got by the noted Black Prince, and are well worthy the attention of gentlemen wishing to breed valuable stock.

SALMON North, Wethersfield, May 26, i 8 io.

Either of the above horses are to be sold on a credit of twelve months, and the profits during the season go to the benefit of the purchaser. The horse to remain at his present stand, at the expense of the purchaser. One of the horses will be sold at public auction on the $2 \mathrm{~d}$ day of August next, if not otherwise sold before said time.

The stud horse Black Prince. At the stable of Samuel Endicott, South Wilbraham, Mass., this season. April 26, I 8 I I.

A stud horse for sale. The subscriber offers to sell the noted stud horse, Royal Prince, on a liberal credit, if desired. Said horse is full sixteen hands high and well proportioned-equal in figure and strength to any horse in this State; he was four years old last grass, got by the celebrated imported Black Prince, from a full blooded mare. For particulars, inquire of

SALMON NORTH.

The noted stud horse imported from Arabia, by Gen. William Eaton, will stand at the stable of the subscriber in East Hartford, the present season. The price for each mare will be six dollars-good pasturing and the best attendance.

Joв Beckwith, East Hartford, May 3, I8 i i.

For Sale at Public Auction. On the 23d of April, inst., at Jonathan Ramsey's stable, the noted stud horse Royal Prince. The terms will be liberal and will be made known at the time of the sale, or by inquiring at said Ramsey's stable, where said horse may be seen. Hartford, April 9, I8I2.

The subscriber has purchased the noted horse, Forrester, a full blooded hunter, imported from Scotland; he is a fine bay, sixteen hands high, and well proportioned, and undoubtedly is one of the 
best stock horses in the United States. Will be kept this season at Col. Utley's, Hartford, near the bridge.

$$
\text { Joseril Tucker, May I i, i } 8 \text { I } 2 .
$$

The full blooded Arabian horse, Young Dey of Algiers, will be kept at Hartford and East Hartford this season only. Youny Dey is in almost every respect very much like the old Ranger-from which more excellent saddle horses were bred than from any other horse ever imported into America-he is, however, stouter built, has more bone, and if possible, more nerve.

April 27.

Young Prince will be kept this season at the stable of Landlord Loveland's, in Berlin, Mondays, Tuesdays and Wednesdays in each week, and at Dr. Hough's, in Meriden, Thursdays of each week, and from thence to the stable of the subscriber in Middletown. Young Prince is four years old, sixteen hands high, of a bright black color, and is well proportioned; he is one of old Prince's colts, formerly belonging to Jonathan Ramsey of Hartford; terms reasonable.

Joseph Wells, Middletown, May 28, i 8 I 2.

Young Messenger, a valuable stud horse, brought from New Jersey, sixteen hands high, full of speed, of a bay color, and of a good stock-will be kept at the stable of the subscriber during the season, in Morgan Street, near the bridge.

May 25, I8I 3 .

For sale by the subscriber, a stud horse, four years old this season, of a bright bay color, sixteen and an half hands high; for beauty, activity and strength, perhaps he is not equaled by any horse in this or neighboring States. If not sold by the first of May, he will be let to mares.

Apollos Fitch, Coventry, April I2, I8I4.

Young Black Prince, will be kept at the stable of the subscriber throughout the season, except on Tuesdays, at Mr. Joseph Merrick's, Inn-keeper in Willington, and on Fridays at the Mills, formerly owned by Thomas Swift, in the easterly part of Mansfield, on very accommodating terms. Likewise, will be kept at the subscriber's stable a very noted horse, called the Ellcorn (late from the State of New Jersey,) and a very likely, full blooded Spanish Jack, one third of the time, the remainder at Mr. Simeon Woodworth's of said Mansfield. Edmond Howe, Mansfield, May 20, I8I4.

The noted horse Tamerlane, will be kept at the stable of $\mathrm{Mr}$. James Williams, inn-keeper, one mile from the bridge in East Hartford, except on Thursdays, when he will be at the stable of Joseph 
Wells, in Glastenbury, at the usual price. Tamerlane is a bright bay sixteen hands one inch high, was from the noted horse Tamerlane, was bred in the State of Pennsylvania; said horse has been kept two seasons in this place and is highly approved of.

\section{Lemuel Butler, May i4, i 8 i 4.}

Rockingham will be kept the ensuing season at the stable of Martin Hills, in East Hartford, first society, through the season, excepting other times mentioned, etc. At Vernon, Monday, May I 5 th, and there to attend every other Monday, in Ellengton, Wapping so called at the stable of Horace Gaylord, and at Glastenbury. Rockingham will be five years old this spring, a beautiful bay, sixteen hands high, well proportioned, he was by the old Rockingham, an imported horse from England; his grandam was by the Comet, an imported horse from England; dam a mare by the Bucephalus. The terms are four dollars the season. Good pasturing for mares.

Maritin Hills, East Hartford, April 26, i 8 I 5.

Stud Horse for Sale. The very promising horse colt Macedonian, will be three years old in June next, and now stands fifteen hands. He was got by a son of the full bred elegant imported horse Goldfinder, from a high bred Virginia mare, his color, marks and actions unexceptionable. May be seen after Wednesday next at Mr. Ramsey's stables, of whom, or John Caldwell, Esq., the terms of sale may be known.

April I 3.

For Sale. The fine stud horse, Tom Hilarion, of the Arabian breed, raised in Pennsylvania. Those wishing to purchase will do well to call soon. Enquire of

E. Porter, Hartford, April 22, i 817.

For Sale. One of the best stud horses in this State, four years old. Apply to

Phineas Hurlburt, West Hartford, April I2, i 8 i 9.

For Sale. The first rate stud horse Hampton Arabian, four years old the I $5^{\text {th }}$ of June last, fifteen and one-half hands high, dapple gray, a cross of the best blood, English, Arabian and Narragansett breed of horses, and exhibits as much activity and elegant symmetry of form as any horse of his age. If not sold by the $15^{\text {th }}$ of April, will be let for the season.

John Watson, JR., East Windsor, March I9, I 822.

Highlander. The premium of twenty dollars was awarded to the Highlander at the last exhibition of the Hartford County Agri- 
cultural Society, conditioned that he be kept in the county this season. Those gentlemen who are desirous of raising a valuable breed of horses for the saddle and harness, are informed that this elegant and valuable young stud horse will be kept during the season at the stable of John Watson, Jr., in East Windsor, eight miles from the city of Hartford.

Ralph Watson, East Windsor, May 28, 1822.

For Sale, a three-year-old stallion horse, in blood, symmetry, movement and color, equal to any in the State. Apply at the late residence of Calvin Pitkin, Esq., deceased.

Austin Pitkin, Somers, March 25, I823.

Highlander. This celebrated horse will be kept this season at the stable of the subscriber in East Windsor, eight miles from the city of Hartford, where may be seen several of his colts, which are unrivalled. The Hartford County Agricultural Society, also, the Hampshire, Hamden and Franklin Counties Agricultural Societies, have awarded premiums to the Highlander, at their exhibitions of elegant horses.

RaLph Watson, May 27, 1823.

The celebrated stud horse Superior, will be offered for sale at public auction, by order of the Hon. Court of Probate, within and for Farmington district (unless previously disposed of at private sale), on the I 9 th day of April, next, at I o'clock p. m., near the store of Messrs. Hough \& Root in Bristol. This noble horse is of the stock of the much celebrated Messenger, is seven years old, and it is said his sliperior is not to be found in this State; he is of a shining black, his limbs are excellent and exhibit the appearance of great strength and activity-his proportion can hardly be excelled. Said horse belongs to the estate of Norman Lewis, late of Bristol, deceased, and has been kept in Southington, Cheshire, Berlin and several other towns for two or three seasons past, where his stock may be seen, and it is said is among the first in the country. The use of the said horse has amounted to several hundred dollars each season.

\section{Bristol, March 9, i 824. $\left.\begin{array}{l}\text { TRACY PECK, } \\ \text { REUben Hough, }\end{array}\right\}$ Administrators.}

The subscribers now offer for sale two fine full-blooded stud horses, viz. Messenger from Jane on the Green, a full bred Virginia mare, got by the celebrated turf horse Hamiltonian, who was by old Messenger, and is a beautiful dark bay, $15 \mathrm{r} / 2$ hands high, five years old next June. Sir Edward, is from Jane on the Green, and was 
got by Col. Talmadge's full bred horse Highlander, is a bright, beautiful bay, $151 / 2$ hands high, and will be four years old next June. There is probably no stock as good in New England in point of blood and symmetry of shape. They will be sold at prices to offer a great inducement to purchasers.* * * Should the two horses not be sold, will let them or either of them on fair terms, to some good trusty man on shares for the season. Young Hamiltonian, six years old, a full brother to the above Messenger, will stand as usual at the stable of the subscribers the ensuing season.

Samuel Hurlbut \& Co., Winchester, March 26, i 824.

The elegant English and Arabian stud horse, Highlander, which has obtained the first premiums of the Hartford, Hampshire, Hamden and Franklin Agricultural Societies, will be kept this season at the stable of the subscriber in East Windsor.

\section{Ralph Watson, East Windsor, April i2, i 824.}

Arab, a beautiful and superb young horse of this name has been brought from New York within a few days past to be kept in this City. He was bred by J. M. Ely, Esq., of New York, from the celebrated Bussorah Arabian, imported from Bussorah on the banks of the Euphrates at the head of the Persian Gulf, and is of the Germany cast held in the highest estimation by the Arabs. For further particulars see hand bills, or apply at Mr. Morgan's Coffee House, Hartford or to E. White of Bolton. April 4, I 825.

The subscriber offers for sale his elegant English stud horse Hampton Gray,- which for beauty, activity and elegance of movement is not surpassed by any in the State, his color gray, $153 / 4$ hands high, will be five years old next June.

Alfred Owen, Windsor, April I8, I825.

Sachem, A Narragansett Pacer.-For the purpose of reviving that most valuable breed of horses, so highly esteemed for their extraordinary performances under the saddle, as well as for a good many other good qualities, the above mentioned horse will be kept in this City during the present season. $\mathrm{He}$ is a dark brown of moderate size, well made, and for strength and speed has few equals. The price three dollars to be paid at the time of service, being barely sufficient to pay for the keeping of the horse. Apply to J. Ramsey near the market or to H. Kirkham. Hartford, May 29, I826.

Watson's celebrated Highlander, Gen. Lafayettc's favorite horse, 
will be kept at the farm of Ralph Watson in East Windsor through the season,-where his stock and pedigree may be seen.

East Windsor, June 19, 1826.

Advertised also in I 829 by Ralph Watson.

Dey of Algiers.-This elegant stud horse will be kept at the farm of Ralph Watson the ensuing season. Terms liberal.

East Windsor, April 9, 1827.

Advertised also I 828, '29.

For sale 2 elegant stud horses, Dey of Algiers and Young Highlander, both by the celebrated horse Highlander. Inquire of Ralph Watson. East Windsor, April 2.

Improved stock.-The beautiful full-blooded turf horse, Hamiltonian, will be kept at the stable of the subscribers this season. The stock from Hamiitonian is too well known to need any recommendation. S. \& L. Hurlbut, Winchester Center, May 9, I 828.

Dey of Algiers and Ranger, two elegant stud horses of the English and Arabian breed, got by the celebrated Highlander (Gen. Lafayette's favorite horse), will be kept on the farm of Ralph Watson through the season. It is presumed these fine animals will receive their share of patronage. They will not be taken from place to place, but may be found at all times at their stand; where their terms and pedigree will be made known.

East Windsor, May I2, I 828.

Highlander will be kept at the stable of Henry Cowles in New Hartford, on Mondays and Tuesdays; at the stable of Lorrain Thrall in Torrington on Wednesdays and Thursdays; and on Fridays and Saturdays at the stable of Levi P. Blakesley in Plymouth, through the season.

Lorrain Thrall, April 23, I829.

Also advertised, I830.

Sir Harry. The subscriber having taken for a term of years this elegant, valuable young Arabian horse, the property of Henry Degroot, Esq., of England, will place said horse under the care of a competent and careful man (Mr. Nathaniel Newell), on a regular route from this place to Hartford and return every week through the season, unless prevented by heavy storms or unavoidable accidents. Pedigree: Sir Harry was by the Bussorah Arabian, bred at Bussorah, on the banks of the Euphrates, at the head of the Persian Gulf, and reared under the eye of Dr. Colcuhoun of Bombay, formerly of Bus- 
sorah, and for many years the East India Company's resident at that place, of whom he was purchased by the agent of Abraham Ogden, Esq., and by him imported in the fall of 1819 , in the ship Horatio, from Bombay. He is of Germany breed, a caste held in the highest estimation by the Arabs, as well for their beautful symmetry of form, as for their flinty hardness in the endurance of fatigue. His dam Maria, bred by Dr. Samuel Thorne of North Carolina, was got by the old imported horse Diomed, who was the sire of Duroc, Potomac, Florizel, Sir Archie, and in fact of most of the best stock of the South. Maria's dam was Lively, grandam Wild Goose, brought from South Carolina by Col. Samuel J. Alston. She was a high bred mare, and her stock was run with great surcess by Col. Alston. The public are invited to examine the points and properties of this valuable young horse.

Charles Robinson, Southington, March 30, i 830.

Sir Edward. The services of this "noble animal" will be offered to the inhabitants of Torringford, Winchester, Norfolk, Coldbrook and New Hartford, the present season. He will pass through the above mentioned towns each week through the season. Extraordinaries excepted. In point of blood, elegance of form and carriage, Sir Edward is not surpassed by any horse in New England-and I can say without fear of contradiction, that his stock is superior to that of any horse that has ever been kept in this section of country. For pedigree and further particulars, see hand bills.

Perry Moor, New Hartford, April io, I830.

Gay Highlander will accompany the Bussorah Arabian, Sir Harry on his regular route, one week, commencing the 5 th of July. Gay Highlander was bred by Joseph Woolman, Esq., New Jersey; was by the imported horse Gay Highlander, and his dam by the imported race horse Expedition. He is over seventeen hands high, of fine form and proportion, of a beautiful bay color.

Charles Robinson, Southington, June 29, I 830.

Besides the foregoing stallion advertisements are a number of notices of horses escaped, stolen, or wanted for shipment. We add the following as examples because of their historic interest:

TwENTY-FIVE DOLLARS REWARD-Taken from the subscriber, in his absence, on the evening of the I 4 th ult., a dark brown mare, 
half blooded, four years old last spring, about fourtecn and one half hands; trots and canters.

Simule DAY, Wrentham, Mass., Fcbruary I2, I 800.

HoRsEs.-Joseph Hart wants to purchase immediately, sprightly well made riding and round strong draught horses,-_for which good sweet flavored rum will be given. Hartford, March 15.

Wanted to purchase by the subscriber, a few likely smooth shipping horses, fit for Barbadoes market.

Tilomas Sanford, JR., Hartford, March 28.

Jonathan Ramsey, wants to purchase, horses and cattle, fit for shipping.

Hartford, April 7, i 800.

Shipping Horses.-Bull, King \& King, are purchasing likely shipping horses, and paying therefor in good brandy and rum.

Hartford, June 2, I 800.

F. Seymour, wishes to exchange rum, molasses and salt, for horses. Hartford, Aug. 4, I 800.

For sale.-A likely horse and sulky, to be sold separately or together.-Also to let several good horses, a sulky, and other carriages. Enquire at the City Hall. Hartford, Sept. I, I800.

Shipping Horses, wanted by Simeon Belden, Jr., for which he will pay rum, sugar and salt. Wethersfield, Oct. 20, I 800.

IT WILL be seen that the advertisements of the last 50 pages are from the Hartford (Conn.) Courant. 



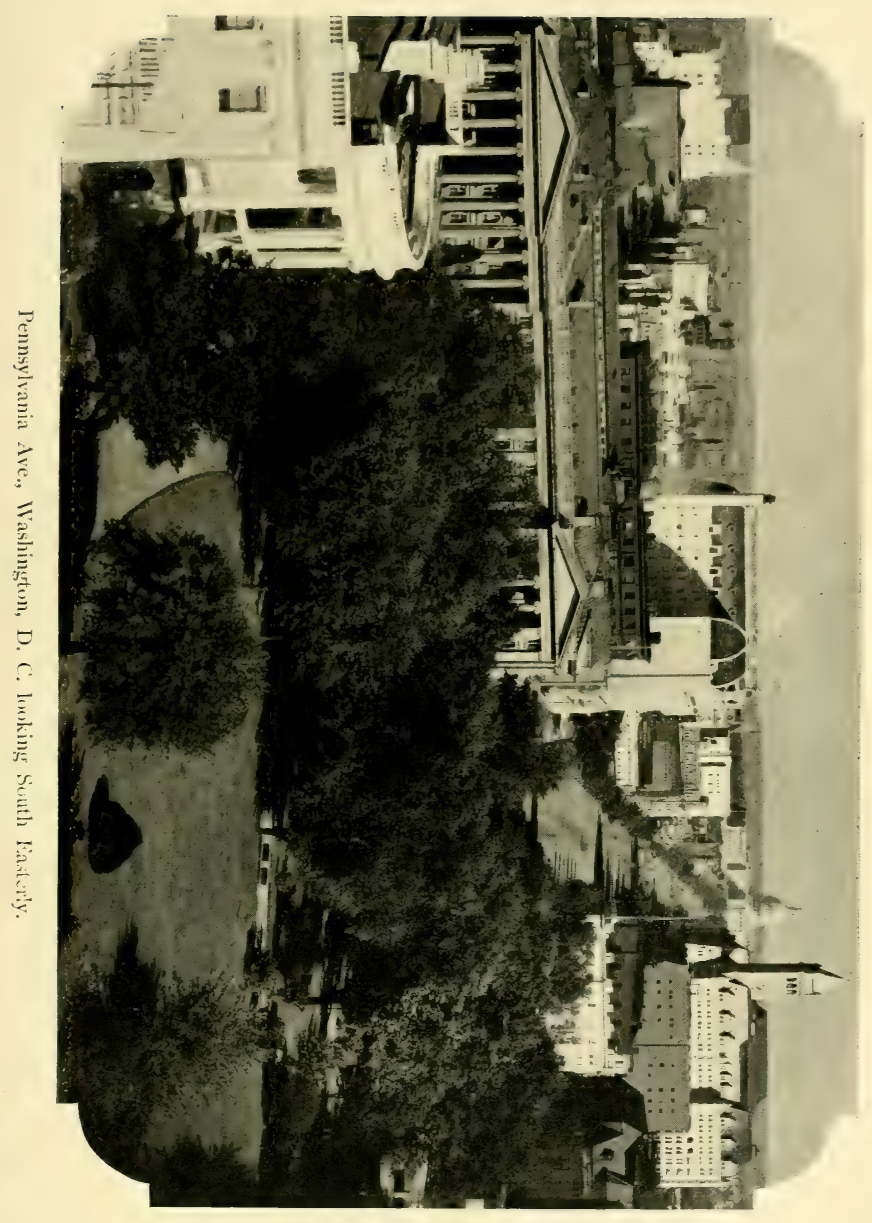




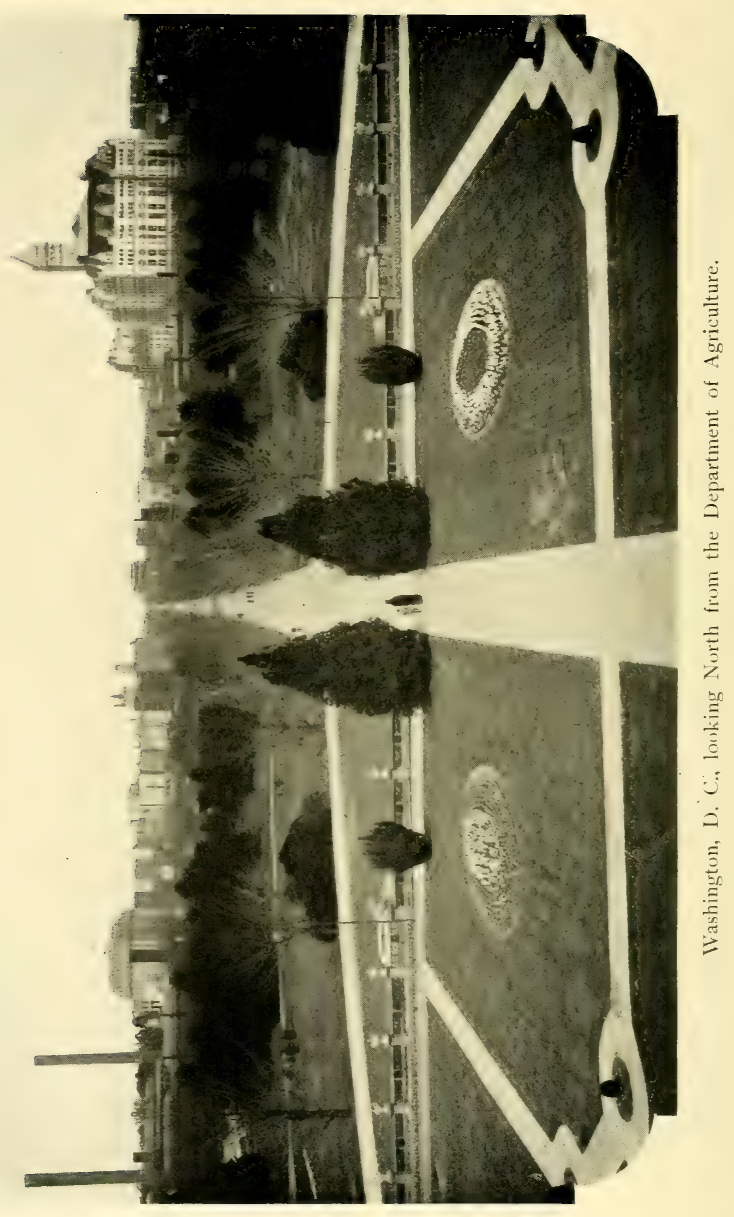




\section{AMERICAN STALLION REGISTER.}

\section{VOLUME II.}

D

ABSTER, bay, 15 hands; foaled I 764 ; said to be by Valiant. Advertised 1773 in Charles County, Md.

DAILY NEWS, bay; foaled 1889; bred by Nathan Burnham, Cassopolis, Mich.; got by Sagerser, son of Jim Monroe: dam Daisy, said to be by Owosso Prince; and $2 \mathrm{~d}$ dam by Post Boy Frank. Advertised in the Michigan Horse News, Aug. 30, I893, by J. H. Gaylord, Prop., Stockbridge, Mich.

Sire of Daily Bread, $2: 203 / 4$.

DAINTY DAVIE, bay; foaled I752; bred by Duke of Cleveland; got by Traveler : dam Slighted by All, foaled 1738 , bred by Mr. Crofts, got by Fox Cub; 2 d dam said to be by Jigg; and $3 \mathrm{~d}$ dam Brown Farewell, by Matchless. Said to have won more gold cups than any horse that ever started.

DAKOTA ( $\mathrm{I}-32)$, bay; foaled I875; bred by Hugh Williams, Racine, Wis.; got by Swigert, son of Alexander's.Norman: dam Merrimac, chestnut, bred by Richard Richards, Racine, Wis., got by Richard's Bellfounder ; 2d dam Lady, said to be by White Stockings, son of Richard's Bellfounder; and $3 \mathrm{~d}$ dam by Rockingham. Sold to Henry S. Sabin, Fon-du-Lac, Wis.; to W. M. Longenecker, Mason City, Ia. ; to John Benton, Fargo, Dak., and kept in Cortland, N. Y. Information from John C. Keefe, Locke, N. Y., breeder of Dotwick.

Sire of Dotwick, $2: 293 / 4$; Merrill, $2: 213 \frac{3}{4} ; 3$ dams of 3 trotters, I pacer.

DAKOTA BOY (3-32), chestnut; foaled I $89 \mathrm{I}$; bred by W. B. Needham, Boonsbow, Ia.; got by Aquarius, son of Pancoast : dam Nelly Jackson, chestnut, foaled $\mathrm{I} 885$, bred by J. W. and N. D. Peck, West Cornwall, Vt., got by Lambertus, son of Daniel Lambert ; 2 d dam Quauk, chestnut, foaled r 882 , bred by J. W. and N. D. Peck, got by Aristos, son of Daniel Lambert; 3d dam bred by J. W. and N. D. Peck, got by Smith's. 
Patchen; and 4th dam Doll, by Douglas Black Hawk. Sold to A. Peck, Woonsocket, S. Dak. Pedigree of dams from N. D. Peck.

Sire of Harry Booth, $2: 23$.

DALGAMO (5-1 28), black; foaled I 878 ; bred by George W. Burch, Georgetown, Ky.; got by Dictator, son of Hambletonian : dam Amanda, said to be by Blackwood, son of Alexander's Norman; and $2 \mathrm{~d}$ dam Salvisa, by Alexander's Abdallah. Sold to Noah Armstrong, Helena, Mont.; to Marcus Daly, Hamilton, Mont.; to G. W. Ware, Como, Mont. ; to Geo. Palmer, Woodside, Mont. Pedigree from P. J. Shannon.

Sire of Justina, $2: 19 \frac{1 / 4}{2} 2$ pacers $\left(2: 14 \frac{3}{4}\right) ;$ I dam of 2 trotters.

DALGHETTY (I-64), brown, I6 hands, I I 25 pounds; foaled I89 I ; bred by R. P. Pepper \& Son, Frankfort, Ky. ; got by Norval, son of Electioneer : dam Devotion, brown, bred by R. P. Pepper, got by Blackwood, son of Alexander's Norman ; 2 d dam Cathedral, brown, bred by R. P. Pepper, got by George Wilkes; 3 d dam Kate Tarltan, bay, bred by Hunt Bros.,

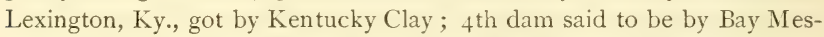
senger. Sold to Peter Truax, Eau Claire, Wis., where he was kept till I902; at Lima, O., I903. Pedigree from Peter Truax.

Sire of Dal Dewey, $2: 23 \frac{1}{2}$; dam of I pacer.

DALLAS (5-64), roan, I $5 \frac{1}{2}$ hands, I roo pounds; foaled I 846 ; bred by N. B. Turner, Gallatin, Tenn.; got by Harris' Davy Crockett, son of Juno, by Craig's Copperbottom : dam bay, bred by N. B. Turner, got by Tecumseh, Canadian; $2 \mathrm{~d}$ dam bred by N. B. Turner, got by son of Pacolet, thoroughbred. Kept, $1849-50$, by N. B. Turner, and $\mathrm{I} 85 \mathrm{I}$ by Dr. J. M. Head near Gallatin. J. D. Martin, Gallatin, Tenn., writes:

"He was a horse of great power, fine style and action, fine disposition and a very fast pacer in his day. He got more strictly good saddle or road horses than any ten sires of his day. They were almost universally gentle and kind to work or ride and they had a great power of endurance."

See The Morgan Horse and Register, Vol. I., page 776.

Sire of dam of Molsey, $2: 21 \% / 4$, winner of 12 races.

DALLAS NEIVS, ( I-I2S), $2: 29$ T/4, brown; foaled 1896 ; bred by William Russell Allen, Pittsfield, Mass. ; got by Plebicite, son of Re-election : dam Edita, bay, foaled I $\$ 86$; bred by Charles Backman, Stony Ford, N. Y., got by Kentucky Prince, son of Clark Chief; 2 d dam Elise, brown, foaled I 877 , bred by Charles Backman, got by Messenger Duroc, son of Hambletonian ; 3d dam Green Mountain Maid, brown, foaled 1862 , bred by Samuel Conklin, Middletown, N. Y., got by Harry Clay, son of Cassius M. Clay Jr. ; and $4^{\text {th }}$ dam Shanghai Mary, foaled i 848 . Sold to A. H. Bels, Dallas, Tex. Information from catalogue of Chas. Backman.

Sire of Exa, $2: 24 \frac{1}{4}$. 
D.ALLAS TEXAS (3-1 28$), 2: 21 \mathrm{I} / 4$, brown : foaled 1896 ; bred by Henry Exall, Lomo Alto Farm, Dallas, Tex.; got by Dean Forrest, son of Electrite: dam Blue Jay, roan, foaled 1887 , bred by E. T. Lillard, Nicholasville, Ky., got by Jay Bird, son of George Wilkes; 2d dam Pauline, said to be by Bell Morgan, son of Cottrill Morgan; and $3 \mathrm{~d}$ dam Puss, by Davy Crockett (Riley's). Died rgor. Pedigree from breeder.

Sire of Col. Henry, $2: 121 / 4$.

DALL BRINO (I-32), bay, I5 hands, rooo pounds; foaled I88I; bred by M. L. Hare, Fisher's Switch, Ind. ; got by Hambrino, son of Edward Everett: dam Linda, bay, bred by David Penn, Scott County, Ky., got by Alexander's Abdallah; 2 d dam, Katy Darling, said to be by Bald Stockings, son of Tom Hal; and 3 d dam by Whalebone. Sold to P. R. Eycke, Washington Court House, O.; to L. H. Westerman, Ellsworth, Kan., who sends pedigree. Died 1902.

Sire of May Brino, $2: 261 / 2,5$ pacers $\left(2: 12 \frac{1}{2}\right)$; I sire of I pacer; dam of I pacer.

DALLGETTY, $2: 14 \mathrm{I} / 4$, bay; foaled 1885 ; bred by Charles Nolan, Centre Square, Penn.; got by Thorndale, son of Alexander's Abdallah : dam Lilly Dale, bay, bred by Richard Richards, Racine, Wis., got by Alden Goldsmith, son of Volunteer ; 2d dam Queen of Meadow Lawn (Viola), bred by V. C. Monroe, Racine, Wis., got by Goldsmith's Abdallah, son of Volunteer; 3d dam said to be by Richard's Bellfounder. Gelded.

Sire of Tennehinch, $2: 161 / 4$.

DALLMEYER (3-I28), bay, I63/4 hands, I240 pounds; foaled I 888 ; bred by W. W. Aldrich, Tipton, Ia.; got by Lord Wellington, son of Cuyler : dam Maud O., chestnut, bred by John Bradshaw, Shelbyville, Ky., got by Shelby Chief, son of Alexander's Abdallah; 2d dam Fanny Gratz, by Mambrinello, son of Mambrino Chief; and $3 \mathrm{~d}$ dam by Hunt's Commodore, son of Mambrino. Sold to H. J. Reynolds, Jefferson, Ia., later Eugene, Ore.; to W. H. McAlister, Jefferson, Ia., whose property he died by fire, $\mathrm{r} \delta_{9 \mathrm{r}}$. Information from H. J. Reynolds.

Sire of Dell Wellington, $2: 24^{1 / 4}$.

DALY (5-128), 2:22 I/2 ; foaled I883; bred by Leland Stanford, Menlo Park, Cal. ; got by Gen. Benton, son of Jim Scott : dam Dolly, brown, I51/2 hands, foaled 1879 , bred by Leland Stanford, got by Electioneer; $2 \mathrm{~d}$ dam Lady Dooley, $2: 3 \mathrm{I} 3 / 4$, brown, bred by Mr. Hedge, California, got by McCracken's Black Hawk, son of Black Hawk; 3d dam Hedge Mare. Pedigree from catalogue of breeder.

Sire of 7 trotters $\left(2: I_{7}\right)$; I sire of 2 trotters, I pacer.

DALY BIRD (3-I28), brown; foaled 1892 ; bred by J. F. Bailey, Lexington, Ky.; got by Jay Bird, son of George Wilkes: dam Susie Patchen, 
brown, bred by J. F. Bailey, got by Mambrino Patchen, which see ; 2 d dam Lena, said to be by Christian's Edwin Forrest ; and $3 \mathrm{~d}$ dam Mallis, by Comet. Sold to J. W. Daly, Mt. Kisco, N. Y., who gives pedigree.

Sire of Berdina, $2: 10 \frac{1}{4}$.

DAMO (3-64), bay, off hind foot white; foaled 1885 ; bred by $H$. C. Jewett, Buffalo, N. Y.; got by Jerome Eddy: dam Bessie Gilpin, bay, near hind foot white, and small star, $15 \mathrm{~T} / 2$ hands, foaled 1880 , bred by Herbert Lathrop, Willink, N. Y., got by John Gilpin, son of Strader's Cassius M. Clay Jr.; 2 d dam Kitty, said to be by Hamlin Patchen, son of George M. Patchen; and 3 d dam by Arabian Morgan, son of Billy Root. Pedigree from catalogue of breeder. Sold to Dygert Bros., Springville, N. Y., Dec. I I, I 893 .

Sire of 5 trotters $\left(2: 19 \frac{1}{2}\right)$; Niano, 2:161/4, I dam of I trotter, 2 pacers.

DAMON, bay, I5 hands; foaled about I776; bred by Colonel Baylor, Virginia; got by Junius, son of Fearnaught: dam by Fearnaught; $2 \mathrm{~d}$ dam Steady Sally. Advertised as above in Maryland Gazette, April 26, I 78 I.

DAMON, $2: 23 \frac{3}{4}$, brown; foaled I 869 ; bred by Billings Holdridge, Batavia, N. Y.; got by Ames' Bogus, son of Ballard's Bogus: dam Old Gray, foaled I 858 , bred by Hiram F. Cash, Batavia, N. Y., got by Gray Eclipse, said to be by a son of Cash's son of American Eclipse; $2 \mathrm{~d}$ dam gray, bred by Hiram Cash, got by Cash's son of Bush Messenger; 3d dam gray, bred in the Cash family. See The Morgan Horse and Register, (Under ten race winners.), Vol. I., p. 866.

Sire of Daisy Dean, $2: 29 \frac{1}{4}$, and winner of I9 races.

DAN (I-I6), bay, I5 I/2 hands; foaled I 888 ; bred by W. Buer, Carrollton, Ky. ; got by Gurlit's Brown Pilot: dam untraced. Sold to Crouch \& Grobmyer, Carrollton, Ky.

DANA McGREGOR (I-32), bay; foaled I 886 ; bred by D. W. Price, Lexington, $\mathrm{Ky}$,; got by Robert McGregor, son of Major Edsall: dam Mementress, said to be by Administrator, son of Hambletonian; and 2d dam by Stockbridge Chief. Sold to Powell Bros., Springboro, Penn.; to Dr. J. D. Dunlop, Alpena, Mich. Pedigree from Powell Brothers.

Sire of Time Lock, $2: 261 \frac{1}{2}$.

DANA-SWAZEY HORSE, black, one hind foot white, very light mane and tail, good head, large ears, near I 6 hands, I 200 pounds; foaled about I 825 ; bred by M. Swazey, Danville, Vt.; got by a colt of the Ayres Horse. Moses Stevens of North Danville, said:

"I came here in I $88_{3}$; was married in $\mathrm{r} 825$. I married the oldest daughter of Mr. Swazey, who raised the Dana-Swazey Horse. Philip 
Swazey had a colt from the Ayres Horse, and the colt got the DanaSwazey Horse. The Ayres Horse was a good-sized gray horse of the Quicksilver stock. Dana bought this Swazey Horse and kept him two or three years. The Dana-Swazey Horse was born about the time I was married. Swazey kept him until he was five or six years old. Am certain Dana bought him about $\mathrm{I}_{3} \mathrm{I}$ and took him West about I $_{35}$. ."

DANA WILKES, $2: 29^{\mathrm{T}} / 2$, bay, one hind foot white, small star, $15 \frac{\mathrm{T}}{2}$ hands, 950 pounds; foaled $x 888$; bred by Fred H. Leonard, Fair Haven, Vt. ; got by Victor Wilkes, son of Victor Von Bismarck, by Hambletonian : dam Diana Baker, foaled 1878 , bred at Hampton, N. Y., by Howard Leonard, Fair Haven, Vt., got by Bona Fide, son of Hambletonian; 2d dam Lady Bell, bay, foaled I87o, bred by Clanson Warren, New Preston, Conn., got by Warren's Cassius M. Clay Jr.; 3d dam Belle of New Hampshire, said to be by Jones' Cassius M. Clay, son of Cassius M. Clay. Sold to Esek Bussey, Troy, N. Y. Pedigree from breeder.

Sire of Vera Fish, $2: 221 / 2$.

DAN BROWN (I-32), $2: 32$, sorrel, white hind feet, I $5 \frac{1}{2}$ hands; foaled about I 864 ; I I 100 pounds ; said to be by Poscora, son of Moscow : and dam, the advertisement says, "of the far-famed Peacock stock." This advertisement if correct suggests very strongly that this horse was bred in Canada. The Petit Coq family of horses which originated at Contre Cœur, P. Q., is printed quite frequently in English "Peacock." Sold to A. C. Babcock; to Walker Bros.; to J. F. Rumsey, all of Canton, Ill. ; to James T. Mershon and Robert Dilworth, Vermont, Ill. Trotted I873-78. Information from James T. Mershon, I89I, who says, above pedigree is as published by A. C. Babcock. Mr. Mershon also writes: "His colts mostly bay and sorrel; good style and disposition; nothing better in country from crdinary mares."

Sire of 2 trotters $(2: 24), 2$ pacers $\left(2: 16 \frac{1}{2}\right) ; 4$ dams of I trotter, 3 pacers.

DANCER, ( $\mathrm{I}-32)$, bay, with hind pasterns white, $\mathrm{I} 5 \mathrm{~T} / 2$ hands, Iooo pounds ; foaled May 31, I886 ; bred by Col. J. Y. Clopper, Bennet, Colo. ; got by Alarm, son of Walkill Chief : dam Omaha Maid, chestnut, said to be by Mambrino Chief Jr., son of Mambrino Chief; 2d dam Nellie, bred by G. W. Van Sken, Coldwater, Mich., got by Magna Charta, son of Morgan Eagle; 3 d dam Fanny, said to be by Thunderbolt, son of Henry. Sold to C. S. Owens, Ryers, Colo. Pedigree from Charles M. Darling, Living Springs Farm, Bennet, Colo.

DANCOURT (3-128), 2 : $161 / 2$, black, foaled, 1890 ; bred by S. A. Brown \& Co., Kalamazoo, Mich.; got by Ambassador, son of George Wilkes : dam Lowland Girl, 2 : 19 $1 / 2$, bred by James Wilson, Rushville, Ind. ; got 
by Legal Tender Jr., son of Legal Tender ; 2 d dam Fanny, said to be by Blue Bull.

Sire of Gray Gem, $2: 09 \frac{1}{2}$.

DAN CUPID (I-I28), 2 :091/2, bay, foaled I 888 ; bred by O. P. Alford, Lexington, Ky.; got by Barney Wilkes, son of George Wilkes: dam Astermore, bay, bred by Geo. W. Bowen, Paris, Ky., got by Strathmore, son of Hambletonian; 2d dam Asteria, bay, bred by A. J. Alexander, Spring Station, Ky., got by Asteroid, son of Lexington ; 3d dam Heiress, bred by R. A. Alexander, Spring Station, Ky., got by imported Scythian; 4th dam Heads I Say, said to be by imported Glencoe; $5^{\text {th }}$ dam imported Heads or Tails, by Lottery, etc. (see A. S. B. Vol. III., p. 42). Sold to F. J. Berry, Chicago Ill. Pedigree from breeder.

Sire of Raz Allen, $2: 27 \frac{1}{4}$, Red Top, $2: 24 \frac{1}{4}$.

DANDY, $2: 37 \frac{\mathrm{T} / 4}{4}$, bay; foaled about $\mathrm{x} 850$; said to have been bred on Long Island, and got by Long Island Black Hawk, son of Andrew Jackson. Owned by Philip Dater, New York, N. Y., and afterwards by John McGraw, Ithica, N. Y., who sent him to Bay City, Mich. Information from Joseph McGraw, Ithica, N. Y.

Sire of Jenny, $2: 29 \frac{1 / 4}{4}$ I dam of 2 trotters.

$D A N D Y, 2: 12 x / 2$, bay, I 6 hands, I IOo pounds; foaled r 888 ; bred by L. H. Westerman, Ellsworth, Kan. ; got by Dall Brino, son of Hambrino : dam Mayflower, bay, said to be by Kimbraugh's Abdallah, son of Alexander's Abdallah. Won a I 2 -heat race at Independence, Ia., I89r. Sold to C. E. Hamilton, Little River, Kan. Pedigree from breeder.

Sire of Dandy Way, 2:I81/4; dam of I pacer.

DANDY BOY (MORGMONT) (I -32), $2: 293 / 4$, brown, I 6 hands, IIoo pounds; foaled $\mathrm{I} \delta 8 \mathrm{I}$; bred by Toll \& Rardin, Clinton, Ia.; got by Almont Rattler, son of Almont: dam Nelly Toll, brown, bred by John Clark, Prophetstown, Ill., got by Baker Horse, son of McKenzie, by Sherman Black Hawk. Information from breeder.

Sire of Billy F., $2: 19 \frac{1}{2}$.

DANDY JIM ( $\mathrm{I}-8$ ) foaled $\mathrm{r} 857$; bred by Benjamin Stanton, Richmond, Ill.; got by Jemmie, son of Gifford Morgan : dam bred by Benjamin Stanton, got by Sir Henry, brought from New York to Green Lake, Wis., by Mr. Goodspeed. See The Morgan Horse and Register, Vol. II., page $9 \mathrm{I}$.

Sire of dam of Saint Charles, $2: 26$.

DANDY JIM (I-I6), 2 :I9 $1 / 2$, dark gray, I $53 / 4$ hands; foaled 1885 ; bred by Z. E. Simmons, Lexington, Ky.; got by Young Jim, son of George Wilkes : dam Capprara, gray, bred by H. S. Willis', Medford, Mass., got by Daniel Lambert, son of Ethan Allen; 2 d dam Fanny, said to be by 
Garabaldi; and 3 d dam Nonona, by Black Hawk. Owned by N. I. Buster, Faulconer, Ky. Gelded young. Pedigree from breeder.

DANDY TIME ( $\left.\mathrm{I}-3^{2}\right)$, bay, I6 hands, I 200 pounds; foaled $\mathrm{x} 887$; bred by J. M. Christy, Des Moines, Ia.; got by Mark Time, son of Robert McGregor : dam Maggie C., bay, bred by George Lowe, Davenport, Ia., got by Felter's Hambletonian, son of Hambletonian; $2 \mathrm{~d}$ dam Flora, said to be by Green's Bashaw; and 3d dam Belle, by Tom Thumb. Sold to A. F. Sevaney, Kellogg, Ia. Pedigree from breeder.

Sire of Dandy Time Jr., $2: 25$.

DANDY WHITE STOCKINGS (I-32), $2: 27 \mathrm{~T} / 4$, chestnut, $15 \mathrm{~T} / 2$ hands, rooo pounds; foaled June 2, I879; bred by Pohattan Gott, East Worcester, Otsego County, N. Y. ; got by Rocket Jr., son of Rocket, by Young Myrick, son of Sherman Black Hawk: dan Maggie, cream, bred by H. H. Nipton, Ticonderoga, N. Y., got by Toronto Chief; 2 d dam bred by H. H. Nipton. Sold to B. H. Bradt and P. Scully, Schenectady, N. Y. Gelded young.

DAN G. (I-64), bay, strip in face, left hind foot white, I $5 \frac{\mathrm{T} / 2}{2}$ hands, 1000 pounds; foaled 1877 ; bred by John Beals, Veedersburg, Ind.; got by Bald Hornet, son of Gifford's Bald Hornet, by Arnold's Red Buck : dam bay, bred by Enos Harper, Millsboro, Ind., got by Mill's Cadmus, said to be a son of Iron's Cadmus ; 2 d dam a saddle mare. Died I902. Pedigree from James Glascock.

Sire of 3 pacers $\left(2: 13^{1 / 4}\right)$.

DAN G. (I-16), steel gray, $15 \frac{1}{2}$ hands, 1200 pounds; foaled 1883 ; bred by A. G. Pratt, London, O.; got by Young Mohawk (Pratt's) son of Clark's Mohawk Jr., by Mohawk, son of Long Island Black Hawk : dam Topsey, bred by Benjamin Linson, Madison County, O., got by John Gayno, a Kentucky saddle stallion sent from Bourbon County, Ky., during the war, to Jesse Linson, Madison County, O., and said to be by Tom Hal; 2 d dam brought from Kentucky, by Benjamin Linson, said to be by Tom Hal. Owned by a man in Plain City, O., when 20 years old. Young Mohawk's dam Bird, by Flying Morgan ; 2d dam by old Yellow Jacket a fast pacer. Pedigree from breeder, who writes :

\section{Mr. Joseph BATTELL,}

$$
\text { London, O., Nov. 5, I904. }
$$

Dear Sir :-I enclose herewith the pedigree of the stallion Dan G. the sire of Gray Ben, $2: I_{5} 3 / 4$. I owned the dam of Dan G. and his sire Pratt's Mohawk, at the time he was bred and I also owned the dam of Pratt's Mohawk, Byrd.

The dam of Dan G., was bred and raised by the late Benjamin Linson, and sold by him at five months old to the late Marion Slaughter all of this (Madison) County. Sold by Slaughter to Allen Critz of Clark County and I bought her from Critz. We called her Topsy. 
I owned Pratt's Mohawk and the dam of Gray Ben both, when I bred Gray Ben. Gray Ben's dam Minnie is the dam of Gray Ben, $2: 153 / 4$, Ben K., $2: 24 \frac{1}{4}$, Lilly B., $2: 221 / 4$, and Pat Rooney, $2: 261 / 4$. Will give any further information wanted if this is not sufficient.
Very truly yours,
A. G. Pratt.

P. S.-John Gayno was a Tom Hal and was sent to Jesse Linson instead of Ben (a brother of Ben's).

Sire of 2 pacers $\left(2: 15 \frac{3}{4}\right.$; I dam, I pacer.

DAN HARDING ( $1-32$ ), black; foaled I8-; bred by Polk Bros., Columbia, Tenn.; got by Gibson's Tom Hal Jr., son of Kittrell's Tom Hal: dam Reveille Girl.

Sire of $\mathrm{Hal} K ., 2: 14^{1 / 4}$.

DAN HOWELL, 2 :I9 $1 / 2$, bay, I53/4 hands, II 75 pounds; foaled I 864 ; bred by Theodore Narston, Middletown, O. ; got by Young Highlander, son of Gray Highlander: dam bay, bred by Jere Marston, Middletown, O., got by Bellfounder; $2 \mathrm{~d}$ dam gray, bred at Middletown, O. Gelded young. Pedigree from breeder who writes:

"Yours of the 5 th inst., received, and in reply, will say, I did raise the horse Dan Howell, but it was a good many years ago, and I was under the impression the horse had been sent across the ocean to England. I had been so informed, but if the horse is still living and owned in Vermont, and is yet so good his owner wants his pedigree, I will gladly give it so far as I am able to do so. Dan Howell was foaled the spring of I 864 in Butler County, O. His sire was a young horse (only three years old, I think at the time), whose sire was Gray Highlander, a horse imported by a stock company, then in existence in Butler County, from Kentucky, a very showy horse but not noted for speed. The dam of Dan Howell's sire was a roan Medley mare, a natural pacer of good action. Dan Howell's dam was a bay mare got by Bellfounder, a noted horse which had been brought to Middletown, O., from Long Island, N. Y., about the year 1842 . He was a superior foal getter and was the sire of more good horses perhaps than any other horse that had ever been kept in Ohio. His colts were all good square trotters, with excellent endurance and constitutions. Dan Howell's $2 \mathrm{~d}$ dam on dam's side was a gray mare bred and raised by my grandfather, but I cannot give her pedigree, but will say she was as spirited and showy little mare as ever was saddled or harnessed and lived to be 30 years old and every foal partook of the same spirit which was transmitted down to the gray colts. Dan Howell's dam was bred and raised by me. I exhibited her 7 times till she was four years old and never failed to take the premium on her. She would apparently grow two inches in height when on exhibition. I parted with Dan Howell when he was four years old, which was before he was trained to trot. I had broken him to race under the saddle and had never driven him much to buggy. His great spirit with his lasting qualities made him a success."

DANIEL ALLEN (3-32), black, I53/4 hands, weight II 50 pounds; got by Delong's Ethan Allen, son of Ethan Allen: dam Milwaukee Girl (record 
2:1 8 ), said to be by Hambletonian. Owned 1907, by E. L. Stagg, Panton, Vt.

DANIEL BOONE (3-32), bay, $15 \frac{1}{2} 2$ hands; bred by John Keitley, Boone County, Ky.; got by Tom Crowder, son of Pilot: dam Paoni, 2 :30, said to be by Copperbottom; and $2 \mathrm{~d}$ dam by Blackburn's Whip. Sold to Lyman L. Dayton, St. Paul, Minn., whose property he died, I865.

Sire of Cooley, $2: 26$; I dam of I trotter.

DANIEL BOONE (I-8), bay; foaled I 856 ; bred in Kentucky; said to be by Captain Walker, son of Tecumseh: and dam by Pilot. Owned successively by Dr. Herr, Lexington.; John K. Alexander, Eli Butler, both of Franklin, Ind.; and L. O. Raymond, who kept him in Wisconsin and Iowa. In I 872 he went to Cherry Hill, Neb.

DANIEL BOONE (I-32), $2: 3 \mathrm{I} 3 / 4$, bay; foaled $\mathrm{I} 862$; bred by Joseph Harker, New York, N. Y.; got by Hambletonian: dam Kate, black, brought from Canada and said to be by Bellair, which see; and $2 \mathrm{~d}$ dam a pacing mare of the Dansereau breed. Sold to A. C. Archer, Fairfield Center, Me.; I 876 to D. M. Foster, Canada Point, Me.; to T. J. Shaw, Cream Brook Farm, Hartland, Me. H. A. Archer, Skowhegan, Me., May 28 , 1898 , writes that Daniel Boone was brought to Maine in spring of 1876 and owned there 13 years.

Mr. Joseph Battell,

Everett House, New York, April 13, I89o.

Dear Sir :-Yours of the $9^{\text {th }}$ received. Kate was purchased about I 856 in Canada by an Irishman by the name of Gourley, now dead, who had a small stock farm a short distance from Newburgh on the North River. He raised Brunette, Bruno and Daniel Boone. He sold Brunette as a three-year-old for $\$ 500$. He sold Bruno and Daniel Boone at one and two years, I think, for $\$ 350$ for the two. He then sold old Kate to Major Norton, a neighbor, for \$9o. The Major raised Young Bruno, Miss Brunette and Bruno, and then I think he gave the old mare to Mr. Backman. I bought Brunette and Bruno from Mr. Monoto, now dead, as four and five-year-olds, for $\$ 30$,ooo. They trotted in $\mathrm{I} 867$ to my road wagon weighing 180 pounds in $2: 25 \frac{1}{4}$. If Bruno had been as steady as the mare, they would have trotted in $2: 15$. They trotted a half mile four days previous to their trial on the Fashion track in I : $06-$ first quarter in 34 , second in 32 . I bonght Young Bruno at five years old and Miss Brunette and Breeze when two and three years old. I owned Lulu, Gazelle (formerly Nashville Girl), half sister to Lulu, Mattie and Maud S. I bought Maud S. as a four-year-old and let Mr. Vanderbilt have her as a special favor. I paid $\$ 20,000$ for her; in $\mathbf{1 8 8 6}$, the year after Mr. Wm. H. Vanderbilt sold her to Mr. Bonner, I offered the latter for a friend of mine $\$$ roo,ooo for her. I sold my brood mares and four of their colts to Gov. Stanford. I have been driving on the road but very little for the past five years.

Very truly yours,

JOSEPH HARKER.

Sire of to trotters $\left(2: I_{7} \frac{3}{4}\right) ; 4$ pacers $(2: 181 / 4) ; 6$ sires of 6 trotters, Io pacers; I3 dams of 7 trotters, 8 pacers. 
DANIEL BOONE, said to be by Kremer's Rainbow.

Sire of Chimes C. $2: 23$, bred by C. L. Clancy, Edinburg, Que.; 3 dams of 3 trotters.

DANIEL BOONE JR.

Said to be sire of Bunch, $2: 23 \frac{1}{2}$.

DANIEL CLARK HORSE. See La Touche Horse.

DANIEL L. ( $1-32$ ), chestnut, I 5 hands, 900 pounds; foaled I 887 ; bred by Nelson Richards, Panton, Vt.; got by Montello, son of Almont: dam chestnut, bred by Nelson Richards, got by Daniel Lambert, son of Ethan Allen. Sold to Albert Larrow, Ferrisburgh, Vt., who sends pedigree.

Sire of Pixie, $2: 15 \frac{1}{2}$.

DANIEL LAMBERT ( $\mathrm{I}-8)$, chestnut, with stripe in face, and one white hind foot, mane and tail of lighter color than body, $151 / 4$ hands, I0zo pounds; foaled I 858 ; bred by Wm. H. Cook, Ticonderoga, N. Y. ; got by Ethan Allen, son of Black Hawk: dam Fanny Cook, a high strung handsome chestnut mare and a natural trotter, bred by Montfort Van Kleeck, Chester, Orange County, N. Y., got by Abdallah, son of Mambrino ; 2d dam chestnut, bred by Montfort Van Kleeck, got by Stockholm's American Star, son of Duroc, by imported Diomed; 3d dam a mare bought by Montfort Van Kleeck, in Dutchess County, N. Y., breeder and breeding unknown. We have received the following letters concerning the dam :

Chester, N. Y., Dec. I6, I 885 .

Editor Register :-In reply to yours of Nov. 9, would say that my father got the grandam of Fanny Cook at Fishkill Plains, Dutchess County, N. Y., but of whom and how old she was I cannot tell. I am fifty years of age and I can just remember her as an old mare; and, as all the parties to the transfer of her are sometime dead, it will be almost an impossibility to trace the matter. My information in regard to the matter was received from my father, which he gave to Mr. Cook at the time he sold Fanny Cook, then three-years-old.

$$
\text { Yours truly, H. D. VAN KLEECK. }
$$

Mr. Joseph Battell,

$$
\text { Chester, Orange County, Sept. I, } 1885 \text {. }
$$

I received your letter making inquiries concerning the pedigree of the mare bought by my father for Mr. Cook of Ticonderoga.

I was extremely busy at the time and the sons of Mr. Van Kleek, having moved to a distant part of the country, I deferred the matter until a few days ago when visiting them, I got the enclosed pedigree from Mr. Van Kleek, the son of the man who bred Fanny Cook and her dam.

Mr. Van Kleek bred Fanny Cook's dam in Dutchess County, and brought her with him to this county when he moved here forty-three years ago. I remember her distinctly as a chestnut mare very highstrung, handsome and a natural fast-trotter. She afterwards became 
lame with a bog-spavin. There can be no possible doubt of the correctness of the enclosed pedigree.

Son of the late Seely R. Roe.

$$
\text { Yours, David RoE. }
$$

Fanny Cook by Abdallah, foaled r 847 . Fanny Cook's dam by Stockholm's American Star, by Duroc. Mr. Van Kleek gives no Red Bird cross.

In an article by W. H. Bliss on Daniel Lambert, published in the Middlebury Register, Aug. 2, I889, Mr. Bliss says :

"The portrait here produced was one of the best of the graphic likenesses from the pencil of the lamented H. S. Kittredge, an artist, who for the quality of faithfulness to life in his sketches of horses has never been surpassed. It shows this famous trotting sire, not a fancy picture, but as he really was shown in his prime at Cream Hill.

"Daniel Lambert was the most prepotent son of Ethan Allen, he by Black Hawk; the dam of Daniel Lambert was Fanny Cook, by Abdallah, son of Mambrino; second dam by Stockholm's American Star, son of Duroc.

"Fanny Cook and her dam were both bred by Montfort Van Kleeck, late of Chester, Orange County, N. Y., and it is settled by his statement, and has never been disputed, that Fanny Cook was by old Abdallah and that her dam was by Stockholm's American Star, by Duroc, by imported Diomed. The mare that brought the dam of Fanny Cook was purchased by Montfort Van Kleeck while he was living in Dutchess County, N. Y., and her breeding and breeder are as yet unknown.

"We have made this statement before, and have published the correspondence with a son of Mr. Van Kleeck showing it to be accurate, and it is somewhat surprising that it should continue to be iterated by journals that ought to be authority, that the third dam of Lambert was by Red Bird-he, as some say, by Bishop's Hamiltonian, and according to others, by Eclipse, son of Duroc. No one ever pretended to name the breeder of this mare, and therefore no one has any claim to know her sire. Neither has any one, so far as we know, ever pretended to name the breeder of either of the above named Red Birds, nor given any evidence that either ever existed.

"The following description and history of Daniel Lambert is taken largely from an article in The American Cultivator:

" "Daniel Lambert is a chestnut horse with mane and tail verging on the flaxen order, left hind foot white and stripe of white in face. He is of the Morgan pattern, standing about fifteen hands, has a neat bony head, large expressive eyes, set well apart, short lively ears always carried erect, clean cut throttle, handsomely arched neck of good length well set upon strong, oblique shoulders, giving him naturally an upheaded, lofty appearance. His back is of medium length, and very strong, ribs well sprung from the spine, giving him a round barrel, which is deep, of good length and ribbed closely to the hips, loin broad and well muscled, coupling strong and smooth, hips long and roundly turned, rump rather straight, the whirl bone and tail being set high, quarters well muscled, hocks well let down, forearms long, broad and muscular, cannons short, the bone being of good size in proportion to weight of body. His hind leg is fairly straight, but the lower part is joined to the hock at something of an angle, giving it a conformation found in many speedy trotters. His 
pasterns are short and strong, feet well-shaped and of size in preportion to that of body and limbs. By common consent the Morgans have enjoyed the reputation of being the most beautiful horses, as a family, $\mathrm{cr} r$ produced on this continent, and Lambert, when in his prime, was unquestionably one of the finest specimens of that family. No ho:se could be found that excelled him in beauty of form, ease and elasticity of action, elegance of style and grandeur of poise, whether at rest or in motion. Few horses have ever lived that possessed greater power of stamping their offspring with the above characteristics, and imparting the ability to perpetuate them through succeeding generations.

" "Daniel Lambert was bred by William H. Cook of Ticonderoga, N. Y., and foaled in 1858 . When a yearling, Lambert was sold to . Ir. John Porter of Ticonderoga, N. Y., the former owner of Aristos ( $2: 273 / 4)$, and was known in his earlier years as Hippomenes, also as the Porter Colt. He was naturally a very fast trotter, and in his three-year-old form, driven by Dan Mace, won a race on the old Sangus track, beating Lady Anderson and Young Mack, the latter being distanced the first heat, which was won by Lady Anderson in $2: 49 \mathrm{~T} / 2$. Lambert was evidently not sent for that heat, however, as he took the next two with ease in $2: 43,2: 42$. When the race was finished Mace leaped from his sulky, bounded into the judges' stand and, swinging his hat declared that Lambert was the greatest three-year-old trotter in the world, offering to match him at from $\$ 500$ to $\$ 5000$ a side against anything of his age that could be produceú.

" In his five-year-old form Daniel I ambert was bought by Mr. A. C. Harris for R. S. Denney, then living in Boston, who used him one season at Saratoga, N. Y., for road purposes, beating the best trotters found at that famous summer resort. A few years later Mr. Denning sold him to Benjamin E. Bates, who sent him to A. C. Harris, then located at Cream Hill Stock Farm, Shoreham, Vt., where the horse remained from I 866 to 1877. It has been supposed by many that Mr. Harris owned an interest in the horse, but that is a mistake. Previous to his being sent to Shoreham he get but few foals. During the time that Mr. Harris had charge of him he was bred to I 042 mares, but the number of foals resulting is not definitely known. His service fee during his last years at Cream Hill was \$ Ioo the season. From Shoreham he was taken to the Bates Farm, Watertown, Mass., where he stood in charge of William Tourtelotte until the fall of I880, when he was bought by David Snow of Andover, Mass., for $\$ 2500$, being then in his twenty-third year. After passing to the ownership of Mr. Snow his service fee was advanced to \$20o and later raised to $\$ 500$ the season. In the fall of $\mathbf{I} 88_{4}$, when in his twentyseventh year, he was bcught at public sale by some Middlebury, Vt., gentlemen for $\$$ I550, probably the largest price ever bid for a horse of that age in America.

" "The season of 1885 he made at Middlebury, and was then taken to the farm of Joseph Battell in Weybridge, two miles north of Middlebury village, where he made the season of $\mathrm{r} 886$. In these two seasons he got about thirty foals, about the same number each season. This practically closed his stud career, though he is said to have produced two foals in in 1887 , one of which, however, was born dead. These thirty children of his old age have all the vigor, elegance and speed promise of those of his prime, and are very highly valued. The only one we know to have started in a race was a bay filly bred by W. W. Moore of Shoreham (breeder and owner of Gillig, $2: 23^{\mathrm{T}} / 2$ ), and she won the yearling race of the Vermont Breeders' Association in 1887 over a large field, with great 
ease. Daniel Lambert himself was shown both to bridle and in harness at the Breelers' meeting at Rutland in August, 1888 , then thirty years of age, and commanded universal applause for his action, style and fire. He was frequently exercised in harness up to the time of his death, which occurred on June 29 th last at Middlebury. He ate well and was active up to the day of his death, which was not apparently, from old age, although he was then thirty-one, but from an acute attack of mad staggers, from which he died in about seven hours. He was still owned by the Middlebury company, but from I $885 \mathrm{Mr}$. Battell owned a majority of the shares." "

The above is an excellent, and from the stand point from which it was written, a truthful description of this horse.

From another stand point we will paint the picture, having seen hundreds and owned and driven a very considerable number of his get.

To a most remarkable degree Lambert was a producer of speed. There were very few of his colts but what had it, and we feel very certain that if they had all been developed, as has practically been the case with some more favored sires, the number of his $2: 30$ trotters would have amounted to hundreds, and exceeded that of any stallion to the present time. Quite a number of those we owned were timed close to or under $2: 30$ but they were never given a technical record, as we were too much otherwise engaged, to attend to it. The get of Lambert, too, were generally remarkably attractive in their appearance. But it was their speed which made them so great favorites.

We remember well the first time we saw the horse. It must have been about I 870 , after he had been several years at the Cream Hill Stock Farm, Shoreham, Vt. We had a mare to breed, a favorite saddle mare which had been purchased in Virginia, and ridden in the army by Gen. James Warner of the I I th Vermont, late of Albany, N. Y.

The reputation of Lambert was becoming quite extended in our county, and we rode her 25 miles to breed her to him. We were shown the horse in his stall, and were disappointed in his size, and also especially in the lightness of his hind quarters, and so did not breed the mare, but instead rode her to Shelburne, some 30 miles, where at the time Holabird's Ethan Allen was doing service, and being very much pleased with the size and elegant appearance of the horse, bred to him. The service fee was about the same and did not enter into our decision. In this case we got no colt. Perhaps if we had it would have changed future purchases, but living near the Lamberts and seeing them excel in good looks and speed, we soon began to purchase them for road purposes and from that time to this have used almost exclusively for driving the get of Lambert or his sons, generally having from 25 to 50 of them of different ages, and have scarcely ever driven any horses that pleased us better. In our case nearly all were inbred to Morgan dams, and so were the larger part of the get of Lambert, or sons, which have made fast records.

We can remember well, too, the first time that we saw Black Hawk. 
It was when kept at Mr. Hill's in Bridport, several years after he came to Vermont. He too, was in his stable but was led out on the barn floor. In this case there was no disappointment. We were ourselves but seven or eight years old, but remember well the supremely perfect contour of the horse, evenly balanced in front and behind. But in after years as the county became filled with his descendants to quite an extent inbred, a good many of them were small with delicate limbs. The best in our county were descendants of Ethan Allen and these have always been good.

I can remember in my life three other stallions and only three that similarly with Black Hawk and Holabird's Ethan impressed me each in his own way as being very perfect and very beautiful. The first was Slander at the Fashion Stud Farm, Trenton, N. J., comparatively a small horse of the Pilot family, but wonderfully handsome. This beauty we supposed in part to connect with his dam Daisy Burns belonging to the Kentucky Hunters.

In this visit to the Fashion Farm I had the greater pleasure of seeing to much advantage in her winter quarters and winter dress, Goldsmith's Maid. A very different mare she appeared from her picture in trotting condition. A plain well appearing mare evenly balanced throughout and no semblance of coarseness about her; bay, I should judge about $15 \mathrm{I} / 2$ hands, rooo pounds, good head, good ears, good neck, broad chest, rounded body and excellent legs and feet.

The next stallion I saw which impressed me in a remarkable manner was a horse of entirely different size, and in that respect, at least, conformation. This was in California, and a descendant in male line of the famous California pacer St. Clair, from dam tracing through Jack Hawkins, son of Boston, to the thoroughbred, and $2 \mathrm{~d}$ and $3 \mathrm{~d}$ dams by St. Clair, and McCracken's Black Hawk, to the Morgan.

This animal was a golden bay, I6 $1 / 2$ hands, 1275 pounds, of supremely elegant conformation though entirely different from Holabird's Ethan Allen. For the last horse as I remember him was inclined to a roach back, but the St. Clair stallion, Yolo Chief, was entirely different, or of the sway-back pattern.

All of these stallions Black Hawk, Holabird's Ethan, Slander, Yolo Chief, belonged to the Morgan family. The last stallion that I would now mention was a thoroughbred at the great Belle Meade farm, Nashville, Tenn.

I had visited the farm on foot and alone, and did not intend to make myself known, and partly on this account strolled into a barn at one side. But here very soon I met a gentleman who was evidently the proprietor, and, when I told my name, he met me in a most cordial manner by saying that I must stay over. night with him. He then showed me the young stock and afterwards the stallions, and later I was introduced to his hospitable home and most interesting family. 
The leading stallions were running in large Paddocks enclosed with double fences. One of these impressed me again as very beautiful and very perfect. Involuntarily my mind swept back through the long cycle of years to the days of De Lancey's Wildair. Whether with reason or not I cannot say, but it seemed to me as if this horse might rejresent torlay what Wildair did in his day, the best of his race.

The stallion's name which I refer to at the Belle Meade farm was Luke Blackburn. To my question to Mr. Jackson whether he had a price for him the answer was, "If I should be offered \$I50,000 I could not afford to sell him."

We add the usual list given to Daniel Lambert, although it is understood that several of his get made standard records, which were concealed. Of these records reported thirty-seven were made in bona fide races. See The Morgan Horse and Register, Vol. I., pages I9I, $55^{6}$

Sire of 38 trotters $\left(2: 19 \frac{1 / 4}{4}\right)$ I pacer under $2: 30 ; 35$ sires of 122 trotters, 25 pacers; 62 dams of 86 trotters, 16 pacers.

DANIEL LAMBERT JR. (WESTCOTT'S) (I-8), chestnut, with small star, hind feet white, I 5 T/4 hands, 975 pounds; foaled $\mathrm{\tau} 874$; bred by H. H. Draper, Fair Haven, Rutland County, Vt. ; got by Daniel Lambert, son of Ethan Allen: dam Lady Allen bay, bred by H. H. Draper, got by Ethan Allen, son of Black Hawk; 2 d dam gray, bred by Lyman Harwood, Rupert, Vt., said to be by a son of Bishop's Hamiltonian. Sold to Hamilton Westcott, Fair Haven, Vt. See The Morgan Horse and Register, Vol. I., p. 582 .

Sire of Fenny Lambert, $2: 20$.

DANIEL LAMBERT JR. ( I-8), $2: 3 \mathrm{I}$ T/4, chestnut, with star, $15 \mathrm{~T} / 4$ hands, Iooo pounds, foaled $\mathrm{I} \$ 79$; bred by E. D. Vaughn, Sandy Hill, N. Y.; got by Aurora, son of Daniel Lambert: dam Lady Sherman (dam of Judge Davis, $2: 183 / 4$ ), chestnut, bred by A. Sherman, Sandy Hill, N. Y., got by Bellfounder (Milliman's), son of the Morse Horse; $2 \mathrm{~d}$ dam Dolly said to be by Green Mountain Morgan. Sold, when two, to A. A Wheelock; to Wm. H. Hicks, Delta, N. Y., for \$rooo. Pedigree from breeder. See The Morgan Horse and Register, Vol. I., p. $5^{87}$.

Sire of 2 trotters $(2: 293 / 4)$.

DANIEL WEBSTER (PERRY HORSE) (I-8), black roan, white hind foot, I $5 \frac{1}{2} 2$ hands, I Ioo pounds; foaled I 848 ; bred by William S. Perry, Shoreham, Vt.; got by Black Hawk: dam, black roan, bred on Long Island, said to be by Monmouth Eclipse, son of American Eclipse. Sold, 1857 , to Wm. A. G. Arthur, Ticonderoga, N. Y., who kept him one season at Whitehall, N. Y., and sold to Augustus Noble, New York, who took him to New Jersey. Kept at Fort Ann, I 855; Fort Ann and Hartford, N. Y., I 856-7. Stylish, of easy action and kind. Stock noted for beauty, kind disposition and hardiness of constitution. Awarded 
first premium at Addison County (Vt.) fair, 1852. See The Morgan Horse and Register, Vol. I., p. 470.

Sire of dam of Wm. H., $2: 181 / 2$, winner of 29 races.

DANIEL WEBSTER (I-I6), black, I5 $5 \frac{1}{2}$ hands, I050 pounds; foaled I 85 I ; bred by B. and L. Hammett, East Montpelier, Vt.; got by Peck Horse, son of Black Hawk: dam, the dam of Andrew Jackson (Hammett Horse), which see. Taken to Philadelphia with his full brother, Henry Clay, and half brother, Andrew Jackson, and supposed to have died there. See The Morgan Horse and Register, Vol. I., p. 406.

DANIEL WEBSTER, chestnut, with blaze in face and white feet; foaled r 852 ; bred by Mr. Sears, Fort Hamilton, N. Y.; got by Long Island Black Hawk, son of Andrew Jackson: dam Lady Kate, said to be by an Arabian Horse. Kept in Orange County, N. Y., about Coldenham, I86-. Pedigree from J. Madara, M. D.

DANIEL WEBSTER ( I-32), bay, 15 hands, IO40 pounds; foaled about I 853 ; bred by John B. Decker, Deckerstown, N. J. ; got by Cassius M. Clay, son of Henry Clay: dam, dam of Goldsmith's Maid, pedigree untraced. See Stranger by Gen. Washington. Sold to W. H. Gifford, Syracuse, N. Y., it is said, in 1875 . Advertised 1878 at stables of subscriber, Candee House, Syracuse N. Y., by C. E. Candee. Information from Mr. Gifford, who writes as follows :

$$
\text { East Syracuse, N. Y., Dec. I6, ig03. }
$$

Mr. Joseph Battell,

Dear Sir:-Answering your letter of the 9 th inst., as to the horse Daniel Webster, all I know about him is as follows:

In Vol. III., of Wallace's American Trotting Register, pages I59, r6o, I find Daniel Webster, bay, foaled i 855 , got by old Cassius M. Clay, son of Henry Clay; dam, the dam of Goldsmith's Maid, bred by John B. Decker, near Deckertown, N. J., and owned by him till sold I 875 to W. H. Gifford, Syracuse, N. Y.

He was a bay horse with black points, 15 hands high and weighed ro4o pounds. I drove him and bred him to a few mares owned by me but was bothered so much by people who wanted to breed mares to him that I sold him in $\mathrm{I} 877$ to a man, I think his name was Minor Barnes of St. Thomas, Canada. In $\mathrm{I} 88_{3}$ I received a letter of which the following is a copy :

Mr. W. H. GiFFORD,

$$
\text { Orwell, Elgin County, Ont., April 30, r883. }
$$

Dear Sir :-I was reading over some of the letters you wrote F. W. Smith when he owned old Dan and thinking you might be glad to hear from the horse thought I would write to you. I have owned him nearly two years and intend to keep him as long as he lives. He is looking the best he has since he has been over here, feels and acts more like a colt than a horse of twenty-eight years. He is getting some very good colts here. I have two very fine colts from him, and will breed three 
horses of my own to him this year. $\mathrm{He}$ is as sure a foal getter as we have here.

If you have time to answer this, anything speaking in favor of the horse or his get will be of interest and perhaps of value to me. What did you do with Cassock? Would like to hear.

$$
\text { Yours etc., William McCrady. }
$$

Since this above letter I have heard that the horse had died. His colts were a little under size, but they were up headed and stylish, lively and enduring roadsters, and all trot. The old horse had good trotting action and a fine temper-he was a gentleman.

Sire of Nellie C., $2: 263 / 4$.
Yours etc.,
W. H. GIFFORD.

DANIEL WEBSTER (I-64), black, I 300 pounds; foaled $\mathrm{r} 866$; bred by Joseph Curtis, Winterport, Me. ; got by Gen. Shermon, son of Gen. Knox : dam said to be of French and English blood.

DANIEL WEBSTER ( -16 ), said to be by Weasel, son of Ramsay, by Royal Morgan; and dam Bay Fan, by Morgan Jim (dam the Locke Mare, by Bellfounder), son of Post Boy.

DANIEL WEBSTER JR., bred by William E. Sears, Montgomery, N. Y. ; got by Daniel Webster, son of Long Island Black Hawk, by Andrew Jackson : dam said to be by Walden Messenger, son of Jordan's Wildair, by Beach's Wildair, son of imported Wildair. Pedigree from William McNeil, Montgomery, N. Y., who in letter dated :

Montgomery, Orange County, N. Y., Jan. 28, r89o, writes : Joseph Battell, EsQ.

Dear Sir-Please excuse delay in the matter of pedigree of Edgar, chestnut gelding, bred by William McWorter of Montgomery, N. Y.; got by Col. Winfield, he by Edward Everett, by Hambletonian : Edgar's dam a bay mare by Daniel Webster, Jr., owned by William E. Sears ; 2 d dam a roan mare by Seeley's American Star. The bay mare and roan mare were both bred by John Crowell, Montgomery, N. Y.

Daniel Webster Jr., was by Daniel Webster, owned by William Sears at Fort Hamilton, N. Y. Daniel Webster, a chestnut, white feet and blaze in face, by Long Island Black Hawk, son of imported Bashaw.

Daniel Webster, Jr.'s dam was by Walden Messenger, he by Jordan's Wildair, he by Beak's Wildair, he by imported Wildair. From your papers I should think you were after the Morgan strain. If there is any Morgan in Edgar it must come from the dam of Daniel Webster, and, as he was bred at Fort Hamilton, I do not know positively, but think she was a Morgan. You will notice two Sears in the ownership of the horse, one lives at Montgomery, the one at Fort Hamilton has been dead for some years.

$$
\text { Respectfully, WM. MCNEAL. }
$$

Col. Winfield was owned by my brother and myself; his dam was by Royal George.

DAN JENKINS, $2: 28 \mathrm{~T} / 4$, gray, I $5 \frac{\mathrm{T} / 2}{2}$ hands, II 50 pounds; foaled 1878 ; bred by John M. Kennedy, Vails Mill, Fulton County, N. Y., got by 
Joe Brown: dam bay, bred by Mr. Kennedy, Vails Mills, N. Y., got by Chalmer's Jupiter, son of Rich's Jupiter ; 2 d dam black, bred by David Kennedy, Vails Mills, N. Y. ; got by Morrison's Norman, son of Alexander's Norman. Sold to Henry Bradt and Patrick Scully, Schenectady, N. Y., and Dr. Ward of New York City. Pedigree from breeder, who says that he campaigned him for two seasons, in one of which he won $\mathrm{I} 7$ races out of 22 starts, on half-mile tracks; and got a record of $2: 28 \mathrm{~T} / 4$. He also says that Rich's Jupiter was by old Jupiter and he by Long Island Black Hawk.

Yours truly,

JoHN M. KENNEDY.

DAN LOGAN (3-64), $2: 32 \frac{1}{2}$, bay, white on one heel, $15 \frac{1}{2}$ hands, 1050 pounds; foaled 1879; bred by A. W. Mannon, New Boston, Mercer County, Ill.; got by Wineman's Logan, son of Wadleigh's Logan : dam bay, bred by Jonah Pratt, Jr., New Boston, Ill., got by Drury's Ethan Allen, son of Black Hawk ; 2d dam a sorrel mare, bred by Jonah Pratt, Jr., got by Topgallant, son of imported Topgallant; 3d dam bay, bred by Jonah Pratt, Sr., New Boston, Ill., got by Tiger Whip; 4 th dam bay, brought from Ohio, by Jonah Pratt, a good road mare. Pedigree from A. W. Mannon, who writes: "Was a very beautiful horse of the Morgan type with ability to trot in $2: 20$ or better."

Sire of Dan Wilson, $2: 23 \% 4$.

DAN MACE (I-I28), said to be by Strangemore, son of Columbia Chief, by Mambrino Black Hawk: dam Indian Pet, $2: 28 \mathrm{I} / 2$, brown, foaled I 876 , bred by John Dilatush, Downey, Ia., got by Marshall Ney, son of Stonewall Jackson; 2 d dam Dilatush mare, said to be by Read Horse, son of Hazzard.

Sire of Try Me, $2: 24 \frac{1}{4}$.

DAN MACE. See Aeous, Vol. I.

D.AN MACE (I-I6), $2: 35$, bay, I 5 ז/2 hands, I Ioo pounds; foaled I 88 I ; bred by Wm. Decker, Mercer, Me.; got by Bacon Horse, son of Howe's Bismarck, by Gen. Knox: dam Decker Mare, chestnut, said to be by Young Columbus, son of Columbus ; and $2 \mathrm{~d}$ dam Dolly, by Morse Horse, son of European. Sold to A. S. Walker, West Medway, Mass.; then sold and went to Nova Scotia. The dam of Bacon Horse was by Blanchard Horse, son of Young Morrill. Pedigree from Wm. M. Allen, Franklin Park, Mass.

Sire ot Maud Mace, $2: 201 / 4 ;$ Fim Mace, $2: 19 \frac{1}{4}$.

DAN MITCHELL, (7-I 28), $2: 223 / 4$, bay, one white hind ankle, $153 / 4$ hands, I 100 pounds; foaled I 886 ; bred by John G. Carter, Jackson, Mich. ; got by Regulator, son of Mapes Horse : dam Dolly Fritts, chestnut, bred by H. K. Fritts, Niles, Mich., got by Marshall Chief, son of Kilburn's 
Hero ; $2 \mathrm{~d}$ dam Buckskin, said to be by Henry Clay, son of Andrew Jackson. Sold to A. H. Iarling, Onondaga, Mich.; to Cyrus Mitchell, Tompkins, Mich. Pedigree from Mr. Darling.

Sire of Darling, $2: 20 \frac{1}{4}$.

DANNEMORA, $2: 29$, black, I5 $1 / 2$ hands, Iooo pounds; foaled May 17 , $\mathbf{r} 88_{3}$; bred by Baker \& Harrigan, Comstock, N. Y.; got by Kernwood, son of Wedgewood: dam chestnut, bred by John N. Conley, Woodburn Tavern, Ky., got by Woodford Mambrino, son of Mambrino Chief; $2 \mathrm{~d}$ dam said to be by Voorhees' Abdallah; and 3 d dam by Long Island Black Hawk. Sold to H. V. and A. D. Bump, Cambridge, N. Y., who send pedigree.

$D A N P A T C H$ (I-32), I :55 I/4, bay, I6 hands, I I 50 pounds; foaled r 896 ; bred by D. A. Messner, Jr., Oxford, Benton County, Ind. ; got by Joe Patchen, son of Patchen Wilkes : dam bay, bred by Doctor Patton, Remington, Ind., got by Wilkesberry, son of Young Jim ; 2 d dam said to be by Pacing Abdallah, son of Alexander's Abdallah; and 3d dam by Wells' Yellow Jacket, son of Pyle's Yellow Jacket. Owned by M. E. Sturges, New York City; M. N. Savage, Minneapolis, Minn. Kept at Minneapolis, I900, I901; Savage, Minn., I903,-1907. Above pedigree and information from breeder.

Pedigree of Wilkesberry (I-I 28 ), sire of dam, bay, foaled I 888 , bred by W. L. Simmons, Lexington, Ky., got by Young Jim, son of George Wilkes : dam Lady Adams, bay, bred by Charles Vealie, Washington Hollow, N. Y., got by Cassius M. Clay Jr. (Neaves'), son of Cassius M. Clay; 2 d dam said to be by Jupiter, son of I.ong Island Black Hawk. Sold to Patton \& Tribby, Remington, Ind.

The following history concerning the dam is from her breeder :

Joseph Battell, EsQ., Middlebury, Vt.

WOOdWard, OKLa., Nov. 7, I905.

Dear Sir :-Your letter of the Ist inst., was forwarded to me here from Remington, Ind., my former home.

Yes, I bred, raised, and registered Zelica, the dam of Dan Patch. I owned her dam Abdallah Belle and her sire, Wilkesberry. The former I purchased through Dr. J. S. Hood of Nepton, Fleming County, Ky., of a Mr. Dobyns who then (about I 878 ) lived in Mason County, Ky. She was by Pacing Abdallah, dam by Wells' Yellow Jacket (sire of Thos. L. Young, $\left.2: 19^{1} / 2\right)$. I did not learn anything further of her breeding. Dr. Hood might be able to find out more.

Abdallah Belle was a bay in color to hoofs. She weighed in good flesh about II 50 pounds, was $15^{1} / 2$ hands high, slightly arched over coupling. I drove her on the road in my practice for ten years. She was foaled in 1873 . In 1885 she foaled a bay filly by Indianapolis which I named Colette and registered in Trotting Register Vol. VII. She procured a pacing record of $2: 19 \mathrm{~T} / 2$ and may have lowered it, as she was sold to a party at Johnstown, Penn., where I lost trace of her.

Zelica was foaled June I 7, I $89 \mathrm{r}$, and sold by me in August, I893, to 
the late Dan Messner, Jr., of Oxford, Ind., at my closing out sale for $\$ \mathbf{2 2 5}$.

Old Belle was very heavily muscled in hind quarters, was a fast walker and when driven fast would always start in a pace which she was apt to change into a trot. She was naturally speedy on the road but was never trained. Her legs were as clean and smooth as those of a deer, and up to her death in 1899 she never had a bunch or pimple on her. She was of a highly nervous temperment but very intelligent and tractable. Her daughter, Zelica, is almost her exact image.

I purchased Wilkesberry from Wm. L. Simmons of Ash Grove Stock Farm at Lexington, Ky., in $\mathrm{I} 890$, when he was two years old, paying \$I ooo for him. Gave him one season handling and a half mile track record of $2: 30$. He was capable of trotting much faster; was sold and gelded and sent East as a road and park horse. If anything further is desired will be glad to assist in any way possible.

Very respectfully,

D. H. Patton.

Nepton, Kr., Nov. 20, 1905.

Joseph Battell,

Dear Sir:-Your letter received. By reference to annual diaries I found where on the 28 th day of June, I $88 \mathrm{I}$, I bought a bay mare from Daniel Dobbins or Dobyns of Wedonia, Mason County, Ky. I shipped her to Dr. D. H. Patton of Remington, Ind., a few days after I purchased her. He ordered me to purchase a mare by Pacing Abdallah for him. It was understood when I bought her that her sire was owned by Robert Turner of Mt. Gilead, Mason County, Ky., known as Pacing Abdallah. The sire of her dam I was assured by Mr. Dobbins was by Wells' Yellow Jacket, sire of Thos. L. Young. The sire of the dam of Dan Patch was Wilkesberry. The sire of Abdallah Belle was Pacing Abdallah.

I received a letter some two years ago stating that the Dobbins mare was the second dam of Dan Patch. The letter was from Dr. D. H. Patton, Woodward, Okla.

A letter addressed to W. M. Collins, Flemingsburg, Ky., or Daniel Dobbins, Wedonia, Mason County, Ky., or Robert Turner, Mt. Gilead, Mason County, Ky., might give you some light as to pedigree, etc., of Yellow Jacket owned by George Wells. A letter to each of these men will be honestly answered.
I am very truly yours,
J. S. HOOD.

$D A V R$. (I-64), $2: 191 / 2$, chestnut; foaled $\mathrm{I} 88_{2}$; bred by James Tanner, Como, Miss.; got by Smuggler: dam Fanny, said to be by Brahan's Copperbottom.

Sire of Tom Tipton, $2: 15^{1 / 2}$.

DAN RICE (I-32), brown; foaled 1877 : bred by W. C. Tarreltson, Pescadero, Cal.; got by Gen. McClellan, son of North Star: dam Tarreltson Mare. Died, I888, property of J. D. Doty, Napa, Cal.

Sire of 2 trotters $(2: 20 \%)$.

DANSEREAU (I-4), black, with white ankle behind; small, spirited, handsome ; foaled about $\mathrm{I} 88_{32}$; bred by Louis Dansereau, Verschères, P. Q. ; got by Papillon (Vassar Horse), which see: dam Jeanne D'Arc, dam of Papillon. Said to have been sold to go to the States. Fast pacer and trotter. 
DANSEREAU 2D (I-4), black with a little white on end of nose, $15 \frac{\mathrm{I} / 4}{4}$ hands, 950 pounds; foaled about 1836 ; bred by Louis Dansereau, Verschères, P. Q. ; got by Papillon (Vassar Horse), son of Carillon or Duhamel Horse: dam Jeanne D'Arc, dam of Papillon (Vassar Horse), which see. Owned at four years old by breeder and described to us by a son-in-law of Jean Baptiste Recollet of Sorel, P. Q., who owned at one time the Duhamel Horse, and who bred a mare to him that year. This horse is almost certainly the one mentioned by Mr. Barnard of Sherbrooke, P. Q., in letter to the New York Spirit of the Times I 84 I. See The Morgan Horse and Register, Vol. I., p. 277.

DANSEREAU 3D (I-8), chestnut with white stripe in face and white feet, I 5 hands, rooo pounds; foaled about I 830 ; bred at Verchères, Que., and of the Dansereau breed. Information from Napoleon Chicouagne, Verchères.

DANSEREAU JR. ( I-8), brownish black, about I5 hands, Iooo pounds; foaled I837; bred by Louis Dansereau, Verschères, P. Q..; got by Dansereau. Purchased by Mr. Charlebois, Montreal, who sold to M. Bouriceau, and he to John Schenck, New Jersey, probably about 1850 . He had a little hump on the side.

DAN TUCKER, bay; foaled I886; bred by Edward Pyle, Humboldt, Neb.; got by George P. Tucker, son of Maxie Cobb : dam Belle. Sold to C. G. Jesse, Mound City, Mo. ; to Boston Fear, Baltimore, Md. Information from C. C. Waters, Germantown, Md., breeder of Minnie $W$., $2: 2 \mathrm{I} / 2$.

Sire of Minnie $W_{\cdot, 2}: 21 \frac{11}{2}$.

DANUBE (I-I6), $2: 26$, bay, left fore and left hind feet white, I5 I/4 hands, I 000 pounds ; foaled I 876 ; bred by Dr. N. O. Blaisdell, Newcomb, Ill.; got by Chickamauga, son of Vermont Boy (Fanning's), by Green Mountain Morgan : dam brown, bred by Edward Garnett, Pelsie Mo., got by Trojan, son of Jackson's Flying Cloud; 2d dam gray, bred by Dr. Wilson, Saline, Mo., got by a gray pacer. Owned by S. M. French, Denver, Colo. Pedigree from breeder.

DAN UNDERHILL (5-64), bay, I5 hands, Iooo pounds; foaled about I 854 ; bred by T. T. Jackson, Flushing, L. I. ; got by Jackson's Flying Cloud, son of Black Hawk: dam the Dan Underhill Mare, bred by W. H. Williams, Lakeville, L. I., got by Cassius M. Clay, son of Henry Clay; 2 d dam gray. Taken, $\mathbf{1} 858$, to Urbana, O., by A. C. Jennings, who sold him to go to Kentucky. Stylish and a fine roadster; could trot easily in 3 :oo. See The Morgan Horse and Register, Vol. I., p. $45^{8}$.

Mr. Joseph Battell,

Urbana, O., Oct. 20, I 889 .

Dear Sir :- I saw Mr. Abe Jennings and made inquiry of him as to 
what horses he brought here when he started his fine breeding farm. He said he brought some thirty-six head, among which were nine stallions, as follows: St. Lawrence, large bay horse, black points; Moro, bay with white face and white legs; Long Island Cloud, very fine small black horse; Arabian Knight, a little bay horse of no account; Dan Underhill, nice, good bay horse, solid color; Flushing Boy, got by Cloud. He says he bought Pete Jones of Mr. Tim Jackson of Flushing, L. I. Mr. Jackson brought several horses here along with said colt and Long Island Cloud in the fall, he thinks, of $185^{8}$. Some of the mares were Lady Jones, large and brown, that could trot in three minutes; Alice, a gray mare, and Rachael, a little brown mare. Pete Jones, when full grown, would weigh in good flesh 1400 pounds, and, although he got crippled when a colt, he could trot quite fast and won some races. He says that Mr. Tim Jackson and a Mr. Waltermire owned Rachael in partnership; that he never saw Rachael, but understands she was a large bay mare and could trot fast; got by a Narragansett pacer, and that he understood she was sold after he got Pete for $\$ 1300$, but did not know where she went or who bought her.

$$
\text { Yours truly, G. W. FreEman. }
$$

DANVERS BOY. See Henry W. Genet.

DANVILLE (SHERMAN MORGAN JR.) (I-8), bay, I5 I/2 hands, rooo pounds; foaled about I 850 ; bred by Dr. Tobey, Roxbury, Mass.; got by Napoleon, son of Flint Morgan : dam said to be a very fine and fast mare, got by Morrill, son of Jennison Colt. Bought when a colt by Robert Farley, Ipswich, Mass., who sold him to P. M. Slicer, Baltimore, Md. Mr. Slicer sold him to Nathan Holland, East Norfolk, Va., who sold to Frederick Waddy, Accomac Court House, Va., and he to Worthy Smith, Norfolk, Va., by whom he was taken to Norfolk, Va., and was afterwards traded for a patent right to a Mr. Price, who lived near New Harrisburg, Carroll County, O.

Sire ot Elsie Groff, $(2: 25)$, and winner of 35 races; I dam of I trotter.

DANVILLE WILKES (I-64) $2: 27$, mahogany bay, with star and left hind foot white, $15 \frac{1}{2}$ hands, I roo pounds; foaled 1877 ; bred by Lee T. Yeager, Danville, Ky.; got by Lyle Wilkes, son of George Wilkes : dam Flora, sorrel, bred by J. T. Yeager, got by Skedaddle, son of Oliver; $2 \mathrm{~d}$ dam, sorrel, bred by Silas Figg, Bryantsville, Ky., got by Waxy, son of Berthume, thoroughbred; 3d dam sorrel, bred by Silas Figg, got by Shelton's Telegraph; $4^{\text {th }}$ dam, sorrel, bred by Dr. C. Pittman, Danville, Ky., got by Wagoner, son of Sir Charles. Kept in Garrard and Boyle Counties, Ky. Pedigree from breeder.

Sire of 2 trotters; dam of I trotter.

DANVILLE WILKES (I-64), brown; foaled I 886 ; bred by W. J. Lyle, Danville, Ky. ; foaled the property of B. J. Treacy, Lexington, Ky., got by Lyle Wilkes, son of George Wilkes: dam Madam Herr, black, I5 I 2 hands, foaled 1875 , bred by L. Herr, and Samuel Chom, Fayette 
County, Ky., got by Mambrino Patchen; 2d dam Beckey, bay, right hind ankle white, I5 $3 / 4$ hands, bred by Mr. Christian, Jessamine County, Ky., got by Alexander's Edwin Forrest; 3d dam Dixie, said to be by Nambrino Prince; and $4^{\text {th }}$ dam Miss Webster, by Webster's Highlander. Pedigree from catalogue of breeder.

Sire of Lady Selby $\left(2: 24 \frac{1}{4}\right)$.

DAN VOORHEES (I-8), $2: 23^{1} / 2$, chestnut, I $5 \frac{1}{2}$ hands; foaled 1868 ; bred by George Fisher, Petaluma, Cal. ; got by Gen. McClellan, son of North Star, said to be by Bulrush Morgan: dam Ocean Nell (dam of Duke McClellan, which see). Sold to Charles McLaughlin, San Francisco, Cal. See The Morgan Horse and Register, Vol. II., p. 94.

Winner of Io races and sire of 2 trotters $(2: 20) ; 3$ dams of 2 trotters, I pacer.

DAN WILKES untraced.

Sire of 2 pacers $\left(2: 07 \frac{1}{4}\right)$.

DAPPLE GRAY. Brought from Canada in 1787 ; part English and part French ; is good for the saddle and very excellent for the draught. Nervous, fiery, strong, well-built. Advertised as above, 1788 , in Hampshire Gazette, Northampton, Mass.

DAPPLE GRAY MESSENGER; foaled I 825 ; bred by Ira Sanford, Canton, N. Y. ; got by Freeman Horse, son of Ogden's Messenger. Advertised, r 829 , by A. M. Hobbs of Waltham, Vt., to be kept in Waltham, Weybridge and Vergennes, Vt., at $\$ 4$ to $\$ 6$.

DARE DEVIL (OLD JOHNSON COLT), bay, foaled I 792 ; bred by Mr. Johnson, Kentucky; got by Don Carlos: dam said to be by Harmless. Ran in Kentucky, I797-8, and advertised in Kentucky Gazette, I805-10 $-I I-I 2$.

DARE DEVIL (3-128), black; foaled 1 893 ; bred by C. J. Hamlin, East Aurora, N. Y.; got by Mambrino King, son of Mambrino Patchen : dam Mercedes, bay, foaled I 889 , bred by C. J. Hamlin, got by Chimes, son of Electioneer; 2 d dam Satory, bay, foaled I 884 , bred by C. J. Hamlin, Buffalo, N. Y., got by Almonarch, son of Almont; 3d dam Molly O., brown, foaled $\mathbf{1} 877$, bred by C. J. Hamlin, got by Hamlin's Patchen, son of George M. Patchen; 4 th dam Mermaid, said to be by Dictator, son of Hambletonian; $5^{\text {th }}$ dam Lady Ketchum, bay, foaled r860, by Osirus, an imported English horse; and 6th dam Madam Loomer, by Warrior, son of White Warrior by Winthrop Messenger. Sold to Mr. Lawson, Boston, Mass. Pedigree from catalogue of breeder.

DARIUS. Advertised in Tennesee, by Burwell Jackson, I 788, as follows:

"The noted horse Darius will be kept the ensuing season at Mr. John Caldwell's on Cartright's Creek, in Nelson County, Tenn.; terms fifteen 
to forty shillings. Darius was bred by Mr. Daniel Hardaway of Amelia County, Virginia, and was got by the noted imported horse Janus, his dam and grandam by the same, his great-grandam by the imported horse Spanker."

DARK CHIMES (I-32), black, I5 5 /2 hands, I050 pounds; foaled I894; bred by C. J. Hamlin, East Aurora, N. Y.; got by Chimes, son of Electioneer : dam Darkness, black, little white on left forefoot, foaled i 888 , bred by C. J. Hamlin, got by Mambrino King, son of Mambrino Patchen ; 2d dam Lady Barnes, bay, hind ankles white, foaled I877, bred by C. J. Hamlin, got by Hamlin's Patchen, son of George M. Patchen ; $3 \mathrm{~d}$ dam May Day, said to be by Field's Royal George; and $4^{\text {th }}$ dam by McCracken's Black Hawk. Owned by D. S. McCann, Hillsdale, O., who sends pedigree.

Sire of Tilly Chimes, $2: 231 \frac{1}{4}$.

DARKEY (3-32), black, I5 I/4 hands, Iooo pounds; foaled 1852 ; bred by Dexter Gilbert, Tinmouth, Rutland County, Vt.; got by the Rounds Horse, son of Black Hawk: dam bay or brown, bred by Landon Ray, Tinmouth, Vt., got by Andrus' Hamiltonian, son of Judson's Hamiltonian; 2 d dam Ray Mare, bay, bred by Landon Ray, got by Comet, son of Bishop's Hamiltonian.

Advertised by A. W. Barker in Rutland (Vt.) Herald, I 868 , to be kept in Brandon and Castleton, Vt., and at Granville Corners, N. Y. "Darkey was the sire of Young Darkey and the Harlow Colt of Claremount, N. H." Died the property of O. P. Pinchin, Aug. I7, I875, at Fort Ann, N. Y.

See The Morgan Horse and Register, Vol. I., p. 45 I.

Sire of Highland Gray, $2: 28 ; 2$ sires of 7 trotters, 2 pacers; 8 dams of 9 trotters.

DARKEY JR. (5-64) bred by Nathan Fassett, Clarendon, Vt.; got by Darkey : dam, said to be by Andrus' Hamiltonian ; and $2 \mathrm{~d}$ dam by Green Mountain Morgan. Owned by Samuel Perry, Granville, N. Y.

DARK NIGHT (I-64), $2: 37 \mathrm{I} / 2$, black, two white hind feet, I5 I/2 hands; foaled I 882 ; bred by Englishman \& Welch, Danville, Ky.; got by Alcyone, son of George Wilkes: dam Noonday, gray, foaled $\mathrm{r} 87 \mathrm{I}$, bred by A. J. Alexander, Spring Station, Ky., got by St. Elmo, son of Alexander's Abdallah; 2 d dam Midnight (dam of Jay-Eye-See, 2 : го, etc.) by Pilot Jr. Sold to Welch \& Dunn, Danville, Ky., January, I884; to J. H. Crughton, Omaha, Neb. ; to Brook Curry, Lexington, Ky. ; to Bowerman Bros., January, I889; to W. E. France \& Son, I89o; to Bowerman Bros., I89I ; to J. F. Curry ; to St. Clair \& Curry, Lexington, Ky. ; to Schuarte, Drusseldorf, Germany. Pedigree from breeder.

Sire of $I_{3}$ trotters $\left(2: 09 \frac{1}{2}\right), 9$ pacers $\left(2: 03 \frac{1}{4}\right)$; I sire of 5 trotters, 2 pacers; 2 dams of $I$ trotter, I pacer.

DARLBAY $2: 40$, bay, I6 $1 / 4$ hands; foaled 1867 ; bred by G. Drummond 
Hunt, Sr., Lexington, Ky. ; got by Mambrino Patchen : dam Peggy, bay bred by G. D. Hunt, Sr., got by Brignoli, son of Mambrino Chief ; 2 d dam Bertha, sorrel, bred by G. D. Hunt, Sr., got by Berthune (thoroughbred) ; 3d dam bred, by G. D. Hunt, Sr., got by Scott's Highlander, son of Hunt's Highlander; 4th dam said to be by Hunt's Brown Highlander. Died the property of Hunt Bros., who send pedigree.

Sire of 2 trotters $(2: 231 / 2) ;$ I sire of I trotter.

DARLEY ARABIAN, bay with blaze, near fore foot and both hind feet white I5 hands, strongly and elegantly formed. The American Turf Register, Vol. II., I830, says :

"The fame which the Darley and Godolphin Arabian acquired in England in laying the foundation for the present improved stock of English race horses, stands pre-eminent. They both richly deserve their respective reputations, considering that, for the last century, all the best English race horses have been deeply imbued in their blood, or entirely derived from them. Previous to the importation of the Darley Arabian into England, several Barbs, Turks, and Arabians, mares as well as horses, had been brought in to that country and crossed on each other; but none of them had been able to establish any imposing reputation by imparting to their stock that size, bone, strength and substance, those extraordinary and unequaled powers of speed and continuance, which were afterwards attained through the agency of this noble animal.

"The Darley Arabian was imported in $\mathrm{I}_{703}$, then four years old, and about twenty-five years before Mr. Coke brought the Godolphin Arabian into England. Of course the latter horse had the advantage of all the labors and improvement of stock accomplished by the former. Far from having that variety of mares that afterwards annually poured in upon the Godolphin Arabian, the Darley Arabian covered very few except those of his proprietor, Mr. Darley; but from these sprung the largest and speediest race horses which were ever known.

"Mr. Darley, brother of his subsequent owner, of a sporting family in Yorkshire, being a mercantile agent in the Levant, became the member of a hunting club at Aleppo, and thereby obtained interest enough to procure this most valuable horse, which fully established the worth and value of the Arabian stock."

The following excellent account of this horse is from the American Stock Journal, Vol. I., I 859, published by D. C. Linsley, author of Morgan Horses :

"We take pleasure in presenting to our readers the above spirited engraving of the Darley Arabian, imported into England in 1703 . It was executed by the well known firm of N. Orr \& Co., No. 52 John Street, and can be relied upon as a correct portrait of this celebrated horse. The drawing is taken from an engraving published in the American Turf Register, in September, 1830.

"However breeders of the present day may differ as to the expediency of engrafting fresh scions of these desert coursers upon our present stock of horses, it cannot be successfully denied that the introduction of this blood into the English horse produced in this instance, a marked and decided improvement. We say 'in this instance,' because although 
long before this, Arabians, Barbs and Turks had been used by the English breeders, to cross with their native stock, the result was not in a majority of cases attended by any distinguished success. Indeed, of many horses imported during the seventeenth century, almost the only ones worthy of note were the beautiful horses known as Place's White Turk, purchased of Mr. Place by King James, and the Helmsley Turk, imported a few years later by the Duke of Buckingham. These undoubtedly produced a marked and decided improvement in the character of the English horses, but the results were not so immediate and surprisirg as those.which followed the introduction of the horse we are describing.

"The Darley Arabian was imported by a Mr. Darley, who was of a sporting family in Yorkshire, England, and being for some time a mercantile agent in the Levant, he became a member of a hunting club at Aleppo, and thereby obtained sufficient interest to enable him to procure this most valuable horse. He was landed in England in $\mathrm{I}_{703}$, being then four years old. He was fifteen hands high; his color was bay, with a little white on his near fore foot, and both hind feet were white above the fetlock; he had also a white stripe in the face, a small white spot on the nose, and a few white hairs just back of the withers. His body was long and well formed, the neck was long and well arched, the head lean and small, and the eye remarkably fine and lively. The shoulders were beautifully modelled, and the loins and quarters excellent. The limbs would by many, if not most horsemen of our time, be considered decidedly too light. They were, however, clean, sinewy, and elastic.

"Nothing is known of his qualities as a racer, except what may be inferred from the character of his stock, and judging from this, he must have been a horse of extraordinary powers. His son, 'Flying Childers,' and grandson, 'English Eclipse,' were beyond all question the fastest horses, that up to that time, ever ran in England, and his almost equally celebrated great-grandson, 'Sampson,' was remarkable not only on account of his great speed, but as being one of the most powerful horses that ever appeared on the turf.

"The marked improvement which the 'Darley Arabian' made upon the English race-horse roused and stimulated breeders to continue their efforts, and the impulse then given to this branch of breeding in England is felt even to this day.

"Many of his descendants have been imported into this country-indeed a great number of our thoroughbred horses trace their pedigrees by various routes up to this distinguished source, and the breeder of racehorses, whether in this country or in England, will point with pride to his favorite animal as a lineal descendant of this famous Arabian."

DARLING DENMARK (I-32), bay, I6 hands; foaled I883; bred by Isaac Wilson, Nelson County, Ky. ; got by Happy Cross, son of Garrard Chief: dam Fanny Offutt, said to be by Humbolt; and 2 d dam Clara Fisher, by Davy Crockett. Sold to J. O. Wilkinson, Habit, Ky.

DARLINGTON, bay, I6 hands; foaled I $_{7} 87$; said to be by Clothier : dam by Highflyer; and $2 \mathrm{~d}$ dam by Little John. Advertised as above by J. R. Smith, Northalerton, March 3, I 792. Advertised, I793, by John Hoomes, Bowling Green, and said to have been imported from London. 
DARLINGTON (3-64), 2 : $181 / 4$, bay, I63/4 hands, Ir 35 pounds; foaled 1882 ; bred by B. H. \& M. H. Henderson, Sharon, Penn.; foaled the property of A. B. Darling, Ramseys, N. J. ; got by Wellington, son of Kentucky Prince: dam Boadicea, bay, bred by (iuy Miller, Chester, N. Y., got by Hambletonian; 2 d dam Agnes Ethel, bay, bred by Hammond Mathews, Ashland, Penn., got by Magnolia, son of American Star; 3d dam Dolly, brown, bred by Hammond Mathews, got by Seely's lilack Hawk, son of Long Island Black Hawk; 4th dam said to be by Bertrand. Sold to Guy Miller. Pedigree from breeders except $2 \mathrm{~d}$ and $3 \mathrm{~d}$ dams which is furnished by Guy Miller, who writes: "I have no doubt the Bertrand mare was by the horse from the south kept in Bradford County, Penn."

Sire of Bloom Boy, $2: 283 / 4$; Mabel D., $2: 161 / 4$.

DARLINGTON CHIEF (I-32), bay, two white hind ankles, I6 hands, I 200 pounds; foaled $\mathrm{I} 883$; bred by A. B. Darling, Ramseys, N. J. ; got by Starlight, son of Kentucky Prince: dam Emily T., bay, I5 $5 / 2$ hands, off fore and near hind foot white, foaled $\mathbf{1} 877$, bred by $\mathrm{S}$. McKean Taylor, Williamsport, Penn., got by Volunteer, son of Hambletonian ; $2 \mathrm{~d}$ dam Novelty, chestnut, bred by Guy Miller, Chester, N. Y., got by Iron Duke, son of Hambletonian; 3d dam Fanny Learned, said to be by Stevens' Bellfounder, son of imported Bellfounder. Sold to Edwin F. Carpenter, Ramseys, N. J., who sends pedigree.

Sire of Lucy B., $2: 24 \frac{1}{4}$.

DARTMOUTH. Owned in Vermont, by W. M. Parker, and said to be a son of Volunteer.

Sire of 3 trotters $(2: 261 / 2)$; I sire of I trotter; I dam of I trotter.

DARIVIN (ABDALLAH CHIEF) (I-64); foaled I 869. Owned by John R. Woodside, Thomasville, Mo. See Abdallah Chief, Vol. I., page $6{ }_{5} 6$. Sire of Donald H., $2: 181 / 2$.

DARIVIN (5-64), brown : foaled I 876 ; bred by J. A. Green, Muscatine, Ia.; got by Green's Bashaw, son of Vernol's Black Hawk: dam Miss Nebraska, bay, bred by J. A. Green, got by Nebraska thoroughbred, son of John Black, by Charmer, son of imported Glencoe; $2 \mathrm{~d}$ dam Fanny Foss (dam of Bashaw Jr., $2: 243 / 4$ ), chestnut, foaled I 855 , bred by J. A. Green, got by Young Green Mountain Morgan, son of Green Mountain Morgan ; 3d dam Fanny Green, brown, bred in Massachusetts, said to be by Green Mountain Morgan, son of Gifford Morgan; and $4^{\text {th }}$ dam by Sherman Morgan. Sold to Frank Switzer, Fairfield, Ia. Pedigree from breeder.

Sire of Frank P., $2: 25$; I dam of 2 trotters.

DASHWOOD (1-32), bay; foaled I879; bred by Henry Graves, Chicago 
Ill. ; got by Legal Tender, son of Moody's Davy Crockett: dam Graves Mare, said to be by Volunteer, son of Hambletonian; and $2 \mathrm{~d}$ dam by Oneida Chief. Sold to Monroe Salisbury, Pleasanton, Cal. ; to H. W. Johnston, Los Angeles, Cal. ; to George Hinds, Wilmington, Cal. Information from S. E. Kennedy, Wilmington, Cal.

Sire of 2 trotters $(2: 24) ; 4$ dams of 2 trotters, 2 pacers.

DAUBIGNE, bay, I6 hands, I250 pounds; foaled I873; bred by Hunt Bros., Lexington, Ky.; got by Mambrino Patchen: dam Puggie, bay, foaled I 862 , bred by Hunt Bros., Lexington, Ky., got by Brignoli, son of Mambrino Chief; $2 \mathrm{~d}$ dam Bertha, chestnut, bred by G. Drummond Hunt, Lexington, Ky., got by Berthune; $3 \mathrm{~d}$ dam said to be by Scott's Highlander; and 4th dam Mary Hunt, by Hunt's brown Highlander. Sold to L. B. Tracey; S. S. Hyde, Monroe, Wis., who kept him at Dayton, Wis., I $877-8 \mathrm{I}$; at Monroe I88I-92. Died $\mathbf{I} 893$. Information from S. S. Hyde.

Sire of 4 trotters $\left(2: 26^{3} / 4\right)$; I dam of I trotter.

DAUNTLESS (I-I28), bay, with small star, I 5 hands, Iooo pounds; foaled I 867 ; bred by Charles Backman, Stony Ford, N. Y.; got by Hambletonian, son of Abdallah: dam Sally Feagles, brown, bred by Samuel Lutes, Westtown, N. Y., got by Smith Clay, son of Cassius M. Clay Jr., by Cassius M. Clay; 2 d dam, said to be by Hickory, son of Hickory. Sold 1873 , to J. H. Walker, Worcester, Mass. ; to parties in Michigan ; to Dennis Connell, Nuscatine, Ia. Pedigree from F. A. Wright.

Sire of 33 trotters $\left(2: 15 \frac{1}{4}\right), 3$ pacers $\left(2: 16 \frac{1}{4}\right) ; 9$ sires of 6 trotters, 6 pacers; Io dams of II trotters, 3 pacers.

DAUNTLESS JR., bay, I6 hands, r roo pounds; foaled I882; bred by Williain H. Lewis, Pokagon, Mich.; got by Dauntless, son of Hambletonian: dam Topsey, chestnut. Sold to Frank E. Warner, Dowagiac, Mich.; to George W. Webb, Niles, Mich. Pedigree from breeder.

Sire of Dauntless L., $2: 201 / 4$; Harry, $2: 17^{3} \frac{4}{\text {. }}$

DAUPHIN, I5 I/2 hands; foaled I 779 ; said to be by Floyd's Traveler : dam by imported Figure; $2 \mathrm{~d}$ dam by imported Dove; $3 \mathrm{~d}$ dam by imported Othello; and $4^{\text {th }}$ dam by the Godolphin Arabian. Advertised I 795, at Goshen, Conn.

DAVE BARNETT ( $1-16$ ) ; foaled about 1880 ; said to be by General Sherman, son of Young Columbus: dam by Daniel Lambert; and $2 \mathrm{~d}$ dam by Colonel. Owned by the Cheshier Improvement Co., East Ridge, N. H. A correspondent of Turf, Field and Farm, writes :

"It devolved upon me to tabulate the pedigree of Dave Barnett and I had information that Colonel was owned by Mr. George Parish of Ogdensburgh, N. Y. The stud books showed no imported Colonel, but a horse named 'The Colonel' appeared as being imported; but refer- 
ence to his breeding showed that he was foaled in this country, and was by imported Priam, from imported My Lady. Col. Bruce remembered well that this was the horse that George Parish owned, and it is the horse called Parish's Colonel, who got the dam of Lookout, $2: 31$, by Abraham. The same mare is the grandam of Dave Barnett."

D.AVE BONNER (3-64), black, I 6 hands, I 200 pounds; foaled 1877 ; bred by Richard Richards, Racine, Wis.; got by Swigert, son of Alexander's Norman: dam Bay Fanny, bay, bred by Richard Richards, got by Richard's Bellfounder, son of Hungerford's Blucher ; 2d dam Lady Mary, said to be by Signal (Singleterry's Rattler); and 3 d dam old Kate, bred in Connnecticut, and said to be of Messenger blood. Sold to $\mathrm{Wm}$. Bonner, Beaver Dam, Wis., who sold to Chester Hazen, Brandon, Wis. Pedigree from William Bonner

Sire of Mayflower, $2 ; 22 \frac{1}{2} ; 2$ dams of 2 trotters.

DAVE HILL (CASE'S) (I-r6), bay, with star, black points, $153 / 4$ hands, I I50 pounds; foaled I86I; bred by Henry M. Montgomery, Orwell, Ashtabula County, O. ; got by Pelton's Dave Hill, son of Black Hawk : dam spotted, bred in New York, and brought to Orwell, O., by a man that was moving West, breeding unknown, but said to be Arabian. Sold I 864 to C. S. Case, Kinsman, Trumbull County, O. See The Morgan Horse and Register, Vol. I., p. 4 I 2.

Sire of 4 trotters $(2: 25)$; I sire of I trotter; 4 dams of 3 trotters, I pacer.

DAVE HILL (EASTON'S) ( $\mathrm{I}-8$ ), black, I5 I 12 hands, I Ioo pounds; foaled June 9, I 849 ; bred by Oliver Russell, Shoreham, Vt. ; got by Black Hawk : dam bay, thick-set, about ${ }_{5} 5$ hands, very energetic and a great roadster, said to be English blood. Mr. Russell gave half of this horse to his son-in-law, E. A. Birchard, who handled him, and, in I855, sold him for $\$ \mathbf{2} 800$ to Benjamin Fish, acting as agent for Ansel I. Easton, San Francisco, Cal., whither he was shipped by way of Panama, and kept for service at \$Ioo without a warrant. He was very popular in California where the banker Rallston had a fast four-in-hand team all by him. He could trot in $2: 40$. At two years old he was awarded first premium at the Addison County Fair, and at three years old received first at same Fair, also at New York State Fair, and at Springfield, Mass., National Fair. He trotted at four years old in $2: 50$. He was bought from the stable of the owner of Black Hawk, sold by his son and Mr. Birchard. $\mathrm{He}$ arrived in California, April r4. A certificate of Mr. David Hill states that the horse was bred by Oliver Russell of Shoreham. See The Morgan Horse and Register, Vol. I., p. 487.

DAVE JENNINGS JR. (EDWARDS') (I-8) ; said to be by Dave Jennings, son of Hatch Horse: and dam Lady Gifford, by Gifford Morgan. 
Information from May Overton, Nashville,'Tenn., President Tennessee Live Stock Association.

Sire of T. P., 2:161/4.

DAVENANT (I-32), $2: 26 \mathrm{I} / 4$, gray; foaled 1879 ; bred by A. J. Alexander, Spring Station, Ky.; got by Belmont: dam Dahlia, gray, foaled I863, bred by R. A. Alexander, Spring Station, Ky., got by Pilot Jr. ; 2 d dam Madam Dudley. Sold to Baker \& Harrigan, Comstock, N. 'Y. Pedigree from catalogue of breeder.

Sire of Bergmont, $2: 25,2$ pacers $\left(2: 15^{3 / 4}\right)$; I sire of 3 trotters ; 4 dams of 4 trotters.

DAVID (THAYER HORSE, THAYER'S MORGAN) (3-I6), sorrel with star and one white hind foot, flaxen mane and tail, I43/4 hands, 925 pounds; foaled May I8, I 850 ; bred by Thayer Brothers, Swanton, Vt. ; got by Warner Horse, son of Billy Root: dam sorrel, said to be by Smalley \& Adams' Young Comet, son of Billy Root; 2d dam bred on Long Island. A gentleman in Franklin, Vt., name not remembered, in interview, I89o, said: "The Billy Root horse was here two seasons. The Thayer horse of Swanton, by Billy Root, was a good Morgan horse and here twenty years ago, sorrel, I5 hands, 950 to 975 pounds. Prompt little horse. I raised colts from him that were very good." See The Morgan Horse and Register, Vol. I., p. 293.

DAVID BONNER, mahogany bay with star, left hind foot white, I53/4 hands, I 200 pounds; foaled I867; bred by Taylor Stock Farm, Turner, N. Y.; got by Robert Bonner, son of Hambletonian : dam bay, bred by Josiah Mead, Orange County, N. Y., got by Roe's Abdallah Chief, son of Abdallah; 2 d dam Tempes, said to be by Tempest. Sold to N. B. Mann, Manville, N. Y., who sends pedigree.

Sire of Mark B., $2: 281 / 4$; I sire of 2 trotters; I dam of I trotter.

DAVID C. $(1: 32)$, said to be by Case's Dave Hill.

Sire of Sampsons, $2: 29^{1 / 4}$.

DAVID CONNOR (3-64), bay, I $5 \frac{3}{4}$ hands, I Ioo pounds; bred by Dr. E. T. Billmeyer, Cherry Valley, Ill.; got by Blue Bull: dam Cora Phillips, black, bred by Dr. E. T. Billmeyer, got by Dick Consternation, son of imported Consternation; 2d dam Beauty Phillips, black, bred by Joseph Anderson, Roscoe, Ill., got by Leach's Black Hawk. Pedigree from Wm. Todd, who advertised the horse at Chebanse, Ill., I89 I.

Sire of Pegleg. $2: 22 \frac{1}{4}$.

DAVID HILL (I-I6), dark bay, I6 hands, I 255 pounds; foaled $\mathrm{r} 852$; bred by John Brittell, Weybridge, Vt., got by Black Lion, son of Black Hawk : dam bay, small stripe in face, and white hind foot, about $\mathrm{I}_{5} \mathrm{I} / 2$ hands, Iooo pounds, foaled about I830, a little inclined to be coarse, 
with long neck, untraced. Sold, I 855 , to Chester Pratt, Bridjort, Vt., who took him that season to Troy, Wis., and left him there with James H. Hall, a hotel keeper, who sold him the next spring. Afterwards purchased by J. G. McCracken, who took him, I 860 , overland to California, and kept him at Sacramento, and after I 868 sold to a Mr. Ashley, San Joaquin County, Cal., whose property he died 1872 . Mr. McCracken is said to have refused an offer of $\$ 10$, Ooo in gold for him when gold was worth $\$ 2.50$ in paper. He could trot in $2: 40$. He left much good stock both in Wisconsin and California. Received first premium at California State Fair, I 864 ; also in I 866 and $\mathbf{I} 868$, shown with ten of his get. A fine appearing, bold looking horse of great power. Above is from Chester Pratt, his second owner, who states that he tried to trace the dam after Mr. Brittell's death but was not able. He thinks though, that she was represented to be a Hamiltonian, and looked like it. See The Morgan Horse and Register, Vol. I.

Sire of Black Divan, $2: 281 \frac{1}{2} ; 3$ sires of 3 trotters, 2 pacers; I dam of I trotter.

DAVID HILL (I-8), dark bay, I5 $1 / 2$ hands, Io75 pounds; foaled May, I 84 ; bred by Lawrence Brainerd, St. Albans, Vt. ; got by Green Mountain Morgan: dam Fanny, dark bay, bred by Lawrence Brainerd, got by Black Hawk. Kept at St. Albans, Vt., and Belmont, N. Y. Died about I864. See The Morgan Horse and Register, Vol. I., p. 72 I.

DAVID HILL (HETH'S) (I-8), chestnut, I6 T/4 hands, I 200 pounds; foaled 1856 ; bred by C. Newman, Addison, and D. Hill, Bridport, Vt. ; got by Black Hawk: dam said to be by Smith's Young Hamiltonian (Pone), son of Bishop's Hamiltonian. Sold to Charles Heth before I 865 ; to Leroy Graves, both of Fond du Lac, Wis.; to N. J. White, Adams County, Wis., March 26, I872. See The Morgan Horse and Register, Vol. I., p. 542.

Sire of dam, of Don Quixote, $2: 291 / 4$.

DAVID HILL (PELTON'S) ( I-8), black, white face, two or three white feet, I 5 hands, Iooo pounds; foale 1 about I 845 ; bred by Samuel James, Weybridge, Vt. ; got by Black Hawk : dam black, bred by Samuel James, got by Duroc Messenger, owned by E. R. Pratt, Cornwall, Vt., and said to be a son of Duroc, by imported Diomed. Sold to S. G. Foote, Medina County, O., about I 849 ; to Lysander Pelton, Gustavus, O., I 853 , for $\$ 2000$. Died 1868 , property of D. Reeder, Gustavus, O. See The Morgan Horse and Register, Vol. I., p. 4 I 2.

DAVID HILL (WILLIAMS'). Entered by Alfred Williams, Concord, Ill., at the Illinois State Fair, I86o.

DAVID HILL JR. ( $1-32$ ), bay, r Ioo pounds; foaled I 864 ; bred by J. G. McCracken, Sacramento, Cal.; got by David Hill 2 d, son of Black Lion : 
dam said to be by St. Lawrence. Sold to James McDonald, Mountain View, Cal. Could trot in about $2: 45$. Exhibited with his sire David Hill 2 d, by J. G. McCracken, at the California State Fair, I866, and received premium as the best two-year-old stallion; also first premium, I868. See The Morgan.Horse and Register, Vol. I., p. 424.

Sire of 2 trotters $\left(2: 25 \frac{1}{4}\right)$; I sire of I trotter; 4 dams of 3 trotters, I pacer.

DAVID HILL JR. (SCOTT's), said to Бe by David Hill Jr.

Sire of Vidette $\left(2: 23^{3} / 4\right) ; 2$ dam of Col. McNassar, $2: 20$.

DAVID JENNINGS (LITTLE DAVE) (I-8), dark chestnut, white face and two white feet, $\mathrm{I} 4 \mathrm{I}^{\mathrm{I}} 2$ hands ; foaled $\mathrm{I} 862$; bred by Talbert Fanning, Nashville, Tenn.; got by Green Mountain Black Hawk, son of Neal Dow, by Lightfoot, son of Black Hawk : dam Lady Gifford, bought by T. Fanning in Vermont, said to be by Gifford Morgan. Sold to J. C. Dunlap, Elias Napin, May Overton, A. J. Fanning, John Overton, all of Nashville, where he was kept. Style and action very fine; remarkably docile. Sire of valuable and stylish roadsters. Trotted under $2: 40$ when three or four.

Mr. Geers, the noted driver and trainer, in interview said:

"Little Dave was the first horse I ever won a race with, a pretty gaited horse. What a sweet gaited little horse he was. He was one of the best road horses I ever saw in my life. I won the race with him in $3: 04$. He was a beautiful horse with good feet and legs and got nice roadsters."

See The Morgan Horse and Register, Vol. I., page 428 .

Joseph Battell, EsQ.

Nashville, Tenn., May 23, r905.

My Dear Sir:-Your letter of inquiry was turned over to me and I have been endeavoring to trace the pedigree of the pacer T. P. I met his owner Phillips this morning and found out that the horse was by IV. H. Edwood's Dave Jennings (sometimes called Dave Jennings Jr.) $\mathrm{He}$ could not give the breeding of the dam of the Edwoods Horse. Old Dave Jennings, I once owned. He was by the Hatch Horse, dam Morgan. T. P's. dam was by McCurdy's Hambletonian.

$$
\text { Very truly MaY Overton, }
$$

President of Tennessee Live Stock Breeders' Assn., 42 Arcade St.

DAVIE BELMONT ( I-64), gray ; foaled I 889 ; bred by Dr. Boyd, Defiance, Ia. ; got by Davenant, son of Belmont : dam Ruly, said to be by Brethard.

Sire of 3 trotters $\left(2: 23^{3 / 4}\right)$.

DAVY CROCKETT (BLACKBURN'S), brown, about I5 hands, rooo pounds. The best information of the horse that we have yet seen is contained in the following letter of Dr. Luke Blackburn which appears in Wallace's Monthly of February, 1878 :

"The horse known as Blackburn's Davy Crockett was sent to me from Detroit, Mich., in 1837 , by a gentleman of great wealth, named Brush, who recently died in that city. The horse was placed in charge of a 
man by the name of Dwight, who brought him across the country to Kentucky, and arrived at Georgetown the week of the race at that place. I was attending the races that week, and there first saw the horse. Dwight had with him a large amount of money and he publicly offered to bet that Crockett could beat any pacing horse in the world, any distance and for any amount under \$10,000. In this offer he excepted Oneida Chief, who had beaten Davy Crockett some time before, on the Poughkeepsie track in the then extraordinary time of $2: 26$.

"Davy Crockett was a beautiful brown, fourteen hands three inches high, with long body, fine carriage, flowing mane and tail, and of great substance and endurance. I drove him in a sulky, and rode him under saddle, between his regular seasons. - He was, without question, as fine a driving or saddle horse as ever moved in harness or under saddle. $\mathrm{He}$ made many, many seasons in Woodford County, and my father sold him to a Mr. Moody, Shelby County, where he died. He was the sire of the celebrated stallion, Drennon, and the getter of more fine saddle horses than any horse ever in Kentucky. After his death it was impossible to purchase one of his colts at any price, their owners holding them as priceless treasures. Crockett, in his prime, was the fastest pacer and the fastest trotter in the State of Kentucky. I never knew anything of his pedigree, but always considered him what might be called a fullblooded Canadian."

This is very evidently one of the famous fast pacers bred by Louis Dansereau, Verchères, P. Q., Can., from his famous Mare Jeanne D'Arc, and got by Pappillon, or a son. Pilot belonged to this same family. See Pappillon.

C. W. Kennedy of Montgomery, Ala., born I8I 5 , all his life interested in horses, says in interview, I889:

"Uncle Ned Blackburn had Davy Crockett and Tecumseh about the the same time, I think Tecumseh came first. Crockett was a Canadian, very good looking, dark brown, I5 hands, Iooo pounds. I think he had a white foot or two, very stout, long tail, heavy mane and tail, head larger than Pilots but clean, not a bad one, no great rise of crest."

J. H. Harding, Pleasureville, Ky., in letter, dated Jan. 28, ז889, says :

"If half that 'the oldest inhabitants' say is true, there was never a better or faster pacing Canadian imported than Drennon's sire, old Davy Crockett, who made his last season and died within 500 yards of where I now write. He was the most 'prominent citizen' at all stallion shows, fairs, and musters, and the redoubtable militia Colonel never looked more warlike than when astride of proud 'old Davy.' He never encountered a horse that could out pace him, and his rival Tecumseh was the only one who could make him extend himself. He was sire of Drennon, founder of the Drennon family. He begat Canada Chief, who got the dams of Blanche, $2: 25 \mathrm{I} / 4$, Coaster, $2: 26 \mathrm{I} / 4$, and Governor, $2: 30$. He begat Moody's Davy Crockett, who got Legal Tender, sire of Red Cloud, 2 :I 8 ; Legal Tender, $2: 27$ I/4; Legal Tender, $2: 28$ and Black Bassinger, $2: 29 \frac{1}{2}$. And Legal Tender got Legal Tender Jr., who in turn got Lady Elgin, $2: 25 \mathrm{~T} / 4$; Legal R., $2: 30$; Lowland Girl, 2 : I 9 I/4; Bob Ingersoll, $2: 30$; Laura J., $2: 27 \mathrm{I} / 4$, and Wonderful, $2: 25 \mathrm{~T} / 4$. Indeed the blood of Davy Crockett figures in the pedigrees of many of our best trotters and producers of trotters. Had he received the fostering care 
of some great breeding establishment like Woodburn, he would have founded a family as famous as the Pilot Jr. tribe. No one has been sufficiently interested in him to give us a full and connected account of this great horse and his numerous descendants."

"Observer" writes: "Legal Tender, sire of Red Cloud, etc., was by Moody's Davy Crockett, pacer, by Blackburn's Davy Crockett, pacer. The last was a Canadian owned by Alpheus Dwight, who took him to Kentucky about 1838 , farmed him out several seasons and then sold him about 1844 to E. M. Blackburn of Woodford County, Ky., who sold him to E. W. Moody of Eminence, Ky., whose property he died about I $855 . "$

Mr. George T. Graddy, Versailles, Ky., discussing the old time trotting and pacing sires of Kentucky, said in interview, May, r905:

"Davy Crockett was a purely Canadian horse. A horse of rather low carriage, fine mane and tail, and great speed in the pace. Would pace over 50 logs and never break. Very great burst of speed at that gait, a square pacer. He got one of the handsomest stallions I ever saw, Drennon, a great show horse and got show colts.

"Davy Crockett was small a little over I5 hands, a horse of length, Canadian build, low carriage, not much style, fair looking neck, fairly well turned head, a little chunky but wide between the eyes and not an unshapely head; heavy wide breast like all those Canadian horses."

Sire of $3^{\mathrm{d}}$ dam of Zulu, $2: 29^{1 / 2}$.

DAVY CROCKETT (BUTTON'S) (I-8), bay, said to be by Blackburn's Davy Crockett: and dam by Snap. Owned by James Button, Cross Plains, Ind., whose property he died, $\mathbf{I} 875$. See The Morgan Horse and Register, Vol. II., p. 96.

Sire of Business, $2: 29$.

DAVY CROCKETT (COULTER'S) (I-I6), said to be by Moody's Davy Crockett. See The Morgan Horse and Register, Vol. II., p. 96.

Sire of Rostrever, $2: 23 ; 4$ dams of 4 trotters, 2 pacers.

DAVY CROCKETT (CUMMINGS') (I-8), said to be by Davy Crockett. Sire of dam of Butterscotch, 2:20.

DAVY CROCKETT (HENDERSON'S) ( $\mathrm{I}-8$ ), said to be by Davy Crockett. Sire of second dam of Bell Simmons, $2: 18$.

DAVY CROCKETT (LUCAS') (I-4), bay, said to be by Bald Stockings, son of Tom Hal : and dam by Copperbottom. Brought, i 85-, from near Cynthiana, Ky., to Rush County, Ind., by Rev. Joseph D. Lucas, who sold him to Benjamin Marshall, Arlington, Rush County, Ind. He was a pacer.

DAVY CROCKETT (MILLER'S) (I-8), said to be by Dary Crockett. Sire of dam of Commander, $2: 261 / 4$. 
DAVY CROCKETT (MOODY'S) ( $\mathrm{x}-8$ ), brown; foaled I8-; bred by J. W. Moody, Eminence, Ky.; got by Blackburn's Davy Crockett: dam said to be by Collector, son of Sir Charles. See The Morgan Horse and Register, Vol. I., p. 780.

Sire of Sam West, $2: 29$; Harry $E, 2: 23 \frac{1}{4}$.

DAVY CROCKETT (PARISH'S) (I-I6), bay, I53/4 hands; foaled 1860 ; bred by Dabney Parish, Clark County, Ky.; got by Cavin's Davy Crockett, son of Blackburn's Davy Crockett. Sold about r 865 , to William McCracken, Lexington, Ky. See The Morgan Horse and Register, Vol. II., p. 96.

Sire of Etta Jones, $2: 20$; I dam of I trotter.

DAVY CROCKETT (SCRUGGS') (I-8), pacer; probably by Blackburn's Davy Crockett. Brought from Clintonville, Bourbon County, Ky., to Kenton County, near Covington, by Volney Scruggs. See Cresceus, note under, Vol. I.

Sire of dam of Doble, $2: 28$.

DAVY CROCKETT JR. (I-S), said to be by Davy Crockett. Sire of dam of Gover Wilkes, $2: 24 \%$.

DAVY MACK (I-64), chestnut, I5 I/2 hands; foaled I 884 ; Iroo pounds; bred by Wilson McAdams, Jr., Rushsylvania, O. ; got by Mambrino Buckeye, son of Mambrino King: dam Kate L., chestnut, bred by Wilson McAdams, Jr., Marysville, O., got by Lex, son of a horse called Lexington; 2 d dam Lightning Bug, bred by Wilson McAdams, Jr. Zanesville, O., got by Young Montreal, son of Montreal; 3d dam Kate Breckenridge, bred by Wilson McAdams, Jr., Urbana, O., got by Breckenridge, son of Lexington; $4^{\text {th }}$ dam Mag Paymaster. Davy Mack was sold several times, went back to Wilson McAdams, Jr., who again sold to Pugh Bros., whose property he died, I904. Pedigree from breeder.

Sire of Dolly Carr, $2: 12 \frac{1}{4}$.

DAWN (I-64), $2: 183 / 4$, chestnut, star and near ankle white, I6 hands, I I6o pounds; foaled I $88 \mathrm{I}$; bred by A. P. Whitney, Petaluma, Cal. ; got by Nutwood, son of Belmont: dam Counters, chestnut, bred by S. B. Whipple, San Mateo, Cal., got by Whipple's Hambletonian, son of Guy Miller; 2d dam Fly, bay. Sold to A. L. Whitney, Petaluma, Cal., who sends pedigree. Died about $\mathrm{I} 895$.

Sire of 5 trotters $(2: 2 \mathrm{I}): 4$ dams of 4 trotters, 2 pacers.

DAWNING (I-I6), bay, black points, small star, I5 I/2 hands, I Ioo pounds; foaled April 24, I89o; bred by G. DeWitt 'Tyler, Union City, Mich.; got by Dauntless, son of Hambletonian : dam Patti Tyler, bay, bred by G. DelWitt Tyler, got by Magna Charta, son of Morgan Eagle ; $2 \mathrm{~d}$ dam Kitty Cave, bred by Cave Bros., Union City Mich., got by Buell's Path- 
finder, son of Benedict's Pathfinder ; $3 \mathrm{~d}$ dam Gin, said to be by Jimmy ;

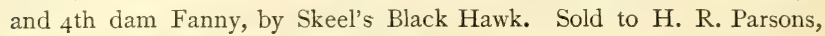
Union City, Mich., who sends pedigree.

Sire of $\operatorname{Earl} W ., 2: 17 \frac{1}{4}$.

DAWN R. (I-64), $2: 20$ brown, I5 I/2 hands, rooo pounds; foaled I 887 ; bred by Elizur Smith, Lee, Mass.; got by Alcantara, son of George Wilkes : dam Dainty, $2: 263 / 4$, bay, white hind ankles, $15 \frac{1}{4}$ hands, foaled I879, bred by Richard West, Lexington, Ky., got by Dictator ; $2 \mathrm{~d}$ dam Vic, bay, bred by A. Hurst, Midway, Ky., got by Mambrino Chief ; 3d dam Fly, said to be by Barclay's Columbus; $4^{\text {th }}$ dam Paradine, by $2 \mathrm{~d}$ Duke of Bedford; and 5 th dam Peg, by Matchless, a Narragansett pacer. Sold to W. M. Roberts, Bar Harbor, Me.; to Thomas Tracy, Ellsworth, Me.; to P. W. Ford, to E. S. Clark both of Bar Harbor; to a Mr. Hall at Dover, Me., where he died. Pedigree from catalogue of breeder.

Sire of Matin Belle, $2: 27 \frac{1}{2} ;$ Beatrice Greeley, $2: 201 \frac{1}{4}$.

DAY BEI.L ( $1-32$ ), black; foaled I 892 ; bred by Leland Stanford, Menlo Park, Cal.; got by Palo Alto, son of Electioneer: dam Beautiful Bells, $2: 29 \mathrm{~T} / 2$ (dam of Bell Boy, which see). Pedigree from catalogue of breeder.

Sire of Jimmy Michael, $2: 2 \mathrm{I}^{1 / 2}$.

DAY DAWN (I-I6), bay, I6 hands, Iooo pounds; foaled July I 7, I885; bred by Charles B. Dare, Levant, Me.; got by Judge Advocate (dam by Neaves' Cassius M. Clay Jr.), son of Messenger Duroc: dam Nelly Morrill, said to be by Winthrop Morrill, son of Young Morrill ; $2 \mathrm{~d}$ dam Duchess Fearnaught, by Young Fearnaught (dam by Brandywine), son of Fearnaught; and $3 \mathrm{~d}$ dam Nellie Grant, by General Grant, son of General McClellan. Sold to Birch Grove Farm, H. E. Haley, Proprietor, Monroe, Me., who sends circular for 1893 with pedigree as above.

Sire of Walton S, $2: 21^{1 / 1} / 1$.

DAYLIGHT PATCHEN. Untraced,

Sire of Starlight Patchen, $2: 201 / 4$.

DAY STAR (I-I6), brown, hind ankles white; foaled I884; bred by T. H. Blewett, Bethpage, Tenn.; got by Duluth, son of Cabell's Lexington : dam Sally, said to be by Montrose, son of Diamond Denmark, by Gaines' Denmark ; 2 d dam Black Mollie, by Buntin's Denmark, son of Diamond Denmark; and 3d dam by John Boston's Highlander. Sold to W. N. Turner, Bethpage, Tenn., who sends circular with pedigree.

DAY STAR (I-32), $2: 17$, bay, with star, and white hind feet, $153 / 4$ hands, I I oo pounds ; foaled I 886 ; bred by John W. Lemark, Pendleton, Ind.; got by Chestnut Star, son of Arnold's Red Buck, by Copperbottom: 
dam Belle, bay, bred by Theodore Hudson, Pendleton, Ind., got ly Wood, son of Curtis' Hambletonian ; $2 \mathrm{~d}$ dam, bay, bred by Mattie Brux, Warrington, Ind., got by a horse owned by Stokely Hayes ; 3 d dam brown, bred by Mr. Cass, Pendleton, Ind., got by Southern Ranger, brought from Canada. Died I899. Pedigree from breeder. Mr. Lemark says in advertisment, I 894 :

"Day Star's sire, Chestnut Star, has a record of $2: 22$ in seventh heat of a winning race and is also the sire of Red Star.

"Red Buck, sire of Chestnut Star, $2: 22$, Captain Jack, $2: 243 / 4$, Columbus Girl, $2: 273 / 4$; he also got the dam of Mambrino Star, he the sire of the dam of Jay Bird, and he the sire of Allerton, $2: 07 \frac{1}{4}$. Flora Voss, the dam of Chestnut Star, $2: 22$, Buck Dickerson, $2: 25^{1 / 2}$, and Sorrel Frank, said to have had a trotting record of $2: 30$, was by Sleepy Abe, son of Tom Crowder (Sleepy Abe's dam was a Tom Hal mare; second dam of Chestnut Star was by John L. Brown's Tom Crowder)." .

Sire of 3 pacers $(2: 161 / 4)$.

DAZZLER (3-64), $2: 26 \mathrm{I} / 2$, roan, I6 I/4 hands, I 200 pounds; foaled I $89 \mathrm{I}$; bred by A. R. Talbott, Stony Point, N. Y.; got by Wellington, son of Kentucky Prince: dam Bettie Higgins, roan, foaled 1877 , bred by P. Higgins, Shawhan, Ky., got by Joe Downing, son of Edwin Forrest ; $2 \mathrm{~d}$ dam Pic, said to be by Picciola, son of Tom Crowder; 3 d dam Susan, by Allen's Robert Bruce, son of Clinton, by Sir Charles, son of Sir Archie ; and $4^{\text {th }}$ dam by pacing Pilot, son of Pilot Jr. Sold to F. G. Babcock, Hornellsville, N. Y. Pedigree from J. G. Callison, Windsor, Mo., breeder of Dazzle Flower.

Sire of Dazzle Flower, $2: 30$.

D. C. (3-128), dark bay, with black points, 15 I/2 hands; foaled 1884 ; bred by N. Craig, Georgetown, Ky. ; got by Dictator, son of Hambletonian : dam chestnut, bred by N. Craig, got by Antar, son of Almont: 2 d dam Dutch bred by N. Craig, got by John C. Breckinridge, son of Johnson's Toronto ; 3 d dam Nubtail, bred by N. Craig, got by imported Yorkshire ;

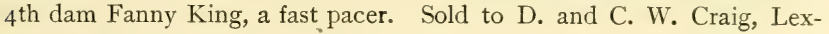
ington, Ky. Pedigree from Dill Craig.

D. C. SIMMONS, chestnut, with white face, and four white feet, $15 \mathrm{I} / 2$ hands, I 200 pounds; foaled I886; bred by J. Barton, Millersburg, Ky.; got by Simmons, son of George Wilkes : dam Alice Drye, said to be by May's Sir Wallace. Sold to J. W. Ferguson and W. H. Wilson, Cynthiana, Ky. ; to J. W. Ferguson, Sharpsburg, Ky. ; to George P. Richmond, Prophetstown, Ill., who sends pedigree.

Sire of Irene, $2: 15^{3 / 4}$,

DEACON ( $\mathrm{I}-32$ ), black, I5 hands, I050 pounds; foaled I865; bred by E. P. Whiting, Rochester, Minn.; got by Messenger Black Hawk, son of 
Naugatuck, by Black Hawk: dam brought from Racine County, Wis., and said to be a descendant of Gifford Morgan. See The Morgan Horse and Register, Vol. II.

DEACON (I-32), mahogany bay, black points, I6 hands, I250 pounds; foaled I 869 ; bred by H. S. Russell, Boston, Mass. ; got by Robert Bonner, son of Hambletonian : dam Fanny Prewitt, bay, bred in Kentucky and said to be by Ericsson, son of Mambrino Chief; and $2 \mathrm{~d}$ dam by Woodford. Sold to John Winthrop, Stockbridge, Mass. ; to Harrison Calkins, Alford, Mass. ; to George W. Clark, Cedar Falls, Ia. ; to William Bryant, Waterloo, Ia. Pedigree From Geo. W. Clark.

Sire of Victor V., $2: 19 \frac{1}{2} ; 4$ dams of 2 trotters, 2 pacers.

DEACON ( $\mathrm{I}-64$ ), brown; foaled $\mathrm{x} 887$; bred by Huntley \& Clark, Helena, Mont.; got by Bishop, son of Princeps: dam Lady Graves, bay, bred by J. M. Graves, Lexington, Ky., got by Smuggler, son of Blanco, by Iron's Cadmus; $2 \mathrm{~d}$ dam said to be by Excelsior Morgan. Sold to S. S. Huntley, Toston, Mont.; to R. B. Ogilvie, Madison, Wis.; to Wm. Montgomery, Banks, Kirkcudbright, Scotland.

Sire of 2 trotters $\left(2: 17 \frac{1}{4}\right)$.

DEACON (RILEY'S), black, I5 hands, I I50 pounds; foaled i 882 ; bred by John Riley, Prince County, Prince Edward Island; got by Dean Swift, son of Bush Messenger : dam gray, said to be by Sambo, imported; and $3 \mathrm{~d}$ dam Pemeps, by imported Colbus. Sold to Dean Swift, to Robert Fitzsimons, Long River, New London. Pedigree from Theodore Bernard, Tignish, P. E. I.

Sire of Onward, $2: 25 \frac{1}{2}$.

DEACON HUNTER, $2: 39 \frac{\pi}{4}$, bay with white points, $15 \frac{1}{2}$ hands, rooo pounds; foaled I 885 ; bred by J. R. Smith, Falls City, Neb. ; got by Shakespeare, son of Jupiter Abdallah: dam bay, bred by J. C. Furgis, Humbolt, Neb., got by Hambletonian Prince, son of Administrator. Pedigree from breeder.

Sire of So!dout, $2: 22^{3} / 4$.

DEADWOOD. Untraced. A brown stallion of this name with record of $2: 283 / 4$ was owned by John Palmer, La Crosse, Wis, previous to 1889 and said to be a broncho.

Sire of Live Oak Girl, $2: 22^{3} / 4$.

DEAN FORREST (LOMO ALTO) (I-64), $2: 24 \frac{T}{4}$, bay, I $5 \frac{3}{4}$ hands, I Ioo pounds; foaled I 893 ; bred by Henry Exall, Dallas, Tex.; got by Electrite, son of Electioneer: dam Norissa, brown, bred by H. L. and F. D. Stout, Dubuque, Ia., got by Nutwood, son of Belmont; 2d dam Frances Medium, bay, bred by W. T. Withers, Lexington, Ky., got by Happy Medium, son of Hambletonian; $3 \mathrm{~d}$ dam Annabel, brown, bred 
by A. S. Talbert, Lexington, Ky., got by (ieorge Wilkes; $4^{\text {th }}$ dam Jessie Pepper (dam of Alpha, $2: 25 \frac{1}{2}$, which see). Sold to W. H. Gray, Brookfield, Penn.; to Charles A. McIonald, McDonald, Penn. Pedigree from breeder.

Sire of Dallas Texas, $2: 21 \frac{1}{4}$.

DEAN SAGE $(3-64)$, brown, with stripe in face, near fore foot and hind ankles white; foaled I 873 ; bred by Charles Backman, Stony Ford, N. Y.; got by Hambletonian, son of Abdallah : dam Nellie Sayre, brown, bred by Jacob Crosby, Wallkill, N. Y., got by American Star; 2 d dam said to be by Hulse's Hickory, son of Hickory; and $3 \mathrm{~d}$ dam by Latourette's Bellfounder. Sold in 1876 , to Charles M. Read, Erie, Penn.; to Lackey \& Carmony, Cambridge City, Ind. ; to J. W. Gray, Randolph, Vt. ; to Nicholas Lenz; to Peter Lenz, Ellsworth, Minn., March 3, I 896 ; to Crandall \& Kern, Ellsworth, Minn. Pedigree from F. A. Wright.

Sire of 2 trotters $\left(2: 25^{1 / 2}\right)$; I sire of 3 trotters, 2 pacers; 2 dams of 2 trotters.

DEAN SWIFT. Owned by Mr. Bushong of Pennsylvania, about i 846. His son, Henry Bushong says: "He got a colt that was kept for a stallion, blue dun, a stripe down his back."

DEAN SWIFT ( $1-64$ ), brown; foaled $\mathrm{I}_{7} 82$; bred by Robert Fitzsimmons, Long River, Prince Edward Island, Can.; got by Bush Messenger : dam Fairy Queen, said to be by Smith's Farmers' Glory, son of Columbus ; 2d dam Lady Gray.

Sire of 2 trotters $\left(2: 29 \frac{1}{2}\right) ; 2$ sires of 3 trotters; 2 dams of 3 trotters.

DE BARRY (3-64) ; bred by Timothy Mealey, Philadelphia, Penn. ; got by Nil Desperandum, son of Belmont: dam bay, said to be by Happy Medium, son of Hambletonian; and $2 \mathrm{~d}$ dam County House Mare, by Seely's American Star. Pedigree from breeder.

DEBS (3-1 28), brown; foaled r894; bred by Caton Stock Farm, Joliet, Ill. ; got by Highwood, son of Nutwood: dam Ilma Cossack, brown, foaled I 888 , bred by Caton Stock Farm, got by Don Cossack, son of August Belmont; 2 d dam True Blue, bay, foaled 1878 , bred by James Wilson, Rushville, Ind., got by Blue Bull; 3 d dam Miss Davidson, said to be by Pocahontas Boy, son of Tom Rolfe. Pedigree from catalogue of breeder.

Sire of Miss Connier, $2: 281 / 4$.

DECATUR (own brother to Sir Peter Teazle), bay, I6 hands; bred by Stephen Hunt, New Jersey; got by Sir Solomon: dam Rosalinda, by imported Trafalgar; $2 \mathrm{~d}$ dam by imported Magnetic Needle; 3d dam by Bajazette; 4th dam Selima, by Selim; $5^{\text {th }}$ dam Molly Pacolet, 
owned by Jacob Heiltzheimer of Philadelphia. Advertised with pedigree as above, 1823 , in New Jersey.

DECATUR CHIEF ( $1-128$ ), brown, with star, left hind and right fore foot white, I5 I $/ 2$ hands, Iooo pounds; foaled I 883 ; bred by A. M. Studer, Peoria, Ill.; got by Durango, son of Strader's Cassius M. Clay Jr. : dam Lady Lightland, bay, bred by James Wadsworth, Chicago, Ill., got by Ashland, son of Mambrino Chief ; 2 d dam Maria Ward, said to be by Hambletonian; 3 d dam by Abdallah; and $4^{\text {th }}$ dam by imported Shark. Sold to R. R. Montgomery, Decatur, Ill., who sends pedigree. Died I 894 .

Sire of Hazel N., 2:26; I dam of I pacer.

DECEIVE (DEAN'S HAMBLETONIAN), bay, I5 I/2 hands, Io6o pounds, one hind foot white; foaled I 863 ; bred by Joseph B. Dean, Patterson, N. J.; got by Hambletonian: dam untraced. Sold to John Hinchman, Goshen, N. Y.; to Joseph Gavin, Chester, N. Y.; to O. T. Atwood, New York, N. Y.; to Fred N. Kilborn, Copenhagen, N. Y., who sends pedigree. Died I 895 .

Sire of 4 trotters $\left(2: 25 \frac{1}{2}\right)$, Mascot, $2: 04$.

DECK WRIGHT (I-I6), $2: 193 / 4$, winner of 53 races; bay, with star and two white feet, I5 hands, 900 to 950 pounds; foaled 1869 ; bred by Edward Wicks, Antwerp, N.Y. ; got by Hinsdale Horse, son of Hinsdale Colt, by Sammy Blucher : dam Doll Wicks, dam of N. J. Fuller, $2: 26 \mathrm{~T} / 4$, bred by Edward Wicks, got by Young North Briton, son of North Briton, said to be by Justin Morgan or a brother ; 2 d dam Fan Wicks, brown, I $53 / 4$ hands, I Ioo pounds, bred by Edward Wicks, got by Young Duroc, son of old Duroc. Gelded young. Information from Sam Wicks, son of breeder, in interview at his home, July, I906. Recording this horse in I894, we found that at that time he had trotted 157 races, the most of any horse living or dead. Mr. Wicks was positive that Young North Briton, which his father brought with him when he emigrated to this part of the State from near Troy about I 830, was in direct descent from True Briton, sire of the original Morgan Horse. See Young North Briton.

DECK WRIGHT ( $1-64$ ), 2 :091/2, chestnut; foaled $\mathbf{1} 887$; bred by Wear Cassady, Rushville, Ind.; got by Quilna Chief, son of Pocahontas Boy : dam Kate C., bay, foaled I874, bred by Wear Cassady, Rushville, Ind., got by Blue Bull ; 2d dam Ribbon. Sold to George Foster, South Whitley, Ind. ; to W. W. Kirby, Peru, Ind. ; to D. W. Hisey, Mentone, Ind. Information from Mrs. W. W. Kirby.

Sire of 4 pacers $\left(2: 14 \frac{1}{4}\right)$.

DECLARATION (3-I28), bay, I6 hands; foaled I887; bred by William Dunn, Wilton Place, O.; got by Young Jim, son of George Wilkes : dam Lady Bunker, chestnut, bred by William Dunn, got by Mambrino 


$$
\text { I }
$$




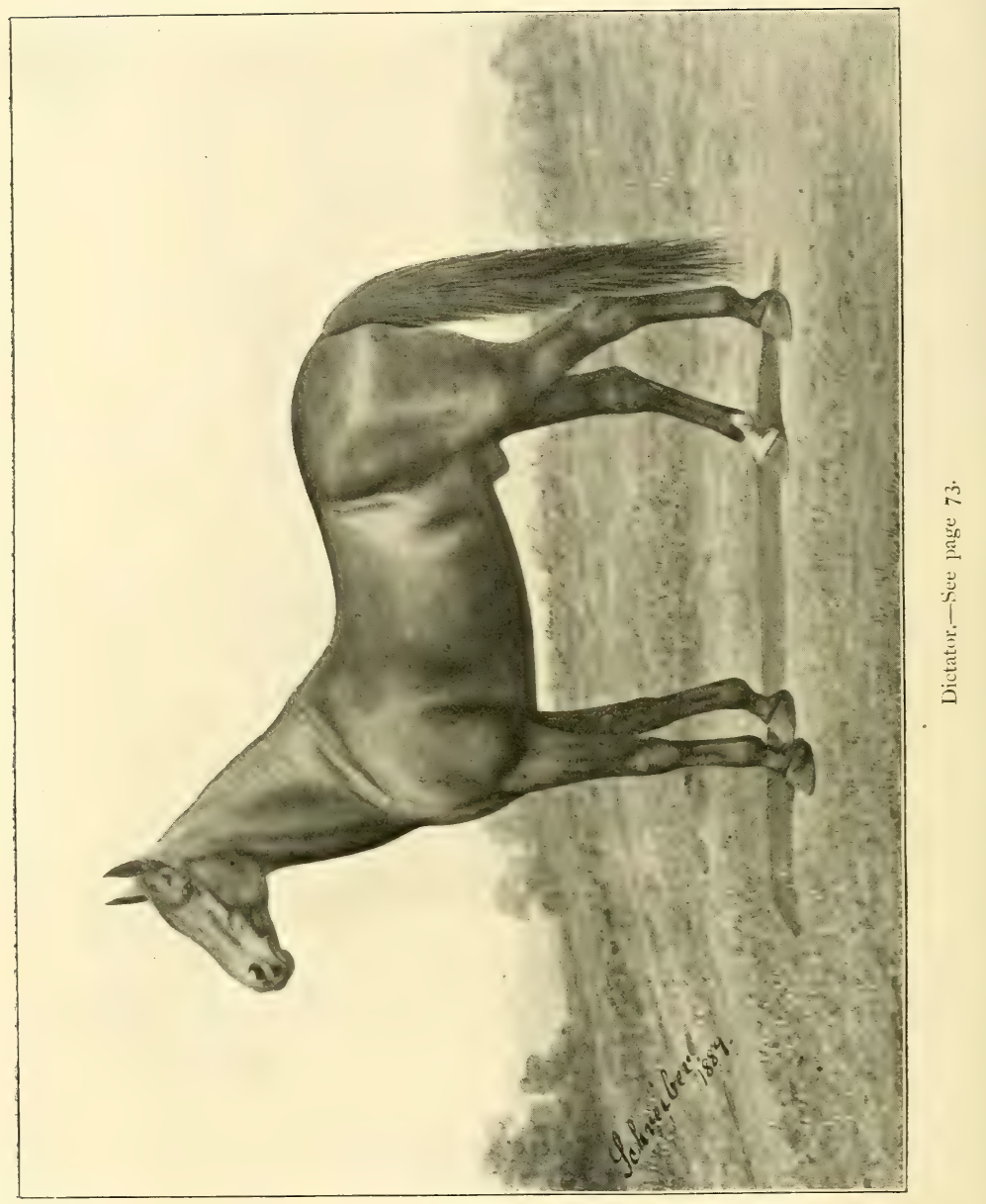


Patchen; 2 d dam Lady Dunn, gray, said to be by American Star; 3d dam untraced. Sold to Herman Lackman, Cincinnati, O.; to Robert Grear, Winton Place, O. Advertised with pedigree as above in Spirit of the Times, 1890 , by $\mathrm{Wm}$. N. Todd, Winton Place, O. ; also by James Walker, Coldwater, Mich., in the Horse Review, I905.

Sire of 7 trotters $\left(2: I 8 \frac{1}{2}\right), 2$ pacers $(2: 2 I) ; x$ sire of I pacer; 2 dams of I trotter, I pacer.

DECORAH ( $1-32), 2: 263 / 4$ bay; foaled 1884 ; bred by Wm. L. Simmons, Lexington, Ky.; got by Mambrino Patchen, which see: dam Hattie Allen, bay, bred by Wm. L. Simmons, got by George Wilkes; $2 \mathrm{~d}$ dam Danish Girl, bay, bred by Wm. L. Simmons got by Honest Allen, son of Ethan Allen; 3d dam Molly Stout, brown, bred by Wm. Stout, Midway, Ky., got by Gaines' Denmark. Sold to John W. Stiles, Decorah, Ia. Pedigree from breeder.

Sire of 5 trotters $(2: 181 / 2)$; George T. $2: 131 / 4$.

DECORAM, $2: 30$, bay, stripe, two white hind feet, $153 / 4$ hands, 1265 pounds; foaled I 890 ; bred by F. M. Ice \& Son, Mount Summit, Ind. ; got by Anderson Wilkes, son of Onward : dam Tattycoram, bay, foaled I 885 , bred by J. W. Gray, Ridgewood, N. J., got by Dean Sage, son of Hambletonian; 2d dam Bertha Duroc, chestnut, foaled I 874 , bred by B. Burchard, Cornwall, Vt., got by Messenger Duroc, son of Hamble. tonian; 3 d dam said to be by Hambletonian; and $4^{\text {th }}$ dam by Black Hawk: Sold to B. B. Pressnall \& Son, New Castle, Ind. Information from B. D. Fort, Kingston, Ind., breeder of Decoram Wilkes.

Sire of Decoram Wilkes, $2: 141 / 4$.

DECORATE $(3-64), 2: 27$, chestnut, with stripe in face, and white hind legs ; 16 hands, $x 200$ pounds; foaled I 884 ; bred by George Starr, Coldwater, Mich.; got by Masterlode, son of Hambletonian: dam Lady Lakin, chestnut, bred by Taylor Lakin, Rushville, Ind., got by Blue Bull; 2 d dam Lakin, said to be by General Taylor, son of General Taylor. Sold to F. D. Richardson, Coldwater, Mich.; to W. A. Ely, to M. A. Pounds, both of Elyria, O. Pedigree from W. A. Ely.

Sire of Delegate, $2: 29 \frac{11}{4}$; I dam of I trotter.

DECORATOR (I-16), $2: 221 / 2$, roan; foaled 1882 ; bred by E. B. Ferguson, Bangor, Mich.; got by Masterlode, son of Hambletonian: dam Pet Ferguson, dark sorrel, stripe in forehead and one white hind foot, about I roo pounds, bred by John Mix, Hartford, Mich., and sold to Silas Delancy, Bangor, Mich.; to the Bangor Furnace Company; to E. N. Ferguson, Bangor, Mich.; got by Mingo Chief, son of Green Mountain Morgan Boy, by Royal Morgan. Sold to W. H. Lanford and Dudley Johnson, Montague, Mich. ; to William Sharp, Muskegon, Mich.; to 
A. J. Haws, Johnston, Penn., May, I888. Pedigree from combination sale catalogue of Ray Warner \& Co., Coldwater, Mich.

Sire of Dorothy, $2: 2 \mathrm{I} 3 / 4$.

DECORATOR D. ( $\mathrm{I}-64$ ), light bay, $\mathrm{r} 6$ hands; foaled $\mathrm{r} 886$; bred by Henry Haywards, Alameda, Cal. ; got by Director, son of Dictator : dam Chess, said to be by Cardinal, $2: 37$, trial $2: 28$ (dam by Joe Gales of Ohio, son of Marlborough, from the Duchess of Marlborough, by Southern Eclipse ; 2d dam old Duchess of Marlborough, by Sir Archy ; 3 d dam by imported Diomed), son of Gen. Gifford, a Morgan horse ; and $2 \mathrm{~d}$ dam a Morgan and Messenger mare. Sold to M. Salisbury, Pleasanton, Cal., who advertises him with pedigree as above in the Breeder and Sportsman, April, I 890 . Died I 89 I.

Sire of Decorator 7 r., $2: 193 \%$.

DECORATOR JR.; said to be by Decorator.

Sire of 2 pacers $\left(2: 22^{3} / 4\right)$.

DEDRON (I-I 28 ), $2: 24 \% \frac{\mathrm{T}}{2}$, brown, I 6 hands, I 200 pounds; foaled I 890 ; bred by S. E. McKee, Aledo, Ill. ; got by Game Onward, son of Onward : dam Lucy B., bred by Joseph McKee, Aledo, Ill., got by Blayney's Abdallah, son of Wideawake; 2 d dam Jenny, said to be by Tuckahoe. Sold to L. B. Morey, Aledo, Ill.; to O. F. Berry, Carthage, Ill., who sends pedigree.

Sire of Dedron Jr., 2:241/4; Carthage Girl, $2: 09 \frac{1}{4}$.

DEENWOOD (I-32), bay; foaled $\mathrm{x} 889$; bred by James E. Clay, Paris, Ky. ; got by Aberdeen, son of Hambletonian: dam Valtura, bay, bred by A. Herr, St. Matthews, Ky., got by Nutwood, son of Belmont: 2 d dam Guatunca, bay, bred by R. S. Veech, St. Matthews, Ky., got by Auditor, son of Hambletonian; 3d dam Gossip, bay, bred by R. S. Veech, got by Princeps, son of Woodford Mambrino; $4^{\text {th }}$ dam Dial, bay, bred by W. Swigert, Spring Station, Ky., got by Delmonico, son of Guy Miller; $5^{\text {th }}$ dam Hagar, bay, bred by A. M. Alexander, Fayette County, Ky., got by Alexander's Abdallah; and 6th dam by Downing's Bay Messenger. Sold to J. H. Thomas, Marion, O., who advertised him with above pedigree, 1892 in Western Horseman.

Sire of 2 trotters $\left(2: 12^{3} / 4\right)$.

DEERFIELD MORGAN (3-I6), chestnut, III3 pounds; foaled I 847 ; got by Green Mountain Morgan: dam said to be by Morgan Cock of the Rock. Exhibited at the first National Horse Show at Springfield, Mass., by Mr. Weir of Walpole, N. H.

DEFENDER $(3-64), 2: 26$, black; foaled 1877 ; bred by John Bowman, Lexington, Ky. ; got by George Wilkes : dam Mist, said to be by Ward's Flying Cloud, son of Black Hawk; and $2 \mathrm{~d}$ dam by Daniel Boone, son 
of Bertrand. Sold to R. P. Pepper, Frankfort, Ky.; to J. W. Wilcox and Dr. Davis, Wilkesbarre, Penn., who send pedigree and say in their advertisement in The Spirit of the Times, May, 17, 1890: "The value of Black Hawk blood is daily becoming more manifest as seen in Belle Hamlin, $2: 123 / 4$, Nelson, $2: 141 / 4$, Gene Smith, $2: 15^{1 / 2}$, Gloster, $2: 17$, and scores of others."

Sire of 3 trotters $(2: 261 / 4) ;$ I dam of I trotter.

DEFIANCE, chestnut sorrel, $15 \% \frac{1}{2}$ hands; foaled $179^{2}$; said to be by imported Othello: dam by a colt of True Briton; and $2 \mathrm{~d}$ dam by Lightfoot. Advertised in the Poughkeepsie Journal, 1796, to be kejt in Philipstown, N. Y.

DEFIANCE, $17 \frac{1}{2}$ hands; foaled 1798 ; said to be full-blooded. Advertised $\mathrm{I} 8 \mathrm{o}_{3}-4$, by James Paddock to be kept at Berlin and Barre, Vt.

DEFIANCE, said to be by Justin Morgan. A horse Defiance is advertised in the Windsor (Vt.) Republican of $\mathrm{r} 809$, by Kendall Hadlock, Pomfret, to be kept at Josiah Tilden's, Hartford, and also at Pomfret, and Woodstock. Terms, $\$ 2$ to $\$ 3$; “bright bay; colts very good."

Ezekiel B. Beckwith, Claremont, N. H., advertises in the Windsor Republican of i 8 II: "The noted horse Defiance, in Windsor, at $\$ 3$ to $\$ 5$. Said horse $151 / 4$ hands, of a bright bay, nerves regular, of high carriage, and great speed. His stock is remarkably good and is more highly approved of than any other horse in the vicinity."

Mr. Wait advertises in the Danville North Star of 1823 , the noted Dutch horse Defiance at Peacham, Cabot and Danville, Vt., terms $\$_{3}$. The testimony that there was a horse called Defiance, by Justin Morgan, has come to us from a number of sources in Caledonia County, Vt., including such intelligent horsemen as Mr. Aaron Smith of Danville, and Mr. T. Bridgeman of Hardwick.

DEFIANCE said to be by Revenge, son of Justin Morgan. Mr. F. A. Weir, Walpole, N. H., in interview, 1885 , said :

"There was a gray horse in Stanstead, P. Q., called Defiance, about I 5 hands, 950 to Iooo pounds, a trotter and got trotters; got by Revenge, son of Justin Morgan. I have often seen Revenge, a good horse, bay, I $4 \frac{1}{2}$ hands, $95^{\circ}$ pounds, in fair flesh, good airy, sprightly looking horse, good metalled horse, gait a little heavy.

"Cock of the Rock stood in Stanstead, P. Q. ; think Osman had him; one or two stallions from Danville., Vt., were kept there.

"I went into Canada, first time when I 3 years old (I 830 ). Three or four years after, Bellows employed me and I went for them I 2 or I 3 years, once a month or twice a month; used to call on Steele, have owned 9 or ro horses got by the old Justin Morgan, bred 3 of his mares to Gifford, got Gifford in the fall of 1844 ; have had 58 stallions, Gifford was the boss. Old Mr. Gifford told me he went over to New Haven, Vt., with him one season himself. 
"Mr. Deinning raised a stallion from Revenge; one was raised at Windsor, another, Wheeler had at Claremont. Think Wheeler once owned Revenge. The Wheeler Horse was a buckskin, black mane and tail, stripe on back, powerful goer, think he was a Revenge. Revenge stood within 5 miles; man by the name of Gibson had him. I sold one of his colts at Providence for $\$ 500$. Next year $1832-33$, sold 14 horses, 6 Morgans.

"Bellows first settled in Walpole; came from Lunenburgh, Mass. There were three Josiah Bellows, one of them called uncle Si. died I 2 years ago. Uncle Josiah when twenty years old kept store here; great lover of horses, he and Josiah $2 \mathrm{~d}$ had droves of horses and mules, used to trade with Ward that owned old True Briton. He saw horse there; tried to trade for him.

"Sent True Briton at one time away to Springfield for season. They stopped to see horse at Springfield, and saw him. Man by the name of Morgan had him; he was a beautiful cherry bay. Spoke about his fine coat.

"I saw John Morgan's son in Pennsylvania, same son that lived at Windsor. He went to Pennsylvania. He told me what John Morgan's mother's name was. Old man went away when this fellow was quite young; left him with mother's connection. Been to old Justin's place, West Springfield; he kept a little boatman hotel.

"Judge Griswold knew him well, he worked for the Judge lots, copying. Judge quite a man in those days; I knew him for years. Never could find a scrap of paper in family of Morgan of Stockbridge. Judge Griswold said that Justin Morgan had a name for his horse. He told where he used to go with him, down to Royalton, old acquaintance at Lebanon, and Woodstock, at Wm. Rice's a good deal.

"Old Bulrush, Woodbury, Gifford all foaled on the little farm of Mr. Gifford at Tunbridge. Beppo was foaled at Ben Cushman's, old uncle Ben's ; dam old mare, by Justin Morgan, in I 847 , knowing where Beppo was from, traced it ; found dam living; got one of her colts by Morgan Eagle.

"Morgan Eagle was bred by a man of by name Morgan, of Royalton. Sold to Sprague, by him to Farnham. Farnham went to Wisconsin; I have visited him there; Farnham sold Morgan Eagle to Foster of Woodstock, who moved to Barre, or kept the horse there. Foster was a stage man at Woodstock. The dam was a moderate sized bay mare that paced a little at first, then took a good gait; looked like a Morgan. Old Mr. Gifford said he thought she was a Henry Dundas colt; don't know what that was, some said he was by True Briton.

"Old Bulrush was a long-gaited horse for a Morgan; came of a French mare; Belknap said so and so did old Mr. Gifford, who traded with Belknap for her when in foal. Bulrush was foaled Gifford's, but he returned the colt.

"Sherman had a lean head with smallish eyes; Revenge and Woodbury's eyes stuck right out; Bulrush's were good fair ones. Sherman had a fine figure coming towards you; not so good going from you; good feet, reasonable bone ; a little finer than the rest in bone ; a good trappy, free rider and driver. Bulrush was a little more leggy and could trot the fastest ; I knew him for years."

DEFIANCE, gray, bred it is thought by Capt. Eber Richmond, Barnard, Vt. Information from Mr. Davis, Barnard, Vt., born, I $8 \mathbf{I o .}$ 
DEFIANCE, brown, I 5 I/2 hands; foaled about $1 \delta_{29}$; bred by A. Archambeau, L'Assomption, Que.; said to be by Cock of the Rock, son of Duroc ; also said to be by a son of Sir Walter. Kept at Berthier, P. Q.; bought about' $8_{37}$, at L'Assomption, Que., by Charles Hatch, who sold him to Capt. Gilman of Stanstead, P. Q. Mrs. - , housekeeper of the man who owned Defiance, says that Charles Hatch bought him at L'Assomption. The man's wife who owned him was afraid of him, and she sold him about $\mathrm{I}_{37}$ in Rebellion times. Owned for some time at Stanstead, P. Q. Mr. N. F. Sheafe of Derby Line, Vt., says, that Capt. Gilman owned Defiance; thinks he got him in St. Hyacinthe.

M. Charlebois, Montreal, in interview, r891, says :

"Bellaire was a Sir Walter, bred back of Berthier, at Challoupe; Dr. Mull bought him; he could trot in three minutes. The doctor bought him of the farmer that bred him and owned him two years, and sold to Spaulding. He was about the same age as Defiance. Defiance was bred at L'Assomption. Archambeau bred Defiance. An American that lived here bought him. He died on track, a good horse, trotter, I6 hands. Father of Lady Moscow.

"Bellaire by Bleury's horse. Thos. McRady had a black stallion that he bought at St. Marie, a trotter."

In an interview, October I 889 , Walter S. Prendergast, Cote des Neiges, near Montreal says :

"There was a thoroughbred horse here, old Defiance that got Lady Moscow, she was bred at Berthier opposite Sorel. A man named Clark, who lived there got her afterwards and brought her into notoriety. I have seen her trot; when I saw her last she was pony-built, earlier more slim. Defiance was a brown thoroughbred and stood at least $15 \mathrm{I} / 2$ hands. I do not think he was bred in Canada, he once stood in Stanstead. I saw Cock of the Rock run in a race against Sir Walter, here at Montreal, also saw Sir Walter run at Brent."

Mr. Sheaf of Stanstead, P. Q., in interview, I887, said that Gillman claimed that Defiance was by Sir Walter.

Sire of Lady Moscow, whose dam is said to have been Morgan.

DEFIANCE, jet black, I6 $1 / 4$ hands. Owned at Springville, Erie County, N. Y., I 843 , by a Mr. Capen, who it is thought brought him from Canada. He was blind and being turned out to pasture after the season got cast among some logs and died. He had very fine arched neck and was a prompt actor. A son of his called Young Defiance bred by Charles Wilder, was afterwards owned by John Gregor of Fultonville, N. Y.

Editor Dunton's Spirit of the Turf :-I notice in the Feb. Igth number of your paper an inquiry for the pedigree of the blind horse Defiance, which the writer says was from Pennsylvania, about forty years ago, and was the sire of Young Defiance, with one white hind foot to pastern and small white spot on the other hind foot, kept at Springville, Erie County, N. Y. Undoubtedly, I can say more about those two horses than any other man living, while they were there at Springville, 
but when he asks for the pedigree of a French horse, he has us all beat. Notwithstanding, he was a good horse of his kind, and I will prove it before I get through I will also show that this Young Defiance never did any service at Springville. In June, I843, a man by the name of Capen, brought this blind horse to Springville for service. It was then said he brought him from Canada. At any rate he was a French horse, but one of the large kind; was a jet black, marked almost as the description of Young Defiance, which was correct. This old horse stood certainly $16 \mathrm{I} / 4$ hands, with one of the most arched necks we often see; so deep and so arched that it would fall four inches out of line; was a fine prompt actor to the bridle, though as blind as a bat; had as good folding knee action as I ever saw. Why I remember him more distinctly it was my first stallion season. $\mathrm{He}$ was standing at $\$ 5$, and so was my horse. This was the highest price going in our country. He got a few mares in foal and that was his first and last season there. After the season he was turned out in a log pasture and, being blind, fell over among the logs, got cast and died. The next season, I 844 , his produce began to come along and among them this Young Defiance now in question. $\mathrm{He}$ was raised by Charlie Wilder, up to two years past. In the fall of 1846 , in November, I had a friend down at Fultonville, Montgomery County, forty miles West of Albany, by the name of John McGregor. He came to visit me and while there, I showed him around among the colts and horses, and he bought the Charlie Wilder colt, then about two and a half years old. He calculated to lead him through on foot, 300 miles, so when he got ready to start, I was to go with him as far as we could go in one day, then come back the next. The mud was deep and I pritied the fellow and kept on with him the second day, down the Genesee flats, mud still deeper. The second night I got him to consent to put the colt on the cars at Rochester, so the third day we pointed for Rochester and got in there some time after dark; we had made about roo miles in the three days. The next morning, the fourth day, I pointed back for home, after taking the last look at the colt, and with a promise that he would put him on the cars and take him through. But he did no such thing. Something was wrong about the cars and the Scotchman took him through the next 200 miles on foot, he leading him. Now this article has come to be quite lengthy, but to do the old blind hero justice, I will say, I never saw a poor colt by him, and he got the first trotting horse I ever owned. I sold him to Mr. Joseph Hall of Rochester, the owner of old St. Lawrence, and George M. Patchen.

DEFIANCE ( $1-32$ ), bay, I5 ז/2 hands, I I5o pounds; bred by Col. Thompson, Shefford, P. Q. ; got by Royal George, when owned by Mr. Prendergast: dam a small dark bay mare, said to be Morgan. Owned by Charles S. Hall, Waterloo, P. Q., who in interview, r89 I, said: "Defiance got the trotting gelding known as the Hall Horse which I sold to Col. Foster of Shefford for $\$ 500$. Foster sold him to Goddard of Richford, Vt. This was a bay gelding under 15 hands, said to have a record below 2 :30."

DEFIANCE, said to be of Morgan blood.

Reputed sire of the dam of Camors, $2: 25 \frac{1}{4}$, winner of 10 races. 
DEFIANCE (I-8), 2 :34, black, I 6 hands, I I oo pounds; foaled I 867 ; bred by T. J. and A. F. Hoyt, Grafton, N. H. ; got by General Lyon, son of Morrill : dam bred by A. S. Heath, Grafton, N. H., got by I.itchfield Horse, son of Kossuth, by Black Hawk. See The Morgan Horse and Register, Vol. I., p. 867.

Trotted $187 \mathrm{I}-75$. Winner of 10 races.

$D E F I A N C E$. A horse of this name was owned at one time by D. Young of Colebrook, N. H., and a son of his in 1867 , by H. French in Eaton, P. Q.

DEFIANCE, $2: 27 \mathrm{~T} / 4$, brown, I 6 hands, $\mathrm{r} 200$ pounds; foaled $\mathrm{I} 880$; bred by R. P. Pepper, Frankfort, Ky., got by William Rysdyk, son of Hambletonian : dam Begum, said to be by Alcalde; 2 d dam by Giltner's Whip; and 3 d dam, by Paddy Burns, son of Gray Eagle. Sold to S. Reynolds, Plymouth, Ind. Died I 903. Pedigree from Carl V. Reynolds, Plymouth, Ind.

Sire of 2 trotters $(2: 2 \mathrm{I})$.

DEFIANCE (RAYMOND'S), bay, I61/2 hands, I 300 pounds; foaled is 88 ; bred by IV. H. Raymond, Puller Springs, Mont. ; got by Com. Belmont, son of Belmont: dam Sue Preston, bay, bred by General Preston, Lexington, Ky., got by Forrest King, son of Mambrino Patchen. Sold to John Donegan, Puller Springs, Mont. Pedigree from breeder.

Sire of 2 trotters $\left(2: 18 \frac{1}{4}\right)$.

DEFIANCE (I-I 28 ), bay, star, I6 hands, I 200 pounds; foaled I 883 ; bred by J. Q. Smith, New Carlisle, O. ; got by Schuyler Colfax, son of Hambletonian: dam black chestnut, said to be by Mohawk (Reed's Harry Reed), son of Charles Mohawk; and $2 \mathrm{~d}$ dam by Tip Cranston, $2: 26$. Gelded when I3 years old. Died about 1904. Pedigree from F. E. Freeman, Phoneton, O., breeder of Ginger.

Sire of Ginger, $2: 131 / 4$.

DEFOE HORSE. The American Cultivator, Boston, Mass., says :

"St. Jacob $(2: 29 \mathrm{I} / 4)$, appears in the list of new $2: 30$ performers of I887, and is credited by several authorities to Hiram Drew. Mr. J. B. Burbank, states that St. Jacob was bred by Louis Twombly of Danville, P. Q., and got by the Defoe Horse, which was by the Pinard Horse, and from a common mare. The Pinard Horse was by the Shaw Horse from a common mare. The Shaw Horse was a good animal, got by imported Roseberry, a Cleveland Bay. The dam of the Shaw Horse was brought North from Kentucky during the war by a Southerner named Scales. She had the appearance of being a well-bred mare of running stock. The dam of St. Jacob was a small sorrel mare that came from below Quebec. She was a very inferior animal and a poor traveler 'When five years old,' says Mr. E. T. Tinker, 'St. Tacob was sold to a Mr. Snow of Richmond, Canada, who developed his speed and campaigned him through Canada, northern New York and northern Vermont. 
He was a good campaigner, and if I remember correctly, won thirty out of thirty-four races in which he started, and always got a piece of the purse. Snow sold him two years ago this spring; reported price $\$ 2700$. He was about fifteen hands and would weigh about Iooo pounds.'"

DE JARNETTE (I-64), 2 : I 7, bay, black points, I 6 hands, I I 75 pounds ; foaled 1883 ; bred by Joshua Barton, Millersburg, Ky., and W. H. Wilson, Cynthiana, Ky.; got by Indianapolis, son of Tattler : dam Belle, said to be by Litton's Warfield, son of Lewis' Warfield; and $2 \mathrm{~d}$ dam by Skinner's Joe. Sold to W. H. Wilson, Cynthiana, Ky.; to L. W. Green, Indianola, Ill. Died I899. Pedigree from L. Green, Jr., Maple Grove Stock Farm.

Sire of 2 trotters $(2: 281 / 2), 2$ pacers $\left(2: 13 \frac{1}{2}\right) ; 3$ dams of $I$ trotter, 5 pacers.

DE LANCEY (3-128), bay; foaled about I888; bred by J. H. Engleman, Danville, Ky. ; got by Director, son of Dictator : dam Nell, chestnut, bred by Harvey Helm, Stanford, Ky, got by Balsora, son of Alexander's Abdallah; 2 d dam Noonday, gray, foaled $187 \mathrm{I}$, bred by A. J. Alexander, Spring Station, Ky., got by St. Elmo, son of Alexander's Abdallah; 3d dam Midnight, gray, bred by R. A. Alexander, Spring Station, Ky., got by Pilot Jr. ; $4^{\text {th }}$ dam Twilight, bay, foaled 1858 , bred by R. A. Alexander, got by Lexington; and 5 th dam Daylight, chestnut, foaled I 850 , by imported Glencoe-Darkness by Wagner-Sir Richard -Ogle's Oscar-imported Knowsley-imported Diomed. Pedigree 3d dam from A. J. Alexander's catalogue.

Sire of Satin Slippers, $2: 13$, I pacer $2: 09$

DELBECK, chestnut, stripe in face, three white feet, $15^{\mathrm{I} / 2}$ hands, II 50 pounds; foaled I 889 ; bred by R. P. Pepper, Frankfort, Ky.; got by Onward, son of George Wilkes : dam Dream, bay, bred by R. P. Pepper, got by Administrator; 2d dam Taglioni, bay, bred by Henry George, Woodford County, Ky., got by Alexander's Abdallah; 3d dam Mary, said to be by Monmouth Eclipse, son of American Eclipse ; and $4^{\text {th }}$ dam, Bertrand Mare. Sold to Thomas H. and W. H. Ruth, De Smet, S. Dak., who send pedigree.

Sire of Minnah Dell, $2: 24 \frac{1}{2}$.

DELBERT (I-64), $2: 2 \mathrm{I}$, bay, I $53 / 4$ hands, II 75 pounds; foaled I $89 \mathrm{I}$; bred by C. E. Pickering, West Liberty, Ia.; got by Gameleon, son of Gambetta Wilkes : dam Altama, bay, bred by Frank Warfield, Muscatine, Ia., got by Attorney, son of Harold; 2 d dam Anna Dickinson, brown bred by B. Hershey, Muscatine, Ia., got by Hershey's Royal George, son of Royal George, by Black Warrior; 3d dam Dolly, bay, bred by B. Hershey, got by Iowa, son of imported Glencoe ; 4 th dam Dolly Aldrich, the trotting mare brought from Akron, $\mathrm{O}$. Pedigree from breeder.

DELBERT A. Untraced but probably by Delbert, son of Gameleon.

Sire of Little Diamond, $2: 22$. 
DELECTUS (I-I6) 2 :I $81 / 2$, black, right hind pastern white; fcaled I 887 ; bred by B. J. Treacy, Lexington, Ky. ; got by Dictator, son of Hambletonian: dam Pattie Patchen, dam of Bermuda, which see. Pedigree from catalogue of breeder.

Sire of 3 trotters $\left(2: 22^{1 / 4}\right)$.

DELEGATE ( $1-32$ ), $2: 19 \frac{1}{4}$, dark brown, black legs, three white ankles, $153 / 4$ hands, I 200 pounds; foaled $\mathrm{I} 884$; bred by V. C. Cromwell, Lexington, Ky. ; got by Dictator, son of Hambletonian: dam Fanny H., bay, bred by J. A. Hugely, Burgin, Ky., got by Red Wilkes, son of George Wilkes; 2d dam old Forrest, bred by Samuel Hughes, Kino, Ky., got by Hughes' Edwin Forrest, son of Alexander's Edwin Forrest; 3d dam by Gray Eagle, son of Woodpecker. Sold to H. and W. K. Brown, Piqua, O. Pedigree from J. T. Hugely and T. C. Brown.

Sire of Bud McCockle, $2: 22 \frac{1}{4} ; 4$ pacers ( $\left.2: 14 \frac{3}{4}\right)$.

DE LEON (3-64), brown, small star; foaled 1885 ; bred by R. P. Pepper, Frankfort, Ky. ; got by Pretender, son of Dictator : dam Dagmar, bay, bred by R. P. Pepper, got by King Rene, son of Belmont; 2d dam bay, bred by R. P. Pepper, got by Mambrino Champion ; 3d dam brown, bred by O. H. Taylor, got by Donophan (dam by Pilot), son of Davy Crockett. Sold to A. R. Hall, Carbondale, Ill. ; to J. C. Curryer and C. H. Piper, Garden City, Minn. Kilied by lightning, I 898 . Pedigree from J. C. Curryer, St. Paul, Minn.

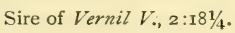

DELEVAN (3-32), $2: 25 \mathrm{I} / 2$, gray, $153 / 4$ hands, I Ioo pounds; foaled r 887 ; bred by Walter Clark, Battle Creek, Mich. ; got by Pilot Medium, son of Happy Medium: dam Belle Paddock, bay, bred by E. J. Paddock, Girard, Mich., got by Magna Charta, son of Morgan Eagle; 2 d dam bay, said to be by Hollenbeck Horse, son of Magna Charta. Sold to Alexander Davidson, Williamsport, Penn. Pedigree from breeder.

Sire of Peerless, $2: 251 / 4$.

DELEWARE MINGO, dark brown, I 6 hands; foaled about I84o. Owned by Springer McDaniels, New Castle County, Del., said to be by a running horse that was brought from Kentucky to Philadelphia, Penn. : dam unknown. Kept at Stanton, Del., and Blue Ball Tavern, Brandywine, Del. Information from John S. Pettitemanger, Claymont, Del., and A. G. Forward.

Sire of Flora, dam of Brandy Boy, $2: 201 / 4$.

DELGARDO (I-I 28 ), bay; foaled I 886 ; bred by Richard West, Lexington, Ky.; got by Egbert, son of Hambletonian: dam Illinois, bay, bred by George W. Burch, Georgetown, Ky., got by Contractor, son of Ajax; 2d dam said to be by Mambrino Champion, son of Mambrino Chief; 
and $3 \mathrm{~d}$ dam by Black Prince, son of Ticonderoga. Sold to Powell Bros., Springboro, Penn., who send pedigree.

Sire of Rob Roy, $2: 30$.

DELGARDO (AUSTRAL) (I-64), bay, with white heels behind, I5 I/2 hands, I050 pounds; foaled r894; bred by Hermitage Stud, Nashville, Tenn.; got by Bow Bells, son of Electioneer : dam Rosie Morn, brown, bred by John S. Clark, New Brunswick, N. J., got by Alcantara, son of George Wilkes; 2d dam Noontide, gray, bred by R. A. Alexander, Spring Station, Ky., got by Harold, son of Hambletonian ; 3d dam Midnight, 3 d dam of De Lancey, which see. Sold to Bowerman Bros., Lexington, Ky. ; to O. T. Mackey, New York, N. Y. Pedigree from Bowerman Bros.

Sire of Asquith, $2: 261 / 4$.

DELINEATOR (7-128), 2 :18, bay, I5 1/2 hands, I050 pounds; foaled I 882 ; bred by R. West, Lexington, Ky. ; got by Dictator, son of Hambletonian: dam Missie, brown, bred by G. C. Logan, Fayette County, Ky., got by Shelby Chief, son of Alexander's Abdallah; 2 d dam said to be by Pilot Jr., son of Pilot; and 3 d dam thoroughbred. Owned by J. N. Dickerson, Indianapolis, Ind., who sends pedigree, and writes that the horse then in four-year-old form could trot a quarter in 30 seconds.

Sire of 3 trotters $\left(2: 2 I^{1 / 4}\right), 12$ pacers $\left(2: 09 \frac{1}{4}\right) ; 2$ sires of 2 trotters; 3 dams of I trotter 2 pacers.

DELMAR, $2: 163 / 4$, bay, four white feet, I5 hands; foaled I 887 ; bred by Leland Stanford, Menlo Park, Cal.; got by Electioneer: dam Sontag Dixie, chestnut, bred by Charles Stanford, Schenectady, N. Y., got by

- Toronto Sontag, son of Toronto Chief; 2 d dam Dixie, said to be by Billy Townes, son of Billy Townes. Sold to R. S. Strader, Lexington, Ky.; to John Madden, Lexington, Ky. ; to William E. Spier, Glens Falls, N. Y. Pedigree from catalogue of breeder. See Boydell.

Sire of Io trotters $\left(2: 05 \frac{1}{2}\right) ; 2$ pacers $\left(2: 19 \frac{1}{4}\right)$.

DELMARCH, 2 : II I $/ 2$, bay, I51/2 hands, ro5o pounds; foaled 1884 ; bred by M. L. Hare, Indianapolis, Ind.; got by Hambrino, son of Edward Everett, by Hambletonian: dam Ella G., bay, bred by T. J. Montague, Lexington, Ky., got by George Wilkes, son of Hambletonian ; $2 \mathrm{~d}$ dam Widow Rantoul, chestnut, bred by T. J. Montague, got by Ulverston, son of Lexington; 3 d dam Bridget, said to be by Paddy Burns, son of Gray Eagle ; and $4^{\text {th }}$ dam Peggy, by Boston. Sold I 889 to George W. Ingraham, Dixon, Ill. ; I 893 to J. M. Daly, Mt. Kisco, N. Y. ; to Abner S. Deysher, Reading, Penn. Pedigree from breeder.

Sire of 25 trotters $\left(2: I_{4} \frac{3}{4}\right)$, I9 pacers $\left(2: 05 \frac{1}{4}\right) ; 2$ sires of I trotter, I pacer; I dam of I pacer.

DELMONICO, bay; foaled I86I ; said to be bred by George N. Remer, and 
got by Guy Miller, son of Hambletonian : dam Harvey Adams mare, by Hambletonian; and $2 \mathrm{~d}$ dam by imported Bellfounder. Sold $\mathrm{r} 868$ to D. Swigert, Bowling Green, Ky.; 1870 to Thomas C. Calvert, Bowling Green, Ky. Died in the fall of $\mathbf{1} 872$, the property of Miles Kelly. This pedigree is that usually published of this horse, but all of it unless the sire very doubtful.

Sire of Darby, $2: 16 \frac{1}{2}:$ I sire of 2 trotters, 4 dams of 4 trotters.

DELMONICO SPRAGUE (3-128), brown, star, white hind ankles, I6 hands, I 200 pounds ; foaled I88I ; bred by Logan Railey, Versailles, Ky.; got by Governor Sprague, son of Rhode Island: dam Ketura, sorrel, bred by Logan Railey, got by Delmonico, son of Guy Miller ; $2 \mathrm{~d}$ dam said to be by Tom Crowder; 3 d dam by Gray Diomed; and $4^{\text {th }}$ dam by Paddy Burns. Sold to Nathan Case, Hoosick Falls, N. Y.; to H. R. Murray, New York City. Pedigree from William H. Ely, Hoosick Falls, N. Y.

Sire of 2 trotters $(2: 181 / 4)$.

DELMONT (I-I6), $2: 30$, bay, three white feet, I6 I/4 hands, II 70 pounds ; foaled r 884 ; bred by John Hall, Creston, Ia. ; got by Howe's McGregor, son of Panic, by Royal George: dam bay, bred by John Hall, got by Young Defiance, said to be an inbred Sherman Morgan; 2d dam brown, bred by William Hall, got by Spencer's Black Hawk, son of Granite State Black Hawk; 3d dam brown, bred by William Hall, got by Nelson Horse ; $4^{\text {th }}$ dam black, bred by William Hall, got by a horse called Sir Henry and Thunderbolt. Pedigree from breeder.

DELMONT, $2: 12 \mathrm{~T} / 4$, bay, one white hind foot, $153 \frac{3}{4}$ hands, $\mathrm{I}$ I 75 pounds; foaled ז89г ; bred by Howard Johnson, Dixon, Ill. ; got by Delmarch, son of Hambrino: dam Daisy, bay, bred by Mark M. Johnson, Dixon, Ill., got by Royal Chief, son of Niagara Chief ; 2 d dam Kitty, said to be thoroughbred; 3 d dam Miss Colby. Pedigree from breeder.

Sire of Dell S., $2: I_{1} \frac{1}{2} ; 2$ pacers $\left(2: I^{1} 1 / 4\right)$.

DELMONT CHIEF (I-32), 2 :I5, chestnut; foaled I 889 ; bred by John Perry, Oxford, Mich.; got by Detractor, son of Gossip : dam Molly D., said to be by Goldenbow, son of Satellite ; 2 d dam Lady Norman, by Sleepy John; 3d dam Flora, by Hough Horse ; and 4th dam Fanny, by Oakland Black Hawk. Sold to Ira A. Case, Carsonville, Mich.

Sire of Kate $M_{.,} 2: 24 \frac{1}{4}$.

DELMONTE (I-I6), $2: 2 \mathrm{I} 1 / 2$, brown, I5 I/2 hands, 950 pounds; foaled I88o; bred by H. M. Sollace, Bridport, Vt. ; got by Firefly, son of Daniel Lambert : dam brown, bought by Mr. Sollace of George F. Davis, Windsor, Vt., who writes that he purchased her of O. J. Greer of Brooklyn, N. Y., who called her a Hambletonian. Gelded young. 
DEL NORTE (r-64), 2 :o\$, black; foaled I 888 ; bred by Jay Beach, Vancouver, Wash.; got by Altamont, son of Almont: dam Tecora, brown, bred by W. T. Whithers, Lexington, Ky., got by Strader's Cassius M. Clay Jr.; 2 d dam said to be by Brignoli, son of Mambrino Chief; $3 \mathrm{~d}$ dam Ware Mare, by Canada Chief, son of Dary Crockett; and 4 th dam by Karanaugh. Sold to Frank M. Barrows; Walla Walla, Wash. Pedigree from Thomas H. Brents, breeder of Helen Norte.

Sire of Helen Norte, $2: 261 / 4 ; 5$ pacers $(2: 161 / 2)$.

DELONG W: (BILLI WILKES) ( I-32), bay with star, hind feet white, I6 hands, I 200 pounds; foaled I $88_{5}$; bred by Willard A. Miller, Girard, Mich.; got by Hambletonian Wilkes, son of George Wilkes: dam Nellie T., (dam of Thacher's Hambletonian), bred by Willard A. Miller, got by Black Hawk Morgan (Holmes Horse); $2 \mathrm{~d}$ dam said to be by a son of Bush Messenger. Sold to Mrs. M. E. Millard, Girard, Mich.; to C. J. Merrifield, Tekonsha, Mich.; to J. D. Bonine, Vandalia, Mich.; to Harmon Delong, Penn, Mich., who sends pedigree.

Sire of Midget Wilkes, $2: 23 \frac{1}{2}$.

DELPHI (3-I28), 2 :I21/4, black, said to be by Director, son of Dictator : dam Etta, by Dexter Prince, son of Kentucky Prince: and $2 \mathrm{~d}$ dam by Priam, son of Guy Miller.

Sire of Toppy, 2:10.

DEL REI (I-64), $2: 29$, chestnut, I $53 / 4$ hands, I Ioo pounds; foaled I 886 ; bred by Silas Skinner, Napa, Cal.; got by Clay Duke, $2: 29$, son of Alcona: dam Madonna, bay, bred by Gen. Withers, Fairlawn, Ky., got by Cassius M. Clay Jr., son of C. M. Clay; 2 d dam Kate Downing, said to be by Joe Downing, son of Edwin Forrest (Alexander's). Sold to J. W. Martin, Woodville, Tulare City, Cal., who sends pedigree.

DEL SHORT, bay; foaled r 893 ; bred by S. A. Browne \& Co., Kalamazoo, Mich.; got by Delmarch, son of Hambrino: dam Embassy, bay, foaled IS85, bred by J. E. Williams, Upper Sandusky, O., got by Ambassador, son of George Wilkes; $2 \mathrm{~d}$ dam Jenny, said to be by Fillingham Jr.; and $3 \mathrm{~d}$ dam Flo, by a son of Bush Messenger. Pedigree from catalogue of breeder.

Sire of Sunshine, $2: 15^{1 / 4}$.

DEL SLR (I-I6), $2: 24^{I} / 2$, black, star, white hind feet, $153 / 4$ hands; foaled I $\$ 76$; bred by L. J. Rose, Los Angeles, Cal.; got by The Moor, son of Clay Pilot: dam Gretchen, black, foaled I866, bred by Morgan Tance, Lexington, Ky., got by Relf's Mambrino Pilot, son of Mambrino Chief; 2 d dam Kitty Kirkman, pacer, black, foaled I853, bred by John Kirkman, Nashville, Tenn., got by Fanning's Canada Chief; 3d 
dam said to be by Fanning's Tobe; and 4th dam by imported Leviathan. Owned in Kentucky by D. Swigert. Information from L. J. Rose, Jr., Los Angeles, Cal.

Sire of 4 trotters $\left(2: \mathbb{1}_{4} \frac{1 / 2}{2}\right) ; 4$ pacers $\left(2: \mathrm{I}^{3} / 4\right) ;$ II dams of II trotters, 3 pacers.

DELTA (1-32), $2: 121 / 4$, bay; foaled 1890 ; bred by Daniel Alderman, Middlefield, Mass.; got by Palatka, son of Nutwood: dam Hattie, bay, foaled I $8 S_{3}$, bred by George I. Seney, Barnardsville, N. J., got by Heptagon, son of Harold; 2d dam Lady Gavin, said to be by Seeley's American Star. Sold I 892 to H. W. Phelps, Minneapolis, Minn. Pedigree from W. P. Alderman, Chicopee, Mass., who writes: "I bought Hattie for my brother, of A. F. Wildes, Chicopee Falls, Mass. He bought her at one of Kellogg's sales and her breeding was given as above in catalogue of breeder."

Sire of 2 pacers $(2: 20)$.

DEMOCRAT, roan; foaled 1856 ; bred by Benjamin Prince, Brooklyn, N. Y.; got by Columbus, son of Napoleon : dam Lady Ann, bay, bred by Mr. Martense, Flatbush, L. I., got by Abdallah, son of Mambrino; 2d dam Angeline, bay, said to be by American Eclipse; and $3 \mathrm{~d}$ dam by Financier. Sold 1869 to $\mathrm{Wm}$. Green, Glen Cove, L. I.

Sire of Fred, 2:30.

DEMOGORLS, said to be by Augustus, son of Claudius, by imported Janus. Advertised in the "Raleigh Register," I803.

DEMIONIO (I-64), 2 :II I/4, bay; foaled I895; bred by Oakwood Stock Farm, Danville, Cal.; got by Charles Derby, son of Steinmay: dam Bertha, said to be by Alcantara, son of George Wilkes; and 2d dam Bercena, by Bayard, son of Pilot Jr.

Sire of 4 pacers $\left(2: \mathrm{II}^{1} / 2\right)$

DENIS RYAN (r-64), $2: 29$, brown; foaled 1880 ; bred by E. M. Skaggs, Sacramento, Cal.; got by Berlin, son of Blackbird: dam Lady Washington (dam of Ewing, $2: 2 \mathrm{I} / 4$ ), bay, bred in California and said to be by American Boy Jr. Sold to S. C. Ewing, Salt Lake City, Utah.

DENMARK, bay; foaled I 839 ; bred by Samuel Davenport, Kentuckr : got by imported Hedgeford: dam Betsey Harrison, bay, foaled I 828 , said to be by Aratus, son of Director, by Sir Archy; 2d dam Jenny Cockracy, by Potomac; 3d dam by imported Saltram; th dam by imported Wildair ; and 5 th dam by imported Driver. This is a very famous four-. mile race horse, from which the great saddle family of Denmarks in Kentucky, is descended in male line. It will be seen that his pedigree is in the best lines, including Delancer's famous Wildair. Adrertised, 
I 849 , to be kept at the Kentucky Association Race Course, by Beard \& Bradley.

DENMARK. Untraced.

Sire of Tom Dallas, $2: 161 / 4$.

DENMARK (BANTA'S) (3-I28), brown, hind feet white, I6 $1 / 4$ hands; foaled 1877 ; bred by Will Banta, New Castle, Ky.; got by Sumpter Denmark, son of Gaines' Denmark : dam untraced. Sold to P. T. Berry, New Castle, Ky.

DENMARK (COLLINS'), said to be by Price's Denmark.

Sire of Edgar A., 2:231/4; I sire of I pacer; I dam of I trotter.

DENMARK (GAINES', BLACK) ( $1-32)$, black, hind feet white, small star; foaled I $85 \mathrm{I}$; bred by Wm. V. Cromwell, near Lexington Ky.; got by Denmark, son of imported Hedgeford: dam, the Stephenson Mare, brown, owned by Judge John Stephenson, Fayette County ; farmed I 850 to W. V. Cromwell, said to be hy Cockspur that went to Kentucky from Missouri, son of Cockspur a Canadian pacer, imported from Canada to Missouri; and $2 \mathrm{~d}$ dam, by Dick Singleton, thoroughbred, son of Bertrand, by Sir Archy. Sold I $\delta 54$ to E. P. Gaines, Scott County, Ky., for $\$ 1$,ooo. Died from an accident I 864 .

The National Saddle Horse Register, Vol. I., says: "It was not the old race-horse himself, but his sons which were originators of the saddlefamily. But three of the sons of Denmark, viz. : Graines' Denmark, Rob Roy and Muir's Denmark, are known to have been sires of saddle-gaited colts, and of these, the former stands at the head as a great progenitor. The entries to this volume show that nine-tenths, or more, of the present race of Denmarks trace to Gaines' Denmark.

"It may be further said that the Denmarks show the fine style and finish of their thoroughbred ancestry. They are universally intelligent and add to a graceful movement at all the gaits under saddle, a way of going in harness that peculiarly fits them for a place in the all purpose class. They are also intelligent, tractable, hardy and generally useful where a safe family horse is wanted.

"The best results have come from mating the Denmark sires with mares from certain strains of Canadians or other pacing blood."

A correspondent in Wallace's Monthly says :

"During the war, his owner (Major Henry Nichols) fearing lest he should be stolen, ran him into Alexander's place, where he remained for some time and passed as the property of R. A. Alexander, who being a British subject, held his stock in safety. In this way the horse acquired the name Alexander's Denmark. He fell into a well and killed himself.

"As the stable companion of Mambrino Chief he made many seasons in Kentucky, and his produce is scattered throughout that State.

"By far the most celebrated of his get, however, were the four stallions Sumpter Denmark (the Goddard horse), in southern Kentucky, Star 
Denmark and Washington Denmark, in central Kentucky, and Denmark Chief, in the northern counties."

DENMARK, said to be by Denmark. Isaac S. Cook, Chillicothe, O., writes :

"Mr. Brown raised three colts from Balley (she by Whitehall), by Denmark, viz., Winder, Clara B. and a black colt sold by Mr. Brown when two years old, and as I think went to Indiana. Mr. Brown raised several other colts from Balley. I do not know who owned Denmark when he was here, as I was then away from home. Denmark was from Kentucky, stood in this county two years and was taken back to Kentucky."

Sire of Winder, $2: 21$.

DENMARK CHIEF (3-64), dark brown, black points, $15 \frac{1}{2}$ hands ; foaled I 866 ; bred by A. M. Hume; got by Gaines' Denmark, son of Denmark: dam Brown Kitty, said to be by Veech's Highlander (dam by Copperbottom) son of Downing's Black Highlander, by Steele's Crusader, son of Blackburn's Whip, by imported Whip ; 2d dam a Kentucky saddle mare, said to be part bred. Owned by Nicholas Longworth, Cincinnati, O. He was famous as a saddle horse and fast roadster; became blind, and also had stringhalt. He took many premiums and among them, a very high one offered at St. Louis, Mo., Fair, I 874 for the best horse for all uses.

DENMARK JR., said to be a son of Gaines' Denmark.

Sire of A. K. Davis, $2: 2 \mathrm{I} 1 / 2$.

DENMARK JR., bay; foaled I8-; said to be by Denmark.

Sire of Kenton Belle, $2: 30$.

DENNING ALLEN (3-16), bay, star and four white feet, $151 / 2$ hands, I 35 pounds; foaled 1874 ; bred by Major Luxton, New York, N. Y., then of Lexington, Ky. ; foaled the property of J. B. Bowman, Lexington, Ky.; got by Honest Allen, son of Ethan Allen: dam Rena, black or brown, with four white feet, foaled $\mathbf{1} 866$, said to be by Ward's Flying Cloud, son of Black Hawk, by Sherman Morgan. Sold 1878 to Gen. D. P. Upham, Little Rock, Ark., and in $\mathrm{r} 882$, by his Administrator to E. S. Rice, Little Rock, who, in April I893, sold to Joseph Battell, Middlebury, Vt., whose property he died, 1898 .

An article on Lord Clinton as a Trotter, in New York Sun, 1893 says :

DENNING ALLEN, SIRE OF LORD CLINTON, RACE RECORD, $2: 101 / 4$.

[LATER $2: 083 / 4$ ]

"Denning Allen arrived at Middlebury on the $\mathrm{I} 3^{\text {th }}$ inst., and was immediately taken to his new home at the Bread Loaf Farm, two miles down the river from the village. Although he had been a full week on the cars, he came in full of life and play, looking like a young race-horse. Since his arrival he has been visited by many of the local horsemen, and 
by several from other towns within and without the State. It is too little to say that he has been the center of admiration from all comers. No one expected to find such an example of the highest equine beauty, combined harmoniously with the noblest exhibition of strength and substance. Old admirers of Ethan Allen see in Denning Allen a faithful copy of his handsome grandsire, with increased size, more substantial limbs, darker bay color, and less abundant mane and tail. In carriage, contour, marks and disposition, he is a very close counterpart of Ethan Allen, the 'Eagle of our hills.'

"Denning Allen is a very dark bay horse, with two white hind ankles, one fore foot white and a touch of white on the other, with small star and snip; he stands full $151 / 2$ hands and weighs 1050 pounds. $\mathrm{He}$ was foaled in 1874 ; bred by I. B. Bowman of Lexington, Ky., and got by Honest Allen, son of Ethan Allen. His dam was Rena, by Ward's Flying Cloud, son of Black Hawk, by Sherman Morgan. The dam of Honest Allen, is registered in the American Trotting Register as by the Brooks Horse, son of Sherman Morgan. The dam of Ward's Flying Cloud was by the Hackett Horse, son of Gifford Morgan and sire of Flying Morgan. Thus, without considering remoter crosses, it appears that Denning Allen is among the strongest inbred Morgans living. It was because of this intense Morgan breeding, matched with his noble individuality and his success as a sire, that induced Mr. Battell to purchase him in Little Rock, Ark., and send him back to the home of his ancestors to lay anew the foundation of a future race of Morgans, with all the beauty, pride and intelligence of those of the olden time, but with increased size, and the power to attain the highest trotting speed.

"Denning Allen has been kept in a region of no trotting bred animals, and has done little service in the stud, being used largely as a driving horse. He got the famous black gelding, Lord Clinton, from a small brown mare. Lord Clinton, at the end of last season, had a list of $\mathbf{2} \mathbf{I}$ trotting victories to his credit, 60 heats in $2: 30$ and better, and a race record of $2: 10 \mathrm{I} / 4$ in the second heat of a race which he won; a race record never equalled by a stallion and never beaten by a gelding. To show the quality that he displayed in his races we will copy the summaries of two, adding the records as they stand of the defeated horses :

“Independence, IA., Sept. I, I892. Purse \$iooo; $2: 17$ Class.

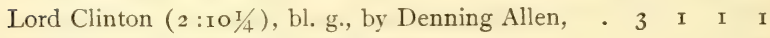
Lobasco $(2: 103 / 4)$, b. h., by Egmont, . . . . I $32_{2}$ Little Albert ( $2: 10 \mathrm{I} / 4$ ), ch., g., by Albert W., . . . $\begin{array}{lllll}5 & 4 & 5 & 4\end{array}$ Canary Bird (2:191/2), ro. m., by Jay Bird, . . $\begin{array}{lllll}4 & 5 & 4 & \mathrm{dr}\end{array}$ Time, $2:$ II I $/ 2,2: 101 / 4,2: 11,2: 133 / 4$.

“Indianapolis, Sept. 23, I892. Purse \$iooo; $2: 15$ Class. Lord Clinton ( $2: 101 / 4)$, bl. g., by Denning Allen, . . . . . . . . . . . 2 I $4 \begin{array}{lllll} & 2 & \text { I } & 4 & \text { I }\end{array}$ Azote $\left(2: 14 \frac{1}{2}\right)$, b. g., by Whips, •. . . $4 \begin{array}{ccccccc}4 & 4 & \text { I } & 3 & 2 & \text { I } & 2\end{array}$ Magnolia (2:1 2I/2), b. m., by Haw Patch, I $\quad 2 \quad 2 \quad \begin{array}{llllll}4 & 4 & 2 & 4\end{array}$ Cheyenne (2:14 I/4), b. h., by Nutbourne, $\begin{array}{lllllll}3 & 3 & 3 & \text { I } & 3 & 3 & 3\end{array}$ Grattan (2:171/2), br. h., by Wilkes Boy, dis. - - - - -

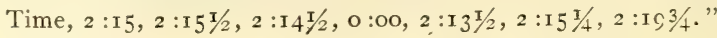


Mr. Ernest L. Featherston writes, Lexington, Ky., dated Jan. 16, 1906 :

Mr. Joseph Battell, Washington, D. C.

My Dear Sir :-Yours of Jan. 2 nd., received and was glad to learn you had at last gotten the correct pedigree of Revenue Jr., sire of dam of Gen. Gates. In regard to your inquiry of Major Luxton, his name was Major E. D. Luxton, and while here in Kentucky was connected with the Kentucky University, of which college John B. Bowman was Regent. You in your catalogue give the horse Denning Allen as having been bred by Major Luxton and passed to J. B. Bowman. Now my investigation leads me to believe, he was bred by J. B. Bowman. Two old horsemen whom I have talked with remember Bowman having a brown mare, white feet and white face, a very handsome and fancy mare he having gotten her from Mr. John Hudson, who formerly lived here, but so far as I can now learn no one knows what became of him. The two horsemen referred to above are Mr. James Crystal of Walnut Hall Farm, Donerail, Ky., and Mr. John C. Curd of Lexington, Ky., whom I introduced you to when you were here last spring. I have been trying to see Col. William L. Simmons of this place to find out if he still has the stud books of Honest Allen, if he has that would settle the question of the breeder. Prof. J. H. Neville of Kentucky State College to whom I am indebted for the initials of Major Luxton, says that the Major was practicing law in New York City in 1879 and that he afterwards moved to New Mexico, but to what part, or whether he is now living or dead, he does not know. From my investigation, I think that the dam of Denning Allen can be said to have been a very handsome brown mare, four white feet and a white face, got by Ward's Flying Cloud; also that no one to whom I have talked ever remembered Major Luxton to have been interested any in horses, though J. B. Bowman was known to have had a great many, and made sales, not only here but in New Orleans as well.

A recent communication from a reader of Clark's Horse Review contains the following reliable information to readers as to the breeding and early training of that well-known free-for-all gelding Lord Clinton $2: 083 / 4$ :

"I notice in the stock papers many stories as to the early life of Lord Clinton, $2: 10 \mathrm{I} / 4$, all of which are wrong at some point. He was bred by J. Biscoe of Little Rock, Ark., got by Denning Allen (who took first premium at the World's Fair in the Morgan horse ring) : dam Fannie, a fast road mare, of compact, muscular form and very gay. He was sold to James Keates as a saddle-horse, and was used as such, but never ran a quarter race in his life. He was sent out to pasture in the summer of I 89o, on Lakeside Stock Farm, Little Rock, which is owned by L. C. Balch; his son drove him on track three weeks, and he showed a mile in $2: 35$; he was then raced at several small county fairs, winning all his races. While out on this circuit he was sold for about $\$ \mathrm{I}, 750$, to G. F. Martin of Little Rock, who put him in the hands of Bill Wright to train. In $\mathbf{I} 89 \mathrm{I}$, he was raced by Martin for a short while, but not being on to the ropes, he lost him, since which time every horseman knows of his career and ownership."

SubSCRIBer, Little Rock, Ark. 
LENVER WILKES ( $1-32$ ), $2: 08 \frac{1}{4}$; foaled $187-;$ said to be by George Wilkes : dam Ella Robinson, by Ericsson; 2 d dam Luna, by Swigert's Lexington; and $3 \mathrm{~d}$ dam Eagless, by imported Glencoe. Sold to J. Kearney, Lexington, Ky.

Sire of 3 dams of I trotter, 2 pacers.

DEPUTY (I-64), 2 :I $9^{\mathrm{I} / 2} 2$, bay, I $53 / 4$ hands; foaled 1884 ; bred by J. B. Haggin, Sacramento, Cal.; got by Echo, son of Hambletonian : dam Marie Rose, bay, bred by L. J. Rose, Los Angeles, Cal.; got by Inca, son of Woodford Mambrino; 2 d dam Cecelia Clark, said to be by Clark Chief, son of Mambrino Chief; 3d dam thoroughbred mare, by Capt. Beard. Sold to Marcus Daly, Anaconda, Mont.; to J. W. Daly, Mt. Kisco, N. Y., Oct. 5, I892. Pedigree from John Mackey, Supt.

Sire of 3 trotters $\left(2: I_{3} \frac{1}{4}\right)$.

DERACHO (3-128), brown, I5 hands, 950 pounds; foaled I 895 ; bred by J. C. Newton, South Pasadena, Cal.; got by Direct, son of Director: dam brown, bred by J. C. Newton, got by McKinney, son of Alcyone ; 2d dam bay, bred by I.. Titus, San Gabriel, Cal., got by Echo, son of Hambletonian; 3d dam chestnut, bred by Mr. Haggin, Rancho Del Paso, Cal., got by imported Joseph, son of Hernum; 4th dam said to be by Williamson's Belmont. Pedigree from J. H. Vance breeder of Jessica, $2: 233 / 4$.

Sire of 2 trotters $\left(2: 12^{1 / 4}\right)$.

DERBY ASH (I-64), bay; foaled I89I ; bred by estate of Seth Cook, Danville, Cal.; got by Charles Derby, son of Steinway: dam Addie Ash (dam of Cibolo $2: 13^{1 / 2}$ ), foaled I884. Sold to John F. Boyd, Danville, Cal.

Sire of Deputy, $2: 13 \frac{1}{2}$.

DERMOT MIUSCOVITE (I-64), $2: 26$, bay, I 6 hands, II5o pounds; foaled IS94 ; bred by Fred Seacord, Galesburg, Ill. ; got by Muscovite, son of Nutwood: dam Browny Allerton, brown, foaled r89r, bred by George L. Weeks, Independence, Ia., got by Allerton, son of Jay Bird; 2 d dam Mattie Russell, chestnut, foaled 1884 , bred by R. G. Stoner, Paris, Ky., got by Mambrino Russell, son of Woodford Mambrino ; $3 \mathrm{~d}$ dam Bessie, said to be by Strathmore, son of Hambletonian; and $4^{\text {th }}$ dam Daisy, by Albion. Sold to McConchie Bros., Oneida, Ill. Pedigree from David McConchie, Oneida, Ill.

Sire of Don Muscovite, $2: 16 \%$, Harry $D ., 2: 081 / 4$.

DESERTER (3-256), chestnut; foaled I 888 ; bred by Huntley \& Clark, Toston, Mont.; got by Kentucky Volunteer, son of Volunteer: dam Ethel West, black, foaled I883, bred by Huntley \& Clark, got by Abdallah West, son of Allie West ; 2 d dam Ethel, bay, foaled I879, said to be bred by Alexander Coons, Fayette County, Ky., got by Contractor, 
son of Ajax; 3d dam by American Clay, son of Cassius M. Clay Jr.; and $4^{\text {th }}$ dam by Gano.

Sire of Fosephine D., $2: 16 \frac{1}{2}$.

DE SOTO (3-I28), bay, one white hind foot, I $5 \frac{1}{2}$ hands, I roo pounds; foaled r $88 \mathrm{r}$; bred by A. J. Alexander, Spring Station, Ky.; got by Harold, son of Hambletonian : dam Sonnet, bay, bred by W. C. Goodloe, Lexington, Ky., got by Bourbon Chief, son of Mambrino Chief; $2 \mathrm{~d}$ dam Little Ida, bay, bred by W. C. Goodloe, got by Edwin Forrest, son of Young Bay Kentucky Hunter; 3d dam Ida May, said to be by Red Jacket, son of Comet; 4th dam Amra, by Kinkead's St. Lawrence ; and $5^{\text {th }}$ dam a Trustee mare. Sold to F. Messenger, Hillsdale, Mich. Pedigree from catalogue of breeder also from F. Messenger.

Sire of 5 trotters $\left(2: 16 \frac{1}{4}\right), 7$ pacers $\left(2: 14^{3 / 4}\right) ;$ I sire of I pacer.

DESPOT (I-32), $2: 29$, blue roan; foaled 1878 ; bred by A. F. Woods, Washington, Ky.; got by Dictator, son of Hambletonian: dam Spray, roan, said to be by Munson. son of George M. Patchen; and $2 \mathrm{~d}$ dam Longbody, a superior road-mare. Sold to W. W. Baldwin, Maysville, Ky.; to E. B. Bulkley, Antwerp, N. Y. Died I889. Pedigree from breeder who writes: "My father bought Spray of Dr. Carter of Philadelphia, who said she was bred in New Jersey. She had thirteen foals, all able to trot in three minutes, or better."

Sire of Edward B., $2: 20$.

DETECTIVE (I-256), bay; foaled I88I ; bred by Frank Warfield, Muscatine, Ia. ; got by Attorney, son of Harold: dam Fashion, bay, bred by B. Hershey, Muscatine, Ia., got by Gen. Hatch, son of Strader's Cassius M. Clay Jr. ; 2 d dam Dolly, bay, bred by B. Hershey, got by Iowa, son of imported Glencoe ; $3 \mathrm{~d}$ dam Dolly Aldrich, the trotting mare brought from Akron, O. Sold to H. F. Kidder, Goshen, Ind.; to J. B. Cobb, Goshen, Ind., who sends pedigree.

Sire of Decoy, $2: 19^{1 / 4}$.

DETECTIVE PATCHEN (I-I28), bay; foaled I8-; said to be by Star Patchen, son of George M. Patchen : and dam by St. Lawrence.

Sire of 2 trotters $\left(2: 21^{1} / 4\right)$.

DETRACTOR (3-64), black, I5 I/2 hands, I06 5 pounds; foaled 1877 ; bred by William Burnes, Haw River, N. C. ; got by Gossip, son of Tattler, by Pilot Jr.: dam Evening Rose, said to be by Black Dutchman, son of Doble's Black Bashaw, by Young Bashaw ; 2d dam Rebecca Becket, by Ben Patchen, son of Burlington, by George M. Patchen ; 3d dam May

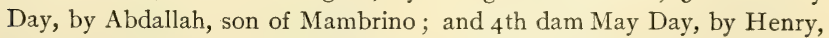
son of Sir Archy, by imported Diomed. Bought spring of $\mathbf{1} 888$, by Martin Halfpenny and W. G. Hinman, Pontiac, Mich. Said to have 
paced a half-mile in I :oo. See The Morgan Horse and Register, Vol. I., p. 792 .

Sire of 6 trotters $\left(2: 24 \frac{1}{4}\right), 4$ pacers $\left(2: 14^{1 / 4}\right) ; 2$ sires of I trotter, J pacer; I dam of I pacer.

DEUCALION, $2: 22$, bay, $153 / 4$ hands; foaled 1867 ; bred by J. E. Haring, Spring Valley, N. Y.; got by Hambletonian: dam Trusty, chestnut, foaled I 860, said to be bred in New Jersey, and got by Marlborough, son of imported Trustee; and $2 \mathrm{~d}$ dam by Henry Duroc, son of Essex, by Henry. Trotted $\mathrm{I}_{874}-\delta_{3}$ and winner of $\mathrm{I}_{3}$ races.

Sire of I6 trotters $\left(2: \mathrm{IO}^{3 / 4}\right)$; Pacing $T i, 2: \mathrm{Ig}^{1 / 2} ; 3$ sires of 6 trotters, 2 pacers; Io dams of 9 trotters, 3 pacers.

DEUXMILLION (3-64), $2: 29$, chestnut, I6* hands, I Ioo pounds; foaled I 885 ; bred by Joseph Bacon, Burlington, Vt. ; got by Deucalion, son of Hambletonian : dam Blanche B., bay, bred by C. B. Holabird, Shelburne, Vt., got by Holabird's Ethan Allen, son of Ethan Allen; 2d dam Breeze, brown, bred in Kentucky and said to be by Brignoli, son of Mambrino Chief; 3d dam Little Betsey, by Wake up Jake, son of Downing's Bay Messenger; and $4^{\text {th }}$ dam Betty, by Tom Jefferson. Sold to D. Lawrence, Winooski, Vt. Pedigree from E. F. Brownell, Burlington, Vt.

Sire of Duex, $2: 221 / 4 ;$ I sire of I pacer.

DEW DROP (I-S), dark bay, both hind feet white to ankles, I6 hands; foaled $\mathrm{I} 88_{2}$; bred by K. D. Nicoll, Simpson County, Ky.; got by Miller's Lexington (dam by Green Mountain Black Hawk, son of Sherman Black Hawk; 2 d dam a Lexington mare), son of Cabell's Lexington (dam by old Cockspur, 2d dam by old Copperbottom), by Gist's Black Hawk (dam by old Copperbottom), son of Blood's Black Hawk: dam said to be by Leet's Davy Crockett (dam by Zingaree, thoroughbred), son of Leet's Drennon (dam an imported mare from France), by Drennon (dam by Shylock Jr., a fine saddle stallion), son of old Davy Crockett ; $2 \mathrm{~d}$ dam by Stewart's Davy Crockett, son of old Davy Crockett ; and $3 \mathrm{~d}$ dam thoroughbred. Sold to Alexander Hill, Owensboro, Ky. Awarded first premium, Illinois State Fair, I887. Above pedigree is taken from advertisement of the horse season I 890 , sent by Mr. Hill.

DEWEY HORSE. See Walloomsack.

DE WITT CLAV (I-64), black; foaled I86r; bred by Henry DeWitt, Quarryville, N. J.; got by Sayre's Harry Clay, son of Neaves' Cassius M. Clay Jr., by Cassius M. Clay : dam said to be thoroughbred. Sold to James McKee, Goshen, N. Y.

Sire of Mary Powell, $2: 22^{3} / 4$.

DE IVITT CLINTON, said to be by Bishop's Hamiltonian. Joseph Bishop, born in Castleton, $\mathrm{Vt}$., $\mathbf{I} 8 \mathrm{o} 8$, in interview said, that his father and Judge H. Hodges, hired of Isaac Bishop of Granville, Vt., for one 
season for \$roo, a horse called De Witt Clinton, by Bishop's Hamiltonian, and kept him at Clarendon, Vt.

DEXTER (3-64), $2: 17 \frac{1}{4}$, brown; foaled I 858 ; bred by Jonathan Hawkins, Walden, Orange County, N. Y.; got by Hambletonian: dam Clara, black, foaled $18_{4} 8$, bred by Jonathan Hawkins, got by Seeley's American Star, son of Coburn's American Star, by Cock of the Rock, son of Sherman Morgan, by Justin Morgan, the original Morgan horse. See Dictator. Gelded young. Wallace says-he beat all the world on the trotting turf, and was sold to Robert Bonner of New York, for $\$ 33$, ooo. Facts concerning Clara, dam of Dexter :

Editor American Horse Breeder:-I have your favor of the $4^{\text {th }}$ inst., and note your question regarding Clara. She was about $151 / 4$ hands high. She was a natural trotter. She was never trained, but the fall of I $86 \mathrm{I}$, when she was carrying Lady Dexter, my brother took her out of pasture and drove her to wagon in $2: 58$. She could show a $2: 40$ gait hitched light. She was a mare of fine nerve and good temper, a free, pleasant driver, and ready for a brush on the road any time.

At the age of 18 months, in trying to jump a fence, she caught her front foot which threw her a complete somersault. This hipped her and left her crooked, one hip was too high and the other too low, but although she went a trifle sidewise it affected her gait very little if any.

I did not breed Clara the spring of 1858 , after Dexter was foaled, thinking I would need her to drive. She sprained one of her hind legs during the spring of 1859 , which resulted in a bone-sparin. Had I left her at breeding this of course would never have happened.

Jonathan Hawniss, Englewood, N. J., Jan. 8, is94.

The Horse Review of Chicago says :

"Jonathan Hawkins of New York, who in conjunction with his father Jonas, bred and owned the famous mare Clara during her entire career, was lately in Chicago, and during the course of a call upon the Review talked very entertainingly concerning her and her family.

Speaking of the McKinstry Mare, her dam, Mr. Hawkins said: "She was a very handsome mare, a brown, about $153 / 4$ hands with four white feet, and weighing say 1050 or I Ioo pounds, of very fine disposition and a great deal of intelligence. She was a trotter-not very fast, for in her day there was no fast trotting-and was not considered anything out of the ordinary. Her breeding was unknown and could never be traced. She produced six foals, of which Clara, by American Star (the best trotting stallion of his day in our locality), was the first, and the fifth Shark, by Hambletonian. He was quite a trotter and took a record of $2: 301 / 4$ in harness and $2: 273 / 4$ under saddle. All her foals were distinguished by their markings. Clara had three white feet; her second foal, by a son of Long Island Black Hawk, was a chestnut with three white feet; the third had a blazed face, white eyes and four white feet; the fourth, by Cassius M. Clay, had a blaze and four white feet; Shark had four white feet, as had her sixth and last foal, by Magnolia, son of American Star while it also had a blazed face and a white spot on the belly.

"Clara was, as I have said, the first foal of her dam, and was bred by my father. She was black, about $15 \mathrm{~T} / 4$ hands and a natural trotter. My brother drove her a mile over the Stony Ford track to skeleton wagon 
in $2: 53$, and although never trained, she could trot almost as fast as Shark. She was very trappy-gaited, but had a bold determined action, and was a whirlwind in a brush-there was nothing in our locality that could speed with her. She was of the most perfect disposition imaginable, very intelligent and had a great deal of resolution. She was foaled in 1848 , and Dexter, her first foal, May $5,1858 . "$

DEXTER (5-32), mahogany bay with stripe in face, hind feet white to hocks and right fore foot white to knee, I6 hands, I 200 pounds; foaled April 8, I872; bred by Jesse Logsdoin, Alto, Columbia County, Wash.; got by Bellfounder, son of Chas. Milliman Horse, by Morse Horse: dam sorrel, bred by John Wren, Corvallis, Benton County, Ore., got by Mulkey's Sumpter, son of imported Sumpter; 2d dam black, bred by Mr. Avery, Corvallis, Ore., got by Welch's Lummox; 3d dam black, said to be Morgan. Sold to Robert Kennedy, Van Delashmat and Misner Brothers. Pedigree from breeder.

Robert Kennedy, Walla Walla, Wash., writes Dec. 24, I889: “I received your letter in regard to Dexter. The mother was got by Sumpter at Corvallis, Ore, an imported horse handled by Wallis. Dexter's grandmother was brought across the plains and called a Morgan. Can't tell you anything further. He is I 8 years old this spring."

Joseph BATTELL,

Alto, Columbia Co., Wash., Feb. I3, I89o.

Sir :-Am in receipt of your inquiry in regard to Dexter. His dam was by Sumpter. He was owned by one Alf. Mulkey near Corvallis, Benton County, Ore., bred by one John Wren, her dam by old Lummox, brought to Oregon by one Welch, don't know his given name, but lived near Salem, Ore. A man by the name of Avery bred her grandam, a Morgan Mare, to Lummox, he also lived in Benton County, near Corvallis.

Mr. Joseph Battell,

J. F. Logsdoin.

Corvallis, Ore., Mar. 2 I, I89o.

Dear Sir :-Your letter of the I I th of March, has just been received. Replying thereto I will state that I am a son of James L. Mulkey who bred and brought to Oregon the thoroughbred horse Sumpter, to which you refer. My father was a great admirer of fine horses and got the best blood that he could obtain in Kentucky and Virginia. He brought Sumpter across the plains to Oregon in 1844 . He was then a two-yearold and I think died in $\mathrm{I} 859$ I have no pedigree of Sumpter at hand at present, but will try to obtain one and write you further. I will only state here positively that he was got by Sumpter of Kentucky and is of the Hamiltonian and Diomed stock. The old Lummox was brought to Oregon a few years later by a Mr. Owenby and was of about the same stock as Sumpter, though not considered as fine a bred horse. I was well acquainted with Mr. Owenby (who is dead long years ago) and with his horse the original Lummox.

Sumpter was a thoroughbred horse, had no Morgan blood in him. I have seen Kitty Lynch trot several times, but do not know her stock. I 
will refer you to William Gird, Corvallis, Ore., for information regarding the Lummox stock, as he is a horseman and has lived in this County for over 30 years.
Yours truly,
A. G. Mulkey.

DEXTER (I-I6), dark bay, I5 hands; said to be by Harrodsburgh's Boy, son of Blood's Black Hawk: dam by a son of Harrison; and $2 \mathrm{~d}$ dam by a Whip horse. Advertised in 1879 by W. H. Stewart in Lexington (Ky.) papers.

DEXTER (I-I6), brown, I51/2 hands; foaled 1887 ; bred by C. Carpenter, Carrollton, Ky. ; got by Riley's Cloud, son of Flying Cloud: dam said to be by Drennon. Sold to Crouch \& Grobmyer, Carrollton, Ky.

DEXTER BRADFORD, bay; foaled I866; bred by Charles Robinson, Fishkill Plains, N. Y.; got by Hambletonian, son of Abdallah : dam Baby Belle, bay, bred by Charles Robinson, got by Eureka, son of Long Island Black Hawk; 2d dam said to be by Dover Messenger, son of imported Messenger. Pedigree from catalogue of breeder.

Sire of 3 trotters $\left(2: 19 \frac{1}{4}\right)$; I sire of 4 trotters, 2 pacers; I dam of I trotter.

DEXTER H. Untraced.

Sire of Pearl A., $2: 25$.

DEXTER L. (3-64), $2: 25$, dapple gray, I53/4 hands, I roo pounds; foaled I 889 ; bred by John Line, La Porte, Ind. ; got by Abdamed Allen, son of Woodward's Ethan Allen, by Ethan Allen, son of Black Hawk: dam gray, bred by John Line, La Porte, Ind., got by Tempest Jr. Gelded. Died about I goo. Pedigree from John Line, Jr.

Sire of Mona C., $2: 22 \frac{1}{2}$.

DEXTER PRINCE (GOVERNOR) (3-64), bay, I 6 hands, I 200 pounds ; foaled I 879 ; bred by Charles Backman, Stony Ford, N. Y. ; got by Kentucky Prince, son of Clark Chief : dam Lady Dexter, bay, stripe in face, white legs, foaled I $86 \mathrm{I}$, bred by Jonathan Hawkins, Walden, N. Y., got by Hambletonian; 2 d dam Clara, black, foaled $\mathbf{1} 848$, bred by Jonas Hawkins, got by Seely's American Star; 3d dam McKinstry Mare. Sold to Senator Stanford; to I. M. Morse of Lodi, Cal.; to Dan. McCarty ; to A. B. Speckels and leased by him to Palo Alto Stock Farm for several years. Died I904. Pedigree from E. E. Morse.

Jonathan Hawkins says: "The winter that Dexter was five years old, Mr. Alley came up to the farm to buy his sister, Lady Dexter (since the dam of the great young California sire, Dexter Prince). I knew nothing about what Dexter was doing at this time, and I said to Mr. Alley, 'My opinion is that if nothing has happened and he gets properly developed he will trot as fast as any horse has ever trotted.' He did not believe, however, that any horse, could ever beat Flora Temple, $2: 193 / 4$. But he bought the sister and gave me $\$ 500$ for her. She was a bay with 
four white feet, a very speedy natural trotter, and would have been fast if trained."

Sire of 46 trotters $\left(2: 08 \frac{1}{2}\right), I_{3}$ pacers $(2: 10) ; 5$ sires of 8 trotters, 5 pacers; 8 dams of 5 trotters, 3 pacers.

\section{DEXTER THE ORPHAN BOY. Untraced.}

Reputed sire of Alabama Coon, 2:093\% .

DEXTERWOOD (DEXTER P.) (I-32), chestnut with star and white ankles, I 6 hands, I 250 pounds; foaled I 886 ; bred by L. U. Shippee, Stockton, Cal.; got by Dexter Prince, son of Kentucky Prince : dam Jollyette, bay, bred by James M. Learned, Stockton, Cal., got by Nutwood, son of Belmont; 2d dam Maud, gray, bred by James M. Learned, got by Mambrino Rattler, son of Biggart's Rattler; 3d dam said to be by Green Mountain Morgan. Sold to D. McCarthy, Pleasanton, Cal.; to Clifton E. Mayne, Joplin, Mo. Pedigree from Dan. McCarthy.

Sire of Pinky H., $2: 17 \frac{1}{2}$.

DEXTKORSAL, $2: 143 / 4$, bay with white feet behind; foaled,r 889 ; bred by A. C. Fisk, Coldwater, Mich.; got by Dictator Almont, son of Dictator : dam Nell Buckman, bay, foaled i 875 , bred by A. C. Fisk, Coldwater, Mich., got by Masterlode, son of Hambletonian; $2 \mathrm{~d}$ dam Dollie, said to be by Fisk's Mambrino Chief Jr. son of Mambrino Chief. Sold to Charles R. Blair, Montgomery, Mich.; to Thomas Barrington, St. Marys, O. Pedigree from C. R. Blair.

Sire of Harry Van, $2: 21 \frac{1}{4}$.

DEYO, $2: 24$, bay; foaled $\mathbf{1} 88$ - ; said to be by Dauntless, son of Hambletonian.

Reputed sire of Benjamin, 2:30.

DEY OF ALGIERS, white with brown spots on neck and shoulders, 14 hands $2 \frac{1}{2}$ inches; foaled about 1794 . Presented together with two mares, Latonia and Capadocia, by the Emperor of Arabia, to Grand Bailiff Fromm of Prussia. After the Bailiff's decease, at the sale of his stud at Fehebillen, Prussia, in I799, the horse together with the mares then five years old, were bought by Lieut. Gen. Frederick, Baron of Diemar, by whom they were sold to Col. Swann of Massachusetts, then in Europe, and by him shipped from Hamburg to Gen. Jackson, Boston, Mass., in the spring of 1801 , who sent the stallion in the spring of 1802 to Gen. John Mason of Georgetown, D. C., and he was kept in that vicinity at a service fee of forty dollars. He made several seasons in Maryland. Advertised in $\mathbf{1} 807$, in Virginia Herald by Gen. Mason. Died in July r 807 , near Fredericksburg, Va. His advertisement in $\mathbf{r} 80 \mathbf{r}$ in the Worcester Spy, to stand near Charlestown Bridge, says: "He 
is remarkably long, healthy and vigorous, and for beauty, figure and blood has not his equal in the United States."

A correspondent writes to the Turf Register in $183_{2}$, as follows:

HORSES OF THE OLDEN TIME.

DEY OF ALGIERS.

Mr. Editor :-On the cover of the last (November) number of your Turf Register I find a remark concerning a horse called Dey of Algiers, and said by "A subscriber" to be "the horse sent to Thomas Jefferson, President, by the Bey of Tunis." Now I have a paper before me, purporting to be an account of a horse called Dey of Algiers, who was kept as a covering horse, in Prince George's County in the season of 1803 , at Mount Air, near Piscataway, and advertised by a Mr. Edward Edelin, in the following manner:

"Dey is of full stature for his race. He measures exactly fourteen hands, two inches and a half. His color is nearly white, with a few brown spots dashed over his neck and shoulders. In figure and bone it is believed he will stand the test of the best judgment. $\mathrm{He}$ is of fine and commanding presence, attractive carriage and remarkably vigorous and active. He will be let to mares at forty dollars per mare and one dollar to the groom."

The paper before me (and on its authenticity I think I can rely) further states his history to be as follows:

"This beautiful animal was brought from Arabia, in the year I798, at four years old, by the late Grand Bailiff Fromm of Prussia into that kingdom, and was purchased at the sale of the Bailiff's stud, after his decease, at Fehebillen, in the year I799, by Lieutenant General Frederick Baron of Diemar, by whom he was sent to Hamburgh to Col. Swann, whence he was by that gentleman shipped to America; and to attest which and to prove him to be a genuine Arabian horse, original certificates are in my possession."

This correspondent adds: "He was surely well thought of at that day from the high price at which he stood, and the great encouragement he is said to have received, at least in the lower counties of Maryland."

$$
\text { Yours, sir, }
$$

B.

DEY OF ALGIERS; foaled $\mathrm{x} 82 \mathrm{I}$; bred by J. H. Underwood, Fayette, Me. Advertised in 1825 , together with Harlequin six years old, at Fayette, Me.

A horse of this name, very probably same horse, is advertised in Eastern Argus, Augusta, Me., June, I 836 , at Stable of J. G. W. Coolage, Winthrop, and Baker \& Hobbs, Augusta, Me. Also advertised in The Age, June, $188_{3} 6$. Advertised for sale in Maine Farmer, June, 1837 , by Edward H. Watson, East Windsor, Conn.

In the Maine Farmer, 1836 , is an advertisement which reads as follows : "Dey of Algiers at Winthrop and Augusta."

DEY OF ALGIERS (YOUNG) See Young Dey of Algiers.

DIABLO (I-64), 2 :09 I/4, chestnut, I 5 I/2 hands, I I 50 pounds; foaled I 889 ; 
bred by Seth Cook, Danville, Cal. ; got by Charles Derby, son of Steinway : dam Bertha, bay, bred by Elizur Smith, Lee, Mass., got by Alcantara, son of George Wilkes; 2 d dam Barcena, bay, bred by A. J. Alexander, Spring Station, Ky., got by Bayard, son of Pilot Jr.; 3d dam Blandina, brown, bred by George W. Burch, Scott County, Ky., got by Mambrino Chief; 4th dam Burch Mare, brown, bred by Howard Parker, Lexington, Ky., got by Parker's Brown Pilot, said to be son of Copperbottom. Sold to William Murray, Pleasanton, Cal. Pedigree from catalogue of breeder.

Sire of Hazel D., $2: 21 \frac{1 / 4}{4}$ ig pacers $\left(2: 03^{3 / 4}\right)$.

DIADEM (3-г28), bay; foaled I 873 ; bred by Powell Bros., Springboro, Penn.; got by Satellite, son of Robert Bonner : dam Maud, bay, bred by C. D. Hawkins, Montgomery, N. Y., got by Volunteer, son of Hambletonian; 2 d dam James O. Miller's mare, said to be by American Star ; and $3 \mathrm{~d}$ dam by Sir Henry. Sold to C. S. Phillips, Tecumseh, Neb.; to John Caroll, Elwood, Neb. ; to T. C. Mustain, Milford, Neb.; to F. H. Wright, El Reno, Okl. ; to Harry Croskey, Wichita, Kas. Pedigree from breeder.

Sire of 2 trotters $\left(2: 22^{3 / 4}\right) ;$ Dan $D ., 2: 15$.

DIAMOND, bright bay, medium height, stout built with heavy mane and tail, hairy legs, a smooth traveler, bred in East Hartford, Conn.; foaled about I779; got by Church's Wildair, son of imported Wildair: dam stated by Justin Morgan to have been "a good mare" but is not traced. Diamond was advertised by Justin Morgan in the Massachusetts Gazette of April 29, $178_{3}$, as follows:

"Will cover this season at the stable of Mr. Justin Morgan, in West Springfield, the horse called Diamond, who sprung from a good mare and from the horse formerly owned by Mr. Church of Springfield."

In the Connecticut Gazette, New London, June 4, I 790, is the following advertisement :

"A beautiful bright bay horse calied the Diamond will cover etc., in Montville, at four to eight shillings. It is well known how remarkable he has always proved for colts."

ANDREW FITCH.

Mr. John Morgan late of Lima, N. Y., formerly of Springfield, Mass., in a letter to F. A. Weir, Jan. 9, I 845 , speaking of the dam of the original Justin Morgan, said: "Her sire was the Diamond, a thick, heavy horse of middle size; he had a thick bushy mane and tail, hairy legs; a smooth traveler. He was raised in East Hartford, Conn., and was kept one season, in West Springfield, Mass., by Justin Morgan. His sire was the Wildair, known as the Church Horse." (See Wildair, Church's or Hooker's).

Sire of the dam, of the original Justin Morgan.

DIAMOND, the fine blooded horse by American Eclipse, will be kept during 
the season at the stable of the subscriber in the town of Hamptonlurgh. He is 16 hands high and of fine action. Breeders of good horses are invited to call and see him.

\section{Charles Heard, Monday, April 23, I832.}

DIAMOND, said to be by Denmark: and dam by Mambrino Chief.

DIAMOND GOLDDUST (3-I2S), bay, no marks, I6 hands, I 200 pounds ; foaled ISSS; bred by D. C. Diggs, High Hill, Mo.; got by Porter Taylor's Mark Diamond, son of Old Mark Diamond: dam Collie, bay, bred by D. C. Diggs, got by Milton Golddust; 2 d dam Fan Brown, bred by F. W. Diggs, got by Morgan, son of old Morgan ; 3d dam Fanny Fern, bay, bred by J. H. Wickersham, St. Louis, Mo., got by Hamiltonian. Sold to J. B. Hines, Lexington, Mo. Pedigree from breeder who writes, Sept. I I, I905: "Very stylish and handsome horse; good action and good disposition. Fanny Fern's 3 d dam, was run at Natchez in 1855 by J. H. Wickersham."

DIAMOND LEXINGTON (I-32), bay, star and snip, hind feet white, I 6 hands; foaled I $\$ 86$; bred by S. B. Sublett, Bowling Green, Ky. ; got by Lexington Denmark: dam Florence, bay, bred by J. S. McElwain, Rockfield, Ky., got by Duluth; 2 d dam Kit, black, said to be by Stonewall; and 3 d dam Puss, by a Morgan horse. Sold to W. E. Stone, Owensboro, Ky. Pedigree from breeder.

DIAMOND MONTROSE (3-64), brown, double diamond on nose, hind feet white and inside of left forefoot also white, I6 $1 / 4$ hands, 3350 pounds; foaled April 25, I $88_{5}$; bred by $\mathrm{W}$. P. Summers, Huntsville, Mo.; got by Montrose, son of Diamond Denmark: dam bay, bred by W. P. Summers, got by Jack Sportsman Jr., son of Jack Sportsman. Died 1903 by accident. Pedigree from breeder.

DIAMOND VOLUNTEER ( $\mathrm{I}-\mathrm{I} 6$ ), black, $\mathrm{I} 53 / 4$ hands; foaled about $\mathrm{I} 872$; bred by H. C. Goodrich, Chicago, Ill. ; got by Volunteer, son of Hambletonian : dam Lady Diamond, said to be by Billy Rix, son of Gifford Morgan; and $2 \mathrm{~d}$ dam by Gamble's Gray Eagle. Sold to E. Sheely, Montezuma, Ia.

Sire of 2 trotters $(2: 23)$; I dam of I pacer.

DIATONIC (I-I2S), $2: 27 \mathrm{I} / 4$, black, one hind foot white, I53/4 hands, I roo pounds; foaled I $88_{3}$; bred by A. G. Danforth, Washington, Ill. ; got by Fairy Gift, son of Hero of Thorndale: dam Nelly, gray, bred by Rufus King, Chicago, Ill., got by Gage's Logan, son of Hambletonian. Sold to Y. D. Scales, Springfield, Ill. ; to a company at Roodhouse. Ill. Pedigree from breeder.

Sire of 2 trotters ( $2: 19)$; I sire of I pacer. 
DIAWOOD, 2 :I I, chestnut; foaled I895; bred by Mrs. J. P. Callendine, Sacramento, Cal.; got by Diablo, son of Charles Derby: dam Abbie Woodnut, chestnut, foaled 1889 , bred by B. C. Holly, Valejo, Cal., got by Woodnut, son of Nutwood; $2 \mathrm{~d}$ dam Phyllis, said to be by Admirable ; 3d dam Daphne, chestnut, foaled I875, bred by Fred Arnold, Stockton, Cal., got by Hambletonian (Whipple's), son of Guy Miller; 4th dam Phoebe Carey, chestnut, foaled I 868 , bred by J. H. Dodge, Stockton, Cal., got by Chieftain, son of Hiatoga. Sold to E. C. Peart, Colusa, Cal., and advertised with pedigree as above in the Western Horseman, Feb. 10, 1905 .

Sire of Seymow, $2: 23$.

DIBBLE CLOUD (3-32), bay; foaled I863; bred by C. Eastman, Oconomowoc, Wis.; got by Black Flying Cloud, son of Black Hawk: dam Dolly. Sold to H. M. Dibble, Fort Atkinson, Wis.; to J. M. Anderson, Whitewater, Wis. Died I887.

Sire of Sorrell Ned, $2: 25^{1 / 4}$.

DICK (3-128), roan, one white hind foot, $15 \%$ hands, r 050 pounds; foaled I872; bred by Noah Everitt, Knoxville, Penn.; got by Buckskin, son of Wood's Hambletonian : dam dark bay, bred by J. Y. Coleman, Sussex County, N. Y., got by Bolivar; 2 d dam bred in New Jersey, said to be by Balsora ; and $3 \mathrm{~d}$ dam by Bullfrog. Died i 880 the property of Noah Everitt, Knoxville, Penn., who sends above pedigree and says that the dam of Buckskin was a Highlander.

Sire of Qugomar, $2: 291 / 4$.

DICK. Untraced.

Sire of Pomp, $2: 22$.

DICK (3-64), $2: 261 / 4$, bay, $153 / 4$ hands, ro6o pounds; foaled 1872 ; bred by Newton Smith, Henderson, N. Y.; got by Major Benton, son of Jim Scott: dam brown, said to be by Bacon's Ethan Allen, son of Ethan Allen. Gelded young. Pedigree from A. L. Benton.

DICKARD, $2: 25 \frac{1}{4}$, chestnut with blaze in face, $14 \frac{1}{2}$ hands, 890 pounds; bred by Sylvester Doane, Shoreham, Addison County, Vt.; got by Daniel Lambert, son of Ethan Allen: dam chestnut, bred by Sylvester Doane, got by Smith's Young Columbus, son of Columbus; $2 \mathrm{~d}$ dam bred by Schuyler Doane, Shoreham, Vt., got by Black Hawk, son of Sherman Morgan; 3d dam blood bay, owned and perhaps bred by M. Hulett, Pawlet, Vt., who sold her to Fitch Clark, who took her to New York, afterwards bought by S. Doane who paid $\$ 300$ for her, said to be by Bishop's Hamiltonian, son of imported Messenger. Gelded young. Pedigree from breeder, who writes: "Reese, Mich., March 5, I 890 , I am in my $84^{\text {th }}$ year. I saw the man who said he bought old Columbus at Montreal." 
DICK BENTON (I-I6), bay with snip, one white hind foot, 16 hands, I 200 pounds; foaled I 882 ; bred by F. H. Penny, Henderson, N. Y., got by Col. Benton, son of Jim Scott : dam black, bred by F. H. Penny, got by Black Diamond, son of Thomas Jefferson; $2 \mathrm{~d}$ dam said to be by Phil Sheridan son of Andrew Jackson, by Bulrush Morgan. Pedigree from B. M. Penny, Henderson, N. Y.

Sire of Lena Belle, $2: 24^{1} \frac{1}{2}$.

DICK BOGUS, brown bay, $151 / 4$ hands; foaled 1789 ; said to be by imported Tom Bogus : dam by DeLancey's famous horse Lath, that won more prizes running than any other horse in America; $2 \mathrm{~d}$ dam by True Briton; 3d dam by old Wilddeer (Wildair). Advertised in the Rutland Herald, with pedigree as above, 1797, by John Wood, to be kept at Bridport, Vt.

The three horses which got the dams are all understood to have been imported by Mr. DeLancey. See letter of Mr. Edward F. DeLancey, under True Briton.

In the advertisment of Weasel in the Vermont Gazette of May 24, 1793, True Briton is called an imported horse as follows:

"The beautiful horse Snip, will cover, etc., at the stable of Benjamin Skinner in Williamstown. Snip is a full blooded horse, etc. At the same place also the young horse Weasel, at twenty shillings the leap or twenty-four shillings to warrant. Weasel is a bay horse, sired by Weasel, a colt of the old True Briton, an imported horse; his dam is a fullblooded mare, and the same that brought the Russell Horse, or the Wildair. Both horses in the care of Mr. Hudson, who offers himself to the public as a good Farrier. Pay to be made to Samuel Sprague."

Here again the name of De Lancey's Wildair appears with that of True Briton.

DICK DIMPLE (1-32), $2: 30$, bay, 15 I $/ 4$ hands, 950 pounds; foaled I 886 ; bred by Geo. C. Smith, Nelson, Nuckolls Co., Neb. ; got by Peoria, son of Arnold : dam bay, purchased at Quincy, Ill., said to be by Singleton's Silverheels, son of Black Hawk. Gelded young. Pedigree from breeder.

DICK EDDY (I-I 28), $2: 2 \mathrm{I} \frac{\mathrm{I}}{2}$, brown, star, one hind ankle white, I53/4 hands, I Ioo pounds; foaled May 22, I886; bred by C. D. Ely, Clyde, Wayne Co., N. Y.; got by Jerome Eddy, son of Louis Napoleon : dam Daisy, black, bred by Wm. H. Saunders, Clyde, N. Y., got by Index, son of James R. Reese; 2d dam Jane Brown, bred by John Brown, St. Catharine's, Ont., got by Prince of Wales, son of Royal George ; $3 \mathrm{~d}$ dam said to be by Hoagland's Gray Messenger. Pedigree from breeder.

DICK EDIWARDS ('I-I28), bay, small star, two white feet behind below pasterns, I6 $1 / 2$ hands, 1400 pounds; foaled 1878 ; bred by Edmund 
Collier, Millersburg, Ky. ; got by Clark Chief Jr., son of Simms' Clark Chief Jr.: dam Young Dun, said to be by Pacing Abdallah, son of Alexander's Abdallah; and 2 d dam Pigeon, by Yellow Jacket, son of Wells' Yellow Jacket. Sold to Vasey Bros., Grundy Centre, Ia. Pedigree from Albert Vasey.

Sire of 2 trotters $\left(2: 24 \frac{1}{2}\right)$.

DICK FLAHERTY (I-I6), $2: 29 \mathrm{~T} / 4$, chestnut with small stripe in face and one white ankle, I 6 hands, I250 pounds; foaled I 883 ; bred by C. O. Barnes, Albany, Ore.; got by Flaherty's Fearnaught, son of Fearnaught Jr. : dam Belle Drew, pacer, bay, about I 200 pounds, foaled about I 87 I, bred by a widow at Petaluma, Cal., got by Dodd's Nelson, son of John Nelson ; 2 d dam said to be by Butterfield's St. Clair ; 3 d dam by Black Leg, son of Biggart's Rattler; 4th dam by Jack Hawkins, son of Boston ; and $5^{\text {th }}$ dam by old St. Clair. Advertised, season of $\mathbf{I} 890$, by $\mathbf{E}$. LaForest, Albany, Ore., who sends pedigree and says he drove him at Salem, Ore., trials in $2: 24 \frac{1 / 2}{2} 2: 35$ and $2: 26 \frac{1}{4}$. See The Morgan Horse and Register, Vol. I., page 639.

DICK FLETCHER (I-S), black, very little white, if any, full mane and tail, I050 pounds; said to be by Black Hawk, son of Sherman Morgan : and dam by Post Boy (doubtless Doolittle's). Purchased by Dr. Wm. Studwick, Hillsborough, N. C., about i 856 . Died i860. Mr. James Norwood of Hillsborough, in interview, said:

" $\mathrm{He}$ did a great deal for the improvement of stock in this and adjoining counties; a perfect picture of a horse as you ever saw, attracted great attention at State and other fairs. Colts kept as stallions trotted very fast, a number of them better than $2: 30$. Dr. Moore introduced at same time a stallioṇ and two mares."

DICK H., 2 :I 8 , black, $15 \% \frac{1}{2}$ hands; foaled March 7,1887 ; bred by William S. Hall, Mays, Rush County, Ind.; got by American Boy, son of Pocahontas Boy: dam Daisy, black, bred by William S. Hall, Raleigh, Ind., got by General Putnam, son of Alexander's Edwin Forrest; 2 d dam Mary Shawhan, black, bred by William S. Hall, got by Virginia Whip; 3 d dam gray, bred by William S. Hall, got by Bashaw; 4th dam gray. Owned by Richard Hunt, Anderson, Ind.; and afterwards by George Mashinger, Richmond, Ind. Pedigree from breeder.

Sire of Mabel F., 2:211/2.

DICK H., ( $\mathrm{I}-32), 2: 27 \frac{1}{2}$, bay, I5 $1 / 2$ hands, I I 50 pounds; foaled 1892 ; bred by I. Hanks, Bushnell, Ill. ; got by Brilliant Golddust, son of Golddust : dam Molly, bay, bred by I. Hanks, got by Orphan Boy, son of Humbolt. Pedigree from Albert Sperry, Bushnell, Ill.

Sire of Little Girl, $2: 13^{1 / 4}$.

DICK HAMBLETONIAN (3-64), brown; foaled I863; said to be bred in 
Sussex County, N. J., got by Hetzell's Hambletonian; and dam by American Star. Owned by Brainard T. Smith, New Iberia, La.

Sire of 2 dams of 4 trotters.

I)ICK HUBBARD, (I-I2S), 2 :093/4, bay; foaled I 890 ; bred by W. C. France \& Son, Lexington, Ky.; got by Allandorf, son of Onward : dam Sally Brass, $2: 36 \frac{1}{2}$, bay, bred by W. L. Simmons, Lexington, Ky., got by George Wilkes; $2 \mathrm{~d}$ dam said to be by Nonpareil, son of Long Island Black Hawk. Sold to J. I). Minchison, Tyler, Tex. Pedigree from catalogue of breeder.

sire of Masgie Hubbard, $2: 11 \frac{1}{4}$.

DICK HUNTER, said to be by Locomotion.

Sire of Peter Turney, $2:$ II $^{1 / 4}$.

DICK JAY ( $1-32$ ), $2: 29$, bay, I $_{5}^{1 / 2}$ hands, rooo pounds; foaled about I 879 ; said to be by Gen. McClellan Jr., son of Gen. McClellan : dam thoroughbred. Gelded young. Information from C. A. Durfee, who writes at Los Angeles, Oct., 24, I885: "I bought the horse of Mr. N. Johnson of Santa Barbara, Cal., and trotted him several races, was steady, level and game to a fault and could trot much faster than his record. $\mathrm{He}$ is on the road here, Mr. Johnson told me his dam was thoroughbred."

DICK LOOMER (3-I28), bay; foaled I87I; bred by Harrison Durkee, New York, N. Y.; got by Dictator, son of Hambletonian : dam Madam Loomer, chestunt, foaled I 857 , bred by Edward Loomer, Jackson, Carlton County, New Brunswick, got by Warrior, son of Young Messenger, by Winthrop Messenger. Sold to Isaac C. Smith, Milford, Conn., who sends pedigree.

Sire of Elastic Starch, $2: 24$; I dam of 2 pacers.

DICK McNAIR (I-32), chestnut, I 6 hands, rioo pounds, stripe in face, and two white socks; foaled r 867 ; bred by George B. Sargent, Muscatine, Ia. ; got by Green's Bashaw, son of Vernol's Bashaw : dam Mary Blane, bay, bred at Long Island and got by Long Island Black Hawk, son of Andrew Jackson. Sold to M. P. Donahey, Washington, Ia., who sends pedigree. Died i 886 .

Sire of Dick Crocket, $2: 281 / 4$.

DICK PREBLE (YOUNG BLACK HAWK) (3-32), dapple bay, I6 hands, I050 pounds; foaled I 873 ; bred by P. S. Preble, Bridport, Vt. ; got by Daniel Lambert, son of Ethan Allen: dam brown, bred by Nathaniel Joiner, Moriah, N. Y., got by a son of Black Hawk. Kept one season at Canton, St. Lawrence County, N. Y., then gelded. Pedigree from breeder. 
DICK REYNOLDS ( $\mathrm{I}-32$ ), said to be by Cassius M. Clay, son of Henry Clay : and dam Indian Queen, by Andrew Jackson.

DICK SLIDER (5-64), $2: 35$, trial 2 : 8 , dark chestnut with star, snip and white hind feet, $153 / 4$ hands, I 200 pounds; foaled June I9, r 866 ; bred by Mr. Junkeith, Lithopolis, O.; got by Paul Jones, son of Hammett Horse, by Black Hawk: dam dark chestnut, said to be by Wardell's Eclipse, son of Iron's Cadmus; and 2 d dam by Red Bird, son of Rattler, by Sir Archy. Sold to Ezra Courtright, Fairfield County, O., I873; A. H. Shaeffer, M. D., Circleville, O. Kept in Clinton and Warren Counties, O. Started in 92 races, won 66 , and a part of purse in all but 8. Died i 88o. Information from Dr. Shaeffer who speaks very highly of the horse.

Sire of Sanford H., $2: 12 \frac{1}{4}$; dam of I pacer.

DICK TAYLOR (5-32), jet black, Iooo pounds; foaled I 860 ; said to be by the Harvey Horse, son of Black Morgan : dam Colby mare. "Unsurpassed for style, beauty and speed." Advertised as above in Stanstead (P. Q.) Journal by D. F. Harvey at T. Winn's and East Hatley, r 865 .

DICK TURPIN; said to be by a horse called Scipio.

Sire of Black Dick, $2: 24 \frac{1}{4}$.

DICK TURPIN (I-I6), dark bay, one white foot, I6 $1 / 4$ hands; bred by N. E. Deland, Carthage, N. Y.; got by Swinburn's Hambletonian (bred and owned by Dr. John Swinburn, Albany, N. Y.), son of Tucker's Hambletonian, by Mambrino Paymaster; $2 \mathrm{~d}$ dam said to be by a son of Vermont Morgan, and $3 \mathrm{~d}$ dam by a son of Clark's Blossom. Died $\mathbf{I} 877$. Information from Geo. L. White, Iroquois, Ill.

DICK TURPIN (CLARK CHIEF JR.) (I-I6), brown; foaled I866; bred by J. D. Featheringill, Pine Grove, Clark County, Ky.; got by Clark Chief, son of Mambrino Chief : dam Bonny, said to be by Doniphan, son of Caven's Davy Crockett; 2 d dam Ellen, by Hunt's Highlander, son of Scott's Highlander; 3d dam Ragland's Crook Neck, by Bevin's Whip; $4^{\text {th }}$ dam by Robin Gray; and $5^{\text {th }}$ dam a running mare. Sold to James T. Talberts, Cynthiana, Ky. ; to Henry Bramblet, Bramblet, Ky. ; to Willis Simms, Virden, Ill., I873; to A. G. Barnes, Taylorville, Ill. Pedigree from breeder.

Dick Turpin made a season in I 870 at James D. Talbot's, Millersburgh, Bourbon County, Ky. Mr. Talbot sold him to Henry Bramblet, Carlisle, Ky., and in I 873 he sold him to Willis Simms, Virden, Ill. Mr. John Simms, son of Willis Simms, writes that his name is now Clark Chief Jr., and is owned by Mr. A. G. Barnes, Tavlorville, Ill. "I have given pedigree as furnished by his breeder, Mr. Featheringill. I do not know under what name or pedigree he is registered or whether he is 
registered or not. I give all the facts as furnished me, so his produce under either name, Dick Turpin or Clark Chief Jr., can be identified."

T. E. Mooke, in Dunton's spirit of the Turf.

DICK WILKES ( $\mathrm{I}-32$ ), bay, 16 hands; foaled I 885 ; bred by J. W. Duncan, Georgetown, Ky.; got by Petoskey, son of George Wilkes: dam Sally, bay, bred by J. W. Duncan, got by Dictator and $2 \mathrm{~d}$ dam Henrietta, sorrel, bred by John Duncan, Georgetown, Ky., got by Adams' Bald Chief, son of Alexander's Bay Chief ; 3d dam Fanny, brown, bred by John Duncan, got by John Dillard; $4^{\text {th }}$ dam Fanny, said to be by Ben Franklin, son of Hazrack; and $5^{\text {th }}$ dam Nance, by Saxe Weimar, son of Sir Archy. Died I 894. Pedigree from breeder.

Sire of Turner Boy, $2: 2 \mathrm{I} \frac{1 / 4}{4}$ : Hamilton, $2: 231 \frac{1}{4}$; dam of I pacer.

DICTATOR; foaled I 790; bred by Gen. McPherson of New York State; got by imported Mexican, son of Snap : dam by imported Flimnap ; 2 d dam imported and bought at Duke of Bridgewater's sale in $1762 ; 3 \mathrm{~d}$ dam by Newcomb's Arabian. Pedigree given by John E. Colhoun in the American Turf Register, May i $\dot{\delta}_{3} \mathrm{r}$.

DICTATOR (3-64), brown, one white ankle, I 5 hands; foaled I 863 ; bred by Jonathan Hawkins, Walden, N. Y.; got by Hambletonian, son of Abdallah: dam Clara, dam of Dexter, $2: 17 \frac{1}{4}$, by Seeley's American Star, son of Coburn's American Star, by Cock of the Rock, son of Sherman Morgan, by the original Justin Moran. See Dexter.

"Dictator was sold when a colt by his breeder, Jonathan Hawkins, to Harrison Durkee, whose farm was on Long Island, a few miles from New York City. Mr. Durkee was a wealthy gentleman, who frequently paid very high prices, but kept his horses much more for amusement than for profit, and did very little towards obtaining patronage for any of his stallions, whose fees were placed at almost prohibitory figures.

When first taken to Kentucky, which was in 1876 , and he then remained only two seasons, Dictator's fee, was placed at $\$ 200$, which was then a very high fee, double that of George Wilkes, Almont, Belmont, or Harold, which Kentucky breeders generally would have preferred even at the same price, consequently he received but a very limited patronage, and still less after he was returned to New York State. He attracted no very marked attention as a sire until i 883 , when Jay-EyeSee reduced his record to $2: 103 / 4$, which placed him a close second on the list and gave him the five-year-old championship. Phallas finished a remarkably good campaign with a record of $2: 151 / 2$, taken the second heat of a winning race, which placed him within a quarter of a second of the best stallion record, while Director came down through the circuit sweeping nearly everything before him, and finishing the greatest winner of the year with a record of $2: 17$.

Dictator, though 20 years old, was then sold to a company composed of H. C. McDowell, Col. R. West and, I think, David Bonner, for $\$ 2 \mathrm{O}$,0oo and the following season he made his only full season in the stud, sixty mares being sent to him that year. The next year Mr. McDowell 
became sole owner, on a basis of $\$ 25,000$ and kept him that year as a private stallion, since which time he has allowed him a limited amount of outside patronage at $\$ 500$, but for several years that was so high a fee as to be in a great measure prohibitory. This, taken in connection with the fact that Dictator was never more than ordinarily sure, and a portion of the time not at all so, accounts for his total being much smaller than that of any other prominent son of Hambletonian, still from so limited a number have come Jay-Eye-See, which reduced the trotting record to 2 : Io, and for a brief period held the trotting championship, Phallas, that reduced the trotting-stallion record to $2: 133 / 4$, the fourth heat of a race, Director (2:17), which has proven such a remarkable sire as to bring $\$ 75,000$, a price only two other trotters have ever equaled, and over 40 other trotters and pacers with records from $2: 16 \mathrm{I} / 4$ to $2: 30$. Though maliciously reported as impotent several years ago, that was never strictly true and he has held out wonderfully well, begetting more or less each year. Three mares are believed now to be safely with foal by him from the present season's service. His total number of foals is estimated at about 400 .

Twenty of Dictator's sons are already in the list of sires, Director having proven among the most sensational, having to his credit Direct, which took a four-year-old trotting record of $2: 181 / 4$, then two years later took a pacing record of $2: 06$, which was then the fastest mile that had ever been made at either trotting or pacing, Directum, with a three-yearold race record of $2:$ II $1 / 4$, which no other haş equalled, Margaret S. $\left(2: I_{2} 1 / 2\right)$, Evangeline $(2:$ I $3 / 4)$, and numerous others in $2: 30$.

Daughters of Dictator are proving even more sensational as producers, Nancy Lee being the dam of Nancy Hanks, whose record of $2: 04$ is $3 \frac{1}{2}$ seconds faster than any other, while her size and characteristics generally are more nearly those of the Dictators than of Happy Medium, her sire, or any other strain in her pedigree. Another daughter of Dictator, is the dam of Lockhart $\left(2: I_{3}\right)$, and two others in $2: 30$, another has produced Keller Thomas $(2: 123 / 4)$ and New York Dictator $(2: 29 \mathrm{I} / 4)$, while Gauntlet is the dam of Brown, which reduced the four-year-old stallion record to $2: 183 / 4$, Williams $(2: 201 / 2)$ and Integritv, five years $(2: 271 / 2)$. Another daughter of Dictator has two with records below $2: 20$, and several others have produced quite sensational performers.

When the individual qualities of the Dictators, together with their remarkable courage and endurance, is taken into account, his real superiority, as a sire must be acknowledged, and it is fair to presume he possessed to a high degree the speed and gameness he has so uniformly transmitted."

- American Horse Breeder, June 10, 1893.

W. C. Tremble of Newburgh, N. Y., an experienced horseman says:

"The dam of Dictator was a little, black, American Star mare, about I $4 / 2$ hands, badly hipped, owned by Mr. J. Hawkins, who bred her to Hambletonian, and got Dexter and afterwards Dictator. Dexter was her first colt.

Jay-Eye-See is not over 15 hands and is pony built. In form he is a fac-simile of old American Star; compact form all over. Almost all the Stars have white hind feet, white spot on the nose, and star.

The Stars were of fine disposition, the kindest horses I ever saw ; very tough and hardy. Star was the gamest horse we ever had in the country; all his colts were game." 
MCKINSTRY MARE.

Joseph Batteli, EsQ.,

Montgomfry, N. Y., Nov. 30, 1904.

My Dear Sir:-Yours received. Christopher McKinstry and Jacob McKinstry, were brothers, and Mrs. Abraham Laquer, a sister, lived there: all are dead. Floyd McKinstry, and John McKinstry, sons of Christopher McKinstry, live at Tuttletown, N. Y., but Abraham Laquer, who lives at the Palace Hotel this place, can give you (likely) all the information you may desire.

Yours truly,

John F. Wilken, P. M.

Letters written Mr. Laquer have not been answered.

Jonathan Hawkins says :

"Dictator I bred personally. He is a very dark brown, and unlike most of the family, has no white markings save the off hind pastern. As a colt he was a phenomenal trotter, and in the lot could never be scared from a trot when beside his dam. I think he had as much natural speed as Dexter. When he was eleven months old I sold him to Harrison Durkee, who left him on the farm until he was two years and a half old. $\mathrm{He}$ was then sent to Alden Goldsmith at Washingtonville, who broke him, and from there he went to Mr. Durkee's farm at Flushing. I am not positive, but believe he trotted a mile with him better than $2: 30$."

From Western Sportsman, i89r :

Dictator, that has for many years past been the property of Major H. C. McDowell, Ashland, is commented on as follows in the Breeders' Gazette :

Wallace savs Lockhart, $2: 14 \mathrm{~T} / 4$, is the fastest trotter by Nutwood, and it is a noticeable fact that his dam is by Dictator. The fastest trotter by Happy Medium-Nancy Hanks 2 :09-is also from a Dictator mare, and with these striking examples in mind it is plain that Dictator is producing extreme speed through his daughters as well as through his sons. A few year ago when Jay-Eye-See, 2 :I0, Phallas, $2: 133 / 4$, and Director, $2: 17$, were all on the turf at once and were the sensations of the hour there was a mad rush to secure Dictator blood, because all three of those great trotters were by the brother to Dexter, and in addition to speed they had other race-horse qualities in the way of level heads and intense gameness. Director has, like his sire, transmitted extreme speed to his sons and daughters, as the 2 :06 of the pacer Direct and $2: 121 / 2$ of the trotter Margaret S., show, and now that a couple of trotters like Nancy Hanks and Lockhart, that are from Dictator mares have come to the front, it would seem that the brother to Dexter is to have a revival of the interest that centered around his name when his three sons, Jay-Eye-See, Phallas and Director were winning races every week. Although from his colthood until he had passed middle age Dictator was owned by a wealthy gentleman who took an interest in trotters, he never had much of a chance in the stud, as his younger days were passed on Long Island and at that time the Kentuckians had little use for an outside stallion, no matter what his blood lines might be. It was only after the horse had fairly been forced upon him, that the late Col. Richard West consented to take Dictator to Kentucky, and it is a matter of common knowledge among horsemen, that so far as public patronage was concerned, the venture was a total failure, as the Kentuckians would not 
breed to Dictator on account of his size, overlooking the fact that his blood lines were all right and he was the brother of the champion of his day, Dexter, $2: 17 \frac{1}{4}$.

From Breeder and Sportsman, 1893:

\section{DEXTER AND DICTATOR.}

The old saw that the brother of a famous horse is seldom good for much will hardly hold true in respect of trotters, as in many instances horses that are full brothers have gained a good deal of fame both on the turf and in the breeding ranks. Take Dexter and Dictator for instance. The former was just as much a champion trotter of his day as is Nancy Hanks at the present time, and when his record of $2: 17 \frac{1}{4}$ was made at Buffalo in $\mathrm{I} 876$, it was so far ahead of the mark made by the preceding champion trotter, Flora Temple, whose record was $2: 193 / 4$, that the brown gelding with the white face and wicked eye was justly looked upon as a phenomenon. Predictions were freely made that his record would not be lowered for ten years, but that it did not stand such a great length of time is ancient history and not of interest here. Budd Boble, who drove Dexter to his best record, grows enthusiastic today when that horse's name is mentioned, and is firmly of the belief that had he been allowed to remain on the turf he would have been the first to trot in $2: 12$, if not in $2: 10$. In appearance Dexter was a very impressive horse, although not one of great size. But his whole being was so instinct with action and there was such a vigor in his every movement that he attracted and fascinated those who saw him perform. Dictator the brother of Dexter, is now about ready to die, being thirty years old, and therefore a fair estimation of what he has accomplished in the stud may be made. In brief it is as follows :

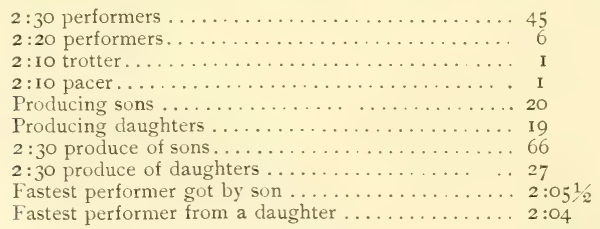

Not many trotting stallions can equal this showing, as Dictator is the sire of the fastest combined trotter and pacer in the world-Jay-Eye-See, $2:$ Io trotting, $2: 06 \mathrm{I} / 4$ pacing; sire of the dam of the fastest trotter in the world-Nancy Hanks, 2 :04, and grandsire of the third fastest pacer in the world-Direct, $2: 05 \frac{1}{2}$. Like his brother, Dexter, Dictator was a fast trotter, being able to show a $2: 20$ rate of speed, and in Direct and JayEye-See he got a couple of race nags that resemble Dexter in many particulars, showing that the blood which produced the champion of I 876 was as potent in the horse that was kept for breeding purposes as in the one whose mark was made on the turf. There is still living down in New York a man who occasionally breaks loose in the turf journals with a screed to the effect that Dexter was by Harry Clay and not by Hambletonian. This remarkable statement appears to have as its only foundation, the fact that in his marking of four white feet and a blaze, Dexter resembled the Clays more than he did the Hambletonians. It has never been claimed, however, that Director was not by Hamble- 
tonian, and the last lingering suspicion that may have existed in the mind of any sensible man as to the parentage of Dexter would be removed if he would but talk with Budd Doble about the great resemblance between Jay-Eye-See and Dexter, the uncle and the nephew.

[It will be remembered that the grandsire of Seeley's American Star, Cock of the Rock, by Sherman Morgan, was strongly marked with white.]

THE POWER OF DICTATOR'S BLOOD.

The blood of Seeley's American Star carried with it many evidences of thoroughbred character. In silken quality and bloodlike appearance nothing in the Stud Book surpassed it. It is much diluted as we find it in these days, yet it is a powerful factor in trotting pedigrees, especially where the task is to carry a high rate of speed through broken heats. American Star handed down most of his greatest bequests through his daughters, though his son Magnolia has transmitted much excellence. Among so many of Star's daughters that were great, it is difficult to choose, but Clara, the dam of Dexter and Dictator, probably transmitted a more valuable influence than any other. Her blood carries a breeding force with it that is remarkable, not only for the frequency with which its trotters appear, but the extreme limits to which many of them trot. Dictator got very extreme speed, as all know, and his daughters are breeding in kind. A sister to Dictator produced Dexter Prince, that is regarded by most California breeders as one of the greatest sires that has ever been taken to that State, having added eleven new trotters to the list this year, and they having racing quality as well as speed.

Clara's influence, as shown through Dictator, is almost incomparable. Director, by Dictator, is proving one of the greatest sires of very extreme speed at early ages that has appeared, all of his get having the racing instinct. Phallas, by Dictator, held the stallion championship in his day, and added eight new trotters to his list this year. Jay-Eye-See, after holding the world's trotting record in his day, came out this year from a long retirement as a pacer, "shouldered his crutch, and showed how fields were won" taking a record of $2: 06 \mathrm{~T} / 4$. It was a daughter of Dictator that gave us Nancy Hanks, the queen of the tracks; it was a daughter of Dictator that gave us Lockhart, $2: I_{3}$, the fastest trotter that his famous sire, Nutwood, has got to date; it was a daughter of Dictator that produced Keller Thomas, $2: \mathbf{I}_{2} 3 / 4$, by far the fastest trotter ever got by Pilot Duroc; it was a Dictator mare that produced Pancoast's great five-year-old son, Garnet, $2: 13 \frac{1}{2}$, and it was a Dictator mare that produced Brown, $2: 183 / 4$ (4), Williams, $2: 201 / 2$, etc., the fastest got by Combat. When Dictator's blood becomes an active force in a pedigree it is liable to impart a degree of capacity for extreme speed seldom attained by other trotting strains. Whether this is due to the refined organism which American Star handed down through many channels but most copiously through Clara, the dam of Dictator and the ex-king, Dexter, or to other causes, must remain a matter of conjecture, but the results are there whatever they come from.

From Randall's Horse Register, June 3, I 893. DICTATOR DEAD.

A week ago last Thursday evening (May 25th) the famous trotting sire Dictator died at the home of his owners, H. C. McDowell \& Son, Lexington, Ky. It is said that he was apparently in good health up to 
two or three hours before he breathed his last. His suffering was intense as the disease was acute inflammation of the bowels. He was foaled in I 863, and was therefore thirty years old. He was a full brother to Dexter, $2: 171 / 4$, who was about three years younger when his death occurred. Both horses were by Hambletonian 10, dam Clara, by Seeley's American Star, grandam the McKinstry mare, the dam of Shark, saddle record $2: 273 \frac{1}{4}$. He was bred by Jonathan Hawkins of Orange County, New York, who sold him to Harrison Durkee, of New York City. His opportunities in the stud were very limited, and though kept by the late Col. West near Lexington, for two seasons before being sold to Maj. McDowell, he was bred to very few mares, and being over twenty years of age when he became the property of the last named gentleman, his stud business was not extensive, yet few stallions have accomplished as much. He only served four mares last season, three of which are believed to be in foal.

Sire of $4^{6}$ trotters $(2:$ IO $)$, II pacers $(2: 061 / 4) ; 5^{6}$ sires of 179 trotters, IO2 pacers; 7 I dams of 78 trotters, 24 pacers.

DICTATOR ALMONT (I-32), black, I6 hands; foaled June 3, I 884 ; bred by John B. Wilkins, Lexington, Ky.; got by Dictator, son of Hambletonian: dam Alice W., said to be by Allie West, son of Almont; 2 d dam Balsorina, by Balsora, son of Alexander's Abdallah; 3d dam Lady

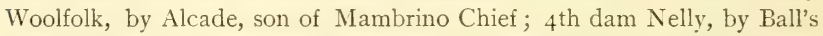
Vermont, son of Downing's Vermont ; 5 th dam Betty, by Hunt's Commodore, son of Mambrino; and 6th dam, a fast trotting mare brought from Canada to Kentucky, I $8_{3} 6$, by David Castleman. Sold to "A. C. Fisk, Coldwater, Mich.; to R. G. Hart, Lapeer, Mich., Jan. I I, I89o ; to D. Watson, Lapeer, Mich., who sends pedigree.

Sire of 5 trotters $\left(2: 20 \frac{1}{2}\right), 3$ pacers $\left(2: I_{4}^{3 / 4}\right)$; I sire of I trotter.

DICTATOR CHIEF (I-32), bay, I6I/2 hands, I 275 pounds; foaled I 877 ; bred by W. S. Harris, Versailles, Ky. ; got by Dictator, son of Hambletonian: dam Birdcatcher, bay, bred by G. H. Buford, Lexington, Ky., got by Edwin Forrest, son of Bay Kentucky Hunter; 2d dam said to be by Mambrino Chief; 3d dam by Hunt's Commodore, son of Mambrino; and $4^{\text {th }}$ dam by Sir Leslie. Sold to A. G. Barnes, Taylorville, Ill. ; to Captain Haultz, Carlinville, Ill. Pedigree from W. E. Barnes, Taylorville, Ill.

Sire of 2 pacers $(2: 25)$; I sire of I trotter; 3 dams of I trotter, 2 pacers.

DICTATOR CHIEF (3-I28), $2: 2 \mathrm{I} 1 / 2$, bay, I53/4 hands, II6o pounds; foaled I 882 ; bred by J. B. Oliver, Milwaukee, Wis.; got by Dictator, son of Hambletonian: dam Judy, bay, bred by R. R. Ferris, Oswego, Ill., got by Plato, son of Long Island Black Hawk; $2 \mathrm{~d}$ dam bred by John Gilman, Oswego, Ill., got by Louk's Kentucky Whip, son of Kentucky Whip; 3d dam bred by Ira Hawkins, Oswego, Ill., said to be by a son of imported Messenger. Sold to C. H. Nelson, Waterville, Me. From catalogue and letter of Mr. Nelson.

Sire of I2 trotters, 3 pacers. 
DICTATOR DUNCAN (I-32), bay; foaled I 879 ; bred by Richard West, Lexington, Ky.; got by Dictator, son of Hambletonian: dam Kate Forrest, bay, bred by Thomas Steele, Lexington, Ky., got by Erlwin Forrest son of liay Kentucky Hunter; $2 d$ dam said to be by Tarlton. Sold to Truman Skinner, Baltimore, Md.; to B. F. I)arbie, Clermont Mills, Md.

Sire of 2 pacers $(2: 171 / 4)$.

DICTATOR FOREST, bay; foaled 1877 ; bred by Wm. Muir, Scott County, Ky.; got by Dictator, son of Hambletonian: dam N'ay Forrest, said to be by Edwin Forrest; $2 \mathrm{~d}$ dam by Woodford; and $3 \mathrm{~d}$ dam by Bertrand. Sold to W. J. Perkins, Valley View Ranch, Laurin, Nont.; to W. H. Raymond; to T. J. Farrell, Virginia City, Mont., who sends pedigree.

DICTATOR G. (I-64), brown; foaled I885; bred by Frier \& Gibbs, Bowling Green, Ky.; got by Prince Dictator; son of Dictator: dam bay, said to be by Toronto; 2 d dam Polly.

Sire of Skewball, $2: 25$.

DICTATOR PRINCE (5-I28), $2: 2 \mathrm{I} \mathrm{I} / 4$, bay; foaled I 889 ; bred by J. B. Houston, New York, N. Y.; got by Dictator : dam Vineland, bay, bred by Charles Backman, Stony Ford N. Y., got by Kentucky Prince, son of Clark Chief; $2 \mathrm{~d}$ dam Vienna, bay, bred by Charles Baçkman, got by Messenger Duroc; 3d dam Virgo, black, bred by Jacob R. Feagles, Amity, N. Y., got by Roe's Abdallah Chief, son of Abdallah; 4th dam Catbird said to be by Whistle Jacket, son of Mambrino; and 5 th dam Lyon Mare, by the Bertholf Horse. Sold to Oakleigh Thorne, Millbrook, N. Y. ; to L. Bank Wilson, Creston, Ia., who sends pedigree.

Sire of 2 trotters $\left(2: 19^{1 / 4}\right)$

DICTATOR IWILKES (3-64), brown; foaled I 884 ; bred by Vincent Cromwell, Lexington, Ky.; got by Red Wilkes: dam Nancy Lee (dam of Nancy Hanks $2: 04$ ), bred by Hart Boswell, Lexington, Ky., got by Dictator ; $2 \mathrm{~d}$ dam Sophy, said to be by Edwin Forrest; and $3 \mathrm{~d}$ dam by Parker's Brown Pilot. Sold to Hugely and Robinson, Harrodsburg, Ky.; to H. B. \& H. D. Allen, Waterloo, Ia., I 887 , who advertise with pedigree as above in Dunton's Spirit of the Turf, r89 г.

Sire of 4 trotters $\left(2: 19 \frac{1 / 4}{4}\right) ; 6$ pacers $\left(2: 09 \frac{1}{2}\right) ; 3$ dams of 2 trotters I pacer.

DICTATOR WILKES (r-I6), bay; foaled I888; bred by L. U. Shippee, Stockton, Cal.; got by Dictator, son of Hambletonian : dam Manola, bay, bred by Calvin Burgin, Richmond, Ky., got by George Wilkes; 2 d dam Lizzie Brinker, said to be by Brinker's Drennon; 3d dam by Millions' Copperbottom; $4^{\text {th }}$ dam by son of Blackburn's Whip; $5^{\text {th dam }}$ 
by Post Boy, son of Henry; and 6th dam by Bishop's Hamiltonian. Pedigree from catalogue of breeder.

Sire of Monroe S., 2:161/4.

DICTATOR JR. (I-64), bay with black points, 15 T/2 hands, II 50 pounds ; foaled I 883 ; bred by Mr. Shepard, Lovington, Ill. ; got by Shepard's Commander, son of Dictator: dam Dusty, bay, bred by Mir. Shepard, got by a son of an Arabian horse ; 2 d dam bay, said to be by old Medoc. Sold to James Douk; to Dr. J. Leslie, Elwin, Ill.; to G. A. Wadell, Ohio. Information from Dr. Leslie.

Sire of Merit, $2: 17^{1 / 1} / 4$

DICTATUM ( $1-32$ ), bay; foaled $\mathrm{r} 882$; bred by Richard West, Lexington, Ky.; got by Dictator, son of Hambletonian : dam Sally, bay, bred by E. D. Smith, Great Crossings, Ky., got by Monroe Chief, son of Jim Monroe ; 2 d dam Queen, by Mambrino Medley, son of Mambrino Chief ; 3 d dam Mary, bay, bred by M. M. Kenedy, Paris, Ky., got by Joe

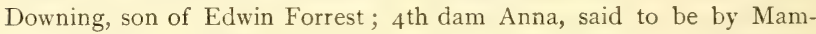
brino LeGrand. Sold to S. C. Wells, Leroy, N. Y., who sends pedigree. Sire of 2 trotters $\left(2 \cdot 29 \frac{1 / 4}{4}\right)$.

DICTATUS (3-64), $2: 083 / 4$, chestnut; foaled 1890 ; bred by W. C. France \& Sons, Lexington, Ky. ; foaled the property of J. W. Robinson, Savanna, Cal. ; got by Red Wilkes, son of George Wilkes: dam Miss Lollie, bay, bred by L. Herr, Lexington, Ky., got by Dictator, son of Hambletonian ; 2d dam Gold Pen, chestnut, bred by Logan Railey, Versailles, Ky., got by Mambrino Abdallah, son of Mambrino Patchen; 3d dam Lady Harold, bay, bred by Logan Railey, got by Harold, son of Hambletonian ; $4^{\text {th }}$ dam Emily Chester, said to be by Mambrino Patchen; and $5^{\text {th }}$ dam Patsy, by Snowstorm. Sold to George H. Reed, Los Angeles, Cal.; to F. W. Day, Belmont, Cal. Pedigree from J. B. Iverson, Salinas City, Cal., breeder of Dictatress.

Sire of Ama A., $2: 161 / 2: 2$ pacers (2:091/2).

DICTIONARY, 2 :30, brown, I6 $1 / 2$ hands, 1250 pounds; foaled $\mathrm{r} 884$; bred by D. Edgar Wasson, Versailles, Woodford County, Ky. ; got by Dictator, son of Hambletonian: dam brown, bred by Chas. Alexander, Versailles, Ky., got by Administrator, son of Hambletonian ; $2 \mathrm{~d}$ dam said to be by Hichcock's Ashland. Sold to Railey Bros., Versailles. Ky.: Steve Maxwell, Washington, C. H., Ohio, who owned him, I892. Pedigree from breeder.

DIC ГОR, ( I-I6), brown, I51/2 hands, Iooo pounds; foaled I 888 ; bred by Andy Yetter, Shirley, Ind.; got by Delineator, son of Dictator: dam Dollie Yetter, sorrel roan, bred by Andy Yetter, got by little Joe, Cans. 
dian; 2 d dam Beck, said to be by (ien. Taylor; and 3 d dam Eliza, by Peter Tysel. Pedigree from catalogue of breeder.

Sire of Slickaway, $2: 281 / 2$.

DICTUM ( $\mathrm{r}-32), 2: 20^{\mathrm{I} / 2}$, brown ; foaled $\mathrm{x} 888$; bred by Mrs. I.ouisa Mizner, Burr Oak, Mich.; got by Dictator Almont, son of Dictator : dam Hetty (dam of Mambrino Maid, $2: 293 / 4$ ), said to be by Frank Moscow, son of Moscow, by Green's Bashaw ; 2d dam, Maggie, chestnut, bred by C. C. McCarty, Knoxville, Tenn., got by Magna Charta, son of Morgan Eagle ; 3d dam Maggie Wilson, said to be by Sir Talton Sikes, son of Stumps.

Sire of Rextel, $2: 23 \frac{1}{2}$.

DIETETIC ( $\mathrm{I}-64$ ), bay; foaled I $89 \mathrm{I}$; bred by L. Herr, Lexington, Ky. ; got by Allandorf, son of Onward: dam King Girl, chestnut, foaled I878, bred by R. S. Strader, Lexington, Ky. ; got by Mambrino King, son of Mambrino Patchen; 2 d dam Lelah, chestnut, foaled 1867 , bred in Indiana, said to be by Wilson's Blue Bull; 3 d dam by Tom Hal; and $4^{\text {th }}$ dam by imported Glencoe. Sold to George Campbell, Parkersburg, W. Va.; to J. S. Bascom, Athens, O. Pedigree from catalogue of breeder.

Sire of Dr. Chase, $2: 17$.

DIE-VERNON, bay; foaled I8I9; bred by Benjamin Ogle, Esq. of Maryland; got by Ball's Florizel-Oscar-Hero, by Hall's Union-Gabriel -Active, By Chatham-Shepherdess, by Slim-Shrewsbury, by Hamilton's Figure-Thistle, by Dove-Stella, by Othello-Col. Benjamin Tasker's imported mare Selima. Edgar.

DIGNUS (GUADALQUIVER) (3-64), bay; foaled I 888 ; bred by H. C. McDowell \& Son, Lexington, Ky. ; got by Dictator, son of Hambletonian : dam Sally Wilkes, bay, foaled I 879 , bred by J. A. Shackelford, Richmond, Ky., got by George Wilkes ; 2 d dam Laura, chestnut, bred by J. T. Shackelford, Richmond, Ky., got by Joe Hooker, son of Mambrino Chief ; 3d dam Minna, bay, bred by F. P. Kinkead, Midway, Ky., got by Red Jacket, son of Comet (Billy Root) ; $4^{\text {th }}$ dam Undine, said to be by Gray Eagle; 5th dam Rowena, by Superior, son of Whip; 6th dam by Buzzard thoroughbred; 7 th dam by imported Shark; and 8 th dam by Union. Four last dams very doubtful. Sold to H. C. McDowell, Lexington Ky. ; to J. U. Bradley, Georgetown, Ky. Pedigree from catalogue of breeder.

Sire of 2 pacers $\left(2: 05 \frac{1}{4}\right)$; dam of $x$ pacer.

DILIGENCE (HARRIS'). Registered in the Percheron Norman Stud Book. Imported from France, about r839-40. Kept $\mathrm{r} 848$, at the hotel of Wm. Cottman, Jenkintown, Penn., ten miles north of Philadelphia, who owned a half interest in him several years.

Advertised at Jenkintown, I 847, by Wm. Cottman and Edward Harris. 
DILIGENT (I-32), $2: 28 \mathrm{I} / 2$, brown, $15 \frac{1}{4}$ hands; foaled $\mathrm{I} 883$; bred by S. Craig, Georgetown, Ky. ; got by Dictator, son of Hambletonian : dam Jane Carlisle, chestnut, bred by S. Craig, got by Antar, son of Almont ; 2 dam chestnut, bred by S. Craig, got by John C. Breckenridge, son of Johnson's Toronto; $3 \mathrm{~d}$ dam Stubtail, bred by S. Craig, got by imported Yorkshire. Pedigree from breeder. Sold to B. J. Treacy, Lexington, Ky. ; to John Condon and J. G. R. McCorket; to Thomas B. Lovatt, Philadelphia, July, I 890.

Sire of Jean W., $2: 261 / 4$.

DILLARD ALEXANDER ( $\mathrm{I}-64$ ), 2 :30, brown; foaled I $88_{3}$; bred by John Hughes, Muir, Ky.; got by France's Alexander son of Ben Patchen: dam Moonbeam (dam of Wick $2: 26 \mathrm{~T} / 2$ ), said to be by John Dillard. Sold to Theodore Bray, Council Bluffs, Ia.; to G. H. Jones, Audubon, Ia., who sends pedigree.

Sire of Alex Gray, 2:21 1/4 ; I sire of I pacer; I dam of I pacer.

DILLARD DENMARK (COOPER'S) ( $\mathrm{I}-64)$, black, left fore and left hind feet white; foaled $\mathbf{r} 887$; bred by W. D. Bonta; got by Sumpter Denmark Jr., son of Sumpter Denmark : dam Black Bell, said to be by John Dillard; 2d dam Rock Ann, by Plow Boy; 3 d dam by Blackburn's Whip. Sold to Jos. A. Cooper, Todd's Point, Ky.

DILLARD DENMARK (I-32), bay, 15 1/2 hands; foaled I 888 ; bred by H. Gaines, Sonora, Ky. ; got by Denmark Chief, son of Cromwell : dam said to be by Eureka, son of Green Mountain Morgan; and $2 \mathrm{~d}$ dam by Red Oak. Sold to A. J. Hoover, Sonora, Ky.

DILLARD DENMARK ( $\mathrm{I}-64$ ), said to be by Mark Diamond: dam by John Dillard; and $2 \mathrm{~d}$ dam by Rob Roy Denmark. Advertised in Lexington (Ky.) papers by W. W. Adams.

DILLARD DUDLEY (I-32), dark bay, I53/4 hands; foaled I 869 ; said to be by John Dillard: dam by Star Davis Jr.; 2d dam by Mark Antony; and 3 d dam by Aratus. Advertised in 1876 by Ray Bralert in Lexington (Ky.) Papers.

DILLINGHAM (3-128), bay, I61/2 hands, I 300 pounds; foaled 1879 ; bred by J. Harding, Pleasureville, Ky. ; got by Volunteer Star, son of Volunteer : dam Em Siddell, bay, bred by D. Swigert, and R. T. Thompson, Spring Station, Ky., got by Alcalde, son of Mambrino Chief; 2 d dam Alice, said to be by Crockett's Bellfounder, son of Brown's Bellfounder ;

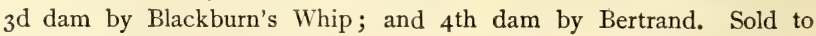
Charles Cookston ; to F. R. Eversole, St. Louis, Mo. Pedigree from catalogue of breeder.

Sire of Hasdenbal, $2.271 / 2$. 

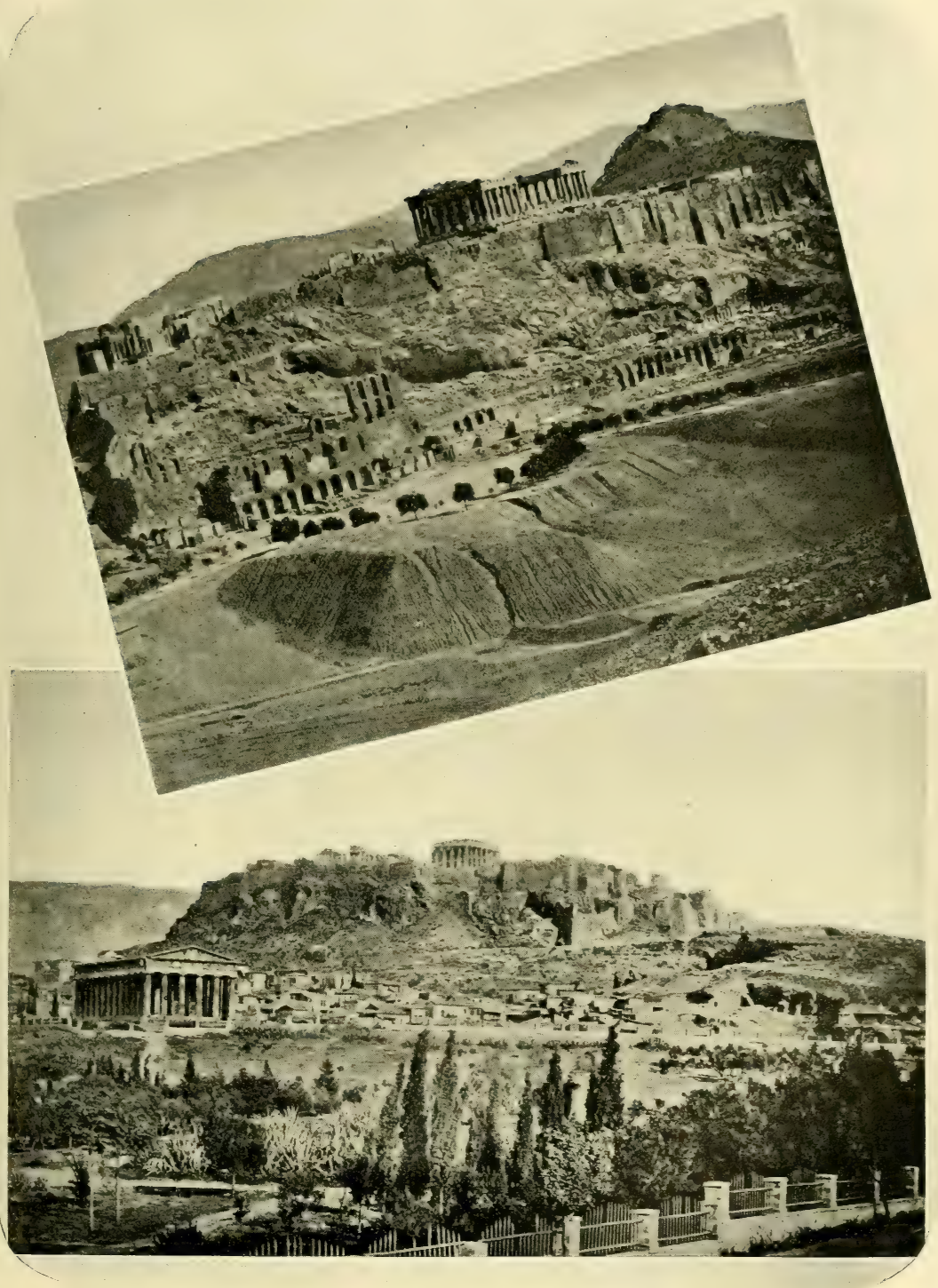

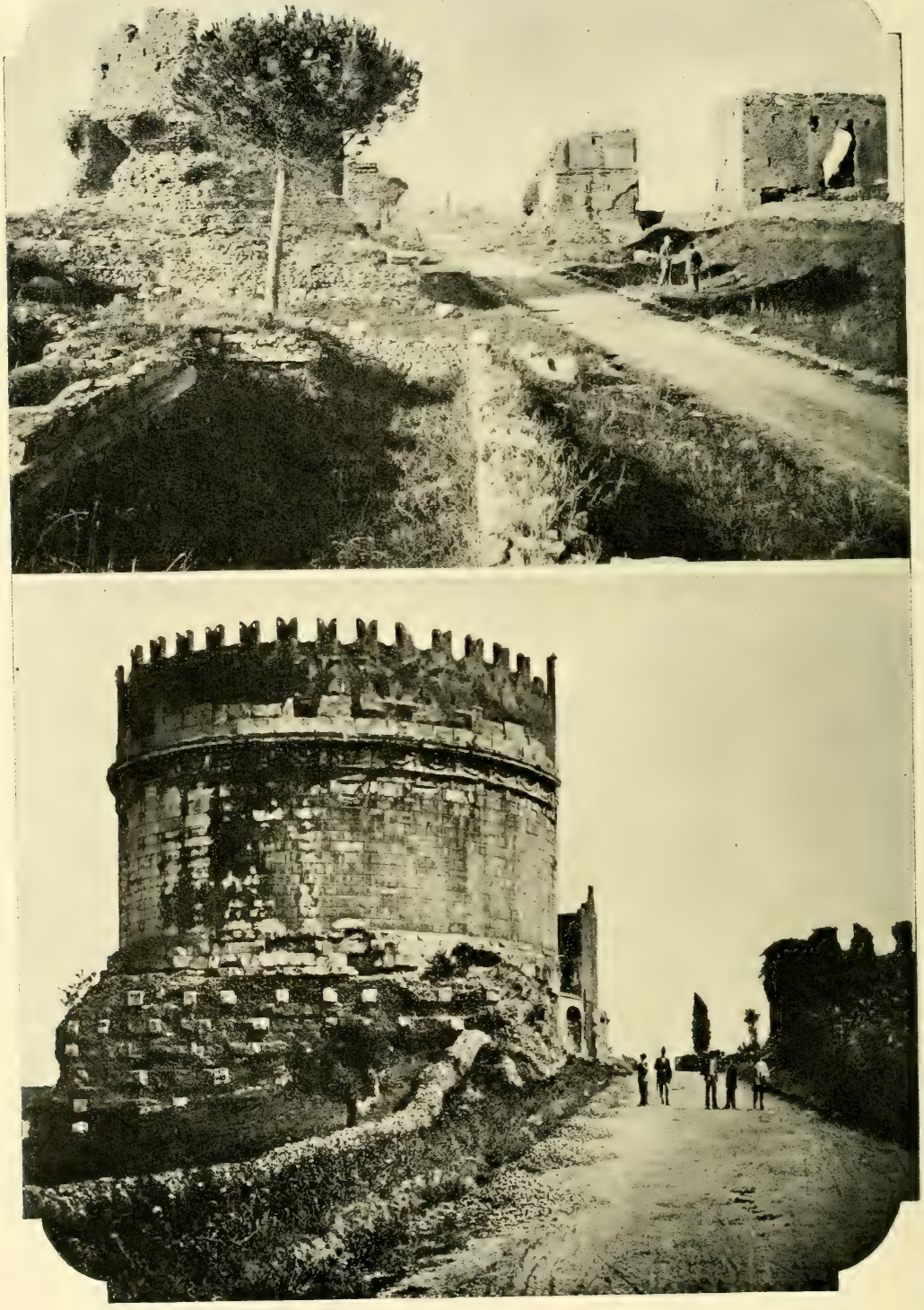

Appian Way, Italy. 
DING DONG (I-64), $2: 26 \frac{1}{4}$, brown, I $5 \frac{1}{4}$ hands, Iooo pounds; foaled 1889 ; bred by C. C. Seaman, San Diego, Cal., foaled the property of Watson \& Jefferson, Mason County, Ky. ; got by Bell Boy, son of Electioneer : dam Miss Unknown, bay, bred by Charles Stanford, Schenectady, N. Y., got by Sir Walkill, son of Hambletonian; 2d dam Unknown, brown, bred by Andrew Yerkes, Orange County, N. Y., got by Harry Clay, son of Neaves' Cassius M. Clay Jr. ; 3 d dam, said to be by Liberty. Sold to C. C. Seaman, San Diego, Cal.; to T. C. Jefferson, Lexington, $\mathrm{Ky}$, who sends pedigree.

Sire of 2 trotters $(2: 221 / 4)$.

DINWIDDIE (DIOMED), bay, no white, I5 $\frac{1}{2} 2$ hands; foaled June 2, I 804 ; bred by Dr. Wm. Cutter, Dinwiddie, Va., got by imported Diomed : dam by Wildair; 2 d dam by Apollo; 3 d dam by Partner ; 4 th dam by Fearnaught; and $5^{\text {th }}$ dam imported, property of John Bland, Esq. Sold for $\$ \mathbf{I}, 000$, when four years old, to John Earle and Luther Smith, who advertised him at Hardwick, Mass., from 18 Io to $\mathrm{r} 8 \mathrm{I}_{3}$; to C. W. Van Ranst, who advertised him, $1824-5-6$, to stand at West Farm and near Jamaica, Long Island, for $\$ 20$. This advertisement states that he has great depth of chest, length of waist, and breadth of loin, and that he has been kept under the name of Diomed in the eastern part of Connecticut, the counties of Worcester and Berkshire, Mass., and Rensselaer, N. Y.; to a company at Utica, N. Y., I825, who kept him at Deerfield, where he died $\mathrm{r} 826$. Pedigree by C. W. Van Ranst, in American Turf Register, October, I83 1 .

DIO (3-32), $2: 30$, bay, bred by Lionel G. Fish, Shrewsbury, Vt.; got by Gen. Sherman, son of Young Columbus: dam brown, bred by James Congdon, Clarendon, Vt., got by Ethan Allen. Gelded young. Pedigree from breeder.

DIOMED, chestnut; foaled 1777 , bred by the Hon. Richard Vernon of Newmarket and sold to Sir T. C. Bunbury, Bart, England; got by Florizel, son of King Herod, by Tartar, son of Croft's Partner, by Jig, son of Byerly Turk : dam by Spectator ; 2d dam by Blank ; 3d dam by Flying Childers; $4^{\text {th }}$ dam by Gray Grantham; $5^{\text {th }}$ dam by Paget Turk; and 6th dam by Leede's Arabian. Imported into Virginia, I799, by Col. John Hoomes, whose property he died r8o8. He was a successful runner in England, and became a very successful sire in America.

The following excellent historical article on Diomed, is by S. W. Parlin, the distinguished editor of The American Horse Breeder, Boston, dated March I I, I902 :

"Diomed was foaled in I777. The English author, 'Frank Forrester' (William Henry Herbert), in his 'Horse of America' says of him: 'Diomed was a very distinguished racer in England, the first winner of the Derby, and, as a stallion, although placed in competition with High- 
flýer, Sir Peter Teazle, Rockingham, Pegasus, etc., was no less celebrated.' The above author names a large number of progeny that Diomed left in England; among them Gray Diomed, that he pronounced one of the most celebrated horses that ever ran in England, afterwards ran with such success in Russia, that several of his stock were sent for from that empire. Diomed was imported into Virginia in I 799, by the late Col. John Hoomes of Bowling Green. The horse was then twenty-two years old. He lived until I8o8, but we believe that he got no foals after the season of $\mathrm{I} 805$.

What Diomed did in those few years in the way of improving the racing stock of America, may be pretty accurately estimated by a set of tables published in I 843 , which shows the best races at one, two, three and four miles, that had been run in America up to that time. These tables may be found in a work, entitled 'Youatt on the Horse,' edited by the well-known authority, J. S. Skinner, and published in 1843 . The table of the best races for one mile is as follows:

Best Races. Mile Heats.

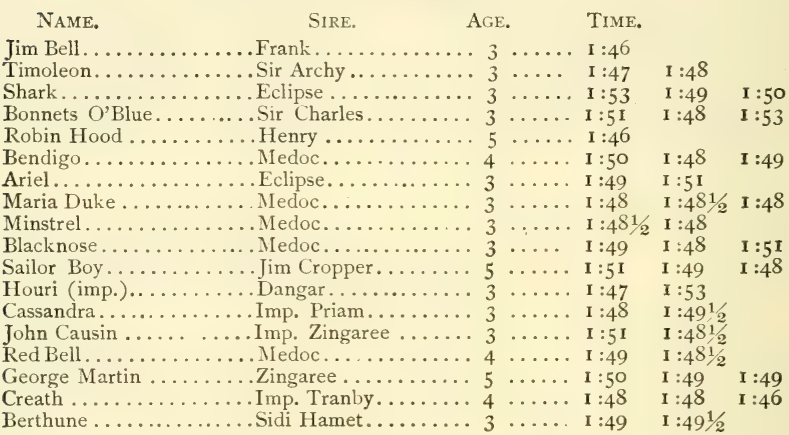

Above are the eighteen best races by the records that had been run in America up to $\mathrm{I} 843$. Of the animals that made these best records, the following are direct descendants in the male line of imported Diomed, viz. : Jim Bell, Timoleon, Shark, Bonnets O'Blue, Robin Hood, Bendigo, Ariel, Maria Duke, Minstrel, Blacknose, Sailor Boy, Red Bell, George Martin and Berthune. It seems that $\mathrm{I}_{4}$ of the $\mathrm{I} 8$ best records of mile heats, up to that time, had been won by direct descendants in the paternal line of imported Diomed. It was Diomed against all the stallions in America, and fourteen for Diomed, against barely four for all the others. But this was not all. Three of those four others were from dams that were descendants of Diomed, viz.: Cassandra, John Causin, and Creath.

The pedigrees of the dams of Cassandra and John Causin, each show a double cross of the old first Derby winner. The only one in the whole lot that is not a descendant of or quite closely related to old Diomed is Houri.

Let us now examine the table of best records of two-mile heats that had been made in America, from the earliest period of racing, up to 1843. It is as follows: 
Best Races at Two-mile Heats.

Name. Sire. AGE. Time.

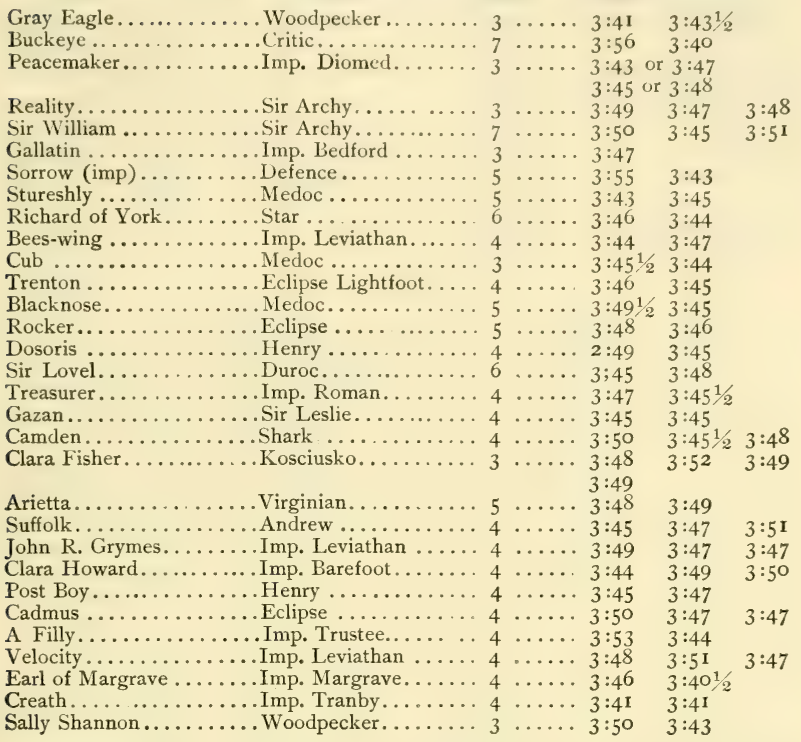

There are thirty-one records in the above list, and twenty-one of them were made by animals that trace directly in the paternal line to imported Diomed. They are Gray Eagle, Buckeye, Peacemaker, Reality, Sir William, Stureshly, Richard of York, Cub, Trenton, Blacknose, Rocker, Dosoris, Sir Lovel, Gazan, Camden, Clara Fisher, Arietta, Suffolk, Post Boy, Cadmus, and Sally Shannon. The pedigrees of the dams of three of the others, viz.: Treasurer, Earl of Margrave and Creath, also show a cross of Diomed. Here we have Diomed against all the thorough-bred stallions that had ever done service in America, as sires of winners of the best two-mile heats. Result, Diomed twenty-one, all the other stallions ten, and three of the ten are related to Diomed. The next table is as follows :

Best Races at Three-mile Heats.

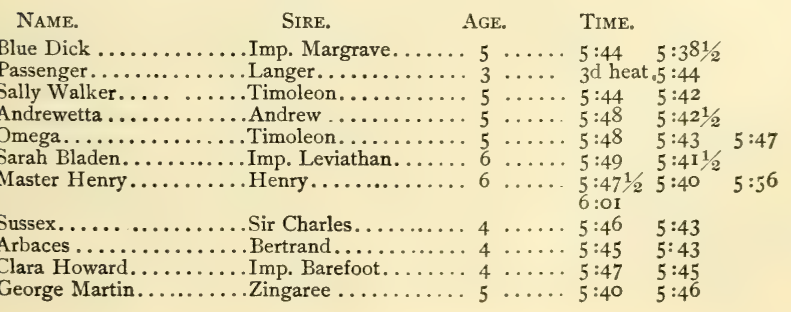




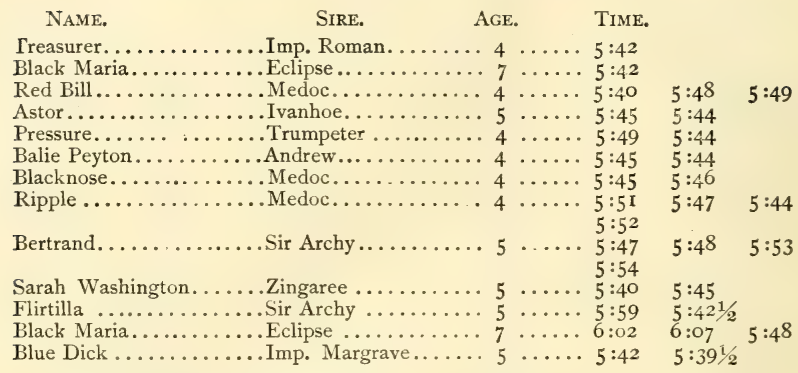

There are twenty-four records in the above list, and the winners of sixteen of them are direct descendants in the male line of imported Diomed. These are Sally Walker, Andrewetta, Omega, Master Henry, Sussex, Arbacas, George Martin, Black Maria, Red Bill, Balie Peyton, Blacknose, Ripple, Bertrand, Sarah Washington, Flirtilla and Black Maria. The name of the latter occurs twice, as does also that of Blue Dick. Each won races in which they beat different horses. It is Diomed against all other thoroughbred sires in America again, and the score stands sixteen for Diomed against eight for all the others. The dams of four of these eight were also from descendants of Diomed. The last table is as follows :

Best Races at Four-mile Heats.

Name. Sire. Time.

\begin{tabular}{|c|c|c|c|}
\hline Imp. Trustee ......... & $\cdots \cdots 7: 321 / 2$ & & \\
\hline .......... Duroc........... & …7: $7: 37^{2}$ & $7: 49$ & $8: 2$ \\
\hline Boston............... Timoleon..... & $\ldots \ldots 7: 40$ & & \\
\hline Wagner................... Sir Charles 5 & $\cdots \cdots 7: 48$ & $7:$ & \\
\hline Wagner ..................... Sir Charles.... & $\ldots \ldots 7: 51$ & $7: 43$ & \\
\hline Gray Medoc........................ 6 & $\begin{array}{ll}\cdots & 7: 35 \\
8: 17\end{array}$ & $8: 19$ & $7: 4$ \\
\hline den & $7: 44$ & $7: 43 \frac{1}{2}$ & $7: 56$ \\
\hline$\ldots \ldots \ldots$ Fra & & $7: 40$ & \\
\hline$\ldots \ldots \ldots \ldots \ldots \operatorname{Im}$ & $8: 02$ & $7: 8$ & \\
\hline h Bladen..............Im & $\cdots 7: 45$ & $7: 4$ & \\
\hline .............. Tim & $\therefore 7: 4$ & $8: 0$ & \\
\hline$\ldots \ldots \ldots \ldots \ldots \operatorname{Im}$ & .. $7: 421 / 2$ & $7: 581 / 2$ & \\
\hline ...........Sir & -. $7: 48$ & $7: 53$ & \\
\hline scombe......... & $\cdots$ & & \\
\hline Margaux & $\cdots$ & & \\
\hline$\ldots \ldots \ldots \ldots \mathrm{I}_{1}$ & $\cdots$ & & \\
\hline Miss Foote............. & ……7:361/2 & $7: 39$ & \\
\hline
\end{tabular}

There are seventeen records in the above table, and the winners of ten of them trace directly to Diomed through their sires, viz., Eclipse (American), Boston, Wagner, Wagner, Gray Medoc, Lady Clifden, Jim Bell, Omega, Fanny Wyatt and John Bascombe. It is ten for Diomed, against seven for all the other stallions in America. The dams of three of the seven, viz., Fashion, Duane and Eutaw, were inbred to Diomed. Fashion at that time held the four-mile record. Her dam was Bonnets O' Blue, by Sir Charles, son of Sir Archy, and her second dam was Reality, by Sir Archy.

The total number of best records in the four tables is 9o. The winners of $6 \mathrm{I}$ of them trace directly through their sires to imported Diomed, 
and the dams of $\mathrm{I}_{3}$ of the others were descendants of the old Derlay winner. It is Diomed against all other sires in America, and the score stands $6 \mathrm{r}$ for Diomed against 29 for all of the others, and the dams of I 3 of the 29 are descendants of Diomed, most of which were inbred to him.

We have several times stated that Diomed did more to improve the speed of American horses than all the other stallions that had been imported up to his time. Our readers can judge from the above tables of best records whether that statement is well founded or not. We have also stated that the name of Diomed is found in the pedigrees of all the record breakers in this country whose blood lines are known, whether runners, trotters or pacers. Our readers can easily learn for themselves whether that statement is correct or not by analyzing the pedigrees of those record breakers.

The portraiture of Diomed, such as it is, though more highly finished as an engraving is faithfully copied, as to the outline and figure, from the plate in the first volume of the English Sporting Magazine; in regard to which, the editor of that work says:

'No expense has been spared, and they trust it will entitle them and the artists concerned, to the credit of not having performed more than they were capable of performing.' In few arts, however, have greater progress been made, since that day, $179^{2}$, than in the fine art of engraving. We shall regret it if the figure be not found to correspond with recollections of the horse; It was the only copy we could get. For the following brief description, as well as for some of the names on the list of his get, in this country, we are indebted to J. C. Goode, Esq., whose father was at one time, his owner in part: 'He was a fine horse, about I 5 hands 3 inches high, a little dish-faced, as the farriers call it; rather straight in the hocks, and bent a little too much in his hind fetlocks. He was a fine clear chestnut, without white, except a small touch on one of his hind heels scarcely perceptible. On the whole, he was a fine and beautiful horse.'

Diomed, a chestnut horse, foaled in 1777 , was bred by the Hon. Richard Vernon of Newmarket, and sold to Sir Thomas Charles Bunbury, of whom he was purchased by Messrs. Lamb and Younger, for the sum of 50 guineas, and imported into Virginia, in the spring of 1798 , when twenty-one years old.

He finished at Bowling Green, the season which had been there commenced by Cormorant. At Newmarket fall races, of that year, he was purchased of Col. Hoomes by Col. M. Selden, who was afterwards joined in the purchase by Thomas Goode, Esq. He made the two next seasons at Mr. Goode's, in Chesterfield.

Diomed was got by Florizel, from a Spectator mare (the dam of Pastorella, Laure, Fancy, etc)., her dam (sister to Horatius) by Blank; grandam (Feather's dam and full sister to the grandam of Cygnet and Blossom), by Childers, from Miss Belvoir, by Gray Grantham ;-Paget Turk-Betty Percival, by Leede's Arabian.

At Newmarket, second spring meeting I 780 , Diomed won a sweepstakes of 500 guineas each, half forfeit, (six subscribers), beating Antagonist, Diadem and Savannah; betting two to one against Savannah, five to two against Diomed, and seven to two against Diadem.

Diomed was beaten six times in $178_{3}$; viz:- at Newmarket, for the Craven stakes, won by Aleric:-in the first spring meeting, for the $£$ 50 plate, by Laburnum and Drone ; also, for the King's plate, by Drone ; at 
Ascot Heath, by Soldier and Oliver Cromwell :-at Winchester for the King's plate by Anvil:- and at Lewes, for the King's plate, by Mercury and Diadem. He fell lame, in running at Winchester, and was put out of training. The above were all of his engagements, from which it will appear, that he was beaten eight times, and paid one forfeit; and won ten races and received one forfeit. He won when three years old seven races without losing one; among these were the Derby stakes, at Epsom ; and a sweepstakes of 500 guineas each, at Newmarket. This unvarying success gave him great eclat and reputation as a race horse. After this he ran many races with indifferent success.

Diomed commenced serving in England in 1785 , at 5 guineas, and in 1789 , he was raised to ten guineas. Some of his colts proving obstinate and restiff, he went out of fashion as a stallion, having covered his last season, in $\mathrm{I} 798$, at the reduced price of two guineas. $\mathrm{He}$ got many winners in England, and several of the best runners of their days have sprung from his loins.

After the season of 1798 , Sir T. Charles Bunbury sold Diomed for 50 guineas; but after landing in America, he was resold for 1000 or 1200 guineas. He was kept several seasons in Virginia where there is scarcely a good horse without a cross of himself or one of his descendants.

Some of the most distinguished of his get, in England, were:

\begin{tabular}{|c|c|c|}
\hline & & \\
\hline David $\ldots \ldots \ldots \ldots \ldots \ldots \ldots \ldots \ldots$ & " & $\ldots \ldots$ \\
\hline Hermoine . . . . . . . . . . . . . . . . . . . & & $\ldots \ldots 1780$ \\
\hline 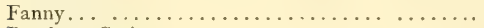 & & $\ldots \ldots \quad 1790$ \\
\hline B c from Carina $\ldots \ldots \ldots \ldots \ldots \ldots \ldots \ldots \ldots \ldots \ldots \ldots \ldots \ldots$ & " & $\ldots \ldots 1790$ \\
\hline 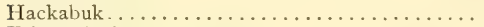 & " & $\ldots \ldots$ I 791 \\
\hline 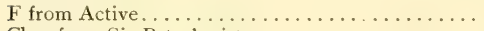 & “ & $\ldots \ldots 1790$ \\
\hline Ch c from Sir Peter's sister................ & & $\ldots \ldots, \mathbf{I} 794$ \\
\hline 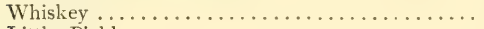 & & $\ldots \ldots 178$ \\
\hline 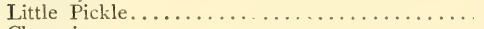 & & $\ldots \ldots 1790$ \\
\hline Champion...$\ldots \ldots \ldots \ldots \ldots \ldots \ldots \ldots \ldots \ldots \ldots \ldots \ldots$ & & $\ldots \ldots 179$ \\
\hline 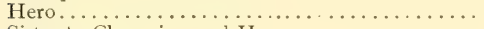 & " & $\ldots \ldots 1792$ \\
\hline Sister to Champion and Hero............. & " & $\ldots \ldots 179$ \\
\hline 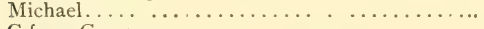 & 6 & $\ldots \ldots 1790$ \\
\hline C from Crane $\ldots \ldots \ldots \ldots \ldots \ldots \ldots \ldots$ & 6 & $\ldots \ldots \mathbf{I} 79$ \\
\hline 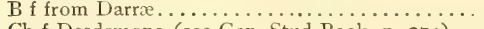 & & $\cdots \cdots$ \\
\hline Ch f Desdemona (see Gen. Stud Book, p. 274)... & " & $\ldots \ldots$ \\
\hline ella's dam........................ & 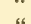 & $\cdots \cdots$ \\
\hline key (see Gen Stud Book p. 275 ) & 66 & $\cdots \cdots 179$ \\
\hline & & \\
\hline
\end{tabular}

Gray Diomed, one of the most celebrated horses that ever ran in England; afterwards ran with such success in Russia, that several of his stock were sent for from that empire.

Ch $\mathrm{f}$ sister to Gray Diomed ............. foaled..... I 788

Ch $\mathrm{c}$ brother to Gray Diomed ............ " $\ldots \ldots$ I 789

Robin Gray...................... * ..... I I 790

Cedar.......................... " ..... I

Grayhound ..................... ‘ ..... I 794

Popular....................... " .... 1795

B c from Dax....................... I79 I

Monkey....................... " .... 1 786

Martezuma..................... " ..... 1783

Instlavaca ..................... “ .... I790

Guatimozin . .................... " . ... I I

Ch $\mathrm{f}$ sister to do.................... " ..... I790

Ch c from Grenadier's dam............. $\ldots \ldots \ldots$ I 787

C from Flycatcher.................. " ..... 1790 


\begin{tabular}{|c|c|c|}
\hline & & \\
\hline Charles, brother to do................ & ". & $\ldots \ldots 1790$ \\
\hline 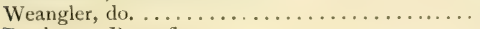 & “ & $\ldots \ldots \quad 1794$ \\
\hline 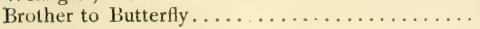 & " & $\ldots \ldots 1790$ \\
\hline 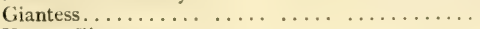 & “ & $\ldots \ldots 1798$ \\
\hline 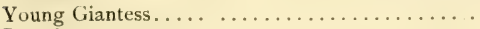 & " & $\ldots \ldots 1790$ \\
\hline 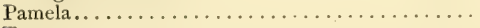 & " & $\ldots$. \\
\hline 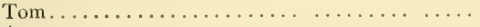 & “ & ...... \\
\hline 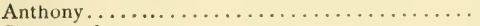 & " & $\ldots \ldots$ \\
\hline 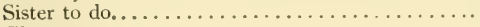 & " & 1790 \\
\hline$\ldots \ldots \ldots \ldots \ldots \ldots \ldots$ & " & $\ldots \ldots$ \\
\hline$\ldots \ldots \ldots \ldots \ldots \ldots \ldots$ & " & $\cdots \cdots$ \\
\hline 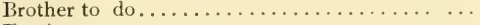 & “" & $\ldots \ldots$ \\
\hline$r \ldots \ldots \ldots \ldots \ldots \ldots \ldots \ldots \ldots \ldots$ & “ & ..... \\
\hline Sister to do (Snug's dam) $\ldots \ldots \ldots \ldots \ldots \ldots$ & “ & $\ldots \ldots$ \\
\hline from Isabel. ..................... & “ & $\ldots \ldots$ \\
\hline Brother to Amazon..... . . . . . . . . . . . & “ & ...... \\
\hline$\ldots \ldots \ldots \ldots \ldots \ldots \ldots \ldots \ldots \ldots \ldots \ldots \ldots \ldots$ & " & $\ldots \ldots$ \\
\hline o do $\ldots \ldots \ldots \ldots \ldots \ldots \ldots \ldots \ldots \ldots \ldots$ & " & ... \\
\hline 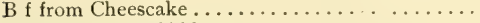 & " & $\ldots \ldots$ \\
\hline Ch f from Mrs. Siddons . . . . . . . . . . . . . . . & " & ...... \\
\hline 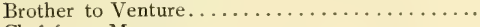 & 6 & $\ldots \ldots$ \\
\hline Ch f from Mopsqueeser.................... & 6 & $\ldots \ldots \quad$ I 790 \\
\hline 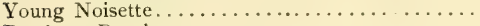 & 66 & $\ldots \ldots 178$ \\
\hline B c from Rosaletta....................... & "6 & $\ldots \ldots$ I 79 \\
\hline 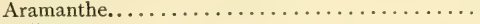 & व6 & $\ldots$ \\
\hline$\ldots \ldots \ldots \ldots \ldots \ldots \ldots \ldots$ & “ & ...... \\
\hline$\ldots \ldots \ldots \ldots \ldots \ldots \cdots \cdots \cdots$ & “ & ...... \\
\hline$\ldots \ldots \ldots \ldots \ldots \ldots \ldots \ldots \ldots$, & “6 & ...... \\
\hline B f from Temperance... . . . . . . . . . . . & & $\ldots .$. \\
\hline 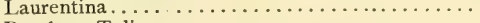 & $"$ & $\ldots \ldots$ \\
\hline 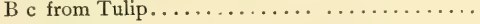 & $"$ & ..... \\
\hline
\end{tabular}

In America, the most renowned of his progeny, as now recollected, are : Sir Archy: dam by Rockingham; bred by Col. Tayloe, afterwards owned and run by W. R. Johnson, Esq. ; foaled I 805. Florizel : dam by Shark; in 1805 beat Peace Maker, the celebrated match, four mile heats.

Potomac, ran and was at Petersburg, two miles in $3 \mathrm{~m} .43 \mathrm{~s}$.; the quickest race to this day, in America-Mr. Wilkes, I8or.

Peace Maker : bred by Col. Hoomes; afterwards owned and run by Col. Tayloe, r 8or.

Top Gallant: dam by Shark-Mr. Clayton; afterwards owned and run by Col. Tayloe, I80I.

Hamlintonian : dam by Shark-Mr. Hamlin; afterwards owned and run by Col. Tayloe, r8or.

Vingtun: dam by Clockfast (sold in 1803 , for $\$ 27 j 0$ ) -Gen. Wade Hampton and Gov. Ed. Floyd, r8or.

Stump the Dealer: dam by Clockfast-W. R. Johnson and Ralph Warmeley, I80 I.

Duroc: dam by Gray Diomed-Wade Mosby-W. M. and Mr. Badger, r8o6.

Hampton : dam by Gray Diomed-Gen. Hampton-Mr. J. V. Bond, I806.

Am. Truxton-Gen. Andrew Jackson, I806.

The dam of Henry, r8o6.

And the dam of Eliza White, I8o6.

Lavinia, Lady Chesterfield, Rusty Robin, Monticello, Wring-Jaw, Miss Jefferson, Wragland's Diomed, Perkin's Diomed, the dam of Roxana, Fitz Diomed, Wonder, St. Tamany, the dam of Bobtail, Herod, Tryon, 
Medisin, Constitution, Wrangler, Superior, Hornet Sting, Minerva, Virginnis ; dams of Sir Alfred, Henry, Sir Walter, Diomed, Eagle, Shylock ; Bolivar's grandam, Corporal Twins' dam, Clifton's dam.

Diomed died in 1808 , aged 31 years."

DIOMED, I5 $3 / 4$ hands, chestnut ; foaled 1816 ; said to be by Duroc, son of imported Diomed: dam by Gen. Condit's Collector, son of imported Rockingham; and $2 \mathrm{~d}$ dam Nameless, owned by Judge Meade. Owned by Warren Delancey, Dutchess County, N. Y. Kept at Pleasant Valley, N. Y., I826-7 and 9. Advertised as follows:

"Diomed. Formerly the property of Warren DeLancey of Dutchess County.

"Diomed will commence his stand for the season, at the stable of Jeremiah Drake, in the village of Goshen, on Tuesdays, Wednesdays and Thursdays of each week, during the season-the remainder of each week he will be at the stable of James Palmer, in the town of New Windsor, Little Britain, changing alternately throughout the season, at $\$ 7$ the season and $\$$ Io to insure a mare with foal.

"Diomed is a chestnut sorrel eleven years old, I6 hands high, strong, bony, active and moves well, and his colts are very fine.

\section{GosH \\ Peter Dean.
arch io, i 828 .}

"Diomed, formerly the property of Warren DeLancey Esq., of Dutchess County, will stand the ensuing season at the stable of John C. Nicholson in the village of Montgomery and the stable of James Palmer, in Little Britain, town of New Windsor, three days at each place changing alternately throughout the season. For particulars refer to handbills.

Benjamin H. Mitchell, Charles Palmer.

Monday, March 22, I830."

DIOMED; foaled I820; said to be by Dinwiddie, son of imported Diomed. Advertised 1824 at Hartford and Norwich, Vt., and is probably the same horse described as bay, medium size, that was afterwards owned by Mr. Page of Keene, N. H.

DIOMEDE, bay; bred by Dr. William Cutter, Dinwiddie County, Va. Advertised, I82x by Luke Francis at stable of Joseph Wadsworth, Pittstown, Rensselaer County, N. Y., I5 miles from Troy, on Troy and Lansingburgh road. Mr. Francis states that Diomede was kept in Pittsfield, Berkshire County, Mass., four seasons past.

DIOMEDE, brown with star, $161 / 2$ hands; foaled 1817 ; said to be by imported Nimrod (Gates'). Advertised in New Jersey, I822, by Joshua English.

DIOMEDE OR WHIP, bay, I6 hands; foaled I 823 ; said to be by Virginia Whip, son of imported Whip : dam by Ganymede, son of Diomed. Advertised by John Stearns, Indiana, in 1828 . 
DIOMEDE, bay, I5 $5 \frac{1}{2}$ hands; foaled 1820 ; bred by Samuel F. White \& John L. Lloyd; got by Duroc: dam said to be by old Messenger. Advertised with pedigree as above in the Danbury (Conn.) Recorder, I 826 , by O. S. Chase.

DIOMEDE (HEMENWAY'S), dapple bay with white face and thrie white feet, Io6o pounds, $15 \frac{1}{2}$ hands; foaled 1828 ; bred by Asa Hemenway, Bridport, Vt.; gnt by Post Boy, son of Dinwiddie : dam bay, bred by John Bosworth, Bridport, Vt., got by Aurelius a large bay horse, son of Satterly Horse; 2 d dam Fancy, brought from New Jersey by a Mr. Carter. Kept at Longueil, P. Q., two seasons about I $835-6$, and returned to Vermont. Died 1852 . Pedigree from son of breeder.

DION, bay, I $5 \frac{1}{2} 2$ hands; foaled 1795 ; bred by W. Garforth, England; got by Spadille, son of Highflyer : dam Faith, by Pacolet; 2 d dam Atlanta, by Matchem; and $3 \mathrm{~d}$ dam Lass of the Mill, by Oronoko-old Traveler - sister to Clark's Lass of the Mill-Mr. Holmes' Miss Makeless, by Greyhound-old Partner-Woodcock-dam of Lampton-Miss DoeCroft's Bay Barb-grandam of the Ancaster Starling-Makeless-Desdemona's dam-Brimmer-Dicky Pierson-son of Dodsworth-the Burton Barb Mare. Imported from London, fall of $\mathrm{r} 8 \mathrm{or}$ by John Hoomes, Bowling Green. Advertised as above at Madison Court House, Tenn., r 806 by Wm. T. Banton, who states that pedigree is from General Stud Book.

DIPLOMAT ( $\mathrm{I}-\mathbf{3 2}^{2}$ ), bay with black points; foaled $\mathbf{1} 885$; bred by estate of J. C. McFerran, Louisville, Ky.; got by Nutwood, son of Harold: dam Ada Duroc, bay, bred by Charles Backman, Stony Ford, N. Y., got by Messenger Duroc, son of Hambletonian; 2d dam Montgomery Maid, black, bred by John McNeal, Montgomery, N. Y., got by American Star. Sold to William Cottrell, Mt. Clemens, Mich. ; to Scott Bros., Caledonia, Ont., Can. Pedigree from catalogue of breeder.

Sire of Dwyer, $2: 27 \frac{1}{4} ; 8$ pacers $(2: 281 / 4) ; 2$ dams of I trotter, I pacer.

DIRECT (3-128), $2: 18 \mathrm{I} / 4$, pacing $2: 05 \mathrm{~T} / 2$, black, I 5 I/2 hands, 970 pounds ; foaled 1885 ; bred by Monroe Salisbury, Pleasanton, Cal. ; got by Director, son of Dictator: dam Echora, (2:231/2), black, bred by L. H. Titus, San Gabriel, Cal., got by Echo (3-1 28$)$, son of Hambletonian ; $2 \mathrm{~d}$ dam said to be by Jack Hawkins, son of Boston, but really entirely untraced. Sold to James Butler, East View Farm, N. Y., I896, whose property he died, March, 1905. Pedigree from Pleasanton Stock Farm by J. H. Neal, who writes :

"Direct held the world's record of $2: 06$ to high wheels, and in the stud has got four with a faster average record than any other stallion. His 2 : I O performers are nine in number, and include Directly, $2: 03 \mathrm{~T} / 4$; Direct Hal, 2 :04 T/4 ; Bonnie Direct (4), 2 :05 T/4 ; King Direct, 2 :05 I/2; 
Prince Direct, $2: 07$; Directum Kelly (4), $2: 081 / 4$; Trilby Direct, $2: 081 / 2$; Direct View, $2: 083 / 4$; and Rey Direct, $2: 10$. Twenty-one of his get are in the $2: 15$ list, forty in $2: 20$, and fifty in $2: 25$.

"Direct, 2 :06, the champion pacer, is only about' 15 hands high, but very strongly and compactly built. Size does not always cut the greatest figure, but the elastic and nervous force of the right texture, driven by a constitutional desire with a bull-dog tenacity makes many a champion when handled with a masterly mind."

The American Horse Breeder says :

"Direct stands at the head of the list of double performers. He made a trotting record of $2: 181 / 4$ at Sacramento, Cal., Sept. 19, 1889, and took a pacing record of $2: 15 \mathrm{I} / 4$ in the third heat of the $2: 24$ race which he won at Cleveland last week. One would have to look some ways in his pedigree to find where the inclination to pace comes from. He is bred in orthodox trotting lines. His sire, Director, has a record of $2: 17$, and was by Dictator, full brother to Dexter, dam Dolly, by Mambrino Chief. Direct's dam was Echora, trotting record of $2: 23 \frac{1 / 2}{2}$. She was by Echo, trotting record $2: 37 \frac{1}{2}$, by Hambletonian. Direct gets a double cross of Seely's American Star, which got the dam of Dictator, and also got Magnolia, which got the dam of Echo. It is claimed that Direct could not carry his speed quite to the wire when trotting. $\mathrm{He}$ finishes strong when pacing."

\section{A TROTTING BRED PACER.}

The world's champion pacing record, I :59 I/4, is held by a pacing bred stallion, Star Pointer. Nearly all the other pacers, however, that have taken records from $2: 001 / 2$ to $2: 05 \frac{1}{2}$ were got by standard bred sires. Direct $(2: 061 / 2)$, is trotting bred on both sides.

Direct is a very strongly made, smoothly turned black stallion, not far from 5 hands high. He is a big little horse, low in stature, but a perfect little giant in conformation, and a genuine bull-dog in courage. He was bred by Monroe Salisbury, Pleasanton, Cal., and foaled in $\mathbf{8} 885$. His sire, Director ( $2: 17$ ), was by Dictator, full brother of Dexter ( $\left.2: 17 \frac{1}{4}\right)$, and from the noted old Dolly, by Mambrino Chief. The dam of Direct was Echora $\left(2: 23^{\mathrm{T} / 2}\right)$, by Echo, a son of Hambletonian.-American Horse Breeder, Nov. I2, I90I.

Sire of 20 trotters $\left(2: 08 \frac{1}{4}\right) ; 23$ pacers $\left(2: 03^{1 / 4}\right)$.

DIRECT HAL (3-64), $2: 04 \frac{1}{4}$, black, white face, left front ankle white; foaled I 896 ; bred by E. F. Geers, Buffalo, N. Y.; got by Direct, son of Director : dam Bessie Hal, said to be by Tom Hal Jr.; 2d dam Princess, by Prince Pulaski ; 3 d dam Velitie, by Bostick's Almont Jr.; and 4th dam by Elliston's Rattler. Sold to Village Farm. Pedigree from Village Farm catalogue.

When Direct Hal, $2: 04 \% / 4$, was purchased at auction last winter, his new owners fixed his fee for 1905 , at $\$ 150$ and advertised that the five best mares booked by March $I_{5}$ th would be bred free. The selection was left to a committee of prominent horsemen and breeders and the five mares they selected out of some forty or fifty booked were the following :

Ellen M. (dam of the pacers Fanny Dillard, 2 :033/4, and Hal B., 
$\left.2: 04^{1 / 2}\right)$, by Blue Boy, son of Blue Bull : 2 d dam by Blue Bull.

Jane (dam of Angus I'ointer, $2: 04^{1 / 2}$, and Annie Sprague, $2: 2$ I I 2 )

by Grant's Hamiltonian : dam by imported Highlander.

Fanny Egthorpe, $2: 27$ I/4 (dam of Morning Star, $2: 04 \frac{1}{2}$ ), by Egthorn, $2: 12 \frac{1}{4}$ : dam by Magnetic.

Ophelia (dam of Strathline, 2 :07 1/2, Blackline, $2: 22$, and Dr. S., $2: 22 \frac{1}{2}$ ) by Strathmore: first dam by Smuggler.

Maggie Hernley (dam of A. J. D., 2 :09 1/4, Maggie Anderson, 2 :09 1/4, and Andy W., $2: 17 \mathrm{~J} / 4$ ), by Regalia: dam by Mambrino Pilot.

Maternal Speed Lines of Direct Hal, May, I 906 :

"At the time that Bessie Hal, was foaled, Hon. Frank G. Buford who bred her, was actually engaged in the business at Buford's Station, Giles County, Tenn. Not only did he breed Bessie Hal, but he also bred her dam, Princess, by Prince Pulaski, and Vidette, the third dam of Direct Hal, by Almont Jr. (Bostick's). He also owned the three great sires of the pacers, Tom Hal, Prince Pulaski and Bostick's Almont Jr. ****

"Direct Hal's second dam was Princess, by Prince Pulaski, sire of Mattie Hunter, $2: 123 / 4$. She was a brown mare bred by me (Mr. Buford), and as she was intended for the harem was bred without training. She produced twice to Tom Hal-Bessie $\mathrm{Hal}$ and an equally promising bay filly that received internal injuries from slipping on the ice from which she died. Princess had a tragic and inglorious end, through the instrumentality of a vicious mule, by which she was run onto the sharp point of a walnut stump in the pasture and killed, so there is no dam or full sister left.

"Prince Pulaski, sire of Princess, was a rich dark chestnut with star and two white feet behind, standing a shade under 16 hands, weighing close to 1200 pounds and was the greatest saddle and show horse of his day. His form was almost ideally perfect, combining in a remarkable degree size, style, beauty, symmetry and stamina. He was in these respects the Mambrino King of Tennessee pacers. In fact, he resembled Mambrino King very much and was his equal in the show ring. He was remarkably fast in all the saddle gaits and no doubt could have paced fast had he been handled in that way. From Prince Pulaski have decended Mattie Hunter, $2: 123 / 4$, Ella Brown, $2: 111 / 4$, Tom Vaughn, $2: 09 \frac{1}{4}$, and other fast ones. Direct Hal's third dam was Vidette, a brown mare, by Bostick's Almont Jr., 2 :29, a very game, high-strung and fast roadster, bred by Mr. Hill, Brentwood, Tenn., of whom I bought her at public sale. She was a trotter, though strongly inclined to single foot when pressed.

"Almont Jr., her sire was a rich bay, of grand individuality, standing I $61 / 2$ hands high, weighing over I 300 pounds, a horse of great length, broad, clean bone, good style and great substance; with the exception that his head was a little heavy, he was one of the grandest types of the trotting horse that I have ever seen, before or since his day. He was possessed of remarkable speed, of which his record of $2: 29$ gives but little idea. He was one of the greatest trotting sires in the south. In disposition the Almont Juniors, were as a rule very high strung. $\mathrm{Had}$ it not been for this characteristic, and the poor handling that most of his get received, his $2: 30$ list would be much larger.

"The fourth dam of Direct Hal was by Elliston's Rattler, a son of Biggart's Rattler and Dairy Maid, by Black Hawk, son of Sherman Morgan. Dairy Maid was the dam of Tennessee, $2: 27$, one of the best known of our early day trotters. I never owned or knew this fourth 
dam, but my recollection of information received from Mr. Hill is that she was bred by his father and was a great road mare.

"The fifth and last dam of which I have information was by Driver, a brown pacing stallion of considerable speed, well known in Williamson County, at an early day and called a Canadian. [This Driver we suppose to have been the Morgan horse of that name bred in Kentucky]. In conclusion, Tennessee should feel proud, indeed, of the part she has played in the production of the unbeaten phenomenon, Direct $\mathrm{Hal}$, as he was not only bred by the well known horsemen, E. F. Geers and Chapin Bros., Columbia, Tenn., but his dam Bessie Hal, is a daughter of Tennessee's greatest old sire, and every dam in the pedigree was bred within her borders, and the sire of every dam was hers by breeding or adoption."

From a letter by Hon. Frank G. Buford to "Trotwood" in the Horse Review, Jan., I3, 1903.

DIRECTION (MIDLOTHIAN) ( $1-32), 2: 08 \frac{1}{4}$, black, I5 hands, rooo pounds; foaled 1887 ; bred by R. S. Veek, St. Mathews, Ky.; got by Director son of Dictator: dam Lulu Wilkes, bay, bred by Simmons Bros., Lexington, Ky., got by George Wilkes; 2 d dam Lucy, bay, bred by Lemuel Worth, Rouses Point, N. Y., got by Sherman Black Hawk; 3d dam the McGee or Baxter Mare, said to be by Barney Henry. Sold to James H. Oglebay, Kansas City, Mo. Pedigree from J. F. Clark.

Sire of Bridget, $2: 27 \frac{1}{4} ;$ Correct, $2: 13 \frac{11}{4}$.

DIRECTION ( $1-64$ ), seal brown, said to be by Director son of Dictator : dam Roxana. Owned successively by Mr. Salisbury, Cal.; Mr. Hess, Bay City, Mich. Pedigree from E. G. Soverign.

Sire of Garibaldi, $2: 18 \frac{1}{4}$.

DIRECTIVE (3-128), black, $153 \frac{3}{4}$ hands, about ro5o pounds; foaled 1889 ; bred by Emil Seibel, Watertown, Wis.; got by Endicott, son of Milwaukee : dam Nellie R., black, foaled 1878 , bred by David Rowlands, Racine, Wis., got by Swigert, son of Norman; 2d dam Kate, said to be by Blue Bull. Sold to A. B. Donelson, Pontiac, Mich.

Sire of Dexter $R, 2: 15 \frac{1}{4}$.

DIRECT LINE (3-128), $2: 25$ I $/ 2$, bay; foaled I 889 ; bred by Martin Carter, Irvington, Cal.; got by Director, son of Dictator: dam Lida W., bay, bred by Wm. C. Wilson, San Jose, Cal., got by Nutwood, son of Hambletonian; $2 \mathrm{~d}$ dam Belle, chestnut, bred by J. H. Yoell, San Jose, Cal., got by George M. Patchen Jr., son of George M. Patchen; and $3 \mathrm{~d}$ dam Rebel Daughter, by Williamson's Belmont, son of American Boy.

Sire of Merion Maid, $2: 221 / 2$.

DIRECTLY (I-64), 2 :03 T/4, black; foaled I 892 ; bred by I. D. Cunningham, Haywards, Cal. ; got by Direct, son of Director : dam Mabel, black, bred by Mr. Russell, Haywards, Cal., got by Naubuc, son of Toronto 
Chief ; 2 d dam said to be a St. Lawrence mare, bred by Mr. Russell. Sold to Monroe Salisbury \& Cunningham, Pleasanton, Cal. ; to John H. Shults, Parkville, N. Y. Advertised with pedigree as above by the Woodland Heights Stock Farm, Liberty, Ind., I905.

Sire of Daffodill, $2: 19 \frac{3 / 4}{3} ; 3$ pacers $\left(2: 17 \frac{114}{4}\right)$.

DIRECTLY BOY (3-64), 2 : 15 1/4, black, 16 hands; foaled 1902 ; bred by James P. Hauratly, Clarksville, Tenn.; got by Directly, son of Direct: dam Miss Hearst, 2 : 1 $9 \mathrm{~T}^{\mathrm{T}}$, bay, bred by M. C. Campbell, Spring Hill, Tenn., got by Brown Hal, son of Tom Hal ; $2 \mathrm{~d}$ dam, Mandina, bay, bred by M. C. Campbell, got by Bay Tom Jr., son of Bay Tom ; 3d dam bay, said to be by Pat Malone. Pedigree from breeder.

DIRECTOR (I-16) bay; foaled I868; bred by Judson H. Clark, Elmira, N. Y., got by Hambletonian: dam Lady Bellfounder, chestnut, bred by Joseph Walling, Goshen, N. Y., got by Weber's Tom Thumb; 2 d dam said to be by Crabtree Bellfounder; and 3 d dam by imported Bellfounder. Sold to Crandall Bros., Edinborough, Penn.; to E. J. Hinckley, to Jacob Bolard, to A. Sherwood, all of Cambridgeborough, Penn.

Sire of McClelland Stewart, $2: 28$.

DIRECTOR (I-32), 2 :17, black; foaled I 877 ; bred by Col. R. West, Lexington, Ky.; got by Dictator, son of Hambletonian: dam Dolly, bay (dam of Onward, $2: 25 \mathrm{I} / 4$, and Thorndale, $2: 22 \mathrm{I} / 4$ ), foaled I $86 \mathrm{I}$, bred by J. R. Adams, Georgetown, Ky., got by Mambrino Chief, son of Mambrino Paymaster; 2d dam Fanny, chestnut with white hairs, bred by John W. Carter, near White Sulphur Springs, Scott County, Ky., got by Ben Franklin, son of Hazrack ; 3d dam Nance, dark bay, bred by James

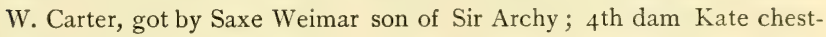
nut, pacer and trotter, owned by Henry Brand, Bourbon County, Ky., who sold her when about four years old to James W. Carter. Owned by John W. Conley \& C. ${ }^{* H}$. McConnell, Chicago, Ill. Sold to G. Brasfield, Lexington, Ky.; to John W. Conley, Chicago, Ill. ; to Monroe Salisbury, Pleasanton, Cal. ; to A. H. Moore, Philadelphia, Penn. Trotted I88o-83. Winner of $2 \mathrm{I}$ races.

The following history of Dolly is from Otto Holstein in $\mathrm{I} 882$ :

“EDITOR DunTon's SpIRIT OF THE TURF : I now lay before your readers the particulars in the matter of the pedigree of the famous brood mare, Dolly. Heretofore it has been accepted as by Mambrino Chief, first dam by son of Potomac; second dam by Saxe Weimar, and so remained unchallenged for the ten or fifteen years. The facts are these: A number of years ago, at the home of the late James Carter, living in the locality of White Sulphur Springs, Scott County, Ky., a nephew named Henry Brand of Bourbon County, Ky., was making a prolonged visit, riding there a good looking chestnut filly, then perhaps four years old, that could pace and trot. During Brand's stay there he traded the filly to Mr. Carter and in turn of events she was named Kate. When Kate 
reached the age of six or seven years Mr. Carter bred her to Saxe Weimar, the son of Sir Archy, that then was in service at the stable of William Glass, about two miles from Carter's. The result of this union of Saxe Weimar and Kate was a dark bay or brown filly, which was in turn called Nance, and an ordinary animal she proved herself; a good worker and could trot fairly. When Nance attained her fifth year, Mr. Carter let his son, John W. Carter, who was at that time about fifteen years old, have her to raise a colt from. At that time there was in service at Threlkeld's Mills, about four or five miles from Carter's, a fine saddle stallion, racker and trotter, called Ben Franklin, and he was owned by James B. Wilkinson, now of Belltown, Bell County, Texas. Mr. Wilkinson was not, in the ordinary sense of the word, a horseman, and so little or nothing was ever heard of Ben Franklin without a radius of a few miles. Young Carter, John W., bred Nance, and the result was a chestnut filly, with her coat considerably charged with white, which afterwards became Fanny, and she, to the cover of Mambrino Chief, produced Dolly, the dam of the famous triumvirate-Thorndale, Director and Onward. Fanny, of course was foaled the property of John W. Carter, and he traded to his father, who in turn, presented her to his daughter, Mrs. William Nutter, and at a public sale of Mr. William Nutter's, Fanny was purchased by Steve Lucas. She subsequently passed into Dr. Adams' hands and he sent her to Mambrino Chief.

"But to return to Ben Franklin, the alleged son of Potomac. Between twenty-five and thirty-five years ago there was in the vicinity of the Stamping Grounds, near Threlkeld's Mills, a bay mare by Johnson's Copperbottom, pacer, dam by Saxe Weimar, owned by Mr. William Hazelrigg, that was noted throughout the region for her great qualities as a pacing and brood mare. This mare Mr.Hazelrigg bred to a saddle horse, and the result of this union was a fine looking bay colt, which at four years old, and this was in 1845 , was purchased by Mr. James B. Wilkinson, and called Ben Franklin. The horse Hazrack, a bay, was a famous saddle horse in his day about Georgetown, was bred by A. Louis Offutt of Scott County, and among others who owned him was Mr. F. G. Ford, father-in-law of Dr. Adams, the breeder of Dolly. Hazrack was by Golden Farmer, also called Fearnaught, and his dam was by Johnson's Copperbottom, the pacer. Golden Farmer, also Fearnaught, came from Virginia, and was doubtless thoroughbred or nearly so.

"That the cross of Hazrack is an element of import in the composition of Dolly's three great sons is patent when we reflect that a line of it appears in another celebrity to wit: Lula, the second dam of which, Mary Blane, was by Texas, who was by the gray horse Texas and from a mare by Hazrack. Still another and an extraordinary piece of mechanism, is Sannie G., her dam being by Texas."

This excellent piece of tracing by Otto Holstein brings out in bold relief the constant tendency of giving a thoroughbred, or what is considered the best, pedigree instead of a true one, and illustrates how constantly in the thoroughbred pedigrees as given, a trotting element will be found if the correct pedigree is traced. This trotting element may be derived from Messenger, but in all parts of the country is more apt to come from the Morgan either of Canada or Vermont. In this case it was a cross of Copperbottom from Bolton, Canada, or rather a double cross. In another, if in Kentucky, it will be a cross of Blood's Black 
Hawk, Downing's Vermont, Red Jacket, Morgan Eagle or some other Morgan horse from Vermont, or from Pilot, Davy Crockett, Tom Hal, John Dillard, Snowstorm, Cuur de I,ion, Canada Chief or some other horse from the Province of Quebec, Canada, just over the Vermont line generally if not always of in part Vermont origin, more or less inclined to pace, but also more or less inclined to trot ; doing whichever they may be taught to do. And this represents the famous pacing cross, only on enlarged scale; for it includes the American Star cross in Orange County, N. Y., without which there would have been no Dexter, the May Day cross in New Jersey, the Henry Clay cross in Long Island, without which there could have been no Electioneer-and a thousand other minor crosses. And this is the famous pacing cross of Mr. Wallace, but comes not from the Narragansett or any other known strictly pacing line except through dams, but from the Morgan, which equally with Messenger and Diomed, especially when the two were commingled, has been drawn upon to form nearly or quite all our fastest trotters or pacers. The other elements, which Mr. Wallace was especially anxious to ignore, assert equal recognition. Bellfounder, without which the Messenger would largely drop out, and the thoroughbred, especially Diomed.

Sire of 40 trotters $\left(2: 05 \frac{1}{4}\right)$, I6 pacers $\left(2: 05 \frac{1}{2}\right) ; 27$ sires of 69 trotters, 50 pacers; 27 dams of 25 trotters, II pacers.

DIRECTOR CHIEF (I-64), black, I5 I $/ 2$ hands, I Ioo pounds ; foaled I 886 ; bred by J. P. Dunn, Oakland, Cal.; got by Director, son of Dictator : dam Monte, bay, bred by J. P. Dunn, Oakland, Cal., got by Admiral, son of Volunteer : 2 d dam Oakland Maid, said to be by Capt. Webster, son of Williamson's Belmont ; and 3d dam Eastern Girl, by a thoroughbred. Sold to A. McDonnell, San Francisco, Cal. ; to Monroe Salisbury, Pleasanton, Cal.; to A. W. Langley, Chicago, Ill.; to H. D. McKenney, Janesville, Wis., who sends pedigree.

Sire of Coupon, $2: 261 / 4$.

DIRECTOR H. (7-256), $2: 27 \mathrm{~T} / 2$, brown, with white points, I $4 \frac{1}{2}$ hands, 900 pounds; bred by Luel Harris, Yuba City, Cal.; got by Director: dam Esmeralda (dam of Don Lowell, 2 :14 T/4), bay, bred by P. Slattery, Marysville, Cal., got by Brigadier, son of Happy Medium ; 2d dam Col. Dexter Mare, bred by P. Slattery, got by Whipple's Hambletonian, son of Guy Miller. Sold to T. L. Smith, Yuba City, Cal.; to Mr. Philip Byrne, Grass Valley, Cal. Pedigree from breeder.

Sire of Lockinvar, $2: 2$ I.

DIRECTOR'S JUG ( $\mathrm{x}-32$ ), 2 :29 ז $/ 2$, black, I 5 I/4 hands; foaled I 885 ; bred by Monroe Salisbury, Pleasanton, Cal. ; got by Director, son of Dictator : dam Lizzie (Dam of Brown Hal, $2: 12 \frac{1}{2}$, which see). Sold to Fred Dietz, New York, N. Y. Advertised with pedigree as above by W. R. 
Janvier, New York City, April 2, I 895 and by W. N. Burgess, East Lynne Stock Farm, Flemington, N. J., February, I904.

Sire of 2 trotters $(2: 261 / 2)$.

DIRECTORY (3-128), bay, right fore and hind pastern white; foaled I 888 ; bred by W. H. Gentry, Lexington, Ky. ; got by Director, son of Dictator: dam Sunbeam, chestnut, bred by W. H. Gentry, got by Red Wilkes, son of George Wilkes; $2 \mathrm{~d}$ dam Hope, said to be by Beecher, son of Blue Grass; and 3 d dam Border Bell, by Donerail, son of Lexington. Sold to Oliver \& McDuffie, Cincinnati, O. Pedigree from catalogue of owners.

Sire of Princess Inez, $2: 23 \frac{1}{4}$,

DIRECTUM (I-64), 2 :05 ז//4, black; foaled I889; bred by John Green, Dublin, Cal. ; got by Director, son of Dictator : dam Stemwinder, $2: 30 \mathrm{~T} / 2$, black, bred by John Green, Dublin, Alameda County, Cal., foaled i 878 , got by Venture, $2: 27 \frac{1}{4}$, thoroughbred, son of Williamson's Belmont ; $2 \mathrm{~d}$ dam Kate, bay, bred by John Green, got by Roodhouse's St. Lawrence, $2: 3^{2} \mathrm{~T} / 4$, bought in Canada by Ben Roodhouse of Carrollton, Ill., and a partner named Gregory and sent to California ; 3 d dam Quien Sabe, dark bay, almost chestnut, bred by Martin Mendenhall, Livermore, Cal., got by Langford, thoroughbred, son of Williamson's Belmont ; 4th dam Polly, bred by Martin Murphy, near San Jose, Cal., got by Duroc, a stallion bought by Mr. Murphy of some emigrants and claimed to be a descendant of Duroc, by imported Diomed; $5^{\text {th }}$ dam purchased by Mr. Murphy of the same emigrants of whom he purchased Duroc. Trotted nine races in 1892 ; won all in three heats; good appearance, perfect action, kind disposition, good stock. Duroc was purchased by Mr. Murphy from emigrants from Kentucky in the early fifties. Pedigree from breeder.

Dublin, April 20, I893.

Mr. J. Battell,

Dear Sir: Yours of 12 th at hand. I have filled out enclosed form and return it to you. I have been endeavoring to trace the pedigree of Duroc. All that I have found out so far is that he was purchased by Martin Murphy of Santa Clara County, Cal., since deceased, from a party of emigrants that crossed the plains in early days. They claimed that he was a thoroughbred horse brought to Kentucky from Canada. Directum's action when trotting is pronounced by all horsemen here to be as near perfect as possible and his disposition is as good as can be. $\mathrm{He}$ is perfectly gentle in the stall or hitched up and does not pay any attention to the crowds or other horses passing him on the track. His record was made on the Cumberland track, Nashville, Tenn., when he beat Kentucky Union three straight heats, $2: 15,2$ :12, 2 :1 I I $/ 4$. Hoping you will receive this $\mathrm{O}$. $\mathrm{K}$. I remain,

Yours respectfully,

JoHN GREen.

THE DAM OF DIRECTUM ( $2: 1 \mathrm{I} / 4$ ).

Editor Breeder and Sportsman :-After seeing the accounts of the trotting of the colt Directum it looks like wonders would never cease. 
Then after seeing what he had done, I began to inquire where he came from and how he was bred, and, before long, the Breeder and Sportsman says that he was by Director, dam Stemwincler, by Venture. The next question was what was the dam of Stemwinder? I had seen her trot, but never knew how her dam was bred. It now seems that the colt was by Director : dam Stemwinder, by Venture ; second dam by Meek's St. Lawrence; third dam by Langford.

Venture was by Belmont (Williamson's) ; first dam by American Boy Jr.; second dam, Fanny Mostyn, by Gray Medoc ; third dam imported Lady Mostyn, by Feniers; fourth dam, Invalid by Whisker, etc.

Invalid, by Whisker, was the dam of Camden, by Shark, and Camden got Simpson's Blackbird, the sire of A. W. Richmond and Reavis' Black Bird.

Venture was not only by Belmont, but his dam was by American Boy Jr., son of American Boy, the sire of Belmont, and American Boy Jr.'s dam was by Cincinnatus, a son of Stoughtonborough's Shakespeare, from Brown Highlander's dam, and Shakespeare was by Valerius, from a mare by imported Expedition. American Boy Jr., was a horse of splendid trotting action, very little inferior if any to Belmont.

I never doubted the potency of the Belmont or American Boy cross in the trotter, and felt a delicacy about saying all I thought, as many people would think I was unduly biased; consequently it is gratifying to me, because it is a verification of a theory I have always had about the way to breed, and this colt has certainly proved one of the best ever foaled.

To prove that I have been sincere in this opinion, I have been breeding, for the last three years a mare bred very much like Stemwinder, though better bred, and a finer mare to look at.

San Jose, Cal., Nov. 22, I 892 .

$$
\text { Respectfully, W. M. Williamson. }
$$

The San Francisco Chronicle of 1893 , says :

"Directum was bred by John Green of Dublin and is still owned by the old pioneer. Dublin is a little town distant about six miles from Pleasanton and ten from Haywards. John Green has been the village postmaster there for thirty years. $\mathrm{He}$ has also been engaged in the breeding business for that many years. Mr. Green from early youth has had a fondness for both thoroughbred and trotting horses and has experimented a great deal in crossing the thoroughbred and trotting stock, although he never went into the breeding business on an extensive scale.

"Twenty years ago Mr. Green purchased from Martin Mendenhall of Livermore a race mare known to fame as Quien Sabe. She was by Langford, and could run a half in 50 seconds over the half-mile tracks which were in the majority in those days. Quien Sabe was retired from the turf and was bred to St. Lawrence, a trotting stallion owned by L. B. Anway, who lived near Haywards. St. Lawrence was quite a goodlooking horse, but his breeding could not be called fashionable. In fact St. Lawrence was called upon to do plebian work, such as pulling the plow. At all events the result of the union was a filly, who was given the ordinary name of Kate. She was used as a road mare, and was eventually sold to ex-Supervisor Smith of Oakland. Before being sold Kate had a foal by the thoroughbred horse Venture. The newcomer at the Dublin ranch was Stemwinder, the dam of the now famous Directum.

"Stemwinder was a resolute little trotter and was campaigned for 
several seasons. She was a coal-black mare, with not a white hair on her body. She never got a very fast mark, but in a trial showed her ability to trot in about 2:22 with good handling. Mr. Green, however, decided to keep Stemwinder for a brood mare. She was first bred to Richard's Elector six years ago, and the result was a black filly, Electrina, who last week took a record of $2: 20$ at Woodland. The following year Stemwinder was bred to Director, and this mating gave to the world the wonderful little stallion Directum. He was given this name by William Layng, editor of the Breeder \& Sportsman, who is very proud of the conquests of the black colt.

"There is a two-year-old half-brother of Directum now at Pleasanton taking kindergarten lessons in trotting; and he gives promise of developing into a wonder. There is also a suckling at Dublin, by Direct, dam Stemwinder, that should be heard from some day.

"The student of breeding will have observed that Directum has a strong infusion of thoroughbred blood on his dam's side. Stemwinder's sire was from a thoroughbred mare, Quien Sabe, by Langford. Director, the sire of Directum, was known as the 'Iron horse,' and his breeding is too familiar to horsemen to require further remark than that he was trotting bred."

For further information of dams see St. Lawrence (Roodhouse's).

Sire of II trotters $(2: I 11 / 4) ; 2$ pacers $(2: 20)$.

DIRECTUM BOY (I-I28), $2: 173 / 4$, bay; foaled 1889 ; bred by T. C. Anglin, Lexington, Ky.; got by Directum, son of Director: dam bay, foaled I $89 \mathrm{r}$; bred by T. C. Anglin, got by Wilkes Boy, son of George Wilkes; 2 d dam bay, foaled I $88 \mathrm{I}$, bred by T. C. Anglin, got by George Wilkes; 3d dam chestnut, foaled I 869 , bred by T. C. Anglin, got by Kentucky Clay, son of Cassius M. Clay Jr.; 4th dam brown, foaled I866, bred by R. D. Mahone, Lexington, Ky., got by Mambrino Patchen. Sold to W. B. Anglin, Lexington, Ky. Pedigree from breeder.

Sire of The Veteran, $2: 191 / 4$.

DIRECTUM KELLY (3-256), 2 :08 1/4, bay; foaled I 894 ; bred by Pleasanton Stock Farm Co., Pleasanton, Cal.; got by Direct, son of Director : dam Rosa Ludwig, bay, bred by Elmer Ludwig, Santa Rosa, Cal., got by Anteeo, son of Electioneer; 2 d dam Rosa, said to be by Limerick Boy, son of Ringgold ; and 3 d dam Young Chicago Maid. Sold to James Butler and advertised, by him 1898-9, 1904-5 at East View Farm, East View, N. Y.

Sire of Black Pebble, 2:121/4.

DIRECTWOOD (5-I28), black; foaled I89o; bred by G. W. Hancock, Sacramento, Cal.; got by Director, son of Dictator : dam Zephyr, bay, foaled I882, bred by G. W. Hancock, got by Nutwood, son of Belmont; 2d dam Jenny St. Clair, said to be by old St. Clair. Sold to L. U. Shippee, Stockton, Cal. ; to R. J. Taylor, Chicago, Ill.

Sire of Commeta, $2: 24 \frac{1}{4}$. 
DIRIGO (GEORGE B. MCCLELLAN), $2: 29$, brown with black points, I5 3/4 hands, ro5o pounds; foaled I 854 ; bred by John Heagan, Prospect, Waldo County, Me.; got by Drew, which see: dam dark chestnut, $151 / 2$ hands, Iooo pounds, brought from the Provinces, by a Mr. Mosman of Searsport, Me., a good driver, no speed. Sold to Andrew Mudgett, I857; to Frank Berry, both of Belfast, Me; to Horace McKinney, Monroe, Me., I864; to Captain Sandford, Bangor, Me., for $\$ 7000$, I864; to David Quimby, Corinna, Me.; to Judson Higgins, Palmyra, Me.; to parties in Dexter, Me. Died $\mathrm{x} 884$; Mr. Thompson in Maine Bred Horses, says: "A horse of fine style and carriage." Information from Charles McKinney, Monroe, Me. We have received the following letters :

Mr. Joseph Battell,

South Exeter, May i 9, r 887 .

Dear Sir :-Your letter to hand; it came when I was away from home. I should be pleased to inform you of the breeder or breeding of Dirigo's dam but I cannot do so. I do not think I can put you on track of a man who can. You might write Charles McKinney of Monroe. This is the son of Horace McKinney who owned Dirigo from the time he was four years of age until he was ten. I owned Dirigo three years; he was one of the finest stallions in New England. Several parties have tried to get the breeding of Dirigo's dam but could not succeed. I should be pleased to accommodate you could I do so. I should like to go up and stop on your stock farm. You will see by this my addess is South Exeter now, not Covinna as it used to be. Write me when you get this. Yours truly, David Quimey.

Mr. Battell,

Monroe, June 5, I887.

Dear Sir:-Yours of May 23, was duly received, and contents noted. The breeding of the dam of Dirigo is not known to anyone in this vicinity. Dirigo was not bred by my father, but by a man by the name of John Heagan, in Prospect, Me. As good authorities as there are in these parts say that all that is known about the dam is that she was brought from the Provinces by a man by the name of Mosman, who then lived in Searsport, this State. I have my information from an uncle of mine living in Wintersport, Me., who lived very near Mr. Heagan. His name is D. H. Smith, and he knew Dirigo before father got him and all the time we owned him. I should have answered your letter before, but could not till I had seen different parties and got the facts, which I think I have given you. Any information I may have will be cheerfully given at any time.

$$
\text { Yours truly, Charles McKinney. }
$$

Mr. Joseph Battell,

Monroe, Aug. 2, I89o.

Dear Sir:-Enclosed will find pedigree filled out. I should have returned sooner but had to correspond with parties which made a delay. As to the sire of old Drew he is supposed to be an English colt that was imported. This is all the information that I can give you. I see that 
you have Dirigo as foaled in 1856 , this is wrong; he was foaled in 1854 . Hoping that this will be satisfactory, I am

$$
\text { Yours truly, }
$$

Charles McKinney.

Sire of 4 trotters $\left(2: 25^{1 / 4}\right), 2$ pacers $\left(2: 21^{1} \frac{1}{4}\right) ; 2$ sires of 3 trotters; 6 dams of 5 trotters, I pacer.

DIRKEE V. (3-128), gray; foaled 1883 ; bred by John M. Viley, Great Crossings, Ky. ; got by Dictator, son of Hambletonian : dam Suse, said to be by John C. Breckenridge. Sold to James F. Taylor, Ladoga, Ind. ; to J. T. Bronaugh, New Ross, Ind; to E. E. Coats, Veedersburg, Ind. Sire of Anna B., $2: 27$, bred by M. V. Offutt, Georgetown, Ky.

DISCOUNT (5-I 28 ), bay; foaled r884; bred by Robert Prewitt, Lexington, Ky. ; got by Dictator, son of Hambletonian: dam Gossip, brown, bred by A. J. Alexander, Woodburn Farms, Ky., got by Tattler, son of Pilot Jr.; 2 d dam Jessie Pepper (dam of Alpha, $2: 25 \mathrm{~T} / 2$, which see). Sold to B. J. Treacy, Lexington, Ky.; to Charles Friel, Pittsburg, Penn. Pedigree from Howell Prewitt.

Sire of $D r . H ., 2: 13 \frac{1}{4}$.

DISOWNED (3-I28), brown, with black points, snip, left hind foot white ; foaled I87I ; bred by James B. Bach, New York, N. Y.; got by Peacemaker, son of Hambletonian: dam Violet, bay, bred by J. L. Seavey, Waterville, Me., got by Gideon, son of Hambletonian; 2d dam Lady Bach, said to be by Hiram Drew, son of Drew Horse; and $3 \mathrm{~d}$ dam the Sweetser Mare, by Eaton Horse, son of the Avery Horse. Sold to William G. Gardiner, Northport, Long Island; to Charles A. Kittle, agent Long Island, City, N. Y. Pedigree from breeder.

Sire of Harry Gardiner, $2: 22 \frac{1}{4}$.

DISPATCH (WINDSOR) (I-I6), $2: 24 \frac{1}{2}$, roan, I5 hands; foaled 1872 ; bred by Joseph Littlefield, Auburn, Me.; got by Lewiston Boy, son of Pollard Morgan : dam bred by J. W. Sydleman, Durham, Me.; got by Berry Horse ; $2 \mathrm{~d}$ dam brought from Canada.

DISPATCH (I-64), bay, with star, both hind feet white above ankles, I6 hands; foaled I 882 ; bred by Thomas Mahoney, Frankfort, Ky. ; got by Onward, son of George Wilkes : dam Lucille, said to be by Bayard Jr., son of Bayard; and $2 \mathrm{~d}$ dam by Donerail, son of Lexingten. Sold to Alexander Hill, Ormsboro, Ky., who sends tabulated pedigree in which dam of Bayard Jr. is given as by Mambrino Chief; 2 d dam Fly, by Barclay's Columbus, son of Columbus (Smith's), sire of Confidence, $2: 28$. This is the accepted pedigree of Dispatch and would appear to be a correct statement of the sire of Barclay's Columbus, which at the time Dispatch was born, should have been easily got.

Sire of 4 trotters $\left(2: 24 \frac{1}{4}\right)$; Carrie $M_{.,} 2: 21 \frac{1}{4} ;$ I sire of I pacer; I dam of I trotter.

DISPATCH Jr. (I-I28), bay, small stripe in face, two white feet $\mathrm{r} 6$ hands, 
I 60 pounds; foaled I 884 ; bred by Sam Givens, Panther, Ky. ; got by Dispatch, son of Onward: dam chestnut sorrel, said to be by Goddard, son of an imported race horse. Sold to Felix Murphy, West Louisville, Ky., who sends pedigree.

Sire of Silver Sam, 2:18.

DISPUTANT (I-64), $2: \mathrm{I} 8$, bay, right hind ankle and left hind coronet white; foaled I 886 ; bred by A. J. Alexander, Spring Station, Ky.; got by Harold, son of Hambletonian : dam Debutante bay, foaled 1878 , bred by A. J. Alexander, got by Belmont ; 2 d dam Dahlia, gray, foaled I 863 , bred by R. A. Alexander, Spring Station, Ky., got by Pilot Jr.; 3d dam Madam Dudley gray, said to be by a Bashaw horse. Sold to R. K. Hart, Poplar Plains, Ky. Pedigree from catalogue of breeder.

Sire of 5 trotters $\left(2: 13 \frac{1}{4}\right)$,

DISPUTE (3-I28), 2 :I5 I/4 , black; foaled $189 \mathrm{I}$; bred by E. D. Sherman, Great Crossings, Ky.; got by General Wilkès, son of George Wilkes : dam Lady Sherman, bay, foaled 1885 , bred by Linn Smith, Lexington, Ky., got by Hambletonian (Sherman's) son of Hambletonian; $2 \mathrm{~d}$ dam Sue ( $2 \mathrm{~d}$ dam of Allie Wilkes, $2: 15$, which see). Sold to J. F. Taylor, Ladoga, Ind.

Sire of 2 trotters $(2: 101 / 2) ; 2$ pacers $(2: 2 I)$.

DISSENTER (I-I28), chestnut; foaled I889; bred by R. P. Pepper, Frankfort, Ky.; got by Madrid, son of George Wilkes: dam brown, bred by R. P. Pepper, got by Egbert, son of Hambletonian; $2 \mathrm{~d}$ dam said to be by Lagow, son of Belmont; 3 d dam Belle, by Norman, son of the Morse Horse; $4^{\text {th }}$ dam Vic, bay, bred by Dr. A. Hurst, Midway, Ky., got by Mambrino Chief. Sold to T. B. Nettleton, Ashton, Ill. ; to G. W. Meyers, Ashton, Ill., who sends pedigree.

Sire of Marion, 2:181/4.

DISTINGUE (5-64), brown ; foaled I880 ; bred by T. O. Harris, Jr., NashVille, Tenn., got by Blackwood Jr., son of Blackwood: dam Alamode, bred by D. Swigert, Woodford County, Ky., got by Almont; 2d dam Celeste, brown, bred by Enoch Lewis, Woodford County, Ky., got by Mambrino Chief; 3d dam Big Nora, said to be by Downing's Bay

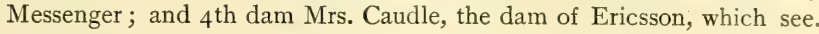

Sire of Temple $0 ., 2: 2 \mathrm{I} 1 / 4$.

DIXIE (1-32), bay, I5 I/4 hands; foaled I874; bred by James Reynolds, Milwaukee, Wis. ; got by Swigert, son of Norman : dam Lilly, chestnut, said to be by Bellfounder, son of Hungerford's Blucher. Sold to V. Simpson, Winona, Minn.

Sire of Dixie, V., $2: 25 \%$.

DIXON (3-64), $2: 363 / 4$, bay, $153 / 4$ hands; foaled 1868 ; bred by Robert 
Galloway, Suffern, N.Y. ; got by Happy Medium, son of Hambletonian : dam a mare purchased of W. W. Corcoran, Washington, D. C., said to be by Morrill.

Sire of 2 trotters $\left(2: 29^{3 / 4}\right)$; I dam of $x$ trotter and I pacer.

DIXONEER, $2: 24 \mathrm{I} / 4$, dark bay, black points, I 6 hands, I I 50 pounds; foaled 1892 ; bred by Benjamin \& Sutherland, Saginaw, Mich.; got by Sphinx, son of Electioneer : dam Jessie Dixon, brown, foaled I872, bred by J. M. Dickson, Anderson, Ind., got by Mambrino Patchen; 2d dam a fast pacing-mare. Sold as a weanling to Dana Rhodes, Groton, N. Y., who sends pedigree.

Sire of 3 pacers $\left(2: 11 \frac{1}{2}\right)$.

D. MUNROE, $2: 283 / 4$, bay, I5 I/2 hands; foaled 1872 ; bred by Garrett Powell, Georgetown, Ky.; got by Jim Munroe, son of Alexander's Abdallah: dam Betty, bay, bred by Joe Duvall, Franklin County, Ky., got by Duvall's Mambrino, son of Mambrino Chief; $2 \mathrm{~d}$ dam bay, bred by Joe Duval, got by Macklin's Whip, son of Blackburn's Whip. Pedigree from breeder.

Sire of 2 dams of 2 trotters.

D. N. T. (7-I28), $2: 273 / 4$, chestnut, white stripe in face, 16 hands, 1200 pounds; foaled I 880 ; bred by D. N. Tripp, Coldwater, Branch County, Mich.; got by Masterlode, son of Hambletonian: dam bay, bred by Maklon Barnhart, Union, Mich., got by Magna Charta, son of Morgan Eagle; 2d dam bay, bred by Maklon Barnhart, got by Nero, son of Nero, by Flag, son of American Eclipse. Gelded young. Pedigree from breeder, who writes :

"Wallace has the breeding of dam of D. N. T., record $2: 273 / 4$ and Princess $2: 29^{\mathrm{I}} / 2$ different than I give it to you, but I have positive proof that it is as I give it. I have asked Wallace to tell me where or how he got the breeding of the dam of D. N. T., and Princess but he does not tell me. I am positive none of the owners ever gave it to him as two of them were dead long before she was recorded.
Respectfully yours,
D. N. TRIPP."

DOBLE (3-32), $2: 28$, black; foaled 1870 ; bred by K. C. Barker, Detroit, Mich.; got by Ericsson, son of Mambrino Chief : dam Belle, bred by Mr. J. Bagby, near Covington, Ky., got by Scrugg's Davy Crocket. Sold to J. J. Miller, Maysville, Ky. ; to W. Wheeden; to G. R. Pierson, Chillicothe, O.

Sire of 4 dams of 7 trotters.

DOC (I-I6), bay; foaled I 858 ; bred by Charles Lowell, Sacramento, Cal. ; got by St. Clair, which see. Sold 1863 , to a party in Oregon; died on the trip. See Occident.

Sire of Occident, $2: 16 \% / 4$, the world's trotting record when made; I dam of $\mathrm{I}$ trotter. 
DOC CHRISTIE (I-64), bay; foaled I888; bred by E. M. Tresslar, Franklin, Ind.; got by Anteros, son of Electioneer : dam Thomette, bay with star, and near hind foot white, foaled $188 \mathrm{I}$, bred by W. T. Withers, Lexington, Ky., got by Happy Medium, son of Hambletonian ; $2 \mathrm{~d}$ dam Country Girl, bay, bred by William McCracken, Lexington, Ky., got by Country Gentleman, son of Hambletonian ; 3d dam, dam of Joe Hooker, which see. Sold to James S. Neville, Bloomington, Ill., April 3, I 894 . Pedigree of dain from catalogue of breeder.

Sire of Minnie Christie, $2: 13 \frac{1}{4}$.

\section{DOCK. Untraced.}

Sire of Dauntless Bess, $2: 21^{3} / 4$; dam of I pacer.

DR. BUNNELL (I-I28), $2: 16 \pm / 4$, bay with star and white hind ankles, 16 hands, II 80 pounds; foaled April I5, I 895 ; bred by John Lance, Cheney, Spokane County, Wash. ; got by Ingam, son of Volunteer : dam Sadie Kitbie, bred by John Lance, got by Young Kisber, son of Kisber ; 2d dam Miss, bred by A. A. Lance, Cheney, Wash., got by Sidney, son of Santa Claus ; 3 d dam Doll, bred by Adam Fisher, Portland, Ore., got by Oregon Pathfinder; 4th dam Lillie, bred by Adam Fisher, got by Jack Hawkins. Pedigree from breeder.

Sire of Fack Wilmoth, $2: 191 / 4$.

DR. CARVER ( $1-64), 2: 29 \frac{1}{4}$, bay, about I 5 hands; foaled 1885 ; bred by Keller Thomas, Paris, Ky.; got by New York Dictator, son of New York, by Hambletonian : dam Kitty Morgan, chestnut, bred by Kellar Thomas, Paris, Ky., got by Joe Downing Jr, son of Joe Downing. Sold to F. A. Tolger, Kingston, Ont. Information from E. M. Harrington, Picton, Ont., breeder of Long Carver.

Sire of 2 trotters $(2: 201 / 4) ; 3$ pacers $(2: 211 / 2)$.

DR. CATON (I-64), 2 : 18 I $/ 4$, black; foaled I 888 ; bred by John W. Monical, Vincennes, Knox County, Ind.; got by Ganymede, son of Princeps : dam Atalanta, bay, bred by Arthur Caton, Joliet, Ill., got by Don Cossack, son of August Belmont ; 2d dam Misnomer, bay, bred by A. G. Peters, Mount Sterling, Ky., got by Alta, son of American Clay ; $3 \mathrm{~d}$ dam said to be by Edwin Forrest. Pedigree from breeder.

Sire of Doctor Shepard, $2: 24 \frac{1}{4}$.

DOCTOR COX (I-64), 2 :201/2, brown with star, I6 hands, I 200 pounds ; foaled I 890 ; bred by H. C. Harvey, Eureka, Kan.; got by Domineer, son of Red Wilkes: dam Necklace, bay, bred by Samuel Haggins, Donerail, Ky., got by Hector Wilkes, son of George Wilkes ; $2 \mathrm{~d}$ dam Alice, brown, bred by Samuel Haggins, Donerail, Ky., got by Jacinto, son of Almont; 3d dam Joe Mooney, said to be by Long Island Bashaw, son of Hawkeye; $4^{\text {th }}$ dam Joe, by Washington Denmark; and $5^{\text {th }}$ dam 
Arab, by Richard's Masson. Sold to T. K. Lisle \& Co., Butler, Mo. Pedigree from J. C. Clark and W. N. Skinner, Butler, Mo., at one time part owners.

Sire of Warren Cox, $2: 2 x$; Belle C., $2: 19 \frac{1}{4} 4$.

DR. FRANKLIN (I-8), black with small star, brown flanks and muzzle, $15 \frac{1}{2}$ hands, 1000 pounds; foaled May 3,1871 ; bred by Peter Letourneau, West Waterville, Me.; got by Gen. Knox, son of Vermont Hero : dam Lady Bird, dark bay or brown, black mane and tail, I 5 hands, rooo pounds, foaled June 9, I865, bred by Alanson Perry, Winthrop, Me., got by Winthrop Morrill, son of Young Morrill; $2 \mathrm{~d}$ dam Jane, black, about I $43 / 4$ hands, 900 pounds, brought from Canada to Gardiner, Me., breeding unknown. Owned by E. J. Lawrence, Somerset Mills, Me., who in January, x888, sold him to C. P. Whitney, Caribou, Aroostook County, Me. Pedigree from E. J. Lawrence. See The Morgan Horse and Register, Vol. I., p. 379 .

Sire of 4 trotters $\left(2: 24 \frac{1 / 2}{2}\right)$; I sire of I trotter; 7 dams of 4 trotters, 3 pacers.

DOCTOR HAILE ( $\mathrm{I}-64), 2$ : I I I $/ 4$, bay with star, left hind ankle white, I6 hands, 1200 pounds; foaled I 888 ; bred by M. F. Hill, Oakley, O.; got by Guy K., son of Guy Wilkes : dam Lady Kohn, brown, bred by A. T. Rice, South Elkhorn, Ky.; got by Bushwhacker, son of Joe Hooker; 2d dam Allie Furst, said to be by Robin Clay, son of Star Clay, by Strader's Cassius M. Clay Jr.; and $3 \mathrm{~d}$ dam by Capt. Walker, son of Tecumseh. Sold to W. O. Morris and B. J. Wilson, Rochester, Ind.

Sire of 5 pacers $\left(2: 1_{5} \frac{1}{4}\right)$.

DR. HERR ( I-I28), $2: 36$, bay, very little white in cleft of left fore-foot, I5 $1 / 2$ hands; foaled 1868 ; bred by R. S. Strader, Lexington, Fayette County, Ky. ; got by Mambrino Patchen, which see : dam bay, bred by R. A. Alexander, Spring Station, Ky.; got by Edwin Forrest, son of Young Bay Kentucky Hunter; 2 d dam Telltale, chestnut, foaled about r85o, bred by James K. Duke, Scott County, Ky.; got by Telamon,

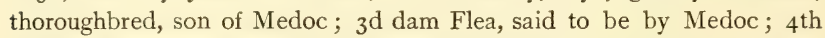
dam by Sumpter; $5^{\text {th }}$ dam Double Head; 6th dam by imported Buzzard, etc. Sold to I. N. Shepard, Paris, Ill. Pedigree from breeder and from I. N. Shepard's catalogue.

Sire of 8 trotters $(2: 16 \%) ; 5$ pacers $(2: 10) ; 4$ sires, I trotter; 4 pacers, 22 dams of I3 trotters, I5 pacers.

DR. HERR JR. (I-32), seal brown with star, left hind foot white, 6 hands, I220 pounds; foaled I89I; bred by John Dora, Charleston, Ill. ; got by Dr. Herr, son of Mambrino Patchen : dam Black Belle, bred by John Walling, Oakland, Ill., got by Green Mountain Morgan, son of Green Mountain Black Hawk; 2d dam black, bred by James DeSain, Oakland, Ill., got by Green Mountain Morgan, son of Green Mountain 
Black Hawk; 3d dam chestnut, bred by James DeSain, and got by a Highlander horse. Sold to F. S. Hansel: to Melvin Crews. Black Belle was bred to Dr. Herr, at Paris, Ill., in spring of 1890. Pedigree from John H. Halsey, Oakland, Ill.

DR. HICKS (3-128), brown, x6 hands, I 25 pounds; foaled 1892 ; bred by M. W. Hicks, Sacramento, Cal.; foaled the property of L. H. McIntosh, Chico, Cal. ; got by Durfee, son of Kaiser : dam Gazelle, bay, foaled 1878 , bred by M. W. Hicks, got by Buccaneer, son of Iowa Chief; 2d dam Mary, bay, foaled I866, bred by George Lawrence, Mahaska County, Ia., got by Flaxtail, son of Pruden's Blue Bull ; 3d dam said to be by Bright Eyes.

Sire of Edwin $S_{.,} 2: 08$.

DR. HOOKER (I-64), $2: 233 / 4$, bay; foaled 1890 ; bred by R. P. Fox \& Son, Richmond, Ky.; got by Vatican, son of Belmont : dam Mary Ann bay, bred by Milton Walker, Richmond, Ky., got by White's Hambletonian, son of Curtis' Hambletonian, by Hambletonian ; 2d dam Maggie, said to be by Black Diamond, son of Gray Harry, pacer. Advertised in The American Sportsman, in Shanklin and Walker sale, Lexington, Ky., r903.

Sire of 3 trotters $\left(2: 13^{3 / 4}\right)$; Raoul $W_{0,2: 201 / 4}$.

DOCTOR H. SHEPARD ( $1-\mathrm{r}_{2} 8$ ), $2: \mathrm{I}_{4} \mathrm{~T} / 4$, chestnut; foaled $\mathrm{r} 895$; bred by H. C. Shepard, Lovington, Ill.; got by Dr. Caton, son of Ganymede : dam M'Liss, bay, foaled x 884, bred by Henry C. Shepard ; got by Commander, son of Dictator; 2 d dam Little Lassie. Sold to I. H. Gregg, Tuscola, Ill.

Sire of Golden Rod, $2: 291 / 4$.

DR. M. Untraced.

Reputed sire of Ed O'Brien, $2: 14^{1 / 4}$.

DR. MAXWELL, said to be by Little Arthur, son of Glencoe.

Sire of Abner F., $2: 24^{1 / 4}$.

DR. MILLER, 2 : 19 1/4, chestnut, said to be by Hambletonian (McCurdy's), son of Harold.

Reputed sire of Lady Miller, $2: 2 \mathrm{I}$.

DOCTOR MONICAL, 2 :083/4, bay or brown; foaled I903; bred by G. \& C. P. Cecil, Danville, Ky.; got by Gambetta Wilkes, son of George Wilkes : dam Me Too, said to be by C. F. Clay, son of Caliban; 2 d dam Susie Wilkes (dam of Coleridge, $2: 05 \mathrm{~T} / 4$, which see). Pedigree from breeder who writes, April, x908: "Dr. Monical, $2: 083 / 4$, was the fastest four-year-old stallion to make a record in 1907 pacing." Wallace in his table of $2: 25$ pacers, published, I908, gives Dr. Monical $2: 09 \mathrm{~T} / 4$.

Sire of Doctor Image, $2: 21 \frac{1}{4}$. 
DOCTOR MORELAND (I-128), bay; foaled I886; bred by Dewey \& Stewart, Owosso, Mich.; got by Louis Napoleon, son of Volunteer : dam Miss Moreland, bay, foaled r882, bred by J. S. Boyd, Cynthiana, Ky., got by Indianapolis, son of Tattler; 2 d dam known as the Todd, or Moreland Mare. Pedigree from catalogue of breeder.

Sire of foe Archer, $2: 23^{1 / 4}$.

DR. PITZER (I-64), 2 :I2 I/2, brown, I53/4 hands, II 75 pounds; foaled I892 ; bred by Americus Seely, Whitehall, Ill.; got by Arsaces, son of Alcyone: dam bay, bred by Americus Seely, got by Port Leonard, son of Ben Patchen; 2d dam Maud A., bay, bred by Americus Seely, got by Almont Forrest, son of Almont; and 3 d dam Maud, bay. Pedigree from breeder.

Sire of Excello, $2: 291 / 2$.

DOCTOR SHEPHERD (I-32), $2: 29 \frac{1}{4}$, bay, near hind fetlock white, $151 / 2$ hands, Iooo pounds; foaled 1875 ; bred by Dr. E. T. Billmyer, Cherry Valley, Winnebago County, Ill.; got by Blue Bull : dam Bird, seal brown, bought of a Michigan horse dealer by Dr. Swain, Chicago, who sold her to a Mr. Zoller, and he to Frank Cunningham from whom Dr. Billmyer had her, pedigree unknown. Pedigree from breeder.

DR. SMITH (3-64), $2: 293 / 4$, spotted, I $53 / 4$ hands; foaled 1878 ; bred by Algernon Bradford, Turner, Me.; got by Gov. Morrill, son of Winthrop Morrill : dam Dixie, said to be by a gray stallion brought from Prince Edward Island, called thoroughbred; and $2 \mathrm{~d}$ dam by the Whitcomb Horse, said to have come from Canada, and called Arabian. Sold to Dr. Smith, Turner, Me.; to Lemuel Ricords, Buckfield, Me. Gelded young. Information from J. Thorp.

Joseph BATtell,

Turner Center, April, 24, I89o.

Sir:-It is very little I can tell you about the dam of Dr. Smith. She was a roan mare about I 5 hands high and about 900 pounds weight and although never trained she was quite speedy. I had her of Joseph Brown of Monmouth Center, Me. She was bred in Sagadahoc County, and got by a gray horse owned in Brunswick and said to have come from Canada.

Mr. BATTELL,

$$
\text { Yours truly, C. H. BRADFORD. }
$$

Turner Center, May 7, I89o.

Dear Sir :-In reply to your question about the sire of Dixie the dam of Dr. Smith I will say he was called the Whitcomb Horse and was owned by a man by the name of Whitcomb of Brunswick. Don't know his initials.

$$
\text { Yours truly, } \quad \text { C. H. BRADFORD. }
$$

Richmond, ME., March 22, I 892.

Joseph Battell, Ripton, Vt.

Sir :-I received a letter from you some time since asking for informa- 
tion concerning the pedigree of the dam of Dr. Smith-I have macle careful inquiry but can get only blood lines. The sire of Dixie, Dr. Smith's dam, was by Prince Albert brought from Prince Edward Island, he by a horse belonging to the government supposed to be thoroughbred. Prince Albert's color was dapple gray,-Dixie's dam was a spotted Arabian mare of great endurance as a road mare and could trot in 3 :00 or better on the ice, never was trained to track. This is all I can learn of her breeding.

$$
\text { Yours respectfully, S. W. THOMPSON. }
$$

DR. SPARKS, 2 :I $21 / 4$, brown, I6 $1 / 4$ hands, I 200 pounds; foaled 1887 ; bred by Thomas Hook, Stamping Ground, Ky.; got by Cyclone, son of Calaban: dam Lilly, gray, bred by James Thomas, Stamping Ground, Ky., got by Monroe Chief, son of Jim Monroe; $2 \mathrm{~d}$ dam Jenny, gray, bred by Ben Peake, Georgetown, Ky., got by Leo, son of Texas. Pedigree from A. J. Hook.

Sire of 2 trotters $\left(2: 24 \frac{1}{2}\right)$; Sally Hook, $2: 09$.

DR. SPAULDING. Untraced.

Sire of Goldust, $2: 18 \%$.

DOCTOR SPEERS (I-I6), black, two white feet, I6 $1 / 2$ hands, I 200 pounds ; foaled 1876 ; bred by William Lucket, La Belle, Wis.; got by Boxer (Spear's Morgan), son of Col. Walter : dam Kate Lucket (also called Escape) said to be by Blanco, son of Iron's Cadmus; 2d dam Milly Hambleton, by a son of 'Cook's Whip; and $3 \mathrm{~d}$ dam a fast pacing roan mare. Sold to D. M. Ramsey, Bunker Hill, Mo. Pedigree from Thos. Bevans, Williamstown, Mo., breeder of Speers.

Sire of Speers, $2: 14 \frac{1}{4}$,

DOCTOR SPURR, bay; foaled I 883 ; bred by R. J. Spurr, Greendale, Ky.; got by young Jim, son of George Wilkes: dam Daisy, said to be by Mambrino Patchen; 2 d dam by imported Eclipse ; 3 d dam by Cracker ; $4^{\text {th }}$ dam by imported Margrave; and $5^{\text {th }}$ dam Mistletoe, by Cherokee. Sold to A. B. Peterson, Chicago, Ill. Pedigree from E. V. Spurr.

Sire of Jim Dean, $2: 291 / 4$; dam of I trotter.

DR. STRONG ( $1-32$ ), bay, near hind ankle white, r6 $1 / 4$ hands ; foaled 1884 ; bred by H. P. Strong, Beloit, Wis. ; got by Prosper Merimee (Weeping Thomas), son of Gasacus, by Harold, son of Hambletonian, or Athlete, son of Almont: dam Anticipation, brown, bred by George C. Stevens, Milwaukee, Wis., got by Stevens' Clay Pilot; $2 \mathrm{~d}$ dam Lady Forrest, bay, bred by R. A. Alexander, Spring Station, Ky., got by Alexander's Edwin Forrest; $3 \mathrm{~d}$ dam One-Eyed Scott mare, pedigree untraced. J. C. Strong, Beloit, Wis., writes : "My father died I 883 . A colored groom employed many years previous to and at the time of my fathers death, says : 'Dr. Strong was bred by your father and was shipped to Michigan about 1885, as a two-year-old. He was by Prosper Merimee, and dam 
Anticipation.' The above information is all at my command now." Sold to George E. Bryant, Madison, Wis.; to Foote \& Bryant, Pueblo, Cal.; to Foote Bros., Memphis, Mo., who send pedigree.

Sire of Governor Strong, $2: 101 / 4$; I sire of 3 trotters; dam of I trotter.

DR. TALMAGE (3-128), bay, I6 hands, I 200 pounds; foaled May I8, I 883 ; bred by D. W. Thomas, Wayland O.; got by Onward, son of George Wilkes : dam Minnie L., bay bred by J. C. McLarran, Louisville, Ky., got by Cuyler, son of Hambletonian; $2 \mathrm{~d}$ dam said to be by Clark Chief; 3d dam by Kavanaugh's Gray Eagle, son of Gray Eagle ; 4th dam by Payton's Tranby; and $5^{\text {th }}$ dam by Boliver. Sold to Wayland Dover, about i 888 . Pedigree from breeder.

Sire of 2 trotters $\left(2: 25 \frac{1}{4}\right)$; I sire of I trotter, 2 pacers; 2 dams of 2 trotters.

DOCUMENT (3-I 28 ), bay, I 5 I 2 hands; foaled I89o; bred by M. Salisbury, Pleasanton, Cal.; foaled the property of F. S. Gorton, Chicago, Ill.; got by Director, son of Dictator : dam Sibyl Wilkes, bay, bred by M. Salisbury, got by Guy Wilkes, son of George Wilkes; $2 \mathrm{~d}$ dam Epithet, bay, bred by R. S. Veech, St. Mathews, Ky., got by Princeps, son of Woodford Mambrino: 3d dam Fantress, bay, bred by Edwin Thorne, Millbrook, N. Y., got by Hamlet, son of Volunteer; $4^{\text {th }}$ dam Favorita, bay, bred by O. P. Beard, Lexington, Ky., got by Alexander's Abdallah; $5^{\text {th }}$ dam said to be by Mambrino Chief; and 6 th dam by Tom Crowder. Sold to E. C. Whitacre, McLain, Kan. Pedigree from A. C. Pancoast, Galva, Kan., breeder of Docarro.

Sire of 2 pacers $\left(2: 21 \frac{1}{4}\right)$.

DOC. VAIL (I-32), bay, I5 $1 / 2$ hands; foaled I 880 ; bred by W. T. Vail, Manhattan, Kan.; got by Swigert, son of Norman : dam Lady Gano, said to be by Stephen A. Douglas, son of Hambletonian; and $2 \mathrm{~d}$ dam Guinea Hen, by Long Island Chief, son of Plow Boy. Sold to William P. Higginbotham, Manhattan, Kan. Pedigree from James Beck, South McAlester, Ind. T., breeder of Ben Hadad.

Sire of Ben Hadad, $2: 23 \% \frac{3}{4}$,

DODD PEET, 2 :I 8, gray, I5 hands; foaled I884; bred by A. G. Herr, St. Mathews, Ky.; got by Pancoast, son of Woodford Mambrino: dam Belle Dudley, gray, bred by A. J. Alexander, Spring Station, Ky., got by Belmont, son of Alexander's Abdallah; 2d dam Madam Dudley, gray, said to be of Bashaw stock. Sold to Norvin T. Harris, St. Mathews, Ky., who sends pedigree. Broke three-year-old world's pacing record at Lexington, Ky., r $887,2: 23$. Died spring of 1897 .

Sire of Gazelle, $2: 21 \frac{1}{2} ;$ Hurstbourne Maid, $2: 23 \frac{1}{2}$.

DOLAN (BLACKBIRD) (I-I6), black with star, one hind foot white, I5 hands, 900 pounds; foaled about $\mathrm{r} 860$; said to be by Thomas Jeffer- 
son, son of Black Hawk. Irought from Canada when advanced in years, by John Dolan, a Canadian; afterwards owned by David Mack \& J. Mixter, North Adams, Mass. Kept at Eagle Bridge, Cambridge, Johnsonville, N. Y., and North Adams, Mass. A nice smooth-turned horse. See The Morgan Horse and Register, Vol. II., p. IO3.

Sire of Kitty Ives, $2: 281 / 4$.

DOLLAR (I-I6), bay, I6 hands, I I 50 pounds; foaled $x 878$; bred by H. J. Starr, Carey, O. ; got by Almont Clay, son of Almont : dam Silver Cloud, brown, bred by H. J. Starr, got by Orr's Flying Cloud, son of Black Hawk; 2 d dam Het, bred by H. J. Star, a fast road mare, not traced. Sold to Thomas Whitefield, Clyde, O., who sends pedigree.

Sire of Miss Maud, $2: 27 \frac{3 / 4 ; 4}{4}$ dams of 3 trotters, I pacer.

DOLPHIN, bay, I6 $1 / 2$ hands; foaled I 782 ; said to be by Godolphin : dam Kitty Fisher, owned in Maryland. Advertised at Lexington, Ky., I 789 .

DOLPHIN, foaled about 1832 ; bred by Herbert Savage, Anson, Me.; got by Highlander, a running horse brought to Skowhegan, Me., by Jacob N. Shaw, who is said to have brought him from New York: dam called a Dolphin. J. W. Thompson in Maine Bred Horses, Vol. I., says, "The dam of Dolphin, belonged to what was then known as the Dolphin breed, and from which he took his name. He was a running horse, like his sire, and is thought by many to be the sire of Witherell."

DOLPHIN (BAKER'S) (I-I6); foaled I85I; awarded premium at the North Summit County Fair, Ky., I859. Owned by Chandler Baker, and called French and Morgan.

DOLPHIN ; foaled I 857 ; bred by. T. J. Cox, Zanesville, O.; got by Pataskala, son of Boston: dam Marcia, said to be by Sir John Stanley; 2 d dam Ella Douglas, by Surprise, son of Sir Solomon; and $3 \mathrm{~d}$ dam by a thorough-bred horse brought to Ohio by Robert Fulton. Taken to Nashville, Tenn., by breeder in 1864 , was sold by him and it was said went North, and trace lost, although a horse of same name, said to be this horse, appears afterwards at Brookville, Penn.

DOLPHIN (I-I6), bay, I5 hands, I200 pounds; foaled I858; bred by Sewal Stinchfield, Androscoggin County, Me.; got by Eaton Horse, son of Avery Horse: dam said to be Morgan. Owned in California and advertised as above in 1867 by Sewal Stinchfield, Santa Clara, Cal., who it is thought brought him to the State from Maine. Information furnished by H. W. Meek, San Lorenzo, Cal., in letter dated April 15, I894.

Sire of dam of $\mathrm{I}$ trotter and dam of Cricket, 2 :Io.

DOLPHUS ( $\mathrm{r}-8$ ), bay, $15 \mathrm{x} / 2$ hands, ro5o pounds; foaled $\mathrm{r} 849$; bred by Capt. J. P. Wilson, East Berkshire, Vt.; got by Nimrod, son of True 
American : dam bay, said to be by Telescope. Taken to Carthage, O., I 855 by Capt. J. P. Wilson, who was killed in the war and the horse was sold to Mr. Bonham, Hamilton County, O., whose property he died.

Advertised in Springfield, Hamilton County, O., I856, as follows :

"Bay, I5 $1 / 2$ hands; foaled I 849 ; got by Nimrod, son of True American, by Quicksilver, son of imported Dey of Algiers; True American's dam, a fine bay mare by imported All Fours, kept at Stonington, Conn. Nimrod's dam a beautiful bay mare, got by old Morgan himself on a fine English mare. Dolphus' dam an elegant bay mare by old Telescope. Dolphin was brought to Ohio from Vermont, fall of 1855 , by Samuel L. Hourmedien. Trotted last season by O. W. Dimmock, in New Orleans, in $2: 4 \mathrm{I} / 2$, which is the greatest trotting speed ever made by any stallion west of the Alleghanies."

Joseph Battell, EsQ.,

Lockland, O., March 24, I888.

Dear Sir:-In reply to yours of the 8 th. The horse Dolphus was owned first by a man named Jesse Wilson. He was a colonel in the war and was killed in action. At his death the horse was sold to a man named Bonham, who, I think, kept him till he (the horse) died. John Bonham, a son, is living in Reading, Hamilton County, O., and I think he could give you the information desired. The get of this horse Dolphus were not remarkable for speed, but were good all-round horses, and excellent in disposition. One mare from him named Bay Mollie, was quite fast. I think she had a record close to $2: 20$. I saw her make a mile on the old Buckeye track in $2: 27$. She was taken East and when last heard from was in Canada, where at 20 years old, she had foaled a colt. A good many Dolphus horses are about here yet.

You might also address Sam. Foreman, Carthage, Hamilton County, O. I think he is a relative of Wilson.

Yours truly, Raby Shinkle.

Sire of 2 trotters $\left(2: 27^{1 / 2}\right)$; dam of I trotter.

DOMESTIC (I-64), 2 :201/2, bay, I5 $5 / 2$ hands, 975 pounds; foaled I 880 ; bred by Alden Goldsmith, Washingtonville, Orange County, N. Y.; got by Volunteer, son of Hambletonian : dam Gordova, bay, bred by Alden Goldsmith, got by Godfrey Patchen, son of George M. Patchen; 2 d dam Faustina, bay, bred by George H. Morrison, Montgomery, N. Y., got by Volunteer; 3 d dam Stella, bay, bred by George H. Morrison, got by Seeley's American Star. Died January, I89o. Pedigree from J. H. Goldsmith.

DOMINATOR (3-64), bay with star, snip, hind feet white; foaled I 886 ; bred by J. A. Sherman, Lexington, Ky. ; got by Hambletonian (Sherman's), son of Hambletonian: dam Hattie Lawrence, bay, slight strip in face, $153 / 4$ hands, bred by W. G. Baldwin, Ticonderoga, N. Y.; got by Daniel Lambert, son of Ethan Allen; 2d dam Jenny, black (dam of Nonesuch, $2: 25 \mathrm{I} / 2$, and Col. Moulton, $2: 28 \mathrm{I} / 2$ ), said to be by Bigelow Horse, son of Black Hawk. Pedigree from catalogue of breeder. 
DOMINEER (I-32), $2: 20$, bay with black points, I 6 hands, 1350 pounds ; foaled 1887 ; bred by A. Smith McCann, Lexington, Ky; got by Red Wilkes, son of George Wilkes : dam Lizzie H., black, bred by P. Dolan, Payne's Depot, Ky., got by Star Almont, son of Almont; 2d dam said to be by Long Island Black Hawk; and $3 \mathrm{~d}$ dam by Washington Denmark, son of Gaines' Denmark. Sold to J. C. Taylor, Chebanse, Ill. ; to J. D. Yeomans, Onawa, Ia. ; to H. C. Harvey, Eureka, Kan.; to W. P. Keefe, Sioux City, Ia., who sends pedigree.

Sire of 4 trotters $\left(2: 15 \frac{1}{2}\right), 6$ pacers $(2: 15) ; 2$ sires of 2 trotters, 2 pacers.

DOMINICK BURNETT. Trotted or paced in California, 1852, entered by a Mr. Bailey. Best time $2: 45$.

DOMINION (I-32), bred by Capt. James Mains, Melbourne, Que., got by the Cleveland Bay horse Roseberry, imported from Yorkshire, England by an agricultural society, which paid for him $\$ 2000$ : dam chestnut, I 6 hands, said to be by a horse bought in the City of Quebec, brought to Quebec from England, by an army officer, and called thoroughbred; $2 \mathrm{~d}$ dam brought to Canada from the vicinity of Derby Line, Vt., said to be by a son of Royal Morgan. Sold when seven or eight years old to George F. Davis then of Claremont, N. H. Information from Mr. Parlin in American Cultivator, who credits the same to Geo. F. Davis; Windsor, Vt., and several other gentlemen.

DOMINION ( $\left.\mathrm{I}-3^{2}\right)$, chestnut, white hind foot, I5 hands, Iooo pounds; foaled I 883 ; bred by John Duncan, Georgetown, Ky., got by Red Wilkes, son of George Wilkes : dam Dillie, said to be by Dictator, son of Hambletonian; 2 d dam Henrietta, by Adam's Bald Chief, son of Bay Chief; 3d dam by John Dillard, son of Indian Chief; $4^{\text {th }}$ dam Fanny, by Ben Franklin, son of Hazrack; and 5 th dam Nance, by Saxe Weimar, son of Sir Archy. Died 1903. Sold to Vincent C. Cromwell, Lexington, Ky.; to A. Smith McCann, Lexington, Ky.; to John W. Coffman, Bridgeport, W. Va. ; to Jesse H. Willis, Bridgeport, W. Va., who sends pedigree.

Sire of 4 trotters $\left(2: 19 \frac{1 / 4}{4}\right), 2$ pacers $\left(2: 23 \frac{1}{2}\right) ; 2$ sires of 3 trotters; 3 dams of 3 pacers.

DOMINION GEORGE. W. C. Bingham, Aylmer, Ont., writes : “Dominion George was raised about Hamilton and was traveled here for about $3 \mathrm{c}$ years. He was owned by George Parker, whose son Byron lives on the old homestead at Dunboyne, Ont."

Sire of 2 dams of 3 pacers.

DOMINIX. Dr. McCarthy, Nashville, Tenn., born in Martinsburg, Lewis County, N. Y., I 826, in interview 1892 said:

"I was born in New York State, went to Wisconsin in 1836 , came to Tennessee in 1876 . There was a Stallion called Dominix that went to 
California from Wisconsin where he was owned by Carson Newman of Fon du Lac. The horse belonged to a breed of pacing horses in Wisconsin, called the six-penny breed and said to be in part of French stock. Dominix was 15 hands, dapple gray, full mane and tail, a handsome horse, fully developed and strong at all points. The color of the sixpenny breed were generally chestnut and roan. The Indian ponies were from I $3 \frac{1}{2}$ to I 4 hands, 700 to 800 pounds, some with beautiful forms. The Mustangs are larger would average $\mathrm{I} 4$ to $\mathrm{I} 4 \mathrm{I} / 2$ hands, occasionally one 15 hands."

Dr. McCarty in a second interview said :

"I am satisfied that the six-penny horses were introduced into Wisconsin at the time of the French War. I think they were part running blood. They were red roans or chestnuts, some gray, no bays and not a single black. The Tom Hal stock are like the Copperbottom stock, blocky built. The Copperbottom was quite a compact horse and remarkable for his staying qualities, a block horse $15 \frac{1}{2}$ hands, rather fine."

DOM PEDRO (I-64), bay I 6 hands; foaled 1876 ; bred by E. D. Montague, Marshall, Mo., got by Mambrino Champion, son of Mambrino Chief: dam Lucille, bay, bred by E. D. Montague, got by Hartford Hambletonian, son of Hambletonian; $2 \mathrm{~d}$ dam Glencoe Belle, bay, foaled 1858 , bred by James A. McHatton, Jefferson County, Ky, got by Ole Bull, son of Pilot; 3d dam Glencona, said to be by imported Glencoe ; 4 th dam

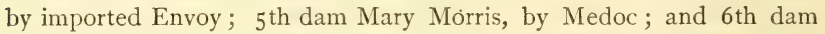
Miss Obstinate, by Sumpter, son of Sir Archy. Sold to G. B. Blanchard, Marshall, Mo., who sends pedigree.

Sire of 4 trotters $\left(2: 19^{3 / 4}\right) ; 2$ dams of I trotter 2 pacers.

DON, said to be by Hermit.

Sire of Billy Cleveland, $2: 231 / 4$.

DON A. ( $1-64)$, bay; foaled I 8-; said to be by a son of Fayette Mambrino, son of Mambrino Patchen : and dam by Morgan Rattler.

Sire of Lady Don, $2: 291 / 2$.

DONALD C. ( I-64), bay; foaled I88I ; bred by Caton Stock Farm, Joliet, Ill.; got by Don Cossack, son of August Belmont : dam Lotta, bay, bred by J. L. Wilson, Rock Isiand County, Ill., got by Bashaw Drury, son of Green's Bashaw ; 2 d dam said to be by Star Gazer. Sold to F. S. Cole, Grundy Centre, Ia.

Sire of Prince Idler, $2: 291 / 4$.

DONATIS, $2: 14 \frac{1}{4}$, bay, said to be by Anderson Wilkes, son of Onward. Sire of Ben Hur, $2: 15 \frac{1}{4}$.

DON CARLOS. Advertised in Lexington (Ky.), Gazette, I789, as follows : "Will stand at Gen. Chas. Scott's. A beautiful bay in color, I5 hands high, of as good parts as any horse in the Universe. Got by Dr. Hamil- 
ton's imported horse Figure (who won four King's P'lates) from famous mare Primrose. Primrose was got by the imported I)ove, dam Stella, by Othello, dain Selima. Selima was imported and got by the Godolphin Arabian. Primrose, Don Carlos' dam, won five purses against the best and most capital horses on the continent and was to have been taken to England to run for the King's Plate of a thousand guineas but was prevented by the non-export Resolves in 1775 . DANIEL SCOTI."

DON CARLOS ( $1-64$ ), $2: 23$, bay, $15 \frac{1}{2} 2$ hands, I075 pounds; foaled 1880 ; bred by J. C. McFerran \& Co., Louisville, Ky. ; got by Cuyler Clay, son of Cuyler: dam Lady Abdallah, bred by Herman D. Ayres, Bourbon County, Ky., got by Alexander's Abdallah; 2 d dam Ayres Mare brought from Ohio. Sold to John R. Graham; to Graham \& Conley both of Quincy, Mass. Pedigree from John J. Conley. Died 1897.

Mr. Joseph Battell, Middlebury, Vt.

Breckenridge, Mo., May 25, 1906.

Dear Sir :-I bought Bay Kit, pacer, the dam of Lady Abdallah at a public sale near Millersburg, Bourbon County, Ky., in I 857 or 8 from a man from Ohio by the name of I.ewis. He has been dead a long time. He said she was by a horse that was brought there from New York but did not give his breeding. I bred her to Abdallah, the year he came to Kentucky, and Lady Abdallah was one of the first crop of colts that Abdallah had, foaled in Kentucky. The dam of Lady Abdallah was a great road mare, and Lady Abdallah was the greatest lot trotter I ever saw. I was born and raised in Bourbon County, Ky., and moved from there to Missouri in 1878 .

Respectfully H. D. Ayres.

Sire of $I_{5}$ trotters $\left(2: \mathrm{IO}_{1} / 4\right), 3$ pacers $\left(2: \mathrm{I}_{5}\right) ; 2$ dams of 2 trotters.

DON COSSACK (I-I28), $2: 28$, bay, I6 $1 / 4$ hands, I 300 pounds; foaled I 876 ; bred by J. C. McFerran \& Son, Louisville, Ky. ; got by August Belmont, son of Hambletonian: dam Laytham Lass, bay, foaled 1863 , bred by James Laytham, Bourbon County, Ky., got by Alexander's Abdallah; 2 d dam bred by J. B. Neale, Bourbon County, Ky., got by Mambrino Chief; 3 d dam sent from Ohio to be bred to Mambrino Chief, and said to have been a Bellfounder. Owned at Caton Stock Farm, Joliet, Ill., where he died I 889. Pedigree from catalogue of breeder.

Sire of 9 trotters $(2: I 61 / 4), 2$ pacers $(2: 161 / 2): 5$ sires of 4 trotters, I pacer; 17 dams of 20 trotters, 2 pacers.

DONCASTER (I-32), bay, I6 hands, I 225 pounds; foaled Sept. 25, I 880 ; bred by Gen. W. T. Withers, Lexington, Ky.; got by Happy Medium, son of Hambletonian : dam Headley Mare, said to be by Regular, son of Volunteer ; 2d dam Melissa, by Crockett's Bellfounder; and $3 \mathrm{~d}$ dam Kate, by Conflagration. Sold to John Brehman, Bucyrus, O., who writes : "He resembled Happy Medium. Died fall of $\mathrm{r} 886 . "$

Sire of De Witt C., $2: 29 \frac{114}{4}$.

DONCASTER, $2: 281 / 4$, bay, white nose and hind stockings, $153 / 4$ harids, 
I 250 pounds; foaled I 880 ; bred by W. H. Raymond, Pullerspings, Mont.; got by Commodore Belmont, son of Belmont: dam Virginia, bay, foaled 1873 , bred by Benj. Gratz, Spring Station, Ky., got by Mambrino Champion, son of Mambrino Chief; $2 \mathrm{~d}$ dam bay, bred by Benj. Gratz, got by Hunt's Commodore, son of Mambrino; $3 \mathrm{~d}$ dam bred by Joseph Boswell, got by Blackburn's Whip, son of imported Whip. Pedigree from breeder.

DON CLAY (I-128), bay, said to be by Kentucky Clay, son of Cassius M. Clay Jr.

Sire of Blanche Brown, 2 :30.

DON CORBETT (DICK IVILKES) (1-32), 2 :093/4, bay, black points, heavy mane and tail, I 6 hands, Ir 80 pounds; foaled $\mathrm{I} \delta 90$; bred by William English, Elmwood, Ill.; got by Olmstead's Young Wilkes, son of George Wilkes : dam Miss Southard, sorrel, bred by R. W. Southard, Magnolia, Ill., got by Robert Mac (dam by Silverton's Silverheel's, son of Black Hawk), son of Robert McGregor ; $2 \mathrm{~d}$ dam Belle Ford bred by D. Southard, Magnolia, Ill., got by Van Wagoner ; 3d dam Grace Tower,

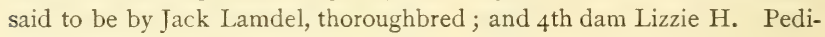
gree from breeder.

Sire of 2 pacers $\left(2: I_{4} 1 / 4\right)$.

DON FELIX, $2: 271 / 4$, bay, ${ }_{5}$ hands; foaled 1884 ; bred by Leland Stanford, Menlo Park, Cal ; got by Electioneer: dam Adelaide, chestnut, bred by Wm. White, Lexington, Ky., got by Black Donald, son of Mambrino Chief ; 2 d dam Alicia, said to be by Capt. Beard, son of imported Yorkshire. Sold to W. S. Chamberlain, Cleveland, O. Pedigree from catalogue of breeder.

Sire of 2 trotters $(2: 26 \% / 4)$.

DONFONSO (3-64), gray, I5 I/2 hands, 950 pounds; foaled $189 \mathrm{I}$; bred by A. H. Stickles, West Stockbridge, Mass.; got by Alfonso, son of Baron Wilkes: dam Ora, gray, bred by A. H. Stickles, got by Young America, son of Hoagland's Gray Messenger; 2 d dam Dame Trot, said to be by Black Hawk, son of Sherman Morgan; 3 d dam Lady Peck, by Post Boy, son of Blossom; and 4th dam Molly Clark, by Blossom, son of L. E. Ray's Blossom. Pedigree from breeder.

Sire of Silversmith, $2: 27^{1 / 4}$.

DON FOSTER, bay ; foaled r 8 - ; bred by L. T. Foster, Youngstown, O.; got by Oberlin, son of Harold: dam Nelly.

Sire of Colonel B., $2: 291 / 2$.

DON GOTHARD (3-ז28), $2: 27$, bay; foaled $\mathrm{r} 884$; bred by S. C. Wells, LeRoy, N. Y. ; got by St. Gothard, son of George Wilkes : dam Crescent, bay, foaled I 880 , bred by G. W. Agnew, Mobile, Ala., got by Contractor, 
son of Ajax; 2 d dam Stockbridge Belle, said to be by Stockbridge Chief; $3^{\mathrm{d}}$ dam Sue Letcher, by Norman; and $4^{\text {th }}$ dam the Letcher Mare. Pedigree from catalogue of breeder.

Sire of Nelly C., $2: 2.4^{1 / 2}$.

DONIPHAN (3-16), bay, I53/4 hands; foaled about 1846 ; bred by H. M. H. Taylor, Clark County, Ky.; got by Cavins' Dary Crockett, son of Blackburn's I)avy Crockett: dam sorrel, bred by H. M. H. Taylor, got by Pilot; $2 \mathrm{~d}$ dam said to be by Copperbottom; and $3 \mathrm{~d}$ dam a Narragansett. Kept at Colby and Franklin County, Ky., went to Missouri, but returned, and died the property of Colby \& Taylor, Franklin County, Ky. A very muscular horse of good appearance and action, and very kind disposition; stock excellent. See The Morgan Horse and Register, Vol. I., p. 777 .

Sire of 4 trotters; dam of Clark Chief Jr.

DON J. ROBINSON (3-64), chestnut, I5 hands; foaled r868; bred by Daniel B. Hibbard, Jackson, Mich.; got by Marshall Chief, son of Kilburn's Hero : dam Kitty Bates, gray, bred by Joseph F. Bates, New York, N. Y., got by Hambletonian, son of Abdallah; 2 d dam Belle of Richmond, said to be by Nottingham's Norman, son of the Morse Horse. See The Morgan Horse and Register, Vol. I., p. 48 r.

Sire of 4 trotters $\left(2: 24 \frac{1}{4}\right)$; Plush, $2: 23 \frac{1}{2} ;$ I sire of I pacer; 5 dams of 3 trotters, 2 pacers.

DON JUAN, bay, I6 hands; foaled I875; bred in Kentucky, said to be by Doniphan, son of Davy Crockett: dam by Abdallah Jr. Owned by Major Brown of Tennessee, who sold to W. C. Goth, Huntsville, Ala. Information from Capt. M. C. Campbell, Spring Hill, Tenn.

Sire of Shamrock, $2: 19^{3 / 4}$.

DON L. (1-128), $2: 283 / 4$, bay, with star, tan flanks and white hind ankles, I 5 I/4 hands, ro4o pounds; foaled I 884 ; bred by Phil E. Evans; got by Fieldmont, son of Almont: dam Nutmeg Maid, brown, bred by W. B. Smith, Connecticut, got by Thomas Jefferson, son of Toronto Chief; 2 d dam said to be by Godfrey's Patchen, son of George M. Patchen. Pedigree from S. E. Larrabie, Deer Lodge, Mont., who writes that Nutmeg Maid was purchased by him in Kentucky from a Mr. Royster, and that she was brought to Kentucky from Connecticut by a Mr. Hudson.

Sire of Bud L., $2: 23 ; 2$ pacers $\left(2: 2 I^{3} / 4\right)$.

DON LORENZO (I-I6), $2: 173 / 4$, bay; foaled I 889 ; bred by G. \& C. P. Cecil, Danville, Ky. ; got by Gambetta Wilkes, son of George Wilkes : dam Lady Yeiser, bay, foaled I 876 , bred by Dr. Yeiser, Danville, Ky., got by Garrard Chief, son of Mambrino Chief ; $2 \mathrm{~d}$ dam Jewell, chestnut, about $15 \% \frac{1}{2}$ hands, 900 pounds, bred by Dr. Henry Yeiser, Danville, Ky., got by Gill's Vermont, son of Downing's Vermont ; 3d dam Brown Kate, 
said to be by Black Jack, son of Hacket Horse, by Gifford Morgan ; $4^{\text {th }}$ dam Little Black, by Black Hawk, son of Sherman Morgan; and $5^{\text {th }}$ dam by White Mountain Morgan. G. \& C. P. Cecil in letter received Dec. I 2 , 'o7, write :

"We have owned the produce of three mares named Jewel each got by Gill's Vermont and each has made quite a family. Jewel, dam of Lady Yeiser, the dam of eleven with standard records, foaled Lady Yeiser when she was five or six years old and Lady Yeiser was her only foal. She was a very fast mare and died the winter or spring Lady Yeiser was coming one year old. Also, she was a very handsome mare and a great road mare and was killed by a very long and hard drive about seventy miles in winter or early spring from here to Lexington and return in one day-and most likely a great number of other miles while at or near Lexington. Several young men were driving her and she had trotted in about $2: 35$ or $2: 38$ before she foaled Lady Yeiser and would have been trained had she lived. We think she was only five years old when she foaled Lady Yeiser. This Jewel was a great show mare and was never beaten in the show ring."

Sire of 2 pacers $\left(2: 19 \frac{1}{4}\right)$.

DON LOWELL (1-32), $2: 20$, bay, white points, $15 \frac{1}{2}$ hands, 1050 pounds ; foaled I 889 ; bred by Samuel Harris, Yuba City, Cal.; got by Don Marvin, son of Fallis, by Electioneer: dam bay, bred by Patrick Slattery, Maryville, Cal., got by Brigadier, son of Happy Medium ; $2 \mathrm{~d}$ dam bay, bred by Patrick Slattery, got by California Dexter, son of Whipple's Hambletonian; 3 d dam sorrel, brought across the plains and said to be by Copperbottom. Sold to Munroe Salisbury, Pleasanton, Cal. Record made at Napa, Cal. Pedigree from breeder.

Sire of 2 trotters $\left(2: 12 \frac{1}{4}\right)$.

DON MARVIN (3-I28), brown with star, near hind foot white, $15 \frac{1}{2}$ hands ; foaled I 884 ; bred by Leland Stanford, Menlo Park, Cal. ; got by Fallis, son of Electioneer: dam Cora, bay, bred by Leland Stanford, got by Don Victor, son of Belmont; $2 \mathrm{~d}$ dam Clarabel, bay, bred by Charles Backman, Stony Ford, N. Y., got by Abdallah Star, son of American Star Jr. ; 3d dam Fairy, bay, bred by William M. Rysdyk, Chester, N. Y., got by Hambletonian; $4^{\text {th }}$ dam Emma Mills, chestnut, bred by William Hill, Walkill, N. Y., got by American Star; $5^{\text {th }}$ dam said to be by Rediker's Alexander W., son of Alexander W., by Cole's Messenger. Sold to F. P. Lowell, Sacramento, Cal. Pedigree from catalogue of breeder.

Sire of 5 trotters $\left(2: 1_{4} 1 / 2\right)$, I sire of 2 trotters.

DON McGREGOR (5-I28), chestnut, I 6 hands, I I 50 pounds; foaled 1883 ; bred by Andrew Wilson, Kingsville, Kan.; got by Robert McGregor, son of Major Edsal: dam Flora Leslie, bay, said to be by Florida, son of Hambletonian; 2d dam Lily Woodward, bay, bred by W. W. Frazier, Cynthiana, Ky., got by Abdallah (Kimbrough's) ; 3d dam Dark, said to 
be by Alexander's Edwin Forrest. Sold to Thomas Wilson, Pleasant Plains, Ill., who sends pedigree.

Sire of 4 trotters $(2: 11), 6$ pacers $\left(2: 08 \frac{3}{4}\right)$.

DON MIFF ( $1-64), 2: 23$, brown with white to pastern on all four feet, $153 / 4$ hands, II 85 pounds; foaled 1885 ; bred by Archy Finch, Montezuma, Poweshiek County, Ia. ; foaled property of Mayerall Bros., Atlantic, Ia.; got by I iamond Volunteer, son of Volunteer: dam bay, bred by Dr. E. Vest, Montezuma, Ia., got by Vest Bashaw, son of "Bull of the Woods," by Green's Bashaw ; 2 d dam roan pacer brought from Indiana, 1874 . Sold to James Sheeley, Atlantic, Ia. ; to Dr. W. C. Morse, Eldora, Ia. Pedigree from S. C. Wells.

DON MONTIETH, $2: 29 \mathrm{~T} / 2$, bay, crescent in forehead, near hind foot and outside of off hind foot white, I61/4 hands; foaled I 885 ; bred by Leland Stanford, Menlo Park, Cal.; got by Electioneer, son of Hambletonian : dam Mamie C. dam of Azmoor, $2: 201 / 2$, which see. Sold to Robert Steel, Philadelphia, Penn. Pedigree from catalogue of breeder.

Sire of Zuleika, $2: 25^{3} / 4$.

DONNYBROOK (I-I6), black, I6 hands, 950 pounds; foaled May I2, I 868 ; bred by John H. Tucker, Fairfield, Somerset County, Me.; got by Gilbreth Knox, son of Gen. Knox, by Vermont Hero, son of Sherman Black Hawk. See The Morgan Horse and Register, Vol. II., p. IO4.

DONNYBROOK, bay with star; foaled 1872 ; bred by Allen D. Sedgewick, Verona, N. Y. ; got by Autocrat, son of Volunteer : dam bay, bought of T. \& J. Dyett, Rome, N. Y., said to be by Kentucky Hunter. Sold to L. Pomeroy, Rome, N. Y.; to Dexter Bennett, Philadelphia, N. Y.; to William Beach, Ganonoque, Ont., Can. Pedigree from breeder.

Sire of 2 trotters $\left(2: 25 \frac{1}{4}\right)$, Skip, $2: 183 / 4$.

DON OZRO (3-64), bay with right hind fetlock white, r6 hands, I I fo pounds; foaled May 30, I878; bred by D. M. Brooks, Little Valley, Cattaraugus County, N. Y.; got by Major Edsall, son of Alexander's Abdallah: dam chestnut, bred by John F. Mosher, Leon Centre, N. Y., got by Springville Chief, son of Fields' Royal George ; 2 d dam chestnut, bred by Stephen Mosher, Leon Centre, N. Y., got by Rough and Ready, son of Black. Hawk; 3 d dam chestnut. Kept at the stables of the owner, W. J. Smith, Little Valley, N. Y., who sends above information and writes: "breeding of third dam is unknown to me. In other pedigrees she is said to be by imported Trustee."

Sire of 2 pacers $\left(2: 21^{3} / 4\right)$.

DON PEDRO (3-64), black, $15 \% \frac{1}{4}$ hands, 950 pounds; foaled about I 870 ; 
bred by Cyrus H. King, Welchville, Me.; got by Tom Patchen, son of Geo. M. Patchen : dam the dam of Patchen (King's). Sold to C. H. C. Buckman, Mechanics Falls, Me. Mr. L. D. King, who bred King's Patchen from the above dam, in a letter dated Welchville, Aug. 5, I89o, writes: "she was by a son of Vermont Black Hawk." Again Mr. King writes, Nov. 5 , I89 I :

Dear Sir :--I received your letter in reference to the pedigree of Don Pedro and the King mare. Will say that the King mare was bred by a Mr. Wardwell of Otisfield. My brother bought the mare of Mr. Wardwell when she was three years old, paid $\$ 300$ for her. My brother, Cyrus H. King, of Welchville, bred the King mare to Tom Patchen, he by George M. Patchen, and raised two horse colts. My brother died when the first colt was two years old. I bought the oldest colt of the widow for $\$ 300$, had him registered as King's Patchen. The colt that was one year younger was sold to C. H. C. Buckman of Mechanics Falls.

I lived in West Gray at the time the King mare was sold to Isaac Wardwell of Monmouth for $\$ 400$. He bred her to Winthrop Morrill and raised four colts, then I traded a colt three years old for the mare, sold her to George — of West Gray. I think the King mare is dead, she was got by Black Jack, said to be by Black Hawk.

Don Pedro was the second colt from the King mare, by Tom Patchen, he by George M. Patchen. This is all the information that I can give. Saw Buckman and he will write you giving pedigree of Don Pedro.

$$
\text { Respectfully, yours, L. D. King. }
$$

DON PEDRO (I-64), $2: 24 \frac{\mathrm{T}}{4}$, brown, 16 hands, I 200 pounds; foaled $\mathrm{r} 875$; bred by A. B. Scutt, Binghamton, Broome County, N. Y.; got by Knickerbocker, son of Hambletonian: dam black, bred by James Johnson, Middletown, N. Y., got by Mulvey's, Clay, son of Harry Clay; $2 \mathrm{~d}$ dam Hickory, said to be by Hickory, son of Hickory (thoroughbred). Sold to A. B. and A. P. Scutt, Binghamton, N. Y. Pedigree from breeder, who writes :

"Dam of Mulvey's Clay : A Campbell's Andrew Jackson mare, from a mare by Engineer 2d. I purchased the dam of Don Pedro of James Johnson the man who bred her, I bought in February, I87o. She was foaled in $\mathrm{I} 866 . "$

Sire of Topsey S., $2: 24^{3 / 4}, 2$ pacers $(2: 181 / 4)$.

DON PEDRO, bay, bred by Thomas Havens, Vermillion, Marshall County, Kan.; got by Beattie's Black Hawk of Vermillion, Kan. : dam black, bought of William Rutledge. Pedigree from breeder.

DON PIZARRO (1-16), $2: 143 / 4$, bay, 15 $5 \frac{1}{2}$ hands; foaled 1886 ; bred by G. \& C. P. Cecil, Danville, Ky. ; got by Gambetta Wilkes, son of George Wilkes : dam Lady Yeiser, bay, bred by Dr. Yeiser, Danville, Ky., got by Garrard Chief, son of Mambrino Chief; 2d dam Jewell, brown, bred by John S. Gill, Lancaster, Ky., got by Gill's Vermont; 3d dam Brown Kate, said to be by Black Jack, son of Hacket Horse, by Gifford Morgan; 4th dam Little Black, by Black Hawk, son of Sherman Mor- 


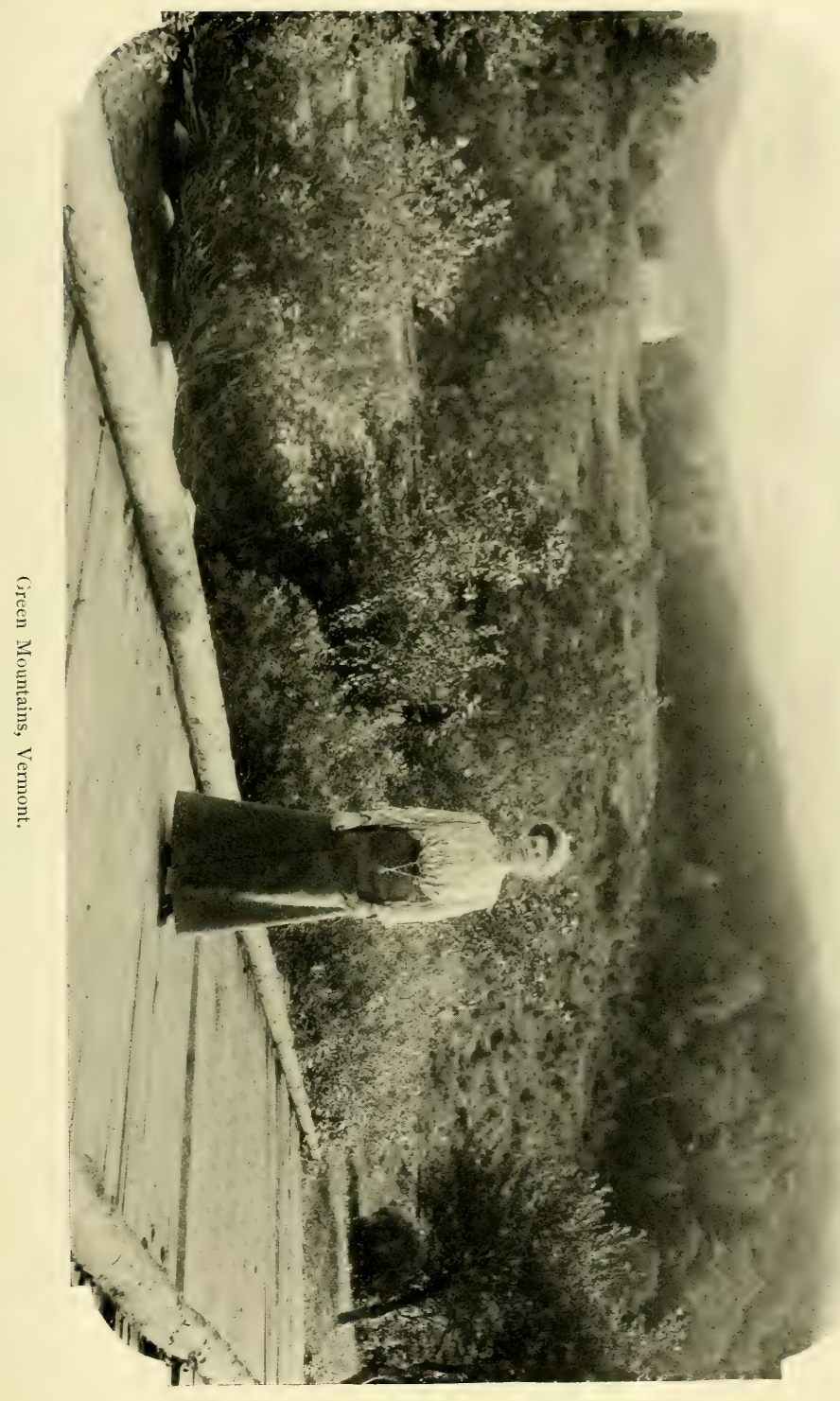




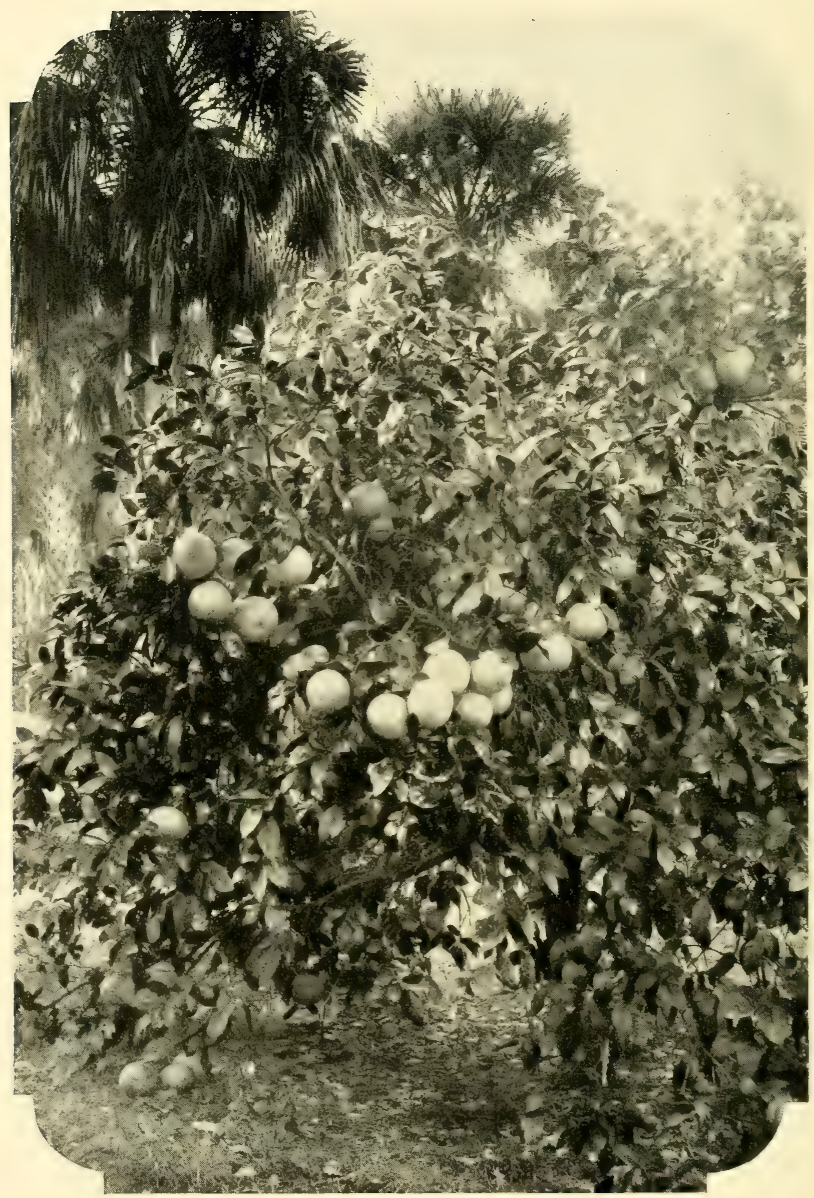

Oranges, Florida. 
gan; and $5^{\text {th }}$ dam by White Mountain Morgan. For Jewel, see Don Lorenzo. Pedigree from catalogue of breeder.

Sire of Don A., $2: 201 \frac{1}{2}, x_{3}$ pacers $\left(2: 09 \frac{1}{4} ;\right.$ I sire of I trotter, 1 pacer.

DON QUIXOTE, chestnut; foaled 1784; bred by Mr. Taylor, got by Eclipse : dam Grecian Princess (sister to Grecian), bred 1770 by Mr. Popham, got by William's Forester, son of Forester; 2d dam (bred in Ireland) said to be by the Coalition Colt, son of Godolphin Arabian; 3d dam by Bustard (sent to Ireland) son of Crab; and $4^{\text {th }}$ dam Iord Leigh's Charming Molly, by Second, son of Flying Childers.-General Stud Book, Vol. I., pages 176,396 . It is stated in the Obituary of Stallions, that he died in 1806 , which may or may not have been accurate.

Edgar records this horse as follows:

Don Quixote (imported into Virginia), chestnut; foaled 1784 ; bred by Mr. Taylor; got by O'Kelley's Eclipse: dam Grecian Princess, by Forester-Coalition Colt-Bustard-Lord Leigh's Charming Molly, by Second, full sister to his Diana. New York 1833 .

If as Edgar states, the horse was imported to America, the year of his death would not probably have been known in England. It is not stated in the General Stud Book, that he went to America, but Mr. Bruce, probably copying from Edgar, records him as having been imported into Virginia.

This is the only intelligent record that there is of a Don Quixote during this period (unless that of the one in Vermont advertised in 1820 as a Spanish horse by Mr. Barnum), and this is quite meager. It would appear from the fact that Mr. Edgar draws upon New York for his authority that the horse was kept in that vicinity, and, if so, probably on Long Island, and, if this was true, it was probably during the later part of his life and quite possibly as late as I 8 IO-I 8 I4

DON QUIXOTE, I5 hands, said to be Spanish. Advertised by A. W. Barnum, in the Burlington, (Vt.) Sentinel, r820, as follows. "The Spanish Horse Don Quixote recently brought into this country, will stand at Painter's stable Vergennes, terms $\$ 5$ to $\$ \mathbf{I} 2$. He has been in America four years."

A horse of this name, probably this horse, was advertised at St. Albans in 1826 , by James Weeks at stable of Mr. Catlin. Included in an auction sale of horses advertised in the Burlington (Vt.) Free Press, at about this time, is a sorrel horse four years old by Don Quixote.

In the fall of $\mathrm{i} 8 \mathrm{ig}$ Gen. Barnum, purchased Cock of the Rock, by Duroc, son of imported Diomed, of Gen. Coles of Long Island and brought him to Vermont. It would appear to be very probable that at the same time he purchased Don Quixote on Long Island; and it is at least possible, that this Don Quixote was sire of the dam of the 
great early trotter Lady Suffolk, which dam it is reasonably certain was bred on Long Island, about I8I6-20 (possibly before) and got by a horse called Don Quixote, but what horse Don Quixote was, who bred him, or his breeding is wholly unknown.

In interviews in 1890 with elderly inhabitants of Orange County, N. Y., Mr. Levi Snyder, Kingston N. Y., born I8I8, said :

"Don Quixote having several distinct colors was kept here three years ; came from Otsego here ; was got by a circus stallion." This is possibly the same horse, but if so must have drifted from Vermont to Otsego.

Crocker's Eclipse is registered in Vol. I., p. I 20 of Wallace's Register as follows :

Eclipse (Crocker's) ; foaled I801 ; got by Don Quixote, son of imported Messenger, or his son Commander: dam unknown. Taken from Long Island to Seneca County, N. Y.

In Vol. III., p. $\mathrm{x} 84$, he is registered again as follows :

Eclipse (Crocker's) foaled I 8- ; got by Don Quixote, son of Potomac, by imported Messenger : dam by Bajazet ; grandam by imported Messenger.

Mr. Wallace states that this rendering is from a bill printed about r83o, and found in Seneca County, N. Y. See Eclipse (Crocker's).

Eclipse (Tunison's) appears as follows :

Foaled I $83_{-}$; got by Crocker's Eclipse, son of Don Quixote : dam by Liberty, son of Messenger, copied, as Mr. Wallace states, from an old poster dated I 843 .

It will be seen that Mr. Edgar has connected the horse Don Quixote, which he records by O'Kelleys Eclipse, with New York, which makes it highly probable that he was at one time kept on Long Island. He is too, a son of the great Eclipse, so that it becomes very probable that Croker's Eclipse, if bred on I Long Island in $180-$ and got by a horse called Don Quixote, as stated in Wallace, was by this horse. If got by a horse called Don Quixote that was got by Potomac, son of Messenger, why is he called Eclipse? In that case there would not be a known drop of Eclipse blood. The poster referred to may be genuine, but many a genuine poster has given the extension of a pedigree incorrectly.

Mr. Wallace makes the following record in Vol. I., of his Register :

"Don Quixote, br. h.; foaled I 8- ; got by imported Messenger : dam not known. Owned by Mr. Kissam, Long Island."

In Vol. III. Mr. Wallace tries again as follows :

"Don Quixote, br. h. ; foaled I8I- ; got by Potomac, son of Messenger: dam by imported Messenger. The late David W. Jones of Long Island was present when this daughter of Messenger was bred to Potomac. [Corrected from Vol. I]."

Nothing is said here of Mr. Kissam, and it will occur to the reader that if Mr. Jones was present he should have known who bred the mare and where and when, and also her description. 
It becomes at least quite possible from these records, that Crocker's Eclipse was got by imported Don Quixote, son of Eclipse. Because first, there is no intelligent record or suggestion of any other horse of this name kept on Long Island at the time when Crocker's Eclipse is supposed to have been born. And second, because there would appear to be no reason to call the Crocker's horse "Crocker's Eclipse," if descended from a son or grandson of Messenger.

Still that record would appear to have descended with the Crocker Horse, and we found it repeated in a stallion advertised in Vermont, and which appears in this work, but whose name we cannot now recall. That is, we have found another stallion advertised some 60 or more years ago, as running back to Don Quixote, by Potomac, son of Messenger.

In both of these cases, the record is far back enough to avoid the temptation to invent a pedigree that would fit the great trotter Lady Suffolk; but in both cases an erroneous pedigree may have been given to Don Quixote. It certainly is to be hoped that something more definite may yet be learned of a horse called Don Quixote, which was owned or kept on Long Island between I 800 and I 820 .

Smith Burr of Long Island, in interview said :

"Don Quixote was by Messenger and stood here at Huntington, owned by one Kissam, this was before Engineer 2 d.

"The dam of Lady Suffolk was owned by I-eonard L. Smith on Long Island, she was by Don Quixote. The Floyds had that mare. I think you can find out in the town of Huntington who had Don Quixote. It was always said he was by old Messenger."

Still it will be seen Don Quixote was a Will-o-the-Wisp.

It is of course possible that there was upon Long Island about this time a Don Quixote descended from Messenger, but very thorough inquiry on Long Island and elsewhere, and long continued search through old files of newspapers has failed to secure any accurate information of such horse. So far as we know no breeder was ever discovered for him or even suggested, and no person has ever reported to have seen him.

DON QUIXOTE, said to be by Marshall Duroc. Mentioned in Vol. VIII., p. 5 Io, American Turf Register.

DON REM ( $1-32$ ), bay, I51/2 hands, 950 pounds; foaled I 885 ; bred by Vick K. Glass, Georgetown, Ky., got by King Rem, son of Belmont: dam said to be by Monroe Chief, son of Jim Monroe; $2 \mathrm{~d}$ dam Fanny, by John Dillard, son of Indian Chief; and $3 \mathrm{~d}$ dam by a Copperbottom horse. Sold to B. W. Ford, Lexington, Ky. Pedigree from W. J. Carter.

Sire of Little Don, $2: 26$. 
DONUM (5-I 28$), 2$ :19, bay, I $5 \frac{3}{4}$ hands, I050 pounds; foaled 1889 ; bred by George N. Black, Ellsworth, Me., got by Nelson, son of Young Rolfe : dam Fanny, said to be by Hambletonian Knox, son of Gilbreth Knox. Sold to F. H. Osgood, Ellsworth, Me., who sends pedigree.

Sire of Salinas, $2: 17 \frac{1 / 2}{2}$

DON VICTOR, chestnut, white on off side of near hind heel; foaled I 862 ; bred by W. H. Williamson, California, got by Williamson's Belmont: dam Maria Downing, said to be by American Eclipse; $2 \mathrm{~d}$ dam Brownlock, by Tiger ; 3 d dam by imported Speculator; and $4^{\text {th }}$ dam by imported Dare Devil. Sold to Leland Stanford, Menlo Park, Cal. Pedigree from catalogue of Leland Stanford.

Sire of 7 dams of 9 trotters.

DON WILKES (I-64), $2: 243 / 4$, brown, star and left hind foot white, I $5 \mathrm{I} / 2$ hands, Iooo pounds ; foaled $\mathrm{I} 88_{3}$; bred by Robert Prewitt, Athens, Ky., got by Alcyon, son of George Wilkes: dam Gossip, brown, bred by R. A. Alexander, Spring Station, Ky., got by Tattler, son of Pilot Jr.; 2 d dam Jessie Pepper, brown, bred by L. P. Pepper, Woodford County, Ky., got by Mambrino Chief; 3 d dam said to be by Sidi Hamet, son of Virginian. Sold to John R. Graham and John J. Conley, Lexington, Ky. ; to Charles H. Thayer, Boston, Mass.; to D. C. Palmeter, Berlin, Wis. Pedigree from breeder.

Sire of 9 trotters $\left(2: 2 I_{1}^{1 / 4}\right) ; 6$ pacers $\left(2: I 2 \frac{1}{4}\right) ;$ I sire of I pacer; I dam of I trotter.

DON WILKES $(3-64), 2: 29 \frac{1}{2}$, bay, white hind feet to ankles; foaled May I 2, I887; bred by D. S. Coleman, Lexington, Ky., got by Red Wilkes, son of George Wilkes: dam Princess C., chestnut, bred by D. S. Coleman, got by Mambrino Pet, son of Mambrino Patchen; 2d dam Lady Mary, chestnut, bred by D. S. Coleman, got by Pilot Jr. ; 3d dam brown, said to be by Copperbottom. Sold to J. W. Coleman; to J. Thayer; to Brook Curry ; to Bowerman Bros. ; to J. E. Madden : all of Lexington, Ky. ; to D. Scott Quintin, Trenton, N. J. Information and pedigree from $\mathrm{J}$. W. Coleman, son of breeder.

Sire of So So, $2: 24^{1 / 2}$.

DORCHESTER, bay ; foaled I 786 ; bred by Duke of Bedford, got by Highflyer, son of Herod (King Herod), by Tartar: dam Careless Mare, bred by Duke of Kingston, got by Careless, son of Spanker ; $2 \mathrm{~d}$ dam Snappina, bred by Duke of Kingston, got by Snap, son of Snip ; 3 d dam said to be by Moore's Partner, son of Partner; and 4th dam Childers' Mare, bred by the Duke of Devonshire, got by Childers. General Stud Book, Vol. I., $p .55$.

DORCHESTER, dark bay, I61/2 hands; foaled I790; bred in England. 
Advertised 1795 by Joseph Ives, to be kept at Norfolk, Conn. Terms, $\$ 2.50$ to $\$ 7.00$. Probably same as Dorchester, by Highflyer.

DORIMANT, chestnut; foaled I 772 ; bred by Lord Ossory ; got by Prophet, son of Regulus: dam Babraham Mare, by Babraham, son of the Godolphin Arabian; 2 d dam Chiddy, bred by Duke of Somerset, got by Hampton Court Arabian; 3d dam Duke of Somerset's Bald Charlotte, bred by Captain Appleyard, got by Royal, son of Holderness Turk;

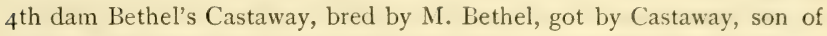
Merlin; $5^{\text {th }}$ dam said to be by Brimmer. General Stud Book, Vol. I., p. 25 .

DORSEY GOLDDUST (I-I6), chestnut, $15 \frac{1}{2} 2$ hands, xo6o pounds ; foaled I869; bred by L. L. Dorsey, Middletown, Ky. ; got by Golddust : dam Nora McShean. Sold to Mrs. M. L. Moody, West Medway, Mass.; I 87 I, to A. T. Newhall, Newburyport, Mass. ; 1878 , to Grant Bros., York, Me.; 1884 , to C. F. Prendergast, Newmarket, N. H. See The Morgan Horse and Register, Vol. I., p. 731.

Sire of 2 trotters $(2: 231 / 4)$; dam of I trotter.

DOSIVELL, chestnut, I5 5 /2 hands; foaled 1867 ; bred by Chastain White, Ashland, Va.; got by Planet : dam Deucalia, chestnut, bred by C. White, got by Deucalion, son of Revenue ; $2 \mathrm{~d}$ dam Bostona, chestnut, bred by C. White, got by Boston ; 3 d dam Crenza, said to be by imported Priam; $4^{\text {th }}$ dam Miss Valentine, by imported Valentine; and $5^{\text {th }}$ dam by John Richards. Sold to W. G. Bennett, Winton, W. Va., and others; to P. Hays, Gilman County, W. Va., whose property he died about r882. Pedigree from W. G. Bennett.

Sire of 2 dams of 2 trotters.

DOTTEREL, gray; foaled I 750 ; bred by Mr. Greville; got by old Starling, son of Bay Bolton : dam Foxhunter Mare, said to be by Cole's Foxhunter, son of Brisk: 2 d dam (sister to Cato) bred by Sir W. Strickland, got by Partner, son of Jigg ; 3d dam (sister to Roxanna), bred I719, by Sir W. Strickland, got by Bald Galoway, son of St. Victor Barb; $4^{\text {th }}$ dam (sister to Chaunter) bred by Sir W. Strickland, got by the Akaster Turk, -General Stud Book, Vol. I., p. go.

DOTTEREL, I53/4 hands, bred by Sir John Pennington. Advertised in Virginia Gazette 1775 as for sale (the advertisement stating that he was the swiftest horse in England, Eclipse excepted), as follows :

"Dotterel a high formed horse, $x_{5} \mathrm{~T} / 2$ hands, a healthy, strong boned horse; he was imported; got by Changeling; his dam by a son of Wynn's Arabian; $2 \mathrm{~d}$ dam by a son of the Longsdale Arabian; 3d dam by the Black Arabian; $4^{\text {th }}$ dam by a son of the Bay Barb from the Burton Mare. 
"N. B. Changeling was as famous a horse as any in England, in every respect. The above pedigree was given by Sir John Pennington, Stratford, Westmoreland County, Va., I 766.

Phillip Ludwell LeE."

DOUBLE STROKE ( $\mathrm{I}-32$ ), bay, stripe in face, four white feet, I6 hands, I 200 pounds ; foaled I 886 ; bred by W. L. Simmons, Lexington, Ky. ; got by Monte Christo, son of George Wilkes: dam Beckie Sharp, bay, bred by W. L. Simmons, got by George Wilkes; $2 \mathrm{~d}$ dam Madam Sharp said to be by Honest Allen, son of Ethan Allen; and 3d dam Fly, by Bell Morgan, son of Cottrill Morgan. Died i 889. Sold to A. C. Turner, Ross, O., who sends pedigree.

Sire of Bell West, 2:101/4.

DOUGLAS, bay; foaled I 877 ; bred by A. Noble, Tinmouth, Vt., got by Blackstone, son of Hambletonian: dam Jessica, bay, bred by A. Noble, got by Abe Lincoln, son of Columbus ; $2 \mathrm{~d}$ dam bred by A. Noble, got by Richard Goldfinder (Richard P. Robinson); 3d dam said to be by Comet, son of Bishop's Hamiltonian; 4th dam by Flag of Truce; and

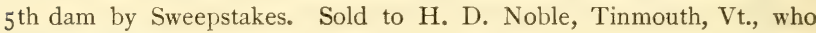
- sends pedigree.

Sire of 4 trotters $\left(2: 18 \frac{3}{4}\right)$.

DOUGLASS, $2: 38$, brown, I 6 hands, I 200 pounds; foaled I 868 ; bred by Mr. Hedershot, North Pelham, Ont.; got by Pelham Tartar, son of Toronto Chief : dam brown, bred by Mr. Hedershot, got by Black Prince, son of imported Black Prince thoroughbred; $2 \mathrm{~d}$ dam said to be by Hamiltonian, son of American Eclipse. Sold to John Elliott, Toronto, Can. Kept at St. Catherines for a number of years, also at Toronto. Pedigree from Geo. Gibson, St. Catherines, Ont.

DOUGLASS (I-I6), $2: 25$, gray, bred by John H. Clárk, Washington, D. C. ; got by Washington, son of Ethan Allen: dam owned at one time by C. Vanderbilt and driven by him in a team, then sold to Mr. Acinna, New York City ; to Mr. Foote, son of Com. Foote; to Wm. Turner, Washington, D. C. ; to Mr. Clark. Sold to Mr. Miller of Maryland; to G. H. Green, Washington, D. C. ; to Mr. Shuly, Brooklyn, N. Y., for \$50oo. Gelded young. Pedigree from breeder.

DOUGLASS ALMONT $(3-64), 2: 33$, bay, two white hind feet, $15 \frac{1}{2}$ hands, I 100 pounds; foaled I 879 ; bred by J. W. Ford, Lexington, Ky. ; got by Allie Gaines, son of Almont: dam Fanny, brown, owned by James Ford, said to be by Rattler, son of Stockbridge Chief, by Black Hawk; and $2 \mathrm{~d}$ dam by Tom Benton Jr., supposed to be son of Tom Benton, 
by Sherman Black Hawk. Sold to Wm. Douglass, Sturgis, Mich., who sends pedigree and writes: "A great show horse, stock fine. Died I 899."

Sire of 2 pacers $\left(2: x_{5}\right) ; \mathrm{I}$ dam of $\mathrm{I}$ pacer.

DOUGLASS HAROLD ( $\mathrm{I}-64$ ), brown, I 5 hands, 950 pounds; foaled I 886 ; bred by John Corrigan, Cleveland, O. ; got by Harold, son of Hambletonian : dam Jip. D., said to be by Stephen A. Douglass, son of Hambletonian; 2 d dam Black Kit, by French Rover; and 3d dam a Black Hawk mare. Information from breeder.

Sire of Billy G., $2: 201 / 4$.

DOUGLASS T. ( I-32), brown, I $5 \frac{3}{4}$ hands, I050 pounds; foaled I 888 ; bred by F. M. McDaniel, Winterset, Ia. ; got by Paramount, son of Swigert : dam Molly L., brown, bred by Richard Richards, Racine, Wis. ; got by Pluto, son of Wedgewood; 2d dam Harriet, brown, bred by Richard Richards, got by Swigert, son of Alexander's Norman; 3d dam Bay Fanny, bay, bred by Richard Richards, got by Richard's Bellfounder, son of Hungerford's Blucher; 4th dam Lady May, said to be by Signal; and $5^{\text {th }}$ dam Old Kate, of Messenger blood. Sold to J. A. White, Springfield, Mo. Pedigree from J. S. Atkinson.

Sire of Alvin R., $2: 14 \frac{1}{4} ;$ Fack, $2: 25$.

DOUGLASS WONDER ( $\mathrm{I}-32)$, bay with star, left hind ankle white, $15 \mathrm{I} / 2$ hands, Iooo pounds; foaled May I6, I883; bred by Levi Oakes, Forestville, N. Y.; got by Stephen A. Douglass, son of Hambletonian : dam Clara, gray, said to be by Tom Wonder (dam by Saratoga, son of Hiatoga) son of Tom Crowder, by Pilot; and $2 \mathrm{~d}$ dam by Coman's Gray Eagle, (dam by Alexander a circus horse), son of Black Hawk. Sold to Michael P. Toomey, Dunkirk, N. Y., who sends pedigree; to George C. Corning, Denver, Colo., March I887. Mrs. Levi Oakes writes: “My father J. W. Bennett, bought the dam Clara in Slaterville, N. Y."

Sire of Mizzie Douglass, $2: 231 / 4$.

DOVE, gray, I $5 \frac{1}{4}$ hands; foaled 1756 ; bred by Thomas Jackson, Sr., North of England; got by Young Cade : dam said to be by Teaser; $2 \mathrm{~d}$ dam by Seawings Arabian; 3d dam Gardner Mare a runner, that won six royal plates of a hundred guineas each. Imported Nov. 16, 1761, by Dr. Hamilton. Advertised in "Maryland Gazette," I 762, to stand at Dr. Hamilton's during that season and $1765-7$ in Cecil County, Md., by Wm. Dames. Advertised I77I-5, by John Van Mater to be kept at Monmouth County, N. J. He ran in $I_{7} 6_{3}$ at Annapolis, Md.

It is stated in Skinner's American Farmer, Vol. IX., p. I9 8 that old Dove was imported by Dr. Hamilton and kept in Maryland and New Jersey ; that whilst in New Jersey, in leading, he kicked at other horses got entangled in traces, fell and died. Above pedigree is from an advertisement of Dove in 1772 , by John Van Mater. 
DOVE, gray; foaled 1813 ; said to have been bred by James Dubois of Salem County, N. J., and got by Saratoga. Sold when four years old to Isaac Elwood, also of Salem County, and died young. A horse of this name $163 / 4$ hands, is advertised in the New Jersey Emporium, together with Solan I6-1, Nimrod I6-2, Black Messenger i6-2, Bay Richmond ז5-2, Brown Highlander I6, gray, for sale I823, by Wm. I. Phillips of Lawrence.

DOVER BOY, bay; foaled I 842 ; bred by Jonas Cooper; got by Mambrino Paymaster, son of Mambrino: dam brown. Sold to Joshua Dutcher, Dover Plains, N. Y.

Sire of the grandsire of Addie E. C., $2: 281 \frac{1}{2}$, and winner of 18 races.

DOVER MESSENGER, gray; foaled about I798, said to be by imported Messenger. Kept several seasons at Dover, Dutchess County, N. Y. Died in Russia, Herkimer County, N. Y.

DOWNER HORSE, gold sorrel, very light mane and thin tail, $153 / 4$ hands. In the possession of, and probably owned by an American or Englishman named Downer, in the Province of Quebec, between r830-1840. Supposed to have been by Sir Walter, son of Hickory; or a son of Sir Walter.

Mr. Julie Richard whom we first interviewed as to the breeding of the Simard Horse, thought that he was bred by Mr. Twombly, and got by the Downer Horse. He said :

"Twombly raised the Simard Horse and sold him to Simard when a little colt. An English or American horse stopped at Twombly's house. The sire of the Simard Horse was owned by Jack Twombly, two miles from here. The Twombly Horse was by the Downer Horse I think, which an American used to lead by the bridle, running his horse ahead. Gold sorrel, $x_{5} 3 / 4$ hands, etc. (as above), Twombly horse got the colt that Foy had.

"The dam of the Simard Horse died at $2 \mathrm{I}$. I am 72 (I $89 \mathrm{I}$ ). She was born before me. She would have trotted fast. Downer was a large man about forty, sandy hair, not black. The Twombly Horse was sorrel, one white foot behind, dam I don't know.

"Joseph Twombly dead, another son gone to States. Jack Twombly came from Quebec. The Twombly Horse was sold when four years old for $\$ 300$, on Dec. I5. He trotted like Ben Morrill, made like Morrill. It was between 45 and 50 years ago that Downer was here."

The testimony that we got afterwards in regards to the Simard Horse, coming from those more closely connected with the horse, and who did not qualify with "I think," and which will be found in the interviews under that horse, made it, we think, certain that the Twombly Horse, sire of the Simard Horse was owned by Mr. Twombly, and brought by him, or the son of the horse brought by him from Quebec. See Twombly Horse.

But we were very glad to get this description and information in 
regard to the Downer Horse, and the Mr. Downer who owned him. For this is the horse that was the sire of North American or the Bullock Horse, which appears quite considerably in the records of American trotters. We think there is little question that this Downer Horse was the thoroughbred horse Sir Walter or a son of his. See North American, and under it the interview with Mr. Mayo.

DOWNING ABDALLAH (I-I 28 ), bay, I $5^{\mathrm{I} / 2}$ hands, I050 pounds; foaled I 867 ; bred by James T. Talbott, Millersburg, Ky. ; got by Joe Downing, son of Edwin Forrest, by Young Bay Kentucky Hunter: dam Trotting Sister, bay, bred by J. T. Talbott, got by Alexander's Abdallah; 2 d dam Lydia Talbott, brown, bred by H. D. Ayres, Millersburg, Ky., got by Taylor's Messenger, son of General Taylor. Sold 1873 , to W. H. Wilson, Cynthiana, Ky.; to W. A. Parks, Carlisle, Ky., where he died. Pedigree from breeder.

Sire of Lady Martin, $2: 23$.

DOWNING HORSE ( $\mathrm{I}-8$ ), brown, said to be by Pollard Morgan, son of Whalebone, by Sherman Morgan : dam Roxy, by the Avery Horse, son of Bucephalus. Owned by Mr. Downing, Monmouth, Me. Information from correspondent of Middlebury (Vt.) Register.

Sire of dam of Ed. Gretchell, $2: 27$.

DOW S. (I-I6), chestnut; foaled I 887 ; bred by P. L. Drennan, Nyack, N. Y., got by Cyclone, son of Young America: dam Pepper.

Sire of 2 trotters $\left(2: 23 \frac{1}{2}\right)$.

DRACO (I-8), $2: 28 \mathrm{I} / 2$, black, I5 $5 / 2$ hands, I050 pounds; foaled $185 \mathrm{I}$; bred by Robert Lane, Danville, Vt.; got by Perkin's Young Morrill, son of Morrill: dam brown, bred by Gilman Buswell, Danville, Vt., got by the Josiah Hoyt Horse, son of the Bailey Horse, by Woodbury Morgan; 2d dam gray, brought to Danville by a peddler, breeding unknown. Second premium for roadsters was awarded to "Draco," at the Illinois State Fair, I860, entered by J. W. Holcomb, Ticonderoga, N.Y. Died the property of Charles L. Sharples, Philadelphia, Penn. See The Morgan Horse and Register, Vol. I., page 624 .

Winner of $I_{3}$ races and sire of 3 trotters $\left(2: 24 \frac{1}{4}\right) ; 2$ sires of 2 trotters; 6 dams of 7 trotters, 3 pacers.

DRACO LAMBERT (3-32), bay, I5 hands, 950 pounds; foaled r88o; bred by W. H. Tourtellotte, Watertown, Mass. ; got by Daniel Lambert, son of Ethan Allen: dam Jennie, bay, bred by John Durkee, South Royalton, Vt., got by Draco, son of Perkin's Young Morrill ; $2 \mathrm{~d}$ dam chestnut, said to be Morgan. Sold to William H. Greenleaf, Watertown, Mass. ; to Harry H. Martin, Plainfield, Vt., who sends pedigree. Died 1905. See The Morgan Horse and Register, Vol., I., p. 590.

Sire of Susie Starr, $2: 21 \frac{1}{2}$, 
DRACO MEDIUM ( I-16), dark bay with star and snip, four white feet, I53/4 hands, I050 pounds; foaled May 3, I 877 ; bred by Austin A. Wright, Hightstown, N. J.; got by Happy Medium, son of Hambletonian: dam Eva Bradley, brown, said to be by Draco, son of Perkin's Young Morrill. Died I888. Pedigree from breeder.

Sire of 5 trotters $(2: 181 / 2) ; 4$ dams of 4 trotters.

DRACO PRINCE (I-8), $2: 24 \frac{1}{4}$, black, I 6 hands, I Ioo pounds; foaled I 860 ; bred by Ansel Burbank, Bethel, Vt. ; got by Draco, son of Young Morrill: dam black, bred by Ansel Burbank, Bethel, Vt., got by Capt. Lightfoot, son of Black Hawk; 2d dam gray, bred by Abner Morse, Bethel, Vt., got by Rice Horse, son of Babbitt Horse, by Woodbury Morgan; 3d dam the Gov. Converse Mare, said to be by Gen. Hibbard, son of Woodbury Morgan. Trotted $\mathrm{x} 864-73$, winning I 2 races. See The Morgan Horse and Register, Vol. I., page 869

DRAGON. Advertised in 18 ro in Kentucky Gazette as follows :

"Celebrated imported real bred turf horse. Stands at stable of John Hunt. Dark chestnut, handsomely marked with a star and snip, and is fully 16 hands high, descended from the best running stock in England and is brother in blood to the famous horse Diomed, whose stock is so highly esteemed in Virginia.

He was got by Woodpecker, one of the best sons of King Herod, his dam June (who is also the dam of Young Eclipse, and full sister to the dam of Diomed), by Spectator, his grandam (sister to Horatius), by Blank; his great grandam, (Feather's dam and full sister to the grandam of Cygnet and Blossom), by Childers from Miss Belvoir by GranthamPaget Turk-Betty Percival-Leede's Arabian.

DRAGON (WILCOX'S) said to be by imported Dragon from Canada.

Sire of dam of Derby (Alvin B., and Dutchman), $2: 25 \frac{1}{2}$, winner $1_{3}$ races.

DRAGON LAFAYETTE, chestnut, star and white ankles, I 6 hands, I I5o pounds; bred by Thomas Mefford, Russelville, Brown County, O. ; got by Lafayette, son of Potomac, running horse in Monongahela County, Va. : dam chestnut, bred by Frank Chips, Morgantown, got by a pacing horse of the Dragon stock of Virginia. Pedigree from G. A. Wilson.

DREAD, said to be part English and part French. Advertised I 788 together with an old horse called Dappled Bay, in the Hampshire, Mass. Gazette, which states that he was brought from Canada, and is good for saddle and very excellent for draft. A nervous, firm, small built horse.

DREAD. "The noted horse." Advertised in The Country Journal and Poughkeepsie Advertiser March 3, I 789 , to be sold at public sale, at the house of Stephen Hendrickson in Poughkeepsie.

DREAD ( $\mathrm{I}-64)$, brown, slight stripe in face, $15 \mathrm{~T} / 4$ hands, 950 pounds ; foaled 
r 874 , bred by R. R. Haggett, Norwood, N. Y., got by Commonwealth, son of Phil Sheridan, by Smith's Young Columbus: dam Lady Haggett, gray, said to be by Fenian Chief, son of Canada Gray Eagle ; 2d dam gray, bred by John Whalen, Louisville, N. Y., got by Post Boy, son of Blossom, by LaRay's Blossom; 3d dam gray, bred by Wm. Clark, Waddington, N. Y., got by Blossom, son of imported Blossom; $4^{\text {th }}$ dam gray, bred by Wm. Clark, got by Ogden Messenger, son of imported Messenger. Sold to B. B. and C. J. Lord, Sinclairville, N. Y. Pedigree from B. B. Lord.

The American Cultivator of Boston says :

"This Canada Gray Eagle strain, appears to nick as well with Phil Sheridan, and his descendants, as Seeley's American Star with Hambletonian. Among the speedy turf performers which have resulted from this combination was Phyllis, $2: 14^{1} / 2$, one of the most remarkable trotters of her day."

Sire of 4 trotters $\left(2: 23 \frac{1}{4}\right) ; 2$ pacers $\left(2: 18 \frac{1}{4}\right)$.

DREADNAUGHT, chestnut, said to be by old Traveler. Advertised in Philadelphia 1772 by Jacob Hetzheimer.

DRENNON (BRINKER'S) ( I-8), bred by James Adams, Pleasureville, Ky. ; foaled I84-; got by Blackburn's Davy Crockett: dam a bloodlike bay mare that could trot fast, bought by James Adams of Parmenius Johnson a neighbor who bought her out of a mover's wagon that was going south from Indiana. Mr. J. H. Harding, Pleasureville, Ky., writes :

"Drennon was a perfect saddle horse, could rack, pace and trot fast; was seldom if ever beaten in a fair ring."

J. G. Adams son of James Adams, says of the dam: "She was a fine high-strung blood-like bay and could trot fast. Nothing whatever is known of her breeding."

J. G. Adams writes to Mr. Harding :

Pleasureville, Ky., Dec. I3, 1888 .

"In answer to your inquiry will say that my father, James Adams now deceased, bred Drennon, son of Davy Crockett. He purchased Drennon's dam from an adjoining neighbor, Parmenius Johnson, who traded for her out of a mover's wagon. The man from whom Johnson got her was moving south from Indiana. Nothing whatever is known of this mare's breeding. She was a very fine high-strung, blood-like bay mare, and could trot very fast."

Yours truly, J. G. Adams.

Mr. Kennedy, Montgomery, Ala., former correspondent of New York Spirit of the Times, says: "A very handsome horse, he was bay, $151 / 2$ hands, not so stout as Pilot, more after the style of Pilot, Jr."

DRENNON. Owned by W. D. Bouta, Pleasureville, Ky. Awarded second premium on saddle stallions at the Illinois State Fair, I 864.

DRENNON (BELL'S) (JOE DRENNON) ( $\mathrm{I}-8$ ), roan, bred by Thomas 
Grundy, Springfield, Ky.; got by Dunphy's Drennon, son of Davy Crockett: dam said to be a Copperbottom. Sold to Mr. Howard; to Hilary Bell, Fairfield, Nelson County, Ky., I869; after two years to J. C. Troutman, Owensboro, Ky.; to James Miles, Eminence, Ky.; who traded him to parties at West Louisville, Ky., where he was kept several seasons then sold to James Small. Information from Hilary Bell, who says: "He was a very fine and game horse, could trot or rack in three minutes."

DRENNON JR. (I-I6), bay; foaled I 856 ; bred by J. H. McGruder, Bardstown, Ky.; got by Drennon, son of Davy Crockett: dam said to be by Medoc; and 2 d dam by Woodpecker, son of Bertrand, by Sir Archy. Owned at different times by Harry Evans, St. Louis, Mo., George L. Bailey, Eureka, Kan., and J. P. Decker, New Haven, Ill. Died I884.

Sire of Roan Drennon, sire of dam of Libby S., $2: 16$.

DRESDEN ( $1-64$ ), brown ; foaled I879; bred by R. P. Pepper, Frankfort, Ky. ; got by Administrator: dam Parepa, bay, said to be bred by Mr. Curry of Kentucky, got by Delmonico; and $2 \mathrm{~d}$ dam by Pilot Jr. Sold to John Klein \& Sons, Rensalaer, Mo.

Sire of 2 trotters $(2: 23) ;$ fohn $C ., 2: 22 \frac{1}{4} ; 3$ dams of 2 trotters, 2 pacers.

DRESDEN PRINCE ( $1-32$ ), bay with star, hind ankles white; foaled I 884 ; bred by Charles Backman, Stony Ford, N. Y. ; got by Kentucky Prince, son of Clark Chief : dam Mineola, bay, star, spot on nose, near hind ankle white, foaled I 868 , bred by S. R. Banker, Chester, N. Y., got by Hambletonian; 2 d dam Lady Banker, bay, said to be by Roe's Abdallah Chief; and 3d dam by Saltram, son of Webber's Kentucky Whip. Pedigree from catalogue of breeder.

Mr. Joseph Battell,

$$
\text { PARIS, Ky., Dec., 28, I905. }
$$

Dear Sir :-My father David M. Dodge died three years ago. ' I don't remember the breeding of Dresden Prince, but am almost sure his dam was a full sister to Banker (son of Hambletonian), sire of Bermuda, 2 :20 $1 / 2$. His sire was "Kentucky Prince." Mr. Jeff. Vimont of Millersburg, Ky., owned him when he got Princess Maid and I think still owned him when he died.

$$
\text { Yours Truly, I James L. Dodge. }
$$

Sire of Princess Maid, $2: 19 \frac{3 \%}{4}$.

DREW HORSE ( $1-3^{2}$ ), brown bay, black points, $15 \frac{1}{4}$ hands, rooo pounds ; foaled 1842 ; a catch colt property of Hiram Drew, Exeter, Me.; thought to be by a three year old bay colt, I 6 hands, purchased of an English officer in New Brunswick, and brought to Maine, by A. G. Hunt, said to be by a thoroughbred running horse in England and imported to America in his dam. Mr. Hunt turned this colt into his pasture at 
Exeter which joined Mr. Drew's and from which he was taken several times and here in Mr. Drew's pasture he is thought to have got the Drew Horse which is, probably the only colt he ever got, as Mr. Hunt had him gelded shortly after and sold him : dam Grace Darling (Boston Girl) bay, black points, about $151 / 2$ hands, foaled about ${ }_{1} 836$, bred by Mark Pease, Jackson, Me., who sold her when four years old to Wm. Morton of Exeter and he to H. Drew, got by Sir Henry, bred by Elder James Lewis, Gorham, Me, and got by a son of American Eclipse, taken from Connecticut to Maine by Dr. Brewster; 2 d dam Lady Jane, gray, purchased by Mr Pease of Nathan Andrews then of Augusta, Me., said to be by Winthrop Messenger; 3d dam gray, said to be Morgan. Boston Girl, dam of the Drew Horse was taken to Massachusetts in r 843 , by Mr. Drew and sold to F. W. Lander, afterwards known as Gen. Fred Lander who was killed during the war. Gen. Lander sold her, and after several transfers she was bought of Ives G. Bates by Dr. Saunders, V. S., who sent her to Vermont where she died on a breeding farm without further produce. She is said to have made a record of $2: 37$ at or near Boston. Sir Henry sire of Boston Girl was bought March, 1834 , by Simeon Pease who brought him to Jackson and in September following sold him to his brother Mark Pease. The Drew Horse died property of breeder at Fairfield, I 866.

J. W. Thompson from whose "Noted Maine Horses," Vol. I., above history is in part taken, says :

"His appearance has been described as follows by one who saw him shortly before his death: 'He was of genteel form and fine style and action, shoulders extremely high, broad and deep; neck light at the head, well arched and deep at the body; face a little rounding, eyes not very prominent, ears good length and well cut; body small, loins a trifle arched, hips very long and beautifully turned, limbs large, pasterns long, feet high, black and nice, mane spare, tail in waves, and hair short and fine all over his body.'"

We have tried hard but have been unable to verify breeding of $2 \mathrm{~d}$ and 3 dams. Mr. Thompson says in his introduction to Vol. II., of Maine Horses :

"There is a claim made that the sire of Drew was a son of imported Buzzard; and I will say that some of the circumstances point to such a conclusion."

We have received the following letters in regard to this horse.

Mr. BatTell,

$$
\text { JACKSON, Me., June I, I89o. }
$$

Our Postmistress received a letter from you and asked me to write you. My grandfather had a horse named Sir Henry, and he raised the mare Grace Darling and sold her to Wm. Mathews when she was three years old. Father says the mare was bay with black points. The dam of Grace Darling was gray and the grandam was gray. Father says the dam was Messenger. It was so long ago that I don't know much about 
it. Grandfather has been dead ten years. I have heard lots said about old Henry and the horse has got no pedigree that I can find. Mark Pease bought Henry of his brother that lived in Cornish, Me. The sire of old Henry was a horse that was brought from England so they say.

$$
\text { In haste, M. C. PE.ASE. }
$$

Mr. Battell,

JACKson, Nov. 2, I89o.

Would have written you before, but my father died since I wrote you last, and I had to write to some of his folks to find out who grandfather got the gray mare of. He got her of Nathan Andrews and he lived in Augusta then, I think he has moved and lives in Corinna. They tell me that Mr. Andrews is living, and I will write him and find out about her. They say she could trot close to $2: 40$. If there is anything more I can help you I will in regard to those Drew Horses.

$$
\text { Yours in haste, M. C. Pease. }
$$

This is in answer to the following letter.

M. C. PEASE,

$$
\text { Middlebury, Vt., Oct. 3, I89o. }
$$

Much obliged for yours of June ist. Is it possible for you to find out where and of whom your grandfather Mark Pease, got the gray mare that was the dam of Boston Girl. I would like exceedingly to learn this. Please let me hear from you soon.

$$
\text { Truly yours, Joseph Battell. }
$$

But two of the Drew Horse's get have trotted in $2: 30$ or better, these being the bay horse Gen. McClellan, $2: 26$, dam by Shark; and Dirigo, $2: 29$. Gen. McClellan is not represented in the $2: 30$ list by any of his get. Dirigo has six.

In a letter from J. Hamilton Reid, President of the York County Agricultural Society, Frederickton, N. B., dated August 26, I905, Mr. Reid says: "I claim that the sire of old Drew that was bred in this city and taken to Houlton, Me. and from there to Exeter, Me., by J. S. Hunt, Houlton, Me., was bred from Fairy by Lofty, dam Zoe, imported by the Duke of Kent, Queen Victoria's brother; and the produce (Drew) by our imported Buzzard, the son of Sparrowhawk in England. From all the Messenger and Quicksilver Mares, covered by this stallion of that time, no such horse as old Drew wàs produced. He made Maine noted for her road horses and trotters.

"Edward Elliot, a veterinary, who belonged to a British horse regiment and was appointed to this post, owned the mare Fairy by Lofty (see extended pedigree of old Drew). Whilst his, she trotted to a heavy carryall in $2: 55$. He bred her to Buzzard and sold her in foal to Jacob Allen, a young man in the Crown Land office, and she produced a colt that got old Drew whilst in the pasture after his arrival at Exeter, Me. Fairy was sold to an American and the foal was kept his, and we always thought that it was the man that got Fairy that came back and got the Buzzard colt when two years old; but we found that it was a man by the name of J. S. Hunt, that traded a gelding with Jacob Allen. 
"Fairy was the dam of the sire that got old Drew, and mare called Leadbeater got her dam old Zoe, and I am of opinion that this mare, called the Leadbeater Mare, was the dam of the Stone Messenger, by Winthrop Messenger, the very best son of that horse. Leadbeater was a trader in horses and oxen between Maine and Miramichi (river) in the 30 's, and saw this mare with filly foal by Lofty (the fourth she had by that horse)."

\section{DREW HORSE (ORIGIN OF).}

Mr. S. W. Parlin in the American Horse Breeder of April 19, r 898 writes :

"The writer talked with Mr. Hunt many times in regard to this colt which got the Drew Horse. Mr. Hunt always maintained that the colt was thoroughbred, and that he got him in New Brunswick from an officer of the British army. This colt had quite good trotting action, but after he became a gelding was trained and raced by Mr. Hunt successfully as a runner, and beat all the best in eastern Maine. Mr. Hunt says that he finally sold the horse to a Rhode Island horseman named Carpenter. I think he called him Ard Carpenter. Mr. Carpenter also raced him quite successfully.

"The writer had a somewhat lengthy correspondence in regard to this colt a few years ago with Mr. J. H. Reid, then of Frederickton, N. B., and evidently one of the best-posted horsemen in the Provinces. In retracting his charge of falsehood against Mr. Hunt for stating that he obtained this colt in New Brunswick, and that he was thoroughbred, Wallace states in Vol. III., that J. H. Reid of Frederickton, N. B., has found some evidence that the colt (sire of the Drew Horse) was a son of the imported horse Buzzard. During our correspondence with Mr. Reid in regard to this colt we received from him the following letters upon this subject:

Frederickton, New Brunswick, Canada, April i9, I892.

S. W. Parlin, Esq., Boston, Mass.

Dear Sir:-Yours of the $15^{\text {th }}$ inst., is duly to hand and contents noted. Mr. T. B. Barker, St. John, N. B., and myself were passing the Barker House, this city, in 1878 , and seeing A. G. Hunt in the office, Mr. Barker said: "There is Mr. Hunt," and we went in. 'This was the only time I saw him to talk with him.

I referred to the matter of the sire of the Drew Horse and letters that I said he wrote to J. H. Wallace. He denied that he had written any of these, but did admit that he dictated them and was present when they were made. In one letter he said the colt was got in St. John and the other at Frederickton. He explained this by saying that he got the colt on the St. John at Frederickton. He said that he got him from a British officer in a trade for a bay road horse that he was then driving to a sleigh.

He got in with him (this officer) and they drove down to a stable that had two doors. This was the Sheriff Miller stable, where this colt was stabled. They traded, and Hunt, whose memory at times seems 
defective, forgot all the facts of the case, and evidently made up a story after his own idea of what this officer said to him. Mr. Wallace and I had a lengthy correspondence about this matter, and we also talked it over in Wallace's office in New York.

Now the exact facts in this case are these: I had the stallion Robert R. Morris and wanted him registered. His dam was the double-team mare Stella, and I traced this mare to her breeder, N. B. Pease. She was called the Pease Mare or Black Sal, and I got it from Drew and also from Pease, that she was by the Drew Horse, and her dam was also bred by Pease, and was also called the Pease Mare. She was got by Shark, he by Quicksilver, son of imported Dey of Algiers, an Arabian horse. Her dam was the Nat Batchelder Mare, by Winthrop Messenger.

The sire of the Drew Horse was Young Buzzard, that Mr. Hunt took from this city in the winter of 1839 . I have letters in my possession that prove this much. You want to know how this Young Buzzard was bred. His sire, imported Buzzard, was bred in England, Yorkshire, and came to this province in 1825 , being then six years old. He was got by Sparrowhawk, son of Buzzard. For the latter's importation into Virginia, U. S., in 1804 , see Wallace's Stud Book, 377, page 8 r.

The dam of our Buzzard was a thoroughbred Clothier Mare. This horse Buzzard was never harnessed, but under the saddle could trot in I 836 , one mile on the road in three minutes. His stock were trotters and of good size. In 1838 a horseman named Witherow of Houlton, Me., took him to that town and there he died.

Now as regards the dam of Young Buzzard, sire of the Drew Horse, she was owned by the late Hon. Thomas Baillie, Heninbags, near this city, and could trot in three minutes before a heavy carryall, and he also had a pair of geldings called Tom and Billy, 16 hands high, that could trot from his residence to McCafferty's Tree, just a mile, in three minutes and a little less sometimes. This mare called Fairy, was a bay with a slit in the face, and one white fetlock behind. She stood $151 / 2$ hands high, and weighed about rooo pounds. She was got by Lofty a son of imported Wildair, from imported Doll: her dam Zoe, was imported from England by Queen Victoria's father, the Duke of Kent. No doubt this mare was thoroughbred. Her foals all raced or trotted. I knew them all.

This Fairy went lame, and Mr. Baillie had her covered in 1836 by Buzzard; she had this colt, which got the Drew Horse in 1837 , and $\mathrm{Mr}$. Baillie sold both the mare and foal to Jacob Allan, then of Shogomoc, this County, and after the colt was weaned, he sold the mare to an American.

The year of the Aroostook war, Allan was drafted into the militia and came to this city to dwell. He brought this colt with him. While here he had no use for the two-year-old, and traded with Mr. Hunt for this gelding. Hunt fully explained that the officer wore a blue coat, cape and pants with gilt buttons. This was the uniform of the militia at that time. The regulars wore dark gray with gray lambskin trimming.

The stable in which Allan kept this colt, opened with two doors, one above the other and no other stable in the city did the same but Col. Maxwell's in the barrack. To my knowledge, no British officer had an imported mare in this city since $\mathrm{I} 83 \mathrm{I}$. What officer sent here when war was imminent would carry around a brood mare? The Government would not allow him to do so if he was so inclined.

I have the pedigrees of all the horses imported into this province since 
I789, and if you ever come to this city I will show you all this Drew correspondence and all these pedigrees; also the pedigree of Capt. Absolute, that got the dam of Hill's Black Hawk, from a mare by imported Wildair. Wildair's stock raced and trotted.

Now I will give you some more news. The dam of the Stone Horse, a son of Winthrop Messenger, was sold to a horse dealer named Leadbeater, and this was old Zoe, imported by the Duke of Kent etc. Her daughter Fairy that brought Young Buzzard, sire of the Drew Horse also went to the States, and we thought because she trotted that her owner came back and got the colt from Allan, until this Drew matter turned up in hunting for the pedigree of Stella. Mr. Baillie failed in 1840 , and his horse was sold. I owned the best trotting horse in this city at the time that Mr. Hunt says I was not born. I am now 69 years old, and know all about the early history of all of our horses, and have owned some of the best ever owned in the Dominion of Canada.

J. H. REID.

P. S. I have in my possession the printed pedigree and notice of sale of the late William Taylor, M. P. of this city who sold imported Buzzard at public auction to Col. Harding of Mangrimbo, Semtrey County to be kept in the province for ten years. Capt. Douglas son of Sir Howard Douglas, brought Zoe from Halifax, N. S., after the Duke left for England.

Capt. Hill $\mathbf{5}$ and regiment bought Zoe from Douglas when he left for England in 1827 , and Dr. Woodford bought her from Capt. Hill when his regiment left in I829, and when the cannons were fired at our old training in $183 \mathrm{r}$, she was home with him. He was captain of the troop. She became lame and he had her covered by Lofty, a son of imported Wildair, from imported Doll, and sold her to Capt. Campbell, an old 422 Highlands officer on the Nashwalk River, and he bred her to Lofty, the only thoroughbred horse here at the time, and she produced Fairy, Zoe, and Selim, and a mare that went to Chatham and was lost sight of.

He then sold old Zoe to Leadbeater of your State for 40 pounds, which was a large price at that time. He saw her trotting in the pasture. She was a chestnut, and all her colts were chestnut except Fairy, the dam of Young Buzzard, sire of the Drew Horse.

Sire of 2 trotters $(2: 26) ; 2$ sires of 5 trotters 3 pacers; 6 dams of 6 trotters.

DREXTELL ( $1-64$ ), bay; foaled I89x; bred by Mrs. A. J. Barnhart, and C. W. Williams, Independence, Ia. ; got by William L., son of George Wilkes: dam Lou, brown, bred by H. L. \& F. D. Stout, Dubuque, Ia., got by Mambrino Boy, son of Mambrino Patchen ; 2d dam Bird Mitchell, got by Mambrino Royal, son of Mambrino Pilot. See Axtell. Sold to Budd Doble, who writes: "Drextell was bred and raised by C. W. Williams of whom I bought him as a yearling. I sold him when four years old to a gentleman in Indiana; bred but a few mares to him whilst I owned him." Pedigree from breeder.

Sire of Princetell, $2: 231 / 2$.

DRIFTAWAY (3-128), $2: 19 \frac{1}{4}$, bay; foaled 1897 ; bred by C. S. Rex, Creston, Ia. ; got by Red Baron, son of Baron Wilkes : dam Drift, chestnut, foaled r 890 , bred by Church Bros., Frankfort, Ky., got by Onward, 
son of George Wilkes; 2d dam Lorena, bay, foaled $\mathrm{r} 88 \mathrm{r}$, bred by Thomas Thompson, Duckers Station, Ky., got by King Rene, son of Belmont; 3d dam Lothairess, said to be by Woodford Abdallah, son of Woodford Mambrino; and $4^{\text {th }}$ dam by Doniphan, son of Davy Crockett.

Sire of Clear Drift, $2: 20 \% \frac{1}{4}$.

DRIFTON B., $2: 20$, bay, both hind and near front ankles white, narrow strip in face, I6 hands, I Ioo pounds; foaled I 893 ; bred by H. F. \& F. K. Balch, Lakeville, Minn. ; got by Antevolo, son of Electioneer : dam Alcyona, bay, bred by L. M. Bedford, Paris, Ky., got by Alcyone, son of George Wilkes; 2 d dam Culter, said to be by Coaster, son of Caliban; 3d dam Clara B., by Caliban, son of Mambrino Pilot; and 4 th dam Malt Eagless, said to be by Lexington. Pedigree from F. K. Balch, Lakeville, Minn.

Sire of Lady Drifton, $2: 24 \frac{1}{4}$; May Drifton, $2: 21 \frac{1}{4}$.

DRIVER, bay; foaled I 727 ; bred by Duke of Ancaster; got by Wynn Arabian : dam Lady, by (Old) Pert, son of The Ely Turk; 2d dam by St. Martin, son of Spanker; 3d dam by Sir E. Hale's Turk, from the Oldfield Mare, of which nothing is known, but she was described as highly bred.-General Stud Book, Vol. I., p. I2.

DRIVER, said to be by Othello: dam by imported Spark; and $2 \mathrm{~d}$ dam by Gov, Ogle's Barb. Advertised 1762 by R. Tyler in the Maryland Gazette at thirty shillings. Also advertised $\mathrm{I}_{764}$ and $x_{765}$, ten to thirty shillings.

DRIVER, bay, large, said to be by imported Wildair : dam by Briton; and $2 \mathrm{~d}$ dam by old Dawson. Advertised $\mathrm{r} 778$ at Inklin Barrack Hill about 3 miles from New York City. Driver moves well, is handsome, strong, active, and is remarkable for getting fine stock.

DRIVER, by Saltram. Advertised as follows in the (Middlebury, Vt.) Mercury of May I6, 1804:

"During the present season the noted imported horse Driver, will stand at the stable of Gamalial Painter in Middlebury. Said horse has been kept in Connecticut for six years past. He will be let to mares at $\$ 8$ each. He is a beautiful bay, I $^{1 / 2} / 2$ hands, bred by the Duke of Queensbury, sired by Saltram, son of Eclipse : his dam by Woodpecker, son of King Herod, who was the sire of Gindo and many of the first studs and mares of England. Driver's grandam was own sister to the celebrated Highflyer. He is as high-bred a horse as any imported into America, beautiful in form, carriage, etc. Also will stand at the same stable the beautiful horse Young Driver, at the moderate price of $\$ 4$ the season, sired by the above-mentioned Driver, and from a full-blooded English mare. Young Driver needs no further recommendation than to say that he is the same horse the subscriber has kept for two seasons past.

A horse of same name, probably the same horse, is advertised in 
Orange County, N. Y., r8o6, by S. Dimmick and P. Boyce and said to have been foaled $\mathrm{r} 795$, and imported by Cajt. Ramsey of Hartford.

A horse of the same name described as dark bay, I 6 hands; foaled r790, is advertised 1795 , at Henniker, N. H., by J. Gibson and called a natural trotter.

DRIVER ( $1-8$ ), bay; foaled I 856 ; bred by Elias Dorsey, Jefferson County, Ky. ; got by Vermont Morgan : dam Big Archy, dark bay ; foaled I 850 ; said to be by Young American Eclipse; and 2 d dam by Archy. Sold, I86o, to Arthur C. Barton, Franklin County, Ala., from whom he was taken during the war.

Sire of dam of Mattie Hunter, $2: 12^{3} / 4$.

DRIVER (I-8) black, under sized, very strong and fast, said to be by Tecumseh, Canadian, which see. Bought in Kentucky of a Mr. Hough, a stage - proprietor, and kept one season near Lewisburgh, Tenn. Died when 24 .

DROMILL HORSE (3-I6), said to be by Cobb's Brandywine: and dam by Whalebone, son of Sherman Morgan. Information from Gideon Bearce, West Minot, Me.

DRONE, bay; foaled I76I ; bred by H. R. H., the Duke of Cumberland; got by Young Cade, son of Cade: dam Cypron, bred by Sir W. 'St. Quintin, got by Blaze; 2d dam Salome or Selima, by Bethell's Arabian; 3d dam by Graham's Champion, son of Harpur's Arabian ; 4th dam by Darley Arabian; 5th dam by Merlin (Old), son of Bustler.General Stud Book, Vol. I., p. 74 .

DRONE bay; foaled I 777 ; bred by Mr. Panton; got by Herod, son of Tartar: dam Lilly, bred by the Duke of Ancaster, got by Blank, son of the Godolphin Arabian; 2d dam Peggy, bay, bred by Duke of Ancaster, got by Cade, son of the Godolphin Arabian ; 3d dam Partner Mare (sister to the Widdrington Mare), bred by Mr. Crofts, got by Partner (Croft's), son of Jigg; 4th dam Bay Bloody-Buttocks, bred by Mr. Crofts, got by Bloody-Buttocks ; $5^{\text {th }}$ dam Brown Fairwell, said to be by Grayhound. It was stated in former editions that Drone was drowned on the passage to America, but he appears in the American Stud Book to have covered two seasons there.--General Stud Book, Vol. I., p. I7.

This horse was brought from Litchfield, England, in I 797, by Cephas Butler, Litchfield, Conn., and advertised in I 798 at Greenfield, Mass. Also advertised by Chas. Butler in I799. Advertised in Orange County Gazette, Goshen, N. Y., I807. See Brown Highlander imported at same time.

DRONE, bay, I $5 \frac{1}{2}$ hands; foaled $\mathrm{I} 80 \mathrm{I}$; said to be by old Drone of England. Advertised in Orange County Gazette, Goshen, N. Y., I807. 
DRUID, chestnut; bred by Earl Grosvenor and imported into Virginia in I8oo; got by Pot-8-os, son of Eclipse: dam Maid of the Oakes, by King Herod; 2 d dam Rarety, by Matchem; 3d dam Snap Dragon, by Snap.-American Turf Register, Vol. II., No. 8.

DRUMBO (I-I28), black with star, I5 I/4 hands, Io5o pounds; foaled I 888 ; bred by W. C. Fair, Cleveland, O. ; got by Brown Wilkes, son of George Wilkes : dam Melissa, chestnut, bred by W. C. Fair, got by Monaco, son of Belmont: 2d dam Lizzie, black, bred by Dr. Herr, Lexington, Ky., got by Mambrino Patchen; 3d dam Lettia, bred by Joseph H. Ewalt, Lexington, Ky., got by Joe Downing; and $4^{\text {th }}$ dam by Herr's Coeur de Lion. Sold to Wm. C. Hilton, Dunkirk, N. Y., who sends pedigree. Sire of 2 trotters $\left(2: 20^{1 / 4}\right)$.

DRUMMER BOY (3-I28), $2: 34 \frac{1}{4}$, said to be by Senator L. son of Renshaw by Onward.

Sire of Arthur G, $2: 30$.

DUANE (7-128), $2: 27 \mathrm{I} / 2$, bay, I6 hands, I 200 pounds; foaled I 885 ; bred by J. \& T. M. Tierney, St. Albans, Vt. ; got by Deucalion, son of Hambletonian: dam Belle D., bay, bred by E. D. Hinds, Pittsford, Vt., got by Daniel Lambert, son of Ethan Allen ; 2 d dam Belle Hinds, said to be by Darkey, son of Round's Horse, by Black Hawk; and 3d dam Queen of Vermont, by Churchill Horse, Son of Black Hawk. Sold to A. B. Rooney., East Fairfield, Vt., who sends pedigree.

Sire of Jed P., $2: 28$.

DUBUQUE (3-I28), bay; fcaled I887; bred by H. L. \& F. D. Stout, Dubuque, Ia. ; got by Nutwood, son of Belmont: dam Nora Wilkes, bay, bred by J. C. McFerran, Louisville, Ky., got by George Wilkes ; 2 d dam Nora Lee, bay, bred by A. J. Alexander, Spring Station, Ky., got by Woodford Mambrino, son of Mambrino Chief ; 3 d dam Young Portia, said to be by Mambrino Chief; and $4^{\text {th }}$ dam Portia, by Roebuck. Sold to Frank Watson, Chenoa, Ill ; to A. B. Stribling, Virginia, Ill. Pedigree from Catalogue of Breeder.

Sire of Idea, $2: 30$.

DUCCO PHALLAMONT (I-32), bay, I5 5 /2 hands; foaled $\mathrm{x} 888$; bred by H. D. McKinney, Janesville, Wis.; got by Phallamont, son of Phallas : dam Athlene, bay, bred by Geo. Houston, Beloit, Wis., got by Athlete, son of Almont ; 2 d dam Lady Fletcher, by Richards Bellfounder, son of Hungerford's Blucher; 3 d dam Polly Jr., by Vermont Boy; and 4th dam One-Eyed Scott Mare. Pedigree from breeder.

Sire of Frank Alright, $2: 291 / 4$.

DUDE (I-32), 2:27 I/2, bay, right hind ankle white; foaled 1877 ; bred by 
Fashion Stud Farm, Trenton, Mercer County, N. J. ; got by Jay Gould, Son of Hambletonian : dam Mary, bay, bred by John W. Scrobey, near Allentown, N. J., got by Geo. M. Patchen, son of Cassius M. Clay ; 2d dam, said to be by Saladin, son of Young Bashaw; and $3 \mathrm{~d}$ dam by Monmouth Eclipse, son of American Eclipse. Sold to Geo. Smith, Chicago, Ill., who owned him Aug. 6, I884. Pedigree from Fashion Stud Farm, per E. L. S.

DUDLEY (1-64), 2 : I 4, seal brown, I5 1/2 hands, I075 pounds; foaled 1887 ; bred by Frank W. Dudley, Oakland, Cal.; got by Anteos, son of Electioneer : dam Lily Langtry, black, bred by Frank W. Dudley, got by Nephew, son of Hambrino; $2 \mathrm{~d}$ dam Miss Trahern, said to be by Gen. McClellan, son of North Star, by Bulrush Morgan; 3d dam Belle Mahone, by Norfolk, son of Lexington ; and $4^{\text {th }}$ dam Maid of Oaks, by Jack Hawkins, son of Boston. Sold to Judge Greene, Oakland, Cal. ; to W. H. E. Smith; to B. H. McNeil, Rohnerville, Cal., who sends pedigree.

Sire of Brice McNeal, $2: 19 \frac{1}{4}$.

DUDLEY BUCK (I-8), bay, I5 hands, 950 pounds, bred by C. C. Trafton, St. Albans, Me.; got by Winthrop Morrill, son of Young Morrill : dam said to be by Hendrick Hudson, son of Roe's Abdallah Chief; 2d dam by Witherell. Sold to John F. Mills, Somerville, Mass.; to Mr. Geo. Hall, Adams House, Boston, Mass.; to Hon. H. G. Foss, Auburn, Me.; to Mr. Milliken, Augusta, Me. Gelded at four years old. Pedigree from John F. Mills, who writes that he was a very fine horse.

Sire of Lady Goodwin, $2: 201 / 2$.

DUE HAL (1-32), bay, I6 hands, I Ioo pounds; foaled I 897 ; bred by J. R. and C. J. Smith, Spring Hill, Tenn.; got by Duplex, son of Bay Tom Jr. : dam Banquette, black, foaled $\mathrm{i} 883$, bred by Campbell Brown, Spring Hill, Tenn., got by Brown Hal, son of Tom Hal Jr.; 2 d dam Bonnie Annie, said to be by Omega, son of Traveler (McMeens') ; 3d dam Lettie, chestnut, foaled $186_{3}$, bred by Isaac Milner, Santa Fe, Tenn., got by Driver, son of Vermont Morgan. Sold to S. H. Butler, Como, Miss., who writes that Due Hal was bred by M. C. Campbell, Spring Hill, Tenn. ; to A. L. Campbell, Jr., Greeley, Col.

Sire of Hallina Morgan, $2: 14 \frac{1}{4}$.

DUEX (I-32), $2: 22 \frac{1}{4}$, bay, $5_{5}^{1 / 2}$ hands, rooo pounds; foaled r 889 ; bred by Jerry Mungeon, Winooski, Vt. ; got by Duexmillion, son of Deucalion : dam Dolly M., bred by Dr. Howe, Jericho, Vt., got by Young Fearnaught; and $2 \mathrm{~d}$ dam Dr. Howe mare, said to be by Silver Heels. Pedigree from W. R. Chambers.

Sire of Grace Pinney, $2: 20^{3} / 4$. 


\section{DUFF GREEN. Untraced.}

Reputed sire of the dam of Bay Dick, $2: 29 \frac{1}{2}$, and winner of Io races.

DUFORT HORSE, black. Sold by Chas. LaChambeau, L'Epiphanie, P. Q., to M. DuFort, who sold him at Three Rivers for \$1 500 .

DUFREIN HORSE, black, I300 to I 400 pounds; bred by M. DuFrein, Point DuLoi, nine miles from Three Rivers, P. Q. Information from the Captain of the steamboat on St. Lawrence, who said further that DuFrein had a fast red mare got by Jean de Baptiste. He also referred to a fast pacer blue and white, bought from a baker at Three Rivers of Louis Goden, about I85o, the fastest horse then in that locality from I 4 to I 5 hands, bred at Three Rivers and also to another small black stallion owned by Charles DeNebirville.

DUHAMEL HORSE (See Carillon).

DUKE ALEXIS (I-128), bay, bred by T. F. Mapes, Monroe, N. Y. ; got by Iron Duke, son of Hambletonian : dam Lady Juno, said to be by King's Champion Jr., son of Grinnell's Champion by Almark.

Sire of St. Elmo, $2: 25 \frac{1}{2}$, foaled 1879 .

DUKE MCCLELLAN (I-I6), chestnut; foaled I 872 ; bred by Geo. Fisher, Petaluma, Cal.; got by Gen. McClellan, son of North Star, by Bulrush Morgan: dam Ocean Nell, dam of Dan Voorhees, 2 :23 $1 \%$. Owned by Chas. M. Laughlin, who sold, I88r, to W. H. Taylor, San Louis Obispo, Cal. Died fall of r89o. W. H. Taylor, San Louis Obispo, Cal., Jan. 29, I89r, writes :

"In answer to your inquiry about the breeding of the dam of Duke McClellan, I can only say she was also the dam of Dan Voorhees, $2: 23 \frac{1}{4}$, and known as the Fisher mare at Petaluma, Cal."

Sire of Maid of Oak, 2:23; I dam of I trotter.

DUKE OF BEDFORD, bay, said to be by imported Bedford: dam by Voltaire; and $2 \mathrm{~d}$ dam Nancy Washington, by imported Stephen. Brought to Kentucky by Capt. Edmund Bacon, about I806 or 1807 , purchased of Colonel Hoomes. Called one of the best breeders ever in Kentucky. -American Turf Register, Vol. IV., No. I2.

DUKE OF BRUNSWICK, bay; foaled I 864 ; bred by Harrison Durkee, New York, N. Y.; got by Hambletonian : dam Madam Loomer, chestnut, foaled $185 \mathrm{I}$, bred by Edward Loomer, Jackson, New Brunswick, Can., got by Warrior, son of White Warrior, said to be by Winthrop Messenger. Sold to Geo. M. Jewett, Zanesville, O., who advertised him in Turf, Field and Farm, I 883 ; to Alexander Conklin, Delhi, N. Y.; to M. and A. G. Smith, Wellsville, O.

Sire of 3 trotters $(2: 23) ; 5$ sires of 6 trotters, 3 pacers; 6 dams of 5 trotters, 2 pacers. 
DUKE OF CRAWFORD, bay, 16 hands, 1200 pounds; foaled I87x; bred by Powell Bros., Shadeland, Crawford County, Penn.; got by Satellite, son of Robert Bonner, by Hambletonian: dam Roxie, bay, bred by Albert Fish, Crawford County, Penn., got by Sterling's Eclipse, son of Telegraph, by imported Abderhamon: 2d dam bred by Albert Fish, got by Lawson Horse, said to be a grandson of imported Messenger. Sold to A. B. Nye, Fenton, Mich. Pedigree from breeders.

Sire of Stickfast, $2: 27$; I dam of I trotter.

DUKE OF GLEN LAKE, bay ; foaled I 879 ; bred by John Stout, Midway, Ky. ; got by Mambrino Abdallah, son of Mambrino Patchen : dam Puss Prall, bay, bred by J. A. Prall, Midway, Ky., got by Mark Time, son of Berthune; $2 \mathrm{~d}$ dam said to be by Daniel Webster, son of Lance. Sold to Moorhead \& Knowles ; to C. W. Aldrach, Clear Lake, Utah. Information from Mrs. Aldrach.

Sire of 2 trotters $(2: 2 \mathrm{I} 1 / 4)$.

DUKE OF SARATOGA (I-I6), bay, I5 $1 / 2$ hands; foaled I 868 ; bred by John Minchin, Goshen, N. Y. ; got by Young Woful, son of Long Island Black Hawk: dam Belle of Saratoga, brown, bred by D. Edgar Hill, Bridport, Vt., got by Black Hawk; 2 d dam Poll Roe. Sold to G. S. Stevens, Minneapolis, Minn. Advertised with pedigee as above by George F. Stevens, Utica, N. Y., I873, in New York Spirit of the Times. (Young Woful's dam by Ross' Abdallah Chief; 2d dam by old Richmond). Gelded.

Sire of Molly B., $2: 28$,

DUKE OF YORK, bay, I6 hands; foaled I 85-; bred by Alfred Warner, Wilmington, Ill. ; got by Small's Duke of York, by a son of Sir Henry, by Sir Archy : dam untraced. Owned in Illinois.

Sire of Duke, $2: 261 / 2$.

DUKE PATCHEN, bay, left hind foot white, I6 hands, I225 pounds; foaled I 878 ; bred by Geo. M. Jewett, Zanesville, O.; got by Duke of Brunswick, son of Hambletonian: dam Kit Patchen (dam of Almont Wagoner, $2: 29^{\mathrm{I}} / 2$ ), said to be by Wild Wagoner, son of George M. Patchen; and 2 d dam Kathleen, by Hiatoga, son of Rice's Hiatoga. Sold to B. Donaldson, Steubenville, O.; to L. S. Gardinier, Damascus, O. Advertised at Dewfield, O., I 886. Pedigree from Samuel Phillips.

Sire of Sleepy Jim, $2: 24 \frac{1}{4}$,

DULUTH (3-32), bay with star, snip, and one white foot, $15 \frac{1}{4}$ hands, I050 pounds; foaled I869; bred by Whit McElroy, Lebanon, Ky. ; got by Cabell's Lexington, son of Gist's Black Hawk, by Blood's Black Hawk : dam gray, said to be by Davis' Flying Morgan, son of Young Telescope ; 2d dam by Boyd McNary; 3d dam by Oregon; 4th dam by Lamp- 


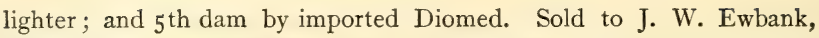
Bowling Green, Ky., about I876 ; to Mr. Horn, Milan, Tenn., about I 878 ; to Nat Mercer, Bowling Green, about I 880 ; to James T. \& T. H. W. Blewett, Woodlawn, Ky., about I883. Died August, I889. A horse of fine appearance and went all the gaits. The National Saddle Horse Register, says: "Won a sweepstakes premium once at a St. Louis fair; over $9^{6}$ competitors. He was a fine saddler and great sire of show horses. His son, Duluth Jr., won the $\$ 500$ sweepstakes for the best saddle stallion at Mexico, Mo., August, I892." See The Morgan Horse and Register, Vol. I., p. 433.

DULUTH BOY (I-32), bay with white face and legs, I6 hands, II50 pounds; foaled I 887 ; bred by W. C. Barham, Milan, Tenn.; got by King Duluth, son of Duluth : dam Claybank Mare, bred by Riley Moore, Atwood, Tenn., got by McLemore's Golddust, son of old Dick Johnson. Sold to R. Y. McConnell, Jordan, Ky. Pedigree from breeder.

DULUTH CHIEFTAIN (I-I6), bay with white marks, I6 hands, I 200 pounds; foaled I88ra; bred by Mr. Ragsdale, Mexico, Mo.; got by Duluth, son of Cabell's Lexington : dam said to be by Hann's Orphan Boy; and $2 \mathrm{~d}$ dam by Copperbottom. Died i 894 . Sold to R. T. Freeman \& Son, Mexico, Mo., who furnishes above information.

DULUTH, J. C. (I-32), black, one hind foot and one fore foot white ; $153 / 4$ hands, I Ioo pounds; foaled r 889 : bred by Captain Edmonston, Laddonia, Mo.; got by Duluth Jr., son of Duluth : dam said to be by Kentucky Denmark, son of Washington Denmark; and 2d dam by John Randolph, son of Marshall Ney. Sold to George Rainey, Laddonia, Mo., who sends pedigree.

DULUTH JR. (3-32), black with white mark; foaled I879; bred by Robt. Hann: got by Duluth, son of Cabell's Lexington: dam•Annie L.; said to be by Stonewall Jackson; and $2 \mathrm{~d}$ dam by Copperbottom. Owned by Brockman \& Spencer, Centralia, Mo.

DUMAS (3-64), $2: 183 / 4$, bay ; foaled I 883 ; bred by R. P. Pepper, Frankfort, Ky., got by Onward, son George Wilkes: dam Mistress, bay, bred by Mr. Payne, Scott County, Ky., got by Hamlin's Almont Jr., son of Almont ; 2 d dam said to be by Doniphan, son of Cavin's Davy Crockett ;

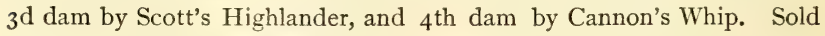
to I. H. Lamb, Jerseyville, Ill.

Sire of 4 trotters $(2: 201 / 2)$; Io pacers $\left(2: 10 \frac{1}{2}\right) ; 3$ sires of 2 trotters, 5 pacers; 3 dams of 3 trotters, 2 pacers.

DUMONT S. (3-т28), 2 :20, bay; foaled I 900 ; bred by S. B. Wright, Santa Rosa, Cal. ; got by Lynwood W., son of Guy Wilkes : dam Maud Fowler, $2: 2$ I $3 / 4$, bay, foaled I 888 , bred by Isaac DeTurk, Santa Rosa, Cal., got 
by Anteeo, son of Electioneer; 2d dam Eveline, bay, foaled I883, bred by Lot D. Slocum, San Francisco, Cal., got by Nutwood, $2: 183 / 4$, son of Belmont. Sold to Pat Cunningham, Santa Rosa, Cal; to Lewis Charlton, Ukiah, Mendocino County, Cal. Full brother to Sonoma Girl, 2 :07. Kept at Ukiah, 1907.

DUNBAR HORSE (WHEELER HORSE) (3-32); foaled r844 the property of Stephen Mead, Middlebury, Vt. ; got by Hackett Horse, son of Gifford Morgan : dam purchased by Stephen Mead on the East side of the Green Mountains, and said to be by Gifford Morgan. Owned by J. B. Dunbar, Beloit, Wis., who writes dated April 1 2, r891. "I did not have a pedigree of the horse but can refer you to George F. Wheeler of Ripon, Wis., who raised him in Vermont." See The Morgan Horse and Register, Vol. II., p. 346.

DUNBARTON, brown; foaled r 863 ; bred by Fletcher Brooks, Washingtonville, N. Y.; got by Hambletonian: dam bred by Fletcher Brooks, got by Long Island Black Hawk, son of Andrew Jackson. Sold to B. K. Johnson, East Coldenham, N. Y. ; to A. B. Paine, Saginaw, Mich. Died i $\delta 90$.

Sire of Bensine, $2: 24 \frac{1}{4} ;$ I sire of 4 trotters; 3 dams of 3 trotters.

DUNCAN WILKES (I-I28), bay, I6 hands, I250 pounds; said to be by Billy Wilkes, son of Harry Wilkes, by George Wilkes: dam Doll by Rolfe (dam Polka 2 :3 I, by Iron's Cadmus), son of Sam Hazard; and $2 \mathrm{~d}$ dam by Woodmansey's Tuckaho. Owned and perhaps bred by Mr. Tapp, Pekin, Ill. Sold to WV. C. Burgett, Duncan Mills, who advertised him I 895 .

Sire of Dick Iates, $2: 24 \frac{1}{4}$.

DUNDEE ( $1-32$ ) , $2: 25$, dark bay with small star, I6 1/2 hands, I 200 pounds ; foaled 1876 ; bred by Jesse Tyson, Baltimore, Md. ; got by Jay Gould, son of Hambletonian: dam Meta bay, foaled i 870 , bred by Jesse Tyson, got by Mambrino Pilot, son of Mambrino Chief ; $2 \mathrm{~d}$ dam Lady Rattler, roan, bred by Jesse Tyson, got by Rattler (Rockwell's), son of Rattler; 3d dam old Roan, said to be by Rockwell's Rattler. Kept at Rosemont Stock Farm adjoining Berryville, Va. Pedigree from C. H. Boxwell, Manager for Jesse Tyson, Berryville, Va.

Sire of 5 trotters $(2: 19)$; I sire of 4 trotters; I dam of I pacer

DUNDEE ( $\mathrm{I}-64$ ), chestnut with bright star; foaled $\mathrm{I} 884$; bred by B. J. Treacy, Lexington, Ky. ; got by Abdallah West, son of Allie West : dam Bantam, gray, bred by R. S. Veech, Louisville, Ky., got by Auditor, son of Hambletonian; 2d dam Dulce, gray, bred and owned at Woodburn Stock Farm, Woodford, Ky., got by Belmont, son of Alexander's Abdallah; 3d dam Madam Dudley, supposed to be of Bashaw Stock; and 


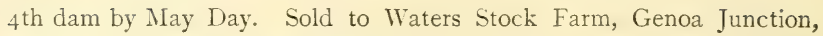
Wis. ; to D. E. Stone, Mt. Pleasant, Md. ; to John C. Walter, Frederick, Md.; to R. S. Delander \& Co., Broad Run, Md.; to Goe. G. Hanen, Eau Claire, Wis.; to Simon M. Hostetler, Hanover, Penn. Pedigree from Catalogue of breeder.

Sire of Colswain, $2: 2 I_{1 / 4}^{1 / 4}$; s sire of I pacer.

DUNGANNON, imported. Advertised, I 807 at Goshen and Newburgh, by T. L. \& J. I. Brooks.

DUNGANNON. Advertised as follows in Kentucky Gazette, $\mathrm{I} 8_{35}$ :

"By Sumpter. At Oakland Course, near Louisville, Ky., beautiful red chestnut sorrel, sixteen hands high; foaled in $I \delta_{27}$; his dam was by the Duke of Bedford; his grandam, by Carlisle's Union; his great-grandam by old Union, who was got by the imported horse Shakespeare; his dam by Nonpareil; grandam the imported mare Pocahontas, by Godolphin Arabian. Carlisle's Union, was by old Union; his dam by Mahomet (he by Lindsey's Arabian); his grandam by Fearnaught.

"Duke of Bedford was by imported Bedford; his dam by Voltaire; his grandam Nancy Washington.

\section{JAMES L. BRADLEY."}

DUNHAM ABDALLAH, bay; foaled I 878 ; bred by Dunham Bros., Alma Creek, O.; got by Erie Abdallah, son of Roe's Abdallah Chief : dam Gray Lucy, said to be by Champion.

Sire of Dan Mace, $2: 23 ; 2$ dams of 2 pacers,

DUNKIN. D. B. Haight of Dover Plains, Dutchess County, N. Y., in a letter to Wallace's Nonthly of April, i $S_{77}$, upon Northern stock taken tc Tennessee in $18_{57}$, says:

"I notice, in your Monthly of February an article speaking of stock purchased by Fanning \& Allen, of Tennessee. These two men were sent North, by a stock company, to buy blooded stock of different kinds.

"They came to my place, and stayed with me for some days. In the meanwhile, I took them to see such stock as I thought good. They then went to Maine, where they bought the Eaton Horse, and a number of his get. The old horse and all his colts were sorrel. They gave me orders to buy for them here. Accordingly, I purchased Mambrino Messenger; the Dunkin Horse, a yearling colt by the Hustis Horse, he by Dunkin Horse, and from a gray mare, pedigree unknown, but supposed to be of Messenger blood; a filly by the Dunkin Horse; a fine bay stallion, bred by my father, Jacob N. Haight (not D. N. Haight, as it was written in the Monthly), two years old, and got by a fine bay horse, called Hambletonian: dam by Henry Clay; grandam by old Mount Holly; great-grandam by Bay Captain; great-great-grandam by Blaze; greatgreat-great-grandam by True Briton. Hambletonian, above mentioned, was here one season. He was from the dam of Iron Duke, son of C. M. Clay, and was owned by Timothy T. Jackson, Long Island. I do not remember what horse got Hambletonian. He was not by a Hambletonian, but was full of Messenger blood. This colt that my father bred 
I considered first-class, so far as pedigree was concerned, and he was really a fine colt.

"I also bought Naugatuck, and paid $\$ \mathbf{x , 2 0 0}$ for him. He had a good dam by the Burton Horse, son of old Mambrino.

"The Dunkin Horse was large and fine, and got good stock,-extra stock, considering the chances he had. He was the property of a drunkard and met with harsh treatment; but though he had the poorest mares in the country, his fine qualities were plainly to be seen in his foals. I sold these same gentlemen, South-down sheep and Berkshire pigs. I also bought for them a Devon bull, and took all to New York, where I met them with their Maine Messengers, as they called them. They didn't look much like our Messenger stock, as they were pale sorrels. I think the old horse had some gray hair on his rump and around his tail. If I am not mistaken, too, he had big flat feet; still his get had quite a name, as travelers. I would like very much to hear of some trotter descended from Mambrino Messenger, or the colt my father bred, for they both had fine pedigrees, and if crossed upon good mares, could hardly fail to get trotters.

\section{B. Haight."}

DUNRAVEN ( I-64), bay; foaled I879; bred by J. C. McFerran, Louisville, Ky.; got by Cuyler, son of Hambletonian: dam Mary Mambrino, bay, foaled r 870 , bred by A. S. Talbert, Lexington, Ky., got by Mambrino Patchen; 2 d dam Belle Wagner, bay, bred by W. C. Bell, Lexington, Ky., got by Embry's Wagner ; 3d dam Lady Belle, bay, bred by Dr. Herr, Lexington, Ky., got by Bellfounder Jr., son of Bellfounder (Brown's) ; $4^{\text {th }}$ dam Multiflora, said to be by Monmouth Eclipse, son of American Eclipse ; and $5^{\text {th }}$ dam by Rosicucian-Young Bedford-Arion-Brilliant. Sold to C. M. Dunlap, Mt. Sterling, Ill. Pedigree from catalogue of breeder. Sire of 2 pacers $\left(2: 10^{3 / 4}\right)$; I sire of I pacer.

DUNTON IVILKES, bay, I $53 / 4$ hands, I I 60 pounds; foaled 1882 ; bred by A. M. Waddell, Lexington, Ky.; got by George Wilkes: dam Kate Jr., said to be by Brown Dick (dam Fanny King by imported Glencoe), son of imported Margrave ; and $2 \mathrm{~d}$ dam Kate Smith, by Spaulding's Abdallah, son of Abdallah. Sold to D. W. Marsh, Cleveland, O.; to H. B. \& H. D. Allen, Waterloo, Ia., who advertised with pedigree as above in Dunton's Spirit of the Turf, I 888.

Sire of 3 trotters $\left(2: e_{4}\right)$; Io pacers $\left(2: 09 \frac{1}{4}\right) ; 2$ sires of 3 trotters, 2 pacers; 2 dams of 3 pacers.

DUPIGNAC ( $\mathrm{I}-64$ ), bay ; foaled I 889 ; bred by Q. V. Baker, Jr., Comstocks, N. Y.; got by Meander, son of Belmont: dam Mab, black, bred by H. S. Russell, Milton, Mass., got by Harry Vane, son of Smuggler; $2 \mathrm{~d}$ dam Gwendolen, bay, bred by A. J. Alexander, Spring Station, Ky., got by Harold, son of Hambletonian; 3d dam Guava, said to be by Woodford

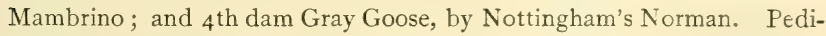
gree from breeder.

Sire of 2 pacers $\left(2: 05^{1 / 4}\right)$. 
DUPLEX (I-I28), $2: 17 \frac{1}{4}$, bay; foaled I 883 ; bred by J. W. Lee, Duplex, Tenn.; got by Bay Tom Jr., son of Bay Tom: dam untraced. Sold to W. S. Coffey, Belfast, Tenn. ; to John Lee, Duplex, Tenn. Pedigree from E. F. Geers.

Sire of 20 pacers $\left(2: 07^{3 / 4}\right) ; 2$ sires of 3 pacers; 3 dams of 3 pacers.

DUPREE (1-32), black, I53/4 hands; foaled I 888 ; bred by Fashion Stud Farm, Trenton, N. J. ; got by Rumor, son of Tattler : dam Daisy, (dam of Digma $2: 25 \mathrm{1} / 4$ etc.), chestnut, bred by Henry N. Smith, Fashion Stud Farm, Trenton, N. J., got by Socrates, son of Hambletonian; 2 d dam Daisy Burns, $2: 293 / 4$ (dam of Slander, $2: 281 / 2$ ), said to be by Skenandoah (Kentucky Hunter), son of Broken Legged Kentucky Hunter ; 3 d dam by Harden Horse-Harden's Kentucky Hunter. Sold to A. P. Sauer, Houston, Tex. ; to A. Goldman; to V. E. Goldman, Victoria, Tex. Pedigree from Fashion Stud Farm Catalogue.

DUQUESNE, $2: 173 / 4$, chestnut with stripe, two hind feet white, $153 / 4$ hands, I 100 pounds, foaled I 875 ; bred by Charles L. Sharpless, Philadelphia, Penn.; got by Tippo Bashaw, son of Black Bashaw : dam Wild Rose, bay, bred by William J. Tuthill, Blooming Grove, N. Y., and purchased by Mr. Sharpless of Alden Goldsmith, got by Hambletonian, son of Abdallah; 2 d dam, Gipsey, said to be by Abdallah. Sold to P. H. Hacke, Pittsburgh, Penn., who sends pedigree.

Sire of 2 trotters $(2: 2 \mathrm{I}) ;$ Dr. Snyder, $2: 17 \frac{1}{4} ; 3$ dams of 2 trotters, I pacer.

DURANGO ( $\mathrm{I}-64$ ) $, 2: 233 / 4$, left hind foot white, I6 $1 / 2$ hands, I 200 pounds; foaled 1877 ; bred by W. T. Withers, Lexington, Ky., got by Cassius M. Clay Jr., son of Strader's Cassius M. Clay : dam Mattie West, bay, foaled I 872 , bred by Richard West, Edge Hill, Ky., got by Almont, son of Alexander's Abdallah; 2d dam Monogram, bay, bred by the Rev. J. P. Boyce, Charleston, S. C., got by Mambrino Chief, son of Mambrino Paymaster ; 3 d dam a road mare sent from South Carolina by J. P. Boyce, to be bred to Mambrino Chief. Sold to A. M. Studer, Peoria, Ill., I887 ; to A. G. Danforth, Washington, Ill.; to Wesley A. Miller, Rose Lawn, Ind. ; to A. L. Booth, Gardner, Ill. Pedigree from A. G. Danforth's Catalogue.

Sire of 18 trotters $\left(2: 17 \frac{114}{4}\right) ; 7$ sires of 12 trotters, 6 pacers; 16 dams of 20 trotters, 6 pacers.

DURANGO CHIEF (I-32), black with star, one hind foot white; foaled April $24^{\text {th, }} 1883$; bred by P. B. Hunt, Harlan, Ia. ; got by Durango, son of Strader's Cassius M. Clay Jr.: dam Sparta, bred by J. H. Prescott, near Avoca, Ia., and foaled the property of P. B. Hunt, Harlan, Ia., got by Longstrider, son of Sweepstakes; $2 \mathrm{~d}$ dam Tempie Abdallah, black, bred by J. A. Green, Muscatine, Ia., got by Gifford Morgan Jr. (Seymour's), son of Gifford Morgan ; 3d dam Sally Green, bred by Joseph A. Green, got by Hambletonian, son of Abdallah; 4th dam 
Belle, dam of Green's Bashaw, which see. Sold to John Colwell, Atlanta, Ia., r886, who sold one-half interest to M. H. P'orter, same placePedigree from Edna A. Hunt, Harlan, Ia.

Sire of 4 trotters $(2: 22)$; Durungo Prince, $2: 19^{3} / 4 ;$ I sire of I trotter; clam of I trotter.

DURFEE (I-64), bay ; foaled I 888 ; bred by W. H. Wilson, Cynthiana, Ky. ; got by Kaiser, son of George Wilkes: dam Julie, bay, bred by U. W: Kitson, St. Paul, Minn., got by Revenue, son of Smuggler; $2 \mathrm{~d}$ dam Juliet, bay, bred by Richard Richards, Racine Wis., got by Western Chief, son of Curtis' Hambletonian ; 3d dam Bay Fanny, dam of Alexander, $2: 283 / 4$, which see. Pedigree from catalogue of breeder.

sire of 3 pacers $\left(2: 12 \frac{1}{2}\right)$.

DURHAM IVILKES, said to be by Colonel Wilkes.

Sire of Wapella Wilkes, $2: 20$.

DUROC, chestnut, I $53 / 4$ hands; foaled June 4 , I 806 ; bred by Wade Mosby, Powhatan County, Va.; got by imported Diomed : dam Amanda, chestnut, foaled $\mathbf{r} 800$, bred by John Broaddus, Virginia, got by Gray Diomed, son of imported Medley (she was a fine appearing mare and a fast racer; sold to John Hoomes, I804; to Wade Mosby, same year); $2 \mathrm{~d}$ dam bay, by Bedford ; 3 d dam by old Cade ; $4^{\text {th }}$ dam by Col. Hickman's Independence, son of imported Fearnaught (Independence's dam was Dolly Fine, by imported Silver Eye); and $5^{\text {th }}$ dam by imported Badger. Above is as certified to by John Hoomes.-Skinner's American Turf Register, Vol. I., p. 59 .

The following extract from Col. Hoomes' stud book is given in Skinner's American Turf Register, Vol. I., p. 52 I :

"Bay mare purchased of J. Broaddus. She was got by Bedford, her dam by old Cade, grandam by Col. Hickman's Independence; Independence was by old Fearnaught, from Dolly Fine, Dolly Fine by old Silver Eye, great-grandam by the imported horse Badger.

"Wade Mosby's Mare Amanda, the dam of Duroc, was from the above mare ; Amanda was by Gray Diomed."

Sold at Washington, I8Io, to Bela Badger, Bristol, Penn., for \$2500, who sold him, I8I3, to Townsend Cock, Oyster Bay, L. I., where he was kept for many years, and was finally sold to Henry Kelsey, Hyde Park, L. I., in whose hands he died of a sudden illness, I 826.

Advertised at Townsend Cock's stable, I 8 I6. Advertised in Skinner's American Turf Register. Advertised $\mathbf{1} 825-6$ to be kept at Florida, N. Y., by H. Kelsey, who says: "He was sire of Blucher, Wellington, Marshall Duroc and all the best horses in the State." Advertised in Orange County Patriot at Washington, N. Y., I82I, by J. L. Fonda, at \$I 5 .

In fall of $\mathbf{1} 8$ I 4 , Duroc won the four-mile heat over the Fair View Course against Bond's famous Hampton, in 7 minutes 53 seconds said to be the 
fastest ever run in Pennsylvania up to that time. His record as a fast racer was cut short by his getting into the habit of bolting.

Mr. Townsend Cock's advertisement in 1816 is as follows :

"The elegant full-bred turf horse Duroc at Oyster Bay, Queen's County, at $\$ 12$ to $\$$ I 6 , strong, bony and fine action. Duroc has proved himself a sure foal-getter and his colts are allowed by good judges to be the first of any horse that ever coursed on Long Island. By imported horse old Diomed, from Amanda.

"I do hereby certify that Amanda, the dam of Duroc, was got by Gray Diomed; Gray Diomed by old Medley, her dam by old Cade ; grandam by Col. Hickman's Independence; Independence by old Fearnaught, from Dolly Fine; Dolly Fine, by old Silver Eye; great-grandam by the imported horse Badger. A copy from the breeder's certificate."

JoHN HOOMES

"Duroc was purchased of Mr. Wade Mosby at the city of Washington, in the year I 8 Io, then four years old, by Mr. Bela Badger of Philadelphia, for the sum of $\$ 2500$, and was trained to run the spring following and won a purse over Fair View Course, four-mile heats, beating Mr. Bond's celebrated horse Hampton. This was allowed to be the greatest race ever seen in the State of Pennsylvania, being run in 7 minutes 53 seconds. In the spring of $\mathrm{IS}_{3} 3$ he covered 50 mares and in the fall was trained and ran the four-mile heats over New Market course, beating Pegasus and Volunteer."

Towrsend Cock.

In an interesting article upon Duroc in his Nagazine, Mr. Wallace says :

"About this time, Mr. Cock owned quite a number of very fine stallions, perhaps as many as a dozen, and among them were sereral sons of Messenger, such as Plato, Hamiltonian, Hopper Boy, etc., but, from the superior excellence of Duroc in his high racing form and commanding style, he was the favorite of his owner for a number of seasons. These stallions were divided into squads of two or three, and scattered about in the river countries and in Jersey, in charge of different competent men. Duroc was kept at the head of the home squad and was in the personal charge of Mr. Daniel T. Cock, then quite a young man. In competition with this squad, the stallions of Tom Jackson -and George Tappan were special antagonists. At the head of their string they had the incomparable Engineer, and he was one of the finest horses that ever trod the earth. He was as white as chalk, over sixteen hands high, perfect in form and balance, and unequaled in style and elegance. This is substantially the description of Engineer as given to us by Mr. Daniel T. Cock himself; and to oppose so much excellence, Duroc was selected out of all the stable, and he did not suffer by comparison, except in size, and his well-tried racing powers and exploits made good that deficiency in the public estimation.

"IVe are not able to fix the year that Mr. Cock sold this horse, but think it was about $\mathrm{ISI}$. Mr. Henry Kelsey, who purchased him and kept him till he died, was a citizen of Poughkeepsie, and about 1830 removed to Schoharie County, taking Wellington with him. He kept a livery stable in Poughkeepsie, and had a farm about two miles out, where Duroc was kept during the winter. From I 8 I 3 to 18 I6, inclusive, he was on Long Island. in I 817 , he was at Fishkill; $182 \mathbf{I}$, at the town of 
Washington; I $\$_{22}$, twelve miles from Poughkeepsie; and I $\$_{25}-6$, he was at a place called Hyde Park, on Long Island, about eighteen miles from Fulton Ferry, where he died in the fall of 1826 . We have no knowledge of his whereabouts the year he is not located. but we think he was, at least one year, further up the river than Dutchess County, and probably male a season at Newburg, in Orange County.

"A number of his get were race horses and as a rule they were all good serviceable animals. We find his descendants very widely sprearl through the breeding counties of New York, as well as New Jersey and other States; and his sons, that were kept for stock purposes, were to be found everywhere. This general and wide dissemination of his blood is an incontrovertible proof of the high estimate in which it was held. Among his sons that were the most prominently connected with the trotting lines, may be enumerated Diomed, of Dutchess County, Post Boy, Shakespeare, Seagull, Wellington and Blucher."

DUROC (BOYCE'S); bred in New York; said to be by $\cdot$ Hambletonian. Sold to Tom Thompson, Ripley, O. Information from Dr. Vinsen, Catlettsburg, Ky., who writes: "I got the mother of Dorothy Brown, $2: 23 \frac{1}{4}$, from a Dutchman in Riplev, O. She was said to be by Pacing Abdallah, and Dorothy was by Boyce's Duroc."

Sire of 2 trotters $\left(2: 10^{3 / 4}\right)$.

DUROC (BROIVN'S), chestnut, 15 I 2 hands, I050 pounds; bred on Long Island, said to be by Duroc son of imported Diomed. He ran on Long Island when three years old, then broke down, and was bought by Jack Hills of Claremont, N. H., who sold him to Jonathan Hall of Plymouth, Vt. ; and he to John P. Brown of Ludlow, Vt. Mr. Brown writes: "He was a very intelligent horse with beautiful head, eye and ear and left some good stock."

DUROC (CASE'S), bay; foaled I 835 ; bred by Isaac Masser, Saegerstown, Crawford County, Penn.; got by Steele's Eclipse, son of American Eclipse : dam said to be by Fox (Perkin's Horse), son of Grand Signeur, by imported Grand Signeur; and $\mathbf{2 d}$ dam by American Eclipse. Owned by Joseph Case, Coons Corners, Crawford County, Penn., who sold to Hannah Bros., Meadville, Penn. Information from Powell Bros., Shadeland, Penn.

DUROC (CHICKESTER'S), bred by Nathaniel Chickester near Jericho, L. I. ; got by Duroc, son of imported Diomed : dam said to be by a horse called Volunteer; and $2 \mathrm{~d}$ dam by Merry Momus.

DURÓC (CLEVELAND'S), chestnut, I5 I/4 hands, Iooo pounds; foaled I 25 ; bred by Stephen Cleveland, Poughkeepsie, N. Y.; got by Duroc, son of imported Diomed: dam said to be by imported Messenger. Taken with the dam to Bethel, Vt., by Mrr. Cleveland, Jr., of Bethel, Vt., who sold him when four years old to Capt. Austin of same place. In I 835 he was sold and went to Salem, Mass. 
H. B. Hatch, Bethel, Vt., writes: "I think Mr. Packard of Stony Brook, Stockbridge, would know what became of the Wolcott Morgan. Epaphro Seymour of Brattleboro, Vt., bought a chestnut stallion that Ben Abbott of Stockbridge bred, got by old Gifford, a splendid horse. Dan Cushing handled Green Mountain Morgan for Mr. Woodbury. Never owned him. Capt. Austin of Bethel owned many years ago, a thoroughbred stallion, $15 \frac{1}{2}$ hands, 1000 pounds, that came from Long Island; was said to be by Duroc. Old Deacon Cleveland traded for the mare and colt in New York. Freeman T. Mathews of Pittsfield, a merchant, brought Duroc from Long Island; he was a race horse, chestnut, $15 \frac{1}{4}$ hands, rooo pounds. Lady Sutton trotted twenty miles in an hour and was the second horse to do this. The Dana horse of Woodstock was brown, I5 hands, Iooo pounds."

We have also received the following letter:

"The Capt. Austin, owner of Duroc, was my wife's father. The horse was got by Duroc, foaled the summer of 1825 , the property of Stephen Cleveland of Poughkeepsie, N. Y., dam by imported Messenger. I have always thought that pedigree correct, knowing the circumstances about the horse as I did.

"Stephen Cleveland, Sr., or as he was called by his neighbors, the old "Esquire" not "Deacon" as friend Hatch has it, brought the old mare and colt home to Bethel, when the colt was about two months old, I5o miles behind a chaise. The Cleveland farm joined my father's. When the colt was raised I was about 12 years old. Stephen Jr., said the colt was bred the same as Eclipse.

"Father Austin bought the horse at four years old and kept him for stock until February, 1835 , when his son, Charles, sold him in Salem, Mass. He was a horse of great endurance and a free driver and his stock were good."

DUROC (DOMINICK'S), dapple bay; foaled I825; said to be by Sir Benjamin Duroc. Advertised for sale, 1829 , by George Dominick in The People's Friend and Gazette, Little Falls, Herkimer County, N. Y.

DUROC (DUBOIS'), chestnut; bred by Cornelius Dubois; got by Bay Duroc, owned by Joseph Wood of Newburgh, N. Y., son of Duroc: dam black, bought of Michael Wygout, Marlboro, N. Y., said to be by old King William, a blind horse owned by William Acker. Owned by breeder twenty-six years. Both the horse and his sire were very ugly.

DUROC (HILL'S) ( I-64), $2: 261 / 4$, brown, I6 I/4 hands, I 250 pounds ; foaled I 869 ; bred by Whiteside Hill, Greenwich, N.Y.; got by Banker's Messenger, son of Hambletonian: dam Lady Parker, said to be by American Citizen, son of Adam's American, by Whitehall; and $2 \mathrm{~d}$ dam by Milliman's Bellfounder, son of Bellfounder, by Morse Horse. Information from advertisement. Went to Indiana.

Sire of 7 trotters $\left(2: I 7 \frac{1}{2}\right) \quad 2$ dams of 2 trotters. 
DUROC (HALL'S), bay, I6 hands, I roo pounds, owned by Jonathan Hall. Mr. Bates of Sherburne, Vt., says in interview I 888: "Mr. Hall of Plymouth, Vt., had a good sized horse called 'Duroc' that came from New Hampshire, 50 years ago, Isaiah Wheeler of Sherburne, now alive, tended him."

Mr. Dicks of Plymouth, Vt., I 888 , says: "Johnathan Hall owned old Duroc-a large bay horse, 16 hands, 11 oo pounds, 45 years or more ago. He was a powerful horse and called a good one. Mr. Green of Highlock Hills, owned Duroc; he boarded with Hall. Duroc was here a number of years."

DUROC (LATOURETTE'S, DUROC OF RICHMOND), dapple gray, I6 hands; foaled I 822 ; said to be by Duroc owned by Gen. Coles, L. I. : and dam of well known Messenger stock. Advertised in $\mathrm{I}_{2} 8$ as fullblooded and a race horse at Hampton, Manchester and Clinton. Advertised 1830 near Herkimer Village on canal road to Utica by Stephen Latourette, owner, Staten Island, Richmond County, N. Y., in People's Friend and Gazette. Advertised at Utica and Manchester by T. B. Hoyton, J. McElnance, and A. Country.

DUROC (ONDERDONK'S), bright bay, with white on front feet, about $\mathrm{I} 5 \mathrm{I} / 2$ hands; bought when four years old at St. Johns, P. Q., by Jacob Onderdonk, Monsey, Rockland County, N. Y., where he kept the horse a number of years and sold him about 1859 .

Mr. Onderdonk states that he bought him the last year that the cholera prevailed near New York, and that he was assured that he was a genuine Morgan horse.

DUROC (RHEA'S), said to be by Duroc, son of imported Diomed: dam Pheasant. Advertised $\mathrm{I} 824$ by G. Rhea at Hunterton, N. J.

DUROC (ROBINSON'S,) chestnut, I $7 \frac{1}{2}$ hands; foaled 1823 ; bred on Long Island; said to be a descendant of Duroc, son of imported Diomed. Advertised at Salem, N. Y., I832, and called a fast trotter.

Advertised with pedigree as above by $\mathrm{S}$. Robinson to be kept at Hebron, N. Y., at $\$ 3$ to $\$ 6$.

DUROC (SHERMAN'S), bright bay, I 7 hands; foaled I808. Advertised in the Rutland Herald, I8I 7, at West Rutland, Vt., by Nathan C. Sherman. Terms, \$8. Mr. Judivine of Hardwick, Vt., says: "About I8zo, there was a large, powerful horse they called Duroc in this locality."

DUROC BOY, bay; foaled I882; bred by C. M. Munroe, Canton, O.; got by Duroc, son of Volunteer : dam Daughter, said to be by Hanley's Hiatoga, son of Rice's Hiatoga.

Sire of Lottie S., $2: 25$. 
DUROC L. R. (FALCONER'S), chestnut; foaled I 824 ; bred by George M. Lloyd, Lloyd's Neck, N. Y.; got by Duroc, son of imported Diomed : dam Queen Mab (dam of Long's Eclipse), bred by John Lefferts, Flatbush, L. I., got by Bajazet, son of imported Tanner; $2 \mathrm{~d}$ dam said to be by Mercury, son of imported Janus ; $3 \mathrm{~d}$ dam by imported Messenger ; and $4^{\text {th }}$ dam, by Badger son of imported Badger. Owned successively by John Bedell, and Robert Falconє), Sugar Grove, Warren County, Penn. Died at Kalamazoo, Mich, about I 844 .

DUROC MESSENGER (BLIND DUROC, MESSENGER DUROC), dark chestnut; foaled I8r8; bred by Reuben Vincent, Freedom, Dutchess County, N. Y.; got by Duroc, son of imported Diomed : dam Vincenta, brown, I $5 \frac{1}{2}$ hands, untraced. The pedigree hitherto given to this mare (see I. A. S. B., p. 388), is said to be fraudulent, though we do not know upon what grounds. Sold $\mathrm{r}_{2 \mathbf{2}} \mathrm{I}$ to Samuel Haight, who sold $\mathbf{r} 8 \mathbf{2} 8$, to Ulysses Sage, Stafford, Genesee County, N. Y. In I 830 he was purchased by Ambrose Stevens and brother of Batavia, N. Y. He was kept 1823 to $I_{2} 8$ in Seneca and Tompkins Counties, N. Y., in I $_{3} I_{1}$ at Batavia, I $8_{32}$ Niagara, Can., I $\delta_{33-4-5}$ at East Hamburg, Erie County, N. Y., and was sold July $\mathrm{I} 835$ to James Shy who it is said, took him to Kentucky. Advertised in American Turf Register, I831, at Batavia, N. Y., by E. Stevens, at \$1 5 ; \$25 to insure.

The following letter referring to this horse and giving other valuable information has been forwarded us by Mr. J. C Beecher of Buffalo, N. Y.

Jas. C. Beecher, Esq.,

$$
\text { VikgiL, Ont., March 24, I } 886 .
$$

Dear Sir:-in reply to your letter I may simply state-The mother of Niagara Champion was a pure-blooded English mare brought to this country by Capt. Armstrong of the British army in $18+2$. The father of Niagara Champion, was Sir Laten Sax, brought to this country by John Powel, now living at Lewiston, on American side. He brought him from England with a pure pedigree. The mother of the Fred Pratt mare was a Black Warrior mare, from a Duroc Messenger mare. The Black Warrior was a very speedy horse. Bill Secord owned this Black Warrior mare, he went from here to East Saginaw where he died. $\mathrm{He}$ traded her to Mrs. West and she bred these two Niagara Champion mares and I bought them from her. I afterwards sold them to Fred Pratt.

If you desire any information regarding the Sir Laten Sax Horse, by writing to John Powel at Lewiston you will receive it.

J. C. Beecher of Buffalo, N. Y., writes, Feb. 22, i 888 .

"Old Messenger Duroc was kept in Batavia, and over in Niagara County at Lewiston and elsewhere prior to I 835 . He stood in Niagara, Can., which is close by Virgil, in $\mathbf{1} 832$. He was known as Duroc Messenger and by other names."

In another letter dated March I2, I904, Mr. Beecher writes: "This horse Duroc Messenger, or Messenger Duroc is undoubtedly the old blind Messenger Duroc in the pedigree of C. J. Wells, as he stood in Batavia and doubtless traveled North to I.ewiston and the surrounding 
country after the fashion of those early times and new communities. It is only a short distance from Batavia to Lewiston and Niagara and the Canadian Peninsular, and he or his colts could easily get over there for breeding purposes."

DUROC MESSENGER, dark chestnut interspersed with gray hairs, 16 hands, I I 50 pounds, said to be by Duroc son of importerl I lomed: and dam by a descendant of imported Messenger. Brought when nine to twelve years old, perhaps more, from Dutchess County, N. Y., where he is supposed to have been bought of a Mr. Hazzard, by E. R Pratt of Cornwall, V't., who kept him several years, when he was sold and went to Boston. Advertised 1834 , by E. R. Pratt, and A. W. Dana, in Cornwall, Vt., at $\$ 3$ to $\$ 5$, in which advertisement pedigree is given as above. A horse called Duroc Messenger, foaled $\mathbf{I} \$_{2} \mathbf{I}$, and said to be by Duroc, son of Diomed : dam by a son of Messenger; was advertised near Poughkeepsie, I 825 , by Gabriel Bishop and is probably the same horse as above.

The advertisement of 1834 reads :

"Duroc Messenger is from the best stock in America. He was by the old Virginia Duroc; his dam is a descendant of old Messenger, one of the best horses ever imported. He is half brother to the celebrated American Eclipse. Duroc Messenger is I 6 hands, admirably proportioned, spirited and graceful. He is thick and strong built, dark chestnut interspersed with gray hairs, and he is the fastest trotter and walker in Vermont."

$$
\text { Signed by Elisha R. Pratt and Amon W. Dana. }
$$

DUROC MESSENGER (CANADA ECLIPSE) ; Said to have been foaled in 1837 ; and got by the Howland Horse. Owned and kept at Port Huron, Mich., I $\$_{5} 6$, where he was brought from Canada. Information from H. B. Groff, Grand Island, Mich., who writes:

Dear Sir:-Yours received today. I do not remember the colt but I have heard them talk of him. Garibaldi was got by a running horse from Canada by the name of Eclipse, that stood at Port Huron one season and then returned to Canada. The dam had some excellent blood, of what kind I know not but was a fine animal, owned by whom I know not. If you will write to George B. Wright, Utica, Mich., mentioning that it is a horse that J. H. Groff and Jim St. John (old Jim) bought up on the plains about 30 miles from Utica in 1859 , he may be able to trace the matter for you. Let me hear from you when traced.

Sire of Garibaldi (Stevens'), which see.

DUROC PRINCE, $2: 45 \%$, black, I6 hands, IIOo pounds; foaled 1877 ; bred by Charles Backman, Stony Ford, N. Y. ; got by Messenger Duroc, son of Hambletonian : dam Levinia, brown, bred by William B. Babbitt, Newton, N. J., got by Truesdell's Hambletonian, son of Hambletonian; 2 d dam Babbitt Abdallah, bay, said to be by Abdallah; and 3 d dam by 
Phillips, son of Cole's Messenger. Sold to John Redmond, McMinnville, Ore. ; to George V. James, Hillsborough, Ore. ; to George Owens, McMinnville, Ore. Pedigree from C. W. Redmond, Hillsborough, Ore.

Sire of 2 pacers $(2: I 6) ; 4$ dams of I trotter, 3 pacers.

DUROC VOLUNTEER, bay, foaled $18_{7-}$; bred by Nathaniel Higgins, White Plains, N. Y.; got by Messenger Duroc, son of Hambletonian : dam Juno, said to be by Volunteer, son of Hambletonian ; $2 \mathrm{~d}$ dam Dolly, by Belbrino; and $3 \mathrm{~d}$ dam by Young Mambrino. Sold to Jules Reynolds, White Plains, N. Y.

Sire of 2 trotters, $(2: 181 / 2)$, I dam of I trotter.

DUSTER DENMARK ( $\mathrm{I}-32)$, bay with black points, I51/2 hands; foaled I 885 ; bred by J. E. Woolford, Woodford County, Ky. ; got by Duster, son of Granger: dam said to be by Conscript; 2 d dam by Cockspur; $3^{\text {d }}$ dam by Copperbottom; $4^{\text {th }}$ dam by Whalebone. Pedigree from Harry Moody, Eminence, Ky. Sold to Williams \& Hopkins, Eminence, Ky.

DUSTER GOLDDUST (3-64), chestnut with star, and left hind ankle white, I51/2 hands, I roo pounds; foaled May I 9, I 865 : bred by L. L. Dorsey, Louisville, Ky.; got by Golddust: dam bred by L. L. Dorsey, got by Golddust; 2 d dam said to be by imported Glencoe. Sold about i 868 to Albert Irwin, Morristown, Tenn. Quite fast.

A correspondent of the Spirit of the Times writes from Meadville, Penn., June 9, I877:

DEAR SPIRIT :- In a previous letter I failed to mention some of our prominent breeders of this section, among whom we find Mr. Albert Erwin, Mr. John Weller, The Messrs. Powell Bros., and others. Mr. Erwin has always had a penchant for Golddust stock, and as early as 1867 , he made a trip to the Blue Grass region of Kentucky, the result of which was the purchase of Duster Golddust then two years old, from Mr. L. L. Dorsey. His predictions regarding the stock have been verified as among the get of Duster Golddust we find such good ones as Lady Dahlman, Orlando, Annie Golddust, and others.

Sire of Imogene, $2: 30$.

DUSTY MILLER (GRAY EAGLE), $2: 36$, gray, dark spot on shoulder, I 6 hands; foaled I 854 ; bred by James Roddy, Ferrins Point, Ontario, Can.; got by Canada Gray Eagle, brought from near Montreal, which see: dam (dam of Fenian Chief) chestnut, medium size, said to be by Sir Walter. Purchased about I 866 , for $\$ 800$, at St. Catherines, Can., by John Goodyear, for Joseph Caravan, Philadelphia.

Sire of 2 trotters $\left(2: 20 \frac{1}{2}\right) ; 4$ dams of 4 trotters.

DUTCHMAN, $2: 32$, bay; foaled I 828 ; bred by David Denny, near Salem, N. J.; got by Capt. Tufts' Tippoo Saib Jr., said to be by Tippoo Saib 
son of Messenger: dam said to be by Mambrino, alias Foxhunter, and also said to be by a horse called Black Messenger; and $2 \mathrm{~d}$ dam by Swallow a fast natural pacer. Gelded young. Wallace says :

"He was well-known in Salem County for his splendid natural trotting action. Denny called him Tippoo, but he was generally known as the Denny colt. About $1833^{-4}$, he was sold for $\$ \$_{120}$, to some parties in Philadelphia, one of whom, B. Tindall, was formerly a citizen of Salem; and he was named Dutchman, under which cognomen he became very famous on the trotting turf."

As above pedigree is fairly well sustained by independent researches of Cyrus Lukens of Philadelphia, an especially intelligent and reliable turf writer, we presume it to be mainly correct

The following is from Vol. IX., I 837 of the American Turf Register:

"Extraordinary trotting match between Dutchman and Rattler. The first is a handsome bay gelding of great size and substance, about I 6 hands high; he is what is termed a meaty horse and looks when in fine condition like an ordinary roadster in good order. Rattler is a brown gelding of about $15^{1 / 2}$ hands, and a fine one to look at. His style of going is superior to Dutchman's; he spreads himself well and strides out clear and even. Dutchman does not appear to have perfect command of his hind legs; instead of throwing them forward he raises them so high as to throw up his rump, and consequently falls short in his stride. The main dependence of his backers was placed upon his game. Rattler won the first heat, three miles, in $7: 54 \frac{1}{2}$, Dutchman won second heat in $7: 50$; third heat dead. Dutchman won the last and the race. It was the fastest three miles to date."

A correspondent of Wilkes Spirit of the Times, Sept. 6, 1862, writes:

"When I first knew the celebrated horse Dutchman he belonged to Dan Jeffries of Philadelphia, and worked in the lead in a team which carted brick in a brick yard, and did other kinds of work.

"In 1834 he was sold to Peter Barker, and in the fall Mr. Barker trotted him to saddle on the old Harlem Park Course beating George Woodruff's horse Locomotive in 2 minutes, 39 seconds. In 1835 , he trotted a wagon race the length of the road $3 \mathrm{~d}$ Avenue, and beat the then celebrated horse Yankee Doodle. The horse was then sold to Henry Jones who named him Tom Cooper and took him to Philadelphia. He trotted a race there against Gray Rollo, and I think, beat him. But, the race ended in a wrangle and unsatisfactorily. I go now to Spring of I836, when he was put under the management of John Conklin, who had Wm. Wheelan attending to him. His first race was a "big thing." We had not got to such speed then as now, but three whose names will live in annals of the old lovers of good horses, met that day. It was two miles and repeat, in harness. There was Dutchman driven by Joel Conklin, Fanny Pullen by Harry Jones, and Confidence, who was afterwards taken to England, by James Hamill of Philadelphia. It was won by Dutchman. His next performance was the day of the famous race over Union Course in which the North ran a horse against the South, It was for $\$ 5$, ooo a side to name at the post. The North ran Post Boy, and the South John Bascomb, who won. That same day, Dutchman trotted a race, four miles to saddle, on Centreville Course against the 
gray mare Lady Slipper for $\$ 2,000$ a side, and won. The balance of his performances may be found in the Turf Register. Where or how he was bred I am unable to say."

Cyrus Lukens, writes:

DUTCHMAN, THE TROTTING HORSE.

Editor American Horse Breeder:- "Dutchman was bred by David Denny, a ship carpenter, living on 'Brickhouse Farm,' two miles from Salem, N. J. He was a poor man with only one brood mare, which he called old Mambrino. He represented her to have been by Gray Mambrino. From I 809 to about I \& I5, there was a son of Messenger called Mambrino that was owned and kept in or near Salem, N. J. This horse was advertised for service at Flemington, N. J., in I807. $\mathrm{He}$ was sometimes called Foxhunter and sometimes Mambrino. His dam was by Pulaski, thoroughbred son of Gov. Edison's Why Not. This Mambrino was probably got by Messenger, when he stood at Cooper's Point, N. J., in I $\mathbf{8} 02$. Captain Tuft of Salem, N. J., owned Tippoo Saib Jr., son of thoroughbred Tippoo Saib, by Messenger. He was a large, plain, dark bay or brown stallion, and stood at the low price of $\$ 5$. This was the sire of the trotting horse Dutchman, whose three miles in $7: 32 \frac{1}{2}$, always aroused Hiram Woodruff's admiration, and which remained unbeaten for so many years.

Denny called the colt Tippoo. In I 834 , he sold the colt to Ben Tindall of Philadelphia, Penn., who brought him up to this city and took him to John Bosler's livery stable, northeast corner of Sixth and Brown streets. In this identical old frame building, William D. Rogers (deceased) established his reputation as a light and family carriage builder. The writer remembers the old building very well. The brickmakers and contractors were prominent as the local horsemen of those days. They met frequently day and evening at John Bosler's liverystable, and among their number Ben Tindall, Thomas H. Irvin, Daniel Jeffries and others. Tindall kept Dutchman at this stable.

"One afternoon Benjamin Crossin and George Gorgas went out for a ride in saddles, the former on Dutchman, the latter on his own mare, that was known to be able to beat three minutes. Upon their return Crossin assured everyone that he had beaten Gorgas' mare. This came to the ears of Daniel Jeffries, who was a brickmaker and quite a horseman. After driving Dutchman a few times, he bought him from Tindall for about $\$ 225$. The horse had a sympathetic ailment of the eyes resulting from the dental period, just as many another young horse has had, and Jeffries turned him out to pasture in a lot he kept for the purpose, as he was a great horse fancier. Hence to the brick-cart and brick-yard story, all of which originated in the fertile imagination of the brain of an old writer for sensational purposes. Neither Dutchman nor the dam of Andrew Jackson, that had been owned by Jeffries eight or ten years prior to his owning Dutchman, were ever worked to a brick-cart.

The majority of these facts I had from Thomas H. Irwin, himself a brick-maker, in $1867-8-9$, while he was living in a brick house, one of a row built on the grounds of the old Haymarket lot at Fifth and Green streets, within a few squares of where all of these interesting circumstances happened in his younger days. The pasture lot into which Dutchman was turned for grass and liberty was the spot where Hiram Woodruff first saw the horse."

April, I903.

Crrus Lukens. 
DUTCHMAN, black, said to be by Ablallah son of Mambrino. Owned at Freehold, N. J. Information from Nelson L. Smock, Jamesburg, N. J., I $8 S 6$.

DUTCH MORGAN TROTTER ( $\mathrm{I}-4)$. Advertised in New Hampshire Patriot at Concord, $\mathbf{I} 829$, as follows :

"A grandson of the old Dutch Morgan horse and a fair sample of his grandsire. His size is 15 hands and well proportioned; as it respects bone, muscle and speed he has no rival in this section of country. To stand at J. Bean's, Holderness; Sam M. Sentor's, Center Harbor ; Josiah Fiske's, Moultonborough; N. Vinton's, Sandwich; J. Wiggins' Somerworth; E. Renwick's, Tamworth, etc. W. B. Chapin, Moultonborough, I 830 . Terms $\$ 3.50$ to $\$ 5$." See The Morgan Horse and Register, Vol. I., page 757 .

DUTCH PRINCE (I-4), dark chestnut, said to be by Sherman Morgan. Advertised in the Danville (Vt.) "North Star" of April I 9 th, I 814 , by W. W. Carpenter, to be kept at Lyndon Centre, Kirby and Waterford at $\$ 2$ to $\$ 4$. The advertisement says: "Said horse is of as good blood and pedigree as any in the country, of good size, well built, and is a dark chestnut color."

He is advertised again in the "North Star" of May, I 827 , by Joseph Pope, at Wheelock, Danville and Peacham, Vt. This advertisement says: "Dutch Prince was by the noted Sherman Horse, and for size, elegance of proportion and goodness of stock, is exceeded by none in this vicinity." See The Morgan Horse and Register, Vol. I., p. 302.

DUTCH WEASEL ( $\mathrm{I}-4)$. Advertised in Danville North Star as follows:

"Dutch Weasel a horse four years old will stand at stable of subscriber one mile north of St. Johnsbury Plain, terms $\$_{1}$ to $\$_{3}$. Said horse is I 5 hands high, stout built, and was got by celebrated full-blooded Dutch horse kept at St. Johnsbury last season.

St. Johnsbury, Vt., i 8 ro."

Richard IV. FENTON.

See The Morgan Horse and Register, Vol. I., p. I 26.

DYNAMICS ( I-I6), bay; foaled I 887 ; bred by Walter Clark, Battle Creek, Mich.; got by Pilot Medium, son of Happy Medium : dam Silky Lambert, chestnut, bred by A. Orcutt, Cummington, Mass., got by Daniel Lambert, son of Ethan Allen; 2d dam said to be by a son of Black Hawk. Sold to L. F. Kline, Berlin Centre, O.; to Emery Miller, Alliance, O.; to John C. Welty, Canton, O.; to E. A. Riley, Hinckley, O. Pedigree from L. F. Kline.

Sire of Nancy Medium, $2: 22 \frac{1}{1}$.

DYNAMITE (I-64), bay, I6 hands, I Ioo pounds; foaled May I9, I882; bred by J. B. Curtis and Sons, Oak Grove Stock Farm, North Ternon, Ind. ; got by Hambletonian (Downing's), son of Miller's Hambletonian, 
own brother to Jim Monroe : dam Maud, chestnut, bred by J. B. Curtis \& Sons, got by Mambrino Patchen Jr., son of Mambrino Patchen (Herr's) ; 2d dam Carrie W., chestnut, bred by J. B. Curtis \& Sons, got by Morgan Messenger, son of Fulton, by Black Hawk ; 3d dam Puss, black, bred by John Ulery, Vernon Ind., got by Mohawk (Leed's), son of Canadian pacer; 4th dam Belle, bay, bred by John Ulery, got by Henry's Rainbow, son of Stucker's Rainbow. Sold to Judge Wm. D. Williams, Marquette, Mích. Pedigree from breeders.

$\mathrm{E}$ AGLE, bay, I6 hands; foaled I 796; bred by Sir Francis Standish; got by Volunteer: dam by Highflier-Engineer-Cade-Lass-of-the-Mill, by Traveler-Miss Makeless, by Young •Grayhound-Croft's PartnerWoodcock-Croft's Bay Barb-Makeless-Brimmer-Dickey Pearson (son of Dodsworth) - Burton Barb Mare. Generally got bad racing stock in America. Imported in the fall of $181 \mathrm{I}$, by Mr. Bell, into Virginia.

EAGLE, white, about rooo pounds, a very good looking horse, handsomer than Shark. Owned by Mr. Williams of Barnston, P. Q. Information from Gardner Morse, Hatley, P. Q.

EAGLE BIRD (3-64), $2: 21$, roan, 15 hands; foaled 1882 ; bred by L. E. Simmons, Lexington, Ky.; got by Jay Bird, son of George Wilkes : dam Tansey (dam of Butterfly, $2: 193 / 4$ ), brown, bred by W. L. Simmons, got by George Wilkes; 2 d dam Dame Tansey (dam of Busbey, $2: 291 / 4$ ), chestnut, bred by Dan Mace, New York City, got by Daniel Lambert; 3 d dam Quarter Mare, said to be thorough-bred.

Sire of 32 trotters $\left(2: 09 \frac{1}{2}\right)$, Io pacers $\left(2: 15 \frac{1}{2}\right) ; 4$ sires of 9 trotters, 4 pacers $; 4$ dams of 2 trotters, 2 pacers.

EAGLE HURST (5-I28); bred by Mrs. C. J. Hurst, Lexington, Ky. ; got by Eagle Bird, son of Jay Bird: dam Georgie S. (dam of Timorah, $\left.2: 12 \frac{1}{4}\right)$, brown, bred by Bryan Hurst, Lexington, Ky., got by Nutwood, son of Belmont; 2d dam Lotta Prall, bay, bred by John Stout, Midway, Ky., got by Mambrino Patchen ; 3d dam Puss Prall, bay, bred by Col. J. A. Prall, Midway, Ky., got by Mark Time, son of Berthune; 4th dam said to be by Daniel Webster, son of Lance.

Sire of Rossie Higgins, 2:181/2; King Fisher, 2:171/2.

EAGLE TIME (1-32), roan, I53/4 hands; foaled I 888 ; bred by Mrs. S. L. Stout, Faywood, Ky.; got by Eagle Bird, son of Jay Bird: dam Kate Time, bay, bred by Mrs. Nannie Craig, Georgetown, Ky., got by Mambrino Time, son of Mambrino Patchen; 2d dam Nannie Craig, said to be by Joe Downing, son of Edwin Forrest; and 3 d dam Nannie, by 


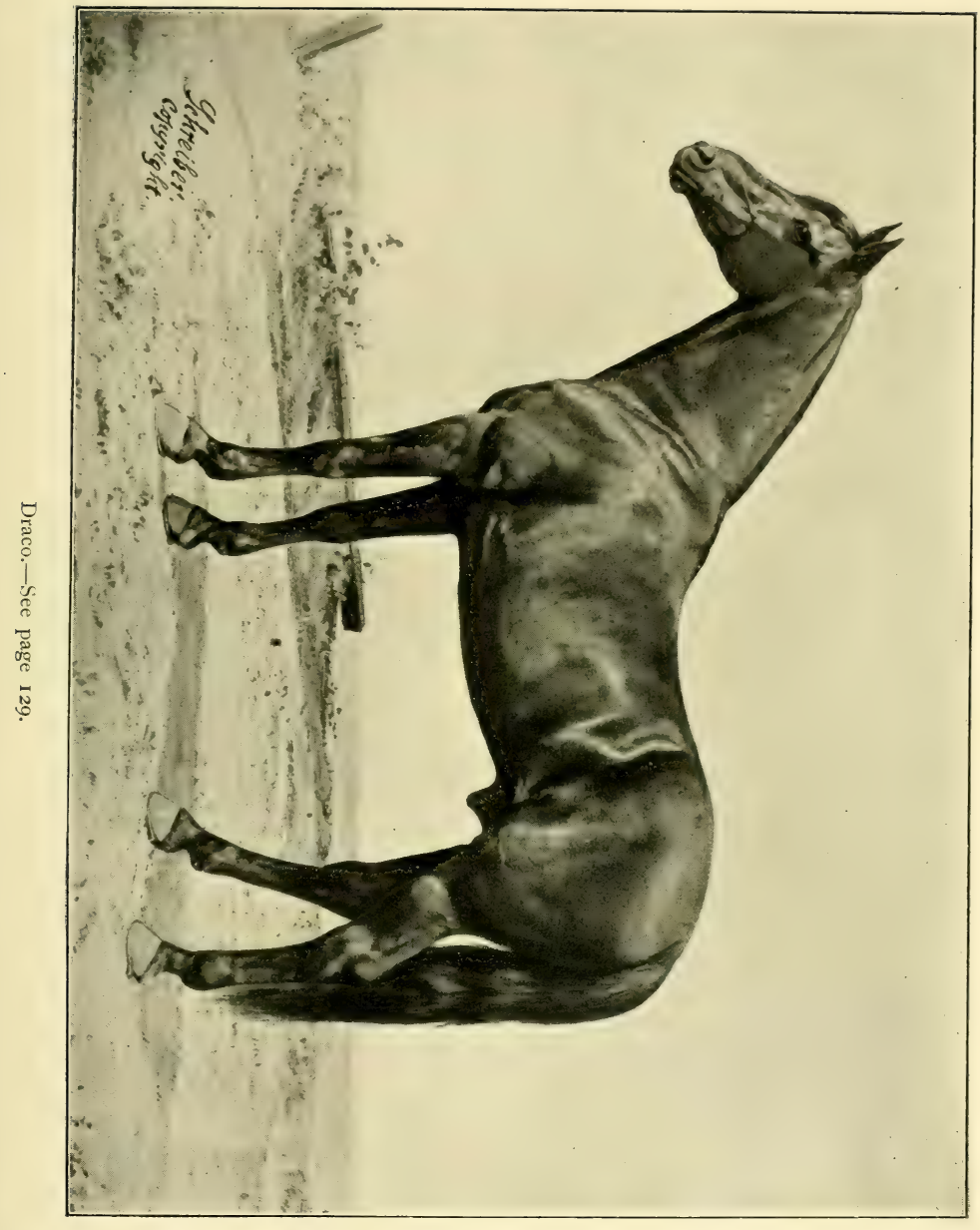




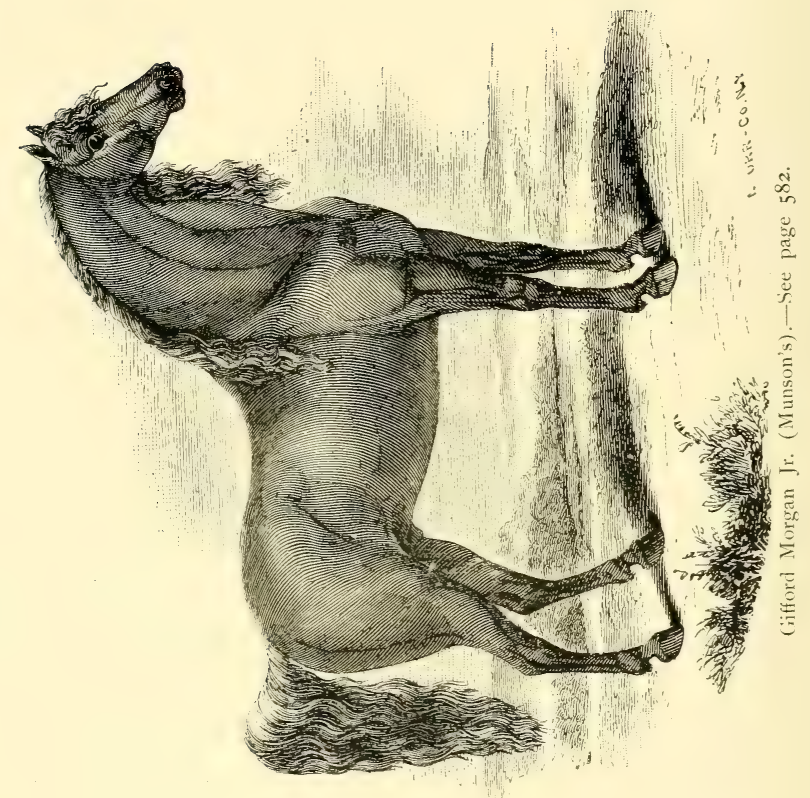


Mokhladi (Arabian). Sold to J. K. Borders, Choccolocco, Ala., who sends pedigree.

Sire of Eagle Boy, 2:30.

EARL ( $1-32), 2: 20 \mathrm{~T} / 4$, chestnut, white hind legs, white stripe in face, $153 / 4$ hands, 970 pounds; foaled 1876 ; bred by J. O. Bickerstaff, Edina, Mo.; got by Young Revenue, son of Revenue, by Medoc son of American Eclipse : dam a Copperbottom mare. sold to Jno. Prior, Providence, R. I. Pedigree from W. T. Esterbrook, Great Bend, Penn.

EARL, $2: 233 / 4$, bay, stripe in face, four white feet, $153 / 4$ hands; foaled 1880 ; bred by R. S. Veech, St. Mathews, Ky. ; got by Princeps, son of Woodford Mambrino: dam Juno, bay, bred by John Stewart, Boston, Mass., got by Hambletonian, son of Abdallah; 2 d dam Lady Morrison, chestnut ( 2 mile record, 5 :I4). Sold to Augustus Sharpe, Louisville, Ky.; to Ben Johnson, Bardstown, Ky.; to L. L. Dorsey, Middletown, Ky. ; to G. D. Nock, Louisville, Ky. Pedigree from catalogue of Augustus Sharpe.

Sire of 27 trotters $(2: I 61 / 2) ; 2$ sires of 2 trotters; 4 dams of 4 trotters.

EARL BALTIC (3-256), $2: 17$, bay; foaled I 887 ; bred by R. G. Stoner, Paris, Ky; got by Baron Wilkes, son of George Wilkes: dam Alpha Russell (dam of Baron Russell, $2: 24 \frac{\mathrm{T}}{4}$, which see). Sold to R. S. Veech, St. Mathews, Ky. Pedigree from catalogue of R. S. Veech.

Sire of 3 trotters $\left(2: 1_{3} 1 / 4\right) ;$ Bethel $2: 18 \frac{1}{4} ;$ I dam of I trotter.

EARL BELMONT ( $\mathrm{I}-64$ ), $2: 26 \mathrm{I} / 2$, bay, I 5 hands, Iooo pounds; foaled I 888 ; bred by Lester Witherspoon, Versaills, Ky. ; got by Belmont, son of Alexander's Abdallah: dam Betsey Baker, $2: 30$, bay, bred by Lester Witherspoon, got by Dictator; 2 d dam Mother Hubbard (dam of Aldine, $2 \cdot 19 \mathrm{I} / 4$ ), bred by Richard Johnson, Scott County, Ky., got by Johnson's Toronto Chief, son of St. Lawrence. Killed by lightning, I 895 . Pedigree from breeder.

Sire of 2 trotters $(2: 263 / 4)$; Christine B., $2: 131 / 4$.

EARL McGREGOR (I-8), $2: 2 \mathrm{I} I / 2$, chestnut, white stripe in face, $\mathrm{I}_{5} \mathrm{I} / 2$ hands, I050 pounds; foaled I 879 ; bred by L. C. Lloyd, Denver, Col. ; got by Robert McGregor, son of Major Edsall: dam Leona, chestnut, bred by William Robinson, Plattsville, Ill., got by Bay Billy, son of Ira Allen; 2 d dam Star, bred by W. Wrenn, Washington, Ill., got by Little Cassius, son of Cassius M. Clay; 3 d dam said to be by Post Boy. Sold to L. C. Lloyd, Denver, Col. ; to Peter Bear, Petersville, Ill.; to James A. Graham, Briggsville, Ill., who sends pedigree.

Sire of 3 trotters $\left(2: I_{4} \frac{1}{2}\right)$.

EARL MEDIUM (3-64), bay, hind feet white, I $53 / 4$ hands; foaled I 888 ; bred by William T. Withers, Lexington, Ky.; got by Happy Medium, 
son of Hambletonian : dam Francisca, bay, bred by W. T. Withers, got by Almont; 2 d dam Frances Breckenridge, bay, bred by John C. Breckenridge of Kentucky, got by Sentinel, son of Hambletonian ; $3 \mathrm{~d}$ dam said to be by Bavard, son of Pilot Jr.; $4^{\text {th }}$ dam Luna, by Swigert's Lexington; and $5^{\text {th }}$ dam Eagless, by imported Glencoe. Sold to E. M. Norwood, Lexington, Ky., who sends pedigree. Died I904.

Sire of 2 trotters $\left(2: 24^{1 / 4}\right) ; 4$ pacers $\left(2: 1_{3} \frac{1}{4}\right)$.

EARLMONT (3-64), $2: 25$, bay, I6 hands, I 200 pounds; foaled I 885 ; bred by J. W. Farley, Edison, O.; foaled the property of Ulysses Schanck, Pulaskiville, O.; got by Almont Gift, son of Almont Chief : dam Ally S., bay, bred by D. C. Mogier, Edison, O., got by Ethan Allen Jr., son of Bacon's Ethan Allen ; 2 d dam Lizzie Jones, chestnut, said to be by Paul Jones. Sold to Lauer \& Madean, Monroe, Mich. ; to E. G. J. Lauer, Monroe, Mich. Pedigree from breeder.

Sire of 2 trotters $\left(2: 12 \frac{1}{4}\right)$.

EARLMONT (3-128), $2: 25$, bay, one hind ankle white, т 6 hands; foaled I889; bred by John A. Lyle, Paris, Ky. ; got by Belmont, son of Alexander's Abdallah: dam Lady Lyle, bay, bred by John A. Lyle, got by George Wilkes, son of Hambletonian : 2d dam Maggie R., black, bred by Robert Taylor, Winchester, Ky., got by Justin Morgan, son of Lowe's Comet Morgan; 3d dam said to be by Blood's Black Hawk. Pedigree from breeder.

Sire of Miss Healey, $2: 241 / 4 ; 3$ pacers $(2: 121 / 4)$.

EARL VAN DORN, bay, said to be by Thompson's Traveler.

Sire of Cora Mack, $2: 22^{3} / 4$.

EARLY BIRD (3-64), 2 : I0, roan, $15^{\mathrm{I} / 2}$ hands, rooo pounds; foaled 1886 ; bred by E. W. Ayres, Duckers, Woodford County, Ky. ; got by Jay Bird, son of George Wilkes: dam Beulah, bay, bred by E. W. Ayres, got by Harold, son of Hambletonian ; $2 \mathrm{~d}$ dam Sallie B., bay, bred by J. R. Scott, Duckers, Ky., got by Lever, son of Lexington; 3d dam Bay Fanny, brown, bred by J. R. Scott, got by Pilot. Sold to B. F. Curry, Lexington, Ky. ; to George Levitt, Boston, Mass. ; to Dr. Drake, Pittsfield, Mass. Pedigree from breeder.

Sire of 2 trotters $\left(2: 15 \frac{1}{4}\right)$; Early Bird Fr., 2:II $1 / 2$.

EARLY PIONEER, bay; foaled ז $88_{3}$; bred by H. G. Finkle, Moorehead, Minn.; got by Pioneer, son of Volunteer, by Hambletonian : dam Grace, bay, bred by Dr. L. Herr, Lexington, Ky., got by Mambrino Patchen; 2d dam said to be by Marengo, son of Messenger Duroc. Sold to W. E. Steele; to T. B. Marrett, St. Paul, Minn.; to W. F. Holmes, Lake City, Minn.

Sire of Cresco Chief, $2: 29 \frac{1}{4} ;$ I sire of I trotter. 
EARLY REAPER ( $1-128$ ), $2: 093 / 4$, bay, I 6 hands; foaled 1895 ; bred by Caton Stock Farm, Joliet, Ill.; got by Highwood, son of Nutwood : dam Atalanta, bay, bred by A. S. Talbert, Lexington, Ky., got by Alcantara, son of George Wilkes; 2 d dam Starling, bay, bred by A. S. Talbert, got by George Wilkes; 3d dam Jessie Pepper, brown, bred by R. P. Pepper, Woodford County, Ky., got by Mambrino Chief, son of Mambrino Paymaster; $4^{\text {th }}$ dam, brown, bred by W. W. Dickey, Woodford County, Ky., got by Sidi Hamet; $5^{\text {th }}$ dam the Wickliffe mare, said to be by Darnaby's Diomed. Pedigree from W. R. Wylie, Supt. of Caton Stock Farm. Sold to I. IV. Newton, Darlington, Wis.

Sire of Cabaliet, $2: 19 \frac{1}{4} ;$ Fosie B., $2: 24^{3 / 4}$.

EARNEST, bay, white pasterns behind, $15 \frac{1}{2}$ hands, I roo pounds; foaled I 873 ; bred by Alden Goldsmith, Washingtonville, N. Y. ; got by Volunteer, son of Hambletonian : dam Misfortune, gray, owned by W. J. Tuthill, Blooming Grove, N. Y., said to be by Plow Boy, son of Long Island Black Hawk; and 2 d dam by Mambrino Paymaster. Sold to F. D. Norris, Brooklyn, N. Y. ; to R. Steen, Wilmington, O., who sends pedigree.

Sire of 3 trotters $\left(2: 19 \frac{1}{4}\right), 5$ pacers $(2: 101 / 2) ; 3$ dams of 3 pacers.

EARNEST W. (3-I 28 ), brown; foaled 1885 ; bred by E. V. Haden, Minneapolis, Minn. ; got by Adrian Wilkes, son of George Wilkes: dam Flora (dam of Roy Wilkes, 2 :061/2), said to be Morgan. Sold to I. C. Seeley, Minneapolis, Minn., and owned by his estate, I905.

Sire of 2 pacers $(2: 161 / 2)$.

EARTHQUAKE (I-32), black with star, I5 hands, Iooo pounds; foaled I 862 ; bred by L. E. Ferris, South Hero, Vt.; got by North Hawk, son of Sherman Black Hawk: dam, black, bred by L. E. Ferris, got by a chestnut stallion purchased when three years old by Frank Childs, Grand Isle, Vt., of a doctor in Canada, and said to be by old St. Lawrence. Sold to Capt. Warren Corbin, South Hero, Vt., whose property he died. See The Morgan Horse and Register, Vol. I., p. 394 .

Sire of Rex, $2: 221 / 2$; I dam of I pacer.

EARTHQUAKE PILOT (I-I6), bay, said to be by Brooks Horse. Owned by B. P. Kirk, Mason City, Ia. Kept one season at Portland, Ia.

Sire of Earthquake Pilot, $2: 23$.

EASTERN BOY ( $\mathrm{I}-64$ ), bay, white snip, one hind foot white, I $53 / 4$ hands ; bred by George Moody, deceased, Henderson, Jefferson County, N. Y.; got by Little Eastern, son of Gen. Benton: dam River Lily, bay, bred by George Moody, got by Gen. Benton, son of Jim Scott ; 2 d dam black, a Canada mare. Sold to Mr. Baggs, Springfield, Mass. Pedigree from Melvin Moody.

EASTERN KING, chestnut ; foaled r 886 ; bred by D. C. Dawson, Halifax, 
N. S. ; got by Melbourn King, son of Mambrino King: dam Pandora, bay, bred by D. C. Dawson, got by Olympus, son of Almont; 2d dam Hopeless, bay, bred by Edwin Thorne, East Greenwich, R. I., got by Hamlet, son of Volunteer; 3d dam said to be by Hector, son of Latourette's Bellfounder; and 4th dam by Gridley's Roebuck, son of Carr's Roebuck. Sold to A. H. Sutherland, Port Hastings, Can.

Sire of Dolly King, $2: 29 \frac{1}{2}$.

EASTERN STAR, bay, I 5 hands, said to be by the Whitehouse Horse kept in Vassalborough. Advertised at Augusta, Me., by Howard Pettingill, I 824 .

EASTERN STAR (BLACK JIM) (I-8), said to be a descendant of Sherman Morgan. Advertised at the stable of the subscriber, in Sangamon County, Ill., six miles south east of Waverly, and six miles south west from Auburn, by William W. Post, I857, in the State Journal, Springfield, Ill. A horse called Eastern Star was entered at the Illinois State Fair, I860, by S. P. Griswold, Whitehall, Ill. See The Morgan Horse and Register, Vol. II., p. Io8.

EASTLIGHT (3-256), chestnut, I5 $3 / 4$ hands; foaled $188 \mathrm{I}$; bred by Littleberry M. Bedford, Paris, Ky.; got by Mambrino Patchen : dam Greenwood Maid, chestnut, bred by Hart \& Wm. Talbot, Paris, Ky., got by Strathmore, son of Hambletonian; 2 d dam Belmont, bred by A. J. Alexander, got by Belmont, son of Abdallah; 3 d dam Venus, said to be by Seeley's American Star. Died in I 886 . Pedigree from breeder.

Sire of Roan Boy, $2: I 6 \frac{1}{4} ; 2$ dams of I trotter, I pacer.

EASTMAN MORGAN (I-I6), bay, I 5 I/ $/ 4$ hands, I I 50 pounds; foaled I 848 ; bred by Dorson Eastman, East Rupert, Vt.; got by Green Mountain Morgan, son of Gifford Morgan: dam bred by Dorson Eastman, got by the Stoddard Horse, son of Judson's Hamiltonian ; 2 d dam, bay, bred by Elijah Eastman, East Rupert, Vt., got by Paddock's Magnum Bonum ; 3d dam brown, bred by Enoch Eastman, East Rupert, Vt., got by imported Matchem; 4th dam black, said to be by a small black horse named Abdallah owned before $\mathbf{x} 806$, by David Robinson and called an Arabian. Sold to Hiram Sikes who took him to Westfield, N. Y., later to Marietta, O., and sold him $\mathbf{r} 866$, to go to a town on the Mississippi River between Wisconsin and Iowa; afterwards owned by S. Stockwell, Clinton, Ia. Died about I875. Pedigree from Breeder. See The Morgan Horse and Register, Vol. I., p. 703.

Sire of Little Fred, $2: 20$; I dam of I trotter.

EASTON, brown, foaled I 805 ; bred by Lord Fitzwilliam; got by Stamford, son of Highflyer: dam Rupee, bred by Lord Fitzwilliam, got by Coriander, son of Pot-8-o's by Eclipse; 2 d dam, Matron.-General Stud Book, Vol. I., p. 35 I. 
EASTON WILKES, said to be by George Wilkes.

Sire of Stranger, $2: 12 \frac{1}{2}$.

EATON HORSE, said to be by Arabian Ranger (Wyllis') : dam Princess of Beauty, by the Chapman Narragansette pacing horse. Advertised at East Windsor and Enfield, Conn. "Has covered at Tolland for several years."

EATON HORSE. See Roebuck advertisement in r8ı. See Young Eclipse; foaled I8r i ; owned by Mr. Sellick of Fayston, Vt.

EATON HORSE (I-I6), dappled sorrel, heavy mane and tail the same color, narrow white stripe in face, I6I/2 hands, I450 pounds; foaled 1840 ; bred by Thomas Pelton, Anson, Me.; got by the Avery Horse (which see) : dam the Pelton Mare, roan, I 300 pounds, foaled 1828 , bought by Thomas Pelton of Mathew Benson, Madison, Me.; bred by Philip Dinsmore, Madison, Me., got by Winthrop Messenger. Sold to E. D. Robinson, Wilton, Me., I 844 ; to Caleb Jones also of Wilton, who kept him one year and sold back to Robinson, of whom in the fall of $\mathrm{r} 846$, he was purchased by Eliab L. Eaton then of Farmington. Mr. Eaton sold him in 1854 , to William Beal, of Winthrop, who sold him in 1858 , to parties in Nashville, Tenn., where he was kept one season then went to Hopkinville, Ky. Above information is from Jos. G. Pelton of Anson, Me., son of breeder, who writes :

Mr. BatTell,

Anson, May 3 rst.

The Postmaster at Anson received a letter from you last night for information in regard to the dam of the Eaton Horse. My father raised the Eaton Horse and sold him to parties that you speak of. The mare was a large roan and weighed about $\mathrm{I} 300$ and it was always claimed that she was by the old Messenger, but there is no question but she was by a Messenger horse, for she had the Messenger gait and form. The mare had quite a lot of trot in her, it would take a good stick to lick her into it but she could get there, I used to ride on her back when a small boy. I could always leave the best of them. The Eaton Horse weighed 1500 . When a colt he was light sorrel but when older he was dark with dapples all over and heavy tail and mane. He was sold to parties in Tennessee, I think, and died soon after. If there is anything more that you want to know write to me and I will help you all I can. Shall mail this in Madison but direct to Anson.

Joshua G. Pelton.

Mr. BatTell,

Anson, June II, I89o.

I received your letter in due time all O. K. Will say in reply to your questions that the dam of the Eaton Horse was by old Messenger sure, I rode over two or three towns and talked with every one that knew anything about it, at last I found a man about 80 years old I asked him what sired the dam of the Eaton Horse. He said she was by the old Messenger and he knew it. He said she was got the same year that the Stone was. The Stone Horse was raised here in Anson, my 
father bought her of Mathew Benson of Madison. It was always said that Philip Dinsmore of Madison raised her. It was 40 or 50 years ago, you see its hard finding out anything about it. The men that knew are all dead. If I can find out anything more I will write you. I don't live here, I live in Dakota, I stop here part of the time.

$$
\text { Yours in haste, Joshua G. Pelton. }
$$

See The Morgan Horse and Register, Vol. II., p. ro8.

Sire of Stranger, $2: 30$; I sire of I trotter; 3 dams of 3 trotters.

EBERSTON, imported, formerly the property of Mr. Osbaldeston in England. First season in Kentucky, at farm of James Weir, two miles from Lexington on the Railroad, under the care of Mr. Baxter. Advertised as above in Lexington (Ky.) Gazette, $\mathbf{1} 847$.

EBONY (EBONY BASHAW) (I-ז6), black; foaled I 874 ; bred by J. A. Green, Muscatine, Ia.; got by Green's Bashaw, son of Vernol's Black Hawk : dam Bessie, said to be by Addison Jr., son of Addison, by Black Hawk. Pedigree from C. E. Lewis, Chatham, Ill.

WAVERLY, Dec. 3I, I905.

Dear Sir :-I received this note and in reply will say that I raised a black mare foaled in I 886, by Ebony, son of Green's Bashaw : dam by Cadet, thoroughbred, grandam by Tom Hal, from a Morgan mare. I sold her some years ago to a man by the name of Jackson, but I don't know where he is. I heard the mare died. I don't think she is the one that you refer to but I will keep the blank and fill it out the best that I can if you think she is the right one. Jacob Leonard of Chatham owned Ebony but he is dead and has been some years. The horse was here at Waverly, Ill., after I 884 until he died but the man that kept him is dead.

Sire of Baby Bashaw, $2: 30$; I dam of I pacer.

A. W. Moulton.

EBONY SPINK (3-64), 2 :29 $1 / 4$, black; foaled I 884 ; bred by Henry Peterson, Lodi, N. Y. ; got by Spink, son of Andy Johnson : dam Fanny, bred by Henry Peterson, got by Grayhound, son of Black Hawk; 2d dam Nelly, said to be by Chance, son of Chance (Royall's) ; 3d dam Dolly B., by Gen. Gifford, son of Morgan Deforest by Cock of the Rock, son of Sherman Morgan; and 4th dam by Sweetbriar (Swartout's). Sold to George S. Doud, Winona, Minn.; to Rockdale Farm Co., Milwaukee, Wis. ; to W. P. Cook \& Bro., Oconto, Wis., February, I894.

EBONY WILKES (3-128), $2: 293 / 4$, black, I6 hands, I 200 pounds ; foaled I 883 ; bred by W. H. \& E. Vogel, Chicago, O. ; got by Ambassador, son of George Wilkes : dam Nettie E., bay, bred by W. H. \& E. Vogel, got by Joe Hooker, son of Tom Hyer, by Black Hawk; 2 d dam Kit Logsden, gray, bred by Joe Logsden, Upper Sandusky, O., got by Gray Eagle; and $3 \mathrm{~d}$ dam said to be by Backus. Sold to J. W. Voglesong, Elyria, O., who sends pedigree ; to Russell Lams, Gibsonville, O.

Sire of Yemew, $2: 25$. 
E. C. BAYARD, ( $1-16)$, bay, one hind foot white, $15 \frac{1}{2}$ hands, ro5o pounds; foaled I 887 ; bred by E. C. Walton, Alliance, O.; got by Bayard, son of Pilot Jr.: dam Nora Burns, brown, bred by E. C. Walton, got by Starmont, son of Almont ; 2 d dam Bess Perkins, said to be by Belding's Hambletonian, son of Robert Bonner; and $3 \mathrm{~d}$ dam by Searcher $2 \mathrm{~d}$, son of Searcher. Sold to Chauncey Hopkins, Granger, O. Pedigree from breeder.

Sire of Monte Bayard, $2: 13 \frac{1}{2} ; 2$ pacers $\left(2: 21 \frac{11}{4}\right)$.

ECHO (3-I28), $2: 371 / 2$, bay, no white, I5 $3 / 4$ hands; foaled 1866 ; bred by Jesse 'T. Seeley, Warwick, N. Y. ; got by Hambletonian, son of Abdallah : dam Fanny Fetter, bred by Abram Young, Orange County, N. Y., got by Magnolia, son of Seeley's American Star: $2 d$ dam said to be by Webber's Kentucky Whip ; and 3d dam by Shakespeare, son of Duroc. Sold October, I870 to L. H. Titus, Los Angeles, Cal. ; to J. B. Haggin, San Francisco, Cal. Died 1893 . Information from Breeder and Sportsman, Cal., Oct. 28, 1893 .

Sire of $I_{4}$ trotters $\left(2: I 6 \frac{1}{4}\right), 2$ pacers $\left(2: 24 \frac{1}{4}\right)$; II sires of $I 6$ trotters, 8 pacers; 22 dams I2 trotters, I4 pacers.

ECHO (I-32), $2: 37$, brown, I5 I/4 hands; 950 pounds; foaled about I 874 ; bred by Andrew H. Rice, Waterville, Me.; got by Victor, son of Gen. Knox : dam Gipsey, brown, a mare brought from Canada, said to be Arabian. See The Morgan Horse and Register, Vol. II., p. Io9.

Sire of Superb, $2: 29 \frac{1}{2}$; I dam of I trotter.

ECHO CHIEF (I-32), $2: 2 \mathrm{I} / 4$, golden chestnut, I 6 hands, I 200 pounds; foaled 1877 ; bred by H. Hamsboro, Columbus, Miss. ; got by Octihaba, son of Jeff Davis (Jennison Black Hawk) : dam Lady Bounce, said to be by Orr's Mambrino, son of Mambrino Chief; 2d dam Fashion, by Pacolet; 3 d dam, by Leesboro. Dam of Octihaba, Lady Beck, said to be by Silvertail, thoroughbred. Information from correspondent of Dunton's Spirit of the Turf.

Sire of Sir Tatton Chief, $2: 23 \frac{1}{4}$; I sire of I trotter; I dam of I trotter.

ECHO CHIEF JR. (3-I28), sorrel with star, about $153 / 4$ hands, II 50 pounds; foaled 1889 ; bred by Vernon Harris, Lawrence, Kan.; got by Echo Chief, son of Octihaba: dam bay, bred by E. A. Smith, Lawrence, Kan., got by Almont Pilot, son of Almont. Sold to J. H. Glathart, Lawrence, Kan., who sends pedigree.

Sire of Stella S., $2: 25$.

ECHO ROYAL (3-256), bay with star, I6 hands, II 75 pounds; foaled I 882 , bred by J. B. Haggin, San Francisco, Cal., got by Echo, son of Hambletonian : dam Booth, said to be by Gov. Booth (Pilgrim), son of George M. Patchen; 2d dam Demirep, by Melbourn, son of imported 
Knight of St. George ; 3d dam Methilde, by imported Scythian; and

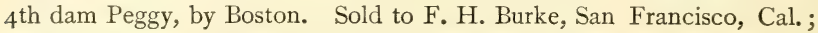
to S. L. Wattles, Healdsburg, Cal., who sends pedigree.

Sire of Nina L., $2: 17 \frac{1}{4}$.

ECKFORD (3-32), $2: 25 \frac{1}{4}$, bred by A. P. Carver, Whitehall, N. Y.; got by Woodward's Ethan Allen : dam bred by A. P. Carver, got by Spirit of the Times, son of Black Murat, by Wicker's Flying Cloud.

ECLAIR (3-32), I5 T/2 hands, I025 pounds; foaled I87o; bred by William and A. S. Parker, Skowhegan, Me.; got by Gen. Knox, son of Vermont Hero: dam Kate, black, bred by Samuel Morrell, Athens, Me., got by Merrow Horse, son of Witherell. Sold to I. H. Herson, Oakland, Me. ; to Charles W. Kimball, Rumford Point, Me., I875; to J. I. Parsons, Colebrook, N. H. Pedigree from breeder. See The Morgan Horse and Register, Vol. II., p. Io9.

Sire of Tainter, $2: 26 ; 4$ pacers $(2: 16) ; 4$ dams of 2 trotters, 2 pacers.

ECLIPSE, chestnut; foaled I764, during the great Eclipse, whence his name; bred by Duke of Cumberland, got by Marske, son of Squirt, by Bartlett's Childers : dam Spilleta, bred by Sir Robert Eden, foaled I 749, got by Regulus ; 2 d dam Mother Western, by Smith's son of Snake ; 3d dam by Lord D'Arcy's old Montague ; $4^{\text {th }}$ dam by Hautboy; $5^{\text {th }}$ dam by Brimmer.

The American Turf Register, says :

"This celebrated horse, bred by the Duke of Cumberland, the uncle of King George III., received his name in commemoration of the fact that he was foaled during an extraordinary eclipse in the year I763. His breeder predicted but did not live to see the great performance of the horse. The stud was dispersed by auction, and Eclipse, then a yearling was sold. The story proceeds: 'Mr. Wildman, a sporting gentleman arrived soon after the sale had commenced, and after a few lots had been knocked down. Producing his watch, he insisted that the sale had begun before the time advertised. The auctioneer remonstrated: Mr. Wildman was not to be appeased, and he demanded that the lots already sold should be put up again. This dispute caused a loss of time as well as a scene of confusion; the purchasers said if there was any lot already sold which he had an inclination to, rather than retard progress it was at his service. Eclipse was the only one he had fixed upon, and was transferred to him at the price of 75 guineas. At four or five years old Captain O'Kelley purchased him of Mr. Wildman for I70o guineas.' Colonel Dennis O'Kelley called Captain in the foregoing extract) purchased the estate of Cannons, near Edgeware, and had another estate at Epson, where he kept Eclipse, and had his wellappointed training stables. On his death in ${ }^{7} 787$ he bequeathed, Eclipse to his brother, Philip O'Kelley, but the horse, soon afterwards losing the use of his legs, was removed from Epson to Cannons, where he died on February 27 I 789 . His heart is said to have weighed fourteen pounds. The size of this organ was presumed to have greatly enabled him to do what he did in speed and strength. 
"First started 1769 . As a racer, his stoutness, form and action were excellent; he had a vast stride and certainly never horse threw his haunches below him with more vigor or effect; his hind legs were so spread in his gallop that a wheelbarrow might have been driven between them; his agility was great; his speed extraordinary; and he was conceded to be the fleetest horse that ever ran in England since the time of Childers."

ECLIPSE, I5 3/4 hands, bay, well formed, got by Bright's Partner : dam by Bloody Buttocks - Grayhound-Makless-Brimmer-Places's White Turk-old Dodsworth. Imported by Col. Harris, of Virginia, and called “Harris' Eclipse." In Virginia I769; died on Meherrin River, Va., in $177 \mathrm{r}$.

ECLIPSE, said to be by Liberty, son of Dove : dam by Brutus. Advertised in New York Mercury, I774, to be kept in Winchester.

ECLIPSE, bay, I5 hands ; foaled I 773 ; said to be by Young Traveler : dam Camilla, by Fearnaught. Advertised in "Virginia Gazette," I777, to stand in Gloucester, Va., by Lewis Beersall.

ECLIPSE, chestnut; foaled I778; bred by Sir John Shelby: got by O'Kelley's Eclipse: dam by Cottingham - Snake-Bald Galloway Lord Carlisle's Turk. Imported and owned by Richard B. Hall, Esq. of Prince George County, Md., and called "Hall's Eclipse."

ECLIPSE, dark brown, raised in New York, upwards of sixteen hands, well proportioned, three quarters English. Is the same horse that was kept last year on Little Rest Hill, where his colts may now be seen. Will stand at stable of Henry Potter, South Kingston, I 794, terms \$4.-Newport Mercury.

ECLIPSE (CALLED ALSO NORTHERN ECLIPSE), chestnut, large, strong and well formed; consigned to Messrs. Wallace \& Muir of Annapolis, got by O'Kelley's Eclipse: dam Amaryllis, by AdolphusBaboon-old Traveler-Snake.

ECLIPSE, sorrel, I 6 hands ; foaled I 790 ; got by Obscurity : dam by ApolloValiant-Tryall. Advertised in 1796 in Prince George County, Va., by William Cole with pedigree as above.

ECLIPSE. Said to be by Wallace's imported Eclipse: dam by Sweeper. Advertised in Maryland Gazette, $\mathbf{1} 795$.

ECLIPSE bay, r6 hands; foaled I7- ; said to be by Eclipse and dam by Mambrino. Imported from England to Halifax with Phœnix, by Mr. Sands in 1800 ; kept in Duchess County, N. Y., I808 and I809. See Phœnix. 
ECLIPSE (BONDS), chestnut, $15 \frac{1}{2}$ hands; said to be by First Consul, son on Flag of Truce: dam Selima III., chestnut with star and snip, I $5^{\mathrm{I} / 2}$ hands, by Hall's Eclipse, son of Eclipse; $2 \mathrm{~d}$ dam Young Ebony, foaled May, Io, I777, by Don Carlos, son of Figure; 3d dam Young

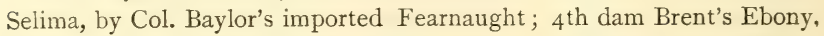

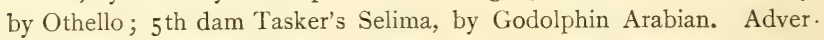
tised together with Sea Gull at Goshen, N. Y., I 826. Terms \$10 to \$12.

American Turf Register Sept. I 837 , contains copy of pedigree as above, certified by William Thornton, Washington, D. C., Oct. I, I8o3. Selima's dam was by Fox, and $2 \mathrm{~d}$ dam by Flying Childers.

ECLIPSE, chestnut with star, I5 hands; foaled I80I. bred by George Brown; got by the running horse, old Columbus of Virginia: dam said to be by imported Emperor. Owned by Sam Crowell, Newville. Advertised in the Cumberland Journal of r8o8-9-ro.

ECLIPSE, dark bay, I6 hands; foaled I806. Advertised r8I at Craftsbury and Hardwick, Vt., by Royal Corbin.

ECLIPSE. A horse of this name is advertised in the Reporter Vol. I., as follows: "Eclipse, near Lexington; five years old; got by imported Speculator: dam by Eclipse etc.

\section{Oliver."}

ECLIPSE (BRADLEY'S) bright bay, I5 I 2 hands; foaled 1772 ; said to be imported. Brought by Gen. Bradley from the Southern States and advertised I 794 to be kept at the stables of Samuel Cole, Westminster, Vt., and Landlord Bellows, Walpole, N. H.

A horse of this name, called English, was advertised in 1796 in Winslow, Me.

ECLIPSE (CROCKER'S) ; foaled I8I-; said to have been bred on Long Island, and got by a horse called Don Quixote, untraced : and dam by Bajazet, son of imported Tanner. Owned in Seneca County, N. Y. See Don Quixote. A correspondent Theodore Coleman in Wallace's Monthly, February, I88I, says :

"Mr. Crocker of Northville, Cayuga County, brought Crocker's Eclipse to Western New York. He proved to be a valuable horse for this section. As a matter that may be curious or useful, I will give you the copy of a handbill dated April 2oth, I83I. The original is, or was lately, in the possession of Mrs. Christopher, of this county. Her husband exhibited the Lagrange Tunison horse at Elmira and then sold him to some one in Chicago. The handbill advertises President, a son of Crocker's Eclipse, and is as follows :

'President, by Crocker's Eclipse; he by Don Quixote; he by Potomac ; he by imported Messenger. Eclipse's dam by imported Bajazet ; grandam by imported Messenger. Owned by Mr. Leffert, Long Island.' President was advertised as eight years old, so Crocker's Eclipse must have been brought to this section about $1820 . "$ 
If this horse was got by a horse called Don Quixote, it is highly probable that it was imported Don Quixote, by English Eclipse; Ist because there is no authentic record of any horse of this name having been got by imported Messenger or a son; and $2 \mathrm{~d}$ because in no other way can we account for his being called Eclipse. See I)on Quixote.

Mr. Wallace had previously said that Crocker's Eclipse was got by Don Quixote, son of Potomac, by imported Messenger. He had before this recorded this horse, Don Quixote, as by Messenger, and also by Commander, son of Messenger, no breeder or owner given.

The $2 \mathrm{~d}$ dam of Lady Suffolk, the first $2: 30$ trotter to sulky, is understood to have been bred by Gen. Floyd, and got by a horse called Don Quixote. In interview with Mr. Leonard Lawrence, Smithtown, L. I., born 1795, breeder of Lady Suffolk, he said :

"Lady Suffolk's dam was an old mare that Gen. Floyd used to ride on parade. I think I got her of Charley Little, a young man that traded horses all the time. At one time she belonged to Richard Floyd. I don't know where he got her. I never understood what her blood was. I never knew anything about it. I got her in haying time and owned her six or eight years."

Mrs. Leonard Lawrence, born I802, said :

"We did not own that mare only two or three years before Lady Suffolk was born. I do not know anything at all where Mr. Floyd got her. Lady Suffolk was foaled in $1833 . "$

Mr. Lawrence thought that the mare was I6 or 17 years old when he got her. Mrs. Lawrence's impression was that Gen. Floyd raised her, and said that she remembered her before I82I, when Richard Floyd used to ride her.

From this it would appear that the dam of Lady Suffolk was foaled as early as $1814-16$, and perhaps as early as 1805 or 6 .

ECLIPSE (LONG'S), dapple chestnut, 16 hands, I 250 pounds ; foaled i 823 ; bred by George M. Lloyd, Lloyd's Neck, N. Y. ; got by American Eclipse, son of Duroc: dam Queen Mab, foaled I 806 , bred by John Lefferts, Flat Bush, I. I., got by Bajazet, son of imported Tanner; 2 d dam said to be by Mercury; $3^{\text {d }}$ dam by imported Messenger; and $4^{\text {th }}$ dam by Ogle's Badger. Owned I 83 I by Edward Long, Cambridge, N. Y. Advertised in $\mathrm{I} 843$, by E. and D. Long at Bridport and Shoreham, Vt., and in 1847 , by N. D. Long at Pittsford and Rutland, Vt.

Dorson Eastman, of Dorset, Vt., says that Mr. Long had two Eclipse horses, the first a good one, the last not.

Gen. Grandy of Vergennes, Vt., says: "Long's Eclipse at Vergennes proved a failure ; frail stock, no endurance."

Awarded ist premium at the New York State Fair at Albany, I842.

Advertised as follows by Mr. Long, I8 31 :

BLOOD HURSES.

"The subscriber respectfully informs the breeders of horses that his 
celebrated thoroughbred horses, Eclipse and Henry 2d, four years old, will stand the ensuing season at the stable of the subscriber in Cambridge. They have been selected of as pure blood as any in the United States, and from the best crosses ; and it is believed will add greatly to the improvement of the breed of horses. Eclipse is a son of American Eclipse; Henry $2 \mathrm{~d}$ a son of the noted turf horse Henry, the competitor of American Eclipse. Pedigrees can be examined at the chequered house.

\section{EDWARD LONG.}

Cambridge, N. Y., May 2, $1831 . "$

ECLIPSE (KINCADE'S, RUSSELL'S), sorrel, bred in Argyle or Hartford, Washington County, N. Y.; supposed to be by Long's Eclipse. Kept in Washington County, N. Y., many years, also owned by Ephraim Fitch Clark, Pawlet, Vt., and went from Pawlet to Orwell, Vt., or that vicinity. Mr. Clark bred a son of this horse which he kept as a stallion until five years old then gelded him. From letters of Mr. Clark's widow and Dr. W. B. Sargent of Pawlet, we understand that these were the only stallions owned by Fitch Clark. Dr. W. B. Sargent, who has furnished us much valuable information regarding the horses of South Western Vermont and the adjacent counties in New York writes :

Joseph BATtell,

Pawlet, May 28, i 890.

Dear Sir:--Mr. Ephraim F. Clark that you referred to owned two stock horses, one called Kincade's Eclipse, raised in Argyle or Hartford, a very fine horse, a bright sorrel, he stood in Washington County, N. Y., many years and was called Russell's Eclipse. It is I think 35 or 40 years since. He was well patronized. He went from here to Orwell or Sudbury, or in that vicinity. Mr. Clark had a five year bay stallion son of this horse which he matched and sold for a high price to I think a party in North Adams, Mass.
Yours truly,
W. B. Sargent.

ECLIPSE (LAWRENCE'S), chestnut ; foaled I 827 ; bred by Robert Morris, Fordham, N. Y; got by American Eclipse, son of Duroc: dam Doll, bred in Claverack, N. Y., said to be by Algerine. Sold about I830 to Peter Lawrence, of Fordham or vicinity.

Sire of $2 \mathrm{~d}$ dam of Strader's Cassius M. Clay.

ECLIPSE (LA GRANGE TUNISON'S, GURNEE'S) ; said to be by the Philip Tunison Eclipse, son of Croker's Eclipse : dam by Favorite ; 2d dam by Revolution; and 3 d dam (dam of Philip Tunison Eclipse) by Liberty, thoroughbred. Above information is from a son of the Philip Tunison, who came to Madison County, N. Y., from New Jersey bringing with him some well-bred horses. In the Catalogue of E. S. Wadsworth appears Eclipse (Gurnee's), as follows : foaled I 8-; by Tunison Eclipse, by Crocker's Eclipse : dam by Favorite, by Grand Signeur, by imported Messenger. The National Live Stock Journal of April i 87 r, says: "Gurnee's Eclipse was formerly owned by Walter S. Gurnee of 
Chicago and sold to go East eight or ten years ago. Awarded premium at the New York State Fair, over Hambletonian."

"The horse that beat Hambletonian.-In a recent number, the fact was brought out that in $\mathbf{1} 855$, at the State Fair at Elmira, Hambletonian was beaten by a large, good looking bay horse, called an Eclipse. Mr. R. N. Denton of Willard, N. Y., writes us that this was the horse known and recorded as Gurnee's Eclipse. He was bred by Daniel Christopher, Seneca County, N. Y., and exhibited by him; was sold at the fair to Mr. Gurnee of Chicago. He was by Tunison's Eclipse, son of Crocker's Eclipse."-Wallace's Monthly', Vol. VII.

ECLIPSE, large; foaled I 8 I9; said to be by Magnum Bonum : and dam by Shakespeare. Advertised in Rutland, Vt., Hearld, 1824 and 1827 , by Moses Lester, with pedigree as above.

ECLIPSE, by Eclipse ; foaled I 828 : dam by Mars. Advertised by Lewis Nicholson, I $\delta_{33}$, to be kept at Fort Ann, N. Y., as follows :

"Full-blooded Horse Eclipse.-Eclipse is a beautiful bay, I 6 hands high, five years old this spring and descending, we believe, from a stock of horses the highest in estimation of any in the United States, and is considered by good Judges as valuable a young horse as any in this vicinity, partaking of the most important points necessary for a good horse so rare to be found in that animal, elegance of figure and well proportioned in every way. Although he is yet young, Eclipse was got by the celebrated full-blood horse Eclipse, whose pedigree and character are so well known throughout the United States, we omit giving it publication.

"Eclipse's dam was by the full-blooded horse Mars, raised by Gov. Ridgeley of Maryland; his grandam by the full-blooded horse, Bay Figure. She drew the premium at three years old as the best mare exhibited against all ages; great-grandam by the imported horse, Matchem; great-great-grandam was Dido, and got by the full-blooded horse Bogus, purchased at $\$ 2100$; great-great-great-grandam was Lutestring; she was sold for $\$$ IOO at four months old, and for $\$ 200$ before she was three years old, and was got by the full-blooded horse Cincinnatus; great-great-great-great-grandam was an English mare owned by Dr. Perry of Woodbury, Litchfield County, State of Connecticut, and got by the imported horse Syphax. By this pedigree you may perceive that Eclipse is undoubtedly as thorough a bred horse as any in America."

ECLIPSE, bay. Owned by Edward Myers, Manchester, York County, Penn., about ${ }_{1} 857$.

ECLIPSE. See American Eclipse.

ECLIPSE. See Capt. Beaumont.

ECLIPSE (ASHTON'S) ; bred by William Ashton, White Creek, N. Y ; got by Long's Eclipse, son of American Eclipse : dam said to be by Signal that was burned in a barn near Buskirk's Bridge. Purchased about 1837 , by Thomas Bingham, Newburgh, N. Y. 
ECLIPSE (MARTIN'S) gray ; foaled 1848 ; bred by Wm. Winn, Muskingum County, O., got by Porter's Eclipse, son of Wilson's Eclipse : dam pacer, said to be by Rice's Hiatoga. Sold, I 855, to Allen Bowers and J. C. Barnes, who took him that year to Henry County, Ia.

ECLIPSE (PHILIP TUNISON'S), said to be by Crocker's Eclipse: and dam by Liberty thorough-bred. Owned in Seneca County, N. Y. Died of poison when young.

ECLIPSE (PORTER'S) ; foaled r838: bred by Jarmon Hare, Brownsville, Penn.; said to be by Wilson and Siddle's Eclipse (old Jim), son of American Eclipse; and dam brought from Pennsylvania. Kept in Muskingum and Guernsey Counties, $\mathrm{O}$.

ECLIPSE (STERLING'S), said to be by Telegraph, son of imported Abderhamon.

Sire of dam of Golden Girl, $2: 281 / 2$.

ECLIPSE (YOUNG), bay; foaled I799; bred by Mr. Wilson; got by Young Eclipse: dam Highflyer Mare, bred by Mr. Tattersall, got by Herod; 2d dam said to be by Squirrel; 3d dam Sophia, by Blank, son of Godolphin Arabian; 4th dam Lord Leigh's Diana, by Second, son of flying Childers.-General Stud Book, Vol. I., p. 293.

ECLIPSE (YOUNG), bay; foaled I8oo; bred by Duke of Gloucester ; got by Young Eclipse: dam Augusta, foaled 1784 , bred by H. R. H., the Prince of Wales, got by Eclipse ; 2 d dam Hardwick's dam Herod Mare, bred by Mr. St. Leger Douglas, got by Herod, son of Tartar; 3d dam Nettle, bred by Mr. Douglas, got by Bajazet, son of Godolphin Arabian;

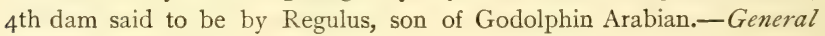
Stud Book, Vol. I., p. 229.

ECLIPSE (YOUNG), bay, I $^{1 / 2}$ hands, said to be a grandson of American Eclipse. Brought from New York State to Washington, Vt., and owned in part for several years, about 1830 , by I. D. Davis of Williamstown, afterwards, Barnard, Vt. Mr. Davis in interview, said :

"He was a slim built horse not large. The horse was cross. Elisha Gale of Williamstown bought him when six years old. I brought him to Barnard and kept him here two or three years then sold to Baxter M. Gaines, Springfield, Vt. They kept him one season then sent him west of New York State. I let him go to Brookfield one year for \$roo. He left some splendid stock."

ECLIPSE (ZIELLEY'S), bay; foaled I 822 ; bred by Henry W. Cruger, New York, got by American Eclipse, son of Duroc: dam said to be an imported thoroughbred mare by Highflyer. Sold I823, to Walter Livingston, who sold about 1827 , to John F. Zielley and H. B. Vrooman, Montgomery County, N. Y. From Poster. 
ECLIPSE CLAY ( $1-64), 2: 32$, bay, snip on nose, I6 hands, I 50 pounds; foaled I 870 ; bred by C. Kirtley, Covington, Ky.; got by Cassius M. Clay Jr. : dam Lady Hockaday, sorrel, bred by Ed. Hockaday, Greenup County, Ky., got by Trimble's Eclipse, son of American Eclipse ; and $2 \mathrm{~d}$ dam said to be by Brown's Bellfounder, son of imported Bellfounder. Sold to S. W. Stubbs, Cainden, O., who sends pedigree. Died I 897 .

Sire of Molly G., $2: 29 \frac{1}{4}$; I dam of I trotter.

ECLIPSE FAGDOWN, gray, I6 hands; foaled 1823 ; said to be by the noted traveling horse Fagdown of Philadelphia, son of the celebrated Fagdown of New Jersey, by imported Messenger: dam by imported Eagle; $2 \mathrm{~d}$ dam by imported Buzzard; and $3 \mathrm{~d}$ dam by imported Diomed. Advertised in the Rutland Herald, Vt., I830-3I with pedigree as above by Daniel Mallory, Hampton, Washington County, N. Y., who states that he has in his possession all the evidence that can be required to prove the correctness of the pedigree, and also says that the Fagdown stock of horses is one of the most celebrated for trotting in the United States, and that the above named horse is half brother to the well known trotting horse Bull Calf owned in Philadelphia. Refers for Fagdown horses, to James M. Hart and Samuel D. Rogers, Philadelphia, and Messrs. Stanley \& Co., Merchants, Baltimore.

ECLIPSE HICKORY, by Hickory : dam by Eclipse ; 2d dam by Baronet ; 3d dam by Messenger. Advertised 1833, by John Willis, Newburgh, N. Y.

ED ANNAN (1-32), $2: 161 / 4$, bay, small star, I4 $1 / 2$ hands, about 800 pounds; foaled I 880 ; bred by G. W. and M. J. Smiley, proprietors Dauntless Stock Farm, Bangor, Van Buren County, Mich.; got by Dauntless, son of Hambletonian : dam Bay Fanny, bay, bred by G. W. \& M. J. Smiley, got by Night Hawk, son of Grennell's Champion; 2d dam, brown, bred by John Meachem, Lawrence, Van Buren County, Mich., got by Fox Hunter (Southworth), son of Fox Hunter (Whaley's). Sold to J. W. Page and from him he passed to Maj. Dickerson of New York City. Gelded at two years old. Pedigree from breeders.

ED. BARTON (Mambrino Messenger), $2: 27$, brown, $153 / 4$ hands, 1200 pounds; foaled I 874 ; bred by J. Q. A. Shelden, Manhattan, Kan. ; got by Shelden's Messenger, son of Alexander's Abdallah : dam bred by G. King, Massilon, O., got by Perry's Hiatoga, son of Hanley's Hiatoga Sold to J. Willits, Santa Anna, Cal., who sends pedigree. Died I897.

Sire of Nemo, $2: 211 \frac{1}{4} ; 2$ dams 2 trotters.

ED. BENNOR (3-64), bay; foaled I866; bred by Ira H. Coleman, Sheldrake, N. Y. ; got by Coleman's American Star : dam Cayuga Maid, bred by Ira H. Coleman got by Grinnell's Champion; 2 d dam Mary Tracy, said to be by Abdallah. 
ED. BROWN HORSE (5-32), light chestnut or sorrel, with light colored mane and tail, 900 pounds; foaled about $\mathbf{1} 865$; bred by Nathan C. Fassett, Clarendon (afterward of Wallingford, Vt.) ; got by Riford's Morgan Eagle, son of Young Gifford: dam the Fassett mare (dam of Bludsoe and Young Darkey), bay, about 16 hands, foaled about I85o, bred by Warren Potter, Clarendon, Vt., got by Andrus' Hamiltonian, (dam a Morgan mare), son of Judson's Hamiltonian ; 2d dam bay, traded for, when two, by Hannibal Woodruff, Rutland, Vt., of Caleb Hall, Clarendon Falls, Vt., breeding unknown. Hannibal Wondruff states that about $\mathrm{r} 840$, Caleb Hall had a dozen coits or so on a meadow and that he traded an old mare even with Hall for a bay filly, two years old, of good proportions, and that this filly was the dam of the Fassett mare. He made no inquiries, whatever in regard to her origin. Mr. Hall is dead, and although various suggestions have been made as to the blood of of the filly, we are unable to find that she was ever traced. The Ed. Brown Horse was owned by Edwin Brown, formerly of Tinmouth, now of Middletown Springs, Vt. He* was a close-built, rather stylish horse and had very good action.

Mr. Edwin Congdon says that Mr. Fassett told him that his wife's oldest brother said that the dam of the Fassett mare was by a Morgan horse that used to be kept at Brandon, which was all he knew of her pedigree. We add the following letter of Wm. Daly:

\section{Joseph BATTELL,}

East Poultney, March 4, 1885 .

Dear Sir:-The pedigree of Polly Daly, the dam of Florence, is as follows: "She was by the Ed. Brown Horse, he by the Ed. Congdon Horse, he by Young Gifford, he by Little Putnum, he by Gifford Morgan, or as he is commonly called, old Gifford, and he by Woodbury, by old Justin Morgan. The dam of the Ed. Brown Horse, the sire of the dam of Florence, was the famous Fassett mare, the dam of Bludsoe and Young Darker, both of which trotted ice low in the twenties; the dam of Ed. Congdon Horse is by old Gifford, as is Little Putnum, making him an inbred. The Fassett mare is by Andrus' Hamiltonian. The breeding of Polly Daly's dam is not known, more than that she was by a horse called Paul George, owned in Peru-owned I think, by George Stevens, but he is dead. The Ed. Congdon Horse was bred by O. \& S. Riford of Braintree, Vt., and was sold for western land to Frank Post of Wallingford. Otis Riford lives in West Randolph, Vt. Please send me down the pedigree and list of trotters of Daniel Lambert when you get them out; also price of service, as I have a mare by Highland Gray, dam by Ethan Allen. She is full sister to Lady Haner, who drew a road wagon last summer at New York, one half mile in $1: 121 / 2 . "$

$$
\text { Yours truly, }
$$

WM. DALY.

Sire of Polly Daly, dam of Florence, $2: 23 \frac{1}{4}$ (winner of 15 races and fifty race trotter) ; Don Carlos, $2: 281 \frac{1}{4}$, and Roscoe C., $2: 301 \frac{1}{4}$.

Ed. CUSTER, 2 :r $3 \frac{\mathrm{T} / 2}{2}$; foaled $\mathrm{r} 903$; bred by D. C. Palmeter, Berlin, Wis. ; got by Baronmore, son of Baron Wilkes: dam Marble, said to be by King Clay, son of Sayre's Harry Clay; 2d dam Medio, by Cooper 
Medium; and $3 \mathrm{~d}$ dam Topsey, by Mambrino King, son of Mambrino Patchen.-American Horse Breeder, Aug. 28, 1906.

EDDIE MCGREGOR (5-64,), chestnut; foaled 1887 ; bred by E. P. Weathers, Avon, Ky.; got by Robert McGregor, son of Major Edsall : dam Flaxy, chestnut, bred by E. P. Weathers, Clintonville, Ky., got by Bourbon Wilkes, son of George Wilkes; 2 d dam Kit, bay, bred by Charley Barnett, Lexington, Ky., got by Clark Chief, son of Mambrino Chief ; 3 d dam Nelly, bred by Thos. Owen, got by Gray Denmark. Sold to Mrs. Kate L. Muir and John Buchanan, Clintonville, Ky. Pedigree from breeder.

Sire of Tenny $S_{., 2} 2: 14 \frac{1}{2}$.

EDDIE WILKES, $2: 29 \frac{1}{4}$, black, bred by John R. Farnum, Waltham, Middlesex County, Mass. ; got by Commonwealth, son of Phil Sheridan, $2: 26 \mathrm{I} / 2$ : dam Lady Wilkes, brown, bred at or near Vernon, Mass., said to be by Jimmie Rattler son of Biggart's Rattler. Sold when a weanling to Mr. Nesmet, Lowell, Mass. Gelded young. Pedigree from breeder.

EDELFLUTE ( $1-64$ ), black, I53/4 hands II50 pounds; foaled I89o; bred by John E. DuBois, DuBois, Penn.; got by Roy Wilkes, son of Adrian Wilkes : dam Jenny Lind, brown, bred by J. M. Burtle, Pawnee, Ill., got by Longstrider, 2 d dam Lady, untraced. Sold to W. R. Ford, Springfield, Ill. Died I900. Pedigree from breeder.

Sire of Edfield, $2: 161 / 4$.

EDEN GOLDDUST ( $1-8$ ), brown with white hind foot, $161 / 2$ hands, 1300 pounds ; foaled about I 862 ; bred by L. L. Dorsey, Louisville, Ky. ; got by Golddust : dam Rose, bred by William Winchester, Louisville, Ky., got by Vermont Morgan, son of Barnard Morgan; 2d dam said to be by Wonder. Sold to D. L. Chase, Lodi, N.Y., I872; to James Hepburn, St. Thomas, Ont., whose property he died, I884. See The Morgan Horse and Register, Vol. II., p. I Io.

Sire of Gold Ring, 2 :I8.

EDGARDO (I-I6), $2: 103 / 4$, bay; foaled I 885 ; bred by H. N. Smith, Trenton, N. J. ; got by Rumor, son of Tattler : dam Lucia, bay, bred by H. N. Smith, got by Jay Gould, son of Hambletonian; 2d dam Lucy, 2 :1 $81 / 4$, bay, bred by Job Butterworth, Burlington, N. Y., got by George M. Patchen; 3d dam Lady Clifton, bay, bred by Job Butterworth, got by May Day, son of Henry; $4^{\text {th }}$ dam Kate, bred by Job Butterworth, got by Prizefighter. Sold to W. F. Todd, Calais, Me. Pedigree from Fashion Stud Farm by E. L. S.

Sire of 7 trotters (2:I0); Maud K., $2: 22 \frac{1}{4}$,

EDGAR DUDLEY (I-I28), $2: 173 / 4$, bay; foaled 1887; bred by John P. Crozer, Upland, Penn.; got by Ion, son of Belmont: dam Heiress, bay, 
bred by George F. Stevens, Ilion, N. Y., got by Administrator, son of Hambletonian; 2d dam Lost Heiress, bay, bred by E. S. Wadsworth, Waukegan, Ill., got by Woodburn Pilot, son of Pilot Jr. ; 3d dam Idalis, chestnut, bred by R. P. Todhunter, Lexington, Ky., got by Idol, son of

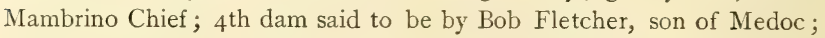

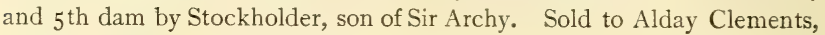
Crumpton, Md. Pedigree from breeder.

Sire of 3 trotters $(2: 201 / 2)$.

EDGAR WILKES (I-I6), $2: 24 \frac{\mathrm{T}}{4}$, bay, black points, $153 / 4$ hands; foaled I 885 ; bred by W. H. Kerr, North Middletown, Ky.; got by Ethan Wilkes, son of George Wilkes : dam Callie T., said to be by Kentucky Prince son of Black Prince, by Ticonderoga, son of Black Hawk; $2 \mathrm{~d}$ dam Doll, by Black Prince, son of Ticonderoga; 3d dam Black Kitty, by Skinner's Joe ; and 4th dam Brown Kitty, by Kerr's Copperbottom. Sold to I. N. Sheppard, Paris, Ill. Pedigree from I. N. Sheppard's catalogue.

Sire of two trotters $\left(2: 22^{1 / 2}\right)$; Io pacers $\left(2: 10^{3 / 4}\right) ; 2$ sires of 2 pacers; I dam of I pacer.

EDGECLIFF (I-32), $2: 29 \mathrm{~T} / 4$, bay; foaled I 875 ; bred by Martin Tourtelotte, Pleasant Prairie, Wis.; got by Baybrino, son of Swigert: dam Moll, gray (dam of Moody, $2: 181 / 2$ ), bred by Martin Tourtelotte, got by Ward Horse, said to be son of Reindeer Messenger; 2d dam Brown Moll, brown, bred by Frank Chase, Bristol, Wis., got by Dragon; 3d dam Morgan brought from Vermont by Major J. Otis. Gelded Young. Pedigree from breeder.

EDGEHILL (3-I 28$), 2: 25$ I $/ 2,153 / 4$ hands, I I 50 pounds; foaled April 29th, I 879 ; bred by Col. Richard West, Georgetown, Ky.; got by Dictator : dam Sue (dam of Dr. West), said to be by Thorndale; and 2 d dam, by a son of Glencoe. Sold to Jerome I. Case, Racine, Wis. Pedigree from Jacobs Bros'., Stock Farm.

Sire of II trotters $\left(2: I^{1}{ }^{1 / 4}\right) ; 3$ pacers $\left(2: I 7^{1 / 4}\right) ;$ I dam of $I$ trotter.

EDGEMARK (1-64), $2: 16$, bay, right fore and left hind feet white, $153 / 4$ hands; foaled April $5^{\text {th, }}$ I 885 ; bred by Claude Thomas \& Bro., North Middletown, Ky., got by Victor Von Bismark, son of Hambletonian : dam bay, bred by Thomas J. Megibben, Cynthiana, Ky., got by Edgewater, son of Curtis' Hambletonian; 2d dam Easter, bred by Smith \& Marders, Pine Grove, Ky., got by American Clay; 3d dam Nanny Marders, bred by Smith \& Marders, got by Ericsson, son of Mambrino Chief; $4^{\text {th }}$ dam said to be by Vermont Morgan. Sold to Col. H. S. Russell, Milton, Mass.; to C. W. Thomas \& Bro., North Middletown, Ky., who send pedigree.; to H. S. Russell, Milton, Mass.; to Horace Cheney, Boston, Mass.

Sire of I6 trotters $\left(2: 07 \frac{1}{2}\right) ; 4$ pacers $\left(2: 15^{1 / 4}\right) ;$ I dam of I trotter. 
EDGERTON ( $\mathrm{I}-32), 2: 26 \mathrm{I} / 2$, bay; foaled $\mathrm{I} 885$; bred by R. P. Pepper, Frankfort, Ky. ; foaled the property of G. \& C. P. Cecil, Danville, Ky. ; got by Blackwood, son of Norman, by the Morse Horse : dam Enterprise (dam of Nuthurst, $2: 2 \mathrm{I}$ ), bay, bred by R. P. Pepper, got by Onward, son of George Wilkes; $2 \mathrm{~d}$ dam Bell Thorne, bay bred by R. P. Pepper, got by Hero of Thorndale, son of Thorndale; 3d dam Abutillon, bay, bred by F. P. Kinkead, Midway, Kentucky, got by Belmont; $4^{\text {th }}$ dam Minna, bay, bred by F. P. Kinkead, got by Red Jacket, son of Billy Root, by Sherman Morgan; $5^{\text {th }}$ dam Undine, said to be by Gray Eagle. Sold to D. K. Shoop, Wauseon, O.

Sire of Nola, $2: 19 \frac{1}{4}$.

ED. GETCHELI, (I-8), brown, bred by A. J. Crowell, Winthrop, Me.; got by Winthrop Morrell, son of Young Morrell: dam bay, bred by Mr. Prescott, Monmouth, Me., got by Downing Horse, son of Gaslin Horse ; 2d dam bay, bred by Mr. Prescott, got by Avery Horse; 3d dam black. Pedigree from breeder who writes:

"He is the same age of Honest Harry; they were sold and went away together when three years old."

EDGEWATER (I-I28), bay; foaled I 872 ; bred by Joseph Boggs, Richmond, Ky., and L. Curtis, Indianapolis, Ind.; got by Curtis' Hambletonian, son of Hambletonian : dam said to be by Embry's Lexington; 2d dam by American Clay; 3 d dam by Ericsson; and 4th dam the Hutchcraft mare. Sold to T. J. Megibben, Lair's Station, Ky. Information from Claude Thomas, Frankfort, Ky., who writes, Feb. 2, I 890 :

"My recollection is that Smith and Marders, Pine Grove, Ky., bred the American Clay, and Ericsson mares; the $4^{\text {th }}$ dam was known as the Hutchcraft mare, breeder unknown."

Very truly, Claude Thomas.

Sire of 2 trotters $\left(2: 27 \frac{1 / 4}{4}\right) ; 5$ dams of 2 trotters, 3 pacers.

EDGEWOOD ( $1-32$ ), $2: 27 \frac{1}{4}$, brown, 16 hands, I075 pounds; foaled I 879 ; bred by W. B. Midway, Sioux City, Ia.; got by Black Ranger : dam bay, said to be by Revenge (sire of Chicago Maid etc.) See letter under Elmwood Chief. Pedigree from breeder.

EDGEWOOD (I-64), bay; foaled I887; bred by the Estate of J. C. McFerran, Louisville, Ky. ; foaled the property of Edgewood Stock Farm, Terre Haute, Ind.; got by Nutwood, son of Belmont: dam Melrose, bay, bred by J. C. McFerran, got by George Wilkes; 2 d dam Moss Rose, brown, bred by A. J. Alexander, Spring Station, Ky., got by Woodford Mambrino, son of Mambrino Chief ; 3d dam Primrose, bay, bred by R. A. Alexander, Spring Station, Ky., got by Alexander's Abdallah; 4th dam Black Rose, bred by John Marder, Winchester, Ky., got by Tom Teemer, 
son of Tom; $5^{\text {th }}$ dam said to be by Cannon's Whip. Pedigree from Edgewood Stock Farm catalogue.

Sire of 2 trotters $(2: 181 / 4), 4$ pacers $(2: 101 / 4)$.

ED. GRAHAM (I-I 28 ), bay, I6 hands, I I 50 pounds; foaled I 879 ; bred by John S. Henwood, Centreville, Wayne County, Ind.; got by Gen. George H. Thomas, son of Mambrino Messenger: dam Queen, bay, bred by John S. Henwood, got by Cloud Mambrino, son of Dan Underhill; $2 \mathrm{~d}$ dam a fast mare brought from Kentucky. Pedigree from breeder.

EDICT S. (I-32), black, I6 hands, I 200 pounds, foaled I884; bred by C. W. Hartley, Goodland, Ind.; got by Dictator, son of Hambletonian : dam Minnie, said to be by Normandie; and $2 \mathrm{~d}$ dam Fanny, by Comet. Sold to D. L. Thomas, Rushville, Ind. ; to W. Tarleton, Greenwood, Ind. ; to C. Lawrence, Morgantown, Ind., 1903, who sends pedigree.

Sire of Black Bess, $2: 24^{3 / 4}$; Prince Edict Fr., $2: 22$.

EDIFICE (3-256), 2 :20, bay, I6 hands, I 250 pounds; foaled I 888 ; bred by Latta Bros., Ligonier, Ind.; got by Jerome Eddy, son of Louis Napoleon: dam Verney, gray, bred by Latta Bros., got by Haw Patch, son of Hambletonian; 2d dam Diana, gray bred by, Latta Bros., got by P. H. Baker, son of Magna Charta ; 3d dam Topsey, gray, bred by Mr. Miller, Goshen, Ind., got by Tuckahoe Post Boy, son of Irwin's Tuckahoe; $4^{\text {th }}$ dam said to be by Printer. Sold to Patrick Summers, Ligonier, Ind., who sends pedigree.

Sire of 3 trotters $2: 22 \frac{1}{4} ;$ I dam of I trotter.

EDINBURG, bay; foaled I $88_{4}$; bred by J. W. Blakemore, Farmdale, Ky.; got by Onward, son of George Wilkes : dam Molly, said to be by Glencoe Jr.

Sire of Rossdile, $2: 12$.

EDISON (3-32), $2: 283 / 4$, bay; foaled $187 \delta$; said to be by Gen. Knox, son of Vermont Hero: and dam May Bug, by Aberdeen, son of Hambletonian.

EDITOR, $2: 233 / 4$, black; foaled I 880 , bred by R. S. Veech, St. Mathews, Ky. ; got by Princeps, son of Woodford Mambrino: dam Duroc Maid, bay, bred by J. D. Willis, Middletown, Ky., got by Messenger Duroc ; $2 \mathrm{~d}$ dam Lady Winfield, chestnut, bred by J. D. Willis, got by Edward Everett; 3 d dam said to be by Rattler, son of Abdallah.

Sire of Ignus Fatuus, $2: 201 / 2$; I sire of I trotter.

ED. KIMBI,E (I-I28), bay with black points, I5 I/2 hands; foaled 1872 ; bred by R. West, Georgetown, Ky. ; got by Almont, son of Alexander's Abdallah : dam Mary C., bay, bred by A. K. Richards, Georgetown, Ky., 
got by imported Knight of St. George ; 2 d dam Mary Christmas, said to be by Rhoderick Dhu. Sold to Harvey Helm, Stanford, Ky. ; to C. I. Pittman, Parksville, Ky., who sends pedigree. Died I 887 or '88.

Sire of 2 trotters $(2: 281 / 2)$; I sire of I pacer; I dam of I trotter.

ED. LONG (I-32), bay, I $43 / 4$ hands, 900 pounds; foaled 1887 ; bred by E. T. Long, Bethlehem, Ky.; got by Ethan Wilkes, son of George Wilkes : dam Patella, bay, bred by E. T. Long, got by Volunteer Star, son of Volunteer; 2d dam Etta Mambrino, bay, bred by George T. Allman, Cornersville, Tenn., got by Henry Mambrino, son of Mambrino Chief; 3d dam Molly C. Pedigree from W. C. Russell, New Castle, Ky., breeder of Dr. L.

Sire of Doctor L., $2: 17 \frac{1}{4}$; I pacer, $2: 12 \frac{1}{2}$.

ED. MACE (3-64), $2: 261 / 4$, brown; foaled 1880 ; bred by Ed. J. Saunderson, Somerset Centre, Mich.; got by Hambletonian George, son of Masterlode (dam by American Star) : dam Flora, said to be by Johnnie Slasher; and 2d dam by Magna Charta, son of Morgan Eagle Jr., by Morgan Eagle, son of Woodbury Morgan. Sold to P. Hall, Jackson, Mich.; to McIntyre \& Dikeman; to E. B. Dikeman, Grand Rapids, Mich. Gelded young. Information from E. B. Dikeman, Grand Rapids, Mich., who writes, May 30, I 887 :

"The man who raised the dam of Ed Mace, did not remember sire's name, but H. Baker of Union City who owned Ed's sire, said his name was Johnnie Slasher-a black stallion that was owned near Moscow 20 years ago. Ed's dam now is 20 years old if living."

EDMORE, $2: 29 \frac{1}{2}$, bay with black points, $15 \frac{1}{2}$ hands, Iooo pounds; foaled I 88 I ; bred by Dewey and Stewart, Owosso, Mich.; got by Louis Napoleon, son of Volunteer : dam Fanny Mapes, bay, bred by John W. A. Brewster, Goshen, N. Y., got by Alexander's Abdallah, son of Hambletonian; 2d dam bred by Willett Underhill, Glencoe, L. I., got by Burr's Napoleon, son of Young Mambrino, by Mambrino; 3d dam Brooks, bred by Charles Brooks, Harlem, N. Y., got by Long Island Black Hawk, son of Andrew Jackson; 4th dam bred by Gen. Fox, Harlem, N. Y., got by imported Trustee. Sold to Dr. F. B. Galbreth, Pontiac, Mich. Pedigree from breeder.

Sire of Edmond, $2: 161 / 4 ; 3$ dams of 2 trotters, I pacer.

EDRAMON ( I-64), $2: 2 \mathrm{I} \mathrm{I} / 2$, brown, I $5 \frac{1}{2}$ hands, I I 50 pounds; foaled I 890 ; bred by L. B. Morey, Aledo, Ill.; got by Game Onward, son of Onward : dam Mattie, bay, bred by S. Spreaker, Preemption, I1l., got by Carenot (Sisson's), son of Benedict Morrill. Sold to H. M. Brookman, Andalusia, Ill.; to Mr. Keel, Edgington, Ill. Pedigree from breeder.

Sire of 2 pacers $(2: 2 \mathrm{I})$.

ED. R. B. (5-5 I2), bay; foaled 1887; bred by Daniel Hayes, Muscatine, 
Ia. ; got by Tramp, son of Logan : dam Mary Compton (Chiquita), said to be by Harry Compton, son of Kirkwood; and $2 \mathrm{~d}$ dam Col. Horton's Spotted mare. Sold to Schermerhorn \& Banks; to Ed. R. Banks, Nevada, Ia.; to Frank Wallace, Eldora, Ia.

Sire of Farmer Boy, $2: 263 / 4$.

EDSALL CLAY ( $1-128$ ), brown; foaled $186-$; said to be by Harry Clay, son of Cassius M. Clay Jr., by Cassius M. Clay : dam untraced.

Sire of Vision, $2 ; 261 / 4$,

EDSALL STAR (BIG THUNDER) ( $\left.7-\mathrm{I}_{2} 8\right)$, chestunt with star, right fore and left hind ankle white, $\mathrm{I} 53 / 4$ hands, II50 pounds; foaled 1879 ; bred by Judson H. Clark, Elmira, N. Y.; got by Major Edsall, son of Alexander's Abdallah : dam Lady S., said to be by American Star Jr., son of American Star; and $2 \mathrm{~d}$ dam Miss Cadmus (dam of Stephen M., 2 :29), by Long Island, son of Napoleon (Burr's). Sold to T. D. Hodgens, London, Ont. ; to H. DeGraw ; to J. O. Crandall, Brookfield, Mo., and W. A. White, St. Joseph, Mo., who send pedigree.

Sire of 2 trotters $(2: 161 / 4)$

ED. SHERMAN (3-32), bay with star and white hind ankles, I6 hands, I 50 pounds; foaled I 864 ; bred by Edmond Sherman, Danby, Vt. ; got by Gen. Sherman, son of Young Columbus : dam Nancy, bay, with star, snip and four white feet, bred by John Sherman, Danby, Vt., got by Andrus Hamiltonian, son of Judson's Hamiltonian; 2 d dam bay, small blaze and white hiad ankles, bred by John Sherman, got by American Figure, son of old Childers; 3 d dam black, bred by John Sherman, got by Barker's Speculator. Sold to E. R. Sherman who owned him two years and sold to J. S. Strand, St. Albans, Vt. Pedigree from E. R. Sherman. Record of $2: 52$ in his only race at Rutland Fair. Died I 885 .

Sire of Morris, $2: 29$.

EDSON ALLEN (3-32), $2: 171 / 4$, brown, I6 hands, I Ioo pounds; foaled I 885 ; bred by Simeon H. Edson, Colchester, Vt. ; got by Ethan Allen (Holabird's), son of Ethan Allen : dam bay, bred by S. H. Edson, got by Patchen, son of Mambrino Patchen. Sold to B. A. Austin; to D. E. Grosvenor, Bridport, Vt. Pedigree from E. F. Brownell, Burlington, Vt. Sire of Cinderella, $2: 24^{1 / 2}$.

ED. SUTHERLAND (5-128), $2: 29 \frac{1}{2}$, bay, $153 \frac{3}{4}$ hands, I IOo pounds; foaled I 884 ; bred by Mrs. W. D. Sutherland, Winchester, Ky. ; got by Egbert, son of Hambletonian : dam Lizzie Winn, sorrel, said to be by Ericsson, son of Mambrino Chief ; 2d dam Fanny by Doniphan, son of Davy Crockett; $3 \mathrm{~d}$ dam, by Quicksilver, son of Diomed (Benton's) ; and $4^{\text {th }}$ dam by Cadet, son of Medley. Sold to E. G. Sutherland, 
Winchester, Ky. ; to B. F. Leggett, Cawker City, Kan., who sends pedigree. Died I 900 .

Sire of $Q . R . Z, 2: I_{4}^{1 / 4}$

EDWARD (I-32), 2 :19, chestnut; foaled April II, 1872; bred by J. A. Cook, Elkhart, Ind.; got by Masterlode (dam by American Star), son of Hambletonian: dam Dolly, bay, foaled 1852 , bred by Chas. Norton, Cassopolis, Mich., got by a Morgan Horse owned by a Mr. Haskins then of Muskegon, later of Iowa. Gelded young.

Mr. Battell,

$$
\text { Cassopolis, Mich., Oct. 2, I892. }
$$

Sir :-Yours of the $25^{\text {th }}$ received and in reply would say that the mare Dolly dam of Edward was by a horse claimed to be Morgan. He was owned by a Mr. Haskins now of Iowa if I can get his address will send it to you. Her dam was a bay mare brought to Michigan from Ohio, about the year 1840 . Think it would be impossible to establish her breeding.

Dolly was a bay with long mane and tail, a perfect type of a Morgan. She was foaled in $185^{2}$, passed through many hands before Mr. Cook got her.

$$
\text { Yours truly, M. Z. NoRToN. }
$$

EDIVARD, said to be by Bell's Copperbottom, son of old Copperbottom : dam by Cannon's Whip. Information from Ashland Park Stock Farm, catalogue, I888, B. J. Treacy, proprietor, Lexington, Ky.

EDWARD A. (I-I28), $2: 25$, bay, I 6 hands, I 200 pounds; foaled I 888 ; bred by Otis Hall, Eldora, Ia.; got by Alaric, son of Cuyler : dam Bessie E., bay, bred by Otis Hall, got by Dick Edwards, son of Clark Chief Jr ; 2d dam Elmira, bay, bred by Otis Hall, got by Alfred, son of Charles Backman. Sold to Thomas Young, Eldcra, Ia. Killed by lightning I 898 . Pedigree from H. S. Martin, Eldora, Ia.

Sire of Quicksituer, $2: 24 \frac{1}{4}$

EDIVARD EVERETT (GEN. MOTT, MOTT COLT, GRAND ISLE CHIEF) (3-32), $2: 361 / 2$, dark chestnut, I5 hands, Iooo pounds; foaled I 855 ; bred by Joseph M. Mott, Alburgh, Vt.; got by Sherman Black Hawk: dam bay, bred by Joseph M. Mott, got by Morgan Bellfounder, son of Putnam Morgan; 2d dam bay, bred by Benjamin Mott, Alburgh, Vt.; got by a horse from Canada called Gamester; $3 \mathrm{~d}$ dam chestnut.

Part interest sold to Edward Mott, I 855 . Taken 1859 , by Horace W. Brown, to Village Stock Farm, Buffalo, N. Y., and later sold to R. S. Veech, and J. B. Parks, St. Mathews, Ky., for \$200o. Dr. R. W. Pearce of Louisville, Ky., writes: "Edward Everett was a typical Morgan and could trot in about $2: 37$; was a great show horse seldom beaten in the fair ring, and won many match races. He got many fast roadsters." See The Morgan Horse and Register, Vol. I., p. 397. 
Interesting letter from Cyrus Lukens, Esq :

Philadelphia, Penn., June, i I, I 888.

Editor Register:-Among your extracts in issue of June 8, from American Cultivator, the stallion Gen. Mott is referred to. $\mathrm{He}$ was not gelded, but stood a few years for service near Newtown, Bucks County, Penn., and was then owned by Henry West. Mr. West took great delight in describing a great flight of speed Gen. Mott once showed hooked in double harness. This stallion was afterwards taken to the west of Albany in New York State and was still standing for service there a few years since. He got some speed, but his peculiarly sullen temper rendered him useless in a race and has caused singular trouble among his get. While near Newton, Bucks County, Penn., he met with many mares by Black Bashaw (Doble's). After he went to west of Albany he met with mares by Freehold Bashaw, full brother to Black Dutchman, both by Black Bashaw (Doble's). Freehold Bashaw was a very stylish horse and will be remembered by many horsemen of Northern New Jersey as being the handsome black stallion that was shown at Somerville and other fairs by old John Doty, the trainer and driver. This stallion had gone to the west of Albany some years before Gen. Mott arrived there. Henry West always said that Gen. Mott could impress his form upon the produce of any mare by any other stallion, Hambletonian or otherwise, except the mares of Black Bashaw (Doble's), or mares from Freehold Bashaw. Whenever a man brought a mare to Gen. Mott, by Doble's Black Bashaw or by Freehold Bashaw, Mr. West said he always told the man to look at his own mare for there was his colt's head.

$$
\begin{array}{lr}
\text { Yours etc., } & \text { Crrus Lukens. } \\
& 933 \text { Melon St. }
\end{array}
$$

EDWARD EVERETT (MAJ. WINFIELD), $2: 48$, bay; foaled I 855 ; bred by Thomas George, Newburgh, N. Y.; got by Hambletonian, son of Abdallah: dam Fanny, pedigree unknown. Sold December r 869 to Robert Bonner, New York. Died Aug. 25th, I878. Edwin Thorne, Millbrook, N. Y., writes, Oct. I2, I 887 :

"I am trying to find the present address of Thomas George, who bred Maj. Winfield, better known as Edward Everett, and gave him his pedigree which was a fraud. He was a lawyer in Newburg, N. Y., and ran away between two days, leaving many creditors behind."

Leander Clark, Newburgh, N. Y., Feb. 17, I892, writes :

"Pedigree of dam of Edward Everett,--said to be by Margrave,-I know of my personal knowledge was made by Thomas George, and was bogus."

From Spirit of the Turf.

"Edward Everett was a small but lengthy-appearing horse, $6 \mathrm{I} \mathrm{I} / 2$ inches or $I 5$ hands $I \frac{1}{2}$ inches, in height; his shoulder extending forward, like that of his sire, and far backward at the buttock or posterior, which gave him his appearance of length of body. His withers rose more prominently than did those of his sire, his tail or croup stood not quite so high, and his whirlbone, being much lower, gave him the sloping rump, or drooping hind quarters, quite unlike the Messenger and Bellfounder families. His skin was of the finest texture, and he showed a glossy 
golden bay coat, not equalled by any son of Hambletonian-all pointing to a horse of very high breeding. His eyes were wide apart and very prominent. In point of temper he was not of the best. When we last saw him, his keeper was afraid of him, and he was tied with three halters, no one, as it seemed, daring to approach him. This we were told, was in large part owing to improper treatment by those who raised him."

Sire of $I_{3}$ trotters $(2: 18)$; 12 sires of 90 trotters, 22 pacers; $I_{4}$ dams of 17 trotters, I pacer.

EDIVARD G. (HORACE GREELEY, JOHN B.) (I-32), bay; foaled IS-; bred by Charles Redmond, Paris, Ky.; got by John Dillard, son of Indian Chief: dam said to be by Cook's Whip, son of imported Whip. Property of J. W. Browning, Indianapolis, Ind.

Sire of Kentucky Girl, $2: 281 / 4$; I dam of I trotter, I pacer.

EDIVARD H. (I-I6), 2 :32, bay; foaled I 874 ; bred by Alexander Davidson, Williamsport, Penn.; got by Champion, son of King's Champion, by Grinnell's Champion, son of Almack; dam Mary Brown, gray, said to be by American Star. Gelded when four years old. Pedigree from breeder.

Sire of Pilot Boy, $2: 20$.

EDWARD KING (7-64), bay; foaled I 889 ; bred by E. M. Phelon, Cherry Valley, N. Y.; yot by Wilkes' Spirit, son of George Wilkes: dam Antoinette, brown, bred by E. M. Phelon, Cherry Valley, N. Y., got by Aristos, son of Daniel Lambert ; 2 d dam Bay Fanny, said to be by Abraham, son of Daniel Lambert; 3d dam Fanny Allen, by Ethan Allen, son of Black Hawk; $4^{\text {th }}$ dam Fanny Cook (dam of Daniel Lambert), by Abdallah, son of Mambrino. Pedigree from breeder.

EDWARDS HORSE (I-I6), bay, I5 I/4 hands, IO25 pounds. Purchased in Sherbrooke, P. Q., for J. H. Edwards, Winooski, Vt., by William Brooks. Owned by Edwards and White, Winooski, who sold to David Murray \& Sons, California. A. B. Edwards of Winooski, brother to J. H. Edwards writes :

"When in Sherbrooke some years ago I was shown the dam, dark bay with heavy tail, said to have been imported from England, owned by an English officer. Don't know sire of horse. Horse trotted or paced in $2: 25$, two miles in less than five minutes, no record. (A. J. Morrill's track)."

Sire of dam of Billy Ring, sire of dam of Mac, $2: 163 / 4$.

ED. WILKES $(\mathrm{I}-32), 2: 26 \mathrm{~T} / 4$, brown, one white foot, I6 hands, I 200 pounds; foaled I 882 ; bred by Hiram Bush, Globeville, Mich.; got by Young Wilkes, son of George Wilkes: dam Flora Bush, bay, said to be by Ireland Horse, son of One-Eyed Morgan. Died igor. Sold to Clarence Van Buren, Decatur, Mich.; to Daniel B. Knight, Decatur, Mich., who sends pedigree.

Sire of Perfecto, $2: 181 / 4$. 
ED. WILKES (I-32), $2: 28 \frac{1}{2}$, black, $15-3 \frac{1}{2}$ hands, I050 pounds; foaled I 885 ; bred by E. W. Robbins, Columbus, Bartholomew County, Ind. ; got by Bartholomew Wilkes, son of George Wilkes, by Hambletonian : dam black, bred by Anderson Newton, St. Louis Crossing, Ind., got by Girard's Stockbridge Chief, son of Stockbridge Chief, by Black Hawk, son of Sherman Morgan; 2 d dam brown, bred by Washington Burns, Hope, Ind., got by Woolley's Whip (sire of Longfellow's Whip), son of Kentucky Whip. Sold to S. E. Larrabee, Deer Lodge, Mont. Pedigree from breeder.

EDIVIN DOWNING, dark bay i 6 hands, said to be by old Joe. Advertised near Paris, Ky. (about I876), in Lexington (Ky.) papers.

EDWIN FORREST. Gelded young. One of the most famous of the early trotters, bred, at least owned in Massachusetts, said to be Morgan. We have seen a very circumstantial account of the early history of this horse with statement that he was of Morgan origin, and published in such form as to be preserved, so that we shall expect to come across it again, but it is now mislaid.

A correspondent of Wallace's Magazine states that he was foaled I 827 , the property of Joseph Strong, South Hadley, Mass: dam a small bay mare that Mr. Strong came into possession of when in foal.

This correspondent further states that the colt was purchased in I8 31 of Mr. Strong by John Goodrich of Springfield, Mass., for $\$ 65$ and taken with other horses to Hartford, Conn., for sale.

Mr. Barnard of Sherbrooke, P. Q., in a letter to The Spirit of the Times, I $8_{4-}-$, asks :

"What horse is sire of the celebrated trotter Edwin Forrest? It was said he was got by a small Canadian sorrel horse called Tuscarora, owned in his old age by Gen. Emory, of Centerville, Eastern Shore, Md."

The New York Spirit of the Times says, May I2, I 849 :

"Is said to have been bred in Maine and in I $\$ 49$ was owned and driven in Philadelphia."

The American Turf Register, Vol. V. (1833), says :

"In race between Sally Miller and Edwin Forrest, the latter won first heat in the unprecedented time of two minutes, thirty-one seconds. In the second heat the mare made several bad breaks and Forrest won it with apparent ease in $2: 33$, we believe this to be the quickest trotting on record, and Edwin Forrest has now established his character as the fastest mile horse in the United States."

EDIWIN FORREST (ALEXANDER'S), bay, black points, I6 hands, I roo pounds; foaled June, 1850 ; bred by Barnes Davis, Oneida, Madison County, N. Y.; got by Bay Kentucky Hunter, son of One-Eyed Kentucky Hunter : dam Doll bred by Wm. Crane, Deerfield, Oneida County, 
N. Y., got by Watkins' Young Highlanter, son of imported Brown Highlander; $2 \mathrm{~d}$ dam said to be by a horse called Inuroc. Sold to H. S. Barker, Clinton, Oneida County, N. Y., and by him, i 856 , to J. L. I owning, Kentucky, who sold to R. A. Alexander, Kentucky. He made the season of I 865 , at Aurora, I1l., was brought back to Kentucky same fall and sold to W. H. Sample, Keokuk, Ia., and later to G. W. Ferguson, Marshalltown, Ia., where he was burned 1883 in the stable.

Hart Boswell, Lexington, Ky., breeder of Nancy Hanks, $2: 04$, in interview with author, 1893 , said :

"Edvin Forrest was a great horse but had no opportunities. He was the right horse to breed to, for a show horse. He was a splendid looking horse vith a great deal of style. Bay, $15 \frac{1}{2}$ to 16 hands and could trot in 3 minutes. Stout enough. A model horse. One of the finest horses to lool: at, ever brought to this country."

Mr. Barnes Davis writes :

"Kind, high action, very stylish, natural trotter. He trotted at Springfield, Mass., fall of 1854 ; drew me and I 35 pound cart in $2: 58$, without any training. Think he was the first three-year-old that ever made that time in this State. He was burnt with ten others in Iowa, 33 years old, sound, vigorous and active as ever."

Advertised as follows in Kentucky, 1857 :

"The Northern Horse, Edwin Forrest: at stable of J. L. Downing, three miles from Lexington, Ky., on Versailles Pike. Bay, seven years old this spring, sixteen hands one inch high. He was got by Bay Kentucky Hunter, by Highlander."

There are several erroneous statements in the advertisement as for instance, that Bay Kentucky Hunter, was the sire of Flora Temple ; and dam of Flora Temple, by old Kentucky Hunter.

Mr. L. M. Jones, Vernon, N. Y., writes in Wallace's Monthly :

"In the November number of the Monthly, page 743, Hopeful says :

'The dam of Mambrino Dudley was by the pacing-bred Edwin Forrest, himself a converted pacer.' Without contradiction, this goes on record as a fact. Let us go back thirty years, and see if he was a converted pacer. The first time I ever saw Edwin Forrest was at the Oneida County Fair at Rome in I 852 (Mr. Davis would say a year or two earlier, but I think I am correct), when he was two years old he was shown in harness, hitched double beside his dam. He certainly trotted square then as also did his dam. I thought so well of him there that I bred to him next season. At the same Fair, in $\mathrm{I}_{\mathbf{8}} \mathbf{5 3}, \mathrm{Mr}$. Davis drove him to harness, being able to distance any other three-year-old there; it was said, and I never heard it disputed, that he trotted a half mile in $\mathrm{I}: 2 \mathrm{I} / 2$, a $2: 43$ gait. Certainly, he was a very fast trotter (not pacer). That year Mr. Davis sold him to Mr. H. L. Barker; I bred to him and saw him often for the next two years, when he was sold to Mr. Alexander of Kentucky. I never heard him called a converted pacer; he must have been converted very young. Was he pacing bred? I have said his dam was a trotter. She was by Watkins' old Highlander (a square trotter), from a fast trotting mare known as the Widow Crane Messenger mare. 
The sire of Edwin Forrest was Bay Kentucky Hunter. I bred to him also, and knew him well; I never saw him in harness; don't know that he was ever harnessed; have seen him on the road often, and at Fairs; I never saw him pace. His grandsire I never saw; but I always heard he was a square trotter. In his great-grandsire, old Kentucky Hunter, I find the only pacing element in the pedigree. He was a fast trotter, also a fast pacer, but he was by Watkins' old Highlander, a trotter, dam a square trotting mare, brought from Kentucky, by Louis Sherrill of New Hartford, and said to be thoroughbred.

L. M. J."

This would appear to be entirely correct so far as the gait of Edwin Forrest is concerned. The testimony is somewhat conflicting in regard to his sire, but our information we think is conclusive, that he was bred by George W. W. Loomis of Sangerfield, Oneida County, N. Y., foaled I839, got by One-eyed Kentucky Hunter, then a two-year-old colt owned by Mr. Loomis. The dam of One-Eyed Hunter is understood to have been also bred by Mr. Loomis, and a sister to the stallion Bogus, bred ky him, and which, whilst he owned him, got Flora Temple. See Bay Kentucky Hunter, and One-eyed Kentucky Hunter (Hunter Morgan).

Oneida, N. Y., March I I, I 885 .

Editor Register :-Yours received and contents noted. I cannot give you the information you want. I think Watkins' Highlander was bred in Connecticut, but I am not sure. Watkins lived at Whitestown, four miles from Utica. I bred a mare to Watkins' Highlander over 40 years ago. I think if you will write Wallace Jones and direct to Westmoreland or Vernon, he will answer you; he has been looking up pedigree of Edwin Forrest for two or three years and I have given him all the information I have.

$$
\text { Yours truly, Baries Davis. }
$$

Oneida, N. Y., March I6, I885.

Editor Register :-Yours received. I cannot fix the exact date that I took the mare to Highlander, but think it was in I834. Edwin Forrest was foaled in $\mathrm{r} 850$, and his dam was by Watkins' Highlander. Watkins' Highlander was bay, black points, about I 5 hands I inch high and about Iooo pounds, and he was as handsome a horse as you ever saw : he stood up like a game cock and had good action. I remember well when the mare kicked him and broke his leg, but I cannot fix the date; think if you write Morris Cushman, Vernon, or Wallace Jones, Westmoreland, you can get what information you want.

$$
\text { Yours truly, Barnes Davis. }
$$

Editor of the Register to Barnes Davis.

Barnes Davis, Esq.,

Middlebury, May 21, I885.

Dear Sir :-I notice in your letter to me of March I I, '85, that you say you think Watkins' Highlander was bred in Connecticut. Did Mr. Watkins own two horses called Highlander, or was it the horse called Young Highlander that you suppose was bred in Connecticut? Do you 
understand that this horse was got by imported Brown Highlander? Will you please return this letter with your reply and greatly oblige.

Mr. BatTeLL,

$$
\text { Oneida, N. Y., May 23, I } 885 .
$$

Yours received and contents noted. I am very sure Watkins' Young Highlander was bred in Connecticut and just as sure he was got by imported Brown Highlander. I have always understood it was so and think there is no mistake about it.

$$
\text { Yours respectfully, Barnes Davis. }
$$

Mr. Joseph Battell,

$$
\text { Lairdsville, N. Y., Feb. 5, r } 906 .
$$

My Dear Sir :-Yours of February 2d, received. Mr. Ferguson sold Bay Kentucky Hunter in the fall of $\mathbf{1} 849$ or spring of $\mathbf{1} 850$. He was not here during the season of 1850 , as Edwin Forrest was foaled that year and Mr. Davis would have bred the mare Doll back to him if he had been here. Now that is my recollection. I know he bred to BrokenLeg Hunter in I 850 the produce being Womack's Highland Messenger. I have records that Edwin Forrest was shown and took first premium at the Oneida County Fair as a two-year-old in 1852 , of course he was not named then. Bay Kentucky Hunter was not brought back to this county; if he had been, I certainly should have heard of it, as he was noted as the sire of Edwin Forrest. An old horseman from Clinton was here recently. He says Robinson's Washtenaw Chief was always kept at Clinton and died in Mr. Robinson's stable.

Yours truly, L. M. JonEs.

Mr. Wallace writes in his Monthly:

"We have received quite a long communication about the true pedigree of Edwin Forrest and Highland Messenger (Wamock's), in which some facts are brought out that we had already secured from another source, but which have not been known to the public. Alexanders's Edwin Forrest and Wamock's Highland Messenger were both bred by Barnes Davis of Oneida, Madison County, N. Y., and were both from the same mare. Mr. Davis called this mare Doll,' and she was got by Watkins' Highlander; her dam was a chestnut mare owned in the Crane family.

"The old horse had a son called Chestnut Kentucky Hunter, and this horse had a son called Broken-Legged Kentucky Hunter, that was the sire of Highland Messenger. These facts we obtained recently from Barnes Davis, through the kindness of Mr. L. M. Jones. 'Mr. Davis sold Edwin Forrest to Mr. Barker of Clinton, N. Y., and Mr. Barker sold him to Mr. Downing, of Kentucky, and not to Mr. Alexander, as it has been generally understood. Whether Mr. Alexander was in partnership with Mr. Downing in the ownership of the horse from the start we do not know, but he was kept by Mr. Downing some seasons in Kentucky, before Mr. Alexander became the sole owner of him, and transferred him to Woodburn. He was foaled in $185 \mathrm{I}$, and Highland Messenger was one year younger. Mr. Wamock's attention was drawn to Highland Messenger by having seen Edwin Forrest and trying to buy him, but was too late. Mr. Davis then told him he had a half-brother that he would sell him on a guarantee that he would show three minutes on the track, or no sale. He says he went to see the horse, held his watch on him, and he trotted the mile in $2: 43$. This is a little better than we sup- 
posed either of these horses could trot, but we knew they were both esteemed fast for their day. It is only recently that we have been able to account for the speed in the Kentucky Hunter family. In all that has been written about him, the fact has been studiously concealed that the original was a fast pacer." "

Sire of 2 trotters; 7 sires 8 trotters, 4 pacers; II dams I4 trotters, I pacer.

EDIVIN FORREST (BUCKLEY'S); foaled I85-; said to be by Edwin Forrest, son of Bay Kentucky Hunter: dam by Woodford, son of Kosiusko, by Sir Archy.

Sire of I trotter, also of Ned, dam of 4 with records from $2: 15^{1 / 2}$ to $2: 25 \frac{1}{4}$.

EDWIN FORREST (CARR'S) (I-32), bay with star, I6 $1 / 2$ hands, I 200 pounds; foaled I859; bred by Dabney Carr, Chilesburg, Ky.; got by Alexander's Edwin Forrest, son of Bay Kentucky Hunter: dam Kate ( $2 \mathrm{~d}$ dam of Ambassador), black, bred by Dabney Carr, got by Todhunter's Sir Wallace (see Ambassador); $2 \mathrm{~d}$ dam bay, bred by David Carr, Lexington, Ky., got by Darnaby's Copperbottom ; 3d dam black, bred by Richard Chiles, Chilesburg, Ky., got by Hunt's Highlander. Made four seasons in Fayette County, Ky., and was sold about I 866 to John W. Martin, DeKalb, Buchannan County, Mo. Information from Dabney Carr, who in interview at Lexington, Ky., May, I905, said that the 2 d dam was roan, a fast pacing Copperbottom mare, could pace faster than she could run.

EDWIN FORREST (GRATZ') (3-64), bay, I53/4 hands; bred by M. B. Gratz, Spring Station, Ky.; got by Alexander's Edwin Forrest: dam Portia, bred by Mr. Gratz, got by Roebuck, Canadian. Information from Mr. George T. Graddy, a very intelligent gentleman of 8o years or more, whom we met at Versailles, Ky., May, 1905. Mr. Graddy said :

"Blind, a trotter, and could trot in $2: 30$. Portia could not trot at all but nothing could pass her on the road. Edwin Forrest was a nice shaped bay horse, a handsome horse, $153 / 4$ hands. He had the broad forehead between the eyes that the family has. A good arched neck, and a good head. He died about 1888 .

"Alexander's Edwin Forrest was one of the handsomest stallions you ever looked at; a horse of remarkably fine courage and all his colts of great style and speed. He was about 16 hands, fine neck and head, slightly peaked behind."

Sire of Little Belmont 2:30.

EDWIN FORREST (GRINNELL'S) ( I-64), bay, I 6 hands, I 200 pounds ; foaled I86-; bred by Wm. Grinnell, Oxford, Ky. ; got by Edwin Forrest, son of Bay Kentucky Hunter: dam bay, bred by Ben. Shropshire, Leesburg, Ky., got by a Cleveland Bay ; $2 \mathrm{~d}$ dam bred by Ben. Shropshire, got by Shropshire's Whip Comet. Sold to D. B. Lee, Carrollton, O. Information from Thomas K. Shuff, Leesburg, Ky.

Sire of Kate Owen, $2: 261 / 4$; I dam of I trotter. 
EDWIN FORREST (HADDOCK'S) ; foaled I87I; bred by J. N. Haddock, Harrisonville, Mo.; got by Brannock's Ned Forrest, son of Joe Downing, by Alexander's Edwin Forrest : dam Fanny Monday, by Smiling Tom, dark chestnut, I5 hands, son of Sidi Hamet. Gelded and sold to Robert Bonner, New York, for $\$ 16,000$. His record is $2: 18$, but he made a public trial at Hartford in 1878 in $2: 141 / 2$, and in 1879 , he trotted a trial in harness in $2: 113 / 4$, and to a wagon over Mr. Bonner's track, in 2:I 5 1/4.-Middlebury, Vt., Register, Vol. LII.

EDIWIN FORREST (HUGHES'), bay, small star, i6 hands, about i Ioo pounds; foaled I 859 ; bred by James Holbert, Keene, Ky.; got by Alexander's Edwin Forrest, son of Bay Kentucky Hunter: dam bay, bred by James Holbert, got by Enoch Smith's Gray Highlander; 2 d dam bay, said to be by Buford's Cripple, son of Medoc. Sold to Samuel C. Hughes, Keene, Ky.; to James C. Graves, Pinkard, Ky. Died about 1876 in Keene, Ky. Pedigree from breeder.

Sire of Cleveland, $2: 281 / 4$.

EDIVIN FORREST (STANHOPE'S) ( I-64), bay; foaled I 85-; bred by Wm. F. Stanhope, Lexington, Ky.; got by Edwin Forrest son of Bay Kentucky Hunter : dam said to be by Abdallah.

EDIVIN THORNE, $2: 23 \frac{1}{2}$, chestnut, I 6 hands; foaled 1873 ; bred by George Gordon; got by Thorndale: dam said to be by Ashland, son of Mambrino Chief; and 2d dam by Eureka, son of Long Island Black Hawk.-National Live Stock Journal, 1880.

EDIVIN V. (I-32), chestnut, I6 hands, II 50 pounds; foaled I892; bred by S. H. Wheeler, Chicago, Ill. : got by Egotist, son of Electioneer : dam bay, bred by J. I. Case, Racine, Wis., got by Phallas, son of Dictator : $2 \mathrm{~d}$ dam Mabel H., chestnut, bred by L. H. Thompson, Kingston, Mo., got by Col. West, son of Almont; 3d dam Nelly Gray, said to be by White Mountain Jr. Sold to D. D. Darling, Chicago, Ill.; to George Vogel, Solon Mills, Ill., who sends pedigree. Died, I904.

Sire of Bub O'Reil, $2: 061 / 4$.

EGALITE (3-64), $2: 20 \mathrm{I} / 2$, chestnut, I6 $1 / 4$ hands; foaled I $88 \mathrm{I}$; bred by R. West, Lexington, Ky. ; got by Egbert, son of Hambletonian : dam Stockbridge Belle, chestnut, bred by John Landrigan, Lexington, Ky., got by Stockbridge Chief, son of Black Hawk; 2 d dam Sue Letcher, said to be by Alexander's Norman. Sold to W. R. Letcher, Richmond, Ky. Pedigree from catalogue of owner.

Sire of 5 trotters $\left(2: 15 \frac{1}{4}\right)$; Bettie Mack, 2:161/4; I sire of I trotter; 2 dams of 2 pacers.

EGBERT, bay, small star, snip, near hind ankle white, $15 \mathrm{~T} / 2$ hands; foaled I 875 ; bred by J. H. Walker, Worcester, Mass. ; got by Hambletonian : dam Camptown, bay, bred by David R. Feagles, Chester, N. Y., got by 
Messenger Duroc, son of Hambletonian; 2d dam Miss McCloud, bred by Peter J. Brown, Pine Island, Orange County, N. Y., got by Hobert Colt, son of Hambletonian; 3 d dam said to be by Utter Horse, son of Hoyt's Comet; and 4th dam Virgo, by Roe's Abdallah Chief, son of Abdallah. Owned by Col. Richard West, Lexington, Ky. Died i 896 . Pedigree from breeder.

Sire of 67 trotters $\left(2: I_{2} \frac{1}{2}\right)$, I8 pacers $(2: 12) ; 39$ sires of 62 trotters, 49 pacers; 41 dams of $3^{6}$ trotters, 18 pacers.

EGBERTIE (I-32), chestnut, I5 I/2 hands, Iooo pounds; foaled 1884 ; bred by R. West, Lexington, Ky.; got by Egbert, son of Hambletonian : dam Annie, bred by W. T. Chambers, Eden Grove, Va., got by Cottrill Morgan, son of Black Hawk; 2 d dam said to be by Consul Horse. Sold to W. P. Janes, Warren Park Farm, Terre Haute, Ind., who sends pedigree; to M. A. McDonald, West Lebanon, Ind.

Sire of 2 pacers $(2: 161 / 2)$.

EGG HOT ( $\mathrm{I}-32$ ), bay; foaled I 888 ; bred by Richard West, Lexington, Ky.; got by Egbert, son of Hambletonian : dam Laura, (dam of McAllister $2: 27$ ), said to be by Billy Adams, son of Almont; $2 \mathrm{~d}$ dam Tilter, by Ward's Flying Cloud, son of Black Hawk; and 3d dam by Toronto, son of St. Lawrence. Sold to T. O. Forman, Lexington, Ky. ; to J. V. Baker, Paris, Tenn.

Sire of Hetty G., $2: 05^{1 / 4}$.

EGG N()G, $2: 153 / 4$, black, I5 1 $1 / 2$ hands, I050 pounds; foaled I 886 ; bred by John H. Cooper, Georgetown, Ky. ; got by Egbert son of Hambletonian : dam Fanny, said to be by Long Island Bashaw. Sold to J. A. McElwain, Bowling Green, Ky. Kept at Carthage, Mo., I 894 .

Sire of Frank Temple, $2: 25$.

EGLAMOUR (I-32), dark bay, I5 hands, I050 pounds; foaled I 883 ; bred by H. L. Russell, Milton, Mass. ; foaled the property of G. M. Thomas, New York City, N. Y.; got by Smuggler, son of Blanco, by Iron's Cadmus, son of Cadmus, by American Eclipse, son of Duroc: dam Kalphunia, said to be by Caliban, son of Mambrino Pilot, by Mambrino Chief; 2 d dam by Clark Chief, son of Mambrino Chief; 3 d dam by

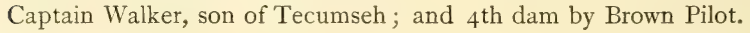

EGROE (I-64), $2: 143 / 4$, roan; foaled I 885 ; bred by Rody Patterson, Jr., Lexington, Ky. ; got by Egbert, son of Hambletonian : dam Uzella, gray, bred by R. P. Todhunter, Lexington, Ky., got by Mambrino Patchen; 2 d dam Morning Dawn, roan, bred by R. P. Todhunter, got by Marengo ; 3d dam (dam of White Oak), said to be by Roebuck; and 4th dam by Sam Slick, son of Pilot. Sold to J. E. Madden, Lexington, Ky. ; to P. B. Conn, Steubenville, O.

Sire of 2 pacers $\left(2: 17^{3} / 4\right)$. 
EGMONT ( $1-32$ ), bay, $153 / 4$ hands, Ir 50 pounds; foaled 1873 ; bred by A. J. Alexander, Spring Station, Ky. ; got by Belmont, son of Alexander's Abdallah: dam Minerva, brown, foaled 1863, bred by R. A. Alexandcr, Woodburn Farm, got by Pilot Jr.; 2 d dam Bachante Mambrino, gray, foaled r 858 , bred by R. A. Alexander, Spring Station, Ky., got by Mambrino Chief, son of Mambrino Paymaster ; 3d dam Bachante, gray, bred by R. A. Alexander got by Downing's Bay Messenger. Sold, I874, to R. P. Pepper, Frankfort, Ky. ; to Bruen \& Peasely, Carmen, Ill. Pedigree from Pleasant View Stock Farm.

Sire of 32 trotters $\left(2: 10^{3 / 4}\right), 9$ pacers $\left(2: 14 \frac{1 / 4}{4}\right) ; 21$ sires of 37 trotters, 15 pacers; 18 dams of 11 trotters, 12 pacers.

EGMONT CHIEF (3-128), $2: 24 \frac{1}{4}$, brown; foaled 1882 ; bred by W. H. Robinson, La Harpe, Ill., got by Egmont, son of Belmont: dam Lady Frankfort, said to be by Frankfort Chief, son of Bay Chief ; 2 d dam Peasley mare, by Rover, son of Vermonter, by Black Hawk; and $3 \mathrm{~d}$ dam Lucy, by Rockingham (Sinclair's). Sold to A. W. Florea, Eldorado, Kan.

Sire of 3 trotters $\left(2: 13 \frac{1}{2}\right), 2$ pacers $\left(2: 23^{3} / 4\right)$.

EGMORE M. (3-256), bay, I5 hands, ro5o pounds; foaled I 888 ; bred by Curtis Holgate, Defiance, O. ; got by Alhambra Chief, son of Almont Chief : dam Egertie, bay, bred by Richard West, Lexington, Ky., got by Egbert, son of Hambletonian; 2 d dam Twilight, said to be by Thorndale, son of Abdallah; 3 d dam Magnolia, by Cadet, son of Diomed

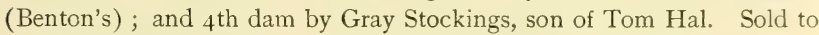
W. C. Martin, Broyan, O., to D. S. Moots, Bellefountaine, O., who sends pedigree.

Sire of Pete W., $2: 25$.

EGO (I-64), $2: 243 / 4$, bay, white hind feet, I $5 \frac{1}{2}$ hands; foaled 1880 ; bred by George C. Cable \& Sons, Berwick, Ill. ; got by Chief Justice, son of Sallite, by Robert Bonner: dam Almaid, bay, bred by George C. Cable, got by Almore, son of Almont; 2 d dam Nelly, brown, bred by Geo. C. Cable, got by Tom Benton, son of Gen. Benton ; 3d dam brown, bred by George C. Cable, got by Green Mountain Black Hawk, son of Crown Point Black Hawk. Pedigree from breeder.

Sire of Flora Ego, $2: 291 / 4$.

EGOTIST (I-32), $2: 221 / 2$, bay, left hind heel white, I 6 hands, I 200 pounds ; foaled I 885 ; bred by L. Stanford, Menlo Park, Cal., got by Electioneer : dam Sprite, chestnut, bred by A. J. Alexander, Spring Station, Ky., got by Alexander's Belmont, son of Abdallah; 2d dam Waterwitch (dam of Mambrino Gift, $2: 30$ ), which see. Sold to Glenview Stock Farm, Louisville, Ky. Pedigree from catalogue of breeder.

Sire of 40 trotters $\left(2: 12 \frac{1}{4}\right), 3$ pacers $(2: 061 / 4) ; 5$ sires of 12 trotters, I pacer; 5 dams of 5 trotters. 
EGROE (I-I 28), $2: 181 / 4$, bay; foaled I 886 ; bred by H. P. Headley, Lexington, Ky. ; got by Egbert, son of Hambletonian: dam Nina Munroe, chestnut, bred by Noah Sagersor, Paris, Ky., got by Jim Munroe, son of Alexander's Abdallah; 2 d dam Jenny, said to be by Andrew Jackson (Sidener's) ; and 3d dam Rabbit, by Tom Hal (Shawhan's). Sold to G. A. Goodrich, Shelbyville, Ind.

Sire of 2 pacers $(2: 20)$.

EGTHOME, $2: 18$, brown with white hind ankles, I $53 / 4$ hands, I Ioo pounds ; foaled I 882 ; bred by Richard West, Lexington, Ky. ; got by Egbert, son of Hambletonian: dam Sue, chestnut, bred by John A. Adams, Great Crossings, Ky., got by Thorndale ; $2 \mathrm{~d}$ dam said to be by Glencoe, son of imported Glencoe; 3d dam Dolly. Sold to Richard Baker, Watkins, N. Y. ; to Moss Brook Farm, Friendship, N. Y.; and went to Baltimore, Md., Oct. 9, I891. Pedigree from Richard Baker, who writes, dated Watkins, N. Y., April 2 1, I 893 :

"The enclosed pedigree blank was forwarded me from Lexington, Ky., to fill out. I purchased Egthome from Col. West, when two years old and owned him till he was seven past. Have never been able to trace him farther than the enclosed pedigree shows."

Sire of 7 trotters $(2: 14), 3$ pacers $\left(2: 10^{3 / 4}\right)$; I sire of I trotter, I pacer; 2 dams of I trotter, I pacer.

EGWOOD (I-32), $2: 14 \frac{1}{2}$, bay, I5 $5 \% 2$ hands; foaled 1885 ; bred by W. W. Estill, Lexington, Ky.; got by Egbert, son of Hambletonian: dam Lucille Blackwood, brown, bred by W. W. Estill, got by Blackwood, son of Norman; 2d dam Julia, bred by W. H. Sheffer, Lexington, Ky., got by Basil Duke, son of Iron Duke ; 3d dam bay, bred by Jacob Hughes, Lexington, Ky., got by Downing's Bay Messenger; 4th dam bay, bred by Jacob Hughes, got by Hunt's Commodore. Sold to J. C. Twyman, Lexington, Ky. ; to H. C. Chamberlin, Richmond, Va. ; to Whitby Farm, Richmond, Va.; to Joseph Lasser, Richmond, Va.; to James Stackhouse, Marion, S. C. Pedigree from breeder.

Sire of 2 trotters $\left(2: 22 \frac{1}{4}\right)$.

EL AMEER (7-256), bay, I 6 hands, I roo pounds; foaled I 888 ; bred by John Cline \& Sons, Rensselaer, Mo.; got by L. Capitan, son of Alcantara: dam Dolpha, brown, bred by John Cline \& Sons, got by Dresden, son of Administrator; $2 \mathrm{~d}$ dam Pinnie Pepper, said to be by Challenger, son of Almont, by Alexander's Abdallah; 3d dam Bounty, by Duvall's Mambrino, son of Mambrino Chief; and 4th dam by Paddy Burns, son of Gray Eagle, thoroughbred. Pedigree from breeders.

Sire of 2 pacers $(2: 201 / 4)$.

ELANDER H. See Alexander H. Sherman, Vol. I. 
ELBA, said to be by the famous horse Arabian: dam imported in 1815 . Advertised at Brunswick, Me., by R. H. Gardner, in I 824 .

ELBANECIA ( I-64), $2: 23 \frac{1}{4}$, black; foaled I 888 ; bred by Elizur Smith, Lee, Mass. ; got by Alcyone, son of George Wilkes : dam Remembrance (dam of Tennessee Dictator), brown, bred by W. L. Simmons, Lexington, Ky., got by George Wilkes; 2 d dam Alice, said to be by Corbeau Jr.; 3d dam Black Emily, by Kinkead's St. Lawrence; and $4^{\text {th }}$ dam by Aratus, thoroughbred. Sold to N. W. Martin, Lake City, Minn.; to Pengelly \& Ellenger, Dodgeville, Wis.

Sire of 2 trotters $(2: 241 / 4), 2$ pacers $(2: 191 / 4)$.

EL BENTON (3-128), $2: 23$, bay, 15 hands; foaled 1888 ; bred by Leland Stanford, Menlo Park, Cal.; got by Electioneer: dam Nelly Benton, (dam of El Rami, 2 :14), bay, bred by Leland Stanford, got by Gen. Benton, son of Jim Scott; 2 d dam Norma (dam of Norval, $2: 143 / 4$ ), gray, bred by S. F. Gano, Georgetown, Ky., got by Alexander's Norman; 3 d dam said to be by Todhunter's Sir Wallace. Sold to Gilbert Thompkins, San Leandro, Cal. Pedigree from catalogue of breeder.

Sire of Nelly Emmett, $2: 191 / 2$.

ELBERT (3-256), $2: 29$, chestnut; foaled I 883 ; bred by Fitzgerald \& Kellogg, Cortland, N. Y., got by Egbert : dam Dictator Belle, said to be by Dictator; $2 \mathrm{~d}$ dam Lena Rivers, chestnut, bred by Isaac Webb, near Versailles, Ky., got by imported Consternation; 3d dam Milly Ribbon, said to be thoroughbred. Pedigree from catalogue of breeders.

Sire of Ben E., $2: 15 \frac{1}{4}$.

ELBERTON (3-64), chestnut, white hind ankles, 15 r $/ 2$ hands; foaled 1885 ; bred by A. E. Whyland, New York City ; got by Kentucky Prince, son of Clark Chief : dam Molly Sanford, bay, bred by John S. Baxter, Rutland, Vt., got by Middletown, son of Hambletonian; 2 d dam Kitty, said to be by Rattler (Biggart's), son of Sir Henry; and 3 d dam Isaiah Wilcox mare by Burdick's Engineer. Pedigree from catalogue of breeder.

Sire of Dick, $2: 12 \frac{1}{2}$.

ELCANO (3-1 28 ), bay with stąr, white off hind ankle; foaled I 886 ; bred by Charles Backman, Stony Ford, N. Y. ; got by Mansfield, son of Messenger Duroc: dam Fairy, bay, bred by Wm. M. Rysdyk, Chester, N. Y., got by Hambletonian, son of Abdallah; 2d dam Emma Mills, chestnut, dam of Sweepstakes (son of Hambletonian), which see. Pedigree from catalogue of breeder. Sold to George K. Russell, Bellows Falls, Vt.

Sire of Elcamont, $2: 25 \frac{1}{4}$.

EL CAPITAN (I-32,), $2: 263 / 4$, dark bay, no marks, 16 hands, 1200 pounds ; foaled I 883 ; bred by Geo. Sweet, Washington Hollow, Dutchess County, N. Y.; got by Thorndale, son of Alexander's Abdallah : dam Glen, chest- 
nut, bred by Fred B. Schultz, Bulls Head, Dutchess County, N. Y. : got by Superb, son of Ethan Allen; 2 d dam chestnut.

A correspondent writes: "The dam, Glen, was bought of James F. Frost then of Washington Hollow, the owner of Superb."

EL CAPITAN $2: 20^{1 / 2}$, bay, I5 $1 / 2$ hands, IOoo pounds; foaled 1884 ; bred by John Wilbur, Palmer, Mass. ; got by Alcantara, son of George Wilkes : dam Piedmont Maid, chestnut, bred by Leland Stanford, Menlo Park, Cal., got by Piedmont, son of Almont; $2 \mathrm{~d}$ dam said to be by Hambletonian. Sold to Elizur Smith, Lee, Mass.; to John Cline \& Sons, Renselaer, Mo., who send pedigree.

Sire of 2 trotters $\left(2: 27^{3} / 4\right), 6$ pacers $(2: 131 / 4) ;$ I sire of 2 pacers.

EL CAPITAN (3-64), $2: 29$, bay, I 6 hands, I I 50 pounds; bred by William Abbott, Plainsburg, Cal.; got by Nutwood, son of Belmont: dam bay, bred by William Abbott, got by Easton's Black Hawk. Sold to R. P. \& IV. L. Ashe, Mercedo, Cal. Pedigree from F. P. Wickerham, Fresno, Càl.

Sire of Bolivar, $2: 30 ;$ Ashton, $2: 17 \frac{1}{2}$.

ELDER BOONE (5-64), 2 : I 8 1/4, black with star and snip, near forward and hind foot white, 15 hands, 900 pounds; foaled $\mathrm{I} 888$, bred by R. G. Dunn, Canton, Me.; got by Daniel Boone, son of Hambletonian : dam Lady Leighton, black, bred by Otis Preston, Strong, Me., got by Ethan Allen (Dolbier's) ; 2 d dam bay, bred by Charles F. Packard, Winthrop, Me., got by Winthrop Morrill, son of Young Morrill. Sold to Walter Merrill, Pittsfield, Me.; to E. L. Gove, Waterville, Me.; to Ellery Poland, Canton, Me. Pedigree from breeder.

Sire of The Deak, 2: $231 / 2$.

ELDORADO (3-I28), bay; foaled I888; bred by Wm. Corbitt, San Mateo, Cal. ; got by Guy Wilkes, son of George Wilkes : dam Adella bay, bred by E. H. Miller, Jr., Alameda, Cal., got by Electioneer, son of Hambletonian; 2 d dam, Addie Lee, bay, bred by E. J. Winegar, Fort Jones, Cal., got by Black Hawk (Culver's), son of Vermont; 3d dam Old Nancy, said to be by Morrill, son of the Jennison Horse. Sold to C. H. Tenney, New York, N. Y. Pedigree from catalogue of breeder.

Sire of 2 trotters $(2: 27)$.

ELDRIDGE (5-128), bay; foaled I877; bred by Robert Bonner, New York, N. Y.; got by Edward Everett: dam Jessie Kirk (dam of Majolica, $2: 15$ ), brown, bred by John D. Marders, Winchester, Ky., got by Clark Chief; 2d dam old Lady, black, bred by Rolly Southerland, Clark County, Ky., got by Captain Walker; 3d dam said to be by Parish's Pilot; and $4^{\text {th }}$ dam by Parker's Brown Pilot.

Sire of Cartridge, $2: 14 \frac{1}{2}$, Edmund, $2: 22 \frac{1}{2}$ : I sire of 2 trotters; I dam of I trotter. 
ELECTANT, bay ; foaled I 89o, bred by Leland Stanford, Menlo Park, Cal.; got by Electioneer, son of Hambletonian : dam Mano, chestnut, bred by Leland Stanford, got by Piedmont, son of Almont; 2d dam Mamie, chestnut, bred by S. B. Whipple, San Mateo, Cal., got by Hambletonian Jr., son of Whipple's Hambletonian; 3d dam Gilda, said to be by imported Mango. Sold to McCormick Live Stock Co., Bowling Green, Mo.,

Sire of Electant Belle, $2: 221 / 4$.

ELECTED, said to be by Electioneer : dam Cora, dam of Don Marvin, $2: 28$; 2d dam Clarabel.

Advertised as above by Sutherland \& Benjamin, Saginaw, Nich., in The New York Sportsman, Aug. 8, I $89 x$.

ELECTEEO (I-I 28 ) , $2: 29$ I $/ 2$, gray, I $53 / 4$ hands, I I 00 pounds; foaled I 886 ; bred by H. H. Helman, Tulare, Cal. ; got by Anteeo, son of Electioneer : dam Maud Medium, gray, bred by H. H. Helman, got by Milton Medium, son of Happy Medium; 2d dam Lady Renfrow. Sold to T. E. Bishop, Tulare, Ca!.; to J. A. McDonald, San Rafael, Cal.; to J. R. Rippey, Glenwood, Mo., who sends pedigree.

Sire of Fessie $0 ., 2$ :I6; I dam of I trotter.

ELECTIME, bay; foaled I88I; bred by A. P. Hotaling, San Francisco, Cal.; got by Electioneer, son of Hambletonian: dam Inez, said to be by Nordale, son of Norfolk; 2d dam Lizzie. Died I $\$ \$ 6$.

Sire of 2 trotters $(2: 27)$.

ELECTION ( I-I 28 ), bay, I5 I/2 hands, I075 pounds; foaled I 884 : bred by Leland Stanford, Menlo Park, Cal. ; got by Electioneer, son of Hambletonian : dam Lizzie H., said to be by Whipple's Hambletonian, son of Guy Miller ; 2d dam Lizzie Harris, by Comus, son of Green's Bashaw ; and $4^{\text {th }}$ dam by Arnold Harris. Pedigree from L. Holly, Vallego, Cal.

Sire of Little Mac, $2: 27 \frac{1}{2}$.

ELECTION (3-64), bay, with black points, $151 / 2$ hands, 1000 pounds; foaled 1885 ; bred by Leland Stanford, Menlo Park, Cal.; got by Electioneer, son of Hambletonian; dam May Queen, bay, bred by F. G. Hill, Paris, Ky., got by Alexander's Norman, son of Morse Horse ; $2 \mathrm{~d}$ dam Jennie, said to be by Crockett's Arabian, son of Mokhladi; and $3 \mathrm{~d}$ dam by Davy Crockett. Sold to William Marks, Philadelphia, Penn. Pedigree from Atwood B. Hoskins, Glen Riddle, Penn., breeder of Alice Barnes, by Election.

Sire of 5 trotters $(2: 101 / 4) ;$ Clover Leaf, $2: 22 \frac{1}{2}$.

ELECTION BEL (5-256), bay; foaled I 891 ; bred by H. L. \& F. D. Stout, Dubuque, Ia.; got by Saint Bel, son of Electioneer: dam Aline, brown, bred by Dr. A. S. Talbert, Lexington, Ky., got by Belmont, son of Alex- 
ander's Abdallah; 2 d dam Alma Mater, dam of Alcantara, 2 :23, which see. Sold to J. C. Lineman, Lima, O. ; to G. K. \& J. L. Whitworth, Nashville, Tenn.

Sire of 3 trotters $\left(2: 12 \frac{1}{2}\right)$.

ELECTIONEER (3-128), bay, white hind feet, $153 / 4$ hands; foaled May 2, I 868 ; bred by Charles Backman, Stony Ford, N. Y.; got by Hambletonian, son of Abdallah: dam Green Mountain Maid, brown, star and white ankles, foaled I862, bred by Samuel Conklin, Middletown, N. Y.; got by Sayre's Harry Clay, son of Neave's Cassius M. Clay Jr. ; 2 d dam Shanghai Mary, with blaze and four white legs, foaled about I 849, traded for, fall of $185_{2}^{2}$, by Horton \& Smith Wilcox, of a young man near Canton, O., who represented that he had ridden her a long distance, breeding unknown. Sold to Leland Stanford, Palo Alto, Cal., I 876, for \$I 2,500. Died I 890.

The following statement of Horton Wilcox, is from an interview with him by W. H. Markham, Rochester, N. Y., published in Wallace's Monthly, May, I887.

"In August or September of the year I 850 , I with my brother took a flock of sheep into Ohio and sold and traded them to farmers. Among the trades on my way out was one with Dr. Bonfield, about four miles south or west from Canton, O., with whom I traded sheep for a little mare partially blind. On my return from the West I stopped at Dr. Bonfield's for the little mare. She was not good to lead, and while getting her with my other horses into the road preparatory to starting, a young man came along riding a young sorrel mare. She was poor, with very little hair on her tail, apparently eaten off by calves. I asked the young man whom I should say was about twenty-five years old, to lead the mare for me to Canton and leave her at the hotel stables, which he agreed to do. After starting he changed his saddle to my mare and led his own, and after going a little way he said: "Stranger, maybe you would like to trade horses?' 'Yes,' I replied, 'I will trade, but you had better look at my mare's eyes before trading. 'Her eyes are good enough for me,' he retorted.

" 'You have a good leather halter on your mare,' I observed 'and if you will leave the halter on, when you get to Canton you can leave whichever mare you choose.'

"He rode on and when I reached the stable at Canton, I found the sorrel mare. She was three years old, had no shoes, and her feet were badly broken and sore; she was weary and had apparently traveled a long distance. I put her in with my lot of horses and led her through to Livonia, Livingston County, N. Y. She was looking so badly that I was ashamed to bring her into town, and had her pastured with a neighbor about three miles away'and left her there about six weeks, when a young man-Curtis Ridley by name-wanted to buy a cheap horse. I drove with him down to the pasture and showed her. I asked him fifty dollars for her. He said he would take her if I would take a yoke of steers at forty dollars towards payment providing she would drive. We harnessed her up but she wouldn't budge an inch. He finally said he thought he could break her and paid me ten dollars and the steers and took her. 


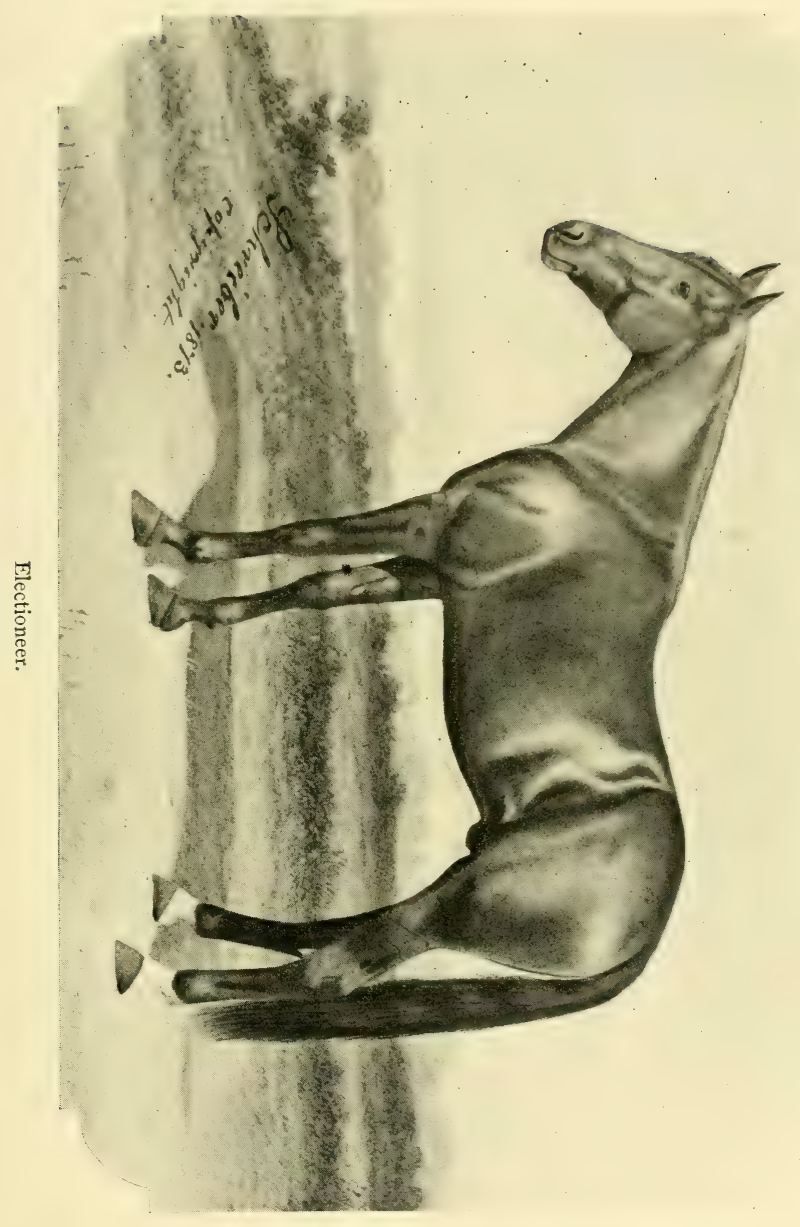



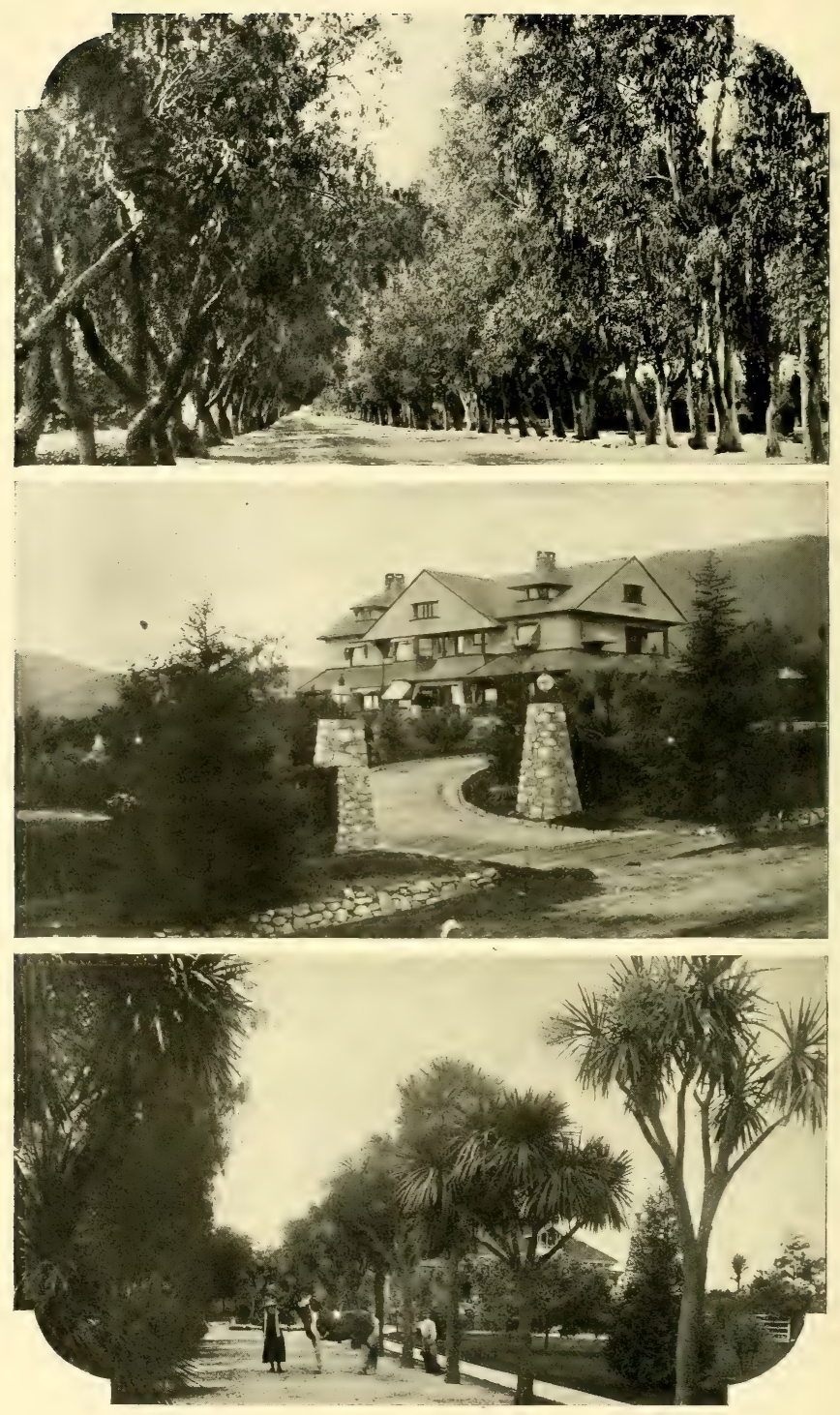

California Scenes. 
He took her home and broke her to drive, and she made a very nice road animal.

"Next spring she dropped a bay filly (which he afterwards sold to Charles Shepherd). He used her during the summer and sold her to Charles Shepherd, Avon, N. Y., for \$75. Shepherd had her docked and pricked and put her in fine condition, and she proved a valuable roarlster, fine stepper, and having great endurance. While in use he drove to Caledonia to Mr. Hotchkiss' Hotel. Hotchkiss said as Shepherd drove up:

" "Charley what will you take for your mare?"

" “Two hundred dollars,' replied Shepherd.

Hotchkiss drew his wallet and without the slightest hesitation said:

" 'Here's your money.'

Shepherd then said he had spoken hastily, and added :

"'I don't want to sell the mare, and will give you twenty-five dollars and say no more about it.'

"To which Hotchkiss replied :

" "That is all very well, but she isn't yours to sell- she is my mare. Here is your money.' Shepherd took the money, and Hotchkiss took the mare. Hotchkiss kept her about a year and sold her to Fred Harlson of Angelica, N. Y., for $\$ 700$, and Fred sold her after a time to Hiram Woodruff for \$I 400 since which I have known nothing personally of her history.

"The bay filly which was afterwards purchased by Charles Shepherd and named Fanuelle, subsequently owned by his son Charles H. Shepherd of Avon, N. Y., was kept by him for breeding. She was about $151 / 2$ or $153 / 4$ hands high and was a fine driving mare to buggy. She was never trained but would show a better than $3: 00$ minute gait any time on the road. I remember several of her colts that trotted fast, one of which Fanny Lee, I owned and bred to Narragansette Alamode."

\section{SHANGHAI MARY.}

We wrote and received the following letters:

Messrs. IVILcox,

$$
\text { Middlebury, Vt., April 29, } 1885 .
$$

Dear Sirs:-I notice in Vol. X., Wallace's Monthly page II5, that you purchased Shanghai Mary, by exchange of another mare valued at fifty dollars, of a boy on a highway in Ohio, and the same fall shipped her with others to Livonia; that the mare was at that time two years old, as indicated by her teeth, and proved to be in foal; that during the following winter she was sold to Messrs. Ripley Bros. of Livonia for 50 dollars. Is this an accurate statement of the matter? and if so will you please state in what town in Ohio you bought the mare, the boy's name if you know it, of whom you bought her, and what he said in reference to her breeding; also please give description of the mare and oblige,

$$
\text { Truly yours, JOSEPH BATTELL. }
$$

Mr. Joseph BatTell,

Rochester, N. Y., May $4^{\text {th, }}$ I885.

Dear Sir :-The statement as you find it in Wallace's Monthly is substantially true, I traded for a sorrel mare on the road near Canton, O., with a boy that said he had ridden about two hundred miles. My impression is that she came from Kentucky. There was nothing said 
about her breeding. The mare was quite leggy, with four white feet and white stripe in her face. She changed hands here several timesfinally Fred Harston of Angelica, sold her to Hiram Woodruff of New York. I did not learn the boy's name, it was one of those quick trades on the road-but little said.

Horton WiLcox.

Mr. Wallace in speaking of the dam says :

"Now, the truth about Shanghai Mary's appearance as given by those who knew the mare well, and as represented in the picture which hangs in Mr. Backman's sitting-room, cannot be denied. Her conformation was in a very marked degree what has been designated as the 'pacingconformation,' which is the very antipodes of the thoroughbred. When we take into consideration the capacities of the mare and the fact that she not only possessed but really showed speed that was phenomenal as a trotter, we must conclude that she inherited trotting-speed, whether at the lateral or the diagonal way of going. No thoroughbred ever trotted in $3: 00$, and it is just as reasonable to look for cherries on oak trees as to look for trotting-speed in running blood."

The American Horse Breeder says :

"Following the quotations from Wallace's Monthly, or interspersed with them, we made the following remarks, giving our personal view of the matter. See American Horse Breeder, March 24, I887, p. 315. It is the belief of the writer that if the pedigree of Shanghai Mary is ever brought to light, it will be found that she was by Iron's Cadmus, sire of the famous Pocahontas $(2: 17 / 2)$. Iron's Cadmus also got Blanco, sire of the renowned trotting stallion Smuggler $\left(2: 15 \frac{1}{4}\right)$. The Breeder article with the above comments evidently came to the notice of Mr. Herschel I. Fisher of Lebanon, O., who contributed an article in the Christmas number of the Review for $\mathrm{r} 894$, from which we extract the following :

" "Away back in $1877, \mathrm{Mr}$. Wallace called attention to the resemblance between old Pocahontas and Shanghai Mary, and recorded his belief that if the breeding of Shanghai Mary was ever established it would be found that they had descended from the same stock of horses as Iron's Cadmus, a horse bred and long owned by the late Goldsmith Coffin of Red Lion, O., and his partner John Irons. The suggestion was unknown to me until the present summer, when I saw some reference to it, and at once determined to follow up the clue. I called the attention of the veteran horsemen of Warren County, through the columns of the Western Star, the oldest paper in the country, which is edited by me, to the fact that the Electioneers had descended from a sorrel mare, with white feet and face, that was three years old in 1850 , and that might have been a Cadmus. They were asked to communicate with me in case they had any knowledge of such a filly, having been disposed of at or near Canton, O., in 1850 , by a young man or a boy. I thought it possible that he might turn up in the person of some citizen still residing in this vicinity.

" Not a person was found who had any knowledge of the horse trade in the highway near Canton, but it was not long before several old gentlemen called attention to the disappearance of Thadeus Coffin from Red Lion with his father's sorrel filly, marked with white face and legs, in the summer or fall of ${ }^{8} 850$. The incident would probably not have been recalled had not his father, Goldsmith Coffin, been the most prominent 
horseman in the county at that time, and the filly a well-known member of his stable.

" "From three men who were living in the immerliate vicinity of the Coffin farm at that time, and were intimately acquainted with the younger members of the family, I learned that when Thadeus arrived at the age when he began to want to do for himself, he asked his father to give him a part of the money he had won for him on the turf as a rider, and that a controversy arose between them, which led to an estrangement which lasted as long as they both lived, or at least prevented Thadeus from ever becoming a member of the family circle again.

"He disappeared, and it was the common report that he had taken the filly with him, in lieu of pay for his services as a Jockey. It does not now appear whether he had any proprietorship in her, but certainly no one blamed him for keeping her, unless it was the old gentlemam himself. Three other persons, all members of the Coffin household then, or about that time, remember the incident wholly, or in part, and the Rev. Samuel Gallagher, who was a nephew of Goldsmith Coffin, and was raised by Goldsmith Coffin, Sr., on an adjoining farm, remembered the filly and her breeding.

"It may be well to say that I was led to consult Mr. Gallagher by the repeated assurance of the elderly men of the neighborhood that he knew more about the Coffin horses than any other man now living, as he was not only a nephew but the trusted lieutenant of Mr. Coffin and handled his horses for him in the early fifties. He was represented as being an enthusiastic and successful rider and trainer.

"Mr. Gallagher replying to an inquiry as to whether he recalled the filly, said he remembered her well; that she was by Iron's Cadmus, sire of old Pocahontas, and out of a mare by Jerry. The time was too short to permit of much correspondence before the Christmas number of the Horse Review went to press, and I was unable to fully identify Jerry. But judging from the general character of Mr. Coffin's stud, I expect to find that he was a thoroughbred, or at least a highly bred running horse.

"The disappearance of a young man in Southwestern Ohio, riding a sorrel mare with four white legs and a blaze in her face, leaving home after an estrangement serious enough to prevent his ever returning, the appearance of a young man of about the same age in Eastern Ohio 250 or 300 miles away, the same fall, riding a mare of the same age and with the same peculiar coloring, and the fact that he did not seem disposed to talk about himself or the animal, make a chain of circumstantial evidence that in the absence of a single fact pointing in any other direction would convince most persons that the two fillies were one and the same. But when it is shown by competent witnesses that the Southern Ohio filly had lost her tail, as is stated by Rev. Mr. Gallagher, and that the filly the boy rode in Eastern Ohio, looked like her tail had been eaten off by the calves, the presumption becomes very strong in favor of the theory that the foot sore animal that Wilcox Bros., bought and took to New York State was the Cadmus filly Thadeus Coffin rode away the same summer.'

"Now we do not claim that the disappearance of a young man and a peculiarly marked three-year-old filly, by Iron's Cadmus from Red Lion, O., and the appearance of a young man at Canton, O., some time afterwards with a filly whose age, color and general description even to the abbreviation of the tail corresponds with the one which vanished at Red Lion, is proof positive that they were one and the same, but it fur- 
nishes good grounds for believing that they were. If the filly taken from Red Lion should turn out to be Shanghai Mary, there seems to be little room for doubt that she was by Iron's Cadmus."

Mr. B. F. Gustin, Red Lion, O.

Middlebury, Vt., June $4^{\text {th, }}$ I9o6.

Dear Sir :- In trying to trace a celebrated horse, I am anxious to fix a few dates connected with the Goldsmith Coffin family that I understand resided in your town in $\mathrm{I} 840$, and I suppose for some time after. - It is said that Goldsmith Coffin had a son whose name was Thadeus, I want to learn what year this son was born and also what year he left home.

Are there any descendants of Mr. Coffin living at Red Lion or can you refer me to any parties who could give above information? Any assistance in this matter will exceedingly oblige,

$$
\text { Yours very truly, JOSEPH BatTell. }
$$

Mr. Joseph Battell,

Franklin, O., Oct. 7, 'o6.

Dear Sir :- I received a letter from you sometime since in regard to a celebrated mare raised at Red Lion, Warren County, O. There was a mare there and was stolen by Thadeus Coffin, and traded to some parties at Canton, O., and then shipped to California. I traced this for some parties some years ago, they came and took some pictures of the homeplace of the mare. I married into the Coffin family but this happened some years ago and will be hard to trace.

B. F. Gustin.

MR. B. F. Gustin,

Bread I.oaf, Vt., Oct. i6, I906.

Dear Sir :-Your letter of Oct. 7 th, received and I am much obliged for same.

It has seemed to me that the suggestion that the filly traded for upon a highway in Ohio and that afterwards became the $2 \mathrm{~d}$ dam of the stallion Electioneer, might be the one bred by Mr. Coffin and ridden away by his son, but it requires to be yet shown that the dates of Mr. Coffin's son going away and the trading for the filly in Ohio, should practically correspond. This proven, the case would be very strong, but without it remains weak. I therefore wrote to you to get if possible the year of the birth of Mr. Coffin's son and the year that he finally left home. It seems to me there should be some date by which these two facts could be accurately settled. Should you be able to do it or refer to any person who can please write me again.

Yours very truly,

JOSEPH BATTELL.

To this last letter we have received no reply. If Mr. Goldsmith Coffin had a son named Thadeus, it should be yet a feasible matter, for parties living at Red Lion, or that vicinity, to learn when he was born and at what year he left home.

Sire of $I_{5} 8$ trotters $\left(2: I_{1}^{1 / 4}\right), 2$ pacers $(2: 23) ; 4^{8}$ sires of $8 I 7$ trotters, 227 pacers; 83 dams of 158 trotters, 13 pacers.

ELECTIONEER $(3.256)$, bay with star, hind feet and ankles white; foaled I 889 ; bred by Leland Stanford, Menlo Park, Cal. ; got by Electioneer, son of Hambletonian : dam Miss Beecher, chestnut, bred by Leland Stanford, 
got by Piedmont, son of Almont; 2d dam Lady Beecher, bay, bred by Andrew Wilson, Walkill, N. Y., got by Reserve, son of Hambletonian; and $3 \mathrm{~d}$ dam said to be by Friday, son of imported Trustee. Sold to H. Setzer, Jr., Bridgeport, Conn. Pedigree from catalogue of breeder. Sire of Joe Watts, $2: 101 / 4$.

ELECTIONEER (CAMPBELL'S) (1-64), 2 :1 $73 / 4$, bay; foaled 1886 ; bred by L. Stanford, Menlo Park, Cal.; got by Electioneer : dam Edith Carr, bay, bred by A. J. Reed, Lexington, Ky., got by Clark Chief; $2 \mathrm{~d}$ dam Easter Carr, bay, bred by Dabney Carr, Chilesburg, Ky., got by Carr's Edwin Forrest, son of Edwin Forrest ; 3d dam said to be by imported Margrave; and $4^{\text {th }}$ dam by Shakespeare. Sold to L. M. Shippee, Stockton, Cal. ; to W. E. Campbell, Kiowa, Kan. Pedigree from F. M. McKee, Hutchinson, Kan.

Sire of 5 trotters $\left(2: 19 \frac{1}{4}\right)$, Symboleer, $2: 09 \frac{1}{2} ;$ I sire of I trotter, 2 pacers.

ELECTION TIME (3-I2S), bay, 15 I/2 hands, rooo pounds; foaled I $89 \mathrm{I}$; bred by Church Bros., Frankfort, Ky.; got by Electrotype, son of Electioneer: dam Jenny, brown, bred by Church Bros., got by King Rene, son of Belmont; 2 d dam Lothia, said to be by Woodford Abdallah, son of Woodford Mambrino. Sold to Harry Crookham, Knoxville, Ia., who sends pedigree; to Elisha Nichols, Perry, Ia.

Sire of Ben $H . G_{0}, 2: 21^{1 / 1} / 4$.

ELECTMONT (I-32), $2: 22 \mathrm{I} / 4$, black, left hind ankle white, I 6 hands, I I 80 pounds; foaled I 889 ; bred by C. J. Hamlin, Buffalo, N. Y.; foaled the property of C. H. Phelps, St. Marys, O.; got by Chimes, son of Electioneer : dam Cologne, bay, bred by C. J. Hamlin, got by Mambrino King, son of Mambrino Patchen ; $2 \mathrm{~d}$ dam Annie Scott, bay, bred by C. J. Hamlin, got by Hamlin's Almont Jr., son of Almont ; 3d dam Black Woful, black, bred by C. J. Hamlin, got by Hamlin's Patchen, son of George M. Patchen; $4^{\text {th }}$ dam Woful, bred by C. J. Hamlin, got by Young Woful, son of Woful, by Long Island Black Hawk; $5^{\text {th }}$ dam Miss Sears, said to be by Hero, son of Abdallah. Sold to Wm. C. Dickinson, Hatfield, Mass. Pedigree from Mr. B. Fralick.

Sire of 2 trotters $\left(2: 28 \frac{1}{2}\right)$.

ELECTOR (3-64), $2: 3 \mathrm{I}$, seal brown, hind feet gray, I $53 / 4$ hands, I 175 pounds; foaled I 879 ; bred by Leland Stanford, Menlo Park, Cal. ; got by Electioneer, son of Hambletonian: dam Gilberta, bay, with star, I 5 I $/ 2$ hands, foaled 1872 , bred by Leland Stanford, got by Fred Low, son of St. Clair; 2 d dam, Lady Gilbert, black, said to be by Gen. Knox. Sold to Charles Marvin, who sold to C. E. Perkins, Stockton, Cal., and he to L. A. Richards, Grayson, Cal. Pedigree from catalogue of breeder.

Sire of $I_{4}$ trotters $(2: 16), 2$ pacers $\left(2: 1_{7}\right) ; 2$ dams of 2 trotters.

ELECTOR (I-I28), $2: 2 \mathrm{I} 1 / 4$, bay; foaled I880; bred R. N. Graves, San 
Francisco, Cal.; got by Electioneer: dam Lady Babcock, chestnut, bred by Stephen B. Whipple, Stockton, Cal. got by Whipples' Hambletonian; 2 d dam Dubois Mare, said to be by a son of Eaton Horse, son of Avery Horse. Sold to Mr. Morrow, to Orin A. Hickok both of San Francisco, Cal. ; to Miller \& Sibley, Franklin, Penn.

Sire of 2 pacers $\left(2: I_{5}\right) ; 2$ dams of I trotter, I pacer.

ELECTOR (5-128), black; foaled I88I ; bred by Leland Stanford, Menlo Park, Cal.; got by Electioneer, son of Hambletonian: dam Juniata, brown, bred by Lehand Stanford, got by Fred Low, son of St. Clair ; 2d dam Maid of Clay, brown, 15 T/4 hands, foaled 1856 ; bred by Catlin Webster, Phelps, N. Y., got by Henry Clay, son of Andrew Jackson; 3d dam said to be by Dey's Messenger, son of Liberty: and 4 th dam by Baldface Consul. Sold to A. G. Fell, Ogden, Utah; to E. A. Snyder, Mattison, Mich. Pedigree from catalogue of breeder.

Sire of 2 trotters $(2: 20)$,

ELECTORAL (3-128), chestnut with star, hind ankles white; foaled I 889 ; bred by Charles Backman, Stony Ford, N. Y.; got by Mansfield, son of Messenger Duroc : dam Camille, bay, bred by Charles Backman, got by Hambletonian, son of Abdallah; 2d dam Emma Mills, dam of Sweepstakes, which see. Pedigree from catalogue of breeder.

Sire of Katherine, $2: 2 I^{1} \frac{1}{2}$.

ELECTOR H. ( $1-32)$, black, both hind feet white, I 6 hands, I 200 pounds ; foaled I 885 ; bred by Alf. Hagerman, Oxford, Mich., got by Agile, son of Dictator: dam Dolly H., brown, bred by Alf. Hagerman, got by Western Fearnaught, son of Fearnaught; 2d dam Gray Dolly, bred by John Hagerman, Lakeville, Mich., got by a great-grandson of imported Messenger; and $3 \mathrm{~d}$ dam said to be by Bacchus. Pedigree from breeder.

Sire of 3 pacers $\left(2: 19^{1 / 4}\right)$.

ELECTRIC ( $1-\mathrm{I} 28$ ), chestnut, rogo pounds; foaled 1883 ; bred by Col. R. P. Pepper, South Elkhorn Stock Farm, Frankfort, Ky.; got by Onward, son of George Wilkes: dam Diana, black, bred by Cleveland Scott, Kenton County, Ky., got by Challenger, son of Almont; 2 d dam Flushing Girl, brown, bred by Cleveland Scott, got by Scott's Thomas, son of Gen. George H. Thomas; 3 d dam Lady Barnes (running-bred) said to be by imported Hiawatha; $4^{\text {th }}$ dam Patty Taylor, by imported Sovereign; and $5^{\text {th }}$ dam by Leviathan. Sold to W. D. Harnish, Mount Carroll, Ill., who sends pedigree; to J. W. Mercer, Council Grove, Kan.

Sire of Ethington, $2: 25$.

ELECTRIC BELL (3-128), bay, hind feet and pasterns white, $15 \% \frac{1}{2}$ hands, I 100 pounds; foaled I 888 ; bred by Leland Stanford, Menlo Park, Cal. ; 
got by Electioneer : dam Beautiful Bells, black, bred by L. J. Rose, San Gabriel, Cal., got by The Moor, son of Clay Pilot; 2 d dam Minnehaha, bay, bred by George C. Stevens, Milwaukee, Wis., got by Steven's Bald Chief, son of Alexander's Bay Chief; 3 d dam Nettie Clay, said to be by Strader's Cassius M. Clay Jr. ; $4^{\text {th }}$ dam the Col. Morgan Mare, by Abdallah, son of Mambrino; and 5 th dam by Engineer, imported from Canada about I 8r 5, which see. Sold to Miller \& Sibley, Franklin, Penn., who send pedigree. Advertised by Miller \& Sibley, I 89 I.

Sire of $x$ trotters $\left(2: 09^{1 / 4}\right)$, I2 pacers $(2: 20)$.

ELECTRICIAN (I-32), $2: 24 \frac{1}{4}$, bay with star and snip, near hind leg white, I 5 hands; foaled I884; bred by Leland Stanford, Menlo Park, Cal, ; got by Electioneer, son of Hambletonian: dam Rebecca, bay with snip, I 6 hands, foaled 1878 , bred by Leland Stanford, got by General Benton, son of Jim Scott; 2 d dam Clarabel, bay, bred by Charles Backman, Stony Ford, N. Y., got by Abdallah Star, son of American Star Jr., by American Star son of Coburn's American Star, by Cock of the Rock, son of Sherman Morgan; 3d dam Fairy, said to be by Hambletonian; 4th dam Emma Mills, dam of Sweepstakes, by American Star, which see. Sold to Wm. Simpson, New York City, N. Y. ; to John S. Ferguson, New York, N. Y. Pedigree from catalogue of breeder. Sire of Electrimont, $2: 2 \mathrm{I} 1 / 4 ;$ Midi, $2:$ II ; I dam of I trotter.

ELECTRICITY (I-32), $2: 173 / 4$, brown, near hind foot white, I6 $1 / 2$ hands ; foaled I 884 ; bred by Leland Stanford, Menlo Park, Cal. ; got by Electioneer, son of Hambletonian : dam Midnight, gray, bred by A. J. Alexander, Spring Station, Ky., got by Pilot Jr., son of Canadian Pilot ; $2 \mathrm{~d}$ dam Twilight, bay, bred by R. A. Alexander, Spring Station, Ky., got by Lexington, son of Boston; 3d dam Daylight, chestnut, bred by R. A.

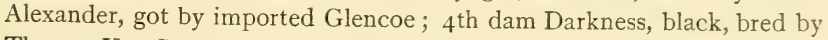
Thomas Van Swearenger, got by Wagner, son of Sir Charles. Pedigree from catalogue of breeder.

Sire of $\mathrm{I}_{3}$ trotters (2:IO), Spark, $2: 19 \frac{1}{4}$.

ELECTRIC KING, $2: 24$, bay, some white on near hind foot, $153 / 4$ hands; foaled I887; bred by Leland Stanford, Menlo Park, Cal.; got by Electioneer: dam Mamie C., thoroughbred, dam of Azmoor, $2: 20$, which see. Sold to R. T. McDonald, Fort Wayne, Ind. ; to L. Gray, Celina, O. Pedigree from catalogue of breeder.

Sire of Fine Edge, $2: 201 / 4$; Major Centliver, $2: 101 / 4$.

ELECTRITE ( $1-64$ ), $2: 28 \mathrm{r} / 2$, bay; foaled $\mathrm{r} 888$; bred by Leland Stanford, Menlo Park, Cal.; got by Electioneer: dam Sprite, dam of Egotist, $2: 22 \frac{1}{2}$, which see. Sold to W. R. Allen, Pittsfield, Mass., who sends pedigree ; to Henry Exall, Dallas, Dallas County, Texas, who owned him, 1905.

Sire of 35 trotters $\left(2: 13 \frac{1}{2}\right)$, I9 pacers $\left(2: 12 \frac{1}{2}\right) ;$ I sire of I pacer. 
ELECTRO (3-I28), $2: 29$, brown, near hind foot and ankle white, off hind foot white, $151 / 2$ hands; foaled 1884 ; bred by Leland Stanford, Menlo Park, Cal.; got by Electioneer: dam Fatima, black, bred by E. H. Miller, San Francisco, Cal., got by Berlin, son of Reavis' Blackbird; 2d dam Lady Lowell, dam of Ladywell, $2: 161 / 2$, said to be by Shultz's St. Clair, son of St. Clair ; 3d dam Laura. Pedigree from catalogue of breeder.

Sire of 2 trotters $\left(2: 29 \frac{1}{4}\right)$; I sire of I pacer.

ELECTROBENTON ( $1-64), 2: 24 \frac{1}{2}$, bay with small star; foaled I889; bred by Leland Stanford, Menlo Park, Cal.; got by Electioneer : dam Nettie Benton, bay, bred by Leland Stanford, got by Gen. Benton, son of Jim Scott ; 2 d dam Nelly Walker, bay, 16 hands, bred by George W. Burch, Georgetown, Ky., got by Thorndale, or a son of Alexander's Edwin Forrest ; 3d dam Rosalina, bay bred by George W. Burch, got by Alexander's Abdallah; 4th dam Burch Mare, brown, bred by Howard Parker, Lexington, Ky., got by Parker's Brown Pilot, son of Pilot, or Copperbottom. Sold to Schneulback \& Park, Wheeling, W. Va. Pedigree from catalogue of breeder.

Sire of Henry Mull, $2: 271 / 1$.

ELECTROID ( $1-64$ ), $2: 281 / 4$, black, I $53 / 4$ hands; foaled I 890 ; bred by F. H. Burke, San Francisco, Cal.; got by Eros, son of Electioneer : dam Rosa Bonheur, bred by Frank Burke, of California, got by Erwin Davis, son of Shenandoah (Kentucky Hunter), by Broken Legged Kentucky Hunter; $2 \mathrm{~d}$ dam Rose Washington, said to be by Washington, son of Geo. M. Patchen Jr. Sold to W. C. Hendrickson, Trenton, N. J., who sends pedigree.

Sire of 2 trotters $\left(2: 23 \frac{11}{4}\right)$,

ELECTROTYPE (I-32) bay, I5 I/2 hands; foaled I885; bred by Leland Stanford, Menlo Park, Cal. ; got by Electioneer : dam Addie, bay, bred by Daniel Kennedy, Cornwall, N. Y., got by Hambletonian Chief, son of Hambletonian; and 2d dam Manton, called a Harry Clay mare. Sold to Jas. W. Cook, Philadelphia, Penn.; to Augustus Sharp, Louisville, Ky. Pedigree from catalogue of Augustus Sharp and from Look \& Smith at Louisville Stock Farm, Ky.

Sire of 6 trotters $(2: 221 / 4)$; Election Time, $2: 15^{1 / 2} ;$ I sire of I trotter; I dam of I trotter.

ELECTUARY, bay; foaled I887; bred by Leland Stanford, Menlo Park, Cal. ; got by Electioneer : dam Maria, bay, I 5 hands, foaled 1879 ; bred at Palo Alto, got by Don Victor, thoroughbred, son of Belmont ; $2 \mathrm{~d}$ dam Minnie, said to be by Sparkle, son of Hambletonian; 3d dam Laura Keene, by Hambletonian; 4th dam Fannie, by Eclipse, son of American Eclipse; $5^{\text {th }}$ dam Mary Marvin, by Young Traveler; and 6th dam 
by Sea Gull, son of Duroc. Owned by Herrick \& Ellsworth, Worcester, Mass. Pedigree from catalogue of breeder.

ELECTWOOD ( $1-64$ ), $2: 20$, bay ; foaled I 886 ; brerl by Leland Stanford, Menlo Park, Cal.; got by Electioneer, son of Hambletonian: dam Anna, bay, 16 hands, foaled I 879 ; bred by W. L. Coombs, Chicago, Ill., got by Nutwood. Sold to C. H. Styles, Chicago, Ill. Pedigree from catalogue of breeder.

Sire of 6 trotters $\left(2: 15 \frac{1}{4}\right) ;$ Edect Wave, $2: 19^{1 / 4}$.

ELECTWOOD (I-64), chestnut; foaled I 890 ; bred by Wilfred Page, Colate, Cal. ; got by Mortimer, son of Electioneer : dam Clara B., bay, bred by T. F. Kerr, Sturgeon, Cal., got by Nutwood, son of Belmont; $2 \mathrm{~d}$ dam Jenny, said to be by St. Lawrence (Roodhouse's). Sold to T. C. Snider, Sacramento, Câl; ; to J. A. Estabrook, Denver, Colo. ; to Wm. G. Getz, Phœnix, Ariz.

Sire of Etta C., $2: 281 / 2$.

ELECTWOOD JR.; said to be by Electwood.

Sire of Hilda $N ., 2: 201 / 2$.

ELEPHANT; foaled I 734 ; said to be by Sir M. Newton's Arabian : dam by Bay Bolton, son of Gray Hautboy.-General Stud Book, Vol. I., p. 380.

ELEPHANT, chestnut; foaled I 757 ; bred by Mr. Sotheron; got by Regulas : dam Cullen-Arabian Mare, bred by Mr. Osbaldeston, got by CullenArabian ; 2d dam, Almanzor Mare, bred by Mr. Osbaldeston, got by Almazor; 3 d dam a full sister to Bay Bolton, said to be by Gray Hautboy;-General Stud Book, Vol. I., p. 71 .

ELEVATOR ( $\mathrm{I}-\mathrm{I} 6$ ), brown, I $53 / 4$ hands ; foaled September, I 866 ; bred by Mr. Willing, Warwick, Orange County, N. Y.; got by Hambletonian : dam said to be by Bull Frog, a fast pacer brought from Canada to Orange County, N. Y., where he was kept several years and is said in an article in Spirit of Times, March, I880, to have been extremely popular, " his get turning out well, almost without exception, and naturally taking to the trotting gait ;" and 2 d dam by Black Hawk, son of Sheman Morgan. Sold to J. A. Sherman, Lexington, Ky. ; to Macey Bros., Versailles, Ky.

Sire of 4 trotters $(2: 28), 3$ pacers $\left(2: I_{3} \frac{1}{2} ;\right.$ I sire of I pacer.

ELFINWOOD (3-I28), 2 : I $5 \frac{1}{4}$, chestnut, I 6 hands, I 200 pounds; foaled I 889 ; bred by H. L. \& F. W. Stout, Dubuque, Ia. ; got by Nutwood, son of Belmont: dam Amora, chestnut, bred by C. H. Seymour, Muscatine, Ia., got by Attorney, son of Harold ; $2 \mathrm{~d}$ dam True Grit, roan, bred by Daniel Hayes, Muscatine, Ia., got by Tramp, son of Gage's Logan, by 


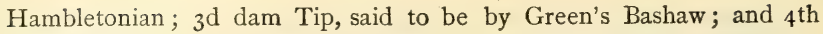
dam Florence, by Kincaid's Morgan, son of Green Mountain Morgan. Sold to Dolan \& Schlatter, Bellevue, Ia., who send pedigree.

Sire of Minerva D., 2:21 $3 / 4 ;$ Eldora, $2: 24 \frac{1}{4}$.

ELF KING ( $1-64$ ), brown, I53/4 hands; foaled 1880 ; bred by A. J. Alexander, Spring Station, Ky.; got by Harold, son of Hambletonian : dam Fairy Belle, bay, bred by F. P. Kinkead, Midway, Ky., got by Belmont, son of Alcxander's Abdallah; 2d dam Waterwitch, bay, bred by F. P. Kinkead, got by Pilot Jr., son of Canadian Pilot ; 3d dam Fanny, said to be by Kinkead's St. Lawrence, son of St. Lawrence ; and $4^{\text {th }}$ dam Brenda, thoroughbred. Sold to Robert Steele, Philadelphia, who sends pedigree.

Sire of Uncle Tom, $2: 14^{3 / 4}$.

ELGIN BOY (I-32), chestnut, star and white hind feet, $153 / 4$ hands, I roo pounds; foaled 1878 ; bred by James Wilson, Rushville, Ind.; got by Pocahontas Boy, son of Tom Rolfe: dam Nelly, bay, bred by James Wilson, got by Blue Bull, son of Pruden's Blue Bull ; 2 d dam Kit, said to be by Reed's Whip, son of Superior Whip ; and 3d dam Fan, by old Cedar. Sold to W. A. Jones, Rushville, Ind., r884, who sends pedigree ; to parties near Harrison, $\mathrm{O}$.

Sire of Nelly Lloyd, $2: 22 \frac{1}{2}$, I5 pacers $\left(2: 17 \frac{1}{4}\right)$; I sire of I pacer; 5 dams of 3 trotters, 4 pacers.

\section{ELGIN MORGAN (WILLARD HORSE BY BARDEN MORGAN),} bay with snip, one white hind foot ; bred by Wm. C. Kimball, Elgin, Ill. ; got by Barden Morgan, son of Cock of the Rock, by Sherman Morgan : dam called thoroughbred. Sold to a Mr. Willard, Crystal Lake, Ill. We have received the following interesting letter concerning this horse and others of the family:

Elgin, Ill., May I 7, I885.

EDITOR REgister:-In answer to your enquiry of March 30 , I will say, Black Prince, sire of Ada Mason, was a very superior horse, much resembling Vermont Black Hawk. His style and action were perfect and very fast; his weight was about I200; was formerly owned by a Mr. Potter of Eau Claire, Wis., and afterwards purchased by I. S. Mason of Black River Falls, who kept him until he died, which event happened about one year after he got Ada Mason. Mason had his pedigree in full and where and by whom raised, but he has long been dead and his papers are scattered. He was never trained, but could trot a mile in $2: 38$.

Barden Morgan-This horse by a son of the old Sherman : dam by Justin Morgan, was perhaps the best or one of the best of the Morgan family. His weight was about 1000 , or perhaps a little more in good flesh; was a dark chestnut; three white feet, a small white stripe in the face, a long waving mane reaching to his knees; a heavy tail hanging almost to his hoofs. His style and action surpassed either that of Gifford or Green Mountain; was a square trotter, yet he would pace rapidly. He was longer bodied and a little taller than either Woodbury 
or Gifford. His limbs were perfect, without a puff or a blemish. $\mathrm{He}$ had been badly foundered before reaching the West: was a very fast trotter for his time. Mr. Barden showed me his pedigree, who raised him, and trotting record, as he was trotted on the ice in Vermont. I do not recollect who raised him. We were always too careless about such things, only I know he made his mile in a little less than $2: 40$. He left excellent stock and to my mind was the best horse I ever saw. The best of our horses now are produced from descendants of his offspring. I thinl: only three of his colts were saved as stallions, namely, the Willard Horse, Morgan Tiger and the Stephens Horse. I will mention these separately: Colby's Morrill was an excellent horse; was brought from Vermont by Colby himself. He brought two-one a black horse. This he sold to some parties in Iowa. The one you refer to was a bay horse; weight about I Ioo, good style and could trot any time with two men in a common buggy in three minutes or less. He left fine stock; he has been dead some four or five years. I have now two fine mares from him -Belle Helene and her own sister, as you will see by referring to Wallace's Trotting Register, Vol. II. I have perhaps got some of the best Morgan blood west, and perhaps in the world. As I get time I will mention some of them. Write me freely at any time and I will do the best I can to promote your good work.

Paddelford's Black Hawk-by Vermont Black Hawk : dam by Woodbury, was a jet black with one white hind foot, heavy mane and tail; resembled Woodbury very much except a little more rangy; weight about 1025 ; never was trained on a track as we call it, but could haul two men in a buggy on a good road in less than three minutes any time; was one of the best Morgans. His colts were either black or chestnut. When the late war commenced they were much sought for parade horses and they soon became scarce. He died several years ago from a cancer on his lips. His owner, Mr. Paddelford, employed the best medical service in the country, but his time had come and he passed over the river in the full vigor of life.

I regret very much I cannot give you more dates and names of persons. You mentioned Linsley's omitting some noted horses, for instance, the Richardson of Rochester, a son of Gifford, a very good horse ; also the Frazier horse, raised in Barnard, a son of Gifford, a bay horse much resembling Gifford; would weigh about ro75 and I think one of Gifford's best colts. He was sold for $\$ 500$ and taken, I think, to Massachusetts or somewhere in that direction. He was, in my judgment, a far better horse than the Richardson horse. His style and action were as good as Giffords, but he was longer bodied and taller, which added to his good appearance.

Then the Stevens' Horse, got by Barden Morgan : dam by Morgan Emperor, chestnut, one white hind foot with the white snip on the nose, so characteristic of the Shermans. His mane and tail were very heavy; he weighed about rooo; good style and fine action; left excellent stock; was owned by Albert Whitcomb of Bethel, Vt., was foaled about I842; raised by A. L. Stevens of McHenry County, Illinois.

Morgan Tiger you will find in Trotting Register, another of Barden Morgan's colts, an excellent horse.

I will now speak of the Willard horse, got by Barden Morgan : dam a thoroughbred mare owned by the late ex-mayor of Elgin, Wm. C. Kimball. Willard was a bay horse with a snip on the nose and one white hind foot; weight about I025; very much resembled Barden. His 
colts were numerous and excellent. He was bred and kept until he died, some years ago, by a Mr. Willard of Crystal Lake, Ill., and, as I said before, all of our best horses come through those strains of Morgan blood; and through all the cross the Morgan predominates. For instance, my horse Caliph, by Green's Bashaw, dam Hinda, by Morgan Tiger, got by Barden, is a perfect model of the Morgans and transmits it to his colts; he is an excellent horse.

Then I have Maj. White, by Maj. White, a grandson of Hambletonian. Maj. White's dam is by the Willard Horse and his colts come out real chestnut Morgans, closely resembling the Shermans; he too, is an excellent horse; weighs about I300. Caliph weighs about II 50 .

Yes, there was another very good horse in your section owned by my brother, Albert Whitcomb, now of Bethel. This was by Gifford and raised by a Mr. Wolcott of Stockbridge; was called the Wolcott Horse ; was chestnut; much resembled Gifford. Wolcott sold him to some parties when about five years old, and he was taken out of the county. My brother will tell you more about him.

I have always kept track of the Morgans and kept breeding them, and the fastest horses we have here have Morgan blood coursing in their veins,

$$
\text { Yours truly, E. K. Wнiтсомв. }
$$

EL HODJI (I-I6), bay, left hind ankle white, $15 \frac{1}{2}$ hands, Iooo pounds; foaled I 885 ; bred by A. J. Alexander, Spring Station, Ky. ; got by Lord Russell, son of Harold: dam Aida, bay, bred by Jonathan Hawkins, Walden, N. Y., got by Hambletonian, son of Abdallah; 2d dam Clara, dam of Dictator, which see. Sold to Thomas Kinsman, Kinsman, O., who sends pedigree.

Sire of Pearl H., $2: 21 \frac{1}{4}$

ELI ( $5: 128), 2: 291 / 2$, brown no marks, I5 $3 / 4$ hands, II 80 pounds; foaled I 885 ; bred by J. E. Brown, Wyoming, Otoe County, Neb.; got by Black Hawk Harry (dam Lady Kearsage, by Kearsage), son of Lightfoot (bred at Burlington, Vt.), by Black Hawk, son of Sherman Morgan : dam dark bay, bred by J. E. Brown, Wyoming, Neb., got by Sir Wm. Wallace Jr., son of imported Sir William Wallace; $2 \mathrm{~d}$ dam gray a noted mare for running, returned from the War. Sold to Dell Barker, Richlawn Stock Farm, Greenwood, Mo. Pedigree from breeder.

ELIAL G. (5-128), brown, I5 $1 / 4$ hands, Iooo pounds; foaled 1872 ; bred by J. E. McAllaster, Gouverneur, N. Y.; got by Aberdeen, son of Hambletonian : dam Lady Mac, brown, bred by A. D. Gardiner, Theresa, N. Y., got by Humbird, son of Tom Jefferson, by Black Hawk ; 2d dam said to be by Tippoo. Advertised in Plaindealer, Canton, N. Y., r89o, by Wm. Sheldon. Terms $\$ 25$. Pedigree from breeder.

Sire of 25 trotters $(2: 181 / 2)$, II pacers $(2: I 6) ; 5$ sires of 5 trotters, 3 pacers; II dams of 9 trotters, 3 pacers.

ELIAL G. JR. (1-64), bay ; foaled I 879 ; bred by J. E. McAllaster, Gouverneur, N. Y., got by Elial G., son of Aberdeen.

Sire of Jessie Sheridan $2: 2 \mathrm{I}^{3} / 4$; I dam of I pacer. 
ELIRE (I-I28), $2: 29 \frac{1}{4}$, chestnut, with star, two white hind feet, $15 \frac{1}{2}$ hands, Iroo pounds; foaled $\mathbf{r} S 92$; bred by A. J. Alexander, Spring Station, Ky.; got by Expedition, son of Electioneer: dam Elite, bay, bred by Charles Backman, Stony Ford, N. Y., got by Messenger Duroc, son of Hambletonian ; 2d dam Green Mountain Maid, dam of Electioneer, which see. Sold to Jonathan Hay, St. Paul, O., who sends pedigree.

Sire of Modesty, 2:17 $1 / 2$.

ELKADER BOY (ALONDO) ( $\left.\mathrm{I}-3^{2}\right)$, bay; foaled $\mathrm{r} 89 \mathrm{I}$; bred by L. J. Rose, Los Angeles, Cal. ; got by Redondo, son of Stamboul : dam Lady Corbitt, brown, bred by L. J. Rose, Cal., got by Arthurton, son of Hambletonian : 2d dam, bay, bred by L. J. Rose, got by Owen Dale, son of Williamson's Belmont. Sold to M. P. Dunn, Elkader, Ia., who sends pedigree ; to Geo. Russell, Elkader, Ia.; to parties in Illinois.

Sire of Elkader Girl, $2: 22 \frac{1}{2}$.

ELK-DICTATOR ( $1-32$ ) (full brother to Delineator), brown, $15 \frac{1}{2}$ hands, Iooo pounds; foaled I888; bred by Andrew Kaul \& Shelby Co., St. Marys, Penn.; got by Dictator, son of Hambletonian : dam Maisie, brown, bred by Brasfield and Swade, Lexington, Ky., got by Shelby Chief, son of Alexander's Abdallah; $2 \mathrm{~d}$ dam Logan mare, said to be by Pilot Jr., son of Pilot. Sold to G. H. Heisey, Newark, O. Pedigree from breeder's circular.

Sire of 2 pacers $\left(2: 23^{1 / 4}\right)$.

ELK NUTWOOD ( $1-64$ ), chestnut, I $53 / 4$ hands, I075 pounds; foaled I 889 ; bred by H. L. \& F. D. Stout, Dubuque, Ia.; got by Nutwood, son of Belmont: dam Alicia, bay, bred by Dr. A. S. Talbert, Lexington, Ky., got by George Wilkes; $2 \mathrm{~d}$ dam Alma Mater, dam of Alcantara, 2 :23, which see. Sold as a weanling for $\$ 6,000$, to T. C. Jefferson, Lexington, Ky.; to A. Kaul \& Son, St. Marys, Penn. Pedigree from T. C. Jefferson.

Sire of 2 trotters $(2: 2 I), 2$ pacers $\left(2: I_{5} \frac{1}{4}\right)$.

ELLERSLIE WILKES ( $1-256)$, black, hind feet white, $151 / 2$ hands, II 25 pounds: fodled r 880 ; bred by Timothy Auglin, Lexington, Ky.; got by George Wilkes : dam Aileen, bay, bred by Timothy Auglin, got by Mambrino Boy, son of Mambrino Patchen ; 2d dam Betty Brown, brown, bred by R. D. Mahone, Lexington, Ky., got by Mambrino Patchen ; 3d dam Pickles, bay, bred by General A. Buford, Lexington, Ky., got by Mambrino Chief, son of Mambrino Paymaster; $4^{\text {th }}$ dam said to be by Brown's Bellfounder, son of Bott's Bellfounder; and 5 th dam by Gray Eagle, son of Woodpecker. Sold to A. A. Kitzmiller, Lexington, Ky. Pedigree from son of breeder.

Sire of 20 trotters $\left(2: \mathrm{II}^{1} / 4\right) ; 7$ pacers $(2: 10) ; 3$ dams of 3 trotters, I pacer. 
ELLERY. See Robert S.

ELLINGTON BOY (I-64), $2: 36$, dapple gray, I 5 T/2 hands; I I oo pounds ; foaled I 875 ; bred by E. B. Lewis, Ellington, Ill.; got by Amboy, son of Green's Bashaw: dam Fly, gray. Sold to Sweet \& Lusk, Barry, Ill. Kept also at Plainville, Ill. Information from J. I. Little.

Sire of Ellington B., $2: 263 / 4$; I dam of I trotter.

ELLIOTT WILKES ( $1-32$ ), brown, $153 / 4$ hands, about II50 pounds; foaled I 884 ; bred by Hugh Patterson, Steubenville, O. ; got by Forwardson of George Wilkes: dam Sally Elliott, bay, bred by Wm. Emerson, near Lexington, Ky., got by Pilot Temple, son of Pilot Jr.; 2d dam said to be by Rattler, son of Stockbridge Chief ; and 3 d dam by a Whip horse. Pedigree from Dio Rogers, Steubenville, O., breeder of Summit Chief.

Sire of Summit Chief, $2: 17 \frac{1}{4}$.

ELLISTON, black, near hind foot white around coronet, $153 / 4$ hands; foaled I 886 ; bred by Leland Stanford, Menlo Park, Cal.; got by Electioneer : dam Lady Ellen, $2: 28$, bay, $151 / 2$ hands, foaled 1875 , bred by Jesse D. Carr, Salinas, Cal., got by Carr's Mambrino, son of Mambrino Patchen; $2 \mathrm{~d}$ dam said to be by Owen Dale, son of Belmont (Williamson's); 3d dam Ida May, by Williamson's Belmont, son of American Boy, and 4th dam by Red Buck, son of Bertrand. Sold to B. F. Holway, Sedalia, Mo. Pedigree from catalogue of breeder.

Sire of 3 trotters $(2: 28)$.

ELLIVOOD ( $1-64$ ), bay with star, snip on nose, both hind feet white, $151 / 2$ hands, I roo pounds; foaled $188_{5}$; bred by J. B. McFerran, Louisville, Ky.; got by Nutwood, son of Belmont: dam Amy, said to be by Magic, son of American Clay; $2 \mathrm{~d}$ dam Kitty Cruso, by Abdallah. Jr; and $3 \mathrm{~d}$ dam Kitty. Sold to J. E. Brewster, Chicago, Ill. ; to R. W. Conn, Valley Station, Ky. ; to Andrew McKueber, Atchison, Kan. ; to D. W. Thomas, Algonquin, Ill.; to C. B. Augustin, El Paso, Ill., who sends pedigree.

Sire of 2 pacers $\left(2: 17^{1 / 4}\right)$.

EL MAHDE (3-128), $2: 251 / 2$, chestnut; foaled 1885 ; bred by Wm. Dunn, Cincinnati, O.; got by Onward, son of George Wilkes : dam Lady Bunker, chestnut, bred by William Dunn, got by Mambrino Patchen ; $2 \mathrm{~d}$ dam Lady Dunn, gray, bred in New York, got by American Star; 3d dam the Captain Roberts mare. Sold to V. C. Cromwell, Lexington, Ky. ; to H. A. Moyer, Syracuse, N. Y. Died I 893.

Sire of 6 trotters $(2: 163 / 4), 3$ pacers $\left(2: 11 \frac{1}{2}\right) ; 3$ sires of I trotter, 2 pacers; 2 dams of 2 trotters.

ELMBROOK (5-128), $2: 26 \frac{1}{4}$, roan; foaled 1885 ; said to be by Hambletonian Chief (dam by American Star), son of Middletown, by Ham- 
bletonian: dam Pet Knox, gray, foaled Aug. I7, r867, owned by George Ellis, Belfast, Me., got by Gilbreth Knox, son of Gen. Knox.

The American Cultivator says, 1889 :

"The four-year-old roan stallion Elmbrook is another example of the same line of breeding. Elmbrook, won the $2: 35$ race at Lewiston, Me., June 25 , in straight heats, finishing the $3 \mathrm{~d}$ mile easily in $2: 26 \mathrm{~s} / 4$, which considering the time of the year, and also that the performance was over a half-mile track, stamps him as a remarkable four-year-old. Elmbrook is by Hambletonian Chief; dam, Pet Knox, by Gilbreth Knox $(2: 261 / 4)$, and Gilbreth Knox was by Gen. Knox : dam a mare brought from Vermont, as we are informed by the late Hiram Reed, which possessed unmistakable characteristics of Morgan lineage. Gen. Knox traced directly to Justin Morgan in the paternal line, and also inherited a Morgan strain through his dam, which was by Searcher, and Searcher according to Linsley, was by Barney Henry, also known as Hatch Hill Henry, from a daughter of Gifford Morgan.

"Hambletonian Chief, sire of Elmbrook, was by Middletown, son of Hambletonian; his dam was Mary Hulse, by American Star. Mary Hulse, by the way, was also bred to Messenger Duroc and produced the well known trotter, Charley Champlin, $2: 2 \mathrm{I} 3 / 4$, known in New England during the past few years under the name of Home Rule. But few four-year-old stallions have made records of $2: 261 / 4$, so far this season on a half-mile ring."

ELMIRA BOY (I-32), black; foaled I888; bred by Judson H. Clark, Elmira, N. Y.; got by Pocahontas Boy, son of Tom Rolfe : dam Rushville Maid, bay, bred by James Gerighty, Rushville, Ind., got by Blue Bull ; 2 d dam said to be by Tom Hal, son of Sorrel Tom (Shawhan's Tom Hal).

Sire of Belle Whitworth, $2: 18 \frac{11}{4}$.

ELMO, $2: 27$, chestnut, star and snip, three white ankles, I6 hands, I Ioo pounds ; foaled $186_{3}$; bred by Robert Robinson, Fredericktown; O. ; got by Mohawk, son of Long Island Black Hawk: dam bay, said to be by Sir Richard's Thoroughbred, son of Sir Archy; 2d dam by Gray Eagle; and $3 \mathrm{~d}$ dam by Medoc. Sold to Mr. Cresen, Chicago, Ill.; to Charles Andrews, Milwaukee, Wis.; to Orrin Hickok, San Francisco, Cal. Pedigree from George S. Hall, Fredericktown, O.

Sire of 6 trotters $(2: 161 / 4), 2$ pacers $\left(2: I_{5}\right) ; 2$ sires of 1 trotter, 2 pacers; 6 dams of 9 trotters, 2 pacers.

ELMO (I-8), $2: 29 \mathrm{~T} / 4$, bay, I 6 hands, I Ioo pounds; foaled I876; bred by Frank Morse, Jr., Whitefield, Me.; got by St. Elmo, son of Gen. Knox : dam bay, bred by Frank Morse, got by Tiger, son of Dr. Call Horse; 2d dam said to be by Bullrush. Sold to Oscar S. Chaffee, North Vassalboro, Me., who sends pedigree; to Dr. Strickland, Charlottetown, Prince Edward Island. See The Morgan Horse and Register, Vol. I., page 368 .

Sire of Bess, $2: 291 / 4$. 
ELMWOOD CHIEF ( $1-64$ ), 2 : I $83 / 4$, dark bay bordering on brown, small star, hind feet white, $153 / 4$ hands, I075 pounds; foaled 1875 ; bred by W. B. Treadway, Sioux City, Ia.; got by Black Ranger: dam bay, brought by a man named Swaine from Elgin, Ill., said to be by Revenge, son of Napoleon, by Sherman Black Hawk. Mr. Treadway writes: "I Sold Elmwood when a yearling to R. T. Kneebs, Sioux City, Ia. He drove and developed him and a year or two ago sold him and his full-brother Edgewood to parties who took them to Boston. His turf performances are matters of record the country over." Gelded. Pedigree from both breeder and R. T. Kneebs, who writes:

Joseph Battell, EsQ., Ripton, Vt.

$$
\text { Sioux City, Ia., June I 2, I889. }
$$

Dear Sir:-Enclosed please find the pedigree of Elmwood Chief, $2: 183 / 4$. It is not very complete but think it is all we can find out. His dam was brought here by a man named Swaine, who bought her in Elgin, Ill. Swaine is dead and we do not know whom he bought her of. $\mathrm{He}$ claimed she was by Revenge, sire of Chicago Maid, and Troubadour. She died in 1886 . I owned her at the time of her death.

Yours truly, R. T. KNEEBS.

W. B. Treadway, EsQ.,

Middlebury, Vt., March 28, I891.

Dear Sir:- Will you please inform me of whom you purchased the dam of Elmwood Chief and Edgewood. I would like to trace her to her breeder if possible. Yours truly,

Joseph Battell.

Dear Sir :-in answer to within,-of H. I. Merrill, Sioux City He bought her of Thomas Hance of Marengo, Ill., this was quite a number of years ago. Mr. Merrill tells me that he has talked with Marengo people about her since her sons have become so noted, and some of them quite up in horse literature think she was by a horse called old Dash, brought into lllinois from Vermont. I give you this for what it is worth. As a rule I take but little stock, in these conjectures, but it might lead to her identification. Mr. Merrill will cheerfully give you any information he may be possessed of, or anything further that I can furnish you I will cheerfully do.

W. B. TReadway.

EL. RAY (I-64), $2: 24 \frac{1}{4}$, black, I5 hands, Iooo pounds; foaled I 890 ; bred by H. D. \& R. C. Thompson, Malone, N. Y.; got by St. Bel, son or Electioneer : dam Acme, bay, bred by Elizur Smith, Lee, Mass., got by Alcyone, son of George Wilkes ; $2 \mathrm{~d}$ dam Alice Stoner, $2: 24^{\mathrm{T}} / 2$, bay, bred by T. J. Snyder, Paris, Ky., got by Strathmore, son of Hambletonian ; $3 \mathrm{~d}$ dam Ned, bay, bred by Thomas Turner, Mt. Sterling, Ky., got by Berkeley's Edwin Forrest, son of Edwin Forrest ; 4th dam Lady Turner, gray, bred by Hon. Thomas Turner, Montgomery County, Ky., got by Mambrino Chief; and $5^{\text {th }}$ dam said to be by Gray Eagle. Pedigree from breeder.

Sire of 2 pacers $(2: 151 / 4)$. 
ELSMERE (3-128), $2: 29 \frac{1}{4}$, chestnut, $15 \frac{1}{4}$ hands; foaled 1887 , bred by D. W. Foster, Canton Point, Me. ; got by Albino, son of Almont : dam Elcho, gray, bred by A. K. Foster, Canton Point, Me., got by Daniel Boone, son of Hambletonian; $2 \mathrm{~d}$ dam Alice Dunn, gray, bred by Sewall Dunn, Canton, Me., got by Farnum Horse, son of Brandywine. Pedigree from J. W. Thompson.

Sire of Eldora, $2: 21$.

ELSMERE (I-I28), bay, I6 hands, I200 pounds; foaled I 888 ; bred by Leland Stanford, Menlo Park, Cal.; got by Electioneer: dam Winona, black, I 6 hands, foaled I 870 , bred by Richard West, Lexington, Ky., got by Almont, son of Alexander's Abdallah; 2d dam Dolly, bay, bred by Dr. J. R. Adams, Fort Worth, Tex., got by Mambrino Chief, son of Mambrino Paymaster ; 3d dam Fanny said to be by Ben Franklin (dam by Copperbottom), son of Hazrack (dam by Copperbottom); and $4^{\text {th }}$ dam Nance, by Saxe Weimar, son of Sir Archy. See Onward. Sold to Andrew G. Leonard, Lexington, Ky. Pedigree from G. B. Blanchard, San Jose, Cal., and catalogue of breeder.

Sire of 2 trotters $(2: 181 / 4)$.

ELIVOOD MEDIUM (I-32), $2: 243 / 4$, bay, $153 / 4$ hands; foaled 1874 ; bred by Robert Steel, Philadelphia, Penn.; got by Happy Medium: dam Blanche, bay, I 6 hands; bred by Frederick Farr, Sr., Cranberry, N. J., got by Voorhees' Abdallah, son of Abdallah.

Sire of Conte Rosso, 2:22; I dam of I trotter.

ELYRIA (I-32), $2: 25 \frac{1}{4}$, chestnut, I $5 \frac{\mathrm{T} / 2}{2}$ hands; foaled March 25, I882; bred by E. D. Herr, Lexington, Ky. ; got by Mambrino King, son of Mambrino Patchen: dam Maggie Marshall, bred by Truman Pollock, Augusta, Ky., got by Telegraph, son of Black Hawk; $2 \mathrm{~d}$ dam said to be by Prince Richard, thoroughbred. Sold to George H. Ely, Elyria, O., who writes, dated May 27, I887:

"Maggie Marshall, the dam of Elyria was by Telegraph, son of Vermont Black Hawk, dam by Prince Richard thoroughbred, she was raised by Truman Pollock, of McLean, Ill., who at the time he raised the mare lived in Augusta, Ky. When Mr. Pollock's daughter was married to E. D. Herr, son of Dr. Herr, he gave the mare to Herr or his wife and she remained in Herr's hands until last September when I bought her."

Elyria took first premium at Loraine County Fair in 1885 and also sweepstakes.

Sire of 54 trotters $\left(2: 11 \frac{1}{4}\right)$, I3 pacers $\left(2: 18 \frac{1}{4}\right) ; 5$ sires of 5 trotters, I pacer; I dam of I trotter.

ELYTON; said to be by Trumps.

Sire of Alabama, $2: 291 / 4$.

EMANCIPATION, bay, black legs, mane and tail, I 6 hands, commanding figure; foaled 1827 ; bred by Mr. Riddle; got by Whisker (own brother 
to Whalebone) : dam said to be by Ardrossar, son of John Bull; 2d dam, Lady Eliza, by Whitworth; 3d dam, X. Y. Z.'s dam, by Spadille; and $4^{\text {th }}$ dam Sylvia, by Young Marske. Advertised, I838, at Col. Wade Hampton's estate, five miles below Columbia, S. C.

EMANCIPATION. Owned by James Clark, Tioga, Penn. Kept several years at Elmira and Chemung, N. Y.

EMBASSADOR (3-г28), bay; foaled 1872 ; bred by A. Whipple, Sægertown, Crawford County, Penn.; got by Satellite, son of Robert Bonner : dam Minerva, said to be by the Crawford County Champion, son of Grinell's Champion; and 2 dam the Dr. Gamble mare. Sold 1875 to Powell Bros., to D. S. Parry, Monmouth, Ill.; to James A. Graham, Biggsville, Ill.; to W. B. Bryson, Xenia, O. Pedigree from Powell Bros.

Sire of Herman H., $2: 21 \frac{1}{1} / 4$; I sire of 2 trotters; 2 dams of 3 trotters.

EMBASSADOR ( I-I28), $2: 25$, black, left hind heel white, I 6 hands, II 75 pounds; foaled $\mathrm{x} 880$; bred by Joseph Webster, Jewett, O. ; got by Ambassador, son of George Wilkes: dam Julia Anderson, brown, bred by Thomas Anderson, Buckland, Auglaize County, O., got by Highlander (Campbell's), son of Shylock (Shurr's) ; 2 d dam old Julia Ann, bay, bred by Cornelius Crabtree, Deersville, Harrison County, O., got by Argolain a beautiful and fast black horse originally from Kentucky; $3 \mathrm{~d}$ dam Titus, bred by Timothy Titus, Deersville, Harrison County, O., got by Expedition thoroughbred, from a Consul mare. Owned by Joseph Webster, Ohio. Fine appearance and good action. Pedigree from A. T. Moore.

Sire of 6 trotters $\left(2: 24^{1 / 4}\right), 4$ pacers $\left(2: 2 I^{1 / 4}\right) ;$ I sire of 2 pacers; I dam of I trotter.

EMBLEM (I-32), bay, I5 I/2 hands, Iooo pounds; foaled I 886 ; bred by Fashion Stud Farm, Trenton, N. J.; got by Stranger, son of Gen. Washington: dam Empress, said to be by Dictator; $2 \mathrm{~d}$ dam Blanche (one of a fast pair driven by August Belmont). Sold to Hugh Linton, Pawtucket, R. I., who sends pedigree.

EMERSON GOLDDUST (I-I6), chestnut, I53/4 hands, Iroo pounds; foaled I 865 ; bred by L. L. Dorsey, Middletown, Ky., got by Golddust : dam Sally Messenger, bred by S. R. Womack, Jefferson County, Ky., got by Womack's Highland Messenger. Owned near Nashville, Tenn. See The Morgan Horse and Register, Vol. II., p. II I.

Sire of Nelly Woods, $2: 281 / 2$.

EMERSON HORSE ; said to have been brought from Kentucky, to Macomb County, Mich. (probably Shelby township), and a descendant of Gray Eagle, thoroughbred. 
Mr. Battell,

Sharon, Wis., June 24, 1894 .

Sir :- In answer to your letter would say the dam of Charley Ford was foaled in Shelby township, Macomb County, Mich., the spring of I 858 . She was by a horse owned in same county, called the Emerson Horse, who was brought from Kentucky some years before, and said to be a son of the imported Gray Eagle. This Emerson Horse was the sire of a great many extra road horses, a majority of his colts were gray.

I owned the mother of Charley Ford and drove her from Michigan to Kenosha County, Wis., in January, I862. A man by the name of Bastader owned her when she foaled the colt Charley Ford. I suppose this is all the information you wanted from me. I bought her (Ford's dam) from Ezra Wright, the man that owned and brought out Magna Charta. Hoping this will be satisfactory. I am,
Yours respectfully,
G. W. ScOtт.

Post Master, Utica, Mich., Sept., 28, 1905.

Dear Sir :-Please inform me if Ezra Wright who lived in your town in 1857 , is still living, and if so, his present address. I am trying to trace a stallion known as the Emerson Horse that was kept in your county about $1850-60$. If Mr. Wright is not still living, please refer me to some old-time horseman who can give information about this horse. And much oblige

\section{Truly yours, JOSEPH BATTELL.}

Mr. Ezra Wright died several years ago. I saw his brother and he says the horse referred to was a thorough-bred running horse, but does not know his breeding, was a horse about $151 / 2$ hands, dark, bay or brown. That is about all the information I could get of anyone here.

$$
\text { Yours truly, Stuart BeatTy. }
$$

Sire of dam of Charley Ford, $2: 163 / 4$, and winner of $3^{8}$ recorded races.

EMERSON KING (I-32), $2: 27 \frac{1}{4}$, black, left fore foot and hind ankles white; foaled 1887 ; bred by C. J. Hamblin, Buffalo, N. Y.; got by Mambrino King, son of Mambrino Patchen: dam Mandrake, black, bred by C. J. Hamlin, got by Blackwood Chief, son of Blackwood; 2d dam Black Bess, said to be by Hamlin Patchen, son of George M. Patchen; 3d dam Annie Tucker, by Fields' Royal George; and 4th dam Bidwell mare, a fast pacer. Pedigree from catalogue of breeder.

Sire of Nancy King, $2: 131 / 4$.

EMERY FEARNAUGHT (I-I6), $2: 33 \frac{\mathrm{T}}{4}$, bay with black mane and tail, I 5 hands, rooo pounds; foaled I868; bred by Samuel B. Emery, Sanford, Me.; got by Minokin Boy (Western Fearnaught), son of Danville Boy Jr.: dam said to be Morgan. Owned by Samuel W. Berry, Biddeford, Me. Pedigree from breeder. See The Morgan Horse and Register, Vol. I., p. 628 .

Sire of 3 trotters $\left(2: 20 \frac{1}{4}\right)$; I dam of I trotter.

EMIGRANT (GENESSEE GRAY), flea-bitten gray, $153 \frac{3}{4}$ hands; foaled about 1823 ; bred by Dr. Barlow, Bethany, N. Y.; got by True Whig, said to be by an imported horse brought to Cayuga County, N. Y. : dam 
one of a pair of gray mares brought by Dr. Barlow from the East, some say Vermont. Purchased when a colt by John Jenne of Bethany, N. Y. Half interest owned by John Darrell of Hamburg, Erie County, N. Y., for a long time. When 26 years old sold to Mr. Roberts and went to Michigan. Information from S. B. Luck, in National Live Stock Journal, May, r88o.

EMIGRANT; foaled I 835 ; said to be by Souvenir, son of Recorder : and dam by Thunderbolt, thoroughbred. Imported into Canada, I84r. Kept some years in Connecticut.

EMIGRANT (I-I6), chestnut sorrel, $15 \frac{1}{2} 2$ hands, III 2 pounds, said to be bred in Wisconsin by a Mr. Vincent, got by Billy McCracken, son of McCracken's Black Hawk, by Black Hawk: dam by Daniel Vincent's Messenger, son of Cartwright's Messenger of New York. Advertised as "The fast trotting Black Hawk Stallion," by Sherlock, Bacon \& Titus at stable of Sherlock \& Bacon, Portland, Ore., in the Weekly Oregonian, I 863 and I864. Won in five mile heat race, over S. B. Parish's Honest George, and W. C. Walker's Fly-by-Night 2d, at Oregon State Fair, r 865. Terms $\$ 50$ the season. See The Morgan Horse and Register, Vol. II., p. III.

FMIGRANT (HOPEFUL) The highest bred horse ever imported to America, tracing back through sire and dam to Eclipse. Advertised as above by D. Fox, Beauport, Que., in the Quebec Mercury, $\mathbf{1} 845$.

EMIGRANT. Untraced.

Reputed sire of Captain Jenks, $2: 27 \frac{1}{4}$, at Armenia, N. Y., I874.

EMIGRANT JR., bay ; foaled I 84 - ; bred in Canada, said to be by imported Emigrant: dam by Henry son of Sir Archy; and $2 \mathrm{~d}$ dam by American Eclipse, son of Duroc. Went to Connecticut.

EMIN BEY (5-128), $2: 2 \mathrm{I} 1 / 2$, bay; foaled I 888 ; bred by K. D. Wise, Los Angeles, Cal.; got by Guy Wilkes, son of George Wilkes: dam Tempest bay, bred by F. M. Slaughter, Chino, Cal., got by Sultan, son of The Moor; $2 \mathrm{~d}$ dam Belle Mason, dam of Bob Mason, $2: 271 / 2$.

Sire of Planxty, $2: 24 ;$ Linnette, $2: 17 \frac{1}{2}$

EMPEROR; foaled probably before 1805 ; bred by Col. Burrell; got by imported Emperor: dam said to be by imported St. George; $2 \mathrm{~d}$ dam by Haines' Eclipse ; and 3 d dam by Sir Payton Skipwith's Figure.

EMPEROR, bay with black points, I 5 hands, said to be by the imported horse Quicksilver owned by Mr. Bellows. Advertised by R. Wallace, Milford, N. H., I82 I, I822. 
EMPEROR. A horse of this name entered by H. F. Smith, was awarded the second premium for speed at the New Hampshire State Fair, 1853 .

EMPEROR (BLACK DAN) (I 32), $2: 29 \frac{1}{4}$, black with star, I $5 \frac{1}{2}$ hands, Iooo pounds; foaled I865; bred by Charles Haley, Lewiston, Me.; got by Newman Horse, son of Rollins' Horse, by Rising Sun : dam gray, bred by Samuel Haley, Lewiston, Me., got by Lewiston Boy, son of Pollard Morgan; 3d dam gray, bred by Samuel Haley, got by Quicksilver, son of imported Dey of Algiers, Arabian. See The Morgan Horse and Register, Vol. I., p. 87 I.

Trotted $1874-77$, and winner of 18 races.

EMPEROR (BATES') (I-32), bay; foaled I853, bred by Robert Arthur, Ticonderoga, N. Y.; got by Bridges' Emperor, son of Napoleon : dam chestnut trotting mare Lady West, said to be Morgan.

EMPEROR (BRIDGES'), chestnut, I5 3/4 hands; foaled about 1839 ; bred by James Bridges, Long Island; got by Burr's Napoleon, Son of Young Mambrino: dam Fanny Pullen, sorrel, $15 \frac{1}{4}$ hands, rooo pounds, foaled I 825 , said to have been foaled the property of Sullivan Pullen, Anson, Me., breeder not known, and got by Winthrop Messenger; also said to be bred by James Pullen, East Winthrop, Me., and got by his horse Quicksilver, son of Shark.

There were two Fanny Pullens, bred in Maine about the same time, one of these by Sullivan Pullen of Anson, Me., said to be by Winthrop Messenger, the other by James Pullen of East Winthrop, later of Augusta, Me., and got by Quicksilver as above. Both mares were sold and it is understood went to Boston. One of the mares went to New York in I 835 , and became the property of James Bridges. Mr. Wallace states that this mare was seen at New York by James Pullen of Augusta, Me., who bred Fanny Pullen, by Quicksilver, "who fully identified her as the mare he bred." It has since been claimed that this mare was traced and was the mare foaled the property of Sullivan Pullen and said to be by Winthrop Messenger.

Fanny Pullen is recorded in the first volume of Wallace's Register, "ch. m., foaled r82-, got by Quicksilver, son of Dey of Algiers, bred by James Pullen, East Winthrop, Me."

She is recorded in the third volume "ch. m., foaled I 826 , got by Winthrop Messenger, son of imported Messenger: dam a mare purchased in Winthrop, Me., in foal to Winthrop Messenger, by Sullivan Pullen, of Anson, Me., pedigree not traced. Foaled the property of Sullivan Pullen; found her way to New York ; was owned by James Bridges, L. I., and produced the famous twenty-mile gelding, Trustee. She was very fast for her day, and was at last destroyed in Boston, when old. [Corrected from Vol. I.]"

Mr. Wallace says in his Monthly of July, I89r : 
"A case in point illustrating the uncertainty of identification after a term of years is furnished in connection with this Trustee family in the mare, Fanny Pullen. She was a noted trotter in her day and afterward became the dam of the famous twenty-mile Trustee. She was owned by James Bridges of Long Island. Her name was a clue to the name of her breeder, and James Pullen came all the way from Maine and fully identified her under oath as the mare he had bred. True, there was some trouble about the history and dates, but the 'identification' was without doubt. Soon afterward the truth came out with complete historical proof, and it was shown that the mare was foaled the property of Sullivan Pullen of Anson, Me. There was no need of 'identification' the history of the animal proved it, and that is what is needed in this case."

The trouble with this is, that no testimony is given. It is clear that Fanny Pullen, the sorrel mare that was the dam of Emperor, appeared in New York in the Summer of 1835 , and won two races at Harlem, entered by Horace Jones, getting a saddle record of $2: 35$. In 1836 she was beaten in a race of two-mile heats by Dutchman (time $5: 17 x / 2$, $5: 181 / 2)$, and was subsequently purchased by James Bridges and bred to Trustee, the produce being Trustee (gelding) the first horse to trot twenty miles inside an hour, which he did in 59 minutes $35 \frac{1}{2}$ seconds. After breeding Emperor, James Bridges sold Fanny Pullen to Spencer J. Vinal of Boston, probably in 1839 .

Under date N. Anson, Me., March I, I885. Mr. Silas G. Pullen, son of Sullivan Pullen wrote us as follows :

"I received a letter from you directed to my father, inquiring the color and build of Fanny Pullen. As he is not living, I cannot give you a full description of her. Mother says she was light bay; long, slim, bowing neck, star in forehead; long large head; carried her head very near the ground; was quite tall with high sloped rump and small, slim legs. As to the pedigree of her dam, I know nothing further than she was an old, worn-out, spavined mare that he bought in Winthrop."

We also received the following letter from J. W. Thompson, author of Maine Bred Horses :

Mr. Joseph Battell,

Canton, Me., Feb. 5, r885.

Dear Sir:-I do not find all the papers at this late day concerning Fanny Pullen. I remember the question was very fully gone into in the Maine Farmer at the time I was collecting material for my work on Maine Bred Horses. There were two mares claiming to have been the real Fanny Pullen. One bred by a Mr. Pullen of Augusta and got by Quicksilver.

The other a mare raised in Anson, Me., and got by Winthrop Messenger. Mr. Spencer Vinal of Boston, now I think dead, knew the real Fanny Pullen from the time John Swan of Anson, Me., took her to Massachusetts, until she died his (Vinal's) property. He could not be mistaken. The discussion I remember attracted Mr. Wallace's attention and he accepted the proof as conclusive that Fanny Pullen was by Winthrop Messenger. I enclose two letters bearing on the subject which you will please return.

Yours truly,

J. W. Thompson. 
Mr. J. IV. THOMPSON,

$$
\text { N. Anson, Dec. II, I } 873 \text {. }
$$

Dear Sir :-In regard to the horses you inquire of me about. I can give you but little information except Fanny Pullen. Said mare was foaled and raised on my farm in Anson, where I now live. She was by the Winthrop Messenger, and Trustee was one of her colts.

Sullivan PUllen.

Mr. Vinal wrote Oct. 5, I875, to J. W. Thompson, as follows :

"The mare I had was the genuine Fanny Pullen, brought to Boston in 1832 or ' 33 from Anson, Me., by John Swan and sold to Mr. Iull of Boston. She was here one season and trotted a number of races on the Dedham Turnpike against a pacer and a mare called Blinker. Then she went to New York and went into the hands of James Bridges; he bred her to Trustee and got the twenty-miler *** I bought Fanny of him. Fanny Pullen was a pale sorrel, stood $15 \frac{1}{2}$, and weighed 1000 pounds. She was a coarse-hipped, low-shouldered mare, and trotted down-headed. Saddle was her place to trot fast.

"P. S. Mr. Swan died since you were here."

The trouble with this tracing is that it does not appear that Mr. Vinal ever saw the mare till he bought her, or that John Swan or any body else identified her as the mare Swan brought to Boston from Anson, but the description agrees very well with that given to us by letter I 885 , by Mrs. Sullivan Pullen.

We add letters received by us :

Mr. Battell,

East Winthrop, ME., Oct. I 2, I89r.

Dear Sir :-There is but one child of Mr. James Pullen living that I know of. He may give you the information required. His address is, Mr. Charles Pullen, Skowhegan, Somerset Co., Me.

Mr. Charles Pullen is over 60 years old. I do not know of any one here in East Winthrop who would be likely to give you the desired information.
Yours very respectfully,
G. A. WADSWORTH,
Bread Loaf InN, Vt., Oct. 20, I891.

Charles Pullen Esq., Skowhegan, Me.

Dear Sir:--I am informed that your father James Pullen, some 6o years ago, raised a mare known by the name of Fanny Pullen. Will you please, if this is true, give me on this paper a description of this mare and state to whom and where she was sold, and return to

$$
\text { Yours truly, Joseph BatTell. }
$$

Skowhegan, ME.

Dear Sir :-I received your letter. I remember that my father once owned a mare called Fanny Pullen I remember of hearing it talked of by my father and brothers but they are all dead and I being quite young at that time don't remember anything in particular about the mare or to whom she was sold. I should be pleased to give you the information you ask if I could. My older brothers could have done so if they were living.

$$
\text { Yours respectfully, Charles W. Pullen. }
$$


This is also an unsatisfactory letter and strengthens the belief that the mare was not bred by James Pullen.

Mr. BatTELL,

East Winthrop, Me., Dec. I 2, I903.

Dear Sir :-Your letter of inquiry at hand. Yes, Mr. James Pullen was a resident of this town. I knew him, I think he had four sons. One of them is living; as to the others, two of them I cannot say. One of them is not living. His widow, Martha Pullen or Mrs. George Pullen can be reached. Address her, Winthrop, Me. She has two daughters. You can also address a son, Mr. Chas. Pullen, Skowhegan, Me.

$$
\text { Respectfully, G. A. Wadsworth, }
$$

Mr. Charles Pullen,

Middlebury, Vt., Dec. I4, I903.

Dear Sir :- I am trying to trace the mare known as Fanny Pullen, foaled about i 825 . She came from Maine.

Do you know whether your father bred the mare?

"I don't know anything in regard to the mare. I was only two years old, being born in $1823 . "$

How long has your father been dead, and how many brothers have you living? If any please give me their address.

"Father has been dead 40 years next February. I have one brother living, Carroll J. Pullen, Pawtucket, R. I."

Did you ever have any sisters? If so please state their Christian names, and if any of them are living, also your mother's first name.

"I had two sisters, neither is living. The oldest was Serephim and the other was Lucinda. Mother's name was Hannah."

An answer to these questions, for which I have left a space under each, will exceedingly oblige,

$$
\text { Yours very truly, }
$$

Joseph Battell.

This is a very satisfactory answer to questions asked, but gives no evidence that the mare was bred by James Pullen.

The following letter in regard to Fanny Pullen is from the Spirit of the Times, I862 :

Dear Spirit:-I have seen in your paper an inquiry about pedigree of the mare, Fanny Pullen. I had this from the man that raised her, Mr. James Pullen of this place; Fanny Pullen was by Quicksilver (he by imported Arabian horse, Dey of Algiers) from an English mare, dam of Fanny Pullen, common breed of that day. At four years Fanny Pullen showed more speed and bottom than any in these parts. She was sold to a man who took her to Long Island. It has been so long since that Mr. Pullen has forgotten the name of the man he sold her to. I saw the man I5 years since and got these facts, but I did not think to ask his name or where he lived. She has been claimed to be a Messenger, but there was not one drop of Messenger blood in her veins. Hoping this will satisfy those wishing to know the facts, I remain,

$$
\text { Yours truly, }
$$

Geo. W. Pullen,

East Winthrop, Me.

This is not a satisfactory letter. Indeed it is very unsatisfactory. From all this evidence, especially the description by Mrs. Sullivan Pullen, it would appear, as we think, quite conclusive that Fanny Pullen 
was foaled the property of Sullivan Pullen, Anson, Me. Breeder and therefore breeding unknown. It will be noticed that Silas J. Pullen, son of Sullivan Pullen says :

"As to the pedigree of the dam, I know nothing, further than that she was an old, worn-out mare that he bought in Winthrop, Me." As Winthrop Messenger is understood to have been kept at Winthrop, the year in which this mare was bred, this is not antagonistic to the statement that she was got by Winthrop Messenger. But it appears from the record in Vol. III., of Wallace's Register that this mare was in foal when Sullivan Pullen bought her and the foal was Fanny Pullen, nor is there any evidence whatever by whom Fanny Pullen was bred. That is, the breeder of Fanny Pullen is not known, and therefore her breeding is not with certainty known.

In conclusion we cannot help but think that Mr. Wallace was mistaken as to Mr. James Pullen's identifying the mare at New York. That story in itself is exceedingly improbable, and doubtless originated from Geo. W. Pullen's letter in the Spirit of the Times.

Mr. W. G. Baldwin, Ticonderoga, N. Y., says that Bridges' Emperor was a good chestnut in color, nearly 16 hands high, with long body and a short neck after the French pattern; also a good trotter and left good stock.

EMPEROR (HENDRICK'S). See Black Tom.

EMPEROR OF MOROCCO. Advertised in the Virginia Gazette, I879.

EMPEROR WILKES (I-I6), $2: 203 / 4$, bay, little white on each hind heel, I 5 I/2 hands, I025 pounds; foaled I 886 ; bred by Joseph H. Bryan, Lexington, Ky.; foaled the property of O. H. Chenault, Richmond, Ky. ; got by William L., son of George Wilkes : dam Pilot Anna, gray, bred by Caleb Wallace, Lexington, Ky., got by Pilot Jr.; 2 d dam Puss, said to be by Drennon, son of Davy Crockett. Pedigree from O. H. Chenault, Richmond, Ky.

Sire of 8 trotters $\left(2: 13 \frac{1}{4}\right), 5$ pacers $\left(2: 09 \frac{1}{4}\right)$.

EMPEROR WILKES (I-I6), chestnut, I 5 hands, 950 pounds ; foaled 1887 ; bred by John W. Porter, Ticonderoga, N.Y.; got by Charley Wilkes, son of Red Wilkes: dam Ella Jackson, chestnut, bred by J. W. Porter \& David Snow, Andover, Mass., got by Daniel Lambert, son of Ethan Allen; 2d dam Fanny Jackson, brown, bred by B. B. Brown, Ticonderoga, N. Y., got by Arthur's Stonewall Jackson, son of Williamson's Black Hawk; 3 d dam black, bred by Terry Condon, Shoreham, Vt., whose breeding Mr. Terry Condon told us in interview at his home that he did not know.

Sire of Ethan Wilkes, $2: 19 \% \frac{1}{4}$.

EMPEROR WILLIAM (I-I6), $2: 27^{1 / 2}$, bay with black points, I 6 hands, 
I050 pounds; foaled May, I867; bred by C. H. \& M. Skinner, St. Albans, Me.; got by Gen. Knox, son of Vermont Hero: dam Lady Hollis, a fast pacing mare brought from Massachusetts. Sold to parties in New York City, where he was later owned by John D. Rockefeller. Pedigree from breeder. See the Morgan Horse and Register, Vol. I., p. $37 \mathrm{r}$.

Sire of 2 trotters $(2: I 6)$; I sire of I trotter.

EM PIERCE (3-64), $2: 23 \frac{1}{4}$, gray, 16 hands, 1260 pounds; foaled 1888 ; bred by Tip Queen, Salineville, O.; got by Bayard, son of Pilot Jr. : dam Zade, bay, bred by James J. Kane, Cadiz, O., got by Hiatoga Prince, son of Hiatoga; and $2 \mathrm{~d}$ dam Togue, bay, bred by J. J. Kane, Cadiz, O., got by Flying Hiatoga, son of Hiatoga. Pedigree from breeder.

Sire of Alma Pierce, $2: 24 \%$.

EMPIRE (I-I6), dun or mouse color with black stripe on back and front legs, I 5 I $/ 2$ hands, I Ioo pounds; foaled I $84-$. Purchased at Rivier de Loupe, P. Q. Can., by a merchant at Sorel, who sold to a Mr. St. John of La Priarie, P. Q., who sent him to New York in the care of Mr. Spaulding, where he was sold to Pierson Hendrickson, Red Bank, N. J.

M. Charlebois, Montreal, a well known horseman, says: "He was a good looking horse and a better horse than Sarsaparilla, looked like the Dansereau breed but not as pure bred. Could trot in about $2: 40$. "

Wallace says : "He gave many of his colts his color and black stripe on the back. He was a valuable horse and could trot better than $2: 40$, and left good colts."

An advertisement by poster of this horse whilst owned in Monmouth and other counties, N. J., states that he is a Morgan horse, got by the horse which got St. Lawrence, and his dam, the dam of Lady Moscow, a Morgan. The trouble with the poster is that it claims too much Morgan. It has always been said that the dam of Lady Moscow, $2: 30$, was a Yankee mare, and it is very probable that she was Morgan, and so It is quite possible that this horse was got by one of several Buckskin stallions, got by Royal Morgan, one of which called Buckskin Morgan, was kept at Dudwell, P. Q. Royal Morgan was foaled about I82I-4. See the Morgan Horse and Register, Vol. I., pages 306 and 3 ro. We do not think the sire of this horse had any connection with the sire of St. Lawrence whose sire we traced. See St. Lawrence.

Royal George is said to have beaten Empire at Rochester, N. Y., March 6, I858.

John Doty the old time driver in interview, April $4, \mathbf{I} 89 \mathbf{I}$, at New York said :

"Empire was from Canada. Pierson Hendrickson of Red Bank, N. J., got him from St. Johns, Canada, either he or Spaulding, a Canadian who brought Sir Charles to Bull's Head.

"Empire was a light bay, black lists, $15^{1 / 2}$ hands, light barrelled, 
dock tail, no white. A nice styled going horse; a great deal of style; a good goer; was beaten by Sarsaparilla another stallion from Canada owned by Nat Roberts.

"St. Charles was a roan stallion, not high headed, a heavy good block of a horse; $15 \mathrm{I} / 2$ hands, heavy made, deep chested, went to Burlington County.

"Sarsaparilla came there abont the time that George M. Patchen was four years old. Empire was one or two years before. St. Charles about the same time as Empire."

In a later interview in $189 \mathrm{r}, \mathrm{Mr}$. Charlebois, Montreal, said :

"Empire was mouse color, black stripe on front legs. St. John of La Prairie, bought him at Rivière de Loup. A man who kept a big store at Sorel, bought him at Rivière de Loup. I knew his breeder. The merchant sold to St. John who sent him to New York in care of Spaulding. A nice well cut horse. Looked like a French horse 15-2 or 3, I roo pounds. About same age as Sarsaparilla, could trot in about 2 :40. A good looking horse, better horse than Sarsaparilla. Might have been of the Dansereau breed looked like them, only Dansereau pure and looked better."

Sire of dam of Flora Windsor, $2: 30$ and winner of 12 races.

EMPIRE (I-I6), bay with star, I6 $1 / 4$ hands, I 200 pounds; foaled May 5, r869; bred by James S. Morrell, Albion, Me.; got by Gen. Knox, son of Vermont Hero: dam dark brown, bred by Elnathan Taylor, Albion, Me. See The Morgan Horse and Register, Vol. II., p. I I 2.

Sire of Nathan, $2: 291 / 4$.

EMPIRE, bay, some white on hind feet, I 7 hands, I 250 pounds ; foaled 1874 ; bred by James Miller, Paris, Ky.; got by Mambrino Patchen: dam Favorite, chestnut, bred by James Miller, got by Alexander's Abdallah; 2d dam Lizzie Peebles ( 2 d dam of Bourbon Wilkes, which see). Sold to S. A. Browne \& Co., Kalamazoo, Mich. Pedigree from breeder.

Sire of 3 trotters, $\left(2: 15 \frac{1}{4}\right)$; I sire of I trotter; 4 dams of 5 trotters.

EMPIRE STATE, black, I roo pounds ; said to be bred in Wyoming County, N. Y.; and got by a thoroughbred horse.

EMPIRE WILKES (I-64), $2: 30$, bay, I5 I/2 hands, I050 pounds; foaled I 882 ; bred by L. Herr, Lexington, Ky.; got by George Wilkes : dam Jane Moseley, bred by L. Herr; got by Mambrino Patchen; $2 \mathrm{~d}$ dam said to be by Tom Crowder. Died in rgor. Sold to Geo. Van Campen Jr., Olean, N. Y.; to C. A. De Graff, St. Paul Minn.; to Mike Bowerman, Lexington, Ky. Pedigree from A. H. Farwell, Independence, Ia., breeder of Elfah.

Sire of 6 trotters $\left(2: I_{4} \frac{1}{4}\right), 3$ pacers $(2: 05 \%) ;$ I sire of I pacer; 5 dams of 4 trotters, 2 pacers.

ENCHANTER, brown, I53/4 hands; foaled 1867 ; bred by Jonathan Hawkins, Wildair, N. Y.; got by Administrator, son of Hambletonian : dam Dolly, bay, foaled I85-; bred by Robert Blair, Bordentown, N. J., 
got by Black Bashaw, son of Young Bashaw; 2d dam said to be by Saladin, son of Young Bashaw, by imported, Grand Bashaw. Owned by Powell Bros, Springboro, Penn.

Sire of 2 trotters $\left(2: 28 \frac{1}{4}\right) ; 3$ sires of 2 I trotters, 7 pacers; 7 dams of 6 trotters, 3 pacers.

ENDYMION (I-34), $2: 23 \frac{1}{4}$, black with white hind heels, $151 / 4$ hands; foaled April 9, r879; bred by Gus Eastman, Lexington, Ky.; got by Dictator (dam by American Star), son of Hambletonian: dam Annie Eastin, black, bred by August Eastin, Lexington, Ky., got by Morgan Rattler, son of Green Mountain Morgan; 2 d dam Annie said to be by Mambrino Chief ; 3d dam Helen Mae, by Downing's Bay Messenger; and $4^{\text {th }}$ dam Red Bird, by Cannon's Whip. Sold to J. Q. Case, Racine, Wis.; to S. A. Browne \& Co., Kalamazoo, Mich. Died I889. Pedigree from breeder.

Sire of 4 trotters $\left(2: 1_{3} \frac{1}{2}\right) ; 3$ sires of 2 trotters, 3 pacers; 2 d dams of I trotter, I pacer.

ENERGY (I-64), 2 :29 I/4, bay; foaled I 886 ; bred by R. P. Pepper, Frankfort, Ky.; got by Onward, son of George Wilkes: dam Fanchon, brown, bred S. R. Buchanan, Woodford County, Ky., got by Hamlin's Almont Jr.; $2 \mathrm{~d}$ dam said to be by Alexander's Edwin Forrest; and $3 \mathrm{~d}$ dam by Star Davis.

Sire of 2 trotters $(2: 18)$.

ENFIELD (3-64), $2: 29$, bay, I5 $1 / 2$ hands; foaled I 868 ; bred by Gabriel Wood, Middletown, N. Y. ; got by Hambletonian, son of Abdallah : dam Julia Machree, chestnut, foaled I $\delta_{53}$; bred by P. H. Duryea, Goshen, N. Y., got by Seeley's American Star, by Coburn's American Star, son of Cock of the Rock, by Sherman Morgan; $2 \mathrm{~d}$ dam said to be by Pintlar's Young Bolivar, son of Sam a cream colored horse, foaled i 832, bred and owned by James Ross, Callicoon Depot, N. Y. (See Bolivar, Pintlar's). Sold to W. R. Elliston, Nashville, Tenn.; to Will \& V. L. Polk, Columbia, Tenn., and died March, I887, the property of Campbell Brown, Spring Hill, Tenn. See The Morgan Horse and Register, Vol. II., p. I 12 .

Sire of 4 trotters $\left(2: 19 \frac{1}{4}\right) ; 5$ sires of 5 trotters, I pacer; 29 dams of 36 trotters, I5 pacers.

ENFIELD JR. (3-128), bay ; foaled I874; bred by E. H. Douglas, Franklin, Tenn.; got by Enfield, son of Hambletonian: dam said to be by Black Hawk Rattler, son of Biggart's Rattler; 2 d dam by Highlander, son of Glencoe; and $3 \mathrm{~d}$ dam by Rocky Mountain. Pedigree from breeder.

Sire of Betty B., $2: 291 / 4 ; 2$ dams of 2 trotters.

ENGINE. An imported Hunter at Mr. John Rose's Plantation near Leeds, fees 40 shillings payable to Thomas Hodge. 
Advertised as above in the Virginia Herald and Fredericksburg Advertiser, Leeds, Feb. 25, 1790.

ENGINEER, brown; foaled I 756 ; bred by Mr. Fenton; got by Sampson : dam Young Grayhound Mare, said to be by Grayhound (Young) ; and $2 \mathrm{~d}$ dam by Curwen Bay Barb which was a present to Louis the Fourteenth from Muly Ishmeal, King of Morocco. Engineer died at Wentworth in 1782.-General Stud Book, Vol. I., pp. 97, 395.

ENGINEER, brown, said to be by Lath: dam DeLancey's Cub Mare. Advertised i 7 So to be kept at Newtown, N. J. Terms $£ 4$.

ENGINEER ( $\mathrm{I}-2)$. Breeder and breeding unknown, but it is quite probable that he was got by the original Morgan horse. The first authentic information of him is from an advertisement in the Long Island Star, May 8, 1816, as follows :

"The elegant horse Engineer at Daniel Seely's near Queen's County Court House, and in Jericho; $\$ 5$ to $\$ \mathrm{I} 2$. Gray, I6 612 hands, lofty carriage and finely formed. He has a great show of bone and sinew, promises an excellent temper and is considered a very superior mover. He was brought into this place last fall and served a few mares, and proved himself a sure foal-getter. The manner he came into this Country is such that I cannot give an account of his pedigree, but his courage and activity show the purity of his blood, which is much better than the empty sound of a long pedigree too often inserted.

Jericho, April 3, I 8 г6."

Thomas Jackson, JR.

In 1886 we made a visit to Long Island to examine into the pedigree of the early horses of that locality, and perhaps never have we enjoyed more a trip of this kind, both because of the picturesqueness of the Island and the hospitality of its people.

We spent one night at the exceedingly pleasant home of the well known horseman and breeder Carl Burr. And from his father Smith Burr, then a gentleman of over 80 , got many important facts. In regard to the Engineers, Mr. Smith Burr who at one time owned Engineer $2 \mathrm{~d}$ the sire of Lady Suffolk, said:

"The sire of Engineer 2d, old Engineer, was brought here by one Jackson. I do not know where he came from. He stood here one season at Cold Spring. They said he was from Canada and had a story of his history. Some thought it true, but Sam Whitson told me that they made the story up. I was well acquainted with Sam Whitson. He did not give any other pedigree. I do not think Engineer stood there but one year.

"Whitson and John Tappen pretended to own old Engineer, but they never owned him. I think they hired the use of him from some one and he went back to his owner.

"Old Engineer was a clean smooth-made horse of good size; I6 hands and pretty well turned; did not run; Engineer $2 \mathrm{~d}$ did; rather 
coarse horse, big, raw-boned, strong made horse, gray, $161 / 2$ hands, he was wind broken, raced a little. I never heard of any other son of old Engineer. Engineer 2 d was on the track at Westbury."

This story which they made up we suppose to have been that Engineer was captured from Gen. Packenham at the battle of New Orleans, which story followed Burdick's Engineer and Young Engineer, sons of Engineer, through their lives-although in this case the Burdick horse was supposed to be returning to Canada.

Mr. Wallace quotes a sentence from the above advertisement of Engineer and then says :

"It is here suggested that the horse was imported, and the story which Jackson told was that he was brought from England to Canada, by a British officer, and by some surreptitious means found his way from Canada to Long Island."

How or from whom Mr. Wallace got this last information does not appear, as there is hothing of the kind in the advertisement. Nor did we obtain any such in our inquiries upon Long Island, except the fact that he came from Canada.

In the Spirit of the Times, Vol. XXII., ( 1852 ), page 30 , an admirer of Messenger stock speaks of Lady Suffolk, by imported horse Engineer.

An article in the New York Spirit of the Times, Jan. 7, r860, says:

"Engineer the first was white, of medium size, light in the carcass with very heavy bones and strong feet, his action was lofty and remarkably stylish, but his get generally were not particularly distinguished. Lewis' Engineer, the sire of Lady Suffolk and many other good ones, was, by old Engineer, from a Plato mare."

It will be noticed that the party who wrote this and who appears to have been well acquainted with the horse speaks of him, and we presume correctly, as of medium size. Mr. Burr called him $x 6$ hands. The advertisement if correctly copied says $16 \mathrm{x} / 2$ hands; but advertisements of stallions are quite apt to overstate. All accounts speak of him as stylish which always makes a horse look larger when driven. We notice this party calls him a white horse, and Mr. Burdick, who owned a son speaks of him as a gray horse faded white, which would suggest that he was at least ro years old, and might have been considerably older when kept on Long Island.

Of the sons of Engineer, Engineer 2d, the sire of Lady Suffolk, resembled the Messengers, being both somewhat large and coarse, and it has generally been stated that his dam was got by Plato, son of imported Messenger; and although the breeder of the dam of Engineer $2 \mathrm{~d}$, is not known there is a very strong probability from his appearance, and character, and the locality where he was bred, that the pedigree given to him is correct.

The two other sons of Engineer, whose history has been handed 
down, are Burdick's Engineer that for many years was owned in Washington County, N. Y., and the Kasson Horse owned in Orange County, Vt. The breeder of neither of these horses is known, but the time and locality in which they were bred, together with their description and qualities, and the statement handed down in regard to their sire, make it reasonably certain that they were both by Engineer.

We made very thorough investigation into the pedigree and history of these stallions which will be given under their names. In each case the statement was made to us by reliable parties, who got it from their owners, that their sire had been captured from an English officer.

The story told us of the sire of Burdick's Engineer was by Mr. William A. G. Arthur a very prominent citizen and horseman of Ticonderoga, N. Y. Mr. Arthur said :

"A man by the name of Weatherhead had Engineer at West Moriah, in 1836 or 37 . They said he was twenty years old when they had him up here. I was born I 822 , bred a mare to Engineer 1836 or 37 at Crown Point. He was a handsome chestnut horse 16 hands high, very round barrel the roundest I ever saw. He was a little thick headed, short thick head, not fine. He was a good quarter horse and could trot in 3 minutes. He went back to Warrensburg, and at last to Glens Falls, where, I think, he died.

"The story they told of his origin was that his sire was captured from General Packenham at New Orleans. He was ransomed and they were taking him back to Canada, stopped at Warrensburg over night, when the horse was stolen out of the barn and bred to two mares, one of which had this colt, the other a filly."

To the question whether this was believed Mr. Arthur replied: "I and others believed it just as much as you believe that you have got your hat upon your head."

Mr. Wallace says in his Monthly, Vol. IV., p. 375 :

"All that Mr. Burdick could say about his pedigree was, that he was got by a gray horse, faded white, called Engineer, that was a very elegant horse and a great traveler. He told a story that accompanied the gray horse, to the effect that he had been ridden in Canada by a British general, and afterwards brought to the States. Dr. Streeter considered this story so apocryphal that he did not send it to us at first, but apocryphal as it is, it proved to be the 'key to the situation.' The same identical story accompanied the horse when he first appeared on Long Island and was there represented as an imported horse."

The Kasson Horse was also gray and was brought from Connecticut to Vermont, in or about i 8r9. The statement made by Mr. Kasson was that he was got by a horse said to have been captured from a British officer. This statement we had from Mr. C. M. Huckens, Topsham, Vt., quite a noted Vermont horseman who said that he had often talked with Mr. Kasson, Sr., about the horse.

A son of Mr. Kasson told us that his father got him in Connecticut when two years old, about 1819 , and that he was part Morgan, but on 
which side, sire or dam, he did not know. This was corroborated by his mother, Mr. Kasson, Sr., being dead when the investigation was made.

The two prominent parts that appear in these stories is that the horse had been owned in Canada, and was stolen from a British officer. The description of the horse, and the time and location from which he came, suggest that he was probably a Morgan horse, and that the story of his having been captured from an English officer, came from the fact that he was by the son of a horse so captured. We know of no so probable an explanation of the extraordinary appearance and disappearance of this horse, for had he been a thoroughbred horse he would unquestionably have been so advertised; or had his assumed owners known his pedigree they would have told it.

If a Morgan horse it is, perhaps, more probable that he was brought to Long Island from Vermont than from Canada, but possibly from the latter as only a boundary line divided Vermont, where at that time the Morgans abounded, from the Province of Quebec, into which unquestionably Morgan horses were imported previous to $\mathrm{I} 800$, and after that date were both imported and bred in large numbers.

Mr. Wallace's description is: "Very elegant in his style, form and proportion." Mr. Burr's: "A clean, smooth made horse of good size, I6 hands and pretty well turned."

The advertisement speaks of him as "The elegant Horse Engineer, of lofty carriage and finely formed."

All of these descriptions apply well to a Morgan horse. And although in height he is described as decidedly above the average, quite occasionally, we have known Morgan horses fully i 6 hands, and also preserving in contour and quality the general characteristics of the Morgan.

Gen. Hammond, a very prominent and wealthy business man and horseman of Crown Point, N. Y., in describing Burdick's Engineer said that he was a horse of about the same size, and looked very much like Russell's Fearnaught. Russell's Fearnaught it will be remembered was an intensely in-bred Morgan horse and at one time held the world's trotting record.

Brutus the first of the get of the original Justin Morgan after he came to Vermont, whose history is known, is described as $153 / 4$ hands, and of his two known sons one was a gray. Other sons of the original Morgan were described to us as weighing over r 200 pounds. See The Morgan Horse and Register Vol. I., pp. 124-756.

It corresponds, too, with the custom in New York of calling Morgan horses Canadian. A custom so universal that we do not know of a single instance previous to $\mathrm{I} 845$ or $\mathrm{I} 850$, when a Morgan horse is mentioned under his right name in the horse literature of that city. Lady Surry, from Surry, N. H., dam of Henry Clay; Tom Thumb sire of dam of Green's Bashaw ; and American Star (by Coburn's American Star, son of Cock of the Rock, by Sherman Morgan), sire of the dam of 
Dexter the fastest of Hambletonian's get, and, indeed, sire of the dams of all the trotters of Hambletonian with records of $2: 20$ or better, Dexter, $2: 17 \mathrm{I} / 4$, Nettie, $2: 18$, and Orange Girl, $2: 20$, and 15 of the forty $2: 30$ trotters credited to that horse,-only one other stallion and that a Canadian stallion Bellair, having as many as three,-were called Canadians.

And so the great trotter Mac, by a son of Woodbury Morgan, vanquisher of Lady Suffolk, was called a Messenger, though not having a known drop of Messenger blood. The Morgan was a rival, and a successful one, to the horses bred on Long Island, and hence, perhaps, this disposition by New York City horsemen whether owners or drivers to ignore the name, though the explanation may have been that the Morgan horse, even in Vermont at that time, was often called Canadian.

Another son or grandson of Engineer, known as Young Engineer, was owned for some years at Clarenceville, P. Q. A similar story was told of his origin. See Engineer 2d, Engineer (Burdick's), Kasson Horse and Young Engineer.

Mr. Wallace, permitting his predjudices to control his judgment, recorded this Engineer as got by imported Messenger. But in his Monthly, Vol. III., p. 244., he says :

"It would be hard to find a man who would doubt that old Engineer of Long Island was a son of imported Messenger. But, notwithstanding the general faith, there is not a particle of historical evidence sustaining it. It all rests on the internal evidence of the resemblance of his offspring to the Messengers, and particularly in their common inheritance of the trotting instinct."

This certainly disposes of the Messenger pedigree.

Again, since it is understood that Engineer returned to Canada, we have thought it might be possible that he was identical with the horse European, of similar color, form and quality, which was brought from Canada to Cambridge, N. Y., about 1830 , being then quite an old horse.

But however this may be all known facts point to the Morgan origin of Engineer. First, the appearance and quality of the horse, and the time he lived. Second, the universal contemporaneous statement that he came from Canada, where the Morgans from the beginning abounded almost equally as in Vermont. Third, the fact that crossed to a dam by Plato, son of Messenger, he produced the sire of the famous trotter Lady Suffolk, as the Morgan and Messenger has always been a successful cross for speed; and last because of the statement of the sire being captured from a British officer, it being so easy in such a case to confuse a horse with an ancestor. Thus in Vol. I., of The Morgan Horse and Register, р. гог, is an instance of this recorded, when an excellent witness, Dea. Benham, who gave us some very valuable testimony of the original Morgan Horse being kept at or near Burlington, Vt., spoke 
of him as having been imported by an officer, and captured in the Revolution, which was true of his sire, but not of him.

With these facts all pointing in this direction, and it being notorious that the pedigree given by Mr. Wallace is entirely without foundation and contrary to all known facts, we have entered Engineer in the Morgan Register as foundation stock with rating of $\mathrm{I}-2$.

ENGINEER, chestnut, I6 hands, of great strength and good proportion, said to be by imported Eagle, son of Volunteer: dam by imported Arch Duke.-American Turf Register, November, 1823.

ENGINEER (I-I6), I 5 hands, 850 pounds; foaled I 885 ; bred by Alexander Gowan, Globe, Tenn.; got by Locomotive, son of Tom Hal : dam bay, said to be by Blue George, son of Hardee ; and $2 \mathrm{~d}$ dam gray, bred by Mr. McCrory, Hudsonville, Ill., got by Bull Pup. Pedigree from $\mathrm{H}$. H. Austin.

Sire of Roy H., $2: 181 / 4$.

ENGINEER 2D. (I-4), gray, I $53 / 4$ hands; foaled about I $8 \mathrm{I} 8$; said to be bred by a Mr. Jones or Mr. Underhill of Setauket, L. I., and got by Engineer, which see: dam said to be by Plato, son of imported Messenger; and $2 \mathrm{~d}$ dam by Rainbow, son of imported Wildair. Sold when two or three years old to Alec Lewis, Crab Meadows, L. I., and taken when four years old to Bridgeport, Conn. He remained in Connecticut or elsewhere in New England, ten years, when Josiah Bowers and John Vail, of Smithtown, L. I., traced him up and found him at Portland, Me., and brought him back to Long Island in the Spring of $\mathbf{I} \delta_{32}$, where he was purchased by Smith Burr and Alec Rose, who owned him when he got Lady Suffolk.

Above pedigree and history is from the Breeder's Trotting Stud Book by J. H. Sanders, and is fuller and probably nearer correct than any other account that has been given to the public. Carl Burr, born I8o4, in interview at his home, 1886 , said :

"The sire of Lady Suffolk was bred by Alec Lewis, from a pretty good running mare.

"Mount Holly was by Messenger and owned at Quog, Suffolk County, by Rich and Smith. I do not know what the blood of Potomac was, they called him a well bred horse. Don Quixote was by Messenger and stood here at Huntington, owned by one Kissam. This was before Engineer 2d.

"Whitson Oakley at Bulls Head should know something about Engineer.

"Engineer 2d got on the track at Westbury. The dam of Lady Suffolk was owned by Leonard Lawrence of Smithtown, L. I., who is alive yet. She was by Don Quixote. The Floyds had that mare. I think you can find out in the town of Huntington who bred Don Quixote. It was always said he was by old Messenger. I knew Rylander, but don't believe he had a son of Messenger." 
It will be remembered that the original Maine or Winthrop Messenger, brought to Maine about 1816 from Paris, N. Y., was owned previous to that by Rylander on Long Island. It has always been a question whether Winthrop Messenger was by a son of Messenger or by Messenger himself, or by some other horse from a daughter of Messenger. He had very strongly the Messenger characteristics and was always called Messenger, but as he was advertised as eight years old in 1819 , and as Messenger died in January, 1808 , if the statement of his age is correct, he could not have been got by imported Messenger.

Mr. Smith Burr was positive that the pedigree of Amazonia, dam of Abdallah was unknown $\mathrm{He}$ knew the mare well. Mr. Burr thought that Abdallah lacked in vigor; that when he went to Kentucky he had to stop on the way to rest.

In interview I 886 , at his home on Long Island with Leonard Lawrence, born Jan. 21, I 795, breeder of Lady Suffolk, Mr. Lawrence said :

"Engineer $2 \mathrm{~d}$ was rather coarse. He was the sire of Lady Suffolk; her dam was an old mare that Gen. Floyd used to ride on parade."

Mrs. Lawrence, born $\mathbf{1} 802$, wife of Leonard Lawrence, interrupting said : "She was a very splendid and dark brown mare."

Mr. Lawrence continued: "I think I got her of Charley Little, a young man that traded horses all the time. At one time she belonged to Richard Floyd, the Doctor that died South. I don't know where he got her. I never understood what her blood was. I never knew anything about it. I got her in haying time and had her six or eight years."

The old lady said: "We did not own that mare only two or three years before Lady Suffolk was born. I do not know anything at all where Mr. Floyd got her. Lady Suffolk was foaled in 1833 , her dam was fair size, rather large."

Mr. Lawrence's son, born 1827 , said: “I remember very well when they traded for the dam, they traded a bay horse for her with Charley Little." The old gentleman thought the mare was 16 or 17 years old when he got her, and said he paid $\$ 4$ for the service of Engineer. The old lady thought the dam was very stylish and rapid; her impression was that Gen. Floyd raised her. She said :

"I remember her when she was very young, before I 82 I ; remember her very well, Richard Floyd used to ride her; he came often to our house. She was very stylish. He rode her I know when she was young. We always called her Jenny. The General rode her on parade training days. I rather think she belonged to his son. My first recollection of her is seeing him ride her from church. I recollect her being so gay, prancing about. The young men rode horseback to church instead of in a buggy. The Floyd family is all gone; there isn't one of them left. I used to have a good many rides after that mare in my younger days."

Undoubtedly Lady Suffolk has a strong cross of Messenger blood through the dam of her sire Engineer $2 \mathrm{~d}$, which dam is understood to 
have been got by Plato, son of Messenger, although her breeder is not known any more than that of Engineer. But the horse Engineer 2d was a large coarse gray horse of good trotting action, showing very decidedly the Messenger characteristics.

The other sons of Engineer that we have mentioned were very differently organized, patterning more after their sire.

TROTTING MARE FOR SALE.

"The subscriber offers for sale his justly celebrated trotting mare Lady Suffolk, and he would recommend her as being perfectly sound in all respects, and kind in all harness. The performances of the mare are too well known to require description. If it be considered that she has invariably performed under the greatest disadvantage, it must be allowed that she is entirely unequalled, more especially if her age be taken into account, she being only five years old last June. The mare has had about two months training, and she will be sold on the following conditions; viz.: If on a trial being made, whenever an individual wishes to purchase the mare, she performs two miles in $5: 05$, the price will be $\$ 5,000$, - two miles in $5:$ I0, the price will be $\$ 4,000$ - and if she fails to perform either of the above, $\$ 3,000$. Terms one half cash, the other half approved paper for six months. Signed,

David BRyan, JR., Commack, L. I." - Spirit of The Times, December, 1838 .

The following pedigree of the celebrated trotting mare Lady Suffolk, owned by D. Bryan, Jr. of Commack, L. I., has been furnished for publication :

"Lady Suffolk was got by Engineer, from a Quixote mare (Quixote by Messenger, from a Messenger mare), grandam by Rainbow, from a common mare. The dam of Lady Suffolk was owned and bred by Gen. John Floyd of Smithtown, L. I., and sold by his son to Charles Little, Esq., of Smithtown, from whom she passed into the hands of Richard Blaydenburgh, Esq., who bred Lady Suffolk."-Spirit of The Times, Sept. 14, 1839 .

As the breeder of Lady Suffolk is incorrectly given in this, we cannot place much confidence in the pedigree, although the statement that her dam was sold by Gen. Floyd to Chas. Little is correct, and we think, also, that this dam was bred by Gen. Floyd, and also, probably that this mare was got by a horse called Don Quixote, but the breeder and breeding of Don Quixote is entirely unknown. It will be seen, too, that no attempt is made to extend the pedigree of Engineer.

We add the following letters :

Mr. Joseph Battell,

Commack, L. I., Jan. 2 I, I 886.

In reply to yours I will give you what facts I have gathered from my grandfather, Smith Burr ( 82 years old), relative to the horse Engineer $2 \mathrm{~d}$, sire of Lady Suffolk. Alec Lewis of Long Island owned a good looking mare that could run fast, and he bred her to Engineer and she produced Engineer 2 d. This mare was strongly bred. The old gentleman forgets how ; Lewis let a man by name of Smith have half of Engi- 
neer $2 \mathrm{~d}$; this man took the horse East; he says it was Connecticut, and sold him. Dr. Bowers and John Vail of Long Island, heard where he was, bought him, and brought him back to Long Island. Smith Burr and Brewster Rose then purchased the horse and kept him for two years at my grandfather's farm. During this time he got Lady Suffolk. In the fall they sold him to a carman in New York, who afterwards sold him to Colklin Carl of Long Island, and he died the following Spring. These facts I believe to be correct, as my grandfather has his mind perfectly, the only thing bothering him being dates. Hoping this will give you information desired, I am

$$
\text { Yours truly, CARL S. BURR, JR. }
$$

Mr. CARL Burr, Jr.,

Middlabury, Vt., Jan. I8, I887.

Dear Sir :-Will you please find out of your grandfather if he knows

I. Who bred dam of Lady Suffolk and her sire?

A. "Mr. Floyd bred dam of Lady Suffolk. Don't remember who bred Don Quixote."

2. Sire of her grandam?

A. "Don't remember."

3. See if he can now remember sire of the dam of Engineer 2 d? $\mathrm{He}$ described her as a brown mare that ran well.

A. "Plato sired dam of Engineer 2 d he remembers it well."

Answers returned on this will much oblige.

$$
\text { Truly yours, JOSEPH BATtell. }
$$

The following description of Lady Suffolk, - is from The Horse Review of Chicago, Feb. 22, 1898, furnished by D. O. Fowler :

Editor Horse Review :-I notice in your issue of Jan. 25, an article signed by Mr. M. R. Barteau in relation to the great mare, Lady Suffolk, in which his dates and facts are both sadly at fault. * * * Lady Suffolk, as most people are aware, was a gray mare, I5 hands 2 inches, with a beautiful mane and tail, a fine Arab head, an unusually long body, with the best of feet and legs. She was by Engineer 2 d., son of Engineer.

It will be seen from this description that Lady Suffolk strongly resembled the Morgans. The same is evident in the picture we publish of her with Black Hawk.

Lady Suffolk was on the turf nearly i6 years, trotted i6 I races, winning 88 and losing 73 .

In the same issue of The Horse Review is another article upon Lady Suffolk by "Sedgewick," describing the great race between her and the inbred Morgan mare Lady Sutton, of which the writer was an eye-witness, as follows :

\section{LADY SUFFOLK AND LADY SUTTON. ****}

"The race following the above [between Suffolk, Pelham and Jack Rossiter] was between Lady Suffolk and Lady Sutton; Pelham's race the week before cooked him; he paced most of the time, but was no good in this race. The first two heats were won by Lady Suffolk, the next two by Lady Sutton; the fifth heat was a dead heat; the sixth heat, on the first turn, the sulkies came together. Then the drivers commenced 
whipping each other, and they kept at it to the quarter pole, all this time the two old mares going for dear life, came into the stretch neck and neck, and passed under the wire too close to place them from where I sat. The judges finally decided it "no heat." One of the judges, who acted as timer and starter, was the then editor and proprietor of the New York Spirit of the Times, Mr. Wm. T. Porter. A crowd then tried to pull the judges out of the stand, when Tom Hyer, Bill Poole, Charlie Duane and others of that class took a hand in it and quieted matters, so that, at nearly dark, the horses were called for the seventh heat. Bean with his blue velvet cap and blue velvet Jacket, and his face considerably cut from Ike Woodruff's whip, looked pretty disconsolate. Ike shaking his head seemed pretty determined. Both mares were game and showed but little distress for such a hot night. They got away for the 7 th heat all right, which heat and the race was won by Lady Suffolk. Time of the heats, $2: 291 / 2,2: 3 \mathrm{I}, 2: 30,2: 3 \mathrm{I} 1 / 2,2: 32$, $2: 3$ I, $2: 38$. Lady Suffolk's races were most all very severe ones. Out of the 160 races she won more than half of them; the tracks were hard, no turns thrown up, and many over a mile; sulkies weighed from 80 to nearly Ioo pounds. No horse was trained as they are to-day for speed, and, during the many years that I saw Suffolk trot many of her competitors lost their places in her class.

- The Horse Review, Feb. $28,1808$.

SEDGEWICK."

From this testimony it is evident Engineer 2d was by Engineer, the horse advertised in the Long Island Star, I $\delta$ I6, by Thomas Jackson, Jr. : dam by Plato.

Breeding of Don Quixote, probable sire of dam of Lady Suffolk, unknown.

Sire of Lady Suffolk, $2: 261 / 2$ ( $2: 26$ saddle). The Spirit of the Times, 1854 , states that Lady Suffolk trotted I6I races, winning 88.

ENGINEER (BURDICK'S), dark chestnut, I6 hands; foaled about I8I 7 ; said to have been bred on Long Island; and got by Engineer (which see). Purchased on Long Island when three years old for \$350 by Henry Newland, Stillwater, N. Y., who sold to George Rockwell, Luzerne, N. Y. Afterwards owned by Nathan Burdick, Warrensburg, N. Y., and later by Daniel Weatherhead of Schroon, N. Y., who kept him for a time at West Moriah and Crown Point, N. Y. Died the property of J. Eldredge, Fort Edward, N. Y., about I 850 . Whilst owned by Mr. Rockwell, he was kept at Warrensburg, Luzerne and Thurman, N. Y., he was also owned by James R. Berry, of Warrensburg, N. Y., and at one time kept, and was probably owned in Vermont; at another is said to have gone to Canada, and to have remained there one or two years. His colts were generally, sorrel or chestnut with mane and tail of pretty good length but rather thin, and were generally rangy horses of pretty good height, not blocky.

In 1886 we visited Whitehall, Argyle, Fort Ann, and Warrensburg; and, among much other information, gathered the following concerning Burdick's Engineer : 
Gen. Hammond of Crown Point, one of the most successful business men of Northern New York, and a most excellent judge of a horse, in interview said:

"I remember old Engineer, thought he was the finest horse ever made. He got lots of stock. A beautiful dark chestnut horse 16 hands, he was kept for some time in Schroon, brought there from Ticonderoga by Daniel Weatherhead of Schroon. It must have been about 40 years ago. His stock was uniformly excellent. The picture of Col. Russell's Fearnaught [a doubly in-bred Morgan horse] reminded me very much of Engineer."

Mr. Wyman of Crown Point said that Daniel Weatherhead brought Engineer to Schroon about 1830 ; very handsome chestnut horse, stock not very heavy made.

Mr. Hammond, Warrensburg, said :

"James R. Berry of Warrensburg, owned Engineer. He lived in the same district that Isaiah Wilcox did. He said there were two of these Engineers, brothers, one went South I think, from Long Island. Engineer got around into Nathan Burdick's hands. The Newlands had Engineer before Berry did. Berry said that Isaiah Wilcox raised the bay mare [dam of Princess] and that she was by Engineer. Engineer went to Canada, gone two or three years. They saw him there. James Berry went to Biggarts at North Troy and bought Engineer. Berry's claim was that whilst he owned him he got the dam of Princess.

"Newland had Engineer before Berry. Engineer went to Canada, gone two or three years. Berry went to Biggart's and bought Engineer at North Pawlet."

Both these statements in regard to dam of Princess are errors, as Mr. Wilcox, bought this dam when two years old, one of a pair; and she was foaled sometime before Mr. Berry owned Engineer. See Happy Medium.

Mr. Darius Bepnett, Warrensburg, said :

"Nathan Burdick owned Engineer quite a number of years; owned him when he died at 32 years of age. Engineer went to Vermont. Good sized rangy horse, chestnut, very fine horse.

"Coman lived at Luzerne. Dr. William went to Wisconsin. They have a colt now. Old Henry Clay, Wilson owned at Tye; was by Black Hawk, good sized gray horse, rooo pounds. He was kept in this county within 20 years, a very nice horse. Nathaniel Brown, Bolton, raised a gray stallion from him not quite so heavy.

"Stewart Horse called Black Hawk, owned at French Mountain by Robert Stewart.

"Don't think Engineer got trotters. The Engineers rather rangy slimmish horses. Griffin, horse at Bolton, very nice horse; a Black Hawk. Griffin's son living.

"White Cloud, by Joe Brown at Johnsburg, N. Y., bred by George Jackson.

"Stewart Horse a son of Engineer owned by Jim Stewart, Warrensburg; black, I6 hands, I Ioo pounds, long neck and good proportions, foaled about $\mathbf{1} 845$. 
Mr. Jackson a farmer, Warrensburg, N. Y., said :

"I remember Engineer when they took him from here, the time Eldredge got him at Fort Edward.

"Ed. Vaughn, Vaughn's Corners, bred Judge Davis' dam; and Ben Odel, Queensbury, N. Y., bred Mary Russell. I remember first time I saw Engineer. Hi. Bennett tended him. George Rockwell \& Cameron bought him together. About I5 when I went to Langworthy's,must have been five or six years before that. I was born I8I9. Rockwell \& Cameron sold Engineer to Weatherhead in Essex County, for $\$ 300$. From there he went to Whitehall a number of years ; he went South from there and back to Whitehall again. I lived with Ned Warren when Jim Berry and Pingree went to Whitehall, and bought him, and brought him back to Warrensburg, somewhere about I 846 . I know Berry never owned him before that.

"Engineer went from Weatherhead to Vermont. Pingree kept him one year and sold to Nathan Burdick, somewhere about I840. A woman brought Engineer from England, Cameron some connection. She went back to England and brought back two spotted studs. Cameron bought them.

"Magnum Bonum, I 6 hands, I roo pounds. Owned by old Uncle Jim Griffin; ugly, swapped him off at Tye; horse went South. Both here about one time, old Engineer, I think, first. Man from Washington County, brought him here; swapped for cattle; fine horse, got ripping stock; here only one year; here before I went to Langworthy's, about time I went there. I lived with Wilcox a year. I know they called Wilcox's horses some kind of a horse; I think they said Morgan horses. I know they had two ends to them.

"It does kind o' seem to me as if I remember about old Azariah having a pair of colts of Warren. Old Uncle John Moon and Jim Stuart, might know, lived right there. Rockwell kept Engineer at Luzerne, Warrensburg, and Thurman; I 5 or I 6 miles to Luzerne; Hi. Bennett tended Engineer after I went to Langworthy's. He had stood at Warrensburg, before I went to Langworthy's. He stood at Warrensburg and Luzerne first season. I kept store some years before I went there. Wilcox had to pass Langworthy's to go to Warrensburg. Big horse, Magnum Bonum, all big, and all bay. Hardly ever see a bay colt by Engineer, generally between sorrel and chestnut, not very heavy, generally from $15 \mathrm{I} / 2$ to 16 hands; good long neck, set up well; bulge in head big as fist, not over and above heavy mane and tail, pretty good length but rather thinish; generally curly. Generally pretty good, rangy, lengthy horses, pretty good height, seldom blocky. Pretty sound, round bodied, long hipped.

"Pendle had team, got them of some farmer. Nat. Griffin lived at Athol, horseman. When I was a boy he sent mares to Cambridge, to Eclipse [Long's]. Newland of Stillwater let Rockwell have Engineer."

Dr. Howard, Warrensburg, said :

"Old Engineer trotted, had to run sharp to keep up with him, naturally a trotter, no question about it at all, his step and everything indicated it. He was here when I came here. It was after, when Berry and Pingree owned him; I came 1837. Engineer very old before Burdick got him; a splendid horse, splendid figure. Not a very handsome head, transmitted it; beautiful neck, body, legs; head large and rather long; 


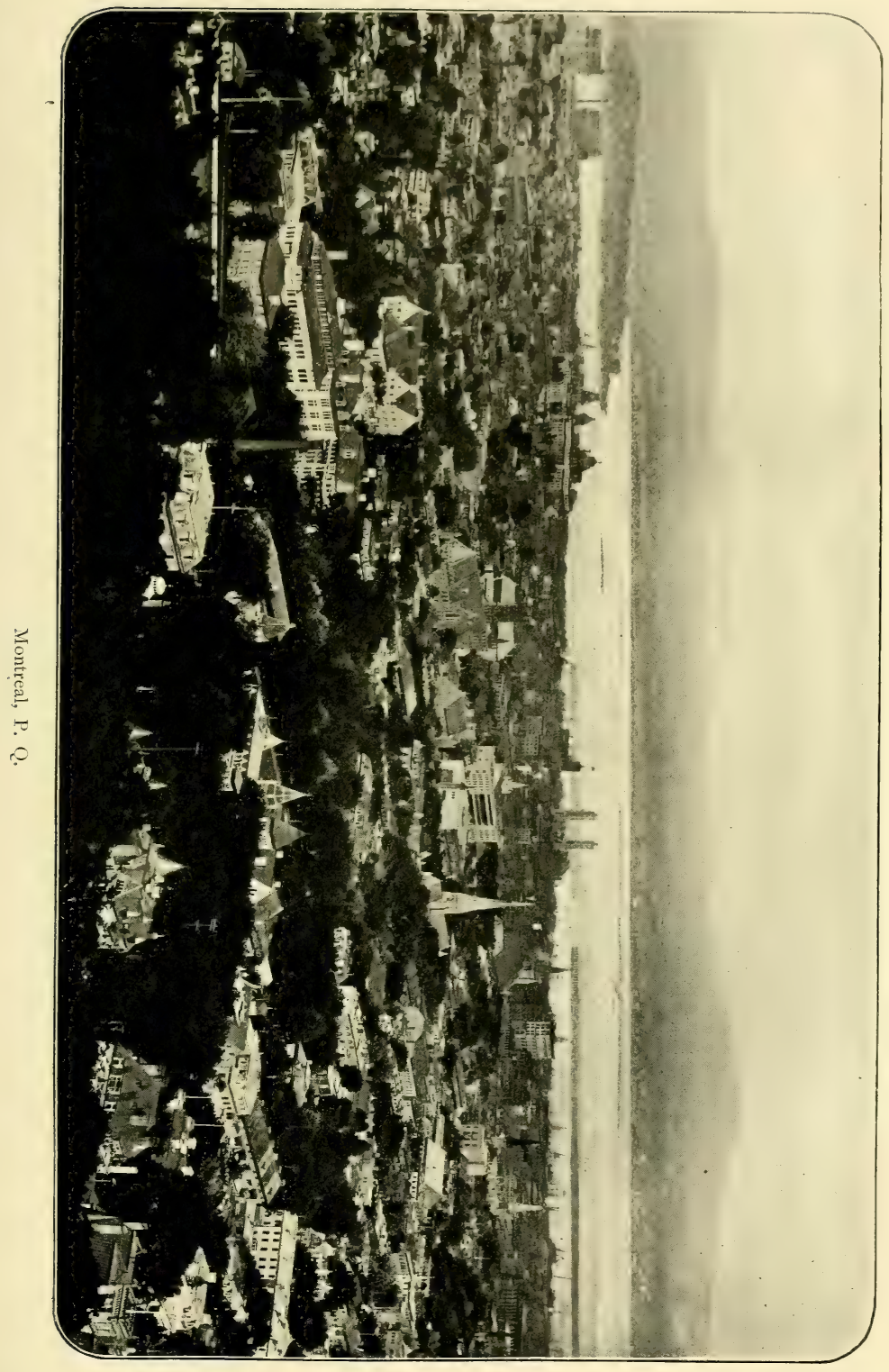




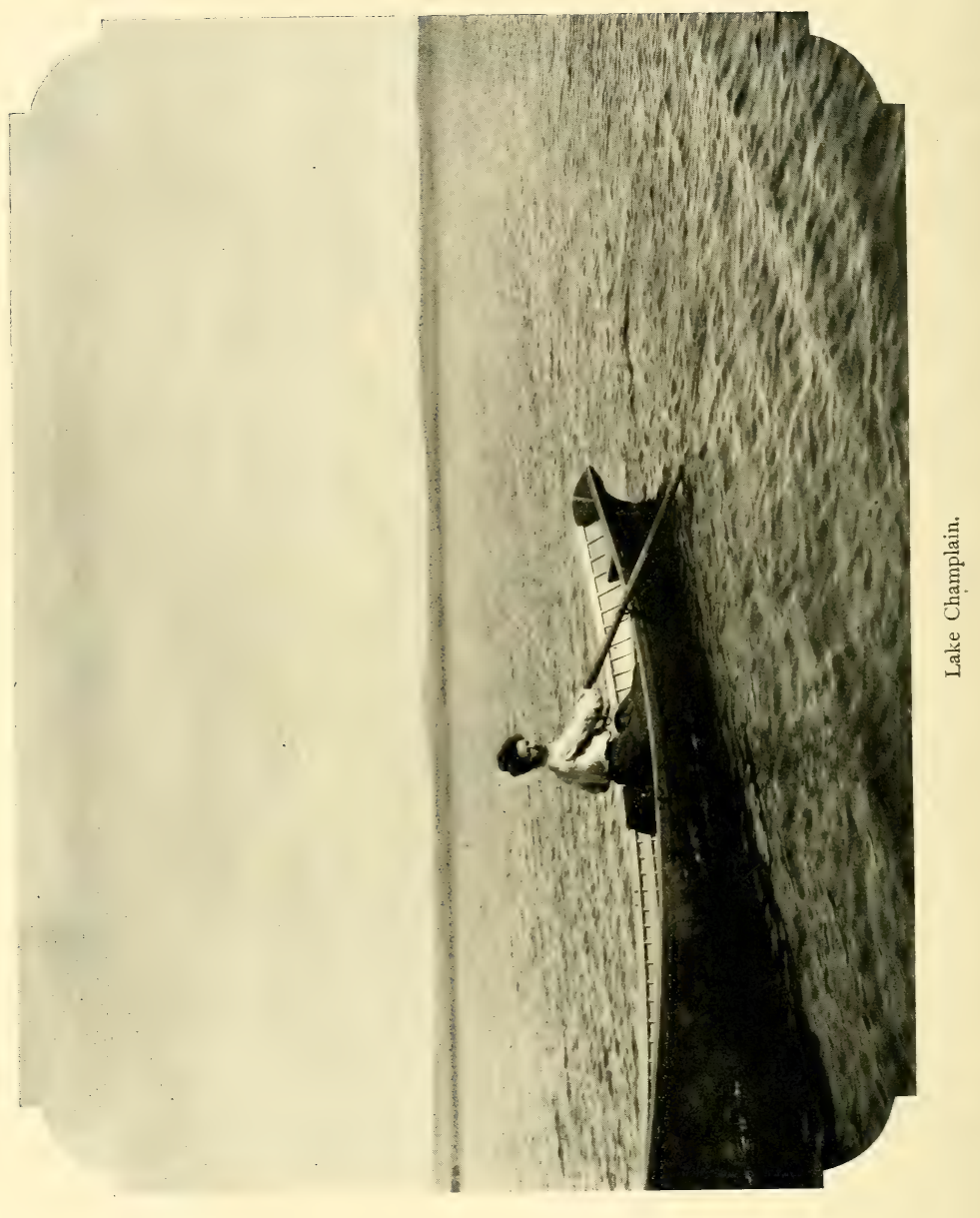


nose not thin, rather large, rather hollow ; transmitted his build to most all his posterity; very few of them pony built unless they took it from the dam. Old Engineer heavy, tail not very heavy.

"Lone Star owned at Chester, and one older Black Hawk, man named Eaton owned them both, M. C. Eaton. There were quite a good many called Morgans about Black Hawk's time, and before, about I850. I bought a Morgan, drove him 2I years; 29 years old and died. Splendid horse. Sire kept at town of Johnsburgh, N. Y., owned by a farmer there, had been kept there some years then. As long ago as I842, I bought him then eight years old. Wesley Somerville owned him, I bought my horse of him. I heard much of him, got by a stallion there of same kind; solid, heavy, square built horse. I know it was somewhere about the time they had Engineer colts.

"King William was at Fort Ann, and Roaring Lion a terrible horse came from Vermont, most vicious horse I ever heard of, good horse; He was ridden 90 miles between sun and sun from Philadelphia to New York. William Bardwell owned him at Fort Ann about r820-25; large heavy raw boned horse; grew up sound, plump, I300 or I 400 pounds. King William same time, a light springy horse; Mr. Crocker owned him. David M. Cameron owned Engineer with Geo. Rockwell, Stony Creek, N. Y."

Mr. Burdick said :

"I think Engineer must have come here in county before 1829 ; I began carding wool in 1828 . He was used before that time. McEwen tended him, owned by Jeremy Rockwell at Luzerne (I 7 miles). $\mathrm{He}$ stood up here; my brother owned him and I think Rockwell bought him of Newland at Waterford, N. Y.; have heard said that Gen. Packingham rode him at New Orleans. From Rockwell, he went to Weatherhead, of Schroon; six or seven years old when Rockwell got him about I $830 ; 32$ miles to Schroon; didn't stand here again until Nathan Burdick owned him somewhere about I $838-40$. I think Jim Berry owned him before my brother ; somewhere 30 years old when my brother owned him, I didn't have him a year, I think bought him of Orville Nelson, Warrensburg. I . think no other noted stallion here then; not matured till six years; were like iron,--pretty generally rather rangy horses. Jim Berry owned Engineer when he lived on the farm about $1845 . "$

Seth Russell said :

"A man was here to trace Engineer. Geo. Rockwell of Luzerne first brought him here. My impression is he got him from some one who brought him from Long Island."

ENGINEER (PAUL'S) (I-4). Brought to Wells, Vt., from New York State about $\mathrm{r} 84 \mathrm{O}$ by Apollus Hastings, who sold to Caleb Harrington, Middletown, Vt., and he to Nelson Paul. Mr Paul kept him several years and sold to Jack Williams. We think this horse is the same as Engineer Burdick's, but he may be a son. Mr. John P. Williams writes dated Perkinsville, Vt., April Ist, 1892 :

Mr. J. BATTELL,

Dear Sir :- I am just getting about from a two months tie-up of sickness, and in looking over correspondence, I find an inquiry from you which I do not think I have ever answered, and I will try as best I can 
to comply with your wishes. I cannot fill out the blank with pedigree of Paul's Engineer. Sometime in October, I89o, I called upon Mr. Nelson Paul (whose P. O., address is Wells, Vt.) especially to inquire about the said horse and jotted down the following in my note book:

Paul's Engineer was brought to Wells by Apollus Hastings from York State ; he passed from Hastings to Caleb Harrington, a Lawyer in Middletown then to Nelson Paul (Mr. Paul thinks this was in I839), from Paul to John Williams (known as Josh), and he died soon after. Mr. Paul had him several years, and thinks he sold him somewhere in the 40's. Mother thinks it must have been about i 846 . William Goodrich of Wells may perhaps know where Hastings got the horse. Adams' American was born before my father had Whitehall, and I think Otis Hamilton sold him to Mr. George Adams, and doubtless R. K. Hamilton of Fair Haven can tell his breeder.

Mother remembers nothing of where Nimrod came from, had brown strip in face, four white feet and very handsome, think he sold him to Comstolk.

$$
\text { Respectfully, John V. Williams. }
$$

ENGINEER (YOUNG, POTTER' HORSE). Supposed to be a son of Burdick's Engineer. Owned by John Potter and kept at Castleton, Vt., and adjoining towns.

ENGLAND, bay, bred by John Holme, Carlisle, England.; got by Young Starling: dam by Regulus; 2 d dam by Round-head, son of Flying Childers, etc. Advertised i 765 , to be kept in Market St., Philadelphia. Advertised with pedigree as above in the New York Mercury 1766-7, to be kept at Cow Neck. Terms 2 guineas for season and 50 cents to groom. Advertisement states that he ran at Philadelphia, with Selim, and was beaten only by a neck. Advertised I768, at Elizabethtown, N. J. It appears from advertisement in 1765 that he was beaten by Young Starling at the October meeting at. Hempstead Plains, L. I., probably I 764 .

Advertised in New York Mercury, for sale, December, 1767. Advertised 1769 in New York Gazette.

ENGLISH BALL, said to be imported. Advertised 1798 by James Hart, Philadelphia. A horse of this name, probably the same horse is advertised, I805 in the Pennsylvania Intelligencer, and said to be a draft horse imported 1797 .

ENGLISH DRAY HORSE, I 7 hands. Imported by Col. Francis. Advertised by Marmaduke Cooper to be kept in Philadelphia, I 775 .

ENGLISH HORSE. See Lofty.

ENGLISH MORGAN. See Young Whirlwind.

ENOCH (ENOCH ARDEN) (I-8), bay, I5 T/4 hands, Iooo pounds; foaled June, I 867 ; bred by Henry A. Hall, Bridgewater, Mass.; got by 
Ethan Allen : dam sorrel a mare used in the army in Virginia, said to be thoroughbred. Gelded young. See The Morgan Horse and Register, Vol. II., p. I 13 .

Sire of Riley, $2: 30$.

\section{ENOCH ARDEN. See Enoch.}

ENOS MCGREGOR (7-I28), chestnut; foaled 1892 ; bred by Ethol $\mathrm{H}$. Enos, Fair Haven, Vt. ; got by Robert McGregor, son of Major Edsall : dam Lady Mills, bay, bred by A. C. Harris, Cream Hill, Vt., got by Broken Leg, son of Hambletonian ; $2 \mathrm{~d}$ dam bay, bred by A. C. Harris, got by Daniel Lambert, son of Ethan Allen; 3d dam Milkmaid, said to be by American Star. Pedigree from breeder.

ENRIGHT (1-32), 2 :I $81 / 4$, bay, white on hind ankles; foaled 1885 ; bred by J. C. McFerran, Louisville, Ky. ; got by Nutwood, son of Belmont: dam LaGracie, bay, bred by J. C. McFerran, got by Cuyler; 2 d dam Nora Norman, bay, bred by Andrew Steele, Fayette County, Ky., got by Blackwood; 3d dam said to be by Norman; and $4^{\text {th }}$ dam by Smith's Highlander. Sold to L. Kinney, Albion, Mich.; to J. S. Karns, Canal Dover, O. Pedigree from catalogue of breeder.

Sire of 6 trotters $\left(2: 09 \frac{1}{4}\right), 2$ pacers $\left(2: 12 \frac{1}{2}\right)$.

ENSIGN (3-256), $2: 281 / 2$, bay ; foaled 1873 ; bred by Powell Bros., Shadeland, Penn.; got by Enchanter, son of Administrator: dam Oneta, bay, foaled I 866 , bred by Johnathan Hawkins, Walden, N. Y., got by Volunteer, son of Hambletonian; $2 \mathrm{~d}$ dam Cad, chestnut, foaled $\mathbf{1} 868$, said to be by John Harris, (dam by Black Rock, son of Gridley's Roebuck, 2d dam said to be by imported Messenger), son of Daniel Webster, by Long Island Black Hawk (dam of Daniel Webster, Lady Kate, by an Arabian horse) ; and $3 \mathrm{~d}$ dam by American Star. Sold to C. A. Lisle, Burlington, Ia. Pedigree from breeders, who write:

"John Harris was owned by John Harris of Orange County, N. Y., of whom we bought the mare Cad."

Sire of 18 trotters $\left(2: 15 \frac{1}{2}\right), 7$ pacers $\left(2: 08 \frac{1}{4}\right) ; 2$ sires of 2 trotters, I pacer: I 9 dams of II trotters, 16 pacers.

ENTERPRISE. See Morgan Messenger.

ENTERPRISE, bay, I $5 \frac{1}{2} 2$ hands; foaled I 790 ; bred by Ephraim Ludlow, Long Island; got by Allen's Figure: dam said to be by Lath. Advertised I 796, in Connecticut Courant at Hamden, Conn. Advertised 1797, at Vergennes and Charlotte, Vt. Advertisement states that he has beaten the famous Messenger.

ENTERPRISE. Advertised at Corinth, Bangor, Athens and vicinity, Me., by Ephraim Currier, Corinth. 
ENTERPRISE (FITZGERALD'S) (I-32), chestnut, I6 hands, I 200 pounds; foaled I880; bred by Crit Davis, Harrodsburg, Ky.; got by Red Wilkes, son of George Wilkes: dam Lizzie Witherspoon, chestnut, bred by Thomas Van Dyke, Mercer County, Ky., got by Wagoner (Gough's). Sold to James W. Fitzgerald, Marysville, Ky. ; to T. Pollock, Normal, Ill.; to Henry James, Mitchell, Ont., February, I894, who sends pedigree; to John Jundt, Milverton, Ont., I 899, whose property he died the same year.

Sire of 2 trotters $\left(2: 29 \frac{1 / 4}{4}\right)$.

ENVOY. Imported. Advertised $\mathbf{1} 844$ in Fayette County, Ky., at stable of Thomas Hughes, six miles from Lexington, on Maysville Turnpike.

ENVOY (I-I 28$), 2: 28$, brown, white hind heels, I 5 I 22 hands, 1000 pounds ; foaled I 87 I ; bred by B. Hershey, Muscatine County, Ia.; got by General Hatch, son of Cassius M. Clay Jr.; dam Dolly, brown bred by B. Hershey, got by Iowa, son of Glencoe; $2 \mathrm{~d}$ dam bay. Pedigree from breeder.

Sire of Environ $(2: 261 / 2)$; I dam of 3 trotters, I pacer.

ENWOOD (I-64), bay, I $53 / 4$, hands, I I 50 pounds; foaled I 889 ; bred by J. W. Turner, Hermitage, Tenn.; got by Wedgewood, son of Belmont: dam bay, bred by M. S. Cockrill, Nashville, Tenn., got by Enfield (dam by American Star), son of Hambletonian; 2 d dam bred by R. A. Alexander, Spring Station, Ky., got by Edwin Forrest, son of Bay Kentucky Hunter. Pedigree from breeder.

Sire of Irish Girl, 2:19.

EOLUS, $15 \frac{1}{2}$ hands, I 000 pounds; foaled $188_{4}$; bred by James Ellis, Worcester, Mass. ; got by Wedgewood, son of Belmont : dam Lady K., black, owned by James Ellis, Worcester, Mass., said to be by Godfrey's Patchen, son of George M. Patchen. Sold to G. J. Shaw, Hartiand, Me. ; to Goodridge \& Ireland, Canaan, Me., who send pedigree.

Sire of Maud Ellingwood, $2: 25 ; 3$ pacers $(2: 181 / 4)$.

EOS (I-I 28 ), chestnut, I 5 hands, Iooo pounds; foaled I 885 ; bred by R. P. Pepper, Frankfort, Ky. ; got by Onward, son of George Wilkes : dam Hecla, bay, bred by R. P. Pepper, got by Strathmore, son of Hambletonian: 2d dam bred by Richard West, Lexington, Ky., got by Clark Chief, son of Mambrino Chief. Sold to C. W. Coons, Mount Vernon, O., who sends pedigree. Died 1898 .

Sire of 2 pacers $(2: 201 / 4)$.

EPAULET, 2 :I9, bay with star, white hind foot, I6I/4 hands, I 250 pounds ; foaled I 880 ; bred by R. S. Veech, St. Mathews, Ky. ; got by Auditor, son of Hambletonian: dam Pantalette, bay, foaled $\mathrm{I} 875$, bred by R. S. Veech, got by Princeps, son of Woodford Mambrino; 2d dam Florence, 
bay, foaled r 868 , tred by Bateman Brooks, Orange County, N. Y., got by Volunteer, son of Hambletonian; $3 \mathrm{~d}$ dam Nell; and 4 th dam Welling mare, by Shark. Sold to L. L. Dorsey, Louisville, Ky.; to Robert Steele, Philadelphia, Penn. Pedigree from Cedar Park Farm catalogue. Sire of 3 I trotters $\left(2: 07 \frac{1}{2}\right), 2$ pacers $\left(2: 17 \frac{1}{4}\right) ;$ I sire of I trotter; 4 dams of 4 trotters.

EPH MAYNARD (3-16), dark bay, 15 hands, 975 pounds; foaled I 865 ; bred by Mr. Clark, who kept the ferry on Snake River, Idaho Ter., not - far from Shoshone Falls; got by Bucephalus, son of Black Hawk (Bucephalus was owned by Mr. Maynard, who lived near Boise City) : dam brought by Mr. Clark from Mich., in 1864 , said to be Morgan. Sold to F. Morse; in 1866 to S. B. Linsey; to C. D. Bacon, who owned him many years at Portland, Ore. Kept at Boise City until six years old, after that at Portland, Ore. Used most of the time as a road horse and bred to but few mares. Information from S. B. Linsey.

EPHRAIM MORRILL HORSE. See Leopard.

EPICURE ( $1-128$ ), bay, I $81 / 2$ hands, I 300 pounds; foaled 1880 ; bred by R. S. Veech, St. Mathews, Ky.; got by Princeps, son of Woodford Mambrino: dam Favorite, bay, bred by O. P. Beard, Lexington, Ky., got by Alexander's Abdallah, son of Hambletonian; $2 \mathrm{~d}$ dam said to be by Mambrino Chief ; 3 d dam by Brown's Tom Crowder, son of Tom Crowder; and $4^{\text {th }}$ dam by Gray Eagle. Sold to W. A. Ely, Coldwater, Mich.; to F. J. Richardson, Coldwater, Mich., who sends pedigree. Died I 902.

In answer to our inquiries as to the turf career of Epicure, we received the following graphic description from one of his owners:

"Never was raced. He was a counterfeit. He was a great big lobster. He died in 1902, it would have been far better if he had died at birth, sorry he lived so long. He was a mean cuss, and all his colts were like him."

Sire of 4 trotters $(2: 261 / 4) ; 3$ dams of 3 trotters, 2 pacers.

EPOCH ( $\mathrm{I}-32)$, dark bay, right hind foot and coronet white; foaled June 2 I, I 888 ; bred by Henry N. Smith, Fashion Stud Farm, Trenton, N. J.; got by Sultan, son of The Moor : dam Rosebud (full sister to Stranger) bay, $153 / 4$ hands, foaled $188 \mathrm{I}$; bred by Henry N. Smith, got by Gen. Washington, son of Gen. Knox; 2d dam Goldsmith Maid, 2 : I 4, bay, foaled I 857 , bred by John B. Decker, Deckerstown, N. J., got by Alexander's Abdallah; 3d dam untraced. Pedigree from catalogue of breeder.

EQUINOX (1-64), $2: 27 \frac{1}{2}$, brown; foaled 1882 ; bred by W. T. Withers, Lexington, Ky. ; got by Strader's Cassius M. Clay : dam Sally M., bay, bred by David Nutter, Fayette County, Ky., got by Almont, son of Alexander's Abdallah; $2 \mathrm{~d}$ dam, said to be by Edwin Forrest, son of 
Bay Kentucky Hunter; 3d dam by Benton's Diomed, son of Gray

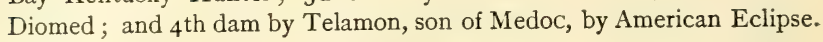
Sire of Dyspepsia Pills, $2: 15^{3 / 4}$; I dam of I trotter.

EQUITY (I-128), bay; foaled 1886; bred by J. C. McFerran, Louisville, Ky. ; got by Wickliffe, son of George Wilkes : dam Rivulet, bay, bred by H. Boswell, Fayette County, Ky., got by George Wilkes; $2 \mathrm{~d}$ dam Sophy, said to be by Edwin Forrest, son of Bay Kentucky Hunter; and $3 \mathrm{~d}$ dam Sophronia, by Parker's Brown Pilot. Sold when six months old to Alex Fraser, Kansas City, Mo., who sends pedigree; to Judge G. L. Chrisman, Independence, Mo., and afterwards went to Topeka, Kan.

Sire of Miss Sarah, $2: 21 \frac{1}{4} ; 4$ pacers $\left(2: 09 \frac{1}{4}\right)$.

EQUIVALENT ( $1-32), 2: 28 \frac{1}{4}$, bay, narrow strip in face, hind ankle white, $15^{1 / 2}$ hands, I075 pounds; foaled 1890 ; bred by Leo Moser, St. Louis, Mo. ; got by Reserve Fund, son of Nutwood : dam Misdeal, brown, bred by J. A. Sherman, Lexington, Ky., got by Sherman Wilkes, son of George Wilkes; 2 d dam Lucinda, brown, bred by Thomas Cahill, Montgomery, N. Y., got by Sweepstakes, son of Hambletonian ; $3 \mathrm{~d}$ dam said to be by Cassius M. Clay, son of Henry Clay, by Andrew Jackson; and

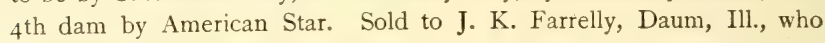
sends pedigree.

sire of Nancy $\mathcal{F}_{\text {., } 2: 141 / 4}$.

ERECTOR (I-32), $2: 25$, brown; foaled 1888 ; bred by E. J. Travis, Chicago, Ill.; got by Director, son of Dictator : dam Milly D., bay, bred by F. Harrison, Springfield, O., got by Mambrino Gift, son of Mambrino Pilot ; $2 \mathrm{~d}$ dam Fanny H., bay, bred by F. Harrison, got by Independence, son of Campbell's Andrew Jackson, by Andrew Jackson; 3 d dam said to be of Copperbottom stock.

Sire of Littie $7 u d y, 2: 183 / 4$.

ERELONG (3.256), bay with black points, 15 I/2 hands; foaled 1878 ; bred by A. J. Alexander, Spring Station, Ky. ; got by Belmont, son of Alexander's Abdallah: dam Eventide, bay, foaled 1872 ; bred by A. J. Alexander, got by Woodford Mambrino, son of Mambrino Chief; $2 \mathrm{~d}$ dam Vara, bay, foaled I 867 , bred by A. J. Alexander, got by Hambletonian, son of Abdallah; 3d dam Venus, said to be by American Star. Sold to Waters' Stock Farm, Genoa Junction, Wis. Pedigree from catalogue of Waters' Stock Farm, and from the Pleasant View Stock Farm catalogue.

Sire of 9 trotters $\left(2: I_{3} \frac{1}{4}\right) ;$ I sire of I trotter; 4 dams of 3 trotters, I pacer.

ERICSSON (MORGAN CHIEF) ( $\mathrm{I}-8)$, brown, I6 hands; foaled $\mathrm{I} 856$; bred by Enoch Lewis, Lexington, Ky. ; got by Mambrino Chief, son of Mambrino Paymaster: dam Mrs. Caudle, a fast trotting mare, sold I 839, by William T. Porter, Editor of The Spirit of the Times, to Henry 
Mangin, of Savannah, Ga. ; after whose death she was sold to I. C. Plant, Macon, Ga., who sold her to Mr. Chapman of Columbus, Ga., and he to Enos Lewis of Lexington, Ky. ; said to have been brought to New York City from New England, and to be Morgan. The Augusta (Ga.) Constitutional in editorial ( 1846$)$ says :

"Mrs. Caudle trotted at Augusta, Ga., Jan. 27, 1846, entered by R. Robinson, 2 mile heats $6: 06,6: 08$, she was third in race; trotted with Kennebec, was within speaking distance all the way but not very close. She is a beautiful trotter but appeared to less advantage from being out of condition. Again correspondent from Augusta, says: Robt. Robinson's bay mare Mrs. Caudle won, time $6: 06-2$ mile heats. Again won rst heat in 3 :or, lost $2 \mathrm{~d}$ and $3 \mathrm{~d}$ in $2: 46 . "$

Cyrus Lukens one of the most reliable and expert of pedigree finders in a letter to Turf, Field and Farm, New York, dated March, 27, 1893, in speaking of Clark Chief says: "The fact that his grandam had been Mrs. Caudle, was the reason I had called Mathers attention to Clark Chief. I knew she had been a fast trotting mare of square gait, and that she had been brought from New England to New York, and was claimed to have been of Morgan descent.

"Mr. William T. Porter, then editor of the only sporting horse paper in New York City, had bought this mare, and had sent her to a friend, for whom he had purchased her, in Savannah, Ga. She was used there some years, and when Mambrino Chief went to Kentucky, she was shipped to Enoch Lewis of Kentucky, who bred her to that stallion, and produced Ericsson, who was driven to wager by Myron Peabody, in his four-year-old form in a race the fourth heat in $2: 301 / 2$.

"The Morgan history of Mrs. Caudle stuck to her through all these years, and Ericsson was for a time, when quite young, known as Morgan Chief, combining the names of the two families in one, as has so frequently been done."

From "Michigan Horses," printed in The Spirit of the Times, Dec. 6, I 862 :

"Ericsson, formerly Morgan Chief, was brought here from Kentucky. He stood this summer for mares at Detroit, for $\$ 50$ the season. He is dark mahogany bay, over I 6 hands and weighs 1200 pounds, was got by Clay's Mambrino, from the trotting mare, Mrs. Caudle. He made fastest time at four years old of any stallion at that age on record. 'This performance is well authenticated by creditable testimony. "Over the Woodlawn Course, on the 26 th of Oct. I 860 , for a purse of $\$ 200$, Morgan Chief beating Kentucky Chief; time $2: 391 / 2-2: 34^{1} / 2-2: 301 / 2$, Kentucky Chief winning the first heat. This was the best time ever made by a four-year-old. Ericsson since four years old has been kept for breeding. We believe he has never appeared in public since on the trotting circle."

Wilkes Spirit of the Times, May 31, 1862, says:

"Mr. H. C. Barker of Michigan, has purchased and brought from Kentucky, the celebrated colt, Morgan Chief, who made the best time ever shown by a four-year-old in the world. Mr. Barker has changed his name to Ericsson. He is a beautiful dark bay, $161 / 4$ hands high; of remarkable symmetry and action. 
From Clark's Horse Review, June i6, i 89 I :

"Ericsson, by Mambrino Chief : dam Mrs. Caudle, was a brown horse, the fastest four-year-old of his day, and his record stood until Bruno knocked a half second off it, $\mathbf{1} 865$. He was a perfectly true-gaited horse and trotted trials far below his record. As a sire of $2: 30$ performers he was not great, having produced but six, the fastest being Rarely, $2: 24 \frac{1}{2}$. His blood, however, seems to be of great value in his more remote descendants, for his daughters are producing fast and enduring race horses, one of them being the dam of J. R. Shedd, $2: 19 \frac{1}{4}$, another the dam of Godelia, $2: 19 \frac{1}{2}$, and seven others are the dams of $2: 30$ trotters, while still another produced the dam of the great race horse Phallas, $2: 133 / 4$, and another one produced the dam of Almont Wilkes, $2: 20$, etc. His son, Williams' Mambrino, got the dam of five in $2: 30$, including the great brood-mare Lady Thorne Jr., dam of Navidad (four years), $2: 22 \frac{1}{4}$, Santa Claus, $2: 171 / 2$, etc. Santa Claus was sire of Sidney (pacer) $2: 19^{1 / 2}$, sire of Gold Leaf (pacer) $2: 111 / 4$, Adonis (pacer) $2:$ II $1 / 2$, Sister V., $2: 181 / 2$, etc. It is, therefore, proven that Ericsson blood has the greatest quality. Mrs. Caudle, the dam of Ericsson, also produced the dams of Clark Chief 89 (sire of Croxie, $2: 19 \frac{1 / 4}{4}$, etc., and grandsire of Guy, $2: 103 / 4$, etc.), and McDonald's Mambrino Chief, whose blood traces in some of our good performers. She is also the fourth dam of Sultan, $2: 24$ (sire of Stamboul, $2:$ I I, etc.) Mrs. Caudle was a noted road mare used about New York City and could trot a $2: 40$ gait to wagon. She was undoubtedly one of the best mares ever mated with Mambrino Chief. Ericsson was a coarse horse and our frontispiece is probably the best that has yet been published."

Sire of 6 trotters $(2: 241 / 2) ; 3$ sires of II trotters; 13 dams of 14 trotters.

ERIE ABDALLAH (I-32), bay; foaled I 857 ; bred by E. N. Wilcox, Detroit, Mich.; got by Roe's Abdallah Chief, son of Abdallah: dam Bess, said to be by Hickory, a Canadian trotter. Owned in Mt. Vernon, O., where he was taken spring of $\mathbf{1} 867$.

Sire of Rienzi, $2: 25 \frac{11}{4} ; 4$ sires of 5 trotters, 2 pacers; 6 dams of 2 trotters, 4 pacers.

ERIE CHIEF (I-64), bay with black points, I6 $1 / 4$ hands, I 250 pounds ; foaled I 871 ; bred by H. C. Bostwick, Newark, O.; got by Erie Abdallah, son of Roe's Abdallah Chief: dam Mary Bostwick. Sold to E. L. Shultz, Croton, O. Pedigree from B. L. Shultz, son of E. L. Shultz, who writes :

"The dam was a bay pacing mare, record $2: 30$, brought from the East by Dr. Heath. As near as we could find out, she was Black Hawk Morgan and Messenger blood. Died about I 892."

Sire of 2 pacers $\left(2: I_{4} 1 / 4\right)$; I sire of I pacer.

ERIE CHIMES (3-128), bay with star, hind ankle white; foaled I888; bred by C. J. Hamlin, East Aurora, N. Y. ; got by Chimes, son of Electioneer: dam Gulvare, bay, bred by C. J. Hamlin, got by Mambrino King, son of Mambrino Patchen ; 2 d dam bay, bred by J. W. Gail, East Aurora, N. Y., got by Almont Jr., son of Almont; and $3 \mathrm{~d}$ dam said to 
be by Chandler J. Wells, son of Royal George. Pedigree from catalogue of breeder.

sire of Churles Sumner, $2: 101 / 2$.

ERIE FOY (I-I2S), $2: 19^{1 / 2}$, chestnut, I6 $1 / 4$ hands, Ir 50 pounds; foaled I $8 \$_{4}$; bred by H. R. Pumphrey, Croton, O. ; got by Erie Chief, son of Erie Abdallah: dam old Daisy, bay, bred by H. R. Pumphrey, got by White Cloud, son of Stranger; 2d dam Fanny Kimble, said to be by Long Island; and $3 \mathrm{~d}$ dam by Sligard. Sold to Pratt Bros., Weston, Mich., I 887 , who speak highly of the horse and his get and send pedigree.

Sire of Kid Lark, 2:161/4.

ERIE KING (5-64), bay, hind feet white; foaled I $\delta 8_{3}$; bred by C. J. Hamlin, East Aurora, N. Y. ; got by Nambrino King, son of Mambrino Patchen : dam Sophia, bay, bred by C. J. Hamlin, got by Hamlin's Almont Jr., son of Almont; 2d. dam Black Woful, black, bred by C. J. Hamlin, got by Hamlin Patchen, son of George M. Patchen : 3d dam Miss Minchen, said to be by Young Woful, son of Woful; and $4^{\text {th }}$ dam Miss Sears, by Hero, son of Abdallah. Sold to R. W. Daniels, Kelso, Dak. Pedigree from catalogue of breeder.

Sire of Dell King, $2: 281 / 2$.

ERIE IVILKES (I-I28), bay with small star, little white on near hind and off front pasterns, I5 $1 / 2$ hands, II 25 pounds; foaled 1882 ; bred by $\mathrm{W}$. L. Simmons, Ash Grove Stock Farm, Lexington, Ky.; got by George Wilkes: dam Traitress said to be by Confederate Chief, son of Clark Chief; and $2 \mathrm{~d}$ dam by Topgallant, by son of Hambletonian. Sold to Henry C. Jewett, Cheney, Kan. ; to James T. Walker, Perryman, Md. Pedigree from catalogue of Henry C. Jewett.

Sire of 4 pacers $\left(2: I^{3} / 4\right) ; 2$ dams of $x$ trotter, I pacer.

ERIE IVILKES (I-I 28 ), black with star, I51/2 hands, I075 pounds; foaled I 885 ; bred by Col. Sackett, Amherst, O.; got by Star Wilkes, son of George Wilkes: dam black, owned by a business man of Pittsburg, Penn., and sold by his son in Cleveland, O. Sold to A. Hasslee, Attica, O. ; to Phil Howe, Chicago, O.; to David Nims, Bellevue, O. ; to a party at Sandusky. Pedigree from Jos. Hasslee.

Sire of Agnes Wilkes, $2: 2 \mathrm{I}^{1 / 4}$.

ERIN (3-256), $2: 243 / 4$, bay, 16 hands, I 200 pounds; foaled I 880 ; bred by A. J. Alexander, Spring Station, Ky.; got by Belmont, son of Alexander's Abdallah: dam Eventide, bay, bred by A. J. Alexander, got by Woodford Mambrino, son of Mambrino Chief ; $2 \mathrm{~d}$ dam Vara, bay, bred by Joseph Gavin, Chester, N. Y. ; got by Hambletonian, son of Abdallah; 
3d dam Venus, said to be by American Star. Sold to Robert Steele, Philadelphia, Penn. Pedigree from catalogue of Robert Steele.

Sire of 2 trotters $(2: 181 / 4)$; Tony, $2: 211 \frac{1}{4} ; 2$ dams of 2 trotters.

ERIN CHIEF, golden chestnut, I $53 / 4$ hands, 1200 pounds said to be by Howe's Royal George, son of Field's Royal George, by Royal George : and dam Erin Queen, by imported Charon.

The report of the Ontario Agricultural Commission, I $88 \mathrm{I}$, says :

"Erin Chief has been nine years in the stud, having in that time got no less than 400 colts, which show his characteristics in a remarkable degree. He has had very little training, but can it is said, trot a mile in $2: 30$ or better. No less than forty-six of his progeny were exhibited at the Toronto Industrial exhibition last fall."

Sire of Syndicate, $2: 25 \%$.

ERNEST, bay; foaled r873; bred by Alden Goldsmith, Washingtonville, Orange County, N. Y. ; got by Volunteer, son of Hambletonian: dam Misfortune, gray, foaled $185^{-}$, purchased of Wm. J. Tuthill, by Mr. Goldsmith, said to be by Plow Boy, son of Long Island Black Hawk; and $2 \mathrm{~d}$ dam, by Mambrino Paymaster. Owned by F. D. Norris, Brooklyn, N. Y.

Sire of I trotter, 2 pacers.

ERNEST WILTON ( $1-64), 2: \mathrm{r} 83 / 4$, black; foaled 1889 ; bred by Allen Bashford, Paris, Ky.; got by Wilton, son of George Wilkes: dam Emma Holstine, black, bred by W. C. France, Lexington, Ky., got by Alexander, son of Ben Patchen, by Burlington; $2 \mathrm{~d}$ dam Emma G., black, bred by Allen Bashford, got by Almont, son of Alexander's Abdallah; $3 \mathrm{~d}$ dam Madam Finch, said to be by Mambrino Drennon; and $4^{\text {th }}$ dam by General Taylor. Sold to A. C. Showalter, Lexington, Ky. ; to O. M. Cole, Centreville, Ia.

Sire of 2 trotters $(2: 231 / 4)$, Maud Oleson, $2: 191 / 4$.

EROS, $2: 291 / 2$, brown with star, I 6 hands; foaled I $\$ 79$; bred by Leland Stanford, Palo Alto, Cal.; got by Electioneer, son of Hambletonian: dam Sontag Mohawk, gray, I6 hands, foaled 1875 , bred by Charles Stanford, Schenectady, N. Y.; got by Mohawk Chief, son of Hambletonian; 2d dam Sontag Nellie, gray, bred by Charles Stanford, got by Toronto Sontag, son of Toronto Chief ; $3 \mathrm{~d}$ dam Nellie Gray, a famous long distance trotting mare, 5 mile record I $3: 45$, pedigree not traced. Sold to Frank H. Burke, Menlo Park, Cal., now of San Jose. Burned in the East, I89-. Pedigree from catalogue of breeder.

Sire of $\mathbf{I} 7$ trotters $\left(2: 07 \frac{1}{4}\right), 2$ pacers $\left(2: 17 \frac{1}{2}\right) ; 4$ sires of 8 trotters, I pacer; 2 dams of 2 trotters.

EROS, brown; foaled 1883 ; bred by R. P. Pepper, Frankfort, Ky.; got by Onward, son of George Wilkes : dam Alva, bay, bred by R. P. Pepper, 
got by Administrator, son of Hambletonian; 2d dam Cachusa, bay, bred by R. P. Pepper, got hy Almont, son of Alexander's Abdallah;

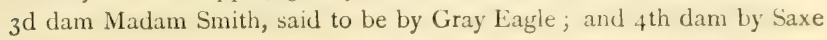
Weimar.

Sire of Go-Ahead, $2: 22 \frac{1}{2} ;$ I sire of 2 pacers; 1 dam of I pacer.

ERVIN M. (1-32), 2 :19, brown with star, 151/2 hands, I050 pounds; foaled I 886 ; bred by E. B. Melvin, Corinna, Penobscot County, Me.; got by Lothair Jr., son of Lothair, by Gen. Knox: dam bay, lired ly Frank Loomis, Palmyra, Me., got by Gen. Grant, son of Gen. McClellan; and $2 \mathrm{~d}$ dam said to be by Gideon. Pedigree from breeder.

Sire of Sebat, $2: 24 \frac{1}{2} ; 2$ pacers $(2: 201 / 4)$.

ERWIN DAVIS (3-128), bay; foaled I865; bred by Erwin Davis, California; got by Shenandoah, son of Broken Legged Kentucky Hunter : dam Lost Diamond, said to be by Vermont Hamiltonian. Owned hy C. S. Crittenden, San Francisco, Cal., and D. Gannon, San Leandro, Alemeda County, Cal., who send pedigree.

Sire of Ed, $2: 26$; I dam of I trotter.

ESCAPE, dark bay, got by Highflyer: dam by Siphon, imported, July, I 772 . Advertised as above 1793 in Dunlap's American Advertiser (Philadelphia).

ESCAPE, bay, bred by Mr. Franco; got by Highflyer: dam Squirrel Mare, bred by Lord Farnham, got by Squirrel ; 2 d dam (sister to Sir J. Low the's Babraham), got by Babraham; 3 d dam said to be by Golden Ball ; $4^{\text {th }}$ dam Bushy Molly, got by Hampton Court Childers; and $5^{\text {th }}$ dam Lord Halifax's Bushy Molly, by the Chestnut Litton Arabian.-General Stud Book, Vol. I., p. 357 .

ESCAPE, bay, 6 hands; foaled I79I ; imported from England, December, I796. Advertised, I797, at Red Hook, N. Y. at six pounds for the season and 5 shillings to the groom. Advertised in Poughkeepsie Journal, March 29, I 797 .

ESCAPE. An Editor of Turf, Field and Farm, New York, I892, writes :

"One day last week there was seated in my office a gentleman from Canada, on the shady side of 60 , who had been a lover of trotters ever since his boyhood, and quite a breeder of them. Speaking of Canada horses, he said : 'Crazy Jane was got by Young Sportsman, son of Sportsman who got Taconey. There is not the slightest doubt of this, for I knew the facts at the time, and two years ago I told Mr. Wallace in his own office that he was all wrong about the breeding of this mare. Her dam was called an Arabian, but I do not pretend to know anything about that.

"Our earlier trotting stock in Canada has been badly mixed up in the books, especially about the Tippoo's. There was a horse that came to 
western Canada between 1820 and 1830 , who got a great deal of notoriety for those days as a stock horse, who was named Escape. I was born, myself in I 829 , and cannot speak of him from personal recollections, but have learned of him from older men than myself, who were horsemen and who had no interest in misrepresenting facts, and the facts, as far as they go, were well known at the time. This horse, Escape, came to Ogdensburg, N. Y., and crossed over to Prescott, driven by a clergyman who states that he had driven him all the way from Rhode Island. He stood for service, principally at Morven, Lexon County, and his get were so well liked that he had a great deal of patronage. Of stallions that were successful in the stud later, I know that he got Black Tippoo, Brown Tippoo, and Bay Tippoo, and a horse named Wild Deer, whose dam was a mare from Lockport, N. Y., said to be of running-blood. Escape died, like old Abdallah, of neglect, on an island of but a few acres in extent just off Adolphustown on the coast of the lake. His name was said to have come from the fact of his being the only survivor of a voyage from Europe, so severe that all the rest of the live stock either perished enroute or were washed overboard and drowned. Escape himself was reported to have been once pitched into the ocean, but swam so strongly that it was possible to save him. I cannot vouch for the truth of this tale, but am very confident that he is the fountain head of the Tippoos and Royal Georges that gave Western Canada her reputation as a producer of trotting stock. He was no doubt, running-bred in part, although probably not thoroughbred. I have many notes at home, made from conversation with older men than myself, which bear upon this subject, and which I may find time to write to you about.'

"I can only add that I hope my friend will carry out his intentions, and give the readers of the Turf, Field and Farm, the benefit of his notes. $\mathrm{He}$ is a thoroughly practical horseman, wants nothing but the truth, and the people he has interviewed would not be likely to give him anything but the truth. The Canadian element in trotting animals has always been rather misty, and whatever can be done to clear away the clouds should be done very quickly before the witnesses have all passed away."

ESCAPE (HORNS), $151 / 2$ hands, chestnut; foaled 1798 ; got by Precipitate: dam by Sweetbriar, from dam of old Buzzard, imported by Col. Homes of Virginia.

ESCOBAR (I-I2S), $2: 15 \frac{1}{2}$, brown; foaled I 893 ; bred by R. S. Veech, St. Nathews, Ky. ; got by Expedition, son of Electioneer : dam bay, bred by R. S. Veech, Louisville, Ky., got by Princeps, son of Woodford Mambrino; $2 \mathrm{~d}$ dam Florence, bay, bred by Bateman Brooks, Orange County, N. Y., got by Volunteer; $3 \mathrm{~d}$ dam said to be by Hambletonian; and $4^{\text {th }}$ dam Welling Mare, by Shark. Sold to J. W. Creect, Herington, Kan.

Sire of Ed. Escobar, $2: 23 \frac{3}{4}$.

ESCORT ( $\left.1-6_{4}\right)$; said to be by Young Rolfe.

Sire of Highland Boy, $2: 29 \frac{1}{2}$. 
ESOPUS BALL, bay, I6 hands; foaled 1791. Advertised, $179^{8}$ at Lower Dublin, Penn., by John Sogers.

ESPARTO REX (1-256), $2: 21$, bay; foaled I891; bred by Leland Stanford, Menlo Park, Cal.; got by Piedmont, son of Almont: dam Extra, bay, bred by Leland Stanford, got by Electioneer, son of Hambletonian; 2d dam Esther, bay, bred by S. B. Wallace, Midway, Ky., got by Express, son of Endorser, by Wagner; 3d dam Coliseum, bay, bred by Warren Viley, Midway, Woodford County, Ky., got by Colossus, son of imported Sovereign. Sold to E. Snyder, Delaware, O. Pedigree from catalogue of breeder.

Sire of 2 trotters $(2: 2+1 / 4)$.

ESPERANZA, brown; foaled I $S S_{9}$; bred by A. J. Alexander, Spring Station, Ky.; got by King Wilkes, son of George Wilkes: dam Esperence, bay, bred by A. J. Alexander, got by Harold, son of Hambletonian; 2d dam Englewood bay, bred by A. J. Alexander, got by Belmont, son of Alexander's Abdallah; and 3 d dam Woodbine, bred by A. J. Alexander, got by Woodford, thoroughbred, son of Kosciusko. Sold to W. R. Allen, Pittsfield, Mass., who sends pedigree.

Sire of Edna Stevens, $2: 261 / 4$.

ESPY BOY (5-128), 2:13, black with two white ankles, I6 hands, I 200 pounds; foaled 1893 ; bred by James L. Crain, Urbana, O.; got by Civilian, son of Civilization : dam Alice C., bay, bred by James L. Crain, got by Stillson, son of Messenger Duroc; $2 \mathrm{~d}$ dam Tip, bay, bred by James L. Crain, got by Tip Cranston, son of Flying Morgan; 3d dam Lucy, bay, bred by J. L. Crain, got by Jenning's Iron Duke; $4^{\text {th }}$ dam bay, bred by C. L. Crain, got by Joe Gales, son of Marlborough. Yedigree from E. E. Powell., who writes: "Of fine appearance and good action."

Sire of Lady Espy, $2: 261 / 4$.

$\operatorname{ESSEX}(5-64), 2: 27 \frac{1}{4}$, chestnut, near hind and near front foot white, $15 \frac{1}{2}$ hands; foaled May 9, I883; bred by Wm. Pickhart, Schroon Lake, Essex County, N. Y. ; got by Aristos, son of Daniel Lambert, by Ethan Allen: dam Nelly, roan, foaled I873, bred by William Simonson, Jamaica, N. Y., got by Black Diamond, son of Superb, by Ethan Allen. Pedigree from breeder.

ESTEY HORSE ( $\mathrm{r}-8$ ), roan; said to be by Nimrod, son of True American. Owned in Sutton, Caledonia County, Vt., and afterwards by a Mr. Estey. in Bolton, P. Q.

ESTILL ERIC (I-I6), said to be by Ericsson.

Sire of Mattie Scott, $2: 25 ; 6$ dams of 4 trotters, 2 pacers. 
ETHAN ALLEN (I-4), $2: 25 \frac{1}{2}$, bay with star and stripe, both hind feet and the right fore foot white, I5 hands, Iooo pounds; foaled June I8, I 849 ; bred by Joel W. Holcomb, Ticonderoga, N. Y.; got by Black Hawk, son of Sherman Morgan : dam gray, bred by John Fields, Springfield, Vt., sold by him I 834 to Frederick Leland, then of Sherburne, afterwards, Middlebury, Vt., who kept her that winter at Sherburne, and the next season drove her for a while on a peddler's cart, when he swapped her at the home of Apollus Austin in Orwell, to Rufus Rising of Hague, N. Y. ; got by Robin or Red Robin, a horse owned by Moses G. Bates, Springfield, Vt., which see; 2 d dam dark brown, bred by Mr. Bemis, Baltimore, Vt., a mare of Morgan build and appearance, said to be by a horse of the blood of Bulrush Morgan; 3 d dam a chestnut mare brought to Chester, Vt., by Dr. Chandler of that place, from Tunbridge, Vt., and said to be by Justin Morgan.

A half interest in Ethan Allen, when a colt, was sold to Orville S. Roe of Shoreham, Vt., and during the earlier years of his life he was owned jointly by Holcomb and Roe. During these years he was kept for service mostly at Larrabee's Point, Shoreham, Vt., and some seasons at Cambridge, Mass. ; but he was used on the track more or less, nearly or quite every season, trotting many races, the most of which he won. In 1862 he was sold to Frank Baker, who, after a time, sold him to Dan Mace and I. D. Walton. In I 866 he was purchased by J. E. Maynard of Boston, who sold him to Eph. Simmons, but afterwards bought him back, and again sold him, November 5 th, 1868 , to Wesley P. Balch of Boston, who in turn sold him to Col. H. S. Russell of Milton, Mass. In I 866 and I 868 he was advertised to be kept in Boston at one hundred dollars the season. In $\mathbf{I} 869$ he was kept at Mystic Park, Medford, Mass., at one hundred dollars the season, and in 1870 at the same place at two hundred dollars the season. He was finally sold, Oct. I 7 th, I 870, to Col. Amasa Sprague of Providence, R. I., for seven thousand five hundred dollars. Col. Sprague kept him at Providence for a time and then sent him to the Sprague and Akers stock farm at Lawrence, Kan., where he passed a serene old age in peace and comfort, and died on the 16 th of September, I876, in his twenty-eighth year. He was buried at the entrance of the trotting park, and there a suitable monument was erected to his memory. His skeleton was afterwards exhumed and now stands in the museum of Natural History at Lawrence.

Perhaps no other horse has ever done so much service both in the stud and on the track, the same season. It appears that all his trotters with fastest records, as well as all his most noted sires, were got during the period while he was kept at Shoreham. Born the same year as Rysdyk's Hambletonian, he got, up to 1872 , a precisely equal number of $2: 30$ trotters; and it would appear not unlikely that had he staid upon the stock farm at Shoreham, as his great competitor did at Chester, 
and, like him, been used solely for stock purposes, he would now have to his credit as full a $2: 30$ list, and that many other such sires as Daniel Lambert, Holabird's Ethan Allen, DeLong's Ethan Allen, American Ethan, Bacon's Ethan Allen and Honest Allen, would have been left to fill the country with the finest race of roadsters and some of the fastest trotters known to the world. See The Morgan Horse and Register, Vol. I., p. 175 .

The Boston Cultivator said in $\mathbf{1} 856$ :

"Ethan Allen is a bay, seven years old, by Black Hawk. He is, so far as known, the fastest trotting stallion in the world. When he was less than four years old he won a match at the Union Course, L. I., in $2: 36$. This course is a half mile with short corners and those who ought to know, consider that there is five or six seconds difference between this and a mile course.

His form is very symmetrical and he has great strength and power for his bulk with a hardy constitution. His style of movement is beautiful, showing clearly the precision of the most perfect mechanism."

Ethan Allen is advertised in The Spirit of the "Times, New York, I866, by John Maynard, to be kept at Boston, terms, \$I Ioo.

The National Live Stock Journal, r871, in an editorial on Ethan Allen says :

"He shows all the speed of his former days; his legs are as clean as those of a sucking foal and his eye has lost none of its youthful fire and determination, He bears fewer marks of age than any horse of his age we have ever seen and a large number of foals will be dropped from him this season."

Advertised at $\$ 500$ the season, 1873 , by Sprague \& Akers in Spirit of the Times.

The National Live Stock Journal, I874, says:

"A vigorous old horse. It is wonderful to note the vigor which the celebrated Ethan Allen displays in his old age. He is now 26 years old, but is to all appearances as young as he was at I5. Last season he covered 37 mares and got 32 foals, and this year he has covered 5 I. We have never known a horse upon which the hands of age rest so lightly as upon this great trotter."

The Breeder and Sportsman, San Francisco, April I5, I893, says:

"Ethan Allen was the only horse, except Axtell, that got to be king of trotting stallions while a colt. He attained this distinction at four years of age and held it six years. During that time he made a record of $2: 28$, which was the first record in the $2: 30$ list by a stallion: he afterwards trotted in $2: 25 \%$, and in $2: 15$ with running mate when eighteen years old. It is also said of him that rigged in that way he once trotted a quarter of a mile in $281 / 2$ seconds, a $\mathbf{I}: 54$ gait."

There has been perhaps no horse that was so great a favorite with the American people as Ethan Allen. For quite a number of years he was invincible upon the trotting turf, and then his manners and disposition 
were fine, his figure handsome and graceful, and his gait the very perfection of motion.

Throughout his generation he was the representative Morgan stallion, and today one of his grandsons of very beautiful form, good disposition and fine action,-Gen. Gates, full brother to Lord Clinton, trotting race record in $1894,2: 083 / 4$, trial $2: 05$, his record beaten then but a very little and only by one stallion,- - stands at the head of the Government Morgan Horse Farm at Weybridge, Vt.

And indeed nearly or quite every animal of this farm, rapidly becoming one of the most marked and largely visited of any upon the Continent, trace in either male or female line, most of them in male and quite a number in both, to Ethan Allen. At the Bread Loaf Stock Farms, Middlebury and Bread Loaf, Vt., there are quite a number of young mares and colts that trace to him, three, and four times, worthy representatives of so renowned a sire.

Unquestionably, too, Ethan Allen's name so appropriately chosen, added to his popularity.

He closed his trotting career in his great race with Dexter. Dexter who had become invincible, went to sulky; Ethan with running mate. We publish towards the close of this history, the brilliant account of this race, by John $\mathrm{H}$. Wallace, one of the most excellent ever written of a horse race.

Of course Ethan had the advantage of the running mate to pull the sulky, but this would have perhaps hindered more than helped, but for his incomparable trotting action.

It is a curious fact that during the lifetime of these two trotters, but very little was known about their dams; nothing whatever of Ethan's except that she was a small but active gray mare. The dam of Dexter it was known, was got by a horse called American Star, and this horse by another very handsome and excellent horse also called American Star.

In both cases it was very plain to any unpredjudiced and astute horseman, that the dams probably belonged to the Morgan family, which we finally fully proved, but only after several years active search.

In Vol. I., of this work, under his name, we have given a very complete tracing of American Star, sire of the dam of Dexter, showing that he was a great grandson of Sherman Morgan the sire of Black Hawk and son of the original Justin Morgan; with one or more lines of Morgan breeding through the dams.

This proved equally true of the dam of Ethan, so that on the female side these two wonderful trotters were nearly related. It was also true that the dams of every one of Hambletonian's trotters with records of $2: 20$ or under, were got by American Star.

Our tracing of the dam of Ethan Allen was made, largely, in company with Judge Bliss, then and now of Middlebury, Vt., and was at the time 
published in the Middlebury, Vt., Register. As it was quite a remarkable, and in the end highly successful, tracing, we copy from the Middlebury Register this contemporaneous account.

\section{PEDIGREE HUNTING;}

OR, THE WRAITH OF THE OLD GRAY MARE.-FROM THE MIDDLEBURY (VT.) REGISTER, I 886.

A few weeks ago I had occasion to drive over to $\mathrm{Ti}$, and whilst there made enquiries in relation to the dam of Ethan Allen. I was referred to William Arthur as reliable, and a man of excellent memory.

Pretty much all, perhaps all, of what purported to be authentic testimony hitherto published about this mare has been given by Wallace. In the April number of his magazine for $\mathbf{I} 877$, in an article with much merit entitled, "History of Ethan Allen by the Editor," Wallace says :

"IVe are now ready to consider what has been discovered about the origin and history of the dam. Notwithstanding all that has been written about this little flea-bitten gray mare, I do not remember that any one has attempted to give a single item of her history that might lead to the tracing and determining of her origin. From information that comes to me from sources that are direct and reliable, there were two brothers, Rufus and Horace Rising, engaged in the manufacture of wooden bowls and other wooden ware at Ticonderoga, New York. Rufus also devoted a good portion of his time to the mercantile part of the business, and traveled extensively, making sales in the district within, say, forty miles, embracing a section along the western base of the Green Mountains in Vermont.

On one of these trips, he brought home with him a little gray mare that afterwards became famous as the dam of Ethan Allen. Mr. Rising has been dead some years, and it is not now known where he got this mare, but there is a tradition that he got her in Vermont: and as she probably came from the region where the Freeman Messenger had been standing for a number of years, the theory that she was by that horse took its rise from that supposed circumstance. Whether Mr. Rising traded his wares, or another horse, for the mare is not now known.

Mr. Rising after some time, sold the mare to George Johnson of Hague, and he to Warner Cook of the same place. Upon the death of Mr. Cook, the mare passed into the hands of Mr. William H. Cook, then and now of Ticonderoga, New York. Mr. Cook bred her to Young Sir Charles, known as the Burge Horse and she produced a fine bay horse about 16 hands high. He was taken into Canada and trotted in a hundred-mile race and won; but whether against time or another horse we are not informed. This Young Sir Charles was a wonderful longdistance horse himself. She was bred again to the same horse and produced a bay filly that got her foot hurt and was put to breeding. Mr. Cook then sold her to George Weed of Ticonderoga, and Weed sold her in the winter or spring of 1845 to Joel W. Holcomb, and that spring he sent her to be bred to Black Hawk. She produced: 
I 843 , b. c. (that trotted 100 miles) by Young Sir Charles.

I 844 , b. f. (put to breeding) by Young Sir Charles.

I846, bl. m., Black Hawk Maid, by Black Hawk.

I 847 , gr. c., Red Leg, by Black Hawk.

I 848 , ch. f. (died at three years old), by Wicker's Sir Walter.

I 849 , b. c., Ethan Allen, by Black Hawk.

I 850 , mare died in foal to Black Hawk."

That one hundred mile race was probably a fraud. Mr. Wallace states it unqualifiedly, although he does not know when it took place, nor where, nor how; but it does help to show where Ethan Allen got his merit, although he was by a Morgan horse. If it could be substantiated it would be another feather in the cap of the little gray mare, and a further credit to the Diomed blood through Young Sir Charles; but it appears to be at best an attempt to make history out of stable talk.

The suggestion of Freeman Messenger is the first seed of another and far greater fraud; one that Mr. Wallace has fostered and allowed to take root in his magazine, where this pedigree has since been stated in a leading article and without qualification. From this source a suggestion so baseless has spread in the guise of an ascertained fact through catalogues and periodicals throughout the country, and has been rapidly ripening, according to the apparent intent of its author, into an established pedigree.

To one unfamiliar with the jugglery whereby Mr. Wallace causes a Messenger pedigree to spring up and bear fruit as it were in a single night, it might be of interest to recur to this case, and " $a b$ uno disce omnes." Note how light a feather, dextrously thrown, turns the scale. He says "It is not now known where he (Rising) got this mare; but there is a tradition that he got her in Vermont; and as she probably came from the region where the Freeman Messenger had been standing for a number of years, the theory that she was by that horse took its rise from that supposed circumstance !" You see at once that nothing whatever is here stated.

Yet this "theory" that arose from the "supposed circumstance," that there was a "tradition" that this mare "probably came" from a "region" (a whole State) in which the Freeman Horse once stood, is the only ground upon which rests the absolute and unqualified statement, that the dam of Ethan Allen was by Freeman Messenger, that appears in the magazine of John H. Wallace, himself the author and finisher of the fraud.

Mr. Allen W. Thomson of Woodstock tells us that Wallace's statement of the colts of the little gray mare is not correct. It is certainly not complete, as will hereafter appear.

I found Mr. Arthur, a tall quiet man with an earnest and kindly disposed eye; his age something over 60.

He told me that the dam of Ethan was brought into Hague either as a foal by the side of her dam or in her dam as early as 1823 by a man 
that lived at Hague; that she passed from this man to Mr. Rising and from him to Mr. Warner Cook and Wm. H. Cook, from him through several hands to Joel Holcomb, who bred from her Jithan Allen and several other colts. The name of Gershom Densmore was finally given to me as the man who brought this mare into Hague.

To verify this statement given by Mr. Arthur, in company with a friend I started towards the last of September for Ticonderoga.

Our first stop was in the town of Cornwall at Mr. Rollin A. Foot's, who gave us the following information of Black Hawk stallions bred or owned by his father Abram Foot, himself and others.

The first was bought by his father for Ezra Foot and Mr. Farnham of Lockport, N. Y. This was a black horse of about I5 hands and 1000 pounds. They kept him at Lockport two or three years, when the barn was struck by lightning and he was burned.

Then they bought of Abram Foot, Black Hawk Jr., black, ${ }_{5}$ hands, Iooo pounds, very fine figure, foaled $\mathrm{I} 8+7$, bred by Abraham F. Abernethy of Cornwall ; dam a little bay mare, well along in years, very sharp stepper, think they called her a Henry. Abernethy bought her of Somers Foot, Weybridge. (Mr. Linsley says this mare was called the Howard mare and got by a colt of Hamiltonian. Mr. Chester Pratt says she was a smooth-turned, handsome bay mare about 900 pounds, bred by Allen Howard of Addison). Abram Foot kept this horse two or three years at Cornwall and quite a number of colts were raised from him. He sold him for \$150o. Abraham Abernethy bred another from same mare one or two years younger which he took West at 4 years old. He was a black horse about 15 hands, rooo pounds, but more chunked than one last described and not so stylish. He also got some colts in Cornwall.

The next horse was Prince, a black horse I 6 hands, over 1200 pounds. Abram Foot and Victor Wright bought him at three years old of Mr. McKenney of Bridport, who bred him. They kept him two or three years at Cornwall and sold him to parties, he thinks in Missouri, for $\$ 3000$. (Linsley states that the dam of this horse was by Young Sir Walter, sire of Moscow, and he by Sir Walter). He also got a good many colts at Cornwall.

The Foot Horse was a dapple horse with 4 white feet and star: dam by Morgan Tiger, owned by Sol. Howe, Bridport. Morgan Tiger was a son of Sherman Morgan. The Foot Horse was bred by Charles Benedict, Cornwall, foaled about $\mathbf{1} 854$, bought at 3 years old by Abram Foot, and always kept at the Foot place, Cornwall, where he died in I878. R. A. Foot bought him when I4 years old of his father. Abram Foot had a filly from Black Hawk, and from her he bred Prince, a large black stallion colt, which R. J. Jones took to California' at two or three years old. Jared A. Foot, Cornwall, had a black good-sized stallion from Prince which he sold West. 
The sluggish Lemon Fair comes near to Mr. Foot's house. We crossed this by a covered bridge and came to Mr. Lyman H. Paine's residence, also in Cornwall. He is the owner of Gen. Allen, black stallion 15-3, I I oo pounds and perhaps the best son of DeLong's Ethan Allen. Gen. Allen's dam is a magnificent black mare by Hammond's Black Hawk, son of Black Hawk. Her dam was by Black Lion. Hammond's Black Hawk was a large black horse weighing $\mathrm{I} 200$ pounds, and quite a successful trotter at local fairs. His dam a large mare purchased at Woodstock, Vt., said to be by Woodbury Morgan, and also said to be by a a son of Morgan Tally Ho.

The dam of Black Lion was by Liberty, by imported King William, or a son. Gen. Allen is a horse of great style and substance; also much beauty. He has the bearing of the old Vermont Morgans. Mr. Paine said that he showed better than $2: 40$ when four years old. Upon a stock farm this horse would have a right to be quite a successful sire. His dam was bred this year to Lambert.

Reaching Bridport we went north two miles to see a two-year-old filly by Gen. Allen. This filly pleased us so much that we bought her for a brood mare. The road from Bridport passed by the old Black Hawk farm, now owned and used as a summer home by a son of David Hill. A great grandson of Black Hawk, Harvester by Daniel Lambert, is kept now on this farm. Continuing south we came to Shoreham village and here stopped for the night. The evening was most pleasantly spent in a visit from Mr. Elmer Barnum and Dr. Pratt, both of Shoreham. Mr. Barnum is a man of very accurate observation and memory; and has a great fund of valuable information about horses of this region. He said :

"There were two Hemenway horses, both by Black Hawk and probably full brothers. The one best known was bay; the other was black, only got six or eight colts and was gelded. The bay was about 15-I, a thick set blocky Morgan model, among the early get of Black Hawk. Addison (dam Ruby by Andrus Hamiltonian), was a black horse bred by John Jackson, Brandon, and sold to Zephaniah Nearing, Orwell, near Benson; rather a thick set, stout horse, not over stylish, above the average Black Hawk size, about i roo pounds. He was quite a trotter, but never on the turf. The Perry horse was an iron gray $\mathrm{I}_{5-2}$, by Black Hawk, bred by Wm. A. Perry, Shoreham. North Star was a bright bay horse 14-2, a perfect beauty, by Black Hawk, dam brown. He was bred by James Frost, Shoreham, went to Pontiac, N. Y., and from there to Long Island. Boaz was a chestnut horse $15-3$, IO 75 pounds. $\mathrm{He}$ had white feet behind, strip in the face, and was very stylish. $\mathrm{He}$ was bred by Solon Lapham, Bridport; sire Superb: dam by Young Columbus, $2 \mathrm{~d}$ dam, the dam of Superb, by Harris' Hamiltonian. He got fine stock.

"Dave Hill was a black horse, good size and elegant, bred by Oliver Russell, Shoreham ; sire, Black Hawk ; dam rather a thickset bay mare, full of vim, would go all day, medium fine, rather heavy mane and tail, about 15 hands, and said to be English bred. Mr. Russell gave half of 
Dave Hill to his son-in-law, E. A. Birchard, who handled him, and at five years old sold him to Mr. Fish for \$200o, who took him to California. He got a few colts about here that were full of courage and long-lived. In California the banker Ralston had a fast four-in-hand all by him.

"Paul Clifford was a bay horse about I 5 hands, thickset, with heavy neck, coarse head, rather heavy mane. He was quite a trotter. Two Black Hawk stallions were bred by Royal Terrill of Shoreham, one black and one bay. Vermont, chestnut, foaled I 849 , bred by Nazro Northrup, Shoreham, $151 / 4$ hands, rooo pounds, thickset, sire Black Hawk, dam a chestnut, by Hill's Sir Charles. Vermont was a good and fine looking horse ; went West, probably to Ohio."

It is six miles from Shoreham village to Larrabee's Point, opposite the old fort Ticonderoga. We passed a number of fine residences, for the country is fertile and the farmers rich.

From Mr. Elmer Jones, now an old man past 8o, we got some information. He said that he raised Prophet. He called him 15-2, 1000 pounds, foaled 1847 . He also raised Red Jacket from the same dam; both by Black Hawk. Red Jacket he thought the most stylish; more like the Morgans than Prophet. Prophet took back more to Sir Charles, and was a little faster than Red Jacket. Mr. Jones further said :

"David Hill's first horse, Aurelius, was a very lazy horse.

"Sir Charles had a broken leg; slick bay horse, 16 hands, very fancy, got good stock.

"I think Allen Smith's Liberty was got by King William, a horse brought in by Col. Doolittle. Doolittle had King William before he had Post Boy. Dr. Needham had a small bay mare by King William. This King William got fine small bay stock, very lively and smart. Post Boy a red roan. The Bishop Horse's stock not thought so much of ; heads were large.

"Felton Horse was bred by Ben Breed, Crown Point. Think he sold him to Wicker of Ticonderoga; then he went to D. Myrick, and he sold to Felton at \$rioo. Beauty, rangy; trotter; high bred.

"Breed Horse, bred by Foster Breed; black, I 5 hands, Iooo pounds, stocky, good horse."

We called, also, before reaching the lake, upon Mr. Larrabee, 82 years old, and as hospitable a man as we have met in all our travels. We wanted to ask him about a colt said to have been bred by Judge John Larrabee. He remembered well a very fine bay stallion colt, bred by Mr. Larrabee, that he was offered a very high price for, for those days, when a sucker; thought afterwards it died or something happened to it. Didn't remember the blood, but finally suggested it might have been Hamiltonian. It was about I820. To the question if Allen Smith didn't get this colt, he thought he might, but couldn't tell.

Lake Champlain, that for roo miles forms the boundary line between Vermont and New York, at this point is something less than a mile wide. It begins a narrow creek at Whitehall, and continues to widen until nearly opposite Burlington, where what is called the broad lake, it has a width of ten miles. The scenery from this lake is beautifully varied, com- 
prising fertile farms, and lofty mountains. To the west is the Adirondack group, with patches of farming land dotted in between the mountains and the lake. North of these comes a broad expanse of rolling country in New York, lined with distant mountains. The Green Mountain range extends along the eastern sky; between it and the lake the beautiful country of Western Vermont. Directly north the plains of Canada mingle with the horizon. As a whole, we believe there is no Lake on this continent that presents a scene so varied, extensive and beautiful.

Crossing the lake we were in the great State of New York. Before going to the village of Ti., we visited the farm of John Porter \& Son. Mr. Porter's house is on a hill above, and perhaps a mile from the lake, and commands a fine view of western Vermont. His stallion Aristos is a trotter; has shown quarters in stud condition in 33 seconds. $\mathrm{He}$ is the sire of H. B. Winship, who with running mate has trotted in 2 :06, the fastest mile yet trotted. Aristos is a lark brown, 16 hands, and in good condition, would weigh over I 100 pounds. Lambertus is light bay, also I6 hands, resembling strongly the Morgan type. He is said to be as fast as Aristos, but as yet has no record.

Fanny Jackson, dam of Aristos and Lambertus, is a black mare, I6 hands, I 200 pounds, foaled the property and always owned by John W. Porter. She was by Stonewall, son of Williamson's Black Hawk, dam Betty Condon, probably by Sherman Black Hawk, but this is not certain.

She was bred first to Daniel Lambert when four years old and successively to him after that until fifteen, getting nine colts.

The following further information we had from Mr. Porter:

"Jubilee Lambert, brown, record $2: 25$; now owned at Lexington, Ky., was bred by John Porter and Thomas Harvey; foaled $\mathrm{x} \$ 62$; sire, Daniel Lambert, dam by Taft Horse, son of Black Hawk. He was kept until 1872 at Ticonderoga, except the season of 1870 , when he was kept at Whitehall, N. Y. At Ticonderoga he got many creditable colts, among them Crown Point Maid, 2:30 I-2; dam the Townsend mare by Ethan Allen. In IS72 Mr. Porter sold him to Mr. Webster of Boston, who sold to John A. Sawyer of Allston, Mass."

Champlain, the Messrs. Porter sold to Mrr. Fabian of Boston, who sold to David Snow of Andover, Mass. ; and he to W. A. McNeil, Esq., of Oskaloosa, Ia., who now owns him.

Bay Lambert, I5 1/4, Iooo pounds, bred by John T. Rich, Shoreham, got by Daniel Lambert: dam Hambletonian. Both Mr. Porter and his son said they saw Bay Lambert trot a mile on half-mile track in $2: 30$. He went to Boston.

Adonis, black, I5 I/2 hands, about Iooo pounds, foaled 1872 ; bred sy Dan Mace. Adonis was got by Ethan Allen, dam Charlotte F., Ethan's running mate.

Mr. Porter kept this horse at Ti. in 1878 , when a few colts were got by him, among them Eolus, black, $161 / 2$ hands, owned by C. B. Wright, Crown Point; trotted in $2: 49$. 
Taft Horse, black, some white feet, $153 / 4$, about 1 roo pounds; good style, good gait; by Black Hawk. Bred by Mr. Taft, Crown I'oint, sold and went to Ohio.

Mr. John Porter said :

"Ethan Allen was foaled in May or June. I saw him when but a few hours old ; it was certainly May or June."

"I bought Daniel Lambert when four months old for \$300. His dam a chestnut mare, I5-I or 2 ; long bodied, long neck, big-gaited mare; good looking mare for brood mare; good barrel and chest. Sold Daniel Lambert when coming five for $\$ 3600$ to Mr. Denny of Boston. He got record when three years old of $2: 42$.

The dam of Ethan Allen, was a chunked, gray mare, not over 15 hands, neck rather thin, not long. She could go in about 4 minutes; not very stylish. Next year after Ethan was foaled they filed her teeth and she could not eat and so died. She was a flea-bitten gray, trappy

On reaching Ti. village we called on Mr. William Arthur. Unfortunately he was out of town, as was also his brother Frank, whom we met with him at the previous interview. We then drove on toward Hague. It was a warm September day. The country was clad in its most brilliant dress. The fields were clothed in plain green, but thc trees upon the hill-sides were decked out in the gaudiest colors. Allowed to choose for themselvs, they were not afraid of looking too pretty. They arrayed themselves in green, in yellow, and in scarlet and stood peeking down the valley, and looking up over the hill-tops. Certainly it was not their fault if they were not admired.

The Densmores of Hague! We made enquiry and were told that one of the family, a youngerly man, lived in a brick house on the main road.

It was a small brick house, with a neatish yard, and small orchard. Mr. Densmore did not know whether there was a Gershom Densmore, or not. He said that he had a brother older, who lived to the right of the road about two miles, that might know; but we kept the straight road for Hague. We had before passed the summer residence of the Rev. Joseph Cook, a newly fitted up building of castellated and somewhat imposing appearance, that stands nestling in the shade of trees and hills near to the road, and seems to be a double house. It is on the site of the old homestead; Mr. Cook's mother now lives in one of the parts. We soon reached another of the Cook mansions, where William Cook, a second cousin of the Rev. Joseph Cook, lives. It was a large brick house with front piazza; somewhat antiquated, but substantial looking, and standing upon a good farm. The Cooks seem to be the Mugwumps of this neighborhood.

I stopped at Mr. Wm. Cook's. To my pull at the door-bell a young woman appeared. The glance I got of the inside of the house showed it to be furnished with luxury. Mr Cook came to the door and took 
a seat on the piazza. He was a heavy man of medium height; had the appearance of a good Methodist, and was certainly a good snuff taker, for he held his snuff box in his hand through this and all subsequent interviews, and seemed to make it a principle to offer it to all guests.

Unfortunately I refused the first proffer of snuff and information came very slow; I refused the second, and it ceased altogether. We left the deacon on the stoop; there were trees in front of the house whose shadows made the road both dark and damp. A trifle further on a heavy maple flamed in the richest vermilion. There was a wood, at the side a mountain, and between, suddenly, like the flashing of a dream, appeared the blue waters of lake George.

It was the first view we had had of the lake, but after this, through the woods, we kept along it several miles to Hague. These woods were to us a little peculiar. Great hanging vines (grapes) grew over them and gave them a Southern look. We passed a summer boarding house, then another, and came to the little village of Hague, where we stopped at a three-story but not very large wooden hotel that stands a little way from, but in full view of, the lake, and whose landlord we found puzzling over the problem, what had become of the profits, his house having been full all summer. This is a very familiar puzzle to summer hotel keepers, and one that many of them have been obliged to give up.

In the morning we had some conversation upon the stoop of the hotel with some of the denizens of this Lake George hamlet; got no information on Ethan's dam, but some references. Joel Rising, who kept this hotel in Hague several years since, now keeps hotel at Chester, about twenty miles west. Rufus Rising lives where his father Rufus used to live, on the hills in Hague, perhaps three miles from the village. We were advised to see Sam Ackerman, living on the same road.

In the morning before breakfast we walked up to the town clerk's office. We found him a man of marked, handsome features, intelligent, and very willing to assist us, but as there were no records of births, marriages or deaths, and records of town meetings did not go back of I 827 , we could not learn much.

The breakfast over, we pulled out for Rufus Rising's. Just outside of the village we were told there was one of the Densmore girls, now Mrs. Hiram Read. We stopped at her house. She thought she had an uncle Gershom, but knew very little about it, and knew very little about the family.

Then came an up-hill ride in this unique country. There was the usual brook that belongs to a hilly region; the road winding along, or near it, then crossing and leaving it to go over the hill. Far up on the hill was Mr. Sam Ackerman's. He was not at home: had gone to Ti., so in continuing we descended the hill, crossing the stream, passed a schoolhouse, and, by a winding way, came to Mr. Rufus Rising's, an ac- 
tive man of 60 ; like all of his family, quite thrifty, and a man very careful and accurate in his statements. Mr. Rising said:

"My father, Rufus Rising, was boin 1795, married ISz2. When I was about 15 years old he moved on to this farm in Hague. Previously to that he owned and lived on a farm in Hague near that owned ly Samuel tkerman, from which he moved to a neighboring farm, which he rented about a year, and thence to this place. My uncle, Horace Rising, did manufacture wooden bowls, etc., at Ti., and his father assisted in peddling. This peddling was done with a one-horse team and only in winter. Horace died at Ti., in 1837 . After that there was no peddling. The same year, 1837 , I had a sister born. This sister was born whilst we lived near the Sam Akerman place. I recollect hearing my father and the neighbors talk about Ethan Allen and the mare. I know they talked about dam of Ethan being amongst the Risings; and I think they may have referred to a man by the name of Densmore. Gershom Densmore had a small family, a girl named Susan, and perhaps a boy. $\mathrm{He}$ lived on the lake shore, about half a mile below the hotel, on the place where Henry Stark now lives. Now you mention it, I have heard one of the Cook's names mentioned in connection with this mare: think it was William."

We left for Ti. by another road. It wound around a mountain, passed a silvery brook that seemed pleading with the mountain air, and came out near to where our friend Mr. Wm. Cook lived. We called again upon him. This time each tried the proffered snuff and such information as he had was forthcoming. He said :

"I don't know much about that mare; but I have heard them say she passed through George Johnson's hands. I think his brother Hoyt would know about her. He lives at New Hague, about three miles from here. I think you would better go and see him."

The day was wearing on, and we wanted to get along, but it seemed as though we ought to see Mr. Johnson, and we drove back. We came again to the beautiful stream, and, just above where this meadow was that the brook coursed through, Hoyt Johnson's house. My friend went in ; he was gone a good while. I hitched the mare and followed. I found him interviewing an elderly lady, and she was a lady. More than 70 years rested over her, bent a little the lithe form, and furrowed some the fair cheeks. She had had trouble. It had come through a long life; had come as the sleet comes sifting down upon us when we mind it not; had come continuously; was not over yet; but the blue eye did its work faithfully and well. The kitchen was clean; the homely house in order ; whilst across the brow forever flashed the broad seal of truth and intelligence.

But I will give the interview with this remarkable woman, the best witness of events more than three-score years gone, by far that we met :

"I was born," she said "at Windsor, Vt., in January, I8rr. My father's name was Andrew Bevins, and my name is Rebecca. We came to Hague from Windsor 70 years ago. 
"Gershom Densmore moved to Schuylerville, and probably died there. His boys were Harry, Ransom and there were three girls. They were confortable livers, but not well off. The Densmores came from Winchester, on the Connecticut river. Leonard Densmore came first and bought a place in Hague. Gershom came next, after the war of I8I2. He came from Lewisville, or Lewis, New York. The people of that place left their homes expecting Indians and got to Plattsburg at time of the battle. We came here a long time before Gershom Densmore came. He did not come right after the battle of Plattsburg. I was married in $\mathbf{1} 827$, and I had two children when Gershom came. My second child was born in I830. I know she was born before he came. She was born in February and he came next fall. He and his wife came in the fall of 1830 , they came to our house and stayed. There was a little snow on the ground. He left Hague in the fall of $\mathbf{I} 842$, if I remember right. One of my girls was born in June, I 842. He was here then and went away the next fall. There was Leonard, Francis, Enoch and Gershom Densmore, sons of Leonard. Leonard came first and was here when we came. His brother Gershom came next; then their father, an old gentleman past labor. I think Leonard had been here five or six years when we came in $\mathbf{I}_{15}$. Gershom and Leonard Densmore were sons of my husband's mother. His father married her at Winchester, or Hinsdale, N. H., about 30 miles from Bellows Falls.

"I knew the Risings. Horace lived at Ti; made and peddled wooden ware. Rufus lived with him at one time. It was after I was married. My husband at one time cut timber for them; it was in the winter of 1836. The Risings had a farm at the time in Hague. Horace Rising died not more than a year after they got the timber. Rufus moved back on the farm. They might have been manufacturing the bowls some years before that; I think they were. Rufus, Jr., was about two years old when I was married; he was their oldest child."

After this interview with Mrs. Hoyt Johnson we looked up her husband, who was in a field below the house digging potatoes. $\mathrm{He}$ was born in $\mathrm{x} 806$. He said :

"My brother owned that mare. Rufus Rising went over the Green Mountains and got the mare. My brother swapped with Rising and got her. He traded with Warner Cook and afterwards Holcomb got her. Rising kept her about a year. My brother kept her a year or two and worked her on a team. Warner Cook kept her one, two or three years, perhaps four. IV. H. Cook was Warner's son. He took her down there and kept her about a year, perhaps, and sold her to Holcomb. George Johnson lived in Hague, where Sam Akerman lives, when he sold the mare to Cook for $\$ 65$. She was a small, low, thickbuilt mare, and good to work. She had good full mane and tail; was iron gray when I first knew her. She was a handsome mare, handsome made, handsome as a log, round all over; good roadster; long hips; square behind; smooth, handsome limbs; not very long neck. Never heard anybody say what her blood was.

"I don't know the town where Rising went. He said he got her at the Green Mountains. He went with his wife to visit his or her relatives. Soon after he got home I said to him: 'You have got a new mare; where did you get her?' He said, 'I got her over to the Green Mountains.'

"My brother came here to live with me before he was married. I 
think I had two children when he was married; should say it was in 1830 . He did not get this mare till some four or five years after he married. When he bought I think she was seven or eight years old.

"Gershom Densmore never owned the mare. He was my uncle and I knew all about him. He lived right here. He never had anything to do with the mare; no Densmore ever did.

"I knew when my brother George traded for the mare. Rising had her only a short time. I knew when George sold her to Warner Cook. I knew when Wm. H. Cook had her, and knew about the time he sold her to Whit. Holcomb. She kept growing white; she never was the darkest iron-gray. George Johnson lumbered with her. Kind true critter as ever was harnessed. Never anybody to own that mare but Rising, Johnson, Cook and Holcomb."

Here followed a long examination for the purpose of fixing dates, which resulted in our returning to the house for the ber efit of Mrs. Johnson's better recollection. Hoyt Johnson and wife said :

"George Johnson lived where Sam Akerman now does when their boy Perry was born. Their children were as follows :

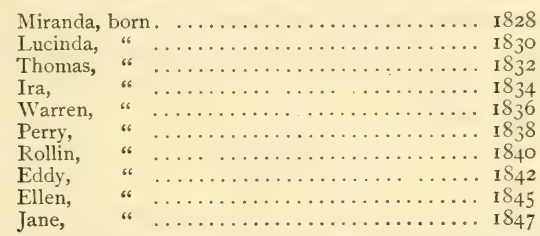

"George Johnson sold the mare to Mr. Cook when he lived on Sam Akerman's place, 1838 . He did not live there more than two years, probably not more than one."

Our next interview was with Mr. Samuel Akerman, whom we met upon the road. He said :

"I hired a gray mare of George Johnson in I84I to go to a ball at Lockwood's, two miles below Schroon. She was a dark iron-gray mare, about 15 hands high, slim built, high-headed, high-strung, a good trotter, then four to six years old. I think he called her worth $\$$ I 50 or more. She was a splendid beast. He used this mare in the woods drawing logs."

At Ti. we stopped again at T. E. Bailey's hotel. Mr. Arthur was still away; but after supper, we saw John A. Pinchin. Mr. Pinchin is 60 years old, a blacksmith and an intelligent man. He said :

"I first knew the dam of Ethan when C. H. Cook owned her. She was not more than seven years old when he got her. I shod her from time to time. When I first knew her she was rather light gray, some dapple. I saw her before Cook had her, Johnson had her before Cook. Rising had her before him ; old Rufus Rising. He used to drive her in a team. Rising, Johnson and Cook all lumbered with her. I have driven her single. She was a fair single driver, but lame. She had two bad bog spavins. Holcomb got her of George Weed, who got her of W. H. Cook for $\$ 50$, paid in boating. J. W. Holcomb got her of Weed; traded a bay horse for her. I should think she was pretty near 30 when she 
died. She brought four colts for Cook. She was a small mare, about 950 lbs.; good clean head and nice square frame; a low mare, say 15 hands; round and plump; good mane and tail; small head. She had a clean neck, pretty long for a mare of her size ; good big shoulder ; broad breast; good stifle; not very high-headed when I knew her, but had good life; looked like a Morgan mare. I think she had but one colt after I drove her ; beleive she was in foal then. She had a good set of limbs and feet. She was spavined by hard drawing. I saw her when not more than five or six years old. Cook bred her to what they called the Burge Horse. He was by Hill's Sir Charles. She had four colts I knew of before Weed got her and she had five colts while Holcomb had her-

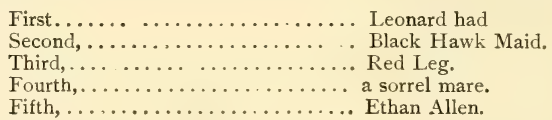

"I think she missed one year. She was bred to Black Hawk the year the sorrel mare was got ; not catching, was bred to Wicker's Sir Walter."

At this point Mr. George Weed came and said :

"I owned the mare six months or a year. I bought of W. H. Cook, and traded her to Joel Holcomb for an old horse good for nothing. I gave the horse away."

Mr. Pinchin-"They traded 40 years ago last fall. It was the fall I was married."

MR. WEED- "She was white when I got her. She was what I called an old mare."

Mr. Pinchin thinks that Mr. Cook worked her three or four years before he put her to breeding. Mr. Pinchin's father was a blacksmith and he himself was always around the shop.

To the direct question on a subsequent interview, whether he remem. bered this mare in the hands of George Johnson, Mr. Pinchin wasn't sure that he did. Mr. Pinchin bred Young Ethan, bay, I 5 hands, Iooo lbs., foaled in 1854 , by Ethan Allen; dam, the dam of Ticonderoga [by the Coburn Horse, son of Col. Doolittle's Post Boy]. This dam was a square, blocky black mare, weighing about I050 lbs.; a fine roadster that never saw a hill. She was foaled about I834. Mr. Pinchin also bred Ti Boy, by Black Hawk, from the same dam. Ti Boy was kept at Ti three or four years; owned by Hammill \& Wicker. He was also one year at Baltimore.

Mr. Pinchin gives the list of foals of dam of Ticonderoga-

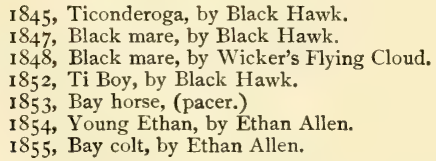

The Densmores of Hague! We have referred to their history, an une- 
ventful one, because we were told that the dam of the old gray mare was brought to Hague by Gershom Densmore as early as 1823. But it has become sufficiently evident that the Densmores had nothing to do with the old gray mare. Gershom Densmore certainly never brought her or her dam into Hague in $\mathbf{r} 823$.

The next morning we interviewed Ben. Delano of Ti., 81 years old, who said :

"I had the Burge Horse by Hill's Sir Charles; dam came from Vermont; I got her of a man by the name of Chillson of Ti., quite a horseman, formerly of Vermont. The Burge Horse was foalded some 45 or more years ago. I sold him to Bly at four years old, and he to Burge. Burge lived and died at Shoreham. Ethan's dam was a low, smallish mare; nothing extraordinary about her; not very chunked, small mare. She used to run in the street here when Ethan was a colt. I knew him until he was two years old. I raised another stallion after the Burge Horse-Burge's Emperor of Long Island. He was a powerful horse, a trotter and the greatest walker I ever knew. I sold him to a drover of Putnam county, N. Y. I have a son 48 years old; don't know as he was born when the Burge horse was bred; know the horse was bred after my marriage in $\mathrm{r} 833$. Dam of the Burge Horse was a large black mare, thick-set, not very tall; pretty good long neck, smooth limbs."

We called upon Mrs. Sally A. Holcomb, widow of Joel W. Holcomb, a very pleasant old lady, now living at a very pleasant home in $\mathrm{Ti}$., who said :

"I think Ethan Allen was foaled in June. The mare had four or five nice colts. My husband got her of Mr. Cook in Hague; never heard Mr. Holcomb say what her blood was. She was a white mare, not considered worth much. He paid only $\$ 25$ for her, I think. She was some lame; not a large mare; should not say she was a very stout mare. Ethan was a Black Hawk. He was got by Black Hawk. He was very tame and gentle. You couldn't get him by the window but that he would put his head in to get a piece of cake."

John Holcomb, brother of Joel W. Holcomb, said :

"Warner Cook bought an old white mare from a man by the name of Rising, who got her over the Green Mountains, in foal when she came here. That was the report. She was smarter than lightning. When Cook got her I think she had a breach on the neck; think she was hipped. Saw her when Cook used to drive her to town. Ethan Allen was then running about the road; I think he was a spring colt.

"Fanny Cook (by Abdallah and dam of Daniel Lambert), was chestnut; looked like a colt at 20 ; I $51 / 2$ hands; narrow withers; short back; good limbs, never better; reck and head couldn't be beat. She had a big head. I thought it was homely, but they said it was the best head in the world. I bought her, when 20 , of W. H. Cook, and sold her to Baldwin. Baldwin bred her to Tom Jefferson when he was at Middlebury, and afterwards sold her to Smith, the owner of Jefferson. She had rather long slim neck, straight, not crowning. My brother got the dam of Ethan of Cook. He got her of Rufus Rising. Rising got her over the Green Mountains. That was the report when she was young."

We met the Rev. Joseph Cook in his carriage near the depot at Ti. 
He was very courteous in trying to assist us, and, in speaking of the mare, said :

"She had long hip, fine limbs, rather long neck and was very graceful. I do not remember when my father got her. He had her at first of my memory in 1842 . She was neither slim nor stont; she was very docile and intelligent; rather nervous. She had the graceful shape of a highblooded horse ; she had the look of an aristocrat."

Justus B. Rising of Ti. son of Horace Rising, and a very fair, candid and careful witness, said :

"Uncle Rufus Rising owned the mare. I knew her when Rufus Rising owned her. He worked her on a farm; can't say as anywhere else. I don't think Uncle Rufus sold her to Holcomb. I think he sold her to George Johnson; Johnson sold her to Warner Cook, Valorus Cook's father. I think she went from Warner Cook to his son, W. H. Cook. I knew her when the Cooks owned her; I know I saw her when Uncle Rufus owned her. That was fifty years ago. I am 65 years old. I was $\mathbf{r} 4$ years old or so. I remember well enough. I drew logs when I was I4 years old with a pair of steers. She was a gray mare when I first knew her, common gray. She was not a big mare; probably in good condition rooo lbs. She was a regular jumper; could't keep her anywhere. She was a good-bodied mare; chunked kind of-that is, there was a good deal of her; about medium height; good head and neck; a good traveler. Never knew of her being fast, but active. She had a good mane and tail ; long tail, nearly down to the ground. When my uncle had her she could not have been more than nine or ten years old. Don't know as she was that. Don't know whether he raised her or not, but think that he had her three years or more. My father used to manufacture wooden bowls. A man by the name of Wallace and another by the name of Curtis used to peddle for him. I am quite sure Uncle Rufus never drove the cart ; couldn't say whether father ever drove it; don't think this mare was ever worked on the cart. My father never went unless in winter on a sleigh. They ran his cart when I was a boy. My father died in 1837 . The cart was never seen after that. They had a shop here at ' $\mathrm{Ti}$. I think the cart was seen pretty near up to the time of my father's death. My father used to have up to his death a sorrel team. I had it after him. This sorrel team was on the cart the last two or three years of his life. They used to run off into Vermont; they went all around. They went off towards the Green Mountains; can't say whether over the mountains or not. I think Curtis peddled for my father about $1830:$ he is dead. There were others that peddled; came along. My father was from Suffield, Ct. ; had relatives in Vermont-the Doanes of Benson ; old Uucle Rubin Doane was cousin to my father. We used to go to visit them. There were two brothers and they had sons about my father's age; George, Calvin, Schuyler, etc. They were farmers in Benson and Shoreham. I think there was also a family in Rupert. Rufus used to go to Doane's frequently. I don't think he went to see other friends in Vermont. He had no other relatives there. My uncle, Rufus, had two grays; one, I think, was a horse; don't know as he had the gray horse until after my father died."

We interviewed Mr. William G. Baldwin, who married Justus Rising's sister. He said : 
"The first I knew of the old white mare Warner Cook used to come out here with her and trot her. I have heard Rufus Rising, after his brother Horace's death, say that the mare was got in Vermont by one of them on a peddler's trip. (In a letter written some years ago to Allen W. Thomson, Woodstock, Vt., and now held by him, Mr. Laldwin states that "It is not known where the mare came from, but that Rumor has it that Mr. Rising got her in Vermont on a peddler's trip," etc.) (ieorge Clark's wife will know when her father, Warner Cook, had the mare of Johnson. Gershom Densmore had a stallion, a big, brown horse, with white feet, called Lion; he had him a number of years; good horse; don't know but Chas. Hanes bought him and perhaps had an interest in him. I am 63 years of age; must have been of age when he had this stallion. George Howe's wife of Ti. was George Johnson's daughter. Benjamin H. Baldwin, my brother, and Byron Woodward looked up the matter and gave Wallace his information.

"Black Murat, son of Black Hawk, was bred by Charles Wicker of Ti. about rooo lbs.; dark brown.

"Black Hawk Telegraph was a black horse with satin coat, bred by me; dam by Wicker's Sir Walter; second dam by Burge Horse. He was very good size when three years old, when he was sold to Denny and Long of Maine. He was burnt at Boston when seven or eight years old. He was the sire of Stride-a-way. Wicker's Sir Walter was by the running horse Sir Walter.

"Patrick Henry was a black horse, I 5 hands, I025 lbs., bred by me; by Black Hawk; dam (also the dam of Col. Moulton;) by Bigelow Horse, son of Black Hawk; $2 \mathrm{~d}$ dam a big chestnut mare said to be by Magnum Bonum. I showed him at the National Horse Show at Springfield, when he took first premium as a three-year-old, $\$ 100$; sold at five or six years old for $\$ 5500$ to Robert Morgan of Halls, Troy Roads, Aberdeen, Maryland. His son Thomas Morgan of same place has a stallion son of Patrick Henry.

"Bigelow's Black Hawk, a black horse, I5 hands, Iooo lbs., and very stylish, was bred by Clark Bros. of Saratoga, who sent the dam a fast mare, to David Hill's, who thought she was not in foal and by their request sold her to one Pratt of Bridport for $\$ 75$. She proved in foal to Black Hawk and Pratt sold the colt to Bigelow of Bridport, who sold to Abraham Wadhams and John Merriam of Wadhams' Mills, N. Y. He was called Wadhams' Black Hawk and was killed on the cars going West."

The Wraith of the old Gray Mare! On every side we see it flitting; it started with us in the mare we drove; it has met us continually on our way ; yon little colt, whose step is so light and whose form is so perfect, comes from the old gray mare; again and again have those colts crossed our path, every one with that faultless form and action is a Wraith of the old gray mare ; you cannot mistake them; there are no others in the world like them; strength, elegance and beauty combined; and swift as the winds that sport among their native hills. This country where she toiled is filled now with her descendants; some are toiling likewise, some are grazing in the fields, many are fitting for the race-course, more are masters of the road; but whichever way we turn, wherever we go, appears the Wraith of the old gray mare. 
Charles G. Wicker, one of the influential farmers and intelligent breeders of Ti., gave us pedigree of Flying Cloud, black horse, one white fore foot, $15 \frac{1}{2}$ hands, by Black Hawk, dam the Ketchum mare by Magnam Bonum.

"My father, Charles Wicker, bought the dam of Oliver Beckwith, Orwell; she was a black mare, 16 hands and very powerful. Flying Cloud was sold when four or five years old, for \$I 200 to Schuyler Doane and Charles Hunsden, Shoreham, Vt., and they sold him to go to Ohio. He was a splendid horse, and a trotter. He could beat Sherman Black Hawk."

Gustavus Wicker, brother of Charles, a substantial farmer and breeder, said :

"The dam of Ethan was quite a trotter. The Risings got her over amongst the Green Mountains. I think Zeno Rising got her there. I had a little French mare that could trot in three minutes. I could just beat old Warner Cook with his mare. After Cook got her she got a spavin. I rode my mare against Warner Cook's coming home from camp-meeting. I bought my mare not over two years after I came here. I am now 69 years old : came from Orwell in 1835 ; owned this mare about three years; this race was about $\mathbf{r} 839$. William $\mathrm{H}$. Cook got her the same fall. I think Wm. H. Cook raised three colts from her; he raised a bay horse, a bay mare and a gray one, I guess he raised four or five. Holcomb raised four from her. When I trotted with her she had never had a colt. I don't think Warner Cook had had her more than two or three months. Warner Cook told me he got her of Rising -Zeno Rising, I think. Zeno Rising told me he got her over the Green Mountains. This was before Ethan was bred. He said over the mountains."

Mr. Wicker says the man who bred Black Warrior, owned by Geo. Adams, lived at Whitehall, and refers to Byron Woodard. The dam of the Felton Horse (Ticonderoga) was by the Coburn Horse of Crown Point. "I bought this dam when Felton Horse was three or four years old; she was I I years old, foaled in $\mathrm{I}_{3} 8$. She was bred by Benj. Breed of Crown Point and from a mare bought from cver the mountains. She was a black mare, I Ioo pounds, $15 \frac{1}{2}$ hands. The Coburn Horse was brown, 15 hands high, a smart little horse. I was probably $\mathrm{I}_{5}$ or I6 years old when I first saw Coburn ride him and the horse was seven or eight years old at that time-a cordy, smart horse. Whitehall was bred by Otis Hamilton of Fair Haven. He was a son of North American. I do not know his dam. I think he was called American first. The Bullock Horse was a big chestnut horse that came from Canada to Isle La Motte, where my uncle, Benager Wicker, bought him and sold to Bullock of Fair Haven, about I 840 . He was said to be by a Sir Walter horse. A Sir Walter horse was owned by Enoch Smith of Sudbury. I took a mare to him about $\mathrm{I} 833$. He was a nice chestnut horse, about I 5-3; would weigh I roo pounds, and a little finer than the Bullock Horse. The Bullock Horse was I6-I ; long, round barrel and long neck. He was quite a trotter. but Black Hawk could jump by him." 
Azro M. Bailey of 'Ti., a gentleman of 70 years, said :

"George Johnson owned the little gray mare. I worked for Wm. H. Cook in I84I, I think; worked there part of one winter. Warner Cook then owned the mare. Johnson got her, I guess, over the lake. Afterwards she fell into the hands of W. H. Cook. 'The old gentleman got involved in debt, and his property went into his son's hands in $\mathbf{1} 842$ or 43. When I was there in I 84 I she had three bay colts-I guess it was before I went there-all from the Burge Horse, bred by Mr. Delano, and a son of Sir Charles. I think she had four colts while the Cooks had her-I think three by the Sir Charles horse. Mr. Wm. H. Cook sold the first one to a man from the East. The next was a mare; she got hurt and they kept her to raise colts. The third one was sold to Abijah Nickinson; he sold to Frank Felton, who got $\$ 490$ for her. These were all the colts she had before Holcomb got her. I think now the first one was foaled in I 840 . She bred three years in succession. I was near neighbor and knew them well. The first colt was raised on the upper place and then W. H. Cook got the present Joseph Cook place and took the mare and colt down there. Warner Cook certainly owned the mare in the winter of 1839 , when Burchard preached here; and perhaps in 1838 . W. H. and Valerous Cook divided the property and the mare and colt went to W. H. I can remember the time the mare came into Warner Cook's hands, but can't fix the date. I think it was in the winter. She was a youngish mare when he got her, four or five years old, and pretty white. He drew logs with her and I think she got a spavin and they put her to breeding. I think she was not more than five or six years old when Cook got her; do not think I can be mistaken ; do not think she was more than I9 or 20 when she died. It was all nonsense letting her die. I think she came from the other side of the lake. I have had that idea some time. Wm. H. Cook always said this mare came from over the mountain. She was not very large; would weigh 950 in good flesh; pretty long body, pretty long slim neck, carried her head up well. She was a screamer on the road. I once drove her to Weybridge by side of a chestnut mare. I never drove a better team ; think this was in 1842 . She was sound; think she had had one colt. She was full 15 hands, perhaps $15 \frac{1}{4}$; pretty good chest; pretty broad; shoulder good; hind leg rather crooked; you would call her a little leggy. She had a very good back; long hip; rather of a coarse neck, dropped forward of her withers, but she could get her head up with any of them; legs rather fine, not heavy. She had a splendid ear, slim, thin, pretty good length; stuck them right up; a handsome mane and tail, good length but not what you would call heavy or bushy; long, slim head, wide between the eyes, not a Roman nose-a mare-faced head a little inclined to be dishing ; first-rate eye : stuck out big as your fist-large, bold-looking eye; a mare of great intelligence; you would say she had got some brains. She was as fine a roader as you ever sat behind-ambitious, full of vim, all day long. She was worth $\$ 25$ in those days. I know she was called a young mare when Cook got her. I think they called her six years old; she could not have been over seven. Alvah Bennett, before Cook got this mare, had a dapple gray horse, very fine looking, large, came from the West. They said he was a full-blood Messenger. Ethan was built some like his dam; he had a long body and not large legs. The first colt out of his dam would weigh I I 50 ; long body, built a good deal like the mare only larger. The first three colts were all bays; every one could trot." 
Mrs. Frinda Ham, wife of George Ham of Ti., is a daughter of George Johnson. She was born in June, 1839 , and remembers a gray that her father had; thinks he did not have it when he died, in March, I849; thinks it was rather a light gray, dappled, a young, pretty mare. George Johnson had four children, viz :

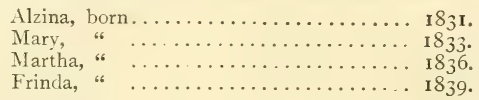

All are dead except Frinda, Mrs. Ham. Geo. Johnson has a sister living at Fort Edward, N. Y. (A letter from her states that she has no recollection whatever about his horse). Mrs. Ham further says: "My father died in Hague on a farm about two miles from the lake. I was born on the Sam Ackerman place; have often been shown the house as my birth-place."

This was the morning of Sept. 30, a very beautiful day, and as there was a fair in progress at Crown Point, we drove to that place, some nine miles distant. On our way we had further talk with Gustavus Wicker, who said :

"Zeno and Joel Rising had the mare. Rufus was older. Zeno's oldest living child is Joel, now of Chestertown, N. Y. The mare was white when IVarner Cook got her; must hare been as much as eight or ten years old. He got a spavin on her. Frank Farrington of Brandon bred the dam of Flying Cloud."

Further on we called on Mr. Alvah K. Bennett, to whom we had been referred. He thought dam of Ethan was raised by a man named Richmond, who lived on Chilson Hill in Ticonderoga ; remembered when old Mr. Richmond worked such a mare before a yoke of oxen; but as he had no idea how Mr. Holcomb got the mare and the testimony was conclusive that the Warner Cook mare was the dam of Ethan, we concluded that Mr. Bennett remembered some other mare. The ride to Crown Point was diversified by much fine scenery, especially that of the lake and the mountains in Vermont. Crown Point is a neat village, though not so large as Ti. It lies very handsomely on a plateau a little way from the lake.

We called upon Mr. Benj. Breed, who lives in the village. He bred the black stallion, Ticonderoga, which has always been spoken of as the handsomest of Black Hawk's get. He sold this horse to D. Myrick, who sold him to Felton. (He is often spoken of as the Felton Horse.) Mr. Breed sold him when coming two at $\$ 200$. Mr. Myrick sold him the fall after for \$I Ioo. The dam was a black mare, sold afterwards to C. G. Wicker, bred by Allen Breed, Jr., got by a horse bred by Allen Breed (informant's father), and sold by him to Mr. Coburn of Crown Point, and known as the Coburn Horse or old Pomp. The second dam of Ticonderoga was bought by Mr. Breed in Vermont and was said to be a Morgan. The Coburn Horse was foaled at least fifty-five years 
ago. He does not remember its sire, but thinks that his brother Foster, fourteen years older than himself, will. He also bred Crown Point, a black stallion, 15-3, I000 lbs., foaled I 845 ; sire Black Hawk; dam from Vermont; and sold him when twelve or thirteen years old to Mr. Jenks of St. Clair, Mich., for \$10oo. He died two or three years afterwards. The Taft Horse was a bay stallion, strip in face, and some white feet, I 6 hands, I roo lbs. Juba Howe of Crown Point raised and sold three stallions from old Black Hawk.

The fair grounds were a mile north of Crown Point village, in a most out-of-the-way-place. As but few people were expected the ordinary price of admission was doubled. There was very little to see by way of show except several people driving around where there had once been a race track. But we met a number of very genial gentlemen, among them, Gen. John Hammond of Crown Point. Gen. Hammond referred to Engineer, a beautiful dark chestnut, at least I 6 hands, that stood for some time in Schroon. See Engineer (Burdick's).

Mr. Byron Murray of Addison had a stallion called Sir John that was got by Cock of the Rock.

Mr. Wyman of Crown Point says that a horse called Old Diomed was owned in Schroon forty years ago and that he was then thirty-two years old. He thinks that Mr. Weatherhead brought Engineer to Schroon fifty-five years ago.

On our return we called on Mr. Foster Breed. The old gentleman, now eighty, was confined to his bed, but showed much enthusiasm in speaking of old times. He remembered well the stallion colt that his father raised and sold to Mr. Coburn, known afterwards as the Coburn Horse : says that this colt was got by Post Boy; that he himself took the mare to the horse while he was kept at Bridport village about I825. The dam was a bay mare, about 900 to Iooo lbs.; he did not know her blood. The Breed Horse, by Black Hawk, was bred and owned until sixteen years old by him, and was also from a dam by Post Boy. From this horse Mr. Breed raised quite a number of stallions which he sold. One went to Westport, N. Y. ; one to Watertown, N. Y., and one to New Jersey. These were all black. The one that went to Westport was sold to a Mr. Polhemus; this one would weigh I roo lbs.

We were glad to learn the true breeding of the dam of Ticonderogashe being one of the many dams of Black Hawk stallions recorded in Wallace as by young Hamiltonian. Instead of a Hamiltonian, there is a strain of Diomed, which appears to be a strain of great elegance as well as of staying power and of speed; and almost certainly another of Morgan.

It was dark when we returned to Ti. After tea we saw Mr. Wm. Arthur. Of his own accord he said:

"My brother gave you the name of Gershom Densmore as the man who brought into Hague the dam of Ethan Allen. He should have 
said Bevens. He said Densmore, but it was Bevens." In a moment our story was on its feet again. Mr. Arthur's story, as retold, was: "Warner Cook bought the mare of Abel Rising. He bought Abel out for \$rooo-all his stuff. I think Rising got her of $1 \mathrm{Wm}$. Bevens. I got the information of Bevens. He said he got the dam where he came from in Massachusetts. This mare was bred in Hague unless Bevens lied about it; and I don't think he did. I had heard that he had bred the mare, and I asked him, and he said he did. Rising did not get $\$$ rooo without trouble. Warner Cook failed and William $\mathrm{H}$. took judgment against him, from which Rising offered to redeem the property and made a tender for that purpose; but the Cooks settled with him rather than let him have the property."

"William H. Cook had Ethan's dam when I first knew her. Holcomb once offered to give her to me if I would let him have the colt. She was then in foal with Red Leg. I would not take her.

"My brother had a little French mare with colt by her side. Holcomb's gray mare also had a colt by Sir Walter. I bought the French mare of my brother. Mr. Hyde, Mrs. Holcomb's brother, took both mares to Black Hawk. I saw them there; they were together. I went and got my mare and left the gray mare there, and she staid there, in the pasture on the James Fletcher place, till fall.

"Holcomb showed me the letter he wrote in the bar-room. I told him he was a great fool to do it, but he said he was going to send it."

Interview with Mrs. Wm. H. Cook:

"We did not raise that mare. We kept her some time. She came from Massachusetts. MIr. Johnson, I belive, up here brought her here. My husband's father got her of Mr. Johnson-I think that was the name. It was somebody in Hague. I first saw her between $\mathrm{I} \delta_{+1} \mathrm{I}$ and $\mathrm{I} \delta_{45}$. We owned her. When Warner Cook had her they used her in a team. I used to drive her myself. Should think her ten or twelve years old. I know she was not raised in Hague by hearing them talk. I have heard my husband talking with others, that Johnson went away and swapped horses and brought this mare back. A man that was here ten years ago inquired her up talking with my husband. My husband let him have a team to go to Hague. She was a spirited horse. We did not own her more than three years. She was hipped, [spavined] I think that is what they call it. When my husband took hold of his father's business that mare was there; I think she had a colt. William H. sold this place and went up to his father's and staid there three years; then he took this farm back. When we came back we brought two nice bay colts, two and three years old, from this mare. We were married in $\mathrm{r} \delta_{37}$; went up three years later-I 840 or ' $4 \mathrm{I}$; staid there three years. The mare was sold before we came back. I am not sure but it was Rising, instead of Johnson, that brought the mare. I think my husband talked with Hoyt Johnson; guess that he got his information of him. That would be about as near as you could get. I can't say sure whether they said she came from Vermont or Massachusetts. She was a very spirited horse. She was afraid of a buffalo. She could trot a good deal faster than I wanted to ride. Warner might have had her two or three years before we went there. My husband sold her to George Weed. I remember now ; know that Warner got her after we were married; that was Jan. 3, I837. He might have got her the next fall. When we were there Warner Cook's affairs were mixed up with Abel Rising's. He had a mortgage or some- 
thing. I know it was paid in gold. I don't think this mare came with the Rising property. I think Warner bought her. I think we had heard the stories about her coming from Vermont or Massachusetts before the man came to make inquiries. I should say that the original story was that she came from Massachusetts. I never heard that it was the dam that came. Don't remember it was ever spoken of when they owned the mare what her blood was."

From Mrs. Cook's we drove direct again to Hoyt Johnson's who said :

" My brother George bid off at Boston a spavined stallion for \$I5. He was gray; think he may have been spotted; a kind horse, about $\mathrm{r}_{5-3}$; thick built. He kept him a year or so; traded him off. It was after he was married. Never knew him to use him for mares, but he might. Knew Zeno Rising. He married a Balcom; had four or five children; she died, and he married my cousin. Cook told me some men over the lake wanted the pedigree."

Mrs. Hoyt Johnson testified that she remembered George Johnson selling a mare (remember that she was dark gray), to Mr. Warner Cook; and Mr. Cook used to ride by on her. He was very heavy. She had one child, born same year, and George Johnson one; doesn't think Mr. Johnson kept the mare a great while after he got her of Mr. Rising. It was when Perry was a child. (Consulting record she said he was born Aug. 26, I838.) That was the summer he sold this mare to Mr. Cook. She knew because she lived right close to them, farms adjoining; houses stood a little way apart. That was the only year George Johnson lived in that house. The next spring he bought a place in south part of town, where he lived till he died. Heard it talked of at the time that he got her of Mr. Rufus Rising; knew the year and the circumstances; knew that Mr. Cook rode her up by. Her impression is that this mare was quite dark with some gray hairs. Seemed as if Mr. Rising had some gray horses; seemed as if Mr. G. Johnson had a stallion; had two horses that were spotted; took them to Boston after he bought this horse of Mr. Rísing. Thinks Mr. Zeno Rising was married next spring after she herself was (I828.) Her father came to Hague when she was five years old [ $\left.\mathrm{I}_{\mathrm{S}} \mathrm{I}_{5}\right]$; didn't bring any horse. Alvah, her brother, got a number of horses over in Vermont. He got a very large bay of a man by the name of Hand. Did not breed this gray mare; never knew him to raise a colt.

"My father went over to Vermont once and swapped horses; he brought back a bay mare; white stripe in forehead. He raised two or three colts from her; one was a gray; yes, a mare; [to question] think that Alvah Bevins had her. It was when I was about ten years old that my father brought back this mare. It was on one of his peddling trips. He was a cooper and in winter used to take his horse c.nd drive over into Vermont and sell his measures, etc; also carried wooden ware at the same time for Horace Rising. He did not go peddling after I was ten. He kept house when I married, in I827, and had this mare there three or four years, and raised two colts 
certain. She had a colt one night; my little brother, six or seven years old, went out to see it. The mare caught him by the shirt bosom and threw him over her back. One of these colts was a gray mare; think she had a colt the spring after he bought her. He bought her-that is, traded for her-in winter; think it was the gray colt she had next spring. My father used to go to Shoreham, Orwell and around there ; did not go very far."

Again we came out by Rufus Rising's, passed the school house and ascended the hill to Sam Ackerman's, where everything was so pleasant that we stopped for dinner.

The weather remained very perfect, presenting a view of the valleys now adorned with their brilliant foliage. Upon the hillsides in the hazy atmosphere the meadows seemed to sleep. An infinite quiet spreads over these vast mountains, vast in extent and bulk if not height, and extends through their valleys. 'Tis rare we strike a pleasanter spot or find a better home.

Mr. Ackerman said:

"I was born March, I822. I went to live with Alvah Bevins when I was nine or ten years old--before he was married. I lived with him until I was I 8, and knew him well after. His first team was a little bay mare and a big bay horse; then, two or three years after, he had a bay and a gray. I have seen Zeno Rising drive a gray mare. $\mathrm{He}$ had a number of gray horses."

Rufus Rising, again interviewed, said :

"Andrew and Joseph Bevins first came. Hoyt Johnson married a daughter of Andrew. She had brothers-Ira, Clark, Alvah, Frank. Ira died here in town. One sister married a Reed; one is living at Bellows Falls, married to a Warner; her name was Sarah. Clark went West; so did Alvah. They went to Illinois. Alvah died; think Clark died, too. Alvah went away from here 25 years ago, I should think. Alvah did business here as a very young man. He lived where Mr. Burgis, the merchant, lives now."

Mrs. Stephen Balcom, who was stopping at next house from Mr. Ackerman's, said :

"My maiden name was Salome Doolittle. I shall be 83 years old tomorrow. I was married 58 years ago. I was married before Zeno Rising was. I think Zeno had a span of white horses, more gray than white. I knew Alvah Bevins; don't remember that he kept much of a team. Zeno had a pair of grays after he got married. $\mathrm{He}$ and Joel were together and they had this gray pair; pretty good size. Rufus Rising peddled wooden dishes. I moved here with the Bevins from Windsor, Vt. They did not keep horses when they came here; don't remember how it was afterwards."

From Mr. Ackerman's we drove to Hague, and ascended a mountain back of the village, from which were extensive views of Lake George with its pure crystal water, and mountains that seemed nearly as plenty as in the vast region of California and Mexico. We passed a second night at Hague; the next morning hired a bay horse, a great-grand-son of 
the gray mare, of the landlord, to drive with Empress, and left for Chester, about 23 miles across the hills.

We made the route again around by Hoyt Johnson's, interviewing a Mr. Clark on the road, who, we were told, was authority on pedigrees. Mr. Clark said : "Warner Cook got this mare of George Johnson. She came from Ludlow, Vt., I think, and Johnson brought her from there."

Mrs. Rebecca Johnson, Oct. 2, said :

"I don't think my father passed the Green Mountains when he peddled. He had a brother that lived in Reading, but he did not go there while he was peddling. I was born Jan., I8II; my brother Franklin, Oct., I8I3. When he got tossed by the mare, he was a little fellow. My father bought roo acres of Ackerman's father and lived on that place till he was past laboring. It is about a mile towards the lake from Sam Ackerman's. He came up and bought the farm and worked on it a year, then went back and got his family. Think old Mr. Ackerman's name was James; not sure. Father did not peddle the first year after he moved here. He began the second winter with a small gray mare, they called a Dutch horse. He used her till he swapped for the bay mare. I know he traded in Vermont in the winter; guess they swapped even.

"I couldn't tell what they did with that gray colt. I recollect the colt. It wasn't gray when born, but I am very sure became so. It wasn't so very light nor so very dark gray, middling. They must have kept it till it got to be quite a colt, don't know how old. The boys were lumbering; they kept one horse for father, to team around as he was a mind to. The boys would trade horses and had different ones. My oldest brother, Clark, was born in $\mathbf{I} 800$; owned the farm next east of Sam Ackerman's, where my father died. He lived there 25 or 30 years. $\mathrm{He}$ had two children before I was married; I was married June, r 827.

"Next brother, Ira; there was one between him and Clark that died. Ira was probably about four years younger than Clark. Next brother was Frank, two years younger than I; then Alvah, about two years younger than Frank. That is all the boys. I had two sisters; oldest child, a sister, long dead; one sister living near Bellows Falls. Franklin is alive; his address is Le Mars, Plymouth Co., Iowa.

"The mare, father got in Vermont was a bay mare, round bodied, not very large, rather long-bodied; star or strip, not on the nose but below the eyes a little, I think. About common size. I used to ride her horseback.

"I don't think father peddled any after I was io years old. $\mathrm{He}$ did not peddle for some time before my youngest sister was born. She was not born for quite a while after he got through peddling. I don't think he peddled more than two, three or four years. He came in spring of $\mathrm{I}_{\mathrm{1}} \mathrm{5}$, and worked during the summer, and in fall of the same year he moved his family here. He did not peddle that winter, but did the next, and two or three years more; think not over. I think it was three, but not positive. I know before my sister was born there had been some years that he had not peddled. It must have been the last year or last but one that he peddled that he swapped horses, and got this mare. He would go and be gone a week or ten days and sometimes go twice in the same winter. I don't recollect of his ever going out with the bay mare after he brought her home ; that would show it was the last year. If he had he would have gone with her. 
"The one he got was the best traveler; the old one was chunky and logy; the new one was more spry. The bay mare's name was Nell. I think he got her of some one he knew, who told her name. He may have got her of Judge Hand of Shoreham, I don't know. Clark married first and left first. They would go driving; then they got married. I don't think Clark took this bay mare. Don't think the bay mare was alive when Sam Ackerman went to live with Alvah Bevins.

"Father peddled with one horse; he was not a very tall man; short, chunked man rather, blue eyes and light hair; wore side whiskers. Was very pleasant."

We now drove around again by Sam Ackerman's, entered the lot east of his house by a newish road that came before long to the old road across one of these large mountains, to Horicon. There were some woods at the top of this.mountain, and a short distance that had not been lumbered, but the lumbering in this part of the country is mostly finished. We went by a small pond on the mountain, then descended to a glen that widened to a valley where was quite a large lake, and beyond this the primitive village of Horicon. Here we found Benager Ackerman, brother of Sam Ackerman, who said :

"I am 78 years old. I knew Andrew Bevins. He bought my father's farm the spring before the cold summer. I think I was nine years old. I guess Bevins did not bring his family when he first came. He farmed it and coopered a little. He carried his wares around and peddled. Don't recollect his horses. We lived about two miles from Bevins.

"Always knew Zeno Rising. Bevins used to carry Horace Rising's bowls around with his pails and measures. Horace Rising manufactured wooden bowls as far back as I can remember. Before we sold out to Bevins we had some of Rising's wooden ware. It seems as though Bevins drove a white or gray horse ; couldn't tell how big it was. Think he did not drive any other because his oldest son went right into farming and had a team of his own. They all lived there together. Think Clark Bevins had first a pair of small browns. Don't remember Clark Bevins having any gray. It kind of seems to me they had a gray colt; couldn't say what became of it. I think the old man Bevins had a gray colt, probably raised it. I think it must have been a colt from the gray mare. I think on hearing Mrs. Johnson's statement that it is correct. I should think Bevins peddled about three years ; might be more ; I think three years.

"Horace was the oldest of the Rising boys; then Rufus, then Abel, then Zeno; Joel, the youngest. Zeno and I were about the same age. Zeno had a span of grays after he was married; must of got them I think three or four years after. One was a mare; don't know where he got them. She was a good-looking, square-built mare, I think about $\mathbf{1} 000$ lbs. Think not over six or seven years old. She used to be driven single and was a good traveler. Couldn't say what he did with her; he got rid of them both at a time. Mare sound as a bullet; did not have hip down.

"Zeno lived, right after he was married, on the hill near the school house by Rufus Rising's.

"I was married in 1830 ; drove this team when my daughter was two years old; that would be 1835 . She was born 1833 . 
"The Risings ran their peddler cart, think likely a dozen years or more. Horace moved his turning works from Hague to Ti. I did not know about their team after that. I don't recollect Abel Rising driving a gray; should think Rufus had some gray horses. Guess he never had one that looked just like this mare of 'Zeno's.

"Think Rufus Rising peddled bowls. Guess Zeno or Joel never did. But Rufe I think peddled considerably, for he went down to Ti. after Horace moved there, and staid a couple of years or so."

It took us but a short time to go from Horicon to Chester, through a level country and where the trickling waters gather that help form the Hudson. Chester is quite a place. Joel Rising, oldest living son of Zeno Rising, keeps the principal hotel here, quite a good three-story one, and though we did not consider that he excelled as a witness, he evidently knows how to keep a hotel.

Mary Balcom, now Mrs. Remington, widow of Joel Rising, senior, said :

"I was born in I823. I remember a pair of grays that Zeno Rising had when I was about I 8 ; a pair of large ones when I was married. Don't believe I can remember any before that. I have heard Zeno tell about the company trying to run by him, on Lake George, when they had a ride or party to Bolton."

Joel W. Rising said :

"There was Curtis Balcom, Caleb Balcom, Stephen Balcom, Rufus Rising, Stephen Starks and others on the ride to Bolton. All had girls with them ; rather think it was after Zeno's marriage."

We stopped at Chester over night at the Rising Hotel. During the night it rained, and at times the next day. Returning, we interviewed Benager Ackerman again. He said :

"I went to Newcomb when I was I 6 and stayed till fall after I was $2 \mathbf{I}$; then worked for a man above Crane Pond, about six miles north of Zeno Rising's, most two years. I was back and forth when I was at Crane Pond ; it was 1828 and I 829 , and perhaps part of $1830 . "$

Myron Balcom, son-in-law of B. Ackerman said :

"I am 56 years old (born I830). I think I heard Rufus Rising owned the dam of Ethan; heard so when Ethan was trotting. I think Rufus Rising had a gray mare. I saw a poor old gray mare he had; should think I was 15 years old."

ACKERMAN- "I think Rufus owned a gray mare about the time I drew the hay ( 1835 ). Seems to me that Rufus Rising owned a gray mare that had a colt later; not very large, not near so good looking a mare as Zeno's; I think a rough-looking beast ; color very much same as Zeno's, lightish gray : wouldn't weigh more than about 900 ; not very fat; not a thick beast like Zeno's. Think pretty middling long slim neck; slim beast; horses in those days used to be pretty chunked. Rufus had one gray or two since then within 30 years. Should think he drove a brown mare or horse with this gray; heavier than the gray; would weigh rooo; more chunked, better order always. Couldn't tell how long he had them. Don't know what became of them or where he got them. Seems as though they came from Ti. when he was peddling wooden dishes; should 
think that was where he got them; should think he had them when I worked on Pond place. Should think he had them then. (Repeated) Kind o' seems as though he had them when I worked for Zeno. Seems as though he had that gray mare when he moved from up this way to where his son now lives. Seems as though he had her then; also the brown one. Think the gray mare of Rufus Rising might have been the gray colt Bevins owned; in age and looks, color about the same; a little lighter when Rufus owned her.

" Shouldn't wonder if Warner Cook had her; don't know. Kind o' seems to me now that I can remember Uncle Warner having that mare of Rufus Rising's ; the more I think he did. Rufus, jr., was quite a boy when his father lived on the Ed. Ackerman place."

BALCOM- "I remember seeing the mare when Rufus moved on to new place ; think after he had a bay team."

ACKERMAN- "I know Rufus drove this gray mare when I was on the Pond place: she must have been five or six years old or more then. He kept her quite a spell."

The old man looked up to me with an expression of intelligence in his eye that carried conviction to my mind of the excellence of his memory. He was as honest as the sun, and habitually cautious in his statements.

Rufus Rising at the third interview said:

"Father lumbered and had a horse team about the time my sister was born; had a team; one of them might have been gray. We had to go 40 rods to water the horses : once I fell off ; two colts jumped over me. Couldn't tell the color of the one I rode. Widow Keziah Hayford, widow of Alvin Hayford, lives at Put's creek, eight miles from Ti. on the Schroon road. She lived right in sight of us when I was nine or ten years old. I think they moved off before my sister was born, in $I_{3} 8$. They might and they might not. We lived at that house two or three years in all."

Samuel ACKerman - "The first pair I knew Rufus Rising to have were bays; before he went from the old place. Then he had a pair with a smallish beast, gray mare, 15 hands, slim neck. He had her quite a number of years. Think he had her when he lived on old place. Wouldn't say whether he had her when he went on to the present Rising place; should rather think he did. Don't know how old she was. I am 64 next March. It strikes me Warner Cook did have such a gray mare. Rufus Rising drove either a dark bay or brown mare or horse with the gray mare. It was large but not very heavy."

Mr. Ackerman we saw upon the road as we were driving to Hague and at the hotel at Hague.

Leaving the Adonis gelding, we went direct to Ti., reaching there after dark.

The following description of the dam of Ethan is from Mr. Wm. Arthur :

"White mare, about I5-I; long slim neck; good length of body ; crooked sickle hind legs; good chest; sharp shoulder; not as high behind as forward. Good pointed mare; prominent big eyes. A plucky mare. Ear right up ; just a fair size, bony, nice-shaped head; no meat on it. Head well up; don't think she would ever weigh more than 95o. Good nice mane and tail ; mane pretty long; good heft of tail. A long-hipped mare; shortish back : long on the belly; good feet. Lame when Holcomb had her, but don't think she was hipped. 
"Frank Pierce was brought to Saratoga by a Frenchman from Canada ; and said to be by an English horse called I'eacock [Petit Coque] and from a French mare. Kept in Ti. in $\times 853-54 . "$

John A. Pinchin- "Nickerson never owned this mare. I knew her when Warner Cook had her; knew her when Wm. H. had her; knew the mare Wm. H. Cook had was the one Warner Cook had and the one afterwards owned by Holcomb, and was the dam of Ethan Allen. George Johnson let old Uncle Warner Cook have her. Couldn't say positively that I saw her in George Johnson's hands, but think I did. It was always said Johnson got her of old Uncle Rufus Rising. They said old Uncle Rising got her over the mountain. Don't think she was a very dark gray. Nickerson bought a colt four months old from this mare of Wm. H. Cook. I think she had this colt when in Warner Cook's hands. Think she raised four horse colts and one mare from Burge Horse."

In driving back to Middlebury from Ti. we interviewed again Lorenzo D. Larrabee, Shoreham, who said :

"The colt Judge Larrabee raised was a bay colt. I think he got damaged somehow and went into the hands of Allen Smith of Bridport. As to his blood-Did you recollect when Hamiltonian came in? Well, sir, nyy opinion is that was a Hamiltonian colt. I have no doubt of it. I think-it rather strikes me that the horse was about here at that time.

"I was born Dec., I 803 , and have always lived here. There was Hamiltonian stock here. I know the judge's colt was Hamiltonion. $\mathrm{He}$ was a large colt, regular square chunk. Uncle John was offered a large price for him, and he was offered more when he followed the mare than he got afterwards. There has been a good deal of inquiry of that colt of me before this. I have an impression, I can't tell why, that he went into the hands of Allen Smith. I know Schuyler Doane said he did. $\mathrm{He}$ and I both thought so.

"The Hamiltonians were called the best breed we had amongst us in those days. I can't remember how the Larrabee colt looked. The Hamiltonians were nice square-built colts.

"The mare that brought the Larrabee colt was a large, stately mare; don't know where he got her, nor how long he owned her.

"I think I was but a boy I 8 or 19 years old. I lived right here in sight. I have lived in this house 54 years, built by Hawlet Thorne. Billy Denton had the place first with log house; he sold to Thorne and he to me."

When we finished our trip the question was-what had been accomplished? It was pretty evident that no decision was warranted by the testimony. It had fallen from the clean, simple statement that this mare was brought into Hague as a colt in her dam, or following her dam, by some one living at Hague, whose name was first given as Densmore, afterwards as Bevins, and had taken on a more gossipy form. The Rufus Rising Vermont story had a large amount of currency, and among men claiming more or less intimate acquaintance with the facts.

On the other hand, the gray Bevins filly seemed almost too old, nor had we been able to trace her beyond her first owner.

The following week was the meeting of the State Horse-Breeders' as- 
sociation at Burlington, on the Monday after which my friend drove back to Ti. to interview again Justus Rising, and several others witnesses ; Wednesday night he returned. His interviews with Justus Rising and Mr. Baldwin satisfied him that it was the George Johnson and Rufus Rising mare.

Mr. Justus Rising was certain that the Rufus Rising mare was the mare Warner Cook had, and afterward the dam of Ethan. He knew her all the way down; knew her when his uncle Rufus had her; knew her when Warner Cook had her, and when Holcomb had her; was just as certain of it as that he was alive. Remembered his uncle Rufus bred a colt from her; he always bred his mares; that she came over from the farm owned by Rufus, Joel and Abel, together, to his father's place, and he set a dog on her.

This testimony was of the best and seemed to locate the mare with much certainty in the hands of Rufus Rising as far back as I 830-34, who raised a colt from her. I asked if he testified he knew her in Geo. Johnsons' hands. The notes showed that this question was asked and he could not say that he did. And besides if the mare was purchased in Vermont we had no testimony of whom.

I remembered now of having received a letter once from Allen W. Thomson, Woodstock, Vt., stating that he had information about the dam of Ethan, looked up a number of years before, that he would furnish at a fair price to pay for his trouble and expense. I remembered, too, that Mr. Wallace had told me once that Mr. Thomson claimed to have discovered the sire of the dam of Ethan; and I determined to interview Mr. Thomson of Woodstock.

The drive from Middlebury to Woodstock is a very different one from that to Ti. We crossed the Green Mountains at their highest pass in Hancock, and in the very heart of Vermont descended through the White River valley to the Locust Creek House, near Bethel ; hence by a smaller valley ascended to Barnard Pond, where, at an excellent hotel, we passed the night. We saw nothing of Lake Champlain this time, only, in the dim distance, a flash of it as we crossed the mountains; but the valleys of Eastern Vermont, though wanting the breadth and magnitude of the Champlain valley, are fertile and well-cultivated, and are the homes of a thrifty and intelligent people. They are, too, exceedingly beautiful, and winding through them are the best of natural roads.

Through a glen that seemed almost like a long winding thread, we drove from Barnard Pond to Woodstock. On entering the village the eye is delighted by the beautiful residence and spacious and elegant grounds of the Hon. Frederick Billings, which occupy a commanding eminence on the right. We crossed a substantial iron bridge which spans the clear Otta Quechee and passed down an avenue of aged trees, mostly elms, as gnarled and stately as those which guard the historic streets of New Haven, Conn. Woodstock is a village of great beauty with many 


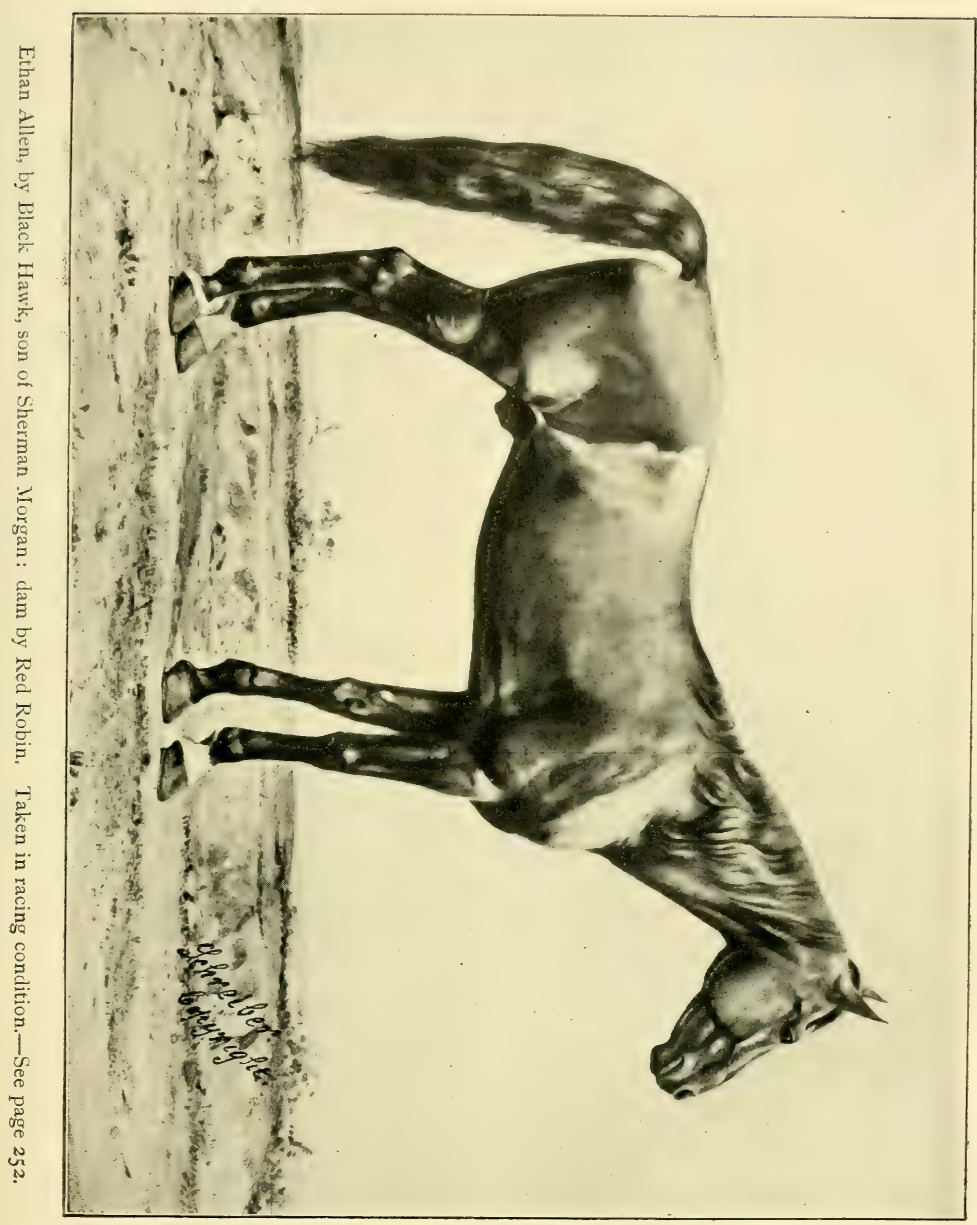




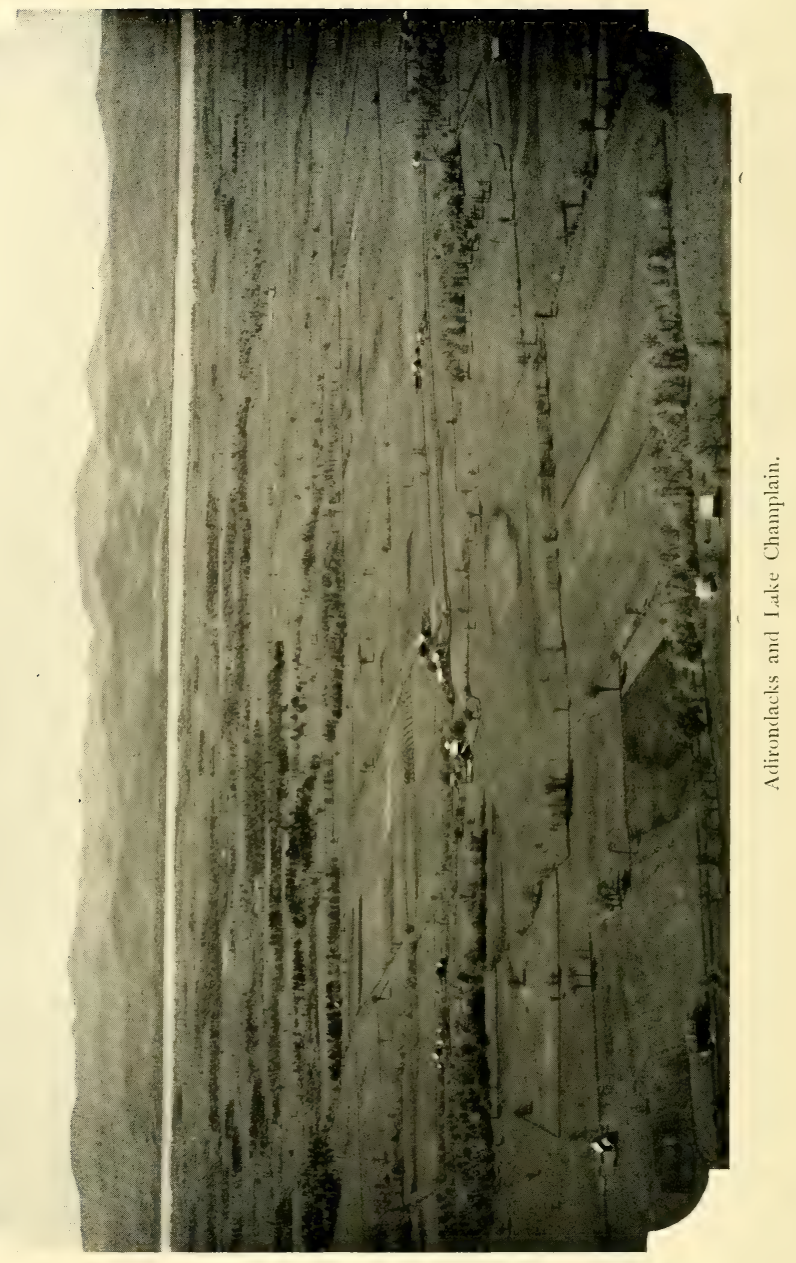


suggestions of taste and refinement and a good degree of wealth in its tasty dwellings, bowers, gardens, and clean and shady streets.

We found Allen W. Thompson a man past middle age, who has spent much time in tracing pedigrees of noted horses, especially those of Vermont. Mr. Thompson at first asked a hundred and fifty dollars for his information, including some on the dam of Black Hawk; said that Mr. Wallace had offered him fifty ; but finally let me have it for one hundred dollars. He had collected this information about ten years before, when several important witnesses, now dead, were living.

We give Mr. Thomson's narrative, in his own language :

"The dam of Ethan Allen was a small gray mare, not quite 15 hands, and would weigh in common flesh about 900 lbs. Her head and eyes were prominent, ears rather large and long. She had a large nostril and straight face, eyes mild and pleasant, neck and body long, withers low, sloping rump, legs not large, but sinewy, hind leg crooked, mane and tail medium as to quantity of hair; hair of tail long. She was long-gaited, and a keen, free, fast driver. All admit she was smart to go. Her faults were, she was a jumper and hard to catch. She was afraid of a buffalo robe behind her. It excited her and made her pull hard. When turned out she went where she was a mind to; no fence stopped her. She wore a poke sometimes, but it did not make much difference. The poke made a bunch on her neck.

"Sometimes, to avoid being caught, she would jump out of the pasture. One time her owner went to catch her; she seemed determined not to be caught, jumped out of the pasture into the road, then into the mowing, went across the meadow and brook, jumped another fence, and went onto the mountain. Her owner (Mr. Cook) followed her, and found her in some bushes where she could not get away. When he came up to her she looked around and by her looks said, 'I am caught, though I tried hard to get away.'

"Mr. Holcomb swapped a horse for her in the fall of 1843 , with George Weed, of Ti. Mr. Weed bought her of Wm. H. Cook, the previous June, with colt by her side, for $\$ 50$. When Mr. Weed traded with Mr. Holcomb he kept the colt. Mr. Cook had her of his father, Warner Cook, in the fall of 1839 . Warner Cook had her of George Johnson, then of Hague, now deceased. It was in the fall of 1837 that Mr. Cook bought her of Mr. Johnson. Mr. Johnson bought her about I834 of Rufus Rising of Hague. (Rufus Rising died about i 870).

"So far the mare is traced without any doubt. Where Mr. Rising got her is not stated for any certainty. It has been the received opinion and is, that he got her in Vermont."

"We visited Ti. and Hague in June, I876; saw Rufus Rising's widow. She was living at Hague; her age about 70 ; health broken, but memory good. Previous to visiting Hague we had written her, asking if she remembered her husband's owning a little gray mare, and if so, where he got her. She informed us that she received the letter, and at that time her husband's brother was with her, and they talked it over about the gray mare. They remembered her well, but could not remember where her husband got her. Her husband's brother told about driving her one time and how smart she was; how he drove by some four or five teams with her. This brother was not alive when we visited Hague.

"We saw Curtis Balcom of Hague, a man about 70 years. He and 
Geo. Johnson married sisters. He remembered Mr. Rising driving the gray mare; that he sold her to Mr. Johnson at his (place, where Curtis Balcom was then living), but he could not tell where Mr. Rising got her.

"We next saw Rufus Rising, son of Rufus Rising, a man of about 50 years. He recollected his father's peddling ; of his being at Goshen, Vt., one time.

"We next saw Hoyt Johnson of Hague, a man of about 7o years. He was brother of George Johnson. He remembered his brother's having the mare, that he had of Rufus Rising. That Mr. Rising got her in Vermont.

"She was bred the 9th of July, I 848 , to Black Hawk, and the next year the 27 th of June, showing that Ethan was foaled about the 18 th of June, provided she was. bred in the usual nine days after foaling. These dates are from the stud books of Black Hawk."

A number of weeks passed after visiting Woodstock before we were able to go again to Ti. Finally there came a fine day in November and, in company with the same gentleman as before, we went. It took two strong horses to pull us through the clay mud, although the roads had partly dried since the rains. It was a mild day, very, for the time of year. A part of the time the sun glanced out on the earth; then the clouds darkened over the sky, the south wind was rising and threatened a storm; but it cleared away in the night with but little rain.

Our first stop was at Mr. John A. Child's in Weybridge. He said :

"Philander Hanks of Addison had a black horse, I5-3, weight I050, by Edrick Adams' horse (of Panton), son of Black Hawk; sold it to A. Drake and myself. Ed. Everest of Vergennes had charge of Adams' horse. Adams' horse was sold West. Everest will know about him.

"Lauren C. Drake of Weybridge owned a grandson of Black Hawk, bought of Reuben Sampson ; bay, rooo lbs. ; correct proportioned horse, say I 5 I-4 to I 5 I-2 ; pretty good trotter; trotted at Vergennes with a horse called White Stockings. Sent to Morgan of Kentucky, who dealt in Morgan horses. Never got his pay. Guess this horse was a son of Philo Jewett's Black Hawk. Thirty odd years ago there was a great show of Black Hawks at Saratoga. Sherman Black Hawk was there; think Ethan was."

Leaving Mr. Child's, we rounded the north end of Snake Mountain, passing first near the banks of the winding Otter. A wide plain stretches to the north and west; it is decidedly the plain of Vermont, and so extensive as to suggest the western prairies, or the flat fields of Holland. At this point Vermont almost loses her character of an upland State.

Our next stop was at the old Allen Smith mansion. Elisha Smith, a nephew of Allen, lives here now, and gave us a most hospitable welcome. The house is of stone, very high between joints, a large two-story house, built in $\mathbf{1} 8 \mathbf{z}$; the date over the door. We stopped to see if Allen Smith's papers could be found. There were none of them at the house; Mr. Smith thought perhaps there might be some with a daughter at Port Henry. 
Mr. Smith said :

"Allen Smith died February, I 862 , aged 74. Don't think he kept a stud book. His only son living is U. A. Smith, Americus, Ga. Allen Smith raised a son of Green Mountain Morgan from a mare bred by him from old Black Hawk. This colt was a chestnut, little white in face and I think some white feet; I5 hands, 1050lbs. ; good stout horse; think foaled about i 855 . He went to Georgia the winter of I $86^{\circ} \mathrm{r}$. Allen Smith's son took him there. They called him Morgan. I don't think he had any other that he used much after Pone. I got this place in $\mathrm{x} 864$. The best horse of late years in this section was the Frost Horse, by Daniel Lambert, from a dam by Ethan Allen. They sold him to Ohio, and he died there. He got excellent stock."

Mr Sheldon, a man something over 70 , whom we met on the road a little south of Elisha Smith's, said :

"Should think Allen Smith had Young Hamiltonian when he had Liberty. He had him quite a long time. We raised three colts from him-one bay, one sorrel, one black; all small. Most of his stock were small ; he was a small horse."

We crossed the lake by the old-fashioned ferry-boat such as has plied, we supposed, a hundred years between the two shores. It is called Frost's landing on the Bridport side. Crown Point is opposite. At Crown Point there are, near the lake shore, large iron works in successful operation, which gives an air of thrift to that side of the lake. The village of Crown Point is beyond this, perhaps half a mile. On the Vermont side the old Frost hotel has scarcely life enough for a ruin. The hillside looks forlorn. The railroads have destroyed the business that formerly flourished on Lake Champlain. The stores that used to prosper at its landings are things of the past.

The following day we drove to Ti. A second call at Mr. Foster Breed's elicited the facts that he bought the dam of the Breed Horse, by Black Hawk, of Swinton of Bridport; who said she was by Post Boy. $\mathrm{Mr}$. Breed sold this horse for \$I 500 to Jerry Jinks and partner, St. Clair, Mich. Sold one black colt by the Breed Horse, I Ioo lbs., middling coarse made, dam Joseph Thomas' mare of Ti., at two years old to Dr. Goodrich. Michigan, who afterwards sold him at \$ I 200 .

Alvah Bennett, who lives on the road between Crown Point and Ti. at second interwiew said:

"The first horse I had was called Messenger; I got him about I $836-$ 8 of my brother, Clark Bennett of Mount Vernon, Ohio; only kept him one day; sold him to a man named Beers Tomlinson, who kept him the next season at Ti., and returned him to me. He was to give me $\$ 400$ for him, but failed up and paid for his use and returned him. After his return I kept him three seasons; sold him to Andrew Wright \& Son of Shoreham; they didn't pay, either, but traded him to Ormsbee of Chipman Point, Orwell. He died there; lived a good many years after I had him, and did a great deal of service. He had a dropsical leg that killed him. He was twelve to thirteen hundred in weight, but pony built at that. I think he was five or six when I got him; he had been trained 
to run. I think he lived as much as ten years in Vermont. He had big, heavy shoulders, head right up; was a good roadster; had rather a fine head and good heft of mane and tail. I don't know as any stallion was kept from him ; much of his stock was dapple gray.

"The next horse I had was a dun horse I raised from a likely horse, breeding unknown, owned by Dea. Harris of Ti. I sold this colt at three years old.

"The next was a jet black colt with no marks, which I bred, by Black Hawk; dam a bay mare, of twelve hundred pounds, by the Burge Horse, son of Sir Charles-both my mares were by the Burge Horse; I raised them both. I sold this colt at three past to Clough \& Holcomb of Ti. for six hundred dollars. They sold him West, and the last I knew of him he was at Little Falls, N. Y. He was about I 5 I-2 hands, Io5o lbs. They called him Black Alvah. Holcomb injured him by driving. He was kept entire."

Oliver P. Pinchin of Ti., who once owned Darkey (son of the Rounds Horse by Black Hawk, and sire of Highland Gray, $2: 28$ ), said :

"Darkey was a great trotter. Rodney Smith used to handle him. Darkey got a good deal of stock. I don't know who bred Young Darkey. He died about five years old. He was an awful trotter; was owned by Chas. Finch, then of Granville, N. Y., now owner of Honest Dan. Bludsoe, son of Darkey, is owned in Amsterdam, N. Y., by a Mr. Green ; he was bred by Mr. Thorington of Castleton, $\mathrm{Vt}$. He was called the Thorington colt when he trotted; has several colts in Ti. W. G. Baldwin had him here one or two years. Bludsoe is a bay horse about fifteen hands high."

We drove toward Hague, and after crossing the boundary of that town, called on Levi P. Covill, a farmer, 58 years old, who said:

"Warner Cook had a dun mare and a white one; the white Warner let William H. have; she was I5 hands, 950 lbs.; not very chunked; a long mare. She was nine or ten years old.

"I saw George Johnson have this same gray mare before Cook owned her; Johnson was a trading man. I am sure Johnson owned this gray mare."

Turning to the north, we followed a rough and rocky hill road to the humble dwelling of Moses Wells, a Frenchman, who used to work for Warner Cook, who said that he was married in February, about 48 years ago, and went right to Warner Cook's to work the next March, and worked there eight or ten years. There was a gray mare at Warner Cook's.

Ascending a little further by this unfrequented road, we passed into the valley where Hoyt Johnson lives, and called again at his house. Mrs. Johnson said :

"There were two William Bevinses, my uncle and my cousin; my cousin married his wife in Rutland. The mare Geo. Johnson had of Rufus Rising, it is impressed on my mind, was dark colored; I have seen the horse many times; I remember it well; it was a dark roan, a little grayish. I saw the horse George sold to Warner Cook soon after Cook got it; George stood in our door-yard when he rode by very fast, and George growled about the way Cook was using the horse he had sold 
him. It was not a sorrel nor light gray. George spoke because he was very tender of his horses.

"I couldn't recommend William Bevins for truth; he was son of Joseph; their family was very different from ours; one son would steal everything he could. William was not very truthful.

"William Bevins was born in June or July, I 800 ; there was only four or five weeks difference in age between him and my oldest brother. William Bevins' father-in-law was a poor man; one of his daughters kept house for him a while. Will Bevins was not married till he was of age. Butters was a very old man when he came here. Never heard him tell of going to Boston. He had had quite a family; three of them were burned up in this house. He had no property when he came here; he brought no horse nor nothing. He did not go back to Rutland at all. If Will Bevins had had a present of a horse from his father-in-law we should have been apt to know it.

"William Bevins had no horse when he came here. I did not know of his having one very young; think he had a span before he was married. He worked at Crane Pond."

We returned to Ti. and spent the night, and the next morning drove up the lake road and called upon Joshua Knapp, who made the following statement:

"I was born April 23, I820. I worked for Warner Cook when I was sixteen years old. He had a pair of mares; he raised one and bought one in Hague. The one he bought was white-most white. He let his son have the white one and she raised Ethan Allen. He had her when I was there. I worked there most two years, and the summer after I went there he got the white mare. My birthday is April 23. I know I was sixty-five last April. I was born in Hague.

"The white mare he drove with the black mare the next winter after I went there; David Walker, now of Hague, drove them.

"When I went from Warner's I went to W. H. Cook's and worked for him three years. I think Warner died the last year I worked for W. H. ; not sure. It was the next year after I went there that they divided the property. W. H. did not live there; he lived at the lower place. This was the first place I ever worked by the month.

"I went there in the spring, and in fall went to W. H.'s and boarded and went to school; then in spring I let myself to W. H. and worked three years. The old man owned this place, the upper place. I was at Warner Cook's first, summer and winter and the next summer till fall. Joseph Cook was born when I was at his father's, W. H. Cook's. He was born in the winter." (Rev. Joseph Cook gives his birth-day January 23, I 838.) "It seems to me as though I had been there a winter before, but not certain. I was with W. H. Cook three winters. He did not sell the farm while I was there. He sold the farm to Cooper and I worked for him after working for W. H. Cook : that was when he went back to his father's, I guess. Cooper failed and went off West. I was at W. H. Cook's three years continuously. All that time he lived where he died. I don't think I ever worked for him again. The first winter I went to school; the next, I went some, I guess; may have been some the third winter, but guess not.

"They had a name for the gray mare, but I forget it. It kind of seems to me as though George Johnson at some time owned that mare. I can't say-don't know. Nobody ever asked me-I never heard of it before 
or since I was there. She was pretty near white; a few dots round among the hair. I think he got the mare in the summer or fall after I went there-the first fall."

We made a last call on Justus B. Rising at Ti., who said that his father (Horace Rising) used to go up to Hague in the fall and log through the winter, and that he went with him when about fourteen and drew logs; he does not remember that he saw the mare at that time, but thinks it was afterwards; used to see her frequently when he was there in the summer, because she ran in the lot next to their place; remembers her having a colt; thinks it was an iron gray colt; thinks the mare was a young mare. (It will be remembered that Mr. Rising was born in $\mathrm{I} 820$ and his father died in 1837.) He thinks it was after his father's death that he saw the mare with the colt, but would not be certain. The mare was quite a jumper, and they used to have a poke on her. Has seen his Uncle Rufus drive her in a team on the farm, but never saw him draw logs with her; does not think he ever drew logs with her; he seldom drew logs; he had a brown mate that he drove with her. Is quite sure that he saw her there before his father's death ; thinks that Ira Potter would be pretty apt to know about the mare, as he lived right there among the Risings, and married Betsey Balcom, a sister to uncle Zeno Rising's wife; he is an honest, square man. William Bevins always lived there. Rufus Rising lived very near where his son Rufus does now, this way a little further south, not more than I5o rods, when the mare had the colt; he moved from there to where Rufus lives now. The old place was near the school house on the upper side of the road. He moved first into a very small house, then built another that has been fixed over into the present one, which was built after his brother Horace's death. The first our informant remembers of his Uncle Rufus he was living at the schoolhouse place, where young Rufus was born. He had the gray mare when he moved into the small house; thinks his (Rufus') daughter was born after he moved on to the present farm

The following correspondence was had with Mr. C. M. Balcom.

C. M. Balcom, Esq.,

$$
\text { Middlebury, Vt., Dec. I } 5 \text {, I } 885 \text {. }
$$

Dear Sir :-I want especially to learn how the gray mare passed from Rufus Rising to Warner Cook. Perhaps it was through Cal. McIntyre. Do you know who he was or do you know whether he ever owned her? Do you think she was owned by John Glazier before she went into Rising's hands? Please state the year of your birth.

Yours truly, Joseph Battell.

Rosendale, Dec. 6, I885.

Dear Sir :-I think the mare you inquire for passed direct from Rufus Rising to Warner Cook. Caleb McIntyre did not live in Hague many years, and I think he left that town before Rising parted with the mare. I am positive that John Glazier never owned her, as the mare that he 
owned and called fast was a dark brown or black, and the dam of Ethan was nearly white. I. was born in Hague, N. Y., in June, I818.

$$
\begin{aligned}
& \text { Yours truly, C. M. Balcom. } \\
& \text { Middlebury, VT., Dec. I5, } 1885 .
\end{aligned}
$$

\section{M. Balcom, Ese.,}

Dear Sir :-Yours of Dec. 6 received. I understand that John Glazier had two mares at some time, one a black or a brown, the other a gray. Do you think this might have been so? I understand now that Warner Cook got this gray mare of a Mr. Wallace, who got her of Wm. H. Balcom, now of Argo, Ill. What do you think of this? Do you think Rufus Rising may have got this mare of Reuben Potter? Can you remember Reuben Potter's owning such a mare, perhaps a colt when he owned her?

$$
\begin{gathered}
\text { Truly yours, Joseph Battell. } \\
\text { Rosendale, Wis., Dec. } 2 \text { I, I } 885 .
\end{gathered}
$$

Dear Sir :-In answer to yours of the $I 5$ th inst., I have to say that I am positive that John Glazier or $\mathrm{Wm}$. H. Balcom never owned the dam of Ethan Allen. The first I remember of her was when I was quite a boy, before I came to manhood. She was owned by Rufus Rising, who owned her a number of years and called her his "old colt". If Rufus sold her to other parties than Warner Cook, they kept her but a short time, and I never heard of the transfer. I do not remember of Reuben Potter's ever owning a gray mare or a gray colt. Mrs. George Clark of Ticonderoga, only surviving child of Warner Cook, may remember of whom her father had the mare.

\section{M. Balcom, EsQ.,}

$$
\begin{array}{ll}
\text { Truly yours, } & \text { C. M. Balcom. } \\
\text { Middlebury, Vt., Dec. } 26, \text { I } 885 .
\end{array}
$$

Dear Sir :-I am much obliged to you for your letter. Will you please state how late you remember Rufus Rising's owning this mare? When did you leave Hague? Did Mr. Rising own her as late as 1838 ? Were you acquainted with Wm. H. Balcom, and do you remember his owning a gray or whitish mare about that time? Do you think Mr. Rising owned this mare as early as 1828 ? Have you any idea when and of whom Mr. Rising got this mare? Did he raise any colts from her? Do you remember the mare in Warner Cook's hands? A further answer will much oblige.

\section{Yours truly, Joseph Battell.}

Rosendale, Jan. 4, i 886.

Dear Sir :-Yours of the 26 th ult. received. In reply-Mr. Rising may have owned the mare as early as 1828 , but I do not remember her until two or three years later. She was not a colt when I first knew her. $\mathrm{He}$ owned her as late as 1838 . Whether he raised or bought hor I do not know ; if he bought her, I have no idea of whom. I do not remember of her having raised any colts while Rising, owned her. I remember her in the hands of Warner Cook. I left Hague in August, I 845. I made my home with Wm. H. Balcom for some years; he owned a gray mare, but she had been hipped and was very lame, and she was not the dam of Ethan Allen.

$$
\text { Yours truly, } \quad \text { C. M. BaLCOM. }
$$

C. M. Balcom, EsQ.,

Middlebury, Vt., Jan. 7, I 886.

Dear Sir. :-Your prompt answer is received. Will you now state when 
you first went to W. H. Balcom's? Also state what year you left him? and what year he owned the hipped mare? Do you know of whom he got this mare? Do you know whether Rufus Rising had owned her previously? Whom did Mr. Balcom let have her, and what became of her afterwards?

Both Mrs. W. H. Cook (now living) and S. B. Woodward of Saratoga Springs, thought that the dam of Ethan was hipped. A number who drove her when Mr. Cook and Mr. Holcomb owned her said she was lame.

Now how do you know that the Wm. H. Balcom mare was not the dam of Ethan? Please think this over carefully and see if you might not be mistaken. We have some reasons to believe it was the same mare. Are there any other Hague people in Rosendale?.

$$
\text { Truly yours, JOSEPH BatTELL. }
$$

Rosendale, Jan. I2, I 886.

Dear Sir:-Yours received. In answer, Wm. H. Balcom's father and my father were brothers, and lived a half a mile apart. After my father's and his father's death I made my home with him and worked out for farmers and others in that vicinity until he left Hague, some two years before I left that place. The Wm. H. Balcom mare was an old, hipped and very lame mare when he bought her of our uncle, Caleb Balcom, for a small sum. I was about fourteen years old at that time. I know that the mare was dead before Ethan Allen was foaled. Nathan Moon of this town came from Ticonderoga here some six years after I did. He lived with $\mathrm{Wm}$. H. Cook from a boy until a man-he can tell you about the mare you inquire for.

$$
\text { Yours truly, C. M. BaLcom. }
$$

Reluctantly leaving this excellent witness, who seemed to have pretty completely refuted the claim that the W. H. Balcom mare was the dam of Ethan, we had with Mr. N. W. Moon this correspondence:

Mr. N. IV. Moon,

$$
\text { Middlebury, Vt., Jan. I6, } 1886 .
$$

Dear Sir :-Will you please inform me about the small gray mare that Wm. H. Cook had of his father, Warner Cook, and that was afterwards owned by Mr. Weed and Mr. Holcomb, and was the dam of Ethan Allen. I want to know what year Wm. H. Cook had this mare of his father, and of whom his father got her. Also her history previously to that time, so far as you know it. Please state your age and what years you lived with Wm. H. Cook. C. M. Balcom refers me to you for this information. An early reply will oblige.

\section{Mr. BATTELL,}

$$
\begin{aligned}
& \text { Yours truly, Joseph Battell. } \\
& \text { Rosendale, Wis., Jan. 22, I886. }
\end{aligned}
$$

Dear Sir :-I received yours of the 16 th and take this opportunity to give you what little information I have about the mare that you inquire about. I went to work for Warner Cook in the year I 840 , in the month of April. He gave me board and clothes for what I could do. I was twelve years old at that time. I was fifty eight years old last August. In the fall of that year, I840, W. H. Cook moved into the house with his father and took charge of the business. That mare was on the place at that time. I think Warner Cook got her in the year I 838 or $1839 . \mathrm{He}$ got the mare of a man by the name of Rising and I think it was Rufus 
Rising, in the town of Hague. When they say she was a gray it is a mistake, for I knew the mare for as much as sixteen years before she died. She was as white as snow. She was rather chunked built, was a good roadster, more than a common one. I worked for the Cooks eight or nine years. When I worked there she was bred to a horse called the Sir Charles, for three years. The first colt was a bay horse colt, the second a mare of the same color; they would weigh about I 200 lbs. ; the third was a gray horse colt. This colt was with the mare when Cook sold her to Weed; he let Weed have the mare and colt for fifty dollars and took it in boating. At that time he was running a lumber business in Toughertown, about three miles from Ticonderoga. While Holcomb owned her she had three colts. One was a black mare, the second a gray horse with one bay fore leg, and the third was Ethan Allen, and when she died she was in foal. She died at Holcomb's. That is about all that I can tell about her, but any further information I can give will be given freely.

\section{Mr. N. W. Moon,}

$$
\text { Yours truly, N. W. MooN. }
$$

Middlebury, Vt., Jan. 30, I886.

Dear Sir :-Will you please inform me if there was any other white or gray mare on the Cook place when you lived there, owned either by Warner or W. H. Cook? Are you sure that W. H. Cook came on to his father's place the same year that you went to work for Warner, and are you sure that W. H. Cook moved on to that place in the fall? Did Warner Cook breed this dam of Ethan to the Sir Charles horse, or was it W. H. Cook that so bred her? Was it the year of the Harrison campaign that you first went to Mr. Cook's? Could it have been in $\mathbf{I} 842$ that you first went there?

$$
\text { Yours truly, Joseph Battell. }
$$

Mr. BAtTEll,

Rosendale, Feb. IO, I 886.

Dear Sir :-It was in I 840 that I went to Warner Cook's, in the month of April. I am sure, for my father died the same year, the $3 \mathrm{~d}$ of July Warner Cook did not breed the mare at all; W. H. was the man that did all of the breeding of that mare while she was in the Cook family's possession. There was another gray mare on the farm when I went there ; if I remember right she was three years old; belonged to W. H. Cook's brother, and after they divided the property, some two or three years, $\mathrm{W}$. $\mathrm{H}$. bought this mare of his brother and bred her to a horse that belonged to Thomas Rogers and she brought a gray horse colt, but it died when a year old. He had a mare, half sister to Ethan Allen, that was bred to the Rogers horse the same year, that raised a roan mare colt. This was in 1848 or ' $49-\mathrm{I}$ think in $\mathrm{I} 848$, for I came West in 1850 .

$$
\text { Yours truly, N. W. Moon. }
$$

Mr. Moon is undoubtedly right in his dates, as the Essex County records show that Wm. H. Cook and wife deeded to Caleb Cooper, Sept. $2 \mathrm{I}$, I840, and Mrs. W. H. Cook, in a letter dated Feb. II, I886, states positively that they moved on to the Warner Cook place October 23, I840.

It will be borne in mind that in 1876 Ira Potter (born in Hague in 
I 8 I 8 , and a resident there till 1855 ) wrote $A . W$. Thomson to the effect that John Glazier sold a gray mare to Dea. Hayford and he to Rufus Rising, who raised from her the dam of Ethan, got by a gray colt owned by him; also that in the fall of $1878 \mathrm{Mr}$. Potter wrote to the same effect to Justin Bugbee, whose letters passed to Mr. Thomson. Having ascertained that Ira Potter's address was Creston, Neb., further letters were recently written him, to which he wrote the following replies:

\section{Mr. Joseph Battell,}

Creston, Neb., Jan. I2, I 886.

Dear Sir :-You inquire if she was half-hipped. No ; she was spavined. I am sure that Rufus Rising raised her. She had no colts while he owned her. He traded her to Cook. W. Bevins did not own the dam of Ethan. I did not know whether she was a catch colt or not.

I did know a mare that W. H. Balcom owned: she was no relation to Ethan Allen. Rising did not own a gray mare at that time.

I was acquainted with the stallions kept at that time; there was but one and that was owned by Joel Norton ; he was a bay, white-faced horse, no name.

The dam of Ethan raised three Sir Charles colts while Cook owned her. He sold her to George Weed, and he sold her to J. W. Holcomb. While he owned her she raised two Black Hawk colts and Ethan.

$$
\text { Yours truly, IRA POTTER. }
$$

Mr. Joseph BAtTell,

$$
\text { Creston, Neb., Jan., i } 886 .
$$

Dear Sir :-The gray mare I did drive most of the time for two or three years; drove her about $\mathbf{I}_{3} 8$ to $\mathbf{r}_{4} 8_{2}$. W. Cook got her, about $18_{3} 8$, of Abel Rising. Rufus Rising raised her. Reuben Potter is dead. $\mathrm{He}$ sold a gray gelding to Rufus Rising in 1834 or ' 35 . Cook raised three Sir Charles colts from her, and sold her and colt to George Weed for fifty dollars, and Weed sold her to J. W. Holcomb. He raised two Black Hawk colts from her and then Ethan Allen.

$$
\text { Yours respectfully, IRA POTTER. }
$$

It will be seen that Mr. Ira Potter's knowledge of the mare began with the time he worked for Warner Cook. After that he knew her history, but apparently did not before.

The Will Bevins story has it that the dam of Ethan was bred by Ambrose Potter and sold to Reuben Potter, who sold her at four or five years old to Rufus Rising. Now this Reuben Potter was own brother to Ira; and Ira states positively that Reuben never owned the dam of Ethan, and that the animal he sold to Rufus Rising was a gray gelding.

Our old friend, Hoyt Johnson of Hague, in response to a letter asking what horses he remembered Rufus Rising's having before $\mathbf{I} 845$, writes under date Nov. 23, I885:

Dear Sir :- I remember Rufus Rising sold Anson Potter one span of three-year-old colts. I also remember his selling Samuel Ackerman one bay team, horse and mare. I also remember his selling a span of three year-old colts to a man by the name of Sawyer; they went to Canada. 
I also remember him having a brown stallion with white strip in face and three white feet; this colt he raised. I also remember his having one bay team that he kept to work on the farm. 'That is all I remember up' to that date.

$$
\text { Yours truly, HoyT JoHNSON. }
$$

In reply to inquiries about the John Glazier mare, these letters came : TiCONDEROGA, Dec. IO, I885.

Dear Sir:-In I826 I had the John Glazier mare to drive to the south part of Vermont. She was a light gray mare, would weigh nine or ten hundred. I also know that Rufus Rising bought the mare of John Glazier about two years after that, which would bring it 1828 when he bought her.

\section{Yours truly, Hoyt Johnson.}

Ticonderoga, Jan. 5, I 886.

Dear Sir :-Rufus Rising must have kept the Glazier mare one or two years; I do not exactly know how long; I know he drove her single and he worked her some. Who he sold her to I don't know.

$$
\text { Yours truly, Hoyt Johnson. }
$$

Concerning the dam of Ethan, Mr. Johnson wrote as follows :

$$
\text { Ticonderoga, Jan. 24, I } 886 .
$$

Dear Sir :-I knew John Harris, but he never owned that mare, Caleb Balcom and son never owned that mare, and George Johnson never sold her to them. No one owned that mare after George got her, till he sold her to Warner Cnok. My wife does not know anything about that.

$$
\text { Yours truly, HOYT JoHnson. }
$$

Concerning the Balcom mare he wrote under date Jan. 21, I886:

Dear Sir :-I was well acquainted with William Balcom until he went West. I also remember his having a gray mare, but who he let her go to I do not remember, and I could not tell who he got her of.

$$
\text { Yours truly, Hoyt Johnson. }
$$

Recent letters from George G. Olney, now of Argo, Ill., state that he was born in Springfield, Vt., in I8I 7 ; went to Hague at two years old and lived there till 1840 , neighbor to John Glazier. Remembers that Glazier had one gray mare about I 826 ; never had but one horse at a time since he can remember; does not know where Glazier got her or to whom he disposed of her; thinks neither W. H. Balcom, John Harris nor W. H. Cook ever had the Glazier mare.

The following three letters are from Mrs. Cook, widow of Wm. H. Cook, late of Ticonderoga.

Mr. BATTELL,

Cliff Seat, Ticonderoga, N. Y., Nov. 26, I885.

Dear Sir:-Your letter asking me to answer some questions is received. I will answer all I can.

First. Our marriage was Jan. 3, I837.

Second. I cannot say certainly that Warner Cook did not own the mare when we were married. The only certain recollection that I have of her was in the summer of $184 \mathrm{I}$. Then I know I drove her.

I have looked through a good many papers of Warner Cook and 
of my husband, William H. Cook, before our marriage, but find nothing relative to the gray mare.

With respect, MRs. W. H. COOK.

Mr. Battell,

Cliff Seat, Ticonderoga, N. Y., Feb. i i, i 886.

Dear Sir :- In reply to your questions I can say postively that our family went to Warner Cook's, my husband's father, to take charge in the year I 840 , October 23.

We came back to our present home some time in May, I844.

I am quite positive that there was no other white horse on the place, and that was the mare there is so much talk about.

I cannot say as to the colts that were on the place when we went there, but I know she had two very large, likely bay colts while we were there, and we took them here and used them for a team here till sold. Likewise I think she had a colt by her side in I 844 when sold to George Weed, which proved to be a valuable horse and was sold at what was thought at that time a great price. You can refer to George Weed, about that colt. The mare was certainly sold to Mr. Weed before we came back here.

$$
\text { With respect, Mrs. W. H. СоOK. }
$$

Cliff Seat, Ticonderoga, N. Y., April i 9, i 886.

Mr. Bliss :- In answer to your questions I can say that there was no such horse on the farm of Warner Cook in the year I84I and I842. Neither did Warner Cook do any such business in those two years. There was no other gray horse on the farm, only the one there has been so much contention about, while we did business there.

With respect, Mrs. W. H. Cook.

This last letter was written in reply to a letter stating that there was evidence that Warner Cook purchased of a man named Wallace of North West Bay, in or about the fall of $\mathrm{I} 84 \mathrm{I}$, an old gray mare for fifteen dollars, to be paid in corn and potatoes; and asking if he ever brought home such a mare, and if he did business of that kind at that time.

This letter shows that Joseph Cushman is mistaken when he says that Wallace sold the mare to Warner Cook. Mr. Cushman is recommended as a very reliable man, but he is eight-six years old and is relating a trivial matter of forty-five years ago. He must be mistaken as to the man to whom Wallace traded her. It is impossible to shake the date on which W. H. Balcom gave the gray mare to Ira Wallace. It was in the fall of $\mathrm{r} 84 \mathrm{I}$, and at that time Warner Cook had got past doing business. It appears to be true, that when the old mare passed out of Ira Wallace's hands she disappeared, and at that time Warner Cook owned and had the younger gray mare, the dam of Ethan, certainly one and almost certainly two or three years.

Azro M. Bailey of Ticonderoga has written that he fixes the time when he worked for the Messrs. Cook at the Warner Cook place as the winter of $184 \mathrm{I}-42$, and says :

"Warner Cook or W. H. Cook, who did the business when I was there, had but one working team of horses, aside from a number of colts from 
one to four years old; some of these they were breaking but not working in the team. The team was this gray mare, the mother of Ethan Allen, and the black mare, which I think he got from McIntyre, but will not be positive-he might possibly have got her from Johnson, but I think notbut the gray mare,I have heard IV. V. Cook, brother of W. H. Cook, say that she was the Johnson mare, at the time I was there, and I have talked with W. H. Cook a good many times since, and he always called her the Johnson mare, and within a few years I have heard him say the same thing."

In a letter dated Nov. 23, I885, Mr. Rufus Rising of Hague, N. Y., writes that his father (Rufus Rising ) moved on to the place where he (the writer) now lives in $\mathrm{I} 839$ or $\mathrm{I} \& 4 \mathrm{O}$; that he was then fourteen or fifteen years old and remembers it well; and that he thinks the horse bought in Rupert, Vt., was exchanged by his father at Stillwater, N. Y., for a mare and colt about the year $\mathrm{r} 8_{35}$ or ${ }_{1} 8_{3} 6$.

Having learned that Mrs. Ann Newton of Hague is a daughter of Ira Wallace, a letter was addressed to her asking what became of the white or light gray mare which her father had of William H. Balcom some forty-four years ago. This letter was answered by Mr. Rising as follows :

Mr. BLISS,

Hague, N. Y., April 23, I886.

Sir :-Yours of the $I_{5}$ th inst. to Mrs. Ann Newton was received. She wishes me to write you that her father never owned a horse to her knowledge ; that he used oxen; that her uncle Nat Wallace owned a gray mare and sold, or let his son Richard Wallace have it. Richard went to Rosendale, Wis., and died there, and his widow, I think, is still living.

I saw in The Register that Warner Cook bought the gray mare about I 839 or ' 40 . I do not recollect as to whether father sold such a mare to Warner Cook, but know that in the year I 839 or $\mathrm{I} 840$ he rented a farm in possession of Warner Cook; whether he let him have the mare or not, I cannot tell.

Yours truly, Rufus Rising.

We had previously corresponded with the widow af Richard Wallace, now living at Rosendale, Wis., and had received from her this reply :

Dear Sir :- I received a few lines from you a few days ago, asking information about a gray mare we used to own. Mr. Wallace had her of Everett Pond from Whiting, Vt., and he sold her to Benager Ackerman in Hague. She was a good horse, a slow walker but a fast trotter.

Jan. $28, \mathrm{I} 886$.

Mrs. S. G. WALLACE.

N. L. Glazier of Waltham, Mass., is a son of John Glazier and was born in Hague, N. Y., in $\mathrm{r} 830$, from which town he thinks they moved in $\mathrm{r} 84 \mathrm{O}$. He writes under date Dec. $4, \mathbf{1} 88_{5}$ :

"I do not know anything about the gray mare, only I have often heard my father tell about a gray mare and a black one that he owned, and of driving them across Lake George, and how quick they went."

Mr. F. Atherton of Argo, Ill, nephew of Charles Atherton, who brought the gray horse from Claremont, N. H., to Ti. writes under date Feb. 8, I886 : 
"The horse my uncle brought to Ti. he took back to Claremont, N. H., about the year I 829 . He brought him from there in the year 1824 or I825. He bought him of a man by the name of Tulle, and as he did not meet with the success he anticipated, took him back and left him. The horse was a fine large one and was considered a fast horse in those days ; could go a mile in about four minutes on the trot, but had been badly foundered before my uncle bought him. He was a French horse-came from Canada, and would weigh probably I250 lbs. He got a number of fine colts. My father owned one that could trot in $3: 30$; and all the colts from him that I knew were more than common roadsters.

"I lived in Ti., from I8I 7 to 1844 , when I came West; and was but a boy only seven or eight years old when my uncle used the horse there; but I remember the horse well. I have seen my uncle ride him often, and he could go like a steamboat."

\section{DAM OF ETHAN ALLEN.}

BY RED ROBIN, OWNED BY MOSES BATES, SPRINGFIELD, VT.; 2 d DAM

THE BEMIS MARE; $3 \mathrm{~d}$ DAM CHESTNUT MARE BROUGHT FROM

TUNBRIDGE TO CHESTER, VT., SAID TO BE BY JUSTIN MORGAN.

[From Editorial, in Middlebury, (Vt.) Register, May I3, I887].

$\mathrm{I}^{\mathrm{T}}$ is the unexpected that happens.

We stopped a few days since to call upon Frederick Leland, at his place in East Middlebury, to make inquiries of him about a bay mare sold by Alix Hope in East Middlebury in 1856 to Fred Plumley of New Haven, Vt., and taken soon after to Boston by the latter; a mare that we have reason to believe was afterwards the dam of Hotspur, $2: 24$, and winner of 27 recorded races. Mr. Leland knew nothing about this mare, but said, as soon as that matter was over, that he knew all about the dam of Ethan Allen, as he himself traded her to Rufus Rising of Hague, N. Y., in I835. Mr. Leland's statement is as follows:

"In I830 I lived with John Field of North Springfield, Vt., with whom I lived two years. I was then 18 years old, having been born in I812. In April, I830, a mare that he owned, called the Bemis mare, foaled a gray filly, got by Red Robin, a horse belonging to Moses Bates, of Springfield. The grandam of this filly, dam of the Bemis mare, was a chestnut mare that came to Chester, Vt., from Tunbridge, Vt., and was said to be by Justin Morgan.

"This gray filly of Mr. Field I bought when four years old in the winter of I 834-5, agreeing to pay for her by peddling some clocks. I wintered her at Sherburne, Vt. ; next spring drove her to Albany, where I left her and went to New York. Returning, I drove her back to Vermont, and just before haying time, I 835, I traded her to Rufus Rising of Hague for a gray gelding. This trade was made at Apollos Austin's in Orwell, where Mr. Rising came from over the lake on purpose to make this trade, in company with Mr. Shaw, who worked for me at the time.

"I afterwards traded the grey gelding that I got, a young horse of fair size, to Frank Farrington of Brandon.

"The year after I traded with Mr. Rising he was at Middlebury with 
the mare; came to see his nephew, Asa Rising, who then lived here, and I saw the mare.

"The next time I saw her she was owned by Holcomb of Ticonderoga. I knew it was the same mare. I afterwards saw her at Mr. Hill's in Bridport, where she had come to be bred to Black Hawk, and I saw him cover her. She was a common sized mare of fair merit. She was not hipped when I saw her at Mr. Hill's.

"She was a good mare, but not a good mare for peddling. She would not stand without hitching, and she would always jump when we took anything out of the wagon. I peddled dry goods, silverware, etc., and I had good goods. I ran two teams, driving one myself, and Mr. Shaw, who worked for me, drove the other. They were both one-horse teams. Mr. Shaw drove this mare, and was over the lake peddling when he met Mr. Rising. I had told him to trade this mare on account of her not standing without hitching, and being frightened so easy when any article was flirted near her, but he didn't like to take the responsibility of trading, and so had Mr. Rising come to Orwell to meet me. I did not know Mr. Rising at that time, but the next year was introduced to him at Middlebury as Mr. Rufus Rising of Hague. I was introduced by Bly, who moved from Ticonderoga to Middlebury, and afterwards moved back to Ticonderoga. Afterwards Bly told me that Rising traded the mare off, and then I saw her when Holcomb had her, and saw her at Hill's covered by Black Hawk, where I had gone myself with a mare. I think this was in I 848 , but I know she had a colt by her side at the time."

Mr. Leland has for many years resided at Middlebury, where he has been a respected and influential citizen, having been repeatedly chosen for selectman, and to other town offices. He has, all his life, been somewhat of a horseman, owning at one time the stallion Gen. Put, which he sold for three thousand dollars.

$\mathrm{He}$ is very deaf, making it necessary to address him in writing only, as he cannot hear conversation; otherwise he is hale and hearty. It would hardly be possible to have a better witness than he in this matter. His statement is unquestionably true, and we believe that when it is added to and compared with the other evidence in the case, it will so harmonize as to be convincing and set the question of the identity and breeding of the dam of Ethan Allen forever at rest.

\section{TRACED AT IAST-THE DAM OF ETHAN ALLEN.}

[From Middlebury Register, May 20, 1887 ].

EDITOR REgister :-Your gratifying announcement in the last issue of the REGister of the solution of this long-vexed question as to the origin of the famous mare has led me to make a rapid, but thorough review of all the evidence hitherto published concerning her. The result is a complete demonstration, as far as dates and circumstances can demonstrate, of the truth and accuracy of Mr. Leland's statement. He has shown us the origin of the dam of Ethan Allen, beyond a peradventure.

When Mr. Thomson, in November last, published his so-called proof 
that the dam of Ethan was the old Wm. H. Balcom mare, I was too busily employed in other matters to give his testimony any examination, and, in fact, till now I have never done so. It is, indeed, far short of proof, and of no avail at all as far as I can see except to prove, from the pen of Ira Potter, that his statement, that this mare was bred by Rufus Rising from the John Glazier mare, he knew only by rumor, hearsay or conjecture, and not of his own knowledge.

While in charge of the horse department of the REgISTER, a year ago, I had given my own guarded opinion as to what the evidence then published tended to show-and that was that the dam of Ethan was bred by Rufus Rising, got by a two-year-old colt of his, and from the John Glazier mare. Perhaps I should not now retract that opinion, on the evidence then published. But when it appeared later by the letter of Ira Potter that he knew nothing personally of such breeding, he being the only positive witness thereto, and one upon whom I greatly relied because he was in a situation to know and had stated all other facts with perfect accuracy and this with equal positiveness-of course the chief foundation of that opinion was gone. On the whole, however, the best evidence of the mare's origin then published was the positive statements of Hoyt Johnson and Willịam G. Baldwin, that Rufus Rising told them he got her in Vermont.

In this connection I also stated, a year ago: "It is impossible to shake the date on which W. H. Balcom gave the gray mare to Ira Wallace. It was in the fall of $\mathrm{I} 84 \mathrm{x}$." I am confirmed in this point by a careful review. W. H. Balcom is a man of more than ordinary intelligence, a clear and careful writer. He first gave the fall of 1842 as the date, but being pressed to be accurate, he goes over the whole matter; says he started on his emigration from Hague to the West, July I3, I 843 ; in June of the same year, a month before he started, he sold his gray mare's last colt, then two years old past ; that when this colt, foaled in the spring of $\mathrm{I} 84 \mathrm{I}$, was six months old, he had given the old mare to Wallace. This statement he has often reiterated in the long correspondence and has never varied it a hair. Mr. Thomson acknowledges it proven that the dam of Ethan was in Warner Cook's hands as early as the fall of $\mathbf{I} 839$; but he gets over the difficulty in dates by assuring Mr. Balcom that his mare was certainly the dam of Ethan Allen, and getting him to acknowledge that he might have had her as early as 1835-this Balcom barely admits as possible; then Mr. Thomson assumes that she produced four foals, $1836,{ }^{2} 7$, ' 8 and '9, and that Wallace got her and passed her over to Cook in the fall of the last year. But Mr. Balcom, in the very letter from which these strained conclusions are drawn, states that the mare produced five foals for him, "three iron gray, one dapple gray with white mane and tail, and one bay"; but Mr. Thomson, whose opportunity for knowing was so much better than Mr. Balcom's, says this is a mistake and that she really produced but four foals for 
Balcom. Mr. Balcom's statement is, in substance, that to his best recollection he got the mare in $\mathbf{I}_{3} 6$; that she produced five foals, in $\mathbf{r} 837$, ' 8 , '9, ' 40 and ' $4 \mathrm{I}$; and that he gave her away in $\mathrm{I} 84 \mathrm{I}$ he never has expressed a doubt since he first gave his mind to the matter. I think his testimony, being practically all there is on the subject, should overcome "proof" from Mr. Thomson's inner consciousness. Moreover, I think it proven that Warner Cook got the dam of Ethan in the summer or fall of $\mathbf{I} 838$, instead of $\mathbf{I} 839$, as I will presently show.

Before leaving this subject, I beg to say that there are other insuperable objections to the theory that the W. H. Balcom mare was the dam of Ethan :

Ist. The Balcom mare was hipped and the dam of Ethan was not.

I believe the idea that the dam of Ethan was hipped rests upon statements to that effect by B. G. Woodard and Mrs. W. H. Cook. What Mr. Woodard's opportunities for knowing were I am not informed, but he evidently mistook the pecular carriage resulting from spavin for the lowering of a hip. As to Mrs. Cook, I myself took her statement. I remember she said the mare "was hipped, I think that is what they called it" ; of course the lady's idea of what the mare's unsoundness consisted of was very liable to be mistaken. Joshua Holcomb also thought she was hipped. On the other hand, Azro M. Bailey of Ti., a life-long handler of horses, who drove the mare in the winter of $184 \mathrm{I}-2$, and found her "as good a road mare as he ever drove," and who knew her well after Holcomb got her; W. G. Baldwin of Ti., a gentleman of high intelligence and one of the best of horsemen; William Arthur of Ti., noted for keen observation and retentive memory; Ira Potter, who drove her in the team when the Cooks owned her, and John A. Pinchin of $\mathrm{Ti}_{\circ}$, the blacksmith who shod the mare many times and knew her perfectly, all agree that she was spavined and not hipped. That seems sufficient to settle the point.

2d. C. M. Balcom, who made it his home at W. H. Balcom's for some years up to the time of the latter's going West, in I843, states positively that he knew both the W. H. Balcom mare and the mare that Rufus Rising had that passed into the hands of Warner Cook, and that they were different mares. He knew the Cook mare when she was in the hands of Rufus Rising and when she was in the hands of the Cooks, and states positively that W. H. Balcom never owned her. He says that the Balcom mare, when given away to Wallace, "was old, hipped and very lame," which seems extremely probable from the fact of her having been given away by a poor farmer in Hague; and he adds that he knows she was dead before Ethan Allen was foaled, which, as he remained about Hague till 1845 , he might well have known. This statement is certainly of as much value as that of the extremely aged Joseph Cushman, who states that Ira Wallace traded such a gray mare to 
Warner Cook; and who, when asked to fix the date accurately, puts it "about I $850 . "$

$3 \mathrm{~d}$. The very significant circumstance that, in all the testimony that has been taken, no hint has ever crept out that the dam of Ethan while in the hands of the Cooks or later was ever referred to as the Balcom mare, or as a mare that W. H. Balcom had ever owned: nor yet as the Wallace mare, or bought of Ira Wallace. On the other hand, A. M. Balcom says that W. H. and W. V. Cook always called her the Johnson mare, and Ira Potter and others say she was called the Rising mare; showing that she was designated, as is almost always the case, by the name of the person of whom she was purchased, or that of a former owner. Not one of the persons connected with Warner Cook, or immediately knowing to his having this mare at the time, ever suspected that she had been owned by W. H. Balçom. A. M. Bailey, Hoyt Johnson, N. W. Moon, Justus B. Rising, Ira Potter, C. M. Balcom, John A. Pinchin, Mrs. W. H. Cook, W. G. Baldwin, and every one else who knew about the matter personally, or had learned from the parties themselves, understood that the mare passed from Rufus Rising through the hands of Geo. Johnson to Warner Cook. Not one of them ever heard of W. H. Balcom's.mare in that connection.

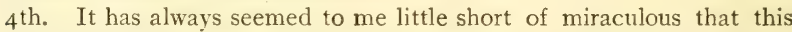
old, badly-hipped, lame, worthless, broken-down brood mare, that so poor a man as W. H. Balcom then was, could afford to give away, evidently because she was not worth keeping, and that the recipient should trade off at once for a little corn (variously stated as two and as fifteen bushels) ; that such a mare as this should appear in the winter of r $84 \mathrm{I}-2$ as described by Azro M. Bailey, when he drove her a long journey. Here is what he says: "She was a screamer on the road. I once drove her to Weybridge by the side of a chestnut mare. I never drove a better team; think this was in $\mathbf{I} 842$. She was sound; think she had had one colt. *** She was as fine a roadster as you ever sat behindambitious, full of vim all day long." (Mr. Bailey has long kept a firstclass livery stable at Ti. and knows what a good road team is). Or, such a mare as Gustavus Wicker, the well-known horse breeder of Ti., who knew her from the time Warner Cook got her, thus alludes to: "I had a little French mare that could trot in three minutes; I could just beat old Warner Cook with this mare; after Cook got her she got a spavin." My imagination has never been elastic enough to take in this mare and the Balcom give-away as one and the same animal.

Now let us take Mr. Leland's statement and see how it adjusts itself to the facts already ascertained and published. He states that this mare was bred by John Field of North Springfield, Vt., and foaled in April, I83o (Springfield is the south-east corner town of Windsor county and lies on the east line of the State on the Connecticut River) ; that she was got by Red Robin, dam, the Bemis mare, to which he assigns no sire, but says 
her dam was a chestnut mare from Tunbridge, Orange county, Vt., said to be by Justin Morgan. Tunbridge joins Randolph, the old home of Justin Morgan, so this is possible enough, and may admit of proof or disproof.

Mr. Leland says he bought her of her breeder in the winter of $1834-5$; wintered her at Sherburne, Vt. ; and after driving her in the spring of I835 to Albany, N. Y., and letting his assistant have her to use on a peddler's cart, trading on the west side of the lake, he traded her at Apollos Austin's in Orwell to Rufus Rising for a gray gelding. (Orwell is in Addison county, west side of the mountains, on the lake and nearly opposite to Ticonderoga). He traded her for the faults of not standing without hitching, and of being frightened if anything was flirted near her. Mr. Rising had seen her in New York State and came over to trade for her.

Now to take up minor points first, of course it strikes every one that this mare had the characteristics of the wily, flighty, spirited gray mare, that was afraid of a buffalo, was hard to catch, and would go just where she chose when turned out. But another thing strikes one as more significant. Several of those who purported to give just what was said, stated that the mare came from "over the Green Mountains." Hoyt Johnson (whom I believe to be a thoroughly accurate and careful witness) says: "Rufus Rising went over the Green Mountains or on to the Green Mountains and got the mare." John A. Pinchin says: "It was always said Johnson got her of old Uncle Rufus Rising. They said old Uncle Rising got her over the the mountain." Joshua Holcomb says Rufus Rising got the mare "over the Green Mountains"; Gustavus Wicker, reporting a conversation he had with Zeno Rising, says : "Zeno Rising told me he got her over the Green Mountain. This was before Ethan was bred. He said over the mountain." This last, in reply to a repeated question, was given with so much emphasis that the "over" was underscored in notes, and appears in the report in italics. Mr. Clark of Hague, who was said to be quite a student of pedigrees, told us he had understood that the mare came from Ludlow, Vt. Ludlow is in the same county and only one town lies between it and Springfield.

Now as to dates. Mr. Leland states that it was just before haying in the summer of 1835 that he traded this gray mare to Rufus Rising. Hoyt Johnson and wife fix the time when George Johnson sold her to Warner Cook with great positiveness. They say it was the year that George lived on the farm where Sam Ackerman now lives, and think he lived there only one year; that was the year that their boy Perry was born, which their family record shows was 1838 , Aug. 26. Mrs. Johnson remembered the sale of the mare perfectly well, and stated that Geo. Johnson also had a child born to him the same year; says she and her husband lived right close to George; the house stood but a little way apart; and she used to see Warner Cook ride by on that mare, a very 
heavy man, and George thought he abused the little mare. It may be set down as established that Johnson sold the mare to Cook in the summer of 1838 .

Hoyt Johnson thinks Rufus Rising had the mare about a year and then traded her to George Johnson, who had her two or three years and sold her to Cook. Justus B. Rising says (summer of 1885 ) that his Uncle Rufus owned that mare "fifty years ago." At the same interview he says: "I am 65 years old. I was 14 years old or so. I drew logs when I was I 4 years old with a pair of steers." All the evidence I have alluded to has been published in THe Register. I have not specified the papers only because it would make this article too cumbersome. I now wish to refer to an interview that I had with Justus B. Rising, Oct. I3, I 885, only an abstract of which has been published. I will give it verbatim. Justus B. Rising said :

"I can't say that Uncle Rufus had the mare when I drove oxen up there at I4 (I834). I think that was before he had the mare. It was right away after that-perhaps a year or more-that Uncle Rufus had the mare. I knew the mare well. I did not see Geo. Johnson have her, but it was always understood that she passed through Geo. Johnson's hands. I knew the mare in Warner Cook's hands and always after that. I was a particular friend of Valorus, Warner Cook's son, and was well acquainted with Warner and his folks. Think he used to ride her. I frequently saw her in Cook's hands-in Warner's and Wm. H. Cook's ; I am just as confident it was the mare my Uncle Rufus had as I am that I stand here. I think he did drive her. He lived close by Rufus, only one farm between.

"I never heard Uncle Rufus say, but I always unc'erstood he got her over the lake. I think after he sold her he had a gray horse. I knew Uncle Zeno's Kate and Charley. Kate was a gray mare; no such mare as this; larger, more of her, good worker, not so good on the road. $\mathrm{He}$ drove her with a gray horse called Charley.

"I think Uncle Rufus raised a colt from the gray mare. I know she had a colt; she got out and came up on my father's place with a colt by her side. Rufus always bred his mares. She came from the place Zeno and Joel and Abel Rising owned together up to our place. I set a dog on her. I noticed that she trotted from the dog. I don't know whether she was kept on the place of Zeno and brothers or stayed there."

The abstract of this interview heretofore published failed to bring out the significant fact that it was a year or so after the teaming in 1834 that Rufus Rising got the dam of Ethan Allen. Taken as it stands, it takes up the mare's history and carries it forward from the very point where Mr. Leland lays it down. At another interview Mr. Rising says he is quite sure he saw the mare there before his father's death, which was in 1837 .

As to the identity of the mare after Rising got her there can be no question. Aside from the testimony of Hoyt Johnson and wife and J. B. Rising, there is that of Curtis Balcom, who states that Rufus Rising sold her to Geo. Johnson at his (Balcom's) place. John A. Pinchin thinks 
he remembers her in Johnson's hands. Ira Potter writes: "Rufus Rising sold the gray mare to Geo. Johnson. *** George Johnson sold her to Warner Cook ; I drove her when both owned her." W. G. Baldwin says he has heard Rufus Rising say that the mare was got in Vermont.

As to the mare's age, this would make her 9 when Ethan was foaled. Justus B. Rising said she was a young mare when his Uncle Rising had her. Azro M. Bailey thought she was in her prime in $184 \mathrm{I}-2$, and thought she was not over 19 or 20 when she died. John A. Pinchin, who "shod her from time to time," thinks she was not more than seven years "old when Cook got her. Hoyt Johnson thinks that when his brother George bought her of Rising she was seven or eight years old. This was probably in 1837 , as Rising got her in the summer of 1835 and bred a colt from her. It does not certainly appear whether this foal was dropped in $18{ }_{3} 6$ or 1837 . Hoyt Johnson thinks Rising had the mare only about a year; J. B. Rising's testimory would indicate that he kept her longer; but it is not material, as it is plain that between Rising and Johnson the mare was owned until the summer of 1838 .

Mr. Leland states that he traded the mare to Mr. Rising for a gray gelding. Ira Potter writes to A. W. Thomson concerning a gray gelding that Reuben Potter, his brother, sold to Rufus Rising about I830: "The horse that Reuben Potter, his brother, sold to Rufus Rising was a gray gelding."

Taken throughout, the case exhibits the harmony which characterizes truth.

$$
\text { Truly yours, W. H. BLIss. }
$$

\section{DAM OF ETHAN ALLEN.}

\section{[Editorial Middlebury Register, March 2, I888].}

The dam of Ethan Allen was bred by John Field, North Springfield, Vt., foaled I830, and got by Robin, bay horse with Morgan characteristics of style and speed, foaled about 1816 , and owned by Moses Bates of Springfield, Vt.

Mr. Thomson has been entirely off in regard to this mare, as he has, so far as we know, in regard to every horse or mare that he has ever written about. He has given the testimony of $\mathrm{Wm}$. Bevins in such a way as to suggest that his story was true, although he is universally spoken of as untruthful. This makes no difference with Mr. Thomson, whose only object would appear to be to write an article that will sell. The story is disproved by Ira Potter, a reliable witness, brother to Reuben, who, Wm. Bevins says, bought the mare of Ambrose Potter and sold to Rufus Rising. Ira Potter says this is not true; that his brother never bought such a mare, or sold any mare to Rufus Rising, though he did sell him a gray gelding about 1834 . And we presume this is the gray gelding 
traded in the summer of $\mathbf{1} 835$ to Fred Leland, at Apollos Austin's in Orwell, by Rufus Rising, for the dam of Ethan Allen.

The fact that the sons of Ambrose Potter, old enough to remember, do not remember that their father ever owned a colt, and are very sure that he did not, fairly disproves this part of Wm. Bevins' story.

Now what remains? There is, first, the story of Ira Potter, that Rufus Rising raised the dam of Ethan from the John Glazier mare. This is unsupported by any testimony except that of Ira Potter, and he when questioned as to how he knows, shows that he does not know, only heard it said. It adds to the proof, abundant otherwise, that Rufus Rising had the John Glazier mare, and is in itself a strong suggestion that that mare was not the dam of Ethan. It is to be remembered that Ira Potter, worked for Warner Cook and drove for him with another horse one or more winters this gray mare that was the dam of Ethan Allen. From that time on Mr. Potter knew her history, but before that he did not.

Second, the story that the John Glazier mare was the dam of Ethan Allen.

And, third, that a mare bought in Vermont by Rufus Rising and sold by him to George Johnson was the dam.

We see the first of these theories is entirely unsupported by admissible evidence.

We will consider the second-that the John Glazier mare was the dam of Ethan.

There is no question but that Rufus Rising at one time owned the John Glazier mare, a gray mare, quite similar in size and description to the dam of Ethan. This is proved by the testimony of Mr. Ackerman and Hoyt Johnson, both truthful witnesses; also by that of Ira Potter, and other testimony. Hoyt Johnson says he himself drove this mare when John Glazier owned her, in 1826 , from Hague to Bennington, Vt. He fixes the date the year after he first went to Hague ( 1825$)$ and the year before his marriage $\left(\mathrm{r}_{227}\right)$ as shown by the family record, and he says that two years after, in 1828 , Rufus Rising got this mare from John Glazier. Benager Ackerman, an upright and most intelligent witness, testified that in 1828 when he was drawing logs at Crane Pond, Rufus Rising had and worked this gray mare. It may, then, be considered as certain that at or about r $828 \mathrm{Mr}$. Rising got this John Glazier mare and owned her a number of years, probably till I 833 or ' 34 , when, after having hipped her in a snowdrift, he sold her and she passed to Caleb Balcom and son, who in turn sold her to Wm. H. Balcom. Wm. H. Balcom raised four or five colts from her and gave her, he said, in the fall of $\mathrm{I} 84 \mathrm{I}$, to Ira Wallace of Northeast Bay. Now Mr. Thomson assumes, and indeed, says, that this was the dam of Ethan Allen. He says this though the testimony is overwhelming that she was not; and he says it in an article that is paraded as 
authoritative without giving or speaking of this testimony, and still he must have read it all, has read it all. It is like his statement that a horse was born a certain year when he knew nothing whatever about it, except the testimony of the owner which he had just given, that it was born four years later. His intuitions are to him above ordinances; they are greater than facts and we are satisfied are deliberately substituted for facts. But whether so or not, such a witness ceases to be of any value. We have very strong testimony that Rufus Rising owned this gray mare, the dam of Ethan, about 1838 , when he moved from his old residence, near the school house, to the new one, where his son now lives. This was certainly after 1837. Benager Ackerman a very accurate witness was very sure he had the gray mare when he moved to the new farm. So was Myron Balcom, and so was J. B. Rising. We may, then, consider it quite certain that Rufus Rising had a small gray mare, and the small gray mare that was the dam of Ethan in $\mathbf{1} 838$. He could not have had the John Glazier mare then, for Wm. H. Balcom had her at that time. We have the testimony of Azro Bailey that he worked for W. H. Cook in I84I or' 2 while Mr. Cook owned this mare; that he drove her to Weybridge, and that she was a young mare, not over seven or eight, or so. At that time the hipped John Glazier mare was over twenty. We have much testimony that the dam of Ethan Allen came from Vermont; that Mr. Rising got her there. This was J. H. Wallace's original statement in regard to the mare, looked up a number of years ago by Messrs. Woodward and Baldwin for him. This is the repeated statement of Hoyt Johnson, who says he knows he got her in Vermont about 1834 or ' 5 , and sold her about I 837 or '8 to George Johnson.

But testimony that is to us conclusive, that she is not the John Glazier hipped mare, comes again from Justus B. Rising. Mr. Rising knew more about the mare than any one else we saw. His testimony made it certain that the mare Rufus Rising had was the dam of Ethan. According to our notes taken at the time of the last conversation Justus B. Rising said :

"My father, Horace Rising, used to go up to Hague in the fall and $\log$ through the winter, and I went with him when about I4 and drew logs; do not remember that I saw the mare at that time, but think it was afterward; used to see her frequently when I was there in the summer, because she ran in the lot next to our place; remember her having a colt; think it was an iron-gray colt: think the mare was a young mare. [Mr. Rising was born in 1820 and his father died in I837.] I think it was after my father's death that I saw the mare with the colt, but would not be certain. The mare was quite a jumper and they used to have a poke on her. Have seen my Uncle Rufus drive her in a team on the farm, but never saw him draw logs with her; do not think he ever drew logs with her; he seldom drew logs; he had a brown mare that he drove with her. Am quite sure I saw her there before my 
father's death; think that Ira Potter would be pretty apt to know about the mare, as he lived right there among the Risings and married Betsey Balcom, a sister of Uncle Zeno Rising's wife; he is an honest square man. Wm. Bevins always lived there. Rufus Rising lived very near where his son Rufus does now, this way a little farther south not more than I5o rods, where the mare had the colt. He moved from there to where Rufus lives now. The old place is near the school house on the upper side of the road. He moved first into a very small house, then built another that has been fixed over into the present one, which was built after his brother Horace's death."

The first Justus Rising remembers of his Uncle Rufus he was living at the school house place, where young Rufus was born. He had the gray mare when he lived there, and, he thinks, had her when he moved into the small house and thinks his (Rufus') daughter was born after he moved on to the present farm.

In another interview Mr. J. B. Rising said :

"I can't say that Uncle Rufus had the mare when I drove oxen up there at I4 (I834). I think that was before he had the mare. It was right away after that, perhaps a year or more, that Uncle Rufus had the mare. I knew the mare well. I did not see George Johnson have her, but it was always understood that she passed through George Johnson's hands. I knew the mare in Warner Cook's hands and always after that. I was a particular friend of Valorous, Warner Cook's son, and was well acquainted with Warner and his folks. Think he used to ride her. I frequently saw her in Warner Cook's hands-in Warner's and Wm. H. Cook's. I am just as confident it was the mare my Uncle Rufus had as I am that I stand here. Abel Rising never owned her; I think he did drive her. He lived close by Rufus-only one farm between. I never heard Uncle Rufus say, but I always understood he got her over the lake. I think Uncle Rufus raised a colt from her; I know she had a colt. She got out and came up to my father's place with a colt by her side. Rufus always bred his mares. She came from the place Zeno and Joel and Abel Rising owned together up to our place. I set the dog on her. I noticed that she trotted from the dog. I don't know whether she was kept or strayed there."

Rufus Rising, Jr., son of the Rufus that owned the mare, born 1824 and now living at the old place, says it was as late as 1838 when they moved on to the new place.

Against this exact and convincing testimony of J. B. Rising, Mr. Thomson puts his intuitions, and says that at the time when Mr. Rising says he saw her repeatedly and constantly at his Uncle Rufus' place, in Hague, while he was living on the next farm, Wm. H. Balcom was owning her and breeding colts from her miles away. The only evidence being an interview at the west with Mr. Cushman, then 86 , in which he is reported as thinking that the John Glazier mare, old and hipped, was sold by Ira Wallace to Warner Cook, and was the dam of Ethan Allen.

Second, a supposed statement, not verified, of Mr. B. Woodward, that the dam of Ethan was hipped. Third, the statement of Mrs. W. H. Cook that she was hipped, but this statement of Mrs. Cook was 
made exactly in this way: "She was hipped, I think that was what they call it." It is to be remembered that twice this number of good men and horsemen say that the dam of Ethan was not hipped but spavined. This is all. There isn't one particle of other evidence that we know of. There is much else we haven't mentioned against the John Glazier and Wm. H. Balcom hipped mare being the dam of Ethan. C. M. Balcom of Rosendale, Wis., writes, under date of Jan. 4, 1886 :

"Yours of the 26 th ult. received. In reply-Mr. Rising may have owned the mare as early as $18 \mathbf{2} 8$ but I do not remember her till two or three years later. She was not a colt when I first knew her. He owned her as late as 1838 . Whether he raised or bought her I do not know ; if he bought her I have no idea of whom. I do not remember of her having raised any colts while Rising owned her. I remember her in the hands of Warner Cook. I left Hague in August, r 845. I made my home with Wm. H. Balcom for some years; he owned a gray mare, but she had been hipped and was very lame and was not the dam of Ethan Allen.

$$
\text { Yours truly, } \quad \text { C. M. BALCOM." }
$$

A second letter from Mr. Balcom says :

"Wm. H. Balcom's father and my father were brothers and lived half a mile apart. After my father's and his father's death I made my home with him and worked out for farmers and others in that vicinity until he left Hague some two years before I left that place. The Wm. H. Balcom mare was an old, hipped and very lame when he bought her of Caleb Balcom for a small sum. I was about $\mathrm{I} 4$ years old at that time. I know that the mare was dead before Ethan Allen was foaled."

In another letter, Mr. C. M. Balcom says :

"I think the mare you enquire for passed direct from Rufus Rising to Warner Cook. I was born in Hague, in June, I8I8." And again in a letter dated Dec. 2 I, I885; "In answer to yours of the I5th I have to say that I am positive that John Harris or Wm. H. Balcom never owned the dam of Ethan Allen. The first I remember of her was when I was quite a boy, before I came to manhood. She was owned by Rufus Rising, who owned her a number of years, and called her his 'old colt.' If Rising sold her to other parties than Warner Cook they kept her but a short time and I never heard of the transfer."

Mr. N. W. Moon writes from Rosendale, Wis., Jan. 22, I 886 :

"I went to work for Warner Cook in the year I 840 in the month of April. He gave me my board and clothes for what I could do. I was I 2 years old at that time; I was 58 years old last August. In the fall of the year $1840 \mathrm{~W}$. H. Cook moved into the house with his father and took charge of the business. That mare was on that place at that time. I think Warner Cook got her in the year of 1838 or $39 . \mathrm{He}$ got the mare of a man by the name of Rising and I think it was Rufus Rising in the town of Hague."

Mr. Hoyt Johnson writes, Jan. 5, r 886 :

"Rufus Rising must have kept the John Glazier mare one or two years ; I do not know exactly how long; I know he drove her single and he worked her some. Whom he sold her to I do not know." 
And he writes again, Jan. 24,1886 , in answer to questions about the dam of Ethan :

"I knew John Harris, but he never owned that mare. Caleb Balcom and son never owned that mare, and George Johnson (the writer's brother) never sold her to them. No one ever owned that mare after George got her till he sold her to Warner Cook."

Here is a witness, living where he should know all about it, who remembers that Mr. Rising had the two mares.

We said once, that we thought Hoyt Johnson's memory not good, but this was based on the idea that he was mistaken about this mare's coming from Vermont. If he was correct in this-and it seems he was-there is nothing to impeach his memory. And it would seem now that perhaps it was Mr. Thomson's memory and ours, that were at fault, and considering the fact that the occurrences took place before we were born it is not remarkable that we should fail to remember them.

The only evidence, then, contrary to the supposition that the mare came from Vermont is Ira Potter's belief that Rufus Rising raised her, which he admits was founded on rumor, and Mr. Cushman's statement that she was the John Glazier, Wm. H. Balcom and Ira Wallace mare.

Let us see how reliable Mr. Cushman is in other statements; for in this way we can best test the value of his testimony. It is admitted by all that he is an honest and worthy man, but he was 86 years old and one witness writes: "You must make allowance for his age." Mr. Cushman says that Zeno Rising disposed of the Glazier mare to Riley and Wm. Balcom. This is certainly an error. The evidence is incontestable that Rufus Rising sold her to Geo. Johnson and he to Caleb Balcom, Sr., and his son Samuel S. who in turn sold her to Wm. H. He thinks it was about i 850 that Warner Cook bought the mare of Ira Wallace. At least seven years out of the way. He doesn't think the mare raised any colts before Holcomb got her. To question whether Mr. Cook raised any colts from her he says, "No. Mr. Cook had another gray mare which he had for many years." This is straight testimony that the Ira Wallace mare was not the dam of Ethan, and we cannot see what other gray mare he could refer to of Mr. Cook's except the dam of Ethan. The Cooks owned the dam of Ethan five or six years and raised three colts from her. It is evident that the old man's memory fails. Then it should be remembered that he has been interviewed only by letter. A personal interview with him might have elicited the fact that he referred to another mare.

To conclude: The testimony is overwhelming that Rufus Rising had two gray mares, the first one the John Glazier mare that he bought about I 828 and sold about 1833 or ' 34 , after he had hipped her in a snowdrift. The second one, that he bought about 1835 and sold about I 838 , and that this last mare was the dam of Ethan Allen. This is very evident entirely outside of the testimony of Frederick Leland of Middle- 
bury, Vt. Then comes Mr. Leland's testimony fitting like a key to a lock to almost all that had preceded it, and, stating that in the summer of $1 S_{35}$ he traded this last gray mare to Rufus Rising for a gray gelding at Apollos Austin's in Orwell ; that said mare was one bred lyy John Field, North Springfield, Vt., foaled in $\mathbf{1} 830$, whilst he was working for $\mathrm{Mr}$. Field; and bought by himself in the winter she was coming four of $\mathrm{Mr}$. Field; and that was got by a horse called Robin or Red Robin, owned by Moses Bates, Springfield, Vt.

Mr. Leland further states that he afterward saw this mare when $\mathrm{Mr}$. Holcomb owned her, and at David Hill's, when brought to be bred to Black Hawk, and that he knows that this was the same mare that he sold to Rufus Rising.

To those who know Mr. Leland, and we have known him for years, this would be conclusive, even though other testimony was adverse, unless it proved that the statement could not be true, but as nearly all the testimony sustains Mr. Leland's, we accept the pedigree of the dam of Ethan Allen, as established. As Porter Champlin of East Middlebury, a neighbor of Mr. Leland, and a man whose uprightness and judgment are the very highest possible, said: "Mr. Leland told me this same story twenty years ago, and it's right."

It is to be remembered that more effort has been made to trace this mare than probably was ever made before in this country in the tracing of any horse, at a cost of at least $\$ 300$, and the testimony obtained was published in the Middlebury ReGister, extending in serial numbers some four months.

STATEMENT of Frederick A. Leland of Middlebury, taken April 23, I888, by Judge W. H. Bliss :

[From Middlebury Register, May 25, i888].

Question.-When and where were you born?

Answer.-I was born in I 8 I I, at a little place now called Perkinsville in Weathersfield in Windsor County, Vt., which adjoins Springfield, where I first saw the colt. I lived in that county, mostly at Springfield, until I was ten years old.

Question.-For whom were you working when you first saw the gray filly that you sold to Rufus Rising, and how old was the filly when you first saw her?

Answer.- I was the first person that ever saw her. My time was out with Esquire Field, but I was staying there on account of the death of my grandfather. Esquire Field asked me to watch the mare, and I did. I took a lantern and went out and found the filly in the sheep shed on the straw by the side of the mare. It was in April i 830 . filly?

Question.-What do you say the man's full name was who bred the Answer.-Esquire John Field, a very nice man. This filly was not 
gray when it was foaled, but a kind of mouse color, and there was some question what the color would be. The dam was black, not very black; some would call her brown. The filly began to show gray hairs and at four years old was gray, not a light gray, but grew lighter as she grew older. When I saw her at Ticonderoga, when at Bly's, she had whitened out a good deal. Esquire Field went West and was drowned in the Mississippi. I think Ethan Allen got his color and a good part of his activity from Red Robin. Red Robin was as handsome a bay horse as ever you saw, a playful horse, supple as a fox, as handsome as Ethan Allen, who looked like him.

Question.-Do you know who bred this black mare that brought the gray mare, and what do you know of her pedigree?

Answer.-She was bred by a man named Bemis, who lived in Baltimore, or the edge of Baltimore, a little three-cornered town adjoining Springfield, Weathersfield and Chester. She came of a chestnut Morgan mare that came from Tunbridge and was brought to Chester by a Deacon Chandler. You see these three towns corner in together, and they all went to the same meeting. They said this mare was by the old Justin Morgan. This mare brought several colts : my grandfather had one, a bay mare, a Morgan mare for all the world, that I used to ride in scrub races when I was about twelve years old. There were two other mares from the Dea. Chandler mare that I remember; one a chestnut. Simeon Keith had a chestnut one, and this Bemis mare, black or dark brown. Don't know as I can give this Bemis' first name. I should think she was a fair fifteen hand mare, this Bemis mare, and a well spread, good-built mare. She went by the name of the Bemis mare; there was the Keith mare, the Leland mare, and the Bemis mare, right there in our neighborhood. All three were fair-sized mares and Morgan to the brim. I think the sire of the Bemis mare was what they called a Bullrush Morgan and that the Leland mare was by a Woodbury, but I wouldn't make oath on either, it is so long ago ; if I had supposed I was to be questioned about it as late as this I should have made more inquiries. But I can look back and see that they were Morgans all over. As quick as I was old enough to see a horse, I saw Morgans. We were full of Morgans then in Windsor County. Mr. Battell's Motion was as much of a Morgan as any I have seen late years.

Question.- How old do you think the Bemis mare was when she brought the gray filly?

Answer.-I declare I can't tell you; she was a middling aged mare; she had two or three other colts.

Question.-Do you know anything of the Bemis mare's qualities?

Answer.-I should say she was a gentle, good working mare. Esquire Field used to work her plowing out corn and other things as a man would use a brood-mare. She was an ambitious mare; none of the three were dung-hills; but I was a boy and didn't pay particular attention to her. She was a brood-mare.

Question.-What horse was sire of the gray filly brought by the Bemis mare?

Answer.-Red Robin, a bay horse owned by Moses Bates of Springfield, $\mathrm{Vt}$.

Question.-How do you know that Red Robin got the gray filly?

Answer.-I was working for Esquire Field at the time and I held the mare when she was bred to Red Robin, and I was the first one that ever saw her filly. 


\section{Question.-Do you know where Moses Bates got Red Robin?}

Answer.- No I do not, but I am inclined to think he bred him; he owned Red Robin as long as $I$ knew anything about him and from the time he was quite a young horse.

Question.-What did you know about the gray filly from the time she was foaled till she was four years old?

Answer.- She was out of my sight those four years. I went on to the mountain farming for about two years and then I went peddling for $\mathrm{Mr}$. Bow of Pittsfield for a couple of years. I went to Esquire Field's when on a visit to Springfield, when the filly was four years old, and he had a lot of Connecticut clocks, sixty of them, that he said he would give me a dollar apiece to sell. I took the Bemis mare, and loaded up with clocks, and peddled them out, and earned sixty dollars. When I left Esquire Field the filly was by the side of the mare. She was now four years old and her color had changed from mouse color to gray. I I thought she was the filly dropped by the Bemis mare before I left, and asked Esquire Field, and he said she was. I wanted to buy a horse for I had arranged with I. C. Shaw of Sherburne, Vt., to peddle for me the next spring. I liked the filly and finally Esquire Field let me have her for the sixty dollars I had earned selling the clocks.

Question.- - Vhat was the history of the mare while you owned her?

Answer.-I kept her at my father's barn, or rather my own barn at the place where my father lived in Sherburne, Vt., during the winter. In the spring before the snow was off I hitched her to a jumper and drove her over the mountain, and staid over night at Oscar Sheldon's, who lived down here about two miles on the Salisbury road where Moses Sheldon now lives. Kneeland Olmstead of East Middlebury had been building me a wagon for peddling. I was delayed a couple of weeks, and then, as the snow was off on this side, I hitched the mare to the wagon and went to Albany, N. Y., where I bought $\$ 2700$ worth of goods and came back. This mare was then five years old and a mare of great bottom. I drove her from Albany, N. Y., to Fair Haven Vt., with those goods in one day. There I met Shaw, who was just going to work for me; he followed my business till i 840 . He had another horse there that belonged to me, and a cart, and then we unboxed the goods prepared them for sale, and we divided them, and started out; and we came along together up by the lake, and he went across the lake and I came up here to Middlebury. He went to Schroon, Hague, etc. Bye and bye we met back at Whitehall. There the mare ran awaydidn't do any damage, but she was so skittish I made up my mind she wouldn't do for our business; we wanted a horse we could make stand without hitching, and we could not make her, she was so full of mettle. Shaw was driving her. I never drove her after I got back from Albany. I had a good horse that I got at Rutland that I drove and which I let Shaw take after I traded the mare, and I took the gray horse. She didn't get away when he was driving her, but he left her at a door and something started her and she ran. She was a good mare, but she was nervous and high spirited. Shaw frightened her once with the bearskin; we had bear-skins over the hames, and in throwing the harness on to her he frightened her so with it that he had to take the bear-skin off from the harness. This was a bear-skin cut in two for the two harnesses, half for each; we used iron hames; these skins went over the top of the shoulders to protect them. If I had the mare today I wouldn't take $\$ 200$ for her, but I made up my mind then I had got to sell or tracle 
her as she was not fitted for that business. She was driven after that by Shaw up through the lake towns to where he crossed the lake, and he went through his trip and was back again with the mare. I had ordered him to trade her, but he felt loath to do so, as it was my horse. $\mathrm{He}$ wrote me to meet him at Apollus Austin's in Orwell. It seems he had a customer. He came to Austin's with a man he introduced as Mr. Rufus Rising. This was in 1835 and I think early in July. Shaw had already got the terms of the trade but had not completed it. I agreed to the terms, and the horses were exchanged, and I got a gray gelding which I took and drove on my peddle cart, and Shaw took the bay I had been driving. The gray gelding I got was a young horse, I don't know just how old, rather a showy horse, about I 5 hands high, not a heavy horse. He was a little dappled on the hips, otherwise a straight gray, with, I think, lightish, mane and tail. The mare when I let her go had got to be considerably gray. She was a good, fair, comfortably gray when she was four years old-she was not white when I let her go but gray. Shaw used to stop with Jewett Bly, who then lived at Ticonderoga, but who moved here to Middlebury the next year, 1836 , and lived here several years and did some lumbering business, and then moved back to Ticonderoga. Shaw got him to look the horses over before the trade and got his judgment on them. I knew this Bly well when he lived in Middlebury. He told Shaw the mare was worth more than the gelding, but perhaps we could afford to trade for our purposes. Bly frequently spoke to me about the mare I traded to Rising, and several years afterward, after he had lived here at Middlebury and had gone back, I was at his place in Ticonderoga and he pointed her out to me on the street and said "there goes your gray mare." I think I I should have known her, though she had grown lighter in color. It was not J. W. Holcomb that was driving her, for I knew him and did not know the man driving the mare. Bly told me what hands she had passed through but being strangers to me of course I did not remember the names. I cannot tell what year it was that I saw her in Ticonderoga.

Question.-When did you next see the mare any where?

Answer.-I don't recollect seeing her again till I saw her at Bridport. David Hill and I were particular friends, and I used to make it my home there when travelling. I had some notion of breeding to Black Hawk, but the terms were pretty high and finally Hill said to me, "bring your mare out and you may breed her for nothing." Upon that I did take a mare there and staid there over night and happened to see this gray mare there. her?

Question.-Did you recognize the mare at Hill's and who was with

Answer.-Oh yes, I knew the mare. Holcomb was with her and a boy. I had just as good a chance to know the mare both times as I should my old mare out here if she had been away a short time.

Question.-Did you tell Holcomb you had owned the mare?

Answer.-Holcomb and I had talked it over before that time, several times, that he had the gray mare I traded to Rising. He understood this was the same mare.

Question.-Did you ever see Rising after you traded?

Answer.-Yes, the next year I 836, after he got the mare. I met him at Middlebury in the barber shop of Mr. Dustin, who kept a sort of grocery store and barber shop, where Asa Rising worked. This Asa was 
some connection of Rufus Rising. I see it reported that I said he was a nephew; I have not said that, but I understoorl he was a connection. Well I was introduced to Rufus Rising in that barber shop, and he and I both said we had met before, and spoke about the horse trade. He had this gray mare in the stable of the Midulebury House and I went up there to look at her, and looked her over.

Question.-Did you see the mare bred to Black Hawk, and if so what year?

Answer.-I did see it. She was bred at night and my mare was bred the next morning. It was in 1848 .

Question.-Are you certain of the year?

Answer.-Yes I am quite certain of the year. It was three years before our first State Fair, which was at Middlebury in $185 \mathrm{I}$. The second State Fair was at Rutland in $\mathbf{I}_{52}$, and Ethan Allen was there, three years old, and Russel Bly and I were there, and he pointed out this bay trottfng colt and told me he was out of this gray mare that I traded to Rufus Rising.

Question.-Did the mare, when you saw her at Bridport, have a foal by her side, and if so what color?

Answer.--Well, sir, I wouldn't swear, but I should think she had a colt by her side that was turning gray. I know about Red Leg, and I remember the Bemis mare had a peculiar mark, of lighter color than the rest, running from the top of her withers down onto the shoulder blade.

Question.-Are you positive that the gray mare had any colt by her side, at Bridport?

Answer.-It is my impression. I wouldn't swear she had any colt, but that is my impression. My mare did not get in foal, and I never raised a colt by old Black Hawk, but did from his sons. From Rolla I bred Gen. Putnam, that I sold for $\$ 3,000$.

Question.-In what month were you born?

Answer.-June I3, I 8 I I.

Question.-How old were you when you got through working for Esquire Field?

Answer.-I got through working for him in the spring of 1830 , and that was the time that this gray filly was born.

Question.-Please describe this gray mare?

Answer.-Well, sir, I don't know, of any great difference from common gray mares. When she was four years old she had got to be considerable gray.

Question.- Was her head fine or coarse?
Answer.-It wasn't a coarse head. It was a fair, comfortable head, and what I call a good face. She had a very pretty ear and a good full eye that showed to good advantage.

Question.-Mane and tail, how were they?

Answer.- Not the heaviest, not the lightest; at five years old she had a good fair mane and tail-gray.

Question.-Neck light or heavy, long or short?
Answer.-A middling neck, not remarkable anyway. A good shaped neck of middling length well set on the withers.

Question.-Was she sound when you traded her?

Answer.-She was as far as I know. I had never discovered any unsoundness about her.

Question.-And was she sound when you saw her at Bridport? 
Answer.-I wouldn't say she was sound then. I didn't look her over in particular. There may have been some blemish about her. Or, she might have been out of fix in some way, I could not say.

I hereby certify that I have carefully read over the foregoing statement, the questions of which were asked by W. H. Bliss, Esq., Middlebury, and the anwers given by me, at my house in East Middlebury on April 23, I888, and that the same is correct and true to my best knowledge and recollection.

East Middlebury, April 26, I 888.

$$
\text { (Signed) F. A. LeLand. }
$$

Statement of Moses S. Sheldon a reliable citizen of Salisbury, Vt., taken May 21, I888.

Question.-What was your father's name and where were you born and when?

Answer.-My father's name was Oscar P. Sheldon. I was born in Salisbury, Vt., Dec. 24, I 824 .

Question.-When did you first know Fred A. Leland, now of Middlebury, Vt.

Answer.-I can't give the date, but he used to peddle for Peleg Bow of Pittsfield Vt., and carry trunks before he had a team; he and Bow both used to peddle and both used to stop at my father's house in Salisbury; this was when I was a boy.

Question.-What, if anything do you remember about Fred A. Leland's coming to your father's house with a gray mare?

Answer.-He did come there with a gray mare: It was in the spring of the year. I cannot give the year but it was when I was ten or a dozen years old. He had just got a new peddler's wagon, made by Mr. Olmstead of East Middlebury. He told father he was just starting out for himself that he had made money for Mr. Bow, and might just as well be making it for himself. He hitched the mare to the post and I can see just how she looked just as well as if it was today, how she looked round as she stood there; she was nervous and had a wild, scary look, as she looked round; she had a large prominent eye and a large nostril; She was a young mare and nervous. Mr. Leland told my father he didn't suppose he could peddle with her, she was so nervous; said she was kind, but he could not leave her without hitching her; said he thought he should have to trade her. She was rather lightish gray on her body; shoulder, hips and legs darker; carried her head well up; a medium sized mare. She had a long tail, I think darker than her body. He said she was raised the east side of the mountain, I think by a man he had lived with, I don't know the name.

Question.-Do you know what became of the mare?

Answer.-I do not. Mr. Leland had a man by the name of Bart. Shaw peddling for him right along after that time, and they both of them used to stop at my father's house and would often stay there over night. I think they had peddled together before and carried trunks. I do not remember Shaw's coming there with a team after that. I do not think I ever saw the gray mare after that time. Leland after that drove different horses; I remember one, a dark colored horse, I think bay or perhaps dark chestnut, that I rode after with him coming home from school. I understood at some time that he and Shaw traded the gray mare away. M. S. SHELDON. 


\section{IMPORTANT LETTER IN MIDDIEEURY REGISTER FROM} MR. W. H. BLISS, CONCERNING THE DAM OF

\section{ETHAN ALLEN.}

\section{Miduleilery, V't., Nov. 9, 1888.}

EDITOR REgister :- In a recent issue of the Manchester Mirror and Farmer appeared an article by A. W. Thomson concerning the above named mare. It contained copies of letters from J. G. Balcom of Gardner, Mass., and Justus B. Rising of Ticonderoga. The latter, it will be remembered, was three times interviewed by Mr. Battell and myself in the fall of 1885 , and the interviews were published in the Register the next winter. Mr. Rising's statements were all clear and consistent to the effect that he saw and knew the gray mare that became the dam of Ethan, first in the hands of his uncle, Rufus Rising, from about $\mathrm{I} 835$ to about $\mathrm{I} 837$ and not earlier, as he thought, than $\mathrm{r} 835$; that he afterwards knew her in the hands of Warner and William $\mathrm{H}$. Cook and J. W. Holcomb; that he learned from the Cooks that Warner Cook had her of George Johnson. In all three interviews Mr. Rising, who is a very candid and trustworthy man, never intimated that he had seen the mare earlier than $\mathbf{1} 835$, which date he carefully fixed by his own age at the time and by the death of his father; nor did he suggest that he ever knew or heard of her being in the hands of any other person than Rufus Rising and George Johnson before Warner Cook had her.

The statement of F. A. Leland, that this mare was bred by John Field of Springfield, Vt., foaled in 1830 , and that she passed through his (Leland's) hands to Rufus Rising in the early summer of I 835 , fitted this testimony of Justus B. Rising as a key fits a lock, and enabled us to give the full history of the mare from birth to death without an interval. The statement was also consistent, at all points, with the great mass of testimony that had been taken by us and published two years before the statement was made, as was pointed out in an article by me in the Register of May 20, I 887 , in which the interviews with Justus B. Rising are quoted. It unfortunately happened, however, that this discovery threatened to demolish the reputation as a pedigree hunter of Mr. Allen W. Thomson of Woodstock; and that being the only reputation which that gentleman seems to have had, he was naturally put out about it. He had pinned his faith to a gray mare that one W. H. Balcom gave away to one Ira Wallace in the fall of $184 \mathrm{I}$, having owned her for some five or six years previously. The fact that the dam of Ethan was clearly proven to have been in Warner Cook's hands as early as 1839 did not shake Mr. Thomson's faith; for he has abundant leisure, and if a person does not state exactly what he desires, he writes letters to him in that mispelled, pot-hook chirography of his until the witness becomes demented. The ugly circumstance respecting the 
Balcom mare was that Balcom bred five colts from her, and therefore (if Cook had her in I839) must have owned her as early as I834. Mr. Thomson's task, then, was to make Justus B. Rising remember that it was earlier than 1834 that he saw the mare in possession of his uncle Rufus, and that she passed through the hands of Caleb Balcom, and son, W. H. Balcom, and Ira Wallace to Warner Cook. Nothing then would remain but the comparatively simple task of sticking letters into W. H. Balcom, until he should remember that he gave the mare away in 1838 instead of $\mathrm{I} 84 \mathrm{I}$. Another trifle in the way was that the Balcom mare was badly hipped, and the dam of Ethan, as appeared by a weighty balance of testimony, was not hipped. Furthermore, the dam of Ethan was spavined and the Balcom mare was not. Again it was beyond dispute that the dam of Ethan, when Warner Cook had her, was sound and in the prime and vigor of life, a gamely and tireless roadster, and able to trot with Warner Cook's two hundred odd pounds on her back very close to a three minute gait; while Balcom's mare was old, badly hipped, and, as he thought, not worth wintering, when he gave her away.

These things were "airy nothings" to Mr. Thomson. He had not manufactured a sire for both Black Hawk and Ethan Allen, and evolved out of his inner consciousness a Hamiltonian dam for Flying Morgan, to be daunted by trifles like these. So he proceeded to write letters.

It so happened that among Mr. Thomson's disciples was a former Hagueite, the said Joseph G. Balcom of Gardner. Letter-writing proving for once too tedious, Mr. J. G. Balcom goes to Ticonderoga loaded to the muzzle with Mr. Thomson's precious information, which he proceeds to impart to Justus B. Rising. That gentleman remembered that W. H. Balcom, back in those early times, had a gray mare something like the dam of Ethan. Having long suffered from the thumbscrew of Mr. Thomson's correspondence, and being now stretched upon the rack by Mr. Balcom personally, Mr. Rising did at last reluctlantly confess, in the Mirror letters, that he thought he did remember the dam of Ethan in the hands of his uncle Rufus as early as $\mathrm{I}_{3} 8_{2}$ or $\mathrm{I} 833$; that Johnson sold her to Balcom, and that she was hipped. Parading these letters in the Mirror, and totally suppressing all the other testimony given by $\mathrm{Mr}$. Rising, the honest and ingenious Mr. Thomson rubs his hands and considers that "half his heavy task is done."

These statements of Mr. Rising, if fairly obtained and really springing from a refreshed recollection, would sharply raise the following questions :

First, whether the dam of Ethan did or did not pass from George Johnson direct to Warner Cook? If she did, Balcom never could have had her.

Second.-Whether she was hipped. If not, she was not the Balcom mare.

There was plenty of evidence all ready published that Rufus Rising 
sold the mare to George Johnson, and George Johnson to Warner Cook. Ira Potter wrote that George Johnson sold her to Warner Cook and that he drove her when both owned her. Not knowing that this point would be disputed, we did not inquire for actual witnesses of the transfer ; and we did not inquire as fully as we might whether the mare was hipped. To get further information on these points, and to learn, if possible, the source and reliability of Mr. Rising's new light in the matter, I visited Ticonderoga and Hague last week. I commenced work Tuesday morning, assisted by that thorough horseman and reliable gentleman, Mr. Stephen C. Bailey of Ticonderoga, who has always taken a great interest in the solution of this problem.

We first saw our old friend, John A. Pinchin, hale and active at $7 \mathrm{I}$, engaged in his favorite pastime of shoeing a horse. His statement, which was carefully read over to and signed by him, is as follows:

\section{Ticonderoga, Oct. 30 , I 888 .}

John A. Pinchin, aged 7 I years Dec. 6, I888, says :

I was married Oct. 2, I 844 , at the Diehl farm house on the lake. Joel W. Holcomb told me to take the old white mare, and I did, and drove her down there. I had known the mare ever since George Johnson had her. Am positive I have seen him drive her in a pair with another gray. I saw her a hundred times when the Cooks had her on the farm. They used her to draw lumber from Brant Lake and she was sharp to draw and they got a spavin on both legs. I have shod her a great many times. Her hips were as straight as any horse's in the world. Know? Of course I know. I always knew the mare well; used to see her very often while Holcomb owned her : used to shoe her then. I shod her after Ethan was foaled. Joel showed me Ethan when he was nine days old; asked me to see the best colt I ever saw. A man named Justin Naramel was tacking some old shoes on the mare then to be taken back to Black Hawk. Holcomb called Ethan a Black Hawk colt; he never said different till he got mad with Hill; he always claimed to me that Ethan was by Black Hawk. When the colt was nine days old I think Frank Robinson, who worked for Holcomb, took the mare back to Black Hawk, or started with her. Justin Naramel is still living in Dresden, Washington County, N. Y. I am not sure, but think it was Frank Robinson.

None of the Balcoms ever had this mare. The hands she passed through, after Rising had her, were George Johnson, Warner Cook, W. H. Cook, George Weed and J. W. Holcomb. I knew the mare all the time after Johnson got her; knew her in the hands of all these owners. I think I saw Rufus Rising have her before that, but am not positive. I know I knew her well from the time Johnson had her. No Balcom ever owned her after Johnson got her.

The above is correct.

Witness, Stephen C. Bailey.

(Signed) John A. Pinchin.

We next saw Geo. C. Weed, who said:

"I bought the mare, with a bay colt by her side, of William H. Cook. I paid him $\$ 50$ and took his lumber to boat for pay. I sold the 
colt, an excellent colt by the Burge Horse, to Abijah Nickerson for $\$ 25$. He sold it to Felton for \$I oo. I think when I had her she had a spavin; one at any rate, might have had two."

Question.-_"How about her hips?"

Answer-"I don't remember. My impression would be that she was hipped, but a horse with a spavin will get a hip down a little and that may have been it."

We then drove up the Hague road to the handsome country place of the Rev. Joseph Cook, and called on that bright and amiable old lady, his mother, widow of the late William H. Cook. Mrs. Cook is quite an accomplished horsewoman, and takes much interest in our efforts to trace this mare. She said:

"I understand that Warner Cook got the mare of Johnson, who had her of Rufus Rising. I never heard of Balcom's having her. Have always understood that Rising went to Vermont and traded and got her. She was not an old mare when we first had her. They drew lumber with her. She could not have been over ten. I drove her a good many times. She never went lame, not to notice, when I drove her. She was a pretty high-lifed mare; went pretty well. I could not tell from my own observation if she was hipped; I do not know what that is; but it seems to me that I heard them say something about her being hipped. She was so afraid of a buffalo that we could not carry one with any comfort. I knew her before we went up to the other place; she was here on this place a good deal before we moved up there in October, I840. I think we had her more than a year before that. I knew we had her here one summer at least before that, for I remember driving her to Hague with my mother, and we had a buffalo in the wagon, and the mare went like a perfect storm. I could not hold her. There was a man behind us, and I got him to drive the mare and I drove his horse."

On our way here we called on Mr. William G. Baldwin. This courteous gentleman, himself one of the leading horsemen of Ti., many years ago attempted to trace this mare, and talked with Rufus Rising about the matter. He learned from Mr. Rising that he got the mare in Vermont. He also learned that she passed through the hands of George Johnson, Warner Cook, W. H. Cook and George C. Weed to J. W. Holcomb; in other words, he traced her through all the hands that she actually passed through after Rising got her; he did not find that any Balcom ever had her. His work in the matter was embodied in an article in Wallace's Monthly. Mr. Baldwin told us that although he was familiar with the mare and frequently described her, he was utterly unable to say whether she was hipped or not; she was spavined, and whether her peculiar carriage behind resulted from that or from her being hipped he could not tell. But he said that John A. Pinchin would know, as he was very observing of such things and has the best of memories and what he said we could rely on. Mr. Weed also told us that what Mr. Pinchin said about it would be reliable. Mr. Baldwin also told us that he had read Leland's statement and had not a particle of doubt but that it was correct, and that the mare Leland traded to Rising was the dam of Ethan 
Allen. No person could make up a story that would fit so perfectly all the known facts.

As we were leaving Mr. Pinchin in the morning he told us that if anybody had any doubt about (ieorge Johnson's having sold that mare to tell them to go and ask Hoyt Johnson; for Hoyt Johnson, and, he believed, his wife, too, saw the mare delivered and the money paid. So, after taking leave of Mrs. Cook, we drove up the somewhat unfrequented road to New Hague. Here we found our two old friends, Hoyt Johnson and Rebecca, his wife, now well started on the seventh decade of their wedded life, but still well and hearty. Two chubby little rogues, five or six years old, the children of a deceased daughter, that have come to them since our last visit, make up their family. Our interview was by the kitchen fire and both Mr. and Mrs. Johnson took an active part in the conversation, joining in nearly all the statements I took down, which are as follows :

Hoyt Johnson says that he was at his brother George's place in the fall of I 838 . (Mrs. J.) "It was quite late in the fall-about this time. Perry, born in August, was quite a little baby say two months old." (Both), "We lived close together, the horses run right in the pasture in front of our house. George Johnson lived on the place where Samuel Ackerman now lives, and we lived in a little house close by." ( $\mathrm{He}$ ) "Warner Cook paid my brother, George, $\$ 65$ and borrowed a bridle and saddle of George and put the saddle on the mare and said to her. 'I will try you with two hundred pounds.' I stood right by ; he got onto her and rode her away. I did not hear the bargain made; it seemed to have been made before, perhaps that forenoon. The mare was then sound. Nothing ever ailed her as far as I knew while my brother had her."

Mrs. Johnson remembers the circumstances; says it was right before their house; says she heard Cook make the remark about trying her with two hundred pounds, and saw him take the mare away; says she had the impression that the mare was darker than the rest say, but thinks now that they are right.

Hoyt Johnson says :

"I lived near Warner Cook after he got the mare. He bought the present Joseph Cook farm for his son, W. H. Cook, and let him have this mare and another horse for a team down there. I knew this mare that my brother, George Johnson, sold to Warner Cook all the time till her death. I knew her when the Cooks owned her and when Holcomb owned her. Saw her a good many times in the hands of each. She was too good a mare to put in a team, but they didn't know it. The Cooks drew lumber with her from Brant Lake. She was never hipped, not when I saw her."

If Allen W. Thomson still thinks that George Johnson sold this gray mare to Caleb Balcom and son and not to Warner Cook, he should lay 
aside all other recreations and go and interview Hoyt and Rebecca Johnson.

We drove immediately back to Ti., left the team at the barn and the first man to attract Mr. Bailey's notice was the veteran horse-breeder, Gustarus Wicker. Mr. Wicker evidently did not recognize me. Mr. Bailey put him this exact question, which I took down, with what Mr. Wicker said in reply :

Question.- "Mr. Wicker, we have got into a little controversy and want you to settle it. The white mare that brought Ethan Allen, was she hipped?"

Answer.-_No, she was not hipped. She was spavined and she favored one hind leg, and that made her carry that hip lower; that is why some thought she was hipped, but she was not. When Holcomb had her she was spavined, but when I first knew her, when Warner Cook had her, she was all sound and right."

Mr. Wicker here told the story, which we have before published, about riding his French mare a sort of highway trotting match against this gray mare, ridden by Warner Cook. He also said that he owned the Sir Walter that got the last colt that this mare had before Ethan Allen; that he took a mare to Black Hawk at the same time that the Holcomb mare was taken there when the Sir Walter sorrel colt was by her side; that he held the Holcomb mare when she was served by Black Hawk, and that he always understood that Ethan Allen was got by this service.

As we were starting out on this trip Mr. Stephen C. Bailey (who is a relative of Mrs. W. H. Cook) told me that he once asked Mr. W. H. Cook what horse got the dam of Ethan Allen, and Mr. Cook replied that he did not know; that he got the mare of his father, who had her of Rising; that she came from over the Green Mountains, and there was nothing definite known about it.

I will say, in passing, that W. G. Baldwin, Gustavus and Charles Wicker, William A. G. Arthur, John A. Pinchin and Azro M. Bailey (since deceased), all old horsemen of Ticonderoga, familiar with J. W. Holcomb from before the time he bred Ethan Allen, have all assured me that the talk about Ethan Allen's being by any other horse than Black Hawk was the merest gammon. I have never yet seen a horseman of Ti. that treated the Flying Morgan theory with anything but contempt.

But, to resume. In the evening we drove up to the Upper Falls and called on Justus B. Rising at his comfortable home. I called Mr. Rising's attention to the Mirror letters and showed him a copy of his interviews, all that he recollected, and according to his best recollection, concerning this mare. He spoke about receiving letters from Thomson, and finally of having had a visit last fall from Joseph G. Balcom, who talked a great deal about this matter. He remembered the W. H. Balcom gray mare, and Mr. J. G. Balcom was so positive that this mare was the dam of Ethan, and that the dam of Ethan was hipped, and that he must 
have seen her in his uncle Rufus' hands as early as 1833 , that he became pretty much convinced that it was so, and that his former recollection was at fault. He had no idea that Balcom had any object in making these representations to him, or that he was at work for Mr. Thomson, but supposed that Balcom was speaking from a clearer knowledge of the facts than he himself had. So when written to by Mr. Thomson he gave him his information as revised and corrected by Mr. Balcom.

I showed him my article of May 20, 1887, and on the evidence therein given Mr. Rising said that had he known those facts, he should not have made the statements contained in the Mirror letters; and he gave me the following written statement, which he signed:

\section{Ticonderoga, N. Y., Oct. 30, 1888 .}

"I hereby certify that, on reviewing the facts concerning the dam of Ethan Allen, contained in an article by W. H. Bliss in the Middlebury Register of May 20, I 887 , I think that what I am there reported as saying is correctly stated, and the facts are as there stated. What I have stated in regard to the mare's being in W. H. Balcom's hands, or being the same mare that W. H. Balcom had, arose principally from conversations I had last fall with Joseph G. Balcom, in which I became pretty much convinced that such was the fact. I now think the W. H. Balcom mare was a different mare, and that Warner Cook got the mare that became the dam of Ethan Ailen direct from George Johnson. It was never clear to me that the dam of Ethan was hipped, or half hipped, and I cannot say now whether she was or not. I remember she was lame when Holcomb had her.

Witness, S. C. Bailey.

(Signed) J. B. Rising."

The former testimony of Mr. Rising, which he now reaffirms, is mostly summed up in the last interview which was taken by me Oct. I3, I885, and which Mr. Rising read over carefully before signing the above statement. It is as follows :

"I can't say that Uncle Rufus had the mare when I drove oxen up there at I 4 ( $\left.\mathrm{I}_{34}\right)$. I think that was before he had the mare. It was right away after that-perhaps a year or more-that Uncle Rufus had the mare. I knew the mare well. I did not see George Johnson have her, but it was always understod that she passed through George Johnson's hands. I knew the mare in Warner Cook's hands and always after that. I was a particular friend of Valorus, Warner Cook's son, and was well acquainted with Warner and his folks. Think he used to ride her. I frequently saw her in Cook's hands, in Warner's and William H. Cook's. I am just as confident that it was the mare my Uncle Rufus had as I am that I stand here."

Mr. Rising fixed dates by his father's death and other events in such a clear and careful manner that I was convinced at the time that he was right. But, if Leland's statement is true, the mare would have first appeared in Rufus Rising's hands in the summer of $\mathrm{I} 835$, as J. B. Rising stated. I cannot help regretting that Mr. J. B. Rising, who is a thoroughly candid and honest gentleman, should have had the clear 
stream of his memory fouled by this donkey's stepping his foot in it. It is not the ordinary case of a variation of statement by a witness who is put on his guard by a hostile cross-examination. It is the case of a couple of shysters putting their heads together, one to go in the guise of a friend and as though he had superior knowledge, and tell the witness a mess of lies about the matter, while the other casually drops a question calling as well for the witness' information and belief, as for his actual knowledge of the matter. Shyster No. 2., has no apparent connection with the case, but seems to want the information. Now the witness gives him, very naturally what he thinks is his best information on the subject, namely, that which he got from Shyster No. I, who seemed to be better informed than he. Shyster No. 2, seizes this answer and parades it before the jury (the readers of the Mirror) as the original and only testimony of the witness on the subject. I will not comment on the practice, but I do say that the entrapping of a witness in this inconceivably dirty way does not destroy his former testimony. His unbiased recollection is entitled to the same weight as before.

- If any further evidence were needed to show the mare in Warner Cook's hands during the year I840, this statement of Mrs. Cook, that they had her at the lower place at least a year before they moved up to the Warner Cook place, supported as it is by Hoyt Johnson, would settle it. For October, I840, is immovably fixed as the time when they went to the Warner Cook place. This alone settles the question, for W. H. Balcom cannot be mistaken in the year he gave his mare away. His oft iterated statement is that he started West July I3, I843; in June, a month before he started, he sold his gray mare's last colt, then two years old past; that when this colt, foaled in the spring of $\mathrm{I} 84 \mathrm{I}$, was six months old, he gave the old mare to Wallace. And so it is conclusively shown that the dam of Ethan was in the hands of Warner Cook for one or two years before W. H. Balcom parted with his mare.

These considerations practically lay out of the case the question whether the dam of Ethan was hipped. If it was shown that she was, it would prove simply that Warner Cook, in the fall of $18_{3} 8$, bought of George Johnson a gray mare then sound that afterwards got hipped; and that at the same time W. H. Balcom owned another gray mare that was hipped. It would not make the two mares one. But it is clear that the dam of Ethan was not hipped, but some people got the impression that she was, in the way explained by Mr. Wicker. Such testimony as that of Mr. Wicker and Mr. Pinchin cannot be explained away. No witness of their opportunities and capacity says she was hipped. On the contrary, aside from the above gentlemen, Azro M. Bailey, W. A. G. Arthur, Ira Potter and Hoyt Johnson, all state positively that she was not hipped. Their testimony ought to settle it.

As to the date when she came into Rufus Rising's hands; there can be no doubt that it was in the summer of 1835 . That was J. B. Rising's 
clear recollection before any fraud had been practiced to get him to change his testimony. Hoyt Johnson, who saw her and asked Rising where he got her, (and was told in reply that she came from over the Green Mountains) thinks it was about three years before Johnson sold her to Cook in the fall of $\mathrm{r}_{3} 8$. The fact that Rising bred a colt from her, shows that he had her at least a year; and there is not now a particle of evidence in the case that tends to contradict Leland's positive statement that he traded her to Rising in the summer of $\mathbf{I} 835$.

The other points that corroborate Leland's statement were fully considered in my former article. That statement is as strongly supported at all points as human testimony, in the nature of the case, can make it.

W. H. BLISS.

One of the most graphic sketches of Ethan Allen ever written was by John H. Wallace, then editor of the "American Trotting Register," and published in "Wallace's Monthly" of April, 1877 . The parts of the article describing the horse and his most famous victory, are here given entire :

66 WITH a list of all the celebrated American horses before him, it would be very difficult, if not impossible for the best-informed horseman to select an animal that has been so great a favorite with the American people, and for so long a time, as the famous Ethan Allen. When four years old, he gave the world a sensation, by eclipsing everything that had appeared before him at that age ; and again, when he was eighteen years old, he renewed and intensified the sensation, by trotting in $2: 15$, with running mate. These sensations of his youth and his age did much to give him a standing with the people; but his wonderful beauty, and remarkable docility and kindness, with the elegance and ease of his action, made him the favorite of everybody.

"He was a bright bay horse, less than fifteen hands high, with three white feet extending a little above the pasterns, a star, and an irregular white streak between his nostrils. Considering his height, he was a horse of unusual length, and very symmetrical in his proportions. His head and neck were very fine, and his shoulders, back, and quarters, were beyond all criticism. His trotting gait was recognized by the best judges and experts as probably more perfect than that of any horse in the world. Others have gone faster singly, but no one has done it with the same style and perfection of motion. In his great flights of speed, he was not bounding in the air, but down close to the ground, with a gliding motion, that steals from quarter-pole to quarter-pole with inconceivable rapidity.

"The chances of tracing and determining the origin of the dam of Ethan Allen are not all exhausted by any means. The death of Mr. Rising cuts off all hope of commencing the trace at that end of the line, but there were two parties to this transaction, and somebody sold or traded this mare to Rising. Now the point is, who was this man?

"Ethan Allen made his first appearance for public honors at the fair 
of Clinton county, New York, when three years old, and won the premium for stallions of his age, over a miserable track, in $3: 20,3: 2 \mathrm{r}$.

"In May following, on the Union Course, he beat Rose of Washington, in $2: 36,2: 39,2: 42$. They were both four years old, and this was the fastest four-year-old time then on record.

"He then went into the stud, and did not appear on the turf again till October, 1855 , when, over the Cambridge Park Course, he beat Columbus, Sherman Black Hawk, and Stockbridge Chief, for the stallion purse of 200 dollars, in $2: 34 \frac{1}{2}, 2: 37$. It is worthy of notice that three of the contestants in this race were sons of Black Hawk.

"The next autumn, I856, he had two contests with Hiram Drew, to wagons defeating him in both, and making a record of $2: 323 / 4$.

"October 15, I858, at Boston, he beat Columbus Jr., and Hiram Drew, for a purse of $\$ \mathrm{I}, 000$, in $2: 37,2: 35,2: 33$.

"On the 28 th of the same month he met the famous Geo. M. Patchen, on Union Course, Long Island, in a match for $\$ 2,000$, to wagons, and distanced him the first heat, in $2: 28$. [This was the first stallion record of $2: 30$ or better].

"July I2, I 860 , on the Union Course, Long Island, he beat Princess, distancing her the second heat, in $2: 291 / 2,2: 251 / 2$. This is his best recognized trotting record.

"The enumeration of his performances here would occupy too much space, and, as they may all be found in the first volume of the "Trotting Register," the reader is referred to that work. His engagements to the stud were so numerous, that for a number of years he was withheld from the track, and the people began to inquire if old Ethan was dead. $\mathrm{He}$ had gone so completely out of the popular mind that, when he reappeared on the Fashion Course, Long Island, in 1867 , being then eighteen years old, not only the public, but the average horseman, inquired if this was the original Ethan Allen.

"On the 2 Ist of June, I 867 , on the Fashion Course, it was my good fortune to witness the crowning event of his life. Some three weeks before, Ethan, with a running mate, had beaten Brown George and running mate in very fast time, scoring one heat in $2: 19$. This made horsemen open their eyes, and there at once arose a difference of opinion about the advantage to the trotter of having a runner hitched with him to pull the weight. This resulted in a match for twenty-five hundred dollars a side, to trot Ethan and running mate against Dexter, who was then considered invincible. As the day approached, the betting was about even: but the evening before the race, word came from the course that Ethan's running mate had fallen lame, and could not go but they would try to get Brown George's running mate, then in Connecticut, to take the place of the lame runner. As the horses were strangers to each other, it was justly concluded the change gave Dexter a great advantage, and the betting at once changed from even to two to one on Dexter. Long before noon the crowd began to assemble, and sporting men everywhere were shaking rolls of greenbacks over their heads, shouting, 'Two to one on Dexter'. I met a friend from Chicago, who sometimes speculates a little, and when he told me he was betting 'two to one on Dexter', I took the liberty of advising him to be cautious for I thought the team would win the race, and that its backers knew what they were doing. Before the hour arrived, I secured a seat on the ladies' stand from which every foot of the course and the countless multitude of people could be taken in at a glance. The vehicles were 


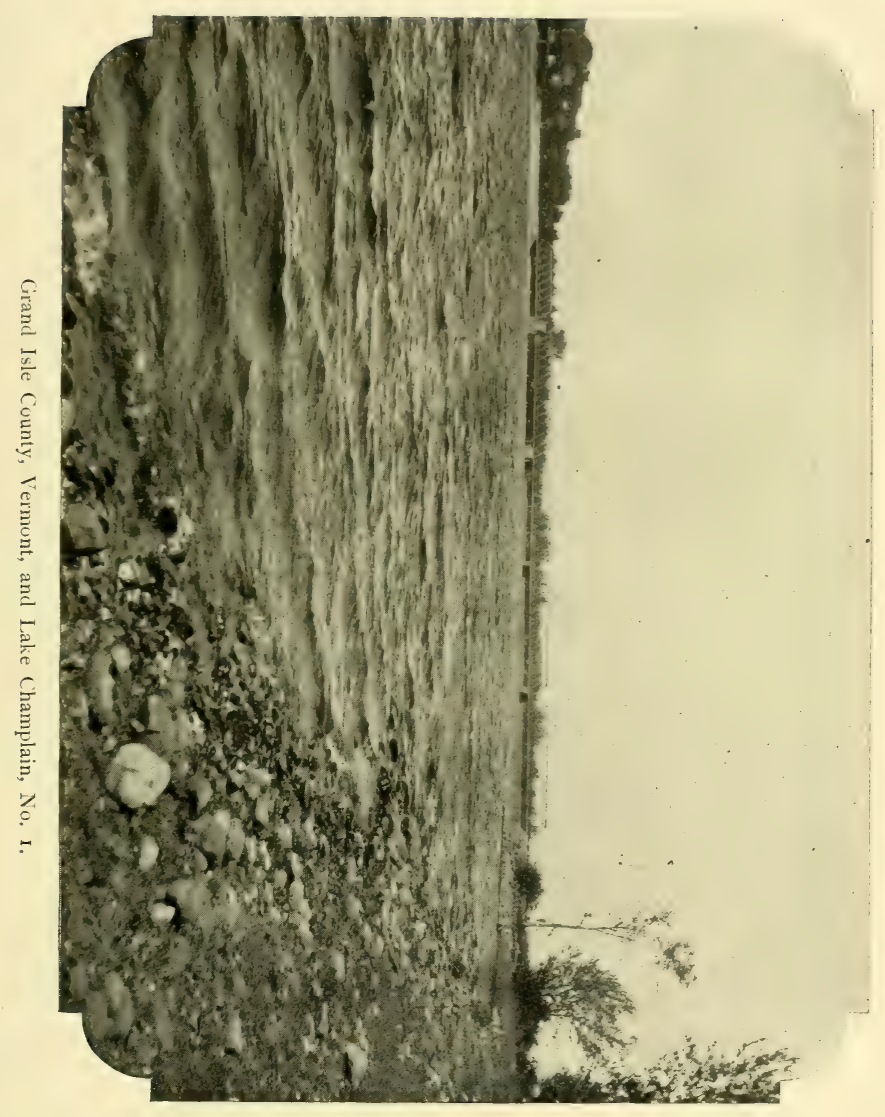




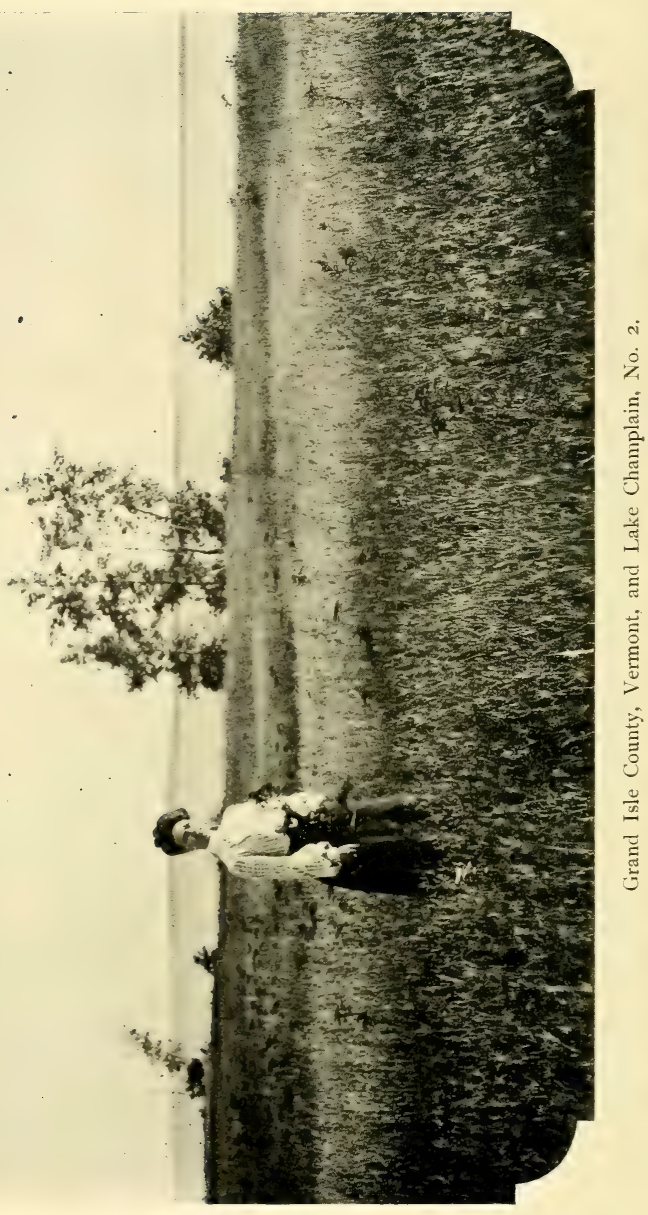


simply incalculable, and the people were like a vast sea. The multitude was estimated at forty thousand!

"Upon the arrival of the hour, the judges ascended the stand, and rang up the horses, when the backers of the team came forwarl, explained the mishap that had befallen the runner, that they had Brown George's mate on the ground, but, as he and Ethan had never been hitched together, they were unwilling to risk so large a sum, and closed the race by paying one thousand two hundred and fifty dollars forfeit. When this announcement was made, there was a general murmur that spread, step by step, through all the vast multitude. The betting fraternity were just where they started, and every spectator realized a feeling of disgust at the whole management. As soon as this had had time to exert its intended effect upon the crowd, the backers of the team came forward again, and, expressing their unwillingness to have the people go away dissatisfied, proposed a little match of two hundred and fifty dollars a side, which was promptly accepted by the Dexter party; and when it was known that there would be a race after all, the shout of the multitude was like the voice of many waters. This being a new race, the betting men had to commence again. The surroundings of the pool stands were packed with an eager and excited crowd, anxious to get on their money at two, and, rather than miss, at three to one on Dexter. The work of the auctioneers was 'short, sharp, and decisive', and the tickets were away up in the hundreds, and oftentimes in the thousands. But the pool stands did not seem to accommodate more than a small fraction of those anxious to invest, and in all directions, in the surging crowd, hands were in the air, filled with rolls of greenbacks, and shouting, 'Two to one on Dexter'! I was curious to note what became of these noisy offers, and I soon observed that a quiet-looking man came along, took all one party had to invest, and then quietly went to another, and so on, till I think every one who had money to invest at that rate was accommodated. The amount of money bet was enormous, no doubt aggregating a quarter of a million in a few minutes.

"When the horses appeared upon the track to warm up for the race, Dexter driven by the accomplished reinsman, Budd Doble, was greeted with a shout of applause. Soon the team appeared, and behind it sat the great master of trotting tactics, Dan Mace. His face, which has so often been a puzzle to thousands, had no mask over it on this occasion. It spoke only that intense earnestness that indicates the near approach of a supreme moment. The team was hitched to a light skeleton wagon; Ethan wore breeching, and beside him was a great, strong race-horse, fit to run for a man's life. His traces were long enough to fully extend himself, but they were so much shorter than Ethan's that he had to take the weight. Dexter drew the inside, and on the first trial they got the 'send-off', without either one having six inches the advantage. When they got the word, the flight of speed was absolutely terrific, so far beyond anything I had ever witnessed in a trotting horse that I felt the hair rising on my head. The running horse was next to me, and, not withstanding my elevation, Ethan was stretched out so near the ground that I could see nothing of him but his ears. I fully believe that for several rods at this point they were going at a two-minute gait.

"It was impossible that this terrible pace could be maintained long, and just before reaching the first turn, Dexter's head began to swim, and the team passed him, and took the track, reaching the first quarter pole in thirty-two seconds, with Dexter three or four lengths behınd. 
The same lightning speed was kept up through the second quarter reaching the half-mile pole in $\mathrm{I}: \mathrm{o}_{4}$, with Dexter still farther in the rear. Mace then took a pull on his team, and came home a winner by six or eight lengths, in $2: 15$. When this time was put on the blackboard, the response of the multitude was like the roar of old ocean. Although some distance away, through the second quarter of this heat, I had a fair, unobstructed side-view of the stallion and of his action, when going at the lightning rate of $2: 08$ to the mile. I could not observe that he received the slightest degree of propulsion from the running horse; and my conviction was then, and is now, that any such propulsion would have interfered with his own unapproachable action, and would have retarded, rather than helped him. The most noticeable feature in his style of movement was the remarkable lowness to which he dropped his body, and the straight gliding line it maintained at that elevation.

"The team now had the inside, and in the first attempt they were started for the second heat, but they did not appear to me to be going as fast as the first heat. Before they had gone many rods Ethan lost his stride, and Dexter took the track at the very spot where he had lost it in the first heat. The team soon got to work, and near the beginning of the second quarter, collared Dexter, but the stallion broke soon after, and fell back, not yards nor lengths, but rods, before he caught. Incredible as it may seem, when he again got his feet he put on such a burst of speed as to overhaul the flying Dexter, in the third quarter, when he broke again, and Mace had to pull him nearly to a standstill before he recovered. Dexter was now a full distance ahead, and the heat appeared to be his beyond all peradventure. I was watching the team in its troubles very closely, and my idea of the distance lost was the result of a deliberate and careful estimate at the moment; and the query in my mind then was, whether the team could save its distance. At last the old horse struck his gait, and it was like a dart from a catapult, or a ball from a rifle. The team not only saved its distance, but beat Dexter home, five or six lengths, in $2: 16$.

"In the third heat Mace had it all his own way throughout, coming home the winner of the race in $2: 19$. The backers of Dexter, up to the very last, placed great reliance on his well-known staying qualities; but he showed that the terrible struggle had told upon him more distressingly than on the team. It is said by those who timed Dexter privately that he trotted the three heats in $2: 17,2: I 8,2: 2 \mathrm{I}$.

"If ever there was an honest race trotted, this was one, but there was such a specimen of sharp diplomacy, of 'diamond cut diamond,' in the preliminaries, as is seldom witnessed, even on a race course. It is not probable that Ethan's intended running mate fell amiss at all, the evening before, as represented; and if he did, it was not possible to send to Connecticut for another horse, and have him there early the morning of the race, as was pretended. This was a mere ruse put out to get the advantage of the long odds. The backers of the team knew just how the horses would work and knew they had speed enough to beat any horse on earth. When the race was called, and they came forward and paid forfeit, it was merely to give the "two-to-one-onDexter' money encouragement to come out. It did come out most vociferously, and was all quietly taken. It was said John Morrissey was the manager-in-chief, and that his share of the winnings amounted to about forty thousand dollars. 
"After witnessing the second heat, and studying it carefully, I am firmly of the opinion the team could have gone the first heat in $2: 12$ if it had been necessary."

The National Live Stock Journal, 1872, says in editorial :

"Ethan Allen is now 24 years old yet he shows all the speed of his former days. His legs are as clean as those of a sucking foal, and his eye has lost none of its youthful fire and determination. He has fewer marks of old age than any horse we have ever seen, and a large number of foals will be dropped from him this season."

In 1876 an article in the same paper under the heading of "A Vigorous Old Horse" said :

"It is wonderful to note the vigor which the old Ethan Allen displays in his old age. He is now 26 years old but is to all appearance as young as he was at 15 . Last season he covered 37 mares and got 32 foals, and this year he has covered $5 \mathrm{I}$. We have never known a horse on which time rests so lightly as upon this horse."

This Journal records the death of Ethan Allen Sept. Io, I 876, and gives his height as 15 hands, $1 / 2$ inch. See The Morgan Horse and Register, Vol. I., pp. I75-I 87 .

Sire of 6 trotters $\left(2: 23 \frac{3 / 4}{4}\right) ; 22$ sires of 92 trotters, 4 pacers; I 4 dams of $I_{7}$ trotters, 2 pacers.

ETHAN ALLEN (ASHLEY'S) (I-8), bay with star, little white on hind heel, $153 / 4$ hands, I Ioo pounds; bred by A. B. Ashley, Milton, Vt. ; got by Ethan Allen (Holabird's) : dam black ; bred by J. Clark, Milton, Vt. ; got by Hawk Eye, son of Black Hawk; 2 d dam bay, 16 hands, bred by G. Clark, said to be by throughbred horse. Pedigree from breeder.

Sire of Little Ethan Allen; $2: 19 \frac{3 / 4}{3} 3$ pacers $(2: 161 / 2 ; 2$ dams of 2 pacers.

ETHAN ALLEN (BACON'S) (I-8), bay, white face, three white feet, 15 I 2 hands, I I 40 pounds ; foaled I 855 ; bred by Harrison Bacon, Barre, Mass. ; got by Ethan Allen: dam, dam of Pathfinder (Benedicts'), which see. Advertised by breeder, I 874 , at Ogdensburg, N. Y. Terms to insure $\$ 50$.

Mr. Bacon, writes :

Copenhagen, N. Y., March 24, I885.

Editor Register:-As regards Ethan; he could turn round more people on the street when he was passing through a city than any horse I ever saw. Men, women and children would stop on the sidewalks and look at him. Ethan was alive last fall. $\mathrm{He}$ was owned at Napence, Can. He will be 30 years old next May, if he is alive. Dam of Ethan was the dam of Benedict's Pathfinder and black stallion, Andrew Jackson; also Young Black Hawk stallion four years old. I sold him for \$150o to H. M. Dennis of DeKalb, Ill. I sold Pathfinder to Mr. George Benedict of Verona, Oneida County, N. Y., for \$I 200 at three years past. I sold the Green Mountain colt, ten months old, to Mr. Potter, Rockford, Ill., for \$20o. You write to Mr. George Benedict, Verona, Oneida County, N. Y.; he can tell you all about the dam, which was raised within four miles of his place. I had her pedigree in full once, but it is gone. Mr. Benedict can give you the pedigree more fully than I can. I raised them all in Barre, Worcester 
County, Mass. Pathfinder and Ethan were first-class stock ; Pathfinder, I 6 hands. I saw him trot at Syracuse to saddle at four years old; he paced two heats without stopping; first heat $2: 38$, second $2: 37$. I trained him myself. Ethan could trot a full mile in 47 to 50 sure. $\mathrm{He}$ could in his day out-show any man's horse on the fair-grounds with his stock. He got 16 hand fellows.

John D. Gillett, of Adams, N. Y., writes under date of Jan. I2, I904:

"Smith's Morgan, was a great brood-mare sire. He got the dam of the only four-year-old that was ever sold for $\$ 10$,0oo in this part of this state. ** I got the customer and counted the money, so I know that he was sold for just $\$ 10,000$ cash. He was purchased by the late Darius Tollman, who used to drive Ben Butler and George M. Patchen. His dam was by Smith's Morgan, son of Bacon's Ethan Allen, by old Ethan Allen, son of Black Hawk. He died the year the epizootic prevailed."

See The Morgan Horse and Register, Vol. I., p. 548.

Sire of 7 trotters $\left(2: 27 \frac{1}{4}\right)$; I sire of 1 trotter; to dams of 9 trotters, 2 pacers.

ETHAN ALLEN (BELLINGER'S) (I-I6), bay with star, snip and three white feet, I 5 hands, I050 pounds; foaled I 868 ; bred by E. Rogers, Adams, N. Y. ; got by Bacon's Ethan Allen, son of Ethan Allen. Sold to N. B. Mann, Mannsville, N. Y. ; to Mr. Van Sickles, Newark, N. J.; to M. D. Bellinger, New York City ; to L. H. Rolland \& Co., Mt. Gilead, O.; to J. M. Farley, Edison, O.; to J. Shaw, Greencamp, O.; to T. B. Masters, Edison, O. See The Morgan Horse and Register, Vol. II., p. II 8 .

ETHAN ALLEN (BROWNELL'S) (5-32), black with star and two white hind feet, $153 / 4$ hands, I050 pounds; foaled 1858 ; bred by Chauncey W. Brownell, Williston, Vt., got by Ethan Allen: dam black, bred by John Wheeler, Shelburne, Vt., got by Adams' Black Hawk (probably Silverheels), son of Black Hawk. Trotted to wagon in $2: 44$. Died I 864, the property of breeder. See The Morgan Horse and Register, Vol. I., p., 595 .

Sire of 2 dams of 2 trotters.

ETHAN ALLEN (DE LONG'S) ( I-4), bay with small star, snip and one white hind foot, $15 \mathrm{I} / 4$ hands, 1070 pounds; foaled June $26, \mathrm{I} 858$; bred by Henry J. DeLong, West Cornwall, Vt.; got by Ethan Allen, son of Black Hawk: dam bay, foaled the property of Mr. DeLong, thought to be Morgan; 2 d dam brought whilst in foal, by Horace Payne, Shoreham, Vt., from his native town in eastern Vermont and sold by him to Mr. DeLong. Died I89o. Pedigree from breeder. Smith Seeley, Middlebury, Vt., in an interview $189 \mathrm{r}$, said :

"I remember the mare that DeLong's Ethan was from, a small mare and looked like a Morgan. Ed. Morton bought a chunked bay mare, I should think a Morgan mare, of Hedding of Salisbury, Vt."

This last mare is supposed to have been the $2 \mathrm{~d}$ dam of Hotspur, $2: 24$, 
by Ethan Allen, winner of 27 recorded races, and the fastest, by the records, of his get. See The Morgan Horse and Register, Vol. I., p. 88I.

Sire of 3 trotters $(2: 261 / 2)$, Belle D., $2: 24 \frac{1}{4} ;$ I sire of 1 pacer; 6 dams of 5 trotters, $x$ pacer.

ETHAN ALLEN (DIXON'S) ( $1-8$ ), bay; foaled $\mathbf{x} 859$; bred by Ir. Dixon, Long Island; got by Ethan Allen : dam Martha, bay, foaled I 849, bred by George Conklin, Chester, N. Y., got by Abdallah, son of Mambrino; 2 d dam, said to be by Conklin's Bellfounder, son of imported Bellfounder ; 3d dam, by Corncracker, son of imported Tranby ; and $4^{\text {th }}$ dam by Hickory, son of imported Whip. Sold to Charles H. Kerner, New York, N. Y. See The Morgan Horse and Register, Vol. II., p. II5.

Sire of Sensation, $2: 221 / 4$.

ETHAN ALLEN (DRURY'S) ( $1-8$ ), bay, I433/4 hands, about Iooo pounds ; foaled I 848 ; owned and perhaps bred by G. A. Austin, Orwell, Vt. ; got by Black Hawk, son of Sherman Morgan: dam said to be by Tippoo Saib, son of Duroc. Taken to Iowa by D. J. Weatherbee, and sold to J. H. Wallace, Muscatine, Ia., about I856; to H. D. Weatherbee; to Mr. Drury of New Boston, Ill., about I858; to N. Puffenberger of same place; to Mr. Style of Dixon, Ill. Died near Dixon, Ill. See The Morgan Horse and Register, Vol. II., p. I I 5.

Sire of Lady Fox, $2: 30$; I dam of I pacer.

ETHAN ALLEN (HOLABIRD'S) (3-I6), bay, I $53 / 4$ hands, I 200 pounds ; foaled $\mathbf{r} 85^{8}$; bred by Cassius Holabird, Shelburne, Vt. ; got by Ethan Allen : dam bay, bred by Soloman Harding, Pomfret, Vt., got by the B. F. Chedel Horse, son of Morgan Tally Ho; 2 d dam bay, large, bred by William Hutchinson, Pomfret, Vt., but foaled the property of William Harding, got by an old bay horse brought from Boston by William Hutchinson, thought to be part French, but pedigree unknown ; 3d dam bay, large, brought from Boston by William Hutchinson, untraced. Died r889. Pedigree from Allen W. Thomson.

DAM OF HOLABIRD'S ETHAN.

Letter from Allen W. Thomson, Woodstock, Vt:

“Mr. Wallace, in his first volume of the 'Trotting Register,' states that Young Ethan's dam was by Vermont Hamiltonian. That Young Ethan was owned by Holabird \& Satterlee, Shelburne. In the second volume he says that 'Holabird's Ethan Allen Jr., was foaled in I860: dam, Fanny, a very fast mare that Cassius Holabird bought in Hartland, Vt., in 1852 , said to be by Vermont Hamiltonian. When about to make her appearance among the fastest, she ran away and injured her hip. Mr. Wallace in 1876 , could not tell who he had this information of ; said he did not have it of Mr. Holabird.'

"On receipt of this letter we wrote Mr. Holabird asking for a few more facts. The following is a copy of his reply : 
'Mr. Allen W. Thomson.

'Shelburne, Oct. I6, I875.

'Dear Sir :-In reply to your letter; as I wrote Mr. Crane, I tried years ago to think of the man's name of whom I had the dam of Young Ethan. I don't think he came from Hartland; it seems as if it might be Williamstown. I know he claimed she trotted and won a purse at Montpelier election-day. He called her Morgan blood. Now for a description of the dam: her face was pretty straight, and intelligent; head, rather long; jowels, a little heavy, large nostrils, long slim neck, high shoulders, short back, long hips and sloping, rather crooked hind leg, heavy arm, I6 hands high, weighed when Ethan was a sucker, II50 pounds. She was rather thin built, but the shoulders very deep; long under the belly. I have got one of her colts that has weighed I304 pounds. Mr. Parker of Bennington has a span of her colts that stand $16 \mathrm{I} / 2$ hands; her stock was generally nice size. She raised a filly that got a record of $2: 40$ on a half-mile track.

'When I bought her we thought nothing of pedigrees. I now see the mistake. She proved to be very valuable as a breeder.

$$
\text { Truly yours, C. A. HolabiRd.' }
$$

"About I $836 \mathrm{Wm}$. Hutchinson of Pomfret, who was then quite a horse dealer, brought from Boston a bay horse that was along in years. It was thought he was part French. Mr. Hutchinson took back the same year, or the next, a large bay mare. She was long bodied, and along in years. The mare and horse were turned into the pasture together. It was not thought the mare would have a colt or that the horse could sire one. That fall the mare was sold to Solomon Harding's father, and the next year she brought a bay filly that was the grandam of Holabird's Ethan. She was not as large as her dam, had a star and one white hind foot; rather low headed, a long neck and low withers. She was called smart to go. She brought a filly by the Walker Horse before the one Mr. Chedel had, that was called faster than the one that was the dam of Holabird's Ethan. Mr. Chedel states she was docked before he got her. The dam of the Chedel horse was bred and owned by Samuel Paul of Pomfret. She was a dark bay or brown. Her sire was a two-year-old gray colt ; dam, a brown mare, called fast. It is well understood that the Chedel horse inherited through his dam another cross of Tally-ho blood, but it is hard now to say just where it comes in. The Chedel horse was a large bay horse ; he was owned by a farmer, who did not do much with him ; he did not breed many colts as he died young. What he left proved well and there was one very fast one."

It will be seen that Mr. Wallace in his first volumes gave to this horse the usual Messenger dam, upon some authority which he doesn't care to state, although he admlts it was not that of his owner and breeder. Had it not been for the researches of Mr. Thomson, which Mr. Wallace had nothing to do with, this pedigree would still be doing service, as that of the dam of the Morse horse, Young Columbus, Goldsmith Maid and a ihousand others, more or less, continue to, that are equally spurious.

Mr. Wallace has done a good deal-we might say a great deal of good work in compiling pedigrees of the trotting horses, but it is questionable whether if his books were not revised he would not accomplish as much harm or more than good; for they contain truth and error in about equal 
proportions, and there is no way to distinguish between them.- Midllebury (Vt.) Register, Nor'. 23, 1886.

See The Morgan Horse and Register, Vol. I., p. 597.

Sire of 4 trotters $\left(2: 24 \frac{1}{2}\right), 2$ pacers $\left(2: 17 \frac{1}{4}\right): 4$ sires of 2 trotters, 7 pacers; 16 dams of 13 trotters, 12 pacers, including Dariel (Lady Wonder), $2: 00 \frac{1}{4}$.

ETHAN ALLEN (HOLLAND'S) (I-8), bay, $143 \frac{3}{4}$ hands, 942 pounds; foaled i 860 ; bred by J. W. Holland, York County, Me.; got by Ethan Allen: dam said to be by Cock of the Rock, son of Duroc. Owned several years in Maine then sold to William Utley, Pontiac, Ill. See The Morgan Horse and Register, Vol. I., p. 603.

Sire of Barney Kelley, $2: 25$, and 50 rae trotter; I dam of $\mathrm{I}$ trotter.

ETHAN ALLEN (KELLY'S) ( I-I6), said to be by Vick's Ethan Allen. Owned in California. See The Morgan Horse and Register, Vol. II., p. I 6 .

Sire of Kate Castleton, $2: 261 / 2$.

ETHAN ALLEN (LADD'S) (I-I6), black, I51/2 hands, I025 pounds; foaled June 8, I86I ; bred by J. D. Ferguson, Frankfort, N. Y. ; got by Bacon's Ethan Allen, son of Ethan Allen : dam bay. Sold to J. Ladd; to C. Casselman, Chicago, Ill., who writes :

"He was fine looking, had good action, and was very gentle. When two, three and four, he received the first premium at Herkimer Fair, N. Y., the last year trotting a race in $2: 50$. When five he was awarded Ist premium at the New York State Fair. When twenty he trotted on a muddy half-mile track in $2: 35$."

See The Morgan Horse and Register, Vol. I., p. 549.

Sire of dam of Silverleaf, $2: 23$.

ETHAN ALLEN (MANCHESTER'S) (I-8), bay, with bo'b tail, about Iooo pounds; said to be by Ethan Allen. Purchased near Philadelphia, Penn., by Robert Manchester, Canfield, O. See The Morgan Horse and Register, Vol. II., p. I 6 .

Sire of Kate Campbell, $2: 25 \frac{1}{2}$.

ETHAN ALLEN (NEELY'S) ( I-I6), bay, I5 I 2 hands, said to be by Gray's Ethan Allen (taken to Canada from New York), son of Ethan Allen, by Black Hawk : dam a fast pacer. Sold to W. J. Neely, Ottawa, Ill. Could trot in 2 :40.-National Live Stock Journal, Chicago, Vol. V.

ETHAN ALLEN (PECK'S, ALLEN ST. JOE). We have received the following interesting letter :

SALEM, O., Aug. i6, I 886.

Editor Register :-In reply to your letter concerning Peck's Ethan Allen will say that he was raised on Sprague \& Ackers' stock farm at Lawrence, Kan.; was owned by a Mr. Peck of Topeka, and for several years kept at Valley Falls, Kan., by the landlord of the Cataract House, Mr. Gardner. I simply presume that this is the horse you have reference 
to. The above party could give you all the information you require. i will state, however, that he is a remarkably fine stallion, foaled probaby in 1874 , or thereabouts ; is light bay, black points, and is rarely equalled in shape and action. I heard it said that he showed $2: 42$ at two years of age. At some great fair at Kansas City he took first prize as a yearling, being greatly admired; heard also that Alden Goldsmith remarked th..t old Ethan would be proud to see that fellow. Should call him I53/4 hands high, and weight r Ioo strong, got by Ethan Allen; dam Belle of St. Joe, a thoroughbred by St. Joe. This mare was purchased by Gen. Grant for $\$ 800$ at their closing-out sale. I have seen this horse (called Allen St. Joe) and think him about the finest animal for driving purposes I ever saw, being a little larger and more rangy than most animals of that family, with full mane and tail, easily driven and of course always attractive; has repeatedly taken first premiums over Hambletonians and other breeds. I saw this stallion at Valley Falls in I 882 and also ' 83 ; have not heard from him since. This same Mr. Gardner also owned old Ben. Patchen by Geo. M. Patchen, dam Miriam by Abdallah.

Capt. Tough of Leavenworth could give you perhaps more and better accounts of this horse than I.

He bought at a sale in Leavenworth the Ethan Allen Jr., stallion, got by old Ethan in ' 76 , or about that year, the last season's colt. I think this was from a running mare called a Lexington mare. The stallion is rather small, about $\mathbf{I} 5$ hands and weighs 950. A prominent lawyer by the name of Clough bred him at Leavenworth, and soon after Mr. Clough's death in about r $\$ 8_{2}$, Capt. Tough bought him. This gentleman, you will remember, formerly owned Smuggler and sold him to Mr. Russell of Milton, Mass. There was owned near here a son of the old horse called Tom Allen, kept on the river near Beaver Falls; a son of his called Tom Allen Jr., was ten years ago kept eight miles from this town on Mr. Penrose's stock farm, New Garden, O.

$$
\text { Very truly yours, G. D. Austin. }
$$

See Allen St. Joe; also The Morgan Horse and Register, Vol. I. p. 6 Iо.

ETHAN ALLEN (WHITE'S, BILLY ALLEN) (3-32), bay, I $5 \frac{3}{4}$ hands; foaled 1878 ; said to be by Holabird's Ethan Allen, son of Ethan Allen : and dam by Gray Norman. Kept in Peru, N. Y., I882-83; then went to Vermont. Purchased 1892 and taken to Chazy, N. Y., by J. B. Sabre, Chazy. Exhibited at Vermont Horse Breeders exhibition at Burlington, Vt., I 885 by a Mr. Franklin White of Burlington, Vt., who probably bred him. In the report of this exhibition, Gray Norman is given as sire of dam.

Sire of J, B. S., $2: 29^{3 / 4} ; 2$ pacers $\left(2: 17^{3 / 4}\right)$.

ETHAN ALLEN (WOODWARD'S) ( $\mathrm{I}-8$ ), bay with narrow stripe in face, right hind ankle white and white mark on left hind foot, $15 \mathrm{I} / 4$ hands, ıooo pounds; foaled ז 860 ; bred by Wm. H. Cook, Ticonderoga, N. Y.; got by Ethan Allen : dam Fanny Cook, dam of Daniel Lambert, which see. Taken by O. Offensend to Batavia, Ill., I863. Sold to David Cornell, Batavia, I864; to S. B. Woodward, Whitehall, N. Y., r87o; to W. Withers, Lexington, Ky, r883 ; to Samuel M. Smith, Jacksonville, 
Ky., ISS7; to Stevenson and Thompson, Georgetown, Ky., r888; to Byerly and Peck, Stamping Ground, Ky., r888, and died that same year. See The Morgan Horse and Register, Vol. I., p. 603.

A horse of this name was advertised 1873 , at the Kansas Stud Farm, Lawrence, Kan., by Sprague and Akers, Lawrence.-National Live Stock Journal.

Sire of 7 trotters $\left(2: 12^{1 / 4}\right) ; 4$ sires of 1 trotter, 3 pacers; 8 dams of 6 trotters, 2 pacers.

ETHAN ALLEN JR. (BAKER'S) ; foaled r86r. Awarded premium at the Illinois State Fair, I865, owned by E. W. Baker, Chicago, Ill.

ETHAN ALLEN JR. (VICK'S) (I-8), bay, I5 I/2 hands; foaled 1858 ; bred by J. W. Holcomb, Ticonderoga, N. Y.; got by Ethan Allen : dam chestnut, great roadster, said to be by Harris' Hamiltonian, son of Bishop's Hamiltonian. Taken to Marysville, Cal., in $\mathrm{i} \$ 60$ by Joseph Vick, and kept there until I 864, then went to St. Helena. He was sold about I 868 to J. C. Morrison, San Francisco, who sold about I 870 to Wm. Hamilton of San Jose; afterward owned by George E. Blanchard, H. E. Barton and John Brewster, Placerville, Cal., and died on a ranch about six miles from Placerville.

In reply to a letter of inquiry regarding this horse, we have received the following answer from a warm friend of the Morgans:

Mr. Joseph Battell,

Whitehall, N. Y., March 3, I905.

My Dear Sir:- I presume you will think me slow in answering a polite inquiry-but the truth is I have waited all this time (since the receipt of your letter of Dec. I, I904), hoping to see some old time horsemen who could give me the desired information; have been to Ticonderoga, Port Henry, etc., but am sorry to say can learn nothing in regard to the two horses you inquire about.

I am greatly interested in the Morgans, the greatest breed of horses that ever lived, or ever will live.-Remember "Black Hawk" and saw "Ethan Allen" trot his first race when two years old over the ice at this place-also saw "Daniel Lambert" trot a race at this place when three years old. I think "Ethan Allen" and "Honest Allen" were the handsomest, best and fastest team ever driven together. Have talked many times with Dan Mace and Dan Walton about this breed of horses.

They always declared them perfection as road horses, and trotters. I have never had the pleasure of meeting you but two or three times, and then you were very busy about the Horse Fairs, but know you well by reputation, and desire to compliment you, as having done more to perpetuate this noble race of horses than any person living. Will only add that you can command me at any time as I will gladly give you any information in my power. I saw an old time typical Morgan a few days since, owned by S. A. Foote of Port Henry, a chestnut stallion should say $15 \frac{1}{4}$ hands, weight about Iooo pounds, was informed that he had a mark of $2: 22$, got by "Aristos." Did not have time to see Mr. Foote to learn his full breeding. 
See The Morgan Horse and Register, Vol. I., p. 600. Sire of Prince Allen, $2: 27$; I sire of I trotter; 3 dams of 3 trotters, I pacer.

ETHAN ALLEN, 2D. Untraced. George W. Fuller of Potsdam, N. Y., writes : Deceiver, brown gelding I remember well. He was brought out and owned at the time by Orrin Partridge of Brasher Falls, N. Y.

Sire of Deceiver, $2: 291 / 4$.

ETHAN ALLEN, 2D (SMITH'S) (I-8), bay, about I 5 hands, 900 pounds ; foaled about $\mathrm{I} 846$; bred by Gen. George W. Grandey, Vergennes, Vt.; got by Black Hawk: dam bred by Gen. Grandey, got by Cock of the Rock, son of Duroc Sold when two, to Robert H. Smith, Pontiac, Ill., who exhibited him at the Illinois State Fair, I86o, taking 2d premium, also a prize as the fastest trotting stallion in a field of $\mathrm{r}_{3}$. Could trot in $2: 50$, left some fine stock. See The Morgan Horse and Register, Vol. I., p. 429 .

Sire of dam of Harry Pulling, $2: 291 / 4$.

ETHAN H. DREW (I-8); foaled 1876 ; bred by Dr. W. H. Willis, Waltham, Mass.; got by Frank Allen, son of Ethan Allen: dam Polly said to be by Admiral Farragut, son of Young Quaker, by Harris Hamiltonian; and $2 \mathrm{~d}$ dam by Young Morrill. Advertised in the Waterloo, P. Q., Advertiser, I882. Terms \$20.

Advertised, I886,--together with Bob Lambert, Black Pride Jr., St. Clair and Villager by Edwin Forrest,- - by Louis Beauregard, to be kept at West Pelee, P. Q. Advertisement says: "Ethan H. Drew traces four times to Justin Morgan the fountain-head of beauty."

ETHAN K. (I-32), $2: 22 \frac{1}{4}$, bay; foaled 1889 ; bred by W. H. Kerr, Cynthiana, Ky.; got by Ethan Wilkes, son of George Wilkes: dam Rita Patchen, brown, bred by W. H. Kerr, North Middletown, Ky., got by Mambrino Patchen; 2 d dam Sting said to be by Strathmore, son of Hambletonian; 3d dam by Country Gentleman; and $4^{\text {th }}$ dam by Ericsson Chief, son of Ericsson. Sold to Rumbarger Live Stock Co., Indianapolis, Ind., whose secretary sends pedigree.

Sire of 2 pacers $(2: 191 / 4)$.

ETHAN MCGREGOR (I-I6), bay; foaled I 884 ; bred by H. H. Gilman, Topeka, Kan.; got by Robert McGregor, 2 :191/2, son of Maj. Edsall : dam Acker's Pet, bred by Amasa Sprague of Sprague and Ackers farm, Lawrence, Kan., got by Ethan Allen, son of Black Hawk; 2d dam said to be a thoroughbred bought in Kentucky by Bruce, for Spague and Akers, and her pedigree together with that of some other mares withheld owing to a quarrel. Pedigree from R. I. Lee, Topeka, Kan., who writes :

"This horse had a severe attack of distemper when I had control of him as a weanling, and perhaps from this cause went blind. $\mathrm{He}$ was 
afterwards presented by Gilman to James Duval, who lives near Richmond, Mo., and I think he owns him at this writing, June I $892 . "$

ETHAN PLUMBWOOD (3-32), brown with star, and little white on hind foot, 16 hands ; 1200 pounds ; bred by R. G. Dunn, Mechanicsburg, O. ; got by Pete Jones, son of Ethan Allen : dam Young Puss, black and a fast pacer, bred by R. G. Dunn, got by Bingham Horse, brought to Columbus, O., by Goss \& Blake, son of Gifford Morgan ; 2d dam Puss, brown, fine saddle mare, bred by Mr. Blackburn, Woodford County, Ky., got by a son of Blackburn's Whip. Sold I 885 ; later to William Minter, London, O. ; to John Lang, Jefferson, O.; to S. E. Freeman, Urbana, O. Said to be a horse of much style and pure trotting action. See the Morgan Horse and Register, Vol. II., p. I 9.

Sire of Columbus Maid, $2: 30 \frac{1}{4}$. And said to be sire of Civilization, $2: 23 \frac{1 / 4}{4}$, sire of 6 trotters $\left(2: 17 \frac{1}{2}\right), 5$ pacers $(2: 111 / 4) ;$ I sire of 3 trotters, I pacer; 4 dams of 4 pacers. See Civilization.

ETHAN S. (I-I6), $2: 27$, bay, with stripe in face, I 5 hands, Iooo pounds ; foaled I 884 ; bred by Arthur L. Woodbury, East Calais, Vt. ; got by Henry S., son of Auctioneer, by Tattersall: dam Gipsy, said to be by Holabird's Ethan Allen, son of Ethan Allen. Pedigree from Geo. N. Jenness, Barton, Vt., breeder of Tramp.

Sire of Tramp, $2: 30$.

ETHAN WILKES (I-I6), bay, I5 $5 / 4$ hands, Iooo pounds; foaled I 880 ; bred by Z. E. Simmons, Lexington, Ky.; got by Geo. Wilkes, son of Hambletonian: dam Lady Ethan (dam of Queen Wilkes, $2: 233 / 4$ ), brown, bred by Sprague \& Akers, Lawrence, Kan., got by Ethan Allen, son of Black Hawk; 2 d dam (dam of Hambletonian Mambrino, $2: 2$ I $1 / 4$, which see). Sold to W. H. Kerr, North Middletown, Ky.; to Bowerman Bros. ; Lexington, Ky. ; to the Rumbarger Live Stock Co., Indianapolis, Ind. Pedigree from breeder.

Sire of 15 trotters $(2: 201 / 2)$, II pacers $\left(2: 07 \frac{1}{2}\right) ; 6$ sires of 4 trotters, $I_{5}$ pacers $; 7$ dams of 2 trotters, 6 pacers.

ETOILE ( $\mathrm{I}-64$ ), $2: 26 \mathrm{~T} / 4$, bay with star, $153 / 4$ hands; foaled 1883 ; bred by E. W. Ayres, Duckers, Ky.; got by King Rene, son of Belmont: dam Ozella, bay bred by Wm. Stanhope, Lexington, Ky.; got by Regular, son of Volunteer; 2 d dam Kate, bred by Wm. Stanhope; got by Edwin Forrest, son of Young Bay Kentucky Hunter; $3 \mathrm{~d}$ dam, said to be by Paddy Burns. Sold to Brant Bros., Haysville, Ohio; to Synder Bros., Galion, Ohio. Pedigree from breeder.

Sire of Charley S., $2: 24 \frac{1}{4}$.

ETRUSCAN (1-32), bay; foaled I887; bred by W. H. Kerr, North Middletown, Ky.; got by Ethan Wilkes, son of George Wilkes: dam said to be by Orphan Boy, son of American Clay; and $2 \mathrm{~d}$ dam by McDonald's 
Mambrino Chief, son of Mambrino Chief. Sold to John Thompson, Delaware, $\mathrm{O}$.

Sire of 2 pacers $(2: 161 / 4)$.

EUCHRE (3-128), gray; foaled 1889; bred by J. G. Parrish, Georgetown, Ky.; got by General Wilkes, son of George Wilkes: dam Lilly bred by J. G. Parrish, got by Homer B., son of Homer; 2 d dam Lizzie Mills, bred by J. G. Parrish, got by a son of Mambrino Patchen; $3 \mathrm{~d}$ dam said to be by Almoor.

Sire of 2 pacers $\left(2: 08 \frac{1}{4}\right)$.

EUCLID (3-256), $2: 281 / 2$, chestnut, 16 hands; foaled I 880 ; bred by J. C McFerran, Louisville, Ky.; got by Glenview, son of Belmont: dam Reina Victoria, bred by J. C. McFerran, got by Hambletonian ; 2d dam Hyacinth, bred by Johnathan Hawkins, Walden, N. Y., got by Volun teer, son of Hambletonian; 3 d dam Clara (dam of Dexter, $2: 171 / 2$ ) bred by Jonas Hawkins, Walden, N. Y., got by American Star. Sold to Samuel Keys, Pittsburg, Penn ; to Wm. E. Fleming, Lousville, Ky. Information from catalogue of breeder.

Sire of 5 trotters $(2: 201 / 4)$, Foe Hartman, $2: 17 \frac{1}{4}$.

EUCLID STAR ( $1-32$ ), bay; foaled I 886 ; bred by B. F. Holway, Fayetteville, Ark.; got by Star of the West, son of Jackson's Flying Cloud : dam Mavourneen, bay, bred by John Overton, Nashville, Tenn. ; got by Chieftain, son of Clark Chief: $2 \mathrm{~d}$ dam Kathleen, said to be by Bay Woodford, son of Edwin Forrest ; 3d dam Jane Maxwell, by Columbus, son of Brown's Bellfounder; $4^{\text {th }}$ dam Emily, by Outrage, son of imported Leviathan. Sold to A. R. Farnham, LeMars, Ia., May, I889.

EUGENCER, $2: 28 \mathrm{r} / 2$, bay; foaled 1887 ; bred by Leland Stanford, Menlo Park, Cal. ; got by Electioneer : dam Lady Ellen, 2 :291/2, bay, bred by Jesse D. Carr, Salinas, Cal., got by Carr's Mambrino, son of Mambrino Patchen; 2d dam Ida May Jr., said to be by Owen Dale, son of Williamson's Belmont; 3d dam Ida May, by Williamson's Belmont and 4th dam by Red Buck, son of Bertrand. Sold to Monterey County Breeder's Association, Salinas City, Cal. Pedigree from catalogue of breeder.

Sire of 4 trotters $\left(2: 15 \frac{1}{2}\right)$.

EUGENE CASSERLY (I-I6), dapple gray, I5 $3 / 4$ hands, Iozo to I Ioo pounds; bred by Eugene Casserly, San Francisco, Cal.; got by Gen. Taylor, son of Morse Horse, by European: dam California Damsel bred by Wm. Hendricson, got by George M. Patchen Jr.; 2 d dam Peanuts, gray, owned by H. A. Mayhew, Niles, Cal., said to be by the Truse Horse son of Gen. Taylor. Pedigree from George Bemont, California, who says that he was a handsome and bold moving horse. Died property of Fred Brown, Windsor, Vt., I885.

Sire of Sweetbriar, $2: 261 / 4 ; 3$ dams of 3 trotters. 
EUGENE IVILSON (3-128), brown, white pastern behind, 16 hands; foaled I886; bred by Dewey and Stewart, Owosso, Mich.; got by Louis Napoleon, son of Volunteer : dam Minnie Wilson, brown, bred by IV. J. Henry, Cynthiana, Ky., got by Indianapolis, son of Tattler; $2 \mathrm{~d}$ dam Puss Patchen, black, bred by H. J. Henry, Cynthiana, Ky., got by Patchen Chief, son of Mambrino Patchen; 3d dam Lady Morgan bred by Charles Morgan, Harrison County, Ky., got by Geo. Woolford, son of

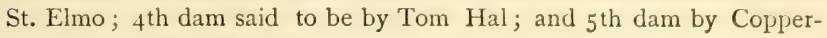
bottom. Pedigree from breeders.

Sire of Green Wilson, $2: 161 / 4$

EUPATORIUM (3-64), $2: 24$, when 2 years old, bay $15 \frac{1}{2}$ hands; foaled r 891 ; bred by E. S. Mills, Glenmore, N. J., got by Prince George, son of Kentucky Prince: dam Minnie H., bay, bred by D. D. Mitchell, Albion, Mich., got by J. W. Bailey, son of Seneca Chief ; 2d dam Lizzie E., said to be by Marshall Chief, son of Kilburn's Hero ; and $3 \mathrm{~d}$ dam Dolly Batchelder, by a horse called Post Boy. Pedigree from breeder.

Sire of Hampton, $2: 22^{3} / 4$.

EUREKA (DANDY JIM, AIKEN HORSE), dark bay, I6 hands; foaled June 14, I 849 ; bred by Isaac Aiken at Quaker Hill, Dutchess County, N. Y. ; got by Long Island Black Hawk : dam Lady Moore. This pedigree is extended in Wallace's register, but above is all that Mr. Robinson gives in advertisement, and Mr. Wallace gives no breeder for Lady Moore. Sold when seven years old to a gentleman in Montgomery, Ala.

Advertised at Fishkill Plains, Dutchess County, I86o, by Charles Robinson, as follows :

"Eureka, known as Dandy Jim or the Aiken Horse, will be kept the ensuing season, at the farm of the undersigned, at Fishkill Plains, Dutchess County. Terms, $\$ 50$ the season, payable at the time of service, with the privilege of the service of the horse the following season free of charge, should the mare prove not in foal.

"Description.-Eureka was foaled June $\mathrm{I} 4, \mathrm{I} 849$ and raised at Quaker Hill, Dutchess County, by Isaac Aiken, Esq., who kept him until he was seven years old when he sold him to a gentleman residing in Montgomery, Alabama. His colts having shown such great speed induced the undersigned to go to Alabama and purchase him at a very high price. $\mathrm{He}$ is a beautiful dark bay, 16 hands high. His action, carriage and beauty of form, with size, strength and speed are unsurpassed by any stallion living.

"Pedigree--Eureka was by Long Island Black Hawk: dam Lady Moore. Any information required by owners of mares in New York and vicinity may be obtained by applying to Morgan L. Mott, 682 Broadway, N. Y.

-Wilkes Spirit of the Times, July 28, 1860 .

Charles Robinson."

EUREKA (I-I6), black, bred by George W. Chamberlin, Sioux City, Ia.; 
got by Gen. Grant, son of Draco : dam, brown, bred by A. K. Emerson, Newton, Ia., got by a black pacing stallion breeding unknown; $2 \mathrm{~d}$ dam brown, bred by Sabin Kellam, Irasburgh, Vt., got by Black Hawk son of Manchester Black Hawk; 3d dam bay, bred by Sabin Kellam, got by Young Bulrush Morgan, son of old Bulrush. Information from G. M. Kellam, who writes :

"The grandam of Eureka I brought from Vermont in I859 to Kansas ; the fall of $x 860$ took her to Newton, Ia. ; on account of drought I wintered in Newton, and the mare being heavy with foal, I traded her to A. K. Emerson. Manchester Black Hawk was owned by S. R. Hall of Manchester, N. H."

EUREKA (BUTLER'S) ( I-8), dark chestnut, about I 5 hands, rooo pounds; foaled Sept. I, I851 ; bred by Asa Tinkham, Windsor County, Vt. ; got by Green Mountain Morgan: dam a handsome, blood-like bay mare and smart trotter, $14 \frac{1}{2}$ hands, rooo pounds, bred by Asa Tinkham, got by Gifford Morgan; 2 d dam said to be by Cock of the Rock, son of Duroc, but more probably Cock of the Rock by Sherman Morgan, as he was kept at or near Woodstock in the thirties. Purchased of Lorenzo Pratt of Woodstock, Vt., son-in-law of Mr. Tinkham, in the fall of 1854 , by Dr. Russ Butler of Woodford County, Ky., who took the horse to his home in Kentucky, and kept him there several years. We are informed that Mr. Butler came from Louisville and bought a place on the Georgetown and Frankfort Pike about 7 miles from Frankfort. The horse was kept by Capt. Steele, the owner of Steele's Snowstorm, several seasons; quite a small horse not over $14^{1} / 2$ hands, altogether different shaped horse from Steele's Snow Storm. He was killed by lightning at the farm of Dr. Gale, New Liberty, Ky., about I860.

William McCracken, Lexington, Ky., says :

"Eureka was as nice a chestnut horse as ever you saw, I5 hands, Iooo pounds; very stylish; owned near Frankfort, Ky.; he stood there all the time. He marked his stock with his own points through three or four generations."

This horse has often been erroneously credited to Long Island Black Hawk, and we believe is still so in the Kentucky Saddle Register, although we took the trouble, supposing this to be an honest mistake, to send the authentic tracing of the horse to the editor of that Register. Possibly the information was not received. It will be seen from following letters that there never was information of any horse more accurate or reliable in regard to sire and dam. It will also be seen that Eureka by Long Island Black Hawk (see p. 337) did not leave New York until ז 856 , when he went to Alabama.

Mr. Joseph Battell, Middlebury, Vt.

Frankfort, Ky., Jan. I3, I89o.

Dear Sir:-Inclosed please find Mrs. Butler's reply to my inquiry respecting "Butler's Eureka." 
I trust this information will answer your purpose.

$$
\text { Very truly, L. J. Cox. }
$$

Any further information wished will be cheerfully furnished.

Mr. Cox,

$$
\text { S4I Second ST., Louisville, Kry., Jan. I3, I } 890 .
$$

Dear Sir :-In looking over an old note book of Dr. Butler's I find the inclosed in regard to "Eureka," and am pleased to give you the desired information, your kind wishes in regard to myself, I fully reciprocate and am

$$
\text { Very truly, MRS. I. R. Butler. }
$$

"Eureka, Chestnut Morgan purchased of Lorenzo Pratt at Woodstock, Vt., fall of 1854 . (September 1859 is eight years old). Pedigree: Eureka was sired by Silas Hale's old Green Mountain known in Linsley's work on Morgan Horses as Green Mountain 2d. His dam was a handsome blood-like bay mare with black legs, without white, and what the Yankee's call a 'smart' trotter, sired by Gifford Morgan, grandam by the thoroughbred horse Cock of the Rock. Green Mountain was sired by Gifford, he by Woodbury, and he by the original Justin Morgan.

"Cock of the Rock was by Duroc, sire of Romp own sister to Miller's Damsel the dam of American Eclipse."

We also received the following letter concerning this horse :

Mr. BATTELL :

Your letter to the Postmaster has been given to me to answer. Mr. Pratt's father-in-law, Tinkham, bred and owned the horse. Mr. Pratt found the chance to sell him. Mr. Tinkham bred his dam, she was by old Gifford Morgan. He they claim was a dark chestnut without marks, and was three when sold. The man that took him to Louisville, Ky., lives here.

Woodstock, Vt., April r6, 1890.

Yours, Allen W. Thomson.

$$
\text { Woonstock, Vt., April } 2 \text { I. }
$$

Mr. BatTell :

Asa Tinkham that bred the Green Mountain colt has been dead for years. His grandson, Mr. Pratt's son lives here, he was young when the colt was sold, but remembers him well. Weighed 1000 pounds, I $41 / 2$ hands high, a great roadster and was got by old Gifford. $\mathrm{He}$ is confident the colt was but three when he was taken away and it was in I855.

Mr. Farwell here that took the colt to Louisville, says it was in the fall of fifty-five that he was four years old. Old Green Mountain stood at Woodstock in $\mathrm{r} 850$ and $\mathrm{r} 85 \mathrm{I}$ so the colt was got one of these years. Mr. Mason Farwell thinks he got a few colts, but nothing is known as to them now. I have looked up the breeding of a noted brood-mare for a breeder in Connecticut, and I find that her dam was bred at Rochester, Vt., and got by Varsil M. Hubbard's Green Mountain stallion called Green Mountain Chief and Green Mountain Boy. It is quite a feather for the Hubbard horse, to have learned the breeding of this dam. Yours, Allen W. THOMPSON.

EUREKA (COLEMAN'S) (I-64), dark chestnut, I6 hands, I 200 pounds ; foaled I 868 ; bred by William L. Coleman, Bedford, Trimble County, 
Ky.; got by Young's Morgan, son or grandson of Eureka, by Green Mountain Morgan : dam said to be by Beckett's Boston, son of Boston; and $2 \mathrm{~d}$ dam by Cannibal, son of Mickle John, by Sir Archy. Sold to Lewis Ellis, Bedford, Ky.; to W. S. Wilson, Eminence, Ky.; to Noah Frazer, Cynthiana, Ky.; to Mr. Shuff, Scott County, Ky.; to W. Gay, Bourbon County, Ky. An advertisement of this horse in the Lexington, Ky., Reporter, I886, says :

"He has taken I 23 premiums out of 124 shows; took the first premium at St. Louis, Mo., in 1877 , for the best combined stallion, mare or gelding, with 42 in the ring. He has raced at several fairs in $3: 00$, and trotted in $2: 361 / 2$. He got the fine show gelding, Woodlake, that beat Lady De Jarnette in $\mathbf{\tau} 885$, and was sold for \$ $\$ 500$. L. Ellis raised and sold ten geldings by him, at an average of over $\$ 500$. He got 70 colts in I 885 ."

The National Saddle Horse Register says :

"Coleman's Eureka was a horse of remarkable power to transmit his good qualities, and Kentucky is full of good stallions and mares that trace to him. Some of the finest saddle horses of the present time have much of his blood. A considerable number of trotting horses with records trace to Coleman's Eureka, and the Eureka stock are esteemed greatly as general-purpose horses." See the Morgan Horse and Register, Vol. I., p. 7 I 2 .

Sire of dam of Lamar, $2: 24 \frac{1}{4}$.

EUREKA (COX'S) (I-I6), chestnut, I5 I/2 hands, Iooo pounds; foaled I 860 ; bred by John A. Holton, Forks of Elkhorn, Franklin County, Ky. ; got by Butler's Eureka, son of Green Mountain Morgan : dam chestnut, bred by John A. Holton, got by Pioneer, son of Blackburn's Whip; 2 d dam bay, bred by Charles O'Hara, Franklin County, Ky., got by imported Birmingham. Sold to L. J. Cox, I862 ; to H. Coham, I874; to Oscar Blackmore, whose property he died, about I885, at Farmdale, Ky. Kept mostly in Franklin County, Ky. A correspondent writes:

"He was exceedingly stylish in appearance being a perfect model of the harness horse. Disposition kind and gentle. $\mathrm{He}$ would trot and pace. His colts all fine and stylish."

L. J. Cox, Frankfort, Ky, writes :

"This was about the most popular breed of horses ever known in this section. They were all noted for style, spirit, docility, endurance and model appearance. The old horse, Butler's Eureka, was but little patronized at first on account of his small size and the then high service fee (\$I5 to insure a colt). If he had lived since his colts came into notice he would have commanded immense patronage."

EUREKA (TAYLOR'S) (I-I28), chestnut, one hind foot white, I6 hands, I roo pounds; foaled I88I ; said to be by Coleman's Eureka. Information from T. A. Massie, Glasgow, Mo., who writes: "He was a good horse and left some good ones in this county." 
EUREKA CHIEF (I-I28), bay, black points, I $53 / 4$ to 16 hands, I roo pounds; foaled $\mathrm{I} 880$; bred by O. Ford, Eminence, Ky.; got by Coleman's Eureka, son of Young's Morgan by Butler's Eureka, son of Green Mountain Morgan: dam bay, bred by O. Ford, Eminence, Henry County, Ky., got by John Dillard, son of Indian Chief [by Tecumseh]. Sold to Lewis Ellis, Bedford, Ky. Pedigree from Harry G. Moody, Eminence, Ky.

EUREKA LAD, chestnut, three white feet, I5 3/4 hands, I I5o pounds; foaled r 888 ; bred by R. H. Beatty, Lexington, Ky., got by Coleman's Eureka, son of Young's Morgan: dam Kit, chestnut, bred by R. H. Beatty, got by Pingue, son of Halcorn. Sold to Charles Rayley. Information from J. P. Beatty, Georgetown, Ky., who writes, Jan. 27 , I908: "He was of good disposition and a blue ribbon horse in his day."

EUROPEAN (JOHN) (I-2), dapple gray, silver mane and tail, variously described as from $\mathrm{I} 5 \mathrm{I} / 2$ to $\mathrm{I} 6$ hands, I 100 to $\mathrm{I} 200$ pounds. Bought by James McNitt, Salem, Washington County, N. Y., at La Prairie, Que., probably somewhere between 1826 and 1830 . Died about 1836 or before.

Mr. R. G. Clark, postmaster and a well known citizen and very intelligent horseman of Argyle, N. Y., in interview, I889, said :

“European wasn't set up on legs. He was built more like a Green Mountain Morgan. A very substantial built horse, dapple gray showed round spot. It was about $\mathrm{r} 829$, I should say, when I saw the horse. McNitt had him a few years. Don't think $r_{32}$ far out of the way when the Morse Horse was foaled. Mr. Hurd corroborated me that the dam of the Morse Horse was gray; Martin Stover said all he knew about the dam, was they said she was a gray mare, one of a team of McNitt's."

Charles Milliman, Warrensburg, N. Y., breeder of Milliman's Bellfounder by the Morse Horse, son of European, in interview with writer, I889, said :

"European was called a French horse when he came to Salem; but I visited the previous owner in Canada and saw his wife who said that he was imported from France and got by Bonaparte's war horse: dam a mare ridden by one of Bonaparte's aids, also of superior blood. She stated that Bonaparte's horse got this horse after he and the dam had been captured at Bonaparte's downfall."

Mr. Milliman also said that McNitt knew nothing about the origin or history of the horse until he (Milliman) got the information; that the horse had a big knee; and that McNitt gave for him an eleven hundred pound hog. Mr. Milliman writes us as follows :

Mr. Joseph Battell,

WARrensburg, N. Y., Oct. 24, I891.

Dear Sir :-I have just received your letter of the $9^{\text {th }}$ of October inquiring of me about the blood of the old McNitt horse. I will give it 
just as I got it. He was a stallion got by Napoleon's war horse and his dam was his first aid's mare. They were the choice of the whole stud that Bonaparte imported from Italy and used for his war horses, and used them as such until he was taken prisoner and banished, then his conquerors sold the whole stud, and the lady's father got a friend of his to buy the horse and mare that himself and Bonaparte rode, for him, and he turned them out to pasture and they remained together until the gray colt came, and when he was three years old she was married to an English officer and went to Canada; then her father gave her the colt and her husband took her and the colt home with him, and she had always used him for her driving horse until he was 20 years old; then McNitt got him and took him home to Salem with him and used him for a stock horse. He bred four mares to him when his leg was broken and he killed him. Now for your questions :

First.-I do not know, she was living in Montreal.

Second.-The colt was three years old at the time she was married. You are correct as to what she told me respecting the breeding of the colt. I have a horse now that I have bred myself the nearest like the horse that McNitt got in Canada, that I ever saw, he trots very fast like that horse. I will give you his pedigree.

Gray Rarus was foaled Oct. 10, I 878 ; he stands $15 \mathrm{I} / 4$ hands high with the finest head and neck that I ever saw on any horse and is called by every judge of horses a perfect beauty of a horse. Sire Darkey : dam by Bay Norman (imported) ; 2 d dam by Wild Irishman (imported) ; $3 \mathrm{~d}$ dam by White Barb an Arabian; Darkey, by old Darkey, he by the Rounds Horse, by old Black Hawk, by Sherman Morgan, by Justin Morgan, by True Briton, or Beautiful Bay, an Arabian. Darkey's dam was by a son of Bishop's Hamiltonian, and he by Imported Messenger.

Rarus was never trained and can trot faster than any horse that I ever drove. I have driven a great many trotters in my time, a gentleman said that he drew my carriage faster than St. Julian did a sulky when he got his record, and gave me a standing offer for him any time that I chose to accept it, my horse was sound at that time; that offer was four thousand dollars for him but I keep him yet and shall. Now any information respecting any horse just write me and I will answer it.

$$
\text { Yours truly, Chas. Milliman. }
$$

From American Roadster and Trotting Horses, by H. T. Helm, r 878 , we take the following extracts, pages $(479-480)$. John Carswell, Racine, Wis., says :

"I lived in Salem, Washington County, N. Y., from my birth in 1809 until 1836 . My father's nearest neighbor was James McNitt, the owner of a farm and distillery, who fattened hogs and marketed them at Montreal and Quebec. He was, also, something of a dealer in horses. On his return from a trip to that region about 1829 or 1830 he brought back a stallion, European that was the sire of the Morse Horse. He represented the horse as having been imported into Canada from France. He was an old horse and showed signs of ill usage being badly knee sprung, but was nevertheless one of the best trotters at that time. $\mathrm{He}$ was a beautiful model, long body, good length of limb and lofty carriage. His color was very light gray or nearly white."

\section{A. Jenkins of La Crosse, Wis., says :}


"James McNitt brought from Canada, to Washington County, N. Y., two stallions one a large dapple gray horse, apparently of some good blood; he was all used up as to legs, having but one sound one; he could hardly walk; knees knocked out of all shape. As to general figure, he was a beauty; long and round, smooth hips, short back, strong loins, neck well set on shoulders with a good head. The other horse bought by Mr. McNitt at the same time was a Canadian pony, a fast trotter, long body, heavy mane and lifted his feet high when trotting."

Martin McNitt son of James McNitt says :

"European was imported from France to Montreal about r814, my father bought him about 1826 or 7 , he was 16 hands high, dapple gray, silver mane and tail, high headed, nice limbs, beautiful flat legs, and as fine appearing a horse as I ever saw, could trot a mile in 3 :0o."

James Mills of Peoria, Ill., says:

"James McNitt bought European at La Prairie, Can., as near as I can recollect in $\mathbf{r} 83 \mathrm{I}$. He was an imported horse and dark gray, weighed over $\mathrm{r} 200$ pounds, had flat bones, with wide legs, fine body well ribbed, tail came from his body straight, neck rather heavy for beauty, nostrils large enough to put your fist in and his wind was like a blacksmith's bellows."

We have long intended to make a special trip to La Prairie, St. John and Montreal, to see if in the old files of papers published in those towns we might not find further information of this stallion, and also of the horse, Engineer, that went from Canada (or possibly Vermont) to Long Island, reported to have been captured from an English officer, and was the grandsire of Lady Suffolk, the first $2: 30$ trotter. We have frequently thought it was possible, that these two horses were identical. The description, characteristics and relative age of the two horses so far as known, and the stories told in regard to each, would appear to sustain this hypothesis. The fact that Engineer disappeared so completely after his season upon Long Island in 1816 , makes it very probable that he was returned to Canada.

But whether identical or not we shall hope to get further information at least of European from the old files of papers in Canada or even possibly from some parties still living who will remember about him.

There is a curiously similar story to that told of the origin of European about another stallion advertised in New Hampshire in 1834 , called Wild Napoleon, which see. Also see Morse Horse.

It will be noticed that all the descriptions of European here given are excellent ones of a Morgan horse of good size. Mr. Clark, who was an uncommonly intelligent horseman and well appearing gentleman, distinctly states that European was a substantial built horse after the Green Mountain Morgan pattern. All agree that for his day he was a fast trotter. And Mr. Milliman compares him to a grandson of Black Hawk, which he himself owned, and which he said had the finest head and neck, 
he ever saw, a characteristic in which Morgan horses have always excelled.

We take no stock in the "Bonaparte war horse story," whether originating with Mr. McNitt, or as Mr. Charles Milliman claims, in information, got by him afterwards in Canada. Stories of this kind are very common with a certain class of horse jockeys, whether French, or otherwise, in regard to their horses, especially those they offer for sale, but repeatedly we have found them to disappear before research like a mist before sunshine. The sire of St. Lawrence was said to have been imported by an English officer, but we found was quite a plebian horse that had grown up in the neighborhood of Chambly, as his sire and grandsire lived there before him.

The same story was told of the fast trotter Petit Coque, whose ancestors with comparative ease we traced back about 30 years, when they were brought into Canada from Vermont. There is little chance that any horse in Canada ever was descended from any of Napoleon's war horses, but there were thousands of Morgan horses which entered the Province of Quebec from Vermont, or were bred in the Province between the years, I 800 and $\mathrm{r} 860$.

Referring to the similarity of the two horses, Engineer that went to Long Island from Canada in $18 \mathbf{1 6}$, and European that was taken through Vermont to New York about I $8 \mathbf{2} 8$, it is quite noticeable that in the story of European he is said to have been imported about I 8 I 4 , which agrees with the story told of Engineer on Long Island in the fall of $\mathrm{I}_{\mathrm{S}} \mathrm{5}$. We are quite inclined to think that they are the same horse, and therefore give them the same Morgan rating, I-2, satisfied that in any case as foundation stock they will make a substantial addition to the Morgan family.

EURYALUS, bay, over I 6 hands; foaled I 790. Imported, fall of 1794 from England. Advertised $\mathrm{r} 795$ in New York Herald at Brooklyn Ferry, Jamaica Road, L. I., at farm of Peter Vandervoort.

EVAN LEWIS (I-32), gray, I6 hands, I Ioo pounds; foaled I887; bred by C. A. Babcock, Canton, Ill., got by George Sprague, son of Governor Sprague : dam Anna B., bay, bred by C. A. Babcock, got by Dan Brown; 2d dam Fan, chestnut, bred by Wm. Babcock, Canton, Ill., got by Lance, son of Flying Morgan ; 3 d dam Queen, said to be by General Gifford, son of Gifford Morgan; $4^{\text {th }}$ dam Fan, by Chancellor, son of Leviathan;

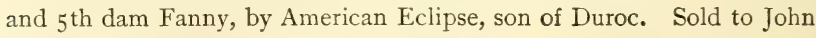
Graham, Dysart, Ia., who sends pedigree.

Sire of Princess Alice, $2: 21 \frac{1}{2} ;$ I dam of I pacer.

EVERETT CLAY ( I-I28), bay ; foaled I882; bred by J. D. Willis, Middletown, N. Y. ; got by Harry Clay, son of Cassius M. Clay Jr. : dam Lady Winfield, chestnut, bred by J. D. Willis, got by Edward Everett, son of 
Hambletonian; and $2 \mathrm{~d}$ dam said to be by Rattler, son of Abdallah. Sold to J. T. Story, Brooklyn, N. Y.

Sire of 3 trotters $(2: 183 / 4) ;$ Clay, $2: 143 / 4$.

EVERETT W. (I-32), $2: 30$, chestnut, $15^{1 / 2}$ hands, I 100 pounds; foaled I 887 ; bred by S. T. Goff, Winchester, Ky. ; got by Bourbon Wilkes, son of George Wilkes : dam Belle, chestnut, bred by R. D. Hunter, Winchester, Ky., got by Belle Morgan, son of Cottrill Morgan; 2d dam Snowstorm, gray, said to be by Steele's Snowstorm; and 3d dam by Tom Crowder. Sold to C. E. Fowler, South Haven, Mich., who sends pedigree.

Sire of Atherton, $2: 23 \frac{1}{4}$.

EVERGREEN (I-32), cherry bay, black points, scant I 5 hands, weight 850 pounds; foaled I 866 ; bred by S. D. Hoagland, Gravesend, King's County, N. Y.; got by Privateer, son of Hoagland's Gray Messenger: dam brown, said to be a Bashaw. Sold to Edward Freel, Brooklyn, N. Y. Pedigree from breeder, who says he could trot in $2: 30$ or better.

EVERMOND (3-256), $2: 24 \frac{1}{4}$, bay; foaled May 5, 1881; bred by A. J. Alexander, Spring Station, Woodford County, Ky. ; got by Harold, son of Hambletonian: dam Eventide, bay, bred by A. J. Alexander, got by Woodford Mambrino, son of Mambrino Chief; 2d dam Vara, bay, bred by Joseph Gavin, Chester, N. Y., got by Hambletonian; 3d dam Venus, said to be by American Star. Sold to A. M. Burke, Cleveland, O. ; to D. C. Webster and son, Valley Falls, Kan. Died I889. Pedigree from L. Broadhead.

Sire of 5 trotters $(2: 161 / 2)$; Everyway, $2: 14 \frac{3 / 4}{2} ; 2$ sires of 3 pacers; 3 dams of $x$ trotter, 3 pacers.

EVERSON ROYALIST ( $\mathrm{I}-64$ ), bay, I 6 hands, I 200 pounds; foaled r $8 S 0$; bred by Richard Richards, Racine, Wis., got by Swigert, son of Alexander's Norman: dam Bay Fanny, bay, bred by Richard Richards, got by Richards' Bellfounder, son of Hungerford's Blucher ; 2d dam Lady Mary, said to be by Signal (Singleterry's Rattler); and 4th dam old Kate, said to possess Messenger blood. Sold to George Everson, Lake Mills, Wis., who sends pedigree; to Dietmeyer \& Skinner, Waukeegan, Ill.; to F. J. Dietmeyer; to John Worthington, Manitowoc, Wis.

Bay Fanny is also dam of Fox, $2: 30$; Alexander, $2: 281 / 4$; Resolute, $2: 27 \frac{1}{4}$; Royalty, $2: 25$; Blue Wing, $2: 27$.

Sire of Tossie D., $2: 25$.

EVOLUTIO (5-256), $2: 133 / 4$, chestnut, $153 / 4$ hands; foaled 1888 , bred by Elizur Smith, Lee, Mass. ; got by Nominee, son of Stranger : dam Katie Smith, bay, bred by Elizur Smith, got by Alcantara, son of George Wilkes; 2 d dam Kate Jackson, bay, bred by James Long, Georgetown, Ky., got by Almont, son of Alexander's Abdallah; and 3 d dam Fanny, 
bay, said to be by Cadmus. Sold to Wm. H. Moody, Claremont, N. H., who sends pedigree.

Sire of 2 pacers $\left(2: 12 \frac{1}{4}\right)$.

E. W. M. (3-1 28$), 2: 29$, I $5 \frac{\mathrm{T}}{2}$ hands, 1080 pounds; foaled I 890 ; bred by E. W. Mosher, York, Neb. ; got by Red Wing, son of Red Wilkes : dam Ollie Scott, bay, bred by J. D. \& C. Butler, Bourbon County, Ky., got by Strathmore, son of Hambletonian; 2 d dam Laura Logan, bay, said to be by American Clay, son of Cassius M. Clay Jr. ; 3d dam Peg, by Crusader (Low's); and $4^{\text {th }}$ dam by Tom Hal. Sold to the Capitol National Bank, Lincoln, Neb. ; to A. J. Vaughan, Westmark, Neb., who sends pedigree. Died I 897 .

Sire of Tony W., $2:$ II $^{1} / 4$.

EXARCH $(3-64), 2: 26 \frac{1}{4}$, chestnut with star, hind ankles white, $15 \% / 2$ hands ; foaled I887; bred by W. B. Fasig, Cleveland, O.; got by Ambassador, son of George Wilkes: dam Lily Bloom, chestnut, bred by B. E. Bates, Shoreham Vt.; got by Daniel Lambert, son of Ethan Allen ; 2 d dam Cook mare said to be by Young Columbus; 3d dam Fanny Cook, dam of Daniel Lambert, which see. Pedigree from V. F. French, Unionville, O.

Sire of Sunlocks, $2: 23 \frac{1}{2} ; 2$ pacers $\left(2: 22 \frac{1}{4}\right)$.

EXCEILENCE $(\mathrm{I}-32), 2: 223 / 4$, bay with star, right fore foot and right hind ankle white, left hind leg white; foaled April 6, I 885 ; bred by C. J. Hamlin, East Aurora, N. Y.; got by Mambrino King, son of Mambrino Patchen : dam Windsweep, bay, bred by C. J. Hamlin, got by Almont Jr., son of Almont; 2 d dam American Girl, bred by C. J. Hamlin, got by Hamlin's Patchen, son of George M. Patchen; 3d dam Woful, bred by C. J. Hamlin, got by Young Woful; $4^{\text {th }}$ dam said to be by Hero, son of Abdallah. Went to Meadville, Penn., Oct. 9, 1891. Pedigree from catalogue of breeder.

Sire of Exonica, $2: 241 / 4$.

EXCELSIOR (I-8); said to be by Black Hawk, son of Sherman Morgan. Advertised for sale by John Gregory, Northfield, Vt., in the American Stock Journal, Vol. II., I 860 .

EXCELSIOR (I-I6), $2: 5 \mathrm{x}$, bay with star, I5 1/2 hands, Iooo pounds; foaled June, I 852 ; bred by Isaac Meacham, Kinsman, O. ; got by Vermont Trotter, which see: dam Lady Revenge, bay, bred by Isaac Meacham, got by Sirocco, son of Count Piper, thoroughbred son of Marshall Duroc ; 2d dam Polly, bred by Isaac Meacham, got by Post Boy, son of Tippo Saib, by Messenger. Sold to Philo Thompson, Brookfield, O., who owned him in 1858 ; to W. Hightree. Trotted many local races. Died about I88o. See The Morgan Horse and Register Vol. II. p. I 20. Sire of I sire of I trotter. 
EXCELSIOR ( $1-32$ ), black, left fore ankle white, hind ankles white; foaled $\mathbf{1} 883$; bred by C. J. Hamlin, East Aurora, N. Y.; got by Mambrino King, son of Mambrino Patchen : dam Moonlight, brown, left fore and both hind ankles white, foaled I 879 , bred by C. J. Hamlin, got by Almont Jr., son of Almont ; 2 d dam American Girl, said to be by Hamlin's Patchen, son of George M. Patchen ; 3 d dam by Young Woful ; and $4^{\text {th dam }}$ by Abdallah. Pedigree from catalogue of breeder.

Sire of Phillips, $2: 29 \frac{1}{4}$.

EXCELSIOR MORGAN (I-8); said to be by Comet son of Chittenden County Morgan. Owned by Jack Carson, Dearborn County, Ind., and taken to Missouri about 1858 .

Sire of second dam of Lady Maxim, $2: 27 \frac{1}{4}$.

EXCELSIOR MORGAN (I-I6), chestnut, I 5 I $/ 2$ hands, Iooo pounds; foaled I 854 ; bred by Gershom Flagg, Paddocks Green, Ky. ; got by Vermont Morgan, sire of Golddust: dam, Kitty Bowes, said to be by Young Buzzard. Sold, $\mathbf{1} 855$, to L. L. Dorsey, Louisville, Ky. Received first premium at the South Western Fair, near Louisville, Ky. ; at Eminence, Ky., I856 ; at St. Louis (Mo.) Fair, I857; and at Kentucky State Fair. See the Morgan Horse and Register, Vol. II., p. I 20.

Sire of $2 \mathrm{~d}$ dam of Vera, $2: 25$.

EXCHEQUER (Thoroughbred), chestnut; foaled 1856 ; bred by Thomas W. Doswell, Richmond, Va.; got by Revenue, son of Imp Trustee: dam Nina, bay, foaled 1848 , bred by R. P. Gray, got by Boston, son of Timoleon; 2 d dam Imp. Frolicsome Fanny, bay, foaled $\mathbf{1} 8 \mathbf{3 2}$, bred by Mr. Kirby, England, got by Lottery (See I. A. S. B. 88) ; 3d dam by Whisker; $4^{\text {th }}$ dam by Bay Trophonius; $5^{\text {th }}$ dam by Slope; 6th dam by Young Marske. Died 1875 . Owned by Maj. W. J. Bacon, Montgomery, Ky., who writes :

Mir. Joseph Battell,

$$
\text { BeLl, Ky., April I, I89i. }
$$

Dear Sir:-Your favor would have had sooner answer, but I had moved away from Montgomery and your letter was finally forwarded to me at my present office, Bell, Ky.

I bought Exchequer of Major Thomas W. Doswell of Richmond, Va. He owned Nina and bred Exchequer and Planet from her, both by Revenue. Nina was foaled in $\mathbf{1} 848$; was by Boston (she was Boston's best daughter, and Lexington, his best son). Nina's dam, imported Frolicsome Fanny, was foaled in 1832 ; and bred by Mr. Kirby of England. She was by Lottery, her dam by Whisker, etc. Exchequer was a great stallion and I think if he had had any chance whatever in the stud he would have demonstrated that fact to the entire satisfaction of all.

He was in Virginia during the war and no one had time then and there to give any thought to breeding. After the war he was purchased and brought to Kentucky in a section of the State where no attention was paid to the breeding of race stock of any description, and only had an 
opportunity of serving two or three thoroughbred mares, owned by myself. I bought a few good saddle mares and bred to him. From them he placed himself as the first and only living thoroughbred horse, under all rules governing stallions, as a standard bred trotting sire. From these few mares he produced two fillies that made public records in contested races in the twenties. Very few of his colts were ever trained, and had more of them been handled and given the opportunity to show their merits on the trotting turf, I feel sure he would have others in the twenties. I wish to call your attention to the stallion Palo Alto, record 2:1 $2 \mathrm{~T} / 4$. His dam, Dame Winnie, was by Planet a full brother of Exchequer.

While I was in the breeding business, I won the two-year-old trotting stake at Hopkinsville, Ky., with one of Exchequer's fillies. Seven twoyear-olds started in the race and two of the starters were winners to twoyear-old race in Kentucky and Tennessee. This filly was sold and used as a roadster and had no other showing on the track or turf. Again, Mr. James S. Parrish a year or so after won the two-year old stake at Hopkinsville, Ky., with a colt of Exchequer. At the same meeting he got the consent of the directors to let his two-year-old colt start in the threeyear-old stake; no objections being made by owners of three-year-olds, his colt started and won over them in two straight heats. This colt of Exchequer was castrated later on in the fall and he had the bad luck to lose him. Mr. Parrish owned and developed Lucille and sold her to Mr. R. C. Pate, but he says the colt he lost was far superior to Lucille.

I hope my delay in replying has not interfered with your plans. I regret very much that Exchequer did not have a little opportunity in the stud. There are only a few of his descendants now in this country. I know of two or three mares that I sold when I quit the stock business that I think would bring winners if bred to Almont or any of Hambletonian's sons. Please let me know if you desire any further information of Exchequer.

Sire of 2 trotters $(2: 2 \mathrm{I}) ; 3$ dams of 3 pacers.

EXECUTOR (PRAIRIE CHIEF) ( I-64), $2: 24 \mathrm{~T} / 4$, bay; foaled $\mathrm{I} 875$; bred by B. J. Treacy, Lexington, Ky.; got by Administrator, son of Hambletonian : dam chestnut, said to be by American Clay, son of Cassius M. Clay Jr.; and 2d dam Miss Montague, by Steele's Snowstorm. Sold to G. W. Snyder \& Co., Greenville, O.

Sire of Trixter, $2: 251 \frac{1}{2}$.

EXPEDITE (I-64), chestnut, I5 1/2 hands, I Ioo pounds; foaled I886; bred by A. L. McCrea, Jr., Gouverneur, N. Y., got by Elial G., son of Aberdeen : dam Elastic, bred by Mr. Gross, Lee, Mass., got by Alastor, son of Almont; 2d dam Kitty, bay, bred by S. Crosby, Lee, Mass., got by Americus, son of Eureka; 3 d dam a pacing mare. Sold to Richard Cole Salem, O. Pedigree from breeder.

Sire of Etta K., $2: 21 \frac{1}{4}$ : Expert, $2: 161 / 4$.

EXPEDITION. An advertisemnet of this horse in New Jersey, r823, by A. Hunt, describes him as sorrel, $153 / 4$ hands; foaled 18 I9 and states that his dam was by Honest John son of Sir Peter Teazle ; 2d dam Zelepha by 
imported Messenger ; 3 d dam Dido, by imported Bay Richmond ; and $4^{\text {th }}$ dam Slammerkin, by imported Wildair. Advertised as "Celebrated full-bred Expedition" in 1832 in New Jersey, by Solomon Boyle.

EXPEDITION (IMPORTED, FIRST CALLED BALLINAMUCH). This famous horse, was advertised, 1827 , by Joshua Humphreys to make the season at Moorestown, New Jersey, nine miles from the city of Philadelphia, at the stable of Thomas Porter, sign of the Golden Fleece, at $\$ 12$ to insure.

The Advertisement describes him, as chestnut, $153 / 4$ hands, movement and action inferior to none; bred by the Earl of Egremont, and got by Pegasus: dam Active, by Woodpecker; $2 \mathrm{~d}$ dam Laura, by Whistlejacket; 3 d dam Pretty Polly, by Starling; $4^{\text {th }}$ dam sister to Lord Leigh's charming Molly and Diana, by Second--Stanyan's ArabianKing William's Barb without a tongue-Makeless-Royal Mare. Pegasus was by Eclipse ; his dam by Bosphorus ; 2 d dam (own sister to Grecian Princess), by Williams' Forrester-Coalitian Colt-Bustard-Second, etc. Pegasus won six of the King's Plates, and Bosphorus won seven. Woodpecker was by King Herod, his dam Miss Ramsden, by old CadeLonsdale's Bay Arabian-Bay Bolton-Darley's Arabian-Byerly Turk —Place's White Turk-Taffolet Barb-Natural Barb Mare. Expedition was a very successful race horse.

EXPEDITION (1-64), $2: 15 \frac{1}{4}$, brown, I $5 \frac{1}{4}$ hands; foaled 1889 ; bred by A. J. Alexander, Spring Station, Ky. ; got by Electioneer: dam Lady Russell, gray, bred by A. J. Alexander, got by Harold; $2 \mathrm{~d}$ dam Miss Russel, gray, bred by R. A. Alexander, Spring Station, Ky., got by Pilot Jr. ; 3d dam Sally Russell, chestnut, bred by John H. Russell, Frankfort, Ky., got by Boston, son of Timoleon; 4th dam Maria Russell, bay, bred by Holton Russell, Frankfort, Ky., got by Thornton's Rattler, son of Sir Archy; $5^{\text {th }}$ dam Miss Shepherd said to be by Stockholder. Pedigree from L. Broadhead, Supt., and catalogue of breeder.

Sire of 32 trotters $\left(2: I_{1} 1 / 4\right)$; Wavelit, $2: 17 \frac{1}{4} ; 4$ sires of 4 trotters, 3 pacers; I dam of I trotter.

EXPERT ( $1-8$ ), chestnut with bald face, and white hind legs to knees; foaled about I 850 ; bred by George Coons, Leesburg, Ky.; got by Bald Stockings, son of Tom Hal : dam said to be by Whip Comet, son of Virginia Whip. Sold together with a full-brother to John W. Gaines; to Simeon Kirtley, who took them to Tennessee, sold the bay and after keeping Expert one or two seasons in Tennessee brought him back to Kentucky and sold him about I86r, to Mr. Warmock, who sold about r864, to Joseph Shropshire, who took him to Woodford County, Ky. He was afterwards bought by James Clarke, Bourbon County, and died I 882 .

EXPERT PRINCE, $2: 13 \frac{1}{4}$, black, left hind ankle white, I61/2 hands, 
I 300 pounds; foaled I 886 ; bred by G. W. Headley, Lexington, Ky. ; got by Egbert, son of Hambletonian : dam Madam Headley, bay, bred by G. W. Headley, got by Stanhope's Edwin Forrest ; 2 d dam Madam Stanhope, said to be by Mambrino Chief, son of Mambrino Paymaster; and $3 \mathrm{~d}$ dam Fanny, by Commodore (Hunt's). Sold to William Anderson, Romeo, Mich., who sends pedigree. Died I9o3.

Sire of 2 pacers $\left(2: 10 \frac{1}{2}\right)$.

EXPRESS (IMPORTED), bay, I6 hands, lengthy and bony, by Postmaster, son of Herod: dam by Syphon, son of Squirt, grandsire to Eclipse.

Advertised as above in Poughkeepsie Journal March 22, I797. A list of races won by Express, is annexed.

EXTON, bay ; foaled I 79I ; bred by Mr. Addy ; got by Highflyer : dam I. O., by Spectator-Blank-Lord Leigh's Charming Molly, by Second-Mr. Hanger's Brown Mare by Stanyan's Arabian-Gipsey by King William's No-tongued Barb called Chillaby-Makeless-Royal Mare.

This horse was imported, but is said to have been a failure, perhaps from want of proper patronage.

EXTON ECLIPSE, bay; foaled I 82-; bred on Long Island; said to be by American Eclipse, son of Duroc: dam by imported Exton, son of Highflyer. Sold, I829, by Mr. DeGrout, of Long Island, to Mr. Green, who took him to Winslow, Me. He was afterwards returned to New York State and stood at Goshen and Warwick from 1835 to 1838 .

Advertised in American Turf Register, I83 1 , in Kennebec County, Me., at \$ 55 and \$2O.

"This elegant full-blooded bright bay horse, may be found the present season at the stable of Virgil Bennett, in the village of Goshen, and will be kept at the stable of James and John Wellings in Warwick, beginning on the 2 oth of April next, and changing alternately each week through the season. He was bred on Long Island, and was owned by C. W. Van Ranst, Esq. Exton Eclipse was by American Eclipse, his dam by the imported English horse, Exton. Exton Eclipse is $153 / 4$ hands high, stout made and of great life and action. For terms and pedigree reference may be had to handbills.

Goshen, N. Y., April I3, I835."

Charles Green.

Sire of $2 \mathrm{~d}$ dam of Captain, $2: 28$, and winner of 16 races.

EXTRA (3-64), black with star and snip, I5 hands, I Ioo pounds; foaled x 877 ; bred by Allen W. Thomson, Woodstock, Vt., got by Lockwood, son of Aberdeen : dam Beauty, bay, bred by Frederick Billings, Woodstock, Vt., got by Woodstock, son of Young Morrill; 2 d dam black, bred by James Rowland, Woodstock, Vt., got by the Harpin Horse, called Young St. Lawrence; 3 d dam bay, bred by James Rowland, got by Morgan Tally-Ho (the Walker Horse), son of Woodbury Morgan; 
$4^{\text {th }}$ dam chestnut, bred by John McKenzie, Woodstock, Vt., got by Financier. Died March, I888. Pedigree from breeder.

Sire of Chevalita, $2: 25 \frac{1}{2}$.

EXTRACTOR $\left(3-25^{6}\right)$, chestnut; foaled 1892 ; bred by A. J. Alexander, Spring Station, Ky. ; got by Expedition, son of Electioneer : dam Rosebush, bay, bred by A. J. Alexander, got by Woodford Mambrino, son of Mambrino Chief; 2d dam Primrose, bay, bred by R. A. Alexander, got by Alexander's Abdallah ; 3d dam old Black Rose, said to be by Tom

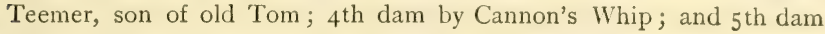
by Robin Gray. Pedigree from catalogue of breeder.

Sire of 2 pacers $\left(2: 24 \frac{1}{4}\right)$.

EZEKIEL, bay; foaled $\mathbf{I} 886$; bred by P. P. Johnston, Lexington, Ky.; got by Wilkes Boy, son of George Wilkes: dam Darlbay's Daughter, bay, bred by Hunt Bros., Lexington, Ky., got by Darlbay, son of Herr's Mambrino Patchen ; $2 \mathrm{~d}$ dam said to be by Morgan Whip ; and $3 \mathrm{~d}$ dam Hunt's Premium Mare, by Highlander (Scott's). Sold to Marshall McCormack, Berryville, Va. Pedigree from breeder.

Sire of 2 trotters $(2: 20)$, Fohnny Taylor, $2: 16 \frac{1}{4}$.

EACTOR, bay, I53/4 hands; said to be by Fearnaught: dam, by Bay Messenger, son of imported Messenger; $2 \mathrm{~d}$ dam by Timoleon; and 3d dam by Bashaw. Advertised in the Spirit of Times, I84 I, for sale by Abraham Miller, Somerstown, Winchester Co., N. Y.

Sire of Greenwich Maid, Dolly, Katy Q, etc.

FACTORY BOY (I-32), 2:20I/4, gray; foaled I879; said to be by Billy Bashaw; and dam by Schofield, owned by H. Schofield, Omro, Wis. Gelded young.

We have received the following letter concerning this horse from Geo. M. Follett, the reputed breeder :

Joseph BATTELL,

Winneconne, Wis., Jan. 23, I89o.

Dear Sir :-I dropped you a card a short time since referring you to Scott Haster of Neenah, Wis., in regard to Factory Boy, claimed to be bred by me, which is a mistake. Scofield was owned by H. Scofield, Omro, Wis. As near as I can find out, he was a heavy horse probably I 400 , of a gray color, resembling the Norman stock, no pedigree worthy of note as a road horse, and I guess pedigree unknown. His age is, or would be if he is alive about seventeen or more years. If you want a more particular description, write to the address above.

Yours truly, Geo. M. Follett.

FAGDOWN, brown; foaled about I80o; bred by Col. Joseph Kickbridge, 
Bordentown, N. J. ; got by Friendship; son of imported Messenger : dam said to be an imported fast trotting mare owned by Joseph Kickbridge. Owned by Wm. Hart, who sold to Wm. Calla, both probably of New Jersey. He is also said to have been owned by Isaac Hackett and Charles Costill and kept several years in Salem County, N. J. He was vicious but got some fast trotters. See Young Fagdown.

Said to be sire of Bull Calf, 2:3r.

FAGDOWN (YOUNG), gray, about I 6 hands, foaled about I 820 ; bred by Amos Bye, Maryland; got by Fagdown, son of Friendship by imported Messenger: dam Lady Damsel, said to be by Revenge, owned in Virginia; and $2 \mathrm{~d}$ dam by Medley. Owned by Emily Bennett, Winchester, Md., who sold about $\mathbf{I} 8 \mathbf{2} 8$ to William and James Armstrong of Ohio, who sold him about 1837 . Whilst owned by the Messrs. Armstrong he was kept in Columbiana County, mostly in Salem and Goshen, Deerfield and Palmira. In 1838 , he was in Mahoning County, O., and it is thought afterwards went to Jefferson County, O.-From old advertisement.

A horse of this name, probably this horse, is said to have been brought from the neighborhood of Philadelphia to Mahoning County, O. $\mathrm{He}$ was a flee-bitten gray, and represented to be a Messenger.

FAILNOT (3-I 28), 2 :I61 $/ 2$, brown; foaled ז889; bred by Miller \& Sibley, Franklin, Penn. ; got by St. Bel, son of Electioneer : dam Almona, bay, bred by W. T. Withers, Lexington, Ky., got by Almont, son of Alexander's Abdallah; 2 d dam Belle Bryan, black, bred by Joseph H. Bryan, Fayette County, Ky., got by Mambrino Patchen ; 3d dam Bryan's Denmark, said to be by Denmark, son of imported Hedgeford; and 4 th dam by Blackburn's Whip. Sold to Frank L. Fuller, Cedar Springs, Mich.

Sire of 2 trotters $\left(2: 24 \frac{1}{4}\right), 6$ pacers $\left(2: 08 \frac{1}{4}\right)$.

FAIR AMERICAN; foaled I803; said to be by old Traveler: and dam thoroughbred. Advertised, I 809, at Shrewsbury, Mass.

FAIRCHILD HORSE (PANGBORN HORSE) (3-32), chestnut, I5 hands, 900 pounds; foaled $184-$; bred by Peter Doyle, Naperville, P. Q. ; got by Billy Root, son of Sherman Morgan. Sold to Mr. Pangborn; to Mr. Nelson, Burlington, Vt. ; to Smith Fairchild, Willsboro, N. Y. See The Morgan Horse and Register, Vol. I., p. 301.

FAIREST ( $1-64$ ), 2 :I 8 , chestnut, I $5 \mathrm{~T} / 4$ hands, 850 pounds; foaled 1883 ; bred by E. S. McCurdy, Lowndesboro, Lowndes County, Ala.; got by McCurdy's Hambletonian, son of Harold : dam Georgia Golddust, bred by E. S. McCurdy : got by Messenger Golddust, son of Golddust; 2 d 
dam Sue McCurdy, (dam of Lulu Hambletonian, $2: 27$ ), not traced. Pedigree from breeder.

sire of $\mathcal{Y} . R . \mathcal{F}, 2: 17 \frac{1}{4}$.

FAIRFAX ROAN (STRAWBERRY, THE STRAWBERRY ROAN), roan; foaled I 764 ; bred by Mr. Simpson, got by Adolphus : dam said to be by Mr. Smith's Tartar, son of Croft's Partner; 2d dam by Midge, son of Snake; and 3 d dam by Hip. Imported (it is believed), by Lord Fairfax, into Virginia during the Revolutionary War. He ran in England five times, winning repeatedly. See English Racing Calendar for the year 1770 .

FAIRFIELD ( $1-32)$, bay; hind feet white, $15 \frac{1}{4}$ hands; foaled 1885 ; bred by W. Field, Lexington, Ky.; got by Aberdeen, son of Hambletonian: dam Cricket, chestnut, bred by J. C. Brown, Sullivan, Ind., got by Tom Crowder (Brown's), son of old Tom Crowder. Sold, I889, to George Agniel, Princeton, Ind. Pedigree from breeder, who writes :

"Second dam was a mare taken from Kentucky to Sullivan, Ind., and known as the Ed. Hanger mare, I tried to trace her but could not do so. She was a good race mare and no doubt thoroughbred."

Sire of George M., 2: 221/4.

FAIRFIELD BOY (I-I6), seal brown, I5 $5 / 2$ hands, I050 pounds; bred by James Ryan, Fairfield, Vt.; got by Peacock, son of Sherman Black Hawk: dam bay, thought to have been bred by James Ryan, sire unknown. Sold after the death of James Ryan, to Edwin Soule, Fairfield, Vt., whose property he died about I884. A fine appearing horse of good disposition and action. See The Morgan Horse and Register, Vol.

I., p. 393.

FAIRHOLM (3-128), bay, star, both hind ankles white; foaled I 886 ; bred by T. H. Cleveland, Jr., Lebanon, Ky., and W. T. Withers, Lexington, Ky. ; got by Aberdeen, son of Hambletonian : dam Judith, said to be by Santa Claus, son of Strathmore.

Sire of Dennis, $2: 14 \frac{1}{4}$.

FAIRLAWN MEDIUM ( $\mathrm{I}-32), 2: 25 \mathrm{~T} / 4$, bay, star and snip, right hind and left front foot white; foaled 1882 ; bred by W. T. Withers, Lexington, Ky. ; got by Happy Medium; dam Tolona, bay, bred by W. T. Withers, got by Cassius M. Clay Jr.; 2d dam Susie West, bay, bred by Richard West, Georgetown, Ky., got by Almont, son of Alexander's Abdallah. Sold to A. H. Kortlander, Grand Rapids, Mich., April 2d, 1886 ; to J. F. Kingsley, Walnut Springs, Texas. Pedigree from catalogue of breeder.

Sire of 9 trotters $(2: 19 \%), 5$ pacers $(2: 08)$; I sire of I trotter, I pacer; I dam of I trotter.

FAIRTHORN (I-64), bay, some white on both hind feet; foaled I890: 
bred by A. J. Alexander, Spring Station, Ky. ; got by Lord Russell, son of Harold : dam Rosebush, bay, bred by A. J. Alexander, got by Woodford Mambrino, son of Mambrino Chief ; $2 \mathrm{~d}$ dam Primrose, bay, bred by R. A. Alexander, got by Alexander's Abdallah : 3d dam Black Rose, black, said to be by Tom Teemer, son of old Tom ; $4^{\text {th }}$ dam by Cannon's Whip; and $5^{\text {th }}$ dam by Robin Gray. Pedigree from catalogue of breeder.

Sire of 2 trotters $\left(2: 19^{1 / 4}\right)$.

FAIRVIEW CHIEF (3-32), $2: 23 \mathrm{~T} / 4$; bred by John P. Kennedy, Putnam, N. Y.; got by Superb, son of Ethan Allen : dam said to be a Black Hawk mare. Died when five.

S. H. Rundle, Danbury, Conn., writes :

"Blue Bells is bred as follows: Black mare, foaled May 26, I887, I $53 / 4$ hands high, weighs 1000 pounds, got by Quarter-master, son of Alcyone: dam Belle Medium, by Fairview Chief, son of Superb; 2d dam Kitty Kennedy, by Nelson's Happy Medium Jr.; 3 d dam a fast road mare bred in Massachusetts and believed to be by a son of Black Hawk, by Sherman Morgan. Belle Medium is the dam also of Stanley, and the winner of the New England bred colts at one and also two years of age, $2: 293 / 4$ at two years.

"Fairview Chief was a beautiful young horse bred and raised by John P. Kennedy of Putnam, N. Y., died when five years old. Mr. Kennedy owned and drove in Wynn for years a pair of black mares, trotters in those davs. They were bought in Massachusetts and as near as we can trace them out, were got by a son of Black Hawk.

"He bought a farm just over the line in New York State, from here, and then bred both mares, one to Happy Medium Jr., the other to Superb. The produce by Happy Medium was Kitty Kennedy (a very fast three year old). The produce by Superb was Fairview Chief. When old enough he bred the two together. The offspring was Belle Medium, the dam of Blue Bells and Stanley. Belle Medium is a very pure gaited, level headed, blocky mare, about I5-I high."

Sire of dam of Blue Bells, $2: 201 / 2$.

FAIRY GIFT (I-64), 2 :30 ; brown or black, tan flanks and muzzle, I 5 hands $2 \mathrm{I} / 2$ inches, I 200 pounds; foaled I 876 ; bred by F. P. Kinkead, Midway, Ky.; got by Hero of Thorndale, son of Thorndale: dam Fairy Belle, bred by F. P. Kinkead, got by Belmont, son of Alexander's Abdallah; 2 d dam Waterwitch (dam of Mambrino Gift, $2: 20$ ), bred by F. P. Kinkead, got by Pilot Jr., son of Pilot; 3d dam Fanny Fern, bred by F. P. Kinkead, got by Kinkead's St. Lawrence; $4^{\text {th }}$ dam Brenda, said to be thoroughbred. Sold to L. S. Rupert, Washington, Ill.; to A. G. Danforth, same place. Pedigree from Melbourne Stock Farm catalogue.

Sire of $I_{5}$ trotters $\left(2: I_{5} \frac{1}{4}\right), 7$ pacers $\left(2: I_{5} \frac{1}{2}\right) ; 7$ sires of 6 trotters, 8 pacers $; I_{3}$ dams of II trotters, 5 pacers.

FALCON, bay; foaled I 872 ; bred by Charles Backman, Stony Ford, N. Y.; got by Messenger Duroc, son of Hambletonian: dam Sally Feagler, 
brown, bred by Samuel Lutes, West Town, N. Y., got by Smith's Clay; son of Neave's Cassius M. Clay Jr. ; $2 \mathrm{~d}$ dam said to be by Hickory, son of Hickory. Pedigree from breeder.

Sire of G. H. F, 2:121/4; Merengo, $2: 161 / 4$.

FALCON, bay; foaled I $\delta_{72}$; bred by Charles Backman, Stony Ford, N. Y. ; got by Messenger Duroc, son of Hambletonian : dam Sally Feagles, dam of Dauntless which see.

FALCON (I-16), bay with black points, $15 \frac{1}{2}$ hands, I050 pounds: foaled I 874 ; bred by James G. Freeman, North Charlestown, N. H.; got by Young Hambletonian, son of Fitch's Hambletonian, by Hambletonian: dam Polly the Van Dorn Mare, at Brattleboro, Vt., said to be by Burbank Horse, son of Woodbury Morgan, by Justin Morgan; and $2 \mathrm{~d}$ dam an imported thoroughbred mare. Sold to G. R. Cummings, South Acworth, N. H. ; to Kimball Flanders, Concord, N. H. ; to George B. Gordon, Bristol, N. H. Pedigree from Sam Hodgson, who writes :

"Mr. Freeman writes as follows: 'Dolly' the Van Dorn mare was by old 'Burbank Morgan' and foaled in Randolph, Vt., dam thoroughbred running stock. I had this from Moses T. Van Dorn in writing, Dolly's owner of whom I bought her. Young Hambletonian was claimed to be a chestnut in color, dam Morgan, and also to have trotted a mile in 2:50; of which I have no reason to doubt as many of Young Hambletonian's get were chestnut from bay and black mares. I sold quite a number of his colts for $\$ 250$ to $\$ 300$ each at 2 or 3 years old. They had good style, good gait, sold readily, and quite a number were speedy from common mares."

Sire of 2 trotters $\left(2: 21^{3 / 4}\right)$.

FALCON JR. (I-I6), $2: 2 \mathrm{I} 3 / 4$, bay, black points, one white heel, 16 hands, I 100 pounds; foaled I 886 ; bred by John B. Gordon, Bristol, N. H. ; got by Falcon, son of Young Hambletonian : dam Dauntless Maid, bay, bred by John B. Gordon, got by Dauntless, son of Hambletonian ; $2 \mathrm{~d}$ dam Lady Lyon, bred by John B. Gordon, got by a son of Gen. Lyon. Sold to Sam Hodgson, Meredith Village, N. H., who sends pedigree.

FALLIS (3-128), $2: 23$, bay, white hind ankles, 15 hands; foaled 1878 ; bred by Leland Stanford, Palo Alto, Cal.; got by Electioneer : dam Felicia, bred by Charles Backman, Stony Ford, N. Y., got by Messenger Duroc; 2d dam Lady Fallıs, bay, foaled I 859 , bred by James M. Mills, Bullville, Orange County, N. Y., got by American Star; 3d dam Beck Mare, said to be by Long Island Black Hawk. Pedigree from catalogue of breeder.

Sire of Io trotters $\left(2: 17 \frac{1}{2}\right)$, I pacer $(2: 19) ; 3$ sires of 7 trotters, 5 pacers ; 4 dams of 4 trotters.

FALLOWER; said to be by Blank, son of Godolphin Arabian: dam by Partner,-Bloody Buttocks,-Grayhound,-Makeless,-Brimmer,- 
Place's White Turk,-Dodsworth,-Layton Barb Mare. Imported to South Carolina, I766, by Mr. Fenwick, who very soon sold him. Kept several seasons in Carolina.

The above is from Milliken.

There are several Partner mares, sisters, with above breeding in the English Stud Book, and one of them in 1761 , had an unnamed colt bred by the Duke of Grafton and got by Blank. Bruce makes Fallower this colt and is probably correct in doing so.

FALMONT, brown; foaled I 893 ; bred by E. B. Millett, Langley, Kan.; got by Falsetto, son of Star IVilkes: dam Fancy Almont, bay, bred by George M. Jewett, Fair Oaks, Zanesville O., got by Almont Chief, son of Almont; 2d dam Kit Patchen, bay, bred by George M. Jewett, got by Wild Wagoner, son of George M. Patchen ; and 3d dam Kathleen, by Flying Hiatoga, son of Hiatoga. Sold to Ira E. Floyd, Ellsworth, Kan., who sends above pedigree; to C. B. Markentin, Newton, Kan., about 1904 .

Sire of 3 trotters $\left(2: 13^{1 / 4}\right)$, Mamie Falmont, $2: 24^{3 / 4}$.

FALMOUTH BOY, $2: 29 \mathrm{I} / 2$, bay; foaled May 23, I 865 ; bred by Josiah Hight, Athens Me.; got by Young Potter Horse, son of Potter Horse, by a Canadian horse : dam said to be by Witherell Horse, son of Winthrop Messenger; and $2 \mathrm{~d}$ dam an English thoroughbred mare, imported to Quebec and brought from Quebec to Athens, Me. Pedigree from breeder.

FALROSE (3-64), 2 :19, bay; foaled I 887 ; bred by G. Valensin, Pleasanton, Cal.; got by Fallis, son of Flectioneer : dam Roseleaf, bay, bred by G. Valensin, got by Buccaneer, son of Iowa Chief; 2d dam Fernleaf, bay, bred by T. T. Tinsley, Mahaska County, Ia., got by Flaxtail; 3d dam Fanny Fern, brown, bred at Wheeling, W. Va., said to be by Irwin's Blind Tuckahoe, son of Herod Tuckahoe; and $4^{\text {th }}$ dam by Leffler's Consul, son of Shepard's Consul. Sold to F. P. Lowell, Sacramento, Cal.

Sire of 2 trotters $(2: 251 / 4), 4$ pacers $(2: 10)$.

FALSETTO ( $1-128$ ), black; foaled 1889 ; bred by Alexander Fraser \& Welsh, Kansas City, Mo.; got by Star Wilkes, son of George Wilkes : dam Mussetta, bay, bred by H. C. McDowell, Lexington, Ky., got by King Rene, son of Belmont; 2 d dam Musette, chestnut, bred by Robert Anderson, Lexington, Ky., got by Mambrino Patchen ; 3d dam Ida, said to be by Gill's Vermont, son of Downing's Vermont; and 4th dam by Snow Ball (Boner's), son of Gray Eagle. Sold to I. M. Millett, Langley, Kan. Pedigree from breeder.

Sire of Falmont, $2: 14 \frac{1}{4}$; I sire of 3 trotters, I pacer; I dam of I trotter. 
FALSTAFF ; said to be by old Cade : and dam well bred. Advertised, 1762 , to be kept at Perth Amboy, N. J., and called one of the stoutest of Cade's get.

FANCY GOLDDUST ( $\mathrm{I}-\mathrm{I} 6$ ), brown with white hind feet, $15 \mathrm{I} / 2$ hands, I 100 pounds; foaled I865; bred by L. L. Dorsey, Louisville, Ky. ; got by Golddust: dam Sally, bay, bred in Shelby County, Ky., said to be by Duprey's Monsieur Tonson; and ad dam by the Duke of Brunswick. Died I 875 . Pedigree from breeder.

Sire of Fred Golddust, $2: 271 / 2$.

FARMER, bay, I6 hands; foaled I794; fit for either saddle or draught. Advertised, as above, at Gettysburg, Penn., in I802.

FARMER; said to be a descendant of Wildair: and dam of the Hunter breed. Advertised,' 1804 , in Portland, Me.

FARMER, dark bay, I5 hands; foaled I $85 \mathrm{I}$. Advertised as above by J. J. Burton at Yamhill County, in the Oregon Farmer, 1859 . Terms $\$ 8$ to $\$ 15$.

FARMER BOY (5-128), $2: 191 / 2$, chestnut, light mane and tail, $153 / 4$ hands, I030 pounds; foaled I 880 ; bred by Parker D. Hubbard, North Amherst, Franklin County, Mass. ; got by Thomas Jefferson, son of Toronto Chief, by Royal George, son of Black Warrior: dam black, bred by W. W. \& G. P. Carpenter, Shelburn, Mass., got by Flying Cloud Jr., son of Flying Cloud, by Black Hawk; 2d dam chestnut, said to be a descendant of Morrill. Sold to W. C. Dule, Hartford, Conn. Gelded young. Pedigree from breeder who writes:

"He worked on the farm until he was six and one-half years old, and at that time could trot in $2: 40$. He was the best farm horse I ever had for the plow or mowing machine. Died I890."

FARMER JOHN, bay with star and white hind feet, 15 I/2 hands, J050 pounds; foaled I880; bred by Orlando Clark, East Montpelier, Vt.; got by Auctioneer, son of Tattersal, by Hambletonian: dam bay, bred by Daniel Stevens, East Montpelier. Died I 895 . Pedigree from breeder.

Sire of Parker Fohn, $2: 21 \frac{1}{4}$.

FARMER MILES (1-32), black, 153/4 hands, rooo pounds; bred by L. D. Morris, Paris, Ill.; got by Dr. Herr, son of Mambrino Patchen : dam black, bred by L. D. Morris, got by Idler, son of Ethan Allen. Pedigree from I. N. Sheppard, Paris, Ill.

FARMER'S BEAUTY (5-I6), bay with black points, I5 hands, Io8o pounds; foaled 1840 ; bred by Dr. Horatio W. Heath, Groton, Vt.; got by Peck's Young Papineau, son of Papineau: dam Peg, bay, about 
Iooo pounds, a favorite mare with Dr. Heath and his family, and a very famous roadster, called "the best mare in those parts," said to be by Sherman Morgan. Sold spring of $\mathbf{1} 842$, to Alden G. Heath, Topsham, Vt., who spring of $\mathrm{I} 843$, sold to Erastus Baldwin of Wells River, Vt. Mr. Baldwin sold him same spring, to David M. Taggart, Goffstown, N. H., whose property he died, I86r. It had long been supposed that Farmer's Beauty was a son of Gifford Morgan. In the winter of r $886-87$ we employed Allen W. Thomson to examine this pedigree for us, which he did, bringing out the fact that he was got by Young Papineau. Our further investigations have brought to light additional facts. We append two letters from A. M. Heath of Groton, Vt., son of Dr. H. W. Heath, breeder of Farmer's Beauty, the first dated July 2 I, I 888 , and forwarded to us by Mr. I. N. Hall :

"I am a son of H. W. Heath. When a boy, my father owned a very noted mare named Peg. A neighbor J. J. Peck, owned a two-year-old Papineáu stallion out of the Tucker mare, by One-Eyed Morgan. I overheard a conversation between my father and Peck, and Peck told my father that a colt from father's mare and his colt would unite the four great strains of the Morgan blood. They traded and the result was Beauty."

The second letter was written on the back of a list of questions which we sent to Mr. Heath, June $26, \mathbf{1} 889$ :

"The dam of Beauty I find was a Sherman Morgan. His sire was Young Papineau. Old Papineau was a very beautiful horse. Young Papineau was from the celebrated Tucker mare-as I have already stated, full-blooded Morgan. Young Papineau was two years old when he got Beauty, and he died in a few months after. He only got three colts. Old Papineau was a beautiful dapple gray. Young Papineau was dark dapple bay."

Farmer's Beauty is described by those who knew him as very intelligent, a fine roadster and parade horse, and a superior stock-getter.

A correspondent of Wilkes Spirit of the Times writes dated April 27 I 86 I :

"The people of Goffstown, N. H., as well as the owner have had a great loss in the death of the famous stallion Farmer's Beauty. He was the sire of Sorrel Frank, Black Warrior, Nat Baker, and a number of other famous trotters, by whose promise and performances his reputation as a successful sire was firmly established. The old horse seemed to be in health to the last and though well stricken in years was thought to be good for ten more to come. The attack was very sudden, and he fell dead as if shot."

See the Morgan Horse and Register, Vol. I. p. 749.

FARMER'S BEAUTY (MOORE'S) (I-8) ; said to be by Tecumseh, son of Black Hawk. Probably owned in New Hampshire. See The Morgan Horse and Register, Vol. II., p. I 2 I.

Sire of dam of Jubilee Wilkes, $2: 17 \frac{1}{4}$. 
FARMER'S DELIGHT, white; foaled I $85_{-}^{-}$; bred by R. McGee, Cedarville, Ill.; got by I'yle's Arabian, son of Farwell's Arabian. Said to be a handsome horse.

FARMER'S FAVORITE, brown, I6 122 hands; foaled 1800 ; said to be by the imported draft horse English Ball : and dam by Chester Lion. Advertised as above in the Lancaster (Penn.) Intelligencer, I805.

FARMER'S FRIEND, bay, 16 hands; foaled I $82 \mathrm{I}$; said to be by Young Messenger, son of Young Hotspur, by Hotspur, son of imported Messenger : dam by Lofty; and $2 \mathrm{~d}$ dam by Paymaster. Young Messenger's dam by Decatur, son of Superior. Young Hotspur's dam by Young Magnetic Needle, son of imported Magnetic Needle; $2 \mathrm{~d}$ dam by old Granby, and 3 d dam by Valient.

Advertised $\mathbf{I}_{27}$, by P. \& A. Reed, in the Trenton N. J. Emporium with pedigree as above.

FARMER'S GLORY; said to be bred by Malcolm McNeill, West River, P. E. I., Can., and got by Columbus.

Sire of dam of Bijou, $2: 24^{1 / 2}$.

FARNSIVORTH, (I-I6), bay; foaled I 892 ; bred by Henry N. Smith, Fashion Stud Farm, Trenton, N. J.; got by Rumor, son of Tattler: dam Falka, bay, bred by H. N. Smith, got by Gen. Washington, son of Gen. Knox ; 2 d dam Inez, bay, bred by H. N. Smith, got by Jay Gould, son of Hambletonian; 3 d dam Western Girl (Angeline), $2: 27$, brown, bred by Seth P. Phelps, Racine, Wis., got by Richards' Bellfounder, son of Hungerford's Blucher; 4th dam Fanny, said to be by Wild Harry. Sold to James R. Cumming, New York, N. Y.; to F. G. Mead, Sing Sing, N. Y., Nov., I893. Pedigree from catalogue of breeder.

FARNSIVORTH HORSE, (I-8), dapple chestnut, I 5 I/4 hands, 900 to 1000 pounds ; said to be by Gen. Gifford, son of Morgan De Forest. Owned by Mr. Mason, Penn Yan, N. Y., who sold about 1860 to Wm Farnsworth, Augusta, Mich. A very fine looking horse with good disposition and action; stock good. See The Morgan Horse and Register, Vol. I., p. 317 .

Sire of dam of Mattie D, $2: 25^{3 / 4}$; 2d dam of Henry Middleton, $2: 261 / 4$.

FARNSIVORTH PATCHEN. See Tom F. Patchen.

FARO. Mr. J. W. Foreman, Little Rock, Ky., in interview in Dr. Herr's stable early in May 1886 , said :

"Old Faro was the first Canadian horse I ever saw. He came from Montreal; John Bayless brought him to Kentucky. Bill Rogers bought Faro of him. He was the same kind of a horse as Pilot, only white."

We add the following correspondence. 
Dr. William Kenney, Paris, Ky.

Middlebury, Vt., April io, i 890.

Dear Sir :-Will you please inform me what was the origin of Barrett's Faro (sire of the Dr. Kenney Horse) and where and by whom the latter was bred?

And who bred and owned Half Indian and what was the origin of his sire, Black Indian? If any of these were brought into Kentucky, please give date of such importation and names of parties who made them; and very much oblige.

\section{Respectfully yours, JOSEPH BATTELL.}

Paris, Bourbon County, Ky., April i3, I8go.

Dear Sir-Your letter of the Ioth is before me. As to Faro I will have to direct you to Wesley Barrett, Cynthiana, Harrison County, Ky. I owned a horse by him, from a gray Whip mare, who got some very promising colts. This horse of mine was bred by a very illiterate man, Rankin, from whom you could learn nothing. Black Indian you might possibly learn something about by writing to Noah Dills, Cynthiana, Ky. I knew nothing about him, except Selim, got by my horse, was from a Black Indian mare, owned by an old friend of mine long since dead. I used him for a riding horse, yet let a friend now and then breed a favorite mare to him. My horse was finally sold to the Owen family of North Middletown, Bourbon County, Ky.

There is a Mr. Wilson, long a resident of Cynthiana, Ky., and proprietor of the Abdallah Park, from whom you might get some information in regard to Barrett's Faro, and Black Indian also. I have no knowledge whatever of Half Indian.

$$
\text { Respectfully, WM. Kenney. }
$$

FAROWIN (I-I2S), chestnut, narrow strip in face, little white on four feet, $15 \mathrm{I} / 4$ hands, 1000 pounds; foaled $\mathrm{I} \mathrm{S}_{92}$; bred by L. W. Nuttall \& Son., Keota, Ia., got by Advance, son of Onward, by George Wilkes : dam Witch, black, bred by F. C. Graves, Washington, Ia., got by Gipsey Boy, son of Stonewall Jackson; $2 \mathrm{~d}$ dam Jessie Graves, bay, bred by John Inus, Washington, Ia., got by Ripple, son of Romulus; $3 \mathrm{~d}$ dam Flora, bay, bred by John Inus, got by Brown's Champion; 4th dam Polly, brown, bred by John Inus, got by old Cub. Sold to J. F. Nuttall, Patterson, Ia., who sends pedigree. Died I9oı.

Sire of Lady Farowin, $2: 24 \frac{1}{4}$.

FARRAGUT $(3-64)$, bay, star and snip, hind ankle white, $153 / 4$ hands, $\mathbf{r} 200$ pounds ; foaled I 887 ; bred by Mark Hopkins, St. Clair, Mich.; got by Sultan, son of The Moor: dam Elsie Good, chestnut, bred by D. P. Shawhan, Rushville, Ind., got by Wilson's Blue Bull; 2d dam Molly Patterson, bred by Joseph J. Shawhan, of Kentucky, got by Alexander's Abdallah; 3 d dam Bolly, said to be by Bald Stockings, son of Tom Hal ; and $4^{\text {th }}$ dam a Gray Eagle mare. Sold to Alex. McVittie, Detroit, Mich. Died I904. Pedigree from J. H. St. John, Utica, Mich.

Sire of 2 pacers $\left(2: 17 \frac{1}{4}\right)$.

FARR HORSE. See Young Soldier, advertised in $\mathrm{s} 8 \mathrm{I} 2$, with King Herod 
FARRINGTON HORSE, gray, $15 \frac{1}{2}$ hands, rooo pounds when two years old ; foaled about 1828 ; bred by Thomas Vincent, Walden, Vt.; got by the Vance Horse, son of Bold Phonix : dam Steele mare, a fair sized mare of about 1000 pounds. Sold when two years old to Nathaniel Farrington, Walclen, Vt., who kept him a number of years and sold to Mr. Dutton of same place. Mr. Farrington President of Bank at Danville, Vt., says :

"My brother owned him at Walden about I $835-40$. Abischall Adams of Hardwick, rode the Steele mare to Burlington in a few hours at the time of the battle of Plattsburg. She was then about six or seven years old. Mr. Vincent got her after that."

Ira Dutton, Craftsbury, Vt. says: "The Farrington Horse was a fine styled horse and he thinks $153 / 4$ hands, 1100 pounds." See the Morgan Horse and Register, Vol. I., p. 20 I.

Sire of the dam of Morrill.

FARR MORGAN (I-4). Mr. Waite, Londonderry, born I795, remembers the Farr Morgan about 75 years ago, and the Bigelow Messenger horse owned in Peru, 6o or 70 years ago; a large dark brown horse.

FARIVOOD ( $\left.\mathrm{I}-6_{4}\right)$, chestnut with star, left hind ankle white; foaled I 890 ; bred by H. L. \& F. D. Stout, Dubuque Ia., got by Nutwood, son of Belmont : dam Nora Wilkes, bay, bred by J. C. McFerran, Louisville, Ky., got by George Wilkes; 2 d dam Nora Lee, bay, bred by A. J. Alexander, Spring Station, Ky., got by Woodford Mambrino; 3 d dam Young Portia, brown, bred by Hyman Gratz, Woodford County, Ky., got by Nambrino

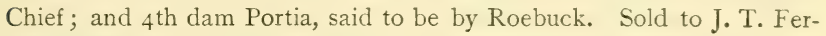
guson, Memphis, Tenn. Pedigree from catalogue of breeder.

Sire of Renato, $2: 22 \frac{1}{4}$.

FASHION (I-I6), bay; foaled I 885 ; bred by H. N. Smith Trenton, N. J. ; got by Stranger, son of Gen. Washington : dam May Day, chestnut, bred by Wm. C. Traphagen, New York, N. Y., got by Aberdeen, son of Hambletonian; 2 d dam May Steers, said to be by John C. Fremont, son of Long Island Black Hawk; and $3 \mathrm{~d}$ dam by American Star. Pedigree from catalogue of breeder.

Sire of Fashion Maid, $2: 24^{1 / 4}+$ I dam of I pacer.

FAST MAIL (3-128), bay; foaled I 887 ; bred by C. S. Eldridge, Chicago, I11. ; got by Nutwood, son of Belmont: dam Arch Duchess, brown, bred by G. H. Buford, Lexington, Ky., got by Administrator, son of Hambletonian; 2d dam Zora, brown, bred by John Dillard, Lexington, Ky., got by American Clay: 3d dam Fillee, said to be by John Dillard, son of Indian Chief : $4^{\text {th }}$ dam Molly Hunt, by Morgan Whip; and $5^{\text {th }}$ dam by Lance, son of Ewing's Lance.

Sire of 4 trotters, $2: 23 \frac{1}{2}$; I dam of I pacer. 
FAUNTLEROY (I-I28), $2: 231 / 4$, chestnut; foaled 1887 ; bred by Granville Childs, Canton Point, Me.; got by Albrino, son of Almont: dam Foster Mare, said to be by Daniel Boone, son of Hambletonian; and $2 \mathrm{~d}$ dam Alice Dunn, by Farnum Horse.

Sire of Victor E., $2: 291 / 2$, Nancy Roy, $2: \mathrm{II}^{3} \frac{\mathrm{4}}{4}$.

FAUSTINO (I-I 28), 2 :I $21 / 4$, brown, hind ankles and one fore ankle white, I 5 I/2 hands, I050 pounds; foaled I 888 ; bred by G. Valensin, Pleasanton, Cal. ; got by Sidney, son of Santa Claus: dam Faustina, brown, bred by G. Valensin, got by Crown Point, son of Speculation; 2d dam Dell Foster, bay, bred by Hancock Johnson, Los Angeles, Cal., got by A. W. Richmond, son of Simpson's Black-bird; 3 d dam said to be by Geo. M. Patchen Jr. Sold to Water's Stock Farm, Genoa Junction, Wis. ; to Fred Pabst, Jr., Milwaukee, Wis., in I 895 , who sends pedigree. Gelded and used as roadster in New York.

Sire of 5 trotters $(2: 181 / 4) ; 2$ pacers $\left(2: 18 \frac{1}{4}\right)$.

FAVORA (5-256), $2: 12 \mathrm{~T} / 2$, brown with star, snip, 2 small spots on nose, off front coronet and near hind pastern white, $15 \frac{1}{4}$ hands, 975 pounds; foaled r 887 ; bred by Henry C. Jewett, Jewettville, Erie Co., N. Y.; got by Patchen Wilkes son of George Wilkes: dam Bessie Gilpin, bay, bred by Herbert Lathrop, Willink, N. Y., got by John Gilpin, son of Strader's Cassius M. Clay Jr. ; 2 d dam, bred by Paul Lathrop, Willink, N. Y., got by Hamlin Patchen son of George M. Patchen. Pedigree from breeder.

Sire of India, $2: 12$.

FAVORITE WILKES, $2: 24^{\mathrm{T} / 2}$, bay, I5 $1 / 2$ hands; foaled 1877 ; bred by James Miller, Paris, Ky.; got by George Wilkes, son of Hambletonian : dam Favorite, chestnut, bred by James Miller, got by Alexander's Abdallah, son of Hambletonian; $2 \mathrm{~d}$ dam Lizzie Peebles, bay, dam of Joe Downing, which see. Sold to J. Rupert, Poughkeepsie, N. Y. Pedigree from breeder.

Sire of 23 trotters $(2: 161 / 4) ; 8$ pacers $\left(2: 07^{3 / 4}\right) ; 7$ sires of 8 trotters, 15 pacers; 7 dams of 6 trotters, 5 pacers.

FAY (I-32) 2:25, bay; foaled 1879; bred by Leland Stanford, Menlo Park, Cal.; got by Electioneer, son of Hambletonian : dam Mary, bay, foaled I 874 , bred by Leland Stanford, got by Fred Low, son of St. Clair ; $2 \mathrm{~d}$ dam Rio Vista Maid, said to be by John Nelson, son of imported Trustee. Pedigree from catalogue of breeder.

FAYETTE; bred by John Park Custus; got by Regulus, the property of Wm. Fitzhugh of Chatham: dam by Othello; grandam by imported Juniper ; great-grandam, by Morton's Traveler ; $4^{\text {th }}$ dam Col. Tasker's imported mare, Selima, by the Godolphin Arabian. Owned by Berley Thornton. Advertised as above to be kept in Charles County, Mo., by Wm. Courts, i 788 . Terms £5. 
FAYETTE CHIEF ( $1-32)$, chestnut, I 6 hands; foaled $188 \mathrm{r}$; bred by James Harp, Lexington, Ky. ; got by Mambrino King, son of Mambrino Patchen, by Mambrino Chief: dam bay, bred by H. C. Harp, Lexington, Ky., got by Ericsson, son of Mambrino Chief; $2 \mathrm{l}$ dam, bred by $\mathrm{H}$. C. Harp, got by Harp's Mambrino, son of Mambrino Chief ; 3d dam said to be by Woodford, son of Kosiusko. Sold to B. H. Neale, Richmond, Ky. ; to Overall \& Morrison, Fayette, Mo. Pedigree from breeder.

Sire of 2 trotters $(2: 161 / 2)$; I sire of I trotter; 2 dams of 2 trotters.

FAYETTE MEDIUM (I-32), gray with small star, hind feet white to ankles; foaled $I_{S} S_{5}$; bred by W. T. Withers, Lexington, Ky.; got by Happy Medium: dam Elsie, gray, bred by R. A. Alexander, Spring Station, Ky., got by Alexander's Abdallah ; 2 d dam Gray Bacchante, said to be by Downing's Bay Messenger, son of Harpinus; 3d dam, by Whip Comet; and $4^{\text {th }}$ dam by Gray Messenger. Sold to C. I. Woolnough, Lexington, Ky. ; to W. B. Linell, Pontiac, Ill.; to W. D. Walton, Paxton, Ill.; to J. V. Borah, Fairfield, Ill. Pedigree from catalogue of breeder.

Sire of 2 pacers $(2: 17)$.

FAVETTE RUSSELL ( $1-32$ ), brown, $153 / 4$ hands; foaled 1889 ; bred by J. A. Skannal, Haughton, La. ; got by Mambrino Russell, son of Wnodford Mambrino: dam Baroness, brown, bred by R. G. Stoner, Paris, Ky., got by Baron Wilkes, son of George Wilkes; zd dam Stocking, bay, bred by F. O. Matheson, Jersey City, N. J., got by Happy Medium, son of Hambletonian; 3d dam County House Mare (dam of Nettie, 2 :I 8), said to be by American Star. Sold to W. W. Edstill \& Co., Lexington, Ky., who sends above pedigree and writes: "was gelded and sold in New York City for \$rooo."

Sire of Ed. Lock, $2: 12$; Bessie Russell, $2: 1_{4}^{1 / 4}$.

FAYETTE WILKES (I-64), bay, I5 $3 / 4$ hands; foaled 1878 ; bred by William M. Kenny, Lexington, Ky.; got by George Wilkes: dam Sally Hamlet, bay, bred by William M. Kenny, got by Hamlet, son, of Volunteer; $2 \mathrm{~d}$ dam Sal, bred by Wm. M. Kenney, got by Canada Chief, son of Davy Crockett; 3d dam said to be by imported Yorkshire; and 4 th dam by Woodpecker. Sold to Chas. Johnston, Alta, Ill.; to B. J. Treacy, Ashland Park Stock Farm, Lexington, Ky., I 885. Pedigree from Ashland Park catalogue.

Sire of Silver Wilkes, $2 ; 261 / 4 ; 3$ dams of 2 trotters, I pacer.

FEARNAUGHT, brown; foaled I 75I : bred by Lord Godolphin; got by the Godolphin Arabian : dam Hobgoblin Mare, bred by Sir John Dutton in 1739 , got by Hobgoblin; 2 d dam foaled $173 \mathrm{I}$, bred by Sir J. Dutton, got by Whitefoot ; 3 d dam said to be by Leedes, son of Leedes' Arabian;

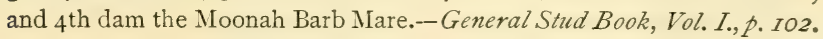


FEARNAUGHT, bay; foaled I 755 ; bred by Mr. Warren; got by Regulus, son of Godolphin Arabian : dam Silvertail (bay), foaled 1737 , bred by Mr. Warren, got by Mr. Heneage's Whitenose, son of Hall Arabian ; 2d dam by Rattle, grandson of Sir H. Harpur's Barb ; 3d dam by Darley's Arabian; 4th dam the old Child Mare, by Sir T. Gresley's Bay Arabian (Bay Roan); 5th dam Mr. Cook's Vixen, by the Helmsley Turk. - General Stud Book, Vol. I., p. 183 .

Edgar says :

"Fearnaught was imported by John Baylor of Virginia, and brought into that State in March, I 764. His first cost including freight, insurance, provender commissions etc., was $£ 2895^{s}$. $9 d$. sterling.

"He afterwards became the property of Mr. Wm. Edwards at Hick's Ford, Va., then Brunswick, but at this time called Greenville County, Va. He was kept at that place in the springs of 1775 and 76 , and died in the fall of the latter year. Terms $£ 6$, Virginia currency, the season, equal to nearly $\mathcal{L}_{5} 5$ at the present time, comparing the value of the property and the price of the country produce during these periods.

"Fearnaught was one of the most distinguished stallions ever in America. He contributed more perhaps to improve the breed of thoroughbred race horses than any other stallion in the United States, of his day.

"Very many deservedly celebrated horses sprang from him, and his name is to be found in almost any 'thoroughbred horse' pedigree in Virginia, which traces back to this time. He left behind him a most brilliant and lasting race.

"Until the days of Fearnaught, no other than quarter races were run in Virginia. Speed had been the only quality sought for; but his progeny were remarkable for their fine figure and lasting bottom, and introduced a taste (in imitation of the English) for course racing, which led the Virginian's to seek for race horses of size and bottom, they having discovered from actual experience, that strength and good wind were the most valuable and desirable qualities, and that long races were the only test of these. He may be truly said to be the 'Godolphin Arabian of America" ".

Silvertail and Fearnaught both appear on page r 39 of the English Stud Book.

Fearnaught is advertised at Newmarket, terms $\mathcal{E}_{\mathrm{I}}$; in the Virginia Gazette, 1767 ; in the same paper, 1771 , 1772 , also, 1773 , in Caroline County, the last four advertisements by John Baylor; 1786 at Hicks Ford, Brunswick County, by William Edwards.

FEARNAUGHT; foaled 1778 ; said to be by King Herod. Advertised, I 782 , to be kept in Philadelphia County, Penn.

FEARNAUGHT, bay; said to be by Moulton, son of Imported Wildair: dam an elegant 7-8 blooded mare, by True Briton; and $2 \mathrm{~d}$ dam by Dawson. Advertised, $\mathbf{1 7 8 8}$, in the Poughkeepsie Advertiser by John Halstead, to be kept near Fredericksburg.

FEARNAUGHT. Advertised in Albany Register, 1795. 


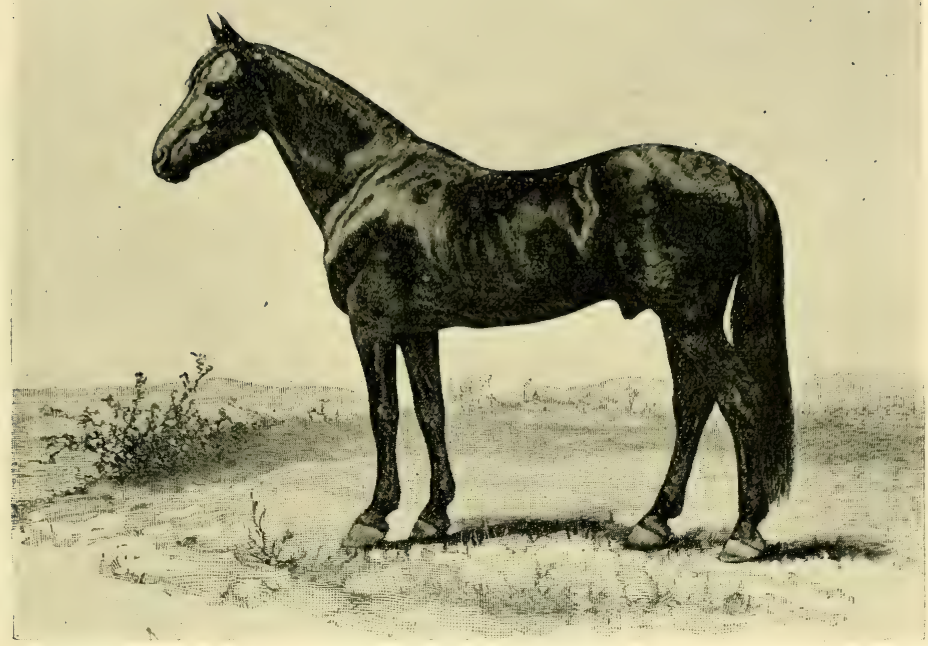

Draco, by Young Morrill.

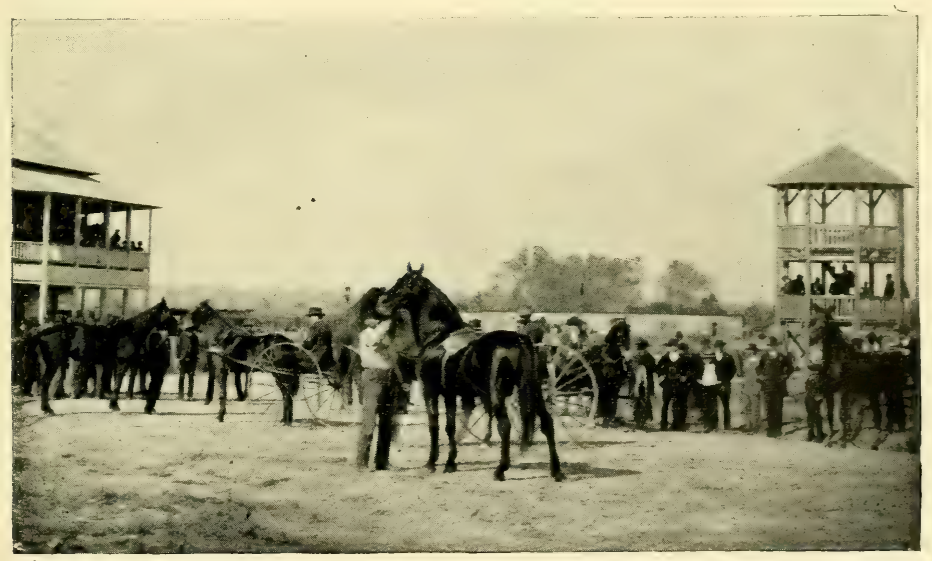

Tornado (by Fearnaught), and his colts. 

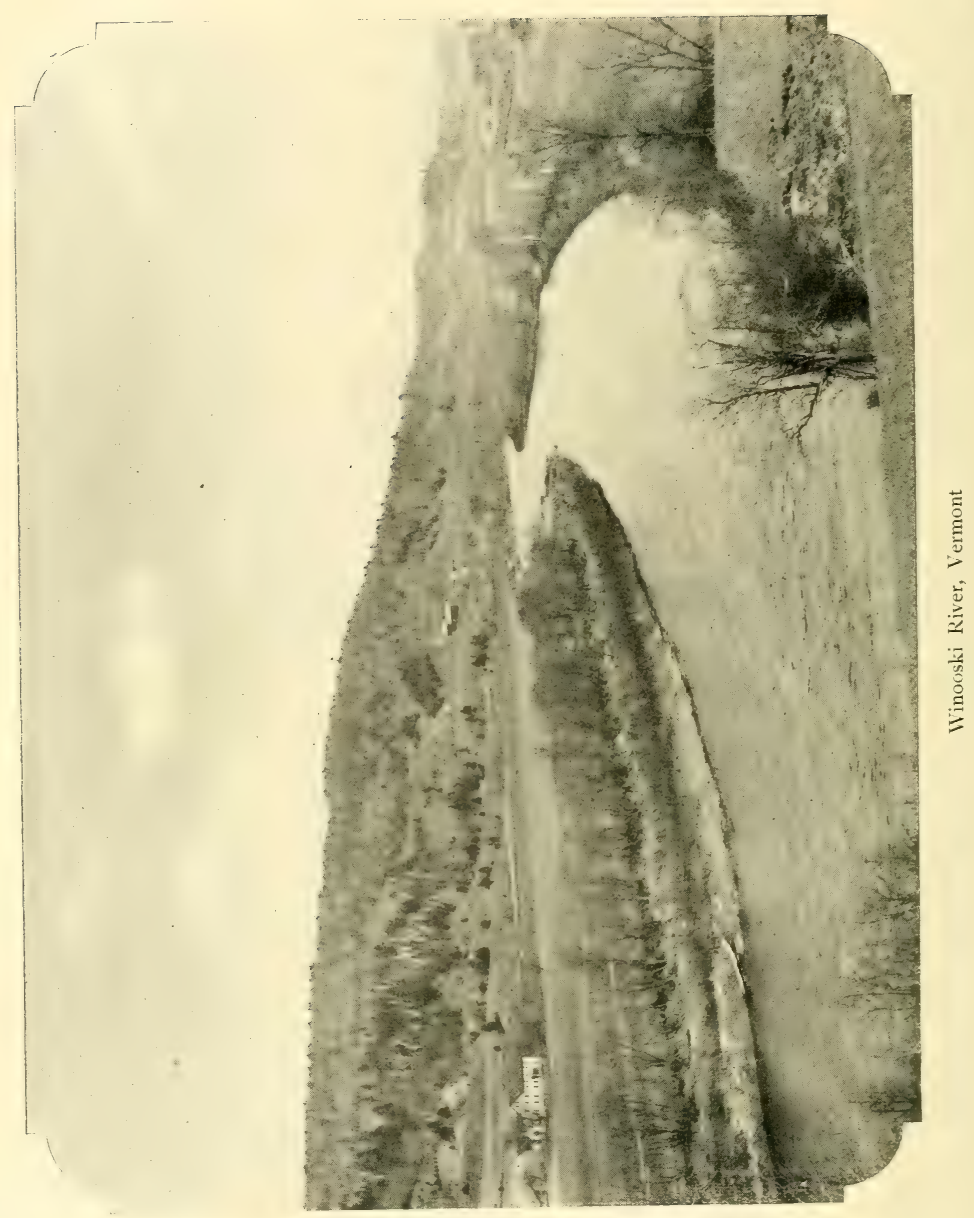
FEARNAUGHT. Advertised in Skinner's "Turf Register," Vol. I., at Newbern, N. C., in 1830 .

FEARNAUGHT $(3-16), 2: 23 \frac{1}{4}$, chestnut, $15 \frac{1}{2}$ hands, rooo pounds ; foaled I 859 ; bred by Greenleaf C. Brown, Stratham, N. H. ; got by Young Morrill, son of Morrill: dam Jenny, foaled 1849 , bred by Nathaniel Batchelder, Pittsfield, N. H., got by Napoleon Morgan, son of Flint Morgan ; $2 \mathrm{~d}$ dam bred by Nathaniel Batchelder, got by Vermont Ieauty, son of Ballard's Quicksilver; 3d dam bred by Nathaniel Batchelder, got by the Piper Horse; $4^{\text {th }}$ dam said to be thoroughbred.

The Morgan Horse and Register Vol. I., thus gives the pedigree and history of Fearnaught:

"Fearnaught (champion trotting stallion of the world when his record was made) ; chestnut with off hind foot white, fifteen and a half hands high, and weighed ten hundred pounds. He was bred by Greenleaf C. Brown, Stratham, New Hampshire, got by Young Morrill, son of Morrill and was foaled in I 859. His dam, Jenny, was bay with black points, no white, fifteen hands, and weighed ten hundred pounds; a high-headed mare of great courage and speed, that it is said could pull two men to a heavy wagon better than a forty clip; foaled I 849 ; bred by Nathaniel Batchelder, Pittsfield, N. H., and sold by him in I 854 to Greenleat C. Brown, who owned her until her death in 1879; got by Napoleon Morgan, son of Flint Morgan : 2 d dam dark bay, bred by Nathaniel Batchelder, got by Vermont Beauty, son of Ballard's Quicksilver; 3d dam brown bred by Nathaniel Batchelder, got by the Piper Horse, a young horse, brought from Vermont to Pittsfield, N. H., I8r9, called a Morgan;

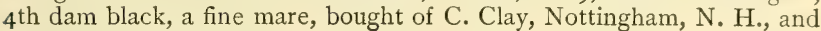
said to be thoroughbred.

"Sold by breeder to B. S. Wright, who sold him for twenty-five thousand dollars to Col. H. S. Russell, proprietor of the Home Farm, Milton, Mass., whose property he died in 1873 .

"He was a horse of great elegance as well as speed. His record was made at Buffalo, in a winning race, for a purse of ten thousand dollars, July 29 th, I 868 .

"S. W. Parlin, the accomplished turf writer, in an article on Fearnaught, after mentioning his races, says :

" "His success in trotting, together with his remarkable beauty, elegant style and superior road qualities, gave him very great popularity. In the show ring he was quite as successful as upon the turf. His last victory as a prize-winner was at the New England fair of 1872 , when he received the premiums and gold medal offered for the best stock horse. His death occurred at the Home Farm, Milton, in I 873. During the last few years of his life Fearnaught's service fee was two hundred and fifty dollars.'

"We add the following very interesting letter from J. J. Batchelder, Warrensburgh, Ill., relating to the dam of Fearnaught and her ancestors, and dated February $22 \mathrm{~d}, \mathbf{1} 890$ :

"I I received yours in regard to the pedigree of Jenny, that my father sold to G. C. Brown; Jenny was a great road mare. So were her first and second dams, either of which could road sixteen miles an hour. Her first dam, Lady Jane, was the most showy, and looked in the har- 
ness much bigger than in the stable. She looked very much like her sire, the Hill Horse. True Hill of Canterbury, N. H., owned him until he died.

"'The Piper Horse, the sire of Kate, her second dam was a young horse brought from Vermont to Pittsfield about the year 1819 , and staid there part of one season; then went to Maine ; left only four colts. I can recollect them all, three bays and one black. They all proved so good when used that they got up a stock company and sent down to Maine to get him back, but he had been gelded. They called him a Morgan.

" "Old Kate I think was the fastest of the four colts. I have heard the old folks talk about them in their younger days; if they wanted to make a quick trip, they were sure old Kate could make it. I have heard father tell of driving her to Boston, seventy-five miles, after machinery for the factory, when they wanted it quick; and one time there was a deed that was found not to be on record at Concord, the county seat, and other parties started to take advantage of the fact. A man got on old Kate, and rode the sixteen miles in an hour.

" "I brought out here in I 859 , a full sister to Jenny, in foal by Young Morrill. She raised a mare colt. I have raised a number of good colts from her. I have one of her colts, now twenty-two years old, by Flint Morgan, son of the Steve French Horse, a little inbred and full of Morgan; I think the best driver I ever rode after.

"I sold one of her colts to a Dr. Reed of Decatur; he drove him three years on the road and sold him to go to Cincinnati; they found he could go, took him to the track and drove him in $2: 30$; they thought he must have been on the track and was a ringer; they offered two thousand dollars for him if he had not been trained. They wrote to me, and as quick as they got word, took him. The next time they tried him he went in $2: 19$, last half in 1 :o8. His owner was offered five thousand dollars for him, but thought he would have him trained the last of the season, and the next year enter him in the races. He sent him to Lexington, Kentucky, in June, and he dropped dead on the track. They called him Stoker Boy. I saw the man that bought him of Reed; he thought they held him too hard and he broke a bloodvessel."

\section{SIRE OF FEARNAUGHT.}

\section{[From Maine Horse Breeder's Monthly].}

"At the request of some of our subscribers we reproduce the following concerning the breeding of the chestnut horse Fearnaught, from the Mirror and Farmer :

" "Every year or two some one questions the sire of the stallion Fearnaught, $2: 23 \mathrm{~T} / 4$, that died August 6,1873 . He was owned by $\mathrm{Col}$. Russell, and had immense popularity at that time. Owing to the bluffing and betting talk of John Iangley, a well-known sportsman, a great many stories were circulated which had not a word of truth in them. They related chiefly to what was said by Joe Mooney of this city and Bob Young, now of Franklin, this State, each of whom says explicitly, that they never said what they have been represented as saying in reference to the matter, and that they have not a shadow of a reason to doubt that Fearnaught was got by Young Morrill. In the spring of 1873 we visited the farm where Fearnaught was bred, at Stratham, this State, and spent a day investigating the subject, and as the result 
published in our daily and weekly the following affidavits, which ought to set the matter at rest:

“'Stratham, N. H., April 29, i 873.

" I, William G. Brown of Stratham, county of Rockingham, State of New Hampshire, depose and say: My father, Greenleaf C. Brown of this town, owned the mare Jennie, the dam of Col. Russell's stallion Fearnaught, fifteen years ago and had owned her several years. I lived then, as now, close to my father, on the same farm. After a good deal of talk, consultation and solicitation, we concluded to take the mare Jennie to Young Morrill, then owned in Manchester, this State, though fifty dollars without warrant seemed a large price. Fifteen years ago I and my brother-in-law, B. Howard Moulton, who lived near us, took the mare Jennie, the dam of Fearnaught, to Manchester, and stopped with Mr. Edgerly, on the west side of the Merrimack river, Mr. Edgerly then having charge of Young Morrill. We got there about two hours before sundown, put the mare in the stable, fed her, staid about the stable till supper time, and then went into the house adjoining the stable and took supper. Afterwards, a little before dark, Young Morrill covered the mare Jennie. There was no teaser in sight and no other stallion to be seen by the mare. We staid about the stable till between ten and eleven o'clock, talking horses. The stable was then closed. What makes me remember the closing was that a large dog was let loose and we were warned to leave or we might get bitten, and he came at me so fast that I started out of the way very quickly. The next morning I paid Mr. Edgerly fifty dollars for the use of the horse, and took his receipt. The receipt I afterwards gave to A. P. Morrison, who bought Fearnaught of me; he wanting it as there had been some dispute about his age.

" "No other horse but Young Morrill teased her, no stallion was near her that night, and the next morning - the morning after we arrived thereabout ten o'clock in the forenoon, we started for home, arriving there the same day. The mare Jennie was kept close by that season, and there was no possible chance for a stallion to get at her. I no more doubt that Young Morrill, owned by Samuel R. Perkins, is the sire of Fearnaught than I have that Jennie is the dam. There is not a particle of truth in the story that Fearnaught was got by any other horse than Young Morrill. Jennie had Fearnaught at a proper time after she was covered by Young Morrill.

Williair G. Brown.

" I, B. Howard Moulton, mentioned in the foregoing statements of William G. Brown, agree to the statements and depose and say that every word is true according to my observation. I have no more doubt that Young Morrill is the sire of the stallion Fearnaught than I have that Jennie is his dam.

\section{B. H. Moulton.}

“"State of New Hampshire, Rockingham, ss., April 29, I 873.

" "The above-named William G. Brown and B. Howard Moulton appeared before me and made oath that the foregoing statements by them subscribed are true.

AdDison WigGrN, Justice of the Peace. Witnesses : $\left\{\begin{array}{l}\text { John B. Clarke, } \\ \text { Addison Wiggin." }\end{array}\right.$ 
"Some idea of the popularity of the Fearnaught stock when at its height may be gained from the fact that at the second annual sale held by Col. Russell, sixteen yearlings were struck off under the hammer for $\$$ I 3,955 , an average exceeding $\$ 872$ per head. One of the secrets of the high prices realized by these youngsters was their remarkable beauty and symmetry of form; neat bony heads, full intelligent eyes, short well set ears, clean-cut throttles, arching necks, sloping shoulders, round barrels, short backs, broad loins, smooth couplings, round turned hips, handsome croups, well muscled quarters, long broad forearms, low-set, clean-cut hocks and short cannons. These were distinguished characteristics of the Fearnaught family, nearly all of which like the best representatives of all branches of the Morgan family, were free-spirited drivers and capital roadsters. After the death of Fearnaught, Col. Russell bought the world renowned Smuggler, which so long held the proud position of King of trotting stallions, with his mark $2: 15 \mathrm{I} / 4$; but to this day the proprietor of Home Farm claims that Fearnaught was the best horse he ever owned. He died Aug. 6, I873."-Middlebury Register, Vol. LII., No. 47.

\section{NEW ENGLAND REMINISCENCES.}

"Now the horses. The most famous of the early purchases was the bay mare Grand Duchess, daughter of Hanley's Hiatoga and such was her speed, endurance and racy qualities that Mr. Mason (Wm. Mason, Taunton, Mass.) paid for her $\$ 5,000$. She was a high-strung mare, inclined to pull, but very fast, and won several good races. In 1872 Grand Duchess was bred to the chestnut stallion, Fearnaught, then owned by Col. Henry S. Russell of Milton, Mass., afterwards the owner of Smuggler, $2: 151 / 4$, and now the owner of Edgemark, $2: 16$. In 1868 , Fearnaught, driven by Dan Mace, had won at Rochester the first $\$$ I o, ooo purse ever given for a stallion, and lowered the stallion record to $2: 23 \%$. Russell paid $\$ 25,000$ for Fearnaught. When Mason sent Grand Duchess over to Milton, Mass., to be mated with Fearnaught, only two stallions had a faster record. In October, I868, George Wilkes, at Providence, R. I., trotted to a record of $2: 22$, and in Aug. I 866, at Buffalo, Jay Gould had a record of $2: 2 \mathrm{I} / 2$. Up to $\mathrm{I} 87 \mathrm{I}$, Jay Gould had been owned by $\mathrm{A}$. C. Greene, of Fall River, under the name of Judge Brigham (Judge of the Superior Court of Massachusetts), only twenty miles from Taunton, but up to that year (I87I) had not shown any particular speed. When Mason bred Grand Duchess to Fearnaught, the other three named stallions were 200 miles away, but at that time the closest student could not have foretold whether Fearnaught or George Wilkes was to be the great sire of the future. We shall presently see the potent influence that a son of Jay Gould had on the Mason Farm trotters, and not a very well bred one on the dam's side, either, as compared with' Jay Gould's dam.

Grand Duchess trotted the 6 th heat of a race in $2: 26 \mathrm{x} / 2$, at Springfield, Mass., and in due time she foaled a sprightly bay filly which was named Galatea. The excessively hot head of the sire, coupled with the high mettle of the dam, were very apparent in the daughter, but she was broken and patiently handled by Mr. Dore, and her speed was so great that at Hartford, Conn., Sept. 19, 1877, Galatea captured the four-year-old record of the world, lowering the figures of Erie, $2: 28 \mathrm{~T} / 2$, son of Ericsson, to $2: 25 \mathrm{I} / 2$. It was a proud day for Mr. Mason to see the first foal he had ever bred take a champion record. Mr. A. B. Darling, of New York was present and offered Mr. Mason $\$ \mathrm{IO}, 000$ for Galatea, but it is doubt- 
ful if twice that sum could have then bought her. Galatea won the crown for four-year-olds. Mason was rich. Dore drove her. In the light of present events, \$10,ooo seems a big price, but it must be remembered that then $2: 163 / 4$ was the trotting record of the world, held jointly by Goldsmith Maid and Occident, and that the pacing record was $2: 161 / 2$, held by the dun gelding, Yankee Sam, and had been unbeaten for four years. *

- The Horse Review, Dec. 17, 1895.

A. A. Austin."

See The Morgan Horse and Register, Vol. I., p. 209.

Sire of 3 trotters $\left(2: 23^{1 / 4}\right) ; 5$ sires of 25 trotters, 7 pacers ; 4 dams of 7 trotters, 2 pacers.

FEARNAUGHT (3-64), $2: 29$, brown; foaled 1866 ; said to be bred by F. Ouimette, St. Rose, P.Q. ; got by Canada Black Hawk, son of Sherman Black Hawk: and dam by Bellair, which see. Taken about 1877 , to West Union, Ia., by M. St. Germaine, a Frenchman who sold him to John St. Albans, St. Paul, Minn., and he to Scobey, Taylor \& Farr, West Union, Ia.

The following letters are from the Middlebury (Vt.) Register.

Charles Brown :

$$
\text { Montreal, April 3, is84. }
$$

I promised when at your stable in St. Paul, along with Dr. Lemmon, that on my return home I would endeavor to send you a more correct pedigree of your horse Fearnaught; what I now write you about his history is correct as I am perfectly cognizant of it on the side of both sire and dam. Fearnaught was by Black Hawk, imported here from Vermont, his dam being then in foal with him. This was in the year I 852 ; his dam was by a sorrel horse called Bellair; this was the name of the man who once owned him, and he was by the sorrel horse Convalescence, and he by old Sir Walter, a road horse of great celebrity in his day. See stud book. Trusting that this will be satisfactory, I am Yours very respectfully, GEORGE SwINBURN,

Veterinary Surgeon.

Joseph Battell, EsQ.,

Montreal, Dec. I, I 885 .

Dear Sir:-I am in receipt of the Middlebury Register of Nov. 20, and in looking over the columns that are devoted to horses, my attention was drawn to a correspondence between myself and Charles Brown of St. Paul, Minn., relative to the pedigree of his horse, Fearnaught. Now, Sir, the letter which appears in the Register, is not quite correct. I visited Charles Brown's stable in company with a veterinary surgeon of Minneapolis, Minn. I never said Sir Walter was a road horse of great celebrity. Sir Walter was a thoroughbred running horse and he was the sire of the horse Convalescence, which was not thoroughbred, although he was a very fine stallion, a great road horse and produced a very large amount of first-class horses. He was located at St. Charles, on the river Richelieu. This is the horse from which sprung the horse Bellair and this horse, Bellair, was sire of the dam of Fearnaught.

Yours truly, GEORGE SwINBURN.

See The Morgan Horse and Register, Vol. I., p. 395.

Sire of Lady Shepard, $2: 281 / 2$. 
FEARNAUGHT (FLAHERTY'S) (I-I6), sorrel, I61/2 hands, I 250 pounds ; bred by Richard Flaherty, now of San Francisco, Cal.; got by Fearnaught Jr., son of Fearnaught: dam Haidee, gray, foaled 1857 , bred by Walter Smith, Orwell, Vt., sold, I860, to Orson Smith, Orwell, Vt., and by him to Joseph F. Billings, West Roxbury, Mass. ; got by Columbus ; 2d dam Red Neck, owned by Mr. Noble, said to be by Harris' Hamiltonian. See The Morgan Horse and Register, Vol I , p. 638 .

Sire of 3 trotters $(2: 19)$.

FEARNAUGHT (HADLEY'S) (I-8), black, I $53 / 4$ hands, I I 50 pounds; bred by E. H. Craig, formerly of Massachusetts, later of Caldwell County, Mo., and foaled the property of T. G. Hadley, Galesburg, Ill.; got by Fearnaught, son of Young Morrill: dam purchased for $\$ 700$, of L. L. Church, Vershire, Vt., by a physician of Springfield, Mass., who sold to H. B. Stevens, Bradford, Vt., and he to Mr. Craig,- - said to be by Morrill ; and $2 \mathrm{~d}$ dam Morgan. Sold to J. A. McKenzie, Galesburg, Ill.

The following reference to this horse is from the Mark Field Monthly :

"About ten miles from Galesburg, Ill., on the Santa Fee road, is located a large farm whose lands are valuable chiefly for grazing purposes, and whose entire resources and facilities are given to the production of horses and cattle. This is the McKenzie farm, the name being derived from that of its owner, the Hon. J. A. McKenzie, one of the ablest and most renowned attorneys in Central Illinois, as well as a born mechanic and live stock farmer.

"Mr. McKenzie is one of the stoutest, most enthusiastic believers in the Morgan tribe, and being at the same time a devoted roadite, and an ardent lover of good road horses, it was quite to be expected that he should have done as he did, several years ago, in preferring the Morgans over all other families in stocking up his place. The choice which he made of an archon for his stud is a tip top portrait of his equine beau ideal. We mean Hadley's Fearnaught, by Russell's Fearnaught; dam by Morrill. Russell's Fearnaught was by Young Morrill, dam by the Steve French Horse, son of Flint Morgan, by Sherman Morgan, son of Justin Morgan; grandam a mare of Batchelder stock. Morrill was by the Jennison Horse, son of Young Bulrush Morgan, by Bulrush Morgan, son of Justin Morgan. This makes Hadley's Fearnaught one of the most strongly inbred Morgans in the world; and according to his breeding do we find his form, his color, his individual qualities and his breeding qualities. Hadley's Fearnaught is a black horse, measuring $153 / 4$ hands, and weighing I 150 pounds. He has the grandeur of presence, which so eminently characterize his family, with that perfection of parts and marvelous power of constitution which are also characteristic of the family."

See The Morgan Horse and Register, Vol I., p. 64 I.

FEARNAUGHT (WHITCOMB'S) (5-32) ; bred by the landlord of the Elm Street Hotel, Boston, Mass. ; got by Fearnaught, son of Young Morrill, by Morrill : dam said to be by Ethan Allen, son of Black Hawk. Sold 
to B. D. Whitcomb, Boston, Mass., for $\$ 500$; to Waldo T. Pierce, Bangor, Me., by whom he was gelded.

The American Cultivator says :

"He was kept too still while growing, and when matured was not only very small, but failed to show speed enough for a fair road gait. He however, left some I 7 foals, five of which showed trials in $2: 30$ or better, and were capital road horses, but too hot-headed for successful turf performers."

See The Morgan Horse and Register, Vol. I., p. 637.

Sire of Lady Brooks, $2: 29 \% \frac{1}{4}$; I sire I trotter.

FEARNAUGHT (RASCONA, MIDNIGHT) (I-32), black with face and fore ankles white, $15 \mathrm{I} / 2$ hands ; said to have been bred by Charles Cantell, Montreal ; foaled at Three Rivers, P. Q. ; and got by Canada Black Hawk son of Sherman Black Hawk. Sold when thirteen to Andy McLaughlin, Boston, Mass., for $\$ 1575$. Reported record, $2: 26 \mathrm{I} / 2$. See The Morgan Horse and Register, Vol. II.

FEARNAUGHT JR., (3-32), $2: 26$, chestnut, with small star and white hind foot, I 5 I 2 hands, I040 pounds; foaled 1865 ; bred by H. P. Wingate, Stratham, N. H. ; got by Fearnaught, son of Young Morrill : dam, brown bay with snip and one white hind foot, about $15 \frac{1}{2}$ hands, 950 pounds, foaled about $\mathrm{I} 845$, bought in May or June 1857 , by Henry P. Wingate of Daniel Perkins, New Market, N. H., who had her of Isaac Copp, who it is said brought her from Connecticut; breeding unknown. Purchased when one year old by B. S. Wright, Manchester, Me., who sold one half interest to E. L. Norcross. Kept at Manchester and Bangor, Me., and one season at Framingham, Mass. He won one race when three and when four trotted five races winning them all.

See The Morgan Horse and Register, Vol. I., p. 638 .

Sire of 2 trotters $\left(2: 231 \frac{1}{4}\right)$; Benny $2: 18 \frac{1}{2} ; 2$ sires of 2 trotters; 6 dams of II trotters, I pacer

FEARNAUGHT GIFT (I-I6), chestnut; foaled I872; bred by A. Dewey, Pontiac, Mich.; got by Western Fearnaught, son of Danville Boy Jr.: dam Golden Rule, said to be by Magna of Avon, son of Magna Charta; and $2 \mathrm{~d}$ dam by Morrill Boy, son of Morrill. Sold to Reuben Armstrong, Pontiac, Mich; to Angus M. McKay, Pontiac, Mich.; to Forbes \& McKay, Ingersoll, Ontario, Can. Died I 876.

See The Morgan Horse and Register, Vol. I., p. 629.

Sire of Molly B., $2: 29 \frac{1}{2} ; 2$ dams of 2 trotters.

FEARNAUGH'T PRINCE. See Prince Fearnaught.

FEARNAUGHT SPY ( $\mathrm{I}-8$ ), bay; foaled $\mathrm{I} 867$; bred by Wm. G. Brown, Stratham, N. H. ; got by Black Spy, son of Manchester Black Hawk: dam Jennie, dam of Fearnaught, $2: 23 \frac{1}{4}$, which see. Purchased in $187 \mathrm{I}$, 
by Daniel Gilman, Exeter, N. H., who took him when four years old to Geneseo, Henry County, Ill., and who owned him about ten years. Mr. Gilman writes :

"He was naturally fast, but was spoiled by bad handling. He never had a chance in the stud. He was not very sure, and the last three years I owned him, did not get a colt."

See The Morgan Horse and Register, Vol. I., p. 404.

Sire of Malvina, $2: 21 \frac{1}{4} ;$ I dam of I trotter.

FEARNAUGHT WILKES (3-128); foaled 1889 ; bred by J. T. Smith, Bristol, Ind. ; got by Hambletonian Wilkes, son of George Wilkes : dam Lucy, bred by John Smith, Bronson, Mich., got by Royal Fearnaught, son of Fearnaught,; 2 d dam Belle, brown, bred by John Smith, got by Vermont Hero, son of Black Hawk; 3d dam bred by John Smith, got by Surprise, son of Bonnie Scotland; 4th dam Magna, bred by John Smith, got by Magna Charta, son of Morgan Eagle. Sold to Thomas Smith, Bristol, Ind.; to Tom Suttles, Elkhart, Ind., then went to Europe. Pedigree from J. M. Cotherman, Goshen, Ind., breeder of Beautiful Bell.

Sire of Beautiful Bell, $2: 22$.

FEARNOT, dapple gray, I5 I/4 hands; foaled I8I5; bred by John Schenck, Amwell, N. J. ; got by Hickory of Virginia, thoroughbred: dam said to be by imported Expedition-Gray Highlander-Traveler-Slammerkin-Wildair-Cub Mare.

Advertised as above in New Jersey, I $82 \mathbf{I}$, by breeder.

FEATHER, light chestnut, $153 / 4$ hands; foaled 1788 ; said to be by imported Light Infantry, son of Eclipse : dam by imported Wildair; $2 \mathrm{~d}$ dam by Dawson. Said to have been an excellent horse. Advertised, r793, in the Poughkeepsie (N. Y.), Journal.

FEEJEE ( I-64), bay with black points, I 6 hands, I I 50 pounds ; foaled I 88 I ; bred by R. P. Pepper, Frankfort, Ky. ; got by Harold, son of Hambletonian: dam Miss Duvall, black, bred by R. P. Pepper, got by Duvall's Mambrino, son of Manbrino Chief; $2 \mathrm{~d}$ dam said to be by Paddy Burns (thoroughbred) son of gray Eagle (thoroughbred) ; and $3 \mathrm{~d}$ dam by Davy Crocket. Sold to Geo. W. Curtis, Mount Vernon, Ind., who sends pedigree. Gelded I 887 , and sold to George Leonard, Evansville, Ind.

Sire of Feather Edge, $2: 18$.

FELIX ( $\mathrm{I}-8$ ), black, I5 $\mathrm{J} / 4$ hands; said to be by a grandson of Carillon owned at St Orme, P. Q., that was gray, ${ }_{5}$ hands and a fast pacer: dam, a fast trotting mare of the Dansereau breed, said to have been one of the first mares to trot fast about Sorel. Owned by J. B. Racolet, 
Sorel, P. Q., who sold him when eight years old to a Frenchman from the States named Felix. He was said to be as handsome as Carillon, and was naturally fast. See Carillon.

FELLOWS HORSE; said to be by Green Mountain Morgan : dam a fast trotter. Advertised, I 860 , by C. W. Fellows.

FENERATE ( $1-32$ ), bay, I63/4 hands, 1400 pounds; foaled 1890 ; bred by John Gilbert, De Witt, Neb. ; got by Pelletier, son of Lord Russell : dam Handmaid, bay, bred by R. P. Pepper, Frankfort, Ky., got by Onward, son of George Wilkes ; 2d dam Mistress, bay, bred by Mr. Payne, Scott County, Ky., got by Almont Jr. ; 3 d dam said to be by Doniphan, son of Cavin's Davy Crockett; 4th dam by Scott's Highlander; and $5^{\text {th }}$ dam by Cannon's Whip. Died I 894. Pedigree from breeder.

Sire of Nicklett, $2: 17 \frac{1}{4}$.

FENIAN CHİEF, dapple gray, I 200 pounds ; foaled about r 856 ; bred by James Roddy, Ferrin's Point, Ont.; got by Canada Gray Eagle, which see : dam chestnut (dam of Dusty Miller) said to be by Sir Walter. Sold to Charles Ferrin, Ferrin's Point, Ont. ; to Joseph Whalen, Massena, N. Y. ; to Mr. McCarthy, Potsdam, N. Y. Also owned by a Mr. Williams. B. B. Lord writes that he was kept during his whole life at different places in St. Lawrence County. Terms from $\$ 12$ to $\$ 25$.

Sire of Captain Smith, $2: 281 \frac{1}{2} ; 2$ dams of I trotter, I pacer.

FENNELL, bay; foaled I888; bred by Sisson \& Lilley, Grand Rapids, Mich.; got by Talmage, son of Byerly Abdallah : dam Lou S., bay, bred by Boyde Pantlin, Grand Rapids, Mich., got by Goldenbow, son of Satellite ; 2 d dam said to be by Brown's Swigert, son of Norman.

Sire of Fawnfoot, $2: 27 \frac{1}{2}$.

FERDINAND, dark bay; foaled I 760 ; said to be by a Spanish horse.

Advertised as above in New York Mercury, 1767 , to be kept in Monmouth County, N. J. Terms £5.

FERDINAND C., chestnut, I53/4 hands, Iooo pounds; foaled June 9, I 867 ; bred by Mayor T. B. Ferguson, Washington, D. C. ; got by Conductor, son of Engineer: dam Sally Fackler, sorrel, bred by Col. James Ferguson, South Carolina, got by Iago, son of Othello; 2d dam Zephyr, said to be by Lafayette, son of Galatin; and 3d dam imported Eliza, by Philo-da-Puta. Owned successively by Gov. Thomas Seenun of Maryland; Dr. C. S. Carter, London County, Va.; Thomas Nelson of Virginia. Said to be very handsome with good action and kind. Died about r88o. Pedigree from Dr. C. S. Carter, Leesburgh, Va.

Sire of Lah-da-dah, $2: 26$.

FERGUS McGREGOR ( 7 -I 28 ), chestnut with small star, I5 hands $2 \frac{1}{2}$ 
inches, Iroo pounds; foaled 1876 ; bred by R. I. Lee, Topeka, Kan.; got by Robert McGregor, son of Major Edsall : dam Miss Munroe, brown, bred by Peter Townsend, Monroe, N. Y., got by Iron Duke, son of Hambletonian ; 2 d dam Young Saline, chestnut, bred by Peter Townsend, got by Guy Miller, son of Hambletonian ; 3 d dam Saline, bay, bred by Mr. Corbit, near Fredericksburg, Va., got by Parmunkey, son of American Eclipse; 4th dam, pedigree lost, but believed by Gen. Mausy, Richmond, Va., who owned her, to be thoroughbred. Sold to Prairie Dell Farm, Topeka, Kan. Pedigree from breeder.

Sire of $I_{4}$ trotters $\left(2: I_{2} \frac{1}{4}\right), 9$ pacers $\left(2: I_{1}^{1} / 4\right) ; 2$ sires of I trotter, I pacer; 7 dams of 5 trotters, 2 pacers.

FERGUSON, brown; foaled 1880 ; bred by Z. E. Simmons at Walnut Hill Stock Farm, Lexington, Ky. ; got by George Wilkes, son of Hambletonian: dam Press Forward (dam of Favorita, $2: 25 \%$ ) said to be by Albion, son of Peter's Halcorn, by Halcorn, son of Virginian, by Sir Archy ; 2 d dam Bell Martin, thoroughbred, by imported Sovereign; 3d dam Icara, by imported Sarpedon; $4^{\text {th }}$ dam Milly Lone, by Rattler: and $5^{\text {th }}$ dam by Potomac. Died I $89 \mathrm{I}$, the property of breeder.

Sire of 4 trotters $(2: 261 / 2), 6$ pacers $\left(2: 10^{3 / 4}\right) ; 2$ sires of 12 pacers $; 4$ dams of 2 trotters, 3 pacers.

FERGUSON'S GRAY; foaled I786; said to be by Symes' Wildair : dam by Col. Skipwith's horse, Comus; and $2 \mathrm{~d}$ dam a well bred mare. Advertised, I790, in Hickman, about seven miles from Lexington, Ky., by Bryant Ferguson.

FERRONS (3-64), brown, I5 T/4 hands; foaled I 886 ; bred by Z. E. Simmons, Lexington, Fayette County, Ky. ; got by The King (dam by Gill's Vermont) son of George Wilkes: dam Leda, bay, bred by Dr. J. L. Wheaten, Pawtucket, R. I., got by Aberdeen, son of Hambletonian; 2d dam Pattie W., said to be by Young Brandywine, son of old Brandywine; and $3 \mathrm{~d}$ dam by Whalebone, son of Sherman Morgan. Sold to Dan Mace; to Z. E. Simmons. Pedigree from breeder.

FESSENDEN (I-8), bred at Watertown, Jefferson County, N. Y.; said to be by Andrew Jackson, son of Bullrush Morgan, by the original Justin Morgan horse. See The Morgan Horse and Register, Vol. I., p. 764; also see Andrew Jackson (Ives), Vol. I., American Stallion Register.

Sire of Fred Casey, $2: 23 \frac{1}{4}$.

FIDDLER ( $\left.\mathrm{ROE}^{2} \mathrm{~S}\right)$; foaled I85-; bred by A. T. Wallace, Bullville, Orange County, N. Y.; got by Fiddler, son of Monmouth Eclipse, by American Eclipse, son of Duroc, by imported Diomed: dam said to be by Ohio Eclipse. Owned by William Roe, Montgomery, Orange County, N. Y. 
FIDDLER (WEBEER'S), bay with white hind feet, $15^{1 / 2}$ hands; foaled I 839 ; bred by Jonathan J. Homes, New Jersey, got by Monmouth Eclipse, son of American Eclipse : dam Music, bred by D. Schanck, New Jersey, got by John Richard, son of Sir Archy; 2d dam Maid of the Valley, bred by D. Schanck, got by Oscar, son of imported Gabriel; 3 d dam said to be by. Hickory, son of imported Whip ; 4 th dam by imported Expedition; $5^{\text {th }}$ dam by Lloyd's Traveler, son of imported Traveler; and 6th dam Miss Slammerkin, by imported Wildair. Owned by Mr. Somerindyke, New York City, who sold to William Webber, Goshen, Orange County, N. Y. Gilbert Turner, Turner's Station, N. Y. says :

"Fiddler had a full breast with good neck, short back and bushy tail. He was brought here about $\mathrm{I} 845$ and kept here four years or more. His wind was remarkable. Tom Thumb could out-trot him but could not stay with him."

Charles Seeley, Chester, N. Y., says: "Fiddler went from here to New Jersey. He was both a trotter and a runner."

Probably sire of the dam of Harold, sire of Maud'S.

FIDOL (1-32), 2 :04 $1 / 2$, bay, black points, $15^{\mathrm{T}} / 2$ hands, 1075 pounds; foaled I 887 ; bred by Charles A. Vogt, Iowa City, Ia.; got by Idol, son of Hambletonian : dam Molly Jackson, bay, bred by Charles A. Vogt, got by Stonewall Jackson, son of Mambrino Chief; $2 \mathrm{~d}$ dam Queen Anne, said to be by Clifton Pilot, son of Pilot Jr; 3d dam Queen by Vermont

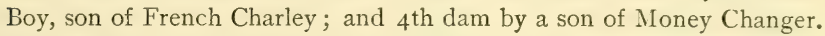
Sold to W. Rivenburg \& Son, Cedar Falls, Ia. Pedigree and information from John A. Mahankee, Parkersburg, Ia., and Carl A. Vogt, Cedar Rapids, Ia. Died Feb. I3, I896.

Sire of 2 pacers $\left(2: 14^{1 / 4}\right)$.

FIELDMONT (I-ז6), bay, right hind and fore feet white, and a blaze in face, I5 $3 / 4$ hands, II 75 pounds; foaled 1878 ; bred by William Payne, Payne's Depot, Ky., foaled the property of W. Field, Lexington, Ky., got by Almont, son of Alexander's Abdallah, by Hambletonian : dam Maggie Gaines (dam of Hamlin's Almont Jr., $2: 26$ ), bred by Joseph Graves, Lexington, Ky., got by Blood's Black Hawk, son of Black Hawk, by Sherman Morgan; 2d dam said to be by Boner's Saxe Weimar, son of Saxe Weimar, by Sir Archy. Sold to S. E. Larabie, Deer Iodge, Mont.; to Henry C. Jewett, Jewettville, N. Y.; to L. A. Davis; J. N. Wetherell; F. M. Foote and, A. C. McCall, Arcade, N. Y. Pedigree from Jewett Farm catalogue.

Sire of 9 trotters $(2: I 8)$; I sire of I trotter 2 pacers; 5 dams of 5 trotters I pacer.

FIGURE, bay, $153 / 4$ hands; foaled 1757 ; bred by His Grace, the Duke of Hamilton; got by old Figure: dam Marianne, by Croft's Partner- 
Luggs-Bald Galloway. Imported by Dr. Thomas Hamilton of Prince George's County, Md., in I 765 .

Bruce and Wallace both furnish another pedigree for the dam of this horse, substituting a Marianne, by Victorious, that they find in the English Stud Book.

An advertisement of Young Figure in New York Gazette, 1777, by Nathaniel Heard, states that Hamilton's Figure won purses at Newcastle-upon-Tyne, Lancaster, Sterling and Busby, also in Maryland; got by old Figure, by Standard (sire of Josiah Lowther's Jason, a good racer) Young Figure's dam Young Marianne, by Crab,_dam old Marianne, by Partner-Luggs-Bald Galloway.

Advertised in Maryland Gazette, I766-68-70; in New Jersey, I 78 I as the gayest and handsomest horse in America. He ran at Annapolis I 766, winning a race at four mile heats, and ran several other races.

Advertised, I773, by James Tallman to stand in Gloucester County N. J.

Advertised, I78I, in the New Jersey Gazette, by Amos Swan as follows: "The noted horse Figure imported by Dr. Hamilton and late the property of Captain Barnard Smock, dark bay, I5 I/ $/ 4$, etc."

FIGURE; said to be by old Figure: dam Brent's running mare Ebony, by Othello; and 2 d dam Tasker's imported Selima.

Advertised, I776 at Mechlenburgh, by Payton Skipwith, in Virginia Gazette.

FIGURE, dark bay, over I5 hands; said to be by old Figure: dam by Othello; and 2d dam Selima; all imported, and well known. Lately from Gloucester. Advertised as above by Clayborne DuVal, Hanover, I 784 , in the Virginia Gazette, or American Advertiser.

FIGURE; said to be by Hamilton's Figure. He was a horse of great elegance, speed and fine action; he was brought from the state of Maryland, by a Mr. Kelley, shortly after the Revolutionary war, into the neighborhood of Hillsborough in the state of North Carolina, where he remained unrivaled as a racer and stallion for many years.-Edgar.

FIGURE, gray, $15 \mathrm{~T} / 4$ hands; said to be by the old noted horse Figure : dam by Dove; and $2 \mathrm{~d}$ dam by Othello. Advertised in New Jersey, 1782 , where it is said that he came from Queen Anne County, Md., and was of great elegance.

FIGURE, dark bay, $15 \frac{\mathrm{T}}{4}$ hands; foaled about 1784 ; said to be raised in Virginia and 7-8 blooded. Advertised by Joel Tilden and S. Bingham at Lebanon, N. H., r 797, together with Cardinal Woolsey, dark bay, I $61 / 2$ hands.

FIGURE, black, I6 hands ; foaled I788: bred in Pennsylvania; and said to 
be by True Briton: dam by Bold Briton; and $2 \mathrm{~d}$ dam by the Narragansett horse, Feather. Advertised, 1793, by Samuel Lattimer at Weathersfield, Conn.

FIGURE (JUSTIN MORGAN) (I), bay, I 5 hands. Advertised May, I 792, by Sam Whitman of Hartford, Conn., and is almost certainly the original Justin Morgan Horse. See Justin Morgan.

We find in Spooner's "Vermont Journal," published at Windsor, Vt., the two following advertisements:

"Will cover this season at Captain Elias Bissell's stable in Randolph and at Captain Josiah Cleveland's stable in Lebanon, the famous Figure horse from Hartford, Conn., at fifteen shillings for the season, if paid down or eighteen shillings if paid in the fall, in cash or grain at cash prices. Said horse's beauty, strength and activity the subscriber flatters himself, the curious will be best satisfied to come and see. Said horse will be in Lebanon the second Monday in May next, there to continue two weeks, and then to return to Randolph, so to continue at said Cleveland's and Bissell's, two weeks at each place through the season.

Randolph, April 8, r 793."

Justin Morgan.

"The beautiful horse, Figure, will cover this season at the moderate price of one dollar the single leap, two dollars the season, if paid down, or by the first of September next; if not paid then, it will be sixteen shillings. Said horse will be kept at the stable of Ezra Edgerton in Randolph, and Lieut. Durkee or E. Stevens in Royalton. He will be kept at Randolph till the second Monday of May, when he will be taken to Royalton, there to be kept every Monday, Tuesday and Wednesday ; then return to Randolph, where he will continue Thursday, Friday and Saturday, and so alternately during the season. The subscriber flatters himself that the horse's strength, beauty and activity will bear examination by the curious. Constant attention will be paid at each of the above places.

Randolph, April 2 I, I 794."

Justin Morgan.

Also in Rutland (Vt.) Herald as follows :

"Figure will cover this season at stable of Samuel Allen in Williston, and at a stable in Hinesburgh, formerly owned by Mr. Munson. He will stand at Williston till the eighteenth of May; then to Hinesburgh, where he will stand one week; then back to Williston, to continue through the season, one week in each place. With regard to said horse's beauty, strength and activity, the subscriber flatters himself that the curious will be best satisfied to come and see.

"Figure sprang from a curious horse owned by Col. DeLancey of New York, but the greatest recommend I can give him is; he is exceedingly sure, and gets curious colts.

Williston, April 30, I 795."

Justin MORgan.

See The Morgan Horse and Register Vol. I., pp. 98, I02, I I 8.

FIGURE, bay, about I6 hands, said to be a full-bred imported horse. Advertised, I796 and r799, at the stable of Capt. Lovell, Newbury, Yt., by Thomas W. Pitkin, terms $\$ 4$ to $\$ 6$. In 1797 , he is advertised by Mr. 
Pitkin at Hartford and Norwich, Vt., also advertised in Spooner's Vermont Journal, 1798 , by Mr. Pitkin.

FIGURE. Said to have been bred on Long Island and got by imported Figure, son of Wildair, after he returned to England. This from an advertisement, I 795 .

FIGURE, bay, blaze and two white feet, I 6 hands; foaled I794; an imported draft horse : dam of Hunting breed nearly full blood. Advertised as above at Gettysburg, Penn., in I802.

FIGURE. The following advertisement appears in the Montpelier Press of I8II:

"Figure known by the name of the Borden Horse, will stand etc., at Col. Moses Morse's in Montpelier Village, Michael Hammett's in Montpelier, Elisha Coburn's and at Gilmores on Cabot Plains, at \$I.5O and \$2.

Calais, April I г, i8 г г." Vial Alien.

We think very probably that this horse was got by Justin Morgan when owned at Montpelier, I 797-8, and called "Figure Horse."

FIGURE (YOUNG), bay; foaled I769; bred by Nathaniel Heard; got by Hamilton's Figure: dam Britannia, gray, foaled I76r, bred by Gov. Sharpe, Maryland, got by imported Othello. Advertised by breeder at Rocky Hill, N. J., I 778 , with pedigree as above. An advertisement of this horse in New Jersey Gazette, of same year extends pedigree of dam as follows:

"Dam Britannia full sister to True Briton and from Col. Grant's Milley. Milley a full sister to Col. Harper's Pacolet, her grandam was Queen Mab, got by Musgrave's Gray Arabian, a smart beautiful horse for which he refused 500 guineas. He was stood at ten guineas the leap. His great-great dam by Gov. Harrison's Arabian; his great-great-great dam by his chestnut Arabian; his great-great-great-great dam was a Barb brought over by Mr. Marshall, and was dam of Mr. Croft's Grayhound."

FILBRO DA PUTA; foaled April I2, I 8 I2; bred by Thomas Hornby Moreland, Esq., of Finchley, Middlesex, got by Haphazard: dam Miss Barnet. Sold to Thomas Hauldsworth, of Farnsfield, Notts., for 3,ooo guineas. A successful racer.-American Turf Register, Vol. II., p. 531 .

FILLMORE (3-128), $2: 213 / 4$, chestnut, near hind ankle and small spot on flank white, I53/4 hands; foaled I 890 ; bred by Ariel Lathrop, San Francisco, Cal.; got by Palo Alto, son of Electioneer: dam Miss Gift, chestnut, bred by Ariel Lathrop, got by General Benton, son of Jim Scott ; 2d dam Addie Lee, bay, bred by E. J. Winegar, Fort Jones, Cal., got by Culver's Black Hawk, son of Vermont ; 3d dam old Nancy, taken to California in the early days, and said to be by old Morrill. Sold to J. B. Dutcher \& Son, Pawling, N. Y., who send pedigree.

Sire of Sister Francis, $2: 22^{3} / 4$. 
FINANCEER; said to be by the famous imported race horse Financeer: dam a beautiful Spanish mare now owned on Long Island. Advertised, I $8 \mathbf{2 4}$, in the New Hampshire Patriot (published at Concord), by James Wilson.

FINANCEER, dark dappled gray, I6 hands; foaled about 1818 ; bred by Michael R. Hallenbeck, Hudson, N. Y., got by Loop's Highlander, son of Brown Highlander: dam, said to be by Messenger. Advertised in the New Hampshire Spectator, Newport, 1826.

FINANCEER, chestnut, 16 hands ; said to be by imported Expedition : dam imported. Described by E. P. Barstow, Augusta, who advertised him in the American Advocate and General Advertiser, to be kept at Augusta, Me. $1822-23$.

"A full blooded, large boned Orring horse. Took first premium at Hallowell, Me., I822. Shown, I821, at State Fair, Hallowell, Me., but not entered for premium. This Financeer was bright chestnut, said to have been bred in Virginia, and to be well known in Massachusetts."

FINANCEER (sire of dam of Ariel), was got by Tippo Saib, who was got by Messenger: dam Col. Thompson's imported mare, by Northumberland. Financeer's dam was by Messenger; his grandam by Bashaw (brother to Slamerkin); his great-grandam by Young Bull Rock; his great-greatgrandam by old Selim ; his great-great-great-grandam by Col. Hopper's Pacolet. Advertised as above at Flatbush, April I, I822, by J. C. Vandeveer.

FINANCEER. A famous racer was owned and probably bred by Isaac Duckett, Esq., of Prince George County, the land of his maternal ancestry. J. V. Bond of Pennsylvania, also ran with success, 1812-1 3, a chestnut horse called Financeer.-American Turf Register, September, 1834 .

FINANCEER (YOUNG) (I-I6), gray, I5 T/2 hands, IO25 pounds; foaled May, I833; bred by Amos A. Walker, Whiting, Vt. ; got by Hammond's Financeer, a dapple gray horse, about I roo pounds, that was kept one season at Jerry Delongs in Cornwall, Vt., then gelded: dam bay roan, foaled $\mathbf{1} 827$, bred at St. Johnsbury, Vt., where she was bought when four by Nathan Wood, Middlebury, Vt., thought to be Morgan. Died I 852 , property of breeder. Kept mostly in Addison County, Vt., and in Dresden, N. Y.

Mr. M. B. Walker, son of Amos E. Walker, says that Hammond's Financeer was a young and handsome horse brought to Vermont from Poughkeepsie, N. Y., by Jerry Hammond, and called a Messenger. Mr. Hammond gelded him and sold him in Boston, Mass.

FINE CUT, chestnut, I $5 \frac{1}{2}$ hands; foaled 1855 ; bred by Leroy Hartland, 
Wisconsin; got by John C. Fremont, son of Black Hawk, by Andrew Jackson: dam said to be by Hobkirk's Sir Henry. Owned by J. E. Newton, Colorado Springs.

Sire of Jackson, $2: 27 \frac{3}{4}$.

FIRE BELL (5-256), bay, $153 / 4$ hands, rooo pounds; foaled 1890 ; bred by J. M. Johnson, Lawrenceburg, Ky., got by Bell Boy, son of Electioneer : dam Rosetta, bay, bred by Erastus Corning, Albany, N. Y., got by Shawmut, son of Harry Clay; $2 \mathrm{~d}$ dam Mistress, bay, bred by Erastus Corning, got by Harry Clay; $3 \mathrm{~d}$ dam Maori, said to be by imported Australian; and $4^{\text {th }}$ dam by Lexington. Sold about 1908 in public sale at Lexingion, Ky. Pedigree from breeder.

Sire of Gipsey Boy, $2: 261 / 4$.

FIRE CLAY (I-64), 2 :30, brown with star, I 6 hands; foaled I 885 ; bred by Erastus Corning, Albany, N. Y. ; got by Shawmut, son of Corning's Harry Clay: dam Mercedes, bay, bred by J. C. McFerran, Louisville, Ky., got by Cuyler, son of Hambletonian; 2d dam Emma Arteburn, black, bred by Dr. Herr, Lexington, Ky., got by Mambrino Patchen ; 3d dam Jennie Johnson, black, bred by Victor Flournoy, Fayette County, Ky., got by Sweet Owen, son of Gray Eagle ; $4^{\text {th }}$ dam Lux, said to be by Wagner, son of Sir Charles. Sold to S. E. Larabie, Deer Lodge, Mont. Pedigree from breeder.

Sire of 2 trotters $(2: 24)$.

FIREFLY (I-8), chestnut, I5 I/4 hands, 950 pounds; foaled I 873 ; bred by Henry N. Hall, Bridport, Vt. ; got by Daniel Lambert, son of Ethan Allen : dam chestnut, bred by Jonathan Wilmarth, Addison, Vt., got by Plato, son of Black Hawk; 2d dam, black, bred by J. Wilmarth, got by Black Hawk, son of Sherman Morgan; 3d dam said to be of English blood. Sold, I8so, to Joseph Battell, Middlebury, Vt. ; resold at Kellogg sale, New York City. See The Morgan Horse and Register, Vol. I., p. 579 .

Sire of Del Monte, $2: 2 \mathrm{I} 1 / 2$.

FIRST CONSUL, bright bay, I53/4 hands; foaled in Philadelphia, I798; said to be by Flag of Truce, son of imported Goldfinder: dam by imported Slender, son of King Herod; and 2d dam imported Diana, by Eclipse. Advertised in a Philadelphia paper, I806, with pedigree as above by J. B. Bond, and in True American, Trenton, N. J., I8o9, by J. M. Bingham, to be kept at Cooper's Ferry.

Advertised in the Washington Advertiser, ISo7, by Mr. Bond who says :

"Consul is of fine figure, beautiful bright bay with a small blaze in his face and his hind ankles white; full $15^{\mathrm{T} / 2}$ hands. It is expected that the stock from Consul and well bred mares will not be surpassed for the turf, carriage or saddle. 
"Slender was got by King Herod, who produced more runners than any other horse in England, as may be seen by the racing calendar, therefore it may in truth be said on the dam's side of First Consul, the two great grandsires were the best horses England ever produced.

"Flag of Truce was bred by Col. Wivel of Virginia, and was esteemed the best turf horse in his day, and was the sire of Col. Taylor's famous running horse Leviathan. First Consul has won either 20 or 22 purses and never started against a horse he did not out-run until the fall he was eight years old. The spring following he won three purses and distanced the field the first day at Newmarket on Long Island."

FIRST CONSUL, bay, I6 hands; foaled $\mathrm{r} \$ 26$; bred by M. M. Sands Long Island; got by Dinwiddie: dam said to be by Flag of Truce, son of imported First Consul; and $2 \mathrm{~d}$ dam by Coriander (dam the Figure Mare), son of Messenger. See Dinwiddie owned by C. W. Van Ranst and kept on Long Island, $1824-26$. Pedigree from advertisement in Middlebury (Vt.) Free Press, May 4, I831, from which we quote as follows :

"First Consul.-Fresh from Long Island.-The subscriber having taken unwearied pains to improve the breed of horses in this section of the country by procuring the most pure-blooded horses from the south that could be had, such as Sir Charles, now owned by David Hill of Shoreham, and the celebrated horse Tippoo Saib, which the subscriber has been prevailed on to let stand in Rutland County the ensuing season, would now present the services of the above named horse to his former customers, and he feels warranted in saying that First Consul is of better and more approved blood, upon Long Island, than either Sir Charles or Tippoo Saib. First Consul will stand at Shoreham and Bridport; $\$ 7$ the season.

Abraham Frost."

FIRST CONSUL, gray, I6 hands; bred at Philadelphia, Penn.; got by Bond's First Consul : dam imported, said to be by Sancho. Advertised with pedigree as above, 1832 , in New Jersey.

FIRST CONSUL, black. Owned about I834, by Jack Williams, who kept him about a year and sold him in Canada. Information from John P. Williams, a son of owner.

FIRST PREMIER, dapple bay, I 5 hands; said to be a full blooded French horse. Advertised at Burlington, Vt., I820, by James Southard.

\section{FISETTE HORSE (SEE VOYAGEUR).}

FISHER PATCHEN (I-I28), bay; said to be by Garwood's Patchen, son of George M. Patchen: and dam by imported Trustee. Taken to Pekin, Ill., by P. H. Kelley in 1862, and died there, I 868 .

Sire of Capt. Jack, $2: 26$ 。

FITCH CLARK, bay; foaled I 884 ; bred by John Terwilliger, Chester, N. Y.; got by Polonius, son of Hambletonian: dam Fanny, said to be 
by Hambletonian (Sackett's) ; 2 d dam Lady Sullivan, by St. Lawrence (Canadian); and 3 d dam Jessie H. Knapp, untraced. Sold to N. Hubbard, Chester, N. Y.

Sire of 2 trotters $\left(2: 29 \frac{1}{4}\right)$.

FITLER (3-64), $2: 23 \mathrm{~T} / 4$, bay; foaled 1887 ; bred by Wm. W. Singerly, Philadelphia, Penn.; got by Red Wilkes : dam Messenger Girl, bay, bred by Clay Mock, Danville, Ky., got by Messenger Chief, son of Abdallah Pilot; 2d dam Rose Chief (dam of Prince Wilkes, 2: r43/4), chestnut, bred by T. J. \& F. Nichols, Harrodsburg, Ky., got by Brown Chief, son of Blood Chief ; 3 d dam Lady Nichols, said to be by John Dillard, son of Indian Chief; and $4^{\text {th }}$ dam Lady Martingby, by Glencoe (Hunter's) son of Glencoe.

Sire of Fred C., $2: 21_{1}^{1} / 4$, Lizzie Wilkes, $2: 081 / 4$.

FITZPARTNER. Advertised as follows in the Lexington (Ky.) Gazette, I 804 :

"Beautiful bay, I6 $1 / 4$ hands high, of great activity and highly formed, got by Partner, son of Morton's imported Traveler, was bred by Col. John Taylor of Richmond County: dam Selima, imported by Col. Tasker of Maryland and is considered by the best judges to be the finest mare ever brought to America and a near descendant of the Godolphin Arabian. He was bred by General Meade of Amelia, dam by imported Aristotle, grandam by the noted horse Whittington, great grandam by Jolly Roger, his great great grandam a Double Bean from an imported mare, the property of Col. Francis Eppes. Fitzpartner's dam was likewise the dam of the well known horses, old Celar, Pilgrim, Tippoo Saib and Clodius.

"Will stand the ensuing season at my stables in Bourbon County at the intersection of the road leading from Paris to Cleveland's and from Lexington to the Iron Works. He is lately from Virginia.

William Clakkson."

FITZ ROY (I-64), bay, black points, I 6 hands, I 200 pounds ; foaled I 88 I ; bred by Elijah Buck, Crystal Lake, Ill. ; got by Lakeland Abdallah, son of Hambletonian: dam Fanny, bay, bred by Charles S. Dole, Crystal Lake, Ill., got by Doles Young Magna Charta; $2 \mathrm{~d}$ dam by old Jack Cook. Died about 1904. Pedigree from D. W. Thomas, Algonquin, Ill., breeder of Jakeo, $2: 20$.

Sire of $7 a k e 0,2: 20$.

FLACO (I-32), dark brown, left hind heel white; foaled May 7, I877; bred by T. B. Muir, Chilesburg, Ky. ; got by Trojan, son of Barkley's Brignolia, by Brand's Brignoli, son of Mambrino Chief, by Mambrino Paymaster : dam said to be by Vindex, son of Blood's Black Hawk; 2d dam by Gano, son of American Eclipse; 3d dam by Potomac, son of imported Diomed; $4^{\text {th }}$ dam by Baronet, son of imported Baronet; and $5^{\text {th }}$ dam by imported Buzzard. Sold to L. D. Buttels, Memphis, Mo., for \$1500. 
Pedigree from J. W. Muir, Calexico, Cal., son of the breeder; also information from John E. Muir, Lexington, Ky.

Mr. Peter Evans, Mt. Sterling, Ky., writes that Flaco was owned by Thomas Muir, Chilesburg, Ky., when Dinah, $2: 281 / 2$, was bred.

Sire of Dinah, $2: 281 / 2$; I sire of I trotter; 2 dams of 2 trotters.

FLAGELLATOR, I $53 / 4$ hands; foaled $182 \mathrm{I}$; bred by Joseph H. Van Mater, Monmouth County ; got by Sea Gull, son of Expedition, by Pegasus, son of old Eclipse: dam said to be by Honesty; 2 d dam Zelipha, by Messenger; 3d dam Dido, by imported Bay Richmond; 4th dam Slammerkin, by Wildair; $5^{\text {th }}$ dam by Sterling; and 6 th dam, by old Partner. Advertised, I8z8, at Bound Brook by John Frost. Advertised in the Jerseyman, Morristown, N. J., I835, with pedigree and description as above. Advertised, I836, at Jacksonville, Ky., by N. Forsyth.

FLAG OF TRUCE, silver-gray, I $5 \frac{1}{2}$ hands; bred by Col. Portress; got by imported Goldfinder, son of imported Fearnaught: dam by Flimnap; 2 d dam by imported Aristotle; 3 d dam by imported Fearnaught. Advertised as above in the Virginia Gazette, I 787 .

Advertised in the Porcupine Gazette, Philadelphia, I 797-98, as follows :

"The noted full-bred horse Flag of Truce in seventh street at three guineas ; by imported Goldfinder, etc."

FLAG OF TRUCE : bred by Peter Schenck; got by Badger's Sir Solomon : dam by Badger's Hickory-imported Expedition-imported Gray Highlander-imported Traveler-Slammerkin Mare, by Wildair-imported Cub Mare. Taken to Ohio, by William Straiter.

FLAG OF TRUCE, black, I5-3 hands; said to be by imported Rockingham: and dam by Granby. Advertised in I8oo in Newark, N. J.

FLAG OF TRUCE, milk white with white mane and tail; foaled I809; said to be by Bond's First Consul, imported. Owned by Squire Harris, Castleton, Vt., about I 8 r 8 .

Mr. Baker, Sr., Comstock's Landing, N. Y. said :

"A milk white horse with white mane and tail, was owned by Caleb Thompson and kept at Fort Ann, when I came, in 1832.

"A man told me he was got by a Messenger horse; told me also about Magnum Bonum and Highlander, that a man from Philadelphia imported the three, and that Flag of Truce was by Messenger or Brown Highlander. He left some beautiful horses here."

Dr. Warren B. Sargent, Pawlet,Vt., said :

"Flag of Truce was a lofty dapple gray horse, as fine a looking horse as ever walked through this place. This was about I820. I think it was Chase who had him and who lived at White Creek. Kept him here and at Danby two years." 
Dr. Eastman, Rupert, Vt., said: "Flag of Truce was I5-2, Iooo pounds, a fine rangy horse, a little leggy.

"A son of this horse was owned in Clarendon, Vt., by Mr. Briggs."

A few items about "Flag of Truce," by Henry D. Noble.

"In your article upon the Sons and Daughters of Messenger, published in the April number of the Monthly, you say that Flag of Truce was sent north and sold, probably in Vermont, and that no trace of him has been found.

"About fifty-two or fifty-three years ago my father traded a Nimrod Mare with William Vaughan of Tinmouth, for two yearling colts, by Comet. One of the colts was from a Flag of Truce mare. This mare was bred by Nero Crompton of Tinmouth. Crompton had a Sweepstakes mare that was a noted traveler. Vaughan got Crompton to breed this mare to Flag of Truce, and was to give him twenty dollars for the colt when it was four months old. Crompton delivered the colt according to the contract, but would not take but eighteen dollars for it, saying it was all that it was worth. I recollect going with my father when he went after these colts. I was ten or eleven years old. There was snow on the ground, and I think it was in the fore part of the winter. We led the mare that Vaughan was to have, and I rode the Flag of Truce mare home, and the colts followed me. I recollect how the old mare looked and how she rode. She had been a noted mare and had trotted her mile in three minutes. They had finished using her as a driving horse. The colt my father got was her second colt, and she brought two afterwards. I cannot tell how old this mare was at this time. She was old enough to be gentle and safe. My opinion is that she was from twelve to fifteen. I don't recollect seeing the old mare after this time, but recollect her two younger colts. I have a brother, older than I am, that remembers her after this time, and thinks that she was older than I am calling her. Calling it fifty-two years ago that my father got these colts, and calling this mare $\mathrm{I} 3$ at that time-and she was probably older-it carried us back sixty-five years. Flag of Truce, foaled in I8o9, would have been eight years old when he got this mare. While it does not amount to an absolute certainty, I have no doubt that the Vaughan mare was by old Flag of Truce."-IVallace's Monthly, 1884.

FLASHLIGHT (I-I 28), black, I5 $3 / 4$ hands, I050 pounds; foaled I 890 ; bred by W. P. Ijams, Terre Haute, Ind.; got by Jersey Wilkes, son of George Wilkes: dam Blanche, black, bred by Richard West, Lexington, Ky., got by Egbert, son of Hambletonian ; 2d dam Dosia Harper, bred by G. W. Nichols and M. N. Peak, Georgetown, Ky., got by Albrino West, son of Almont; 3d dam Sally, bred by M. N. Peak, got by Alexander's Bay Chief, son of Mambrino Chief. Sold to E. J. Helber, Ann Arbor, Mich. Pedigree from breeder.

Sire of 3 trotters $\left(2: 25 \frac{1}{4}\right)$.

FLASK (3-32), $2: 133 / 4$, black with star; foaled I 889 ; bred by H. N. Smith, Trenton, N. J.; got by Rumor, son of Tattler: dam Flageolet, black, bred by H. N. Smith, got by Gen. Knox, son of Vermont Hero; 2 d dam Zither, bay, bred by Charles H. Kerner, New York, N. Y., got by Jay Gould, son of Hambletonian; 3d dam Music's dam, chestnut, bred by 
W. S. Wallace, Middletown, N. Y., got by Roe's Fiddler, son of Webber's Fiddler; and $4^{\text {th }}$ dam by American Star. Pedigree from catalogue of breeder.

Sire of 2 pacers $(2: 19 \%)$.

FLATBUSH ABDALLAH (I-32), bay; foaled $\mathbf{1} 869$; bred by Z. B. Van Wyck, Flatbush, L. I. ; got by Jupiter Abdallah, son of Jupiter: dam Abdallah Maid, said to be by Jackson's Flying Cloud; and $2 \mathrm{~d}$ dam by Van Siclen's Abdallah, son of Abdallah; 3 d dam bred by John Graham, Peekskill, N. Y., got by Hickory. Sold to John J. Van Wyck, Flatbush, L. I.

Sire of Fascination, $2:$ I4.

FLAXMONT, $2: 263 / 4$, chestnut, white points, I $53 / 4$ hands, I Ioo pounds; foaled $\mathbf{r} 88_{3}$; bred by Ivo Gittings, Disco, Ill., and foaled the property of T. M. Paul, Lomax, Ill. ; got by Egmont, son of Belmont : dam Daisy, untraced. Pedigree from T. M. Paul.

Sire of 4 trotters $\left(2: 15 \frac{1}{2}\right) ;$ I dam of I trotter.

FLAXTAIL (BULL PUP JR.) (I-I6), dun or chestnut with star, white mane and tail, and hind legs white to hocks, $153 / 4$ hands; foaled 1854 ; bred by Newton Wiseman, Salem, Ind.; got by Bull Pup (Jesse Mitchell's), son of Pilot: dam a fast pacing bay mare, breeding unknown. Sold I864, to Joseph Mitchell, Salem, Ind., who took him to Iowa, where his name was changed to Flaxtail and it was for a time claimed that he was by Pruden's Blue Bull.

Mr. M. W. Hicks writes that Mr. Mitchell sold him to Mr. T. T Tinsley, Indianapolis, Ia., who sold to M. W. Hicks whose property he died at La Harp, Ill., I88o.

Mr. Hicks describes him as $153 / 4$ hands, crooked hind legs, deep in the chest, short back, high on the loin, steep in the rump.

The following information of this horse is from The Breeder and Sportsman of San Francisco, Cal., April 22, 1893.

\section{FLAXTAIL'S PEDIGREE.}

Editor Breeder and Sportsman:-Those horsemen of California and elsewhere, who are interested in the blood-lines of that good horse Flaxtail should be grateful to you for the great interest you have taken, and the liberal space devoted in the columns of your valuable paper, to the straightening out of his pedigree. The showing made in your paper of last Saturday appears conclusive enough to warrant the Register association to wipe out the present registration of Flaxtail, for that, beyond any doubt whatever, is not correct ; and then, instead thereof, to register him in accordance with the testimony, when presented to the association, which you have shown to the public through your columns.

L. B. Hicks.

The following is a copy of another certificate written and signed by L. B. Hicks, son of Dr. M. W. Hicks : 
To Whom It May Concern :- I have often heard my father say that he was sorry the story that Flaxtail was got by Pruden's Blue Bull was ever printed. This story was first circulated the year that Wilson's Blue Bull got twelve in the $2: 30$ list. I know that father (M. W. Hicks) claimed that Bull Pup was the sire of Flaxtail, but he had been registered as "said to be by Pruden's Blue Bull," and for some unaccountable reason he never had the registration changed as it should have been. Mr. Sam Gamble is right when he said the Blue Bulls and Flaxtails were totally unlike. Most of the Blue Bull's that I have seen were small horses with small ears, short heads, short necks and very short coupled. They were a good deal on the pony order. Now the Flaxtails were nearly all of good size and some of them very large, and most of them had very long heads, long coarse ears, long necks and very long backs, and in fact in conformation, disposition and everything else were as unlike the Blue Bulls as they could be.

\section{San Francisco.}

\section{(Signed), L. B. Hicks.}

\section{IVitness : E. L. RobINSON.}

It seems to me that if the breeders of California, who are interested in having Flaxtail properly registered, would, by some concerted action, cause the evidence that can be produced upon the subject to be properly presented to the Register. association, there would be little trouble in accomplishing the desired object. Although I have no pecuniary interest in the subject, having no animals of that line of breeding, I am ready and willing to give any information and assistance in my power whenever the same may be desired to aid in the proper registration of the horse.

San Francisco, April 26, I 893.

E. I. RoBINSON.

DR. M. W. Hicks,

San Francisco, Cal., Dec. I4, I89i.

Dear Sir :-I am endeavoring to have Flaxtail registered as being got by Bull Pup, and I understand, from conversations with you, that you purchased Flaxtail from T. T. Tinsley, of Mahaska County, Ia., and that said Tinsley informed you that he was by Bull Pup, and that he had purchased him from a man named Mitchell, who came from Salem, Ind. If the facts as herein stated are correct, please certify to the same and oblige,

Alfred H. Cohen.

I hereby certify that the above facts are correct. M. W. Hicks.

From the records of J. H. Wallace above-referred to, and the certificate of Hicks, it appears that the same man, Mitchell, owned Bull Pup and Flaxtail in Indiana; that he took Flaxtail to Iowa and sold him to T. T. Tinsley, from whom Hicks purchased him, and that Hicks owned him subject to a lease to G. N. Nelson until he died in the fall of $\mathbf{I} 880$.

It appears to me that this showing is sufficient to warrant a corrected registration of Flaxtail. I am fully satisfied that he was by Bull Pup (sire of Rowdy Boy, $2: 133 / 4$, Kismet, $2: 243 / 4$, and Twister, $2: 291 / 4$ ), son of Canadian Pilot, sire of Pilot Jr., the sire of the dams of Maud S., 2 :083/4; Jay-Eye-See, 2 : ro, and many other fast ones.
San Francisco, Cal., February 3, I882.
E. L. Robinson.

Mr. Robinson also has in his possession the originals of the letters written and signed by M. W. Hicks, copies of which are as follows :

Mr. E. L. Robinson, San Francisco, SaCramento, February 5, I 892 .

Dear Sir :-Yours of yesterday is received, and in reply I have to say 
that I never heard Mr. Tinsley say by what stable-name Mr. Mitchell called Flaxtail. I have heard others than Mr. Tinsley call him Bull Puj, but never heard any one call him Bull l'up Jr. Mr. 'Tinsley himself called the horse Flaxtail, and nothing else, and in answer to my question as to his breeding, simply answered: "He is a Bull Pup and by Bull Pup." Respectfully, M. W. Hicks.

Breeder and Sportsman :-A friend has just called my attention to a clipping from the Breeder and Sportsman which reads: "From the entry of the registration of Flaxtail, it appears that M. W. Hicks purchased him from Joe Mitchell, which fact straightens out the discrepancy between the names of James and Joseph A., referred to in Iowan's communication." This is a mistake. I bought Flaxtail from a man by the name of Mitchell, from Salem, Ind. He did not give his first name, and in answer to my question as to his stock, said: "He is by Bull Pup." I knew nothing of that stock, and I afterwards came to believe, from what seemed reasonable evidence, that Flaxtail was by the sire of Wilson's Blue Bull.

M. W. Hicks.

Dec. 19, I891.

Dr. Hicks, in a communication to this paper June $13, x 89 \mathrm{I}$, about the horse, writes as follows :

Flaxtail's owner drove him and one of his daughters to a lumber wagon, a hundred and fifty miles to the Iowa State Fair at Keokuk. When he got there his shoulders were raw from the collar. He was shown an "exhibition trial" of a quarter of a mile on the circular half mile track under saddle in thirty seconds. His daughters won all their races, a double team race, two harness races and a saddle race. The stock was sun burned and showed an entire want of training or conditioning. My attention was attracted to them and I bought one. I was so pleased with this purchase that the last of the next February I went to the owner's farm in the interior of Iowa. I arrived after dark and found the old gentleman's "fiddle son" practising his art, and his newly married son quite as happy practising the blanishments that appertain a newly married life. The osculations of the one and the ravishing strains of the other were soon interrupted by a controversy as to whose "turn" it was to feed old Joe (the stable name of Flaxtail) in the morning. The duty consisted in poking eight or ten ears of corn and a lock of prairie hay through one of the many cracks in his pen.

Shall I describe the abode of this wonderful horse? As I have a regard for my reputation for veracity I hesitate, but as I was so impressed by the structure that I can now see it plainly as I write, I will do so, truthfully and without exaggeration. It was a $\log$ pen, ten feet square, made of round logs a foot in diameter, notched together, leaving eight-inch space between the logs. These were not "chinked" and the wind from whatever direction it blowed had a free sweep through this wellventilated structure. Poles were placed across the top and prairie hay piled on them for a roof. This the horse had eaten away until a bunch the size of an ordinary hay cock in the center was all that remained of "the roof." The old South Carolina gentleman was very fond of his horse, but had some peculiar notions, one of which was that a stallion's duties were so exhausting that he should do no other work, and the old horse was never out of his pen from the end of one season to the beginning of the next, except to go to the State Fair and two or three 
of the nearest county fairs. The droppings of the horse from September until the last of February, and the debris from prairie hay that was half rosin weed had raised the floor of his pen about three feet, and when from curiosity I measured the height of the door from the inside, it just reached the second button on my overcoat. When I bought the horse they had to pry up the logs on each side even with the top of the door, and pull out two logs in the end over the door to get him out.

When the old gentleman took me to his "wood pasture" to show me the young things in their kindergarten work, he set the dog on them, and the flight of speed they showed as they fled from the vicious canine was something wonderful, never leaving their feet except to bound over some fallen tree or log that lay in their way. The stock always had a fearful hatred of a dog. His neighbors said he was in the habit of setting the dogs on them. At this time I bought the old horse and five of his daughters, making six in all of his daughters that I owned, five of which I brought with me to California, and have described elsewhere in this letter.

M. W. Hicks.

"We copy the following article, written by L. E. Clement, from the last issue of Coleman's Rural World:

"Western Resources says :

" Flaxtail whose daughters produced the pacers Gold Leaf, 2 :I I I/4, and Thistle, $2: 14$, as well as a number of fast trotters, has always been put down as 'pedigree not traced.' One, Warwick Miller, who lived four miles below Louisville, Ky., now comes to the front with the assertion that he bred, raised and named the horse Bull Pup, sire of Flaxtail. He was by old Pacing Pilot: dam by Tom Hal, son of Tom Crowder, and he by old Pacing Pilot.'

"We do not know personally anything about the horse mentioned below, but as the Flaxtail blood plays a prominent part in many Californian pedigrees, we republish the following, taken from an Eastern exchange :

" 'H. H. P., Oskaloosa, Ia.-Can you tell me anything about a horse called Bull Pup, owned at one time by Jesse A. Mitchell, of Bedford, Ind.? What did Mr. Mitchell do with the horse? I think he is the same horse that came here in $\mathrm{i} 863$ or $\mathrm{I} 864$. He is registered a Flaxtail. This horse was brought here by Mr. Mitchell, who had a lame arm, and he called the horse Bull Pup. We have written to Mitchell and he refuses to answer. This horse's history before coming here was always kept dark. Give us all the light you can and oblige many of your readers.

" 'Answer.-The Bull Pup owned by Jesse Mitchell of Bedford, Ind., was the original of that name, son of old Pacing Pilot. Mr. Mitchell bought him as a five-year-old, from his breeder, a few miles from Louisville, Ky. The Bull Pup that went to Iowa was bred by Newton Wiseman, of Salem, Ind., and was by old Bull Pup (Jesse Mitchell's), dam a small, fast pacing bay mare of unknown breeding. In I 864, a brother of Newton Wiseman, who was half owner of the sorrel Bull Pup, sold him to Joseph Mitchell of Salem, and he took him to Iowa.",

Sire of 2 trotters $(2: 29 \%)$; I 2 dams of I 2 trotters, 9 pacers.

FLEANCE, bay, 151/2 hands; foaled 1 877 ; bred by R. Todhunter, Dover, 
Mo.; got by Marmaduke, son of Marion : dam Lena, light bay, long bodied, bred by Alexander Campbell, Nicholasville, Ky., got by Alexander's Abdallah, son of Hambletonian; 2d dam bred by Alexander Campbell, got by Gaines' Denmark. Sold to J.. P. Noble, Higginsville, Mo.; to J. P. Barnett, Lexington, Mo.; to James M. Burrus, Oak Grove, Wis. Pedigree from Breeder.

Sire of 2 trotters $\left(2: 24 \frac{1}{2}\right)$.

FLEETFOOT (I-32), bright bay, I6 hands, I200 pounds, foaled I87I; said to be by Davis' Black Hawk Morgan, son of Lanfear's Black Hawk : and dam a trotting mare from Long Island. Taken from Toronto, P. Q., to Ashland, Ill., 1877 , by E. G. Johnson and sold to Charles Stout of Ashland. Owned by S. F. Mastick, Pleasant Plains, Ill., I880. Died about r881. A stout and symmetrical horse of high finish and quite fast. Advertised in National Live Stock Journal, I878, at Tallula, Ill., by E. G. Johnson. See The Morgan Horse and Register, Vol. II.

FLEETING RAY (I-I6), chestnut, I5 I 2 hands, I050 pounds; foaled I 865 ; bred by Joseph K. Lippincott, Haddonfield, N. J. ; got by North Morrill, son of Sherman Black Hawk: dam chestnut, said to be by a horse called Shadager, of running blood. Sold to J. H. Borton, Atlantic City, N. J.; to Gates \& Pray, Indianapolis, Ind., by J. W. Silgar, Indianapolis, Ind. Very stylish and handsome; could trot in $2: 45$, colts fine stylish drivers, and some of them speedy. See The Morgan Horse and Register, Vol. I., p. 398.

Sire of Money Hunter, $2: 23 \frac{1}{4}$.

FLEETWOOD; said to be by Janus: dam by Janus. Advertised in the New Jersey Gazette, I 779 .

FLEETWOOD, bay, I 6 hands, said to be full-blooded and from New Jersey and New York. Advertised, I 797, in the Greenfield (Mass.) Gazette, to be kept with Selim at Guilford.

FLEETWOOD, bay; said to be of English and Dutch blood, very probably a son of Justin Morgan, got when he stood at Lebanon, N. H., in I 793. Advertised together with Royal George, I798, in the Concord, N. H., Courier, and said to be fast.

FLEETWOOD, sorrel, hind ankles white, I5 hands, I050 pounds; foaled I 884 ; bred by George Maloney, Sun Prairie, Wis. ; got by Milwaukee, son of Hambletonian : dam Ruby, sorrel, bred by Mr. Bradley, Milwaukee, Wis., got by Baybrino, son of Bay Chief, by Mambrino Chief; 2d dam Fly, black, bred by Mr. Bradley, got by Baybrino, son of Bay Chief. Died July I 888 . 
E. G. Wheeler breeder of Limerick, $2: 22 \frac{1}{2}$, writes, dated Madison, Wis. :

"Limerick's Ist dam Jennie, bay, white hind feet, was by Prince Albert, by Cottrill Morgan, I think, by Black Hawk. Prince Albert was black and had thoroughbred dams for ten or more generations. Limerick's $2 \mathrm{~d}$ dam was a black mare raised by Mr. Wiley of the town of Leeds, got by Green Mountain Boy, by Black Hawk. His 3d dam was claimed to be by Red Bird, by Bishop's Hamiltonian. A man by the name of Moulton and a man by the name of De Forest brought a pair of mares to this state from New York. I didn't get this mare until she was I3 years old, and she was 2 I when she produced the colt Limerick and he will be twenty-one in May, so its going back 42 years to hunt up the breeding. I was a boy at the time these men brought the mares here and always had an interest in trotters, so remember anything pertaining to the breeding of horses. I had the thoroughbred side of Prince Albert but when I had Limerick castrated and had no more colts that were bred like him, I didn't care for the pedigree part. I tried to buy this mare when she was three years old but didn't until ten years later. She raised six foals-Limerick, Ella W., Paddy Flin, Lorrie Doolan, Kildare. Ella W., was oldest of the lot. None of them so fast as Limerick.

"Limerick's dam was 27 when she dropped the foal Kildare, by Hollymont a horse from the Hal family."

In a former letter Mr. Wheeler, writes: "I always took pride in regard to Limerick's breeding as I was born in Vermont, Orange County, town of Thetford. I am a brother of Ella Wheeler Wilcox."

In answer to enquiries Mr. Wheeler writes again, that he could get no authentic information of breeding of $3 \mathrm{~d}$ dam, or of reputed sire Red Bird.

Sire of Limerick, $2: 22 \frac{1}{2}$.

FLEETWOOD ( $\mathrm{x}-\mathrm{I} 6)$, bay, stripe in face; bred by George a Denniston, Goshen, Orange County, N. Y. ; got by Happy Medium, son of 'Hambletonian : dam sorrel, bred by A. McDowell, New Windsor, got by Potter's Bellfounder, son of old Bellfounder; $3 \mathrm{~d}$ dam said to be a Messenger mare bred by A. McDowell. Sold to Selah Edsall; to James McSee. Pedigree from breeder.

FLEETWOOD ( $\mathrm{I}-\mathrm{I}_{2} 8$ ), bay, star, front feet white half to pastern, hind feet white to pastern; foaled I 884 ; bred by S. N. Gage, Chicago, Ill., and J. C. McFerran, Glenview, Ky. ; got by Nutwood, son of Belmont : dam Lottie, bay, bred by, Dr. Price, Lexington, Ky., got by Sentinel, son of Hambletonian; $2 \mathrm{~d}$ dam said to be by Drennon (sire of W. K. Thomas, 2:26) ; 3d dam by gray Eagle, son of Woodpecker; and $4^{\text {th }}$ dam by Blood's Black Hawk. Sold to J. E. Brewster, Chicago, Ill. ; to R. W. Conn \& Co., Valley Station, Ky., who send pedigree.

FLETCHER ( $1-32$ ) ; said to be by Green's Bashaw. Pedigree from A. B. Donelson, Pontiac, Mich., owner of Jim Fuller.

Sire of dam of Jim Fuller, $2: 191 / 2$. 
FLIMNAP, bay with star, $14 \frac{1}{2}$ hands; foaled 1765 ; bred by Sir John Moore; got by South, son of Regulus, by the Codolphin Arabian : dam foaled 1 761, bred by Sir John Moore, got by Cygnet, son of Godolphin Arabian; $2 \mathrm{~d}$ dam by Young Cartouche; $3 \mathrm{~d}$ dam Ebony, ly Childers; $4^{\text {th }}$ dam Ebony, by Barto, 5th dam Duke of Rutland's mare, by Maney's Black Barb. Sold to Sir W. W. Wynn, and at the sale of his stud purchased by Mr. Mansell of the firm of Mansell, Corbet \& Co., Charleston, S. C., who shipped him to South Carolina about 1772 , where he beat all the best horses. Covered at Spring Grove, St. Paul Parish, at $£ 35$ currency, I774. Passed to I. C. Harleston and kept many years by him in St. Thomas Parish, S. C., where his colts proved of good form and good runners. At one time during the war Flimnap was kept in North Carolina. Milliken.

FLIMNAP (PAYNE'S). Advertised in the Lexington (Ky.), Gazette, I804, as follows :

"Stands at the subscribers plantation three and a half miles below Lexington near the town fork of Elkhorn and will cover mares at thirty shillings the season, which may be discharged in good wheat or rye at three shillings per bushel, corn at three shillings per barrel, or twenty shillings paid by the first of August next. The above articles to be paid at the subscribers plantation before the first day of January and not afterwards. Flimnap is rising four years old, of a dark bay, five feet, three inches high, he was got by old Flimnap, dam a Tom Jones and Partner mare.

\section{HaRry Payne.}

FLIMNAP (THORNTON'S). Advertised as follows in Lexington (Ky.), Gazette, I 803 .

"In high perfection, at subscribers' stable in County of Bourbon on road from Lexington, by General Russell's, to Paris, in sight of Capt. Johnston's tavern at the cross roads. His form, activity, and high character as an excellent foal getter, together with his pedigree, which is descended from the most approved horses in England and Virginia renders a pompous recommendation of him unnecessary. He was bred by Col. Anthony Thornton of Virginia, is rising eight years old, black and handsomely marked, full fifteen hands, and three inches high, very lengthy and well formed. Got by celebrated running horse WhistleJacket, his dam by old Aid-de-camp, grandam by Dandridge's Fearnaught, a thoroughbred son of Baylor's old Fearnaught, his great-grandam by old Janus, from the dam of Col. Sim's Wildair, she descended from Jolly Roger and Carter Braxton's Kitty Fisher. Diomed, the sire of Whistle-Jacket, supposed to be the best running horse in America, was a thoroughbred son of Col. Fenwick's imported Flimnap, which horse covered at 200 guineas a mare ; Whistle Jacket's dam Lucy Locket, was got by Belle-Air (bred by Hon. Col. Taylor), a son of Morton's Traveler and Selima, her dam Matchless, by Othello; her grandam Young Kate, by Childers, her great-grandam old Creeping Kate, by the Dancing Master, her great-great-grandam was the Spanish mare imported by Col. Churchill. Aid-de-Camp, the sire of Flimnap's mother, 
was got by Specimen, out of General Nelson's imported mare Blossom. Specimen was got by Baylor's old Fearnaught, from Jenny Dismal. Flimnap's character as a fine foal getter, will perhaps be better evidenced by certificates (in my possession) from gentlemen of the utmost respectability in Virginia, where he is better known.

MaUrice Langhorm."

FLINT MORGAN (BATCHELDER'S, HORNE HORSE) (I-4), dark chestnut, star and white hind feet, $\mathbf{I} 5$ hands, Iooo pounds; foaled June I2, I 852 ; bred by Isaiah Horne, Farmington, N. H ; got by Napoleon Morgan, son of Flint Morgan : dam dark bay, a wonderful roadster, bred by Isaiah Horne, got by Young Sherman Morgan (Cook Horse), son of Sherman Morgan. Sold to John S. Hodgden, Barnstead, N. H. (who took him West in I864); to S. E. Batchelder, Harristown, Ill.; to Frank White, Decatur, Ill.; to J. H. White, Shelbyville, Ill. A great roadster, Morgan type, disposition good; a very showy horse in harness, stock good. One of the last colts got in New Hampshire, by Napoleon Morgan. Died I877. See The Morgan Horse and Register Vol. I., p. 323 .

Sire of dam of Montgomery S., $2: 25^{1 / 2}$.

FLINT MORGAN (PROTECTION) (3-8), dark chestnut, I5 hands, I050 pounds; foaled I 823 ; bred by John Bolton, Danville, Vt. ; got by Sherman Morgan : dam said to be Morgan. (See John Bellows' advertisement below). Sold to George Barker, St. Johnsbury, Vt. ; to Jonas Flint; to John Bellows (then owner of Sherman Morgan), March 3, I 830 , as appears by this bill of sale of that date, now in possession of Mr. S. W. Parlin of Boston, as is also the stud bill given below :

"One stud horse, Young Morgan, six years old last spring, which I warrant sound except a crack in one of his fore feet, at $\$ 350$. Received cash $\$ 100$; note in one year signed by John Bellows and Josiah Bellows $2 \mathrm{~d}$ for $\$ 100$; note due in I 8 months for $\$$ I $50-\$ 350$.

John FLINT."

John Bellows apparently kept him until the spring of 1846 , and sold him back to Jonas Flint, as he is advertised that spring in the Danville "North Star" as follows:

"The subscriber has purchased of Mr. J. Bellows the Flint Morgan horse, formerly known in this vicinity as the Bolton colt. Will stand at Danville, St. Johnsbury and Lyndon, Vt.

Jonas Flint."

The following is from John Bellows' stud bill for $18_{3} 6$ :

"Flint Morgan is a beautiful chestnut, stands I 5 hands, noze eleven years old, was got by old Sherman Morgan, and from his appearance, size, matchless strength and performance, coupled with the fame of the stock and blood of his dam (who was a descendant of the old Goss Morgan), justifies the assertion that he presents a fairer prospect than any horse now extant of perpetuating the fame of his illustrious sire." 
In I $_{3} \mathrm{I}$ John Bellows kept Flint Morgan in the vicinity of Dover, N. H. ; he kept him at other towns in New Hampshire other seasons including one or more at Sandwich. Linsley states that he died at St. Johnsbury, but Stephen French who owned his son Napoleon Morgan, thought that he died in Illinois. Hon. T. S. Lang, who brought to Maine, Gen. Knox and other noted horses, writes:

"When I was a boy and lived at North Berwick, Me., a Mr. Bellows used to come there with a Morgan horse that I think was named Flint Morgan, chestnut, I 5 hands, I050 pounds."

See The Morgan Horse and Register, Vol. I., p. 321.

FLOCHER (I-64), bay, I6 hands, I 200 pounds; foaled I $89 \mathrm{I}$; bred by C. W. Williams, Independence, Ia.; got by Allerton, son of Jay Bird : dam Flossie G., chestnut, bred by J. W. Leffingwell, Columbus, Wis., got by Antar, son of Almont; 2d dam Fancy, chestnut, bred by M. G. St John, Columbus, Wis., got by Iceberg ; $3 \mathrm{~d}$ dam Jenny said to be by Moscow ; $4^{\text {th }}$ dam Lady of the Lake. Information from L. A. Crum, Paxton, Ill.

Sire of Skeeter, $2: 17 \frac{1}{4}$

FLORAMOUR (FRED B. HINES), brown, with one white foot, I 6 hands, I 250 pounds; foaled I 876 ; bred by A. H. Taylor, Central Valley, N. Y. ; got by Florida, son of Hambletonian: dam Lady Woodhull (dam of Hambleton, $2: 26 \mathrm{~T} / 4$ ), bay, hind feet white, bred by Justice Cooley, Little Britian, Orange County, N. Y., got by Hambletonian; $2 \mathrm{~d}$ dam gray, bred by Elias Gerow, Washingtonville, Orange County, N. Y., got by Young Hickory, son of Well's Hickory. Owned by Geo. W. Packer, Lowell, Mich., who writes: "A. H. Taylor bred Fred B. Hines, now called Floramour." Died rgor. Pedigree from breeder.

Sire of 3 pacers $\left(2: I_{5} \frac{1}{2}\right)$; I sire of I trotter, 4 pacers; 5 dams of 2 trotters, 3 pacers.

FLORIDA, bay, I5 1/2 hands; foaled I 867 ; bred by Nathaniel Roe, Florida, N. Y. ; got by Hambletonian, son of Abdaliah: dam, bred by Charles Wheeler, Warwick, N. Y., got by Volunteer, son of Hambletonian; 2d dam brown, brought from the West by A. B. Post, breeding unknown. Sold to A. H. Taylor, Turner, N. Y.

Sire of $I_{5}$ trotters $\left(2: I_{5} \frac{1}{4}\right)$; I 4 sires of $I_{3}$ trotters, 7 pacers; I5 dams of $I_{2}$ trotters, 5 pacers.

FLORIDA M., bay; foaled r 880 ; bred by James Egan, Chicago, Ill., got by Florida, son of Hambletonian: dam Honest Molly. Sold to E. C. Ruddock, Wheaton, Ill. ; to Louisa D. Ruddock, Aurora, Ill.

Sire of Aurora Prince, $2: 16^{5} / 4 ;$ I dam of I trotter.

FLORIDA MONARCH (GENERAL TAYLOR) (I-I28), $2: 17 \% / 4$, black, I6 hands, I050 pounds; foaled I883; bred by A. H. Taylor, Central Valley, Orange County, N. Y.; got by Florida, son of Hambletonian: dam Sontag, bay, bred by Wm. Utley, Racine, Wis., got by Bellfounder, 
son of Hungerford's Blucher; 2d dam bred by Wm. Utley, got by Green Mountain Boy, son of Prince Albert, by Black Hawk. Sold to I. R. Hall, Jr., Bellevian, O.; to George E. Brownell, Elyria, O. Pedigree from breeder.

Sire of Cort R., $2: 22 \frac{1}{4}$; George Berton, $2: 15^{1} \frac{1}{4}$.

FLORIDA WILKES; said to be by Sherman Wilkes, son of George Wilkes.

Sire of Floretta Wilkes, $2: 17 \frac{1}{2}$.

FLORIZEL (BALL'S), chestnut ; foaled i 80 I ; bred by Mr. Roger, Atkinson, Chesterfield County, Va. ; got by imported Diomed : dam, said to be by imported Shark ; $2 \mathrm{~d}$ dam by Harris' Eclipse ; $3 \mathrm{~d}$ dam by imported Fearnaught; $4^{\text {th }}$ dam by imported Jolly Roger; and 5 th dam by imported Sober John; 6th dam bred by Col. Baylor, got by imported Shark. Sold to Major Wm. Ball of Virginia. Above pedigree is furnished to the American Farmer, I 827 , by John C. Goode, who adds: "I have no hesitation in pronouncing him the best race horse I ever saw make a track."

Sire of the $4^{\text {th }}$ dam of Abdallah Boy, $2: 24^{1 / 4}$, winner of 17 races.

FLORIZEL (CARL'S GRAY HORSE), gray ; foaled I $8_{4} 2$; bred by John Carl, Commack, Long Island, N. Y.; got by Smith's broken-legged Bellfounder, son of imported Bellfounder.

A horse of this name owned by C. F. Crosby, Watervliet, N. Y., was awarded $3 \mathrm{~d}$ prize at New York State Fair held at Utica, I 845 .

FLOIVER (3-128), bay; foaled I 89 I ; bred by Jacob Ruppert, Poughkeepsie, N. Y.; got by Baron Rose, son of Stamboul: dam Fleet, black, foaled April, I $S_{7}$, bred by G. Valensin, Pleasanton, Cal., got by Sidney, son of Santa Claus; $2 \mathrm{~d}$ dam Flight, brown, bred by M. W. Hicks, Sacramento, Cal., got by Buccaneer, son of Iowa Chief; 3 d dam Prairie Bird, bay, bred by T. T. Tinsley, Mahaska County, Ia., got by Flaxtail, son of Bull Pup (Jesse Mitchell's) by Pilot; $4^{\text {th }}$ dam Fashion, said to be by John Baptiste, son of Tally-Ho Morgan; $5^{\text {th }}$ dam Fanny Fern, brown, bred at Wheeling, W. Va., by Irwin's Blind Tuckahoe; and 6th dam by Leffler's Consul, son of Shepherd's Consul. Pedigree of dams from breeder's catalogue, r 89 I.

Sire of Albert, $2: 07^{3 / 4}$.

FLYAWAY. See Gen. Meade.

FLY-BY-NIGHT (I-I6), I5 I/2 hands, I I50 pounds; foaled I 855 ; bred by David Derrick, Noyan, Que.; got by Rowe's Black Hawk, son of Black Hawk : dam said to be by Young Norman, son of Black Bashaw. Sold to Truman B. Derrick, Noyan, Que.; to Wm. I. Fayson, Clinton, N. C., I 859, for \$250o. Stolen during the war and taken North.

The Spirit of the Times says : 
"Fly-by-Night was awarded 2d premium at an Agricultural Fair, I 858 , owned by Wm. I. Fayson, Clinton, N. C. and was captured during the war."

\section{A. Homer writes to Dunton's Spirit of the Turf :}

"Tony the dam of St. Hector is a very fast mare and all her colts are fast. She was got by Brownell's Morgan, a son of the horse captured in the south during the war, and answers the description exactly of the horse Fly-by-Night, sold to Wm. I. Fayson, Clinton, N. C., and we are now getting evidence to prove same."

See The Morgan Horse and Register, Vol. I., p. $45^{\circ}$.

FLY-BY-NIGHT, black, I5 hands, bred by David Derrick, Clarenceville, Que., got by Canada Black Hawk, son of Black Hawk: dam a large black Morgan mare. Canada Black Hawk was bred by Col. G. Rowe, Noyan, Can. Fly-by-Night was awarded ist premium for trotting mile heats and for the single dash of 5 miles at the Oregon State Fair, I 864 .

Advertised as above by Eddy \& Wells, Prop's., Portland, in the Oregon Statesman, I 864 and I 865 .

Noyan, P. Q., March 30, I888.

Mr. Battell :

The horse Fly-by-Night I sold in 1859 to William I. Fayson, Clinton, Sampson County, N. C., for \$2500. He was then four years old; he was by Canada Black Hawk, he by old Vermont Black Hawk. Fly-byNight was a blood bay, $15^{1} / 2$ hands high with flowing mane and tail; weight, about I I5o pounds, one of the handsomest colts I ever saw. I must say he was a perfect Morgan. I never timed him, but he was level-headed and could trot very fast for a colt of his age. Mr. Fayson wrote me after the war that this colt was stolen from him and came North, he could not tell where, by some of the Northern officers of the army. The dam of Fly-by-Night was by Young Homer, he by Black Bashaw, he by Young Bashaw, the sire of Jackson, Washington, Saladin and Charlotte Temple; grandsire, old Grand Bashaw, imported Arabian; dam by True American, grandam by old Hickory. Yours with respect,

Truman B. Derrick.

Noyan, P. Q., April 30, I888.

Mr. Joseph Battell,

Dear Sir:-In looking over my books I find this colt Fly-by-Night, that was claimed in Wilkes Spirit, June 24,1857 or 8 ; he was by the Rowe Black Hawk; he was four years old, black with blaze in forehead, I 6 hands high, a perfect model of the Black Hawks. I had sold him to a party in Elizabeth City, N. C., for the sum of $\$ 4000$. I got with him as far as Norfolk, Va. I had then to go some 44 miles to deliver him, through the Dismal Swamp. I took him off the ship Roanoke at Norfolk all right, put him in Webber's stable and there he was poisoned by this rebel, Capt Webber, who I was told, was in the habit of drugging horses and then buying them for almost nothing. He lived about twenty-four hours. Webber offered me $\$ 500$ after he was taken sick. I told him, "No; if he dies he shall die mine," and so he did. This is the colt you have referred to. He was raised by Daria Derrick, a sonin-law of Capt. G. Rowe, the owner of Canada Black Hawk. The dam of Fly-by-Night was a large mare of the Morgan stock and a fast road- 
ster. Fly-by-Night was the most promising trotting colt I ever saw. I sold a mare to Barnard and Carpenter of Hartford, Conn., her name was Noyan Maid. She came to Middlebury, Vt., and was bought by a gentleman by the name of Clay. She was a Black Hawk, got by the McGregor horse, he by the North horse. If I had to write to you all I know about the Morgans and Black Hawks it would take me more than a year.

There were three stallions only that came from the loins of Old Black Hawk in this country, the Ben Hurr, Johnson horse and the Smith horse, all the same age.

Yours with respect, Trunian B. Derrick.

FLYING BANNER (I-8), chestnut with one white hind foot, silver mane and tail, $15 \frac{1}{2}$ hands, 1050 pounds; foaled 1854 ; bred by Caleb Emery, Corinth, Vt., got by Hammett Horse, son of Black Hawk: dam gray, bred by Story Calef, Washington, Vt., got by Caleb Emery horse, that was brought from Montreal; 2 d dam said to be by Woodbury Morgan, son of Justin Morgan. Sold to Chester Huckins, Topsham, Tt. Kept at Corinth and Topsham, Vt. Died about I86I. He was a horse of remarkably fine appearance, action and disposition, and left excellent stock. It is stated that parties were about to purchase the horse at $\$ 10,000$ when he died. See The Morgan Horse and Register, Vol. I., p. 501.

Sire of Fanny, $2: 29$.

FLYING BUCK, brown, ${ }_{5}$ hands, foaled 1788 . Advertised by T. James in 1795 , at Richmond, N. Y.

FLYING CHILDERS, chestnut with white upon his nose and four white feet, 15 hands; foaled 1715 ; bred by Leonard Childers Esq., of Carr House near Doncaster; got by the Darley Arabian: dam Betty Leeds, bred by Sir W. Strickland, got by old Careless, son of Spanker; $2 \mathrm{~d}$ dam Leed's mare, bred by Mr. Leeds, got by Leed's Arabian; 3d dam by Spanker, son of D'Arcy Yellow Turk; 4th dam old Morocco mare (dam of Spanker), said to be by Fairfax's Morocco Barb. Sold when young to the Duke of Devonshire; and died the property of his son, I74I.

"Flying Childers was the fleetest horse that ever ran at Newmarket; he never started, but at Newmarket and there beat with ease the fleetest horses of his time. He appears to have been of the short, compact form in his back and loins; his immense stride being furnished by the length of his legs and thighs. Strength and general compactness of form upwards, doubtless supported the extraordinary reach of Flying Childers and enabled him to make those wonderful springs which are recorded of him. At six years, he ran over the round course 3 miles, 6 furlongs, 93 yards in $6: 40$ : over the Beacon course 4 miles, I furlong, 138 yards in $7: 30$, covering at each round, a space of twenty-five feet. $\mathrm{He}$ also leaped Io yards, on a level ground, with his rider.

"According to tradition he was a vicious horse and was trained as a racer after his great speed and endurance had been discovered in a severe fox chase.

"A Welsh gentleman is said to have offered the Duke of Devonshire, 
for Flying Childer, the weight of the horse in crowns and half crowns, which the Duke refused."-From Lawrence's History and Delineation of the Horse.

FLYING CHILDERS, chestnut ; foaled I 8 I 8 ; said to be by Sir Archy, son of imported Diomed: dam, by imported Robin Redbreast, son of Sir Peter Teazle ; 2 d dam by imported Obscurity, son of O'Kelly's Eclipse; $3^{\mathrm{d}}$ dam old Slammerkin by imported Wildair, son of Cade; and $4^{\text {th }}$ dam imported Cub mare. Owned by Mr. Sleeper, Baltimore, who sold about 1827 to Theron Rudd, Poughkeepsie, N. Y., where he was kept a number of years. Died at Oakville, Can, I853. Advertised I832 as follows :

"This celebrated horse will stand the ensuing fall season at the stable of John Scott, Washingtonville, Orange County, commencing on the Ist day of August inst., and ending on the Ist day of October next. Flying Childers is full brother to Ratler, Elizabeth, Sumpter and Flirtilla. $\mathrm{He}$ was by Sir Archie, the most celebrated stallion of the age, who was the best race horse of his day, and since he has been a stallion has got more speedy first-rate race horses than was ever produced by any one horse in this, or any other county. Besides those names may be added : Virginia, Reality, Sir William, Sir Charles, John Richard's Betsey Richards, Henry, the competitor of Eclipse, John Stanley, etc., all by him. The Charleston City Gazette speaking of one of the races made by Flying Childers on that course makes the following remark: Flying Childers, by Sir Archie, is considered one of the swiftest horses ever known in this State, he is a native of Virginia. For terms, performance and pedigree see handbills."

Monday, Aug. 20, 1832 .

NiCHOLAS JACACKS.

FLYING CLOUD, white, I53/4 hands, I050 pounds. Brought from long Island to Sangerfield, N. Y., where he was kept some Io years by Messrs. Bissett and Pallett. He was trained by Hiram Woodruff ran away and became lame. He got very excellent stock.

We think this the same as following.

FLYING CLOUD (FRANK PIERCE), gray; foaled I $85 \mathrm{I}$; bred by Gen. Hustin, Bullville, Orange County, N. Y.; got by Long Island Black Hawk. Went to Western N. Y.

FLYING CLOUD (3-32), bay; foaled 185-; bred in Ohio; said to be by Orr's Flying Cloud, son of Black Hawk. Both trotted and paced.

FLYING CLOUD, bay, black points, I 6 hands, I 250 pounds ; foaled I 866 ; bred by Seward Crosby, Larwill, Ind., got by Flying Cloud, a bay horse with black points, owned by a Mr. Wm. or Samuel Todd, who lived at South Whitley, Whitley County, Ind. Bought by Gibson and Edwards, Columbia City, Ind., who sold to E. Maynard of Larwill, Ind. Also owned by B. C. Holly, and perhaps others and died property of F. C. Guy, about r88o. 
Above pedigree is from son of breeder, who says the horse was quite rangy and very kind. He was used as a road horse, serving a few mares at \$ro to insure.

Sire of Myrtle, roan, $2: 26 \frac{1}{2}$ (bred by Samuel Larow, Columbia City, Ind.)

FLYING CLOUD, said to be by Peacock. See The Morgan Horse and Register, Vol. I., p. 476.

Sire of Baywood, $2: 17 \frac{1}{2}$.

FLYING CLOUD (3-32), black, I63/4 hands, said to be by Black Flying Cloud, son of Black Hawk: dam by Sir Henry of Milwaukee. See The Morgan Horse and Register, Vol. I., p. 524.

FLYING CLOUD (I-32), black with star, I 6 hands, I I 20 pounds; said to be by Flying Dutchman, owned in Clinton County, O. : and dam brown, by a Morgan horse.

FLYING CLOUD ( $\mathrm{I}-\mathrm{I} 6$ ), jet black, $16 \mathrm{~T} / 2$ hands, said to be by Flying Bill (dam by Felix Granby), son of Sir John by imported Copperbottom. Advertised in Lexington, Ky., papers.

FLYING CLOUD (BLACK). See Black Flying Cloud. A horse of this name was entered by S. Twitchell, Weybridge, Vt., at the Illinois State Fair, is6o.

We have received the following letter:

Joseph Battell, Esq.,

Prairie Du SAC, Wis.

Dear Sir :- Being very fond of good horses, I have read the Middlebury Register with great interest for the last eight months, and in the last issue you describe a Flying Cloud got by Black Hawk that died at Watertown, Wis., six or seven years ago. He was owned and kept for several years at Rolling Prairie, Dodge County, Wis. He was owned there by a stock company. His stock is excellent. Anything that has the name of Flying Cloud is sufficient ; stands very high. The description you give is just the same as it was, only he had one more white foot, he had three white feet and white face. For further particulars address D. J. Woodard, Appleton, Wis.

$$
\text { Yours truly, I. T. HubBard. }
$$

You mention Bullock's North American. He was owned and kept here in this town. He left some very good stock here. He trotted in Milwaukee in $2: 35$. Bullock sold him to a man by the name of Freeman. $\mathrm{He}$ is dead. The horse died near Janesville.

$$
\text { Yours truly, } \quad \text { I. T. HubBard. }
$$

FLYING CLOUD (BURNETT'S) (3-32); bred by George Preadmore, Paris, Ky.; got by Flying Cloud, probably Ward's. Flying Cloud was smuggled out of Kentucky, on account of a mortgage and sold to George Fowler, Camden, Preble County, O. ; 1883 to C. A. Hunt, Losantville, Ind.; to J. S. Burnett, Janesville, Wis., who sends this information. 
FLYING CLOUD (WARD'S) (3-16), black with star, white hind feet and very little white on off fore foot, about 15 hands, i roo pounds; foaled I 849 ; bred by Gustavus V. Cook, New Haven, Vt.; got by Illack Hawk : dam brown with a little white in face and some white feet, a compact Morgan built mare 950 or 1000 pounds, bought by G. V. Cook, of Isaac Atwood, New Haven, Vt., who is supposed to have bred her, got by Hackett Horse, son of Gifford Morgan. Taken to Kane County, Ill., by George W. Cory, fall, 1854 , for the breeder. Kept in Green and Jersey Counties until fall, $\mathrm{x} 85^{8}$; then sold to Minor B. Williams, Glasgow, Mo., and George V. Ward, Georgetown, Owen County, Ky., for $\$ 3,000$. Kept at Georgetown many seasons; in charge of Thomas Brown, $1867-$ '68. Died spring, I869.

He trotted at New Orleans, February, 1860 , for $\$ 5,000$, against Peerless, also said to be by Black Hawk, but was beaten in $2: 511 / 4,2: 53$, $2: 493 / 4$. He is said to have very much resembled his famous sire.

D. H. Gayle, cashier of Citizen's Bank, New Liberty, Ky., writes:

"His colts were all good ones, and the fillies especially valued for brood mares."

The Vermont Stock Journal of January I 857 , published at Middlebury, Vt., and edited by D. C. Linsley, gives the pedigree as we give it, and states that it was furnished by G. V. Cook, the breeder.

Page 546 of Volume for 1858 of the Spirit of the Times says:

"The horse Flying Cloud, by old Black Hawk has been sold by Col. G. V. Cook of Addison County, Vt., to M. B. Williams of Huntsville, Mo., for \$3,000 cash."

THE ST. LOUIS FAIR.

"The chief premium was eventually awarded to Flying Cloud; the second given to Red Morgan, owned by David Ashbury of Missouri. Then came the show of stallions three years, and under four etc." Spirit of the Times, September, 1858 .

\section{FLYING CLOUD AND PEERLESS.}

"At 3 o'clock precisely the horses made their appearance and whilst preparing to start were objects of many studious eyes. Peerless is a black, square built horse, about $5_{5} \mathrm{I} / 2$ hands high and carrying a neck so large as to be out of proportion, in the eyes of many.

"Flying Cloud is a neat trim built, well proportioned black horse, with two white feet behind, about $\mathrm{I}_{5}$ hands high but with nothing in his appearance indicative of much speed. At the call of the judges the horses were brought out for the first heat."-Wilkes' Spirit of the Times, Feb. 18,1860 .

Advertised in $\mathrm{r} 86_{5}$, by Junius R. Ward, at Lexington, Ky.

Mr. Fitts, an old resident of New Haven, Vt., in interview with author, said :

"The dam of Cook's Flying Cloud looked to me very much like a Morgan mare. She was brown with snip, rooo pounds., regular Morgan build, a blocky good mare, beautiful roadster. He traded for this mare 
and a black mare, a gray gelding of about rooo pounds, to Isaac Atwood, New Haven. Cook probably got this mare about 1847 , and she was then about six or seven years old; the black mare younger. The Hackett horse was a fine horse. Sidney Mead of Middlebury bred to him and raised the stallion that passed to Wheeler, who took him later to Wisconsin. Wheeler had another Morgan stallion at about the same time, more rangy but not as good a horse."

Mr. Joseph Battell,

Carson, Colo., Feb. 28, i89r.

Dear Sir :-I see in the Register of the I 3 th a communication from G. D. Wilson to Dunton's Spirit which gave me some information I did not have before about Dorsey's Kentucky Golddust. I knew John York Sawyer and his horses when he first brought them from Vermont, but was not aware that one of them was the sire of old Golddust.

Wilson speaks of other horses (Black Hawk), in that section of Illinois. Knowing all he speaks of, I thought it might be of interest to you to hear what I know about them. I brought Flying Cloud to Greene County, Ill., in the fall of I 854 -Black Hawk: dam Gifford Morgan; died in Kentucky and was known there as Ward's Flying Cloud. $\mathrm{He}$ was raised by Col. G. V. Cook of New Haven. In the fall of $1855, \mathrm{Col}$. Cook, brought to me in Illinois, another Black Hawk-Rising Sun-of his raising, dam a Nessenger mare. He was sold and I think he died in Bunker Hill, Ill. In the fall of 1853 , Seth Wetherby of Jacksonville bought of A. F. Williams of Bridport a three-year-old colt, sorrel with blaze in face and white legs. This was the first Black Hawk stock I ever saw in that section of Illinois. In I 854 , Wetherby bought Live Oak of Ed. Crane of Bridport. He stood for several years in Jersey County and then was taken to California. Champion Black Hawk was raised by Champion Fletcher of Orwell, and was bought in Ohio by a stock company at Carrollton, Ill. Wide Awake was raised by Perry Fletcher of Bridport and was there called Pig Iron. I knew Addison and Silverheels well, but have forgotten who raised them. Sawyer is still living in Alton, I think.

$$
\text { Yours truly, G. W. Cony. }
$$

See The Morgan Horse and Register, Vol. I., p. 490.

Sire of I trotter; 3 dams of 3 trotters; dams of 3 sires of 5 trotters.

FLYING CLOUD '(CORBIN'S) ( $\mathrm{I}-8$ ), $2: 39 \mathrm{~T} / 4$, chestnut, stripe in face, one white hind foot, $153 / 4$ hands, II 50 pounds; foaled 1864 ; bred by S. M. Randall, I ebanon, Wis.; got by Black Flying Cloud, son of Black Hawk: dam chestnut, bred by S. M. Randall, got by Morgan Sultan, son of Gifford Morgan; 2d dam bay, bred in Connecticut, and taken to Wisconsin, breeding unknown. Sold to W. B. Mathews and Dr. A. D. Johnston, Slate Lick, Armstrong County, Penn. Afterward owned by A. Corbin, Jr., Gouverneur, N. Y. ; in I 888 , by V. Sheldon, Canton, N. Y. ; and in $\mathrm{I} 890$, by G. W. Dennis, South Edwards, St. Lawrence County, N. Y.

Advertised in the St. Lawrence (N. Y.) Plaindealer, I 887 , '88 and ' 89 as follows :

"Corbin's Flying Cloud will be kept for service at my farm every day 


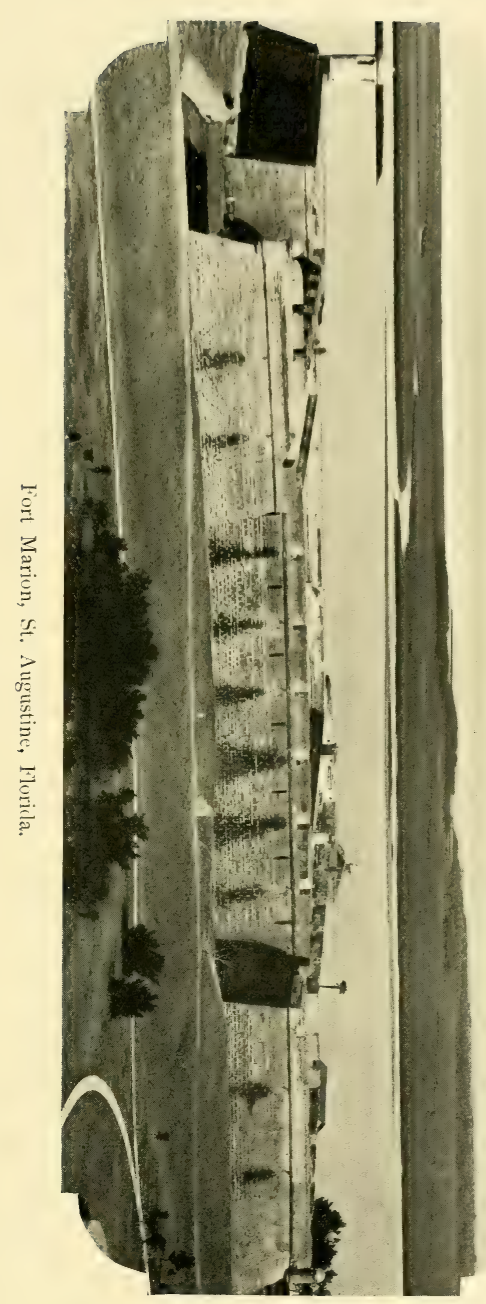




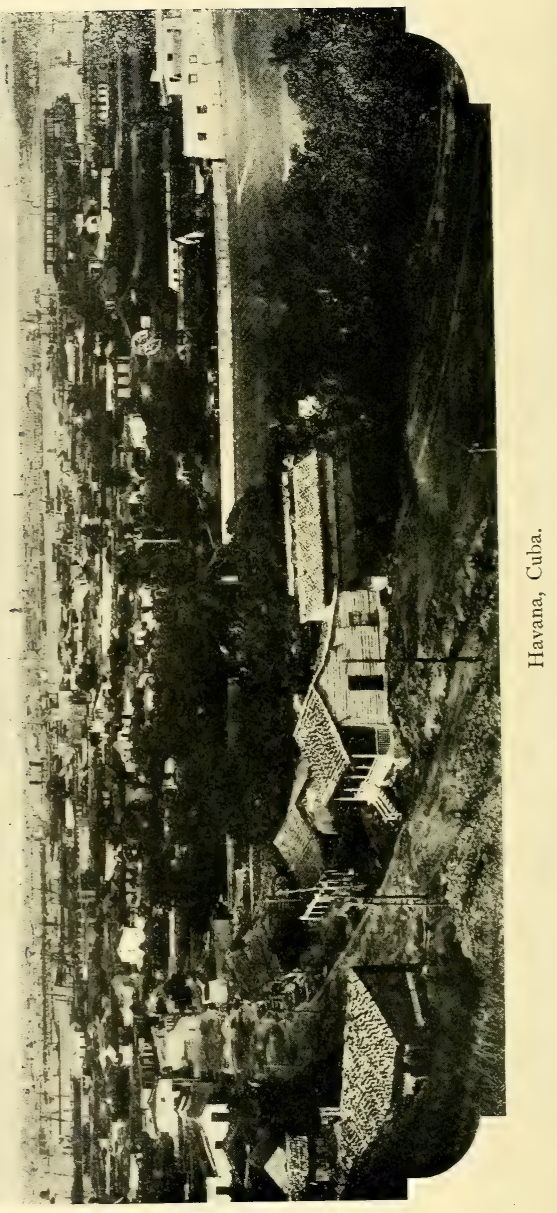


in the week excepting Tuesdays (when he will be at Morley) at ten dollars to insure. He has a record of $2: 3 x$; has got three with records of $2: 30$ or better, and as a sire of high class, good tempered, gentlemen's driving horses, never had an equal in this State. Terms $\$ 12$.

V. Sheldon, Canton, N. Y."

Mr. V. Sheldon writes: "As Stylish as Ethan Allen. His stock was sold for more than the get of any horse that ever stood in St. Lawrence County. One gelding was sold in New York, this season, for $\$ 2500$, by Mr. Dahlman, and a great many others for from $\$ 300$ to $\$ 600$. I have known more than 40 horses by Flying Cloud that have sold for from $\$ 300$ to \$1 200."

See The Morgan Horse and Register, Vol. I., p. 523.

Sire of $\mathcal{F}$ udge Lynch, 2:22; 3 dams of I trotter, 2 pacers.

FLYING CLOUD (DERBYSHIRE'S) (3-32), said to be by Jackson's Flying Cloud.

Sire of dams of Gipsey A, $2: 25^{3 / 4}$, and Aegon Star, $2: 111 / 2$.

FLYING CLOUD (HASKIN'S) ( $1-8$ ), bay with star, one white foot, 15 I 12 hands, 1200 pounds; foaled I 858 ; bred by W. M. Sprague, Texas, Mich. ; got by Blood's Black Hawk, son of Black Hawk : dam Dolly a small but excellent chestnut mare, brought to Dowagiac, by Rev. Wm. Sprague, who claimed that she was by Trimble's Eclipse and brought to Michigan by parties who came from Hillsborough County, O. Sold to A. Haskins, Dowagiac, Mich.

Flying Cloud became enraged at his owner Perry Wilkins, and bit his arm and broke it, and would have killed him had not help been at hand. Gelded about r 866.- - See The Morgan Horse and Register, Vol. II.

FLYING CLOUD (JACKSON'S) ( $\mathrm{I}-8$ ), black with stripe in face, one front and one hind foot white, $151 / 2$ hands, I050 pounds; foaled 1848 ; bred by Andrew Robeson, Fall River, Mass. got by Black Hawk, son of Sherman Morgan: dam black, about Iooo pounds; bred by Andrew Robeson, Newport, R. I., got by Andrew Jackson, son of Young Bashaw, by Grand Bashaw; 2 d dam bred by Mr. Robeson, father of Andrew Robeson, Boston, Mass., got by imported Messenger. Always owned by breeder, excepting, perhaps, his last five years, when he was kept by John Monahan, Springfield, O. Placed when two, in charge of Timothy T. Jackson, Jamaica, L. I., who took him to Urbana, O., I856, and returned him to Long Island, 1857 ; then kept six years on farm of Nelson Haight, Washington, N. Y.; later taken back to Ohio. Kept at Urbana, O., two or three seasons. Died about 1875. Received ist premium as a trotting horse at the New York State Fair, I853. The pedigree of $2 \mathrm{~d}$ dam is furnished us by Nelson Haight, who is certain that it is correct.

Mr. Haight (now of New York City), writes : 
"I can say that he was the handsomest horse, with the finest style and action, that I have ever seen. I think he was about five years old when at a private trial he trotted in $2: 37$ on the Fashion track on Long Island, but soon after he had the misfortune to break his ankle, which rendered him unfit for trotting. His stock were very fine, of medium size, and uniform, many of them carrying his marks"

The "Spirit of the Times" of Nov. 21,1853 , in its report of the National Horse Exhibition said :

"Flying Cloud, owned by 'T. T. Jackson, Flushing, L. I., is a six year old Black Hawk of great merit and promise and will yet be heard from on the turf."

John Monahan writes, dated, Springfield, O., Feb. I8, I885.

Editor Register :-I was the owner of Flying Cloud at the time of his death. He was known as Jackson's Flying Cloud. He had a broken leg. He was got by Black Hawk, first dam by Andrew Jackson. Cloud was in the hands of Timothy T. Jackson of Jamaica, L. I., from a colt till he was at least over 20 years old. He was almost impotent when he came into my hands, but I can say he was about the finest horse I have ever seen.

See The Morgan Horse and Register, Vol. I., p. 456.

Sire of Star of The West, $2: 261 / 2 ; 2$ sires of 15 trotters; 2 dams of 2 trotters.

FLYING CLOUD (ORR'S) ( I-8), black, one white fore foot, $15 \% \frac{1}{2}$ hands, I050 pounds; foaled I 847 ; bred by Gustarus Wicker, Ticonderoga, N. Y.; got by Black Hawk, son of Sherman Morgan: dam Miss Wicker, 16 hands, bought of Oliver Beckwith, Orwell, Vt., said to be by Hammond's Magnum Bonum, son of imported Magnum Bonum; 2d dam bred by Frank Farrington, Brandon, Vt. Sold to James Orr, Nevada, O., who advertised him, $\mathbf{1} 854$, in the Ohio Cultivator: "Kept by D. C. Doane in Huron County last season."

See The Morgan Horse and Register, Vol. I., pp. 25, 426.

Sire of Ohio Maid, $2: 29^{3 / 4}$; I dam of I trotter.

FLYING CLOUD (POWELL'S) (I-I6), gray, I $5 \frac{3}{4}$ hands, II 50 pounds ; foaled about $\mathrm{I} 857$; bred by Ed. L. Powell, Urbana, O. ; got by Jackson's Flying Cloud, son of Black Hawk: dam gray, a saddle mare of much endurance, said to be by Virginia Majesty. Kept near Urbana, O., until about I5, and the remainder of his life near North Lewisburgh, O. Died about I886. See The Morgan Horse and Register, Vol., I. p. 460.

Sire from Daughter; Civilization, $2: 23 \frac{1}{4}, 3$.

FLYING CLOUD (SMITH'S) (9-64), black, about rroo pounds; foaled about I 850 ; bred by Rev. Mr. Knott, in Vermont; got by Black Hawk: dam said to be by Morrill. Gored by an ox when two, and sold to a Mr. Ladd, who sold him next year to N. E. Smith, Laconia, N. H. Kept in Belknap County, N. H., all his life; was a good roadster 
and got a large number of colts, noted for their road qualities. See The Morgan Horse and Register, Vol. I., p. 507.

Sire of dam of Forest Patchen, $2: 19 \frac{1}{4}$, winner of 18 races.

\section{FLYING CLOUD (THOMPSON'S). See Silver Cloud.}

FLYING CLOUD 'JR. (JOSLYN'S) (I-I6); foaled about I 854 ; bred by Samuel J. Jackson, Jamaica, L. I. ; got by Jackson's Flying Cloud, son of Black Hawk : dam said to be thoroughbred, by imported Langford; 2d dam by American Eclipse, son of Duroc, by imported Diomed; and 3 d dam Gertrude, by Post Boy. Bought and taken to Greenfield, Mass., about I 858 , by a Mr. Dwight. Sold, I 860, to Jarvis Joslyn, New Haven, Conn. About r 864 he was brought back to Greenfield by L. D. Joslyn, Dr. A. C. Dean and Edmund W. Russell. He broke his leg and was killed about $\mathrm{I} 866$, then owned by L. D. Joslyn. See The Morgan Horse and Register, Vol. I., p. 458.

Sire of dams of Farmer Boy, $2: 19^{1 / 2}$ and Major, $2: 24^{3 / 4}$.

FLYING DUKE (3-64), blood bay, black points ; I6 hands, I Ioo pounds; foaled I 85-; bred by S. R. Bowne, Flushing, L. I. ; got by Iron Duke, son of Cassius M. Clay, by Henry Clay : dam owned by S. R. Bowne, bred in Vermont and said to be Morgan. Sold I86o, to E. G. Garnett, who sold to E. D. Graves, both of Saline County, Mo. A fine looking horse and very attractive in harness. Died 1880 . Information from T. C. Graves, who writes:

"Mr. Garnett was a brother-in-law of mine. He died, I875. $\mathrm{He}$ bought Trojan and Duke of Mr. S. R. Bowne, Long Island, r860."

FLYING DUTCHMAN, bay; bred in Kentucky; foaled I827; said to be by John Richards, son of Collier : dam by American Eclipse; $2 \mathrm{~d}$ dam by Tippoo Saib; 3 d dam by imported Royalist ; $4^{\text {th }}$ dam by Pastime; and $5^{\text {th }}$ dam by Bashaw, brother to Slammerkin, by imported Wildair, from imported Cub Mare.

FLYING DUTCHMAN, bay; foaled I 845 ; bred by Hon. J. C. Mason, Kentucky; got by Gray Eagle : dam Mary Porter, said to be by Mickle John; and $2 \mathrm{~d}$ dam by Printer, a quarter horse.

FLYING DUTCHMAN, bay; foaled I878; bred by John Whitstone, Kokomo, Ind., got by Sentinel, son of Hambletonian : dam Clara, said to be by Kramer's Rainbow ; and 2 d dam Effie G., by Sam Hazzard, son of Black Sam Hazzard. Sold to Charles F. Bell, Kokomo, Ind.

FLYING DUTCHMAN (FLETCHER'S). A letter from Campbell Bros., Rushville, Ind., dated May I5, I905, says :

"There was a horse kept in this county about 30 years ago called 
Flying Dutchman. He was brought here from Ohio sometime before our day."

California Girl, $2: 26 \mathrm{x} / 2$, George G., 2 :I 7, and Topsey, $2: 233 / 4$, are said to have been got by a horse called Flying Dutchman.

FLYING EATON (3-I6), bay with small star and white hind feet, I5 I/4 hands, 975 pounds; foaled I 850 ; bred by Caleb D. Sawyer, New Sharon, Me.; foaled the property of Joseph Whittemore, Phillips, Me.; got by a bay Morgan stallion, owned by Almon Benson of Wilton, Me.: dam a small rapid going gray mare, brought to Phillips, Me., by Hiram Church, whose father, Charles Church was a merchant at Phillips, Upper Canada; called a Morgan.

Thompson says: "After having several different owners he was purchased in I 866 and brought to Farmington, Me., by Dana Goff, then of Farmington. Goff sold him to Samuel Farmer, the proprietor of the Barden House, Phillips, Me."

There was at one time considerable controversy in regard to the sire of Flying Eaton, it having been claimed by some that he was got by the Eaton Horse, but the matter was looked into thoroughly by Mr. Parlin of the American Horse Breeder, Boston, who found without question that Flying Eaton was got by the Benson Horse, the next year his dam being bred to the Eaton Horse.

Among other witnesses were the owners of the Eaton Horse, who stated that Flying Eaton was not got by their horse.

Mr. Parlin says :

"Flying Eaton was one of the most graceful horses to look upon we have ever seen both in and out of harness. The first horse we ever owned was by him, and he was one of the best roadsters we ever had"

"The sire of Flying Eaton, said Mr. Toothaker, was a little bay Morgan stallion, owned at that time by the late Almon Brown of Wilton, Me. Mr. Brown (Benson) came to Phillips with this stallion in I850, when Flying Eaton was but a few days old, and then told Mr. Toothaker that the gray mare was bred to his Morgan horse the year before, and the colt was by him."-Middlebury Register, Feb. 20, I89I.

Mr. Charles Goff writes :

"Flying Eaton has a very fine coat but quite a coarse mane and tail, with great abundance of both, and they were always flying, quite as you see in a picture. The little children three years old used to play with him and my brother's girl II years old (my brother was a conductor 2 I years), harnessed and drove him one or two years to the depot at Farmington, and left him at the platform unhitched."

FLYING EATON JR. (3-32), dark bay, with a small star, I5 $1 / 2$ hands, Iooo pounds; foaled I 865 ; bred by Mr. Collins, Kingfield, Me.; got by Flying Eaton, son of Eaton. Sold when five years old to Dana Goff, who took him to Farmington, and in 1872 , sold to Sewell Goff, Mexico, Me. 
FLYING FRENCHMAN, red roan, white spot over eye, two white spots on heels, I 5 hands, 925 pounds. Sold to Mr. Burns, P'rince lidward Island; to Robert Ensley, Halifax; to John Hall, Laurencetown, Nova Scotia, who sends information. Died $\mathbf{s} 8 \mathrm{r}$.

Mr. Hall writes dated Laurencetown, N. S., Dec. 6, 'o8:

"Your favor dated Nov. 6, duly received. A gentleman in the State of Maine, happening to be in the Province of Quebec, discovered this very remarkable equine specimen owned by two Frenchmen. After considerable effort, aided by the Parish Priest, the American got the horse. There is no trace of him from that point until sometime after, when he was brought through Quebec and New Brunswick to Prince Edward Island, after which our knowledge of him is more reliable being owned by a gentleman named Burns. From there he came to Halifax, N.S., where he remained but a few months. He was brought to Halifax to race with one of his own sons, called Sammy, a roan gelding owned by a Dr. McKay, and there he became my property. As to size he would weigh 925 pounds, in color he was a red roan of splendid conformation bony head, short ears good crest, muscular shoulders, and breast round as a beaver hat, with rather drooping hips a clean pacer, never wore a boot, standing at ease he was singularly quiet but the moment you drew rein on him, he became a marvel of speed, pluck, and endurance. He was not only a unique individual, but in a phenominal manner he stamped his get with his own superb energy, and stamina. You will readily see that I know nothing about the old horse's dam. I owned "Tom Thumb," who never weighed more than 636 pounds, and was a marvel for game and speed.

"As I look back I can see lack of careful perpetuation, but I have never been without his blood. I have a four year old gelding the fifth generation from the old horse, who exhibits not a few of the qualities of Frenchman."

FLYING GALLOP. Advertised in $\mathrm{r} 800$, in Connecticut Courant: "An elegant imported stud from England, kept by Freeman Kilburne at Hartford."

FLYING HAL (I-I6), $2: 233 / 4$, chestnut sorrel, no marks, I6 hands, I Ioo pounds ; bred by Tittley Bros., Millerstown, Penn.; got by Hal Braden $2: 073 / 4$, son of Brown Hal: dam Belle Brooks, bred by Mr. Mullins, Moorsville, Tenn., got by Shoo Fly, son of Cramer; 2 d dam Sue Mullins, by Brooks (old), son of Brown Pilot; 3d dam Traveler mare, by Stone's Henry Hal; and 4th dam, by Cox's Messenger. Sold I893, to Dr. L. F. Smally, Londonville, O.; to Harmon Clow, Bellville, O. Pedigree from F. M. Plank, Medina, O., breeder of Buckeye Hal, 2 : 2 I 1/4, also from Dr. L. F. Smalley.

Sire of Buckeye Hal, $2: 21 \frac{1}{4} 4$.

FLYING HAMILTONIAN. See Valentıne Horse.

FLYING HIATOGA, dark bay, I6 hands, II 50 pounds; foaled i 853 ; bred by Jackson Couch, Hopedale, O. ; got by Hanley's Hiatoga, son of Rice's 
Hiatoga: dam bay, bred by Jackson Couch, got by Flag-of-Truce, brought from the East; $2 \mathrm{~d}$ dam, said to have been brought from Kentucky. Information from Wm. Couch and Theodore Leggett, who, Mr. J. P. Leggett says: "knew the horse from his birth."

Sold to Moses Hanley; then, to Dr. J. T. and D. B. Updegraff, of Mt. Pleasant, O.; to S. Hallaway, Flushing, O.; to E. Besset, Milan, O., and died his in I872.-Wallace's Monthly, 1888 .

Been driven and ridden in over fifty races and won all, trotted in $2: 26$ and paced in $2: 25$, took first premium in show ring year after year. Good saddler and good roadster.

In a letter to Dunton's Spirit of the Turf, O. P. Updegraff, writes :

"Flying Hiatoga had the misfortune of having no record, his racing was done in a day when we did not want records, the folly of which is now apparent. A few of his offspring are in the 'great list,' though many a son and daughter of his have gone their miles in better than $2: 30$ when records were not given, or else the breeding cannot be established, as in the case of many other sires of his day. We know however that he got Katherine, $2: 30$, Emma Belmont, trial $2: 28$, Bay Harry, trial $2: 22$, Flying Hiatoga Jr., $2: 231 / 4$, and $2: 18$ to the saddle at nineteen years of age, Billy Green, $2: 20$, and the dams of Headlight, $2: 30$, Scott B., $2: 29 \frac{1}{2}$, Mohawk Kate, $2: 263 / 4$, Harold C., trial $2: 35$, and Senator Updegraff, $2: 37$. In Ohio, where he and Scott's Hiatoga are best known, mares by these horses are valued very highly for brood mares, the pacing blood of the Hiatogas being considered as good as that of Pilot Jr., for brood-mare purposes."

Sire of Kathrine, $2: 30 ; 2$ pacers $\left(2: 23 \frac{1}{4}\right) ; 3$ sires of I trotter, 2 pacers; 6 dams of 5 trotters, 2 pacers.

FLYING HIATOGA (I-I6); bred by William Roseman, Ohio; got by Scott's Hiatoga, son of Hanley's Hiatoga: dam said to be by Ethan Allen. Owned by B. Burroughs, Clinton, Ill. Died February $\mathbf{1} 886$. F. M. Burroughs, Chicago, Ill., writes that his father once owned the horse, but the papers concerning him were destroyed.

Sire of Cora B., $2: 27 \frac{1}{2}$.

FLYING HIATOGA JR., $2: 23 \mathrm{~T} / 4$, bay, light blaze or feather in face, I 5 I $/ 2$ hands, IIoo pounds; foaled I882; bred by Elwood Johnson, Flushing, O.; got by Flying Hiatoga, son of Hiatoga : dam brown, owned by Mrs. H. Bargs, Folk's Star, O., got by Rodney (Copeland's), son of Rodney (Cell's); $2 \mathrm{~d}$ dam, bred by Samuel Bealey, Miller's Station, O. got by Copeland's Sunflower, a trotter. Sold to G. A. Chaney, Cadiz, O. Pedigree from C. R. Tiplon, Cadiz, O.

Sire of Macduff, $2: 15 \%$.

FLYING INDIAN (OLD FLYING INDIAN) (I-8); said to be by Pilot. -The Western Sportsman.

Sire of Mollie Owens, $2: 24$.

FLYING JACK (I-8), dark bay or brown, I $53 / 4$ hands, I I 75 pounds ; foaled 
I 853 ; bred by M. Murray, West Addison, Vt.; got by Black Hawk : dam said to be by Barney Henry. Sold to Ira S. Wright, Weybridge, Vt., and T. Warner, Addison, Vt., I853; to L. Gorham, about I859; to Horace Gorham and Lucius Twitchell, who took him to Greenfield, Ill. ; to a company at Macoupin, Ill., half interest for \$rooo; to M. Halliday and S. L. Twitchell, I863 ; to Jacob Leonard, Chatham, Ill.; to parties at Chicago, Ill.

Advertised in the Spirit of the Times, I 859: "For sale-Flying Jack, son of Vermont Black Hawk, seven years old, brown, i ioo pounds. (Signed), Leroy M. Gorham,

See The Morgan Horse and Register, Vol. II. Addison, Vt."

FLYING MAC (I-8), dapple gray, I 5 I/2 hands high; foaled 1859 ; bred by Isaac Mancy, Augusta, Me.; got by a son of Bush Messenger: dam a dapple gray pacing mare, bought in Canton, of Daniel Foster, by George M. Robinson, said to be by Mac, son of Morgan Ceasar (Morgan Post Boy), by Woodbury Morgan. Flying Mac was sold to John Shaw, Augusta, when four months old, and was afterwards taken to Boston. From Maine Bred Horses, Vol. I.

FLYING MORGAN. See Jesse Stowe.

FI,YING MORGAN. See Lance by Davis' Flying Morgan.

FLYING MORGAN. Untraced.

Sire of Little Longfellow, $2: 291 / 4$.

FLYING MORGAN (3-I6), blood bay, white hind feet, about I4 $1 / 2$ hands, 900 pounds; foaled $\mathrm{r} 843$, the property of R. M. Adams, Bristol, Vt.; bred by L. D. Livermore, Hartland, Vt. ; got by the Hackett Horse, son of Gifford Morgan : dam small, owned by Gilbert Allen, a peddler, Granville, Vt.; who traded her to Amory Allen, and he to Mr. Livermore, untraced, but said to be Morgan. Half interest sold, when about two years old, to John Daniels, Bristol, Vt. ; who rented Mr. Adams' farm in Bristol, and kept the horse there until 1849 , when he was purchased by Dr. W. P. Russell, Middlebury, Vt., and kept that season at the farm of Harvey Yale in Middlebury. He was repurchased by Mr. Adams, winter or spring of $185^{\circ}$, and was advertised for stock purposes at Burlington, Vt., April i I, r85o, by Riley Adams, who kept him in Burlington until $\mathbf{1} 857$, then in Massachusetts and New Hampshire until i 864 , when he sold him to Wm. J. Russell, Bombay, N. Y., who kept him at Malone. The horse died about I868, the property of Henry W. Nye, Brasher Falls, N. Y. Flying Morgan was a smoothturned horse, somewhat lazy, so much so as to make him an indifferent road horse. He was quite a fast and reliable track horse for his day, winning a number of races. He left some very creditable stock, among 
them Ira Allen, $2: 30$, the sire of Ripton Boy, $2: 25$, and Lady Griswold, who had no record, but could trot better than $2: 30$, dam of the stallion Kent, and grandam of Wilton, $2: 19^{\mathrm{I} / 4}$, and Albert France, $2: 20 \frac{T}{4}$. He was also sire of the stallion Whalebone and several others of merit. He received second premium in class of foreign horses at New York State Fair, 1863. Soloman Dunham, Hancock, Vt., born in Bethel in $18 \mathrm{r}_{4}$, all his life a breeder of horses and an especially accurate and reliable witness, said :

"I remember well the dam of Flying Morgan when she was owned at Granville, Vt., they always called her a Morgan mare and she looked like one. She was quite smart to go. It has always been my impression that she was got by the Mills' Horse, son of Woodbury Morgan; she certainly resembled that horse's stock very much, many of which were fast trotters."

Linsley says :

"A horse of a great deal of bottom and power; trots fair and square ; goes smart; is perfectly sure for all he can do, and generally makes his best time in the last heat. From heating and overwork his eyes have been injured and he can see but little."

\section{DAM OF FLYING MORGAN AND BLACK LYON.}

Editor Register:- The Mother of Flying Morgan was a small bay or chestnut mare from over the mountain; was attached by Wm. Needham of Bristol, sold at auction, and bought by Riley Adams; was with foal by the Hackett horse when bought by Adams. The colt was Flying Morgan.

$$
\text { Yours truly, HARvey YaLE. }
$$

In interview Mr. Yale said :

"I once owned a half-interest in Flying Morgan. John Daniels lived on Adams' farm and raised Flying Morgan and owned half of him. Dr. Russell doctored Daniels family, and he and I bought the horse in the spring when he was six years old. I kept him through the season and in the fall let Dr. Russell have him to go over the lake. The stud season was over; it was in September; had had 40 to 50 mares; terms $\$ 5$ to warrant. This same fall Adams bought Flying Morgan back, making the trade with Dr. Russell. This was the only time Dr. Russell ever drove him to Ticonderoga. He hardly ever drove him. It was not the year that Ethan Allen was bred."

See The Morgan Horse and Register, Vol. I., p. 681. Vol. II., p. 126.

Sire of Ira Allen, 2:30; I sire of 4 trotters; $2 \mathrm{~d}$ dam of Albert France, $2: 201 / 4 ; 2$ dams of 3 sires of $x 6$ trotters and pacers.

FLYING MORGAN. The fourth premium on stallions was awarded at the New Hampshire State Fair, I 853 , to "Flying Morgan," entered by D. K. Marvel, Milford, and first premium for speed.

FLYING MORGAN. The report of the Iowa State Agricultural Society, I 857 , states that the $2 \mathrm{~d}$ premium for stallion, and five of his colts was awarded to Flying Morgan, owned by S. D. Kerr, of Muscatine County. 
FLYING MORGAN, bay, I5 T/4 hands, rooo pounds, bred in Canada. Owned by Avery Edwards, Winooski, Vt., who sold him to Murry Bros., I856, who took him to California. Seth Murry, San Francisco, Cal., said: "He was gentle, a fine looking horse with very round barrel, two good ends and a pacer." This horse was probably named Flying Morgan after he reached California.

Sire of the dam of Billy Ring, by Young Columbus.

FLYING MORGAN, sorrel, about I $_{5}$ hands, Iooo pounds. Brought from Vermont to Waterloo, Can., and owned about $\mathbf{1} 865$, by Mr. McLaughlin of Waterloo. A son of this horse was owned in 1887 , by Stephen McFarlin of Waterloo.

FLYING MORGAN ( $1-\mathrm{I} 6$ ), bay, I5 I/2 hands, I Ioo pounds; foaled June 16 , I 884 ; bred by J. B. Dodge, Walnut, Bureau County, Ill.; got by Tiger Messenger, son of Morgan Messenger : dam roan, bred by J. B. Dodge, got by Morgan Messenger, son of Hackett Horse ; $2 \mathrm{~d}$ dam gray, bred by Mr. Davenport, New Haven, Vt., got by Foot Horse, son of Hamiltonian (Bishop's). Sold to J. B. Dodge, Walnut, Ill. ; to Lincoln Cool, Grand Detour, Ill.; to W. H. Keedy, Mt. Morris, Ill., who sends pedigree. See The Morgan Horse and Register, Vol. II., p. I 26.

FLYING MORGAN (DAVIS' STANLEY HORSE) (I-I6), dark chestnut with stripe in face and white hind feet, heavy mane and tail, 15 hands, ro5o pounds; foaled May 8, r843; bred by E. A. Stanley, Georgia, Vt. ; got by Joel Laflin Horse, son of Clark's Telescope : dam, bay, with star, long neck well cut up under throat, well shaped, $15 \% \frac{1}{2}$ hands, rangy, foaled about r 835 ; bought by Mr. Stanley of a Mr. Perry, Sheldon, Vt., who got her in Essex, Vt., said to be by an English horse ; $2 \mathrm{~d}$ dam dark chestnut, close built, heavy mane and tail, said to be Morgan. Sold I 852 , to Wm. Guy \& Charles Fullerton of Ohio. He was purchased I 857 at Peoria, Ill., by M. V. B. Davis of Mechanicsburgh, O., who paid for him $\$ 3,000$. Mr. Davis owned him many years. He was kept at Clinton, Ill., I858; Leroy, Ill., r859; Somerville, Tenn., I860-6I. It is stated that the net profits of his first season in Tennessee, was something over $\$ 2,000$.

It is understood that the pedigree given the horse when he went to Ohio, and which was accepted for many years, was fraudulent. As we understand he was in the first place bought by Messrs. Guy \& Fullerton for a company in Ohio. We have been furnished with the affidavit of Mr. Guy, Mr. Fullerton being dead, that the pedigree which they gave with the horse was the one they received at his purchase. Mr. Davis made affidavit to the same effect, and we think he gave pedigree as he received it, supposing it to be correct.

Although the pedigree given,- - by Gifford Morgan, dam by Green 
Mountain Morgan,--was a fraudulent one, the horse was well bred with sufficient of Morgan blood through his dam and probably also, through dam of sire, to make him eligible to registration in the Morgan Register. He was a fast pacer, and got much excellent stock which is said to have very closely resembled the Morgans. Died I 87o.

Dr. W. O. Blaidsdell, an experienced horseman of Macomb, Ill., said :

"He had a fine clean neck at the throat latch and large at the shoulders, short back, closely ribbed up in the flanks with clean legs he truly looked like a Morgan. His stock is scattered all through Ohio, Missouri, Iowa and Illinois, both they and the horse very much resemble the Morgans. He had pretty good length of body and remarkably good limbs."

Mr. Ashley, Milton, Vt., owner of Ashley's Ethan Allen, said :

"J. Clark of Milton had a son of old Telescope that got the Laflin Horse which was the sire of the Stanley Horse. The dam of the Laflin Horse (which see), was small chestnut mare, 950 pounds, low, thick set, sometimes called French, but I think was a Morgan. Stanley bought

- the dam of his horse in Williston. His horse was a good pacer. $\mathrm{He}$ sold him to a couple of men from Ohio.

"Hiram Ballard of Georgia, let Daniel Wood have a pair of mares, one of which was the dam of the Laflin Horse. She was a clean foaled mare with nice head, not as much hair on legs as the other, and think must have been a Morgan mare. She looked like the correct Morgan from up north. The Stanley Horse was a Morgan horse from stem to stern, never a better pattern of a Morgan horse, and his stock around here resembled Morgans; a good many were chestnut. The dam of Davis' Flying Morgan was bought in Essex. There was an older Morgan horse from the old Calhoun Horse that came from Canada, chestnut, about r 833. Calhoun got him at Stukely or Dunham. Benjamin Sabin had a gray horse that was kept here 30 years ago, that was got by the Calhoun Horse. The Laflin Horse was ugly."

John Stanley, Georgia, Vt., in interview, r89 I said :

"My father Edward A. Stanley bred the horse that went to Ohio, and was afterwards known by the name of Davis' Flying Morgan. He was got by the Laflin Horse ; the dam was bay, $15^{\mathrm{T}} / 2$ hands, very rangy, foaled about I 835, bred in Essex, Vt., injured when four years old when trotting on a bet from Essex to Burlington. We sold this mare to Hannan Hill of Georgia, Vt. He bred a bay stallion from her, I5 $1 / 2$ hands, 1025 pounds, foaled about $\mathbf{1} 850$, got by Flying Childers, a Morgan horse owned at St. Albans, - which he took when three years old to Bedford, Ill."

W. H. Dotson, Mechanicsburg, O., writes, dated Jan, I I, I90 :

"Tip Cranston, son of Davis' Flying Morgan, lived to an old age, and died on the farm where he was raised, near Woodstock, $\mathrm{O}$. He left but one entire son that we know of, Morgan Mohawk, that was from Mohawk Bell (which had considerable reputation as a show mare, and was able to trot a public trial over the Springfield, O., track in $2: 35$ ), by Mohawk, son of Long Island Black Hawk; second dam by Montezuma Morgan Morgan Mohawk was a rich dark bay, with black points, $\mathrm{I} 6$ hands, and weighed i 250 pounds, a handsome and well built horse. He was taken out of this community, and we know of but one of his get. This one 
was bred by M. V. B. Davis, who owned old Flying Morgan when he died. Mr. Davis had a matched pair of mares, daughters of old lilying Morgan, that could outstyle, outpull, do more work, and get over more road than any team in the community. They were growing old, and with rare judgment and foresight, he matched Kit (one of the pair). that he often said was the best daughter of the old horse, to Morgan Mohawk.

"The result of this breeding was a chestnut colt, foaled in 1886 , that in many respects greatly resembles old Morgan Mohawk and Flying Morgan. He has the same blood-like head and neck, is taller, longer, more muscular, hardly so highly finished, but is a handsome horse with the clean, heavily corded limbs of the Morgans, and much of the style and beauty of outline of his grandsire. Mr. Davis named him after the agnostic and patriot Tom Paine, and watched his growth with deep interest, prophesying for him a bright future as a sire, but Mr. Davis died, and at the sale of his effects Tom Paine while still a youngster was bought by a farmer, and has been buried ever since, until recently he was bought by an active young horseman, and will now, no doubt be given the chance he ought to have had long ago and will doubtless improve the road qualities of our horse stock."

FLYING MORGAN (FARR'S) (I-I6), I5 $5 \frac{1}{2}$ hands, IOoo pounds; said to be by old Flying Morgan : and dam Hamiltonian. Owned by a Mr. Barker of Granville, N. Y., of whom he was purchased by Hollis G. Stowell, Windham, Vt., who sold him to E. S. Farr, Tioga County, Penn. Afterwards owned by C. L. Aiken, Tioga, Penn., who writes that he trotted in $2: 45$, whilst he owned him and that he went to Long Island.

Hollis G. Stowell writes :

Mr. BatTell,

Springfield, Mass., June i i, 'o6.

Dear Sir:- It has been so many years ago that I have forgotten nearly all about the horse. I bought the horse of a Mr. Barker of Granville, N. Y. He was got by the "old Flying Morgan" and I sold him to E. S. Farr. Sorry I cannot give you more information.

The information published in Vol. II., of The Morgan Horse and Register, that this horse was by Green Mountain Morgan, was from Wm. H. Stowell, and supposed to be correct, but the above from Hollis G. Stowell who owned the horse would appear to be more reliable. See The Morgan Horse and Register, Vol., II., p. 127.

Sire of Priestman, sire of dam of Bert Sheldon Jr., $2: 16 \frac{1}{4}$, said to have trotted the most races of any horse.

FLYING MORGAN (MCMONAGLE'S MORGAN) (I-I6), bay or brown, $143 / 4$ hands, Io 80 pounds; foaled 1856 ; bred by Ebenezer Seaver, Williamstown, Vt.; got by Green Mountain Morgan: dam black, bred by E. Seaver, got by Porter Martin Horse, son of Townsend Horse, by old Soldier (Kasson Horse). Purchased, April 22, 1860, by Hugh McMonagle, Sussex Corners, N. B., and kept about six years at Sussex Corners and vicinity; then traded to B. Ansley, St. John, N. B., who 
used him as a roadster and sold to Mr. Cunningham, Ellsworth, Me., Mr. McMonagle writes :

"He was a low and lengthy colt and became very fast, as a trotter, for the chance he had, as we had no trotting races here then. On the road he was hard to beat. His colts became excellent horses."

See The Morgan Horse and Register, Vol. I., p. 724.

FLYING MORGAN OF PETERSHAM (NORTH STAR, NORTH STAR MORGAN) ( I-8), bay with black curly mane and tail, I 5 hands, I050 pounds; bred by David Lincoln, Greenwich, Mass.; got by Morgan Emperor, son of Bulrush Morgan : dam bay. Owned by Chamberlin and Gibbs, Petersham, Mass., I853. In the Spirit of the Times, I856, Henry Olmstead advertises North Star Morgan at East Hartford, Conn., at $\$ 2$ o. The advertisement states that he received first premium at the Connecticut State Fair, and second at National Horse Fair at Springfield, Mass., I854, where he was called Flying Morgan. Linsley says : "A very symmetrical, well-shaped horse, fine, bold style and excellent action."

The Spirit of the Times 1853 , says :

"A horse named Flying Morgan, owned by Chamberlain \& Gibbs of Petersham, Mass., comes quite up to our ideal of a perfect symmetrical animal. His height is $\mathrm{I}_{5}$ hands, weight 1050 pounds, color bright bay, and his action splendid. His sire was Morgan Emperor, got by Bulrush Morgan. This horse was awarded $2 \mathrm{~d}$ premium at the National Exhibition of Horses, Springfield, Mass., I 853."

A Morgan horse called Flying Morgan was sold, i 856, to Burton and Hathaway, Edenton, N. C., by Thomas Derrick, Province of Quebec.

See The Morgan Horse and Register, Vol. II.

FLYING MORRILL, black, $151 / 2$ hands, 1000 pounds; foaled about $185^{2}$; said to be by Cheney's Young Morrill, son of Morrill. Taken from Vermont to Keokuk, Ia., by W. Snow, who sold him, spring of 1858 , to L. J. Rose, Keosauqua, Ia., who took him to California.

Mr. L. J. Rose, writes :

"I know nothing beyond the fact that I bought such a horse of W. Snow of Keokuk, Ia., and that up to that time I considered him the finest horse I ever saw. He could trot in $2: 50$, and I paid $\$ 3,000$ for him, an extravagant price for that day. He was killed, 1859, by the Indians, and left no stock to me."

The following letter is from The New York Spirit of the Times, March 20, I 858 :

"A very fine stallion, has recently been sold by Mr. W. Snow of Iowa for $\$ 3,500$ to L. J. Rose of Keosauqua, of the same State. The Keokuk Daily Post of the r6th informs us, that it is the intention of Mr. Rose to take him to California the coming season with other blood stock. Flying Morrill has been in this city for the past year. $\mathrm{He}$ is between five and six years of age and comes of fast stock, his sire being Young 
Morrill, owned by Cheney \& Co., of Boston, and has made his mile in less than $2: 40$. He promises to make a very valuable acquisition to the fast stock of California-the enterprising citizens of which golden State are using every endeavor to improve their breed of horses. Good luck to them!"

See The Morgan Horse and Register, Vol. I., p. 627.

FLYING RATTLER. See Morgan Rattler.

FLYING ROCKET (I-I6); said to be by Smith's Honest Allen Jr., son of Honest Allen, by Ethan Allen. Owned at or near London, N. H. See The Morgan Horse and Register, Vol. II., p. I 28.

Sire of dam of Nellie Hastings, $2: 29 \frac{1}{2}$.

FLYING TUCKAHOE, bay; foaled I 846 ; bred by J. S. McGarry, West Liberty, W. Va.; got by Herod Tuckahoe (dam from famous Tom family of pacers in Maryland), son of Tuckahoe, by Florizel : dam Lucy, said to be by Buck, son of Standard, by Sir Archy. Owned by Dr. Alexander Reed of West Virginia, who took him to Brimfield, Peoria County, Ill. He both paced and trotted fast. We add the following letter from the son of Dr. Alexander Reed:

Joseph Battell, Bread Loaf, Vt.,

Chicago, March 27 , 'og.

My Dear Sir:-A letter from you under date, Nov. 6, 'o 8 has been referred to me. In answer, I am very sorry to say we have no pedigree of Flying Tuckahoe. The horse was brought to Illinois in 1855 , by my father who died in January, 1856 ; he made record of $2: 30$ in Wheeling, W. Va., I think in I 854 or 55 , was a beautiful horse, was killed in Battle at Fort Donaldson in ' 61 being ridden by a Union Colonel, and it was stated that he was buried with the same honors given a soldier, as his beauty and disposition were admired by the whole regiment. His get in Peoria County this state and adjoining counties, made fine horses and most of them were endowed with both beauty and speed. Am very sorry I cannot furnish the information that I know you require for the work in which you are engaged.

$$
\text { Very truly, C. M. REeD. }
$$

FLYING WHIRLWIND. See Young Whirlwind.

FLYING YANKEE. See Gen. Grant, by Draco.

FOCUS R. (5-128), $2: 27 \frac{1}{4}$, black, star, snip, with one white ankle, $15 \mathrm{I} / 2$ hands, гог $21 / 2$ pounds; foaled I 885 ; bred by G. C. Hayden, Waterloo, Ia. ; got by Adrian Wilkes, son of George Wilkes : dam Maud ; 2 d dam said to be by a son of Ethan Allen. Pedigree from Russell \& Kohler, Glencoe, Minn.

FOLLY KLAVA (I-I 28 ), bay, I53/4 hands, I roo pounds; foaled I 888 ; bred by B. F. Wilson, Middletown, Ia.; got by Bala Klava, son of Onward: dam Mousie, buckskin, bred by Jacob Leffler, Burlington, Ia., got by Bob 
Burdette, son of Ensign; 2d dam Kilpah, black, bred by Jacob Leffler, got by Ensign, son of Enchanter; 3 d dam gray, bred by a Mr. Smith;

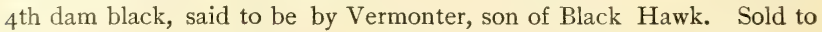
S. O. Thomas, Burlington, Ia. Pedigree from breeder.

Sire Ipsey, $2: 29 \frac{1}{4}$.

FOOTE HORSE. See Hamiltonian (Foote's).

FORBES, said to be by Iron Duke, son of Hambletonian. Sire of Milkmaid, $2: 22 \frac{1}{2}$; I dam of I trotter.

FORDSTAN (STANFORD) ( I-I 28 ), brown; foaled I 879 ; bred by George Taylor, San Francisco, Cal.; got by Electioneer: dam, Annie Laurie, said to be by David Hill Jr., son of David Hill ; and 2 d dam Kitty, by Owen Dale, son of Williamson's Belmont. Sold to R. P. Clement; to Charles P. Harris, both of San Francisco, Cal.

Sire of Melvar, 2:22; I sire of I trotter; I dam of I trotter.

FORERUNNER (I-I28), bay; foaled I887; bred by R. P. Pepper, Frankfort, Ky.; got by Onward, son of George Wilkes: dam Embassy, bay, bred by R. P. Pepper, got by Harold, son of Hambletonian; 2 d dam Virginia, said to be by Billy Townes, son of imported Fylde.

Sire of 2 trotters $\left(2: 19 \frac{1}{4}\right)$.

FOREST BASSETT (DIAMOND JOE) (I-32), chestnut, I6 hands, I I50 pounds; foaled $\mathrm{x} 88 \mathrm{I}$; bred by Cary Bros., Berlin, Wis.; got by Joe Bassett, son of Brown Dick (Billy Bashaw) : dam Cary mare (Roulette, dam of Johnston, $2: 06 \frac{1}{4}$, etc.), chestnut, bred by Cary Bros., got by Ned Forrest (Swetting's), son of Edwin Forrest; 2 d dam Nepenskina, said to be by Kentucky Hunter (Steele's), son of Knight's Morgan, by Newton's Morgan, son of Sherman Morgan. (A horse known as Newton's Morgan in Vermont, registered "by Bulrush Morgan," foaled r 844 , was owned by Owen Newton in Waukegan, Ill., six years and went to Wisconsin, and is probably the Newton's Morgan referred to.) Sold to H. S. Woodruff, Janesville, Wis. ; to Arthur Rice, Oktoc, Miss. (I897I905). Kept at the White Farm, Sand Lake, Ill., I887-8, where he was bought by Mr. Woodruff, when he was named Forest Bassett.

Mr. Woodruff, writes :

"He was known as Diamond Joe, at Berlin, until sold when his name was changed to Forest Bassett. Had a beautiful head carried away up on a flexible neck. Was a square trotter with fine knee action, his colts were like him and all sold readily for city drivers at good prices."

Arthur H. Rice, M. D., writes from Oktoc, Miss., Feb. 16, I906 :

"Brother Dave, $2: 23 \frac{\mathrm{I}}{2}$, and Joe Bassett Jr., $2: 18$, were the other full brothers of Forest Bassett and Johnston, the sire of the dam of Marion Mills, $2: 04 \frac{1}{2}$, guideless, was by Joe Bassett. The greatness of Johnston is heightened by the reflection that it took six years for the turf to furnish a horse, Roy Wilkes, to come within $21 / 2$ seconds of his mark. I am the 
only breeder who has thought his blood worth preserving in the best of pacing crosses."

In answer to inquiries, Mr. Arthur H. Rice, M. D., Starksville, Miss., writes, dated March 25, I909:

"All I know of $2 \mathrm{~d}$ dam of Forest Bassett is what I get from H. S. Woodruff's catalogue, which information I presume you also have: Steele's Kentucky Hunter, by Knight's Morgan, by Newton's Morgan, son of Sherman Morgan : dam Flirt (or Flint), bred near LaPorte, Ind., and brought to Wisconsin in $1849 . "$

FOREST BISMARCK (I-I28), bay, with star, both hind feet white, and a little white on front feet, I 6 hands, about I 200 pounds; foaled May, I $88_{3}$; bred by T. E. Moore, Shawhan, Ky.; got by Victor Bismarck, son of Hambletonian: dam, Mattie Forrest, bred by Wm. Fleming, Louisville, Ky., got by Edwin Forrest; 2 d dam Glencoe Mare, said to be by Glencoe, son of Sultan; 3 d dam by Medoc, son of American Eclipse; and $4^{\text {th }}$ dam by Woodford. Sold to W. H. Wilson, Cynthiana, Ky.; to J. H. Allen, Darbyville, O., who sends pedigree; to H. C. Shepard, Lovington, Ill.; to J. H. Gregg, Brushy Fork, Ill., April, I 888.

Sire of Diamond, $2: 24 \frac{1}{4}$.

FOREST BLACK HAWK (3-64), black, I6 hands; foaled July I8, I887; bred by A. L. DuBois, Wapakoneta, O. ; got by Kinnel's Edwin Forrest, son of Gerles' Edwin Forrest, by Edwin Forrest, son of Young Bay Kentucky Hunter: dam roan, bred by Josh. Mickail, Sidney, O., got by Blue John, son of Black Hawk ; 2 d dam said to be by young Hazard, son of Sam Hazard. Kept in Montgomery County, O. Information from A. S. DuBois, who writes: "Very fine in conformation. Morgan in appearence and action. His sire's $2 \mathrm{~d}$ dam was by Green's Bashaw."

FOREST BRANCH $(3-64), 2: 27$ I $/ 2$, chestnut; foaled I 89 I ; bred by Granville Cecil, Danville, Ky. ; got by Pizarro, son of Gambetta Wilkes : dam Flora, bay, bred by Granville Cecil, got by Mambrino Startle Bonner, son of Startle ; 2 d dam Maud Rowan, bay, bred by P. S. Barber, Bardstown, Ky., got by Almont; 3d dam Kate, said to be by Lear's St. Lawrence; and $4^{\text {th }}$ dam by Lear's Sir William. Sold to G. W. and J. A. Lee, Danville, Ky. Pedigree from breeder.

Sire of Ella A. Branch, $2: 291 / 4$, Madam Nordica Branch, $2: 161 / 4$.

FOREST D., $2: 273 / 4$, bay, no marks, I61/2 hands, 1300 pounds; foaled I 887 ; bred by Thomas Hogue, Webster City, Ia.; got by Senator N., son of Wapsie: dam, brown, bred by Thomas Pidd, Downey, Ia., got by Billy Jacobs Jr., son of Billy Jacobs; 2 d dam, Lucy, bred by A. B. Cornwall, Downey, Ia., got by Jerry. Pedigree from A. C. Whitacre, Downey, Ia.

FOREST DUKE (I-64), bay, I5 I/2 hands; foaled 1887 ; bred by A. G. 
Barnes, Taylorville, Ill.; got by Dictator Chief, son of Dictator: dam Mambrino Duchess, gray, bred hy James Wadsworth, Chicago, Ill., got by Silver Duke; 2 d dam Lizzie Allen, bay bred by James B. Clay, Hamptondale, Ill., got by Mambrino Chief, son of Mambrino Paymaster; 3 d dam Fay (running-bred), said to be by Yorkshire, son of St. Nicholas ; and $4^{\text {th }}$ dam Fury, by Priam, son of Emilius. Pedigree from George L. Banks, Taylorville, Ill., who writes :

"Mr. Barnes bought the mare Duchess of Samuel Granger, Coldwater, Mich. This colt was sold to some one near Paris, Ill., where he got the mare Dora H."

Sire of Dora H., $2: 181 / 2$.

FORESTER. Advertised as follows, I804, in the Kentucky Gazette :

"Will be kept at the farm of the owner in Garrard County, Ky., about one mile from Lancaster and near the road leading to Stanford. Full blooded horse, being got by Magog, his dam a Forester mare; both of which horses were well known on the turf of England, as may be seen by inspecting their Racing Calendar; is a beautiful gray, about 16 hands high, and for speed, power and bottom as a Stag and Foxhunter, (for which, though of the first racing blood, he was long kept) was rarely excelled. Forester's stock in old England, where he was kept three seasons, were in very high esteem,- - his colts in Kentucky, where he has also made three seasons-for symmetry, bone and action, excel. Forester was imported by Dr. Thomas Champney, at whose stable he made his two last seasons."

JOHN BUFORD.

FORESTER, I 6 hands; said to be by Kildeer of Scotland. Imported by Benjamin Colt, Philadelphia. Advertised, r8oo, at Ferrisburgh and Vergennes, Vt. ; I805, at Weathersfield and Springfield, Vt., and Claremont, N. H. ; and I $\mathrm{III}_{\mathrm{I}}$, by D. Jones, in the Washingtonian of Windsor, Vt., to be kept at Weathersfield, Vt. Terms $\$ 2$ to $\$ 6$.

FORESTER. Thoroughbred. Advertised in New Jersey, $\mathbf{1} 832$.

FORESTER (CROFTS'), chestnut; foaled 1736; bred by Mr. Crofts ; got by Hartley's Blind Horse, son of The Holderness Turk: dam Bay Brocklesby, bred by Mr. Crofts, got by Partner, son of Jigg; $2 \mathrm{~d}$ dam Brocklesby's Betty, bred by Mr. Pelham, got by Curwen Bay Barb ; $3 \mathrm{~d}$ dam Leedes' Hobby Mare, said to be by the Lister Turk.-General Stud Book, Vol. I., p. 44 .

FORESTER (YOUNG), chestnut; foaled I79r ; bred by Mr. Smith Barry; got by his Forester, (sent to Ireland), son of Dionysius, by Regulus : dam Amaranthus Mare, bred by Mr. Smith Barry, in Ireland, got by Amaranthus, son of England, by Godolphin Arabian; 2 d dam Flashing Molly, bred by Mr. Smith Barry, got by Oroonoko (sent to Ireland) ; 3d dam Smiling Molly, bred by Mr. Pearson, got by Crofts' Forester, 
son of Hartley's Blind Horse ; 4th dam said to be by Partner.-General Stud Book, Vol. I., p. 227.

FOREST GLENCOE, dark chestnut, $163 / 4$ hands; foaled 1867 ; bred by R. A. Alexander, Spring Station, Ky.; got by Edwin Forrest : dam Little Meg, said to be by imported Glencoe, son of Sultan ; 2d dam by Medoc, son of American Eclipse; and $3 \mathrm{~d}$ dam by American Eclipse. Sold to Mr. Swigert, Bourbon County, Ky. ; to Warlock \& Megibben, Lair, Ky. ; to IV. D. Urmston, Cynthiana, Ky., who sends pedigree. Died r 896 .

Sire of Wildbrier, $2: 22^{3} \%$.

FOREST GOLDDUST (I-I6), chestnut, I6 hands, I250 pounds; foaled I 872 ; bred by L. L. Dorsey, Jr., Louisville, Ky. ; got by Golddust, son of Vermont Morgan: dam Dark, said to be by Alexander's Edwin Forrest, son of Young Bay Kentucky Hunter; $2 \mathrm{~d}$ dam Wanderer, by Desha's Saladin, son of American Eclipse ; and $3 \mathrm{~d}$ dam the West Sparks mare. Kept near Eminence, Ky. Sold to Messrs. Hornsby, Crabb \& Co., Eminence, Ky.; to J. S. Callaway, Smithfield, Ky., April, I884. Died r 885. Mr. Hornsby, writes: "Forest Golddust trotted over the Lexington (Ky.) track privately, in $2: 22 \frac{1}{2}$." See The Morgan Horse and Register, Vol. I., p. 738.

Sire of Circulator, $2: 27 \frac{1}{2} ;$ I sire of $\mathrm{I}$ trotter; 3 dams of 3 trotters

FOREST HAL ( $\left.\mathrm{x}-3^{2}\right)$, bred in Middle Tennessee; said to be by Looney's Hal, son of old Tom Hal Jr.: dam by Bay Tom, 2:23, foaled I869, which see. Sold to J. D. Perkins, Selmer, Tenn. Information from J. H. Haram, Ramer, Tenn., breeder of Rattler Hal, 2:18, also from W. J. Liphr, Pocahontas, Tenn.

Sire of 4 pacers $(2:$ I $21 / 2)$; I dam of I pacer.

FOREST HIATOGA, dun; foaled 1865 ; bred by S. P. Vickers, Coal Run Township, Belmont County, O. ; got by Flying Hiatoga, son of Hanley's Hiatoga : dam dun, bred by Elisha Pickering, said to be by Woodmansee's Snap (thoroughbred) ; 2 d dam dun mare, brought from Loudoun County, Va., and said to be by Will Forester. Sold to E. Bassett, Milan, O.; to I. C. Towner, Elgin, Ill. ; to C. B. Ellis, Huntley, Ill. Sire of Nelly Allison, $2: 19 \frac{1}{4}$.

FOREST HUNTER, blood bay, I 6 hands; foaled about I832; bred by Whitehead Hicks, South Hempsted, Queens County, L. I., got by Chancellor, son of Almack, by Mambrino: dam said to be by Duroc. Kept I 848 and perhaps other seasons, by Aiken W. Hiller at Mayville, Chautauqua County, N. Y., and sold by him, 1849, to Mr. Matterson afterward of Sugar Grove, Warren County, Penn. Information from Thompson Jackson, Jamestown, N. Y.

FOREST KING, chestnut; foaled I 866 ; bred by Dr. L. Herr, Lexington, 
Ky.; got by Mambrino Patchen : dam Minnie McGrath, a pacing mare, untraced. Sold to S. R. Streator, Cleveland, O., about I 870 ; to Mark Richardson; to William Adams, Hubbard, O., whose property he died, June, 1880. Pedigree from E. D. Herr, son of breeder.

Sire of 2 trotters $(2: 201 / 2)$; I sire of 3 trotters; 4 dams of 4 trotters.

FOREST KING ( $\mathrm{I}-32), 2: 27$, brown; foaled June $\mathrm{I} 869$; bred by Willis Hollister, Granville, N. Y.; got by Honest Dan, son of Noble's Hamiltonian : dam bought by Mr. Hollister of M. C. Jones, West Pawlet, Vt., who bought her when three, of a man in Hartford, N. Y., said to be by Wildair, that was brought in his dam from vicinity of Poughkeepsie, to Washington County, N. Y. See The Morgan Horse and Register, Vol. I. p. 875 .

Winner of Io races.

FOREST MAMBRINO, $2: 32$, chestnut; foaled 1876 ; bred by L. Herr, Lexington, Ky.; got by Mambrino Patchen: dam a fast pacing mare that came from New Orleans. Sold to John Carroll, St. Catherines, Ontario, Can. ; to John Leys, Toronto, who sends pedigree.

Sire of 8 trotters $(2: 161 / 4)$; I dam of $I$ pacer.

FOREST PRINCE (I-I 28$), 2:$ I $53 / 4$, bay, with star and four white feet, I6 hands, II 7o pounds; foaled $\mathrm{I} 882$; bred by David Baird, Springfield Center, N. Y. ; got by Hambletonian Prince, son of Hambletonian : dam, Majolica, black, bred by H. R. Rathburn, Albany, N. Y., got by Harry Clay, son of Neave's Cassius M. Clay Jr.; 2d dam brown, bred in Virginia, said to be by Revenue, son of imported Trustee. Sold to C. D. and H. H. Wheeler, West Winfield, N. Y., who send pedigree. Pedigree also from breeder.

Sire of 4 trotters $\left(2: 24^{1 / 4}\right)$.

FOREST TEMPLE, and half brothers of Flora Temple.

A correspondent of Wilkes Spirit of the Times, writes, dated Woodburn, Ky., Oct. I4, I859:

Mr. WiLKES :

I see that you are again giving the history of Flora Temple, and I hope it will not be amis to send you a list of four of her half brothers, who are owned, as well as Madam Temple, by R. C. Alexander. I will give you the list.

Forest Temple, four years old, by Edwin Forrest ; Hunter Temple, three years old, by Edwin Forrest; Norman Temple, two years old, by Norman ; Pilot by Pilot Jr. (weanling).

Edwin Forrest was raised in Oneida County, N. Y., and is of the Kentucky Hunter stock. Norman was by the Morse Horse, near Lansingburg, N. Y., the reputed sire of Gray Eddy. Pilot Jr., is of a famous Kentucky trotting and pacing stock.

All of the above colts are fine size, and form, beautiful bays, not a white foot in the party, and all promise to be fast.

Yours,

H. S. A. 
Forest Temple was owned at one time by J. F. Love, Paris, Ill. He was awarded second premium on roadster stallions, at the Illinois State Fair, I 864 .

FOREST VERMONT (3-128), said to be by James Hurst's Vermont, son of Gill's Vermont: dam by Alexander's Edwin Forrest, son of Young Bay Kentucky Hunter; 2 d dam by Birmingham, thoroughbred, son of Stockholder; 3 d dam by Bertrand, son of Sir Archie; and $4^{\text {th }}$ dam by Sumpter, son of Sir Archie. See The Morgan Horse and Register, Vol. II., p. 128 .

Sire of dam of Katherine S., $2: 17 \%$.

FOREST WILKES, $2: 24 \frac{1}{4}$, bay; foaled I 882 ; bred by T. J. Sydner, Mount Sterling, Ky. ; got by Bourbon Wilkes: dam Ned (dam of Clemmie G., $2: 15^{1 / 2}$ ), bay, bred by Thomas Turner, Mount Stérling, Ky., got by Berkley's Edwin Forrest, son of Edwin Forrest; 2d dam Lady Turner, gray, bred by Hon. Thomas Turner, Montgomery County, Ky., got by Mambrino Chief; 3d dam said to be by Gray Eagle; and 4 th dam by Sir Wm. Wallace, son of Bolivar. Sold to T. C. Wilcox, Ivy Mills, Penn., who advertises him with above pedigree in The Spirit of the Times, May, I89o.

Sire of Diamond Wilkes, $2: 24 \frac{1}{4}$.

FOREST WILKES, $2: 14 \frac{1}{4}$, bay, I $53 / 4$ hands, ro5o pounds; foaled I 885 ; bred by R. H. Moon, Georgetown, Ky. ; got by Bourbon Wilkes : dam Florence C., said to be by Forest Clay, son of Gould Clay ; 2d dam by Harry B. Patchen (Kirtley's) ; and 3 d dam by Expert. Sold to M. F. McHaffie \& Son, Stilesville, Ind., who send pedigree; to Denny Bros., Ligonier, Penn.; to S. M. Klotz, Brooklyn, N. Y.; to A. W. Clapp, Passaic, N. J.

Sire of Phœbe Mack, $2: 261 / 4 ; 5$ pacers $\left(2: 15 \frac{1}{4}\right) ;$ I dam of I pacer.

FORSBURG, bay, I6 $\frac{1}{4}$ hands ; said to be by Cub (imported from England), son of old Belgrade, one of the most noted hunters in North of England. Advertised as above, I796, in Rutland Herald.

FORSEE (MISSOURI ABDALLAH) (3-ז 28$), 2: 29 \mathrm{~T} / 2$, chestnut; foaled I $88 \mathrm{I}$; bred by J. W. Forsee, Williamstown, Mo.; got by Colman's Abdallah Jr., son of Alexander's. Abdallah: dam Missouri Girl (dam of Pearl, $2: 30$ ), black, foaled I 864 , bred by John T. Stewart, Lima, Ill., got by Morey's Lath, son of Rowan's Lath; 2 d dam Fly, said to be by Morgan (Wade's) ; and 3d dam Fly, by Farmer (Leachman's). Sold to R. C. Risk, Williamstown, Mo., who is said to have refused $\$ 2800$ for him. Information from breeder.

Sire of 2 trotters $(2: 291 / 4), 2$ pacers ( $2: 19)$.

FORSHEE HORSE; foaled about i 844. See Royal George. 
FORTISSIMIO (3-32), black; foaled I 886 ; bred by H. N. Smith, Fashion Stud Farm, Trenton, N. J.; got by Slander, son of Tattler: dam Flageolet, black, star, I53/4 hands, foaled $188 \mathrm{I}$, bred by H. N. Smith, got by Gen. Knox, son of Vermont Hero ; 2 d dam Zither, bay, foaled I 874 , bred by Charles H. Kerner, New York City, got by Jay Gould, son of Hambletonian; 3 d dam Music's dam chestnut, foaled about I858, bred by W. S. Wallace, Scotchtown, N. Y., got by Roe's Fiddler, son of Webber's Fiddler ; $4^{\text {th }}$ dam said to be by American Star. Sold to John Newman, Elgin, Ill. ; to H. T. Chandler ; to Rudolph Shenkel, Monroe, Wis. Pedigree from catalogue of breeder.

FORTUNATUS (5-I28), bay; foaled I 878 ; bred by R. P. Pepper, Frankfort, Ky.; got by Almont, son of Alexander's Abdallah : dam Coquette, chestnut, bred by R. A. Alexander, Spring Station, Ky., got by Pilot Jr.; 2d dam Forty Cents, said to be by Wagner; 3d dam Geroine, by Gerow; and 4th dam Quaker Girl, by imported Leviathan. Sold to J. W. Hart, Oswego, Kan. ; to J. L. Morrow, Nashville, Tenn.

Sire of 3 trotters $\left(2: 2 I^{3} / 4\right), 9$ pacers $(2: 20) ; 6$ dams of 2 trotters, 5 pacers.

FORTUNE (I-I6), jet black with star and one white hind foot, I6 hands; foaled I 866 ; bred by James Mabbett, Washington Hollow, N. Y.; got by Superb, son of Ethan Allen, by Black Hawk : dam bay, one of a pair of twin mares bred by James Mabbett, Mabbettsville, N. Y., got by Holme's Washington, son of Mambrino Paymaster ; 2d dam sorrel, bred by James Mabbett, got by Gray Messenger, that stood at Chestnut Ridge, N. Y., son of Mambrino Paymaster ; 3 d dam sorrel, bred by Jacob N. Haight, Little Rest, N. Y., got by Mambrino Jr., son of Mambrino ; 4th dam bay, bred by Jacob N. Haight, got by Gray Childers, son of Brown Childers, by Koulikhan, son of Bajazet. Sold $\mathbf{1} 867$ to Timothy T. Jackson, Long Island, who sold to Alonzo Halliday, Jamestown, N. Y. ; afterwards owned by L. W. Peck, Jamestown, N. Y. See The Morgan Horse and Register, Vol. I., p. 593.

Sire of Weaver Boy, $2: 283 / 4$; I sire of 2 trotters; 6 dams of 7 trotters.

FORTUNE (3-128), bay; foaled I874; bred by James M. Mills, Bullville, Orange County, N.Y.; got by Chosroes, son of Hambletonian: dam Lady Magnolia, said to be by Magnolia, son of American Star; and $\mathbf{2 d}$ dam by Long Island Black Hawk.

FORTUNE (PEPPER HORSE) (I-8), bay or brown, I5 $1 / 2$ hands, I050 pounds; bred by Royal Turrill, Shoreham, Vt.; got by Black Hawk: dam black. Sold to D. E. Rust. Kept at Orwell, Vt. See The Morgan Horse and Register, Vol. II.

FORTUNE HUNTER ( $\mathrm{I}-32$ ), roan, star, snip, left hind foot white, I7 hands, I350 pounds ; bred by Sidney Clay, Lexington, Ky. ; foaled I 888 
the property of Wm. T. Withers, Lexington, Ky. ; got by Jay Bird, son of George Wilkes: dam Senorita, bay, bred by Sidney Clay, got by Coaster, son of Caliban; $2 \mathrm{~d}$ dam Betty B., said to be by Abdallah; 3d dam Joe Love mare, by Herr's Cœur de Lion, son of imported Cceur de Lion. Sold to N. J. Page ; to N. Bartholomew, Des Moines, Ia. Died about rgor. Pedigree from B. M. Page, Dallas Center, Ia., breeder of Sandy $P$.

Sire of Sandy $P_{.}, 2: 08 \frac{1}{4}$.

FORWARD ( $\mathrm{I}-32$ ), black; foaled I 875 ; bred by W. J. Lyle, Danville, Ky. ; got by George Wilkes: dam Lou Coons, bay, bred by E. Lewis, Fayette County, Ky., got by American Clay; $2 \mathrm{~d}$ dam Nokomis, said to be by Mambrino Chief; 3d dam Mrs. Caudle dam of Ericsson, which see. Sold to R. P. Pepper, Frankfort, Ky. ; to Dr. Wm. Croskey, Steubenville, $\mathrm{O}$.

Sire of 3 trotters $(2: 20), 2$ pacers $(2: 181 / 4) ; 3$ sires of 3 trotters, 2 pacers; 2 dams of $I$ trotter, $x$ pacer.

FOSTER BOY (7-256), bay; foaled 1887 ; bred by W. T. Stewart, Kalamazoo, Mich.; got by Fletcher's Hambletonian, son of Masterlode: dam Kate, said to be by Blue Bull; and 2 dam by Woodford Mambrino, son of Mambrino Chief.

Sire of Billy Foster Boy, $2: \mathrm{Ir}^{1} \frac{1}{2}$.

FOSTER PALMER ( $\mathrm{x}-64$ ), said to be by Gideon, son of Hambletonian.

Sire of Lilly B, $2: 28 \frac{1}{4}$.

FOX, bay; foaled I7r4; bred by Sir R. Aston; got by Clumsey, son of Hautboy and the dam Miss D'Arcy's pet mare: dam Bay Peg, bred by Mr. Leedes, got by Leedes' Arabian; 2 d dam Young Bald Peg, said to be by Leedes' Arabian, some accounts say by Spanker; 3d dam The old Morocco Mare (Spanker's dam); and 4th dam old Bald Peg, by an Arabian from a Barb mare, bred by Lord Fairfax. Died at Hampton Court, Weybridge, I738. See General Stud Book, Vol. I., pp. 3, 395.

FOX, advertised in 1775 , as foaled in 1767 , and got by the famous English horse Fox, at Newport, R. I. : dam a Narragansett mare.

FOX, sorrel or chestnut, between $\mathrm{I}_{4}$ and $\mathrm{I}_{5}$ hands; foaled I786. Advertised I 793, in Greenfield (Mass.), Gazette, to be kept in Deerfield, Mass., as follows :

"An excellent saddle horse, remarkably strong built, clean limbed and well gaited, though peculiarly adapted to the saddle is perhaps not excelled in the harness by any horse of his size. He was bred in Rhode Island, and is said to be in part of the Narragansett breed. Has been kept some years in the south part of the county."

Advertised in same paper I 794-5-8 and I 80I-2. 
FOX, said to be by a son of Wildair. Advertised in Vermont Journal, Windsor, Vt., 1796.

FOX, bay; foaled I8r 3 ; bred by Col. Phinney, Shrewsbury, Vt., said to be by Sherman Morgan.

Mr. Harvey Yale, Middlebury, Vt., in interview, I887, said :

"The next horse I got was Fox. He was a handsome bay horse about the size of Arab. Fox was the first Morgan brought into this region.

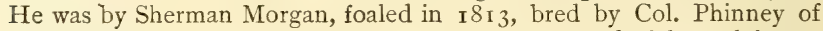
Shrewsbury. I bought him in 1825 . He was a wonderful good horse. $\mathrm{He}$ would march on parade without a rider. You could leave him and he would stand bold as a lion. I kept him the season of 1825 myself, and the next two or three seasons he stood at Huntington in hands of Charles D. and Russel Stevens. I had him back and owned him several years more, and am very sure I sold him the fall before I bought the Saxton farm. In those days I kept a stallion every season. Young Cock of the Rock was the first stallion I bought after I sold Fox. The spring I moved on to that farm I bought of young Smead the bay horse Young Cock of the Rock. I hired that farm and went on to it in the spring and in two or three months I bought it. (Town records show that Mr. Yale bought this farm in July, $\mathbf{r} 834$. Mr. Yale found a bill of sale of Young Cock of the Rock, dated May 29, I834, signed A. Smead)."

FOX, bright bay; foaled I 820 ; said to be by Quicksilver : and dam full bred English mare. Advertised $\mathrm{r} 823$, by Joshua Lane at Hampden, Me., and $\mathrm{I} 824$ by G. Flagg, Hampden, to stand at Bangor and vicinity.

FOX (CORBIN'S) ; said to be a descendant of Justin Morgan. Owned by Royal Corbin, Craftsbury, Vt.

Mr. Rice of Craftsbury, 90 years old (1888), in interview, said :

"I worked for Royal Corbin the fall after I was $2 \mathrm{x}$. He had the Fox horse, that after he sold him, went to Boston. The man that owned him failed up. To save his horse he started for Canada. Two men followed, but Fox got to Canada four hours first; had two hours start. I tended the horse mostly one season. Not a large horse ; probably might weigh 900 or 1000 pounds ; called chestnut, considerably dark, a little dapple [when we saw Mr. Rice a year ago he spoke of the horse as bay], rather short legged, well proportioned, do not think he was especially light behind. Corbin lived in Craftsbury, where Job Allen does now. I worked for the old Squire altogether about one year and a half. The horse had about 60 mares a year. Guess he was about ten years old, perhaps, but don't know ; not an old horse; don't think he raised him. Jefferson Moore raised two colts from the horse. Esquire Corbin bought them and sold them at Montreal for \$1oo each. It was to Stanstead that the man rode the horse from Boston, so I understood. I rather think it was about two years after I worked there that he sold the horse. He wasn't a great horse for a race horse. They tried him once with Morse mare ; mare outran him. I think Mr. Corbin owned him six years or more. I know the horse was owned by him two or three years before I went there and I guess two or three after I left. 
Pretty much all I know about him, they called him the Fox horse. The old Esquire was trading horses all the time. The Corbins were very nice folks. He had two mills-saw and grist. He wasn't at home much; his wife was a sister of Gov. Crafts. I never worked for him before I was $2 \mathrm{I}$. When I was $2 \mathrm{I}$, a neighbor told me he would give me fifty cents a day, and I worked for him till fall, then went to Mr. Corbin's. I know it was the fall after I was $2 \mathrm{I}$.

"Fox was a great traveler on the walk. On the run I think other horses would out-do him. A great roadster they called him, on the road. Wide between the eyes and pleasant looking and was a pleasant horse, easy to handle. No white at all, hind legs to gambrel, rather dark colored. There was not any stallion in Craftsbury, that I knew of before Fox, and I think not in Greensboro, I have been right here 87 years. There were of our family nine children. Five girls and four boys. I was the oldest. All went West but myself and all dead but one sister.

"The old Esquire brought out a white horse from Montreal called a race horse; don't know what he did with him.

"People of this age don't know anything about hardships. Those that came before I did used to go to Peacham to mill. Father came to town in I79I. Man by name of Peck used to preach. No meeting houses; all log houses; used to hold meetings in barns. I was a small boy when Phineas Peck preached; do not think he had any pay; folks not able to pay much in those days. Money was hard; no way to get money. I think the Craft's were Connecticut folks. The Colonel had but one son, the Governor, and one daughter, Matilda, that married Corbin."

\section{Mr. Leonard Hariman of Craftsbury, 86 years old, said :}

"I remember the horse Corbin had; think he was a chestnut. I was perhaps 15 or I6. Not a very large horse; not more than middle size; handsome horse. He had him three or four years, perhaps more. I do not know where he got him. He called him Fox. Don't think I can recollect any stallion before that. Don't think I was over I4. I think they called him a Morgan horse. Don't think he had any white."

Mr. Seaver of East Craftsbury, said :

"I am 66 years old. Little Fox was kind like the Morgans; little black horse; could shave your beard almost, if he had a razor. He was owned by Esquire Corbin; coal black, should say; perhaps some white feet. People thought if they could have one of these little Fox colts they would endure. The old Jennison mare was one of his colts."

Mr. Seaver thought, and was very sure, that when a small boy he saw Little Fox running in Corbin's yard. He also said that Fox was ridden from Boston to Canada in fast time. He said further:

"The Mores Horse at Glover died, perhaps, 25 years ago, bred and owned by Peter Mores, called old Champ, got by a horse in Haverhill called a Champion; long bodied, coal black, rooo pounds, I $_{5-2}$, long, tall, rangy fellow. Ashley Gray was owned by Leonard Morse of Craftsbury - a large horse."

FOX CLINE, blood bay, black points, with three white ankles, about $\mathrm{I}_{5} \mathrm{I} / 2$ hands, 800 pounds; bred by J. L. Cline, Union City, Mich. ; got by Young 
Florizel: dam Jenny, said to be by Spencer's Bacchus, son of Cone's Bacchus. Information from breeder.

FOXHUNTER, $161 / 2$ hands, said to be imported and at one time owned in Maryland. Advertised as above, $\mathbf{1 7 9 6}$, in Connecticut Courant, to be kept at Hartford.

FOXHUNTER, brown, $153 / 4$ hands. Owned at East Troy, Wis., and taken from there to California by Sam Eyckshimer.

Sire of Dirigo, $2: 27$, foaled I8-.

FOXHUNTER. See Gen. Wayne.

FOXHUNTER (KENTUCKY HUNTER) (I-8), chestunt; foaled about I850; bred by Solomon Christy, Oneida County, N. Y.; got by Loomis One-Eyed Kentucky Hunter, son of Kentucky Hunter: dam said to be by Gifford Morgan. Taken when three years old, by breeder to Genesee County, N. Y., where he was afterwards owned by Harry Merriman of North Byron. A correspondent writes:

Mr. Battell,

Dear Sir :-My father sold the mare to Mr. Stebbins the winter of '6I62. She was then four or five years old, dark sorrel, some of her feet white, white stripe in face, I5 hands high, weight about IIoo. Mr. Stebbin's address at that time I am unable to give, he was a man about 25 years of age, in the employ of some man who was through this section buying fat cattle. I have obtained some information of her sire Fox Hunter or more properly called Kentucky Hunter. He was a colt of One-Eyed Hunter owned by G. W. Loomis of Oneida County, N. Y. Solomon Christy of Oneida County, N. Y., raised Kentucky Hunter, brought him to Genesee County, N. Y., the Spring he was three years old. He was chestnut color, white feet, and white stripe in face, about I5 hands high. A greater number of fast very sharp goers have originated from him, than from any other horse in this vicinity; his dam was a Gifford Morgan mare, dark bay, could trot a mile in less than three and repeat in same time under saddle. This Kentucky Hunter was at the time my father used him, owned and kept by Harry Merriman at North Byron, Genesee County, N. Y. He resides there now.

FOXHUNTER (ANTISDALE'S, COOK HORSE), bright bay with very little white on near fore and hind foot, $153 / 4$ hands, I I oo pounds; foaled June Io, I 854 ; bred by Otis Antisdale, Ontario County, N. Y.; got by Van Auken's or Wormley's Foxhunter, son of Whaley's Foxhunter : dam said to be by imported Sampson, known as the Chapman horse and said to be an English draft horse. Sold, I862, to George Potter, Ontario, Wayne County, N. Y., who sold him 1868 for $\$ 700$, after which he changed hands several times, passed to a Mr. Cook and was repurchased in 1877 by his breeder, whose property he died, I878. J. Franklin Antisdale, son of breeder writes : 
"He was in every way a very perfect and beautiful horse, always successful is the show ring and an excellent sire."

Mr. Smith Feek of the Jewett Stock Farm, Willink, N. Y., writes :

"The Cook Horse was in my opinion the best horse of the lot. He got a great many fine roadsters."

FOXHUNTER (BLODGETT'S), bred by Ephriam Blodgett, Canandaigua, N. Y.; got by Foxhunter (Whaley's), which see: dam said to be thoroughbred, by Duroc, son of imported Diomed. Kept all his life in the neighborhood where he was bred. He left excellent stock, noted for intelligence, good disposition, and fine road qualities. Died aged 30 years.

Advertised i 864 at Canandaigua, N. Y., by E. N. Green.

Sire of dam, bred by Jerome Bornhart, Knoxville, Penn., of Christine $2: 29$ T/4, bred by Morris Seeley, Elmira, N. Y. Information from J. S. Brown, Westerly, R. I.

FOXHUNTER (CARTER'S). See Carter Foxhunter.

FOXHUNTER (POTTER'S) (I-32), bred by Seymour Clark, Marion, Wayne County, N. Y. ; got by Antisdale's Foxhunter, son of Wormley's Foxhunter by Whaley's Foxhunter : dam, said to be by Green Mountain Morgan, son of Gifford Morgan ; 2d dam by Gray Messenger ; and $3 \mathrm{~d}$ dam by Goldfinder. From American Cultivator which states that this pedigree is from Mr. Potter.

Sire of Lottie, $2: 29 \frac{1}{2}$.

FOXHUNTER (VAN AUKEN'S OR WORMLEY'S), bred by James Dillon, Farmington, Ontario County, N. Y.; got by Foxhunter Whaley's which see : dam, said to be by Tally Ho; and 2 d dam by Spectator. Owned in Wayne County, N. Y.

FOXHUNTER (WHALEY'S) bay, I6 $1 / 2$ hands, I 360 pounds; foaled about I81 2 ; said to have been bred on the line between Pennsylvania and Virginia, and got by Foxhunter a southern turf horse, son of Selim, by imported Janus, from a dam that was called an English Foxhunter mare : dam said to be by a Tippoo horse and a fast trotter. Taken when two years old to Genesee, Livingston County, N. Y., by a Mr. Mac, who sold him to Mr. Whaley, Sr., and he several years after to James Parker, who took him to Ohio, where he remained four or five years. He was then purchased and brought back to Livingston County, by Samuel Chappee and sold by him to Robert Whaley, who sold him when 30 years old to Welcome C. Ross. Mr. Ross brought him to Farmington, N. Y., where he died.

The above southern turf horse by Selim, son of Janus, was said to have won several \$200o purses. Information from a correspondent of the 
Vermont Stock Journal, June 1858 , who states that he obtained it from D. B. Whaley and others acquainted with the horse.

Completed by information given to Mr. Parlin of the American Cultivator, by J. S. Antisdale. The correspondent of the Stock Journal adds :

"His stock are generally good size and good travelers, but not so hardy and enduring as some."

Clarkson Aldrich of Manchester, N. Y., writes :

"I knew the old Whaley Foxhunter from the time Welcome C. Ross brought him here to Farmington, until his death. I saw Mr. Ross this month. He said he bought the old horse about i 842 . While Ross kept this horse he got a great many good horses; there were quite a number of stallions kept from him, every one a good stock getter. There was one raised by James Dillon of Farmington, Ontario County, N. Y. His dam was said to be by Tally-Ho, her dam by a Spectator horse. This Dillon colt when grown became the Wormley Foxhunter, he got the Otis Antisdale Foxhunter (dam unknown). Otis Antisdale lived in Farmington, Ontario County, N. Y. The Antisdale horse got John Potter's Foxhunter, but I think the dam of Potter's horse did more than his sire for he is a perfect model of a Morgan."

\section{FOXHUNTERS OF WESTERN NEIV YORK.}

"The original of the name, so far as our knowledge goes, was known as the Whaley Horse, and died about $\mathrm{i} 8+5$. He was brought from Maryland by a man named Moak, who sold him to Robert Whaley, of Livonia, in Livingston County. He was afterwards sold to Ohio parties, and repurchased and brought back by Welcome Ross, of Farmington, Ontario County, whose property he died. His breeding was given by Whaley as by Foxhunter, son of Selim, by imported Janus; dam by a Tippoo horse. From the death of Foxhunter in New York, back to the birth of Janus in England we have a full century, and the claim is no doubt a fiction. Indeed, it is probable the horse didn't come from Maryland at all, for it is stated that his dam was by a Tippoo horse, and if this is true it would account for some trot and some pace in his descendants, just as we see these tendencies developing themselves. Mr. Otis Antisdale bred and owned a son of this horse called Foxhunter, and his dam was said to be by imported Sampson, an English draft horse. This horse was owned for a time by George Potter, of Ontario, N. Y., and was repurchased by Mr. Antisdale, whose property he died about 1877 . The trotting mare Lady Pumpkins, with a record of $2: 36$, has been credited to this horse, and also to his sire, but as the dates seem to indicate that the old horse was almost impossible, we will leave the horse with this one until the matter is cleared up.

"Mr. John Potter, of East Webster, Monroe County, bred and reared a colt by the Antisdale or Potter Foxhunter that is still living, and the most prominent of the family. George and John Potter are brothers, and as both their horses, sire and son, were known as Potter's Foxhunter, we were led into confusion in what we have heretofore said on the subject. John Potter's Foxhunter is the the sire of Lottie, with a record of $2: 29^{1 / 2}$, and along with other trotters that his owner enumerates, he claims that he is the sire of twelve pacers. It is said that his dam was brought from Vermont and that she was a Morgan."-Wallace's Monthly. 
FOXIVOOD (5-64), $2: 24^{1 / 2}$, about 15 hands; foaled 1884 ; bred by John S. Clark, New Brunswick, N. J.; got by Nutwood, son of Belmont : dam Lacly Foxie, $2: 24 \frac{1}{4}$, chestnut, foaled 1869 , bred by Chandler Shattuck, Ticonderoga, N. Y., got by Daniel Lambert, son of Ethan Allen; 2d dam old Foxey, bred by Chandler Shattuck, got by Breed Horse, son of Black Hawk. Pedigree from Ridgewood Stock Farm catalogue, Danbury, Conn. Sold to W. Sisson, Crown Point, N. Y. Advertised, 1890-93 in St. Lawrence (N. Y.), Plaindealer.

Sire of 2 trotters $(2: 261 / 4)$; Whitewood, $2: 22 ; 3$ dams of 2 trotters I pacer.

FRANCE, $2: 26$, bay, star and snip on nose, also off hind coronet white, I 6 hands, I 200 pounds; foaled April I 7, r88 I; bred by W. C. France Lexington, Ky.; got by Alexander, son of Ben Patchen: dam Mollie F., bay, bred by Bryan and Castle, Lexington, Ky., got by George Wilkes, son of Hambletonian; 2 d dam Mischief, said to be by Mambrino Chief; and 3 d dam Florella, by Bertrand, son of Sir Archy. Sold to S. H. Godfrey, Jackson, Mich, I 884 , by R. S. Veech, Louisville, Ky. ; to Farrell \& Godfrey. Pedigree from breeder and from Parma Breeding Stables' catalogue.

Sire of 6 trotters $(2: 18), 3$ pacers $\left(2: 14 \frac{1}{2}\right) ; 3$ dams of 2 trotters I pacer.

FRANCIS IVILKES (3-I28), bay, star, one hind foot white, I5 I/2 hands, rooo pounds; foaled I 887 ; bred by John H. Lamb, Jerseyville, Ill. ; got by Dumas, son of Onward: dam bay, bred by John H. Lamb, got by Francis Alexander, son of Ben Patchen; $2 \mathrm{~d}$ dam brown, bred by John H. Lamb, got by Live Oak George, son of Black Hawk. Sold to Mr. Oberlin ; to Dave Ross. Pedigree from Herbert Lamb, son of breeder. Sire of $X$ Ray, $2: 1 \mathrm{II}^{1 / 2}$.

FRANK (CHILSON HORSE) ( I- 8 ), bay, 975 pounds; foaled I 850 ; bred by Wm. Needham, Bristol, Vt.; got by Brown Dick, son of Harris Hamiltonian: dam, old Dilly, 15 I/4 hands, long body, neck and tail, could trot in about $3: 00$, foaled about I830, bought by Mr. Needham of Mr. Furman, Bristol, Vt., said to be by Sherman Morgan; and $2 \mathrm{~d}$ dam by Justin Morgan. Taken by breeder to Wisconsin and sold I 856 for \$ I 200 to O. G. Chilson, Cedar Falls, Ia.

L. A. Squire, Poynette, Wis., writes :

"Frank was typical Morgan, and could trot in 2:42. A good many of his stock took back to the Harris Hamiltonian and were large."

Editor Dunton's Spirit of the Turf:-In your issue of Dec. il, I 89o, Mr. Christianson desires information about the Chilson Horse. O. G. Chilson of Leeds Center, Wis., who owned that horse during his life in Wisconsin, is a brother-in-law of mine, and I lived near neighbor to him while he owned the horse. Frank (sometimes called the Chilson Horse), was bred in Bristol, Vt., got by Brown Dick, son of Harris' Hamiltonian, by Bishop's Hamiltonian, son of imported Mes- 
senger; dam a Green Mountain Morgan mare. Frank was brought into Leeds, Wis., by Mr. Needham (who raised him), of Bristol, Vt., and sold to O. G. Chilson, in the year 1855 or 1856 , for $\$ 1200$, including sulky, harness, blankets, whip and other fixtures, which was considered a large price for a horse in those days. His recorded time in Middlebury, Vt., I think was $2: 42$. He had a very limited chance in the stud, having come to this country a little too early. Frank died, I think, about I 865 .

He left some very fine stock, which was valued very high, and their descendants are much sought after now by horsemen. And if the man owned the horse now with the reputation he has left hehind, it would be a fortune sure.

Poynette, Wis., Dec. 15, I89o.

L. A. SQuire.

Mr. O. G. Chilson writes to Dr. S. M. Blake :

Leeds Centre, Wis., Mar. 28, I 876.

"The pedigree of my old Frank horse as I got it from Mr. Wm. H. Needham, of Vermont, is as follows: Frank was by Young Hamiltonian (Brown Dick) ; grandsire Harris' Hamiltonian, gray ; great-grandsire Bishop's Hamiltonian, son of imported Messenger ; dam by Sherman Morgan; grandam by Justin Morgan. Frank was foaled in I 850 , and I bought him in 1856 , paying $\$ \mathrm{I}_{2} \mathrm{200}$. His weight in good condition, I Ioo pounds, trotting record, $2: 50$. If he was alive now he could do a good business at $\$ 50$ to $\$ 75$ per mare.

$$
\text { Yours truly, O. G. Chilson. }
$$

FRANK, bay ; foaled $\mathrm{s} 852$; bred by Mr. Beaupau, near Montreal, Que. ; got by Prendergast's Young St. Lawrence, son of St. Lawrence : dam said to be by Red Bird. Taken to Indiana, 1856 , by Joseph Pendleton. Owned by George W. Frampton, Pendleton, Que., whose property he died, r879. He could trot and pace very fast.

Sire of 2 trotters $\left(2: 281 \frac{1}{4}\right) ;$ I sire of I trotter; 2 dams of I trotter, I pacer.

FRANK (I-I28), bay; bred by David Johnes; got by Chas. E. Lowe, son of Geo. M. Patchen : dam (dam of William Wallace) chestnut. Above information from Austin A. Wright, Hightstown, N. J., breeder of Ajax, $2: 25$.

Sire of Ajax, $2: 25$.

FRANK (5-64), $2: 20$, black, right hind foot white, I 6 hands, I 200 pounds ; foaled June I5, I867; bred by H. L. Ward, Middleville, N. Y.; got by Guiteau's Young Oneida, son of Pathfinder (Benedict's), by Black Hawk : dam, dark brown, came from Canada, and said to be of Morgan blood. Sold and went to Cleveland, Ohio. Gelded young. Pedigree from breeder. Died I 886.

FRANK JR., black with star, I5 hands, Iooo pounds; foaled I879; bred by W. M. Tockridge; got by old Canadian Frank : dam, bay, said to be by Foxhunter, son of Foxhunter. Sold to Washington Jackson, 
Woodville, Ind. Died r 897 . Information from Chas. R. Jackson, Shirley, Ind., breeder of Roana J., $2: 2 \mathrm{I} 1 / 4$, who writes: "Old Canadian Frank was brought from Canada with Fergerson's pacing Joe, by Joe Haselton."

Sire of Roana $\mathcal{F}_{\text {., } 2: 21 \%}$

FRANK A., $2: 22$, gray, $15 \% \frac{\mathrm{T}}{2}$ hands, 1 Ioo pounds; foaled 1880 ; bred at Clark O., by Frank Lowe, Mt. Vernon, O. ; got by Rex Hiatoga, son of Hiatoga: dam gray, bred by Frank Lowe, got by Splendor. Sold to Walhunter, \& W. Painter, Holmesville, O. Pedigree from Charles Ports, Wooster, O. Gelded young.

Sire of 2 pacers $\left(2: 12 \frac{1}{2}\right)$.

FRANK ALLEN; black, with star and stripe, I $51 / 2$ hands; foaled 1852 ; said to be by Hawkins' Priam, son of imported Priam : dam by Hawkins' Fashion, son of imported Trustee : $2 \mathrm{~d}$ dam by imported Rowton; 3d dam Young Favorite, by imported Bedford; and $4^{\text {th }}$ dam by imported Diomed. Owned, run and sold by D. McDaniel.

Mr. S. P. Salter, Lexington, Ky., writes :

"Frank Allen was an old broken race horse brought from Virgınıa to Columbus, Ga., and kept several seasons, by a man named Philip Pryor. The man that bred Gin Burner is dead, and I could never trace her pedigree. She was a black mare, I $43 / 4$ hands; I bought her, when three years old for $\$ 60$, and raised three foals from her by Barney WilkesMary S., $2: 28$, Lena Wilkes, $2: 29^{1} / 2$, and Sam Wilkes, $2: 291 / 2$. She died in 1885 . Could trot in $2: 54$ and was one of the gamest mares I ever saw."

O. S. Jordan, Columbus, Ga., writes :

"Frank was a long distance runner; his last race was made at this place about 20 years ago, four miles, against Sue Washington and Franklin. Frank Allen won the race and in some way hurt himself and was that day sold to a Mr. Abicrombie for $\$ 150$, and then died in about Io days."

Said to be sire of Gin Burner, dam of Mary S., $2: 28$, Lena Wilkes, $2: 291 / 2$, and Sam Wilkes, $2: 29 \frac{1}{2}$.

FRANK ALLEN ( $\mathrm{I}-8$ ), bay with star, one foot white, $\mathbf{5}$ hands, 830 pounds ; foaled 1857 ; bred by Warren Potter, Danielsonville, Conn.; got by Ethan Allen, son of Black Hawk: dam bay, brought from northern Vermont, near Stanstead, P. Q., by Wm. Bishop. Sold to Leander Sayles, Killingly, Conn. Gelded 1869. Trotted in $2: 37 \frac{1}{4}$ on a half mile track. Got but 33 colts. See the Morgan Horse and Register, Vol. I., p. 555 .

Sire of 2 trotters $\left(2: 24 \frac{1}{2}\right)$.

FRANK ALLEN. A horse of this name was awarded premium at the Illinois State Fair, I86o.

FRANK ALLEN (3-16), 2:39 $\frac{1}{4}$, black, with two white hind heels, I5 
hands, 900 pounds; foaled I 870 ; bred by John R. Farnum, Waltham, Mass.; got by Ethan Allen : dam Nelly Litchfield, a fast pacing mare, said to be by Hiram Drew, son of Drew Horse ; 2 d dam Young Litchfield, by Eaton Horse, son of Avery Horse; 3d dam by Bush Messenger of Maine; and $4^{\text {th }}$ dam Bullard mare, part thoroughbred, brought from Brunswick to Anson, Me. Owned, I 876, by breeder. Record made in sixth heat of a race that he won. See The Morgan Horse and Register, Vol. I., p. 608.

Sire of Star Allen, $2: 261 / 2$.

FRANK ALMONT (3-I2 8 ), $2: 34 \frac{1}{4}$, bay, left hind foot white, $161 / 4$ hands, I Ioo pounds; foaled I884; bred by L. H. Mayberry, Park Station, Morey County, Tenn.; got by Almont Jr. : dam Fly, said to be by Rob Roy, son of Copperbottom. Sold to Hartland Bros., Columbia, Tenn. ; in $\mathbf{I} 888$, to Silas Tyson, Montgomery, Ala., who sold him, I896; to Mitchell Bros., Montgomery, Ala.; to W. R. Wood, Pleasant Hill, Ala. Information from Silas Tyson, Montgomery, Ala.

Sire of 2 pacers $(2: 161 / 4)$.

FRANK B. (I-I6) dark brown with white in face, about I 200 pounds; foaled I 87 I ; bred by C. L. Brown, Leeds, Wis.; got by Royal George, son of Green Mountain Black Hawk: dam said to be by Frank (Chilson Horse), son of Brown Dick, by Harris' Hamiltonian. Sold by breeder in 1883 or ' 84 to his son, A. J. Brown of the same town, who, in January, I885, sold a half interest to Dr. L. A. Squires, Poynette, Wis., but afterwards bought it back. See The Morgan Horse and Register, Vol. I., p. $3^{87}$.

FRANK BENSON (3-256), bay, I61/2 hands, I30o pounds; foaled I 884 ; bred by Lorenzo Benson, Jonesville, Mich.; got by De Soto, son of Harold: dam Elizabeth Tilton, bay, bred in New York, and said to be by Willett's Champion, son of King's Champion. Died 1895. Sold to F. I. Kinney, Onsted, Mich., who sends pedigree.

Sire of Frankie B. R., $2: 221 / 2$.

FRANK BOX, dark bay with star, I6 hands, I 200 pounds; foaled I 880 ; bred by Frank Box late of Connersville, Ky.; got by Leve's Rob Roy, son of Gaines' Denmark : dam chestnut sorrel. Sold to Jake Barres ; to John S. Slatton; to Thos. Brown, Lexington, Ky. ; to John S. Redd, Hinton, Ky.; to Mat Slatton, Scott County, Ky. Information from John S. Redd. W. W. Scott, Baxter Springs, Kan., writes that he bred the dam of Roy S. to Frank Box, at Hinton, Harrison County, Ky.

Sire of Roy S., $2: 231 / 2$.

FRANK BUFORD (3-256), 2 :20, bay; foaled 1883 ; bred by Harrison Davoes, Farmington, Tenn.; got by Almont Jr., son of Almont: dam 
Sleepy Liz, gray, bred by Brit Ezell, Chapel Hill, Tenn., got by Pat Malone. Sold to C. L. Roberts, Murfreesboro, Tenn. ; to J. M Roberts, Readyville, Tenn.

Sire of Jack Buford $\left(2: 26^{3} / 4\right) ; 3$ pacers $\left(2: 09^{1 / 2}\right)$.

FRANK BURGESS, $2: 201 / 2$, bay, I5 hands, 1000 pounds; foaled 1887 ; bred by M. E. Burgess, Bennington, Vt.; got by Peacemaker, son of Hambletonian : dam Clothesline, bay, bred by M. E. Burgess, got by Melrose, son of Victor Von Bismarck; 2 d dam Fanny Peters, bay, bred by T. W. Park, North Bennington; got by Mohamet, son of imported Sovereign ; 3 d dam Mary Ellen, said to be by Mirabeau; and $4^{\text {th }}$ dam Arabella, by Bertrand. Sold to H. E. Burgess, who sends pedigree.

Sire of Beulah B., $2: 23 \frac{1}{4}$.

FRANK CAFFERTY; said to be by Cafferty Horse.

Sire of Fenness, $2: 20$.

FRANK CHAPMAN, dark bay, i6 $6 / 2$ hands, about 1200 pounds; said to be by Tuckahoe. Died at LaGrande, Ore. Information from D. A. McAlister, LaGrande, Ore., who writes dated Mar. 25, 'o9:

"In regard to breeding of Frank Chapman, he was by Tuckahoe. He was brought to Oregon in the sixties, about I868. I don't know much about his pedigree, although I raised quite a number of colts by him. He was bred somewhere in Illinois. A man by the name of Cole brought him to Oregon and sold him to a man in this County (Union). They did not seem to know much about his breeding. Cole has been dead a long time. Frank Chapman was a dark bay, $16 \mathrm{~T} / 2$ hands, weighed about I 200. I bred Blondie ; sold him at two years of age."

Sire of the dam of Blondie, $2: 191 / 2$.

FRANK CHEATHAM ( $\mathrm{I}-32)$, said to be by Andrew's Horse, owned in Tenn. : dam Rose, red roan, by Bill Brown's horse, which was a Copperbottom. Information from W. Thomas, Como, Miss., breeder of William R., $2: 15$.

Sire of William R., 2:15.

FRANK DUNN (YOUNG WINNEBAGO), dark chestnut with narrow strip in face and four white feet, $161 / 2$ hands, I 200 pounds; foaled 1856 ; bred by Oliver Holtshouser, Belmont, Wis. ; got by Winnebago, son of imported Glencoe : dam said to be thoroughbred. Owned many years by breeder. Information from John McKenna, Hollandale, Wis.

Sire of Amy B., $2: 24^{1 / 4}$.

FRANK E. ( I-I28), chestnut with star, silver mane and tail, I 6 hands, I 200 pounds; foaled May 5, I897; got by Joe, son of Canonicus, by Hinsdale Chief, son of Edwin Forrest: dam Lady, said to be by Michigan Boy, son of Gov. Hayes, by. Masterlode; 2 d dam Queen W., by Prince Albert; 
and $3 \mathrm{~d}$ dam Nell, by a grandson of Messenger. Pedigree from A. B. Wakeman \& son, Bedford, Ia.

FRANK EATON, (I-I6), $2: 4 \mathrm{I} \frac{1}{4}$, gray, I6 hands, I220 pounds; foaled I 878 ; bred by John Eaton, Coldwater, Mich.; got by Robert Whaley, son of Night Hawk : dam Kate, said to be by Magna Charta, son of Morgan Eagle. Sold to C. M. Sheldon, Burlingame, Kan., who sends pedigree.

Sire of Kate Eaton, $2: 161 / 2$.

FRANK ELLIS ( $1-32$ ), $2: 261 / 4,151 / 2$ hands, I045 pounds; foaled 1871 ; bred by Fred Hulse, Viola, N. Y. ; got by Happy Medium, son of Hambletonian: dam Dutch Girl, said to be by Edwin Forrest. Sold to Galaway \& Finnegan, Suffern, N. Y.; to C. A. Bush, Ithaca, N. Y.; to J. C. Craig, Hamilton, Ontario, Can.

Sire of 4 trotters $(2: 181 / 4)$; Oakland Boy, $2: 21 \frac{1}{4} ; 2$ dams of I trotter, I pacer.

FRANK ELLIS (I-I28), $2: 29 \frac{1}{4}$, about 15 I $/ 2$ hands, I Ioo pounds; foaled I879; bred by F. M. Camp, Homesville, O.; got by Hermes, son of Harold : dam dark bay, bred by F. M. Camp, got by Stranger (pacer). Sold to C. F. Emery, Cleveland, O.; to Col. Higginson, Boston, Mass.

FRANK F. (1-I6), $2: 26 \frac{1}{4}$, bay, black points, I5 1/2 hands, 1050 pounds; foaled about 1872 ; bred by N. B. Turner, St. Albans, Me.; got by Emperor William, son of Gen. Knox: dam bay, bred by N. B. Turner, got by Batchelder Horse, son of Drew; $2 \mathrm{~d}$ dam said to be Messenger. Gelded young. Pedigree from breeder.

FRANK FORESTER. Advertised for sale at Stable of E. K. Conklin, Philadelphia, in Spirit of Times, 1854 .

Sale of Trotters at auction, July i I, I 854 .

"Mac sold for $\$ 4$ roo to Mr. Mann of Baltimore; Tacony, for $\$ 3700$ to J. G. Bevens, N. Y.; Frank Forester to Mr. Mann, Baltimore, for $\$ 2350 . "$-Spirit of the Times.

FRANK FORESTER (3-I6), dark bay, I5 hands, Iooo pounds; foaled about I 859 ; bred by John Kent; got by Andrew Jackson, son of Black Hawk, by Sherman Morgan: dam bay, said to be by Bulrush Morgan. Died I872. Pedigree from K. F. Seidert of Prophetstown, Ill., who writes dated May 3, I888:

"The dam of Frank Forester was brought here from Vermont and sold to John Nichols. She could draw a buggy handy in 3 minutes on the road, nothing could pass her in this section."

FRANK FORESTER (3-16), dark brown, I5 $1 / 2$ hands, I Ioo pounds; foaled about I 860 ; bred by Mr. Randall, Hustisford, Wis. ; got by Black Flying Cloud, son of Black Hawk: dam brought from New York by 
Mr. Randall. Sold to J. W. Parmele, and taken to Goldfield, Ia., about I 866 ; passed to others in that region and was used mostly for a driving horse until the Black Flying Clouds became noted, then used for stock until his death, r89r. See The Morgan Horse and Register, Vol. I, p. 522 .

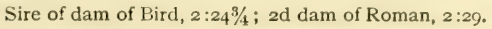

FRANK FORESTER (3-32), bay, small star, right hind foot white, I $53 / 4$ hands, I roo pounds; foaled I 886 ; bred by P. Clark, Coldwater, Mich.; got by Fearnaught Jr. (dam by Revenge, son of Blood's Black Hawk), son of Fearnaught: dam chestnut sorrel, bred by P. Clark, got by Little Dan (dam by Green Mountain Morgan that went from Coldwater to Kentucky), son of Magna Charta; 2 d dam chestnut, bred by P. Clark, got by Young Gifford (dam by Gen. Gifford, 2d dam by Major Gifford), son of Grafton Morgan; 3d dam sorrel, owned by Aaron Barnes, at Coldwater, Mich. Pedigree from George W. Clark, Coldwater, Mich.

FRANKFORT (5-128), $2: 273 / 4$, black, about I $5 \frac{1}{2}$ hands, I I oo pounds; foaled 1886 ; bred by R. C. Church, Frankfort, Ky.; got by Pretender, son of Dictator: dam Lizzie K., chestnut, bred by Charles Alexander, Versailles, Ky., got by Magic, son of American Clay; $2 \mathrm{~d}$ dam Lottie Haskins, bred by Charles Alexander, got by Bayard, son of Pilot Jr ; 3d dam Jenny, said to be by Ashland; and 4th dam by Stockbridge Chief, son of Black Hawk. Information from S. R. Russell, Newton, Ia., breeder of Albino R.

Sire of Albino R., $2: 22 \frac{1}{4}$.

FRANKFORT CHIEF ; said to be by Bay Chief.

Sire of Quicksilver $2: 17^{1 / 4} ; 4$ dams of 4 trotters, 2 pacers.

FRANK H. (3-64), $2: 26 \frac{1}{2}$, chestnut, stripe in face, three white feet ; foaled I880; bred by Abiah Hayes, Elizabethtown, O. ; got by Hambletonian (Strader's), son of Hambletonian: dam Lucy Ferris, bred by Abiah Hayes, got by old Tom Crowder; $2 \mathrm{~d}$ dam said to be by Daniel Boone;

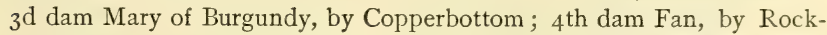
ingham; and $5^{\text {th }}$ dam Fanny Bates, by Diomede. Pedigree from breeder.

FRANK H. (7-64), brown ; foaled I 882 ; bred by Chas. H. Phelps, Orwell, Vt. ; got by Ben Franklin, son of Daniel Lambert: dam Katie C., said to be by Gen. Sheridan (Lapham Horse), son of Black Hawk; and $2 \mathrm{~d}$ dam Katrina P., by Jack Pepper. Sold to Frank Hale, Rutland, Vt. ; to C. H. Gette, Elkhart, Ind. ; to John T. Gray \& Co., Star, Ind. Pedigree from H. R. Lawrence, Brattleboro, Vt. We have received the following certificate : 
"This is to certify that we sold to Geo. Hidden of Brattleboro, Vt., through misinformation, without intending fraud or wrong, a chestnut gelding as Frank R., 2 :19 1/4, by Bourbon Wilkes, dam by Joe Downing; while in fact the horse's real name was Frank $S$., $2: 24$ I 2 , by Frank H., son of Ben Franklin: dam Silver, by Silverduke, son of Ironduke, by Hambletonian.

\section{Warnam Black, Chamberlain \& Co.,} by J. H. Chamberlain.

Subscribed and sworn to before me Albert J. Huber, a notary public within and for the County of Marion and State of Indiana.

Albert J. Huber, Notary Public."

Sire of Frank S. (Frank R.), $2: 19 \frac{1 / 4}{4}$.

FRANK HAMILTON (I-64), bay, I5 hands, Iooo pounds; foaled I865; bred by Dr. E. E. Collins, Otsego County, N. Y. ; got by George Clark's trotting stallion Victor (dam by Rattler, from Harris Hamiltonian mare), son of Cassius M. Clay : dam said to be by Muntholon, son of Mambrino Messenger, by imported Messenger. Sold to Thomas Cunningham, Munroe, Wis., who sends pedigree. Brought to Madison, Wis., from the East. Died I889. Information also from R. W. Hurd, Madison, Wis., breeder of Kitty $D$.

Sire of Kitty D., $2: 24^{1 / 2}$ (dam said to be by Blue Bull).

FRANK HAMPTON (I-256), bay, with star, I6 hands, II50 pounds; foaled i 878 ; bred by George Despeau, Providence, R. I., got by Volunteer, son of Hambletonian: dam Jenny D., bred by George Despeau, got by Godfrey Patchen, son of George M. Patchen; 2d dam Lady Spurr, bred by Thomas N. Beach, Bordentown, N. J., sire unknown. Pedigree from Charles N. Sawyer, Providence, R. I., breeder of Judge Hampton.

Sire of Judge Hampton, $2: 24 \frac{1}{4}$, Canonicus, $2: 19 \frac{1}{2}$.

FRANK HARRIS, $(7-256), 2: 24 \frac{1}{4}$, bay with star and three white feet, I 6 hands, about II 50 pounds; foaled I 885 ; bred by A. H. Willard, Olivet, Mich. ; got by Frank Noble, son of Louis Napoleon : dam Fanny Harris, bay, foaled I 872 , bred by G. W. VanAkin, Coldwater, Mich., got by Masterlode, son of Hambletonian ; 2 d dam Nelly, bay, bred by G. W. Van Akin, got by Magna Charta, son of Morgan Eagle ; 3d dam Fanny, bred by Peter Cokely, Lexington, Ky., got by Thunderbolt, son of Thunderbolt. Pedigree from Wm. D. Emerson, Olivet, Mich.; breeder of Harry E., $2: 24 \frac{1}{4}$.

Sire of Harry E., $2: 24 \frac{1}{4}$.

FRANK HAYES (7-256), bay; foaled I 886 ; bred by J. R. Dady, Waukegan, Ill. ; got by Judge Hayes, son of Robert McGregor : dam Flora Dady, bay, bred by J. R. Dady, got by Menelaus, son of Hambletonion; 2d dam Flora, said to be by Creeper, son of the Peck Horse, by Black 
Hawk; and 3 d dam Brownie, by Rooney Horse. Sold to Appleton Winona Breeding Association, Appleton, Minn.

FRANK HILL ( $1-64$ ), bay, three white feet and snip, i 6 hands, I I 50 pounds ; foaled I 888 ; bred by Jacobs Bros., Hubbard, O.; got by Edge Hill, son of Dictator : dam Belle, brown, bred by George Wilson, Youngstown, O. ; got by Ledger, son of Robert Bonner; $2 \mathrm{~d}$ dam Kate, bay, said to be by Red Bird, son of Bishop's Hamiltonian; and 3 d dam by Maburn. Pedigree from breeder.

FRANK L. (I-I 28$), 2: 14 \frac{1}{2} 2$; foaled April I 3, r 889 ; bred by C. W. Headley, South Elkhorn, Ky.; got by Sentinel Wilkes, son of George Wilkes: dam Patty Haydon, black, bred by W. B. Haydon, Keene, Ky., got by Mambrino Foster, son of Mambrino Patchen; 2d dam Pet, black, said to be by Ashland Chief, son of Mambrino Chief ; and $3 \mathrm{~d}$ dam by New York Beauty, son of Jones Horse, by Black Hawk, or a son. Sold to Mike Bowerman, Lexington, Ky. Owned afterwards by Frank Landrum, Napoleon, Ky. Pedigree from breeder.

Sire of David H. Ray, $2: 24 \frac{1}{4}$.

FRANK LANDERS ( $\mathrm{I}-32$ ), $2: \mathrm{I} 83 / 4$, brown, I6 $1 / 2$ hands, I 200 pounds; foaled 1872 ; bred by M. F. McHaffie, Stilesville, Ind.; got by Saddling Buck, son of Chad's Buck, by pacing Red Buck, 2 :18, son of Copperbottom : dam roan, bred by O. C. Kelsey, Stilesville, Ind., got by Money Changer, son of old Money Changer of Ky.; 2 d dam black, bred by Frank Elliott, Stilesville, got by Argolis of Kentucky, son of Whip. Gelded young. Pedigree from breeder.

FRANKLIN (I-64) ; foaled about I 869 ; bred by Peter W. Jones, Amherst, N. H. ; got by Jones' Cassius M. Clay 3 d, son of Jones' Cassius M. Clay 2d, by Cassius M. Clay, son of Henry Clay: dam said to be by the running and trotting horse Zouave (first called Kentucky Hunter, next Telegraph, then Zouave), son of Bellfounder, by imported Bellfounder. His second dam is given as by Logan, son of Henry Clay and third dam by Abdallah. Whether this pedigree has been investigated or not, so as to establish the second and third dam's breeding, we are unable to state. The dam of Jones' Cassius M. Clay $3 \mathrm{~d}$ was the McWhorter mare, by Abdallah. The dam of Jones' Cassius M. Clay 2d was Lady Freelove, by Abdallah. The dam of Jones' Cassius M. Clay Jr., was by Kissam's Bellfounder. Jones' Cassius M. Clay 3 d was strongly bred in trotting lines. His own dam and the dam of his sire were both by Abdallah, yet his name does not appear among the list of sires of $2: 30$ performers. The dam of Daily News was by the W. G. Sherburn horse, a son of Rising Sun. His second dam was the Dunning mare, by the Thomas Horse, a son of Brown Harry.-American Horse Breeder.

Sire of Daily News, $2: 20$. 
FRANKLIN (3-64), 161/2 hands, I 250 pounds; foaled 1883 ; said to be by Ben Franklin, son of Daniel Lambert: and dam by Smith's Young Columbus. Advertised at Canton, N. Y., I889, by J. A. Hale, Pottsdam, N. Y.

A horse of this name is reported sire of Lady Franklin, $2: 25 \mathrm{~T} / 4$, and Belle Franklin, 2 : 15 I $/ 4$.

FRANKLIN (I-32), 2 :19 $1 / 2$, black, small star, and hind feet white, white spots on each side of withers caused by saddle galls, I5 $3 / 4$ hands, I roo pounds; foaled I884; bred by Mrs. R. C. Dora, Glenwood, later of Fayette County, Ind.; got by Tobe Jr. (Saxon's Blue Bull), son of Blue Bull: dam Fanny Farmer, brown, bred by Garner Clawson, Glenwood, Rush County, Ind., got by American Farmer, son of American Star; 2d dam bay, bred by Garner Clawson, got by Tuckahoe (Gray's), son of Eleck, by old Eleck ; 3d dam bay, bred by Mathew Hastings, Glenwood, Ind., said to be by Shakespeare (Peter Murphy's) and $4^{\text {th }}$ dam thoroughbred. Sold to Robert Saxon; to Wm. Gray; to Morton Nelson; to Garret Wyckoff, all of Groves, Ind. ; to Fred L. Davis ; to S. M. Bartlett, both of Caneadea, Allegany County, N. Y.; to F. A. Hall, Warren, Penn. Gelded young. Pedigree from breeder who writes :

"You ask to especially state who bred the dam of Franklin, black gelding, $2: 19 \frac{1}{2}$. Mr. Garner Clawson bred for her. He is now dead. I bought dam when a weanling. Mathew Hastings is dead and also Mr. Brown, who bought American Farmer, the sire of Fanny Farmer (the dam of Franklin), in Kentucky. Dam was a Vermont Morgan mare and traces back two or three generations to the Morgan families, but owing to the demise of so many of the breeders I have been unable to get certificates to the breeding. I mail card of Indiana Star, full brother of Franklin, $2: 19^{1 / 2}$."

FRANKLIN CHIEF (5-32), chestnut, $153 / 4$ hands, Iooo pounds; foaled I 884 ; bred by H. T. Cutts, Orwell, Vt. ; got by Ben Franklin, son of Daniel Lambert: dam chestnut, bred by Mr. Myatt, Whiting, Vt., got by DeLong's Ethan Allen, son of Ethan Allen; 2d dam the Sampson mare, said to be by Lorin Drake Horse, son of Black Hawk. Sold to S. F. Kelley, Rutland, Vt. ; to B. P. Williamson, Raleigh, N. C. ; to Crowell \& Simpson, Munroe, N. C. Pedigree from breeder.

Sire of Cock Robin, $2: 29 \frac{1}{4}$.

FRANKLIN JACKSON, said to be by Kemble Jackson, son of Andrew Jackson, by Grand Bashaw imported Arabian: dam, Kate Franklin, bred by Dr. Wm. Franklin of Chenango County, N. Y.; got by Kentucky Hunter; 2 d dam said to be by Flag of Truce. Owned by Charles U. Brooks, Harlem, Ill. Died I 857 . The following is taken from The Spirit of the Times, March I 857 :

"We are sorry to learn from Chas. U. Brooks, that his young stallion Franklin Jackson, died at his stable in Harlem. He was a most promis- 
ing young horse and his blood entitled us to expect great things from him, as the following will show. Franklin Jackson was got by Kemble Jackson, one of the fastest trotters of his time; he by Andrew Jackson, and he by Grand Bashaw, a thoroughbred imported stallion.

"The dam of Kemble Jackson was Fanny Kemble, a full sister of Miller's Damsel, the dam of American Eclipse, and got by Duroc, the sire of American Eclipse.

"Franklin Jackson's dam was Kate Franklin, who was bred by Dr. Wm. Franklin of Chenango County, N. Y., her dam was by Flag of Truce.

"Kate Franklin was by Kentucky Hunter, who was bred by Garry Semger of New Hartford, N. Y.

"Kentucky Hunter was the sire of One-Eyed-Hunter."

FRANK LOGAN; said to be by Little Logan, son of Logan, by Hambletonian.

Sire of 2 pacers $\left(2: 19^{1 / 4}\right)$.

FRANK M. (3-64), $2: 29 \frac{\mathrm{T}}{4}$, black, I5 hands, 900 pounds; foaled I877; bred by Harrison Mills, Goshen, Orange County, N. Y.; got by Sweepstakes, son of Hambletonian : dam Beauty, bay, bought by Joseph Gavin, Chester, N. Y., of Charles Ebenspacker, Dobb's Ferry, N. Y., who said she was by Ethan Allen but did not give her breeder. Sold to Chauncey Millspaugh, Goshen, N. Y.; to Messrs. Colyer \& Co., Newark, N. J. Gelded young. Pedigree from George H. Mills, Goshen, N. Y.

FRANK $M$. (I-16), $2: 27 \mathrm{I} / 2$, roan, star, hind ankles white, I $53 / 4$ hands, I 150 pounds ; foaled 1880 ; said to be by Joe Brister, son of Jim Brister, by Copperbottom: dam by Blue Bull; and $2 \mathrm{~d}$ dam by Legal Tender. Sold to William Hughs, Hazelton, Penn.; to Henry Hagemier, Pittsburg, Penn.; B. T. Williams, Sprague, Munroe County, O.; to J. N. Haight, Luzern, Penn., who sends pedigree.

FRANK MAYO (3-64), sorrel, hind ankles white, I $53 / 4$ hands, I050 pounds; foaled $\mathrm{I} 887$; bred by W. S. Flood, Elmira, N. Y.; got by Pocahontas Abdallah, son of Pocahontas Boy : dam Jennie E., chestnut, bred by Dr. P. H. Flood, Elmira, N. Y., got by Mercury, son of Hambletonian; 2d dam Mary Ann, chestnut, bred by W. H. VanDuzer, Horseheads, N. Y., got by Magnolia, son of American Star; 3d dam bay, bred at Horseheads, N. Y., and said to be by McConnel's Champion, son of Scobey's Champion. Pedigree from breeder.

Sire of Little Guy, $2: 17 \frac{1}{4}$.

FRANK MEDIUM (5-256), bay; foaled r 888 ; bred by John Albers, Muskegon, Mich; got by Fairlawn Medium, son of Happy Medium : dam said to be by Louis Napoleon, son of Volunteer. Gelded I89o. Information from breeder.

Sire of Miss Nester, $2: 19 \frac{1}{2} 2$. 
FRANK MORGAN (3-r6), black, I4 I/4 hands, rooo pounds; foaled Sept. 5, I 887 ; bred by Stuart Greenwell, Fairview, Ill.; got by Charley Watson, son of Black Morgan: dam black, bred by S. Greenwell, got by Charley Watson, son of Black Morgan ; $2 \mathrm{~d}$ dam black, bred by John Greenwell, got by Morton Horse; 3d dam sorrel. See The Morgan Horse and Register, Vol. II., p. I 30.

FRANK MORRILL (I-32); said to be by Medoc, son of Walker Morril, by Winthrop Morrill.

Sire of Sport, $2: 161 / 4$.

FRANK MOSCOW, $2: 46$, bay; foaled $\mathrm{x} 860$; bred in Michigan; said to be by Moscow (Fisk's), son of Defiance: and dam Lady Franklin, by Washington, son of Burr's Napoleon, by Young Mambrino. Sold to F. B. Case, Jackson, Mich.

Sire of Frank Moscow, $2: 27 \frac{1}{2} ; 3$ dams of 5 tretters.

FRANK MOSCOW, $2: 271 / 2$, chestnut; bred by James Draper, Jackson, Mich.; foaled I87x; got by Frank Moscow, son of Fisk's Moscow, by Defiance : dam black. Sold to Allen Lyon; to M. S. Dwelley, Jackson, Mich.; to Mr. Cooper, San Francisco, Cal.

FRANK MUNSON (ANDREW J.) (I-I6), $2: 25$, and winner of 29 races, chestnut with small star and one white heel, $15 \frac{1}{4}$ hands, 920 pounds; foaled r868; bred by L. M. Webb, Peach River, N. Y.; got by Paragon, son of Andrew Jackson, by Bulrush Morgan: dam chestnut, said to be by Zimmerman's Duroc, son of Richmond's Duroc, by Hungerford's Blucher. Gelded young. Information from Henry Spicie, Peach River, N. Y. Trotted, I874-So. See The Morgan Horse and Register, Vol. I., p. 875 .

FRANK NICHOLS (1-64), bay; foaled I873; bred by Charles Nichols, Bangor, Mich.; got by Night Hawk, son of Grinnell's Champion : dam Fan, untraced. Sold, I $\& S$ I, to O. A. Rider, Bangor, Mich; to A. M. Minty, Battle Creek, Mich.

Sire of Al. R., $2: 27 \frac{1}{2}$.

FRANK NOBLE, bay, I51/2 hands, I050 pounds; foaled I 879 ; bred by Dewey and Stewart, Owosso, Mich.; got by Louis Napoleon, son of Volunteer: dam Fanny Mapes, bay, bred by John W. A. Brewster, Goshen, N. Y., got by Abdallah, son of Hambletonian ; $2 \mathrm{~d}$ dam said to be by Burr's Napoleon, son of Young Mambrino; 3d dam by Long Island Black Hawk, son of Andrew Jackson; and $4^{\text {th }}$ dam by imported Trustee. Sold to J. W. Parkhurst, Augusta, Mich. Pedigree from breeder.

Sire of 8 trotters $\left(2: I_{5} 1 / 2\right), 6$ pacers $\left(2: 12^{1 / 4}\right) ; 3$ sires of 5 trotters, 6 pacers; 3 dams of 2 trotters, I pacer. 


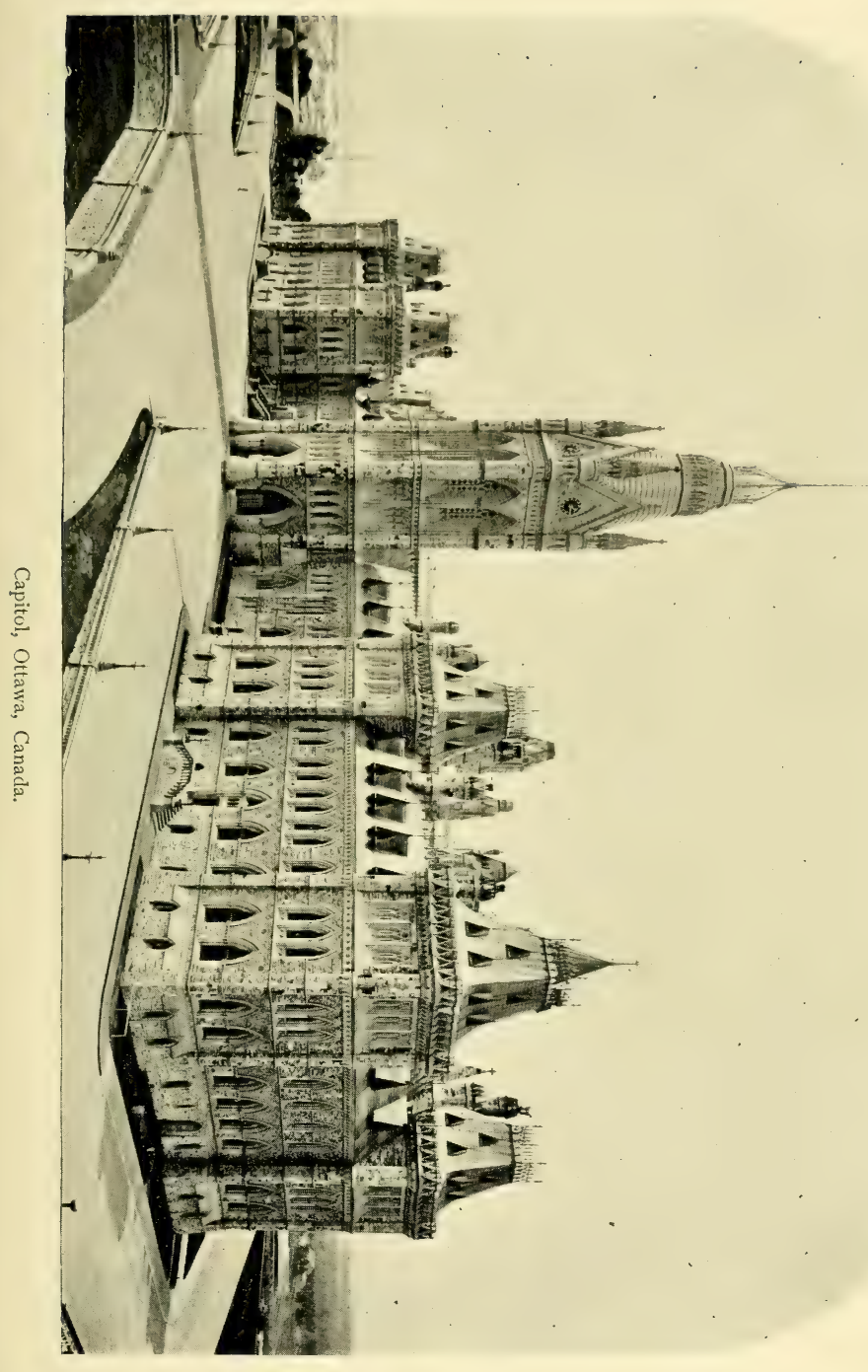




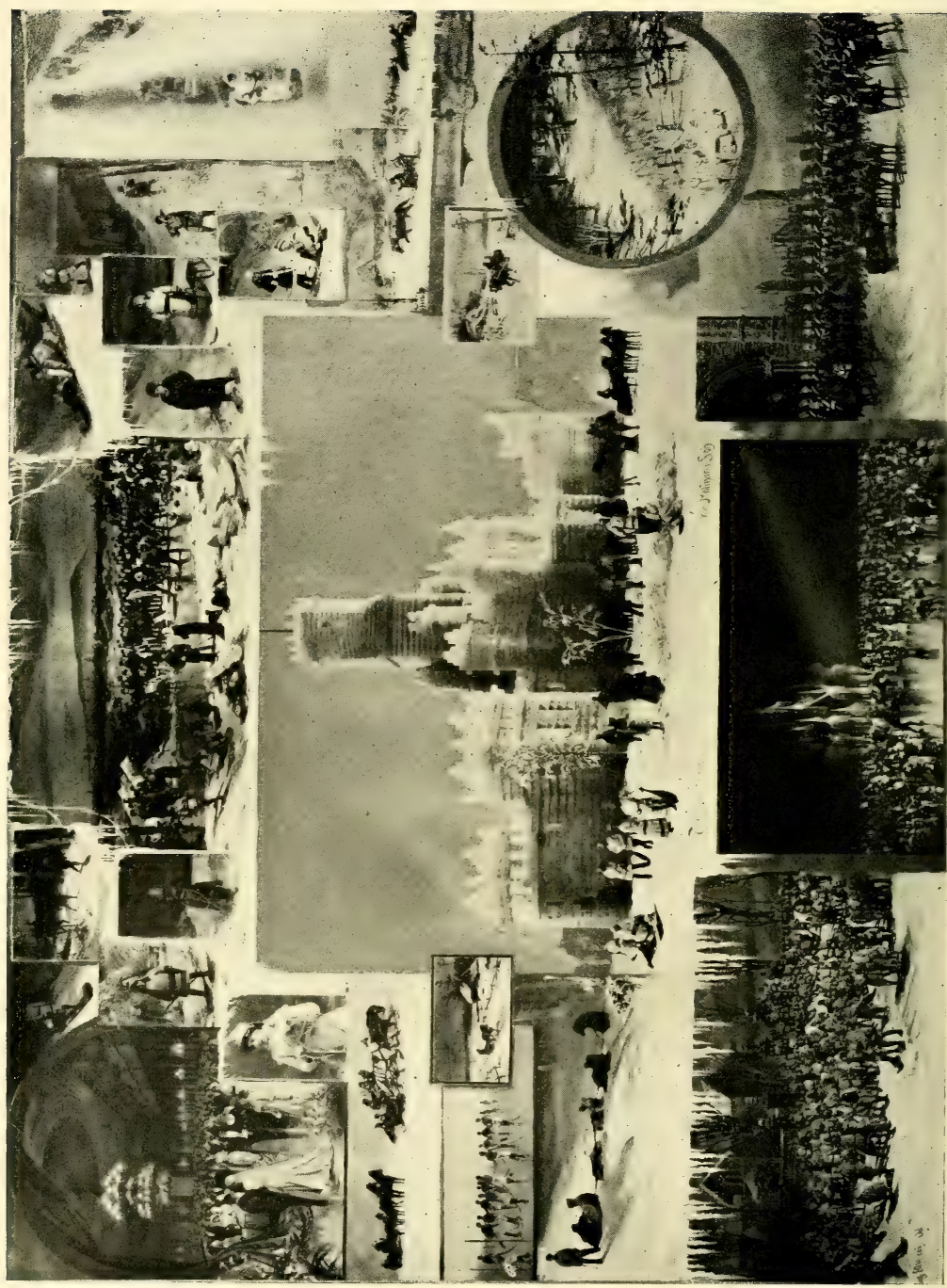


FRANK PATCHEN (r-64), bred by D. C. Andrews, near Sweedsboro, N. J. ; got by Geo. M. Patchen : dam saicl to be by Plack Washington; and $2 \mathrm{~d}$ dam Messenger. Advertised by $\mathbf{W m}$. King of I'hiladelphia, Penn., June, I 862 , in New York Spirit of the Times, pedigree as above.

FRANK PATCHEN ( $1-64$ ), said to be by Charles E. Loew, son of George M. Patchen.

Sire of the dam of Breeze Medium, $2: 29^{3 / 4}$, winner of 26 races.

FRANK PIERCE (3-32), sorrel or chestnut, $15^{1 / 4}$ hands, rooo pounds; foaled about I 848 ; bred by Pierre Chicoine, Verchères, P. Q. ; got by Petit Coq : dam supposed to be of the Dansereau breed. Sold when five years old for \$2,ooo to parties in Whitehall, N. Y., and went to Saratoga. Owned in Whitehall, 1857 .

Mr. Wm. Arthur in interview 1885 said:

"Frank Pierce was brought to Saratoga by a Frenchman from Canada, and said to be by an English horse called Peacock, and from a French mare. He was kept in Ti., I $854-55$."

The horse referred to as English was the French bred horse Petit Coq, which see.

The following authentic account of this horse we had from a gentleman in Canada, who acted as agent in his purchase, but whose name was omitted in copy. Beppo was another name for Petit Coq.

"Franklin Pierce, bred at Verchères, and foaled in $185 \mathrm{I}$ or '52, was the last or next to the last foal got by Beppo before going to the States. I think one of the Privés bred him. He trotted in $2: 40$ when four, over the St. Hyacinthe track-this track was 59 feet over a mile. He was the first horse to trot in this time up to twenty-four years ago-his color was chestnut sorrel. I don't know whether he had any white-he was a heavy horse. I don't know the man's name who bought him, though I remember the man's looks-it was about 1855 , he was four years old when he was bought, the last I heard of him he was near Baltimore, where his stock was thought very highly of as general purpose horses. I don't know about his dam.

"Franklin Pierce Jr., was foaled in 1853 , got by Franklin Pierce, bred by Chicoine near Verchères, about three miles off. I think his dam was Balloon, a chestnut mare. I saw her. They in-bred down there and she was one of the stock thereabouts. He was dark chestnut, I $_{4}$ hands 3 inches high. I took him to Delaware in I 859 and left him about three miles from Newcastle, where he trotted a full mile in $2: 29$, he had a star on his forehead, I think, he went to St. Louis and when the War broke out he passed to unknown hands. I paid $\$ 2$, ooo for him on behalf of John Goodier, of Philadelphia, and Phil Clark, of Harris Corners, Delaware, they were partners. Clark was living about two years ago."

FRANK PIERCE JR. (I-I6), chestnut, no white; foaled about I854; bred by Pierre Chicoine, Verchères, Can. ; got by Frank Pierce, son of Petit Coq: dam supposed to be of Dansereau breed. Brought to the United States and owned by Mr. Cockle, Baltimore, Md., and afterwards 
went to Delaware County, Penn., where he died, 1879. We have received the following letter:

Holmesburgh, Penn., Nov, 2 I, I 888.

Dear Sir :-Mr. McDonald of Sacramento, Cal., bought Brigadier at one of my sales in Kentucky, when a colt. He may have found out about his dam's pedigree. All that I know is, dam by Frank Pierce Jr. I think Mr. McDonald's address is Sacramento, Cal.

See Brigadier, Vol. I.

$$
\text { Very truly yours, Richard Penistan. }
$$

Sire of Phil Dougherty, 2:26; I sire of I trotter; 3 dams of 3 trotters.

FRANK PIERCE, 3D (5-64), jet black, I6 hands; foaled I $86-$; bred by C. I. B. Mitchell, and Pere Wilmer, Maryland, got by Frank Pierce Jr., son of Frank Pierce, by Beppo: dam said to be by Ticonderoga, son of Black Hawk; 2 d dam by Tom Friendship; and 3 d dam thoroughbred, bred by Peyton Randolph, Virginia. Owned by Harry B. Mitchell in Maryland.

Sire of Stonewall, $2: 24 \frac{1}{2}$.

FRANK P. PORTER, $2: 27 \mathrm{~T} / 2$, bay, 16 hands, bred by R. West, Lexington, Ky.; got by Egbert, son of Hambletonian: dam Puss (dam of Antar), said to be by Brown Chief, son of Mambrino Chief; and $2 \mathrm{~d}$ dam by Bertrand, son of Sir Archy. Sold to O. P. Alford, Lexington, Ky. ; to Warren Beckwith, Mount Pleasant, Ia., who sends pedigree.

Sire of 2 trotters $(2: 2 I)$; I sire of I trotter; I dam of I pacer.

FRANK QUIRK, 2 :I 8 I/ $/ 4$, roan; foaled I 884 ; bred by John Donegan, Puller Springs, Mont.; got by Defiance, son of Commodore Belmont: dam Donegan mare. Gelded young.

FRANK REEVES ( $\mathrm{I}-32$ ), $2: 23 \frac{1}{4}$, bred by Joe D. Martin, Gallatin, Tenn. ; got by Skedaddle, son of Whiteside's Black Hawk, by Hall's Black Hawk (a horse that was killed under Gen. W. W. Ball at battle of Shiloh, in April I 862), son of Davy Crockett: dam Molly Hale, foaled I859, bred by Joe D. Martin, was not got by Dallas as usually stated, but by Hall's Black Hawk, owned by Charles Morgan, two miles from Gallatin, on Scottsville Pike; 2 d dam bred by Joe D. Martin, got by Dallas; 3d dam bred by John Martin (uncle of Joe D. Martin), got by Jim House, son of Leviathan. Sold to New York parties it is said for $\$ 8,000$. Gelded young. Pedigree from Joe D. Martin, who writes :

Mr. Joseph Battell, Ripton, Vt., Gallatin, Tenn., April 23, r889.

Dear Sir :-I have filled out the blanks the best I could under all the circumstances though not as full as I would like to. Old Davy Crockett stood near where I have lived since i 838 , a small child then, but I well remember the old horse and was sent there with my father's mares in I 846 and 7 , but can find no one to give his breeding, etc.

Joe D. Martin. 
FRANK STARK (1-64), $2: 29 \frac{1}{4}$, chestnut, I 5 hands, 1150 pounds; foaled I 883 ; bred by S. C. Phillips, Washington Court House, O.; got by Phillip's Blue Bull, son of Wilson's Blue Bull : dam Little Mary, bay, fast trotter, bought of Mr. McColough, Troy, O. Pedigree from breeder. Sire of Hully Gee, $2: 22 \frac{1}{4}: x$ dam of $x$ trotter.

FRANK TUCKAHOE; foaled ז 8 - ; said to be by Tuckahoe.

Sire of St. Elmo, $2: 22 \frac{1}{4}$.

FRANK WILKES ( $\mathrm{x}-64), 2: 28 \mathrm{I} / 2$, black, star and white pasterns, $151 / 2$ hands, I Ioo pounds; foaled IS8I ; bred by S. S. Houghton, Orford, N. H. ; foaled the property of L. T. Tougas, Milford, Mass. ; got by George Wilkes Jr., son of George Wilkes : dam Miss Fry, black, said to be by Lang Horse, son of Pathfinder, by Morrill; 2d dam Smith mare, by Vernol's Black Hawk, son of Andrew Jackson. Sold to Frank E. Stevens, Mendon, Mass., who sends pedigree. Killed by fire, May I903.

Sire of 3 trotters $\left(2: 27 \frac{114}{4}\right)$.

FRANK WOLFORD (I-I6), dark bay, I6 hands, II5o pounds; foaled I86I ; bred by W. W. Baldwin, Maysville, Ky.; foaled the property of Joshua Bell, Frankfort, Ky.; got by Telegraph, son of Black Hawk: dam Gipsey, pacer, and a fine road mare. Sold to E. P. Faulconer, Danville, Ky. ; to Edward Baxter, Gravel Switch, Ky. Died I88o. See The Morgan Horse and Register, Vol. I., p. 49 I.

Sire of Cuckoo, $2: 28 ; 3$ dams of 4 trotters.

FRANK WOOD (3-64), $2: 25^{\mathrm{I}} / 2$, black, 15 1/2 hands; foaled 1885 ; bred by John R. Farnum, Waltham, Mass.; got by Wedgewood, son of Belmont: dam Rose Allen, black, bred by John R. Farnum, got by Frank Allen, son of Ethan Allen; 2d dam Madam Tierman (dam of Commonwealth, $2: 22$ ), said to be by Young St. Lawrence; and 3 d dam by Black Swallow. Pedigree from catalogue of breeder.

FRANTIC ( I-64), 2 : I $73 / 4$, foaled I 886 ; bred by R. G. Stoner, Paris, Ky. ; got by Strathmore, son of Hambletonian: dam Serene, brown, foaled I 874 , bred by James A. Grinstead, Lexington, Ky., got by Sentinel, son of Hambletonian; 2 d dam Twilight (dam of Skylight Pilot, 2 :I9), brown, foaled I864, bred by Robert Logan, Lexington, Ky., got by Mambrino Pilot, son of Mambrino Chief ; 3 d dam said to be by Pilot Jr., (Alexander's). Sold to W. A. Smith, Georgetown, Ky. Pedigree from catalogue of breeder.

Sire of 3 trotters $\left(2: I^{1} \frac{1}{4}\right), 3$ pacers $\left(2: I 7^{1 / 4}\right)$.

FRAZIER HORSE (I-8), bay, I5 $1 / 2$ hands, IIOo pounds; foaled about I 835 ; bred by Daniel Frazier, Barnard, Vt. ; got by Gifford Morgan : dam said to be by Elephant, a large and stocky bay horse with star, I $5 \frac{1}{2}$ hands, I Ioo pounds, owned by Maj. Smith, Pomfret, Vt. Kept in 
Barnard until about eight years old then sold for $\$ 500$ to Leander Utley, and went to Illinois; to Mr. Johnson, Aurora, Ill. Style and action excellent. Elephant, sire of dam we think was the horse of same name that got the $2 \mathrm{~d}$ dam of Henry Clay, which see.

I. D. Davis, of Barnard, born I810, in interview, I891, said :

"The Frazier Horse by old Gifford was bred by Daniel Frazier of Barnard, dam by Elephant a large, good stocky horse, bay with star, I think, $151 / 2$ hands, I I oo pounds, owned by Major Smith of Pomfret. The Frazier horse was bay, quite a good size for a Morgan horse, 15 1 2 , ro5o to I Ioo pounds, a very nice horse. He was sold and went West I think to Illinois. A man by name of Utley from Massachusetts bought him, and took him West. He was a stylish horse, head up, a bright, clean nice horse for those times, and they had better styled horses than now. The dam was bay, a good sized stocky mare. Smith's horse, I think, died his property.

"Mr. Frazier from this same mare bred another horse also called the Frazier Horse got by Pike's horse of Cornish, N. H. I think Pike's horse was named Romeo, and a French horse. The Frazier horse No. 2., was smaller, and not so good style as the Frazier Horse, but very cordy ; a bay, kept here one or two seasons.

"There was another horse from Berlin. A nice, pretty bay horse, big star, called Romeo. Looked like a Morgan. House owned him. A young horse, not as old as Phœnix.

"The two Romeo s were not the same. I have understood that Pike's horse was a French bred horse. House's light mane, not heavy tail, fine made horse, not French. Joe Danforth had the Frazier horse by Pike's horse, and kept him here one or two years.

"As far back as I can remember the Woodbury was the popular horse. More said of him than of any other. I saw him often. Never saw Sherman. From the time I was ro years old Mr. Woodbury owned a mill at Bethel. Woodbury sold his horse to Walker at Hartland, who kept him next season at Bethel and one day here. That was after Gifford was here. He got him after Gifford came home. The two horses were in the same barn. Coolidge had Gifford here five years, I think; I think till twelve years old. Cady had the care of Gifford one or two seasons in this town, and I think, he took him over the Lake."

Learning that Mr. Leander Utley was living at Phœnix, Ariz., We wrote him and have received the following reply:

"I purchased the horse known as the Frazier Horse or Young Gifford of Mr. Frazier, Barnard, Vt., I think winter of I 853, and removed him to Oswego, Kendall County, Ill.; sold him to Mr. Johnson, near Aurora. He was I I years old when I bought him, was a beautiful horse and left good stock."

See The Morgan Horse and Register, Vol. II.

FRAZIER HORSE (YOUNG) (I-I6), bay, I5 hands, 900 pounds; bred by Daniel Frazier, Barnard, Vt.; got by Frazier Horse, son of Gifford Morgan.

FRED, chestnut, I53/4 hands, I200 pounds; foaled May I8, I 860 ; bred by C. J. Brown, Dakota, Ill.; got by John, son of Pyle's Arabian, by 
Farwell's Arabian from Ohio: dam Nell, a fine chestnut saddle mare from Missouri, said to be of Morgan and thoroughbred blood. Went to Iowa. Pedigree from breeder.

FRED. See Waters Horse.

FRED (UTAH). Untraced.

Sire of Birdseye, $2: 291 / 2$.

FRED (McCLAINE'S), chestnut; foaled 1865 ; bred by Wm. Templeton, Dakota, Ill. ; got by Fred, son of John, by Pyle's Arabian : dam Nance, bred by $\mathrm{Wm}$. Templeton, got by the Butterfield Horse (Rockingham); 2d dam Coalie, black, bred by Wm. Templeton, got by Sneider Harse. Sold to Wm. McClaine, Dakota, Ill.

FRED (MITCHELL'S) ( I-32), brown ; foaled I 876 ; bred by S. A. Mitchell, Dakota, Ill. : got by Daughenbaugh's Black Hawk, son of Derry's Captain: dam Fanny, black, bred by S. A. Mitchell, got by Dindoer's Morgan, son of Salveur's Morgan, by Green Mountain Morgan. Information from H. B. Gorham, Freeport, Ill.

FRED ARTHUR (1-64), $2: 12 \frac{1}{4}$, bay; foaled I 884 ; bred by H. Duhme, Jr., Woodlawn, O.; got by Belmont, son of Alexander's Abdallah : dam Gipsey, chestnut, bred by Thos. M. Duke, Knightstown, Ind., got by Blue Bull. Sold to Thurston Russell, Lexington, Ky.; to Louis C. Simon, Columbus, O. Pedigree from catalogue of breeder.

Sire of 4 pacers $\left(2: 17 \frac{1}{4}\right)$.

FRED B. HINES. See Floramour.

FRED BOONE ( $\mathrm{I}-32)$; said to be by Daniel Boone, son of Hambletonian : dam old Mag, brown, by Uncle Shube, son of Gen. Knox; and $2 \mathrm{~d}$ dam Potter Mare, by Eaton Horse, son of Avery Horse.

Sire of Honest Foe, $2: 24 \frac{1}{4}$; I dam of I trotter.

FRED DOUGLAS ( $\mathrm{I}-3^{2}$ ), $2: 24 \mathrm{~T} / 4$, chestnut, I 5 I/4 hands, 970 pounds; foaled I 872 ; bred by Will A. Snoddy, Stylesville, Ind., later of Emporia, Lyon County, Kan. ; got by Black Frank, son of Ben Snatcher Jr. : dam Boggy, bay, bred by Geo. Snoddy, Stylesville, Ind., got by Billy Cass (a white Canadian pony and fast pacer); 2 d dam chestnut sorrel, bred by A. S. Fitzgerald in Kentucky, later of Vermilion, Edgar County, Ill., said to be by Sir Archie. Sold to John Steiner, Indianapolis, Ind. ; to H. V. Bemis, Chicago, Ill. Said to have always taken first premium for light harness roadster, when exhibited. Gelded young. Pedigree from breeder.

"Purchase of Fred Douglas.-At the close of the race he won at Chicago, Mr. H. V. Bemis bought Fred Douglas for $\$ 3,500$. Douglas is a black gelding, $15 \mathrm{I} / 2$ hands, with fine mane and tail, lengthy, and of erect carriage. He is without a spot or blemish, and trots without weights, 
with $\mathrm{I} 4 \mathrm{Oz}$. shoes. He was foaled in $\mathrm{r} 87 \mathrm{r}$, and is by black Frank, a pacer, half brother to Rowdy Boy, both being by a Canada pacer named Bull Pup. Douglas dam was Boggy, a mare by a white pacer, brought to Indiana from Canada, called Billy Cass. Prior to 1877 he was owned all his life by Mr. W. A. Snoddy, of Stylesville, Ind., who broke him for the saddle. He always paced in the pasture, and in April, 1877, Mr. Snoddy turned him over to his present driver, John M. Edwards, of Monrovia, Ind., to train for turf purposes, as a pacer. One day that summer, while taking his work he broke and caught into a trot, going very fast for a short distance, and Mr. Edwards concluded to convert him. He put $7 \mathrm{oz}$. weights on each fore foot, and since then he has always trotted." Spirit of The Times, Oct. 4, 1879.

FRED DOUGLAS (I-I6), $2: 20 \mathrm{I} / 4$, chestnut; foaled $\mathrm{I} 873$; bred by James Bell, Cedar Rapids, Ia.; got by Green's Bashaw, son of Vernol's Black Hawk : dam Nancy Bell, chestnut, brought from the vicinity of Freeport, Ill., by Willam Baxter, and sold by him to Wesley Marine, West Union, Ia., who sold to Messrs. Bell and Son, said to be by Gale's Morgan, son of Green Mountain Morgan; and $2 \mathrm{~d}$ dam by Simpson's Blackbird. Owned by E. H. Smith, Milwaukee, Wis., and entered by him in the $2: 2$ I class, for the National Trotting Stallion stakes, May, I883. Pedigree from breeder. Trotted, I $878-82$, winning 13 races.

Sire of 2 trotters $\left(2: 12 \frac{1}{2}\right) ; 3$ dams of 2 trotters, I pacer.

FRED DOUGLAS, 2 :17 I/4, bay; foaled I 888 ; bred by Charles Rule, Sherman City, Kan. ; got by Phil, son of Arlington Tuckahoe : dam Doll, bay, bred by W. T. Rule, Sherman City, Kan., got by George Scott ; 2 d dam Kate.

Sire of Darkner, $2: 181 / 4$.

FREDERICK, black, I5 hands; foaled I759; bred by William Croftie, Suffolk, Eng.; got by a son of Hobgoblin. Imported 1764 and Advertised in Pennsylvania Gazette, $1765-6$, to be kept at Freehold, N. J.

FREDERICK (5-64), I $53 \frac{4}{4}$ hands, I IOo pounds; foaled 1880 ; bred by Ely Ulery, Mt. Zion, Ill.; got by Regalia, son of Jay Gould : dam bay, bred by Ely Ulery, got by Hambletonian Chief; $2 \mathrm{~d}$ dam said to be by White Mountain Morgan. Sold to D. C. Fletcher, Mechanicsburg, Ill., who sends pedigree; to Mr. Martin, Taylorville, Ill.

Sire of Topsey F., $2: 22$.

FREDERICK PTOLEMY, by James DeLancey's famous horse Wildair: dam Mercury, bred in Virginia, got by Apollo. Advertised as above in New Jersey Gazette, ${ }_{7} 8_{3}$.

FRED FOREST, black, I 6 hands, I Ioo pounds; foaled I 880 ; bred by Jared Gridley, New London, O.; got by Forest King, son of Mambrino 
Patchen : dam Mingee, roan bay, bred by H. E. Bassett, New London, O., got by Erie Abdallah, son of Roe's Abdallah Chief; 2 d dam a good road mare. Sold to C. M. D. Perkins, Wellington, O. Pedigree from breeder.

Sire of 3 trotters $\left(2: 22 \frac{1}{4}\right)$.

\section{FRED JOHNSON (LEANDER).}

The California Spirit of the Times, November, 1858 , says :

"The pacer, Fred Johnson, died last Tuesday. He was originally owned by Peter Weson of St. Louis, Mo., who sent him to Long Island and he was sold to Fred Johnson, wealthy butcher. Johnson sold to Thomas Rolla, who brought him to California. His last race was with Young America, two mile heats to wagon, when Young America won in the unparalleled time of $4: 49,4: 581 / 2$; but the race was close."

FRED KEYES (I-32), black; foaled I 889 ; bred by George H. Ely, Elyria, O.; got by Elyria, son of Mambrino King: dam Etruscan, bay, bred by Harrison Durkee, New York, N. Y., got by Dictator, son of Hambletonian; 2d dam Julia Ann Johnson, said to be by Andrew Johnson, son of Mambrino Chief ; 3d dam Sophy, by Edwin Forrest; and

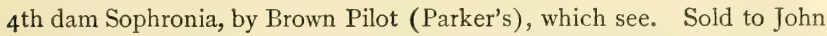
J. Arandt, North Amherst, O.; to Ira M. Nye, Buffalo, N. Y. Pedigree from catalogue of breeder.

Sire of 2 trotters $\left(2: 09^{1 / 2}\right)$.

FRED LOW (ST. CLAIR 2D) (I-8), brown; foaled I 864 ; bred by George Ingles, Sacramento, Cal. ; got by St. Clair : dam Lady Ross. Received first premium at California State Fair, I 865, '70, '7 1 . Sold to John E. Miller, Sacramento, Cal. ; to E. H. Miller, Jr., I880; to W. M. Sutton and taken to Oregon or Washington; to Leland Stanford, Menlo Park, Cal.; to C. B. Miller, Baker City, Ore. See The Morgan Horse and Register, Vol. I., pp. 767-773.

Sire of 2 trotters $\left(2: 25 \frac{\dot{1}}{2}\right) ; 3$ dams of 2 trotters, 2 pacers.

FRED PIERSON ( $1-8$ ), 2 :39, black; foaled I 860 ; bred by Fred Pierson, East Avon, N. Y.; got by Henry Clay : dam said to be by Gifford Morgan. Sold to Fred Fellows, Chili, N. Y. Pedigree from George W. Archer, Rochester, N. Y., breeder of Brookie, $2: 29 \frac{1}{4}$ (dam by Fred Pierson).

Sire of 2 dams of 2 trotters.

FRED S. (I-32), 2 :I6, bay, black points, I6 hands, I045 pounds; foaled I882 ; bred by Mr. Fisher, Rockville, Parke County, Ind. ; got by Lexington Chief (W. P. Swain's), son of Regular, by Volunteer: dam bay, bred by Mr. Fish, got by Red Buck, son of Noah Day's Copperbottom. Sold to Lee Overpeck, Jessup, Ind.; to W. P. Swaine, Belleview, Mo. Pedigree from David H. Swaine, Belmore, Ind. Gelded young. 
FRED SPRAGUE ( $1-32$ ), black, I 7 hands, I 200 pounds; foaled 1883 ; bred by F. Messenger, Hillsdale, Mich.; got by Governor Sprague, son of Rhode Island: dam Bertha, brown, bred by R. P. Todhunter, Walnut Hill, Ky., got by Clark Chief, son of Mambrino Chief; $2 \mathrm{~d}$ dam said to be by Berthune, son of Sidi Hamet; and 3d dam by Downing's Bay Messenger, son of Harpinus. Pedigree from breeder.

Sire of Summit Prince, $2: 24 \frac{1}{4}$.

FRED S. WILKES ( $\mathrm{x}-\mathrm{I} 28$ ), 2 : $1 \mathrm{I} 3 / 4$, roan, black mane and tail, $15 \mathrm{~T} / 2$ hands ; foaled I 887 ; bred by B. H. Payne, Paynes Depot, Scott County, Ky. ; got by George Wilkes : dam Tillie, roan, bred by Ned Gaines, Donerail, Ky., got by Tattler Chief, son of Alexander's Abdallah; 2d dam gray, bred by Keen Richards, Georgetown, Ky., got by imported Knight of St. George ; 3d dam by Snowstorm. Sold to J. R. \& C. J. Smith, Birmingham, Ala. Pedigree from breeder.

Sire of 6 trotters $\left(2: \mathrm{II}^{1} / 4\right), 7$ pacers ( $\left.2: 10\right)$.

FRED WILKES (3-128), bay, star, left hind foot white, I $53 / 4$ hands, 1000 pounds; foaled 1883 ; bred by Edwin Bates, New York, N.Y.; got by Red Wilkes, son of George Wilkes: dam Black Princess, black, I51/2 hands, foaled I876, bred by Herr \& Goddard, Lexington, Ky., got by Mambrino Patchen, which see; 2 d dam Lady Bugg, said to be by Star Davis, son of imported Glencoe ; 3d dam Lizzie Bugg, by Epsilon, son of Pacific; $4^{\text {th }}$ dam Cottage Girl, by imported Ainderby; and $5^{\text {th }}$ dam Princess Ann, by imported Leviathan. Sold to J. S. Ferguson, New York, N. Y. Pedigree from catalogue of breeder.

Sire of of 3 pacers $(2: 09)$.

FRED WILKES ( 3 - 28 ), bay, $153 / 4$ hands, Io50 pounds; foaled 1887 ; bred by F. S. Cole, Meadville, Penn.; got by Brown Wilkes, son of George Wilkes : dam Lizzie C., sorrel, bred by H. H. Clough, North Amherst, O., got by Star Hambletonian, son of Hambletonian ; $2 \mathrm{~d}$ dam Minnie W., gray, said to be by Telegraph; and 3d dam by Baker's Highlander, son of Paul's Highlander, by Kellogg's Highlander, son of Justin Morgan. Sold to J. G. Stewart, Brantford, Ont. Pedigree from breeder.

Sire of 3 pacers $\left(2: 19 \frac{1}{4}\right)$.

FRED WILKES (I-32), 2 : $13 \frac{1}{4} / 4$, bay, 15 I $/ 2$ hands, 950 pounds; foaled I 888 ; bred by Caleb Jones \& Son, China, Me.; got by Wilkes, son of Alcyone : dam Randall mare, bay, bred by L. J. Randall, China, Me., got by Onward (Nelson's), son of Ohio Morrill ; 2d dam said to be by Freeman's Telegraph. Died previously to ז 906 . Pedigree from W. H. Jones, Weeks Mills, Me., who writes :

"The horse Telegraph, sire of $2 \mathrm{~d}$ dam, was I think a Morgan. $\mathrm{He}$ was owned by Thomas Lang, Vassalboro, Me., at the time he owned Gen. Knox."

Sire of Darius, 2:181/2. 
FREE AND EASY; said to be of the true Narragansett breed. Advertised, I 785, by Sam Woolcott, at East Windsor, Conn, as follows :

"Procured at a great expense, and the public are assured that he is of the genuine breed and put at so low a price that those having likely mares may breed them, so that a breed so valuable may not be lost. Terms \$I to $\$ 2 . "$

A horse of this name, light chestnut, called a racker was brought about I790, from Narragansett Bay to Warren, N. C., by Thomas E. Turner of Warren. Frank Forester in The Horse of America says :

" His like I have not seen since. His owner in a ride from Warrentown, after the season, permitted him to go too freely, and he died in consequence. Afterwards Ranger, a dark chestnut, and of good substance, was brought from the same district of country, by Sam Williams, I think, of Warren."

William Williams of Nashville, Tenn., says in Spirit of The Times, Sept. I 2, I 840 :

"My father bred an Eclipse mare to Free and Easy from Narragansett. He was a natural racker (or as sometimes called a natural pacer). He rode the produce, a pacer, till shortly before his death.

"Free and Easy was light chestnut about I 5 hands, handsome forehead and good clean limbs but rather scant in the middle piece. For ease and celerity in the rack I never saw his fellow, but a too long protracted ride in August lost him his life."

FREE COINAGE (3-т28), 2 :I I 3/4, gray, I6 hands, I I oo pounds; foaled I 890 ; bred by George A. Wiley, Danville, Cal. ; got by Steinway, son of Strathmore: dam Nelly E., gray, bred by G. A. Wiley, got by Elmo, son of Mohawk; 2d dam Gray Nel, gray, said to be by Stockbridge Chief. Sold to Wheldon \& Fuller, Emporia, Kan. ; to T. J. Fleming \& I. E. Lambert; to Mr. Lackey, Rocky Ford, Col., who owned him, I905. Pedigree from David Potter, Emporia, Kan.

Sire of 2 pacers, $2: 12 \frac{1}{4}$.

FREE DEAL; foaled I 890 ; bred by George C. Kenyon, Mt. Carmel, Ill.; got by Ideal, son of Idol :

Sire of Douglass T., $2: 163 / 4$.

FREEHOLDER (3-256) ; bred by Mr. Whitney, St. Louis, Mich.; got by Roman, son of Oscar, by Masterlode. Information from Dr. Harry Montgomery, Bridgeport, Mich.

Sire of Gov. Pingree, $2: 201 / 4$.

FREELAND, $2: 19 \frac{1}{4}$, bay; foaled I887; bred by Charles E. Cole, Atica, Ind., got by bald Hornet, son of Robinson's Bald Hornet: dam said to be by Rambler.

Sire of 3 pacers $\left(2: I_{5} \frac{1}{4}\right)$.

FREEMAN (I-I 28 ), bay; foaled I 878 ; bred by T. C. Freeman, Spring 
Station, Ky.; got by Woodford Abdallah, son of Woodford Mambrino: dam said to be by Alcaide, son of Mambrino Chief ; $2 \mathrm{~d}$ dam by Endorser, son of Wagner; and $3 \mathrm{~d}$ dam by Tom Hal. Sold to S. S. Offutt, Georgetown, Ky.

Sire of Belle Freeman, $2: 18 \frac{1}{4}: 4$ dams of 4 trotters, 2 pacers.

\section{FREEMAN HORSE. See Young Messenger (Squier's).}

FREEMAN HORSE (GEN. SHERMAN JR.) (3-32), bay, I6 hands ; bred by Mr. Fish, Ira, Vt. ; got by Gen. Sherman, son of Young Columbus : dam said to be by Tom Howard, son of Black Hawk; and $2 \mathrm{~d}$ dam by Ransom Horse, son of Andrus' Hamiltonian. Sold to Geo. Freeman, West Rutland, Vt., and afterwards went to New Brunswick or Nova Scotia; and later is said to have been taken to England. Reported a fast trotter. Information from Lester Fish, Rutland, Vt.

FREESTONE $\left(7-25^{6}\right), 2: 25^{1 / 2}$, bay, one white hind ankle, 15 $1 / 2$ hands, I025 pounds; foaled I $88 \mathrm{I}$; bred by C. M. Pond, Hartford, Conn. ; got by Gatling, son of Rysdyk : dam Gretchen, bred by James M. Mills, got by a son of American Star ; 2 d dam Lady Fallis, bay, bred by Jas. M. Mills, got by American Star; 3d dam Beck mare, said to be by Long Island Black Hawk. Sold to O. K. Burnham, Royalton, Vt., who sends pedigree.

Sire of Beulah, $2: 27 \frac{1}{4}$.

FREETRADER ( $1-32$ ), bay, I6 $1 / 4$ hands, I 275 pounds; foaled 1880 ; bred by James P. Ford, Versailles, Ky. ; got by Allie Gaines, son of Almont : dam Creta, chestnut, bred by James P. Ford, got by Sam Broaddus, son of Mambrino Chief ; $2 \mathrm{~d}$ dam gray, bred by Wm. Rowland, got by Daniel Boone ; 3 d dam said to be by Bald Hornet; and 4th dam by Blackburn's Whip. Sold to W. H. Sellers, Florence, Kan., who sends pedigree; to I. V. Howard, Aberdeen, Mass.

Sire of Bart Anderson, $2: 23 \frac{1}{4}$.

FRENCH BASHAW (I-I 28 ), gray, $153 / 4$ hands, 1 roo pounds; foaled 1876 ; bred by J. M. French, Detroit, Mich.; got by Black Bashaw, which see : dam Lilly Simpson, gray, bred by R. A. Alexander, Spring Station, Ky., got by Edwin Forrest, son of Young Bay Kentucky Hunter; 2d dam Gray Goose. Sold to W. H. Stevens, Detroit, Mich. Information from H. T. Cole, Monroe, Mich.

Sire of 2 trotters $\left(2: 20 \frac{1}{4}\right)$; Gray Fred, $2: 24 \frac{1}{2}$.

FRENCH CHARLEY (CHARLIE, VERMONT BOY) (3-8) ; foaled about I 845 ; said to be by Billy Root, or a son.

Mr. Joseph BatTell,

St. Albans, Vt., Dec. 2, 1905 .

Dear Sir :-Replying to yours of Nov. $29^{\text {th, }}$ will say, I remember the 
horse referred to very well, he was owned by Frank Stone, who ran the stage from here to East Berkshire sixty years ago. The horse came from the south, but in what state he was raised I do not know. He was a very fine horse. Occasionally Stone would drive him on the lead, and often abused him shamefully - to illustrate, he drove him two miles with near hind leg over the trace, he kicked over it, and Stone in his drunken folly was going to break him of kicking, etc., and it was always in play. He was a fast and fine gaited trotter, very stylish, and to day would be considered way up. Your conjectures as to his coming from Canada were correct, as to sale of the horse I have forgotten. The markings are correct but mane and tail were dark, not silver. Never knew Iouis Barbou. Stone died fifty years ago. Neither Sanderson or Gadcomb ever owned a dollar in him.

Now Mr. Battell I will refer you to Adolfus Paul of East Berkshire, an old man who was always an intimate friend of Frank Stone's father, James Stone, who kept for many years the brick tavern in East Berkshire. Mr. Paul is a well preserved old man, and I feel assured will give you as reliable information as any one can do. I regret I cannot give you such information as you require. I fully appreciate what you are, and always have been doing for our dear good old Morgan stock, the best that ever was raised in the world, and do most sincerely hope you may be well repaid for your kindly acts. The State of Vermont owes you a golden crown for what you have already done. I had the great pleasure of visiting your farm and stables at Middlebury last Friday with my friend C. Williamson. Oh what a beauty that stallion is! [Gen. Gates]. It was well worth walking a long distance to see such a noble horse. I would like a picture of him to hang in. my office. Hoping you may meet with the grand success you richly merit, I am,

$$
\text { Most respectfully, E. D. Fuller. }
$$

"I think I will write a party I know in Berkshire, and will give you the results, so don't write Mr. Paul until you hear from me. Horse was always called Charley, never heard the French put on."

The Pennsylvania Agricultural Report for $\mathrm{I} 853$, states that the $2 \mathrm{~d}$ best premium for best stallion between three and four was awarded to James Torrence of Alleghany County, for his elegant bay of Morgan blood. See Vermont Boy, American Stallion Register, also in The Morgan Register, Vol. I., p. 762 ; and Introduction of this book, p. xxxvii.

FRENCH LION; said to be a full-blooded French horse. Advertised in Greenfield, Mass., I806-7.

FRENCH LION, dark brown, I5 hands; foaled I822. Advertised as above at Middlebury, Vt., I828, in National Standard, by John Ballard, who says :

"He possesses uncommon strength, and is the fastest horse that ever stood in Vermont. He is well fitted for the harness, his stock have great strength and speed. Terms $\$ 3$ to $\$ 4$."

FRENCHMAN (McDONALD'S), said to be by Flying Frenchman.

Sire of Frenchman, $2: 24^{3 / 4}$. 
FRENCH PLATE (3-128), $2: 26 \mathrm{I} / 4$, brown; foaled I 888 ; bred by Hermitage Stud, Nashville, Tenn.; got by Wedgewood, son of Belmont, by Alexander's Abdallah: dam Mary B., brown, bred by T. O. Harris, Nashville, Tenn., got by Alcalde, son of Mambrino Chief ; $2 \mathrm{~d}$ dam Mary Weaver (dam of Don, $2: 22 \mathrm{I} / 2$ ), gray, bred by D. C. Twogood, Canastota, N. Y., got by Black Hawk Vermont, son of Black Hawk; 3d dam Peggy, also called old Reel, a long distance trotter, untraced. Pedigree from Hermitage Stud catalogue, I89o.

Sire of Wyatt, $2: 2$ I.

FRENCH TIGER, I6 hands, I350 pounds; said to be of Norman descent. Brought from Canada to Maine, where he was owned by America Farrar, of Buckfield, afterward by Charles Proctor, of Corinna. Thompson (Maine Bred Horses), says: "A fine horse and fast." The Transaction of Agricultural Societies in Maine, I850-I-2, under Oxford Society, p. 28 I says :

"In I 846 the Committee on Horses awarded to America Farrar, Buckfield, for best stallion, $\$ 4.00$. In I 848 the Committee on Horses have to regret the want of interest in stock horses. The only one entered was the French Tiger by Mr. Farrar. They say he has been owned in the county the last two years, is 8 years old and has a liberal patronage. Town Committee awarded Mr. Farrar ist premium, \$3.0o."

Mr. Barbou, St. Mary, Beauce County, Que., in interview 1906, said :

“French Tiger, an excellent horse was taken from this county to Maine in the forties by my father. I do not know his pedigree."

Sire of 4 dams of 3 trotters, I pacer; 2 dams of 2 sires of 3 trotters.

FRIAR; foaled I 760 ; bred by Sir John Moore; got by South, son of Regulus, by Godolphin Arabian: dam by Babraham-Golden Ball (son of Partner)-Hampton Court Childers-Sophronisba. Imported to South Carolina, I766, and covered, I767, his first season, at Thomas Boone's Plantation, Pon Pon, afterwards the season of 1774 at Beach Hill, at $£ 35$ currency. Milliken.

The General Stud Book has a Babraham mare dam by Golden Ball, on page 27 , and credits her with a bay colt, Friar, foaled 1759 , but gives her grandam as Bushy Molly, foaled $\mathbf{1 7 3 7}$, by Hampton Court Childers, from Bushy Molly, foaled I717, by the Hampton Court Litton Arabian. On page 73, it states that Sophronisba, foaled I717, by Dyer's Dimple produced in 1735 , a filly by Hampton Court Childers.

FRICHETTE HORSE (I-I6), dark chestnut, I6 hands, I30o pounds; foaled about $185_{2}$; bred by Mr. Hibbard, St. Johns, P. Q. ; got by the Simard Horse, son of the Twombly Horse (which see). Sold when three years old to Mr. Frichette, who sold him when eleven to John Cardin, Montreal. Afterwards went to Upper Canada.

Mr. D. C. Meiggs, Bedford, P. Q., said : 
"Joe Frichette, St. Casaire, ownerl the sire of Moose, bay, I6 hands. The old Beloeil horse was owned by the Cooks in l'almer, whe got him of John Cardin, St. Casaire. He was a St. Jawrence horse bay, 15 hands, rooo pounds, a gool horse, here two or three years. The Buckskin stock [Morgan] were not fast but valuable. James Riter of Conorsville, owned Croisier, a running horse sire of Mooce, with fast record. The officers at Chambly used to have thoroughbred horses and when they were old used to sell them. Jupiter Star was bay, $15^{1} / 2$ hands, rooo pounds, owned at Sorel, Que., by Burke, and got trotters."

Mr. Dickenson at Bedford, P. Q., in interview, I 89 I said:

" $\Lambda$ horse called Moose, bay, I6 hands, was owned in French Canada, a great trotter, think he went to the States."

FRIENDSHIP (COMMANDER?) ; said to be by imported Messenger: dam, by Kouli Kahn; 2 d dam by Hyder Alley; 3 d dam by Liberty; $4^{\text {th }}$ dam by imported Dove; and $5^{\text {th }}$ dam Fair Rachæl, imported by Col. James Delancy. Owned by J. Palmer, Pennsylvania. The above pedigree is given in the advertisement of Jersey Fagdown, which see.

FRITZ (SASSACUS), bay ; foaled May 6, I 873 ; bred by A. J. Alexander, Woodburn Farm, Spring Station, Ky., got by Harold, son of Hambletonian : dam Belle, bay, bred by J. W. Embry, Fayette County, Ky., got by Mambrino Chief ; $2 \mathrm{~d}$ dam said to be by Brown's Bellfounder. Sold to H. P. Strong, Beloit, Wis. Died Jan. I878. Pedigree from L. G. Lucas, Spring Station, Ky.

Sire of Prosper Merimee, $2: 24 \frac{1}{4}$; I sire of I trotter, I pacer.

FRITZ (I-64), $2: 29 \frac{1}{4}$, bay, one white hind foot, I $5 \frac{3}{4}$ hands I050 pounds; foaled I 874 ; bred by L. G. Paul, Leroy, N. Y.; got by St. Gothard, son of Geo. Wilkes : dam bay, bred by Alba Paul, Leroy, N. Y., got by Ralph, son of Green Mountain Boy ; 2 d dam brown, bred by Geo. Platt, Leroy, N. Y., got by Bogus, son of Cash's Bogus. Gelded young. Pedigree from breeder.

FRONTINO (3-256), bay; foaled I $88 \mathrm{I}$; bred by R. S. Veech, St. Matthew's, Ky., got by Princeps, son of Woodford Mambrino: dam Ozone, bay, foaled I 874 , bred by Guy Miller, Chester, N. Y., got by Hambletonian; 2d dam Lady Vixen, chestnut, bred by O. Smith, Cooper's Plain, N. Y., got by Magnolia, son of American Star; 3d dam said to be by Seeley's Black Hawk, son of Long Island Black Hawk; and $4^{\text {th }}$ dam by Stevens' Bellfounder. Sold to J. R. Middletown, Louisville, Ky. Pedigree of dam from breeder's catalogue.

Sire of Oakland Prince, $2: 201 / 4$.

FROST (3-64), bay, white marks, I6 hands, I 200 pounds; foaled $188 \mathrm{I}$; bred by Willis Moremen, Valley Station, Ky.; got by Harry Wilkes, son of George Wilkes : dam Bettey, bred by Willis Moremen, got by Golddust; 
son of Vermont Morgan; $2 \mathrm{~d}$ dam bred by Alanson Moremen, Valley Station, Ky., got by Henton's Eclipse. Sold to J. R. Conn, Valley Station, Ky., who sends pedigree. Died I904.

Sire of $\mathcal{F u d ~ N i c k , ~} 2: 20$.

FROST HORSE (I-4), dark bay or brown; foaled about I829; bred by Jeremiah Frost, Waterloo, P. Q.; got by Hawkins Horse, son of Justin Morgan. Sold to Len. Knowlton, Bolton, P. Q., who kept him till quite old, when he went to Stanstead. He is said to have got very fast and excellent stock. See The Morgan Horse and Register, Vol. I., p. 744 .

FRY BAKER HORSE (BAKER HORSE), untraced.

Sire of Argyle, $2: 14^{3} / 4$.

FUGLEMAN, bay, one hind foot white, I6 $1 / 4$ hands, I 75 pounds ; foaled I $88 \mathrm{I}$; bred by R. S. Veech, St. Matthews, Ky.; got by Princeps, son of Woodford Mambrino: dam Miss Fanny, bay, bred by Hunt Bros., Lexington, Ky., got by Hamlet, son of Volunteer ; 2d dam Puggy, bay, bred by Hunt Bros., got by Brignoli, son of Mambrino Chief; $3 \mathrm{~d}$ dam Bertha, chestnut, bred by G. Drummond Hunt, Lexington, Ky., got by Berthune; 4th dam Hunt's premium mare, said to be by Scott's Highlander. Sold to Wood \& Warren, Buda, Ill. Died r896. Pedigree from breeder.

Sire of 5 trotters $(2: 161 / 4), 2$ pacers $(2: 191 / 4)$.

FULANO (3-128), $2: 22 \mathrm{r} / 2$, chestnut; foaled March 29, I 889 ; bred by C. W. Brockunier, Wheeling, West Va.; got by El Mahdi, son of Onward, by George Wilkes: dam bay, I $53 / 4$ hands, foaled 1869 , bred by L. L. Dorsey, Jr., Louisville, Ky., got by Hambletonian; $2 \mathrm{~d}$ dam said to be by Golddust, son of Vermont Morgan; and $3 \mathrm{~d}$ dam by imported Glencoe. Sold to H. A. Moyer, Syracuse, N. Y. Pedigree from breeder. Sire of Maud $W, 2: 1_{5} \frac{1}{2}$.

FULLERTON D. (3-128), 2 :193/4, black; foaled 1878 ; bred by Samuel Powers, Decatur, Ill.; got by Regalia, son of Jay Gould: dam Kate F., said to be by Bourbon Chief, son of Mambrino Chief ; and 2 d dam Black Bess, by Norman, son of Morse Horse. Sold to O. B. Thayer ; to Arthur Moore, both of Clinton, Ill.

Sire of 2 pacers $\left(2: I 1 \frac{1}{2}\right)$; I dam of I pacer.

FULLER WILKES, black, I43/4 hands; foaled I 868 ; bred by W. L. and $Z$. E. Simmons, Lexington, Ky.; got by George Wilkes, son of Hambletonian: dam Alice Gray. Sold to L. N. Fuller, New York, N. Y. Died I882. Pedigree from Z. E. Simmons.

Sire of David L., $2: 191 / 2$.

FULLOM HORSE, cream color, white mane and tail, I6 hands, ro5o 
pounds; foaled I 860 ; bred by Geo. Jenkins, Springfield, Vt.; got by Valentine Horse (Sykes Horse) : dam bay, foaled in Chester, Vt., from a mare owned by Charles Field, Boston, Mass. Sold to H. W. \& H. H. Jenkins, Springfield, Vt.; to Mr. Alvin Fullom, Springfield, Vt. Died I 875 . Pedigree from breeder.

FULTON ( $\mathrm{I}-8)$. Said to have been owned by Sidney Rowley, Ellington, $\mathrm{N}$. Y., and got by Black Hawk. See The Morgan Horse and Register, Vol. I., p. 497.

Sire of one sire of I trotter, 2 pacers.

FULTON, said to be by Tempest, son of Royal George, by Warrior. Sire of Mollie K., $2: 29^{3 / 4}$.

FURMAN HORSE. See Captain Lightfoot.

FUTURE GILBERT (3-I28), $2: 22 \mathrm{I} / 4$, bay, no marks, I 6 hands, I 200 pounds; foaled June I6, I 886 ; bred by E. P. Denton, Hamilton, Ill.; got by Henry Gilbert, son of Clark Chief : dam Red Wing, chestnut sorrel, bred by E. P. Denton, got by Toronto Patchen, son of Ellis Patchen; 2 d dam Lady Lightfoot, bay, bred by E. P. Denton, got by Flaxtail which see; 3 d dam Fanny Stevens, bay, bred by E. P. Denton, got by Stevens' Uwharie, son of Farlow's Uwharie; 4th dam gray, bred at Milan, Mo., said to be by a son of old Gray Eagle. Sold to A. V. Brooking, Macomb, McDonough County, Ill. Pedigree from breeder.

Sire of Bessie Gilbert, $2: 14 \frac{1}{4}$.

FYLDE, bay; foaled I 824 ; bred by Mr. Clifton, said to be by Antonio : dam Fadladinada, by Sir Peter Teazle-Fanny, by Diomed-Ambrosia, by Woodpecker-Ruth (dam also of I. H. Slender), by Blank-Regulus -Soreheels-Makeless-Christopher D'Arcy's Royal Mare. Imported into Virginia in August 1832 by Messrs Avery, Merritt \& Townes.

Fylde got crippled in landing him from the ship.-Edgar.

ABRIEL, chestnut sorrel, little white on hind feet, I6 hands; foaled I I820. Will be kept at Bloomsbury, N. J. (I83I).

Cornelius H. VAnderveer.

GABRIEL, dark bay, 15 I $/ 2$ hands; said to be by Dorimant: dam by Highflyer; 2 dam by Snap; 3 d dam by Sheperd's Crab; and $4^{\text {th }}$ dam by Cade. Advertised in Virginia Herald, r 799, as "just arrived at Norfolk, in the Industry, Captain Vickery," by John Tayioe. 
GAIL BORDEN (3-256), bay ; foaled i 886 ; bred by E. Scherzer, Peru, Ill. ; got by Austerlitz, son of August Belmont.

Sire of Deacon, $2: 28$.

GAIL WILKES (I-I28), $2: 133 / 4$; bred by Chas. Nolan, Center Square, Montgomery County, Penn.; got by Conklin's King Wilkes, son of George Wilkes : dam Gail Hamilton, bred by Ambro Whipple, Crawford County, N. Y., got by Saturn, son of Satellite; 2 d dam said to be by Washington Hambletonian. Pedigree from Cyrus Lukens, who writes: Mr. Nolan bought Gail Hamilton of A. T. Oatman then of Buffalo, N. Y. Sire of Colonel Wilkes, $2: 3_{3}^{3} / 4$.

GALEOTTI (3-128), bay; foaled 1882 ; bred by R. S. Veech, St. Matthews, Ky.; got by Princeps, son of Woodford Mambrino: dam Sister, bay, bred by Alden Goldsmith, Washingtonville, N. Y., got by Volunteer, son of Hambletonian; 2 d dam Lady Sears, bay, bred by John Sears, Coldenham, N. Y., got by Seeley's American Star; and 3d dam said to be by Abdallah. Pedigree from catalogue of breeder.

Sire of Fanny Rice, $2: I_{4} \frac{1}{2}$; I sire of I trotter, 2 pacers; I dam of I trotter.

GALILEO REX (I-64), brown, I $5 \frac{3}{4} 4$ hands, II 50 pounds; foaled I 888 ; bred by W. L. Simmons, Lexington, Ky.; got by Billy Sayre (dam Fanny, by Geo. Wilkes; 2d dam Dame Tansy, by Daniel Lambert), son of Young Jim : dam Dewey Eve, brown, bred by W. L. Simmons, got by George Wilkes; 2 d dam Lady Frank, roan, bred by Chas. Leggatt, Cincinnati, O., got by Mambrino Star, son of Mambrino Chief ; 3d dam Lady Franklin, roan, I4 I 2 hands, about 900 pounds, foaled 1848 , bred by Luther Hayes, Milton, N. H., got by Esty's Black Hawk, son of Black Hawk by Sherman Morgan; $4^{\text {th }}$ dam bay, about 15 hands, said by Mr. Hayes, to have been bred at Gilmanton, N. H., and got by a Morgan horse when coming three. Sold to J. S. Spain and A. Y. Art, both of Hartford, Ia. Pedigree from J. S. Spain and Luther Hayes.

Sire of 6 trotters $\left(2: 12 \frac{1}{2}\right),+$ pacers $\left(2: 17^{1 / 4}\right)$.

GALLANT HERO, bay, I 7 hands; said to be by Cincinnatus. Advertised I 793, I 795, I 798, near Albany, in Albany Gazette.

GALLATIN (WYNN'S), bay ; bred by William Wynn, Sr., Esq., of Virginia ; got by imported Diomed, son of Florizel: dam said to be by Bellair; 2d dam, by imported Master Stephen ; 3d dam by imported Jolly Roger, son of Roundhead; 4th dam by imported Crawford, son of Cumberland Arabian; $5^{\text {th }}$ dam by imported Fearnaught, son of Regulus.-American Stud Book, Vol. I., p. 753 .

Sire of the $4^{\text {th }}$ dam of Dick Moore, $2: 221 / 2$, winner of 14 races.

GALLOWAY; said to be by Mambrino Chief.

Sire of Neddie E, $2: 26$. 
GALOPIN. In connection with this horse the following including statistics of the age of noted stallions is given, and which we presume to be correct.

\section{IONG-IIVED STALLIONS.}

"People are wondering why Mr. Chaplin, who, in partnership with the Duke of St. Albans, owns Galopin, is desirous of turning his stud into a limited liability company, with a cajpital of $\mathcal{E}_{20,000}$. As times go this seems rather a large sum, as Hermit is dead, and Galopin when he next covers will be twenty-one years old. The average life of the English thoroughbred stallion is only sixteen years. Galopin, however, comes of a hardy race. His sire, Vedette, lived to a good old age, and his grandsire, Voltiguer, was twenty-seven when he broke his leg and harl to be shot. This was the age of King Tom when he dierl. Stockwell, who was the most famous stallion of this century, was twenty-one, and his great rival, Newminister, twenty. The Methuselah of sires was rare old Touchstone, who kept on until he was thirty, and several of his descendants have been long lived. Surplice was twenty-six and Orlando twenty-seven, Marsyas twenty-five and Hermit twenty-seven. Gunboat, by Sir Hercules, was shot when he was twenty-nine. Lord Palmerston's only Derby horse, Mainstone, lived to be twenty-seven. It will be seen from these figures that with luck there are four or five seasons still before Galopin, and it is perhaps on this foundation that the capital of the stud in a great measure rests."-Exchange.

GALOPIN ( $\mathrm{I}-32$ ), bay with star, right hind ankle and coronet on left hind foot white; foaled 1885 ; bred by C. J. Hamlin, Buffalo, N. Y.; got by Almont Jr. : dam Gerster, chestnut, bred by A. Hurst, Midway, Ky., got by Hero of Thorndale; 2 d dam Mary, bay, bred by A. Hurst, got by Woodford Mambrino, son of Mambrino Chief; 3d dam Belle, said to be by Alexander's Norman; 4th dam Vic, bay, bred by A. Hurst, Midway, Ky.; got by Mambrino Chief; $5^{\text {th }}$ dam Fly, said to be by Barclay's Columbus Jr. Pedigree from catalogue of breeder.

sire of $\mathcal{F}_{0} \mathcal{F}_{0,2}: 191 / 4$.

GALVANO (3-I28), bay with star; foaled r 888 ; bred by G. \& C. P. Cecil, Danville, Ky.; got by Gambetta Wilkes, son of George Wilkes: dam Enterprise, bay, bred by Col. R. P. Pepper, Frankfort, Ky., got by Onward, son of George Wilkes; 2d dam Belle Thorn, bay, bred by Col. R. P. Pepper, got by Hero of Thorndale, son of Thorndale; $3 \mathrm{~d}$ dam Abutillon, bay, bred by F. P. Kinkead, Woodford County, Ky., got by Belmont, son of Alexander's Abdallah; and 4th dam Minna, bay, bred by F. P. Kinkead, Midway, Ky., got by Red Jacket, son of Billy Root, by Sherman Morgan. Sold to S. B. Hazard, Peoria, Ill. Died I892. Pedigree from catalogue of breeder.

Sire of 2 trotters $\left(2: 21^{1 / 4}\right)$, Galvano Belle, $2: 191 / 4$.

GALVESTON (3-256), black; foaled I 887 ; bred by C. P. Cecil, Danville, Ky. ; got by Gambetta Wilkes, son of George Wilkes : dam Golden Hair, chestrut, bred by C. P. Cecil, got by Mambrino Patchen; 2 d dam 
Fancy, said to be by Norman Messenger; 3 d dam Fly, by Kossuth; and $4^{\text {th }}$ dam Jenny Lind, by Bascomb. Pedigree from catalogue of breeder.

Sire of Nannie Mahan, $2: 261 / 4$.

GALVIN ( $1-64$ ), bay ; foaled I 892 ; bred by G. \& C. P. Cecil, Danville, Ky. ; got by Gambetta Wilkes, son of George Wilkes : dam Nantura, bay, bred by J. C. McFerran, Louisville, Ky., got by Nutwood, son of Belmont ; 2d dam Nora Lee, bay, bred by A. J. Alexander, Spring Station, Ky., got by Woodford Mambrino, son of Mambrino Chief; and $3 \mathrm{~d}$ dam Young Portia, said to be by Mambrino Chief, son of Mambrino Paymaster. Sold to L. B. Hagerman, Springfield, O. ; to F. K. Gelnix, Findlay, O.

Sire of Galbetor, $2:$ II $^{1} / 2$.

GAMALEON (3-I28), $2: 25 \mathrm{~T} / 4$, brown, $15 \frac{1}{2} 2$ hands; foaled 1887 ; bred by G. \& C. P. Cecil, Danville, Boyle County, Ky. ; got by Gambetta Wilkes, son of George Wilkes : dam Lady Pepper, brown, bred by W. H. Robinson, Harrodsburg, Ky., got by Onward, son of George Wilkes ; $2 \mathrm{~d}$ dam Fanny Robinson, brown, bred by William Vance, Harrodsburg, Ky., got by Blood Chief ; 3 d dam Sarah Robinson, said to be by Alexander's Norman ;

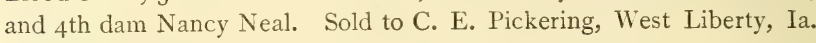
Pedigree from catalogue of breeders.

Sire of 12 trotters $(2: 163 / 4), 4$ pacers $\left(2: 08 \frac{1}{2}\right) ; 3$ sires of 2 trotters, 3 pacers.

GAMARZA ( $\left.1-3^{2}\right), 2: 271 / 2$, brown; foaled I 888 ; bred by Granville Cecil, Danville, Ky.; got by Gambetta Wilkes, son of George Wilkes: dam Winnie Wilkes ( dam of Mambrino Maid, $2: 15 \frac{1}{4}$ ), bay, bred by C. T. \& H. Worthington, Danville, Ky., got by Red Wilkes, son of George Wilkes; 2 d dam Gipsey Queen, said to be by Bourbon Chief, son of Mambrino Chief ; 3 d dam Young Fly, by Red Jacket, son of Billy Root, by Sherman Morgan; 4th dam Fly, thoroughbred, by Bertrand; and

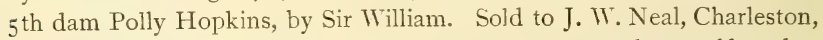
Ill. ; to J. B. Merrell, Hindsboro, Ill. Pedigree from catalogue of breeder Sire of 5 trotters $\left(2: 20^{1 / 4}\right) ; 2$ dams of I trotter, I pacer.

GAMBETTA, bay, I5 5 $/ 2$ hands, II50 pounds; foaled about 1874 ; bred by Bateman Brooks, Washingtonville, N. Y.; got by Volunteer, son of Hambletonian : dam Nell, bred by T. B. Brooks, got by Hambletonian, son of Abdallah; 2 d dam Welling Mare, said to be by Shark, son of American Eclipse. Died I898. Sold to B. Kittredge, Peekskill, N. Y., who sends pedigree.

Sire of II trotters $\left(2: 19 \frac{1 / 2}{2}\right)$; I sire of I trotter; 6 dams of 6 trotters, I pacer.

\section{GAMBETTA. Untraced.}

Sire of Big Bone, $2: 23 \frac{1}{2}$. 


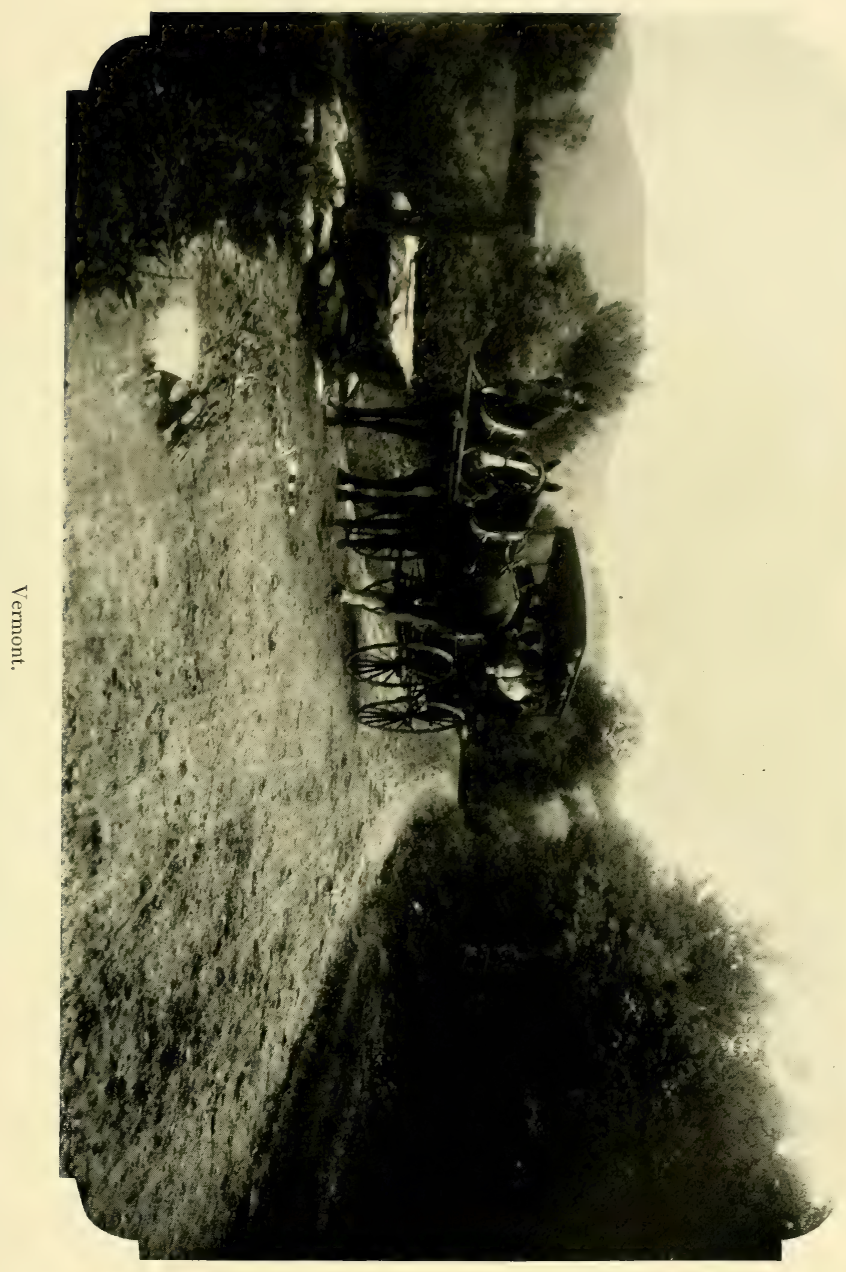




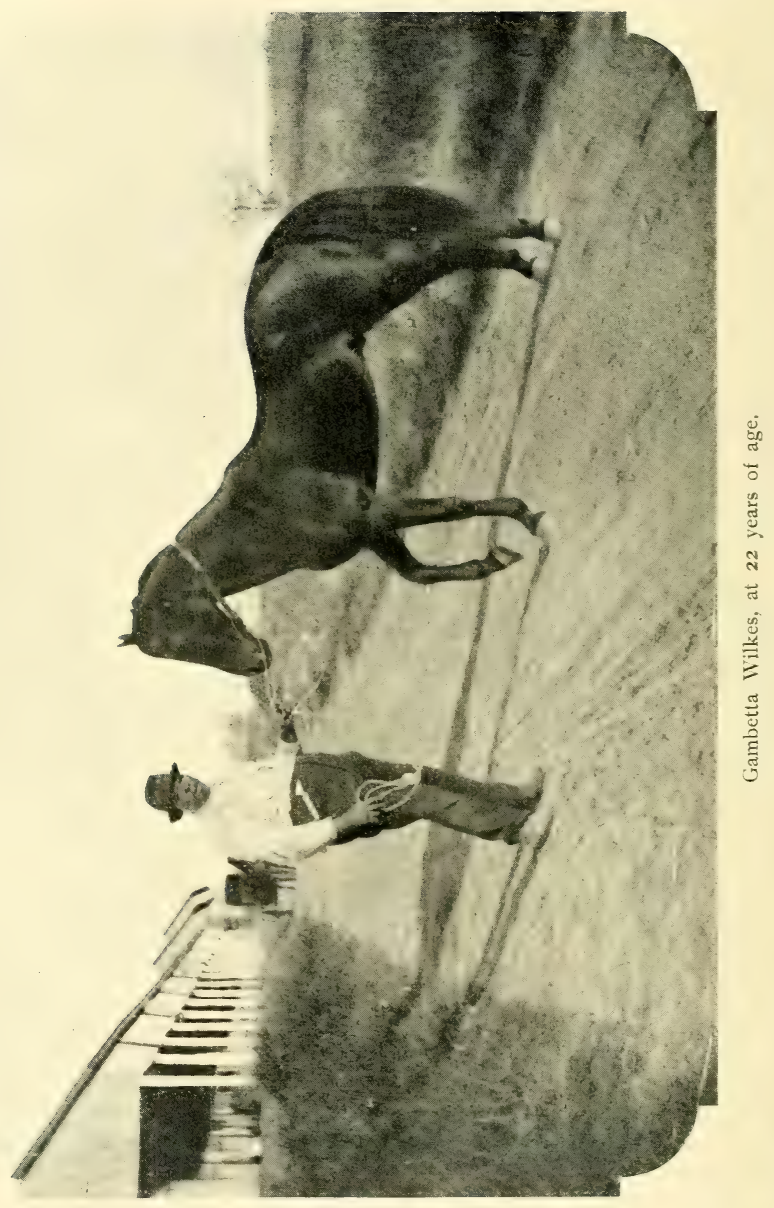


GAMBETTA WIIKLS ( $1-64), 2: 26$, black, $15 \frac{1}{2}$ hands; foaled $188 \mathrm{I}$; breil by R. B. Terrell, Richmond, Ky. ; got by (ieorge Wilkes: dam Jewell, brown, I6 hands, foaled I869, bred hy John S. Gill, Lancaster, Ky. ; got by Gill's Vermont, son of Downing's Vermont, by Black Hawk ; $2 \mathrm{l}$ dam Salter Mare (dam of Black Maria, 2 mile record $5: 133 / 4$ ), bred by Jacob Embry, Fayette County, Ky., got by Cannon's Whip, son of Blackburn's Whip; 3d dam brought from Virginia. Sold to G. \& C. P. Cecil, Danville, Ky., who send pedigree.

"The President, $2: 09 \frac{1}{2}$, trotting, is the fourteenth 2 : Io performer for his sire, Gambetta Wilkes. This puts Gambetta Wilkes far in the lead as an extreme speed sire, numbers considered, and is a strong indorsement of the opinion of Mr. Granville Cecil, one of his owners, expressed years ago, namely, that Gambetta Wilkes would not only eventually lead all sires of his generation as a sire of Standard jerformers, but of extreme speed performers. Prejudices aside, or allowed to count either for that matter, the family of Gambetta Wilkes is a most remarkable one. Not only the 'head of the house' himself, but his sons, daughters, grandsons and granddaughters are wonderfully prolific of not only standard speed, but extreme speed."-Western Sportsman.

Sire of $5^{8}$ trotters $\left(2: 09 \frac{1}{4}\right), 59$ pacers $(2: 05 \%) ; 32$ sires of 56 trotters, 75 pacers; I 8 dams of $I_{3}$ trotters, I2 pacers. (At the close of Igo8 Gambetta Wilkes had to his credit, Ior trotters and ro3 pacers-the largest number of trotters and pacers combined credited to any stallion to that date).

GAMBOLIER ( $\mathrm{I}-64$ ), bay, star and small stripe, right hind foot white; foaled r 887 ; bred by Granville Cecil, Danville, Ky. ; got by Gambetta Wilkes, son of George Wilkes: dam Attie Belle, bay, bred by J. H. Engleman, Danville, Ky., got by Messenger Chief, son of Abdallah Pilot; 2 d dam Nelly, said to be by Balsora, son of Alexander's Abdallah; 3d dam Noonday, gray, bred by A. J. Alexander, Spring Station, Ky., got by St. Elmo, son of Abdallah; 4th dam Midnight (dam of Jay-EyeSee, 2 :Io), gray, bred by R. A. Alexander, Spring Station, Ky., got by Pilot Jr., son of Pilot. Sold to W. A. Powder ; to A. Griffith, \& E. L. Hann, Denton, Tex. ; to Wm. Whitten, Pilot Point, Tex.; to L. E. Brown, Delevan, Ill. ; to Joel Bragg, Deerfield, Ill. Pedigree from catalogue of breeder.

Sire of 2 pacers $(2: 121 / 4)$.

GAMBONITO (3-128), 2 :19 1/4, black, I6 hands, I 60 pounds; foaled I 887 ; bred by William M. Rue, Danville, Boyle County, Ky.; got by Gambetta Wilkes, son of George Wilkes : dam Maud, brown, bred by E. H. Meyer, Danville, Ky., got by Garrard Chief, son of Mambrino Chief; 2d dam Nelly, bay, bred by H. Meyer, got by Tige, son of Billy Boyce, by Corbeau ; 3 d dam said to be by Helm's Yorkshire, pedigree untraced. Sold to L. E. Rue, Danville, Ky., who sends pedigree.

Sire of Gilbert, $2: 281 / 2 ; 2$ pacers $(2: 081 / 2)$.

GAMBREL ( $\mathrm{r}-32$ ), bay; foaled r 887 ; bred by G. \& C. P. Cecil, Danville, Ky. ; got by Gambetta Wilkes, son of George Wilkes : dam Bellfield, bay, 
bred by W. \& V. L. Polk, Columbus, Tenn., got by Enfield, son of Hambletonian ; $2 \mathrm{~d}$ dam Lady Belmont, bay, bred by Marcus Downing, Lexington, Ky., got by Belmont, son of Abdallah; 3 d dam said to be by Ericsson; and $4^{\text {th }}$ dam by Black Hawk, son of Sherman Morgan. Sold to A. L. Winship \& Amos, Rushville, Ind.; to A. B. Butt, Blackwell, Okla. Pedigree from catalogue of breeder.

Sire of 2 trotters $\left(2: 19 \frac{1}{2}\right), 18$ pacers $\left(2: 08 \frac{1}{4}\right)$.

GAM BRUNO (5-5 I 2 ), 2 :29 T/2, black, I $53 / 4$ hands; foaled 1887 ; bred by G. \& C. P. Cecil, Danville, Ky. ; got by Gambetta Wilkes, son of George Wilkes: dam Delilah, bay, bred by Geo. Stevens, Ilion, N. Y., got by Administrator, son of Hambletonian; $2 \mathrm{~d}$ dam Mary Elmore, bay, bred by Joel Atkins, Versailles, Ky., got by Mambrunella, son of Mambrino Chief ; 3 d dam said to be by Star Davis, thoroughbred; and 4 th dam by Brown Pilot, son of Pilot; or son of Copperbottom, by Brutus, son of Copperbottom, by Justin Morgan. Sold to Brown Bros., Griffin, Ga. Pedigree from catalogue of breeder. See Brown Pilot.

Sire of Maggie Baughman, 2:30.

GAM BYRON (5-512), $2: 19$ T/4, bay, 151/2 hands; foaled Narch 6, I887; bred by G. \& C. P. Cecil, Danville, Ky. ; got by Gambetta Wilkes : dam Ada Byron, chestnut, bred by W. \& V. L. Polk, Columbia, Tenn., got by Enfield, son of Hambletonian ; 2 d dam Hippia, said to be by Trouble ; 3d dam by Elliston's Rattler ; and 4th dam by Childe Harold. Sold to Charles Kohlnier; to Milton Garr Richmond, who bought him at Lackey's public sale. Pedigree from catalogue of breeder.

Sire of 2 pacers $(2: 161 / 4)$.

GAME ONIVARD ( $1-256$ ), tay ; foaled $\mathrm{x} 885$; bred by Col. R. P. Pepper, Frankfort, Ky. ; got by Onward, son of George Wilkes : dam Virtue, bay, bred by Col. R. P. Pepper, got by Mario, son of Sentinel; 2d dam Rosette, said to be by Alcalde, son of Mambrino Chief ; 3d dam Mary Nedoc (running bred) by Paddy Burns, son of Gray Eagle; and $4^{\text {th }}$ dam by Gray Eagle, son of Woodpecker. Sold to L. B. Morey, Aledo, Ill.

Sire of 5 trotters $\left(2: 10^{3} / 4\right)$, I 4 pacers $\left(2: I_{2} \frac{1 / 4}{4}\right) ; 2$ sires of $\mathbf{I}$ trotter, 3 pacers; $\mathbf{I}$ dam of $\mathbf{I}$ trotter.

GAMESTER ( I-64), bay ; foaled I 887 ; bred by G. and C. P. Cecil, Danville, Ky. ; got by Gambetta Wilkes, son of George Wilkes : dam Lilly W., bay, bred by Richard West, Lexington, Ky., got by Dictator, son of Hambletonian; 2d dam Hortense, said to be by Messenger Duroc, son of Hambletonian; 3 d dam Nelly McDonald, by Colosus; and $4^{\text {th }}$ dam Maid of Monmouth, by Traveler. Sold to John A. Coyner, Austin, O. Pedigree from catalogue of breeder.

Sire of Belle Hoop, $2: 271 \frac{1}{4}$.

GAMMON, (3-128), 2 :1 8, black; foaled I887; bred by G. \& C. P. Cecil, 
Danville, Ky.; got by (iambetta Wilkes, son of Cieorge Wilkes: dam Fib, chestnut, bred by W. \& V. I. Polk, Columbia, Tenn., got liy Enfield, son of Hambletonian; ad dam Rumor, black, bred by Robert Prewitt, Fayette County, Ky., got by Ashland Chief, son of Mambrino Chief; $3 \mathrm{~d}$ dam Gossip, bay, bred by R. A. Alexander, Spring Station, Ky., got lyy Tattler, son of Pilot Jr.; and $4^{\text {th }}$ dam Jessie Pepper, brown, bred by W. M. Dickey, Woodford County, Ky., got by Mambrino Chief. Sold to George Goodrich, Richland, Ia. Pedigree from catalogue of breeder.

Sire of 3 pacers $\left(2: 15 \% \frac{1}{4}\right)$.

G.AMIWOOD (3-I2S) bay, I53/4 hands, I roo pounds; foaled 1889 ; bred by Granville Cecil, Danville, Ky. ; got by Gambetta Wilkes, son of George Wilkes : dam Nutwood Belle, bay, bred by Granville Cecil, got by Nutwood, son of Belmont; 2 d dam Silly, bay bred by G. W. Rendenbush, Reading, Penn., got by Alert, son of Hambletonian; 3d dam Silence, chestnut, bred by Mason Henry, Woodford County, Ky., got by Alexander's Abdailah; 4th dam Woodbine, brown, bred by Mason Henry, got by Woodford, son of Kosciusko. Sold to J. C. Caldwell, Richmonddale, O., who sends pedigree.

sire of $\mathcal{F} . S, C ., 2: 22 \frac{1}{4}$.

G.ANO, I 6 hands one inch high; said to be by Eclipse: and dam Betsey Richards, by Sir Archie. Advertised, I 844 , to make his second season in Kentucky as imported Trustee, by A. Young, Mt. Sterling.-Observer and Reporter, Lexington.

GANYMEDE (3-128), bay, hind ankles white, I6 $3 / 4$ hands, I 10o pounds; foaled I 882 ; bred by R. S. Veech, St. Matthews, Ky. ; got by Princeps, son of Woodford Mambrino: dam Pearl, bay, bred by Charles Backman, Stony Ford, N. Y., got by Hambletonian; 2d dam Star Queen, said to be by Seeley's American Star; and 3 d dam by Emancipation, son of imported Emancipation. Sold to J. Harding, Pleasureville, Ky., I $\$ \$_{4}$; to John W. Monical, Vincennes, Ind., I887. Pedigree from catalogue of breeder.

Sire of 3 trotters $\left(2: 18 \frac{1}{4}\right)$; I sire of I trotter; 3 dams of 2 trotters, I pacer.

GAN ZOO (I-I28), $2: 24 \mathrm{~T} / 4$, brown; foaled $\mathrm{I} 890$; bred by G. \& C. P. Cecil, Danville, Ky.; got by Gambetta Wilkes; son of George Wilkes : dam Grenada, bay, bred by R. S. Veech, St. Matthews, Ky., got by Princeps, son of Woodford Mambrino; 2 d dam Flora, brown, bred by R. S. Veech, Louisville, Ky. got by Volunteer; 3d dam Flora Belle, $2: 223 / 4$, bay, bred by Harrison Dills, Quincy, Ill., got by Steven's Uwharrie; $4^{\text {th }}$ dam Kit, pedigree untraced. Sold to C. E. Pickering, West Liberty, Ia. ; to Albert \& Perry Hayes, Washington, Ia. Pedigree from C. E. Pickering.

Sire of Me Too, $2: 191 / 4 ; 4$ pacers $(2: 101 / 4)$. 
GARIBALDI (STEVEN'S) (I-32), $2: 33$, bay with star, fore feet tipped with white, about 16 hands, I 150 pounds; foaled 1857 ; said to be bred in Macomb County, Mich.; and got by Duroc Messenger or Canada Eclipse, a running horse brought to Port Huron, Mich., from Canada : dam said to be by a Black Hawk horse ; $2 \mathrm{~d}$ dam by a Messenger horse ; Purchased spring of $\mathbf{I} 859$, by J. H. Groff, who sold him when quite young to a Mr. McCummings of Illinois who took him to California, where he was owned by a stage Company. He was afterwards owned by Frank Stevens and taken by him to Swansea, Mass., and about 1875 , went to Pottsdam, N. Y., where he died, 1878 . Above pedigree is from J. H. Groff, Spickards, Grundy County, Mo., who writes :

"I bought Garibaldi in the spring of $\mathbf{1} 859$, then coming two years old. I was persuaded by a friend to buy him for his fine action and beauty. I have forgotten the man's name, I bought him of, I asked him if he knew the name of the sire, he said he did not only it was a Port Huron horse; this was some fifty miles from Port Huron, near Utica, Mich. After Garibaldi showed extra speed, I enquired for his sire, I found he was a horse brought from Canada to Port Huron, Mich., and they called him Duroc Messenger. He was then I9 years old, left but three colts and went back to Canada. The fast horse, or sporting men said he went by the name of Canada Eclipse, as he was one of the fastest running horses in Canada in his day. I got no further trace of him. Garibaldi's dam was by a Black Hawk horse and her dam by a Messenger horse. Garibaldi trotted in the fall after he was two years old at the State Fair at Detroit in $2: 58 . "$

We have the following advertised letter concerning this horse:

$$
\text { Utica, Mich., July i 2, i } \$ 88 .
$$

\section{Joseph BATTELL,}

Dear Sir :- Yours received with blank enclosed. I gave the blank to Robert S. Campbell of this place, who owned the half-brother of Blue Dick and is the best posted man on pedigrees we have in this section of the Country, and he said he would fill it out and send to you. I saw a Mr. Chapaton, who was a brother-in-law of McCummings, and he informs me that McCummings took a colt from here to California that he called McNeal Chief; that McCummings bought of a Mr. John H. Groff, who formerly lived here. Mr. C. said that McCummings told him the said colt trotted very fast in California. The colt was called by Groff, while here, Garibaldi. If you wish to find the pedigree of this colt, you can address Mr. John H. Groff at Spickardsville, Mo.

Mr. Charles C. Leech owned a colt of a chestnut color; in the fall after the colt was two years old he sold to a man by the name of Williams. This was 22 or 23 years ago. I think this colt was known as Magna Charta Jr. This was not the colt bred by Ed. Leech; Ed. Leech's colt was a bay.

\section{Yours truly, $\quad$ Francis Wright.}

Port Huron, Mich., Nov. io, I89i.

Sir :-I have given considerable time to the matter of the enclosed inquiry and am unable to get any information which I feel sure can be of value to you-one man tells me that about the time you mention, a man named Nathaniel Bates came here from Canada with a gray stallion 
which he said was a Messenger and that the stallion was quite a racer. It is not known whether he left any progeny. He remained here but a short time, and it is said can now be found in St. Louis, Mo. where he is a practicing veterinarian.

A rumor comes to me of a horse in the city of Flint, Mich., at an early date, of about the description you make and $I$ think it probable you could get light by inquiry there. Regretting inability to serve you better, I am,

$$
\text { Yours, A. R. Avery. }
$$

Went to Calfornia in $\mathbf{I} 6 \mathbf{2}$, given to Mr. Stevens, and taken from Marysville, Cal., to Swansea, Mass., in $1 \& 6_{4}$, and from there to Potsdam, N. Y.

A correspondent, name not given, writes, Wallace Nonthly, July i 879 , as follows :

"His pedigree is an unusual one, and of its value, Mr. Wallace, and the readers of the Nonthly can judge. Dan Hibbard wrote Mr. Stevens, he knew it to be correct, knowing the parties. There lies before me the following certificate:

" 'Garibaldi was foaled June i ith, I $857^{\circ}$ '

"'PeDigree.'

" Garibaldi was by Duroc Messenger, of Upper Canada, dam by OneEyed Messenger, and he by Thompson Horse, and he by Mambrino. Garibaldi is a bright bay, black mane and tail, all four feet tipped with white, a small star. He took the first prize at the Michigan State Fair, as a three-year-old trotter, also at the County Fair.'

" "I hereby certify that the above is a true pedigree and age of above Garibaldi."

"“(Signed), Utica, Mich., Jan. r, r86r.

"J. H. GROFF."

"Below in the same paper is written in another hand:

"I hereby certify that I know the above named horse, Garibaldi, that the above pedigree is true, and all set forth therein.' Charta." "

"'(Signed), Ezra Wright, former owner and trainer of Magna

It will be perceived that no where is the breeder of this horse given, and therefore there can be no certainty as to the pedigree. Although as all statements agree that he was by a horse called Duroc Messenger, this can be accepted as most probably correct. Unfortunately the statements of Mr. Groff in regard to the dam do not agree, his letter to the author stating that she was got by a Black Hawk horse. This Duroc Messenger is not the Duroc Messenger by Duroc, but may be a son. I50 :

The following pedigree of this horse is given in Wallace, Vol. IV, p.

"Garibaldi, bay ; foaled 1857 ; bred near Memphis, said to be by Duroc Messenger (owned by J. W. Sage and called Tiger), son of the Howland Horse, by the horse known in Detroit as Callahan Messenger: dam called a Duroc mare. Taken to California and there presented to Frank S. Stevens, by whom he was brought back to Swansea, Mass. He was the sire of Belle Oakley, Archie and other trotters. Record, $2: 33$."

Sire of 2 trotters, $2: 24 \frac{1}{4}$; dam of I trotter. 
GARIBALDI, black, with a long and round, but rather light barrel and long hips, one of which was capped, easy-gaited; said to be foaled about I 860 ; and got by Bennett Horse.

Sire of Bessie Snow.

GARIBALDI ( $1-32$ ), brown; foaled I 860 ; bred by Charles Miner; got by Hambletonian, son of Abdallah : dam Topsy, purchased 1852 by George F. Stevens, Ilion, N. Y., of Ezra Allen, Exeter, N. Y., who bought her of Harrison Edmunds of same place, said to have come from Glens Falls, N. Y., and to be a Black Hawk Morgan. Owned by Wm. Rutter, New York, N. Y.; kept at Poughkeepsie, N. Y. Died I879.

Sire of Birdie C., $2: 281 / 4 ; 4$ dams of 4 trotters.

GARIBALDI (I-32), gray with small white spot on upper lip, I5 I/2 hands, I roo pounds; foaled May, I870; bred by John M. Cook, North Vassalboro, Me.; got by Gen. Knox : dam gray, I 200 pounds, bred by Ezekiel Small, Vassalboro, Me., got by Flying Mac, son of Bush Messenger $2 \mathrm{~d}$; 2d dam chestnut. (The dam of Flying Mac was got by Mac, the famous trotter, son of Morgan Cæsar, by Woodbury Morgan). Owned by Albert Cook, North Vassalboro, Me. See The Morgan Horse and Register, Vol. II., p. I33.

GARFIELD (I-32), $2: 36$, bay, with white front ankles and off hind leg white, $151 / 2$ hands, 1075 pounds; foaled about $\mathrm{x} 880$; bred by George Whitney, Seaforth, Ontario, Can. ; got by Clear Grit, son of imported Lapidest: dam brown, bred by A. M. Hewitt, Brantford, Ontario, Can., got by Black George, son of Royal George; $2 \mathrm{~d}$ dam by Foster's St. Lawrence. Sold to Mr. Corkey; to Geo. R. Roe; to Wm. Galley, all of Seaforth, Ontario, Can. Pedigree from G. R. Roe.

Sire of 2 pacers $\left(2: 21^{3 / 4}\right)$.

GARFIELD (5-5I2), $2: 29 \mathrm{I} / 4$, black ; foaled I 88 I ; bred by C. E. Johnston, Alta, Peoria County, Ill.; got by Durango, son of C. M. Clay : dam bay, bred by C. E. Johnston, got by Red River Dixie; $2 \mathrm{~d}$ dam bay, bred by Thomas Johnston, got by a son of Harris' Hamiltonian. Pedigree from breeder.

sire of Daisy Garfield, $2: 27$.

GARLAND (TWILIGHT JR.) (7-256), bay; foaled I 883 ; bred by T. E. Moor, Shawhan, Ky. ; got by Twilight, son of Hambletonian : dam Lady Miller, bay, bred by Silas Evans, Paris, Ky., got by Joe Downing, son of Edwin Forrest ; 2d dam said to be by Evan's Highlander, son of Veech's Highlander; 3 d dam by Morgan Rattler; and $4^{\text {th }}$ dam by Canada Chief, sire of the dam of Joe Hooker, $2: 291 / 2$. Sold to Geo. L. Banks, Derby, O., I 884 , who sends pedigree; to Elisha Edwards, Washington Courthouse, $\mathrm{O}$.

Sire of 2 pacers $(2: 161 / 4)$. 
GARNET, chestnut, four white legs, strip in face, about 16 hands; foaled May, r $88 \mathrm{r}$; bred by Wm. I. Simmons, I.exington, Ky. ; got by Young Jim, son of George Wilkes : dam bay, said to be hy American Clay; zd dam bay, by Downing's bay Messenger ; and $3 \mathrm{~d}$ dam bay, by son of Sir Archy. Pedigree from breeder.

GARNET WILKES (3-128), bay, I 6 hands; foaled I 883 ; bred by Spencer Bros., Pine (irove, Ky.; got by Onward, son of (ieorge Wilkes: dam Kentucky Belle, chestnut, bred by A. J. Alexander, Spring Station, Ky., got by Harold, son of Hambletonian; 2d dam Juliet, gray, bred by Thomas Hook, Georgetown, Ky., got by Pilot Jr., son of Pilot; 3d dam said to be by Webster, thoroughbred from Medoc; and $4^{\text {th }}$ dam by Cook's Whip. Sold to H. Cunningham, Knoxville, Ia. Pedigree from breeders.

Sire of I9 trotters $\left(2: 14^{1 / 4}\right), 6$ pacers $\left(2: 13 \frac{1}{2}\right) ; 3$ sires of 4 trotters; 3 dams of 2 trotters, I pacer.

GARNET WILKES (I-I28), $2: 37$ I/4, bay, I6 hands, I350 pounds; foaled I 885 ; bred by Holenshead \& Son, Upper Sandusky, O.; got by Ambassador, son of George Wilkes: dam Kate Messenger, bay, bred by Holenshead \& Son, got by Seeley's Messenger, son of Bush Messenger; 2d dam said to be by Monsieur Tonson, said to be by imported Oscar. Pedigree from T. C. Whitehead.

Sire of 2 trotters $(2: 25)$.

GAROLETTE. A French Canadian stallion. Advertised at Morristown, N. J., together with thoroughbred Forester, 1832, by Geo. H. Ludlow and Nathan B. Luse. Same terms as Forester.

GARRARD CHIEF (HIPPY), black; foaled I 859 ; bred by M. H. Gill, Lancaster, Ky. ; got by Mambrino Chief, son of Mambrino Paymaster: dam Dolly Dixie, said to be by Frank, son of Sir Charles, by Sir Archy ; 2d dam by Aratus, son of Director, by Sir Archy ; 3 d dam by Hamiltonian, son of imported Diomed; and $4^{\text {th }}$ dam by imported Diomed. Owned by Jefferson Dume, Garrard County, Ky., who sends pedigree.

"Lady Yeiser, by Garrard Chief, is one of the great brood mares of which little has been written in the turf journals. She is credited with eight stardard performers by the last year book and put two new ones in the list in 1903 , giving her ten with stardard records. Of these six are trotters with records from $2: 28 \mathrm{I} / 2$ to $2: 293 / 4$, and four are pacers with records from $2: 053 / 4$ to $2: 173 / 4$. Her son, Don Pizarro, $2: 143 / 4$, is the sire of sixteen in the list, of which six have records below $2: 15$, and her daughters have produced five. Garrard Chief, the sire of Lady Yeiser, was by Mambrino Chief. Her dam was Jewell, by Vermont, a grandson of Black Hawk. There are several crosses of running blood in Lady Yeiser's pedigree."-The Breeder and Sportsman, Jan. I6, I904.

Sire of Basil Duke, $2: 281 / 4 ; 3$ sires of 4 trotters, I pacer; 7 dams of Io trotters, 5 pacers. 
GARRISON COLT (5-256) ; said to be by Bashaw (Norris') son of KirkWood, by Green's Bashaw.

GARTHWAIT ( $\mathrm{r}-64$ ), bay; foaled $\mathrm{x} 88 \mathrm{I}$; bred by J. E. Haring, Ticonderoga, N. Y.; got by Alert, son of Hambletonian : dam Trusty, chestnut, bred by John P. Huyler, Chester, N. J., got by Marlborough, son of Trustee; and $2 \mathrm{~d}$ dam, chestnut, bred by J. P. Huyler, got by Henry Duroc, son of Essex. Pedigree from breeder.

Sire of $I d a \mathcal{F}^{\prime}, 2: 22 \frac{1}{4}$.

GAS BELI, ( $1-128$ ), bay; foaled May 18, I902 ; bred by J. H. Wellis, Bridport, W. Va ; got by Bright Bell, son of St. Bell, by Electioneer : dam Propose, said to be by Prospect, son of Dominion, by Red Wilkes; $2 \mathrm{~d}$ dam Skip, by Sacramento, son of Woodford Mambrino, by Mambrino Chief; 3d dam Red Bird, by C. M. Clay Jr., son of C. M. Clay; 4th dam by Henderson's Fashion. Pedigree from breeder.

GASFIELD (3-128); said to be by Ajax, son of Hambletonian.

Sire of Gaslight, $2: 19 \frac{1}{4}$.

GATLING (I-64), brown; foaled I 875 ; bred by C. M. Pond. Hartford, Conn.; got by Rysdyk, son of Hambletonian: dam Lady Goldsmith, bay, bred by Alden Goldsmith, got by Hambletonian; 2 d dam bred by Alden Goldsmith, got by Webber's Tom Thumb; and 3 d dam said to be by Commodore, son of Tippoo Saib. Died, I882, property of C. M. Pond.

Sire of Freestone, $2: 25 \frac{1}{2} ;$ I sire of I trotter; 3 dams of 2 trotters, I pacer.

GAT VAN IVAGNER ( $1-32$ ), bay, I61/2 hands, I40o pounds; foaled 1872 ; bred by A. H. Taylor, Central Valley, Orange County, N. Y.; got by Jehu, son of Happy Medium: dam Miller Mare, gray, said to be by Hambletonian; and 2d dam Gray Molly, by Messenger Duroc, (Lawrence's). Sold to H. L. Caldwell, Jackson, Mo., who sends pedigree.

Sire of Frank Kober, $2: 28$

GAVIOTA ( I-I 28 ), bay ; foaled I88 r ; bred by Leland Stanford, Menlo Park, Cal. ; got by Electioneer, son of Hambletonian : dam Lady Ellis, said to be by Mohawk Chief, son of Hambletonian; 2d dam Lady Clay, by Paymaster (Clark's), son of Cassius M. Clay; and 3d dam by Morse Horse. Sold to P. M. Murphy, San Louis, Cal.

Sire of Billy G., $2: 15$.

GAYLORD (I-I6), black, I6 hands, I 200 pounds; foaled I 884 ; bred by Jonas Tickenor, Nelson County, Ky.; got by Black Hawk Chief, son of John Burke (Stone's), by Green Mountain Black Hawk: dam Pinkey, said to be by Joe Drennon, son of Brown's Joe, by Drennon, son of Davy Crocket; and 2 d dam by Pilot Jr., son of Pilot, which see. 
GAYO ; foaled I864; said to be a thoroughbred, by Jeff Davis : dam Ninette, by Revenue, son of imported Trustee; $2 \mathrm{~d}$ dam Nina, by Boston; and 3 dam imported Frolicsome Fanny, by Lottery.

Sire of Shamrock, $2: 261 / 2$.

GAZETTE ( $1-64), 2: 233 / 4$, brown; foaled 1887 ; bred by R. P. Pepper, Frankfort, Ky.; got by Onward, son of George Wilkes : dam Siren, brown, bred by R. P. Pepper, got by Dictator, son of Hambletonian; 2d dam Patti, gray, bred by Dr. Samuel H. Chew, Fayette County, got by Mambrino Chief; 3d dam said to be by Park's Highlander; $4^{\text {th }}$ dam by Gray Eagle; and $5^{\text {th }}$ dam by Bertrand. Sold to John B. Wathen, Jr., Lebanon, Ky. ; to Cyrille Laurin, Montreal, P. Q.

Sire of 5 pacers $\left(2: 07 \frac{1}{4}\right)$.

GENE LEE (7-256), bay; foaled I 889 ; bred by E. W. Lee, Danville, Ky. ; got by Gambetta Wilkes, son of George Wilkes : dam Ella, bay, bred by E. W. Lee, got by Mambrino Startle Bonner, son of Startle; 2d dam Kate Lee, chestnut, bred by Geo. F. Lee, Danville, Ky., got by Hero of Thorndale, son of Thorndale ; $3 \mathrm{~d}$ dam Kate Blake, said to be by Kossuth ; and $4^{\text {th }}$ dam Julia, by Sidi Hamet. Sold to G. \& C. P. Cecil, Danville, Ky.; to G. A. Fitch, Logansport, Ind. Pedigree from catalogue of breeder.

Sire of Gertie Mac, $2: 30$.

GENERAL B. (2-I 28 ), bay with star, I6 hands, I 200 pounds; foaled I 886 ; bred by Ezra Bimm, Dayton, O.; got by Red Wilkes, son of George Wilkes : dam Kentucky Girl, seal brown, said to be by Mambrino Thorne, son of Mambrino Patchen. Sold to E. L. Rowe, Dayton, O. Pedigree from H. H. Bimm, son of breeder.

Sire of Red Streak, $2: 22 \frac{1}{2}$.

GEN. BALLARD ( $\mathrm{I}-32)$; bred by Mr. Austin of Georgia; got by the Blake Horse, son of Whalebone, by Flying Morgan. The Blake Horse was owned by George Blake of Georgia and when sold went to Manchester, N. H., or Lowell, Mass.

GEN. BARKER (3-r6); foaled June, I85 I, the property of Gen. Barker of Henniker, N. H. ; said to be by the Barker Horse (dam by Diomed, owned by Col. Page of Keene, N. H., and he by imported Diomed), son of Woodbury, by Justin Morgan : dam by Culby Horse of Warren, N. H., son of Sherman, by Justin Morgan. Advertised for sale under the above pedigree in the American Stock Journal, Volume I., I 859 .

GEN. BENTON $(3-64), 2: 34^{\mathrm{T} / 2}$, bay, left hind ankle white, $\mathrm{r} 6$ hands, I 2 I 5 pounds ; foaled June II, I 867 ; bred by A. L. Benton, Rural Hill, Jefferson County, N. Y.; got by Jim Scott, son of Hamiltonian (Rich's), 
which see: dam Lady Benton (dam of Jefferson Prince, Sir Walter Scott, Col. Benton and Major Benton), bay, bred by Stephen Wood, Woodville, N. Y., got by Hamiltonian (Gray's), which see ; 2d dam Fanny Wood, foaled about 1852 , bred by Frank Stearns, Ellisburg, N. Y., got by Gifford Morgan (Stearns'), which see (Mr. Stearns sold this mare when about three years old, to a Mr. Tedham, of Woodville, and he in about a year to Stephen Wood of Woodville, from whom she passed to A. L. Benton) ; 3 d dam gray, about $151 / 2$ hands; bought of Hiram Morely by Stillman Kibling, Mannsville, N. Y., who sold about I850 to Frank Stearns, said to be by Partridge's Blucher from Belleville, N.Y.; and 4th dam a gray Messenger mare. Sold to Edward Scott, Rural Hill, N. Y.; and owned afterwards successively by Durfee and Hossington, Belleville, N. Y.; Durfee and Moody; Charles Robinson, Fishkill Plains, N. Y.; Leland Stanford, California. Died February, I 889.

A letter from A. L. Benton, the breeder of Gen. Benton, gives the $2 \mathrm{~d}$ dam as by Partridge's Blucher, and a Messenger pedigree for $3 \mathrm{~d}$ dam. Mr. Benton states name of breeder of first dam, but not that of second and $3 \mathrm{~d}$ dams. This is the pedigree as given in Wallace's Register, and at that time was generally accepted but in further correspondence $\mathrm{Mr}$. Benton writes :

WoOdvil.Le, N. Y., Aug. I9, I906.

Dear Sir:-Lady Benton was foaled in the year of I859. I bought her in the spring of 1865 . She was then with foal by Jim Scott. She had that year a filly that was owned in this vicinity till I87o, when matched up with another and sold as a pair, and since nobody in this vicinity has ever been able to trace her. I think this is all the questions asked. I answer them cheerfully.

A. L. Benton.

Mr. A. L. Benton,

Bread LOAF, Vt., Oct. I2, I906.

Dear Sir :-Your letter of Aug. I9, was duly received and I am much obliged for the same. I notice that Gen. Benton is recorded as bred by you and second dam by Partridge's Blucher. If able please inform me what the horse, Partridge's Blucher, was and where and by whom owned? Also who bred this second dam Fanny Wood?

I am trying to trace this mare and if you are able to give me the above information it might aid very materially.

$$
\text { Yours very truly, Joseph Battell. }
$$

Mr. Battell :

WoOdVILle, Oct. 26, I906.

The dam of Gen. Benton was by Gray's Hamiltonian. I know nothing of Partridge's Blucher; I do not think there is a man living today that can give you the breeding of Fanny Wood, I do not know who bred her.

$$
\text { Yours truly, A. L. Benton. }
$$

Woodville, Jan. 6, igo8.

Friend Battell:

Mr. Wood sold Lady Benton 
to a man by the name of Herbert Spencer. He had her but a short time and sold her to Dr. Harrington. He userl her on the road about six months, and then I bought her. Spencer and Harrington both went West about that time, and are probably both dead years ago.

The mare was sold for a farm horse and no one asked about her breeding, I suppose. I believe no one has yet been able to trace her dam's breeding, and at this late day, I do not think it can be traced.

I think your book will be a very valuable one for the horsemen of this country. I would like a copy very much if they are not too expensive.

$$
\text { Respectfully yours, A. L. BENION. }
$$

Mr. STEPHEN Wood, Woodville, N. Y.,

Middlebury, Vt., Jan. 23, 1904.

Dear Sir :-I am indebted to you for information given several years ago, concerning the $2 \mathrm{~d}$ dam of Gen. Benton, which you purchased of Mr. Tedham, Smithville, N. Y. I would like very much the description of this mare, color, height, etc. Also please inform me if the Mr. Tedham you purchased her from is still living, and what was his first name? And still further very much oblige.

$$
\text { Truly yours, JOSEPH BATTELL. }
$$

In answer Mr. Wood wrote:

The $2 \mathrm{~d}$ dam of Gen. Benton was a gray mare, $15 \mathrm{~T} / 2$ hands, rugged, full made mare, bred by Frank Stearns, Ellisboro now Ellisburg, N. Y.

\section{WoOdVILle, N. Y., Jan. 2 I 892}

Dear Sir :-Stephen Wood lives here, and this is his address, but I don't think he will know the breeding of this mare. He owned her and I remember the mare well, and am interested in this, as I now own a full brother to Gen. Benton and breeding from him now, and the family of Bentons were raised in this neighborhood. I think Alfred Tedham of Smithville, N. Y., is more of a horseman than Wood; and I think Wood had the mare of him. I think you ought to write him, also Nelson Boomer of Belleville, N. Y., an old horseman and I think likely to know something of this matter. Frank Stearns a former owner of this mare you speak of is dead, and would be the most likely to know of any one. I will see that Stephen Wood gets this letter, and find out all I can about it.

$$
\text { Yours truly, GEo. M. Wood }
$$

The pedigree of Gen. Benton in Wallace's Register, and elsewhere, as also that of Rich's Hamiltonian, in extension of the pedigree of the sire, and Gray's Hamiltonian in extension of pedigree of dam, are both incomplete and inaccurate, and, indeed, we found it was well understood in the locality where these animals were bred, that extensions of the pedigree of Gen. Benton on the side of both sire and dam were incorrectly given when the horse was sold for $\$ 25$, o0o to Senator Stanford of California.

Since the above was written we have visited Woodville, and Ellisburg, N. Y., endeavoring to trace $2 \mathrm{~d}$ dam, and with following results. Mr. Stephen Wood, Woodville, N. Y., said:

"I bred Lady Benton. Her dam was gray, about I 5 I/2 hands, I 200 pounds, a full made, resolute, rugged animal; ambitious and free, but kind and intelligent. I bought her of Alfred Tedham. He bought her 
when three coming four, owned her perhaps a year, when I bought her. She was foaled at Ellisburgh the property of Frank Stearns. Lady Benton was the first colt I raised from her. I had one before but lost it. I bred her shortly after I got her and she raised colts for a number of years, and died my property. I do not know her breeding."

A son-in-law of Mr. Wood advised us to see Mr. Frank Smith of Woodville, which we did. Mr. Smith said :

"I knew when Tedham got the gray mare, then three or four years old. Wood got her of Tedhain; not a great deal known about the mother. I think the mare was bred by Frank Stearns upon his farm. Stearns sold her, I think, when quite young, two or three, I should say. Tedham drove her right off after he got her. I have always known the mare; always lived right near her. I am 66 (July, I906). I was working by the month for Steve Wood's brother when Tedham got her. Alfred Benton who is alive yet, owned Lady Benton.

"Some said that she was by a Messenger horse that Washburne had, her dam a Canadian mare; and some that her dam was in foal when she came from Canada, and the foal was this filly. The Harry Washburne horse was gray, a pretty good sized horse. Have always been told that Beebe let Stearns have the gray mare. I never saw her.

"Vickery had 'Tiger Morgan and Gifford Morgan. I had a good pair of mares, chestnut, from Gifford. Sewall of Oswego had one of my first pair. She was from an imported mare and her sire a Black Hawk."

We called upon Mr. Beebe, but he did not remember letting Mr. Stearns have any mare. We then interviewed Mr. Samuel Zufelt, born I833, who said :

"Kibling's house was built in I850. I worked for him about 1853 and went to Canada in October.

"I don't remember his selling any mare to Mr. Wood, and do not remember his having a gray mare before I went to Canada. The first work I did for Stearns was in I854. I came back from Canada July 9, I 857 , and was married Jan. 7, I 858 .

"I first knew Mr. Stearns in I 850 , when Kibling's house was built. Melvin got Gifford Morgan in Syracuse. Melvin and Vickery bought the horse together and Frank Stearns went with Vickery and got him. There was never so good a horse here as this was, and never will be again. Gifford was bred in Vermont, but bought in Syracuse. He was here three or four years; then repurchased and taken back to Syracuse.

"Tiger Morgan was not so good a horse, but got pretty good stock. These and Bacon's Ethan Allen were the best horses we ever had here. I presume Stearns owned the Wood mare when I was in Canada.

"Mr. Stearns bred to the Morgan stallion. He bred to Gifford and raised a colt that Melvin bought, a chestnut, weighed I20o. He had two mares in 1850 , both chestnut, one with white face. Frank Stearns did not take possession of his farm till 1850 . His father owned the farm. Mr. Stearns was from Vermont. My first work for him was in I853. I hired out to Frank for two or three months, and not again till after I was married in 1858 . He had in 1853 four mares, two chestnuts that he worked, and an old chestnut mare that he got of Paul Williams. I think he raised five or six colts from Williams mare, and seven or eight from the mare he got of Trull at Sackets Harbor.

"He had two mares, High-fa-lu-ten and Poll in I850; r 200 pounds. 
Poll had two white hind legs and was three years old when I went to work."

Henry Hessill, Ellisburg, stage driver, said :

"You are going to trace this mare (I ady Benton) back to the Morgans. Mr. Smith had a pair of Morgans. A man owned a stallion, a Green Mountain Morgan, chestnut. Frank Smith owned a team 15 years ago. George Stearns worked a team for Stephen Wood. Wood had old Jane and Fan, white and gray. Fan a dapple gray. She had a pair of blacks; went into the army 1862, three or four years old."

Joseph BatTell,

Belleville, N. Y., May 5, I904.

Dear Sir :-Mr. Wood wishes me to reply to inclosed letter. The $2 \mathrm{~d}$ dam of Gen. Benton was a gray mare, $15 \frac{1}{2} 2$ hands high, a full maderesolute-rugged animal, ambitious and free, but kind and intelligent. Mr. Tedham is not living.

$$
\text { Yours truly, S. W. Frame. }
$$

It is evident from these letters that this $2 \mathrm{~d}$ dam of Gen. Benton was an unusually superior mare.

Dwight Webb, Ellisburg, N. Y., said:

"Stearns brought the old Gifford Morgan here in I 848 or 9, chestnut, showy, very nice horse, stock all good, rugged. I think he died here. I had lots of his colts.

"The second Morgan horse was Tiger Morgan. I think Vickery owned him. Both horses got good stock. I bought Tiger Morgan of Vickery. Hip was knocked down. An old horse, dark chestnut. Traded around. I owned him in I 868 . Gillette lived in Henderson, died here. Vickery owned Tiger Morgan. I bought of him. He got hipped when owned by Vickery. Not much over 15 hands. Very fine horse, stylish and stock all good. Not large, not as large as the Gifford Morgan colts. I never saw a better type of horse than Gifford was. Stearns got Gifford Morgan in Vermont. I remember Frank Stearns had a gray mare that he drove with a roan horse. He worked them about 1854 . He bought the roan in Canada. About that time he was breeding Morgan horses. The old Fan mare was a Morgan, by Gifford Morgan, he bought of Kibling; a neighbor bought a brother and took him in I 856 to Sheboygan, Wis.

"He bought this sister and kept her. My impression is he might have owned the mare three or four years. Think six or seven years when he bought her. The Gifford Morgan was the greatest horse ever in this country. The Rudd horse or Green Mountain Morgan, was kept at Woodville several years, as early as $185^{-}$. It was a gray mare which Stearns bought of Mr. Richard Kibling of Ellisburg. He said she was a Morgan mare. Gifford Morgan was got in Vermont. Stearns and Vickery owned the Gifford a while together, and then Stearns bought Vickery out. I let Mr. Kibling of Ellisburg have the Vickery Tiger. He sold him at once. The Stearns mare Fan was close to i 5 hands. Joseph Delvern, of Woodville, worked for Stephen Wood when he had the gray mare, dam of Lady Benton."

Mr. BAtTELL :

Woodville, N. Y., Aug. I8, I906.

Yours of late date at hand inquiring as regards data of the gray mare 
bought of Tedham by Wood. I have no way to fix the year accurately but it was either in ' 55 or ' 56 and she went by the name of Fanny Wood. Lady Benton was five years old the spring of ' 65 .

\section{F. M. Sмith.}

If this is not sufficient will do what I can to help you, but the older folks are all dead that know anything about it.

Joseph Battell, Bread Loaf, Vt.,

Ellisburg, N. Y., Aug. I3, I906.

Dear Sir:-Yours of the 8th inst. received and in reply I wish to correct you. Mr. Frank Stearns never owned the Gifford Morgan. His brother Melvin Stearns and Joseph Vickery brought the Gifford Morgan to our town some time about I849. You must remember that I was only about twelve years old at the time therefore did not own any colt, but my father bred a Morgan colt from the Gifford Morgan, foaled in I850. Your next, do you remember Frank Stearns having a gray mare that he drove with a roan horse? Yes, he owned them about I85I or 52. Don't know where he got the gray mare. Don't know what her sire was. Mr. Frank Stearns bought a bay mare of Mr. Kibling. She was blood bay, about $151 / 2$ hands, and would weigh about 1000 pounds, they called her Fanny. I should think he bought her about I854 or 5 . As to her age when he bought her, I don't know, but he kept her as long as she lived. Mr. Kibling's first name was Stillman. Your next, did Mr. Kibling build a house about I 850 ? Yes.

This is all that I can think of in regard to the horses you have mentioned. Of course it has been a great many years and perhaps some things that I knew at the time have gone from me.

Yours truly, Dwight H. WEBв.

Important letter from Fisher N. Kibling :

Mr. Battell,

Mannsville, N. Y., Jan. 8, 1908.

Dear Sir :- When you and Mr. Reed were here at my house I did not recollect anything about the gray mare you referred to, but after you went away it came to me. The gray mare that my father let Frank Stearns have about I 850 , was a gray mare my father bought of Hiram Morely, and her mother was a gray Messenger mare, and she was by the Partridge horse from Belleville, N. Y.

I do not remember anything of a Mr. Tedham, veterinary of Woodville. I believe the Stearns brothers came from Rutland, Vt.

These Morelys that my father bought the mare of are all dead and gone.

Mr. Stearns raised a few colts from this mare, and this is all I can remember. Hoping this will help you in tracing the horse you desire, I remain,

$$
\text { Yours truly, Fisher N. KibLing. }
$$

For further particulars of the breeding of this horse see Gifford Morgan (Stearns') in this book, and Hamiltonian (Gray's), Jim Scott, Hamiltonian (Rich's), and Morgan Hamiltonian (Bloomer's) in Volumes III. and IV.

Sire of I9 trotters, $\left(2: 15^{3 / 4}\right) ;$ Benton Boy, $2: 17 \frac{1}{2} ;$ I7 sires of 3 I trotters, 3 pacers; 37 dams of $5^{8}$ trotters, 8 pacers. 
GEN. BENTON JR. (3-128), bay; foaled 1882 ; bred by A. P. Hotaling, San Francisco, Cal.; got by Gen. Benton, son of Gen. Benton: dam Inez, said to be by Nordale, son of Norfolk; 2 d dam Lizzie. Sold to W. D. McKinnon, Rio Vista, Cal.; to William Hulton \& Son, Troy, N. Y.

Sire of Carrie Benton, $2: 28$.

GEN. BEVERLEY ( $\mathrm{I}-64$ ), $2: 2 \mathrm{I} \mathrm{I} / 2$, brown; foaled $\mathrm{I} 886$; bred by Leland Stanford, Menlo Park, Cal.; got by Benefit, son of Gen. Benton : dam Alice, bay, bred by Richard West, Georgetown, Ky., got by Almont, son of Alexander's Abdallah; 2d dam Norma, $2: 33 \frac{\mathrm{T}}{2}$ (dam of Norval, $2: 143 / 4$ ), gray, bred by S. F. Gano, Georgetown, Ky., got by Norman, son of the Morse Horse ; 3 d dam said to be by Sir Wallace, son of Sumter; $4^{\text {th }}$ dam Eagletta, by Gray Eagle, thoroughbred, son of Woodpecker, etc. (See Stud Book).

Sire of Bion, $2: 19 \%$.

GEN. BOYLE (I-64), $2: 24 \frac{1}{4}$, bay; foaled $\mathrm{r} 888$; bred by Granville Cecil, Danville, Ky. ; got by Gambetta Wilkes, son of George Wilkes : dam bay, bred by G. W. Randenbush, Reading, Penn., got by Alert, son of Hambletonian; $2 \mathrm{~d}$ dam Silence, chestnut, bred by Mason Henry, Kentucky, got by Alexander's Abdallah; 3 d dam Woodbine, brown, bred by Mason Henry, Woodford County, Ky., got by Woodford, son of Kosciusko, thoroughbred. Sold to C. M. Clark, Whitewater, Wis.

Sire of I trotter, 2: 22, 2 pacers $\left(2: 09 \frac{1}{4}\right)$.

GEN. BRAYTON (I-I6), 2 :I $9^{\mathrm{I} / 2}$, bay, I5 hands, Iooo pounds ; foaled June 6, I89ı ; bred by N. B. Mann, Mannsville, Jefferson County, N. Y. ; got by Sprague Goldust, son of Gov. Sprague, by Rhode Island: dam Lady Bailey, bay, bred by Clark Bailey, Port Manor, N. Y., got by Bacon's Ethan Allen; $2 \mathrm{~d}$ dam said to be by Tiger Morgan. Pedigree from breeder, who writes :

"I bought Lady Bailey in I875. She is the dam of Blucher, $2: 161 / 2$. The breeder of Lady Bailey has been dead 20 years. She is the dam of Blanchette that I had registered."

The second dam is also said to have been by Smith's Morgan.American Horse Breeder, Feb. 15, 1898.

Sire of Eulalia, $2: 18 \frac{1}{2}$.

GEN. BROCK, $2: 29 \frac{1}{4}$; foaled I $87 \mathrm{I}$; bred by Thomas Fairbanks, Chatham, Can.; got by Rooker, son of a pacing horse called Stranger : dam Blink Bonny, brown, bred by David Walker, Toronto, Can., got by New York Black Hawk, son of Long Island Black Hawk; 2d dam said to be by Charon. Sold to Walter Savage, Chatham, Ontario, Can.; to Taylor 
Bros., Toronto, Can.; to Graham Bros., Claremont, Can.; to N. C. Connor, Stouffville, Can.

Sire of 2 trotters $\left(2: 24 \frac{1}{2}\right), 2$ pacers $\left(2: 2 I^{1} / 4\right) ;$ I dam of I pacer.

GEN. BUTLER; foaled in June, I853; bred by J. A. Mott, Glen Cove, L. I., got by Smith Burr, son of Burr's Napoleon: dam said to be by imported Cleveland Bay; and $2 \mathrm{~d}$ dam by Mount Holly, son of Messenger.

SUMMARY OF TROT.

Match for \$IOoo; mile heats; 3 in 5 , in harness.

J. Morrissey's g. g. Rockingham (S. McLaughlin), . I-2-I-I

H. Genet's blk. g. Gen. Butler (D. Mace), . . 2-I-2-I-2

Time, $2: 27-2: 27 \mathrm{I} / 4-2: 253 / 4-2: 27 \frac{\mathrm{T}}{4}$, on Friday and the next day at 3 o'clock the deciding heat, $2: 25 \frac{1}{2}$.

Friday Oct. $3 \mathrm{I}$, trotting match $\$$ I 000 , mile heats, best 3 in 5 , under saddle.

B. Dobble's g. g. Rockingham, . . . I-I-2-I

D. Mace's blk. g. Gen. Butler, . . . 2-2-1-2

TIME

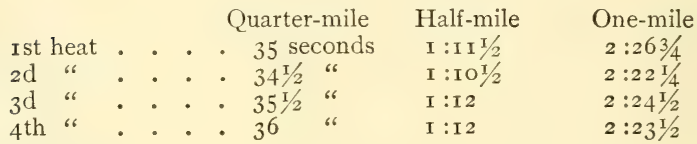

Nov. 8, I862.

The following quotations are from Wilkes' Spirit of the Times :

"Gen. Butler bred by J. A. Mott,- who then kept the Triton House at Glen Cove, L. I.,- -was foaled in June 1853 in a field adjoining farm of William C. Carpenter. When foal was three days old he was sent with his dam to pasture on Townsend's farm at Cedar Swamp, and Mr. Townsend taking a fancy to him bought him for \$IOo the following October. The colts dam was a brown, one-eyed mare, Isadore, who resembled Lady Sherman. Her pedigree is not known but she was reported to have a strong dash of Messenger blood. She was always up to 3 minutes and was a good road nag for a distance. Butler was the only foal she ever had except a filly by Oscar. 'The mare was afterwards hooked by a cow and died in consequence of the injury. Sire of Butler was Smith Burr, by Burr's old Napoleon, dam by imported Cleveland Bay, grandam by old Mount Holly, by imported Messenger."

Dec. 27,1862 .

Review of trotting season on Long Island:

"The match which succeeded caused almost as great excitement, as the Fillingham and Ethan Allen race. It was between Gen. Butler and the brown Hambletonian stallion for $\$ 2000$, mile heats, the former under saddle, the latter in harness. Butler won Ist heat in $2: 2 \mathrm{I} 1 / 2$; Fillingham $2 \mathrm{~d}$ in $2: 243 / 4$ and Butler $3 \mathrm{~d}$ and 4 th in $2: 23$ and $2: 27$. This performance of Butlers took trotting men by surprise for they could hardly credit that he could have made such wonderful improvement since he was beaten by Gen. McClellan in the handicap trot in June last.

"The series of matches between Gen. Butler and Rockingham closed 
the best trotting season ever known on Long Island. The Ist was for $\$ 1000$, mile heats to wagons and was won by Butler, after a magnificent race, during which 5 heats were trotted. Rockingham winning Ist and $2 \mathrm{~d}$, and Butler the last 3 heats-time, $2: 30^{1 / 4}, 2: 291 / 4,2: 28$ and $2: 30.2 \mathrm{~d}$ match was in harness, for a similar sum and here Rockingham turned the tables, winning 1 st heat in $2: 27$ and $3 \mathrm{~d}$ in $2: 253 / 4$, and $5^{\text {th }}$ in $2: 25^{1 / 2}$.

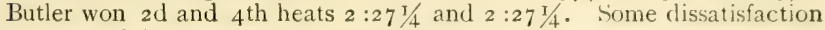
was caused in this match by the Judges after the horses harl each won 2 heats on the day fixed, postponing the deciding heat until next day on account of darkness and declaring all outside bets off. The deciding match was to saddle, mile heats, and again Rockingham was victorious winning Ist, $2 \mathrm{~d}$ and $4^{\text {th }}$ in $2: 263 / 4,2: 22 \mathrm{I} / 4$, and $2: 23 \mathrm{I} / 2$, Butler taking $3 \mathrm{~d}$ in $2: 24 \frac{1}{2}$.

"With this match the trotting season of $\mathrm{x} 862$ terminated. The generous liberality of the association met with its just reward in producing best contests ever witnessed on the soil of L. I. The previous record of fast time has been cut down; notwithstanding the mile time in harness of $2: 193 / 4$ which emblazons the record of the "Queen of the Trotting Turf," the incomparable Flora Temple has not yet been equalled. The performances of the celebrated 'Ledger team,' Lady Palmer, Flatbush Maid, Peerless and Lantern, property of Robert Bonner, far surpasses anything ever before recorded in annals of trotting turf and are worthy of being noted here. The Flatbush Maid and Lady Palmer driven by Mr. Bonner, trotted on Fashion Course, I mile in $2: 26$, and 2 in $5: 01 / 2$. Lady Palmer alone driven by Sim Hoagland, wagon and driver weighing 3 ro pounds, trotted 2 miles in $4: 59$, the ist mile in $2: 29$ and $2 \mathrm{~d}$ in $2: 30$. The bay gelding Lantern driven by Dan Mace with running horse, Socks, trotted a mile the rst time in $2: 20$. The gray mare Peerless was driven to wagon by Hiram Woodruff 2 miles in 4:59, Ist mile $2: 23 \frac{1}{4}$. Well may the enterprising proprietor of New York Ledger be proud of his magnificent stable of American trotters, the equal of which were never owned by any single individual. Probably in the forthcoming year we may see them eclipse even the above unparalleled trotting achievements.

Nov. 22, I862.

GEN. BUTLER (STEVEN'S HORSE) (3-32), dark brown, I 250 pounds, $161 / 2$ hands; foaled 1856 ; got by old Morrill Horse of Vermont $(2: 40)$, son of Randolph, by Justin Morgan : dam by Knight's Horse, noted for endurance and driven 125 miles in a day, from sun to sun, in January. Noted for speed, bottom and style. Advertised as above in Stanstead (P. Q.) Journal, 1864 , by C. M. Stevens. The "Knight Horse" we suppose to have been the famous horse of that name by Sherman Morgan.

GEN. COFFEE, chestnut; called Canadian. Owned by Mr. Sparks, 3rd Avenue, New York.

Sire of dams of Lady Woodruff, $2: 29$, and Rose Washington, $2: 303 / 4$ and winner of ro races.

GEN. CUSTER (I-I 28 ), 2 :50, white, I 6 hands, I 200 pounds ; foaled I 876 ; bred by R. A. Crary, Crary's Mills, St. Lawrence County, N. Y.; got by Valley Chief, son of Phil Sheridan : dam Lady Pierpont, gray, bred by 
Sylvanus Hemingway, Potsdam, N. Y., got by Fenian Chief, son of Gray Eagle (Canadian); $2 \mathrm{~d}$ dam said to be by Gray Eagle (Canadian), Died Dec. I4, 1886. Pedigree from breeder.

Sire of Peter Mac, $2: 29 \frac{1}{2}$; I dam of I trotter.

GEN. DANA, bay, strip in face, three white feet, $15 \frac{1}{2}$ hands, I050 pounds ; foaled 1872 ; bred by Alexander Ely, Petaluma, Cal. ; got by Whipple's Hambletonian, son of Guy Miller : dam Lady Crum (dam of Alexander bay stallion, $2: 3 \mathrm{I} / 4$ ), bay, bred in Columbus, O., said to be by Brown's Bellfounder, son of imported Bellfounder. Sold to Wm. Bihler, Lakeville, Cal. Pedigree from breeder.

Sire of Volunteer, 2:27; I sire of I trotter; I dam of I trotter.

GEN. EVANS (I-32), $2: 263 / 4$, black; foaled I 889 ; bred by G. \& C. P. Cecil, Danville, Ky.; got by Gambetta Wilkes, son of George Wilkes : dam Lady Watson, black, bred by J. B. McClintock, Cynthiana, Ky., got by Indianapolis, son of Tattler, by Pilot Jr. ; 2 d dam Geneva, bay, bred by J. T. Talbott \& W. H. Wilson, Cynthiana, Ky., got by Smuggler, son of Blanco, by Iron's Cadmus, by Cadmus, son of American Eclipse ; 3d dam Lennehan Filly, said to be by Pacing Abdallah, son of Alexander's Abdallah; 4th dam Molly, by Joe Downing, son of Edwin Forrest, by Bay Kentucky Hunter; and $5^{\text {th }}$ dam by Star Highlander. Sold to Myers \& Wagner, Dayton, O. ; to M. W. Janes, Willard, Kan.

Sire of Pilot Evans, $2: 13 \frac{1}{4}, 2$ pacers $(2: 161 / 2)$.

GEN. EWING (I-64), $2: 27$ I $/ 4$, bay, no white, I 6 hands, I 240 pounds ; foaled I875; bred in Ewingville, N. J.; said to be by Windsor, son of Major Anderson, by Geo. M. Patchen : dam by May Day Jr.; and 2d dam bred in Ewingville, N. J., by Tullytown, son of Doble's Black Bashaw. Sold to John Fritz, Trenton, N. J., to Curley Samson of the same place. Pedigree from J. W. Madora, South Elkhorn, Ky.

GEN. FREMONT $\left(3-25^{6}\right)$, said to be by Nutmont, son of Nutbourne. Sire of McGinty, 2:251/4.

GEN. GARFIEID, said to be by Hector.

Sire of H. P. E., $2: 25$.

GEN. GARFIELD, bay ; bred by James M. Hendren, Speedwell, Madison County, Ky.; got by Black Hawk : dam bay said to be by Capt. Walker. Pedigree from breeder, who writes that his records were destroyed by fire.

GEN. GARFIELD (TOM BRIGG'S) (I-I28), bay, one hind foot white, I 6 hands, II 75 pounds; foaled 1873 ; bred by Isaac Stipp, Clintonville, Ky.; got by American Clay, son of Casius, M Clay Jr.: dam Jenny Morgan, bred by Isaac Stipp, got by Sebastopol, son of White- 


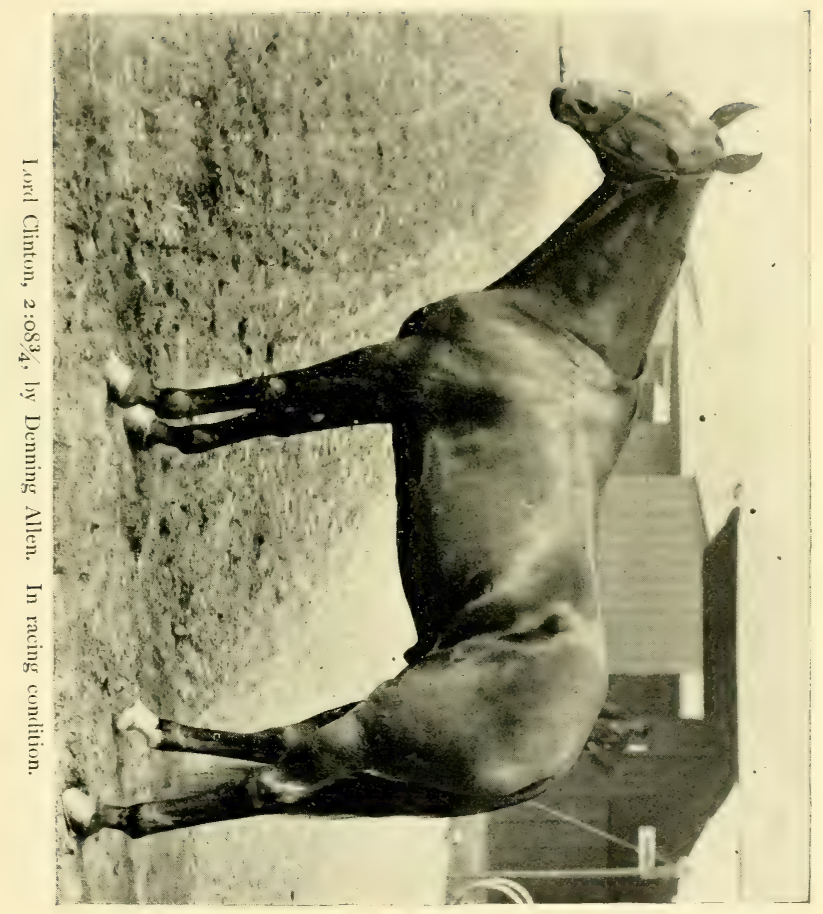




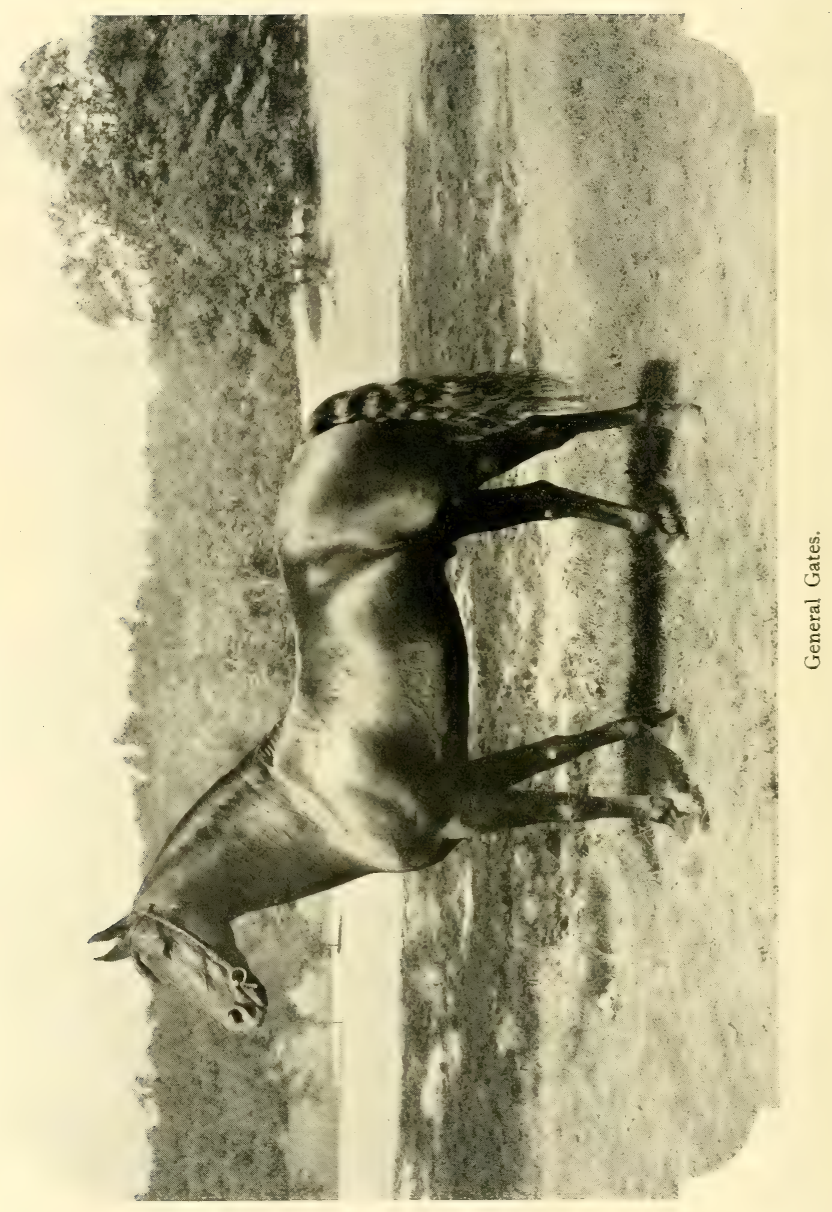


hall, by North American; 2d dam bay, said to be by Peter's Halcorn, son of Virginia. Sold to John S. Wolf, Jr., Cedar Rapids, Neb., who sends pedigree. Died 1894 .

Sire of Osprey, $2: 27 \frac{1}{4} ;$ I sire of I trotter.

GEN. GATES (1-8), black, I5 hands, I045 pounds; foaled May 6, I894; bred by Joseph Battell, Middlebury, Vt. ; got by Denning Allen, son of Honest Allen : dam Fanny Scott (dam of Lord Clinton, trotting race record $2: 083 / 4$ ), brown, with star, scant $\mathrm{I}_{5}$ hands, 950 pounds, bred by E. W. Hughes, Todd, Ky., got by Revenue Jr. (Brown's, recorded in Bruce's Stud Book), son of Revenue, by imported Trustee; $2 \mathrm{~d}$ dam bay with star, $15 \% \frac{1}{2}$ hands, foaled about 1854 , purchased by Mr. Hughes of George Nick Moore, Allensville, Ky., who bought her of Mr. Crab of Elkton, Ky., who is thought to have got her in Indiana, said to be by a Copperbottom horse ; and 3 d dam Stump-the-Dealer stock. Kept at Bread Loaf Stock Farms, Weybridge, Ripton and Middlebury, Vt., till July I, 1907, since which time he has been owned by the United States Government, and kept at the Government Morgan Horse Farm, Weybridge, $\mathrm{Vt}$.

Before buying Denning Allen and Fanny Scott, the dam of Lord Clinton, in March I893, we traced the pedigree of the mare; first visiting Dr. E. S. Rice of Little Rock, Ark., who said :

"Fanny Scott the dam of Lord Clinton was brought here, when four or five, by Bigbee and Christian, with a drove of mules that came from Galloway County Mo., sold to Dr. Bracacher for $\$ 225$, and driven by him six or seven years. He was frightened because she was so high spirited and sold her to Mr. Biscoe, who bred her to Denning Allen. He bred Lord Clinton and two others, one died and the other is owned by Mr. J. Jones."

We then visited Dr. Bracacher of Little Rock, who said :

"I owned the dam of Lord Clinton about six months, bought of parties that brought her here, I think from Pennsylvania, or Kentucky, to Hanger's stable.

"She was a compact well built mare, very nice and very stylish, carried herself elegantly, was extremely well muscled, quick as lightning and gentle, except playful; went like a streak; square trot, square and free. A small brown bay with star, I sold her to Dr. Adams for Mr. Biscoe; represented about six years old when I bought her fully twelve years ago. Fanny Scott was very much like the dam, thoroughbred, of the Blackburn mare, sold at \$8oo."

L. C. Balch, proprietor of Lake Side Stock Farm, Little Rock, Ark., in interview, said :

"The dam of Lord Clinton was scant I5 hands, brown, rather lengthy, on short legs, unusually well muscled, smooth turned, with thoroughbred finish, clean bony head, prominent eye, fore-legs wide apart, broad breast, could show three minutes; very high strung and game; my idea was by a thorough-bred horse, from a road mare, long neck, clear flinty limbs. I came here $188 \mathrm{I}$, she came here before; he had sold her. 
I bought her from Biscoe and Hanger; sold back for $\$ 140$; drove her six months, her first colt was by Ballie. I bought her 1882 , her first colt was I 883 or ' 4 ."

The following letter was handed to me at Little Rock, with address of H. C. Bigbee, Guthrie, Ky., who owned Fanny Scott previous to her going to Little Rock, Ark.

\section{Dear Colonel :}

New Bloomfield, Mo., Jan. Io, I893.

I received a letter from Col. Bigbee that sold you the mare, his address is H. C. Bigbee, Guthrie, Ky. ; and you could write to him if you wish for further information.

\section{(Signed), W. C. Christian.}

Following this direction we went to Guthrie, Ky., where we found Mr. H. C. Bigbee, who in interview, March 3, r893, said:

"I bought the brown mare with star, I5 hands, sold by my brother to a doctor at Little Rock, Ark., of the old man Flood, of Guthrie, she was about 7 or 8 years old, he did not raise her, but owned her about a year, drove her a little on track, could trot in about three minutes; I bought her for $\$ 90$, about I5 years ago; Whit Foot owned her before Flood (of Sadlerville); Flood got the mare of Dick Hughes, Bowling Green, Ky.; or rather, Flood got her from a darkey, who had her from Hughes, fine going mare, mighty speedy."

We then visited Mr. D. B. Hughes of Bowling Green, who we found, and also his father and mother. Mr. D. B. Hughes, said :

"Fanny Scott was bred by E. W. Hughes, Logan County, Todd, P. O., got by a Revenue horse from Virginia, a four-mile racer, kept at that time in charge of E. W. Hughes; dam a Copperbottem, a fine saddle mare, bay, with star, $15 \mathrm{I} / 2$ hands, perfect model, a saddle bred mare, bought by my father, and her dam a Stump-the-Dealer mare.

"Father sold Fanny Scott to me when five years old. I tracked her, she could trot in $3: 20$ when she got frightened; soon after I sold her to a negro, Paul Hand, and he sold her to Bigbee, who shipped her to Little Rock, Ark. We have been here eleven years. I didn't own her but about six months, and the negro six months.

"Revenue Jr. looked like the mare, only larger, a big square built horse, fine made, fine arm, mahogany brown, $151 / 2$ hands, I I oo pounds, the best made horse I ever looked on. He might have been nine or ten when father kept him at Allensville, Todd County, two seasons.

"Fanny Scott was a pony built, heavy brown mare with star; a nice styled mare in harness as ever you saw. I drove her three months on the track."

E. W. Hughes, Todd, Logan Co., in interview said :

"I was born at Powhatten Court House; left when 23; came to Kentucky, to Albermarle; stayed there five years. Brown,low thick-set man, about 45 now, 23 or 24 then. He went back to Virginia. I kept the horse Revenue Jr., two seasons when owned by Brown. He sold him in Nashville, to some big horsemen; cost Brown \$2500. He was a little higher than the mare [Fanny Scott]; very much like her. The dam of mare I bought of a man at Allensville, Todd County, Ky., named George Nick Moore, before the war began. This dam was extra 
fine, splendid rider, work anywhere, one of the best saddle mares I know of. I kept her till 16 all through the war. Not more than four or five when I got her. A right fast pacer, brown, like Fanny Scott; 15 to I5-I or $1 \frac{1 / 2}{2}$; weigh heavy. Moore was a young man. Fanny Scott is about 20. I have been here ten years; six or seven when I sold her. I owned a sister of Fanny Scott, almost like her, sold her to Donaldson, she ran away and killed herself, I think.

"The Revenue horse was bay very much like the mare only larger; a red bay, beautiful horse, lots of life, did not drive him. It was after the war that Brown came to Kentucky, five or six years, I think."

Mrs. E. W. Hughes who was present at the interview thinks Fanny Scott was born about 1870 . Mr. Hughes continued:

"I sold nine or ten colts from the dam of Fanny Scott none less than \$roo. She looked like a blooded animal." The old lady says: "She looked like an Arabian, called her Puss." Mr. Hughes says: "The Revenue colt was the last one we raised from her. I had the dam at least twelve years. (Old lady thinks Fanny Scott may be 25).

In second interview, D. B. Hughes said:

"Revenue Jr. might have been 9 or Io when father had him. Stood here at Allensville, Todd County, two seasons. Father kept him for Brown, did not own him. Must have stood in Allensville about I86970 ; hence Fanny Scott foaled about I 870."

We have received the following letters regarding Revenue Jr. :

Powhatan, VA., Dec. I905.

Dear Sir :-The Brown's, of whom you make inquiry, lived at this place 40 years ago. Soon after the close of the Civil War, they left the county and possibly the State, and for a great many years we have heard nothing of them. The horse was shipped to Kentucky during the war. $\mathrm{He}$ was a fine noble animal, and had a splendid pedigree.

Postmaster at Powhatan, Va.

Mr. Joseph BATTELl,

$$
\text { Powhatan, Va., Dec. I6, I905. }
$$

My Dear Sir:-The horse Revenue alluded to in your letter of the I 4 th was raised at Powhatan, C. H., by Col. Wm. C. Scott, who owned the mother, Pauline; and the sire, old Revenue, I think, was owned by John Minor Botts. After Col. Scott's death, his nephew, young Brown, came in possession of the horse and took him to Kentucky.

If you look up the record of Pauline, owned by Wm. C. Scott, you will get the desired information.

$$
\text { Yours most respectfully, Jos. HoBson. }
$$

Mr. Joseph Battell, Washington, D. C.,

$$
\text { Powhatan County, Dec. } 2 \text { I, I905. }
$$

Dear Sir:- In answer to your inquiries in regard to the stallion "Revenue" carried to Kentucky by Mr. Brown, I have to say, that he was bred by Gen. Wm. C. Scott of this county, and at his death, at the close of the war, came into possession of his nephew Mr. Brown, either by purchase or as his part of the estate.

Revenue was by Revenue, owned by John Minor Botts, a well known Congressman from this State, and the breeder of many noted race horses. 
Gen. Scott also owned many fine thoroughbred horses. Revenue $\mathbf{2 d}$ was a fine horse, I knew him well, as he was raised near me. His dam was Pauline, a thoroughbred mare who took the first premium at one of our State Fairs, before the war, as the best bred mare on exhibition. There is no doubt as to Revenue Jr. being a thoroughbred horse. I think you will probably find his pedigree, or that of his sire in the stud book.

I have given you the information desired as fully as can, I do not know Mr. Brown's address, or whether he is still alive, or I would inform you.

$$
\text { Respectfully yours, DAN J. Hatchen. }
$$

Mr. George N. Moore writes from Marion, Ill., dated Jan. 9, I906:

" My father is still living. The mare he sold to Mr. Hughes, he bought from a Mr. Crab, Elkton, Ky., and thinks he got her in Indiana. I have a brother in Washington, J. P. Moore, older than I, who may be able to give you further information."

Mr. J. P. Moore, 7 13 Post Office Building, Washington, D. C., in interview Jan. I2, I906, said:

"The mare father sold Mr. Hughes, was a very round, plump mare as I remember her, ${ }_{5} 5$ to $15 \frac{1}{2}$ hands, Copperbottom stock; a young mare when he sold her. We took to Missouri with us a mare of the same stock, I think a sister, a very fine saddle mare. He sold the mare to Hughes before he went to Missouri, I think in I 86o. The mare he sold to Hughes was the best one of the two, but both were good."

The Breeder's Gazette, Chicago, thus speaks of Lord Clinton :

"One of the best green horses of the present season was the black gelding Lord Clinton, that was brought up from Arkansas during the midsummer days. When first brought north in the summer he was held for sale at the extravagant figure of $\$ 7,000$, his owner claiming that he could trot in $2: 16$ but although he was a horse of considerable brush there was no time during July and August that he could make good his owner's prediction. As a matter of fact he was beaten at Saginaw in slower time than 2:20 by Little Albert, and during the time that McHenry had him he was hardly first-class. As the cold weather of fall came on, however, Lord Clinton improved very fast in racing capacity, - and at the Nashville and Columbia meetings in October, he could play with a $2: 20$ horse, and seemed to have speed enough to step a mile in $2:$ I 5 or better. During the last week of October Lord Clinton showed up at Birmingham, Ala., where he won the free-for-all race from Ed. Geers' good horse N. T. H., the best mile being $2: 2 \mathrm{I} / 2$, over a new track. From the fact that $2: 20$ was not beaten in this race, and Lord Clinton seemed to be pretty well extended all the time, Geers thought he would be sure to beat him in another race later in the week, in which he was to start, Fred S. Wilkes a horse that can beat $2: 20$ all the time over a first-class track. But when it came to trotting the race instead of talking about it, Lord Clinton stepped three dizzy miles in $2: 2 \mathrm{I}, 2: \mathrm{I} 7$ and $2: 181 / 4$, the best mile and best three heats ever put to the credit of a trotter in the state of Alabama. In as much as the Birmingham track cannot be considered a fast one, this mile in $2: 17$; by Lord Clinton, is considered by horsemen to be equal to $2: 14$ over one of the fast tracks in mid-summer. Lord Clinton has a remarkable history, there 
being no doubt of the fact, that up to 1890 , he was uscd exclusively under the saddle, and last year ran a number of quarter races, being a remarkably speedy horse at the gallop. More than this, he was rirlden to hounds in the South, and by reason of having worn a heavy curb bit his tongue was badly lacerated in one place, leaving a groove that has bothered him ever since he began life as a trotter, and his defeat in a deciding heat in Detroit last summer was said by his driver to be due to the fact that the horse's tongue troubled him and he let go of the bit at a critical moment. It would be interesting and valuable to learn all about the blood lines of Lord Clinton. Of course as soon as it was established that he had run quarter races the men who have a fancy for running blood in trotting pedigrees at once explained all his trotting speed by means of their favorite theory, but the only reason for the horse trotting more than ordinarily fast is that he was by a grandson of Ethan Allen, a stallion that in his day was a champion and whose sons and daughters have produced speed at the trot with more or less uniformity. The fact that Lord Clinton could run well for a short distance does not prove that he is not trotting bred, because Goldsmith's Maid when going, was more than once ridden quarter-mile races on the roads of Orange County, N. Y., and it was also the headstrong filly's favorite mode of recreation to break away from the Decker farm in the night time and roam the country at will, fences of the ordinary kind being no obstacle to her progress. And yet, Goldsmith's Maid was a daughter of Alexander's Abdallah, a son of Hambletonian. Unless some accident befalls him, it is highly probable that next year will see Lord Clinton among the trotting stars, and it is just as well to discard in advance the wild assertions that are sure to be made by the running blood theories on account of his having taken part in quarter races. There are plenty of well bred trotters that can run faster for a short distance than some thoroughbreds."

One statement in the above article "during the time that McHenry had him he was hardly first-class," would seem to need some qualification, as during this season of $\mathrm{r} 89 \mathrm{r}$, Lord Clinton not only beat Little Albert at Saginaw, instead of being beaten by him; but started in 19 races, winning all but three, in which he was second, and his total net winnings amounted to $\$ 5,400$.

Mr. Parlin says in American Horse Breeder :

"Lord Clinton $(2: 083 / 4)$ is one of the very few $2:$ Io trotters that is not related nearly or remotely to either Hambletonian, Mambrino Chief, or Henry Clay, and if we remember correctly he is the only one whose extended pedigree does not show the names of either of these three founders of trotting families. His sire, Denning Allen, was inbred to the Vermont Black Hawk branch of the Morgan family. Denning Allen was by the inbred Morgan, Honest Allen, a son of Ethan Allen $(2: 25 \mathrm{~T} / 2)$, he by Vermont Black Hawk. The dam of Denning Allen was by Ward's Flying Cloud, a son of Vermont Black Hawk.

"We have never been able to learn the breeding of Lord Clinton's dam, but believe that Mr. Joseph Battell has obtained some facts about her that tend to show a close thoroughbred relationship. Some ten years ago we received the following interesting letter concerning her from a gentleman in Little Rock, Ark." 
Editor American Horse Breeder:

Little Rock, ARk., Sept. 20, 1892.

"Yours of the $I 5^{\text {th }}$ inst. to hand, I am the breeder of Lord Clinton. I bought his dam, Fanny Scott, in the fall of $\mathbf{I} 878$, and bred her to a Morgan horse called Ballie in the spring of $\mathrm{I} 88 \mathrm{I}$, and she dropped a horse colt in r 882 . This colt is still in this city and has been used as a family horse, until recently he has broken down from some cause and is no good. This colt, however, never did show any speed, although his sire could trot in about $2: 30$.

"I next bred Fanny Scott to Denning Allen, and Lord Clinton was the result. I bred her to Denning frequently after the birth of Lord Clinton, but could not get her with foal. I afterwards bred her to one of my young stallions, and succeeded in getting two colts. Both of these colts were very delicate and both of them died. Since the birth of these two colts I bred her to Denning again for a long time and also to Executor, but all efforts to raise a colt from her by either of these horses were failures.

"After Lord Clinton made his first mark I sold Fanny to C. M. Simons for \$30o, and he still owns her. I don't think he has succeeded in getting her with foal. I bought Fanny from Dr. Bracacher of this city. I owned her from 1878 to $189 \mathrm{I}$. Fanny is possibly $\mathrm{I}_{5}$ hands high and of very stout build. She is not fast, but a nice roadster."

"After Mr. Joseph Battell bought Denning Allen, he also bought Fanny Scott, the dam of Lord Clinton, and we believe that he succeeded in raising a full brother of Lord Clinton (2:083/4) from her. Denning Allen was foaled in 1874 . Lord Clinton $(2: 083 / 4)$ is the only one of his get that has yet taken a record in standard time.

American Horse Breeder, Jan. 6, 1903.

EDITOR."

GEN. GEO. A. BALLARD, $2: 30$, black, one white ankle behind, $153 / 4$ hands, I050 pounds; foaled I875; bred by Patrick Ryan, Fairfax, Franklin County, Vt. ; got by Young Rix, son of Rix Horse (Chieftain) : dam said to be by Blake Horse, son of Whalebone, by Flying Morgan. See The Morgan Horse and Register, Vol. II., p. I35.

GEN. GEO. H. THOMAS, bay; foaled I 864 ; bred by Joseph S. Kenney, Danville, Ky.; got by Mambrino Messenger (Dunkin Horse), son of Mambrino Paymaster: dam bred by J. S. Kenney, got by Mambrino Chief; $2 \mathrm{~d}$ dam bred by Jessie Bryan, Fayette County, Ky., got by imported Napoleon; $3 \mathrm{~d}$ dam said to be by Tempest, son of Jenkins Potomac. Sold to Ward Macey, Versailles, Ky.; to M. Zeigler and T. T. Oliver, Cincinnati, O., who send pedigree.

Sire of 6 trotters $(2: 20)$; I sire of 4 trotters, I pacer; 8 dams of 9 trotters, 4 pacers.

GEN. GIFFORD (ELDRIDGE HORSE) (I-4), chestnut with strip in face, I5 hands, I040 pounds; foaled June 5, I 840 ; the property of E. A. Eldredge, Warren, Vt., who bought the dam (bay, in foal) of a Mr. McCray. This horse was claimed to be by Gifford Morgan, but F. A. Weir informs us that in trying to verify this pedigree he found that Gen. 
Gifford was bred by a Mr. Parker, North Charlestown, N. H., and got by Morgan DeForest, son of Cock of the Rock, by Sherman Morgan; and his dam by Cock of the Rock.

\section{Mr. Joseph Battell,}

Lodi, Seneca County, N. Y., July 20, 1885.

Dear Sir:-Taking up the Chicago Breeder and Sportsman, I looked over an article relating to the Morgan family of horses; it had reference to you and your breeding farms, called the Bread Loaf Farms, Middlebury, Vt. I have been for many years a breeder of the Morgan Horses. In I 848, Mr. Chas. W. Ingersoll, now deceased, and his cousin, M. H. Ingersoll, bought General Gifford, by Gifford Morgan, by Woodbury, by Justin Morgan, at the State Fair held in Syracuse, N. Y., brought him home, and I soon became interested in him. He was a great horse; we kept him for service; he served from 90 to I 25 mares per season at $\$ 20$ to insure; he never failed to get more than two-thirds of them in foal. In February, I 854, we traded his use to Mr. Nathaniel Seely, of Goshen, Orange County, N. Y., for one season only, for New York Rattler, he by Treadwell's Abdallah, by Mambrino, by imported Messenger. We would not let the General go there without Mr. Seely would have our colored groom come with him and stay with him while he had him, which he did agree to, and I went to Orange County, and took the General and Henry, the groom, and made the exchange and brought New York Rattler home with me. He was a strong-moulded fellow, I6 hands, with three white feet, not high up, strong bay, black tail and mane very thin, but what hair was there was of the very best quality; and if it had been known, he was a better horse than Hambletonian ever was, but we gave him three seasons in the stud here, but he did not take well, and we sold him for $\$ 600$ to a gentleman in Steuben County, N. Y. The same spring I took two stallions by General Gifford to Tecumseh, Mich., a five and three-year-old. One was a glossy brown and the other a chestnut. The brown we called Bussora; he was bred by a Baptist minister of Cayuga County, N. Y. We traded for him the winter he was coming three years old. His first dam was by the imported Arabian horse Bussora ; $2 \mathrm{~d}$ dam by a son of imported Messenger. $\mathrm{He}$ was the best horse ever raised in Cayuga; about $15^{\mathrm{I}} / 2$ hands high, well proportioned with all the style of the Morgans, and fast. I sold him to B. I Bidwell of the same place; also the chestnut colt. The brown horse I got \$ $\$$, ooo for; the other $\$ 600$. We brought Gen. Gifford back to Lodi, Seneca County, after the season was out. In I 855 we kept him in Yates County, N. Y., and the same fall we sold him to go to Gainsville, Ill., for \$I Ioo delivered there. The last time I ever saw him was in I 865 at St. Louis. He was blind. It was caused by standing him crosswise between the doors in the cars. With all that infirmity he could out-show any horse upon the grounds. It was then that I saw Golddust the first time, and in I872 I went to Kentucky and brought to Seneca County, Eden Golddust a dapple brown, I6 $6 / 2$ hands high, an inbred Golddust or Morgan as you might say. Now I have a colt from him which I call Seneca Golddust, a golden sorrel, one white ankle, I 5 I 2 hands high; bred by the late Dr. D. C. White of Dryden-the perfect facsimile of the original Golddust, and quite fast as well as a great stock getter. Now what I would like of you is to get your work upon the Morgan family of horses, and what information you may see fit to give by letter or otherwise, and I will with pleasure do anything that is within 
my knowledge to aid in this work upon the Morgan Horse. As you see I am interested now as well as in the past.

$$
\begin{aligned}
& \text { Yours etc., } \quad \text { D. L. KaSE. } \\
& \text { Lodi, N. Y., Jan. 28, I889. }
\end{aligned}
$$

Mr. Joseph Battell :

Dear Sir:-I ooking over some old letters, I find yours of March 3, I886, asking me to fill out enclosed blanks for Gen. Gifford and other Morgan horses that I was familiar with. I did fill them out, but was taken sick very soon after. I do not find any acknowledgement of them reaching you, or the paper you represent. I have looked over all old papers saved and do not find them. They were sent or cast into the waste basket. My attention was called to you by hearing that you wrote to Mr. Jacob Meeker in regard to Voorhees' Black Hawk. My daughter read the letter to Mr. Meeker. He did not remember the horse. $\mathrm{He}$ is a very old man and cannot write any more, nor read writing. $\mathrm{He}$ did not remember ever breeding to the Voorhees Black Hawk, but he did, and got a fine mare which foaled many fine colts after he let her go. Her dam was by Gen. Gifford, therefore Meeker's Hambletonian had two crosses of Morgan. I have not seen Mr. Meeker or I would know more what you wanted him to do. $\mathrm{He}$ has sold his horse; went to Long Island; he is a fine one, and his fine style and action come from the Morgan family, his size and color from the Hambletonian and Champion. If those papers have not reached you, please wire me, and if they have not been received, send blanks and I will attend to it at once. There were several of Gen. Gifford's colts kept for stud purposes that I can send pedigree of if you wish it ; will send the Vorhees' Black Hawk also.

It is a great mistake that the breeders in this vicinity have let the great Morgan family run so near out. There are but a few that are nearer than the third or fourth remove from the General. He was the greatest Morgan horse I ever saw, and if I had him or his son, Bussora, I would show all, that they would have to come to them if they wanted to breed fine and fast horses. It plainly shows itself in all that have the cross, even if it is four or five crosses off. You will find it so in all sections where horses of good Morgan blood were kept for stud purposes, but the breeders here as a general thing, do not look back further than the second dam or sire, therefore the Morgan cross is forgotten, the very cross that gives the strongest points to their horses. When I remind them of it, they will say that it is so, and let it pass, and go pell mell and breed to something new, instead of trying to find some stallion of fine breeding that has the Morgan cross. By doing so they might breed on and get several crosses of Morgan blood in the horses being bred now. No man unless he has had a well-bred Morgan horse, knows what it is to have a fine and stylish driver and an everlasting stayer.

I drove a pair of mares of $\mathbf{5} 5$ hands, got by Gen. Gifford, I 5 years, and they carried me thousands of miles in the time and did a great deal of hard work besides, and they were just as sound as colts, after all that hard wear and tear, and to think of the pleasure I took when driving them.

I never drove up to even one man standing on the ground but they seemed to think they must show themselves, which is characteristic of the Morgan. I am often asked by a gentleman to look over his stylish Hambletonian, Champion or Clay as the case may be. I ask for his 
dam's breeding and it generally ends up that one of them was a Morgan. I say to him, there is where your horse gets his style and action. "Oh, no: he is a regular 'so and so' ; it's not the Morgan." The fact is that great style and action are rarely found in any other family of horses. Give me a Morgan and $I$ will never tire riding after them, and they are sure to attract attention. I showed Gen. Gifford at Goshen, Orange County, in $\mathbf{1} 854$, against Cassius M. Clay. There were at least I 000 men there and I could take the crowd to a man, except the one who led Cassius M. Clay. They called him pony, but he could look over their brag horse, if he was 17 hands high. When I look back and see the great majesty and power that was in the General my blood fairly boils.

I have a dark golden sorrel colt, foaled April I 8 , I 888 , three white ankles, star and diamond, and fine size, that is a perfect Morgan. He was by Seneca Golddust, he by Eden, and he by S. L. Dorsey's Golddust : dam by Combination, by Middletown, by Hambletonian ; 2 d dam by Gifford's Black Hawk, by Black Hawk; 3d dam by Gen. Gifford ; and 4 th dam by Cornet, a thoroughbred. Seneca Golddust's dam was by Grayhound, he by Black Hawk; 2 d dam by Halden's Hickory, he by imported Whip; 3 d dam by Post Boy, he by Henry, by Sir Archy, by imported Diomed. Combination's dam was by Seely's American Star. This colt has the style and action of the best of the Morgan family. It is hard for me to stop when writing about the great and noble Morgan. Please write me at receipt of this, and say when the book will be issued or ready for sale. Hoping this may find you prospering with it, I am

$$
\text { - Very truly, D. S. KaSE. }
$$

P. S. I have just seen Mr. Meeker and will make out the Vorhees' Black Hawk pedigree, and when I write again will send it. Send blanks for others I have, for I am out of them.

Warren, Vt., March I5, I886.

Editor Register:-Enclosed you will find one of your blanks filled. As I recollect the facts, I bought the horse in $\mathrm{I} 848$, and have lost or given away all of my bills and I write you from recollection. I think his pedigree is given in a book put out by Linsley on Morgan horses.

The dam of Gen. Gifford was a large bay mare brought to this place in 1838 by one Gray from Charleston, N. H., who moved to Waitsfield and has been gone from there a long time.

$$
\text { Yours truly, } \quad \text { E. A. EldREDGE }
$$

Joseph Battell, EsQ.,

Burlington, Vt., April 28, I 888.

Dear Sir :-Your two letters received. Calvin Blodgett, who formerly resided at Waterbury, was my father.

Gen. Gifford was a chestnut, $I_{5}$ hands, white stripe in the face, great style; was purchased from the late Hon. J. P. Kidder, who then resided at West Randolph. Kidder, as I understand it, purchased him from Mr. Eldredge of Warren in $\mathrm{r} 844$. We got him in 1845 and sold him at Auburn, N. Y., the fall of 1846 , to a man by the name of Mason. He was by old Gifford Morgan; the dam I know nothing of. Charley, dapple bay, nearly I 5 hands, about 900 pounds, no white, black points, was from a mare by Green Mountain Morgan, by old Gifford. He must have been foaled near 1850 . We had two other stallions, both chestnut, by old Gifford. One was from a mare said to be by old Woodbury Morgan (the mare was so aged when we purchased her, it was thought doubtful of her 
ever breeding, but she did). The other by old Gifford was from a mare by Gen. Gifford. Both these last named stallions were taken to St. Paul, Minn. I don't remember what did become of Charley. We sold him to J. C. \& S. Brown of Waterbury. S. Brown is now residing at Ogdensburg, N. Y., J. C. is dead. Yours truly, C. H. BlodgetT.

Advertised I 849, in Albany Cultivator by Munro J. Mason in Jordon, Camellus and Belle Isle, at \$ro by Gifford Morgan,dam a Morgan mare.

Sire of $2 \mathrm{~d}$ dam of Kate Sprague, 2 :I8.

GEN. GIFFORD JR. (BROWN'S) (3-I6), sorrel with small stripe in face, I5 hands, 900 pounds; foaled $\mathrm{I} 847$; bred by C. C. Brown, Williston, Vt. ; got by Gen. Gifford, son of Morgan DeForest: dam said to be Morgan. Taken by Mr. Brown to Honeoye, N. Y., where he was kept, I $85 \mathrm{I}-2$, at barn of Wm. R. Pitts. He returned to Vermont and soon after was sold to go West. Mr. Pitts writes, dated Cairo, Pratt County, Kan., June I4, I889:

Joseph Battell,

Dear Sir :-Your letter forwarded to me from Abilene. I send you an informal statement of the breeding of the horse Gen. Gifford Jr., but the best I ever had. As long ago as $185 \mathrm{I}$ pedigree and breeding were not looked for or expected, as at this day; but he was at that time the finest young horse I ever saw, the exact figure of his sire, according to his age. Brown came to Livingston County, N. Y., with the horse, driving through in a sulky looking for a place to make a season. I heard of him, went to him a stranger, and told him he would do well, at our place. He came the next day, and made a good season, staying with me through harvest, after his season driving back to Vermont and returning next season, and left a fine lot of colts, all of them making valuable and useful horses. He was sold soon after returning to Vermont and I could never find where he went. Anything further that I can help you to, will be glad to do so. Am breeding some horses here in Kansas, and would like a copy of your Register, or book on Morgan Horses, as I am more interested in the Morgan stock than in all the horses of the different breeds now on the market. I know of another Morgan horse 22 years old, 200 miles from me; have never seen him, hear well of him. He was Vermont bred. If you send me blank, will get it filled and send to you; can't send you owner's name or P. O. address, as I have lost both, but can get it again and will be pleased to do it for you if you wish. Yours respectfully, WM. R. PITTS.

See the Morgan Horse and Register, Vol. I., p. 317.

GEN. GIFFORD JR. (INGERSOLL'S) ( $\mathrm{x}-8)$, dappled chestnut, I 6 hands, I Ioo pounds; foaled I85 I ; bred by Charles W. Ingersoll, Lodi, N. Y. ; got by Gen. Gifford, son of Morgan DeForest : dam Medick's trotting mare ; 2 d dam said to be by Busiris, son of American Eclipse. Owned I 857 , by B. J. Bidwell, Tecumseh, Mich. Took ist premium at New York State Fair at Utica, 1852 ; premium and medal at Michigan State Fair at Detroit, I854. A good horse, docile, with easy and graceful action. See The Morgan Horse and Register, Vol. I., p. 317 . 
GEN. GIFFORD JR. (YEOMAN'S) (I-I6), chestnut no white except a few hairs in the forehead, 15 hands, 1050 pounds; foaled about 1855 ; bred by Elial Yeoman, Walworth, N. Y.; got by Ingersoll's Gen. Gifford, son of Gen. Gifford: dam said to be of Highlander stock. Sold to a physician at Syracuse, N. Y. Advertised as follows in American Stock Journal, New York, I860:

"This beautiful horse will be sold at a bargain. He is coming six years old, dark chestnut, with no white except a few hairs in the forehead; is I5 hands, and in good flesh will weigh ro5o pounds; spirited but kind in every place as well as in harness. His stock is unsurpassed and uniformly without marks, and is a sure foal getter. He received the first prize at the State Fair at Buffalo, N. Y., I 857 , also two first premiums at the Union Agricultural Society in Palmyra, N. Y. Full particulars given on application.
Walworth, Wayne County, N. Y."
E. Yeomans.

GEN. GIFFORD 3D. See Young Gifford (Carrier Horse).

GEN. GRANT (I-128); said to be by Como.

Sire of Bessie Shedd, $2: 23 \frac{1}{2}$.

GEN. GRANT (ST. LAWRENCE), bay with few white hairs in forehead, one hind foot white, $15 \frac{1}{4}$ hands, Iooo pounds; foaled 1856 ; bred at Longuille, Que., about four miles from the river, south of Montreal; and said to be by St. Lawrence : dam bay called a Messenger mare, said to have been foaled 1835 , to have been a trotter and brought from Long Island. John Reno, Montreal, P. Q., bought him in Longuille, and sold him in I862, to T. P. Jewell, Mt. Upton, N. Y., who sold in fall of I863, to Alick Benedick, Unadilla, N. Y.; and he to Mr. Brown, Pharsalia, N. Y.; he then passed to Mr. Jewell again who sold to Jim Roberts, New Berlin, N.Y.; and he to Nate Harris, whose property he died in 1884. A son of this horse, dapple chestnut, I5 hands, I Ioo pounds, called St. Lawrence Boy, was bred by Milo Hutchinson, Rockdale, N. Y., and passed to Sherrill F. Edwards, Franklin, N. Y. Information from Mr. Jewell, who writes that he was a splendid road horse of kind disposition and fine style, as were also his get.

Sire of Lady Upton, $2: 29$; winner of 24 recorded races.

GEN. GRANT. A horse called Gen. Grant, dark bay, 15 T/4 hands, 950 pounds; foaled about 1856 ; was purchased in Chicago about 1862 at reported price of $\$ 10,000$, by E. C. Bailey, Boston, then owner of Boston Herald; kept at Boston a while then taken to Contoocook, N. H., where he remained some years and got a good many colts. It was said at time of purchase that he had a two mile record in 5 :0o. Advertised I 866 at East St. Johnsbury, Vt.

A physician, name not remembered, in interview at St. Johnsbury, said : 
"The horse Gen. Grant was brought to St. Johnsbury by Mr. Huckins of West Topsham. He was a chestnut horse, silver mane and tail, the proudest horse at speed you ever saw. Huckins bought him in Boston; had him two years; sold to Lorenzo Colby, who had him one year. He died in I871."

This is probably, indeed almost certainly, the horse of same name advertised at East St. Johnsbury in I866, described as dark pay, I6 hands, foaled I858, of beautiful form and great style; by C. M. Huckins and his pedigree given as Hambletonian. We are informed by several that this pedigree was entirely fabricated. In I866, Mountain Chief is advertised at Danville, East Hardwick, and Lyndon, by B. R. Flint, and Major Morrill, at West Concord by G. L. Higgins.

GEN GRANT (FLYING YANKEE) (5-64), black; foaled July I8, I86r ; bred by John S. McFarland, Concord, N. H. : got by Draco, son of Young Morrill: dam bred by John S. McFarland, got by Thurston's Romeo 2 d, son of Esty's Black Hawk. Taken to Chicago, Ill., I 866, by breeder, who sent him from there to Topeka, Kan., in care of George Kellam, where he remained two seasons, then taken to Sioux City, Ia., and kept two seasons, when he was brought back to Chicago, and used by Mr. McFarland as a road horse. About 1877 , he was taken to Bloomington, Ill., where he died July I 8, I 879. Could go about a $2: 30$ gait; but did little service in the stud. See The Morgan Horse and Register, Vol. I. p., 627.

Sire of Eureka, $2: 23$; dams of Cleo (?) $2: 21$, Joe Eastman, $2: 291 / 4$.

GEN. GRANT ( $\mathrm{I}-32), 2: 2 \mathrm{I}$, chestnut with strip in face, $\mathrm{I} 5 \mathrm{I} / 2$ hands, rooo pounds; foaled I870; bred J. L. Wilson, West Liberty, Ia.; got by Wapsie, son of Green's Bashaw : dam Belle Wilson (dam of Gen. Lee, $2: 26 \mathrm{I} / 2$ ), sorrel pacer, bought of $\mathrm{Wm}$. Barnhouse, Hopedale, O., said to be bred by A. C. Jennings, Urbana, O., and got by Hanley's Hiatoga. Sold to Stevens Bros., Joliet, Ill. Pedigree from breeder. Trotted I 8 72-76 and winner of 17 recorded races.

Sire of 6 trotters $\left(2: 25^{3 / 4}\right)$; I sire of $\mathrm{I}$ trotter, I pacer; 6 dams of 6 pacers.

GEN GRANT JR., I5 I/2 hands, I Ioo pounds; foaled 1865 ; said to be by Gen. Grant, bought by E. C. Bailey, Boston, which see. Advertised by J. \& G. W. Styles, Waterford, Vt., in the St. Johnsbury Caledonian, I87o.

GEN. HANCOCK (I-64), bay; foaled I 878 ; bred by H. M. Burgher, Glendale, Hamilton County, O.; got by Geo. Wilkes, son of Hambletonian : dam Peri, brown, foaled I 887 , bred by F. P. Kinkead, Woodford County, Ky., got by Alexander's Edwin Forrest; 2 d dam Waterwitch (dam of Mambrino Gift, $2: 20$ ), bay, foaled I 859 , bred by F. P. Kinkead, got by Pilot Jr., son of Pilot; 3 d dam Fanny Fern, said to be by Kinkead's 


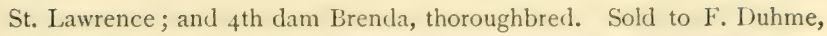
Cincinnati, O., r884. Advertised by him at Woodlawn, O., I 890.

Sire of 3 trotters $(2: 263 / 4)$, I2 pacers $\left(2: 08 \frac{3}{4}\right) ; 4$ sires of 4 pacers; 7 dams of 6 trotters, I pacer.

GEN. HANCOCK $(\mathrm{I}-32), 2: 24 \mathrm{I} / 4$, bay, said to be by Lightning, son of Doble's Black Bashaw : dam Miss Jones, by Perkins' Morrill. Sold from Philadelphia to Henry Seeley a trainer; to S. B. Lovejoy, Minneapolis, Minn., who sends pedigree.

GEN. HARDEE ( $1-64$ ), roan, I5 $3 / 4$ hands; foaled 1863 ; bred by Wm. Fowler, Cornersville, Marshall County, Tenn.; got by George Washington, son of Taylor's Henry Hal, by Kittrell's Tom Hal : dam said to be by Traveler, son of Suggs' Stump, by Stump-the-Dealer, son of Timoleon by Sir Archy. Owned by F. G. Buford, Buford, Giles County, Tenn., whose property he died Aug., I884.

Sire of Gen. Hardee, $2: 27 \frac{1}{4}, 3$ pacers $(2: 22)$; I sire of 2 pacers; Io dams of 12 pacers.

GEN. HATCH (I-64), $2: 47$, bay, white hind ankles and star, I $53 / 4$ hands; foaled I 860 ; bred by Robert Prewitt, Lexington, Ky. ; got by Strader's Cassius M. Clay Jr., son of Cassius M. Clay: dam said to be by Envoy (thoroughbred, foaled $\mathrm{I}_{33}$, and imported by William Wilkes of Pennsylvania), son of Memnon; $2 \mathrm{~d}$ dam by imported Tranby, son of Blacklock; 3 d dam by Aratus, son of Director; and $4^{\text {th }}$ dam by Columbus, son of Sir Archy. Sold to B. Hershey, Muscatine, Ia.

Sire of 3 trotters $\left(2: 23 \frac{1}{4}\right)$; I sire of I trotter; 4 dams of 5 trotters.

GEN. HAVELOCK (3-32), dark chestnut; I6 hands; I 50 pounds; bred and raised in the town of Havelock, Kings County, Province of New Brunswick, by Mr. Ebenezar Ryder, who resided later at Cold Brook, St. John County, N. B. ; got by Deerfield Morgan, son of Green Mountain Morgan by Gifford Morgan : dam said to be by Livingston, son of imported Trustee; second dam by an English blood horse, known as the Roach Horse ; and third dam by a thoroughbred horse known as Wild Deer. Livingston's dam was Itasca, a daughter of American Eclipse. Information from Correspondent of American Horse Breeder, Boston, who writes :

Editor Horse Breeder:-In your issue of Oct. II, I saw an inquiry about the dam of Gen. Havelock; I have been looking for an answer, but have not seen one yet, and as I have a knowledge of his breeding, from a letter which $I$ received from the man who bred and raised him, I will give his pedigree as stated by him:

"Livingston was imported from Long Island, State of New York, to the Province of New Brunswick, Canada, by the late Hugh McMonagle of Sussex, N. B., as was also Deerfield Morgan, brought from Massachusetts. It is not surprising that a stallion by Deerfield Morgan, whose ancestors had been inbred for two or three generations among the best of the Morgan family, united with some of the most noted strains of 
these plastic thoroughbreds, should prove to be what Gen. Havelock was. With such an inheritance it was very easy for him to carry off many first premiums wherever he was entered on exhibition. One of these was won at Fredericton in 1870 , among a field of twenty-five of their best stallions. He, as usual, took the highest honors here.

"Though his stock was never thoroughly trained for trotters, taking them as a lot they were unequalled as roadsters. Lady Sussex $(2: 32)$ is no disgrace to produce among so many poor-blooded mares, though it is stated on good authority that Gen. Havelock could trot a mile in $2: 20$ and was sold for $\$ 3300$. It would afford some of the readers of the Breeder a great amount of pleasure to read the history of this Gen. Havelock after he went to Massachusetts. Let us hear from Mr. Herrick or some one who knew about him.

Lincoln, Me.

B. M. T."

GEN. HAVELOCK. A horse of this name discribed as black, $153 / 4$ hands, I092 pounds, and said to be by an imported horse; was advertised, I874, in Stanstead (Que.) Journal.

GEN. HIBBARD (HIBBARD HORSE) (I-4), blood bay, heavy mane and tail, I 6 hands, I 200 pounds ; foaled 1 826 ; bred by Gen. Lovell Hibbard, Royalton, Vt.; got by Woodbury Morgan: dam bay, I050 pounds, square built, good movement and great ambition, bought by Gen. Hibbard of Mr. Walker, who lived on Christian Hill, Bethel, Vt., and said to be by Young Bullrock (a dark bay, good-sized horse, about I Ioo pounds, well proportioned with splendid front, foaled about I8o6, and bought when four, in Massachusetts, by Gen. Hibbard), son of Bullrock an English horse. Sold to Benjamin Day, Royalton, Vt., about I 842 ; to Woodward \& Sturtevant, Tunbridge, Vt.; to Nathaniel Wheatley, Brookfield, Vt. ; to Uriah Hall, Williamstown, Vt., and died his property, I 854 . While owned by Mr. Hibbard he was kept on the Hibbard farm, Royalton, Vt., except one or two days in a week, for one or two seasons, at Randolph, Vt.

Mr. Bliss of Royalton, Vt., born in $18 \mathrm{~s} 4$, said :

"I remember young Bullrock that Gen. Hibbard owned. He was brought from below. I was only four years old.

"Hibbard bought another mare, a little later, of Peter Woodbury, who lived on Christian Hill, that was by Woodbury Morgan, but she was not the dam of the Hibbard Horse. The Hibbard Horse was foaled the same season of our gray horse, either I 825 or ' 26 .

"The Bullrock was larger than the Woodbury Morgan, but not quite so fine. The Woodbury Morgan was considered the best horse that they had about here, and the Morgan blood was considered the best blood there was in this section."

Linsley says :

"He was a very valuable horse, hardy, enduring, with fine style and action, and a good roadster. Left a great deal of excellent stock."

See The Morgan Horse and Register, Vol. I., p. 663.

Sire of 3 d dam of Draco Prince, $2: 24 \frac{1}{4}$, winner of I2 races. 
GEN. HOWARD (COUNTRY BOY) (3-64), $2: 26 \mathrm{~T} / 4$, brown, $153 / 4$ hands, rooo pounds; foaled 1864 ; bred by John I.owe, Richfield, Washington County, Wis.; got by Badger loy, son of Rossman's Horse by Sherman Black Hawk : dam said to be Canadian. Sold when a colt to Mr. Phillips, Merton, Wis. ; r868, to S. M. Granger of Milwaukee, Wis.; to W. H. Doble, Philadelphia; 1878 , to W. H. Thomson, Wilmington, Del. Trotted I 869-77, and winner of I 8 recorded races. See The Morgan Horse and Register, Vol. I., p. 338.

Sire of John Hall, $2: 25$.

GEN. JACKSON ( $\mathrm{I}-32$ ), dark bay, Iroo pounds; said to be by Bigelow Horse, son of Sherman Black Hawk: dam Messenger mare. Advertised as above in the Stanstead (P. Q.) Journal, by A. Bigelow, at $\$ 9$, I 857 or ' 59 .

GEN. JACKSON. Untraced.

Sire of Mountain Girl, $2: 27^{1 / 1}$.

GEN. JAMES A. GARFIELD, $2: 25 \frac{1}{2}$, sorrel, white face and three white legs, I5I/4 hands, 1025 pounds; foaled I88I; bred by Richard Barclay, Youngstown, O.; got by Mohawk Gift, son of Hall's Mohawk Jr., by Mohawk, son of Long Island Black Hawk : dam Emma B., gray, bred by Fred Blank, Loyd's Corners, O., got by Barnes' Hambletonian, son of Robert Bonner; 2d dam Lizzie B., gray, bred by John Verty, Artentowne, O., got by American Eclipse, son of Empire Eclipse; 3d dam gray, bred by John Verty, got by Mambrino Chief. Died i885. Pedigree from breeder.

Sire of E. P. O., $2: 191 / 4$.

GEN. JOHN STARK (3-64), bay, I53/4 hands, I 200 pounds; foaled June I 876 ; bred by T. W. Park, North Bennington, Vt. ; got by Walkill, son of Walkill Chief, by Hambletonian : dam Dolly Hoyt (dam of Whalebone, $2: 23^{1 / 2}$, also dam of Winooski), bay, bred by James W. Hoyt, Middletown, N. Y., got by American Star. Sold, I883, to Frank Riley, Hoosick Falls, N.Y.; about 1885 to Mr. Mather, Williamstown; to Dr. J. A. Bracken, Pittsfield, Mass., who has kept him on his farm in Canada. Kept season of I888, at Auburn, N. Y. Pedigree from John G. McCullough.

GEN. KNOX (I-8) $\left(2: 31 \frac{1}{2}\right)$, brown, $151 / 2$ hands; foaled 1855 ; bred by Daniel Heustis, Bridport, Vt.; got by Vermont Hero, son of Sherman Black Hawk, by Black Hawk, son of Sherman Morgan, by Justin Morgan : dam a large, good fashioned bay mare, bred by Oliver S. Lapham, Shoreham, Vt., got by Searcher (dam said to be by Woodbury Morgan), son of Barney Henry; 2d dam light bay with star and white ankles behind, a fast quarter mare, traded for when five, about i 840 , by Mr. Lapham, of 
William WV. Hunsdon, Shoreham, Vt., who bought her of Samuel Tichenor, Bridport, Vt., whose son Rollin M., traded a pair of oxen for her with Clint Gage, Panton, Vt. Mr. Tichenor said that she was got by a Morgan horse from a Post Boy mare. She was a fast runner. Our information of the second dam is from Mr. Hunsdon, her third known owner, a very intelligent and reliable man. Sold to Eldridge \& D. A. Bennett, Bridport; to Col. T. S. Lang, of Maine; to Henry N. Smith, Trenton, N. J. See article of Mr. Lang, on Gen. Knox in The Morgan Horse and Register, Vol. I., p. $35^{8}$.

THEN AND NOW.

"I was sitting with the veteran horseman Foster S. Palmer one day at Readville, and the great Cresceus ( $2: 02 \mathrm{I} / 2)$ jogged past the stand amid a deafening din of cheers and hand-clapping, a spontaneous and hearty greeting for a royal horse 'Just think of it,' said Mr. Palmer, 'thirty-seven years ago I drove a horse at Springfield in a winning race, giving him a mark of $2: 3 I^{1 / 2}$, and he got as much of a welcome as Cresceus does now with a record almost half a minute faster." "

"What horse was that?" I enquired, "for his stories of the good old days are full of interest, and he knows how to tell them."

"General Knox," said he, "and he was a trotter, for those days. I went to work for Colonel Lang in 1859 , and I was only a boy. The first horse I had for him was Gen. Knox, then a three-year-old, and not a handsome one at that. He could step about a $31 / 4$ gait, but Colonel Lang gave me an old English training book to go by, and I started in to starve the horse into racing shape.

"It didn't take me long to become disgusted with that method, so I shifted and gave the horse plenty to eat and he commenced to step. $\mathrm{He}$ got so good that the fall he was a four-year-old, I raced him at Augusta, Me., and won in $2: 55$ or thereabouts. From then on he began to attract attention. In I 863 I beat Hiram Drew at Waterville, Me., best time $2: 32$, and the next year, after a long stud service, I raced him for the stallion purse at the New England Fair at Springfield, Mass., beating Draco, Duke of Wellington and one other, and giving him a mark of $2: 3 \mathrm{I} 1 / 2$. Right then and there, Col. Denny offered Col. Lang $\$ 10,000$ and the pacing mare Pocahontas $(2: 17 \mathrm{~T} / 2)$ for him. Then Mr. Beckwith of Hartford offered me $\$ 25,000$ for him, and later offered $\$ 30,000$ to Col. Lang for the horse, but these offers were all refused, as Mr. Lang thought more of the breeding interests of Maine than he did of the flattering proposals.

"Just think of it, and he only had a record of $2: 3 \mathrm{I} / 2$, but I tell you that was pretty good in those days. But here's what I was coming at, the great reception we got when we landed home in Vassalboro, Me. You ought to have seen the crowd about the depot. Everybody in town was there, and forming a procession, headed by the band, they escorted the horse and myself to the stable.

"Across the square, worked in evergreen and flowers, was suspended a banner reading 'See, the Conquering Hero Comes,' and as I led the old horse under the evergreen, the ladies threw over his neck a beautiful wreath of roses.

"It seems funny, doesn't it, in these days when a $2: 20$ horse is only a road horse, and to be really great, a horse must step in 2 :10 or better. 
A few years later Gen. Knox was sold to Henry N. Smith of Trenton, N. J."-American Horse Breeder, Jan. 20, 1903.

Kentucky Agricultural reports I 859 -State Fair.

" 2 d premium to T. S. Lang, for Gen. Knox, cost \$ro,ooo, best oneyear-old.

THOMAS S. LANG AND MAINE HORSES.

"In a sketch of the late 'Thomas S. Lang, formerly of Vassalboro, whose death occurred at the Dalles, Oregon, on Wednesday, The Commercial said :

" In I 859 , Mr. Lang brought the celebrated horse, Gen. Knox, to Maine, and had he done no other service to the material interests of the State, his name would deserve to be held in high esteem by every one interested in the good of Maine.'

"This statement is not over drawn, for the value of this one horse to the agricultural and live stock interest of Maine can hardly be overestimated. In his work on 'American Roadsters and Trotting Horses,' Mr. H. R. Helm says of Gen. Knox :

" He spent nearly all his days prior to 1872 in the State of Maine-a State lucky to have held one such sire, for he has been a most remarkable one. We have produced no stallion in our day that can surpass him.'

"Gen. Knox was purchased by Mr. Lang in Vermont, when three years old, and was then called Slasher. We do not know what Mr. Lang paid for him. When Mr. Lang brought the horse to Maine he renamed him Gen. Knox. He also brought into Maine about the same time the young stallion Black Hawk Telegraph, purchased in New York; the young stallion Gray Fox, by Ethan Allen, the finely bred brood mare, Priscilla; the stallion, Son of Ethan Allen, by old Ethan Allen; the old stallion Bucephalus, by old Black Hawk. Subsequently-but only a year or two after the purchase of Gen. Knox-Mr. Lang bought the stallion Sharon by old Witherell, by Winthrop Messenger; the stallion Ned Davis by old Drew, and the stallion Trenton, by George M. Patchen, a famous horse bred upon the Bonaparte estate in New Jersey. Closely following this purchase, Mr. Lang bought the stallion known as the Palmer Horse, by old Hiram Drew, the gelding Cloudman, by Hiram Drew, and the famous stallion Gideon, by Hambletonian, for which Mr. Lang paid \$2500 when four years old.

"This lot of twelve remarkable horses, all purchased by Mr. Lang within a few years and kept at his stables at North Vassalboro, formed one of the first studs of well bred horses-if indeed it was not the very first that had ever been owned by one person in Maine up to that time. It was at the golden dawn of the prosperous era of horse breeding in Maine. Mr. Lang was a genuine lover of horses. He had been very successful in business, and while purchasing these horses in part for his own pleasure, had also at heart the prosperity of the farmers and breeders of Maine-for he was generous and large hearted, he loved agriculture and he enjoyed doing what would benefit the State. North Vassalboro was the Mecca for all the horsemen of Maine, and 'Tom' Lang-as he was familiarly called by all-was the one great breeder of famous horse stock in the State. His trainer and driver at that time was Foster S. Palmer, who remained with Mr. Lang for many years, afterwards came to the city and subsequently went to Boston.

"Mr. Lang sold Gen. Knox in $187 \mathrm{I}$ to Henry N. Smith, of the Fashion Stud Farm, Trenton, N. J., for \$10,000. 
"Maine could never have attained the high place it has held as a horse breeding state for the past twenty-five years, had it not been for the far-seeing sagacity and liberal purchases of the best foundation animals by Thomas S. Lang.

"His expenditures have helped to make successful breeders of hundreds of Maine farmers, and the hundreds of thousands of dollars that have been left among our farmers for good colts, have been left here because Mr. Lang laid deep and wide the foundation of our horse breeding industry. His name should never be forgotten by our farmers or fail of an honored place in our breeding annals."-The Horse Reviez, July 29, 1895 .

Hon. Joseph Battell,

The Dalles, Oregon, Jan. I3, r89o.

Dear Sir:-Yours of Dec. 3 Ist, came to hand on Saturday. I am glad if I can in the least be of service to you, for I am inclined to believe that you have not a correspondent who would more sincerely desire to be of service to you in this important matter of registering properly.

Mocking Bessie, I took as a "make weight" in a trade with Abner Barrows, who at that time kept a stable on the corner of Mercer and Grand Street, N. Y. He was a gentleman of honor, and for many years a welcome guest at my house, but died I think years since. Jack Nodine or Robert Bonner I think would know, but after I came out here, I lost the association of horsemen.

I brought a few of. Knox stallions out here, but there were but few who cared for any special blood on such characteristics as you and I should prize, a I $61 / 2$ hands, ${ }_{5} 5$ to 1800 Clydesdale and Norman would suit here as well, with the strong line of German and French trotters.

I am glad to see that you are doing so much for the Morgan record. When I was a boy and lived at North Berwick, York County, Me., there was a man named Bellows, who used to come there and stand a Morgan horse. I believe he was named Flint Morgan, a chestnut colored stallion, I5 hands high, and weighed ro5o pounds.

Mocking Bird was stated by Mr. Barrows to me to be thoroughbred and he stated the name of the stallion which produced her, as a stallion that was kept for running purposes in New Jersey.

Mocking Bird was spavined on both hind legs, but would run a quarter very fast. She was brown, I5 hands, or nearly that, and weighed about 860 pounds.

She was stinted August 2, I 864 , July 5, I 865 , June 22, 1866, and June I $2, \mathrm{I}^{8} 67$,

The book which had her history in full was burned. I stili have a memorandum of her taken out of a pocket book and laid away, in which her sires name was mentioned.

I heard that Mr. Abner Barrows died, but do not know. Most of our mutual friends are dead. Col. Stanley, of Augusta, and Abraham Woodward, Bangor, were Barrow's friends, but they are dead. Hiram Woodruff would know if alive. Jack Nodine would know about Mocking Bird. I may find the name of the horse, etc., that sired Mocking Bird, if so, will send it to you. With sincere respect,

$$
\begin{aligned}
& \text { I am yours truly, T. S. Lang. } \\
& \text { N. Vassalboro, Me., Jan. I 5, I89o. }
\end{aligned}
$$

Joseph Battell,

Sir :-In reply to yours of the 3 Ist ult., would say that Thompson's Register has Lady Maud brought by Abner Barrows from New York. She was got by Sabeck by a running horse. For further information 
would refer you to Hon. T. S. I ang, The Dallas, Oregon, and also to John H. Wallace, publisher of Wallace's Monthly, New York.

Yours, Chas. E. Cromweil.

The breeding first given to Gen. Knox by Mr. Wallace and contemporaneous writers following Mr. Wallace, like the majority of the pedigrees of important horses bred differently from the lines which they preferred, was very inaccurate, favoring Messenger lines. Mr. Wallace's entry of Gen. Knox in Vol. I., of the American Trotting Register is :

"Gen. Knox, black; foaled I 855 ; got by Sherman Black Hawk (alias the North Horse) : dam by Hamiltonian, grandam by Hamiltonian. Bred by Denny \& Bush, Shoreham, Vt., owned by Col. T. S. Lang, North Vassalboro, Maine."

This book was copyrighted in $187 \mathrm{I}$.

In Vol. I., No. I., October I 875 of Wallace's Monthly there is an article on Fashion Stud Farm by Hark Comstock (Peter C. Kellogg), who describes and gives pedigree of Gen. Knox as follows:

“ Black, I $5^{1 / 2}$ hands; foaled I 855 ; bred by Daniel Heustis, Bridport, Vt., and passed through several hands to Col. T. S. Lang, of Vassalboro, Me., and was then called Slasher. It was in Col. Lang's hands that he became noted as a sire, and showed fine ability as a trotter. Gen. Knox was got by Vermont Hero, a son of Sherman Black Hawk, otherwise known as the North Horse. His dam was by Young Hamiltonian, a son of Harris' Hamiltonian, and his grandam was by Harris' Hamiltonian. The dam of Vermont Hero was by Young Hamiltonian; and the dam of Sherman Black Hawk was by Young Hamiltonian, his son.

"As Harris' Hamiltonian was by Bishop's Hamiltonian, one of the very best sons of Messenger, it will be seen that Gen. Knox is very strongly inbred of Messenger blood, and in that respect his pedigree very. much resembles that of Hambletonian, save that the latter derives a part of his Messenger composition through Mambrino as well as through Bishop's Hamiltonian. While I would give very little for a line of the blood of imported Messenger, simply because it was such, without evidence either by performance or production, that it possessed and transmitted the qualities for which Messenger's impress has been found usually so valuable; still, when we have that evidence along with the blood, the two facts furnish the perfection of a trotting pedigree.

"Gen. Knox is a natural trotter of high speed, and though never systematically trained, nor fitted for a race, he has been accustomed, after mare season was over, to show speed at the fairs in New England. October 22, 1863 , he beat Hiram Drew at Waterville, Me., in $2: 321 / 2$, $2: 32,2: 34$. In September, I 864, at Springfield, Mass., he beat Draco, Duke of Wellington and one other in straight heats. Time, $2: 311 / 2,2: 37$, $2: 34 \frac{1}{2}$. In the spring of $187 \mathrm{I}$, he was purchased and added to the Fashion string, for trotting purposes, at a cost of $\$ 10,000$, being at that time ${ }_{5}$ years old. He was entered at the Buffalo races, but fell lame on the eve of starting there, but had shown a trial in $2: 26$, and a repeat in $2: 24$, over Prospect Park track. He was never started thereafter.

"At the stud, Gen. Knox has proved remarkably successful, and it is difficult to find one of his get that cannot lay some pretentions to speed. $\mathrm{He}$ is the sire of Plato, Gilbreth Knox, Camors, Lady Maud and others, 
that have honorable records. In Camors and Lady Maud he has two that have beaten $2: 20$, and in the latter, one that has placed three heats in a single race below that figure. As much cannot be said of any sire in existence except Volunteer, by Hambletonian. He is extensively patronized and many mares come to him from remote points."

Mr. Helm, in the American Roadsters, a book perhaps that has more false pedigrees in it than any that was ever written of the same size, together with instruction of the most positive kind based upon these false pedigrees, has this about Gen. Knox :

"This distinguished son of Vermont Hero was foaled in 1855 ; is a black stallion, about fifteen hands high, but on his withers rises perhaps two inches higher; very compactly built; has a short thigh, only 20 inches in length, and trots very close and even behind; he also has a short forearm ; limbs heavy and strong. His dam was by Smith's Hamiltonian, son of Harris' Hamiltonian, his grandam by Harris' Hamiltonian. Thus it will appear that Gen. Knox runs to Harris' Hamiltonian four times, to Smith's Hamiltonian twice, and to imported Bellfounder twice, once to Black Hawk, once to Justin Morgan and Sherman. $\mathrm{He}$ is as strong in the blood of Messenger, all coming through Harris' Hamiltonian, as any horse in America.

"Gen. Knox is owned by H. N. Smith, Esq., at the Fashion Stud Farm, Trenton, N. J., and has spent nearly all of his days prior to ${ }_{1} 872$ in the State of Maine. A lucky State to have held one such sire, for he has been a most remarkable one. He should not be called a Morgan, and should stand today to the credit of the Green Mountain sire, Harris' Hamiltonian, for such in reality he is, and we have produced no stallion in our day which can surpass him."

In Vol. III., of the American Trotting Register, Mr. Wallace records Gen. Knox again thus :

"Gen. Knox, brown; foaled I 855 ; got by Vermont Hero, then known as the 'Rockwood Colt,' son of Sherman Black Hawk : dam by Searcher, son of Barney Henry ; grandam the Hunsden Mare, by Hill's Sir Charles, son of Duroc, and from a mare by Plato. Bred by Daniel Heustis, Bridport, Vt., sold with his dam, $\mathbf{1} 855$, to Oliver Eldridge, and by him the colt alone was sold to D. A. Bennett, all of the same place; at three years old Bennett sold him to Denny \& Bush, representing him to be by Sherman Black Hawk, and the same year he was purchased by Col. T. S. Lang, and taken to Maine, where he stood at the head of all New England stallions till I 872 , when he was purchased at $\$$ I0,00o by his present owner, Henry N. Smith, Fashion Stud Farm, Trenton, N. J. (Corrected from Vol. I.")

It will be seen that Harris' Hamiltonian has been entirely eliminated from this pedigree. The sire substituted for the first dam, Searcher or Morgan Searcher, as he was advertised, is correct. That substituted for the second dam, Sir Charles, is as completely erroneous as the previous one. Tracing this second dam from owner to owner, we learned from interview with Mr. Hunsdon, then living in Ticonderoga, that he got her from Samuel Tichenor, whose son, Rollin M., swapped a pair of oxen for her with Clinton Gage of Panton, Vt., who said that she was by a Morgan horse and from a Post Boy dam. 
We know of no reason to doubt the statement made by Clinton Gage to Samuel Tichenor, and repeated by Mr. Tichenor to Mr. Hunsdon when he purchased the mare:

Post Boy was a bay roan horse, about i 5 hands, Iooo pounds; foaled about I 8 I I ; bred by John Earle, Hardwick, Mass., got by IDinwiddie, son of imported Diomed: dam said to be by McKinney's Roan, son of Celar, by imported Janus. This is an extraordinarily good pedigree connecting Gen. Knox, and his great grandson Stranger with Janus, who with his get were considered the fastest quarter horses of their day, and had so great popularity throughout the Southern States in which they flourished, that Janus is said to have come nearer to founding a distinct family of American horses than any other horse of his day or previous to him.

Post Boy was sold in 1825 to Joel Doolittle of Shoreham, Vt. In I826, he was advertised to be kept at Bridport, Vt.

By correspondence we learned that Clinton Gage though receiving his mail at Panton, was a resident of Ferrisburgh, situated in Addison County and adjoining Charlotte in Chittenden County. As early as I 824 the Dubois Morgan, by Bulrush Morgan, son of Justin Morgan : dam by Quicksilver, son of imported Dey of Algiers Arabian was advertised in Shelburne, adjoining Charlotte in Chittenden County, Vt., he died about I834. We have the record of several sons and grandsons kept as stallions.

Young Brutus supposed to be a son of Brutus, by Justin Morgan, was advertised, I829, by Premier Stearns, Panton, Addison County, Vt.

The horse, Morgan Tiger, is advertised in the Northern Galaxy, Middlebury, Vt., May 28, I 845 , as follows :

Notice:-The subscriber would notify all persons who wish to improve their breed of horses that he offers them the service of the noted horse, Morgan Tiger, whose stock is so favorably known in this country. He will pass with the Morgan Tiger through, etc., Cornwall, Shoreham, Addison and Bridport each week.

WM. S. LANE.

Our correspondence in investigating the pedigree of Gen. Knox has been quite large, included in this are the following letters :

Solon LAPHAM, EsQ., Bread LoAf InN, June 29, I889.

Dear Sir:-Mr. Elmer Barnum writes me that your father bred the dam of Gen. Knox, that you got her dam of Wm. Hunsdon, now of Ticonderoga. Will you kindly answer the following questions.

1.-Please give a full description of this Hunsdon mare?

Ans.-Was a bay mare, $5_{5}^{1} / 2$ hands, white feet behind with star, light bay, showed running stock and was supposed to be thoroughbred.

2.-Did you get her direct from Hunsdon, and if not through what hands did she pass?

Ans.-Traded a three year old colt for her with Hunsdon. 
3.- Have you any information as to her breeder, if so what? Ans.- She was got by Hill's Sir Charles.

4.-What price did you pay for the mare, or did you trade or swap for her?

Ans.-Gave a three year old colt and $\$ 25.00$ for her.

5.- - How old was the mare when you got her, and what year was that?

Ans.-Five years old, cannot tell what year, but was about 50 years ago.

6.-Did the mare have any unsoundness, if so what?

Ans.-No.

7.-What became of her after you had her?

Ans.-Think we kept her till she died.

8.-Did the mare have speed and if so at what gait?

Ans.-She was a good roadster, but her gait was running and she was rapid.

S. LAPHAM.

Solon Lapham, EsQ.,

Middlebury, Vt., Dec. I I, I889.

Dear Sir :-Will you please inform me if you ever knew of whom Wm. W. Hunsdon got the mare that he traded to you, and that was the grandam of Gen. Knox, and much oblige,

Truly yours, JOSEPH BATTELl.

"I can tell nothing about it, it is so long ago it has passed entirely from my memory.

\section{Respectfully, SOlon LapHam."}

Mr. Lapham writes further that he thinks Mr. Hundson did not raise the mare.

Wm. W. Hunsdon writes dated :

Ticonderoga, June I, i889.

Dear Sir :-I received yours of 29 th and one previous, but I was absent from home and could not answer. This mare you wish a pedigree of $I$ bought her from a man by the name of Samuel Tichenor. Now know he is dead. The mare's dam was a Post Boy and sire a Morgan horse. This mare you speak of was a running mare when five years old. Could not be beat in this quarter.

WM. W. Hunsdon, EsQ.,

$$
\text { Yours, WM. W. Hunsdon. }
$$$$
\text { Middlebury, Vt., Dec. I I , I889. }
$$

I am exceedingly obliged to you for letter of June ist stating that you got the mare you traded to the Laphams of Samuel Tichenor, St. Lawrence County, N. Y.

Can you tell me more definitely who this Samuel Tichenor was and what town he lived in, what was his business, where did yo trade with him for the mare, in Vermont or St. Lawrence County, N. Y.?

Please answer these questions, and still further much oblige.

$$
\begin{gathered}
\text { Truly yours, J. Battell. } \\
\text { Ticonderoga, Jan. } 7 \text {, } 1890 .
\end{gathered}
$$

J. BATtell, EsQ.,

Dear Sir:-Samuel Tichenor lived at Bridport, Vt., at the time I traded with him. From there afterwards he moved to St. Lawrence County, N. Y. I don't know what town. I heard that he died there. As to the horse, Orphan Boy, which I sold to Harris Newton of Roches- 
ter, Mich., James F. Frost raised him, he was by old Black Hawk. His dam was the Doctor Neelham Mare by Post Boy.

The horse that Goodhue took West was a Black Hawk that, I think, the Goodhue's raised when they lived in Shoreham, Vt. Afterwards they moved to some part of Michigan. Cannot tell the breeding of Goodhue Horse.

Albert Smith, EsQ., Shoreham, Vt.

$$
\text { Yours respectfully, W. W. Hunsuon. }
$$$$
\text { Middlebury, Vt., May 8, I89o. }
$$

Will you please inform me whether the widow, or any children of your Uncle Samuel Tichenor are living, and if so what their names are and where I can address them.

I wish to learn the breeder and breeding of a light bay mare, I $51 / 2$ hands high, with star in forehead and white ankles behind, said to be a fast runner, which Mr. Samuel Tichenor traded when she was five years old, to the Lapham's of Shoreham sometime before i 850 . Do you know or can you find out about this mare, or can you refer me to any one who would know about her.

$$
\begin{gathered}
\text { Truly yours, Joseph Battell. } \\
\text { Shoreham, May I2, I } 890 .
\end{gathered}
$$

Mr. BATTELL :

I do not know about the mare, but I think that you can find out by writing to Parishville, N. Y. Samuel Tichenor and wife died in that town and I think some of the children are living there now, but cannot tell. One of the children married J. H. Canfield, and I think could tell you all about the matter, if he is living.

Write to the Postmaster and some of the Tichenors may know all about the matter. The Tichenors all lived in Parishville, St. Lawrence County, N. Y.

D. B. Tichenor, EsQ.,

$$
\begin{aligned}
& \text { Truly yours, A. M. Smith. } \\
& \text { Middlebury, Vt., Sept. I6, I89a. }
\end{aligned}
$$

Dear Sir:-Will you please inform me if you are a son of Samuel Tichenor that moved from Bridport, Vt., to Northern N. Y., about 1850 , and if so if you are old enough to remember a light bay mare with star and white hind ankles, $15 \frac{1}{2}$ hands, noted for her running qualities, that Samuel Tichenor sold about i 846 or 8 to Wm. W. Hunsdon of Shoreham, Vt. This mare became the grandam of the very noted stallion Gen. Knox and I am very anxious if possible to trace her breeding. If not able to give information yourself please refer me to any member of Samuel Tichenor's family or any one who can do so, and very much obligf

$$
\text { Truly yours, JosePH BATTELI. }
$$

"The mare in question was traded and got of a man by the name of Clint Gage of the town of Panton by R. M. Tichenor. He was son of S. S. Tichenor who owned the mare, and I remember Rollin telling his father the sire of the mare, and his father said, what in-do I care what the sire was. As mad a man as you would often see for the boy traded a yoke of oxen for her unknown to his father."

\section{Mr. BATtell,}

Sir :-The statement on the back of your letter is by G. H. Canfield. He was living neighbor to Samuel Tichenor at the time the mare was 
brought home, and he was there at the time, and the statement is undoubtedly correct.

Parishville, N. Y.

J. B. TICHENOR.

We will now examine the pedigree of Vermont Hero and Sherman Black Hawk. Mr. Wallace's entry of Vermont Hero in Vol. I., of the Trotting Register is : "black horse, foaled I 849 , got by Sherman Black Hawk (North Horse), dam by Harris' Hamiltonian, bred in Connecticut, stood several seasons in Michigan."

This is corrected in Vol. III., to read:

"Vermont Hero (known as the Rockwood Colt), black, foaled i 850 , got by Sherman Black Hawk, son of Vermont Black Hawk: dam by Young Hamiltonian; bred and raised by Mr. Rockwood of Bridport, owned $\mathbf{I} 854$ by Elias S. Myrick of the same place; sold in the spring of I 855 to A. C. Fish, Coldwater, Mich., owned I 872 , by George Stock Co., at Kalamazoo, Mich. He was the sire of Gen. Knox."

In Vol. IV., Vermont Hero is registered, "foaled I 850 ; got by Sherman Black Hawk : dam by Liberty, son of Bishop's Hamiltonian." And Sherman Black Hawk is registered, "foaled I845, got by Black Hawk, dam by Liberty, son of Bishop's Hamiltonian, grandam by Matchem."

That the dams of these horses, Sherman Black Hawk and Vermont Hero, were by Liberty is almost certainly correct, for it was so stated by the breeders of the mares when they owned them.

Liberty was not by Bishop's Hamiltonian. His pedigree was not certainly known, but it is highly probable that he was got by imported King William or a son. See Liberty.

Liberty was what is called in Vermont a large horse and got what is called good sized stock. At the time when Mr. Smith owned Liberty he owned a smaller stallion which he called Pone and which got small stock. Pone was foaled I 820 , bred by John S. Larrabee, Shoreham, Vt.; and got by Bishop's Hamiltonian.

Sire of I5 trotters $(2: 18 \% / 4) ; 32$ sires of 83 trotters, I5 pacers; 30 dams of $3^{8}$ trotters, II pacers.

GEN. KNOX (3-I28), bay, I 5 hands, 950 pounds; foaled 1872 ; bred by J. H. Clancy, Newburg, N. Y.; got by Billy Denton, son of Hambletonian : dam said to be by Black Harry Clay, son of Harry Clay, and $2 \mathrm{~d}$ dam Jane, by American Star. Died 1902. Pedigree from breeder.

Sire of 2 trotters $\left(2: 21 \frac{1}{2}\right)$.

GEN. KNOX JR. (LARKIN'S KNOX) (5-64), bay, I5 1/4 hands, Iooo pounds; foaled I 864 ; bred by K. Larkin, Farmington, Me.; got by Gen. Knox : dam bay, bred by Mr. Brown, Farmington, Me., got by Beal's Horse, son of the Eaton Horse. Died r872.

Sire of Wallace, $2: 291 / 4$; I sire of 2 trotters, I pacer.

GEN. LEE (I-I6), black; foaled I867; bred by N. M. Prescott, Clinton, 
Me.; got by Black Sultan, son of Gen. Knox : dam said to be by Hiram Drew, son of Drew Horse. Sold to Brown, Seavey \& Co., Boston, Mass.; to J. S. Roberts, Oregon, Ill. ; to Willis Baker, Lake City, Minn. See The Morgan Horse and Register, Vol. I., p. 374.

Sire of Black Diamond, $2: 29 \% 3 ; 2$ pacers $(2: 23): 3$ dams of 3 pacers.

GEN. Lee ( $1-128)$, said to be a son of George M. Patchen Jr.

Sire of Lee, $2: 17^{1 / 4}$,

GEN. LEE ( $1-32), 2: 261 / 2$; foaled 1875 ; bred by Henry D. Bleugh, Fairfield, Ia., foaled the property of William Russell, Spencer, Ia.; got by Bashaw (probably Green's) : dam Belle Wilson, chestnut, (dam of Gen. Grant, $2: 2 \mathrm{I}$ ), said to be by Hiatoga.

Sire of Fay Lee, $2: 25$.

GEN. LEE JR. (JOHNSTON'S). Untraced.

Sire of Joker, $2: 20$,

GEN. LIGHTFOOT (I-I6), dark bay, I43/4 hands, 900 pounds: foaled, July, r 865 ; bred by Watson Blaisdell, Burnham, Me. ; got by Gen. Knox, son of Vermont Hero: dam said to be thoroughbred. Sold to W. D. Atkinson, Pittsfield, Me., half interest, 1873 ; to V. C. Hall, Windham, Me.; to E. N. Perry, Cape Elizabeth; to J. Dyer of same place, whose property he died, July 27, I 884. See The Morgan Horse and Register, Vol. II., p. I37.

Sire of 2 trotters $(2: 28) ; 3$ dams of 3 pacers.

GEN. LOGAN. Second premium on roadsters was awarded to a horse of this name at the Illinois State Fair, I 865.

GEN. LOGAN $\left(3-3^{2}\right)$, chestnut with star and one white hind foot, $151 / 2$ hands, rooo pounds; foaled 1884 ; bred by Charles Crampton, St. Albans, Vt. ; got by Crampton's Lambert, son of Daniel Lambert: dam Annie E. said to be by Snip, son of Cassius M. Clay; and $2 \mathrm{~d}$ dam by Young Engineer, son of Engineer 2d. Sold to Jean Robinson, South Hero, Vt., who sends pedigree.

Sire of William L., $2: 221 / 4$.

GEN. LOGAN (I-I6), bay, I5 I/2 hands, I I50 pounds; foaled I 886 ; bred by John Hoppin, Yolo, Cal.; got by Alexander Button, son of Alexander : dam Minnie, bay, bred by John Hoppin, got by St. Clair (Deitz's), son of St. Clair ; 2d dam Fanny Lewis, gray, bred by John Hoppin, got by St. Charles, son of St. Louis. Sold to A. W. Boucher, Pleasanton, Cal., who sends pedigree. Died 1898 .

Sire of Miss Logan, 2:061/4: I dam of I pacer.

GEN. LOVE, 2 :30, and winner of 14 recorded races; chestnut ; foaled 1867 ; 
bred by John Horter, Buffalo, N. Y.; got by Field's Royal George, son of Royal George. Sold by breeder to George W. Fitzwater, Sr., who took him to Philadelphia, and sold him to Wm. Armour, Sr., of that city. See The Morgan Horse and Register, Vol. I., p. 876 .

GEN. LYON, (7-32), $2: 36 \frac{1}{4}$, black with hind feet and heel of near fore foot white, I 5 hands, I050 pounds; foaled 1859 ; bred by George W. Dean, Danbury, N. H. ; got by Morrill, son of the Jennison Colt: dam gray, bred by Mr. Williams, West Derby, Vt., got by Royal Morgan, son of Sherman Morgan ; 2 d dam Aldrich mare, said to be by Sherman Morgan. Kept mostly at Danbury; one season at Fisherville, N. H. A very good and popular stock horse. Died, property of breeder, I882. See The Morgan Horse and Register, Vol. I., p. 652.

Sire of 3 trotters $(2: 26) ; 5$ dams of 5 trotters, I pacer; three ro race winners and one 50 race trotter.

GEN. MAGEE ( $\mathrm{I}-32)$, bay; foaled I 876 ; bred by Clark Bell, Dundee, N. Y.; got by Andy Johnson, son of Henry Clay : dam Hoopskirt, bred by Chas. H. Caswell, got by Hambletonian; $2 \mathrm{~d}$ dam Topsey. Sold to Elbert Kipp, Peekskill, N. Y., I88o.

Sire of Harry Magee, $2: 27^{1 / 1}$.

GEN. MARION, dark bay, I53/4 hands; foaled I 820 ; said to be by Sir Archie : dam by Citizen. Advertised, I 827 , by Lem'1 Long near Halifax.

GEN. MARION (3-256), $2: 27 \frac{1}{2}$, white hind feet, $153 / 4$ hands, 106o pounds ; foaled 1883 ; bred by R. M. Crouch, Thorntown, Ind., foaled the property of T. J. Terhune, Lebanon, Ind. : got by New Jersey Volunteer, son of Standard Bearer, by Volunteer: dam Fleety, said to be by Baywood (Banner's), son of Blackwood Jr. ; 2 d dam Fleety Long, by Heady's Red Buck, son of Red Buck, by Copperbottom. Sold to Moses King, Galesville, Wis. ; to Thos. W. King, Galesville, Wis. ; to W. P. Veitch, Galesville, Wis., who sends pedigree.

Sire of Marion, $2: 15 \frac{1}{2}$.

GEN. MCCLELLAN (PEASE COLT), bay, black points, 15 T/4 hands, 900 pounds; foaled May I6th, 1854 ; bred by N. B. Pease, Exeter, Me.; got by Drew Horse, which see : dam said to be by Shark, son of Quicksilver. Sold I86 I to George N. Robinson, Augusta, Me., who sold to Span and Stoddard, Bangor. Afterwards taken to San Mateo, Cal., by M. J. Lewis, where he died Feb. I8, I880. Trotted I862-70, winning I3 recorded races.

GEN. MCCLELLAN (RED IRON) ( $\mathrm{I}-8)$, chestnut with small star, $\mathbf{1} 5 \frac{1}{4}$ hands, rooo pounds; bred by L. B. James, Pike Station, Wayne County, O.; foaled at La Prairie, Wis., I 855 ; got by North Star, son of Bulrush Morgan : dam said to be by Brown's Bellfounder; and $2 \mathrm{~d}$ dam by Sher- 

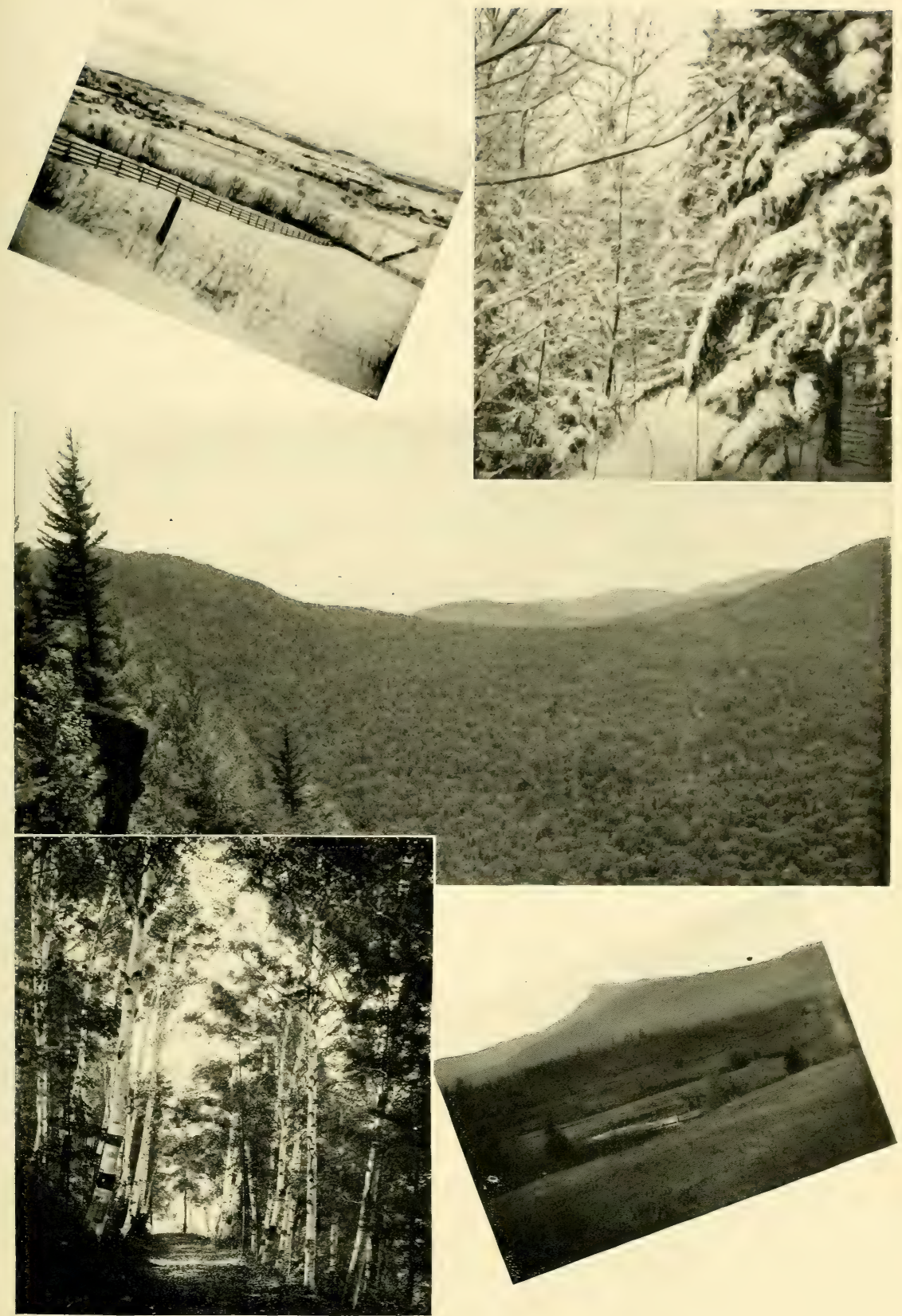


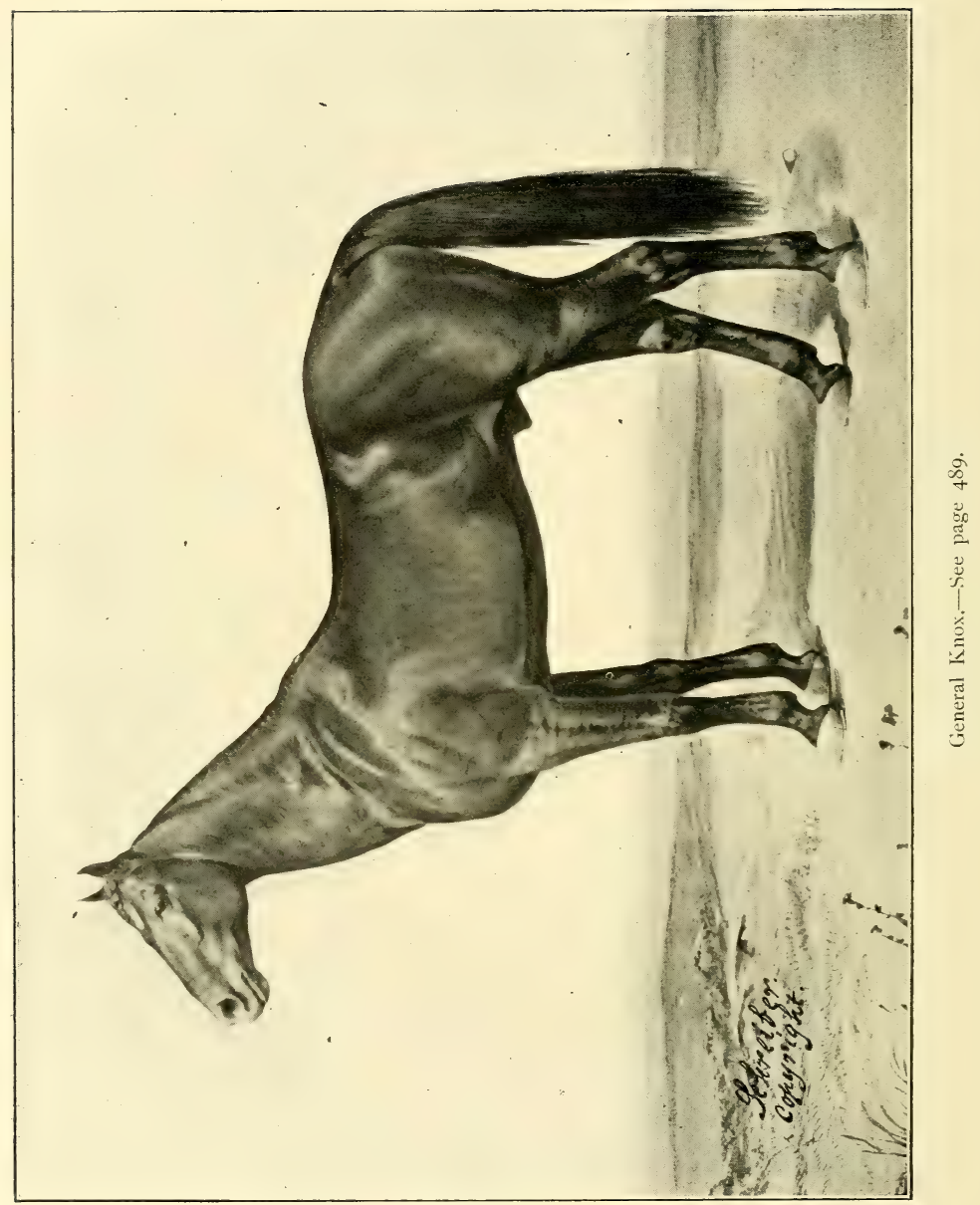


man Morgan. Taken in $\mathbf{1} 86 \mathrm{r}$, by James M. Learned, and Seneca Daniels to California, where he became the property of Mr. Daniels of Sonoma County. This pedigree is from the Breeder's Trotting Stud Book, l'ublished i 88 r, by J. H. Sanders.

We have received the following letter from Mr. Sanders:

Mr. Joseph Battell, Middlebury, Vt.,

$$
\text { Chicago, Ill., Feb. I7, I } 88_{5} \text {. }
$$

Dear Sir :-Replying to yours of the I 3 th, permit me to say that my information in regard to the breeding of Gen. McClellan was derived by direct correspondence in the neighborhood where he was owned and raised, Mr. L. B. James of Pike's Station, Wayne County, O., being among the number. The letters and papers used in compiling the pedigrees for this book have been packed up and stored away, so that it might be the work of several days to find just the ones connected with this horse, but at the time of the compilation I was as clearly and thoroughly satisfied of the correctness of this pedigree as I was of any other pedigree in the book. My own opinion is that it is correct beyond a question.

$$
\text { Yours very truly; } \quad \text { J. H. SANDERS. }
$$

A letter to us from James M. Learned dated Stockton, June I 8 , I $8 \delta$, says that Mr. James told him that North Star was but four years old when he got General McClellan. Mr. H. P. Fales, Madison, Wis., writes :

"Mr. James said that a man was driving a four horse team through his town, all black, well matched and all stallions; that he bred his mare to one of them called North Star."

We have record of Bulrush Morgan (Kimball's), dark bay, or brown, said to be by Morrill, taken to Ravena, O., from Vermont, I $\delta_{54}$, with two other stallions (and perhaps more), one a Black Hawk, another called Sherman Morgan. This Bulrush is called a fine horse, was sold in Ohio at sheriff's sale for $\$ 700$, and it is quite probable was the sire of Gen. McClellan. It would be quite possible that Mr. Kimball exhibited his stallions driven four in hand as they were brought from Vermont to sell.

There was also in Ohio at that time, Austin's Bulrush Morgan (Morgan Bulrush), a small bay horse by Bulrush Morgan, son of Justin Morgan, a half interest of which was sold to Norman E. Austin of Orangeville, O., October, 1848 , where the horse was taken that winter and is said to have been the first Morgan horse taken to Ohio for stock purposes. He is said to have covered 80 mares the ist season he was kept in Ohio, where he was very popular. It would be quite possible that a colt of this horse got Gen. McClellan. For Morgan Bulrush, see The Morgan Horse and Register, Vol. I., p. 6I S.

Sire of 3 trotters $\left(2: 23^{1 / 4}\right) ; 4$ sires of 6 trotters, I pacer; 8 dams of 9 trotters, 2 pacers.

GEN. MCCLELLAN JR. (I-I6), chestnut; foaled I872; bred by J. R. Rose, Lakeville, Cal. ; got by Gen. McClellan, son of North Star : dam 
Eliza, said to be by George M. Patchen Jr., son of Geo. M. Patchen; 2d dam Eliza, brought from Kentucky by H. L. Lovel, Sonoma County, Cal. See The Morgan Horse and Register, Vol. II., p. I38.

Sire of 2 trotters $\left(2: 17 \frac{1}{2}\right) ;$ Lucy L., $2: 22 \frac{1}{2}$; I dam of I trotter.

GEN. MEADE (FLYAWAY) (I-8), $2: 36$, and winner of ro recorded races, black, I6 hands, I050 pounds; foaled 1852 ; bred by J. and R. C. Johnson, Bradford, Vt. ; got by Morgan Eclipse, son of Morgan Cæsar : dam black, bred by J. and R. C. Johnson, got by Black Hawk, son of Sherman Morgan. Sold to N. M. Tribon, Middleborough, Mass.; to William S. Briggs, Taunton, Mass. ; when about four, to James Cole ; to Mr. Thornton, Taunton, Mass. ; to D. T. Harvey, Lanville, Va., and was kept several years in Person and Caswell County, N. C., when it is thought he went to Illinois. Kept for some years near Taunton, Mass., by Dan Mace. He was at one time called the fastest trotter in the Eastern States, and was the first horse to trot in $2: 27$ with running mate. A powerful and very handsome horse. See The Morgan Horse and Register, Vol. I., p. 667.

From The Spirit of the Times, April 27, 1861 :

"There is going to be a good deal of sport this year upon the trotting courses of the New England States. New Hampshire has thrown down the glove to Massachusetts, and it has been taken up, so these States are to contest in the arena. The stallion, Young Morrill of Manchester, N. H., is to trot three races with Flyaway of Taunton, Mass., for $\$ 500$ a side each race. The first is to be at Saugus, Mass., on the 2 Ist of May, mile heats, best three in five to harness. The other events will come off on the $25^{\text {th }}$ and 3 Ist of the same month. Or the $25^{\text {th }}$ they are to go to wagon, and in the third contest to go as they please. Mcrrill is in charge of $\mathrm{Wm}$. Woodruff, and we learn that his chance is considered good. Flyaway will be driven by Dan Mace, and according to all accounts he can go in the thirties.

A correspondent of The Spirit of the Times, I86r, reports as follows :

"Oct. x 8. Proprietor's Purse of $\$ 200, \$ 50$ to the second best for stallions that never trotted better than $2: 38$; mile heats, best 3 in 5 , in harness.

Dan Mace's blk. s. Flyaway . . . . $32{ }^{2}$ I I I

A. Carpenter's gr. s. Tom Carpenter . . . $\begin{array}{llllll}\text { I } & \text { I } & 2 & 2 & 3\end{array}$

W. Woodruff's ch. s. Plowboy . . . . $\begin{array}{llllll} & 2 & 3 & 3 & 2\end{array}$

Henry Smith's gr. s. Ajax . . . . dist.

Time $2: 39,2: 38,2: 40 \mathrm{~T} / 2,2: 433 / 4,2: 46$.

Yours truly, C. T."

GEN. MONTGOMERY (3-64), bay, I6 hands, I 200 pounds; foaled I 897 ; bred by Thos. J. Weeks, Santa Cruz, Cal.; got by Ben Nevis (Boodle), 2 : $12 \frac{1}{2}$, son of Stranger, by Gen. Washington, son of Gen. Knox : dam Nutwood Weeks, bay, I 200 pounds, foaled I 882 , bred by Thos. J. Weeks, got by Nutwood, $2: 183 / 4$ (world's stallion trotting record when made) son of Belmont, by Alexander's Abdallah; $2 \mathrm{~d}$ dam said to be by 
Williamson's Belmont, thoroughbred. Gen. Montgomery is full brother to Ethel Downs, trotting race record, 2 ro. The first dam of Ben Nevis was by Jay Gould, $2: 211 / 2$ (stallion trotting race record when made), son of Hambletonian; $2 \mathrm{~d}$ dam by Ethan Allen, who held the stallion trotting race record for a number of years and was the first stallion to trot under $2: 30$. The dam of Jay Gould was by the great brood mare sire, American Star, son of Coburn's American Star, by Cock of the Rock, son of Sherman Morgan. The dam of Stranger was the celebrated trotting mare Goldsmith Maid, which held several world's trotting records and was perhaps the most distinguished of all trotters, speed and endurance both considered; her pedigree entirely unknown. The dam of Gen. Washington was Lady Thorne, $2: 18 \frac{1}{4}$, also one of the most renowned of trotters. Sold winter of 1905-6, to Joseph Battell, Middlebury, Vt. Died rgo8.

GEN. MORGAN (KURTZ HORSE) (5-64), chestnut sorrel, I5 1/2 hands, I I 50 pounds; foaled May, I858; bred by Jacob H. Pickering, Pickerington, Fairfield County, O. ; got by Paul Jones, son of Hammett Horse, by Black Hawk: dam sorrel, bred by Mr. Bish, Pickerington, O., and sold by him to Jacob H. Pickering, got by Rickett's Printer, son of Snip Printer, by Printer, thoroughbred; 2 d dam chestnut, bred by Mr. Bish, got by Fiery Dragon. Sold to Bowers Bros., Pickerington, O.; to W. H. Kurtz, then of Wagram, O. Died I 867 . See The Morgan Horse and Register, Vol. I., p. 502.

Sire of 3 trotters $\left(2: 20 \frac{1}{4}\right)$.

GEN. MOTT. See Edward Everett (Mott Colt, Grand Isle Chief).

GEN. OATS (3-128), bay; foaled r882; bred by Daniel Hayes, Muscatine, Ia.; got by Tramp, son of Logan : dam Lady Oats, bred by Dr. P. A. Austin, Muscatine, Ia., got by Bashaw (Green's), son of Vernol's Black Hawk; 2d dam Lady Wood, said to be by Young Columbus, son of Columbus. Sold to J. S. Goodwin, Beloit, Kan. I 884 ; to Isaac Shoemaker, Osburn, Mo.

Sire of Blanche B., $2: 20$

GEN. OTIS, $2: 17$ I $/ 4$, gray, 15 hands, 950 pounds; foaled I 893 ; bred by J. W. Laughlin, Pierre, Hughes County, S. D.; got by Turney, son of Attorney: dam Range mare, Gray Eagle Stock, white brand circle (2), left shoulder, bred by Mike Brooks, White Sulphur Springs, Mon. Sold to Sam Strayer, Pierre, S. D. ; to R. B. Mathieson, Pierre, S. D.; to Chas. Johnson, owner of Alex Mitchell Hotel, Mitchell, S. D. Pedigree from breeder.

GEN. PICTON (3-64), 2 :30, gray, bred by Judge Geo. B. Kinkead, Lexington; got by Rattler, son of Stockbridge Chief: dam said to be by Sumner Morgan. Pedigree from breeder. 
GEN. PLEASANTON (I-I28), bay; foaled I889; bred by W. T. Robinson, Faulconer, Ky., got by C. F. Clay, son of Caliban: dam Stradella, chestnut, bred at Kalamazoo Stock Farm, Kalamazoo, Mich., got by Grand Sentinel, son of Sentinel; 2 d dam Governess, bay, bred by Charles S. Dole, Crystal Lake, Ill., got by Governor Sprague, son of Rhode Island; 3d dam black Maria, black, bred by Chas. S. Dole, got by Alhambra, son of Mambrino Chief; 4th dam Enchantress, dam of Harold, which see. Sold to R. E. Jones, Britton, S. Dak.; to Charles A. Alstrom; to Geo. G. Sexton, Langford, S. Dak.

Sire of 2 pacers $(2: 21)$.

GEN. PUTNAM (I-8), mahogany bay, with a gray spot shape of anchor, on left side and black spot on left shoulder, I5 hands, Iooo pounds; foaled I 860 ; bred by Fred Leland, Middlebury, Vt.; got by Rollo, son of Black Hawk: dam bay, bred by Hiram C. Sessions, Middlebury, Vt., foaled (1854), the property of Fred Leland, got by Morgan Eagle, said to be a son of Green Mountain Morgan; 2d dam chestnut, bred by John J. Kelsey, Salisbury, Vt., got by the Jerry Moody Horse of Cornwall, Vt., thought to be Canadian; 3 d dam black, brought to Salisbury, Vt., by John J. Smith. Sold to Geo. Denison, Colerain, Mass.; to I. A. Seward, Greenfield, Mass. Pedigree from breeder. Sire of 1 sire of 3 trotters; 3 dams of 3 pacers.

GEN. RENO ( I-I 6), $2: 303 / 4$, black; bred by W. W. Worthing, Honey Lake Valley, Cal.; got by Tyler's Black Hawk, son of Gen. Stark: dam said to be by Kentucky Boy. Wilbur F. Smith, Sacramento, Cal., writes :

"I knew Gen. Reno, and his history very well. He was a good, almost a great horse, deserving of greater patronage and of being better known."

See The Morgan Horse and Register, Vol. I., p. 489 .

Sire of 2 trotters $\left(2: 19 \frac{1}{4}\right) ;$ Nevada, $2: 24 \frac{1}{2} ; 2$ dams of 2 trotters,

GEN. RUSS ( $1-3^{2}$ ), gray, no marks, $161 / 4$ hands, I 160 pounds ; foaled 1876 ; bred by W. L. Patten, Morristown, Shelby County, Ind.; got by Blue Bull : dam gray, bred by W. L. Patten, got by Tom Crowder, son of old Tom Crowder.

GEN. SCOTT (I-8), black, I 6 hands, foaled I 853 ; said to be by Black Hawk : dam Lady Messenger. Advertised as Black Hawk Gen. Scott, I858-9, at Oakland, Cal., bý F. K. Shattuck, who it is stated imported him in $\mathrm{I}_{5} 6$. Terms $\$ 50$. See The Morgan Horse and Register, Vol. II., p. I 39 .

GEN. SCOTT (I-32), bay, black points, I6 hands; foaled May 9, I856 ; said to be by Tom Brown the 3 d, son of Tom Brown Jr, by Tom Brown, son of Murat, by American Eclipse : and dam by Ticonderoga, son of Black Hawk. Sold to John Davidson, Summit Bridge, Del. In. formation from American Stock Journal, Vol. II. (I860). 
Awarded first premium at several Fairs in I'ennsylvania, and Delaware.

GEN. SCOTT, bay with star, 15 hands, II 50 pounds; foaled r 860 ; bred by Benjamin E. Deyo, Dixon, Lee County, Ill.; got by Brown I)jck, a horse brought from Vermont about 1857 or 8 , with two others, by Harvey Yale, of Middlebury, Vt., said to be Canadian, and sold to S. and B. E. I)eyo, for \$rooo. Sold I 864 , to O. L. R. White, Lanark, Ill., who sold to N. R. Rose. Received ist premium at Illinois State Fair, I 863 .

Sire of 2 trotters $(2: 27)$.

GEN. SCOTT (GREEN MOUNTAIN BOY). Name changed.

EDITOR OF ThE SPIRIT,

Milwalkee, Wis., June i 2.

Dear sir:-If I mistake not, there is no horse named Gen. Scott. That being the case, I wish to change the name of my stallion (formerly called Green Mountain Boy, there being another of that name at Racine), to Gen. Scott. He is a bay, 16 hands.

- IVilkes Spirit of the Times, June 29, 1861.

$$
\text { Respectfully, H. Bensox. }
$$

GEN. SHERIDAN, $2: 35$, bay, $153 / 4$ hands, ro5o pounds; foaled I $\$ 63$; bred by Peter Davis, Canton, N. Y. ; got by Hambletonian Tippoo, son of Ive's Black Messenger : dam bay, bred by Peter Davis, got by Buck Messenger, son of Bush Messenger, by imported Messenger; $2 \mathrm{~d}$ dam said to be by Ogden Messenger, son of imported Messenger. Pedigree from T. G. Thompson, Oswego, N. Y., who writes that he received pedigree from breeder. Died 1887 .

Sire of Fanny, dam of Winona, $2: 2 I^{3} / 4$.

GEN. SHERMAN (3-32), $2: 58$, bay with star, I6 hands; I 200 pounds; foaled I 860 ; bred by Lewis Rogers, Whitehall, N. Y.; got by Smith's Young Columbus, son of Columbus: dam chestnut, I5 hands, rooo pounds, strong with plenty of life, bred by an Uncle of Richard Rogers, Middle Granville, N.Y., and passed in succession to Richard Rogers; Messrs. Hill and Baker; a Mr. Roe; Warren Hopson; J. D. Smead; J. C. Griswold and Rogers, got by a Morgan Horse owned by Dr. Gilman, Salem, N. Y. Information of the dam is from J. D. Smead, Comstocks, N. Y., in letter, dated Aug. 6, I892. Sold to Ed. Sherman, Danby, Vt. ; to George H. Buel, Whitehall, N. Y.; to G. and C. Wicker, Ticonderoga, N. Y.

We have learned, since above was written, that the Dr. Gilman horse was got by Gifford Morgan, son of Woodbury Morgan, the season that Gifford Morgan was owned and kept near Fort Ann, N. Y.

Sire of 3 trotters $\left(2: 25 \frac{1}{2}\right)$; I sire of I trotter; 4 dams of 3 trotters, I pacer.

GEN. SHERMAN JR. See Freeman Horse. 
GEN. SIGEL, bay; foaled I 875 ; bred by Cephas Holloway, Union Village, O.; got by Abdallah (Goldsmith's), son of Volunteer: dam Maggie Rolfe, bred by William Ball, got by Tom Rolfe, son of Pugh's Aratus; $2 \mathrm{~d}$ dam said to be by Brown's Bellfounder; and $3 \mathrm{~d}$ dam by a son of Shakespeare, by Valerious. Sold to Philip Nickel, Monroe, O., who sends pedigree. Died I9or.

Sire of Charlie B., $2: 201 / 4$.

GEN. SLACK; said to be by Sentinel, son of Volunteer.

Sire of Decoration, $2: 30$.

GEN. SMITH, 2 :20, sorrel, I 6 hands, I 350 pounds; foaled I 886 ; bred by Pike Dewar, London, Ontario, Can.; got by Albion, son of Highland Boy: dam Nelly Dewar, chestnut, bred by Jas. Burgess, London, Ont., Can., got by Royal Revenge, son of Toronto Chief. Sold to Robert Smith, London, Ont., Can.; to J. Crouch, Lafayette, Ind., who sends pedigree.

Sire of 3 trotters $\left(2: 12 \frac{1}{4}\right) ; 3$ pacers $\left(2: 11 \frac{1}{2}\right)$.

GEN. SPHINX (3-64), $2: 28 \frac{1}{4}$, bay, I53/4 hands, I050 pounds; foaled I 890 ; bred by George Rowan, Jackson, Mich.; got by Sphinx, son of Electioneer: dam Ada, $2: 29 \frac{1}{4}$, bay, bred by A. R. Eastman, Mt. Clemens, Mich., got by Sir Denton, son of Satellite, by Robert Bonner, son of Hambletonian; $2 \mathrm{~d}$ dam Sweetheart, bred by George Parrott, Mt. Clemens, Mich., got by Magna Charta, son of Morgan Eagle, by Morgan Eagle of Tunbridge, Vt. ; $3 \mathrm{~d}$ dam Polly Parrott, bred by George Parrott, got by Roebuck Abdallah, son of Roe's Abdallah Chief; $4^{\text {th }}$ dam said to be by New York Black Hawk, son of Black Hawk, by Andrew Jackson. Sold to Cowham \& Rowan, Greenwood Stock Farm, Jackson, Mich. Pedigree from breeder.

Sire of Northland, $2: 29 \frac{1}{4}$.

GEN. STANTON ( $\left.\mathrm{I}-3^{2}\right)$, bay; foaled I866; bred by Oliver Crooks, Newtown, N. Y.; got by Hambletonian, son of Abdallah: dam Kate O. Keefe, said to be by One-Eyed Kentucky Hunter, son of Watkins' Highlander, by imported Brown Highlander; and $2 \mathrm{~d}$ dam by Long Island Black Hawk, son of Andrew Jackson. Went to Ontario about I874. Owned by John Batten, Thorold, Ont.

Sire of 26 trotters $\left(2: I_{5}\right), 4$ pacers $\left(2: 1_{4} \frac{1}{4}\right) ; 6$ sires of 7 trotters, 3 pacers; 7 dams of 7 trotters, 2 pacers.

GEN. STARK, said to be by Vermont Hamiltonian. Information from C.

A. Pratt, Verona, Oneida county, N. Y., breeder of Charley Green.

Sire of the dam of Charley Green, $2: 19 \frac{1}{4}$, and Ada Look, $2: 201 / 4$.

GEN. STARK (I-8), black, I 5 hands, 950 pounds; foaled I 854 ; bred by 
Bela Howe, Shoreham, Vt.; got by Black Hawk Chief, son of Black Hawk: dam bred by Bela Howe, got by Black Hawk; 2d dam the dam of Hard Road, which see. The $4^{\text {th }}$ report of the Iowa State Agricultural Society, $\mathbf{I} 857$, states that the first premium on three-year-old stallions was awarded to General Stark, owned by W. E. Small of Johnson County. Owned by George H. French, Boston, Mass., and I 857-58, IV. E. Small, Iowa City, Ia. In State Fair at Muscatine, Ia., I857, he distanced all competitors - no time - and received the first premium. Died 1858 .

IV. E. Small writes :

"Gen. Stark was the handsomest horse I ever saw; have heard dozens of men say they had seen pictures of horses over drawn till they saw Stark. He was very intelligent and speedy, and had he lived would have made a low record."

See The Morgan Horse and Register, Vol. I., p. 488.

Sire of Tyler's Black Hawk, sire of 2 trotters.

GEN. TAYLOR ; bred by Labon Litton, Bourbon County, Ky. ; got by old Pup, said to be a good race horse, owned by Thomas Kanasby, Bourbon County, Ky.

GEN. TAYLOR, foaled probably about I850, gray, over I 6 hands; said to be by imported Hooton (thoroughbred): and dam a well-bred saddle mare. Pedigree from W. E. Stillwell, Winchester, Ky., who writes :

"Gen. Taylor was owned in Mason County some thirty-five years ago and was a famous sire of saddle horses. His son, Phillips' Black Horse, got the celebrated sire and show horse Blue Jeans."

GEN. TAYLOR (I-8), gray, I5 hands; foaled 1847 ; bred by Chauncey Eyclesheimer, Pittstown, N. Y.; got by the Morse Horse, son of European : dam Flora, brought from New York city and owned at one time by Morris Van Buskirk, Lansingburgh, N. Y., breeding unknown. Purchased by Stephen and J. L. D. Eyclesheimer, who in the fall of I 850 took him to Janesville, Wis. In the spring of 1854 Stephen took him overland to California. He was soon after sold to George Bement, near the Mission at the San Bruno Hills. Mr. Bement sold him to E. W. Teacle. Died at Napa, Cal., I 877 . He trotted 30 miles to wagon with Rattler, winning by a scant 3 lengths, in I hour 47 minutes and 59 seconds, which is still the record at that distance. He also beat New York to wagon in 29 minutes $4 \mathrm{I} / 2$ seconds. He got but few colts in Wisconsin. Oct. 25, I860, at San Jose, Cal., John Kelley's gray horse, Gen. Taylor, gained first premium in a race beating Comet. Winner of Io recorded races. 


\section{GEN. TAYLOR.}

\section{WHAT THE LITTLE GRAY MONARCH HAS DONE FOR CALIFORNIA-}

CLASSED AS A NON-STANDARD SIRE WITH

WILLIAMSON'S BELMIONT.

(From The Breeder and Sportsman, San Francisco).

Perhaps it would be interesting at this time to call the attention of the readers of the Breeder and Sportsman to the prepotency of this horse. In the article on Bloomfield Maid, the grand looking gray that nineteen summers have not left their marks upon, reference is made to him. To advance the subject which was so lightly touched upon, it is a well-known fact that Gen. Taylor's blood seemed to " nick" well with any and all families. For stamina, endurance, gentle disposition and iron constitutions they are unequaled. It is hard to find a horse of any age, carrying a reasonable percentage of Taylor blood, that is not free from puffs, galls, spavins or blemishes of any kind, yet, with all the achievements of the descendants of Gen. Taylor, this great little monarch remains non-standard under the present defective rules upon which this standard is based.

Had Gen. Taylor got but a single 2:30 performer and done nothing more he would have been made standard.

There are twenty-three performers in the $2: 30$ list; seven of them in $2: 20$ or better descended on sire or dam's side from Gen. Taylor, every one of them game race horses who have earned their records in races, not a single record of the twenty-three having been made against the watch, yet he is not standard; the same may be said of Williamson's Belmont, who got Venture, $2: 27 \frac{1}{2}$, Captain Webster, $2: 301 / 2$, and the dams of five $2: 30$ performers. The descendants of his sons and daughters are breeding on, notably Captain Webster, sire of Freestone, $2: 29$, and the dam of Adonis, $2: 11 \mathrm{I} / 2$; Cupid, $2: 2 \mathrm{I}$, and others.

Had the manipulators of the watch dropped the half second from Captain Webster's record, Belmont would have been standard, had his descendants never done anything more.

Gen. Taylor lived in a time when records were avoided rather than sought after, and the class of mares he was bred to were anything but first class, but whenever bred to a good mare the result led to greatness, notably in the case of the Lew Mills mare, without a known pedigree.

She was bred to Gen. Taylor and produced Lady Livingston, the dam of Lady Blanchard, $2: 26 \mathrm{I} / 4$. Bloomfield Maid, trial $2: 22$, is the dam of Charley C., $2: 18 \mathrm{I} / 2$; Lilly S., $2: 20 \mathrm{~T} / 2$; Baden, $2: 243 / 4$, all put in the list within thirty days.

Whippleton (sire of Lily Stanley, $2: 17 \mathrm{~T} / 2$; Homestake, $2: 16 \mathrm{~T} / 2$; Flora B., $2: 27$; Coral, $2: 281 / 2$, etc.)

Western, sire of Chapman, $2: 22 \mathrm{~T} / 2$. 
This places Lady Livingston among the greatest of California's broodmares.

Another noted daughter of Gen. Taylor is the mare Nancy, grandam of Una Wilkes, $2: 19 \frac{1}{4}$, and Hazel Wilkes, $2: 20$, the two most noted race winners of the San Mateo Farm.

Gen. TAYLOR-by the Morse Horse.

Thirty-mile record of the worlı............ I $: 47: 59$

Ten-mile to wagon............................. $29: 41_{1}^{1}$

One-mile record under saddle ..................... $2: 41^{1}, 2$

One-mile record to harness ..................... $2: 44$

Controller-(credited to Gen. Taylor by J. H. Wallace).

Ten-mile record of the world................ $27: 23 \frac{1}{2}$

Twenty-mile record, only beaten once $\ldots \ldots \ldots \ldots \ldots \ldots \ldots . \quad 58: 57$

PERFORMERS BY SONS OF GEN. TAYLOR.

Eugene Casserly, record $2: 45$, sire of Sweetbriar ....... 2:261/2

Captain Hanford, record $2: 33^{1 / 4}$, sire of May Howard ........ $2: 24$

\section{DAUGHTERS OF GEN. TAYLOR THAT HAVE PRODUCED 2:30 PERFORMERS.}

Lady Livingston, dam of Lady Blanchard ........... $2: 261 / 4$

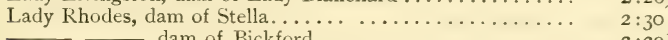

$\overline{\text { Nellie }} \longrightarrow$ dam of Bickford................... $2: 29^{1 / 4}$

Nellie Powers, dam of Wells Fargo $\ldots \ldots \ldots \ldots \ldots \ldots \ldots .2: 183 / 4$

Sallie Taylor, dam of Nerea ................... $2: 23^{1 / 2}$

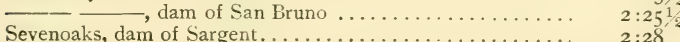

SIRES PRODUCED BY DAUGHTERS OF GEN. TAYLOR.

Whippleton 1883, sired by Hambletonian Jr. I882, dam Lady Livingston, by Gen.

Taylor, sire of

Homestakes, p., dam untraced................. $2: 16^{1 / 2}$

Lily Stanley, dam Dolly McMann, untraced ................. $2: 17^{1} \frac{2}{2}$

Flora B., dam untraced........................ $2: 27$

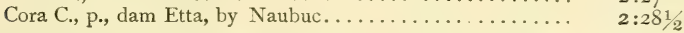

WESTERN (full brother to Whippleton), sire of Chapman, p., dam

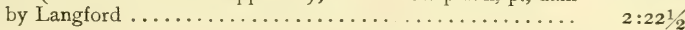

GEN. LEE, BY GEO. W. PATCHEN JR., DAM SISTER, BY GEN. TAYLOR.

Sire of Lee, dam by son of Casserly, son of Gen. Taylor... $2: 20$

STANFORD, BY GEO. M. PATCHEN JR.: DAM BY GEN. TAYLOR.

Sire of Lookout, dam Vineland Maid, by son of John Nelson, $\quad 2: 25$

PRODUCING MARES FROM DAUGHTERS OF GEN. TAYLOR.

Lady Livingston, grandam of Charley C., p......... $2: 181 / 2$

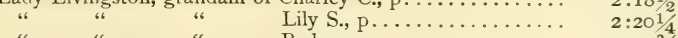

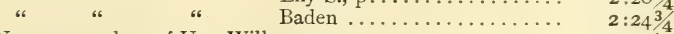

Nancy, grandam of Una Wilkes ................. $2: 19 \frac{1}{1 / 4}$

" " Hazel Wilkes................. $2: 20$

Nerea, grandam of Nerea Patchen ................ $2: 29$

Pineland Maid, the dam of Lookout, $2: 25$, was by a son of John Nelson, whose dam was by Gen. Taylor. Vineland Maid was a granddaughter of Gen. Taylor.

George Bement of Oakland, Cal., said, in interview with writer :

"I owned Gen. Taylor the last ten years of his life. I bought him of Matt G. Shearing of San Francisco, who got him of A. J. Rhodes of 
Sacremento. Eyclesheimer sold him when about six to E. H. Parker of San Francisco; he sold him to a Mr. Teacle of San Francisco, who owned Princess; he sold to Haskell of same place; he to Jack Kelley of same place, and he to Rhodes. I got him in I869. I had Gen. Taylor Jr.'s dam from Columbus, O., said to be by Sir George, thoroughbred. I saw the Morse horse in Northumberland in $\mathbf{I} 842$, he then about seven or eight years old. It was claimed that the sire of the Morse horse was owned by an officer in Canada named Jennett."

Seth Tallcott, San Francisco, Cal., says :

"Gen. Taylor was a round-barrelled and smooth-hipped horse; looked some like the Morgans, but different style. He was a quick stepper, but low headed and without much style. A long-bodied and compact-built, close-jointed horse, I5 hands, Iooo pounds; resembled the old Morgans more than the Black Hawks, but was different from both."

J. D. Eyclesheimer writes from Fon du Lac, Wis., Dec. I4, I872 :

"The dam of Gen. Taylor, by the Morse Horse, we know nothing about, except she was a good road mare. We got her at Lansingburg, N. Y., and raised from her eight colts in eight years. Taylor was the sixth, foaled June, I $847 . "$

San Francisco Town Talk says :

"We have made considerable inquiry concerning the pedigree of Gen. Taylor, but it appears to be a mystery. He was brought to this State some three years ago from the northern part of New York. He is a very handsome gray stallion, fifteen hands and one inch high, with heavy flowing mane and tail, and is one of the most beautifully formed stallions we have seen. He is now owned by Mr. Teacle of this city, who is making active inquiries to ascertain his pedigree."-Porter's Spirit of the Times, March, 1857 .

Advertised, 1855, in California, at the stable of D. S. Campbell, at Union Race Course at $\$ 50$ the season. Advertisement stated that he was half brother to Gray Eddy. Advertised in California Spirit of the Times, I 862 .

Sire of dam of Wells Fargo, 2:183/4; 2d dam of Una Wilkes, $2: 191 / 4$.

GEN. TAYLOR (I-I6), dark chestnut, I Ioo pounds; foaled about I 847 ; bred by Dr. J. Crombie, Francestown, N. H. ; got by Green Mountain Morgan, son of Gifford Morgan : dam the Patterson mare, said to be by Nondescript. Well-built, prompt and spirited, with good action. Advertised at Milford, N. H., in New Hampshire Patriot.

GEN. TAYLOR (I-8), I5 hands, Iooo pounds; foaled I 849 ; bred by Joseph Hatch, Chelsea, Vt. ; got by Black Prince: dam said to be by Bulrush Morgan ; and $2 \mathrm{~d}$ dam by Quicksilver. Owned by Elihu Norton, Chelsea, Vt. Not remarkably bold and active, but symmetrical, hardy and enduring, and an excellent horse. Received the first premium at the Orange County Fair, Vermont, 1851 , and also the first in the class of Bulrush Morgans at the Vermont State Fair in 1854 . 
GEN. TAYLOR (I-16), I5 I/4 hands, gray; foaled I 854 ; said to have been bred in Bourbon County, Ky., and got by Gen. Taylor (pacer), son of Pilot. Bought about 1857 , by S. Donaldson of Rushville, Ind, where he was kept some years. Died at Crawfordsville, Ind., about i 874 .

From Dunton's Spirit of the Turf, May, r 892 :

Edtor Dunton's Spirit of the Turf:

"Can you enlighten me as to the breeding of Gen. Taylor, the sire of the dam of Kate Bennett, $2: 29$, and that was some years in Indiana. Is he the Gen. Taylor of California?"

READER.

Ans. - "The Gen. Taylor you enquire for, made a few seasons at Rushville. He was brought from Nicholas County, Ky., by Mr. S. Boyce, who managed him the first year. Stephen Donaldson became his owner and kept him in 1858 . He was a horse of remarkable beauty, steel-gray in color, very stylish, about $15 \mathrm{I} / 2$ hands high, and was a typical Kentucky saddle horse. Mr. Boyce took great pride exhibiting his gaits upon the streets of Rushville. His full pedigree is as follows: 'Got by old Gen. Taylor of Bourbon County, Ky.: dam by imported French Canadian Tom; old Gen. Taylor by Imported Black Pilot, from a mare by Graves' Whalebone, and he by Barnes' Pilot, an imported horse. He was not the California Gen. Taylor.'"

One of the noticeable things in this paragraph is that the dam was by imported French Canadian Tom, which makes this Gen. Taylor strongly inbred Canadian.

GEN. TAYLOR (STOUT'S), brown; foaled I 840 ; bred by Johr. Stout, Philadelphia, Penn.; got by Young Sir Solomon: dam said to be by John Hill's Comet, son of Alexander Porter's (of Delaware), celebrated running horse Godolphin, from dam by Badger's Hickory; 2d dam by imported Badjazett; and $3 \mathrm{~d}$ dam by Rainbow, son of Blind Granby (from dam by Irish Gray), by imported Granby. (Dam of Rainbow, by Lofty, grandam by Jupiter.) Above pedigree is from one of Stout's posters of $x 856$.

Geo. B. Lobdell writes to Dunton's Spirit of the Turf as follows: "I notice that in your manual for 1886 , Fanny, the dam of Delaware, $2: 28$, is given as follows: 'By Gen. Taylor, by Quimby Messenger.' Delaware was bred by Zadock Townsend, and foaled on a farm partly in the limits of this city and partly in New Castle. He was foaled in the spring of I866, was got by Wyatt's Morgan Black Hawk. His dam was a light bay mare, about 15 hands high, known in this section as Townsend Fanny, and by the Townsends called Yellow Fanny. Fanny's dam was a bay mare said to have been raised on the eastern shore of Maryland, and known here as the Barston mare, from the fact that before Townsend owned her she belonged to Dr. Barston. Fanny was got by Stout's Gen. Taylor, a brown bay horse, I6 hands high. I have one of Stout's bills, dated $185^{6}$, in which he gives the pedigree of Gen. Taylor as follows :

" 'Gen. Taylor was got by Young Sir Solomon, his grandam by Rainbow, his great-grandam by Hector. Rainbow's sire was Blind Granby, his dam by old Irish Gray; his grandsire, imported Granby. Rainbow's dam got by Lofty, his grandam, by Juniper. Gen. Taylor's dam was got 
by John Hill's Comet; Comet was got by Mr. Alexander Porter's celebrated running horse Godolphin, of Delaware State; Comet's dam was got by the 4-mile horse old Hickory, owned by Mr. Bela Badger of Pennsylvania, near Bristol ; grandam by imported horse Badjazett ; greatgrandam, by Gray Figure imported from England; great-great-grandam by imported horse Wildair.'"

"At one time I owned a full sister to Delaware, and know the above to be correct. I often drove Fanny with a mare I now own; she could trot in about $3: 00$, and with my mare Helen, made a good double team. Delaware was three years old when I bought his sister from the Townsends. From the above you will see that Delaware is older than the manual makes him.

Wilmington, Del."

Yours respectfully, GEORGE B. LOBDELL.

Sire of Fanny the dam of Delaware $2: 28$, and winner of 17 recorded races.

GEN. TAYLOR (THOMAS', BADGER), white with 14 black spots on rump, 16 hands, 1200 pounds; foaled about 1840 or '4I; bred by Presley Thomas, Georgetown, Scott County, Ky.; got by Bertrand Horse, son of old Bertrand, thoroughbred: dam Polly Hopkins (dam of Tom Crowder, by Pilot), bay, bred by Mr. Hopkins, Bourbon County, Ky. ; got by Virginia Whip; $2 \mathrm{~d}$ dam bred by Mr. Hopkins, got by old Slashum, son of McKinney's Roan, by Celar, thoroughbred. Advertised in Lexington (Ky.), papers. Pedigree from A. W. Thomas, Georgetown, Ky., son of breeder, who writes :

"My father, Presley Thomas, sold Taylor in the forties to Mr. Hutchinson, Bourbon County, Ky. He was bred to a few mares while my father owned him, also kept a season or so in Bourbon County, Ky. After that I think, went West. He was never trained but was fast in a pace. Fine style and action, good disposition. Taylor's Polly Hopkins was also the dam of old Tom Crowder, got by old Black Pilot.

"IVe called Taylor Badger because of the spots. He was afterwards called Gen. Taylor. The dam of the Bertrand Horse, sire of Gen. Taylor, was a white and spotted mare called Leopard. Father has been dead i5 years."

GEN. THOMAS ( $1-8)$, brown with star, 15 I/2 hands, about rooo pounds; foaled about I 856 ; bred by Calvin Solace, Bridport, Vt. ; got by black Hawk : dam said to be by Sir Charles, son of Duroc; and 2 dam by Post Boy, son of Dinwiddie. Owned by Gardner Conn, St. Johns, Mich. ; John Voorhees, Ovid, Mich.; by Dewey and Stewart, Owosso, Mich., who sold him, 1871. An editorial in the Michigan Farmer, 1871, says :

"Another stallion that is kept here, and which is well up in years, but is a lively, serviceable horse, is Gen. Thomas, a very well bred Black Hawk."

GEN. THOMAS (3-32), bay, foaled I 874 ; bred by A. C. Fisk, Coldwater, Mich.; got by Mambrino Chief Jr., son of Mambrino Chief : dam Black Sal. Sold to B. S. Wright, Detroit, Mich.; to T. Heatherington, Cedar 
Springs, Ontario, Can. ; to S. H. Edmunds, Blenheim, Ont., Can. ; to John Corrigan, Cleveland, O. Information from J. L. Heatherington, Newburg, Ont., 1905 .

Sire of 2 trotters $\left(2: 23 \frac{1 / 4}{4}\right), 3$ pacers $\left(2: 18 \frac{1}{4}\right)$.

GEN. THOMPSON (3-16); said to be by Ethan Allen: and dam by Corbin's Fox.

GEN. TURNLR (I-I 28 ), $2: 263 / 4$, bay; foaled 188 I ; bred by A. J. Alexander, Spring Station, Ky.; got by Harold, son of Hambletonian : dam Claytona, bay, bred by James E. Clay, Paris, Ky., got by American Clay ; $2 \mathrm{~d}$ dam said to be by Young Lord (Cleveland Bay), son of Lord; and 3d dam Cassia, bay, bred by Capt. M. M. Clay, Bourbon County, Ky., got by Strader's Cassius M. Clay Jr. Sold to R. B. Wallace, Wallingford, Conn.; to W. B. Smith, Hartford, Conn.

Sire of Milkmaid, $2: 24^{3} / 4$.

GEN. TWEED $(3-32), 2: 261 / 2$, chestnut; bred by Thomas Hammond, Crown Point, Essex County, N. Y.; got by Myron Perry, son of Young Columbus: dam said to be by Black Hawk, son of Sherman Morgan.

GEN. WASHINGTON, black, 16 hands; foaled 1835 ; said to be by Bashaw, son of Grand Bashaw: dam by Tippoo Saib, and half-sister to Sally Miller. Gen. Washington was half-brother to Charlotte Temple and Andrew Jackson. Advertised, I $8_{4} \mathrm{I}$, for sale by Wm. Robinson, Philadelphia, in The Spirit of the Times.

Advertised in $\mathbf{1} 84 \mathbf{2}$, in The Spirit of the Times, with pedigree as above. He is called a trotting stallion, and challenge is given against any stallion in New York to trot 3 miles and repeat.

GEN. WASHINGTON (3-32), dapple chestnut, I 6 hands; foaled I $85 \mathrm{I}$; said to be by Ticonderoga, son of Black Hawk.

Advertised, I 857 , at stable of Mr. James Montague, five miles from Lexington, Ky., by G. D. Gregory.

GEN. WASHINGTON (I-8), dark chestnut, $153 \frac{3}{4}$ hands, I 200 pounds ; foaled r $85 ?$; bred by O. C. House, Berlin, Vt. ; got by Peck Horse, son of Black Hawk: dam chestnut, rooo pounds, owned by Hon. A. K Warren, Berlin, Vt., of Woodbury, Morgan blood. Owned by H. C. Sessions, East Middlebury, Vt., I 866 to $\mathbf{1} 868$, when he sold him to Hiram Boardman, Columbus, O., whose property he died about 187 I. Advertised as above in Vermont Patriot, 1858 . The writer will always remember meeting this horse once upon the road when owned at Middlebury, because of his wonderful beauty and excellence of form.

Sire of Bill Ed, $2: 28$; dam of I trotter. 
GEN. WASHINGTON (I-I6), bay, I6 hands, I 200 pounds; foaled 1874 ; bred by H. N. Smith Trenton, N. J.; got by Gen. Knox, son of Vermont Hero: dam Lady Thorne, $2: 181 / 4$, bay, foaled 1856 ; bred by Levi S. Rodes, Fayette County, Ky., got by Mambrino Chief, son of Mambrino Paymaster; 2 d dam Gano Mare, bred by Mr. Rodes, got by Gano, son of American Eclipse; 3 d dam bright sorrel, white face and legs from knee to hoof, pacer, bred by Mr. Rodes, Sr., got by a son of a horse called Sir William; 4th dam light bay, 15 I $/ 2$ hands, pacer and never broken to harness, bred by Mr. Rodes, Sr., breeding not remembered. A horse of great power. Sold to James R. Cumming, New York, N. Y.; to George Hilderbrecht ; to L. B. Risdon, Trenton, N. J. ; to Wm. D. Marks, Westport, N. Y.

We append the following letters :

Lexington, Ky., April 24, I875.

H. N. Smith, EsQ., Trenton, N. J.,

Dear Sir :-Yours of the $14^{\text {th }}$ making inquiries in regard to the pedigree of the dam of Lady Thorne's grandam, is received. This missing link cannot by any possibility be supplied, as my father, who bred and owned the great-grandam of Thorne, is long since dead, and while living kept no record of the pedigree of his stock; and whatever has been given to the world relating to the pedigree of Thorne I received partly from his often repeated statements to me and partly from my own knowledge. Were my father living doubtless he could throw light upon the pedigree of Lady 'Thorne's great-grandam. I remember very well however, since my boyhood, the appearance and gait of the afore mentioned animal, and will briefly describe her to you. She was about $15^{1 / 2}$ hands high, a light bay in color, very trimly made, especially in the legs, and a natural pacer, even without bridle or saddle. She never knew any other gait, and under no circumstances was she ever known to trot. Her slowest walk was almost a pace, and it was with great difficulty she could be forced to gallop. She was never broken to harness, and was only used for the saddle, and her gait was so rough that she was seldom brought into use as a riding animal. Lady Thorne's grandam was about the size of her mother, but in color was a bright sorrel, with white face and legs from knee down to hoof. She was likewise a natural pacer, but would occasionly break into a trot or gallop. The sire of Lady Thorne's grandam was a colt of Sir William, and nor imported Sir William. No one living can throw any light upon the pedigree of this colt on the dam's side. This statement I have received often from my father when living, and there can be no doubt about it. There is a bare possibility but no probability that the dam of Lady Thorne was what we call in Kentucky, a thoroughbred, but there were traces of good blood running through the whole family so far back as I can remember them, which dates back to the great-grandam and no further. $* * *$

I will state that I disposed of Thorne when she was two years and four months old, to my neighbor, H. C. Dunlop, Esq. (now deceased), for $\$ 300$ and two boxes of imported plantation cigars by way of bonus. I then had no conception of the future of the animal. Lady Thorne's dam was a very sure and prolific breeder, never failing to produce every 
year and at the first leap. This was a trait of the family. I have endeavored to give you all I know of the obscure points of 'Thorne's pedigree.

$$
\text { Yours very truly, LEW T. RODES. }
$$

Peter C. Kellogg writes in Wallace's Monthly, Vol. I., Pp. 12-13:

"Whatever degree of racing blood prevails in the veins of Lady Thorne through her dam, she shows more of the appearance and quality of the thoroughbred than a large majority of her sire's get. Indeed she was exceptionally fine for one of his family, and the same is true of Mambrino Patchen, the sire of Lady Stout, that as a three-year-old has the fastest record of that age, $2: 29$. The two are as unlike in form as full brother and sister well can be, but they are uniform in the fact that both are eminently more blood-like, than the get of Mambrino Chief in general. Lady Thorne is a large bay mare, I6 I/4 hands, and rather leggy. Her head and neck are clean and show breeding, and her shoulders deep and well laid back, topping out with withers noticeably high. Her body is long, and she is not only long in the sweep from hip to hock, but again from the latter point to the ground. She is decidedly a long strider in action, and goes well apart behind, and in all respects is what is termed 'big gaited.' The first time the writer ever saw this mare was in June, I865, at the old Union Course, where she trotted a match with Dexter and beat him. This was the first time they came together. It was Dexter's second season upon the turf ; he was seven years old and had made a record of $2: 24 \mathrm{~T} / 2$, on the second day of that month. Lady Thorne was two years older, and had won a heat on the first day of that month in the same time. Dexter had never been defeated, and the mare had proved invincible since she came north. When Lady Thorne appeared on the track in her preliminary jogging, the peculiarity of her gait attracted general comment. She bent her knees very little, and had an awkward way of poking out her fore feet with a dwelling action that seemed little adapted to the work before her; but as her speed increased, the dwell was lost without any shortening of the stride. The action of Dexter was decidedly different, having more elasticity and readiness, with a beautiful roll of the knee and hock, but wanted much of the steel-trap vim and electric power that afterwards characterized it. Lady Thorne won the first heat in $2: 24$, and at its termination I formed a conviction that Dexter would never see the day he could beat her when she was right. Of course this is a very nonprofessional admission, since it has proved that she never succeeded in defeating him after that day, though they subsequently came together in several races. However, in spite of the prevailing custom of relating only the wonderful foresight of successful prediction, I own the mistake as it proved to be. The mare beat him in this heat perhaps a couple of lengths, and it is quite evident that she could have increased it materially at will. She got away with her long low-reaching stroke, and out-paced him anywhere she chose on the straight sides. Everytime he made an effort to collar her the great stride of the mare seemed almost imperceptibly to quicken and lengthen, and she would steal away from him. She seemed capable of setting her action to time like the pendulum of a metronome, only with the difference that the farther she went, the faster she went with steady gradual increase and no apparent limit of capacity. She won the second heat in $2: 26 \mathrm{r} / 2$. When she appeared for the third, there was a change in her demeanor. 
"After getting the word she went off with a discontented drive at the bit, and continued to fight it until she reached the back stretch, when she broke, and Dexter got the lead, but he broke himself, and the mare was settled before he got away from her, but she did not act right, and when, well up the home stretch, her driver touched her with the whip, in fear of the too near approach of Dexter, she gave an angry lurch and went into a great, sprawling, awkward break that lost her the heat in $2: 27$. When the fourth heat was called, her restiveness had apparently subsided. She won it at ease in $2: 26 \mathrm{~T} / 4$. It was mere play for her to beat Dexter that day, but the friends of the horse claimed that he was off. This I could afterwards readily believe when I noted his different demeanor in subsequent races, but to those who, like myself had never seen him before, his true measure did not then appear."

Henry N. Smith writes to American Horse Breeder Nov. Ir, I893:

\section{Editor American Horse Breeder:}

'Although I as executor have no longer any financial interest in the trotting stock of Fashion Stud Farm, there is not a member of the stud but is endeared to me by associations which are among the pleasantest of my life. Next to those relatives and friends of the human kind who have added to the happiness of my life, my horses have given me the greatest enjoyment. Twenty-five years ago I had an ambition similar to that of Mr. Robert Bonner, to own the fastest and best trotting horses that money could buy. He bought Dexter and I bought Lady Thorne. The trotting world considered Dexter the greatest horse that had then been produced. On public form he was entitled to all the credit he received.

"Lady Thorne then stood next to him and I believe I would be able to prove she was the greater of the two. But an accident in unloading her from a car ruined her trotting powers, and she retired before her real greatness had been uncovered to the public. I had bought Goldsmith's Maid, but did not at that time consider her the equal to Lady Thorne, nor is it in my judgment today that, great as she was, she could have beaten Lady Thorne at the best that mare was capable of.

"But in some particulars, I think Goldsmith's Maid excelled any trotter that has ever appeared. There have been perhaps a select few that taken at their very best could have beaten her an occasional race, but if the test was a race a week for ro consecutive weeks, I do not know what horse could have beaten her a majority of them. I know that Lucy could have beaten the Maid an occasional race, and, in fact, she did, but as an every-day trotter, traveller and campaigner, I have always felt that in Goldsmith's Maid I owned the greatest piece of horseflesh that has appeared on the trotting turf.

"Although I did not purchase my fast trotters for my private driving, as Mr. Bonner did his, I personally drove all of them many fast miles, and became as intimately acquainted with their traits and peculiarities as any owner does with his road horses. While I greatly enjoyed this intimacy with them, I confess that their popularity with the public was also a subject of great satisfaction to me. I do not think that the horse lives or has lived that was so thoroughly entrenched in the hearts of the people of this country, as Goldsmith's Maid.

"As long as I competed on the public tracks I not only bought the best trotters that could be secured, but I employed the best driving talent-Budd Doble's name grew into fame associated with that of Gold- 
smith's Maid, whose granddaughter, Ballona, is now one of the pets of his stable. Dan Mace, the greatest race driver of his day, had charge of Lady Thorne, Rosalind, and Jay Gould, and Orrin Hickok had Lucy.

"In speaking of these leading animals I by no means limit to their number all in which I took pride and pleasure. Others of less turf value I retired from the tracks to my private driving stable, which at that time was quite an extensive one. Among them wers Tattler, Western Girl, Daisy Burns, Rosalind, Belle stickland, Le Blonde and others. In this way I not only became experienced with fast horses, but with very fast horses, and having for 25 years made a study of them I know the difference between really first-class trotters and those which are but half-way trotters. In $\mathrm{x} 872$, when Fashion Stud Farm was purchased and established as a stock farm, I disposed of all interest in my trotting horses to that establishment, But as manager of that establishment, I have always retained a lively interest in the success of my old trotters and their descendants.

"I have sometimes been amused by the criticisms passed upon my methods of breeding by men who really know very little about first-class trotting stock, though they assume to teach the public. They jumped at the conclusion that because some of our stallions, like Gen. Washington and Stranger, had not been placed upon the turf and given records that they were failures in speed. The fact is, I did not care particularly what people thought until I had multiplied our stock and crossed and recrossed it with the blood of our great trotters, never entertaining a doubt that when it was asked to show speed it would be found there just as superior to the ordinary product of the breeding farms as the original stock was superior to the ordinary trotters of their day.

"I avoided training as much as possible, because I knew the difference between first-class training and the ordinary, as well as I knew the difference between first-class trotters and the ordinary. I could not afford to control the time and talent of Budd Doble on youngsters, and I had no desire to go back to public trotting, as I handled only a few of the stallion colts that I wanted to get rid of until they showed sufficient speed to attract a buyer, and let it go at that. Fortunately their breeding sold most of them at good prices without any training, and the fillies I turned in as brood mares after barely breaking them to harness, no matter how promising.

"I was criticised for using Tattler and also his sons, Rumor and Slander of our own breeding. But I knew that all were horses of very remarkable character, which my critics did not know. For a time they intimated that Stranger was likely to prove a failure, notwithstanding his great ancestry, but now they begin to see a part of what I have known all along, and it was enough to change their tune. While accusing me of being narrow in adhering so largely to stallions of our own breeding, they generally admitted that our mares were unsurpassed. They thought our greatest need was to buy a really first-class stallion. Had they been asked to name the horse we ought to buy, it is ten to one that not a horse would have been named of as great merit as either Stranger or Rumor.

"When I set out to breed trotters, I set out to breed the best. That intention has never been lost sight of in our stallions any more than it has in our mares. I would gladly have bought better stallions than we had raised if I had known where to find them. I don't believe any exist. The training test has never been applied to Fashion Farm 
trotting stock yet. Among the lots sold last March and in the remainder to be sold this month, there are many a colt and filly far greater than either Monbars or Pixley. I am not talking at random. I know what first-class trotting stock is.

"It will be noticed that we bred some of our mares lately to popular outside stallions. It was not because I considered our own stallicns insufficient, but because I knew that there pertained to the outsiders an available fashionable value that I could quickly turn into money undeveloped, particularly where the product was from mares of such breeding as we possessed. In the sale last spring buyers ran after these fashionably-topped youngsters, with the idea that they were getting the best ones. It will be the same in the coming sale of the remainder. They are good colts and fillies, but if I knew anything about trotting stock for practical racing purposes, which is the final test, there are many better ones by the home stallions. Why should they not be better? What horse in the world carries the blood of such trotting ancestors as Stranger?

"Among the stock in the two sales closing out the stud are young horses, which, if they fall into hands of people who will give them firstclass advantages on the trotting turf, will go to the very front as race trotters and champions. Had I expected to give up breeding I would long ago have shown this. Among the first few we sold off, which others developed, were Pixley (2:081/4), Monbars (2:1 $3 / 4)$, Edgardo $(2: 133 / 4)$, Poem ( $2: 14)$, Broomal ( $2: 15)$, etc., yet I left untrained and put to breeding far more promising ones than these among our fillies. The very few mares we parted with were only sold on account of tempting prices and the knowledge that we had better ones of the same families still left. This is why nine-tenths of all the Fashion Farm trotters that have taken records are stallions and geldings and so few are mares.

"Everybody knows that a breeding establishment that does not systematically train gets very scant representation on the records compared with its real merits. Where would Palo Alto, San Mateo, Allen Farm, Village Farm or Pleasanton Farm have been today had they not employed first-class training talent? Yet I always had the feeling we held in our stud the material to surpass any of them whenever I should decide to adopt like methods. I was contented to wait until we had rounded up our number of approved animals to a profitable plane, and then make our demonstrations.

"It will now be left to others to verify my judgment, but, knowing the stock for generations, the conviction still forces itself upon me that time will show that there has never been to this day a stud of horses of equal number, from which so great an amount of very extreme speed and racing quality will appear in the future. I owned the best while I was on the trotting turf, and as manager I have bred the best, as time will show, during my career as a breeder."

\section{A correspondent of Dunton's Spirit of the Turf, writes :}

"The man who discovered America is soon to be honored in Chicago, beyond the common lot of man; but what can we say for him who bred the gamest trotter that ever wore shoes? The death of Mr. Levi T. Rodes, a few days ago, at his home in Lexington, Ky., calls to mind the fact that he is deserving of a monument for having bred so wonderful 
an animal. He had always been a devoted admirer of horses, and among the most noted which he bred was the famous Larly Thorne, whose performances startled the world early in the sixties.

"Mr. Rodes was a gentleman of the old school, courteous, mildmannered and beloved by all who knew him, and in his death Kentucky loses another link in that rapidly shortening chain which binds her to the past.

"Some time early in $\mathbf{I} 889, \mathrm{Col}$. R. S. Strader asked Mr. Rodes to furnish him as much information as he could about the dam, grandam and great-grandam of Lady Thorne. Although suffering greatly with disease that finally carried him to the great unknown, he cheerfully complied, and the following is what he wrote:

" "Col. R. S. STRAder :

“'Lexington, Ky., May 29.

"Lady Thorne was foaled the property of the undersigned. Her dam was by Gano, a thoroughbred from South Carolina, and her grandam by a colt of imported Sir William. Great-grandam's pedigree unknown. The latter, the great-grandam, was a natural pacer, and was noted on the farm as a leader of the herd of horses running at large in the pasture. She never trotted in her life, and was never broke to the saddle or harness. Her gait was so thoroughly that of a natural pacer that it was performed easily without the aid of bridle or saddle. It is not known to me that the grandam of Thorne was thoroughbred and it is not likely, as my father never owned a strictly thoroughbred animal. The sire of Thorne is well known as being Mambrino Chief. There was a large amount of running blood in the dam as well as the grandam, but it is not at all probable that either were thoroughbred. The grandam, as well as the great-grandam, were both natural pacers, but Thorne and her dam never manifested any other gait than that of a trot. The dam, grandam and great-grandam possessed unusually small, neat thoroughbred-like looking limbs, but I am sure that none of them were thoroughbred, but were highly bred.

Very truly yours,

Levi T. Rodes.",

Sire of $I_{5}$ trotters $\left(2: \mathrm{II}^{1} \frac{1}{2}\right) ; 8$ sires of 54 trotters, 8 pacers; Io dams of 18 trotters, I pacer.

GEN. WASHINGTON. See J. H. Welsh.

GEN. WAYNE (FOX-HUNTER), dark chestnut, 15 1/2 hands, I050 pounds ; foaled May 21, I $85 \mathrm{I}$; bred by Mr. Varbonceur, near Montreal, Que.; got by Tamworth, thoroughbred, imported by Capt. Rice of the 23 rd Regiment: dam bay, large, said to be by the C. C. J. DeBleury Horse, sire of Passe Careau (superior to Diamond) known as Gen. Dunham's Moscow, $2: 30$, in I 845 . Information from J. H. Canniff, Walkersville, Ont., who writes, dated March 20, I885:

"Gen. Wayne has shown in public, $2: 56,2: 54,2: 50$. This was done on the turf, but on ice he could beat anything in this country."

A correspondent for The Spirit of the Times, Dec. 6, I862, in an article on Michigan Horses, says :

"Gen. Wayne, formerly Fox Hunter, is a high bred horse. His colts 
show breeding, are of the English Hunter stamp and can trot to the tune of the rattling sulky if they can not run up to the noise of hounds."

GEN. WELLINGTON (I-64), 2 :30, brown; foaled I 884 ; bred by Leland Stanford, Menlo Park, Cal.; got by Electioneer : dam Waxana (dam of Sunol, $2: 08 \frac{1}{4}$ ), bred by Leland Stanford, got by Gen. Benton, son of Jim Scott, by Rich's Hamiltonian; 2 d dam Waxy, said to be thoroughbred, by Lexington, son of Boston. Sold to Judson H. Clark, Elmira, N. Y.

Sire of Lady Wellington, $2: 15 \frac{1}{2} ; 3$ pacers $\left(2: 18 \frac{1}{4}\right)$.

GEN. WILKES ( $\mathrm{I}-32$ ), $2: 2 \mathrm{I} 3 / 4$, gray, $\mathrm{I} 6$ hands, $\mathrm{I} 200$ pounds ; foaled $\mathrm{I} 88 \mathrm{I}$; bred by Louis Cook, Georgetown, Ky.; got by George Wilkes, son of Hambletonian : dam Grace Goodman, said to be by Peacock, son of Benton's Diomed; 2 d dam Belle, by Drennon, son of Davy Crockett; and 3 d dam Alice, by Gray Eagle. Pedigree from R. J. Cook's catalogue of Glengary Stock Farm, near Lexington, Ky.

Sire of 7 trotters $(2: 20 \%$ ), I2 pacers $(2: 12) ; 5$ sires of 9 trotters, 24 pacers; I dam of $\mathbf{I}$ pacer.

GEN. WITHERS (I-I28), chestnut, I $53 / 4$ hands, I IOo pounds; foaled I 875 ; bred by R. West, Georgetown, Ky.; got by Almont, son of Alexander's Abdallah: dam Bloom, bay, bred by Geo. C. Hitchcock, New Preston, Conn., got by Ashland, son of Mambrino Chief; $2 \mathrm{~d}$ dam Lady Brant, said to be by Toronto Chief, son of Royal George; and $3 \mathrm{~d}$ dam Townsend Mare, by old Kentucky (thoroughbred). Sold to G. J. Shaw, Hartland, Me. Kept at Detroit and Hartland, Me., I878-189o, then sold to E. D. Morgan, New York City. Information from G. J. Shaw.

Sire of 3 trotters $\left(2: 2 \mathrm{I}^{1 / 2}\right) ; 7$ sires of 7 trotters, 3 pacers; 4 dams of 4 trotters, I pacer.

GEN. WITHERS JR. (I-32), chestnut; foaled I882; bred by Chas. P. Dore, Levant, Me.; got by Gen. Withers, son of Almont: dam Duchess Fearnaught, bred by C. P. Dore, got by Young Fearnaught; $2 \mathrm{~d}$ dam Nelly Grant, gray, bred by C. A. Babcock, Canton, Ill., got by Gen. Grant. Pedigree from John H. Kimball, son-in-law of C. P. Dore. Sire of 2 trotters $\left(2: 19^{1 / 4}\right)$; Harry L., $2: 21^{1 / 4}$.

GEN. WOOLSLEY (I-32), bay foaled I 880 ; bred by R. S. King, Port Colborne, Ont.; got by Gen. Stanton, son of Hambletonian: dam said to be by Royal George (Lee's), son of Royal George; 2d dam Kate King, by Hamiltonian, son of American Eclipse. Sold to Frank King, Port Colborne, Ont., Can.

Sire of James M., $2: 27 \frac{1}{4}$.

GEN. WOOSTER. See Toronto Sontag.

GENESEE BOY. Said to be by True Whig.

Sire of the $2 \mathrm{~d}$ dam of Clementine, $2: 2 \mathrm{I}$, and winner of $\mathrm{I} 3$ recorded races. 
GENESEE GRAY (EMIGRANT), gray, $153 \frac{1}{4}$ hands; foaled about I 823 ; thought to have been bred by Dr. Barlow, Bethany, Genesee County, N. Y.; and got by True Whig (which see) : dam said to be one of a pair of gray mares brought from the East (some say Vermont), by Dr. Barlow, and used many years in his practice, breeding unknown. Purchased when a colt of Dr. Barlow, by John Jenne of Bethany, N. Y., who sold a half interest to John Derrell, Hamburg, Erie County, N. Y. About I 850 he was sold to a Mr. Roberts and taken to Michigan. A very stylish, showy horse and great roadster.--S. B. Luck, in National Lize Stock Journal.

GENET, bright sorrel ; foaled I 789 ; said to be by Kildare, son of imported Lath: dam a Jersey-bred mare, three-fourths blooded, owned by Col. Ray. Advertised by John Howard, to stand at General Strong's in Addison, Vt., said to be seven-eighths blooded, well built for saddle or draught.

GENEVA ( $1-32), 2$ :II $1 / 2$, chestnut with star, white hind ankles; foaled $\mathbf{I} \delta 87$; bred by Charles Backman, Stony Ford, N. Y.; got by Leland, son of Hambletonian: dam Bessie Forrest, gray, bred by R. A. Alexander, Woodburn Farm, Ky., got by Alexander's Edwin Forrest; 2d dam Diana, gray, said to be by Alexander's Pilot jr., son of Pilot; and $3 \mathrm{~d}$ dam Gray Goose, bred by H. L. Barker, Clinton, N. Y.; got by Bathgate's Gray Norman, son of Morse Horse. Sold to C. and R. A. Stratton, Evansburg, Penn. ; to R. C. Stinson, Briantford, Ontario, Can. Pedigree from catalogue of breeder.

Sire of 4 trotters $\left(2: 15 \frac{1}{2}\right)$.

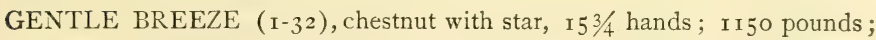
foaled 1870 ; bred by Price Hudson, Louisville, Jefferson County, Ky.; got by Whirlwind: dam said to be by Ole Bull, son of Pilot; and $2 \mathrm{~d}$ dam by John Richards Jr., son of John Richards. Sold 187 I to Wilson Dunn, Bryantsville, Ky. Advertised in Kentucky, I873, by Wilson Dunn. Advertisement states that Whirlwind ran in Nashville, I860, third heat in $2: 443 / 4$, and afterwards trotted in same place to wagon in $2: 30 \mathrm{~T} / 2$; then at Louisville, same season in $2: 26$. Died $x 875$. Pedigree from Chas. Dunn, Stanford, Ky., who writes :

"Gentle Breeze was a nice styled horse, smooth with good bone, intelligent, good trotting action, and kind disposition. The produce are kind but high mettled, some inclined to be double gaited."

Sire of Pearl, 2:30; I dam of I trotter.

GEORGE (ROYAL GEORGE) (3-64), dark bay, black points, I53/4 hands ; foaled June, 1852 ; bred by George P. Barnett, Compton, Compton County, Que.; got by Logan, son of Henry Clay, by Andrew Jackson, son of Young Bashaw: dam bay, bred by Moses Barnett at Compton, 
said to be Morgan. Died June, I88o. Pedigree from W. W. Paige, who writes: "No track record; could step a mile in $2: 45$. Fine appearance, splendid action; the best disposition possible. Stock best in the country." Emmitt H. Hill of Concord, Vt., thinks that the dam of George was by Black Morgan, son of Wilder colt, by Batchelder horse, son of Sherman Morgan.

GEORGE, $2: 32$, and winner of 13 recorded races, brown; foaled 1870 ; said to be bred by Samuel Chapter, Westchester, N. Y.; and got by George Wilkes. See The Morgan Horse and Register, Vol. I., p. 876, under "Ten Race Winners."

GEORGE. Untraced.

Sire of Dexter, $2: 24$.

GEORGE A. $(\mathrm{x}-32), 2: 2 \mathrm{x} 3 / 4$, bay, $\mathrm{x} 6$ hands, I roo pounds; foaled 1876 in April ; bred by John Thompson, Hanover, Licking County, O. ; foaled the property of Martin Soper; got by Truesdale's Abdallah (dam by Mohawk), son of Erie Abdallah, by Roe's Abdallah Chief, son of Abdallah, by Mambrino: dam Kittie Foster, bay, (pacer), bred by Thomas Foster, Jersey, Licking County, O. ; got by old Gurney ; 2d dam Queen (pacer), bred by Thomas Foster, got by Peacock, son of Black Hawk; 3d dam Becky (pacer), said to be by Top Gallant brought from Long Island, by Alfred Whitehead and said to be thoroughbred. Sold to John Thompson; to Martin Laper; to G. A. Wilson. Pedigree from M. G. DeCrow, M. D.

GEORGE B., (3-128), $2: 27$, brown; foaled r 888 ; bred by John Bricker, Cadiz, O.; got by Gold King, son of Atter Gaines : dam Dolly Smith, said to be by Flying Hiatoga, son of Hiatoga; and 2d dam Flora, by Glover Pony.

Sire of 4 pacers $(2: 16 \%)$; I dam of I pacer.

GEORGE BANCROFT (I-64), bay; foaled I 89 I ; bred by S. A. Browne \& Co., Kalamazoo, Mich.; got by Anteeo, son of Electioneer: dam Nelly H., black, bred by L. B. Harris, Upper Sandusky, O., got by Ambassador, son of George Wilkes; 2d dam Lady Greer, gray, owned by J. E. Williams, Upper Sandusky, O., got by Joe Curry, son of Cottrill Morgan, by Black Hawk.

Sire of 2 trotters $\left(2: 22^{1 / 4}\right)$.

GEORGE BAYARD (I-I6), bay; foaled I 885 ; bred by H. H. Stambaugh, Youngstown, O.; got by Bayard, son of Pilot Jr. : dam Curlew, bay, bred by Richard Ingraham, Hempstead, L. I., got by Norwood, son of Hambletonian; 2 d dam Dot, gray, bred by Abram Woodward, Bangor, Me., got by Drew Horse ; $3 \mathrm{~d}$ dam, said to be by French Tiger; and 4 th dam by Eaton Messenger, son of Winthrop Messenger. Sold to Frank 
Rundal, Genoa, O.; to J. V. Newton, Toledo, O.; to John Dinion, Fort Wayne, Ind.

Sire of Cashier, $2: 12 \frac{1}{4}$.

GEORGE BELMONT (I-64), bay, with star, white hind ankles, r6 hands, II 55 pounds; foaled $x 886$; bred by M. B. Gratz, Spring Station, Ky. ; got by Belmont, son of Abdallah: dam Chinchilla, gray, bred by M. B. Gratz, got by Harold, son of Hambletonian; $2 \mathrm{~d}$ dam said to be by Norman, son of Morse Horse; $3 \mathrm{~d}$ dam by Gray Eagle; and $4^{\text {th }}$ dam by Whip (Blackburn's). Sold to Fred Seacord, Galesburg, Ill., who sends pedigree.

Sire of Bell Metal, $2: 161 / 2$.

GEORGE BLACK (3-128), black, $\mathrm{r}_{5}$ hands, rooo pounds; foaled I 890 ; bred by William Barnes, Pontiac, Mich.; got by Blooming, son of St. Jerome, by Hambletonian Wilkes : dam Belva Lockwood, brown, bred by A. C. Fisk, Coldwater, Mich., got by Hambletonian Wilkes, son of George Wilkes; 2 d dam Hester, gray, bred by A. C. Fisk, Coldwater, Mich., got by Belmont, (Fisk's), son of Irish Foxhunter : 3 d dam Hattie Williams, bay, bred by A. C. Fisk, got by Magna Charta, son of Morgan Eagle; 4th dam Bettie, said to be by Othello (Black Prince), son of Black Hawk. Sold to Sutherland and Benjamin, Saginaw, Mich.; to William E. Jewett, Adrian, Mich.; to E. J. Cadwell, Chicago, Ill. Pedigree from breeder.

Sire of McGregor Wilkes, $2: 19 \frac{1}{4}$.

GEORGE B. MCCLELLAN (I-64), $2: 36$, bay, I $53 / 4$ hands; foaled I 868 ; bred by Austin A. Wright, Hightstown, N. J.; got by King's Patchen, son of George M. Patchen: dam Phœbe (dam of Eva, 2:27), bay, bred by William R. Norton, Hightstown, N. J., bought when two years old by Daniel Jones, who sold her to Mr. Wright; breeding unknown. Sold for \$2500 to W. H. Bower, Orwigsburg, Schuylkill County, Penn.; to T. J. Middaugh, Paterson, N. J. ; to Hiram Shilton, Reading, Penn.; to Jacob Booker, Tippecanoe City, O. Information from Austin A. Wright, who writes: "I raised and sold \$I I,700 worth of colts from Phœbe, including George. B. McClellan and Eva. I have spent much time and money trying to get her pedigree ; but of no avail."

Sire of 2 trotters $\left(2: 24 \frac{1}{4}\right)$.

\section{GEORGE B. MCCLELLAN. See Dirigo.}

GEORGE BROOKS (3-32), $2: 33 \frac{1}{4}$, and winner of ro races, brown; foaled about I87I ; bred by A. Brooks, Lewiston, Me. ; got by Gen. Knox, son of Vermont Hero: dam bred by John Gove, Lewiston, Me., got by Lewiston Boy, son of Pollard Morgan ; 2 d dam bred by John Gove, said to be Morgan. Sold to J. P. Norton, Lewiston, Me.; to Charles E. 
Carman, Marlborough, N. J. See The Morgan Horse and Register, Vol. II., p. I 4 I.

Sire of Ida B., $2: 18 \frac{1}{4}$; I dam of I pacer.

GEORGE B. SWAN (I-64), black, foaled I879; bred by George B. Swan, Potsdam, N. Y.; got by Phil Sheridan, son of Young Columbus : dam sorrel, about I 5 hands, said to be Messenger.

Sire of Little Wonder, $2: 24^{\frac{1}{1} 4}$; I dam of $x$ trotter.

GEORGE C. (5-64), jet black (no marks), I $5 \frac{334}{4}$ hands, I Ioo pounds; foaled I 883 ; bred by M. M. McDonald, Hartford, Washington County, N. Y.; got by Ben Franklin, son of Daniel Lambert: dam Flora Cozzens, brown, bred by L. Cozzens, West Granville, N. Y., got by Honest Dan, son of Vermont Hamiltonian; $2 \mathrm{~d}$ dam Cozzens, said to be by Red Jacket, son of Black Hawk. Pedigree from breeder.

GEORGE C. HALL ( $\mathrm{I}-32$ ), gray, about I 6 hands ; foaled about I869; bred by Richard Bradley, Brattleboro, Vt., got by Young America, son of Hoagland's Gray Messenger : dam Rachael, black, said to be by Rocky Mountain, called a wild horse. Died about 1876 .

Sire of Lady Wilds; dam of Wickopee, record, $2: 17 \frac{1}{2}$.

GEORGE CHIEF (I-I28), bay, I53/4 hands, II 75 pounds; foaled I 877 ; bred by Eli B. Minor, Mukwonago, Wis.; got by Milwaukee, son of Hambletonian: dam Black Jane, black, bred by E. B. Minor, got by Bald Chief (Stevens'), son of Bay Chief ; 2 d dam bred by E. B. Minor, got by Dave Hill, son of Black Lion; 3 d dam Jane, bay, bred by A. E. Elmore, Mukwanago, Wis., got by Hickory (Gearley's), said to be thoroughbred. Pedigree from breeder, who writes that he sold him when 18 years old at Combination sale in Chicago.

Sire of Myrtie B., $2: 22 \frac{1}{2}$.

GEORGE DEXTER (3-128), 2 :18 1/4, brown; foaled I 890 ; bred by Buckman and Carragher, Sacramento, Cal.; got by Dexter Prince, son of Kentucky Prince: dam Nelly C., bay, bred by J. B. Haggin, Sacramento, Cal., got by Kilrush, son of Whipple's Hambletonian ; $2 \mathrm{~d}$ dam Firefly, said to be by James Munroe, son of Naubuc, by Toronto Chief ; and 3 d dam Black Susie.

Sire of Telephone, $2: 24^{3 / 4}$.

GEORGE DICKSON (3-128), bay; foaled ז880; bred by H. G. Toler, Wichita, Kan.; got by Ashland Wilkes, son of Red Wilkes : dam Mary G., bay, bred by John P. Gurley, Martinsville, Ind., got by a son of Blue Bull; 2d dam Liza Boston, said to be by Boston, son of Boston. Pedigree from breeder.

Sire of 2 pacers $(2: 161 / 4)$. 
GEORGE D. PATCHEN ( $1-128$ ), bay, I6 1/4 hands, 1300 pounds; foaled I 874 ; bred by John Winne, Geneva, N. Y.; got by Seneca Patchen, son of George M. Patchen : dam Jenny, bay, said to be by Rattler (Thomas'), son of Rattler (Wright's) ; and $2 \mathrm{~d}$ dam by Foxhunter. Sold to J. W. Day, Waterloo, N. Y., who sends pedigree; to James Hicks, Wyoming, Penn.

Sire of Kitty M. Patchen, $2: 30$.

GEORGE DUROC. Advertised in the People's Friend and Little Falls Gazette, I829, to be kept at Manheim and Oppenheim, N. Y.

GEORGE ELLIOT, bay; foaled I 833 ; said to be by a son of imported Leviathan : dam Julia Crump, bay, bred by Mr. Wade H. Bynum, got by Lawrence; 2 d dam bred by John Drummond, Brunswick County, Va.; got by imported Dragon, son of Woodpecker; 3d dam Atlanta, bay, bred by Isaac Gilmour (colored) near Petersburg, Va., got by imported Medley (Hart's), son of Gimcrack; 4th dam Pink, said to be by Mark Anthony (Lee's).-American Stud Book, Vol. I.

Sire of $3 \mathrm{~d}$ dam of Annie W., $2: 20$, and winner cf 2 I recorded races.

GEORGE FLĖTCHER ( $\left.\mathrm{I}-\mathrm{6}_{4}\right)$, said to be by Albany Boy, son of Morrill. Sire of Pronto, $2: 271 / 4$.

GEORGE F. WHEELER MORGAN. Mr. T. W. Markle in letter dated, Waupun, Wis., May I I, I908, says :

"The Briggs Horse was got by G. F. Wheeler's Morgan, a brown or dark bay, $15 \frac{1}{2}$ hands high, 1050 pounds.

"The Freeman Wheeler Horse was a chestnut as you described.

"G. F. Wheeler brought his brown horse from Vermont in the early fifties. I was not so intimate with Freeman as I was with G. F. Wheeler."

GEORGE GIFT (I-I28), $2: 29 \mathrm{~T} / 4$, bay; foaled I 884 ; bred by J. D. Roberts, Glasford, Ill. ; got by Fairy Gift, son of Hero of Thorndale : dam Topsy Talbott, said to be by Long Island Patchen, son of George M. Patchen.

Sire of 2 pacers $\left(2: 23^{1 / 2}\right)$.

GEORGE GOULD (3-г28), bay; foaled ז 885 ; bred by Z. E. Simmons, Lexington, Ky. ; got by Jay Gould, son of Hambletonian : dam Sophia, bay, bred by Simmons Bros., Lexington, Ky., got by George Wilkes, son of Hambletonian; 2d dam Mattie Wilder, bay, bred by Thomas L. Coons, Lexington, Ky., got by American Clay, son of Cassius M. Clay Jr.; 3d dam said to be by Sir William (Smith's); and $4^{\text {th }}$ dam by Highlander (Fisher's). Sold to W. T. Duncan, Denver, Col. ; to A. S. Waltz, Decatur, Ill.

Sire of Linn Gould, $2: 19 \% 4$; 1 dam of I pacer. 
GEORGE HALL (3-64), bay, I53/4 hands, I I50 pounds; foaled about I 873 ; bred by S. W. Matlock, Sharpsville, Ind.; got by Blue Bull : dam bay, bred by S. W. Matlock, Rushville, Ind., got by Shropshire's Tom Hal Jr., son of Shropshire's Tom Hal ; 2 d dam, gray, bred by Thomas Matlock, Rushville, Ind., got by Gen. Taylor Jr., son of Gen. Taylor, by a son of Pilot (Dansereau's) which see; 3d dam sorrel roan. Sold to Nathan Porter and James Brown, Rushville, Ind.; to George Hall, Raleigh, Rush County, Ind. ; to George Gifford and E. H. Shirk, Tipton, Ind. ; to L. C. Clark, Rushville, Ind. Kept 1875-I878 at Rushville ; I879 and part of 1880 at Raleigh ; I88I-I883 at Tipton; I884I 886 at Findlay, O.; fall of $\mathbf{I} 886$ and $\mathbf{I} 889$ at Tipton. In appearance much like Blue Bull, very high-headed, long neck and body; always used as a family horse. Information from George H. Gifford, who adds: "Kind, intelligent and full of courage. In style, form and action much like a Morgan." Died July 8, I 895 .

Sire of Dr. Frank, $2: 27 \frac{1}{2}$, Fenny Hall, $2: 19 \frac{11}{4}$ : I dam of I pacer.

GEORGE H. D., bay ; foaled I 882 ; said to be by Lakeland Abdallah Jr., son of Lakeland Abdallah: dam Gipsey Blanche, by Billy Green, son of Bashaw ; and 2 d dam Nelly Thompson. Sold to James T. Whiteman, Biggsville, Ill.

Sire of 2 pacers $\left(2: 20^{1 / 2}\right)$.

GEORGE H. HAZZARD, $2: 34$, bay; foaled 1877 ; bred by D. C. Ketchum, Boone, Ia., got by Essode, son of Coupon: dam Flora, said to be by Trampaway, son of Tramp; 2 d dam Ann. Sold to Chas. H. Wells \& John Bain, both of Boone, Ia.

Sire of 2 trotters $(2: 261 / 4)$.

GEORGE H. LOWE, bay, r6 hands, I Ioo pounds; foaled I 873 ; bred by A. H. Taylor, Central Valley, Orange County, N. Y. ; got by Florida, son of Hambletonian: dam Mary Hunter, chestnut, bred by John Roach, Highland Mills, N. Y., got by Guy Miller, son of Hambletonian; 2 d dam chestnut, bred by John Roach, got by Friday, son of imported Trustee; 3 d dam chestnut, bred by John Roach, got by Philips, son of Cole's Messenger, by imported Messenger. Sold, I877, to George W. Parker, Lowell, Mich. ; repurchased, 1879, and kept at Marseilles, Ill., until spring of 1890 , when he was sold to J. B. Haggin, San Francisco, Cal. Information from breeder.

Sire of Eva, 2:231/4; I sire of I trotter; 2 dams of I trotter, I pacer.

GEORGE. H. Mitchell (3-32), $2: 26$; bred by Dr. L. B. Reynolds, Saratoga, N. Y.; got by American Ethan, son of Ethan Allen: dam said to be by Long's imported Tornado. Information from C. W. Mitchell, Saratoga Springs, who writes : 
Joseph Battell, EsQ.,

Saratoga Springs, Dec. 5, i 885 .

Dear Sir:-Your favor of inquiry at hand. In reply will say, "Gray York," the dam of American Ethan, was owned by Mr. George Adams at Whitehall, N. Y. She was afterward sold to R. A. Alexander of Kentucky, and raised several fast ones. Mr. Adams is dead, died in Troy, N. Y. Edward Buck, formerly of Fort Edward, bred "Nellie Webster."

GEORGE J. (I-64), chestnut; foaled about I 887 ; bred by G. F. Jacobs, Nevada City, Cal. ; got by Pasha, son of Echo: dam Nelly J., chestnut, bred by J. M. Ellenwood, Cedarville, Cal., got by Friday McCracken, son of Billy McCracken. Dam sold while in foal, to S. A. Eddy, Hanford, Cal. Pedigree from breeder.

Sire of Nelly J., $2: 29^{3 / 4}$.

GEORGE K. (5-12 8 ), chestnut, narrow strip in face and two white ankles, I6 hands, I roo pounds; foaled I879; bred by Oscar Lincoln, Union City, Mich.; got by Mambrino Chief Jr., son of Mambrino Chief : dam Clara Lincoln, bay, bred by Oscar Lincoln, got by Masterlode, son of Hambletonian; 2 d dam Molly Lincoln, said to be by Troy Whig. Sold to George Klose Mendon, Leonidas, Mich., who sends pedigree; to George Caurke, Union City, Mich.; to J. C. Holloway, Kennon, O.

Sire of 2 trotters $\left(2: 24 \frac{1 / 2}{2}\right)$.

GEORGE LEE (I-I6), $2: 23 \frac{1}{4}$, dark bay, about I 6 hands, about I Ioo pounds; foaled I 880 ; bred by R. R. Hodson, Charlottetown, Prince Edward Island, Can. ; got by All Right, son of Taggart's Abdallah : dam bay, bred by Murdock McLeod, West River, Prince Edward Island, got by Prince Edward, son of Saladin, imported thoroughbred; 2 d dam bay, bred by Murdock McLeod, got by Columbus, an English Clydesdale. 'Sold to Alex. McKennin, Charlottetown, Can. ; to George Essory, Highfield, Prince Edward Island; to Winch Bros., Shoe Dealers, Boston, Mass. Pedigree from breeder.

GEORGE L. NAPOLEON, $2: 24 \frac{1}{4}, 153 \frac{3}{4}$ hands, IIOo pounds, brown; foaled I 883 ; bred by Newell Rogers, Brighton, Livingston County, Mich.; got by Louis Napoleon, son of Volunteer: dam Flora R., bay, bred by Henry Beaker, Brighton, Mich., got by Stonewall, son of Kemble Jackson Jr., by Kemble Jackson. Sold to Frank A. Weithoff, Windsor, Ontario, Can. Pedigree from breeder.

Sire of Fred Judson, $2: 281 / 4 ;$ Fim Corbett, $2: 15$.

GEORGE LOGAN (7-256), bay, snip on nose, hind ankles white, I $53 / 4$ hands, ro6o pounds; foaled I882; bred by H. F. Copeland, Whitman, Plymouth County, Mass. ; got by General Withers, son of Almont : dam Olive Logan, bay, said to be by Jules Jurgensen, son of Gen. Knox; and 
2d dam by Eaton Horse. Sold to Everard Powers, Tilton, N. H. Pedigree from breeder.

Sire of Pattie, $2: 291 / 4$.

GEORGE M. (3-128), said to be by Orange Blossom.

Sire of Laertes, $2: 291 / 4$.

GEORGE M. DALLAS (Dallas) ( $\left.\mathrm{I}-3^{2}\right)$, roan, I5 I 2 hands, I roo pounds ; foaled 1846 ; bred by N. B. Turner, Gallatin, Tenn. ; got by Harris' Davy Crocket, son of Janus, by Blackburn's Davy Crocket : dam thoroughbred. See The Morgan Horse and Register, Vol. I., p. 776 .

The following interesting letter refers to several horses of this family, all of which trace back to the Morgans which entered Canada East in the early part of the century, whilst the original Morgan horse was kept for service in Northern Vermont, near the Canada line.

Gallatin, Tenn., March 4, I889.

Mr. Joseph Battell,

Dear Sir :-I fear you will get impatient at my long delay in giving the information desired, but some of the parties are dead and others have moved off, so that it will at best be difficult to get the full information desired, but will do my best, and as soon as I can hear from several parties that have moved away will write you.

Old Davy Crockett (Harris') made the season at Mr. L. Harris' on Deshay's Creek, four miles northeast of Gallatin, in 1845-6-7-8-9. George M. Dallas (pacer) served a few mares as a three-year-old at Col. N. B. Turner's (his owner) on the east fork of Bledsoe's Creek, ten miles northeast of Gallatin, in 1849 , and my father sent me with the Leviathan mare (Bodia) to him, and in 1850 the roan mare Kitty K. (pacer) was foaled, the grandam of Reeves.

Dallas made the season of $185 \mathrm{I}$ at Dr. J. M. Head's, six miles northeast of Gallatin on Scottsville Pike. (Dr. Head is still living at same place). I bred Kittie K. to old Black Hawk (Hall's) in I 858 at Mr. Charles Morgan's, just two miles from Gallatin on Scottsville Pike. (I live just three miles on the same pike) and Molly Hall (dam of Reeves) was foaled April, I859, and in I861 I went in the Confederate army and left Molly Hall in care of a young single sister who claimed her to prevent the Federal army from taking her.

I surrendered with Gen. N. B. Forrest at Gainesville, Ala., in April, I865, and returned home to find all taken, both hogs, sheep, cattle, chickens, and in fact everything except the farm, and Mollie H., was the only animal left of a large stock. Well, I went to work and collected several mares to cultivate my farm and in January, I866, took possession of the old home place and on the roth of January was married, and now we have eight children and my eldest daughter married and we are all for tariff for revenue only and no mistake. Well, I have dropped off our subject. I bred Mollie H., to Skedaddle in I866, and in April 1867 Frank Reeves was foaled. I sold him at three years old to Capt. Tim Walton, and he drove him to his family carriage for some time, and traded him to Robert N. Myers of this county, and he shipped him to Georgia and sold him to Frank Reeves, who changed his name from Gen. Price to Frank Reeves. Mr. Reeves had Mr. Fuller to handle him, 
and he trotted three heats in Nashville against Blackwood Jr., losing the last heat by Blackwood's running. Mr. Reeves sold him to some one in New York, and he was sold at eleven years old at $\$ 8,000$. I received several letters from his owner in New York several years since, but forget the names.

$$
\text { Yours truly, JNo. I). Martin. }
$$

GEORGE MILLER. Untraced.

Sire of Billy Miller, $2: 22 \frac{1}{4}$.

GEORGE MILO, bay, I5 $5 \frac{1}{2}$ hands; foaled 1880 ; bred by Dewey \& Stewart, Owosso, Mich.; got by Louis Napoleon, son of Volunteer: dam Fanny Mapes, bay, bred by J. W. A. Brewster, Goshen, N. Y., got by Alexander's Abdallah, son of Hambletonian; $2 \mathrm{~d}$ dam Smith Mare, said to be by Burr's Napoleon, son of Young Mambrino; and $3 \mathrm{~d}$ dam Fox, by imported Trustee. Sold to Joseph Gavers and Charles Balkman, Goshen, N. Y.; to John E. Bradley, Au Gres, Mich. Died April 9, 1888 . Pedigree from breeder.

Sire of 2 trotters $(2: 20)$; I dam of I pacer.

GEORGE MONMOUTH PATCHEN (I-I6), bay with small star, I6 hands, I I5o lbs.; foaled I 857 ; bred by B. E. Hendrickson, Crosswicks, N. J., got by George M. Patchen Sr., son of Cassius M. Clay: dam dark bay, bred by Joseph Hendrickson, got by a Morgan horse owned by a Mr. Davis of Bordentown, N. J. Sold to Dr. A. V. Conover, Freehold, N. J. Of good disposition with fine action and a fine horse. Died on Long Island about i 862 . Pedigree from breeder.

Sire of St. Albans, $2: 201 / 4$.

GEORGE MONDAY (I-32), $2: 38$, bay, I6 hands, II 50 pounds; foaled I 886 ; bred by C. A. Hodges, Battle Creek, Mich.; got by Pilot Medium, son of Happy Medium: dam Belle of Jefferson, bay, bred by Wm. Tarlton, Oldham, Ky., got by Belmont, son of Alexander's Abdallah ; $2 \mathrm{~d}$ dam Fly, said to be by Woodpecker, son of Bertrand; 3d dam Little Fly, untraced. Sold to James Ladd, Beatrice, Neb. Pedigree from breeder.

Sire of George Tuesday, 2:25.

GEORGE MORGAN (I-8), bright bay, I 5 hands; foaled 1847 ; bred in Chelsea, Vt.; got by an inbred horse of the celebrated Morgan breed: dam unknown. Driven across the plains in a light wagon in $185_{2}^{2}$ to California, and shortly after his arrival he was sold to C. C. Green, San Francisco, for $\$ \mathrm{I}, 000$. Trotted over the Union Course, I 854 , by Mr. Green 20 miles, beating Mr. Shear's bay horse, Fred Kohler; time, $70: 313 / 4$. As a result of the race $\$ 30$, ooo were said to have changed hands. Information from interviews in California, and Spirit of the Times, June I 7 , I854. 
GEORGE M. PATCHEN (I-32), $2: 23 \frac{1}{2}$, bay; foaled 1849 ; bred by Richard Carman, who kept a public house in Park Row near the Park Theatre, New York; got by Cassius M. Clay, son of Henry Clay : dam a large dark bay or chestnut mare, $\mathbf{} 6$ hands, breeder and breeding unknown. Given (it is said), when foaled to Isaiah Sickles of Monmouth County, N. J., who in I85 I, sold him to John Buckley, Bordentown, N. J., for $\$ 400 ;$ Mr. Buckley sold soon after a half interest to Dr. Longstreet of same place; and in $\mathbf{I} 858$, the remaining half interest to Joseph Hall, Rochester, N. Y. Afterwards purchased by Mr. Waltermire, New York City, whose property he died at Goshen, Orange County, N. Y., May I, I 864. His record when made (Union Course, Long Island, Aug. 2, 1860), was the world's trotting record for stallions. Trotted to wagon, June $28, \mathbf{1} 859$, time $2: 30$. Advertised in Spirit of the Times, I 86 I-62, by William Waltermire, Washington Drove Yard, N. Y., to be kept at premises of subscriber near Kingsbridge, New York City. Terms $\$$ roo. Trotted, I857-63 and won 20 recorded races.

Mr. Joshua H. Goodwin, New York City, in interview with author, I887, said :

"The dam of George M. Patchen was an Eastern mare, no mistake about that. An Eastern man kept that tavern; the mare came from Boston. I bred this mare next year to Cassius M. Clay again. She was a big dark colored mare and I think bay; perhaps 16 hands. Carman kept a public house in Park Row near Park Theatre at that time."

Mr. Wallace, in his monthly Vol. III., p. 5 12, says :

"George M. Patchen was foaled in the year I849, near Keyport, Monmouth County, N. J., the property of a Mr. Sickles. He had bred him for the owner of his dam, Mr. Richard Carman, Westchester County, N. Y. Mr. Carman did not think that his mare was in foal, and in a discussion with Mr. Sickles, who maintained that she was, he gave the produce, in case there should be any, to Mr. Sickles. * * *

"In I 85 I he was purchased from Mr. Isaiah Sickles by Mr. John Buckley of Bordentown, N. J. (who trained him and made him what he was), for \$400. A few months afterwards he sold a half interest in him to Dr. Longstreet, of the same place, and he was owned jointly by them until the year 1858 . In 1852 , being then three years old, he was put in the stud, and there remained till the close of $\mathbf{I} 858$. Every season was made at Bordentown, excepting that of 1857 , during which he was kept at Newton, Sussex County, N. J. In 1855 he was exhibited at the United States Agricultural Fair, held at Philadelphia; and he there trotted and won a race. Also, the next year he was shown and trotted at the New Jersey Agricultural Fair, and he was again victorious in $2: 40$, beating, among other animals, Hero and John Nelson. On the roth of October, 1857 , he trotted on the fair ground, Newton, N. J., in harness, and defeated Woful and American Star in $2: 44$ and $2: 4 \mathrm{I}$. The following year he trotted another race at mile heats to wagon, which he won."

Mr. Wallace says in Vol. II., p. I79, of his Monthly under the heading, "George M. Patchen's Pedigree" :

"Notwithstanding all that has been written and said about the blood 
of this famous horse, and all the investigations that have been made, it is probable there is not a word of truth in the pedigree that has been given his dam. As we now remember, John Buckley was the first to assume to enlighten the public about his maternal ancestry, and all the writers who followed merely reiterated his story. We got the pedigree, as it appears in the Register, from Mr. George M. Patchen, of Brooklyn, but as it was merely a reiteration of Buckley's, it is probable he got it from Buckley. A theory was then started by Hiram Woodruff, we believe, that the son of Trustee that got his dam was from the famous mare Fanny Pullen by Winthrop Messenger. After considerable inquiry we were strongly inclined to believe this was true, and, we think, gave some public intimations to that effect. We are now in possession of some facts that go clearly to show that the whole thing, so far as the maternal line is concerned, is fraudulent. It appears to be certain that his dam was foaled in 1836 , and as Trustee did not arrive here till November, I 835 , it is impossible that a son of his should have been the sire of Patchen's dam. We expect to have all the facts in due form soon, and will give them to the public."

Mr. Wallace says in Vol. II., p. 627, of his Monthly under the heading, "George M. Patchen's Pedigree" :

"In the July number we stated that there was some doubt about the pedigree of this famous horse, as it has heretofore been given. At that time we were not in possession of specific information, but what we had appeared to be so direct, that we were disposed to accept it. Very recently we have made further progress in the search, which we will now lay before the public.

"In May, r 835, Mr. Thomas Tone, who now resides on One hundred and twenty-third Street near Seventh Ave., and his brother Richard, arrived in this country. This date is given as a land mark in what will follow: In the spring of 1836 , Richard Tone bought or traded for, a large, coarse and clumsy, sorrel mare. She had slipped a foal a short time before, and was thin in flesh, and cost but little. Mr. Thomas Tone does not remember from whom his brother got this mare. but thinks it was from somebody in the city, and thinks he traded a kicking mare for her. He remembers the mare very well, as he worked her a year in a dirt cart. He describes her as a great, big, homely, awkward mare, with a disposition to start off in a pace, when moved out of a walk. In the spring of 1836 , his brother bred her to a Canadian horse, and the produce was a first-rate work-horse. In $\mathbf{1} 839$, he thinks it was this mare was in pasture at the foot of Breakneck Hill, as it was known, and a twoyear-old colt, owned by Mr. William Bradhurst, in an adjoining field, jumped the fence, and got her with foal, and the produce was a light chestnut filly. At weaning-time, Mr. Thomas Tone bought this filly from his brother Richard, and at two years old, commenced working her to his wagon and general farm-work, and at three she was the best animal to plough corn, he ever drew a line over. She was very severely tried, for so young an animal, and went amiss, and he sold her to James Scanlon, a blacksmith. After a time, Scanlon sold her to Richard F. Carman, who drove her to his road-wagon. Mr. Carman gave one hundred dollars for her, and he drove her as mate to a mare that he gave fifteen hundred for, and the hundred dollar mare was better than the other. On their rattling daily drives from Carmansville down to the city, the high priced mare would quit before she got quite there, but the 
other would take her and the load the balance of the way. Of her speed we know nothing, but she was a game, all-day mare, and, like her dam, when she started off, it was a pace, but she struck a trot directly. She was foundered and permanently stiffened, and Mr. Carman, as we understand the history, sent her to Mr. H. F. Sickles of Monmouth County, N. J., to be bred. She was bred to Cassius M. Clay, and the produce was the famous George M. Patchen."

Mr. Foster says :

'Mr. Wallace has now satisfied himself that the dam of George M. Patchen was got by a thoroughbred horse, a son of imported Trustee. $\mathrm{He}$ has found an old coachman, who confirms what we heard from $M r$. Charles Bathgate, years before. "Patchen's dam was got by a thoroughbred colt (son of Trustee and Itasca, by American Eclipse), who broke out of his pasture, covered an old mare, and got a chestnut filly."

Wallace continues :

"Mr. Foster formally said :

'Some have doubted whether the sire of Patchen's dam was son to Trustee, the twenty-miler, but, after inquiry, I have reason to believe so. Her sire was a three-year-old colt, by imported Trustee, of Fanny Pullen,' etc.

"It is evident, then, that if Mr. Bathgate told him this sire was from Itasca, he had forgotten it when he wrote and revised the book."

Later Mr. Wallace accepts a pedigree which makes a son of imported Trustee the sire of George M. Patchen's dam. Very likely he was correct that Patchen's dam must have been born about 1836 or before, and the colt he makes her sire could not have been born until $\mathbf{1} 838$, and may have been born later.

In the article accepting this pedigree (Wallace's Monthly, March, I877), Mr. Wallace says of the dam :

"As a driving mare she was the delight of Dick Carman's heart for a number of years and was the best on the road."

Which would hardly have been possible if she had been foaled in $\mathbf{I} 84 \mathrm{I}$; the further facts being that she was bred in 1848 , producing George M. Patchen in $\mathbf{I} 849$.

Mr. Wallace's final statement in regard to the mare is that she was a catch colt, foaled in $\mathrm{I} 84 \mathrm{I}$, the property of a Mr. Tone, who sold her to a brother, who broke her and used her when three years old for teaming and plowing, afterwards selling her to a blacksmith named Scanlon, and he sold to Mr. Carman, so that in the four years of $1845-8$ she passed from Tone to Mr. Scanlon, then to Mr. Carman, no mention being made of how long each owned her excepting that she she was the delight of Dick Carman's heart for a number of years.

Nor is there a particle of evidence that any such transfers of the mare, as mentioned, ever took place; nor indeed that any mare was got in foal by any such colt. Mr. Bradhurst's hostler knew they had the colt, but did not know that he ever got with any mare. 
The tracing, so far as it comes from Mr. Wallace, is utterly worthless. Indeed, so far as we know, Mr. Wallace never did any that had any value; that dam of Goldsmith's Maid, of Engineer, dam of George Wilkes and many others being examples. It is perhaps practically impossible for any one to find an obscure pedigree by simply quoting from letters, or getting reports which may drift into an office. All of those who have excelled in finding difficult pedigrees have only done it by persistent travel as well as other effort. Otto Holstein and Mr. Gould of Boston are illustrations of this. But in addition to opportunity Mr. Wallace lacked the judicial temperament, and freedom from prejudices, without which any successful search for facts is impossible. So that, though eminently able in criticising false pedigrees, he had neither opportunity nor faculty to look up true ones. Otto Holstein was, we think, unquestionably the ablest and most accurate of all in this country who have followed this difficult undertaking. Mr. Cyrus Lukens has also done some very creditable work in this line.

As it would appear that others beside Mr. Wallace (Mr. Bathgate, Mr. Foster, and we believe also Randolph Huntington) have accepted this theory, it is possible that it has some warrant, but we have seen nothing as yet that would warrant us to accept it.

\section{DAM OF GEORGE M. PATCHEN.}

"One of our contemporaries is publishing a memoir of the famous trotting stallion, George M. Patchen, which is a rehash of what has been printed over and over again, but never the less, is presented in a very readable form. In a late chapter the author puts some inquiries to Mr. Wallace concerning his rendering of the pedigree of the dam of this stallion. No attempt has been made to establish the fact that the 'Tone filly' was the mare traded for by Mr. Carman, the breeder of George M. Patchen, and Mr. Wallace is called upon to produce his evidence if he has any on this point. ****

- National Live Stock Journal, October, 1878.

An account of George M. Patchen in Porter's Spirit in I860, says :

"Dam was by a son of Trustee."

Article on George M. Patchen by Randolph Huntington says :

"Schieffetin \& Broadhurst were in the drug trade on John Street, New York forty years ago. Broadhurst employed men with dump carts for street cleaning. An Irishman working for him lost his horse and came to Campbell in McChesney's stable at Bull's Head, where droves of horses came for sale, and bought of him for $\$ 40$ a big yellow bay mare that was a kicker. Broadhurst had two colts by Trustee, out of ordinary mares, not thoroughbred. The Irishman bred his mare to one of these colts, and got a bay filly that he sold to Mr. Carman, a brick manufacturer. Carman gave the filly to a relative in New Jersey, who bred her to Cassius M. Clay and the foal was George M. Patchen."-Breeder and Sportsman, Vol. IX., p. 195.

TROTTING AT PHILADELPHIA, PENN.

"Dear Spirit :-Owing to the accident that occurred at the first meet- 
ing of Lancet [by Black Hawk, son of Sherman Morgan], and Patchen, on the Suffolk Park, an account of which was published in your last, another trial of speed was had on Monday the 3 Ist for a premium of $\$$ I500. Previous to the start heavy odds were offered on Lancet. The horses when brought out looked well and started for the race.

"First Heat, pretty even Lancet slightly in the lead. On the turn Patchen lost his footing and a wide gap was soon made between them. The first quarter was made in 36 but on the second quarter, Patchen again broke badly. The half mile was made in $1: 113 / 4$, and Lancet won by about two lengths and a half in the unparalleled time of $2: 25 \mathrm{I} / 4$ I believe this is the fastest ever made under the saddle.

"Second Heat, after the lapse of 20 minutes the horses were again brought out and started for the $2 \mathrm{~d}$ heat, Patchen in the lead, but again on the Ist quarter he made a bad break and Lancet took the lead from him making the first quarter in $35^{\mathrm{I}} / 2$ the half mile in $\mathbf{I}: \mathbf{I} 2$ and winning the heat in $2: 253 / 4$.

"Third heat, after four ineffectual endeavors the horses got off together. Lancet however broke badly on the ist quarter and fell a couple of lengths behind; but brushing up he shot ahead on the home stretch, and won the heat in fine style in $2: 27$. The following is the summary:

“Suffolk Park Course, Monday Oct. 31, I859,-Purse \$I500, mile heats, best 3 in 5 under saddle.

W. Woodruff's blk. g. Lancet

D. Talman's br. h.

. . . . I I I

Time $2: 25 \mathrm{I} / 4,2: 253 / 4,2: 27$.

Yours etc.,

-Wilkes Spirit of the Times, Nov. 12, 1859.

\section{QUAKER."}

\section{TROTTING CHALLENGE TO THE WORLD.}

"I believe George M. Patchen to be the best trotting stallion in the world and to test this fact both as to speed and bottom, I will match him against Ethan Allen or any other stallion, the following races :

"Mile heats, best 3 in 5 , in harness; two mile heats in harness; three mile heats in harness.

Mile heats, best 3 in 5 under saddle for $\$ 2500$ each race, half forfeit.

"All to be trotted next spring during the months of May, and June, good day and good track. The races to be from six to eight days apart and to be trotted on Long Island over the Eclipse or Union Course and when the word "go" is given on the first race, then all the races to be play or pay.

- Wilkes Spirit of the Times, Dec. 3, 1859.

D. Talmage."

Trotting Stock of Monroe County, N. Y., in Wilkes' Spirit of the Times, March ıo, r860:

Wheatland, N. Y., Feb. 2 I.

DEAR SPIRIT :-I had the pleasure yesterday of paying a visit to the stable of Mr. Joseph Hall of Rochester and saw that king of trotting stallions, George M. Patchen. He looks in fine healthy condition, and seems as happy as a clam in his warm winter quarters. Judging from his age (which I believe was six last May) and the fine condition of his limbs, he has a number of seconds shorter time yet to show the host of his admirers when properly brought upon the track. I really hope 
though that he may be kept from the sporting circle one season, and thereby enable the breeders of trotting stock to combine size with speed, as he is one of the largest fast stallions in America.

His grandsire, Henry Clay, son of Andrew Jackson, is owned by Hiram Sayles, of Scottsville, N. Y., is 2 I years old, but retains the life and ambition so characteristic of the Clay stock, and it would puzzle some of the three-minute nags to make a dash on a smooth road with him now. He is, I believe, the sire of more fast stock than any other living stallion. May he live long to increase the number.

We have had the benefit of the service of St. Lawrence for the past three years. He was brought from Canada by Mr. Prendergast and sold to Mr. Joseph Hall, of Rochester, several years ago; was then sold to go to St. Louis and made two or three seasons there; in the meantime his few colts in Monroe County began to show their intentions to "follow in the steps of their illustrious predecessor" and he was again brought back to Rochester by Mr. Leonard Buckland at a cost of about $\$ 3,500$, which, I believe, was a very profitable investment to the present owner. We shall yet hear from some of his colts in St. Louis, for he served a large number of blooded mares in that section. I understand he is to be sold in March next, with ten of his colts.

There are a large number of Harkaway colts in the northern part of the country, and they are great favorites with the sporting men for road horses. They have the finest shoulders for speed I ever saw. Their heads are always up.

$$
\text { C. P. A. }
$$

Sire of 4 trotters; I 4 sires of 7 I trotters, 4 pacers ; 4 dams of 5 trotters.

GEORGE M. PATCHEN ( $1-128$ ) ; said to be by George M. Patchen Jr.

Sire of Bertha, $2: 30$.

GEORGE M. PATCHEN JR. (I-64), $2: 27$, brown with white hind ankles, and a little white on heels of both fore feet, 16 hands; foaled I85-; bred by Joseph Regan, Mount Holly, N. J. ; got by George M. Patchen, son of Cassius M. Clay : dam Belle, purchased by Mr. Reagan of Nathan Hendrickson, Crosswicks, Burlington County, N. J., who writes that she was bred by Joel Middleton, of whom he bought her, and got by Gray Eagle, owned by Joseph Mount of Mercer County, N. J., and kept at Trenton. Mr. Hendrickson, says he looked the pedigree up very carefully. Though different from the usual pedigree given (by Stockton Bellfounder, etc.), we think it correct, and that the horse referred to is Gray Eagle (Acrigg's). See Gov. Wright. George M. Patchen Jr., was

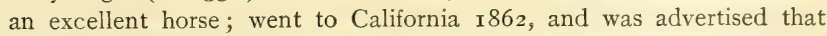
year in the California Spirit of the Times. Sold to P. A. Finnegan, San Francisco, Cal.; J. B. Haggin, Sacramento, Cal., whose property he died in 1887 . Trotted, $1861-69$. Winner of 13 recorded races.

The following letter appears in the American Horse Breeder, July 30 , I9OI :

"OAkland, Cal., July 24, I9ot.

"From the time he brought George M. Patchen Jr. to California, I862, until the trip East, I866, Eoff trained him. Mr. Hendrickson 
accompanied him on that trip, stayed with him until he sold the horse, and again in 1871 , when Eoff took another of his horses East, Shoo Fly, Afterwards James D. McMann was his partner in the expedition. Mr. Hendrickson is a shrewd business man, one of the closest observers, a good judge of horses, and more than usually expert in estimating their racing capacity.

- American Horse Breeder, July 30, 1901, p. 698.

Joseph Cairn Simpson."

Mт. Holly, Feb. I8, I886.

Editor Register :-I bred the horse George M. Patchen Jr., known as California Patchen. His dam was by Stockton's Bellfounder; grandam by Hoot-a-Laddie. He was a brown horse, 16 hands one-half inch in height, two white hind ankles and a little white on the heels of both fore feet. I owned the mare; I bought her of Nathan Hendrickson, Crosswicks, Burlington County, N. J. I sold five horses to William Hendrickson of San Francisco, Cal.

$$
\text { Yours truly, Jos. Regan. }
$$

Sire of Io trotters $(2: 183 / 4 ;)$; II sires of 25 trotters, 3 pacers: I 8 dams of I6 trotters, 7 pacers.

GEORGE M. PATCHEN JR. (r-64) ; said to be foaled 1856 . A horse of this name and age was awarded first premium at the Illinois State Fair, I 860. Owned by T. Smith, Springfield, Ill.

GEORGE M. PATCHEN JR. (I-64), chestnut with star, hind foot white, I 6 hands, II50 pounds; foaled May ıо, 1859; bred by Joseph Hall, Rochester, N. Y.; got by George M. Patchen, son of Cassius M. Clay : dam said to be by Young Wildair, son of Wildair. Owned by John B. Wilson, Oshana, Ont. Died about 1875 .

GEORGE M. PATCHEN JR. (I-64), $2: 3 \mathrm{I}$, brown, I 5 hands, 900 pounds; foaled I 863 ; bred by Isaac Kay, Camden, N. J.; got by George M. Patchen, son of Cassius M. Clay: dam Johnson mare, brown, said to be by Eaton Eclipse, son of American Eclipse. Sold to A. Johnson, Baltimore, Md.; to R. McCrea, Champlain, N. Y., who sends pedigree. Died 1885 .

Sire of 2 trotters $(2: 29)$; Ruby Mac, $2: 21 \frac{1}{2}$; I dam of I trotter.

GEORGE M. PATCHEN JR. See Patchen (Godfrey's).

GEORGE M. RYSDYK (I-I28), bay, star, left hind foot and right forefoot white, $153 / 4$ hands, I 200 pounds; foaled 1878 ; bred by J. P. Wiser, Prescott, Granville County, Ont.; got by Rysdyk, son of Hambletonian: dam Lady Patchen, bay, owned by a Mr. Peck, Hartford, Conn., got by George M. Patchen ; 2 d dam Long Island Maid, said to be by Montauk, son of Cassius M. Clay. Pedigree from breeder.

GEORGE M. VAN NORTE (5-128), chestnut, I6 hands; foaled I86-; bred by John McCauley, New York, N. Y. ; got by Mambrino Pilot, son of Mambrino Chief : dam Lady Prewitt, bay, bred in Kentucky, owned 
by C. P. Relf, l'hiladelphia, Penn., said to be by Iron Duke, son of Cassius M. Clay; 2d dam lanny Prewitt, bay, bred in Kentucky, by Ericsson; and $3 \mathrm{~d}$ dam by Woodford, son of Kosciusko, by Sir Archy. Died I 878 .

Sire ot Katie M. $\left(2: 25 \frac{1 / 2}{2}\right) ; \mathbf{I}$ dam of $\mathbf{I}$ trotter.

GEORGE O. $\left(5-25^{6}\right), 2: 2 \mathrm{I} \frac{1}{2}$, chestnut, star, white spots on left shoulder also little black spots on body, I6 hands; I 150 , pounds; foaled June 5 , x 880 ; bred by Dr. E. A. Beers, McHenry, Ill. ; got by Lakeland Abdallah, son of Hambletonian: dam Fannie B., gray, bred by I). E. A. Beers, McHenry, Ill., got by Autocrat, son of George M. Patchen, by Cassius M. Clay, son of Henry Clay ; $2 \mathrm{~d}$ dam said to be by Young Rowlin, son of General Gifford; and 3d dam by a son of imported Messenger. Sold to George W. Owen, McHenry, Ill., who sends pedigree. Kept at McHenry, Ill., I 887 . Died I904.

Sire of 8 trotters $\left(2: 12 \frac{3}{4}\right), 2$ pacers $(2: 18)$; I sire of I trotter; 2 dams of I trotter, I pacer.

GEORGE ONIVARD, $2: 23 \frac{1}{4}$, brown, small strip in forehead, left forward and both hind ankles white, $15 \frac{1}{2}$ hands, ro6o pounds; foaled I 893 ; bred by R. P. Pepper \& Son, Frankfort, Ky. ; got by Onward, son of George Wilkes: dam Ophelia M., bay, bred by R. P. Pepper, Frankfort, Ky., got by Margin, son of Almont: 2d dam Rachel Russell, black, bred by L. J. Cox., got by Woodford Abdallah, son of Woodford Mambrino; 3d dam Molly said to be by Laver, son of Lexington; and $4^{\text {th }}$ dam Agnes, by Sweeper. Sold to J. L. Edwards, Oberlin, O., who sends pedigree.

Sire of Katy Did, $2: 25$.

GEORGE PALMER ( $\mathrm{I}-32), 2$ :I9 $1 / 4$, and winner of $\mathrm{I} 7$ recorded races; foaled I $86 \mathrm{I}$; bred by Allen Watson, Stafford, Genesee County, N. Y.; got by Ames' Bogus, son of Ballard Bogus, by Lame Bogus, son of Wilmot Bogus, by imported Tom Bogus (presented by Lord Sterling to Gen. Burgoyne during the Revolutionary War) : dam a small chestnut or sorrel mare, said to be Black Hawk Morgan. Sold at an auction when one year old for $\$ 4$ I to John S. Combs; to Thomas H. Combs; to Mr. McVain when five years old; to Mr. Mann; to George Palmer, Rochester, N. Y. ; to Thomas Wilson and A. S. Whitcomb; to Erastus Corning, Albany, N. Y., whose property he died I865. Pedigree from National Live Stock Journal, I878. Gelded young.

"He first gained notoriety as a trotter in 1867 , when only six years old, and during this year trotted twelve races, of which he won eight, and made a record of $2: 30$. The next year he trotted in eleven races, competing with such horses as Rhode Island, Lucy, Lady Thorn, American Girl and Goldsmith Maid and was successful in five of his contests. His fame culminated Oct. 8, 1869, at Narragansett Park, when he won a third heat from Lady Thorn, and made a record of $2: 19 \frac{1}{4}$, being the 
fifth horse to gain a record below $2: 20-$ Flora Temple, Dexter, Goldsmith Maid and American Girl having preceded him. He has been used by Mr. Corning for several years past as a road horse."-National Live Stock Journal, 1878 .

GEORGE PALMER AND HIS BOGUS SIRE.

"George Palmer was got by Ames' Bogus, he by Ballard Bogus, and now comes the great-grandsire Lame Bogus, he by Wilmot Bogus, he by imported Tom Bogus a horse presented by Lord Sterling to Gen. Burgoyne during the Revolutionary War.

"George Palmer was bred by Allen Watson of Stafford, Genesee County, N. Y.; foaled I86I: his dam was a small chestnut or sorrel mare, claimed in some of the records, I believe, to have been a Clay, but I can find nothing to base the claim on. Allen Watson, on account of pecuniary difficulties, left his property in the hands of his brother Ira Watson. He made an auction and John S. Combs bid off George Palmer the fall after he was a year old for $\$ 4 \mathrm{I}$, and sold him to his son Thomas H. Combs the next spring. He kept him till five years old and then sold him to McVain; he to Mann; he to George Palmer of Rochester and his career from this time is well known to all horsemen.

“Ames' Bogus was sold by Samuel Ames of Stafford; foaled Sept. 6, I 855, so says Isaac Durphy a prominent farmer of Byron and President of the Genesee County Agricultural Society. He saw him the next day after he was foaled, and has a memorandum showing the date. $\mathrm{He}$ says of his dam that she was a medium sized gray mare (what is termed flea-bitten), of gamey blood-like appearance, although quite old. I find by inquiry of many who knew her that she was always called a Messenger mare supposed to be from a son of Bush Messenger who made one or two seasons in Stafford and vicinity. She was an excellent road mare and quite noted till she got to be very old. They would take her out of the team and run her a successful quarter race which in her day was more in vogue than trotting. His sire Ballard Bogus, got by Lame Bogus was a fine bay stallion, I 6 hands, a great roadster was bred by Ballard of Stafford, dam a likely bay mare, whose breeding I cannot trace.

"Lame Bogus, great-grandsire of George Palmer was bred by a man of the name of White of Onondaga County, N. Y., got by Wilmot Bogus, he by imported Tom Bogus. I saw him about 1837 , he was then an old horse. As I find my recollection corroborated by those who knew him well, I will give it. $\mathrm{He}$ was dark brown, muzzle and flank inclined to tan color, a little white on one or both hind heels, about $15 \frac{1}{2}$ hands, a good strong made horse; would sometimes show spring halt in one hind leg; one foreleg, I think the near one crippled; said to be and doubtless was caused by a kick when a colt breaking the shoulder. That leg was seven or eight inches shorter than the other and was extended by means of a shoe with three braces. The proper length extending to another shoe and he would get about quite well when so shod. Addison Terry, a reliable resident of Byron, says Lame Bogus was purchased and brought to Byron either in 1832 or I 833 (thinks 1832 ), by his uncle Addison Terry and John Bean. Lame Bogus was then I 4 years old. Remembers they went and saw Mr. White, who bred him, and he said he was no older. He took care of him for them that season; knew when he died and helped bury him; neither he nor any man that I could find could tell just when he died. I went to see the trotting stallion 
Damon, sired by Ames' Bogus (sire of ('eorge Palmer), owned by Mr. Billings Holdridge of Batavia. In answer to inquiry, MIrs. H., said ; 'I lived near neighbor to the late Cyrenus Walker, who owned Lame Bogus when he died, which was the summer my son George was born,' turning to her son, she said. 'How old are you ('ieorge?' He answered, ' 34 , born in I 843.' Now I don't believe in infallibility, except when a mother refers to the birth of one of the children to fix a date. So you will see Lame Bogus died i 8 years before George Palmer was foaled, which would seem to settle the question that he could not have been the sire of George Palmer, if there was no other evidence. There were a good many good road horses got by Lame Bogus and Ballard Bogus, but none ever became especially noted as trotters, that I can learn. Ames' Bogus was sold to Harmon Stone when 5 years old and was sometimes called the Harm Stone Horse. He fell into the hands of an Irishman, McNulty, who was dissipated. He took him to Buffalo and used him on truck at cattle yards till George Palmer became noted as a trotter. $\mathrm{He}$ was then purchased by Cash Bros., and brought back to Stafford and afterwards advertised and called 'Palmer Bogus, sire of George Palmer.' He was bought by some parties at or near Syracuse, but I believe is now at Clyde, N. Y. This horse got some colts that have acted a good deal like trotters. Damon a brown stallion, tan muzzle to flank, I $53 / 4$ hands, 8 years old, bred by the late Billings Holdridge of Batavia, and now owned by his widow, is doubtless the best after George Palmer. He has shown himself a good horse for his opportunities. He has just closed his season and is in good health; his coat shines like a piece of satin. He goes into hands of Wolcott Van DeBogart of Alexander, a careful, thorough and reliable trainer. Whether he will go in the great trotting circuit is not yet determined. His record is $2: 3 \mathrm{I}$.

\section{-National Live Stock Journal, June, 1877.}

S. B. Lusk."

"I see that you and others give the dam of George Palmer as by Henry Clay. When I looked up George Palmer's pedigree I couldn't find a person who believed she was by Clay. H. Stone, who owned and tended the sire, and Combs who saw the mare when she dropped him and bought him when a yearling, after Watson, the breeder, ran away, not only told me then, but a few days since that there was no evidence whatever that she was by Clay. He let his son have George Palmer, and he sold him, when five years old, to the Rochester parties; he never heard of her being by Henry Clay till he saw it in the papers, and the dam had not the first appearance of being by a Clay. The truth is, that the first pedigree of George Palmer was simply made up regardless of facts.

-National Live Stock Journal, May, I880.

S. B. Lusk."

Morganville, N. Y., April 5, I88o.

Mr. Frank B. Redfield,

Dear Sir:-Your letter of inquiry in regard to the dam of George Palmer came to hand in due time, and in reply I can say the mare was brought to my horse when three years old and was served by Ballard Bogus. At that time the mare was owned by George and Hiram Beswicks. She was a small chestnut and called Black Hawk Morgan. The Beswicks sold the mare to Mr. White and Mr. White sold her to 
Mr. Watson. She was then brought to my horse, Ames' Bogus, and bred George Palmer when she was I 3 years of age.

Yours respectfully,

HARMON STONE.

"The Beswicks are both dead so that the mare cannot be traced back of them, but since they are the first ones in the chain of ownership known, and since, according to Mr. Stone, they never gave any Clay version to her breeding, I fail to see how the story originated. I have since seen and talked with Mr. Stone and he says that when the mare was three years old, in the hands of the Beswicks, she was never called Clay, but was called a Black Hawk. It will be seen it was ten years later that Palmer was foaled and the mare had changed hands twice, so that Mr. Watson - on whose authority, it is said, she was called a Clay - could not be in so good a position to know the facts as the Beswicks. Mr. Watson is dead also. The truth is, there is no evidence on which to give the breeding of this mare, certainly none on which to build a Clay mare.

"While I have my pen in hand, I cannot resist the temptation to call your particular attention to the extended pedigree of the two-year-old Sweetheart. Her breeding is a wonderful confirmation of the correctness of the present effort to establish a breed of trotters by mingling tested strains of trotting blood. Tabulated, this pedigree is a much better example than those of Maud S. and St. Julien, which you make use of in the October number of the Journal. It will be seen that we have here two lines to Henry Clay, three to Mambrino Chief, two to Hambletonian, one each to Abdallah and imported Bellfounder (besides those reached through Hambletonian), one to Pilot Jr. and one to Mrs. Caudle, the dam of Ericsson; seven sources of trotting blood in eleven different streams. Can any one claim in the face of this combination of trotting blood and the trot which accompanies it that we are not soon to have a breed of trotters reproducirg their kind with an approach to certainty?

-National Live Stock Joumal, Vol. XI.

Frank B. Redfield."

GEORGE P. TUCKER (9-I28), bay, I5 $5 / 2$ hands, I050 pounds; foaled I 887 ; bred by Edward Pyle, Lincoln, Neb.; got by Charles Caffery, son of Gen. Knox: dam Phobe Willing, bay, bred by George Willing, Philadelphia, Penn., got by Mambrino Pilot, son of Mambrino Chief; 2d dam said to be by Norman, son of the Morse horse. Died I884. Pedigree from breeder, who writes:

Lincoln, Neb., May 22, I905.

Dear Sir :-I enclose you a photo from oil painting of Caffery. $\mathrm{He}$ was shown 48 times and took 45 blue ribbons. There are but two Nebraska bred sires, to sire 2 : Io performers and they are both Caffery's (Askey and Jefferson). The get of Caffery should be just ro more than given in year book. They made an error that has never been corrected; he has seven out of one dam (Eva) and three out of two others.

George P. Tucker was never trained; was killed by lightning at Omaha when four years old. Was got by Caffery, although both sires were used within ten minutes of each other. Caffery's get and Maxie Cobb's get are as unlike as any horse's get can be. Each of George Tucker's get had all the appearance and color of Caffery. Tucker had 
but few foals, and three of his daughters produced Giles Noyes, 2 :05 $1 / 4$, Nell Caffery, $2: 121 / 4$, Wilbur, $2: 12 \frac{1}{2}$, trial $2: 07 \frac{1}{4}$, all blacks and browns.

Yours most respectfully, Edward PyLE.

Sire of Dan Tucker, $2: 161 / 4 ; 2$ dams of I trotter, I pacer.

GEORGE R. (r-8), $2: 24$, chestnut, I 6 hands, rooo pounds; foaled 1877 ; bred by P. S. Preble, Bridport, Addison County, Vt. ; got by Daniel Lambert, son of Ethan Allen : dam brown, bred by Nathaniel Joiner, Moriah, N. Y., got by a son of Black Hawk; 2 d dam said to be Black Hawk and Messenger. Sold to E. J. Smith, Westport, N. Y. ; to George Sherman, Moriah, N. Y. Gelded young. Pedigree from A. C. Preble, West Bridport, Vt., who writes :

Mr. Battell,

$$
\text { WEST BRIDPORT, Vt., }
$$

The brown mare, Fanny, we bought of Nathaniel Joiner, and we bought her for one-half Black Hawk, one-quarter Messenger, one-quarter Post Boy. Mr. Joiner is dead. His son, Fayett Joiner, we understand, lives in Westport, N. Y. He may know something about the matter.

$$
\text { Yours truly, A. C. PREBLE. }
$$

GEORGE R. (I-I6), light bay, white face, white hind ankles, I5 $3 / 4$ hands, I050 pounds; foaled 1872 ; bred by S. N. Beattie, Sanford Corner, Jefferson County, N. Y.; got by Bacon's Ethan Allen. Sold to D. W. Haven, Watertown, N. Y.; to J. Wait of same place. Pedigree from breeder.

GEORGE ST. CLAIR (I-I28), $2: 15 \frac{1}{4}$, bay, with star and near hind foot white; foaled I 888 ; bred by W. L. Simmons, Lexington, Ky.; got by Betterton, son of George Wilkes: dam Ill Wind, bred by W. L. Simmons, got by Young Jim, son of George Wilkes; 2d dam Caro Nomo, bay, bred by A. Welsh, Philadelphia, Penn., got by Hambletonian ; and 3d dam said to be by Doble's Black Bashaw, son of Young Bashaw. Sold to Brook Curry, Lexington, Ky.; to Thomas Savidge, Spring Lake, Mich. Pedigree from breeder.

Sire of 5 trotters $(2: 101 / 2), 2$ pacers $\left(2: 12 \frac{1}{4}\right)$.

\section{GEORGE SHERWOOD. Untraced.}

Sire of Marshal T., $2: 29$.

GEORGE SIMMONS (I-256), $2: 28$, bay; foaled I 884 ; bred by Ephraim Young, Keene, Ky.; got by Simmons, son of George Wilkes: dam Crip, bay, bred by R. H. Stanhope, Lexington, Ky., got by Mambrino Time, son of Mambrino Patchen ; 2d dam Bett, said to be by Regular, son of Volunteer; 3d dam by Profit, son of Profit; and $4^{\text {th }}$ dam by Commodore. Sold to Al. Spottswood, Lexington, Ky.; to C. H. Creighton, Omaha, Neb.; to J. T. Ware, Cynthiana, Ky., who sends information.

Sire of 5 trotters $(2: 123 / 4), 3$ pacers $\left(2: 19 \frac{1}{2}\right)$. 
GEORGE SPAULDING. Said to be by Columbus.

Sire of Simmie, $2: 163 / 4$.

GEORGE SPRAGUE (I-I6), gray, I6 hands; foaled I875; bred by Wm. Babcock \& Son, Canton, Ill.; got by Gov. Sprague: dam Jenny Lind, white, foaled $186_{3}$, bred by George IV. Collins, Fairmount, Vermilion County, Ill., got by Good Ike ; 2 d dam Fanny, said to be by Cherokee. Pedigree from breeder.

Sire of 9 trotters $(2: 15 \%), 3$ pacers $(2: 18) 4$ sires of 2 trotter 5,2 pacers; 6 dams of 5 trotters, 3 pacers.

GEORGE STANTON ( $1-32)$; said to be by Gen. Stanton.

Sire of 2 trotters $\left(2: 24^{1 / 4}\right)$, I pacer, $2: 201 / 4$.

GEORGE STECK, chestnut, three white ankles; foaled 1879 ; bred by Tom L. Sydner, Mt. Sterling, Ky., got by Strathmore, son of Hambletonian: dam Nell, bay, bred by Richard Stofer, Mt. Sterling, Ky., got by Berkley's Edwin Forrest, son of Edwin Forrest; 2d dam Lady Turner, gray, bred by Hon. Thomas Turner, Montgomery, Ky., got by Mambrino Chief, son of Mambrino Paymaster; 3d dam said to be by Gray Eagle; and $4^{\text {th }}$ dam by Sir William Wallace, son of Bolivar. Died I902. Pedigree from breeder.

Sire of I trotter $2: 241 / 4,2$ pacers $(2: 18)$.

GEORGE W. ( I-I6), bay; foaled I 880 ; bred by Dr. W. S. Norris, Baltimore, Md.; got by Orange Blossom, son of Middletown: dam Lady Bashaw, said to be by Bashaw Jr., son of Bashaw ; 2 d dam Flora, chestnut, bred by Dennis Osborne, Newark, N. J., got by Blue Bull.

Sire of Allen $\mathcal{F}_{\text {., } 2: 221 / 4}$.

GEORGE WASHINGTON. Untraced; said to be owned in New Hampshire.

Sire of the dam of Larobe, $2: 261 / 2$.

GEORGE WASHINGTON (I-8), black; bred by a Mr. Eads, New England; said to be by Ethan Allen, son of Black Hawk : dam Eads' Mare. Died the property of W. Naylor, Washington, D. C., Jan. 20, I 878 .

Sire of 2 trotters $(2: 25)$.

GEORGE WASHINGTON (5-128), 2 :I63/4, bay, hind feet white, 16 hands, I 200 pounds; foaled I 886 ; bred by Thomas Smith, Vallejo, Solano County, Cal.; got by Mambrino Chief Jr., son of McDonald Chief, by Clark Chief : dam Fanny Rose, bred by Patrick Dillon, Benicia, Solano County, Cal., got by Vick's Ethan Allen, by Ethan Allen Jr. (sire of the dams of George Washington, $2: 20$, and Bessie S., $2: 29 \frac{1}{4}$, also of Lynwood, sire of Lynette etc., three-year-old record $2: 25 \mathrm{~T} / 2$, also sire of Prince Allen, $2: 27$ ), son of Ethan Allen; 2 d dam Jenny Lind (dam of 


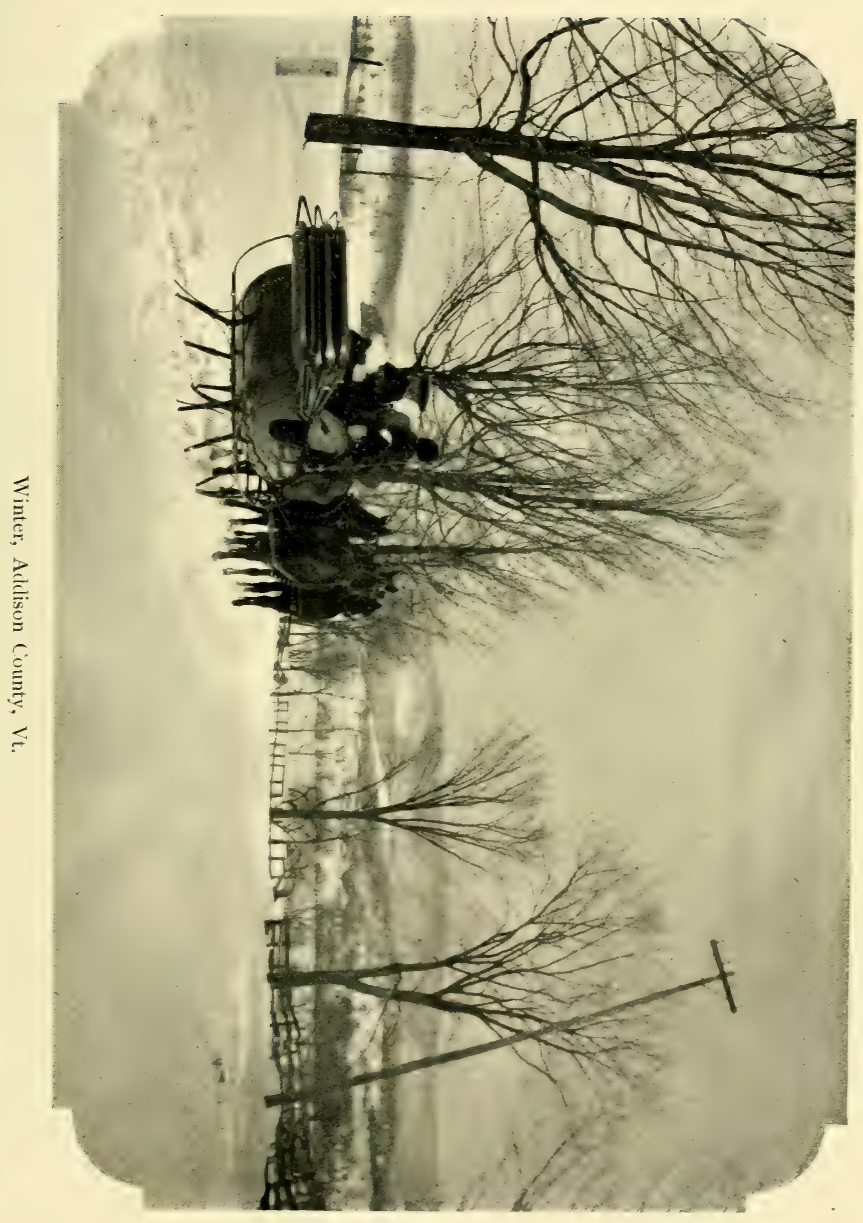




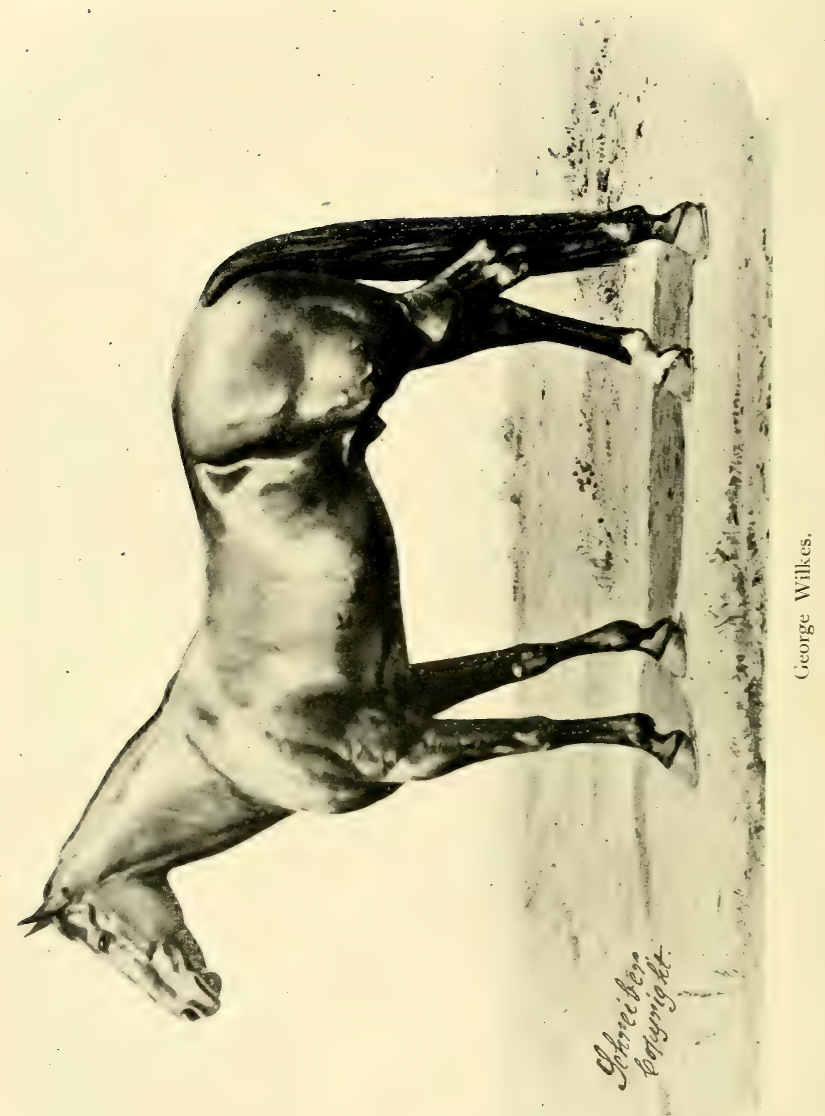


Prince Allen $(2: 27)$, bred in Kentucky and foaled in Solano County, the property of Mr. Harribel, who bought her dam from the man who brought her out, said to be thoroughbred. She has a record of $1: 52$, run without any professional training. Kept at Vallejo in I889. Pedigree from breeder. Advertised by Thomas Smith, Vallejo, Solano County, Cal.

Sire of 2 trotters $\left(2: 15^{1 / 2}\right)$.

GEORGE WASHINGTON ( $\mathrm{I}-64$ ) pacer; said to be by Stephen Slasher, son of Pointer Slasher, by Mountain Slasher. Information from Capt. M. C. Campbell, Spring Hill, Tenn.

\section{GEORGE WASHINGTON. Untraced.}

Sire of Harry Van, $2: 22 \frac{1}{4}$.

GEORGE WASHINGTON. Sale of horses at Springfield, Mass., Nov. 5, I 853 .

"George Washington a large three-year-old colt, by Cassius M. Clay, sold to Plainfield, N. Y., for $\$ 550$. White Mary the dam of Cassius M. Clay, Mr. Bolton, \$400. American Eagle, stallion, a splendid horse, bred at Flushing, L. I., \$I 450.

Coburgh, Can."

D. E. Bolton.

GEORGE W. DAVIS, $2: 26 \mathrm{~T} / 4$, bay, I 6 hands, I 25 pounds; foaled 1878 ; bred by E. Hamilton, Toledo, O.; got by Glencoe Golddust, son of Golddust : dam brown, said to be by Sykes Morgan (Eastman Morgan); and $2 \mathrm{~d}$ dam Canadian. Sold to John Pickett, Toledo, O.; to Wm. Cottrell, Mt. Clemens, Mich. Pedigree from R. J. Wheeler, who writes :

Toledo, O., April 29, I 878 .

Dear Sir :-Your favor received this A. M. I cannot fill blank giving much information about the breeding of the dam of Davis. I have seen her often, a $\mathrm{I}_{5}$ hand typical Morgan, brown, compact, game, resolute and a strong, sound mare when 17 or 18 years old. Every colt she ever raised could go some, and two, George W. Davis, $2: 26 \mathrm{~T} / 4$, and Nasby, $2: 40$ trial $2: 26$, were natural trotters. Hamilton moved to Kansas some years ago. Kent Hamilton, Mayor of Toledo, is a relative and can give you his address. I sold Davis to one Wm. T. Campbell, who bought for Wm. Cottrell of Mt. Clemens, Mich. Glencoe Golddust (Locke's), is in Wallace's Register where the horse's exact age is on record. The Sykes Morgan was a horse owned near Akron, Summit County, O., and one Dr. O. J. Carter, V. S., now living in Toledo, tells me the Sykes Morgan was a grand horse and his colts were all good. I am sorry I cannot give you more and positive information about these two horses' dams. Anything more you may wish to know about the horse I will do all in my power to help you.

Yours truly, $\quad$ R. J. WHEELER.

GEORGE WILKES (ROBERT FILLINGHAM), 2:22, brown, right hind ankle white, ${ }_{5}$ hands; foaled 1856 ; bred by Harry Felter, New- 
burgh, N. Y. ; got by Hambletonian, son of Abdallah : dam Dolly Spanker, brown roan, $15 \frac{1}{2}$ hands, purchased of Edward Gilbert, Phelps, N. Y., for John S. King, Geneva, N. Y., by J. S. Lewis, Geneva, N. Y., and afterwards sold by J. S. Lewis, for Mr. King, to Mr. Delevan one of the proprietors of the Welch \& Delevan Circus, New York, N. Y., who sold her to Harry Felter. The following correspondence gives practically all that is further known about this mare.

\section{FROM THE MIDDLEBURY (VT.) REGISTER OF JULY 29, I 892 .}

THE DAM OF GEORGE WILKES. IS HER BREEDING KNOWN?

In a recent issue of The New York Sportsman appears the following letter :

Phelps, N. Y., April i 8.

"The dam of George Wilkes has been accepted as a daughter of Henry Clay, and the world reads it that way. Still those that owned Dolly Spanker here do not believe it and never will. The mare was once owned here and under the conditions the following facts will be of interest :

"About I 845 Edwin Beardsley and Edward and James Gilbert were located at this place running a distillery. They had work for a number of horses, and in I 850 or thereabouts James Gilbert took a trip to Pennsylvania and bought three or four head. One of the purchases was a brown mare named Dolly Spanker, who afterwards produced George Wilkes. The mare was brought to Phelps and was like all of the other property owned in common by the Gilbert Brothers and Beardsley, who was their brother-in-law. They kept Dolly Spanker about a year and sold her to Captain Joseph Lewis of Geneva, N. Y., for \$80o. This was a tremendous price for a horse in those days. So far as I can learn Mr. Lewis purchased Dolly Spanker for John S. King, a New York gentleman that was building a branch of the Erie road from Elmira to Canandaigua. Mr. King used Dolly Spanker as a road mare and when his contract was completed he turned her over to Joseph Lewis to dispose of. Mr. Lewis sold her to Mr. Delevan of New York. He was one of the proprietors of the Welch \& Delevan circus. He took the mare to New York and after a time she passed into the hands of the Felters.

"Edward Gilbert has been dead some time, but James Gilbert is still among us and in good health. I have talked with him many a time, and he has stated the story over and over as I have related it. I questioned him closely so as to learn whether he or his brother ever bought any horses of the Phillips family in the town of Bristol, N. Y., and he always replied that neither he or his brother ever bought a horse of any kind of any body by the name of Phillips.

"Mr. Edwin Beardsley is alive and well. He lives here in Phelps and is a wealthy, straightforward business man. I see him every few days and he endorses everything that James Gilbert says. Mr. Beardsley tells me that he has a distinct recollection of Mr. Gilbert bringing this mare Dolly Spanker home from Pennsylvania. Also that he had an interest in her. He drove her frequently and also states that she had been gone from here only some nine or ten years when the report came 
back that a young stallion from her had beaten Ethan Allen in a match race for $\$ 5000$ a side. That he said brought everything fresh to his mind. Now here are two living witnesses that can certify that this mare was picked up in Pennsylvania. James Gilbert's address is No. I57 Seventh street, Buffalo, N. Y., and Mr. Beardsley can be found here.

"I have had several talks with Joseph Lewis about this mare Dolly Spanker. He tells the same story over again about the Simmons Brothers writing to him soon after the race between Wilkes and Ethan Allen, asking for information in regard to the breeding of Dolly Spanker. He told me on different occasions about his sending John Dey to trace her, that he traced her to one Clark Phillips of Bristol, N. Y., and reported that she was by Henry Clay. Mr. Lewis went on to tell me what this man Clark Phillips told John Dey, and finally Lewis said to me that Phillips told two different stories about his breeding Dolly Spanker. I asked him to explain to me what the other story was, but I failed to draw him out.

"Edwin Beardsley and James Gilbert both state that during the search by Dey, nobody ever came to them for any information in regard to this mare. The search took place in the fall of 1862 .

"Now a few words about remarks made by John Dey. Late in the fall of 1862 a gentleman by the name of Harrison Prosser of Montezuma, Cayuga County, N. Y., told the writer that Dey told him there was no telling what the breeding of this mare in question was. He also stated that they had reported that she was by Henry Clay, thinking it would please the owners of George Wilkes, on account of the popularity of George M. Patchen. Only last June, John Dey was employed by the Kite Track Association at Newark, N. Y., and while there he told Charles E. Leggett, that it was all a humbug about the dam of George Wilkes being by Henry Clay. He further stated that she was a transient mare and nobody knew anything of her breeding. Leggett told the writer that Dey commenced and told this story of his own accord. Dey was at the bottom of the story that the dam of George Wilkes was got by Henry Clay, and now he comes out and states that this is false. This man Charles E. Leggett is the treasurer of the Kite Track Association at Newark, N. Y. He is also a hardware merchant and a very reliable man.

\section{SMith FeEk."}

This letter is very striking for the force and clearness of its statements and because it gives all names, dates and addresses relevant to the matter, has a date and location of its own, and withal a man's name at the end. It impressed us so seriously that we at once, April 29 last, addressed the following queries to Mr. Edwin Beardsley, Phelps, N. Y., and received on the same paper the following replies and comments in the hand and over the signature of Mr. Beardsley:

\section{Ques.- "Of whom and in what town in Pennsylvania was Dolly Spanker purchased?"}

Ans.- "The mare Dolly Spanker was bought in Pennsylvania, but in what town I cannot say, or the man's name that she was bought of:"

Ques.- "What did you do with her, that is, to whom did you sell?"

Ans. - "Sold her to Joseph Lewis of Geneva, N. Y., for John S. King, railroad man, for $\$ 800$; after one year he turned her over to Lewis to sell again and he sold her the second time, to Mr. Delevan of New 
York, he to the Felters of Newburgh. Heard nothing more about the mare for ten years, then after the trot of George Wilkes, her son, as I understand it, they sent up here for Joseph Lewis to look up the pedigree and he sent out a lackey jockey to look it up; and the yarn he got up is all bosh, not a word of truth in it; found a man by the name of Phillips that had a Clay stud that wanted to claim her as his stock and the thing was cooked up. I don't know' of any man living that knows the sire of Dolly Spanker. She was bought in the woods as it were in North west Pennsylvania by James Gilbert, my brother-in-law, and I had an interest in her; cost $\$ 80$, with the saddle thrown in, was a wonderful roadster. I have thought she may have been stolen from some breeding farm south of where we got her."

Ques.- "What was the name of her sire and his breeding?"

Ans.-_I have no knowledge."

Ques.- "Please fill enclosed blank with pedigree of Dolly Spanker and tell us all you can about the history of this famous mare."

Ans.- "James Gilbert is living; his address is 157 Seventh St., Buffalo. I talked with him two years ago; he does not remember the town where they got the mare or the man's name they had her of. There was a horseman with him by name of Holiday, and I think they bought eight or ten head, and we took Dolly Spanker for single driving, and she was a good one. If anything further, should be pleased to answer. I think it was about $185^{\circ}$ instead of 1845 .

\section{Yours, E. BEARdSLEy."}

The above is verbatim and the italics are Mr. Beardsley's. We had suggested 1845 as about the time of purchase in introducing the question.

At receipt of this letter we addressed Mr. James Gilbert on the subject and received the following reply:

Mr. J. Battell,

I5 2 Seventh St., Buffalo, May i i, I892.

Dear Sir:-Having been out of sorts for the last two weeks $I$ have neglected to answer you as soon as I otherwise should. In I850 I was in partnership with my brother-in-law and my brother in Distilling and Dry Goods. I having been a farmer they thought I knew more about horses, cattle, hogs and sheep, than they did, so it fell on me to look after the Distillery. I bought Dolly Spanker in Southern Pennsylvania in the year 1850 . My brother sold Dolly Spanker to J. S. Lewis for J. S. King in Geneva; it was a price that would not have bought her of me for I knew too well of her speed, which my brother did not know. Dolly Spanker was a brown mare between a light and very dark brown with a black mane and tail. She had fine points and was a splendid driver, she stood $\mathrm{I}_{5}$ hands three inches, as to her pedigree, I did not ask, and I do not think I asked the man's name.

Yours respectfully,

James Gilbert.

Under date of May $2 \mathrm{r}$, last, we addressed to Mr. James Gilbert the following questions, which were returned with the answers written below :

Middlebury, Vt., May 21, I892.

Mr. James Gilbert, 152 Seventh St., Buffalo, N. Y.

Dear Sir :-Your esteemed favor of the I Ith inst., concerning Dolly Spanker, is at hand. As I propose to make a further effort to trace her 
and learn her origin, I will be greatly obliged if you would answer the following questions, on this paper and return to me.

$$
\text { Truly yours, Joseph BATTELL. }
$$

Ques.-Can you tell the town in Pennsylvania where you bought Dolly Spanker? If not, can you give the county and near what large towns and in what direction from them?

Ans.-I was traveling from Meadville towards Erie, I should think, I 5 miles from Meadville in a heavy timbered country, houses and barns were principally built of logs, I cannot give the town or county.

Ques.-Mr. Edwin Beardsley writes that "She was bought in the woods as it were, in North Western Pennsylvania." I understand you bought her in Southern Pennsylvania. Is he mistaken?

Ans.-No.

Ques.-What sort of a place was she bought from by you-whether from a farm or on the road or out of a stable or where?

Ans.-I met the man on the road.

Ques.-For what was she being used when you bought her?

Ans.-Do not know.

Ques.-How old was she when you bought her?

Ans.-The man said she was six years old, I do not think she was older.

Ques.-What did you pay for the mare-and did you buy anything with her?

Ans.-I paid seventy-five dollars for the mare, saddle and bridle.

Ques.-Did she have the name Dolly Spanker when you bought her, or was it given to her afterwards?

Ans.-No the man called her Dolly, I do not know where the Spanker came from. of?

Ques.-What appeared to be the occupation of the man you bought

Ans.-I should think by his looks a farmer.

Ques.-About how old a man was he-and can you describe him?

Ans.-I cannot, I should think by his looks a man about forty, as I remember him. her?.

Ques.-Were there any marks on the mare that would help identify

Ans.-I do not now remember any.

Ques.-Did you learn from the man you bought of, whether he raised the mare or how or where he got her?

Ans.-I did not.

Ques.-Was the mare well trained to buggy or to saddle, or both, when you got her?

Ans.-All I knew of the mare was what I saw of her under the saddle. The man said she was good to wagon and kind and gentle.

Ques.-Any other information that may serve to locate the region where you bought her.

Ans.-None.

\section{FROM THE MIDDLEBURY (VT.) REGISTER OF}

AUGUST 5, I892.

The alleged discovery of the commonly accepted pedigree of Dolly Spanker rests upon the evidence and deductions following: In the 
issue of Wallace's Monthly of February, 1878, under the title, "The Dam of George Wilkes Found at Last," the editor announces his discovery. He begins by saying, in substance, that in December, 1877 , at the dinner of the Breeders' Association at Delmonico's, he found himself in conversation with Mr. Felter and Mr. Simmons, the one the breeder, the other the owner of George Wilkes. That they expressed themselves hopeless of ever finding the pedigree of Dolly Spanker, but he said, if Mr. Felter would let him know of whom he got the mare, he would undertake to find her pedigree. Mr. Wallace proceeds as follows :

"From his old books Mr. Felter informed us that he got the mare from Mr. W. A. Delevan, and that Delevan got her from Mr. James S. Lewis of Geneva, N. Y., who, some twenty-five years ago had been of the firm of Lewis \& Cobb, of that town. Supposing it probable that Mr. Lewis might be dead, or removed from Geneva, we addressed a note to him or his representatives, and enclosed in it a note to the postmaster. By return mail we had a cheerful pleasant letter of Mr. James S. Lewis, assuring us that he was still living and able and willing to answer all questions that were presented to him to the best of his ability. It was the letter of a very intelligent business man, without the least indication of the tremulousness or forgetfulness of age. In it he says :

"Some twenty-six years since I bought a brown mare of a gentleman by the name of James Gilbert, then living in the town of Phelps, in this county, for a friend, and very soon after sold her to W. A. Delevan of New York. She was then about five years old, a fine roadster, and could speed in about $3: 30$. He took her to New York, and after driving her some time sold her to my esteemed friend Harry Felter. I think she passed into the hands of his father and met with an accident. She was bred and had a colt, by Hambletonian, that grew up to be the famous George Wilkes. For the benefit of many persons in New York I lost no time in looking about to learn the pedigree of the mare and of the horse that got her. On seeing Gilbert I learned that he got the mare of an old man, who is now dead, by the name of Josiah Phillips of Bristol, in this county. I lost no time in sending a man who lived with us at the time, by the name of John S. Dey, to Bristol to get all the facts in the mare's pedigree that he could get hold of. He learned through Phillips that the father of this mare was the old Wadsworth Henry Clay, owned for many years by General Wadsworth of Genesee. There is no mistake about this, as I have since learned from his neighbors that she was a Clay colt. Phillips further stated that the mother of the mare was got by a horse called Highlander, a good horse, and owned in that section of country. I have no doubt about this, as there was such a horse in that section about that time. This is all I am able to give you in regard to the pedigree of the Felter mare at this time. When I go to Buffalo, where Gilbert now lives, I may be able to get at more facts in regard to your inquiry and if I can get hold of any thing that will give you more light on the subject before I am down to New York, I will drop into your office to see you.

Very truly yours, etc., J. S. LEwis.'

"The receipt of this letter, so straight-forward and clean cut in its statements, developed a mystery that was incomprehensible to us. 
Dates, names, places, circumstances, all stand out as evidences of the truth of the representation, and also as evidences that Mr. Lewis had fully investigated the matter and given the results of his investigations to his friends in this city; still those friends had never heard the facts, or had entirely forgotten them. How could Mr. Lewis know these things so well and yet all the writers who had undertaken to enlighten the world about this horse for fifteen years fail to know any of them? Was Mr. Lewis untrustworthy, or were the writers and owners of George Wilkes and his dam, unaccountably stupid? Here was a dilemma and in order to determine which horn to take, we resolved to test the accuracy and reliability of Mr. Lewis' statements from a starting point entirely independent of him. Bristol, where the mare was represented to have been bred, is some twenty or thirty miles from Geneva, the place of Mr. Lewis' residence. Fortunately, our esteemed friend, Mr. John P. Ray, secretary of the Sheep Breeders' Association, lives at Honeoye, not very far from Bristol, and we knew there was no more competent or reliable gentleman in the State to look after the matter. We submitted the facts to him, as they appeared from Mr. Lewis' statement, and what he did and how he did it we will give in his own words :

J. H. Wallace, EsQ.,

Honeoye, N. Y., Jan. I, I 878 .

"'Dear Sir :-Your favor of Dec. 28 reached me in due course of mail and I determined not to let this case rust on my hands; so, despite the cold and stormy weather and the extremely rough and unfavorable roads, I started yesterday to make the trip to Bristol to investigate the pedigree of the dam of George Wilkes. On my route I stopped at Honeoye, and booked as my companion for the journey J. C. Paul, a horseman of large experience and thorough knowledge of all the leading horses that have been kept in this section for the last forty years, and a man whom we believe to be entitled to the utmost confi-
dence.

"We found him just the man we wanted when we got to the Highlander cross in the pedigree of the mare under consideration, as he has a thorough knowledge of this family of horses. We first drove to the residence of Mr. E. V. Phillips, nephew and adopted son of Mr. Joshua Phillips (not Josiah as you have it, as no man by that name ever lived in Bristol, as I can learn), now deceased. This gentleman was not at home, and we were obliged to drive two miles farther to Bristol Center, in order to see him. We learned from him that he had always lived with his uncle (Joshua Phillips) from early childhood, and while he was not positive that he could recall and individualize the horses bred and owned by his uncle since he became of years to note such matters, yet he was very positive with regard to the horses that were got by Henry Clay. One of them was a black stallion, another a gelding, called Blueskin, another gelding somewhat peculiar in color, by some called roan, and others a gray; this one was sold to Mr. Munger of Canandaigua; the fourth and last Clay was a mare. This mare and the gelding last named were purchased, when young, of Mr. Clark Phillips, who bred them. The mare was purchased by Mr. E. V. Phillips when a yearling, and kept by him until four years old, and was then sold to his uncle Joshua, and he sold her the next year to some man from the eastern part of the country, but the name of the party he could not recall. He remembered her as a mare about fifteen hands two inches high, and of a dark bay color, with white hair mixed all through her coat, making 
her a sort of roan. Her dam was called old Telegraph, a mare fifteen and one-half hands and upwards in height, and of very dark bay or brown color, and noted as a great roadster. Several other parties who were present at the interview remembered old Telegraph, and all had a good word to say of her. We next drove to the residence of Clark Phillips, and again were obliged to drive two miles farther, to Baptist Hill, in order to reach him, and the following is his statement: "I bred two colts from Henry Clay while he was owned by Kent \& Bailey of this town; one a horse colt and the other a mare. The mare was sold to E. V. Phillips and by him sold to Joshua Phillips, who in turn sold her to some party east of here. Her dam was a brown mare bred by me called old Telegraph; she was got by the Baker Highlander from a bay mare of unknown blood." The Clay mare in question he remembers as a brown roan in color. For the history and description of the Highlander horses that figure in this pedigree we are indebted to $\mathrm{Mr}$. Paul, than whom no man is more competent to speak. The Baker Highlander was bred by Arch. Humphrey of West Bloomfield, N. Y.; was a bay horse about fifteen hands one inch; was got by Paul's Highlander from a mare by Young Lion, who was by Defiance, from a mare said to be an English thoroughbred, that was driven by Parson Steele of East Bloomfield a hundred miles in a day.

" Paul's Highlander was bred by Zebedee Paul of West Bloomfield, now deceased, and was by Highlander, from a mare by Bold Richmond. Paul's Highlander was a beautiful blood-bay color, black points, and nicely finished in every part, and stood fifteen hands three inches in height. He won the first premium at the first fair of the Ontario County Agricultural Society, and was once driven fiften miles with two in a wagon in an hour's time. Highlander was brought from Massachusetts, according to tradition, about the year I 825 , by Thomas Kellogg of East Bloomfield, and was represented to be a son of Morgan, the founder of the Morgan family of horses. He was a blood-bay, black points, about I 5 hands one inch in height.

" "When Henry Clay was being brought from the East to his home in Western New York, he stopped one night at the hotel then kept in Bristol by Mr. Durgan, deceased (the breeder of Castle Boy), and made a season at this place the following year, when he became the property of Kent \& Bailey. He was kept in that town for some years, and then was sold to Cummings \& Sayles. He afterwards became the property of our genial friend, Fred Fellows of Chili, Monroe County, N. Y., and was sold by him in his old age to parties near Ovid, where he died in very advanced years. Clark Phillips thinks he will be able to learn the name of the party to whom Phillips sold the Clay mare. If he can fix it as Gilbert at the end of the line, then the links of evidence, which are now all connected, will be verified, and the pedigree of the dam of Wilkes will be ironclad in all its details. What he writes I will submit to you at once.

John P. Ray.'

"Here we have the whole matter in a shape that is clear, distinct and unmistakable. All the essential facts, and the circumstances sustaining them are given in an intelligent and conclusive form. The mare was bred by Clark Phillips, sold as a yearling to E. V. Phillips, and when four years old, to his uncle, Joshua Phillips, and by him the next year to a man in the eastern part of the county, name not remembered. At this point Mr. Lewis supplies the deficiency, and shows it was to James 
Gilbert, then of Phelps, that the mare passed from Joshua Phillips. We have not yet reached Mr. Gilbert; but as Mr. Lewis' evidence is fully sustained at every point by the facts, as known to the Phillipses, and as there is no discrepancy in their several statements, Mr. Lewis' evidence fully supplies the link that is missing in the evidence of Phillips. The statement of Gilbert would make the matter more complete, but we consider it fully established, either with or without that statement. Clark Phillips not only bred her dam, but he bred her $2 \mathrm{~d}$ dam also, old Telegraph, as she was called, and well known in the vicinity. This mare, Telegraph appears to have been a rare good one, as Mr. Ray says, everybody knew her, and had a good word for her. She was got by the Baker Highlander, a son of Paul's Highlander, and he by the original horse of the name, taken to East Bloomfield by Thomas Kellogg about r825. The grandam of Wilkes, Mr. Clark Phillips says, 'Was a bay mare of unknown blood.'

"It will be observed that, with the exception of Mr. Lewis using the name Josiah instead of Joshua, not an unusual mistake, there is entire harmony between Mr. Lewis' statement and the facts as Mr. Ray found them upon personal investigation on the ground. The identity of the sire, old Henry Clay, by Andrew Jackson, is fully established by the ownership, location and other facts that are well known to the public.

"There remains, therefore, not a single shadow of doubt that Dolly Spanker, the dam of George Wilkes, was by Henry Clay, and her dam by Baker's Highlander. We think we can safely assume to represent the entire breeding public in tendering special thanks to Mr. John P. Ray and Capt. J. S. Lewis for their prompt and successful services in bringing to light so important a fact in the horse history of the country."

In August, I888, of the Monthly, Mr. Wallace again refers to this pedigree, as follows :

"In a sketch accompanying a picture of the famous trotting horse, Joe Bunker, that appeared in the Sportsman for July 7, the writer has fallen into a very grave error in relation to the dam of George Wilkes. He says: "There was a discovery, or pretended discovery, long after George Wilkes had become famous, to the effect that his dam was a daughter of Henry Clay. I am, of course, unable to prove that she was not, for her pedigree was unknown to me, but I do not believe it. Before Judge Felter died he told me all about this mare, Dolly Spanker. It was that she had been driven for years by Mr. Welch of Philadelphia, not the breeder of Parole, Iroquois, etc, etc., but the great circus proprietor, with whom we were both intimately acquainted. Mr. Welch gave her to Mr. Harry Felter and he sent her to his father to be bred to Hambletonian. Dolly Spanker had the brown colt, George Wilkes, and died soon after foaling. Years elapsed before any one ever heard about the Clay blood in this mare, and in my opinion it is nothing but a late invention, similar in kind to the audacious fraud attempted when Dexter was proclaimed to be a son of Harry Clay.'

"We are sorry that 'Privateer's' memory seems to be failing him. It is but a little while since the 'Turf' kicked up quite a row about this pedigree and it was taken before the Board of Censors, who decided unanimously and without hesitation that Dolly Spanker, the dam of George Wilkes, was by Henry Clay and her dam, Telegraph, by Baker's Highlander. Since then the Turf, the owners and everybody else, so far as we know, except Privateer, has accepted the pedigree as fully and 
clearly established. We feel sure that he thus stands all alone because he has forgotten the circumstances of the controversy. We will therefore give the essential facts that were developed in the investigation."

Here follows a re-hash of the matters stated in the article from the Monthly of February, 1878 , above quoted, somewhat colored to favor the result there reached. A characteristic touch is where the genial author changes the statement of E. V. Phillips, that his uncle Joshua sold the mare "to some man from eastern part of the country," thus: "Nobody could remember to whom he sold the mare further than it was to some man in the eastern part of the county." As Phelps is one of the eastern towns in Ontario county (the county in question) this little stroke was peculiarly happy. The eastern part of the country indicated a long way toward the rising sun from where Lewis found her. Leaving out the $r$ and he located her exactly.

The latest evidence that can be cited in favor of the Clay theory is a letter from Clark M. Phillips to John P. Ray, published in a recent issue of the American Horse Breeder, as follows :

JoHn P. Ray, Esq.,

Bristol, Ontario Co., N. Y., Nov. 28, is9i.

"Dear Sir :-Answering your inquiries of recent date I will say that I bred a brown roan filly which I sold when three years of age to E. V. Phillips of this town. He broke her and sold her to his uncle, Joshua Phillips. This filly was got by old Henry Clay (the Wadsworth Horse) when he was owned by Bailey Bros. Her dam was the mare Telegraph, bred by me, and got by Baker's Highlander.

"I do not know who bred her second dam or what horse was her sire. My brother, Phineas, traded and got her of a party whose name I cannot recall, that lived at or near Blood's Corner, N. Y. She was represented to him as being a running mare brought from England. English people who saw her told me that she represented the English thoroughbred. - From her make-up and disposition I always fancied that she might have been a thoroughbred mare.

"Telegraph inherited much of her dam's high-strung, nervous temperament. I paid $\$ 5$ for the service of Henry Clay and the same amount for the service of Baker's Highlander. Telegraph could outrun and out-trot any horse in these parts. She would not draw heavy loads. She was an excellent saddle mare and a single driver. At the time of her death she was owned by Orestes Case of this town and was in foal to Gooding's Champion. She broke a leg and had to be destroyed.

"Both Telegraph and her dam had nice clean limbs. You gave me the first intimation that the brown roan mare first named was the dam of George Wilkes, and you are the only one to whom I have made a statement concerning her pedigree since she left these parts. She was never known or represented hereabouts as other than a daughter of Henry Clay and Telegraph." Yours truly, Clark M. Phillips.

It will be borne in mind that Mr. John P. Ray was the gentleman who made the trip to Bristol at Mr. Wallace's request. There is not the slightest doubt but that Mr. Phillips' statement is candid and contains 
the whole truth. But it does not follow because he bred such a mare and she passed to Joshua Phillips and from him to some party east, that she was Dolly Spanker, the dam of George Wilkes.

The ascertained and established facts, aside from those stated by Mr. Clark M. Phillips concerning the bay roan or brown roan Clay mare, are these: the brothers James and Edward Gilbert, in company with their brother-in-law, Edwin Beardsley, at Phelps, N. Y., about 1850 , owned the brown mare Dolly Spanker, a noted roadster. About that time this mare was sold to J. S. Lewis for $\$ 800$ and she passed from him to John S. King; from him back to Lewis and from Lewis again to Delevan, of the firm of Welch \& Delevan, circus proprietors, and from them she passed to Harry Felter, breeder of Geoige Wilkes as above stated. The only question is whether this mare was, or was not the one bred by Clark M. Phillips. If so, we know her pedigree; if not, we know nothing about it.

On this all-important question, what is the evidence? To support it we have simply the statement of Joseph S. Lewis : "On seeing Gilbert I learned that he got the mare of an old man, who is now dead, by the name of Josiah Phillips." This is all there is of it. If Mr. Lewis is mistaken in this statement, there is not the slightest scintilla of evidence that the Phillips mare and Dolly Spanker were identical. The statement itself is a peculiar one. He does not indicate which Gilbert he saw.

He does not say positively that either Mr. Gilbert made any statement whatever about the matter to him. "On seeing Gilbert I learned," etc. Now Mr. James Gilbert positively states to Mr. Feek that neither he nor his brother ever made or ever could have made any such statement, because neither of them ever purchased any mare of any man by the name of Phillips; and obviously because there was never any doubt or question in the minds of either of them as to the mare's having been brought by James from Pennsylvania. The mare was owned by three partners. One is dead; two are living, respectable and responsible men. The one who bought the mare, brought her in and handled her more than any other until she was sold to Lewis, is here to testify. These gentleman can have no interest to misrepresent this matter.

No room is left for argument This ideal pedigree, combining as it did the three great trotting families, is shorn of its symmetry, and the dam of George Wilkes goes back to the great army of the unknown. If one in studying the breeding problem could have any legitimate object save the discovery and establishment of the truth, we could sincerely say that we regret that this pedigree turns out to be imaginary. But known ignorance, after all, is a far better basis for successful breeding than positive error. 


\section{FROM THE MIDDLEBURY (VT.) REGISTER OF SEPTEMBER I6, I892.}

Since the publication of the evidence in our issues of July 29 and Aug. 5 last, there has been no real question but that the pedigree attributed to Dolly Spanker, dam of this famous son of Hambletonian, is a mistaken one. It will be remembered that she is set down as having been bred by Clark M. Phillips, Bristol, N. Y., and got by Henry Clay, from Telegraph by Baker's Highlander. Also that this pedigree was "discovered" by John H. Wallace in an "investigation" conducted by

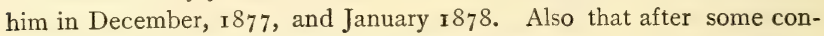
troversy, Mr. Wallace's "Board of Censors" gravely sat upon this pedigree and pronounced it good, since which weighty decision the pedigree has been generally accepted and used in all the registers and catalogues throughout the country.

The re-examination of the question at this time was commenced by a letter of James Feek in the New York Sportsman, which tended to show that Mr. James Gilbert and Mr. Edwin Beardsley, two of the three partners who first owned Dolly Spanker in Phelps, N. Y. (the other being dead), have all along stoutly denied that the mare was bred by Clark Phillips, and have always stated, and still state that she was bought by James Gilbert on an unfrequented road in Pennsylvania, of a man entirely unknown. The evidence published by us was the first public statement of these two gentlemen over their own names, and was so clear and circumstantial as to leave no reasonable doubt of its substantial accuracy, especially as both the gentlemen are indorsed as trustworthy citizens.

It will be recalled that Mr. Wallace began his investigation by writing to Joseph Lewis of Geneva, N. Y., who had purchased the dam of George Wilkes of Gilbert Brothers \& Beardsley in $185 \mathrm{I}$. From this point there never had been any question about the identity of the mare, or any trouble in tracing her. The peculiarity of the investigation was illustrated by the fact that, although the owners of the mare and the breeder and owner of George Wilkes assured the investigator that her pedigree was hopelessly unknown, he did not deem it necessary to communicate with the Gilberts; and this while the mystery had stood for a quarter of a century, and those first known owners were perfectly accessible. In the very first letter that Lewis writes to Wallace, he writes: "When I go to Buffalo, where Gilbert noze lives, I may be able to get at more facts, etc." $\mathrm{Mr}$. Wallace apparently made no effort whatever to communicate with $\mathrm{Mr}$. Gilbert, but naively remarks: "We have not yet reached Mr. Gilbert. The statement of Gilbert would make the matter more complete, but we consider it fully established either with or without that statement." In the apprehension of people not "entirely great," it would seem that 
the establishment of the matter might in some degree have been affected by the question whether Gilbert Brothers and Beardsley bought the mare of Joshua Phillips (to whom the Clay filly passed from Clark Phillips and who sold her to "some party in the eastern part of the country") or whether they picked her up in the woods in Pennsylvania. This question would have been solved by asking it, but it was not asked. On the other hand, the investigator seems to have relied on a most indefinite and unsatisfactory statement of Lewis as to what some unidentified Gilbert said to him, and which James Gilbert, for his part denies.

There was another fact that always seemed to have escaped the eye of the investigator. The Clay filly bred by Clark Phillips is described by him and everyone else that speaks of the matter as having been a roan in color. E. V. Phillips, who bought her of Clark and sold her to Joshua, described her to John P. Ray as of " a dark bay color, with white hair mixed all through her coat, making her a sort of roan." Clark Phillips, in his letter to John P. Ray, speaks of her as " $a$ brown roan filly." On the other hand, all who speak of the real Dolly Spanker, say that she was a brown mare. Joseph S. Lewis in his letter to Wallace (December, I877), writes: "Some twenty-six years since I bought $a$ brown mare of a gentleman of the name of James Gilbert then living in the town of Phelps, etc." James Gilbert in his letter, already published, describes her as a brown mare, between light and very dark brown, with black mane and tail.

Considering these matters, we addressed the following further questions to Mr. James Gilbert, Buffalo, N. Y., and received them back with the annexed replies in the hand of Mr. Gilbert and signed by him :

I.-Did the mare which you bought in Pennsylvania have any white hairs mixed through her coat, in other words, was she roan or inclined to be roan?

A.- She did not.

2.-Did you or your brother or Mr. Beardsley buy a mare about that time or any other time, of Joshua Phillips of Bristol, N. Y.?

A.-We did not.

3.-Did any of you gentlemen above named ever have any interview with Jos. S. Lewis of Geneva, N. Y., on the question of where you got the mare you sold him after the time when George Wilkes trotted or at any time after the sale to him?

A.-We did, and we tried our best to find out her pedigree.

4.-Did you ever answer any question as to the origin of this mare coming from Harry Felter, the breeder of George Wilkes, or from Simmons Brothers, his owners? And, if so, what did you inform them about the matter?

A.-I did not.

5.-Did you ever answer any such question or receive any question in the matter from John H. Wallace of New York or John P. Ray of Honeoye? If you received and answered any such questions, what was the substance of your answers in each case?

A.- - I did not. 
6.-Have you ever made any secret of this matter or refused to give the information to any one wanting it?

A.-I have not.

I57 Seventh St

(Signed) James Gilbert.

If there was any possible question on the evidence already published, we would have to stop here and ask whether a filly that is such a decided roan at three would have come out a clear brown without any white hairs at six.

But there are still further difficulties with this pedigree. Mr. Clark M. Phillips, who bred the Clay filly, and Mr. L. V. Phillips, who had her at three years old, have both failed to state what year she was foaled, although Clark M. has written us that he thinks the dam, Telegraph, was foaled about $\mathrm{x} 843$. There is nothing in this controversy to indicate that either of these gentlemen has been other than perfectly straightforward in the matter. They never made the claim that this Clay filly was the dam of George Wilkes, or thought or heard of such a thing, till Mr. Ray made the fact (?) known to them. And Mr. Ray got his information from Mr. Wallace.

But Clark M. Phillips, in his interview with John P. Ray, in December, 1877, said: "I bred two colts from Henry Clay while he was owned by Kent $\&$ Bailey of this town; one a horse colt and the other a mare." This was the mare in question. Again in his letter to John P. Ray, Nov. 28, I89 r, Clark M. Phillips says: "This filly was got by old Henry Clay (the Wadsworth horse) when he was owned by Bailey Brothers."

Now dates are dangerous things. The fact is that if George Wilkes was produced by this Clay filly bred by Clark M. Phillips while Henry Clay was owned in Bristol by Kent \& Bailey, or Bailey Brothers, he had the anomalous experience of being born before his dam. George Wilkes was foaled in $\mathbf{r} 856$.

Now, whether by design or accident, it is yet a fact that the history of Henry Clay, though comparatively recent and perfectly easy to procure, has never been written. His dates have been steadily ignored since the publication of this pedigree, so that, strange as it may appear, there is not extant a book, so far as we know, that gives the date of his leaving Long Island and going to his new home at Geneseo in Livingston county, Western New York. Since this question has been under consideration we have learned the leading facts in his history from the original sources. They are as follows :

Henry Clay, a black horse with star and right hind ankle white and werghing ro50 pounds, was bred by George M. Patchen of New Jersey and foaled in r837. He was sold by his breeder to Col. William W, Wadsworth, Geneseo, N.:Y., March 27, r845, for one dollar a pound, being \$ro5o; Col. Wadsworth kept him, using him mostly as a driving 
horse, till his own decease, after which, January $\mathbf{I}_{3}, \mathbf{1} 85_{2}$, he was sold by Col. Wadsworth's executors for $\$ 55$, to Nelson Thompson of Penn Yan, N. Y.

These facts stated in the last paragraph are furnished by Mr. W. A. Wadsworth of Geneseo, son of Col. William W., and the dates and figures are taken from the books of Col. W. W. Wadsworth and his estate. Mr. Wadsworth states that his father raced the horse once in Buffalo, but for some reason he was badly beaten. Mr. Thompson kept Henry Clay at Penn Yan about five years, as Mr. E. N. Owen of Penn Yan informs us. Mr. Thompson sold him about 1857 , and he was afterwards owned by Kent \& Bailey, Bristol, N. Y.; Manasseh Cummings, Honeoye Falls, N. Y.; Mr. Sayles, Scottsville, N. Y., who owned him in I862 and kept him in the fall of that year at Ovid. He then became the property of Fred Fellows, Chili, N. Y., who sold him May 26,1865 , to a company at Lodi, N. Y., of which Mr. D. L. Kase of Lodi was a member, and he had charge of the horse at Lodi the season of $\mathrm{I} 866$, when he got twenty-five foals, which were his last. He died the property of this company, April 2I, I867. These last facts and dates are furnished by Mr. D. L. Kase.

Now this record, though not yet entirely complete, shows that up to I 857 the only owners of Henry Clay had been George M. Patchen, Col. Wadsworth, and Mr. Thompson; so that whatever stock was bred from him while owned by any one else was bred after that time, and while George Wilkes was on earth.

Mr. John P. Ray (who has been very courteous in giving us such information as he could), in his letter to Mr. Wallace, January I, I878, says: "When Henry Clay was being brought from the East to his home in Western New York, he stopped one night at the hotel then kept in Bristol by Dr. Durgan, deceased (breeder of Castle Boy), and made a season at this place the following year, when he became the property of Kent \& Bailey." This information is shown to have been erroneous by the testimony of W. A. Wadsworth and the books of his father.

We do not know who gave it to Mr. Ray, but it would seem to have been manufactured to fit this very obvious and fatal gap in the dates necessary to the integrity of this pedigree.

There can be no doubt but that the dam of George Wilkes, Dolly Spanker, was in the hands of Gilbert Brothers and Beardsley in 1850 , believed by them to be six years old at that time. James Gilbert states positively that he bought her in 1850 , and the man he bought her of said she was six years old. Edwin Beardsley thinks it was r85o. J. S. Lewis, writing to Wallace in December, 1877 , says "some twenty-six years since he bought the mare." That would be $185 \mathrm{I}$, and that is no doubt the year he did buy her. And, as has been said, from that time forward there is no question as to her history.

These is no question what must be done with such a piece of work as 
this. Breeders can continue to put it in their catalogues if they desire to make a public display of their ignorance. Periodicals that claim to instruct breeders can ignore the question, shut their eyes to the fact, imitate the wisdom of the ostrich, and, sticking their heads in the sand, imagine themselves hidden. But they will not long continue to get a discriminating public to listen to their teachings. For it will not be long before every intelligent breeder of horses will know that this alleged pedigree was foisted on them by insufficient examination. And they will not stultify themselves by indorsing it after its exposure.

\section{FROM THE MIDDLEBURY (VT.) REGISTER OF NOVEMBER 4, I892.}

JOSEPH S. LEWIS INDORSES GILBERT'S STATEMENT.

It will be remembered that the theory that Dolly Spanker, dam of George Wilkes, was by Henry Clay, has always rested solely upon the statement of Joseph S. Lewis to John H. Wallace, to the effect that his man Dey had discovered that a certain roan mare bred by Clark Philips was the identical Dolly Spanker. We have already demonstrated that Mr. Lewis was mistaken in assuming the identity of the roan mare bred by Philips with the brown mare Dolly Spanker. It appears by the following article by Dudley Miller in the Horse World, with the appended letters, that Mr. Lewis himself now admits that his information, which he gave to Mr. Wallace, was erroneous. In fact, he had been informed, 'some time in the sixties,' by James. Gilbert, on special inquiry to that end, of the true origin of Dolly Spanker. This information seems to have escaped the memory of Mr. Lewis when he wrote his famous letter to Mr. Wallace, which lapse probably occasions Mr. Lewis' very commendable hope, expressed in his appended letter, that the memory of Gilbert and King 'Will be a little better' than his.

Dudley Miller in the Horse World :

"While attending the fall meeting of the Geneva Driving Club, at Geneva, N. Y., last month, I met Mr. Smith Feek, formerly with Henry C. Jewett \& Co. Mr. Feek interested me very much in what he considered an outrage on the breeding world, viz., the breeding of George Wilkes' dam, Dolly Spanker, as given in the American Trotting Register. I have since been spending a little time and trouble investigating the matter, endeavoring to get at the truth.

"Knowing Captain Joseph S. Lewis of Geneva, who, it is known, sold Dolly Spanker, I called on him Sept. 19, I892, and questioned him as to what he knew about the dam of George Wilkes, and the Captain, whom I have known for years, said, that in the 5o's John S. King a contractor on the Northern Central R. R., bought Dolly Spanker, a brown, blocky built mare, of James Gilbert of Phelps, N. Y. (now a malster of Buffalo, N. Y.) About six months after King bought the mare he completed his contract and employed him (Lewis) to sell her.

"He sold her for $\$ 250$ to William Delavan, a circus man, who took her to New York, and sold her to Harry Felter, a liquor dealer, whose 
place was on Broadway, a little below the Metropolitan hotel. Felter drove her on the road a year or two, when she got foot-sore from the hard streets, and he sent her to his father, Theron Felter, in Orange county, N. Y. Theron Felter bred Dolly Spanker to Hambletonian and she died in foaling the colt that was afterwards called George Wilkes, that was brought up by hand.

"Subsequently, at Felter's request, Capt. Lewis sent John Ray to a man by the name of Phillips, at Bristol, N. Y., to ascertain Dolly Spanker's breeding, as it was supposed that he bred her. Ray returned from Bristol after seeing Phillips, who said the mare was got by Henry Clay, a black horse owned by Mr. James Wadsworth of Geneseo.

"After this, Capt. Lewis said, there were rumors and doubts as to Dolly Spanker being by Henry Clay, and some time in the 6o's he called in Buffalo on James Gilbert to ascertain the mare's breeding.

"Mr. Gilbert told him that he bought her in northern Pennsylvania of a cattleman, paying $\$ 80$ for her, with saddle and bridle, that the cattleman knew nothing of her breeding, nor did he know any more.

"Capt. Lezris savs he believes that the pedigree, given to John Ray is wrong, and that Mr. Gilbert's is correct, that he knew Mr. Gilbert well and believes him to be an honest man.

"The captain advised me to correspond with Mr. Gilbert and also with Mr. John S. King, of Orange, N. J., which I have done.

"Herewith is Mr. Gilbert's reply and a letter received from Capt. Lewis subsequent to our interview.

$$
\text { Yours truly, DUdLeY Miller." }
$$

Mr. Dudley Miller, Oswego, N. Y.,

Buffalo, N. Y., Sept. 30, I892.

"Dear Sir:-Your letter of the 27 th came duly to hand, and, in reply, would say I saw in the American Horse Breeder of December I 2, 189I, purporting to be from Mr. Phillips, that I purchased the mare of him in the town of Bristol, Ontario county; that the mare was by old Henry Clay, owned by James Wadsworth. Now, if Mr. Phillips actually made this statement as the paper said he did, it is entirely false in every particular, which I am ready to prove if called on.

"Now for the answer to your questions : First, I claim the honor of bringing Dolly Spanker to New York State. I was in Northwestern Pennsylvania buying horses. I had a man with me named Holiday, who was brought up by Zeley, the old running-horse man in this State. We were riding along one day, I should think, about fifteen or twenty miles from Meadville. I looked up and saw a horse coming towards us. I said to Holiday: 'Here comes a horse running away.' 'No,' he said, 'it is trotting.' I said, 'I am going to stop that man.' I did so. I asked if he would sell the horse. He said, 'I will.' 'At what price?' I said. 'I reckon I will take \$roo.' I asked him if he would let my man ride her a little ways. He did so. Holiday turned off on a cross road; when he got back his face was as white as a sheet. The only thing he said was : 'Buy her; she is a ghost.' Well, I was so much of a gawk that I did not understand what he meant by 'I reckon.' I told the man I was buying to sell, that he wanted too much for her. He wanted to know how much I would give for her. I told him I would give $\$ 75$ for the horse, saddle and bridle. After a great deal of talk he sold her to me. The only thing I asked him was how old she was; he said she was coming six years old. In my opinion she was not any older. To 
describe her color, the best description I could give would be between a very dark and light brown, and no white on her except a very small star; she had very fine points, a fine head and mane and tail, and was one of the nicest drivers you ever saw. This mare, Dolly Spanker, my brother - who is now dead - sold to J. Lewis for John S. King for $\$ 800$. I saw when he got home he was riding with another mare. I asked him if the mare was dead; he said he had got her in his pocket; I told him he had not got the worth of the hairs in the mare's tail. Mr. Lewis knew very well he could not buy her of me for $\$ \mathrm{r}, 000$. As to pedigree, there is no man who knows it.

I 57 Seventh street.

Yours respectfully, JAMES Gilbert."

Mr. Dudley Miller, Oswego, N. Y.,

Geneva, Sept. 28, I892.

"I could only reiterate what I gave to you in full at my house some days since in regard to Dolly Spanker; as I told you, she was a brown mare; I think one white hind foot, weighed about s050; well put together, a fine driver, and I can't say whether I was present when King bought her of Gilbert or not, but I did sell her to Delevan, and he sold her to Harry Felter, and he sold her to his father, and all I told you about sending John P. Ray to Bristol was true, but when you get Gilbert's letter he will tell you the same story that he did to me. His full name is James Gilbert, Maltster, Buffalo. John S. King is at Orange, N. J., you had better write them both, and I hope their memory will be better than mine. Will be glad to help you all I can.

$$
\text { Yours truly, J. S. LEwIS." }
$$

Mr. Clark M. Phillips did not state that James Gilbert purchased this mare of him, or anything like it, as Mr. Gilbert would have seen, had he read Mr. Phillips' letter in the Horse Breeder, in addition to the comments thereon. Mr. Phillips' only material statement has always been that he bred such a roan filly (date not given) and sold her to E. V. Phillips.

It has been suggested that this question should be referred to the board of censors for final decision. This may be well, but it will be a somewhat amusing trial. On the one hand will be the evidence of Clark M. Phillips that at some time later than $\mathbf{x} 85_{2}^{2}$, when Henry Clay was owned by Kent \& Bailey, he bred a roan filly by him which he sold young to E. V. Phillips, who sold her when four to Joshua Phillips, and he sold her when five (I 858 or later) to some unknown party "from the eastern part of the country." The board will then gravely consider the question whether this roan mare was the brown mare in the hands of Gilbert in $185 \mathrm{I}$, then seven years old, sold that year to Lewis for King, driven that year by King and sold, 1852 , to Delevan, driven by him two years (1853-4) and turned over to the Felters, who bred her to Hambletonian in 1855 and produced George Wilkes, foaled in 1856 . Possibly at this point the board may be enabled to decide without calling Gilbert to state where he really did get Dolly Spanker, or Lewis to state that his information was erroneous. 
In view, however, of this remarkable statement in the letter of John P. Ray to Mr. Wallace: "When Henry Clay was being brought from the East to his home in Western New York he stopped over night at the hotel kept in Bristol by Dr. Durgan (the breeder of Castle Boy), and made a season at this place the following year when he became the property of Kent \& Bailey," we think it would be well for the board to take the testimony of Mr. W. A. Wadsworth of Geneseo, son of Col. W. W. Wadsworth, who owned Henry Clay, and have him bring the books of his father and his father's executors. We have already shown from these books that Wadsworth bought Henry Clay March 27, I845, and that his executors sold the horse January I3, I852, to Nelson Thompson of Penn Yan. We now append a letter from Mr. W. A. Wadsworth, showing that the above statement in italics bears the ear marks of some outside party.

Geneseo, N. Y., Sept. 29, I892.

Dear Sir :-Please excuse delay in answering, but had to get hold of several parties to be perfectly sure. There is no record that I can discover and all of whom I have enquired absolutely deny that the horse Henry Clay was ever let for service or ever covered any mares except at home while he belonged to my father.

What he did after he was sold I know nothing about.

$$
\text { Very truly yours, W. A. WADSWORTH. }
$$

Our information is that Henry Clay did not come into the hands of Kent \& Bailey till as late as I 857 , and if Clark M. Phillips ever gives the date of the foaling of the roan filly it will probably be later than that time. But the above evidence ought to satisfy the board of censors.

Of course censors or no censors, this pedigree is ended. We have no doubt, however, that the present board of censors of the American Trotting Register Association will cause the proper correction to be made. They are gentlemen of high standing, chosen by the association for the purpose of ascertaining the truth by fair judicial methods, on disputed pedigrees, without fear or favor, a duty which they will doubtless perform with fairness and ability. We could not have expressed the same confidence in the old board, which, so far as known by its works, would seem to have been a tribunal established to indorse the theories of the then proprietor of the Trotting Register, and did so on occasion at the expense of reason, decency and truth. Their decision sustaining the spurious pedigree under consideration is a fair sample of the value of their work.

As we have said, we should have been better pleased if on investigation this pedigree had turned out to be true. But we do not propose, for this reason to join the majority of our esteemed contemporaries in dodging the truth. The pedigree of George Wilkes is one of the most important in trotting horse history. This part of it came into being 
with a great flourish of trumpets, indorsed and re-indorsed by the originator and substantial author of the American Trotting Register, upon whose authority a vast majority of the earlier pedigrees recorded in that work depend. If this was a solitary mistake, it would be less serious. But we know it is a typical instance of the distortion of facts of which American breeders have been reaping for years the disastrous consequences. We have already exposed a multitude of these errors, and there is a legion yet remaining of whose falsity we have the evidence more or less complete, and some of them are in high places.

These errors will soon be in a large measure corrected. We will give to the public as early as possible a work on "Noted American Horses," in which the result of years of research will be embodied, the truth will be stated, the known will be distinguished from the unknown, and all sources of information will be laid open for examination and criticism; then the blind will no longer have to follow the leadership of the blind.

Since the above articles appeared in the Middlebury Register,which were mainly written by Judge $\mathrm{Wm}$. H. Bliss of Middlebury, then assistant editor,- we have gathered the following information connected with this subject:

From Dunton's Spirit of the Turf, June I5, I 893 :

THE DAM OF GEORGE WILKES.

"' If the question was asked me,' said John P. Ray, in a recent interview, 'Was the Clark Phillips mare by Henry Clay, dam Telegraph, by Baker's Highlander, the dam of the famous George Wilkes', my answer would be 'No'. To sustain this position he submitted the following evidence :

" 'From the book of the late William Wadsworth, Geneseo, N. Y. :

" "Henry Clay bought, March 27, I $\$ 45$. Sold to N. Thompson, Jan. I $3, \mathrm{I}_{52}$.

William A. BRodie.

" "Mr. Brodie is agent for W. A. Wadsworth, son of William Wadsworth, deceased.'

"Statement of John H. Newman, South Lima, N. Y. : 'In March I854, Robert Whaley and I, John H. Newman, South Lima, N. Y., purchased Henry Clay of Mr. Thompson, Penn Yan, N. Y., for $\$ 500$, and stood him at $\$ 25$ to insure. He was bred to seventy mares and got fifty foals. Sold him the next fall to Bailey Bros., for $\$ 700$. The above statement is true, according to my personal knowledge.

Oct. 8, I 892 .

John H. Newman.'"

Letter from Clark M. Phillips :

John P. Ray, EsQ.,

Dear Sir:-Answering your inquiries of recent date, I will say that I bred a brown roan filly, which I sold when three months of age to E. V. Phillips of this town. He broke her and sold her to his uncle, Joshua 
Phillips. This filly was got by old Henry Clay (the Wadsworth horse) when he was owned by Bailey Bros.

Bristol, Ontario County, N. Y., Nov. 28, I89r.

Clark M. Phillips

Mr. Ray had several interviews with E. V. Phillips previous to his death, in reference to this mare. Having always lived with his uncle Joshua, he was able to name all the get of Henry Clay, owned by his uncle. There was but one mare among them, and that one is mentioned in the foregoing statement of Clark M. Phillips. Mrs. E. V. Phillips, was present at one of these interviews and remarked that she well remembered this mare. In a letter from her son, Edson Phillips, which was published in the American Horse Breeder (Christmas number), he states that his parents were married thirty-eight years before, and that he was born in 1856 , and that he well remembers riding this Clay mare when she was four years old, and before her sale by Uncle Joshua, a transaction which did not occur until sometime in the 6o's.

Letter from W. L. Simmons :

JOSEPH BATTELL,

Lexingto̊n, Ky., Sept. 15, 1905.

Dear Sir:-Yours received. I neither owned or drove the dam of George Wilkes. H. D. Felter, corner of Prince St., and Broadway, New York City, used her in his delivery wagon and sometimes to road wagon over the Bloomingdale and Eighth Ave., in his pleasure riding. She was a brown roan, very tough, and could pull two men a 50 clip. Felter always said she was a Mambrino mare and sent her to his father, Theran Felter, Newburgh, N. Y., to breed to Hambletonian, G. W., keeping the foal found standing over the dead body of his dam.

W. L. Simmons.

"Vision" says in Wallace's Monthly, Vol. XIV., p. 785 :

"Very recently I was talking with Simmons about this mare. He spoke of riding behind her and said she was good gaited and a great roadster. He describes her as brown, but with so much gray mixed that she might almost be called a roan. She is given as but eight years
old when she died."

The Spirit of the Times, I862, thus describes George Wilkes :

"He is about I5-I hands high, but all horse. His traveling gear is just what it should be-muscular shoulders, long, strong arms and flat legs, splendid quarters, great length from hip to hock, and very fine back sinews. He stands higher behind than he does forward, a formation we like. This horse has a game-looking style of head, small pricked ears, and noble eyes. He is very wide between the jaws, His coat is fine and glows like the rich dark tints of polished rosewood.

"His temper is kind. We had the pleasure of seeing him at his work, and unless we are greatly mistaken he will make an amazing good one. He has a long and easy way of going, striking well out behind and tucking his haunches far under him."

Mr. Dabney Carr, in interview, Lexington, Ky., May, I905, said: 
"A small horse, about 15 hands; brown horse. Fine action; real nice looking buggy horse; no white ; kind of hitch in gait; goes slow; awkward. No stronger built than Honest Allen (Honest Allen had finer action). Wilkes largest and heaviest."

A correspondent of The Horseman, Chicago, writes :

"Colonel W. L. Simmons' friends, and their name is legion, will be glad to learn that he has so far recovered from his painful and dangerous illness as to visit his office in the Phœnix Hotel on pleasant days. 'I beat about a 200 to I shot,' said the Colonel, 'and I consider it lucky to be able to do that at any kind of a game. The recent developments,' said the Colonel, "place the pedigree of the dam of George Wilkes exactly as I gave it years ago, and where I have always claimed it, as practically unknown. At the time I bought the colt, afterwards known as George Wilkes, little was thought of pedigree in trotters, and I only learned incidentally that he was sired by William Rysdyk's young stallion Hambletonian. After George Wilkes had trotted a few races I began to receive inquiries regarding his breeding. One day I was in Captain Felter's store, and asked him if he knew how Dolly Spanker was bred. His reply was that Mr. Lewis, of whom he had purchased her, said she was probably a Mambrino mare. Perhaps a year after I dropped into the place and was introduced by the Captain to Mr. Lewis, the man from whom he had purchased the dam of my horse. I inquired her breeding, and he repeated in substance the same statement he had made to Captain Felter, that he knew nothing positive about her breeding, as she was one of a number brought in for sale, but he supposed that she was a Mambrino. In a somewhat lengthy newspaper controversy years ago I gave to the public the facts, though they were not accepted by the compiler of the Register, who persisted in giving the sire of Dolly Spanker as by Henry Clay from Telegraph by Baker's Highlander. Dolly Spanker was a compact, rugged, resolute-going mare, and I have ridden after her with two heavy men in the wagon close to a $2: 40$ clip, and she did it like a trotter. She might have been by Mambrino Chief, as he stood in the locality where she was, but was more after the Morgan type. I do not believe that her breeding will ever be known.'"

From The Breeder and Sportsman, San Francisco, Cal., June 3, I893:

IT OUGHT TO BE SETTLED.

"A question appears to have arisen between Mr. Dudley Miller and the Registrar as to the duty of the latter in regard to changing the pedigree of George Wilkes so as to conform to the newly-discovered testimony. The evidence which Mr. Miller published seems to establish the fact pretty conclusively that the dam of George Wilkes belongs to the great unknown. This evidence has been pretty generally published, and many who heretofore thought that there could be little doubt that Dolly Spanker was a daughter of Henry Clay have had their faith shattered," - says Iconoclast in Kentucky Stock Farm.

"The Registrar's position was stated to be that he can do nothing in the matter till a formal petition is lodged in his office suggesting or requesting that the pedigree be made to conform to the facts as they now appear. It would follow, therefore, that if no person outside the Registrar's office takes sufficient interest in the matter to commence proceedings of this character, the Registrar and Year Book are to go on indefi- 
nitely publishing to the world facts about the breeding of George Wilkes that are not true.

"I do not know that the Registrar takes this view of the situation, but if he does, I beg leave most respectfully to dissent. The Trotting Register is the source from which the public derives its knowledge of trotting pedigrees. It is the record, and imports verity. Whenever a strong probability is raised that one of its pedigrees is untrue, the proper officer or officers of the association should take steps to have that pedigree corrected. They should use all proper effort to see that their record does as it professes to do-speak the truth-instead of perpetuating a falsehood. It is the business of the Register Association more than any one's else business to have the records correct, because they are its records, the records which it holds out to the world as the truth. They are not the records of the owner of the horse or of his produce, but of the Register Association, and so far as the general public is concerned, the Register Association is the party responsible for their accuracy. This being true, why should the association wait till some one else files a complaint in regard to the pedigree of any animal? No one has greater interest in making the correction than it, and it may very well be that no one else has any special interest in the matter, but certainly the Register Association has.

"Now, if the evidence which Mr. Miller has adduced is not sufficient to raise a reasonable presumption that the pedigree of the dam of George Wilkes is incorrect, the Registrar is entirely right in ignoring it. If, on the other hand it does raise such a presumption, the matter should be investigated and determined by the association without waiting to be moved to do so from the outside. More especially is this true where a great historical pedigree like that of George. Wilkes is the subject matter of investigation.

"For myself, I think Mr. Miller made a very good showing, and, so far as I have observed, no one has attacked his conclusion. There are those that claim to be able to trace the Clay characteristics in the Wilkes family, but in my judgement a good deal of this is imaginary. One of the horsemen who owned Dolly Spanker thought she had much more of the character of Mambrino than of Clay, and when Mr. Simmons bought George Wilkes his dam was represented to have been a Mambrino mare. This may have been imaginary also. But the fact remains that she has apparently been traced to an unknown source, and there does not seem to be any real foundation for her alleged Clay paternity, at least the facts now appear to be stronger against it than in its favor. So far as the George Wilkes family is concerned, it is really a matter of no importance whether his dam was a Clay mare or a Mambrino mare, or either. The ascertainment of this fact would not add oue cubit to his stature as a sire or a progenitor, but it would be a satisfaction to the breeding public to know either what his dam was or that the fact cannot now be ascertained."

The above remarks of The Breeder and Sportsman are eminently correct. The italics are ours. Since they were written, this pedigree has been corrected in the Trotting Register. But a large number of others, all important and some equally so, and demonstrated to be incorrect, have not been corrected in that Register. Among these is that of the great brood mare sire, Seeley's American Star. Unless effort is 
made to correct errors of this character, that Register will be absolutely worthless as authority on pedigrees.

George Wilkes was sold at four years old to W. L. Simmons, Lexington, Ky., and Horace T. Jones, a trainer, who was handling the colt, for $\$ 4000$ and a mare. Mr. Simmons afterwards became his sole owner, and so remained until the horse's death. He was on the trotting turf twelve seasons, from 1861 to 1872 inclusive, getting a record of $2: 22$, to harness, $2: 25$ to wagon, and $2: 28$ to pole, trotting 69 public races, 29 of which he won, his winnings in purses amounting to over $\$ 50,000$. In 1873 he was taken to Kentucky, and made his first season in the stud near Lexington, where he continued to stand until his death, from pneumonia, May 28, 1882. His success in Kentucky was very marked, placing him among the very first of trotting speed producers in the world.

It will be seen that all the work expended so far has failed to result in any definite knowledge of the breeding of the dam of George Wilkes. It did, however, result in demonstrating that the Clark Phillips mare was not the dam; something that probably would never have been accomplished but for our preliminary work in showing that this thing was impossible because of dates. This we did by first obtaining and publishing accurate information of the life of the stallion Henry Clay.

Of course, as Judge Bliss wrote, we would have been pleased to have had the pedigree prove true, for it introduced several very valuable Morgan strains, as well as others, but we assume that no man in his right mind wishes any pedigree to be sustained which is not true.

And yet hardly anything is more difficult than to expose, thoroughly enough to get rid of, entrenched error. We have ourselves had quite a good deal of experience of this in different directions. But however lax those in authority may be in correcting errors, whether in pedigrees of renowned horses, or in the broader field of Science, those beautiful lines of the American poet must always remain true-

"Truth crushed to earth will rise again, The eternal years of God are hers."

In the American Horse Breeder of March 23, I909, appeared a letter written by Charles Blake, Otego, N. Y., in which he describes a mare called Dolly Spanker, that he bought, he thinks in the fifties, of a man from Canada, and sold later to a man in New York. This mare as he describes her resembles the dam of George Wilkes, and he says after he sold her he understood that she was bred to Hambletonian and produced George Wilkes.

Mr. Blake is highly spoken of as a man of truth and veracity; and for the purpose of obtaining further information we wrote him, Dec. 28 , 1909, and received from him a very courteous reply conveying about 
the same information as his letter published in the American Horse Breeder, excepting dates. In his letter to us he says :

"Now a little about myself. In I 860 , I went out of the [horse training] business, and in I86I I hired out to travel for John Thomas, Jr., Coffee and Spice house. My territory was all driving. I used to buy any horse that I could hear of, if they had the size and age and were sound. I have paid all prices from $\$$ I oo to $\$ 500$. I used to put them on the road and drive them slow all day long, which would educate them and gait them nicely. When I had got them thoroughly educated some one always wanted them.

"I took great delight in handling that class of horses. Never got hurt and horse never got away from me. I have one now that I have had fourteen years ; can go fast but no good in a race."

Mr. Blake closes his letter to us as follows :

"And now a little more about Dolly Spanker. There was a horse in Boston named Jack Stewart, the time I had the mare. They made a great deal of noise that he could beat any horse five hundred miles for $\$ 500$. There was a man in Albany who was very fond of nice horses, but no handler. I used to frequently invite him to take a ride with me. He went up to the half-way-house on the Troy road and put up $\$ 300$ as a forfeit to match and drive according to the rules. Trot at Hartford and I was to drive her. This has not been mentioned before. We never heard any more noise from Boston, but they took the horse Stewart to California shortly after.

$$
\text { Respectfully yours, Charles Blake. }
$$

"All questions cheerfully answered, I am 85 this spring."

George Wilkes was foaled 1856 , and his dam died in foaling. Jack Stewart made a world's ten mile record at Boston in 1867 and a world's twenty mile record in $\mathrm{x} 868$. He was at Boston in 1870 and in California in 1874 . It will be seen from this that the Dolly Spanker owned by Mr. Blake, could not have been the dam of George Wilkes, but was perhaps named after that noted mare.

This wonderful long distance trotter John Stewart as registered in the Trotting Register, is another illustration of serious error in that book, which should be corrected.

He is registered in Vol. VIII., Part II. p. I05, of the Year Book:

"John Stewart (Jack Stewart), b. g. ; foaled I 8- ; by Tom Wonder, r 47 : dam Park Mare, by Hambletonian 2 (IV.) Boston, Mass. Oct. I8, I 87 I. Record 2 :30."

In Vol. IV., of the Register, he is recorded:

"Jack Stewart (John Stewart) (2), br. g. ; foaled I85-; got by Tom Wonder, 147. [See Vol. I.] Record 2 :30."

In Vol. I., we find :

"Jack Stewart, br. g. ; foaled I 85-; got by Tom Wonder: dam Mr. Park's old mare, by Harris Hambletonian; bred by Mr. Harker of New York. [See Calendar under name of John Stewart."]

His true pedigree is : 
John Stewart (3-32), bay gelding; foaled $185^{8}$; bred by W. W. Parks, New York City ; foaled the property of Joseph Harker, of same place; got by Tom Wonder, son of Tom Crowder, by old Pilot : dam black, I5 hands very handsome and fast, purchased by W. M. Parks of Sheldon Leavitt, Brooklyn, N. Y., who bought her of Caleb Tickenor, Middlebury, Vt., bred by Austin Dana, Cornwall, Vt., got by Sherman Black Hawk, son of Black Hawk ; 2 d dam bred by Austin Dana, got by Black Hawk, son of Sherman Morgan. Mr. Harker gave the horse when five years old, to his wife's nephew.

Pedigree from breeder and Caleb Tickenor, now of Great Barrington, Mass., who writes: "She was a very representative mare of the family, with symmetry, soundness, sense, and some speed; could trot a $3: 00$ gait, when I sold her."

Record made at Boston, Mass., Oct. I8, I87 I.

It will be seen that by the erroneous breeding this noted gelding traced to be grandson of Messenger, which Mr. Wallace taught to be the source of trotting speed.

With the true breeding there is no known Messenger blood, but instead, a large percentage of Morgan blood. The dam of Major Edsall, sire of Robert McGregor, is another Vermont mare that went to New York and has been credited without evidence to the Harris Horse, both description, location and time when she was bred make it very certain that she too, was an inbred Morgan mare. See Major Edsall in Vol. IV.

There would appear to be but little if any reason to doubt that the Dolly Spanker sold by J. S. Lewis to Mr. Delevan about I $85_{2}^{2}$, was the mare afterwards owned by Harry Felter, sent to his father at Newburg, N. Y., and bred by him to Hambletonian, producing George Wilkes. This mare was purchased in the woods of Pennsylvania, as represented by Mr. Gilbert, about 1850 , then about six years old, and died in 1856 .

All the testimony would appear to fit perfectly excepting the recollection of Mr. Simmons that she had quite a good many gray hairs in her coat. Mr. Simmons' memory may have been a little off on these, or they may have appeared as she grew older.

We have for a number of years tried to get time to visit the locality where this mare was purchased in Pennsylvania, and if possible trace her, but in all these years since 1892 have seen no time in which we could do it. At one time we wrote to and advertised in the Meadville, Penn., papers for this information, offering quite a reward, but nothing came from it. We hope now this summer to make the long delayed trip, and because of the peculiar conditions of the purchase have yet a good deal of hope that the name of the original owner of this mare may be obtained, and if so through his family or neighbors something definite of her breeding.

It will be seen that Mr. Simmons in interview with a correspondent of 
the Chicago Horseman, suggests that Dolly Spanker was a Morgan mare, which, as described by him,-and there could be no one more competent to describe her,-she might well have been.

Impressed by the remark of Mr. Simmons that she resembled a Morgan, we examined the Registers to see if any Morgan horses were in the vicinity of Meadville, Penn., at the time. In Vol. II., of The Morgan Horse and Register, p. 24I, we found:

“Morgan Tiger (Sepon's), probably a son of Dr. May's Morgan Tiger. Brought from Syracuse, N. Y., to Meadville, Penn., by John P. Sepon about I 850 . He was a very finely built horse, possessed some speed and good courage."

Dr. May's Morgan Tiger is recorded in Vol. I., as follows :

"Foaled about I 833 ; said to be by Morgan Rattler, son of Sherman Morgan. Owned by Dr. Wm. May of Westminster, Vt., where the horse got some colts. Dr. May moved to Palmyra, N. Y., previously to I 843, taking the horse with him. He exhibited him at the New York State Fair, 1843 , and received $2 \mathrm{~d}$ premium in class of stallions four-yearold and upwards."

We add two pictures of Finlay's Morgan Tiger, a son of this horse taken from a daguerreotype, showing a horse of great strength, and fair looks. See Morgan Tiger (Finlay's).

There was still another Morgan stallion of excellent reputation taken from Boston, about 1825 , to East Bloomfield, N. Y., by Thomas Kellogg, who kept him at East Bloomfield several years, then sold to a Mr. Luther of Wyoming County, N. Y.

This horse was called Morgan Highlander, foaled about I8ro, and said to be by the original Justin Morgan. It was a son of his that got the dam of the Phillips Mare. A correspondent writes in the Morgan Horse and Register, Vol., I. :

" $\mathrm{He}$ was a smoothly turned, up-headed, nervy horse, with the best of legs and feet, and left behind a sturdy, sound, race of horses."

He was sire of $2 \mathrm{~d}$ dam of Belle S., $2: 28 \mathrm{r} / 2$ and $3 \mathrm{~d}$ dams of Col. Wood, $2: 2 \mathrm{I} \mathrm{I} / 2$, and Honey B., $2: 25 \mathrm{I} / 2$.

East Bloomfield is about $\mathbf{I} 35$ miles from Meadville; Wyoming County half that distance. The descendants of this Morgan Highlander were much thought of and it is quite possible that Dolly Spanker was one of them.

George Wilkes was sire of 72 trotters $\left(2: I_{3} \frac{1}{4}\right)$, I I pacers $(2: 151 / 2) ;$ IO2 sires of I746 trotters, 775 pacers; 99 dams of I28 trotters, 45 pacers.

GEORGE WILKES JR. (BARNJUM'S), $2: 44$, black with star and four white feet, I5 $3 / 4$ hands, II 25 pounds; foaled I 868 ; bred by Capt. Speight, New York, N. Y.; got by George Wilkes, son of Hambletonian : dam Lady Speight, black, bred by Carl Burr, Long Island, N. Y., got by Smith Burr, son of Burr's Napoleon. Sold to S. S. Houghton; to Geo. 
D. Otis, both of Boston, Mass.; to Barnjum Bros., Lynnfield Center, Mass., who send pedigree. Dead.

Sire of 5 trotters $\left(2: 19 \frac{1 / 2}{2}\right), 3$ pacers $\left(2: 17 \frac{1}{4}\right) ; 2$ sires of 4 trotters; 3 dams of 2 trotters, I pacer.

GEORGE WILLIS (3-I28), $2: 29 \frac{\mathrm{T}}{4}$, brown; foaled 1887 ; bred by W. M. Irvine, Richmond, Ky.; got by Belmont, son of Alexander's Abdallah : dam Mona Wilkes, brown, bred by Wm. M. Irvine, Richmond, Ky.; got by George Wilkes; 2 d dam Hamlettie, brown, bred by Wm. M. Irvine, Richmond, Ky., got by Hamlet, son of Volunteer; $3 \mathrm{~d}$ dam Minna, bay, bred by F. P. Kinkead, Midway, Ky., got by Red Jacket, son of Billy Root, by Sherman Morgan ; $4^{\text {th }}$ dam Undine, said to be by Gray Eagle; 5th dam Rowena, by Superior, son of Whip, etc. (See Stud Book). Sold to McKee and Trainor, Richmond, Ky.; to J. D. Creighton, Omaha, Neb. ; to G. \& C. P. Cecil and G. M. \& J. A. Lee, and T. G. Boyle, Danville, Ky. ; to William Hunt \& Son, Arrowsmith, Ill.

Sire of 2 trotters $\left(2: 15 \frac{1}{4}\right), 3$ pacers $(2: 18)$.

GEORGE WOLF, $2: 30$, dark brown, no white, I $53 / 4$ hands, I Ioo pounds ; foaled June, I878; bred by John A. Blodget, Keats, Kiley County, Kan.; got by Shelden's Messenger, son of Alexander's Abcallah: dam old Chloe, bay, bred by John A. Blodget, got by Charley, son of Young Tyrant ; 2 d dam old Ann, bay, bred by Joseph Vanmeter, Iowa County, Wis., got by American Eclipse son of Duroc; 3d dam said to be by Bertrand. Sold to J. H. Jarvis \& Co., Concordia, Kan.; to Amos Pierce, Belleville, Republic County, Kan. Pedigree from breeder.

GEORGE WOOD (I-64), bay, I5 I/4 hands, 825 pounds; foaled I 880 ; bred by William Cross, Jasper, Greenville County, Can. ; got by George Effler, son of Royal George: dam brown, $153 / 4$ hands, I075 pounds, bred by William Cross, got by Barry's Gray Eagle, son of Gray Eagle; 2d dam gray, bred by Chas. Cross, got by Black Hawk, son of old Black Hawk; 3 d dam brown, bred by John Cross, at Jasper. Sold to David Lynch, Jasper, Can. Information from J. L. Davis, Jasper, Can. Sire of 2 trotters $\left(2: 23^{1 / 2}\right)$.

GEORGE W. PATCHEN (I-32), bay, black mane, tail and legs, no white, $151 / 2$ hands; foaled I 860 ; said to be by George M. Patchen of Long Island: dam Julia, by Hambletonian, the sire of Fillingham, Shark and others. He was raised by John Hannon and brought to Oregon when two years old. Advertised as above in the Oregon Statesman, 1865 , by Bennett \& Wells, proprietors, at Salem. Terms, $\$ 20$ to $\$ 40$.

GEORGIA WILKES (I-I28), bay; foaled I 877 ; bred by A. H. Davenport, Lexington, Ky.; got by George Wilkes : dam Neilsson, bay, bred by Solomon Low, Lexington, Ky., got by Mambrino Pilot, son of Mambrino Chief. Sold to A. V. Reid, Eatonton, Ga.

Sire of 3 trotters $(2: 183 / 4)$; Bas-Bleu Wilkes, $2: 18 \frac{3}{4} ; 4$ dams of 2 trotters, 2 pacers. 
GERAINT (I-64), chestnut; foaled I89I ; bred by R. P. Pepper \& Son, Frankfort, Ky.; got by Onward, son of George Wilkes: dam Susette, bay, bred by S. A. Browne \& Co., Kalamazoo, Mich., got by Grand Sentinel, son of Sentinel; 2d dam Susie Wilkes, bay, bred by Wm. L. Simmons, Lexington, Ky., got by George Wilkes, son of Hambletonian ; 3d dam said to be by Superb, son of Ethan Allen; and 4th dam by American Star. Sold to C. M. Dunlap, Mt. Sterling, Ill.; to H. E. Newton, Chicago, Ill.; to H. N. Johnson and W. T. Brown, Rapid City, S. Dak.

Sire of Euser, $2: 24 \frac{1}{4}$.

GERMAINE ( $\mathrm{I}-32$ ), bay with small strip in face, right fore and hind ankle white; foaled I888; bred by C. J. Hamlin, Buffalo, N. Y.; got by Mambrino King, son of Mambrino Patchen : dam Verdant, bay, bred by C. J. Hamlin, got by Almont Jr., son of Almont; 2d dam Molly O., brown, bred by C. J. Hamlin, got by Hamlin's Patchen, son of George M. Patchen; 3d dam Mermaid, bay, bred by Harrison Durkee, Flushing, N. Y., got by Dictator, son of Hambletonian; 4th dam Lady Ketcham, bay, said to be by Imported Osirus ; $5^{\text {th }}$ dam Madam Loomer, chestnut, bred by Edward Loomer, New Brunswick, got by Warrior. Sold to J. H. Carmichael, Springfield, Mass. Pedigree from catalogue of breeder.

Sire of Columbia, $2: 29 \frac{1}{2}$.

GERMAN BOY (I-I6), $2: 28 \mathrm{I} / 4$, chestnut, three white feet, strip in face, I5 hands, 950 pounds; foaled July I2, 1871 ; bred by Wm. F. Wing, Spring Green, Sauk County, Wis.; got by old Nig, black with star, supposed to be Black Hawk: dam chestnut. Sold to John Bettinger, Spring Green, Wis., for \$150 ; to Capt. Ferguson, Boscobel, Wis. ; to parties in Northern part of State. Gelded young, Pedigree from breeder.

GERMAN BOY, brown, $161 / 2$ hands, 1250 pounds; foaled 1876 ; bred by George Effner, Buffalo, N. Y.; got by Waverly, son of Hambletonian : dam Lady Picard, said to be by Brandywine (thoroughbred). Sold to F. D. Warner, Painsville, O. ; to John W. Corbin \& N. Grant, Mitchell, S. Dak.; to G. W. Hodgins \& Son, Cherokee, Ia., who send pedigree. Sire of German Girl, $2: 27^{3 / 4}$; I dam of I trotter.

GETAWAY, seal brown, $153 / 4$ hands, 1200 pounds; foaled 1849 ; bred by Robert New, Mudlick, Jefferson County, Ind., got by Gossip Jones, son of Vanosdal's Whip, by Blackburn's Whip, son of imported Whip : dam said to be by Hendricks' Hickory, son of Hickory, that was owned in Pennsylvania and said to be thoroughbred. Owned by David Cope, and was purchased about $\mathrm{r} 865$, by Rubb \& Brown. Afterwards sold to Mr. Blossom of St. Louis where he remained three or four years and in the 
spring of 1874 , was bought by D. W. Reed of Middletown, O. He was a fast pacer. Died $\mathbf{8} 879$.

W. H. H. Cope, writes that the pedigree given is from a sworn affidavit of his father.

Sire of 2 trotters $\left(2: 25 \frac{1}{2}\right) ; 3$ dams of $I$ trotter, 2 pacers.

GETTYSBURG, bay; foaled 1875 ; bred by A. Whipple, Saegertown, Penn. ; got by Ryse Duke, son of Hambletonian : dam Flight, bay, bred by A. Whipple, Crawford County, Penn., got by Washington Hambletonian; 2 d dam Frolic, chestnut, bred by Martin Prendergast, Mayville, N. Y., got by Busiris, son of American Eclipse; 3d dam Lucy, said to be by Falconer's Duroc; and $4^{\text {th }}$ dam by Bay Captain.

Sire of George P., $2: 261 / 4$.

GETTYSBURG (3-256), 2 :29, bay; foaled, r 883 ; bred by H. M. Burgher, Glendale, O.; got by Gen. Hancock, son of George Wilkes : dam Nelly (dam of Tom Rogers, $2: 20$ ), untraced. Sold to H. \& F. Duhnee, Cincinnati, O.; to Railey Bros., Versailles, Ky.; to Shelby T. Harbison,

- Lexington, Ky. ; to L. G. Perkins, Norwood, La.

Sire of Anita, $2: 201 / 4$.

GIANT, owned in Calidonia County, Vt., about 1820 . In an interview W. J. Stanton, North Danville, said: "One of the first stallions I remember was the old Sherman; then the horse called the Giant, I6 or I7 hands high; a bay."

GIBRALTAR (3-I28), $2: \mathrm{II}^{\mathrm{I} / 2}$, bay, no white, I 6 hands, I 200 pounds ; foaled 1872 ; bred by George O. Tiffany, Fulton Mills, Cal.; got by Echo, son of Hambletonian: dam chestnut, bred by Edward Every, Anaheim, Cal., got by Owen Dale, son of Belmont, by American Boy, thoroughbred son of Seagull, by imported Expedition; 2 d dam said to be by Owen Dale, son of Williamson's Belmont. Sold to Monroe Salisbury. Kept at San Jose, Cal. Stylish and spirited. Disposition good. Pedigree from breeder.

Sire of 4 trotters $\left(2: 14 \frac{1}{4}\right) ;$ Our Dick $\left(2: 10 \frac{1}{4}\right) ; 4$ dams of 4 trotters.

GIDDING'S HORSE (GIDDI: G'S HAMBLETONIAN). Untraced.

Sire of Capt. O., $2: 29 \frac{1}{4}$.

GIDEON (1-32), gray; foaled I 860 ; bred by Thomas Lewis, Turner's Junction, Orange County, N. Y.; got by Hambletonian: dam Dandy (dam of Silver Duke, $2: 28 \frac{1}{4}$ ), bred by Thomas Lewis got by Young Engineer, son of Engineer; $2 \mathrm{~d}$ dam said to be by American Commander, son of Commander, by imported Messenger ; 3d dam gray, bred by William Hunter, Turner's, N. Y., and called a Messenger. Taken to Maine by Col. T. S. Lang in I864 and owned successively by 


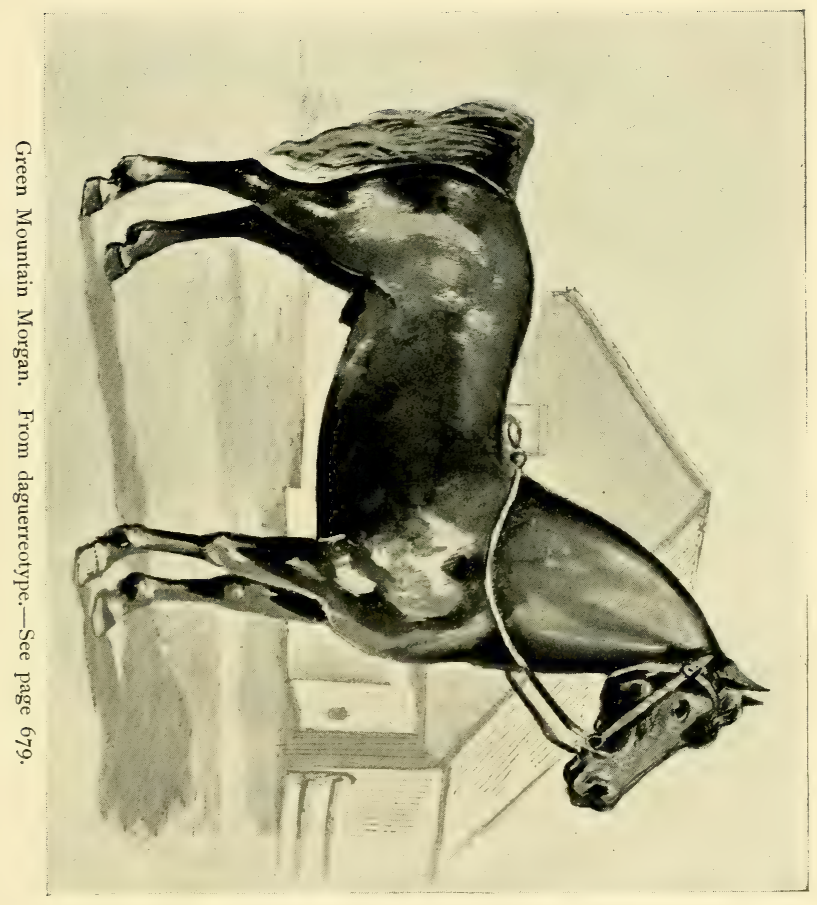




$$
\text { I }
$$


F. S. Palmer, Bangor; Parker \& Otis, Belfast; G. J. Shaw, Hartland, and C. H. Wood, Benton, Me.

Sire of 4 trotters $\left(2: 2 I^{1 / 1} / 4\right)$; Laundryman, $2: 191 / 2 ; 6$ sires of $I_{5}$ trotters; II dams of 16 trotters, 2 pacers.

GIDEON CHIEF (I-I28), bay; foaled I 884 ; bred by C. P: Smith, North Anson, Me.; got by Gideon, son of Hambletonian : dam Topsey, said to be by Carabassett. Sold to E. R. Woodman, E. D. Morgan and J. B. Twaddle, all of North Anson, Me.

Sire of Likewise, $2: 17 \%$.

GIFFORD BLACK HAWK JR. (3-32) ; said to be by Gifford Black Hawk. Information from G. E. Larson, Cambridge, Wis., where Frank E. was bred.

Sire of Daisy, dam of Frank E. $2: 291 / 2$.

GIFFORD MORGAN ( $\mathrm{I}-4)$, chestnut, almost dark brown in the sun, scant I5 hands, weight about rooo pounds; foaled June I3, I824; bred by Ziba Gifford, Tunbridge, Vt.; got by Woodbury Morgan: dam bay, Iooo pounds, foaled June 21 ; 1819 , said to have been by Henry Dundas, son of Woolsey, or Cardinal Woolsey, which see. Sold about I827, to Ira Cooledge, Barnard, Vt., went to Addison, County, Vt., about I830; was sold to Lyman Stewart of Barnard, who it is thought got him in Addison County, and sold him to Leonard Fish. Mr. Fish kept him some two years. He would appear to have had several other owners, and was kept several seasons in Stockbridge, Hancock, Bethel and Warren, Vt., and about 1836 , was taken to Fort Ann, Washington County, N. Y., and kept one season, leaving a number of excellent stallions in that county, and it is thought whilst there got the long distance trotter Fanny Jenks; was then brought back to Vermont, afterwards purchased by F. A. Wier, who sold him to a company at Walpole, N. H., for $\$ 2,000$, where he died Oct. 30,1850 .

Mr. I. D. Davis of Barnard, Vt., born I8ro, said :

"The Frazier Horse of Barnard was by Gifford Morgan, bred by Dan Frazier of Barnard: dam by Maj. Smith's horse of Pomfret. From the same mare Mr. Frazier raised a bay stallion by Pike's Romeo, which, I think, was a French horse a stallion kept here a while. This second Frazier horse was smaller than Gifford and not so good style, but very cordy; the dam was bay of good size, a stocky mare. Smith's horse, I think, died his property. Old Gifford was owned by three or four here in a little time. Russell Topliff owned him, and, I think, let Lyman Stewart have him. Badger owned him first. Topliff sold to Badger, got him back and let Stewart have him. Topliff had him one year perhaps two; Stewart only one, I think; Badger only a month or two. Stewart let Rumello Cady of Barnard have him, who took him to York State.

"Ira Cooledge, who lived three-quarters of a mile from the village, had him first at Barnard and kept him several seasons-always at Barnard, except when he rode around with him. The first colt I saw, sold for 
$\$ 1,000-a$ man in Pomfret raised him. Sargent of Springfield, Mass., owned him and sold him to Fatty Wood of Providence, for $\$ 1,000$; a fine, pretty horse; very pretty horse, one white hind foot, and, I think, a star. He was a chestnut chunk of a horse, not high on the withers. - The man that raised him, I think, lived in North Pomfret, I cannot now remember his name, but Mr. Sargent knew his name and said the horse was got by a Morgan horse and wanted me to look it up. I did so and found he was by Gifford Morgan when Cooledge had him. I went to Cooledge and found that the mare was entered in his book, and served at the right time; this seemed to be positive proof. Cooledge kept Gifford as much as four years. I know nothing about the dam of this Sargent colt.

"Defiance was here when I was at Williamstown. I was born here in I 8 ro and went to Williamstown with my father in I824; came back here in I834. I think Defiance was a gray horse and a good fair-sized horse. The first year that Cooledge had Gifford, I bred a mare to him that I rode from Williamstown. Gifford was four years old that spring and I was 17 or 18 years old when I brought the mare to him. Densmore had the old Bulrush at Williamstown when I was there. He was called at one time the Belknap horse. He was not an old horse then. I do not know that he was there the first year we went there-don't think he was. Densmore came two or three seasons. He stood him at Chelsea, Williamstown, Brookfield Center and East Brookfield. He was as good a horse as there was in Williamstown.

"Col. Wyte had a tall, slimish brown horse there, that died there. Soldier came from Barre; owned by Frank Abbott, who was the first man to get granite at Barre. Blodgett was from East Randolph, had Phœnix there three seasons, a gray horse of quite good size, and well proportioned, very good appearing horse; I don't think they claimed Morgan. I do not think he was over nine or ten years old. Soldier was gray, not as big as Phœenix, nor as old; a resolute, strong-muscled, good horse, shaped more like the Morgans. Phœnix commanded the better class of mares, better prices, got better care. Bulrush got the most business. I owned half of an Eclipse horse before I was 2I. He came from a grandson of old Eclipse. Kasson of Washington, Vt., brought him from New York State. We called him Young Eclipse. He was bay, I5 hands, high shouldered, not a large horse, slim-built. He was cross. Elisha Gale of Williamstown bought him when six years old and sold me half. I brought him here, kept him two or three years and then sold to Baxter \& Gaines of Pittsford, Vt. He afterwards went West; got some good stock. I let him for \$Ioo one year to stand at Brookfield. I never saw any horse with the style and action of Gifford.

"I think that Capt. Eber Richmond of this town raised Defiance. Bulrush was foaled on Brookfield Hill and owned by Belknap before Densmore got him. I owned several of his colts; they were a strong breed of horses with a good deal of energy. Soldier, owned by Abbott, was a good stepping horse, a good gaited horse, but not as fast as Bulrush. The colts of Bulrush were faster than the average of Woodbury's; very cordy and nice gaited horses.

"Pike's Romeo and House's Romeo were not the same. Pike's, I think was French and House's not. Joe Danforth had the Frazier Horse by the Pike Horse and stood him here one or two years. As far back as I can remember Woodbury Morgan was the popular horse; more said of him than of any other. I saw him often; never saw Sherman. Mr. 
Woodbury owned the mill at Bethel, and from the time I was ten years old I went to the mill. Woodbury sold to Walker at Hartland, who kept him the next season at Bethel, and one day here, that was after Gifford was here. Walker got him after Gifford came here. The two horses were in the same barn; Woodbury bit Cooledge. I think Cooledge had Gifford five years, Cady had the care of him one or two seasons in this town and I think took him over the lake. Davis' Gifford or Nat died mine. I bought him when three years old, died when 29."

Mr. Davis says that the first year that Cooledge had Gifford he bred a mare to him; that he went to Williamstown when he was 14 years old, in 1824 , that he was 17 or $\mathbf{1} 8$, when he came back.

Mr. F. A. Weir, in interview said:

"Jim Whitcomb kept Gifford Morgan three years, about 1830, '33, at Hancock, Bethel, Stockbridge, and Warren : also worked him in a meatcart. He got the Joslyn mare at this time, also Green Mountain Morgan and the Hackett Horse. The Hackett Horse lacked nerve and Morgan finish."

Mr. Andrus of Hancock, Vt., said, Nov. 25, 1887 :

"Gifford was the first Morgan horse kept here. He was at Hancock and Rochester, fifty or more years ago. Old Lambert had the same appearance in moving. Their steps were wonderfully alike. The Gifford was a young horse then six to eight years old. The Sherman was here and at Rochester-clean English cut. That was about the same time as Gifford. Parmalee had an English horse about the same time. John Hackett owned the dam of the Hackett Horse three or four years. She was a mahogany bay, 16 hands, well set up; would weigh Iooo pounds. Old Green Mountain I knew right along. Bundy raised him on Bethel Mountain. Joel Huntington had a Morgan horse here and had another fine horse called the Bird Horse. Joel was from Bethel. This Bird horse got the dam of the Perry Horse, by Black Eagle, son of Black Hawk."

Darius Severence of Middlebury, Vt., in interview, r885, said :

"The first Morgan horse I remember was Scott's; he had two, think he owned them, the best they called Gifford. This was about 50 years ago. It was before I was married and that was 48 years ago, both his horses were chestnuts, the best was a low horse. Seems as if they called it the Gifford Morgan. about the color of Motion [dark chestnut], about I 5 hands, would weigh rooo pounds, shortish neck and stocky. The other was taller not heavy. I think he had them as much as two years. He kept them at Middlebury Village. I was about I 8 or 19 years old [born I8I3]."

Mr. Porter W. Champlin of Middlebury, Vt., a very excellent witness said :

"Gifford Morgan was kept on the west of the mountain for two years previous to 1840 . A horse called the Cook Horse also a Morgan was here at the same time and kept by the same man. They were all about this locality as far north as Bristol. The Cook Horse was a chestunt, about 15 hands, from 950 to 1000 pounds. The Hackett Horse was also at Middlebury a number of years both before and after the Gifford and Cook Horse ; Col. Hackett always claimed his horse was by Gifford." 
Leonard Fish, whom we met at the hotel in Braintree, Vt., about I 887, said :

"I owned the purest-blooded horse ever owned here in Vermont, the Gifford, I owned him at Barnard, five or six when I got him, owned him between two and three years, I bought of Lyman Stewart of Barnard, four miles this side of Barnard Center, south of Locust Creek House. Think Stewart got him over the mountain.

"I am 80 years old. I moved from Barnard and bought a farm in Randolph July 26, I852. Must have had him ten years or more before I lived in Barnard. I saw him at old Captain Jonas Bicknell's and Lyman Stewart's. Gifford dark bay, kind and good, was kind as a kitten. James Woodworth, M. D., East Bethel, owned a Black Hawk stallion."

Mr. Washburn of Rochester, Vt., born, 1818 , said :

"Woodbury Morgan was ridden here when I was eight years old, by Sidney S. Heminway. White hind legs and white in forehead. Gifford was owned here by Lyman Stewart. He was owned here a good many years. He got Green Mountain when he stood here, bred by George Bundy who lived in Little Hollow, who sold him when 4 months old. This was about when I was I5 (I833). He was ridden here when five years old. The Gifford horse stood here a good many years.

"Richardson sold Gifford to a man in Randolph. He sold him over the Lake. Richardson brought him from Bethel. Gifford was owned here when he stood here. Every one of his colts was game.

"I have seen and ridden after the dam of Flying Morgan. She was a smart driver. John Stores, or Storrs, owned the dam of the Hackett horse. Sam Flint lives West; he is the brother of George and would know all about the dam of Flying Morgan. Richardson bought Gifford in Bethel and sold him to a man in Randolph, who sold him over the lake. Joe Flint would know. Josiah Richardson raised a dark bay Morgan horse, I050 pounds or over, got by Green Mountain Morgan; foaled about i $\delta_{4} \$$. He left much nice stock here, and sold for $\$ 600$; a regular Morgan built horse, not tall."

Mr. Baxter of Fort Ann, N. Y., in interview, r 888 , said:

"Man came from Vermont, Sam Wyman, married a girl here, he traded horse, got this old stud. He told that he was the old Vermont Morgan. In the fall two men came from Vermont wanted to buy wool, they saw Sam, said he would take $\$ 60$ for the horse, bought him, tickled enough. He was pretty near sorrel, I think, heavy built horse, had shoulders like an ox. Looked logy more like a draft horse, but could stir up most any of them here. He stood in Eaton and got a horse called the Durell horse, Durell Morgan, the image of the old horse, a gray. I think Durell had him, lived in Cambridge, kept there for years. Got good stock, and they were Morgan. The Thomas McFadden stallion from him was gray. A good horse and got good colts, generally about 900 pounds. The Durell Horse was born over 50 years ago."

Mr. Baxter thinks it was over fifty years since Gifford was at Fort Ann.

"The McFadden horse was bred by Thomas McFadden at Fort Edward, some fifty years ago, don't think he lived as late as the war. Henry Harrison of Fort Edward might know of the dam. There were two 
stallions by the Gifford Horse owned by a Doctor in Salem, nice Morgan patterns. Refer to Henry Clark, Salem."

George Kimball of Springfield, Vt., said : "Old Gifford was kept here two or three years, 1842 , or before."

Mr. Ray of Fort Ann, N. Y., in interview, I886, said :

"Col. George Ray came after the revolution. He was a commissary in the English army. He bought out land given to company of artillery, pretty much the whole town. Died here eighty years ago. Only kept three horses, had oxen, mules and niggers. He was uncle to my grandfather, a commissary in the British army at time of revolution."

\section{Mr. Battell,}

$$
\text { Wolcotт, Vт., Dec. 9, I889. }
$$

Dear Sir :-Our postmaster gave me your letter, and as I am in the stock business, and my father raised the old Gifford Morgan, I hold his bills, so that I can trace Morgan blood back a good ways. I have seen a man who told me he thought he raised the horse you are after. His name is Curtis Putnam of Woodbury, Vt. Mr. Clark said he lived neighbor to him, and a man from Chittenden County came through Woodbury some 28 or more years ago with a Morgan horse, and Putnam bred a Morgan mare. She brought a chestnut stud colt, which he sold and it went West. He knew the man, but did not know his given name; he called him Wilson, from Chittenden County. Clark thought that Mr. Putnam could give you the right track of the horse. You had better write him and I will make inquiries and see what I can learn. If I get any more information of him I will let you know. I will do all I can to help anyone trace a Morgan horse's pedigree, for I am a Morgan horse man and claim that there ought never to be any other horses kept for stock. But I have to keep horses to suit people. I enclose you my horse bills, and I can show you as pure a Morgan as stands on four legs nowadays. I raised him, broke him and do all my farm and road work with him, besides covering from thirty to fifty mares a year. I could, if it was called for, trace his blood back to old Gifford Morgan. If I can do any more for you, let me know.

$$
\text { Yours truly, C. H. Gifford。 }
$$

New York State Fair at Syracuse, Sept. I I-I3, I 849 :

"Of the Morgan Stock, there were some excellent specimens from this State, and from New Hampshire and Vermont. The Gifford Morgan twenty-three years old owned by Mr. Weir, of Walpole, N. H., came over to the fair for the third time, not for premium; but just to show that time has not yet left on him any mark of age or decrepitude. Morgan Hunter, owned by Ackley and Gilbert, of East Hamilton, Madison County, N. Y., the General Gifford, exhibited by G. A. Mason of Jordan, N. Y., and the Major Gifford, exhibited by Mr. Blodgett of Chelsea. Vt., are valuable animals, closely resembling their sire, the Gifford Morgan. They attracted great attention. A very fine and showy horse, four years old, got by the noted Black Hawk, was exhibited by H. Felton of Ticonderoga. We noticed an excellent gray stallion owned by Alex. Maxwell of Jackson, Washington County. He is a horse of fine action and handsome appearance.

"A chestnut draft stallion, from Canada, weighing I400 pounds, attracted much attention. 
"Of colts under three years old, there was a large display, though we were unable to learn particulars in regard to many which deserved notice. Mr. Arthur of Ticonderoga, Mr. Hall of Bridport, Vt., and Mr. Austin of Orwell, Vt., each exhibited a fine two-year-old, by Black Hawk. All showed remarkable symmetry and action for their ages. Mr. Burnet of Syracuse, showed a very handsome colt, by Consternation."-The Cultivator, October, 1849 .

Said to be sire of Beppo, 2:30, which see, Vol. I. ; and the long-time trotter, Fanny Jenks, of which Chester gives the following summary:

"Gen. Dunham, Albany, N. Y., May 5, I845, 9:42:57. To beat Io hours. One hundred and one miles."

GIFFORD MORGAN; foaled I848. Advertised for sale, July 24, I852, in Spirit of the Times, at Scottsville, N.Y. A horse of this name is advertised in New Hampshire Patriot in $\mathbf{I} 85 \mathrm{I}$, in New Boston, Milton, Mt. Vernon, etc., by M. D. Perkins.

GIFFORD MORGAN (5-32), dapple chestnut, I6 hands, I275 pounds; foaled about May, I85 I s said to be by Young Morgan of Vermont, son of Gifford Morgan (dam of Young Morgan by Billy Root) : dam by Green Mountain Morgan. Sold to Messrs. Jackson, Helm \& Bridges, Athens, Tenn., r86o. Said to have made as good time in harness as any horse in the South. Pedigree from American Stock Journal, Vol. II. ( ( 860$)$, p. I23.

\section{GIFFORD MORGAN (CLARK'S, CLARK HORSE) (I-8).}

Advertised by Lyman Clark at Cabot and Marshfield, Vt., I87o, in the Vermont Watchman and State Journal.

Mr. Clark in interview said :

"The dam of the Clark Horse's mother was by Bulrush. A. M. George of Washington, I think, bred her. I think dam was bred by George, got by son of Gifford. Keith of Plainfield owned her. I sold the Clark Horse abont 1880 , eight years ago; all Morgan exception of one mare of English blood. I called him Gifford Morgan. I think Dr. George lived in Calais at one time. A great many people came to Danville for Morgan horses in I830-35."

GIFFORD MORGAN (HAMILTON'S) (r-8). Mr. A. W. Goff of Richford says that Mr. Hamilton of Montgomery, Vt., had a Gifford Morgan that he kept there a number of years and that afterwards went back to Woodstock, and also that the Hill Horse, by Black Hawk, was kept on the Island.

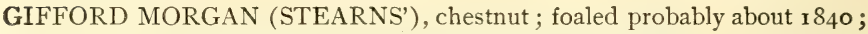
said to have been bred in Vermont, locality and breeder as yet unknown. The author of this book will give a copy to the first person who will furnish name and address of breeder, with proper evidence of its correctness. It is universally understood in the locality where he was kept, that he was got by Gifford Morgan or a son. Purchased by Frank 
or Melvin Stearns, one or both, and Joseph Vickery, it is thought at Syracuse, N. Y., about I 848 , and brought to Jefferson County, N. Y., where he was kept at or near Ellisburg, for several years, and then it is thought went back to Syracuse. This horse was described to us by a number of citizens of Ellisburg and vicinity in July, I906, all agreeing that he was a very excellent horse and left very valuable stock. It will be remembered that the dam of Lady Benton, dam of Gen. Benton, sold to Senator Stanford of California, for $\$ 25,000$, and from which many trotters are descended, was owned by Stephen Wood of Woodsville, N. Y., who stated to us both in letter and interview, that she was bred by this Mr. Frank Stearns, who sold her when about three or four years old to a Mr. Tedham, and he to Mr. Wood. She was foaled about I852, at the time when Mr. Frank Stearns was breeding to Gifford Morgan. Several of the neighbors that we saw of Mr. Frank Stearns, knew that he raised a number of colts from this horse, owned in part and kept by his brother, and it is almost certain that this filly which passed to Mr. Wood is one of them.

It is, too, more than probable that her dam was a gray mare, thought to have been bought when six or seven years old by Mr. Stearns of a neighbor, about I850, and driven by him with a roan gelding that he bought in Canada. This Kibling gray mare was described to us as about I $5_{5}$ hands. Her breeding is unknown. We have received the following letter concerning this horse, and for further information will refer to interviews taken by us in Jefferson County, N. Y., in tracing dam of Gen. Benton, and which will be found under that horse.

Joseph Battell,

Mannsville, N. Y., Sept. 2, I906.

Dear Sir :-I have waited a long time to try and get the pedigree of Gifford Morgan. I remember him perfectly well. He was owned right across the road from where I lived, then a boy of ten years old, now sixty-six years old. I remember him as a great horse, a dark chestnut. I think he was bought by Melvin Stearns and Frank Stearns and Joseph Vickery, but his pedigree I can not give, for everybody is dead; that is why I have waited so long in answering; have tried to find somebody that could tell me all about his breeding. I remember Frank Stearns raising some colts and I remember his having a gray mare but can't say how she was bred. I think Gifford Morgan was by Green Mountain Morgan. If I can find anybody that knows and remembers better than I, will write.

\section{Mr. Fleet Bettinger,}

Yours, Fleet Bettinger.

Bread Loaf, Vt., Oct. I 2, I906.

Dear Sir :-Your letter of September 2 received and has been quite an assistance to me. You say that Gifford Morgan was owned right across the road from where you lived in 1850 . Please inform me:

1.-Color and size?

Ans.—"Dark chestnut, $15.21 / 2$, good length of body, shoulders and 
breast. One of the finest drivers in the world; could step in three minutes, great style."

2.-Did he have a short tail or long; that is, was he docked?

Ans.- "Short tail, carried it fine. Had been docked and pricked as they used to do. I should say weight 1075."

3.-Who owned him at the time? That is, who lived across the road from you?

Ans.—-"Joseph Vickery."

4.-Do you know, or can you refer to any one who might tell from what town in Vermont Melvin Stearns came?

Ans.- "I can not."

5.-Were Melvin and Frank Stearns brothers?

Ans.-_"They were brothers."

6.-I notice that you say you remember Frank Stearns having a gray mare? If possible please state about what year he had this mare and give description of her, size, etc.? You will perhaps remember about what age you were when you remember this mare.

Ans.- "Stephen Wood of Woodville is yet alive, but an old man; he has a son, James Wood, a horseman, that lives with his father. Perhaps son can give you information about the gray mare sold to Woodville."

7.-Can you remember his raising any colts from this mare?

Ans:- "Yes, he raised several."

8.-As I understand, Mr. Frank Stearns sold about i 856 a gray mare to a Mr. Tedham of Woodville, a veterinary, which mare was sold by Mr. Tedham in about a year to Mr. Stephen Wood of Woodville, who raised from her several colts. I am especially anxious to learn the sire of this gray filly that was sold when three or four years old to Dr. Tedham. I am quite suspicious that she was a colt of the gray mare that you speak of. There should be some one in your neighborhood that would remember these facts. Do you think that Mr. Frank Stearns may have bought this gray mare of Mr. Kibling, a neighbor.

Ans.- "He may. Mr. Kibling has a son living in Ellisburg by the name of Fisher Kibling. You had better write him. Address Ellisburg."

9.-Did you know this Mr. Kibling? And is he or any of his children still living? As I understand he built a house in Ellisburg about 1850 .

Ans. - "I think Fisher Kibling can give you more facts about this matter than I in regard to gray mare, but will do all I can for you."

We want this information for a large work on noted American horses we are now publishing.

\section{Yours very truly, Joseph BATTELL.}

A letter sent to a sister at Ellisburg was answered by A. W. Stearns of Dallas, Tex., as follows :

Dallas, Tex., Jan. $2 \mathrm{I}$, 'o8.

Did Frank Stearns breed colts from the stallion, Gifford Morgan? And if so what became of them?

"Yes, quite a number, but cannot say what became of them. His colts always found buyers, a few were left in the country."

Do you remember of his selling a gray filly to Mr. Tedham, a veterinary at Woodville? And which passed to Stephen Wood of Woodville, when about four years old.

"I do not, Melvin and Frank bought, raised and sold many good horses, in fact the Stearns farm had wide reputation for good horses."

Do you remember of Mr. Frank Stearns buying a gray mare of Mr. 
Kibling about $\mathrm{r} 850$, who bought her of Mr. Hiram Morely, and if so, do you remember of Mr. Stearns raising colts from this mare?

"Frank Stearns bought a bay mare, with black points from Stillman Kibling in the 50's. She was from black pacing mare and got by Gifford Morgan. This mare was kept in our family till she died when near twenty-five years old. Do not remember of his ever having owned any other bought from Kibling."

The Parkland, Dallas, Tex., Jan. 20 , I908.

Mr. Joseph Battell, Middlebury, Vt.,

Dear Sir:-In answer to your letter of Jan. IIth, to my sister of Ellisburg, N. Y., beg to say, Melvin and Frank Stearns uncles of mine have been dead many years. As a small boy I remember the stallions referred to, Gifford Morgan owned by Melvin Stearns and Tiger by Joseph Vickery who also bought the former keeping beth in stud many years. Vickery died many years ago but possibly has a brother living in same neighborhood who might give you some information. I think a gentleman by name of Fleet Bettinger lives on the old Vickery farm where the stallions were kept, could give you his address. Bettinger's P. O. Sandy Creek, N. Y. A few years ago, while in Ellisburg, in looking over some old family papers I came across one of Gifford Morgan's stud bills, giving full description and pedigree of the horse, but did not think enough of it to preserve it. I am going to Ellisburg in June, and might learn something of history of these two horses that will aid you in ascertaining what you wish to know, will take pleasure in rendering any assistance possible.

Respectfully yours, A. W. STEARns.

Editor, Northfield, Mass.

Jan. 24, 1908 .

Dear Sir:-Much obliged for your notice in regard to residence of Frank and Melvin Stearns.

I have learned that their father moved from Brattleboro, Vt., to Ellisburg, N. Y., in the early part of the last century.

I am in hopes yet to learn of whom Mr. Melvin Stearns bought the stallion Gifford Morgan. My information is that he bought him in 1849 , in Syracuse, N. Y., but that the horse was raised in Vermont.

The horse was dark chestnut, about $153 / 4$ hands, a good length of body and quite fast. Repeatedly I was told by old citizens of Ellisburg and vicinity that there had never been so good a stallion there before or since.

My interest was aroused in this horse by learning that Mr. Frank Stearns bred the second dam of Gen. Benton,- - a stallion that was foaled r 367 and sold to Senator Leland Stanford, California, for $\$ 25,000$, - at the time his brother was in part owner of Gifford Morgan and another stallion called Morgan Tiger. I also learned from several parties that Frank Stearns bred his mares to these stallions, which with other testimony that I obtained makes it practically certain that the second dam of Gen. Benton was got by one of these Morgan stallions.

From Gen. Benton a large number of celebrated trotters are descended. Besides this $2 \mathrm{~d}$ dam he has several other lines of Morgan blood also connected with Vermont horses, all of which have been left out of the Trotting Register.

In the interest of correct registration we are anxious to see these horses properly recorded in both the Morgan Register, and a still larger 
work, the American Stallion Register, which we are now publishing, and which includes all prominent American stallions.

Truly yours, Joseph Battell.

For further information of this horse see Gen. Benton, page 465 .

GIFFORD MORGAN JR. John W. Phillips under title, Reminiscences of some North Carolina Morgans, writes in Wallace's Monthly, May, I883 :

"Nearly 40 years since, a wealthy planter of this State and county, purchased at a New York State Fair, a Morgan horse, a chestunt about I $5^{1 / 2}$ hands, compactly built, of good style and trotting action, and, there being at that time a number of really fine mares throughout the country, with more or less of the thoroughbred admixture, it is no misstatement of facts to say that this horse begot stock remarkable in an extreme degree for style, temper, speed and bottom: indeed the writer has known some from the loins of this horse that he never expects to see equaled in all that constitutes a first-class road animal.

"I remember that during the late war the father of the writer of this had occasion to go to the Capital of our State, and railroads being uncertain, he drove a pair of these horses, arriving at his destination about two o'clock, having traveled a distance of 70 miles, and having transacted his business, drove twenty miles on his return in one day. I cannot remember now the season of the year, but I have heard him say that he could have driven those horses home easily without scarcely making a stop, if there had been a necessity for it. Is it any wonder that I should state what I know concerning Morgan Horses, when all that is perfect, as a road horse, is impressed upon my memory as regards some of those that I knew and drove years ago? It is needless to say they are extinct now, for the impressing officer, singled all the best animals, for the needs of that stupendous failure, the Confederate Government, and with the advent of peace it was not the improvement of stock, but the production of cotton, that engrossed the attention of the average Southerner. Now I would state that the most excellent of those Morgans were the produce of mares with a full share of the thoroughbred, though the Morgan type were generally impressed upon all. The horse in question bore a striking resemblance to the Gifford Morgan in the American Youatt. It is a matter of great interest to me to know that the individuality of the Morgan is still preserved."

GIFFORD MORGAN JR. (MUNSON'S) (I-4), black, I 5 hands, IIoo pounds ; foaled May 23, I85o, bred by Elijah Judson, Woodbury, Conn. ; got by Gifford Morgan : dam Ribbon Back, said to be by Young Black Hawk, 2d dam taken from Vermont to Connecticut, r 825 , and said to be by Justin Morgan. Owned by H. B. Munson, and kept at Keokuk, Ia. Advertised as above in American Agriculturist, 1857. Is a fine, pleasant traveler, moves in good bold style, very pleasant in temper and very tractable, and is a fine horse.-Linsley.

Advertised at Melrose, Lee County, Ia., I857, as follows :

"Gifford Morgan Jr., by old Gifford. For further particulars, see Linsley's Morgan Horses, page 285. Gifford Morgan Jr., is seven years old in May. He is 15 hands high, thick-set, compact, and weighs over I Ioo pounds; he is a jet black, and his form is a perfect type of the 
genuine Morgan. He is proud and graceful in his movements and though untrained, possesses a high rate of speed combined with extraordinary power and endurance. He has already acquired a great and wide-spread reputation as a stock horse. A yearling colt of his took the first premium at the Lee County Fair, and also took a premium in the class of roadsters at the State Fair at Muscatine, and his owner, Hon. Thomas W. Clagett, president of the State Agricultural Society, was offered and refused $\$ 500$. Terms $\$ 15, \$ 20$ and $\$ 25 ; \$ 5$ to be paid at the time of service.

\section{T. H. Munson, agent for the proprietors."}

Samuel Lee of Baltimore a very intelligent horseman, said in interview, I891 :

"Lyford or some one else owned in Connecticut, a horse got by Gifford Morgan, I think. Not one in a thousand horses is as handsome. His picture is in Lindsley's Book and it is the handsomest picture there. $\mathrm{He}$ was brought here about r 860 and sold to John Thomas of Gen. Wayne's stables, who took him to North Carolina."

DOLLY VARDEN AND GIFFORD MORGAN JR.

$$
\text { Marengo, Ia., July i 9, I } 886 .
$$

J. BATtell, EsQ.,

Dear Sir:-Your favor just received. In reply will cheerfully give you all the information I can. I bought Belle, the dam of Dolly Varden, of Smith Bailey, who at the time lived near Keokuk. Bailey said he raised the mare and that she was got by Gifford Morgan Jr., who was owned by Mr. H. B. Munson of Keokuk, Ia.

Gifford Morgan Jr., was foaled May 23, I850, the property of Elijah Judson of Woodbury, Conn.; sire Gifford; grandsire, Woodbury, by Justin Morgan; dam Ribbon Back, by Young Black Hawk; grandam was taken from Vermont to Connecticut in 1825 and was said to have been by Justin Morgan.

Mr. Bailey has not been heard from by me for a number of years; do not know where to find him, but will make some inquiries. This is all the information I can give you at present. Belle is dead. She was a fine bay mare and trotted a race in $2: 2 \mathrm{I}$ with ten days training; was afterwards used as a road mare in my practice until she was 20 years old, when she died. Dolly Varden was handled 30 days and could easily trot $2: 25$, when she went lame. I have three of her fillies, got by Mambrino Jackson, all very promising. Anything further within my reach will be cheerfully done.

$$
\text { Yours truly, JOHN BRICKES. }
$$

GIFFORD 3D (KARR'S) (I-32), dark bay, black points, I 6 hands, I 300 pounds; foaled I 864 ; bred by John Hammel, Reading, O.; got by Gifford Jr. (Hill's). Pedigree from Burl Karr, Rush County, Ind.

GIFFORD TRAMP, chestnut; foaled I87I; bred by Daniel Hayes, Muscatine, Ia.; got by Tramp, son of Logan : dam Jenny S. Sold to D. C. Gifford, Prairie City, Ia.; to O. H. Henry, Indianola, Ia. Pedigree from breeder.

Sire of Don H., $2: 30 ; 2$ dams of 2 trotters. 
GIFT, bay; foaled 1768; bred by Mr. Lord; got by Cadormus, son of Cade: dam by Second-Starling - Vane's Little Partner-Grayhound -Makeless-Brimmer-Place's White Turk-Layton Barb Mare. Imported into Virginia by Col. Dangerfield of New Kent County. This Second mare was also the dam of DeLancey's famous Cub mare, and appears, with the DeLancey filly and Gift, on page I 78 , Vol. I., of The General Stud Book.

GIFT JR. (7-256), $2: 27 \frac{1}{4}$, brown, black points, over $15 \mathrm{~T} / 2$ hands, II 75 pounds; foaled I874; bred by John \& Adam Colvin, Springfield, O.; got by Mambrino Gift, son of Mambrino Pilot: dam Little Dolly, bay, bred by John \& Adam Colvin, got by Young Bonnie Scotland, son of imported Bonnie Scotland; 2d dam Blink Bonnie, bay, bred by John \& Adam Colvin, got by imported Bonnie Scotland; 3d dam Fair Nell, bay, said to be by Eclipse (Trimble's) ; and 4th dam Jenny Lind, bay, by North Star. Sold to Hugh Huntington, South Charleston, O.; to J. E. Burson, Muncie, Ind. ; to M. S. Claypool, Muncie, Ind. Died July $5^{\text {th, }}$ I 895 .

Sire of 2 trotters ( $2: 10)$; I dam of I trotter.

GIFTMONT (7-256), bay; foaled $\mathrm{I} 885$; bred at Fairlawn Stock Farm, Lexington, Ky.; got by Alecto, son of Almont: dam Lady Gift, roan, bred by T. E. Moore, Shawhan, Ky., got by Mambrino Gift, son of Mambrino Pilot; 2d dam Molly Higgins said to be by Joe Downing, son of Edwin Forrest ; 3d dam Pic, by Picciola, son of Tom Crowder; and $4^{\text {th }}$ dam Susan, by Robert Bruce, son of Clinton. Sold to James W. Madara, Baker's Summit, Penn.

Sire of Silver Lake, $2: 21 \frac{1}{2}$.

GILBERT HORSE (I-I6), black, $15 \frac{1}{2}$ hands; said to be by the Ricker Horse of Stowe, Vt. Owned at Morristown, Vt.

GILBIRDS SPRAGUE (I-64), $2: 2 \mathrm{I} 3 / 4$, black, left hind foot white, $15 \frac{1 / 2}{2}$ hands, Io7 5 pounds; foaled I 876 ; bred by John F. Gilbirds, St. Louis, Mo.; got by Governor Sprague, son of Rhode Island: dam Bohemian Girl, chestnut, bred by Mr. Kirby, Jerseyville, Ill., got by Sir Charles, son of Goliah; 2d dam chestnut, bred by William Frost, Fidelity, Ill., got by Tom Benton. Sold to A. B. Gilbirds; to George H. McCann. Kept at St. Louis, Mo., from $188_{3}$ to 1890 . Pedigree from breeder, who writes from St. Louis, Aug. 31, I 892 :

"I have spent a great deal of time trying to find the breeding of the horse, Sir Charles, but have found out very little. Sir Charles was said to have been a thoroughbred, he was owned somewhere near Jerseyville, Ill., and he was quite a celebrated horse locally.

"Bohemian Girl, dam of Gilbirds Sprague had a record of $2: 32$, and was one of the best road horses ever owned in St. Louis."

Sire of 5 trotters $\left(2: 23^{1 / 2}\right) ; 2$ dams of 2 trotters. 
GILBRETH KNOX (I-8), $2: 263 / 4$, black, I $53 / 4$ hands; foaled 1862 ; bred by Cyrus Guild, Augusta, Me.; got by Gen. Knox, son of Vermont Hero: dam Cahill Mare, dapple brown, dock tail about $151 / 2$ hands, I025 pounds; noted for superior road qualities, fine style and great endurance; purchased by Mr. Guild of Mr. Cahill a railroad contractor, who got her at a sale stable in Boston, Mass., and said that she was brought to their stable by a dealer in a drove of horses from the vicinity of Vermont; said to be Morgan. Owned by A. Wentworth, Boston. Died I874. See The Morgan Horse and Register, Vol. I., p. 362 .

"Gilbreth Knox has proved himself, so far, the most successful descendant of Gen. Knox as a sire of fast trotters. For this reason the breeding and characteristics of his dam are matters of unusual interest to students of the breeding problem. The most intelligent and satisfactory description of the mare which brought this speedy trotter and successful trotting sire comes from the well known horseman Hiram Reed of Augusta, who is familiar with all the noted speed producing sires of Maine, from old Winthrop Messenger, which he had the care of the season Maine Bush Messenger was got, to the present time, and can undoubtedly give a clearer description from personal observation of the form, gait and characteristics of all the different trotting families that ever existed in Maine than any other man living.

"The first knowledge Mr. Reed had of this mare she was brought to Augusta, Me., by a Mr. Cahill, a contractor on the Somerset Railroad, from Augusta to Skowhegan, who used her in his business, traveling between those points. Mr. Cahill stated to Mr. Reed that he bought the mare from a sale stable in Boston, where she had come in a drove of horses brought by a dealer from the vicinity of Vermont. She was a dapple brown with docked tail, and of the genuine old-fashioned Morgan pattern in form, stood about $15 \mathrm{I} / 2$, and weighed in the vicinity of I025 pounds. She was never trained or driven for speed while owned at Augusta, but was noted for her superior road qualities, fine style and great endurance. The average time of her trips from Augusta to Waterville was from an hour and twenty to an hour and thirty minutes, her natural road gait being about ten miles an hour. She was an up-headed animal, even without check-rein, was always spirited, needed no whip, and possessed a wonderful amount of nerve force.

"Mr. Cahill sold this mare to Cyrus Guild of Augusta, who bred at least three foals from her, two of which possessed no special merit; one of these was by the Lewis Horse, known as Young Indian Chief. Mr. Guild bred her once to Gen. Knox, and the produce was a colt now known as Gilbreth Knox, which he kept until two years old, and sold to Hiram Gilbreth (J. H. Gilbreth) of Fairfield for \$200. Mr. Gilbreth kept the colt, developed his speed, won several races with him, and gave him a record of $2: 263 / 4$ in the second heat of a race at Narragansett Park, R. I., Oct. 7, r869.

"Mr. Gilbreth afterward died, and Gilbreth Knox passed into the hands of Arioch Wentworth, Boston, by whom he was owned at the time of the horse's death, which occurred at Beacon Park, July, I874. Mr. Reed is confident that the Cahill Mare, which brought Gilbert Knox, was of Morgan descent, as she possessed the distinguishing characteristics of the Morgan family in a marked degree.-From the American Cultivator

Sire of 6 trotters $\left(2: 22 \frac{1}{2}\right)$; I sire of 3 trotters; 6 dams of 5 trotters, I pacer. 
GILDEROY (3-16); said to be by Massillon Morgan: dam Morgan mare.

"Exhibited at State Fair by R. W. Buck of Judge Kelly's Extra Madeira Farm and received a premium."-Ohio Cultivator, 1856 .

GILES SCROGGINS, bay, I53/4 hands; foaled 1824 ; bred by James W. Jeffries of the Red House, Caswell County, N. C. ; got by Sir Archy, son of imported Diomed; dam Lady Bedford, said to be by imported Bedford; 2 d dam by imported Dare Devil; 3 d dam by Symmes' Wildair, son of imported Fearnaught; 4th dam by Spotswood Appollo, son of

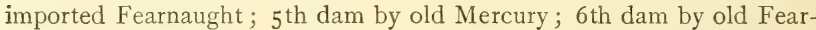
naught; 7 th dam by Jolly Roger; 8th dam Grinnell's imported mare.

Advertised in American Farmer, May 2, I 828, at Sampson C. H., North Carolina, by W. B. Mears, who describes him as "A beautiful blood-bay, with black legs, mane and tail, and a most beautiful coat of hair, which evinces his great purity of blood. He is four years old this spring, and is five feet three inches high. When he attains his full growth (which will not take place under two years more), he will measure fully sixteen hands, and be a horse of great weight and muscular power. His parts are now very fine, particularly in his quarters coupling thigh and back, and when he arrives at the full perfection of his form he will certainly be one of the finest looking horses in this country, and eminently calculated to improve the stock of horses in this section of the State as he combines and partakes more or less of all those fine and valuable crosses which judicious breeders of fine horses hold in such high estimation."

In the American Turf Register, Giles Scroggins was Advertised to stand at Newberne, N. C., in $I_{3} 8$ and $3 \mathrm{I}$, at $\$ \mathrm{I}_{5}$ the season or $\$ 25$ to insure, by Stephen Sampson; in I 832 at Red House, N. C., by Warren Dixon, at $\$ 15$; and $\mathrm{r}_{337}$, by Gilson Yates \& Co., Shelbyville, Ky., at \$3o. In Kentucky a number of his daughters were bred to Golddust and one of his sons, producing fine individuals, great roadsters, and in several instances considerable speed at the trot. He was a successful racer.

GILES SCROGGINS (EPPISON'S), chestnut, $15 \frac{1}{2}$ hands; said to be a descendant of Giles Scroggins, son of Sir Archy; probably a son. Owned about 1844 , by Isaac H. Eppison, near Coffee Creek, Jennings County, Ind., who it is said brought him from near Lexington, Ky. He was trim made and a good looker.

Sire of the dam of the very noted Michigan Morgan sire, Magna Charta.

GILFORD ( I-32), black, two white hind feet; foaled I 888 ; bred by G. \& C. P. Cecil, Danville, Ky.; got by Gambetta Wilkes, son of George Wilkes : dam Dora B., black, bred by G. and C. P. Cecil, got by Mambrino Startle Bonner, son of Startle ; 2 d dam Kate West, black, bred by Capt. Gibson, Maury County, Tenn., got by Enterprise, son of Enfield; 3d dam Young Kate, said to be by McDonald's Mambrino Chief, 
son of Mambrino Chief; and $4^{\text {th }}$ dam a pacing mare of Whip stock. Pedigree from catalogue of breeder. Sold to N. A. Randall, Indianapolis, Ind.

Sire of George Pressor, $2: 24 \frac{1}{4}$.

GILKEY (7-256), $2: 23$, chestnut, $15 \% \frac{1}{2}$ hands, 1075 pounds; foaled 1890 ; bred by A. T. Stark, Allegan, Allegan County, Mich. ; got by President Garfield, son of Masterlode: dam Grass Widow, chestnut, bred by A. T. Stark, got by Pilot Champion, son of Argonaut; 2 d dam Lady, bay, bred by A. T. Stark, got by Henry Middleton, son of Bay Middleton; 3d dam bay, bred by A. T. Stark, got by Thatcher Hambletonian, son of Masterlode; $4^{\text {th }}$ dam bay, said to be by Leon, son of Anthony Wayne, by Andy Johnson, son of Henry Clay, by Andrew Jackson, son of Young Bashaw, by Grand Bashaw, Arabian. Pedigree from breeder.

Sire of Flossie K., $2: 23 \frac{1}{1} / 4$.

GILLIG (I-I6), $2: 23^{1 / 2}$, at four years, brown with white hind ankles, $15 \frac{1}{2}$ hands, 975 pounds ; foaled 1885 ; bred by W. W. Moore, Shoreham, Vt. ; got by Aristos, son of Daniel Lambert: dam Alice, bay, bred by Henry Warren, Meriden Conn., got by Pearsall, son of Jupiter, by Long Island Black Hawk; 2 d dam Lady Snow, 2 :30, brown white hind ankles, 15 I/2 hands, Iooo pounds, said to have been taken from Massachusetts to New York, and owned by Dan Mace, then by George C. Hitchcock, who sold her to Henry Warren. Pedigree from breeder.

We copy the following letters concerning the dam :

Wm. B. Smith, EsQ., Hartford, Conn.,

Middlebury, Vt., June 29, i889.

Dear Sir :-Will you please inform me what is known of the origin and history of Lady Snow 2 :30? I see you bred her to Pearsall and produced the dam of Gillig, four year old record, $2: 233 / 4$. Will you also write me what you know of the history of the dam of Thomas Jefferson, $2: 23$, and greatly oblige.

Mr. Battell,

Very truly yours, Joseph BatTell.

Hartford, Conn., Sept. I2, I889.

Dear Sir :-I first learned of Lady Snow, as having drifted down from the lower part of Massachusetts to New York. This is what Dan Mace said of her origin. She got into Mace's hands, and it was he who rode her in $2: 30$, so said. As I am told she passed from Mace into the team with Ice Pony. I think it was the Baker boys or Baker Brothers, who owned the team. Lady Snow and her mate Ice Pony were known in New York, as the Colgate team and were the first team to beat $2: 40$ to pole driven by Hiram Woodruff on the Fashion Course. They were afterwards bought of Augustus Seeley and R. A. Goodenough by the late Goorge C. Hitchcock, New Preston, Conn., who sold Iady Snow to Henry Warren, Watertown, Conn., who bred Lady Snow to Pearsall twice. The last time Lady Snow produced the little pacing mare, Alice, which I owned, and which I let W. W. Moore have when three or four 
years old. Then I bred Lady Snow and Jefferson. She died in foal. Lady Snow was one of the grandest mares to look at, I ever saw. She had a Morgan and Bellfounder look, a deep dapple bay, weight Iooo pounds, and sound, a handsome long head.

$$
\text { Truly yours, WM. B. SмIтн. }
$$

The American Horse Breeder of March 5, I900, says :

"Of Gillig's second dam, Lady Snow, Mr. George C. Hitchcock, former proprietor of Ash Grove Farm, New Preston, Conn., wrote that he purchased her with her mate, Ice Pony, of Augustus Seeley and R. A. Goodenough of New York City. She was a stout brown mare, standing $15 \frac{1}{2}$ hands, and had two white ankles behind. Mr. Hitchcock. further writes of this pair. 'They were known in New York as the Colgate team and were the first to beat $2: 40$ to pole, driven by Hiram Woodruff on the Fashion Course. I never knew anything about their pedigree. Lady Snow I sold to Henry Warren of Watertown, Conn., he afterwards bred her to Pearsall. They were a very fast team when I owned them.'

"Lady Snow, whose record was made in $\mathbf{I} 865$, as appears by Chester's Trotting and Pacing Record, is said to have come originaily from Massachusetts, and from her build and characteristics was probably of Morgan blood. She was one of the very finest and fastest mares of her day, and is a very valuable element in the pedigree of Gillig." "

A correspondent also writes to the American Horse Breeder :

Editor American Horse Breeder :- “At Worcester Hill Farm, in the heart of the historical horse region of Vermont, Mr. W. W. Moore keeps a small but very choice collection of trotting-bred animals. At the head of the stud is Gillig, "winner of nine out of fifteen races, and champion New England bred colt in both his three-year-old and four-year-old form. His record as a four-year-old is $2: 23^{\mathrm{I}} / 2$.

"Gillig is now a very elegant and substantial brown horse, standing I $5 \frac{1}{2}$ hands, and weighing I050 pounds. He has a faint suspicion of a star, and has two symmetrical white hind ankles. He will be seven years old next July. As a two-year-old he got but one foal, the game and speedy Sue Gillig, that got a three-year-old mark of $2: 25 \mathrm{x} / 4$, at the last New England Breeders' meeting, being I think the fastest of the New England bred three-year-olds, as well as a faster record than ever before stood to the credit of a New England bred sire as young as six years.

"Two of the new foals got by Gillig as a four-year-old have been trained. One, Rupert Gillig, was the winner of the two-year-old race of the Vermont Breeders' Association last season, and the other, Aristo Gillig, took the first heat and second money, and also first premium in his class. These were all bred by Mr. Moore, and Sue and Aristo are at home at Worcester Hill, where I had the pleasure of seeing them last week.

See The Morgan Horse and Register, Vol. I., p. 567 .

W. H. B."

Sire of 7 trotters $\left(2: I_{4} \frac{1}{2}\right), 8$ pacers $\left(2: I_{5}\right)$.

GILLIG (KEITH'S), ( I-8), gray; bred by Mr. P. B. Keith, Campello, Mass.; got by Gillig, son of Aristos, by Daniel Lambert: dam said to be by Abraham, son of Daniel Lambert; 2 d dam by Delong's Ethan Allen; and $3 \mathrm{~d}$ dam by Toot Horse, son of Black Hawk.

Editorial American Horse Breeder, Sept. 22, 1903. 
GILLIS HORSE (I-32), chestnut; said to be by Tornado, son of Index.

Sire of Confidence, $2: 26$.

GILMAN MCGREGOR (5-I28), chestnut; foaled I 884 ; bred by H. H. Lowrey, Frankfort, Kan.; got by Robert McGregor, son of Major Edsall: dam Fanny B., brown, bred by T. T. Smith, Rockford, Ill., got by Star Hambletonian, son of Hambletonian.

Sire of 4 trotters $\left(2: 19 \frac{1}{4}\right)$.

GILMORE BLACK HAWK (CANADA BLACK HAWK) (I-I6), bay.

H. W. Beamish of Blue Bonnets, P. Q., a driver, said in an interview, I889:

"One Gilmore of Lapine Park, near Montreal, owned the Black Hawk stallion that got Farmer Boy, etc.; Alex. Longeoin, Haymarket Square, Horse Exchange, Montreal, drove these trotters. Lady Flinn, Jennie, and Fannie Russell are the same mare, daughter of Daniel Lambert ; she had repeatedly trotted below $2: 30$. I have seen her win in $2: 27 \frac{1}{4}$ on the Lapine track, but she has been given a slower record."

Walter S. Pendergast, Coté des Neiges, near Montreal, said, in an interview, I 890 :

"A man at Lachine owned Canada Black Hawk, whose sire came from Vermont. A man at L'Industrie brought the sire in when two years old from Vermont, a dark brown horse. There were a good many of his sons kept stallions."

See interview with M. Dorion, under Commis.

James Dion of Caughnawaga, Can., 56 years old, a trainer and driver, in interview Oct. 2, 1889, said :

"There is a bay Black Hawk stallion at St. Thérèse probably now living-no better horse ever bred in Canada. He got the trotters Farmer Boy, Village Girl, and Drummer Boy.

"I remember an English horse here 45 years ago; he got good stock; also Black Hawk Morgan came here about 43 years ago. Died a few years ago, about Io. He was more than I 2 years old when I knew him, and that was 30 years ago. I knew him at St. Thérèsa and at Montreal. Charbonneau went to California. The Paquette horse was a son of Black Hawk (Canada), the best son he ever had, now about i 5 years old and in the States. He was short back, five feet, rooo pounds, a fine looking horse, resembled the Canadian horses. Black Hawk was five feet two, brown horse, no white, rooo pounds, tail, mane and legs black, stylish, trotted at about 2 :45."

See Canada Black Hawk.

GILROY (I-I6), foaled $\mathrm{r} 8$ - ; bred at Cambridge, Washington County, N. Y.; got by John J. Crittenden, son of Benson Horse, by Black Hawk. Sire of I trotter $(2: 281 / 2)$.

GILROY ( $\left.1-25^{6}\right)$, black ; foaled $\mathrm{I} 876$; bred by Moulton Bros., West Randolph, Vt.; got by Messenger Duroc, son of Hambletonian : dam Lady Finch (Rosedale), black, bred by Bradick LaHomidu, Middletown, 
N. Y., got by Sayres' Henry Clay; zd dam Miranda, bred in Angelica, N. Y., said to be by Prince Duroc. Sold to Frederick Billings, Woodstock, Vt.

Sire of 5 trotters $\left(2: 20 \frac{1}{4}\right) ; 2$ dams of 2 trotters.

GILT EDGE (1-64), $2: 403 / 4$, dun, silver mane and tail, $15 \frac{1}{2}$ hands, rozo pounds; foaled 1876 ; bred by Henry Hess, Fair Hill, Cecil County, Md.; got by Lyman, son of Bay Chief, by Louis Napoleon (Brouillette Horse, brought from near St. John, Can., to Philadelphia, by M. Bashaw), son of Simard Horse, which see: dam Belle Jackson, brown, bought from Gus Jackson, near Elkton, Md., who bought her in Philadelphia, said to be a Western mare. Always kept in Cecil County. A horse of fine appearance, good action and disposition. Died $\mathbf{I} 897$. Pedigree from breeder, who writes:

Mr. Joseph Battell, Middlebury, Vt.,

FaIR Hill, Ind., Jan. I4, I904.

Dear Sir :- Inclosed find pedigree of Gilt Edge as far as known. Gilt Edge's dam was a brown mare bought from George Jackson near Elkton, Cecil County, Md. He bought her in Philadelphia, said to be a Western mare, could never trace her any farther.

Lyman was a dun horse owned, at the time he got Gilt Edge, by Joseph Gracy of Lewisville, Chester County, Penn.; afterwards sold to Samuel Cregg of Philadelphia, Penn.

Sire of 9 trotters $\left(2: 18 \frac{1}{4}\right)$; I pacer, $2: 24 \frac{1}{2}$ : I sire of 2 trotters.

GILT EDGE; said to be by White Cloud.

Sire of Gray Cloud, $2: 29^{3} / 4$.

GIMCRACK, gray; foaled I 760 ; bred by Mr. Green; got by Cripple, son of Godolphin Arabian: dam Miss Elliott, bred by Mr. Elliott, got by Grisewood's Partner; 2d dam Codia, bred by Mr. Grisewood, foaled r 742, got by Partner; 2d dam Gray Brocklesby, bred by Mr. Crofts,

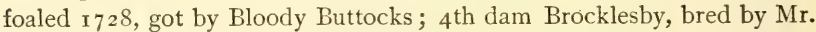
Crofts, foaled I 721 , got by Grayhound; 5 th dam Brocklesby Betty, bred by Mr. Pelham, foaled I 7 I I, got by Curwen Bay Barb; 6th dam Leeds' Hobby Mare, by Lister Turk.

Mr. Parlin, editor of American Breeder, says, Jan. 9, I904:

"Gimcrack, iron gray in youth, hoary white in old age, was one of the most remarkable horses of his day in England. Although small, yet his ability to carry weight was very great, for he frequently gave odds as high as 28 pounds, and he continued on the turf until eleven years of age, thereby showing his uncommon hardiness of constitution and firmness of limb,-qualities which he richly transmitted into the veins of Medley.

"Mr. John Hart of Richmond Va., writes as follows: 'Along with account of great performance of Flying Childers, about $\mathbf{7} 73$, I have somewhere come across statement that Gimcrack ran 25 miles inside of an hour, his last race. Gimcrack died about 1775 , which fact would nearly fix date of his performance as above, if there ever was such a 
performance. Can you lay hands on any statement regarding the matter?'

"The English Author, William Pick, gives a brief history of Gimcrack, in Vol. I., of the Turf Register where he is described as a gray horse, foaled, in 1760 . He began racing in I 764 , as a four-year-old, started five times that season, and won every race. He started in four races as a five-year-old, and won three of them.

"It seems that in I 766, when six years old, Gimcrack was owned by one Count Lauraguias of France. It is stated that he ran a match in France that year of $22 \mathrm{I} / 2$ miles within the hour for a very considerable sum, after which he was brought back to England again. The Turf Register does not give the time made by Gimcrack in that $221 / 2$ mile race nor does it state whether he won or not. It is evident that he did win, however, for the Register states that he was beaten but ten times during his racing career, and gives the date and places of the lost races. The race in France does not appear among the ten that he lost.

"Gimcrack was raced every season up to and including $177 \mathrm{I}$, when he was eleven years old. The $22 \mathrm{I} / 2$ mile race in 1766 is the only unusually long distance race that he ever ran, according to the Turf Register. His last race was at Newmarket, April, I77x. There were nine starters, and Gimcrack won. When nine years old, he was bought by Lord Grosvenor for 1200 guineas, and an offer of I 700 guineas was immediately made for him. He got but few foals.

"According to the Register Gimcrack stood I4 hands and one-fourth of an inch high. His blood lines included two strains of the Byerly Turk, two of the Curwen Bay Barb, one of the Godolphin Arabian and one of the Darley Arabian, the latter through his most famous son, Flying Childers. Gimcrack's sire, Cripple, was by the Godolphin Arabian. Cripple's dam was by Panton's Crab, a son of Basto, and he by the Byerly Turk. The second dam of Cripple was by Flying Childers. The dam of Gimcrack was by Griswold's Partner, and he by Croft's Partner, a son of Jigg, by the Byerly Turk.

"The second dam of Gimcrack was Brocklesby Betty, a daughter of the Curwen Bay Barb. This Brocklesby Betty, according to the Turf Register, was thought to be superior as a runner to any horse or mare of her time. She was used as a brood mare before she was trained for racing. The dam of Croft's Partner was also by the Curwen Bay Barb, sire of Brocklesby Betty. Partner was the best racer of his time at Newmarket. He got Tarter, sire of the famous Herod, a successful race winner, and the most renowned stallion in England, in his day, as a sire of race horses."

GIMCRACK, roan; said to be American-bred, by Hart's imported Medley (the best blood in England) : his dam by Ariel brother to old Partner; $2 \mathrm{~d}$ dam by Whittington; $3 \mathrm{~d}$ dam by Dabster; and $4^{\text {th }}$ dam, Col. Anthony Thornton's celebrated road mare, considered the first of her day in England. Advertised as above at Nottaway County, Va., March, r802, by F. G. Bacon.

GINGER ALE, chestnut, $15^{1 / 2}$ hands, I050 pounds. Taken by Mr. Spaulding together with a gray pacer that he bought at a nunnery, in 
Montreal, and sold at Rochester, N. Y., previous to I86o. Information from Mr. Charlevois, Montreal, I89i.

GIOVANNI (3-64), $2: 28 \mathrm{I} / 4$, chestnut; foaled 1889 ; bred by A. S. McCann, Lexington, $\mathrm{Ky}$; got by Red Wilkes, son of George Wilkes: dam Lady Withers, bay, bred by E. R. Templeman, New Britain, Conn., got by Aberdeen, son of Hambletonian; 2d dam Lady Warwick, bay, bred by Dr. Samuel H. Chew, Fayette County, Ky., got by Delmonico, son of Guy Miller; 3d dam said to be by Strader's Cassius M. Clay ; 4 th dam by Hunt's Commodore; $5^{\text {th }}$ dam by Young's Pilot, son of Pilot Jr.

Sire of Giovanni Jr., $2: 19 \% 4$.

GIPSEY BOY (3-64), $2: 28$, black with star, I5 1/2 hands, rooo pounds; foaled 1874 ; bred by Charles A. Vogt, Iowa City, Ia.; got by Stonewall Jackson, son of Mambrino Chief : dam Fanny Bashaw, brown, bred by J. A. Green, Muscatine, Ia., got by Green's Bashaw, son of Vernol's Black Hawk; 2d dam Tempie Abdallah, bay, bred by Joseph A. Green, got by Gifford Morgan Jr., son of Gifford Morgan, by Woodbury Morgan, son of Justin Morgan ; 3 d dam Sally Green, bay, bred by Jonas Seeley, Sugar Loaf, N. Y., got by Hambletonian; 4th dam Belle (dam of Green's Bashaw), brown, bred by Jonas Seeley, Orange County, N. Y., got by Webber's Tom Thumb; $5^{\text {th }}$ dam the Chas. Kent mare (dam of Hambletonian), brown, bred by Jonas Seeley, got by imported Bellfounder. Sold to M. P. Donahey; to O. E. Marble; to H. E. Yerick, Washington, Ia. Pedigree from Carl A. Vogt.

Sire of 5 trotters $\left(2: I_{4} \frac{1}{2}\right) ; 2$ sires of $\mathbf{I}$ trotter, I pacer; 6 dams of 2 trotters, 4 pacers.

GIPSEY BOY, $2: 23 \mathrm{~T} / 4$, bay; foaled I 882 ; bred by Robert Jackman, Harlem Springs, O.; got by Hiatoga Chief, son of Hiatoga : dam Gipsey Kate.

Sire of 4 pacers $\left(2: 17 \frac{1}{4}\right)$.

GIPSEY CHIEF; said to be by Seneca Chief.

Sire of Tipton Boy, $2: 24 \frac{1}{4}$.

GLADAX ( $1-64$ ), bay, I5 $5 \frac{1}{2}$ hands, 1000 pounds; foaled 1895 ; bred by W. P. Ijams, Terre Haute, Ind.; got by Axtel, son of William L.: dam Gladys, bay, bred by I. M. Martin, Louisville, Ky., got by Hambletonian (Hetzel's), son of Hambletonian; 2 d dam Jule B., brown, bred by A. J. Alexander, Spring Station, Ky., got by Woodford Mambrino, son of Mambrino Chief; 3d dam Bruna, said to be by Pilot Jr.; and $4^{\text {th }}$ dam by Black Snake. Sold to J. E. Robbins, Greensburg, Ind. Pedigree from breeder.

Sire of Old Fashion, $2: 19 \frac{1}{4}$.

GLADIATOR (I-I28), bay, I6 hands; foaled $187-$; bred by John Wilson, 
Vallejo, Cal. ; got by George M. Patchen Jr., son of George M. Patchen ; dam Buttermilk Sal. Pedigree from breeder.

Sire of 2 trotters $(2: 2 I) ; 2$ dams of I trotter, I pacer.

GLADIATOR (3-64), $2: 22 \frac{1}{2}$, bay, black mane and tail, I 6 hands, I Ioo to 200 pounds; bred by James Shera, Laurel, Franklin County, Ind.; got by Blue Bull : dam bay, bred near Andersonville, Ind., got by Cockspur (so-called). Sold to James Wilson, Rushville, Rush County, Ind. Pedigree from breeder, now of Connersville, Ind., who writes :

"Gladiator's dam was a neat, trim built, high spirited mare about I6 hands high. Best saddle mare I ever owned also splendid driver. Had nearly all the gaits."

GLADIATOR, bay; foaled I879; bred by W. H. Wilson, Cythiana, Ky.; got by Smuggler, son of Blanco: dam Mattie Lake, chestnut, bred by Judge West, Cynthiana, Ky., got by Pacing Abdallah, son of Alexander's Abdallah.

Sire of Fred Smuggler, $2: 22$.

GLASSTON (5-256), chestnut; foaled 1887 ; bred by V. K. Glass, Georgetown, Ky.; got by Dictator Jr., son of Dictator: dam said to be by Munroe Chief, son of Jim Munroe; and $2 \mathrm{~d}$ dam by John Dillard, son of Indian Chief, by Tecumseh, Canadian. Sold to A. A. Kitzmiller, Lexington, Ky. ; to E. J. Meyer, Canton, O.; to C. A. McWhinney, Prairie City, Ill.

Sire of Lula Glasston, $2: 191 / 4$; I dam of I pacer.

G. SEE (3-5 г2), bay; foaled I883; bred by Williams and Granville Cecil, Danville, Ky.; got by Onward, son of George Wilkes: dam Fanny Neale, bay, bred by F. R. Neale, Springfield, Ky., got by Star Denmark; 2 d dam Sally Neale, bred by Frank Neale, got by Mambrino Chief, son of Mambrino Paymaster ; 3 d dam said to be by Tenor; and 4 th dam by Double-head. Sold to Cecil \& Williams, Danville, Ky. Pedigree from Granville Cecil.

Sirê of I trotter $\left(2: 24 \frac{1}{2}\right), 3$ pacers $\left(2: 13^{3 / 4}\right)$.

GLENAIR (3-64), chestnut with star and white hind legs, $153 / 4$ hands; foaled June 8, I871 ; bred by Charles Backman, Stony Ford, N. Y. ; got by Messenger Duroc, son of Hambletonian : dam Emma Mills, chestnut, bred by Wm. Hill, Walkill, N. Y., got by American Star, son of Coburn's American Star, by Cock of the Rock, son of Sherman Morgan; $2 \mathrm{~d}$ dam said to be by Rediker's Alexander W., son of Alexander W., which see. Sold to J. H. Walker, Worcester, Mass. Pedigree from T. A. Wright, Manager for Charles Backman at Stony Ford Stock Farm.

Sire of Idlewild, $2: 291 / 4 ; 2$ dams of $I$ trotter, I pacer.

GLENALLEN (7-64), black, $153 / 4$ hands; foaled 1882 ; bred by Lawrence 
Brainard, St. Albans, Vt. ; got by Ben Franklin, son of Daniel Lambert : dam Nelly, bred by Lawrence Brainard, got by David Hill, son of. Black Hawk; 2d dam Bay Fanny, bred by Lawrence Brainard, got by Green Mountain Morgan. Sold to George W. Hendee, Morrisville, Vt.

Sire of B. F. Solon, $2: 22$.

GLENARLTON ( $1-128$ ), $2: 26 \frac{1}{4}$, bay with three white feet, 16 hands, 1200 pounds; foaled 1892 ; bred by A. G. Lyon, Mason, Mich. ; got by Will Carlton, son of Pilot Medium: dam Glimmer, gray, bred by James Steinhoff, Mason, Mich., got by Greenbacks, son of Princeps ; 2 d dam Lady Censor, gray bred by James Steinhoff, got by Censor, son of Washington Hambletonian. Sold to the Belgian Horse Co., Grandledge, Mich. Pedigree from breeder.

Sire of Glenn H., $2: 25$.

GLENARM (3-1 28$), 2: 231 / 2$, bay with white hind ankles, $151 / 2$ hands, ro6o pounds; foaled I 878 : bred by Gen. W. S. Tilton, Togus, Me.; got by Constellation, son of Almont : dam Skip (dam of Independence, $2: 2$ I I $/ 4$ ), gray, bred by C. F. Taylor, South Vassalboro, Me., got by Gideon, son of Hambletonian : $2 \mathrm{~d}$ dam bay, said to be by Indian Chief. Sold to C. F. Taylor, South Vassalboro, Me.; to Gen. W. S. Tilton, Lewiston, Me.; 1880 to C. P. Drake, Lewiston, Me., who sends pedigree.

Sire of Glendale, $2: 25 ; 2$ sires of I trotter, I pacer; 4 dams of 3 trotters, I pacer.

GLENARME JR., said to be by Glenarme, son of Harold.

Sire of Chestnut, $2: 071 / 2$.

GLEN ATHOL (3-256), bay ; foaled I888; bred by G. \& C. P. Cecil, Danville, Ky.; got by Gambetta Wilkes, son of George Wilkes : dam Hallie B., bay, bred by C. A. Anderson, Dayton, O., got by Hambrino, son of Edward Everett; 2 d dam Lady M., black, bred by Richard Anderson, Dayton, O. ; got by Almont, son of Abdallah (Alexander's) ; 3d dam Black Girl, by Cassius M. Clay Jr., son of Cassius M. Clay. Pedigree from breeder.

Sire of 3 trotters $\left(2: 21 \frac{1}{4}\right) ;$ Nancy Athol, $2: 171 / 4$.

GLENBIRD ( $1-64$ ), roan, I53/4 hands, I roo pounds; foaled I 89 I ; bred by A. H. Farwell, Independence, Ia., got by Jay Bird, son of George Wilkes : dam Phœbe Wilkes, bay, bred by C. A. DeCraff, Janesville, Minn., got by Empire Wilkes, son of George Wilkes ; 2d dam Lorelei, bay, bred by C. A. DeGraff, got by Alexander (DeGraff's) son of Goldsmith's Abdallah; 3d dam Frankie P., bay, bred by D. A. Gage, Waukegan, Ill., got by Logan (Gage's), son of Hambletonian; 4th dam Nancy Price, said to be by imported Sovereign. Sold to Victor Vervecke and taken to England. Pedigree from breeder.

Sire of Edmee, $2: 291 / 4$. 
GLENCAIRN, bay; foaled I89 ; bred by Leland Stanford, Menlo Park, Cal. ; got by Lottery, son of Electioneer : dam Glencora, brown, bred by Leland Stanford, got by Mohawk Chief, son of Hambletonian ; 2d dam Lady Gilbert, untraced.

sire of $\mathcal{F o s e p h , ~} 2: 23 \%$.

GLENCOE (3-I28) : said to be by Kentucky Prince.

Sire of Razzle Dazzle, $2: 161 / 4$,

GLENCOE. For pedigree, see Introduction to this book, page 79 .

"Imported stallion Glencoe (sire of Reel, Peytona, Moth, Graciviene, Torch Light, Fanny King, etc.) at Mr. Thomas Flintoff's, five miles below Nashville, Tenn." Advertised, I 845, as above in Observer and Reporter, Lexington, Ky., by Thomas Kirkman.

We add the following pertinent letter from the Turf Field and Farm.

"EdTTOR TURF FiELD AND FARM:-At the first glance this question will be pronounced very absurd, but the unparalleled performances of that greatest of all four-year-old pacing wonders, Arrow ( $2: \mathrm{r}_{4}$ in second heat), having downed with the greatest ease all of the fastest and best trotters and pacers that were pitted against him-pacing no less than nine races, winning them all-is my apology for this inquiry. His breeding is even more astounding than his performances, being sired by the stallion A. W. Richmond, son of Blackbird (from a mare very largely of running-blood), and his dam a thoroughbred daughter of Crighton, son of Glencoe; therefore, he is fifteen-sixteenths thoroughbred at least.

"But the most amazing thing about this most wonderful performer is that he traces directly through sire and dam (in quadruple lines) to imported Diomed, and not to a single animal in his whole lineage that was ever known to pace a step.

"If Arrow were the only performer at the pacing gait carrying the blood of Glencoe, he might be considered a freak of nature, but as I write (without consulting the Register), the following carrying his blood occur to me :

"The dam of Jewett, $2: 22 \mathrm{I} / 2$ trotting, 2 :1 4 pacing, was by John Innes, son of Glencoe.

"The dam of Clara Cleveland, $2: 23$ (trotting), was by Glencoe.

"The dam of Richball, $2: 121 / 2$ (pacing), was by Little Arthur, son of Glencoe.

"The dam of Loretta F., 2 :1 $8 \frac{1}{4}$ (trotting), by Col. Grayson, son of Glencoe.

"The dam of Arrow, four-year-old record 2 :I4 (pacing in second heat), by Crighton, son of Glencoe.

"The second dam of Jay-Eye-See, 2 : 10 (trotting), was from a daughther of Glencoe.

"Col. Lewis (a converted pacer) $2: 18 \frac{1}{2}$ (trotting), was sired by Rifleman, son of Glencoe.

"Abner F. $2: 24^{1} / 2$ (trotting), was sired by Dr. Maxwell, son of Little Arthur, by Glencoe.

"Dolly the dam of Fleta, $2: 29^{\mathrm{T} / 2}$ (trotting), and Envoy, $2: 28$ (trotting), was by Iowa, son of Glencoe. 
"Almonarch, $2: 243 / 4$, has four in the $2: 30$ list (including a $2: 20$ pacer) in 1887 . His dam is Hi (Brilliant), by Asteroid, son of Lexington. The dam of Asteroid was a daughter of Glencoe, and the dam of $\mathrm{Hi}$ was from another daughter of Glencoe, thus making him a double Glencoe, and notwithstanding that no other son of Almont has equaled him, it is not at all probable that any mares worthy of his embrace will be stinted to him, not being bred according to that bundle of 'idiocies' called the 'standard.'

"There are many other performers carrying the blood of Glencoe, which to enumerate would be a tedious task. But there is another very instructive fact in this connection which I would mention for the benefit of any of your readers who may have allowed themselves to be blindfolded by this silly 'standard.' The two very best of those I have enumerated, viz., Arrow and Richball, carry vastly more of the blood of the thoroughbred than any of the others. The latter was by King Pharaoh, a son of American Star (from a mare nearly or quite thoroughbred), and the sire of the former, coupled with a strictly thoroughbred daughter of Bonnie Scotland, produced the only mare on earth with two stallion sons in the $2: 20$ list; also, coupled with two mares of very low breeding, produced Romeo, $2: 19 \frac{1}{2}$, and Len Rose, $2: 27$. Had Richball not received such inhuman treatment he would unquestionably have been the king of pacers; but, like our little king of trotters, was ruined through the unsatiable greed of his owner.

"It is said that Budd Doble has secured Arrow and will bring him East in the spring. Hope the report is true; he couldn't have fallen into better hands. If no accident befalls him he will make a clean sweep of the circuit (unless he is already ruined), or my name is not

\section{LEXINGTON."}

The famous trotter Lord Clinton, $2: 083 / 4$, was by Revenue Jr., son of Revenue by imported Trustee; dam of Revenue Jr., Pauline by imported Glencoe.

Sire of Winnebago, grandsire of Amy B., $2: 24 \frac{1}{4}$, and winner of 16 recorded races.

GLENCOE (I-64), bay, I53/4 hands, I 200 pounds; foaled about I 883 ; bred by Philip Kreigh, Stilesville, Hendricks County, Ind.; got by Glenarnie, son of Harold: dam brown, bred by George W. Lee, Greencastle, Ind., got by Rescue, son of Satellite; 2 d dam black, said to be by Drennon; and $3 \mathrm{~d}$ dam by imported Glencoe. Pedigree from breeder.

Sire of Glenwood, $2: 27$.

GLENCOE JR., chestnut; foaled I870; said to have been brought from Mississippi to Texas in 1879 .

Sire of 3 pacers $\left(2: I_{5}\right) ; 3$ sires of I trotter, 2 pacers; I dam of I pacer.

GLENCOE JR. (I-I6), brown, bred at Spring Hill, Tenn., said to be by a son of imported Glencoe : and dam by Vermont Boy.

Sire of Madge Hatton, $2: 17 \frac{1}{4}$.

GLENCOE JR.; said to be by Davy W.

Sire of Kitty Blossom, $2: 181 / 4$. 
GLENCOE GOLDDUST $(3-32), 2: 32$, rich red chestnut, white hind legs, star, I5 $3 / 4$ hands, II 50 pounds; foaled 1871 ; bred by L. L. Dorsey, Middletown, Ky.; got by Golddust, son of Vermont Morgan : dam Gauze, chestnut with star, $15 \% \frac{1}{2}$ hands, Iooo pounds, bred by E. Dorsey, Jefferson County, Ky., got by Green Mountain Black Hawk, son of Sherman Black Hawk; 2d dam, chestnut, bred by E. Dorsey, got by imported Glencoe, and said to be thoroughbred. Sold to D. R. Locke (Nasby) ; to John Branshew, Bucyrus, O. ; to H. Giltner, Charlestown, Ind. Died about $\mathbf{I} 890$. Pedigree from breeder.

Sire of George W. Davis, $2: 261 \frac{1}{4} ; 3$ dams of 2 trotters, I pacer.

GLENCOE WILKES (I-32), $2: 4 \mathrm{I}$ I/2, bay, I 6 hands, I I jo pounds; foaled I $88 \mathrm{I}$; bred by E. E. Eagle, Lexington, Ky. ; got by Alcantara, son of George Wilkes : dam Betsey I., bay, bred by E. E. Eagle, got by Ericsson, son of Mambrino Chief; 2 d dam Mollie Lincoln, said to be by imported Australian, son of West Australian; and $3 \mathrm{~d}$ dam Lady Bruce, by Star Davis, son of Glencoe. Sold to F. S. Gerald, Laconia, N. H., who sends pedigree.

Sire of 6 trotters $\left(2: 12 \frac{1}{2}\right), 7$ pacers $\left(2: 1 I^{1} / 4\right) ;$ I sire of I pacer; I dam of I pacer.

GLENDALE ( $\mathrm{I}-32$ ), bay with black points, two white hind feet, $\mathrm{x} 6$ hands, I 240 pounds; foaled I 873 ; bred by N. G. Glenn, Jeromeville, O.; got by Hambletonian (Glenn's), son of Volunteer: dam old Fanny, said to be by Independence; $2 \mathrm{~d}$ dam by Star Gazer: and $3 \mathrm{~d}$ dam by Engineer. Pedigree from breeder.

Sire of Mattie Hunter, 2 :30; I dam of I trotter.

GLENDINE ( $\mathrm{I}-32)$, chestnut, with blaze in face and one hind foot white, I 6 hands, I roo pounds; foaled I 886 ; bred by K. D. Wise, Los Angeles, Cal. ; got by Judge Salisbury, son of Nutwood: dam Tempest, bay, bred by F. M. Slaughter, Rincon, Cal., got by Sultan, son of The Moor; $2 \mathrm{~d}$ dam Belle Mason, bred by F. M. Slaughter, got by Williamson's Belmont, son of American Boy; 3d dam, bred by F. M. Slaughter, said to be thoroughbred. Owned by D. K. Wise, Los Angeles, Cal., who sends pedigree. Died 1891 .

Sire of Westminster, $2: 161 / 2$.

GLEN DUROC (3-128), bay; foaled I879; bred by Charles Backman, Stony Ford, N. Y.; got by Messenger Duroc, son of Hambletonian : dam bay, bred by Charles Backman, got by Hambletonian; 2d dam Fanny Star, bay, bred by Dr. W. C. Derby, Ellenville, N. Y., got by American Star ; 3d dam the Morrill mare, said to be by Ethiopian Prince, son of

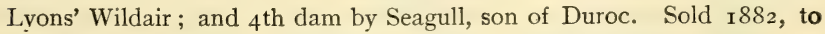
I. McNally, and later to Huffman \& Flack, both of Springfield, O.

GLENELG (3-256), black, I6 hands, I 200 pounds; foaled I 884 ; bred by George W. Sherwood, St. Paul, Minn.; got by Baymont, son of Alden 
Goldsmith: dam Miss Cole, bred by C. T. Bradley, Milwaukee, Wis., got by Milwaukee, son of Hambletonian; $2 \mathrm{~d}$ dam Lady Cole, said to be by Williams' Magna Charta, son of Magna Charta. Pedigree from breeder.

Sire of Lady R. E. D., $2: 163 / 4$, Glenella, $2: 161 / 4$.

GLEN GARIFF (7-I28), bay; foaled I889; bred by Rockhill Bros. \& Fleming, Fort Wayne, Ind.; got by Strathmore (Goodwin Watson), son of Hambletonian: dam Jenny Hall, bay, bred by Volney Forbes, West Haven, Vt., got by Daniel Lambert, son of Ethan Allen ; 2 d dam Hammond mare (dam of John Hall, $2: 25 \mathrm{~T} / 4$ ), said to be by American Ethan, son of Ethan Allen. Sold to Seyster \& Fesler, Oregon, Ill.

GLENGARRY (I-8), $2: 27$, brown, I 5 hands, rooo pounds; foaled I866; bred by Isaac Downing; East Monmouth, Kennebec County, Me. ; got by Winthrop Morrill, son of Young Morrill. Sold to Herhon Titus; to J. D. Packard; to John May ; to John Shepherd, Boston.

GLEN MACK, $2: 161 / 4$, gray; foaled I 888 ; bred by E. R. Biggs, Goshen, Ind.; got by Glen Miller, son of White Line: dam Daisy, said to be by Germalda, son of Joe Downing; and $2 \mathrm{~d}$ dam by Gray Messenger. Sold to James D. Ralston, Fayetteville, Tenn.

Sire of Transvaal, $2: 181 / 4$.

GLEN MESSENGER (I-I6), sorrel, I5 T/2 hands, I050 pounds; foaled May, I 886 ; bred by J. B. Dodge, Walnut, Ill. ; got by Tiger Messenger, son of Morgan Messenger : dam sorrel, bred by G. G. Glenn, got by Como Chief, son of Chieftain, by Andrew Jackson; $2 \mathrm{~d}$ dam bred by Mr. Olds, Sterling, Ill., got by Prophet, son of Black Hawk.

GLEN MILLER, 2 :I8, gray, I 7 hands, II50 pounds; foaled I 876 ; bred by J. N. Conklin, Cambridge City, Wayne County, Ind. ; got by White Line, son of Strong Horse: dam bay, bred by John Mallery, Louisville, Ind., got by Alexander's Abdallah. Sold to Glen Miller, Richmond, Ind.; to J. H. Hall, Bellevue, O. Died July, I887.

Sire of 2 trotters $(2: 261 / 4), 2$ pacers $(2: I 9 \%)$; I sire of I pacer; 2 dams of I trotter, I pacer.

GLEN MORGAN ( $1-64$ ), bay ; foaled April, r905; bred by Martin Ruste, Mt. Horeb, Dane County, Wis.; got by Scott Davis, $2: 24 \frac{1}{4}$, son of Scott Smith, $2: 28$ : dam black, bred by John Pluis, Cross Plains, Wis., got by Major B., son of Onward; 2 d dam Bet, bred by Mike Welch, Blue Mounds, got by Comet Morgan, son of Cutler's Comet ; $3 \mathrm{~d}$ dam Brick, bred by Mike Welch, got by Gray Morgan, son of Cutler's Comet. Sold to Martin Ripham, Mt. Horeb, Wis.

GLENVIEW, bay, 16 hands; foaled 1875 ; bred by A. J. Alexander, Spring 
Station, Woodford County, Ky.; got by Belmont, son of Alexander's Abdallah: dam Fadette, chestnut, bred by R. A. Alexander, got by Alexander's Abdallah; 2 d dam Lightsome, chestnut, bred by H. A. Durley, Lexington, Ky., got by imported Glencoe, son of Sultan ; 3d dam Lerity, bay, bred by H.'A. Durley, got by imported Trustee, son of Catton; $4^{\text {th }}$ dam Bess, bred by Dr. B. W. Durley, Lexington, Ky., got by imported Tranby. Owned by J. C. McFerran \& Son, afterwards several years at Caton Farm, Joliet, Ill., and went to Michigan, I866; sold to A. J. Caton, Chicago, Ill., I884. Pedigree from L. Brodhead.

Sire of 2 trotters $\left(2: 26 \frac{1}{2}\right)$; Easter Girl, $2: 24 \frac{1}{2} ;$ I sire of 5 trotters, I pacer; 3 dams of 2 trotters, I pacer.

GLEN WILKES, $2: 25$, bay; foaled $\mathbf{1} 887$; bred by Timothy Anglin, Lexington, Ky.; got by Wilkes Boy, son of George Wilkes: dam Kitty Tranby, bay, bred by Timothy Anglin, Lexington, Ky., got by Mambrino Tranby, son of Mambrino Patchen ; 2d dam Betty Brown, brown, bred by R. D. Mahone, Lexington, Ky., got by Mambrino Patchen; and $3 \mathrm{~d}$ dam Pickles, said to be by Mambrino Chief. Sold to H. J. Palmer, Grand Island, Neb.

Sire of Lady Montgomery, $2: 29 \frac{1}{4}$.

GLENWOLD (3-1 28 ), bay, I $^{1 / 2}$ hands; foaled 1884 ; bred by M. H. Smith, Louisville, Ky.; got by Nutwood, son of Belmont: dam Miss Ada, bay, bred by Lister Witherspoon, Midway, Ky., got by Almont, son of Alexander's Abdallah; 2 d dam Mother Hubbard, bay, bred by Richard Johnson, Georgetown, Ky., got by Toronto (Johnston's), son of St. Lawrence (Kinkead's). Sold to Samuel J. Look, Louisville, Ky., I886, for Robert H. Stevenson, Boston, Mass. Pedigree from Samuel J. Look.

Sire of 2 trotters $\left(2: \mathrm{II}^{3} / 4\right) ;$ I dam of 2 pacers.

GLENWOOD ( $\mathrm{I}-32$ ), bay; foaled $\mathrm{I} 885$; bred by G. W. Fogg, Nashville, Tenn.; got by Nutwood, son of Belmont: dam Tipsy, gray, bred by A. W. \& T. O. Harris, got by Alcalde, son of Mambrino Chief; 2 d dam Mary Weaver, gray, bred by D. C. Twogood, Canastota, N. Y., got by Black Hawk Vermont, son of Kilburn's Hero, by Black Hawk; 3 d dam Peggy, owned by Gen. Dunham, Troy, N. Y. Pedigree from catalogue of Prairie Dell Farm, Topeka, Kan.

Sire of 2 pacers $\left(2: 14^{1 / 2}\right)$.

GLENWOOD (I-64), $2: 273 / 4$, chestnut, with star, I6 hands, II50 pounds ; foaled about I 875 ; bred by Pliny Nichols, West Liberty, Ia. ; got by Wapsie, son of Bashaw: dam The Bradshaw Mare, bay, bred near Lexington, $\mathrm{Ky}$., brought to Iowa when two years old by a $\mathrm{Mr}$. Bradshaw of Kentucky, who sold to S. Jacobs, he to his son, and he to 
Mr. Nichols, - said to be by Mambrino Patchen. Sold to Dr. O. W. Archibald, West Liberty, Ia. Information from breeder.

Sire of Maud Archibald, $2: 271 / 4$; I dam of I trotter, I pacer.

GLENWOOD (3-128), $2: 29 \frac{1}{2}$, bay; foalet 1888 ; bred by H. L. \& F. D. Stout, Dubuque, Ia.; got by Nutwood: dam Jemima, said to be by Scotland Boy, son of Mambrino Royal, by Relf's Mambrino Pilot, son of Mambrino Chief; 2d dam Cricket, black, bred by J. C. McFerran, Louisville, Ky., got by Cuyler, son of Hambletonian ; 3d dam Evelina, bay, bred by Thomas Cavins, Clark County, Ky.; got by American Clay, son of Strader's Cassius M. Clay; $4^{\text {th }}$ dam said to be by Moody's Davy Crocket. Sold to W. C. Watts, Madison, Ind.; to Frank Fairbanks, Terre Haute, Ind.; to T. B. Taylor, Sandusky, O.; to D. B. Nims, Bellevue, $\mathrm{O}$.

Sire of Glenwood Jr., 2 :25; King Glenwood, $2: 191 / 4$.

GLIDE (TRICOTRIN) (3-32), $2: 24$, chestnut, I 6 hands, I Ioo pounds; foaled I 868 ; bred by Samuel Wood, Haddanfield, N. J.; got by Perkin's Morrill, son of Young Morrill: dam Sleepy, brown, bred by William C. Wood, got by North Morrill, son of Sherman Black Hawk; 2d dam gray, bred by John Lewis, Medfield, N. J., got by Bay Trafalgar, son of Trafalgar; 3 d dam gray. Sold to C. R. Colwell, Philadelphia, Penn.; to Mr. Hitchnell, Baltimore, Md. See The Morgan Horse and Register, Vol I., p. 643 .

GLIDE (5-128), brown, I5-3 hands, Iooo pounds; foaled I 884 ; bred by Dr. Bellinger, Cherry Valley, Ill. ; got by Frank Miller, son of Blue Bull : dam Mattie Stewart, said to be by Pocahontas Boy, son of Tom Rolfe ; 2d dam Jennie. The dam of Pocahontas Boy was Fanny Benson, by Jerry, son of Shropshire's Tom Hal. Information from Wm. T. Weese, Platteville, Ill.

Sire of Neusshine, $2: 23^{1 / 2}$.

GLIDEAWAY, brown ; foaled r 888 ; bred by Wallace Bros., Lexington, Ky. ; got by Wilkes Boy, son of George Wilkes: dam Mary Ferguson, bay, bred by Wallace Bros., Lexington, Ky., got by Ferguson, son of George Wilkes; 2 d dam Lady Ashland, said to be by Ashland Chief, son of Mambrino Chief ; 3d dam Kit, by Mambrino Prince, son of Mambrino Chief; and $4^{\text {th }}$ dam Queen, by Gossip Jones. Sold to G. W. Redmon, Paris, Ky.

Sire of Lazarre, $2: 24 \frac{1}{4}$.

GLOBE (3-32), $2: 143 / 4$, dark bay, small star; foaled May 2, I88I ; bred by C. J. Hamlin, Buffalo, N. Y.; got by Hamlin's Almont Jr., son of Almont: dam Kate Patchen, black, bred by C. J. Hamlin, East Aurora, N. Y., got by Hamlin's Patchen, son of George M. Patchen; 


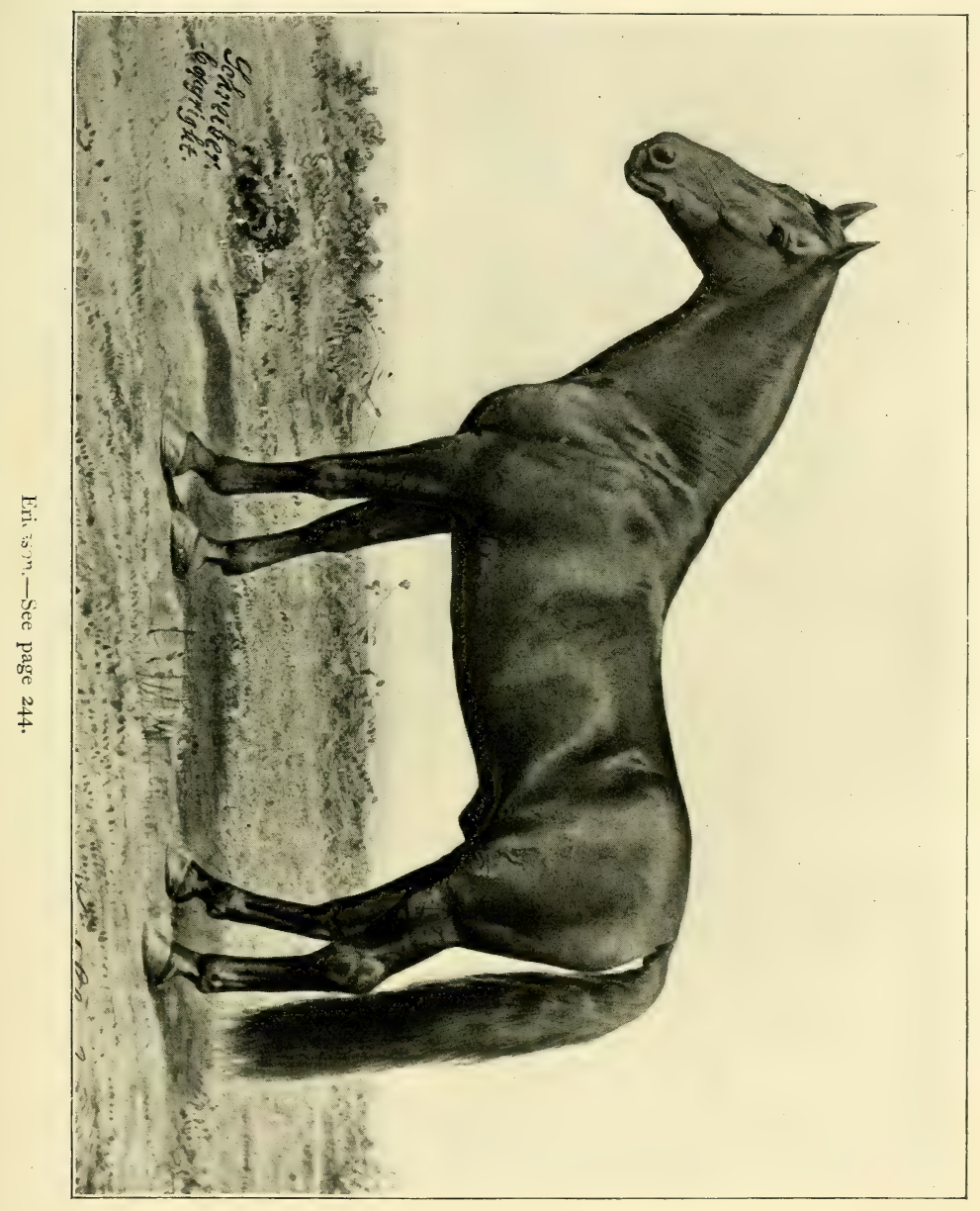




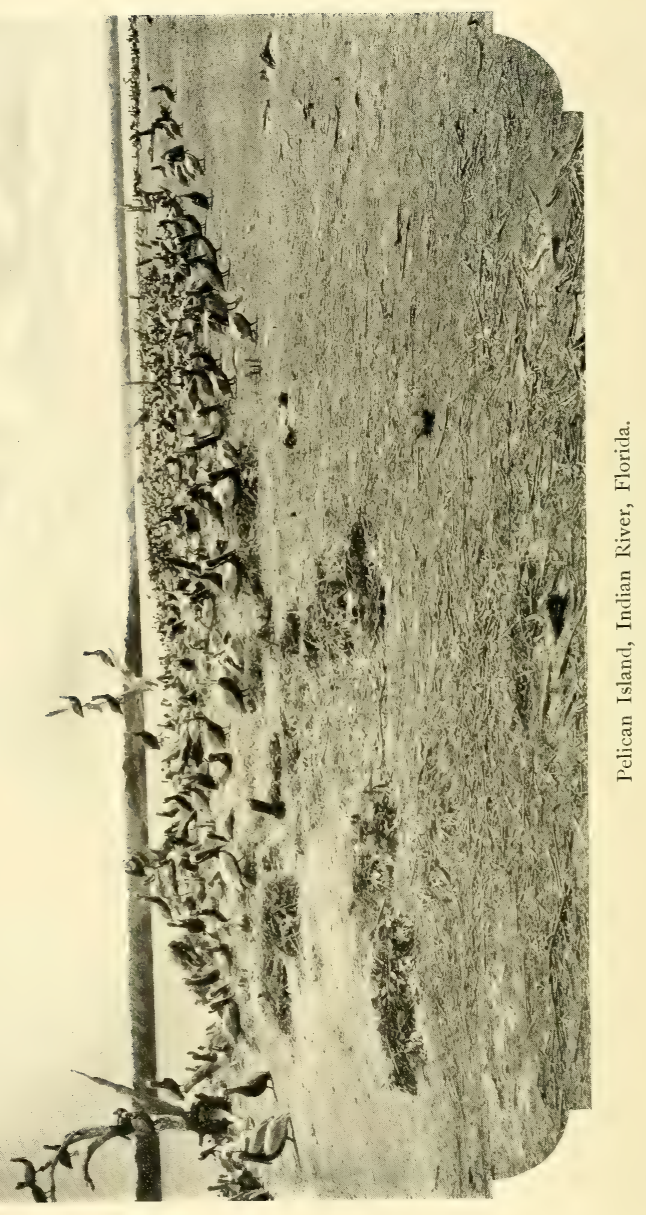


2d dam Dictator Maid, brown, star, hind ankles white, owned by C. J. Hamlin, bred by H. Durkee, Spring Hill Stud, I 87 I, Long Island, N. Y., got by Dictator, son of Hambletonian. Gelded young. Pedigree from catalogue of breeder.

GLOSTER (3-32), $2: 17$, and winner of I8 recorded races; foaled I866; bred by James Roosevelt, Hyde Park, N. Y.; got by Volunteer, son of Hambletonian: dam Black Bess, foaled $\mathbf{1} 854$, bred and owned in Dutchess County, N. Y., purchased by Gardner Howland about I860, of a Mr. Robinson, said to be by Stockbridge Chief, son of Black Hawk; and $2 \mathrm{~d}$ dam by Mambrino Paymaster, son of Mambrino. Gelded young. Trotted $1872-74$. Died 1874 .

The following quite complete and very interesting history of the dam of Gloster is from the American Horse Breeder of Sept. 4, I906:

BLACK BESS, DAM OF GLOSTER ( 2 :I 7 ).

"Gloster was one of the most remarkable trotters of his day. He was a large animal, 17 hands high, with an immense length of stride, yet was a successful race winner, and showed such bursts of speed that horsemen of good judgment believed that he was sure to lower the world's trotting record, then held by Goldsmith Maid. He was taken to California before he had reached the limit of his speed and lived but a short time after reaching the Pacific Coast.

"Gloster was foaled in $\mathrm{r} 866$ and was first campaigned in 1872 . He won a half dozen races that season and made a record of $2: 28 \mathrm{I} / 2$. In I 873 he was started a few times in the Grand Circuit and won several excellent races, one of which was for a $\$ 10,000$ purse and two of the others that he won were for $\$ 5$,ooo each. In I 874 he was campaigned in the Grand Circuit again and was even more successful than during the previous season. He won first money in a $\$ 6,000$ purse at Rochester, August I 4 , that season. The first heat of that race was declared a dead heat between Gloster and Red Cloud and the time was 2 :18. Gloster won the next three, however, in $2: 173 / 4,2: 17,2: 19$.

"Only three other horses in the world had then ever trotted to faster records. These were Goldsmith Maid, whose record was then $2: 16$, Occident $(2: 163 / 4)$, and Lula, whose record was then $2: 163 / 4$. The following week, however, American Girl lowered her record to $2: \mathrm{I} 6 \mathrm{I} / 2$, but on September 2 I following, Gloster beat American Girl, Camors and Judge Fullerton in a race at Fleetwood Park. Gloster was got by Volunteer, son of Hambletonian. His dam was Black Bess, by Stockbridge Chief and his second dam was by Mambrino Paymaster, he by Mambrino, the sire of old Abdallah and from a daughter of imported Paymaster. Mambrino Paymaster was a very large horse and it was doubtless from him that he inherited his size.

"Black Bess, the dam of Gloster ( $2: 17$ ), produced a filly by Volun-teer that was named Princess Ethel. She was mated with Baron Wilkes $(2: 18)$ and the result was Lady Ethel $(2: 243 / 4)$. Princess Ethel also produced two or more foals by Strathmore. One of them was The Phantom $(2: 29 \mathrm{I} / 4)$ and the other was a filly now known as Queen Ethel. Lady Ethel was bred to Constantine (2:12 I/2) and produced the stallion Constenaro $\left(2: 16 \frac{1}{4}\right)$, and the latter got the bay stallion 
St. Elmo, that trotted to a record of $2: 26 \frac{1}{4}$ in 1905. Queen Ethel, by Strathmore, dam Princess Ethel, a full sister of Gloster ( $2: 17)$, has proved remarkably successful as a speed perpetuator. She produced Bumps, wagon record $2: 03 \frac{1}{4}$, the fastest of the get of Baron Wilkes (2:18). Queen Ethel also produced Baron D. (2:10), Baronine $\left(2: 24^{1 / 2}\right)$ and the popular young stallion Moko, all of which were by Baron Wilkes. Moko has no record, but he is the sire of Fereno $\left(2: 05 \frac{1}{2}\right)$, a faster trotter by the records than is credited to any other son of Baron Wilkes. He is also sire of Susie N. (3) $\left(2: 09 \frac{1}{4}\right)$ and Mobel $(2: 101 / 4)$ and several other fast ones, some of which bid fair to enter the $2:$ Io list this season.

"Black Bess was mated with Hamlet, a son of Volunteer, and the produce was a filly now known as Lady Grace, that was mated with Smuggler $(2: 151 / 4)$ and the produce was Grace Smuggler, the dam of the fast trotter Nutboy $(2: 091 / 4)$. Black Bess was the foundation of what bids fair to be a noted and valuable family, founded by Moko. Her sire, Stockbridge Chief, was by Vermont Black Hawk and his dam was by Hill's Sir Charles, a son of Duroc. The dam of Hill's Sir Charles was by Plato. The latter was by imported Messenger and his dam was Pheasant, by Shark. Plato was a full brother of Bishop's Hamiltonian. The pedigree of Black Bess shows a combination of the blood of Messenger Morgan and Diomed, the best combination of forty years ago for producing speed at all the gaits, and no other combination has yet been discovered that has surpassed it in this respect, especially when the Morgan strain has come through Vermont Black Hawk."

The above, we believe, is quite accurate in the pedigrees referred to, excepting that of Stockbridge Chief. His dam, although generally so given, was not by Sir Charles, but by a Morgan horse owned in Charlotte, Vt. See Stockbridge Chief, Vol. V.

GLOSTER (I-32), bay; foaled I 874 ; bred by W. M. Cook, Glenwood, Ind.; got by Blue Bull : dam Fanny.

Sire of 2 pacers $\left(2: 18 \frac{3}{4}\right)$.

GLOSTER (3-г28), $2: 39 \frac{1}{4}$, bay, white ankles behind, I6 hands, ' 1 roo pounds; foaled I 878 ; bred by Ira F. Palmer, Dover, Me.; got by Judge Advocate, son of Messenger Duroc: dam chestnut, bred by Ira F. Palmer, got by Brown Harry, son of Thurston's Black Hawk; 2d dam gray, bred by A. Jackson, Foxcroft, Me., got by French Tiger. Sold to Caleb O. Palmer, Dover, Me. ; to Dr. C. P. Small, Lincoln, Me. Pedigree sent by Fred Davis, Foxcroft, Me. Died about $\mathbf{I} 899$.

Sire of Orrin C., $2: 29 \frac{1}{2}$.

GLOSTER H. (1-32), $2: 17 \frac{1}{4}$, brown; foaled 1888 ; bred by T. D. Hodgens, London, Ont., Can. ; got by Superior, son of Wood's Hambletonian, by Alexander's Abdallah: dam Raven, black, bred by T. D. Hodgens (dam of Silver Star, $2: 30$ ), got by Highland, son of Hambletonian ; 2 d dam Lady Martin, said to be by Whitleck's Black Hawk, son of Black Hawk Warrior. Sold to M. J. Daly, Guttenburg, N. J.

Sire of Lucinda, $2: 261 / 2$. 
GLOUCESTER $\left(3-3^{2}\right), 2: 291 / 2$, bay with star, 15 hands, 980 pounds ; foaled 1889; bred by William Pickhardt, Schroon Lake, N. Y.; got by Wildair, son of Ethan Allen: dam Olivette, chestnut, bred by A. F. Ellsworth, Whiting, Vt., got by Motion, son of Daniel Lambert; 2d dam Olivia (dam of Jonesville, $2: 293 / 4$ ), brown, bred by Vermont Horse Stock Co., Shelburne, Vt., got by Woodburn Pilot, son of Pilot Jr. ; 3d dam Olinda, chestnut, bred in Kentucky, owned by E. S. Wadsworth, Chicago, sold to Vermont Horse Stock Co., Shelburne, Vt., said to be by Oliver; and $4^{\text {th }}$ dam by Chorister. Sold to H. G. Barrett, West Somers, N. Y.

Sire of 3 trotters $\left(2: 24 \frac{1}{4}\right)$.

GO-AHEAD, bay ; foaled I 890 ; bred by D. S. King, Wilmington, O.; got by Eros, son of Onward: dam Zenobia, bay, bred by D. S. King, got by Ohio Knickerbocker, son of Knickerbocker; 2 d dam Nettie Windsor, bay, bred by John G. Wood, West Millbury, Mass., got by Panic, son of imported Glencoe; 3d dam Hambletonian Maid, bay, bred in Newark, N. J., said to be by Hambletonian, son of Abdallah; and 4th dam by imported Trustee, son of Canton.

Sire of 2 pacers $\left(2: I_{5} 1 / 4\right)$.

GODFREY PATCHEN (GEORGE M. PATCHEN JR.) (I-64), bay, foaled $\mathbf{r} 85^{6}$; bred by T. N. Black, Bordentown, N. J.; got by George M. Patchen, son of Cassius M. Clay: dam Lucy, said to be by Hannon's Jersey Henry, son of Sir Henry, by Sir Archy; and $2 \mathrm{~d}$ dam by John Richards. Owned successively by John Buckley, D. B. Godfrey, S. F. Twitchell, and George W. Homer \& Co., Framingham, Mass., where he died May, 1877 .

Sire of 8 trotters $\left(2: I_{4}^{3} / 4\right) ; 4$ sires of 7 trotters, 3 pacers; 6 dams of 7 trotters, I pacer.

GODOLPHIN ; said to be by Fearnaught. Advertised in Virginia Gazette, I 774, by George Baylor.

GODOLPHIN, bright bay, I5 hands, good figure, stands in Lexington. Can beat any horse in the District the four mile heats : dam Col. Braxton's Kitty Fisher and was got by the old Godolphin Arabian. Owned by Nicholas Lafton, Lexington, Ky. Advertised as above, 1789 , in Kentucky Gazette by Nicholas Lafton.

GODOLPHIN, dark bay, I61/2 hands; bred in Virginia by Roger Wardsworth; got by Washington : dam by the old Ranger, called "the famous full blooded horse." Advertised as above in the Courier of New Hampshire, r8oo, to be kept in Dunbarton.

GODOLPHIN. Advertised at Alexandria, Hunterdon County, N. J., by Ely Hoppock and Peter J. Case, 1831 . 
GODOLPHIN ARABIAN, brown bay, dappled on hips and crest and a small white stripe on hind heels, scant 15 hands; said to have been foaled 1724 .

The following description and history are from page 4, Vol. I., of the American Turf Register, published in 1829 :

"This Arabian was fifteen hands in height, of great substance, of the truest conformation for strength and action, bearing every indication of a real courser-a horse of the desert. He was imported into France from some capital or royal stud in Barbary, whence it was suspected he was stolen; and said to have been foaled in 1724. So little was he valued in France that he was actually employed in the drudgery of drawing a cart in the streets of Paris. Mr. Coke brought him over from France and gave him to Williams, master of the St. James Coffee House, who presented him to the Earl of Godolphin. During the years 1730 and 173 I the Arabian served in that noble sportsman's stud, as a teaser to his stallion, Hobgoblin; which horse refusing to cover Roxana, she was in consequence bred to the Arabian and produced a colt foal, the famous Lath, the most elegant and beautiful as well as the best racer of his time. The mutual attachment between the Godolphin Arabian and a stable cat is well known. He died in 1753 , the most successful as a stallion of any foreign horse before or since imported."

A correspondent writes, page $38 \mathbf{r}$ :

"I have seen an original painting in oil of this stallion at Houghton Hall in Norfolk, seat of Sir Robert Walpole.

"Although painted from life it bears not the slightest resemblance to Stubb's picture in any one respect. It represents a square built, short, compact, serviceable saddle horse about $\mathrm{I}_{4}^{\mathrm{I}} / 2$ hands, neck by no means long in proportion, and nothing of that excessive elevation of the crest seen in Stubb's picture."

Mr. Wallace adds (3-IV. M., 294) :

"Nothing more of the origin of this famous animal than here indicated is known. If his origin is here correctly stated, he should rather be termed a Barb than an Arabian. It is also probable that the stories of his acting as a drudge in Paris and as a teaser in England are fictions. 'Lord Godolphin' would not be likely to let such an accumulation of power in any one horse go unemployed. Roxana was probably his best brood mare, and unless the Earl had had strong confidence in the superiority of the horse, he would first have tried him on some of his inferior mares. Indeed, it is likely he did; and as the horse had been in his stud the year before, it is probable that some of his progeny had already made their appearance and justified the Earl in giving him his best mare. Let this be as it may, it is certain that he was bred to Roxana in 1731 , and got Lath; and to another very famous mare in 1732 , and got Dismal, and it is certain in 1733 Roxana was bred back to him and he got Cade. Lath did not make his appearance on the turf till I737, and it was not known till then that Godolphin Arabian would prove himself a great sire. As he was brought to England under very suspicious circurnstances, and as nothing was known, or could be known about his real origin, he must have been superlatively excellent and powerful in his form to have justified the Earl in giving him his best mares." 
Mr. Daniel Chipman Linsley, author of Morgan Horses, says further of this horse :

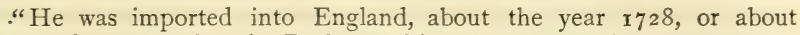
twenty-five years after the Darley Arabian. * * * *

"Although Mr. Coke appreciated to some extent the good qualities of the horse, he does not seem to have placed a very high value on him, and it has been stated that Mr. Coke purchased him for the sum of 18 Louis d'or, or about $\$ 75$.

"Soon after the appearance of Lath, the Godolphin Arabian became immensely popular, and his services were secured for the best mares in the kingdom. His colts proved valuable, and did credit to their sire, both upon the turf and for breeding, and his blood courses in the veins of a large portion of the thoroughbred horses of our time.

"A curious circumstance connected with the horse was the strong mutual attachment which existed between him and a cat. The latter remained almost constantly in the manger or sitting quietly upon the back of the horse, who seemed to derive much pleasure from the purring caresses of his carniverous friend. He died in 1753."

The following is from the "General Stud Book," Vol. I., pp. 392, 395 :

"Godolphin Arabian was a brown bay, about fifteen hands high, with some white on the off-heel behind; there is a picture of him and his favorite cat in the library at Hogmagog, in Cambridgeshire, at which place he died, in the possession of Lord Godolphin in 1753 , being then supposed to be in his twenty-ninth year.

"Whether he was an Arabian or a Barb, is a point disputed (his portrait would rather lead to the latter supposition), but his excellence as a stallion is generally admitted. In $173 \mathrm{r}$, then the property of Mr. Coke, he was teaser of Hobgoblin, who refusing to cover Roxana, she was put to the Arabian, and from that cover produced Lath the first of his get. It is remarkable that there is not a superior horse now on the turf without a cross of the Godolphin Arabian neither has there been for many years past. He was imported from France in 1730 by Mr. Coke, and given by him to Lord Godolphin. He was over I 5 hands high, and his stock generally taller.

"There is an original portrait of this horse in Lord Cholmondeley's collection at Houghton; on comparing which with Mr. Stubb's print of him, it will be seen that the disproportionately small limbs, as represented in the latter, do not accord with the painting. Died at Hogmagog, Cambridgeshire, in December, 1753, age uncertain, but supposed to be 28 years."

GODOLPHIN (PORTER'S), said to be a celebrated horse owned by Alexander Porter of Delaware. See Gen. Taylor by Young Sir Solomon.

GODOLPHIN COLT; foaled I754; bred by Marquis of Rockingham; got by Godolphin Arabian: dam Belgrade mare (another sister to Volunteer), by Young Belgrade; 2 d dam Bartlet's Childers mare, bred by Sir M. IVyrill, got by Bartlet's Childers, son of The Darley Arabian;

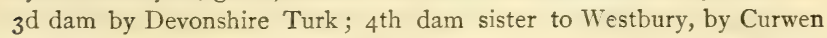
Bay Barb; $5^{\text {th }}$ dam Curwen's (old) Spot, by Selaby Turk (also Marshall's Turk); 6th dam by old Woodcock. 
GOGEBIC (3-I28), bay; foaled 1883 ; bred by A. M. Waddell, Louisville, Ky.; got by Red Wilkes, son of George Wilkes : dam Kate Jr., said to be by Brown Dick, son of imported Margrave; 2 d dam Kate Smith by Abdallah (Spaulding's), son of Abdallah. Sold to Nihlein Bros., Truesdell, Wis.

Sire of 2 trotters $\left(2: 24 \frac{1}{2}\right), 4$ pacers $\left(2: 07^{1 / 2}\right) ;$ I dam of $I$ trotter.

GOGEBIC NUTWOOD (3-128), bay; foaled r 888 ; bred by John E. Barden, Lake Geneva, Wis.; got by Nutwood, son of Belmont: dam Cricket, brown, bred by L. G. Foster, Lake Geneva, Wis., got by Volunteer Swigert, son of Swigert; 2d dam Princess, said to be by Vermont Hero, son of Sherman Black Hawk; and $3 \mathrm{~d}$ dam a Kentucky mare. Sold to Adin Proctor, Janesville, Wis.

Sire of Lady B., $2: 29^{1 / 4}$.

GOHANNA, said to be by Sir Archy : dam Merino Ewe, by Jack Andrews; $2 \mathrm{~d}$ dam Spot, by Bedford; 3d dam by Cade, son of Morton's Traveler; $4^{\text {th }}$ dam by an Alfred mare imported in $I_{7} 8_{3}$, by Edward Carter, Esq.,

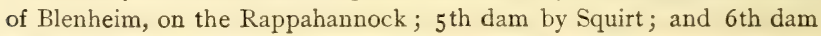
by Crab.

GOLD BAND $\left(3^{-256)}\right.$ said to be by Roy Wilkes.

Sire of Willard T., $2: 24 \frac{1}{4}$.

GOLD BAR (3-128), chestnut, I5 $1 / 2$ hands; foaled 1885 ; bred by A. B. Donaldson, Pontiac, Mich.; got by Goldenbow, son of Satellite : dam Lady Ashland, bay, bred by A. C. Stewart, Pen Yan, N. Y., got by Ashland Pet, 2 :16 $1 / 4$ (dam by American Star), son of Andy Johnson; 2 d dam said to be by Jack Shepard, son of Wadsworth's Henry Clay. Sold to Joseph Pynchen, Butte, Ind. ; to Mr. Woodhull, Angolia, Ind. Pedigree from breeder.

Sire of Millie A., $2: 181 / 2$.

GOLDBEARER (3-128), coal black, $15 \frac{1}{2}$ hands; said to be by The King : dam Lisetta, by Brignoli Wilkes, $2: 14 \frac{1}{4} ; 2$ dam Fannie Morgan, by Whip Gold Dust, son of Highland Golddust ; 3 d dam Fanny J., by old Red Buck, $2: 24$; $4^{\text {th }}$ dam The Briddle mare, said to be thoroughbred. Owned by Hardin Pope, Jonesboro, Ind. Pedigree from circular of Harden Pope.

GOLD BEATER $2.201 / 2$, chestnut; foaled I $88_{3}$; bred by Elizur Smith, Lee, Mass.; got by Alcantara, son of George Wilkes : dam Flora Belle, bay, bred by Harrison Dills, Quincy, Ill., got: by Stevens' Uwharie ; 2d dam Kit. Sold to E. E. Frost, Worcester, Mass.; to W. C. Parker, Boston, Mass.

Sire of 2 trotters $(2: 191 / 4), 3$ pacers $\left(2: 12 \frac{1}{4}\right)$. 
GOLD BOND ( $\mathrm{I}-64$ ), brown; foaled I 889 ; bred by Leo Moses, St. Louis, Mo.; got by Reserve Fund, son of Nutwood : dam Lady Bixby, brown, bred by H. E. Bixby, St. Louis, Mo., got by Corbin Bashaw, son of Amboy; 2d dam Purus, bay, bred by H. H. Bixby, St. Louis, Mo., got by Woodford Mambrino, son of Mambrino Chief; 3d dam Belle of St. Charles, said to be by Getaway, son of Gossip Jones ; 4 th dam Lina, by Vandal, son of imported Glencoe.

Sire of 2 pacers $\left(2: 23^{1 / 4}\right)$.

GOLD BOY (7-32), said to be by Tom Hal Jr.

Sire of 3 pacers $\left(2: I 1 \frac{1}{2}\right)$; I dam of I pacer.

GOLD BRANCH (3-32), bay with star and white hind feet, $15 \frac{1}{4} /$ hands, 900 pounds; foaled 1890 ; bred by Henry Floyd, Eureka, Wis.; got by Cloudy Boy, son of Colonel Cloud, by Black Flying Cloud: dam chestnut, bred by Henry Floyd, Aurora, Wis., got by Bashaw Morgan, son of Floyd's Bashaw, grandson of Green's Bashaw ; 2d dam Golddust, bred by George Sackett, Berlin, Wis., got by Joe Bassett, son of Billy Bashaw.

GOLD BUD (3-32), chestnut with star and right hind leg white; foaled I 89 I ; bred by Henry Floyd, Eureka, Wis.; got by Cloudy Boy, son of Colonel Cloud, by Black Flying Cloud, son of Black Hawk; dam, dam of Gold Branch, which see.

\section{GOLD DROP.}

Lemuel S. Drew, Burlington, Vt., says :

"The dam of Little Dick ( $2: 28 \mathrm{~T} / 4)$ was by Gold Drop, 2 d dam by old Black Hawk. Both dam and grandam were bred by Mr. Saxton, Shelburne, Vt.

"In I 865 I sent Mr. A. M. Danforth to Prescott, Canada. He got this horse Gold Drop there. Gold Drop was bred by a Mr. Roberts of Prescott and said to have been got by Seville, that was by an English thoroughbred from a French mare. Dam of Gold Drop, Mr. Roberts said, was a thoroughbred mare from Long Island that ran races at Montreal and broke down. Roberts called this Gold Drop, Tom Hyer. Danforth advertised him first as Gen. Stannard. He got some very good stock, nothing very fast."

GOLDDUST (THOMPSON'S). Untraced. Probably owned at one time in Ontario, Canada.

Sire of Johnny Golddust, $2: 17$, Axtell, $2: 16 \frac{1}{4}$.

GOLDDUST. Untraced. Owned in Indiana, perhaps at Nollisville.

Sire of Ed. Cloud, $2: 161 / 4$, owned by P. F. Leminger, Fairfield, Ill.

COLDDUST, said to be by the Rising Empire, a half-blooded horse, 17 hands, and was sold for $\mathrm{I}$, ooo silver dollars: dam turf mare, Royal 
Phyllis. Bred in Massachusetts to 243 mares. Terms $\$ 5$. Advertised at South Kingston with pedigree as above, I798, by Cyrus French.

GへLDDUST (I-8), chestnut ; foaled 1855 ; bred by L. L. Dorsey, Louisville, Ky.; got by Vermont Morgan : dam said to be by Arabian Zilcaadi; and 2 d dam by imported Barefoot. Died I 87 I.

Golddust was for his day and opportunities a phenomenal sire of trotting speed. An article in the Middlebury (Vt.) Register of Jan. I, I 886 , says :

Golddust was continuously in the stud from 1859 to $187 \mathrm{I}$, but was the sire of only about three hundred foals. More than one in nine of the whole number have been winners of public races and among them are :

Lucille Golddust, 2 :16 I/4 : dam said to be by Bald Hornet; Fleety Golddust, 2 :20 : dam Flight, by Jehu Morgan ; Indicator, $2: 233 / 4$ : dam Capitola, by Bob Jordan; Rolla Golddust, $2: 25$ (saddle, $2: 2 \mathrm{x}$ ) : dam unknown; Tennyson, $2: 30$ : dam unknown; Rosa Golddust, $2: 32$ : dam unknown, and Gentianella, $2: 35$ : dam by Tecumseh.

Five sons of Golddust are represented in the $2: 30$ list, viz. :

Zilcaadi Golddust, sire of Whirlwind, $2: 24$; Glencoe Golddust, sire of Geo. W. Davis, $2: 261 / 2$; Fancy Golddust, sire of Fred Golddust, $2: 27$; Lexington Golddust, sire of Sir Roger, $2: 23 \mathrm{I} / 4$; Dorsey Golddust, sire of Arthur, $2: 2 S 3 / 4$.

Daughters of Golddust have produced the trotters: Farce, $2: 29 \mathrm{I} / 2$, Orient, $2: 30$; Pathfinder Jr., $2: 30$ and Romance, $2: 291 / 2$, and the worldrenowned pacers, Gossip Jr., $2: 14$, and Johnston, $2: 061 / 4$, the latter being the fastest record ever won in single harness, beating the best record of Maud S., by $21 / 2$ seconds. It will be noted also that Lucille Golddust has the lowest record of any trotter tracing through the sire in direct male line to Justin Morgan.

We have received the following letters :

"Dorsey's Golddust was certainly one of the great old time horses, and founded a great family. He is entitled to the praise of being not only a sire but a progenitor of a line that will live forever in trotting annals. He blended the Morgan blood, that always produced trappy and beautiful horses, with that of the imported Arabian Zilcaadi, and the natural result was a horse of great beauty. His blood made the name of the Eden stud at Louisville famous and furnished the foundation for a great breeding enterprise. Golddust was bred by the late L. L. Dorsey, was foaled in 1855 and died in $187 \mathrm{I}$. He was a chestnut horse of remarkable beauty and a naturally fast trotter. With very little training he trotted to a record of $2: 43$, but was never used for turf purposes, being always kept in the stud."

Euinence, Ky., March 28, 1892.

Mr. Joseph Battell, Middlebury, Vt.,

Dear Sir :-In looking over some old letters I find yours of February $3 \mathrm{~d}$ has been overlooked and not answered. I bred Fleety Golddust and sold her at about i 8 months old to Mr. L. L. Dorsey, the owner of the 
original and first Golddust. Don't know her height, nor do I remember the exact year in which foaled. The record was lost in the fire when my house was burned. A record might be found among Mr. Dorsey's papers, through some of his sons. I have no pedigree of John Morgan. Don't know the 3 d dam of Fleety. Don't think anybody else does. I was well acquainted with Wm. H. Jones and Mr. Wm. Brewer. They were my friends and good men. Both told me the 3 d dam was uncertain. Spider (the dam of Fannie, the dam of Flecty), was got by a horse called Gray Eagle, but it is not sure that he was a son of the great race horse Gray Eagle. The Hornsby Bros., Eminence, Ky., can furnish you with John Morgan's pedigree. Hoping that this may be of some benefit to you, I am Sir,

$$
\text { Very respectfully yours, etc., LEwIS S. ELLIS. }
$$

A correspondent of Dunton's Spirit of the Turf writes :

"Old Golddust was got by a full blooded Vermont Morgan, brought to Monticello, Madison County, Ill., in 185 I or ' 52 , by a 'man by the name of Sawyer. Mr. Levi Dorsey sent a sorrel mare from Jefferson County, Ky., to Mr. Sawyer and had her bred to this Morgan horse. She proved with foal and I saw this colt at St. Louis when he was a two and three-year-old; he was a red sorrel, and Mr. Dorsey called him Golddust. If any one wants to know of old Golddust's history write to Ben or Plute Dorsey of Bunker Hill, Illinois. I knew of several Black Hawk Morgans at that time in that part of Illinois. I will name a few of them : Silverheels at Quincy, Ill. ; Live Oak George at Jerseyville, Ill. ; Flying Cloud at the same place; Champion Black Hawk at Carrollton, Ill.; Rising Sun at Bunker Hill, Ill.; Wide Awake at Alton, Ill.; Addison at Bellville, Ill. They were good size, and fine roadsters, and could all trot below' 40.

$$
\text { G. D. Wilson." }
$$

DAM OF LUCILLE GOLDDUST.

\section{L. Dorsey says :}

"The dam of Lucille Golddust, called Bald Hornet, was purchased in Louisville, Ky., by C. S. Phillips, brother-in-law to him. She was roan with white legs and face and white spots on body; a great saddle mare. She produced a roan stallion called Wild Irishman, record, I think, $2: 42$, sold and went to Missouri. Wild Irishman was by Green Mountain Black Hawk. She produced four fillies by Golddust-Mollie Golddust, record $2: 52$, dam of Gossip, pacer, $2: 18$, sire of Gossip Jr., $2: 13^{1 / 2}$, and Detractor, $2: 261 / 2$; Lucille Golddust, $2: 161 / 4$, dam of Lucille's Baby, $2: 20^{1} / 2$, and Sprague Golddust, $2: 191 / 4$; Lucretia (never broken to harness, used as a saddle mare), dam of Lucina, dam of Lizzie Mack, $2: 243 / 4$. The fourth was Tidy Golddust, trial $2: 32$ at four years old, who produced Tidy by Golddust Jr. and then died."

Sire of 4 trotters $\left(2: 16 \frac{1}{4}\right) ; 18$ sires of 31 trotters, 4 pacers; I2 dams of 18 trotters, I pacer; and sire of 33 trotters with records below $2: 50$ from 302 colts in all.

GOLDDUST (MCCRACKEN'S) ( $1-16)$, chestnut with one white hind foot, I $5 \frac{1}{2}$ hands, rooo pounds; bred by J. G. McCracken Sacramento, Cal.; got by McCracken's Black Hawk, son of Black Lion, by Black Hawk : dam One-Eye, bay, brought across the plains by Mr. Cotton of San Francisco. Pedigree from breeder.

Sire of Artist, $2: 261 / 4$. 
GOLDDUST JR. ( $1-16$ ), 2 :36, brown; foaled 1865 ; bred by L. L. Dorsey, Jr., Lexington, Ky.; got by Golddust, son of Golddust: dam, the dam of Rolla Golddust, by Mohawk Chief. Sold to Charles S. Green, Utica, N. Y.

Sire of Motion Golddust $2: 23 \frac{1}{4}$, Sleepy Tom, $2: 25$; I sire of 1 trotter; 3 dams of 6 trotters, I pacer.

GOLDDUST PRINCE (3-I28), $2: 27 \mathrm{~T} / 2$, bay, two near feet white, $15-2 \mathrm{~T} / 2$ hands, 999 pounds ; foaled June 28 , I882 ; bred by Wm. \& W. R. Clark, Prairie du Chien, Crawford County, Wis.; got by Star Bashaw, son of Campbell's Bashaw, by Bashaw: dam Rose C., bay, bred by Walter Hicklyn, Patch Grove, Wis., got by Sleepy Fred, son of Princeton, thoroughbred; 2 d dam sorrel, bred by J. Hicklyn, got by Princeton, thoroughbred, son of imported Yorkshire; $3 \mathrm{~d}$ dam bay, bred by J. Hicklyn, said to be by Buckshot, thoroughbred. Pedigree from breeder.

GOLDFINDER, chestnut sorrel, $15 \frac{1}{2}$ hands, said to be by Lath. Advertised by George McElroy in the New Jersey Gazette, I $783-85$. Advertised in 1793 in Connecticut Courant at Newtown.

GOLDFINDER, brown, about I050 pounds; kept at Johnsburg, N. Y., by John Sherman.

Dr. Howard of Warrensburg, N. Y., said in interview, $\mathbf{1} 887$ :

"I bought a Morgan horse and drove him 2 I years. A splendid horse. His sire was owned at Johnsburg by a farmer, who kept him there some years. I bought him as long ago as I 842 , then eight years old".

It is possible that Goldfinder, which we learned by other parties to have been kept at Johnsburg, I840, was the Morgan horse referred to above.

GOLDFINDER. Owned by Jack Williams, Rutland County, Vt., who bought him of Capt. Rynders, Boston, kept him two or three years, and sold to David McElwin, Lenox, Mass. Information from John P. Williams a son, who thinks the next stallion his father kept was Harris' Hamiltonian, one season ( 1847 ), and that this was the last season that the Harris Horse made, as he died the winter following.

GOLDFINDER ( $\mathrm{r}-8$ ), black or dark chestnut, I5 hands, rooo pounds; foaled I $85 \mathrm{I}$; bred by S. Ducy, Champlain, N. Y.; got by Black Hawk : dam black, bred at Champlain, N. Y. Sold to Truman B. Derrick, Noyan, P. Q., who sold him for $\$ 5,000$ to Wm. Battell, Rocky Mount, N. C. We have received the following letter from Mr. Derrick giving information of a number of stallions taken South by him :

Mr. Battell,

Noyan, P. Q., March 30, I888.

Dear Sir :-In reply to yours of the 28 inst., it is very hard to place all of the stallions that I have bred, bought and sold. I will give you the 
names of all as near as can be. I sold Goldfinder in Rocky Mount, N. C., to Mr. Wm. Battell for $\$ 5,000$. He was a black stallion by old Black Hawk. I sold a four-year-old stallion by Canada Black Hawk, he by Black Hawk, to Wm. I. Faison, Clinton, N. C., for $\$ 2,500$. His name was Fly-by-night. I sold Artless in Augusta, Ga., he by Black Hawk, for $\$ 4,500$. I sold a four-year-old stallion by Canada Black Hawk, he by Black Hawk, in Elizabeth City, N. C. I sold a number more of the Black Hawk stock. I sold the stallion Sherman Morgan in Plymouth, N. C., one in Edenton, N. C., one in Norfolk, Va., one in Portsmouth, Va. I sold another stallion by Canada Black Hawk, son of Black Hawk, in Hudson, Miss., another in South Weymouth near Boston. If you could come and see me I will give you all the information you require. I have always bred to the Black Hawk stock and have always bred trotters.

Mr. James Norwood, Hillsborough, Mo., in interview, Feb. 9, I893, said :

"William S. Battell of Tarborough or Rocky Mount, N. C., bought Goldfinder. A cracking good horse, rich chestnut; left a lot of stock very highly valued."

GOLDFINDER ( $\mathrm{I}-32), 2: 23 \frac{\mathrm{T}}{4}$, and winner of 30 recorded races, brown; foaled I 87 I ; bred by Charles Moulton, Framingham, Mass. ; got by John Lambert, son of Daniel Lambert: dam gray, brought, when three, from Maine to Middlesex County, Mass., breeding unknown. See The Morgan Horse and Register, Vol. I., p. 878. Trotted I872-87.

GOLDFINDER (I-I6), bay; foaled I882; bred by Benjamin Perrin, Moorepark, Mich.; got by Pathfinder Jr., son of Buell's Pathfinder : dam Lucy Goss, said to be by Vermont Hero, son of Sherman Black Hawk; and $2 \mathrm{~d}$ dam old Jane, by a horse called Kentucky Foxhunter. Sold to A. S. Perrin \& Co., Parkville, Mich. ; to E. Elliott, Paw Paw, Mich.; to Jacob B. Dale, Muscatine, Ia.

GOLDFINDER (COLE'S), (I-4), jet black, about I Ioo pounds; said to be by Young Quicksilver (probably son of Quicksilver, by imported Dey of Algiers, Arabian), and dam a Morgan mare. Owned I820 or before by Dr. Leonard Jarvis, Claremont, N. H., who, his son says, either bought of or sold to Mr. Cole.

Advertised, 1822 , by Stephen Cole, Cornish, N. H. Pedigree as above and advertisement states that he was formerly owned by Clement Chase of Cornish. Terms $\$ 2$ to $\$ 3$.

Mr. Jarvis of Claremont, N. H., in interview, said :

"The Bey of Tripoli made Com. Shaw a present of a stallion; Dr. Leonard Jarvis bought him and brought him to Claremont, N. H.; called him Tripoli. He was a dappled gray, rooo pounds; his mane hung to his knee and he had a heavy tail. Dr. Jarvis owned him six or eight years ; sold him to Vermont or New York. My father had Goldfinder, an imported English horse, before he had Tripoli-r820, and 
perhaps before. He was jet black, of fair size, larger than the Arabian. He bought him of Cole of New Hampshire, or sold to Cole, I have forgotten which."

GOLDFINDER (MERRIMAN'S), sorrel, I5 I/2 hands, I Ioo pounds. Owned a number of years by Mr. Merriman of Georgeville, Canada East, about $1830-35$, and was drowned his property in Lake Memphremagog with his mate, Shark, by breaking through the ice. He is said to have been brought in from the States, but not by Merriman, and may be the Goldfinder also known as the Cutler Horse that was kept one season at Lyndon, Vt., when he got the Coe Colt, sire of the Bundy Horse.

Mr. S. R. Bridgham of Hebron, Me., breeder of Capitola, $2: 22 \mathrm{~T} / 2$, whose dam was by Young Bundy, son of Bundy, by Coe Colt, son of Goldfinder, gives information of the dam of Goldfinder and says:

"Goldfinder was a fine horse and left good stock. He was in your State two years and then went back to Canada. I think all these horses were bred and kept in Burke, Vt."

Goldfinder and Shark, were considered very good in Canada, as fine as any of their day.

GOLD HUNTER (5-64), black, I6I/2 hands, I250 pounds; said to be by Billy Ring, son of Young Columbus : dam Supa, by Black Hawk; and $2 \mathrm{~d}$ dam by Bray's Messenger. Kept at Royalton, Vt., I 883 , by Silas Howard.

GOLD KING (3-64), bay, left hind ankle white, I6 hands, I 200 pounds ; foaled I 879 ; bred by Mr. Wolf, Versailles, Ky., foaled the property of S. Robb, Cadiz, O.; got by Allie Gaines, son of Almont: dam Kentucky Daisy, bay, bred by D. H. Gaines, Lexington, Ky., got by David Aiken, son of Richmond; $2 \mathrm{~d}$ dam said to be by Stanhope's Black Hawk, son of Blood's Black Hawk; 3d dam Mamie S., by Mahomet, son of imported Sovereign; and $4^{\text {th }}$ dam Fay, by imported Yorkshire. Sold to Samuel Robb, Cadiz, O., who sends pedigree. Died I 892.

Sire of Harry L., $2: 21 \frac{1}{4}, 7$ pacers $\left(2: 19 \frac{1}{4}\right)$; I sire of 4 pacers; 3 dams of 2 trotters, I pacer.

GOLD LEAF (5-128), $2: 161 / 2$, brown with star, over $15 \frac{1}{2}$ hands, I 100 pounds; foaled 1883 ; bred by H. P. Wade, Jefferson, Ashtabula County, O.; got by Nugget, son of Wedgewood: dam Maple Leaf, bay, bred by H. P. Wade, got by New York, son of Hambletonian; 2d dam Starlight, chestnut, bred by Philip Rockefeller, Montgomery, N. Y., got by American Star (Seeley's), son of American Star (Coburn's), by Cock of the Rock, son of Sherman Morgan; 3d dam, said to be by Wildair (Beak's), son of Highlander. Kept at Maplewood Stock Farm during seasons of r 885 , '86, '87, '88, and '89; at Cleveland, O., Sept. r7, r89x. 
Sold to H. H. Stambaugh, Youngstown, O. ; to A. S. Wise, Carey, O. Pedigree from breeder.

Sire of 23 trotters $\left(2: 10 \frac{1}{4}\right), 5$ pacers $\left(2: 18 \frac{1}{4}\right): 2$ sires of 3 trotters, 2 pacers : 4 dams of 3 trotters, 2 pacers.

GOLD LEAF JACKSON (5-64), chestnut with star and two white feet, 15 hands, rooo pounds; foaled 1869 ; bred by T. Bailey, South Rutland, Jefferson County, N. Y., got by Andrew Jackson Jr., son of Andrew Jackson, by Bullrush Morgan: dam dark bay, bred by Mr. Hicks, Carthage, N. Y., got by Benton, son of Gen. Benton. Pedigree from George W. Olney, S. Rutland, N. Y.

Sire of A. R., $2: 27^{1 / 2}$.

GOLD RING (3-64), 2 : 18 , chestnut, white strip in face, $153 / 4$ hands, 1 Ioo pounds; foaled $\mathrm{x} 884$; bred by D. C. Davis, Aylmer, Ont.; got by Eden Golddust, son of Golddust: dam Nelly Ingersoll, chestnut, bred by N. Hayes, Detroit, Mich., got by Fearnaught Gift, son of Western Fearnaught; breeder says $2 \mathrm{~d}$ dam a bay, said to be by Eclipse; and $3 \mathrm{~d}$ dam by Royal George. Pedigree from breeder. Sold to Randall Learn, Aylmer, Ont.

GOLDMINE (3-32), chestnut, I6 hands, I 2 I 5 pounds; foaled r883; bred by J. W. Peck, West Cornwall, Vt.; got by Aristos, son of Daniel Lambert: dam Lady Jane, chestnut, bred by Walter Hurlburt, West Cornwall, Vt., got by Smith's Patchen, son of George M. Patchen ; $2 \mathrm{~d}$ dam Doll, bay, bred by Walter Hurlburt, got by Foote Horse, son of Black Hawk. Sold to Gen. Basch, Buenos Ayres, S. A., it is said for a a large price. Pedigree from breeder. See The Morgan Horse and Register, Vol. I., p. 567 .

Sire of Rockaway, $2: 17 \frac{1}{4}$.

GOLD EARNER, blood bay; foaled I82o; got by the celebrated old Figure. Large and not surpassed for muscular strength and beauty. Advertised as above by J. W. Wheelock, Calais, Vt., I825-27. Advertised in Vermont Watchman and State Gazette, 1827 , to be kept in Greensborough, Cabot and Plainfield, Vt., by Benjamin Bushe.

GOLDEMAR, $2: 20$, bay, $153 \frac{3}{4}$ hands, I I 00 pounds; foaled 1877 ; bred by Charles Backman, Stony Ford, N. Y. ; got by Messenger Duroc, son of Hambletonian: dam Lady Burt, bay, bred by James Miller, Warwick, N. Y., got by Hambletonian; 2 d dam said to be by Hero, son of Abdallah. Sold, 1878 , to I. H. Munro, Syracuse, N. Y., who sends pedigree and writes that he bought him a yearling from his breeder, and owned him until he died about 1897 .

Sire of Natalie, $2: 21 \frac{1}{4}$.

GOLDEMAR (1-256), bay ; foaled I $88 \mathrm{I}$; bred by R. S. Veech, St. Mathews, 
Ky ; got by Princeps, son of Woodford Mambrino: dam Duroc Maid, bay, bred by J D. Willis, Middletown, N. Y., got by Messenger Duroc, son of Hambletonian; 2d dam Lady Winfield, got by Edward Everett, son of Hambletonian; 3d dam said to be by Rattler, son of Abdallah.

Sire of 5 trotters $(2: 20 \% 4)$.

GOLDEN (7-64), chestnut; foaled ז 882 ; bred by H. C. Burwell, Bridport, Vt.; got by Royal Lambert, son of Daniel Lambert: dam Nelly Bates, said to be by Daniel Lambert, son of Ethan Allen; 2 d dam Little Betsey, by Sherman Black Hawk, son of Black Hawk; and $3 \mathrm{~d}$ dam Betsey, by Barnes' Horse, a Canadian. Sold to A. W. Windram, Boston, Mass. ; to A. N. Large, Charlottetown, P. E. I., Can.

GOLDEN BALL (MR. ROUTH'S) ; foaled I 735 ; said to be by Partner, son of Jigg, by Byerly Turk: dam by Hutton's White Turk; 2 d dam by Highland Laddie, son of Leedes' Arabian; and 3d dam by Byerly Turk.

GOLDEN BOW ( $\mathrm{I}-32), 2: 273 \frac{3}{4}$, chestnut, narrow strip in face, white stockings behind, II 50 pounds; foaled I $87 \mathrm{I}$; bred by Powell Bros., Shadeland, Crawford County, Penn.; got by Satellite, son of Robert Bonner, by Hambletonian: dam Romper, brown, bred by C. D. Hawkins, Orange County, N. Y., got by Volunteer, son of Hambletonian; $2 \mathrm{~d}$ dam (2d dam of Sir Denton), bred by C. D Hawkins, got by American Star. Sold to A. B. Donaldson, Pontiac, Mich.; to C. M. Koon, Morenci, Mich. Pedigree from breeder.

Sire of 7 trotters $\left(2: 16 \frac{1}{4}\right), 2$ pacers $\left(2: 18 \frac{3}{4}\right) ; 2$ sires of I trotter, 2 pacers; Io dams of 8 trotters, 5 pacers.

\section{GOLDEN BRITAIN (GEER HORSE).}

Advertised, I796, at Plainfield, N. H., by Wm. Dean.

GOLDEN EAGLE (I-8), chestnut, I 200 pounds : foaled $185_{2}^{2}$; said to be by Morgan General, son of Billy Root.

Advertised in Ohio Cultivator, 1856.

GOLDEN FARMER, bay, I 5 T/4 hands; foaled I 772 ; bred by John Hutchinson; got by the noted horse Hercules, who was remarkable for getting famous hunters, son of Snake, from a dam by the Duke of Bolton's Little John, son of Partner, from dam by Bay Bolton: dam a stout hunting mare.

Advertised in New York Mercury, 1776, at Troy, N. J.

GOLDEN FARMER. Awarded a discretionary premium at the New York State Fair, r 846 . Owned by C. Breed, Oswego County.

GOLDEN GATEWAY (3-128), black; foaled 1888 ; bred by William Corbitt, San Mater, Cal.; got by Guy Wilkes, son of George Wilkes : dam 
Sable Hayward, black, bred by William Corbitt, got by Poscora Hayward, son of Billy Hayward; 2 d dam Sable, black, bred by L. J. Rose, Los Angeles, Cal., got by The Moor, son of Clay Pilot; $3 \mathrm{~d}$ dam Gretchen, black, bred by Morgan Vance, Lexington, Ky., got by Mambrino Pilot, son of Mambrino Chief; 4th dam Kitty Kirkman, black, bred by John Kirkman, Nạshille, Tenn., got by Fanning's Canada Chief. Sold to C. J. Hamlin, Buffalo, N. Y.

Sire of The Witch, $2: 29^{1 / 4}$, Inez, $2: 17^{1 / 1} / 4$.

GOLDEN PRINCE (ABDALLAH PRINCE) (3-56), $2: 183 / 4$, chestnut, one fore and both hind ankles white, $153 / 4$ hands, I I oo pounds; foaled June 23, I 877 ; bred by William Barnes, Pontiac, Oakland County, Mich.; got by Goldenbow, son of Satellite : dam bay, bred by Morris Murray, at Oakland County, Mich., got by Erie Abdallah, son of Roes Abdallah Chief; 2d dam Beeby mare, brown, bred at Walled Lake, Oakland County, Mich., said to be by old Printer, son of a very fast running horse called thoroughbred. Gelded young. Sold to Mr. Upson, Mansfield, O., r 883 . Pedigree from breeder.

GOLDEN ROD (I-64), $2: 19 \frac{1}{4}$, chestnut; got by Alcyone, son of George Wilkes: dam Annie Easton (dam of Endymion, $2: 23 \frac{\mathrm{T} / 4}{4}$, and Dolly Davis, $2: 29$ ), said to be by Morgan Rattler, son of Green Mountain Morgan. Gelded young.

GOLDEN RULE (3-128), bay, one white heel, I5 I/2 hands; iooo pounds ; fcaled I 895 ; bred by H. G. Whitenall, Basking Ridge, N. J.; got by John Goldsmith, son of Volunteer: dam Nelly Walker, bay, bred by George Dougherty, Newark, N. J. ; got by Sir Henry, son of American Star; 2 d dam an Eclipse mare, owned by George Dougherty, Newark, N. J. Sold to J. B. Sheeran, Seneca Castle, N. Y. ; to B. N. McCoy, Blossburg, Penn. Pedigree from breeder.

Sire of Frank Barber, $2: 291 / 4$.

GOLDEN SEAL ( $\left.1-\mathrm{I}_{2} 8\right)$, chestnut with star, right forward and left hind foot white above pastern; foaled $\mathbf{1} 882$; bred by Powell Bros., Shadeland, Penn.; got by Satellite, son of Robert Bonner: dam Kitty, said to be by Mambrino Time, son of Mambrino Patchen; 2d dam Helen, by Paddy Burns ; 3d dam by Moseley's Copperhead, son of old Copperhead, by Tom Hal; and $4^{\text {th }}$ dam by Woodford Firo's Aratus. Sold to George E. Morgan, Bellaire, O. Pedigree from breeder who writes:

"As to who the breeder of the dam is will say that we do not know. We hired the use of her to breed to Satellite and got Golden Seal. The late John Stout, then of Midway, Ky., but later of Versailles, Ky., owned the dam, but whether he bred her we do not know."

Sire of Billy Dolan, $2: 27$.

GOLDEN SLOPE (r-64), brown; foaled r889; bred by Leland Stanford, 
Menlo Park, Cal. ; got by Electioneer, son of Hambletonian : dam Addie, bay, bred by Daniel Kennedy, Cornwall, N. Y., got by Hambletonian Chief (Hasbrouck's), son of Hambletonian. Sold to Miller and Sibley, Franklin, Penn.; to Elmhurst Farm, Schmulback \& Park, Wheeling, W. Va.; to J. C. Hoge, Mt. Pleasant, O.

Sire of 3 trotters $(2: 23) ;$ Lady Slope, $2: 15 \%$.

GOLDEN SPRAGUE (I-32), $2: 183 / 4$, chestnut; foaled I 884 ; bred by C. A. Babcock, Canton, Fulton County, Ill.; got by George Sprague, 2 :2 I, son of Gov. Sprague, $2: 20 \mathrm{~T} / 2$ : dam brown, bred by C. Hall, Galesburg, Ill., got by Sam Slick, said to be a Morgan. Pedigree from breeder.

GOLDEN STAR (I-64), chestnut; foaled I 874 ; bred by J. W. Flack, Wausau, Wis.; got by Bashaw Messenger : dam, the dam of Solitude, said to be by Lexington. Sold to C. S. Radcliff, St. Paul, Minn. ; to Herman Greve, St. Paul, Minn.; to E. P. Bassford, St. Paul, Minn., in I88I. Sire of 2 trotters $\left(2: 27 \frac{1 / 2}{2}\right)$.

GOLDEN SUN (3-I28), chestnut; foaled I 888 ; bred by W. A. Sanborn, Sterling, Ill.; got by Combat, son of Hero of Thorndale : dam Westwood, bay, bred by Richard West, Lexington, Ky., got by Egbert, son of Hambletonian; $2 \mathrm{~d}$ dam Steele Gray, gray, bred by Thomas Steele, Versailles, Ky., got by Blackwood, son of Alexander's Norman; and $3 \mathrm{~d}$ dam by Bob Didlake, son of Mambrino Chief.

Sire of Red Sun, $2: 30$.

GOLDEN TOM. Untraced.

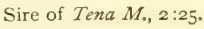

GOLDEN WING ( $1-\mathrm{I}_{2} 8$ ), $2: 243 / 4$, chestnut, 16 hands; foaled about 1882 ; bred by Jere Tarlton, Lexington, Ky. ; got by Satellite, son of Robert Bonner: dam Belle T., chestnut, bred by Jere Tarlton, got by Mambrino Champion, son of Mambrino Chief ; $2 \mathrm{~d}$ dam Jane, chestnut, bred by Jere Tarlton, got by Wagner (thoroughbred) ; and 3d dam Margaret, said to be by Medoc. Sold to Powell Bros., Springboro, Penn.; to B J. Moore, Dunlap, Ia. Pedigree from L. E. Tarlton, Lexington, Ky.

Sire of 2 trotters $(2: 221 / 4)$; George Seeman, $2: 25$.

GOLDSMITH, brown, $153 \frac{4}{4}$ hands; foaled 1863 ; bred by E. E. Hulse, got by Hambletonian: dam Lady Hulse, chestnut sorrel, said to be by imported Trustee. Sold to Alden Goldsmith; to Daniel B. Haight, Washington, Dutchess County, N. Y. ; to Alex. McClintock, Millersburg, Ky., I88o.

GOLDSMITH ELECTOR (I·32), bay, I6 $1 / 2$ hands, 1225 pounds; foaled I89I ; bred by Mr. S. H. Sweet, Chicago, Ill.; got by Elector, son of 
Electioneer : dam Baby, bay, bred by S. H. Sweet, got by Alden Goldsmith, son of Volunteer; 2d dam Buckskin, said to be by a son of Black Hawk. Sold to DeKalb Stock Farm, DeKalb, Ill. Pedigree from W. B. Millard.

Sire of Mystery, $2: 29 \frac{1}{4}$.

GOLDSMITH FRANK (3-128), brown with star, off hind foot white, I6 hands, II 50 pounds; foaled I 882 ; bred by Alden Goldsmith, Washingtonville, N. Y. ; got by Volunteer, son of Hambletonian : dam Madeline, brown, bred by Isaac Smith, Clark County, Ky., got by Goldsmith's Abdallah, son of Volunteer; $2 \mathrm{~d}$ dam said to be by New York Beauty, sire of dam of Black Cloud, $2: 17 \frac{1}{4}$, son of Jones Horse, by Black Lion, son of Black Hawk; 3d dam by Duncan's Monarch, son of Scott's Highlander; and $4^{\text {th }}$ dam by Pilot. Sold to Porter A. Snyder and J. L. Casten, Leon, N. Y., who send pedigree. Died 1902.

Sire of Red Ball, $2: 14^{3 / 4}$.

GOLDSMITH PILOT (3-I28), bay; foaled I882; bred by Richard Richards, Racine, Wis.; got by Alden Goldsmith, son of Volunteer : dam Medora, brown, bred at Woodburn Farm, Lexington, Ky., got by Bayard, son of Pilot Jr.; 2d dam Mabel, brown, bred by Mr. Houghton, Fayette County, Ky., got by Mambrino Chief; 3d dam said to be by Hunt's Commodore, son of Mambrino. Sold to J. Richmond, Topeka, Kan.; to Fairview Stock Farm.

Sire of Robert Ryan, 2 :2I; I sire of 3 pacers; 2 dams of I trotter, I pacer.

GOLDSTONE (7-128), $2: 27 \frac{1}{4}$, chestnut; foaled 188I; bred by A. C. Fisk, Coldwater, Branch County, Mich.; got by Masterlode, son of Hambletonian: dam Chicago Belle, bay, bred by A. C. Fisk, got by Sterling, son of Volunteer; 2 d dam Lady Diamond (dam of Diamond Volunteer), said to be by Billy Rix, son of Gifford Morgan. Sold to Elwin Knapp, Elwell, Mich.; to T. W. Whitney, St. Louis, Mich.; to Frank McGraw, Bay City, Mich.; to James S. Steele, Saginaw, Mich.; to C. L. Barker, Ithaca, Mich.

Sire of 2 trotters $\left(2: 21 \frac{1}{4}\right) ; 2$ dams of 2 pacers.

GOLDZIL ( I-32), $2: 30$, chestnut, blaze face, white legs, I $53 / 4$ hands, I 200 pounds; foaled about I89I; bred by L. L. Dorsey, Anchorage, Ky.; got by Zilcaadi Golddust, son of Golddust: dam Victoria, brown, bred by C. Bate, Louisville, Ky., got by Jefferson Mambrino, son of Woodford Mambrino; 2 d dam brown, bred by C. Bate, got by Norman Temple Jr., son of Norman Temple, by Norman, son of the Morse Horse;

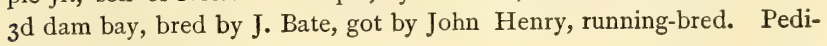
gree from breeder.

Sire of Griffith, $2: 231 / 4 ; 2$ pacers $\left(2: \mathrm{II}^{1} / 4\right)$. 
GOLIAH. Large coach horse at T. Spriggs.

Advertised as above in the Maryland Gazette, I766. A horse of same name, I6 or 17 hands, probably same horse is advertised as follows :

"Bred in England, by old Sterling, one of the fleetest and most beautiful horses in England, to be kept at James Treadwell's, Flanders, N. Y., I775."

And again perhaps same horse in Poughkeepsie Journal, April Io, I 793 :

"The famous bay horse Goliah, at the stable of Joseph Jackson in Hackensack, Dutchess County. Goliah is sixteen hands high and built in proportion"

GO LONG BILLY. See Niagara, roan with star, foaled I844, Canadian.

GOOD BYE (3-128), 2 :19 T/4, bay; foaled I 884 ; bred by Col. R. West \& Capt. M. M. Clay, Lexington and Paris, Ky.; foaled the property of H. L. Dousman, Prairie du Chien, Wis.; got by Egbert, son of Hambletonian : dam Circe, bay, bred by M. M. Clay, Paris, Ky., got by Bell Morgan; 2d dam said to be by McDonald's Mambrino Chief ; 3d dam by a thoroughbred colt running in pasture; and $4^{\text {th }}$ dam thoroughbred, by Rattlesnake, son of Bertrand. Sold to C. L. Hood, LaCrosse, Wis. ;

to Frank Hains, Hastings, Mich.

Sire of 2 trotters $\left(2: 15^{1 / 4}\right)$.

GOOD GIFT, bay, little white on near hind foot, $16 \mathrm{I} / 2$ hands; foaled I 886 ; bred by Leland Stanford, Menlo Park, Cal. ; got by Electioneer : dam Miss Gift said to be (thoroughbred), by Wildidle; 2 d dam Kate Gift, by Lodi. Sold to the Czar of Russia. Pedigree from catalogue of breeder.

Sire of 2 trotters $(2: \mathrm{I} 2) ; \mathrm{I}$ sire of $\mathrm{I}$ trotter.

GOOD IKE. In catalogue of Benjamin Herschey, Muscatine, Ia., said to be a large good-looking bay horse that could trot in three minutes; bred in Ohio, pedigree unknown.

GOOD IKE, gray, large ; foaled 185 - ; bred by Dr. James Tucker, Annapolis, Ind., got by Good Ike a large dapple bay pacing stallion owned by $\mathrm{J}$. Johnson, Annapolis, Ind., and that was bred near Crawfordsville, Ind., and gelded about 1834 . A fast pacer.

GOOD IKE, gray, got by Good Ike: dam by Buford's Whip. More remote pedigree unknown.

Statement of Wesley Randolph, in interview, at Owenton, Ky., May I4, 1905 .

GOOD LUCK (3-32), bay, I5 hands, 985 pounds; foaled I 886 ; bred by Lebin W. Nottingham, Eastville, Va.; got by Walker Morrill, son of 
Winthrop Morrill, by Young Morrill, son of Morrill : dam bay, bred by L. W. Nottingham, got by Sherman Morgan Jr., son of Napoleon Morgan, by Fint Morgan; 2d dam Nina, bred by Wm. D. Waddy, Eastville, Va., got by Rebel, son of Commodore. Kept at North Hampton, Va. Died 1905. Information from breeder.

Sire of Trixy Lee, $2: 2 \mathrm{1} \frac{1}{4}$.

GOOD LUCK, bay. Untraced. Sold to E. T. Billinger, Cherry Valley, IIl.

Sire of 3 pacers $\left(2: 21^{1} \frac{1}{2}\right)$.

GOODMAN HORSE, yellow bay, black points, about $153 / 4$ hands; foaled I 835 ; bred by Samuel Stausburg, Reevestown road, Baltimore County, Md.; got by Archie Tom, which see : dam roan. Sold to Jeff. Goodman who took him about I 84 I to Madison, Ind. Could pace in $2: 40$.

GOOD NEWS (I-128), $2: 293 / 4$, bay; foaled 1887 ; bred by James Walker, Boston, Mass.; got by Madrid, son of George Wilkes : dam Merry Legs, said to be by Hero of Thorndale, son of Thorndale, by Alexander's Abdallah; 2d dam by Simon Kenton, son of American Eçlipse ; and $3 \mathrm{~d}$ dam by Blackburn's Whip.

Sire of Ayesha $G_{.}, 2: 19 \frac{1}{4}$.

GOODRICH ( $\mathrm{I}-\mathrm{I} 6$ ), bay; foaled I89I ; bred by B. P. Williamson, Raleigh, N. C. ; got by Franklin Chief, son of Ben Franklin : dam Opal Lambert, brown, bred by Price Davis, Poultney, Vt.; got by Mountain Boy, son of Daniel Lambert ; 2d dam Lady Davis, said to be by Gen. Sherman, son of Young Columbus. Sold to L. M. Broome, Aurora or Idalia, N. C., Dec., I 893 ; to George J. Studdert, Washington, N. C.; to L. M. Broome, Idalia, N. C. ; to H. A. Creagh, Pollocksville, N. C.

GOODRICH HORSE. See Marshall Chief.

GOODSON, brown with stripe in face, 16 hands, $\mathrm{I} 200$ pounds ; foaled I879; bred by Col. H. S. Russell, Boston, Mass. ; got by Smuggler, son of Blanco : dam Helen, bay, bred by Mr. Hoe, Pittsburg, Penn., got by Hambletonian; 2d dam Hoe Mare, said to be by Rockwell's Rattler. Sold to B. S. Wright; to George G. Whitcomb, Lansing, Mich., who sends pedigree.

Sire of 3 trotters $(2: 151 / 2), 2$ pacers $\left(2: 18 \frac{1}{2}\right)$.

GOODWIN HAMBLETONIAN (3-64), bay, foaled r866; bred by Mr. Sears, New York City, N. Y.; got by Hambletonian, son of Abdallah: dam said to be by American Star. Sold to Wm. Hamilton, New York, N. Y.; to Mr. Goodwin; to Goodwin Estate, Wolfboro, N. H., Sire of 4 trotters $\left(2: 22 \frac{1}{4}\right)$; I sire of 6 trotters, 2 pacers; 2 dams of 2 trotters.

GOODWOOD (I-64), dark chestnut, I6 hands, I I50 to I250 pounds; 
foaled 1872 ; bred by F. M. Wetherbee, Alstead, N. H. ; got by Woodford Mambrino, son of Mambrino Chief: dam Jessie, bred by Elmore Scott, Fayette County, Ky., got by Alexander's Edwin Forest, son of Young Bay Kentucky Hunter; 2 d dam black said to be by Canada Chief, 3d dam by Fanning's Tobe; and $4^{\text {th }}$ dam by imported Leviathan. Kept from 1876 to $\mathbf{I} 88 \mathrm{I}$ at Langdon, N. H. Died August, I883 at Rich Hill, Bates County, Mo. Stylish, upheaded, good action and a fast walker. Pedigree from breeder.

Sire of 2 trotters. $\left(2: 231 \frac{1}{4}\right)$; I sire of 6 trotters, I pacer; 2 dams of 2 pacers.

GOODWOOD JR. (5-I28); foaled I88-; bred by F. M. Wetherbee, Alstead, N. H., and S. E. Clement and M. Ewin, Pierce City, Mo.; got by Goodwood, son of Woodford Mambrino: dam Kitty Morrill, said to be by Young Morrill, son of Morrill; and $2 \mathrm{~d}$ dam Lady Kittridge, by Cassius M. Clay.

Sire of 5 trotters $\left(2: 12 \frac{1}{4}\right) ;$ Frank Enwin, 2:131/1/4.

GOODYEAR HORSE. Owned about $\mathrm{I}_{\mathrm{S}} \mathbf{2}$ in Putney and Westminster, Vt., and considered in his day one of the best stock horses in that locality. He had been a running horse and was blind.

GOOGINS HORSE (I-I6), bay, I5 T/4 hands; said to be by Biggart's Rattler: dam by Raymond Horse, son of Brutus, by Justin Morgan. Owned by Mr. Kimball, in Bennington County, Vt. Information from Dr. W. B. Sargent, Pawlet, Vt., who writes:

Pawlet, June 20, I889.

In answer to your last, I don't know the pedigree of the Morgan Messenger kept here by Mr. Kimble. He was about $15 \% \frac{1}{4}$ hands, stocky and dull bay without marks.

The Googins Horse I learn was by Biggart's Rattler; I think his dam was by the Raymond Horse, he by Brutus, changing the color to gray, which his stock retained but kept the form of bone, mind and energy of Brutus. They were noted for longevity. I call to mind several pairs that went to market at 24 and passed for 12 years old; it was rare that you ever saw an unsound one. With much respect for your endeavors.

$$
\text { Yours, W. B. SARgent. }
$$

GORDAN HORSE, I5 hands; foaled I782. Advertised by A. Jackson, I 79I and I795 to be kept in Chesterfield, Mass.

GORDON (I-I28), bay; foaled I 884 ; bred by Capt. M. M. Clay, Paris, Ky. ; got by Onward, son of George Wilkes : dam bay, bred by Edward Thorne, Millbrook, N. Y., got by Hamlet, son of Volunteer; $2 \mathrm{~d}$ dam Favorita, bay, bred by O. P. Beard, Lexington, Ky., got by Alexander's Abdallah, son of Hambletonian; 3d dam said to be by Mambrino Chief, son of Mambrino Paymaster; and $4^{\text {th }}$ dam by Tom Crowder. Sold to Noe Dills, Cynthiana, Ky.

Sire of Phil Gordan, $2: 291 / 4$. 
GORDON WINDSOR; said to be by Windsor, son of Major Anderson, by George M. Patchen.

Sire of Roger, $2: 281 / 4$; I dam of I trotter.

GOSSIP (I-I6), chestnut; foaled I87I; bred at the Fashion Stud Farm, Trenton, N. J., got by Tattler, son of Pilot Jr.: dam Molly Golddust, said to be by Golddust. Sold at P. C. Kellogg \& Co's. combination sale, New York; to A. Mott, Baltimore, Md., I882.

Sire of Gossip Fr, 2:131/4; I sire of 6 trotters, I2 pacers; I dam of I pacer.

GOSSIPER ( $\left.\mathrm{I}-25^{6}\right), 2: \mathrm{I} 43 / 4$, brown; foaled $\mathrm{I} 885$; bred by W. H. Wilson, Cynthiana, Ky.; got by Simmons, son of George Wilkes: dam Lady Bryan, bay, bred by Joseph H. Bryan and W. H. Wilson, Cynthiana, Ky., got by Smuggler, son of Blanco : 2d dam Mary B., said to be by Bryan's Snake, son of Mambrino Patchen ; 3 d dam old Nannie, by Gossip Jones ; and $4^{\text {th }}$ dam by Mike, son of Bald Hornet. Sold to C. A. Durfee, Los Angeles, Cal. ; to James C. Fair, Sonoma, Cal.

Sire of 5 trotters $\left(2: I_{1}^{1} / 2\right), 2$ pacers $\left(2: I 6 \frac{1}{4}\right)$; I sire of I pacer; 3 dams of 2 trotters, 2 pacers.

GOSSIP JONES, bay, said to be by Vanasdale's Whip, son of Blackburn's Whip : and dam by Snap, son of Crusader, by Virginian, son of Sir Archy. Both trotted and paced. Pedigree from W. C. Phelps, who writes:

Mr. BatTell,

Nicholasville, Jessamine County, March 8, i 886.

Dear Sir :-Having lost my bills of both horses, I am not prepared to give you as full pedigrees as you may wish, but will give what I know to be correct as far as I go: Gossip Jones was got by Vanasdale's Whip, he by Blackburn's old Whip, his dam by Snap, he by Crusader, he by Virginian, he by old Sir Archy.

W. C. Phelps.

Sire of Business, 2:28; 2 sires of 3 trotters; I dam of I trotter; Grandsire of Annie Collins, $2: 231 \frac{1}{2}$ and winner of 24 recorded races.

GOTHAM (I-I6), $2: 29 \frac{1 / 4}{4}$, chestnut; foaled I 884 ; bred by J. C. McFerran, Louisville, Ky.; got by Nutwood : dam Eden Lassie, chestnut, bred by J. W. Hornsby, Shelhy County, Ky., got by Golddust, son of Vermont Morgan; $2 \mathrm{~d}$ dam said to be by Medoc Morgan, son of Vermont Morgan; and 3 d dam Sally Ward, half-bred.

Sire of Sultana, $2: 291 / 4$.

GOV. BAGLEY (3-128); foaled 1877 ; said to be by Hylas, son of Alcalde. Sold to John J. Bagley, Detroit, Mich.; to Ely G. Sawtelle, and John Lillis, Pontiac, Mich. Died 1895.

Sire of Fessie G., $2: 241 / 4$.

GOV. BENTON (BROKEN LEG) (5-256), brown; foaled $\mathbf{x} 875$; bred by 
Simpson Danley, Henderson, N. Y. ; got by Gen. Benton, son of Jim Scott, by Rich's Hamiltonian : dam not traced.

Sire of Gov. Hill, $2: 25 \frac{1}{2}$.

GOV. BENTON $(1-32), 2: 22 \frac{1}{4}$, chestnut with stripe in face and off hind foot white, I $5 \frac{1}{2} 2$ hands, I045 pounds; foaled I 882 ; bred by George Moody, Henderson, Jefferson County, N. Y.; got by Major Benton, son of Jim Scott : dam River Lily (dam of Eastern Boy, $2: 273 / 4$ ), bred by George Moody, got by Gen. Benton, son of Jim Scott ; 2d dam black, bred in Canada. Sold to Wm. Kendall; to John Knibbs, both of Worcester, Mass. Pedigree from Melvin Moody, son of breeder, and A. L. Benton, Watertown, N. Y.

Sire of 6 trotters $\left(2:\right.$ I0), 3 pacers $\left(2: 19 \frac{1}{4}\right)$ : I dam of I trotter.

GOV. BOGG. Untraced.

Sire of Checo, $2: 14$.

GOV. CLARK (I-I6), black; foaled I853; bred by Bennett and Myrick, Bridport, Vt. ; got by Sherman Black Hawk : dam said to be by Young Hamiltonian 2 d, son of Young Hamiltonian (Pone), by Bishop's Hamiltonian. Taken to Toronto, Can., by S. S. Halliday, where he is said to have trotted fast; brought to Philadelphia, about I $86_{3}$, by Mr. Wallace. Sold to John Goodier; to Mr. Barclay, 1866, who kept him at Blue Bell, near Darby, Penn.; to Mr. Smith, Wilkesbarre, Penn., r868, who gelded him. Said to have been a horse of fine appearance.

Mr. Joseph Battell,

$$
\text { Terre Haute, Ind., May i9, I89o. }
$$

Dear Sir :- In the sixties a Mr. James of St. Katherines, Ont., sold to one of our citizens a mare called Daisy Dean, and Mr. James represented her to be by Gov. Clark, dam by Syntax (thoroughbred). We afterward came in possession of this mare and bred her to George Wilkes and got Daisy Wilkes, $2: 30$; then to Young Jim and got J. I. G.; then to Belmont, and got Daisy Belmont (dam of Waupaca, 2:25). By referring to Wallace you will find that Gov. Clark, by Sherman Black Hawk was kept in Ontario about that period.

$$
\text { Respectfully, Frank McKeEN. }
$$

See The Morgan Horse and Register, Vol. II., p. I5o.

Sire of Daisy Dean, dam of Daisy Wilkes, $2: 30$.

GOVERNOR D. (3-64), $2: 26 \mathrm{x} / 2$, black; foaled $188 \mathrm{I}$; bred by A. P. Dutton, Racine, Wis.; got by Swigert, son of Alexander's Norman : dam Dolly Dutton, black, bred by A. P. Dutton, got by Black Douglas, son of Sherman Black Hawk; 2d dam Lady Michigan, chestnut, bred by I. H. Dutton, Memphis, Mich., breeding unknown. Sold to F. W. Williams, Vinton, Ia. ; to A. H. Cramer, Hastings, Neb. ; to R. R. McCaslin, Norway, Ia. Pedigree from breeder.

Sire of Hugh G., $2: 201 / 4$, Commodore, $2: 14 \% 4$. 
GOVERNOR F. ( I-32), $2: 2 \mathrm{I}$, black, white nose, $153 / 4$ hands, IO50 pounds ; foaled I 888 ; bred by Leekley Bros., Galena, Ill.; got by Royalty, son of Swigert : dam Elfrida, chestnut, bred by Andrew McSweny, Galęna, Ill., got by Stocking Chief, son of Clark Chief; $2 \mathrm{~d}$ dam Flora. Pedigree from breeder.

Sire of Doctor B., $2: 281 / 2$.

GOV. HENDEE (I-32), $2: 23$, chestnut; foaled I886; bred by G. M. Jewett, Zanesville, O. ; got by Duke of Brunswick, son of Hambletonian : dam Whirlcloud, bay, bred by G. M. Jewett, got by Jay Gould, son of Hambletonian; 2d dam Belle Cloud, bay, bred by Job Butterworth, Vincentown, N. J., got by Jackson's Flying Cloud, son of Black Hawk; 3 d dam Lady Clifton (dam of Lucy, 2 :1 $8 \mathrm{I} / 4$ ), bay, bred by Job Butterworth, got by May Day, son of Henry (thoroughbred); $4^{\text {th }}$ dam said to be by Prizefighter, son of imported Expedition. Sold to Hammett Stock Farm, North Montpelier, Vt.

Sire of Klondike, $2: 22 \frac{1}{4}$, Belle Hendee, $2: 24 \frac{1}{4}$.

GOV. HENDRICKS (3-64), brown, two white ankles behind, I6 hands; foaled I 884 ; bred by C. Cassleman, Chicago, Ill. ; got by Romeo, son of Menelaus, by Hambletonian : dam gray, bred by C. Cassleman, Utica, N. Y. got by Berringer's Ethan Allen, son of Ethan Allen. Kept at Libertyville, Ill. Pedigree from breeder.

GOV. HILLTOP (I-32), chestnut; foaled I 886 ; bred by H. M. Roseberry, Paris, Bourbon County, Ky.; got by Favorite Wilkes, son of George Wilkes : dam Parepa Rosa, said to be by Robert Lee, son of Norman; 2d dam Lucy Lee, bay, bred by H. M. Roseberry, got by Joe Downing, son of Edwin Forrest ; 3d dam Roseberry mare, brown, bred by Justice Hall, Paris, Ky., got by Mambrino (McConnell's), son of Mambrino Chief. Information from son of breeder.

Sire of Sir Lofty, $2: 26$, Marjorie, $2: 24 \% \frac{3}{4}$.

GOV. MERRIAM (I-64), $2: 28 \mathrm{I} / 4$, bay; foaled $\mathrm{I} 890$; bred by John L. Mitchell, Milwaukee, Wis. ; got by Alford, son of Nutwood, by Belmont : dam Mary Sprague, $2: 2$ r, brown, bred by J. I. Case, Racine, Wis., got by Gov. Sprague, son of Rhode Island; $2 \mathrm{~d}$ dam Little Ellen (grandam of Vic. H., $2: 12 \frac{1}{4}$ ), bay, bred by J. I. Case, got by Goldsmith's Abdallah, son of Volunteer; $3 \mathrm{~d}$ dam the fast trotting-mare, Big Ellen. Sold to Water's Stock Farm, Genoa Junc., Wis. ; to Thos. McGhee, Waterloo, Ia. ; to W. A. Morin, and went to Minnesota.

Sire of Our Billy, $2: 25 \frac{1}{2}$.

GOV. MORRILL (3-32), black with star, I6 hands, I 50 pounds; foaled May, 1875 ; bred by A. I. Allen, Hebron, Me.; got by Knox Morrill, son of Winthrop Morrill : dam, said to be by imported Anfield, a successful running horse brought from England to Nova Scotia, where he was pur- 
chased by Col. T. S. Lang, and brought to Maine; and $2 \mathrm{~d}$ dam Morgan. Sold to L. W. Dyer, East Deering, Me., and Dr. F. C. Dolly, Falmouth, Me. Pedigree from breeder. See The Morgan Horse and Register, Vol. I., p. 63 r.

Sire of Dr. Smith, $2: 261 / 2$.

GOV. PAYNE, bay with black points, I 6 hands, Iroo pounds; foaled about I 875; said to be by Mambrino Chief : and dam by Red Eagle (thoroughbred). Sold to J. C. Van Blarcom, St. Louis, Mo. ; to W. J. Lyle, Sparta, Ill. Pedigree from W. R. Borders, breeder of Orient, who writes :

"If mention is made of Orient, especial mention should be made of her grand old dam, Olga, by Challenger: dam Patti, by Mambrino Chief. Olga was a great brood-mare."

Sire of Orient, $2: 27^{1 / 1} 4$.

GOV. POWELL ( $\mathrm{I}-32), 2: 25$, black, little white on left hind foot, $153 / 4$ hands; foaled July ro, r888; bred by Garret Powell, Georgetown, Scott County, Ky. ; got by Col. Hambrick, son of Dictator: dam Big Mary, bred by Garrett Powell, White Sulphur, Ky., got by D. Monroe, son of Jim Monroe; 2d dam Madame Powell, brown, bred by Dick Johnson, White Sulphur, Ky., got by Alexander's Bay Chief, son of Mambrino Chief; 3d dam bay, bred by Dick Johnson, got by Toronto, son of St. Lawrence. Sold to Jesse Hambrick, Stamping Ground, Scott County, Ky. Pedigree from breeder.

GOV. S. B. BUCKNER ( $1-32)$, bay, 16 $1 / 4$ hands, I 100 pounds; foaled 1887 ; bred by B. S. Rice, M. D., Catlettsburg, Boyd County, Ky.; got by Blue Jeans, son of Phillip's Black Horse : dam Minnie, bay, bought of Wm. Hord, Greenup, Ky., said to be by Goddard's Cockspur, son of old Cockspur, from a Diomed mare; $2 \mathrm{~d}$ dam sorrel, by Taylor, son of Gen. Taylor; and 3 d dam by Buck Rabit. Sold, I9or, to W. F. Rice, Newcombe, Elliott County, Ky. Dead. Pedigree from breeder.

We have received the following letter :

Mr. J. BatTell,

Greenup, Ky., March 2, I9ro.

Dear Sir :-Your letter just received, asking about the bay mare Minnie. I wish I could tell you something about her stock; the man I sold her to I think can give you some information about her, as he pays a good deal of attention to horses. I sold Minnie to him about the latter part of I882, or first of I883. Dr. B. S. Rice, Catlettsburg, Boyd County, Ky., is his address. I have owned and rode a great many horses, but never had one that could compare with Minnie as a saddler. I hope you will get the desired information from Dr. Rice.

I remain, yours \&c., W. T. HoRD.

GOV. SPRAGUE ( $1-64$ ), $2: 201 / 2$, black, no white, 15 1 2 hands, ro5o pounds ; foaled Feb. 24, 1871, bred by Amasa Sprague, Providence, R. I. ; got 
by Rhode Island, son of Whitehall, by North American: dam Belle Brandon (dam of Amy, $2: 201 / 4$ ), supposed to be the mare Lady Howard, bay, about $15^{1} / 2$ hands, 1050 pounds, foaled 1854 , bred by Howard Shaw, Middletown, N. Y., got by Hambletonian; 2d dam mahogany bay, bred by Howard Shaw, got by Beake's Wildair, son of Decator by Highlander ; $3 \mathrm{~d}$ dam a running mare owned by Jesse Worden at Howell's Depot, N. Y., thought to be by Exton Eclipse. Sent fall of $187 \mathrm{I}$ from Rhode Island with other horses, by Gov. Sprague to the Akers Stock Farm, Lawrence, Kan. Broken to harness I 873 , and sold, October, I 873 , for $\$ 1500$, to Higbee Bros. and A. C. Babcock, Canton, Ill., who sold 1876 , to J. I. Case, Racine, Wis., for $\$ 27,500$. Died at Lexington, Ky., May, 1883 .

Above pedigree of dams is from Howard Shaw. Of Lady Howard the mare which he bred, and which, as suggested above, is supposed to be the mare afterwards known as Belle Brandon, we are inclined at this time to think that these mares are identical, but there is no certain evidence of it. Lady Howard was bred by Howard Shaw as here stated, and was sold when 3 years old to Messrs. Dusenberry and King of Middletown, N. Y., who sold her for $\$ 700$ and another horse, it is thought, to go to New Jersey or New York City, but Mr. King was dead when we undertook to trace the mare, and Mr. Dusenberry could not remember to whom he sold her.

By J. W. Hoyt, who drove Lady Howard for Messrs. Dusenberry and King, we were informed that she was sold to a Mr. Otis of New York, and Mr. Hoyt thought he trotted her a number of races and got a record of $2: 26$.

We can find no record of such races, and have been unable to learn who Mr. Otis was, or where he lived, and this is the last definite information so far as we know of the mare Lady Howard, at least, under that name.

Belle Brandon was owned by S. Dexter Bradford, of New York, who bred Amy, foaled r 865. At his death about r 869 , she passed to Gov. Amasa Sprague, Providence, R. I., who bred her to Rhode Island twice before his purchase of Ethan Allen (Oct. 17, 1870), and sent her, 1872, to his breeding farm in Kansas, where she foaled several colts by Ethan Allen.

We have received the following letters concerning Belle Brandon:

Mr. Charles H. Kerner to whom we had been referred for information of this mare, writes, dated Clarenden Hotel, New York, April I I, I89I :

Dear Sir :- In answer to yours of April 4th., let me say. To the best of my recollection a man by name of Balch was the first owner whom I saw driving her on the New York roads. He, I believe, sold her to Mr. Dexter Bradford a friend of mine who owned her for years and then she passed into the hands of Amasa Sprague of Providence, R. I., who bred her. I remember she was the first of Hambletonian's get that showed 
well; she was a handsome little mare and could trot fast. I am speaking of about 30 years ago when I first noticed her.
Yours truly,
Charles H. Kerner.

In New York City learning that the noted horseman and liveryman, Darius Tallman, at one time owned Belle Brandon, we called upon Mr. Tallman who gave us information concerning a number of noted horses. In regard to Belle Brandon he said:

"I bought Belle Brandon of John M. Hubbard, New York, a wealthy man. She was called Belle Brandon when I got her. I traded Panic for her and only kept her about two months. She was light brown, I5 I/2 hands, scant 1000 pounds, very good disposition, all right, six or seven years old. I understood she was by the old Hambletonian. I do not remember the name of the party, whom I sold her to."

Belle Brandon was described to us by George Hopkins, former owner of Hopkins' Abdallah, who saw her when owned by Mr. Bradford, as bay, $15 \frac{1}{2}$ hands, blood-like looking mare, very pretty mare, a young, genteel mare.

The first record of Belle Brandon in the Wallace's Register, is in Vol. II., page in6, where she is thus recorded:

"Belle Brandon, b. m., foaled 1857 , got by Hambletonian : dam by Bacchus. Owned by Sprague and Akers, Kansas Stud Farm, Lawrence, Kan."

In Vol. III., p. 64, she appears as follows:

"Belle Brandon, b. m. foaled I 854 , got by Rysdyk's Hambletonian : dam Jenny (bred by Wm. Shaw), by Young Bacchus, son of Bacchus, from the running mare, Evan Bass, owned by Aaron Leonard; g. d. the Worden mare by Exton Eclipse; bred by Howard Leonard, Middletown, Orange County, N. Y., owned by Sprague and Akers, Kansas Stock Farm, Lawrence, Kan."

In answer to enquiry Mr. George F. Andrews, Chester, N. Y., in whose hands at that time were the books containing record of the mares bred to Hambletonian, wrote us :

"The name of Howard Leonard does not appear in record in 1853 or any other year."

We then wrote to Mr. Andrews as follows:

"I am much obliged to you for prompt reply to my query about Howard Leonard's breeding a mare to Hambletonian. I would like now to trouble you further to learn if a Howard Lockwood bred a mare to Hambletonian, in $\mathbf{I} 853$ or in any year near that. I would also like to know if any gentleman from Middletown, N. Y., bred to Hambletonian that year and if so, who?

$$
\text { Very truly yours, JOSEPH Battell." }
$$

To this we received the following reply:

"Howard Lockwood does not appear on the records in any year. Howard Shaw, Middletown, N. Y., is the only name given as a breeder in 1853 , and he is still alive, and, I think, could give information in the horse line for a number of years back.

Respectfully yours,

George F. Andrews." 
We next wrote to Howard Shaw and got the information here given in regard to Lady Howard. In a second letter Mr. Howard Shaw described Lady Howard as mahogany bay.

Mr. O. E. Learned of Lawrence, Kan., the proprietor of the Journal at that city, in a letter to us described Belle Brandon, as a low, long, blooded looking mare, I think, verging on brown in color.

We add the following descriptions, First of Lady Howard from W. T. Shaw, Middletown, N. Y., son of Howard Shaw, dated Jan. 9, I904:

"Your letter to me with reference to Iady Howard is at hand, I will endeavor to answer to the best of my ability. The mare was bred by my father and broken by me and sold when three years old to Col. D. C. Dusenberry of this city. She was mahogany bay with black points, and was of the genuine Hambletonian stripe. She had a slim neck, long body and very heavy quarters. Her makeup in the flank was such that she had plenty of room for the easy motion of her hind legs. I think she had, without exception, the longest stride of any animal of her size that I have ever seen. While her neck was slim it was not exactly of the Lady Thorn variety, but she had a gait similar to hers, except I think that she gathered herself quicker."

Joseph Battell, Esq.,

Middleboro, May i 5, i 890.

Sir:-Yours of April 25 came duly at hand and contents noted. I have done the best I can in finding out who Belle Brandon was sold to as most of the men that were here and interested are dead. Dusenberry is not much of a horseman and King the man that was with him is dead. I went to see Mr. Hoyt and he was not at home so I wrote him and you will find his letter to me on other side. He is the man that drove her for Dusenberry and King and had charge of her after leaving Shaw's hands until she left here, is a man somewhere about 74 years of age.

$$
\text { Truly Yours, D. W. REEDE. }
$$

Mr. D. W. REEDE,

Lawton, May i4, I89-.

Dear Sir :-Your letter just received. Lady Howard was sold to Mr. Otis of New York. He trotted her in a number of races and got her a record of $2: 26$. They changed her name to Belle Brandon, then he sold to Simmons \& Snyder large stock dealers of Kansas. They owned George Wilkes, Gov. Sprague and Ethan Allen, all fast trotters. Lady Howard had a colt by Gov. Sprague that got a very fast record.

It will be seen that the history of this mare after she was sold by Mr. Shaw until she became the property of Mr. Balch, supposing her to be identical with the mare Lady Howard, is very unsatisfactory, but the general facts, description and all, point to their being the same.

New York Spirit of the Times reports: "A pacing match Aug. 25, I860, at Creighton, Penn., in which owner's bay mare called Belle Brandon won in three straight heats time, $2: 49,2: 54,3: 00 . "$

Again in Sept. 8, r860, the Spirit of the Times reports: "G. Snyder's bay mare Belle Brandon lost in a trot with Sorrel Ned, time, $2: 53,2: 5 \mathrm{I}$, $2: 45$." In letter above to D. W. Reede a Mr. Snyder appears as one of the owners of Belle Brandon. 
Spirit of the Times in $\mathrm{I} 86 \mathrm{I}$ reports: "A race June I I, I86I, on Union Course, Match for \$10oo, between Hiram Woodruff's gray mare, Lady Suffolk and Wm. Tallman's b. m., Belle Brandon, Lady Suffolk winning, time, $2: 493 / 4,2$ :491/2, $2: 48$."

This last mare is unquestionably the Belle Brandon we are tracing. It is evident from the time that her trotting does not at all sustain the reputation, as told to us, of Lady Howard when sold.

\section{LETTER FROM GOVERNOR SPRAGUE.}

Mr. Joseph Battell,

Cowesett, Feb. 2, r89o.

Dear Sir:-Your letter received. The horse Governor Sprague was sent to Kansas when two years old and fell into Mr. I. P. Case's hands. If you will write him you will get all the information you desire. There are some of the questions asked I cannot answer and Mr. Case can.

Respectfully yours,

Amasa Sprague.

The following from The Horse World is quoted in the Breeder and Sportsman, California, Nov. 5, 1904 :

"The great race which Sweet Marie and Tiverton fought out in the Transylvania cannot but call the attention of pedigree students that each of these great trotters carries a dash of the blood of Gov. Sprague, $2: 201 / 2$. McKinney, $2: 11 \frac{1}{4}$, the sire of Sweet Marie, was from a daughter of Gov. Sprague, while Tiverton's third dam was a daughter of that horse. For a horse not bred in what for years has been deemed the most fashionable lines, Gov. Sprague was brilliantly successful in his short stud career. He took his record at $2: 201 / 2$ in 1876 , at which time he was the champion five-year-old trotter, the world's stallion record at that time being $2: 15 \mathrm{I} / 4$. He died in 1883 when only twelve years old but in spite of his early death he established a family that is much larger than that left by many of the most prominent stallions contemporary with him. His standard list contains thirty-six trotters and two pacers. Seven of his produce took records of $2: 20$ or better at a time when $2: 20$ trotters were far less numerous than they now are. Twenty-four of his sons have sired standard speed, and his daughters have produced fifty-seven standard performers. It is really surprising to find what a large number of the descendants of Gov. Sprague, the get of his sons and the produce of his daughters, have taken records of $2: 20$ or better, when it is considered how short his career in the stud was. No less than sixty-one is the representation of his sons and daughters in the $2: 20$ list.

"Governor Sprague was got by Rhode Island, $2: 23^{\mathrm{I}} / 2$, a son of Whitehall, son of North American and his dam was Belle Brandon, dam also of Amy, $2: 201 / 4$, by Hambletonian. The most of Gov. Sprague's stud service was in Wisconsin, although shortly before his death he was sent to Kentucky. What his showing would have been as a sire had he been sent to Kentucky or some other locality where his opportunities would have been good earlier, can only be conjectured. As it is, he occupies a place in breeding history that is far in advance of that occupied by many of the most meritorious sires of his time. Just at present when among his near descendants is numbered a sensational sire that has just been sold for $\$ 50,000-M c K i n n e y, 2: 11 \frac{1}{4}$, the fastest trottıng race mare of the year and probably the fastest racing mare ever seen- 
Sweet Marie, $2: 043 / 4$; the champion trotting race gelding-Tiverton, $2: 04 \frac{1}{2}$, and one of the greatest three-year-old trotters ever seen-Alta Axworthy, 2 : 101/2 - the real worth of Gov. Sprague is likely to be better realized than it has been during the last few years."

The Editor of National Live Stock Journal, Vol. VI., page 383 , in speaking of Belle Brandon, says: "She has three foals younger than Sprague by the famous Ethan Allen."

Hon. Joseph Battell, Middlebury, Vt.,

LaWrence, Kan., Dec. 7, I904.

Dear Sir :-Replying to yours of Nov. 29, I have the Sprague \& Akers' catalogues of ' 73, ' 74 and ' 78 . There is nothing in either of these to indicate that Belle Brandon was bred either in ' 73 , ' 74 , or ' 75 . The only references to having bred at all are Cranston Belle by Rhode Island, from Belle Brandon, foaled 1870 and Gov. Sprague also by Rhode Island, foaled $\mathrm{r} 87 \mathrm{I}$. The record as to Belle Brandon herself is as follows : "Bay mare bred in New York, foaled r 857 by Rysdyk's Hambletonian-dam by Bacchus. Cranston Belle and Gov. Sprague were both bred by Gov. Sprague. Regret I cannot give you further information.

$$
\text { Truly yours, O. E. LEARNARD. }
$$

See very interesting article, "A Chapter of Long Ago," under Wildair (Tommy) by Ethan Allen: dam Belle Brandon.

Letter from S. II. Parlin :

Mr. Joseph Battell,

Boston, Dec. 31, I907.

Dear Sir :-Your favor received: I regret to say that we do not have any of the early catalogues published by Gov. Sprague. I have carefully looked through the several Volumes of Wallace's Monthly to see if they contained any information from Gov. Sprague relating to the stallion Gov. Sprague, $2: 201 / 2$, as I had a faint recollection of reading a letter from Mr. Sprague in one of them years ago.

In Wallace's Monthly for June 1882 page 379 , is the following:

"Sire of Gov. Sprague-Dr. Blaisdell of Macomb, Ill., has forwarded us the following letter from Amasa Sprague which seems to be conclusive :

" "Your letter received. Gov. Sprague was by Rhode Island. I bred him myself and saw him when he covered Brandon. I have the last of Rhode Island's get-a black stallion, not quite as large as Sprague but shows speed. Was broken last winter and I think if he had handling would be as good as Sprague.

$$
\text { Yours respectfully, Amasa Sprague.", }
$$

This is all that I can find from Mr. Sprague in relation to the horse. Wishing you success I am,

$$
\text { Respectfully yours, S. W. PARLIN. }
$$

Sire of 36 trotters $\left(2: 15 \frac{1}{4}\right), 2$ pacers $\left(2: 1 I^{1 / 4}\right) ; 24$ sires of 67 trotters, 26 pacers; 38 dams of 4 I trotters, I3 pacers.

GOV. SPRAGUE JR. ( $\left.1-25^{6}\right)$, bay; foaled I 877 ; bred by David Gaffney, Burlington, Wis.; got by Gov. Sprague, son of Rhode Island : dam Juno. Sold to F. J. Ayers, Burlington, Wis. ; to E. D. Morse, Chicago, Ill. ; to C. C. Davis, Rochester, Ind. Died I902. Sire of 2 trotters $\left(2: 28 \frac{3}{4}\right)$.

GOV. STANFORD ( $1-256), 2: 2$ I, bay; foaled I 885 ; bred by Leland Stan- 
ford, Menlo Park, Cal. ; got by Electioneer : dam Barnes, chestnut, bred by W. H. L. Barnes, San Francisco, Cal., got by Whipple's Hambletonian; $2 \mathrm{~d}$ dam said to be by Chieftain, son of Hiatoga, and $3 \mathrm{~d}$ dam by Jim Crow, said to be thoroughbred. Sold to Samuel McMillan, New York. Sire of 2 trotters $(2: 181 / 4), 2$ pacers $(2: 191 / 4)$.

GOV. STRONG (3-128), bay, 15 I $1 / 2$ hands, Iooo pounds; foaled 1889 ; bred by Foote Bros., Mexico, Mo.; got by Dr. Strong, son of Athlete: dam Julia Wilkes, bay, bred by W. M. Dills, Cynthiana, Ky., got by Gov. Wilkes, son of George Wilkes; 2 d dam Fanny Walton, bred by Frank Rayburn, Cynthiana, Ky., got by Milford's Mambrino, son of Mambrino Chief; 3d dam Jennie Talbot, bred by Frank Rayburn, got by Pacing Abdallah, son of Alexander's Abdallah; $4^{\text {th }}$ dam Puss, said to be by Black Indian. Pedigree from breeders, Labelle, Mo., Nov. 3, r891.

Sire of 3 trotters $(2: 191 / 4)$.

GOV. WILKES ( $1-32)$, bay; foaled 1876 ; bred by Wm. M. Dills, Cynthiana, Ky. ; got by George Wilkes, son of Hambletonian : dam Daisy Burns, bay, foaled $\mathrm{r} 866$, bred by Wm. Dills, Cynthiana, Ky., got by Indian Chief, son of Blood's Black Hawk; 2 d dam Bird, said to be by Gray Buck, son of Messenger (Tucker's); $3 \mathrm{~d}$ dam Nell, by Diomed

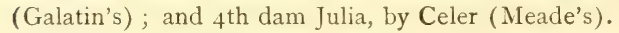

Sire of Taffy, $2: 24 \frac{1}{2}$, Lientenant Wilkes, $2: 231 / 2 ;$ I sire of 1 trotter; 2 dams of 3 trotters, 2 pacers,

GOV. WOOD (1-32), $2: 29$, chestnut; foaled 1879 ; bred by William Crawford, Quincy, Ill.; got by Amboy, son of Bashaw : dam Roxy Ann, bred by J. W. Simpson, Labelle, Mo.; got by Bill Shaker, son of old Crab, imported from Arabia by Col. Dunlap of North America; $2 \mathrm{~d}$ dam said to be by Green Mountain Morgan. Sold to Corbin \& Fisher, Quincy, Ill., $\mathbf{x} 887$, who send pedigree and write:

"Wm. Simpson is a son-in-law of Walter Lear of Labelle, Mo., who owned Bill Shaker and I think bred him. He was one of the most positive of sires, and from the commonest mares got stock of enduring road qualities, and many that could trot in from $2: 35$ to $3: 00$. The dam of Gov. Wood was a great saddle mare and could both trot and single-foot fast.

GOV. WRIGHT; said to have been owned in New Jersey and got by Gray Eagle, thought to be thoroughbred. George W. Graves of Rochester, Minn., writes dated May 27, 1890:

Mr. Joseph Battell, Middlebury, Vt.,

Your inquiry through Joy LaDue regarding breeding of Gov. Wright, at hand. Gov. Wright was brought here about 1860 from New York, or New Jersey, and was said to be by Gray Eagle. In ' 58 or ' 59 he was exhibited by one Aycrigg of Passaic, N. J., at the State Fair, of Connecticut, and he was called thoroughbred. He was run around the track once as an attraction and was awarded premium. Some time after Aycrigg was sent to a private asylum, and, as I heard, soon after died. 
The horse was sent here by his friends. I think if the archives of the Connecticut State Agricultural Society were examined his breeding could be found. The man whom he was sent to here went into the army, and we kept the horse for him and never had a doubt he was thoroughbred. He could run fast, and he was a grand individual. Gray or white when old. Coat like velvet but very light hair on body. Good mane and tail. Yours in haste, George W. Graves.

We have also received the following letter :

Mr. Joseph Battell,

West Cornwall, Conn., Oct. 30, 1905.

My Dear Sir :-In the list of awards in 1858 :

Stallions and mares of all work- 4 to 7 years, to Gardner Aycrigg of New Jersey, a thoroughbred stallion, a very fine animal in the opinion of your committee.

H. R. FARGO,

JEDEDIAH WILSON.

The stallions receiving premiums were Meriden Black Hawk, Traveler, Tornado, and mare, Susietta.

Mr. Aycrigg also received a discretionary premium of eight dollars for a pair of mules.

Mr. Robbins Battell was on two committees of horses.

On the list of officers of the Society only Prof. S. W. Johnson, chemist, and myself survive, and I recognize none of the Judges still living.

$$
\begin{array}{ll}
\text { Yours very truly, T. S. GoLD. } & \text { T. }
\end{array}
$$
N. J.

Gov. Wright was entered in class r, by T. G. Aycrigg, Passaic County,

The following report is from The Spirit of the Times, 1858 :

"Fair of Union Association-Great National Horse Show, Centreville Course. $* * *$ SECOND DAY.

"The grand cavalcade was the first event fixed to come off on Tuesday morning and well worthy a short journey if it was even by that wretched, snail like institution, the Long Island Railroad, to see so splendid a turnout of every sort, kind and description of first class, good, bad, and indifferent steeds. The following is a list of stallions. Class $\mathbf{I}$ and 2 :

STALLIONS CLASS $\mathbf{I}$.

Wm. P. Latham, Philadelphia,

J. \& A. Bathgate, Westchester,

W. H. Aspinwall, New York,

J. B. Welch, Syracuse,

A. Blemger, Haverstraw, N. Y.,

Henry Lloyd, Queens County,

J. B. Monnot, Westchester,

David Garrison, Queens County,

T. G. Aycrigg, Passaic County, N. J.,

James B. Devoe, New York City,

$$
\begin{aligned}
& \text { imp., Arabian stallion Caliph } \\
& \text { " . . . . . Mango } \\
& \text { " . . . . Hatton } \\
& \text { ". . Consternation } \\
& \text {. . . Hero } \\
& \text {. . . Umpire } \\
& \text {. . . . Logan } \\
& \text { - May Fly } \\
& \text { Gov. Wright } \\
& \text { Wild Irishman" }
\end{aligned}
$$

See George M. Patchen Jr., whose dam, we think, was by above mentioned Gray Fagle.

GOWAN ( $1-32$ ), bay; foaled 1889 ; bred by G. \& C. P. Cecil, Danville, Ky.; got by Gambetta Wilkes, son of George Wilkes : dam Effie Davis, 
bay, bred by Walter Davis, Harrodsburg, Ky., got by Red Wilkes, son of George Wilkes; 2 d dam Effie, said to be by Alexander's Abdallah. sold to C. T. Wright, Greenville, Mich.

Sire of 2 pacers $\left(2: 17 \frac{1}{4}\right)$.

G. R. (I-32), brown; foaled I 886 ; bred by Richard Richards, Racine, Wis. ; got by Swigert, son of Norman : dam Lady Belle (dam of Winnie Wick, $2: 24 \frac{1}{4}$ ), chestnut, bred by Richard Jones, Kenosha County, Wis., got by Bellfounder (Richards'), son of Hungerford's Blucher; 2d dam Doll, said to be by Blucher (Hungerford's). Sold to Theodore Schweitzer, 1887 ; to A. L. Kern, Milwaukee, Wis. ; to F. J. Ayers, Burlington, Wis., Sept I $89 \mathrm{I}$; to Smith \& McCullough, Howard, South Dak., January, I 893 .

GRANBY; foaled I 759; said to be by Blank : dam bred by Lord W. Manners, got by Crab; 2 d dam Cyprus Arabian Nare, bred by Lord W. Manners, got by Cyprus Arabian (the Duke of Rutland's) probably the the same as the Hampton Court Chestnut Arabian, about I 720 ; $3 \mathrm{~d}$ dam by Commoner ; $4^{\text {th }}$ dam Chestnut Thornton, by Makeless, son of Oglethorpe; and $5^{\text {th }}$ dam by Brimmer, son of Yellow Turk.

GRANBY, bay; said to be by Morassar: dam by True Briton horse. Advertised in Vergennes (Vt.) Gazette, by Johnson Walker, Ferrisburg.

Advertised at Windsor, Vt., ISo3. Advertised in Weekly Wanderer, April 25, I8o8, published at Randolph, Vt., as follows :

The noted full-blooded horse Granby, lately kept in Royalton, by Maj. Mower, at Bethel, Royalton and Sharon.

GRANBY (1-256), 2 :191/2, bay; foaled I 882 ; bred by R. S. Veech, St. Mathews, Ky.; got by Princeps, son of Woodford Mambrino: dam Hamite, bay, foaled 1874 , bred by Edwin Thorne, Millbrook, N. Y., got by Hamlet, son of Volunteer ; 2 d dam Lindora, bay bred by R. Randall, Cortland County, N. Y., got by Hambletonian; $3 \mathrm{~d}$ dam said to be by imported Consternation; $4^{\text {th }}$ dam by Washington Gray; and $5^{\text {th }}$ dam by Mogg. Pedigree from breeder.

Sire of 4 trotters $(2: 201 / 4)$; I dam of I trotter.

GRAND AIR, bay, I $53 / 4$ hands, said to be by Othello: and dam by Belsize Arabian. Advertised in Pennsylvania Gazette, 1777 , with pedigree as above.

GRAND BARON (3-128), $2: 181 / 4$, bay ; foaled 1892 ; bred by R. G. Stoner, Paris, Ky.; got by Baron Wilkes, son of George Wilkes: dam Nathalia (dam of Barondale, 2 : I I I/4), bay, bred by J. C. McFerran, Louisville, Ky., got by Nutwood; 2 d dam Beatrice (dam of Patron, $2: 141 / 4$ ), bay, bred by J. C. McFerran \& Son, Louisville, Ky., got by Cuyler, son of Hambletonian; 3d dam Mary Mambrino, bay, bred by Dr. A. S. Talbert, 
Lexington, Ky., got by Mambrino Patchen; 4th dam Belle Wagner, said to be by Embry's Wagner. Sold to H. J. Marbold, Greenview, Ill. Sire of Baroletta, $2: 17 \frac{1}{4}$.

GRAND BASHAW (ARABIAN), iron-gray, I4 $1 / 4$ hands; foaled I8I5. Imported to Boston, August, 1820 , from Tripoli, by Joseph C. Morgan. He went from Boston, to Lower Merion, Montgomery County, Penn., and was kept there several years. In 1827 he was at Whitemarsh, I 2 miles from Philadelphia. Received Ist premium at Pennsylvania State Fair, I823, still owned by J. C. Morgan.

Edgar says :

"An elegant Arabian Horse ; imported from Tripoli in August, I 820, by Joseph C. Morgan, of an iron-gray color, foaled in 1816 , full 15 hands high. He was selected by the importer from the best stock of oriental horses in that country, and, it is believed, that in point of beauty, action, and speed, he is not excelled by any horse ever imported into the United States. He arrived in America in 1820, and was kept in Lower Merion township, Montgomery County, near Philadelphia. No pedigree given."

From The American Turf Register, Vol. II. :

"Grand Bashaw, a beautiful iron-gray, 15 hands one inch high, was imported from Tripoli by Joseph C. Morgan in 1820 , then about four years old. Mr. Morgan had resided there several years and selected him from the best stock of Arabian horses known at the time. A premium of $\$ 50$ was awarded him in 1823 by the Pennsylvania Society on account of his superior blood, form, action, etc. Kept $\mathbf{1} 827$ in Whitmarsh township, I 2 miles from Philadelphia."

The following certificate of his pedigree is copied from Pennsylvania Agricultural report for 1823 :

"I, John A. Carstemon, his Danish Majesty's Consul-general at Tripoli in the West, do hereby certify that on the 24 th of May, I8rg, J. C. Morgan, Esq., of the United States of America, purchased from me an iron gray Arabian horse rising four years old. This horse was begotten by the late Bey's favorite horse, Khasmadgar, celebrated in this place for his beauty and other excellent qualities, from a fine mare of the country; is of very best blood to be obtained here.

$$
\text { (Signed), J. A. Carstemon. }
$$

TRIPoli in the West, May 24, I8I9.

"I do hereby certify that I am fully acquainted with all the facts stated in the certificate relating to the famous horse called the Grand Bashaw and that it is entitled to full faith and credit.

W. S. Consul."

(Signed), Richard B. JonEs.

The following interesting letter of Richard B. Jones has been published:

Philadelphia, April 25, I 865 .

Dear Sir :-Still suffering from a neuralgic attack in my head, I comply with your request as far as I can, with perfect reliance on its accuracy. 
In I 8 I 8 I loaned to some Danish officers a very valuable Arabian horse, by accident they killed him. On the following morning I found Grand Bashaw in my stable to replace him. I declined, under the circumstances, any compensation and suggested to Mr. Morgan, residing with me, to purchase, and by virtue of my official influence, would assist him to facilitate his embarkation for America. In 1819 he took him to Italy and from thence to Marseilles, where he joined me on my way to the United States. We sailed from there for Boston, and arrived the 2oth of August, I8zo. From thence he was taken to Lower Merion, Montgomery County, Penn., and kept there several years. Grand Bashaw was a beautiful black with a small star and snip. $\mathrm{He}$ was a Barb of the finest quality in every respect, but these pedigrees are not kept with the care of the Arabians. I have no personal knowledge of the mares bred to him, but have seen many of his descendants, all showing a resemblance to the original sire.

Grand Sultan was imported by me at the same time. He was kept one, if not two seasons at Salem, New Jersey, under charge of Michael Hackett, Esq., about 1822 or 1823 . He was an iron-gray of the Arabian Stock, and had many colts and fillies there.

Saladin was imported by me at the same time, superior, in my opinion, in purity of blood, size, and form, to either of the others. I sent him to North Carolina, where he improved the stock, and from thence to Georgia where he died. Grand Bashaw was about fourteen hands and an inch high.

I write with difficulty, as my vision is yet afflicted by late severe attack. My recollection is perfect so far as I have stated. The stock from all these proved a success; and where their pedigrees can be traced, enhance the value for many successive generations. In conclusion I remain.

$$
\text { Respectfully yours, RICHARD B. JONES. }
$$

The famous Clay and several other trotting families are descended from Grand Bashaw.

From an article in Porter's Spirit of The Times, N. Y., Jan. 23, r858, entitled "A Chapter on the Bashaws" :

"As the Bashaw stock of trotting-horses have of late years attracted much attention an inquiry into their origin and history may not prove uninteresting to the public and to such gentlemen as contemplate breeding that description of stock.

"Grand Bashaw the great original of the Bashaws in this country, was imported from Tripoli in I 820 , by Mr. Joseph Morgan. He was then some four or five years old, and was an Arabian of the highest caste and most perfect form. He was a most superb horse in appearance and his action, whether in the trot or gallop, was extremely graceful and swift. He was the sire of numerous fine road and saddle horses in Pennsylvania ; but from the little attention paid to pedigrees of road and trotting horses, I am unable to say that any of his immediate descendants distinguished themselves on the turf. The famous trotting horse Dutchman is said to have been got by grand Bashaw and not by Young Oscar, but the pedigree of Dutchman is in reality unknown. The locality however, in which he was raised, seems to favor the presumption that he was a Bashaw-a view which I feel somewhat disposed to take myself. The greater part of Grand Bashaw's life was spent in Buck's County, 
Penn., where he died, somewhere in the neighborhood of Newton,leaving as his successor the famous Young Bashaw."

For pedigree of Dutchman, see page ${ }_{15} 8$.

GRAND DUKE ( $\left.1-3^{2}\right)$, chestnut with stripe, hind ankles white, I $53 / 4$ hands, I 200 pounds ; foaled I 8 - ; said to be by Iron Duke, son of Hambletonian : dam Annie Beach, by Bassett's Stockbridge Chief, son of Stockbridge Chief, by Black Hawk; 2d dam by Long Island Black Hawk; and $3 \mathrm{~d}$ dam Sallie Miller, bay, by Mambrino, son of imported Messenger. Sold by J. W. Taylor, Central Valley, Orange County, N. Y., to Dr. Willoughby, Colborne, Ont., and by him to J. W. Morrow, Peterboro, Ont. Died r88ז. Pedigree from Mr. Willoughby as received from J. W. Taylor.

Sire of Sleepy Dan, $2: 29 \frac{1}{4}$.

GRANDEE (3-64), bay; foaled I 86- ; said to be by Hambletonian, son of Abdallah: and dam by American Star. Owned by George C. Hall, New York.

GRANDEE (WILLITT'S) (I-I 28 ), bay with star, I $53 / 4$ hands, I Ioo pounds ; foaled I 88I ; bred by William Sinnock, Massillon, O. ; got by Roxey, son of Florida: dam bred by Wm. Sinnock, got by Buckeye Chief, son of Provincial Chief; 2 d dam a pacing mare, bred by Harris Hatch, Hinkley, O., got by Stranger (Wilson's) ; 3d dam said to be by Gifford Morgan. Sold to J. Willitt, Santa Ana, Cal., who sends pedigree.

Sire of Fingler, $2: 15 \frac{1}{2} ;$ I dam of $x$ pacer.

GRANDEUR (3-256), bay; foaled I887; bred by S. A. Browne \& Co., Kalamazoo, Mich. ; got by Grand Sentinel, son of Sentinel : dam Overture, bay, bred by R. P. Pepper, Frankfort, Ky., got by Onward, son of George Wilkes; $2 \mathrm{~d}$ dam Nashville, bay, bred by R. P. Pepper, got by Woodford Mambrino; $3 \mathrm{~d}$ dam Tennessee, bay, bred by R. A. Alexander, Spring Station, Ky., got by Pilot Jr.; and $4^{\text {th }}$ dam said to be by imported Leviathan. Sold to H. B. Hodgkins, Aylmer, Ontario, Can. Sire of 3 pacers $\left(2: 09 \frac{1}{4}\right)$.

GRAND ISLE CHIEF. See Edward Everett (Gen. Mott, Mott Colt).

GRANDISSIMO (I-64), $2: 23 \mathrm{~T} / 2$, bay; foaled $\mathrm{I} 886$; bred by $\mathrm{Wm}$. Corbitt, San Mateo, Cal. ; got by LeGrande, son of Almont: dam Norma (dam of Grandee, $2: 23 \mathrm{~T} / 2$ ), bred by William Corbitt, got by Arthurton (dam by American Star), son of Hambletonian; 2 d dam Nourmahal, bred by Azariah Prussia, Jackson County, Ia., got by Blackbird (Simpson's). Sold to Heald \& Loeber; to Fred W. Loeber, St. Helena, Cal.; to H. W. Crabb, Oakville, Cal. Advertised, 1892 , by Fred W. Loeber, St. Helena.

Sire of 3 trotters $(2: 18)$. 
GRANDLY (1-32), $2: 2 \mathrm{r} 1 / 4$, black, about I5 hands; foaled I888; bred by J. H. Williams, Lexington, Ky. ; got by Gambetta Wilkes, son of George Wilkes: dam Effie Faulconer (dam of Lucy Yeiser, 2:193/4), chestnut, bred by J. J. Yeiser, Danville, Ky., got by Abdallah Mambrino, son of Almont, by Alexander's Abdallah; 2 d dam Nelly Butler, chestnut, bred by Dr. Yeiser, Danville, Ky., got by Míorrison, son of St. Elmo, by Alexander's Abdallah; 3d dam Brown Kate, bred by Mr. Charles Linsley, Middlebury, Vt., got by Black Jack, son of Hackett Horse ; 4th dam Little Black, bred by Charles Linsley, got by Black Hawk; $5^{\text {th }}$ dam bred by Mr. Linsiey, got by White Mountain Morgan. Sold to O. W. Pickard, Omaha, Neb. ; to Julius D. Creighton, Omaha, Neb. Information from $\mathrm{O}$. W. Pickard, who writes that Grandly was a very handsome horse, with an excellent disposition.

Sire of D'Ogley, $2: 2$ I.

GRAND MARSHALL (3-128), black; foaled I 890 ; bred by Granville Cecil, Danville, Ky.; got by Gambetta Wilkes, son of George Wilkes: dam Mistake, bay, bred by G. \&. C. P. Cecil, Danville, Ky., got by Marshal Kleber, son of Cuyler; $2 \mathrm{~d}$ dam Lady Yeiser, bay, bred by Dr. Yeiser, Danville, Ky., got by Garrard Chief, son of Mambrino Chief; 3d dam Jewell, brown, bred by John S. Gill, Lancaster, Ky., got by Gill's Vermont, son of Downing's Vermont; 4th dam Brown Kate, bred by Mr. Charles Linsley, Middlebury, V't., got by Black Jack; $5^{\text {th dam bred }}$ by Charles Linsley, got by Black Hawk; 6th dam bred by Mr. Linsley, got by White Mountain Morgan. Sold to G. and C. P. Cecil, Danville, Ky.

Sire of Martha Marshall, 2:061/4.

GRANDMONT (3-128), $2: 25 \mathrm{~T} / 2$, bay no white, $\mathrm{I}_{5}$ hands; foaled April 3, I 882 ; bred by W. T. Withers, Lexington, Ky.; got by Almont, son of Alexander's Abdallah: dam bred by W. T. Withers, got by C. M. Clay Jr., son of C. M. Clay; 2d dam, bred by S. N. Steadman, Lexington, Ky., got by Alexander's Norman; 3d dam said to be by Johnson's Toronto. Sold by breeder to the Italian Government for $\$ 5,000$. Pedigree from breeder.

GRAND MOOR (5-I28), black; foaled 1876 ; bred by L. J. Rose, San Gabriel, Cal.; got by The Moor, son of Clay Pilot: dam Vashti, black, bred by L. J. Rose, Sunny Slope, Los Angeles; got by Mambrino Patchen, which see; $2 \mathrm{~d}$ dam Kate Taber, brown, bred by S. G. Taber, New York, got by Mambrino Messenger (Dunkin Horse), son of Mambrino Paymaster. Sold to Newland \& Pumyea, Oakland, Cal.; to H. I. Thornton, San Francisco, Cal.; to G. L. \& A. C. Davis; to A. C. Davis, Port Jefferson, N. Y.

Sire of 3 trotters $(2: 271 / 4) ; 6$ dams of 2 trotters, 5 pacers. 
GRAND SACHEM, bay, $153 / 4$ hands; foaled 1788 ; said to be by Figure, son of imported Figure: dam by imported Othello; and $2 \mathrm{~d}$ dam by imported Lath. Advertised in the Poughkeepsie Journal as follows, March 27, 1793 :

"At the stable of Isaac Merritt and Isaac Huestis in the Nine Partners, Washington town, that beautiful, blooded, bright bay horse Grand Sachem. He is five years old this spring; was got by that famous horse the Figure, and the Figure by the noted imported horse old Figure : his dam by the full blooded horse Lath. He is 15 hands three inches high, of great beauty, bone, and strength and extraordinary carriage."

GRAND SEIGNEUR, gray; foaled I793. Presented by the Grand Seigneur of Arabia to King of England and was brought to Novia Scotia, by the Duke of Kent ; sold to Col. Campbell of Windsor, and then bought by Messrs. Hagard \& Thompson, and brought to New York, October, I 804. Advertised in 1805 , to be kept on Bloomingdale road, three miles from New York; terms $\$ 50$; and, 1806 , at Cooper's Ferry, N. J.

GRAND SEIGNIOR, gray, $153 / 4$ hands; foaled about 1812 ; bred in New Jersey; said to be by Grand Seignior Arabian : and dam by a son of imported Messenger. Owned, I8zo, by Dr. John Perkins of Philadelphia, Penn. Went to Crawford County, Penn., and was sold to Mr. Chauncey Goodrich, near Buffalo, N. Y., who advertised him, 1825 , in the Buffalo Patriot at Buffalo and vicinity.

GRAND SENTINEL (I-I 28$), 2: 27 \frac{T}{4}$, bay, 16 hands; foaled 1873 ; bred by J. B. Richardson, Lexington, Ky. ; got by Sentinel, son of Hambletonian: dam Maid of Lexington, bred by John B. Richardson, got by Mambrino Pilot; 2d dam Brownlock, bred by J. B. Richardson, got by imported Leviathan; 3d dam bred by J. B. Richardson, got by Stockholder. Owned by S. A. Browne \& Co., Kalamazoo, Mich. Died, January, I887. Pedigree from breeder.

Sire of 20 trotters $(2: 181 / 2), 2$ pacers $(2: 161 / 4) ; 9$ sires of 13 trotters, Io pacers; 18 dams of 23 trotters, 5 pacers.

GRAND SENTINEL JR. (I-32), $2: 28$, bay, right hind foot white, small star, $14^{1 / 2}$ hands, 1070 pounds; foaled 1880 ; bred by Asa M. Pringle, Mears, Mich.; got by Grand Sentinel, son of Sentinel, by Hambletonian : dam Nelly, said to be by old Empire of Ohio. Mr. Pringle writes that the dam Nelly was Morgan and Messenger, of great endurance and a fast trotter. Sold to S. E. Crandall, Angola, Ind. Pedigree from catalogue of breeder.

Sire of 2 trotters $\left(2: 23 \frac{1}{2}\right)$.

GRAND TURK, bay, with star and snip ; foaled I 785. Advertised, I791, by James Gove, Preston, Conn., as follows : 
"The Narragansett pacer Grand Turk bred in the neighborhood, bay, etc. $* * * \mathrm{He}$ is of the Narragansett pacing breed generally called the best saddle horses. Well built, paces and trots."

Advertised in Poughkeepsie Journal, April ro, I 793 :

"Grand Turk, at the stable of James Cooper in Fishkill, and at the stable of Richard Everett, in Poughkeepsie. Grand Turk is the first saddle horse in the state, is a chestnut sorrel, sixteen hands high, and is seven-eights Narragansett, strong and bony, and his carriage equal to any horse. The giving a long pedigree of horses has become so ridiculous that the owners of this horse will not trouble the public with any, trusting his figure and movements sufficiently recommend him."

A horse of this name is advertised in Spooner's Vermont Journal, Windsor, May 29, I 798, as follows :

"The beautiful bright bay, full-blooded horse, Grand Turk, will cover this season, on the following terms, - three dollars the leap, five dollars the season, or to ensure as the parties agree. Said horse will be at Mr. Samuel Morgan's, in Weathersfield, on Wednesday morning, the 3oth inst., and return on Thursday to the subscriber's stable in Windsor.

"Grand Turk is the horse which stood at Deacon Wait's stable last season. Gentlemen call and see for yourselves.

May 25, 1 $798 . "$

Benj. Thatcher, Jr.

GRAND TURK. Advertised at Goshen, N. Y., May 2, I825, by David Watkins as follows:

"Grand Turk is a dark chestnut sorrel, I5 $1 / 2$ hands high, well formed of great weight and calculated to get good stock for the turf, saddle or harness. He was bred by Mr. Thornton, near Philadelphia, where he has stood and proved himself a sure foal getter, and his stock very promising. Grand Turk was got by Bela Badger's Marshall Duroc (dam Maid of the Oak, by the noted running horse Count Piper),-Grand Turk's dam by Blossom, grandam by Messenger, great-grandam by Figure, great-great-grandam by Tamberlane. Terms, $\$ 6$ and $\$ 9$.

GRAND TURK (I-32), bay, I6 hands; foaled 1848 ; bred by B. Thomas, Ontario County, N. Y. ; got by Young Turk imported from England by Mr. Nealey of Canandaigua: dam said to be by Morgan Duroc. Advertised, as above in Newark Advertiser, 1854 , to be kept in Eatontown, N. J.

GRANDVIEW (3-128), $2: 18$, bay, I6 hands, I Ioo pounds; foaled I884; bred by Mr. Douglas, Franklin, Penn.; got by Bay Tom, said to be by Blearo's Tom Hal : dam Winnie, by Tom Hal Jr., son of Kittrell's Tom Hal ; and $2 \mathrm{~d}$ dam by Buck's, son of Stone's Pilot. Pedigree from J. W. Tilley.

Sire of 2 pacers $\left(2: I_{7}\right)$.

\section{GRAND WILKES. Untraced.}

Sire of Ike IIilkes, $2: 12 \frac{1}{4} ; 3$ dams of 3 pacers. 
GRANDWOOD (5-256), bay; foaled I 883 , bred by W. W. Mitchell, Ionia, Mich.; got by Pasacas, son of Almont : dam Satinwood, brown, bred by A. J. McKinna, Nashville, Tenn., got by Blackwood Jr., son of BlackWood; 2 d dam, Amanda.

Sire of 2 trotters $(2: 271 / 2)$.

GRANGER (5-64), $2: 24$, chestnut sorrel, I6 hands, I Ioo pounds ; foaled r 868 ; bred by Wm. Knoble, Dent, Hamilton Co., O.; got by Prince, son of Tom Crowder, by Pilot: dam bay, bred by Wm. Knoble, got by Stockbridge Chief, son of Black Hawk. Sold to Albert Miller; to John Yaney, Cleaves, O.; to James Walker. Said to have paced one-half mile in $\mathbf{I}$ :oo. Gelded young. Died 1876 .

GRANGER ( $1-32)$; said to be by Excelsior, son of Green Mountain Black Hawk: dam by Red Tiger, son of Clinton, by Sir Charles; $2 \mathrm{~d}$ dam by Giles Scroggins, son of Sir Archy; and 3 d dam by Hancock's Hambletonian. Advertised, 1873 , by Walter E. Robertson, Shelbyville, Ky.

GRANICUS. See Time Medium.

GRANITE STATE (5-32), bay, I 5 hands, Iooo pounds; foaled 1852 ; bred by D. Frew, Plainfield, N. H. ; got by Barnard Morgan, son of Gifford Morgan : dam bay, said to be by Morgan Tally Ho. Sold 1855 , to John C. Sawyer; 1858 , to J. C. Higgins, Bunker Hill, Ill., where he died, 1878. Awarded ist premium at the Illinois State Fair, I858. A noted stock horse. See The Morgan Horse and Register, Vol. I., p. 683.

GRANITE STATE BLACK HAWK. Entered at the New Hampshire State Fair, 1853 by Z. J. Wiggin, of Stratham.

GRANTHAM (GRAY); said to be by Brownlow Turk. Gray Grantham got Green's Galloway, an extraordinary horse of his size; Miss Belvoir, Shadow and the Grantham Filly, very capital mares, particularly the two former ; also the Confederate Filly, a good mare at light weights. There was a brother to Gray Grantham.-General Stud Book, Vol. I., p. 380.

GRANTHAM (SLAVE), chestnut; foaled I750; bred by the Duke of Ancaster; got by the Ancaster Starling, son of Bolton or old Starling: dam, Whitefoot Mare, said to be by Whitefoot; 2d dam by Alcock's Arabian, son of Crab ; 3 d dam by Pelham (or Curwen) Bay Barb; and

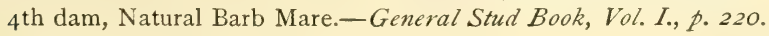

GRANTHAM CHIEF, bay, I 6 hands, I 50 pounds; foaled I $85^{8}$; bred at St. Catherines, Ontario, Can.; got by Royal George, son of Black Warrior. Sold to Wm. M. Tweed, New York, N. Y. ; to a Mr. Storms ; to Peter McQueen, Chicago, Ill ; to B. D. Parker, Gardner, Ill., whose 
property he died, July 27, 1888. Information from B. D. Parker, who writes: "A very stylish horse with great action."

Sire of 2 trotters $(2: 261 / 2) ;$ I dam of I trotter.

GRAPHIC (I-128), black, one white pastern, small star, I6 hands, I I50 pounds; foaled $187 \mathrm{I}$; bred by R. S. Strader, Lexington, Ky. ; got by Mambrino Patchen : dam Black Girl, said to be by Strader's Cassius M. Clay Jr., son of Cassius M. Clay; $2 \mathrm{~d}$ dam by Gray Eagle, thoroughbred, son of Woodpecker, by Bertrand; and $3 \mathrm{~d}$ dam by American Eclipse, son of Duroc. Sold to W. S. Frazier, Aurora, Ill., who sends pedigree.

Sire of Novelty, 2:29; I sire of I trotter; 2 dams of I trotter, I pacer. .

GRASMERE (5-64), chestnut; foaled I 888 ; bred by P. A. Cheney, Grasmere, N. H. ; got by Viking, son of Belmont: dam Electa, chestnut, bred by Spencer Borden, Fall River, Mass., got by King Philip, son of Jay Gould; 2 d dam Black Bess, black, bred by Robert Williams, Putnam, N. Y., got by Tom Howard, son of Black Hawk. Pedigree from breeder.

Sire of Lady Grasmere, $2: 281 / 4$.

GRATEFUL (I-I 6 ), $2: 28 \mathrm{I} / 2$, sorrel, 16 hands; foaled I 867 ; bred by Andrew Fish, Stark, Ne.; got by Brown Horse (dam a Black Hawk mare), son of Sandy River Trotter, by Eaton Horse: dam foaled I 850 , said to be by Crawford Horse, brought to Maine from Canada; and $2 \mathrm{~d}$ dam by Black Hawk. Sold to George Everett, Boston, Mass., 1874. Gelded young. Pedigree from breeder.

GRATTAN (I-12S), 2 :13, black, star and short strip, white hind feet, I6 hands, I050 pounds; foaled 1887 ; bred by Timothy Anglin, Lexington, Ky.; got by Wilkes Boy, son of George Wilkes: dam Annie Almont, brown bred by John D. Ballentine, Pulaski County, Tenn., got by Almont Jr. (Bostwick's), son of Almont; 2 d dam Bandella, said to be by Brown Dick; 3 d dam by Jack Malone; and $4^{\text {th }}$ dam by Childe Harold. Sold to T. W. Brandt \& Son, Montgomery City, Mo., I 895 . Pedigree from W. R. Anglin.

Sire of 3 trotters $(2: 08), 5$ pacers $\left(2: 07 \frac{1}{4}\right)$

GRAVELIN HORSE (ALLEMANDE) (I-4), described as strawberry roan, about $15 \mathrm{I} / 2$ hands, Iroo pounds; foaled about I $810-12$; owned when six or eight months old, by Vital Duprés of St. Ours, P. Q., who sold to Gascon LaRoque, and he, when the horse was three or four years old, to Joseph Gravelin of the same place, who, it is thought, afterwards sold to some party, at St. Francois, near Sorel, P. Q., who took him, or sold him, to go to the States.

Mr. Louis Duprés born Feb. I3, I798, in interview, 1888, said: 


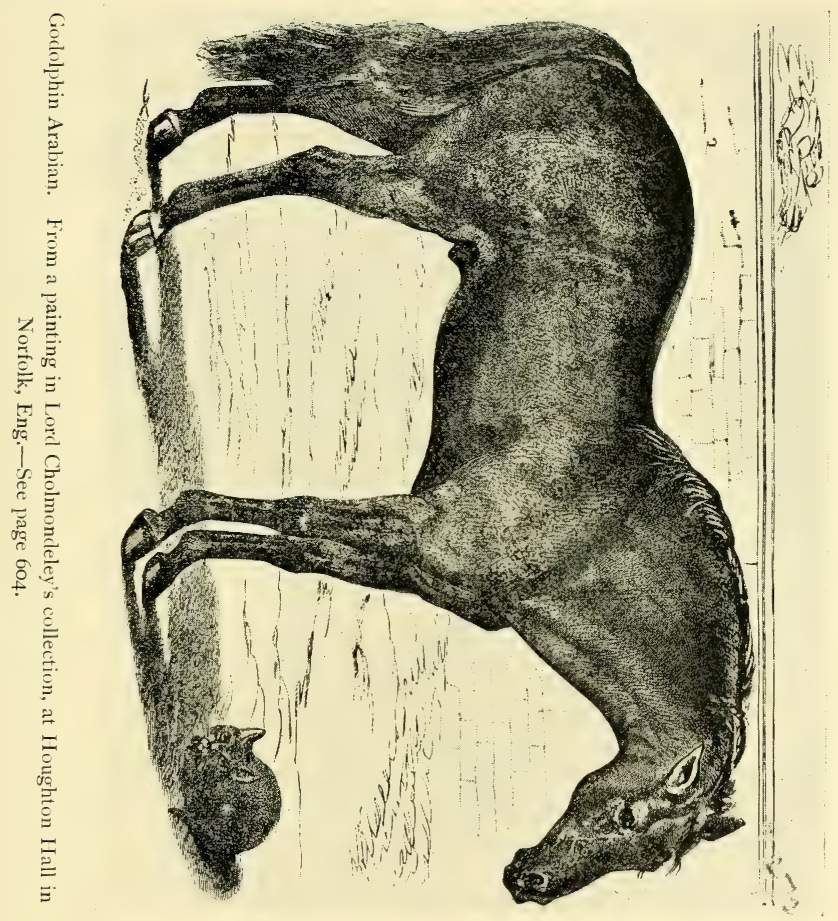




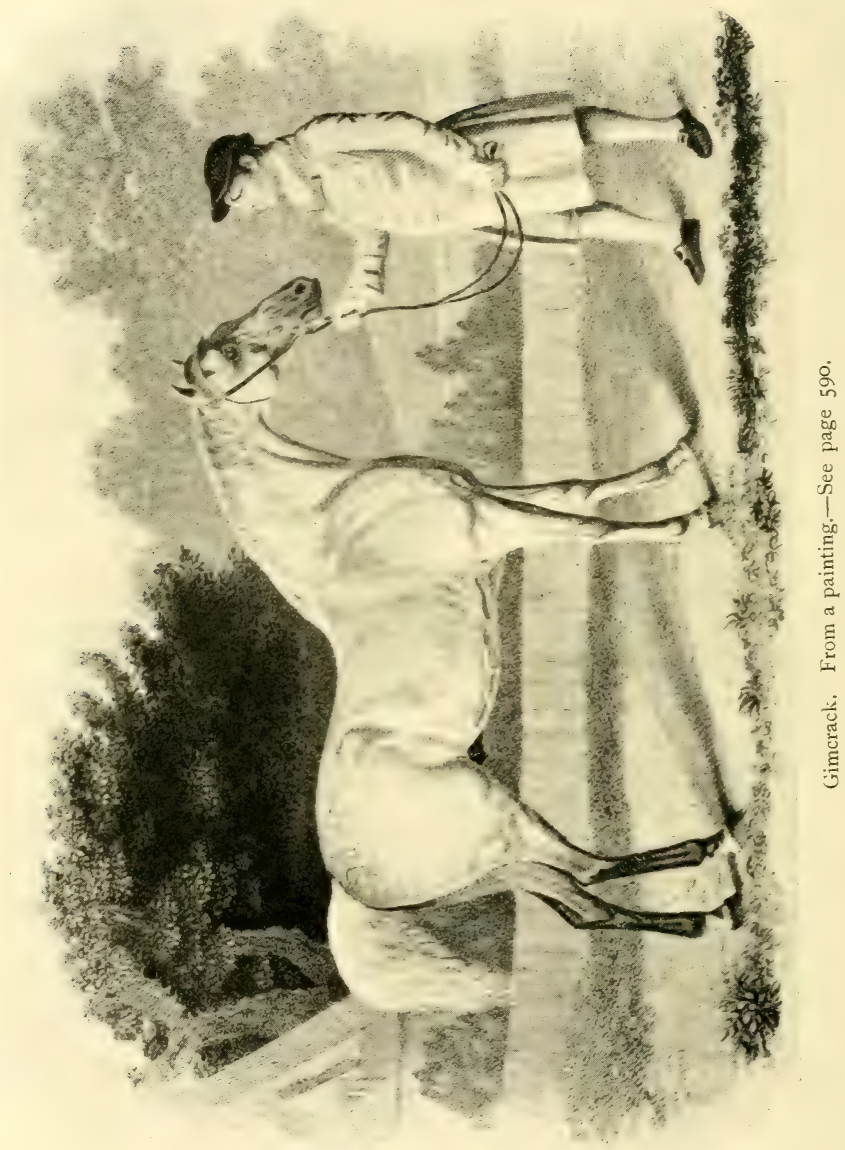


"The Gravelin Horse of St. Ours was gray black white red [roan], very fine horse, a pacer, over 15 hands, fine large horse. Dansereau and he had races. Duhamel horses were about the same kind, there were a large number of horses from both."

M. Chapdelaine, St. Ours, P. Q., born I 809, said :

"Duhamel had two horses a black and a gray they were pacers. The Gravelin Horse was older than the Duhamel Horse and fast, but not as fast. He was roan not higher than the Duhamel Horse but broader and heavier. These horses were handsomer than most horses about. I was twelve years old. He sold him to go to Șt. Francois, below Sorel."

An old gentleman of St. Ours born I798, whose name we failed to take, said :

"I remember the Gravelin Horse, a pacer and trotter; he was heavy with a large chest. When I was about 15 they raced the pacers here on the ice."

Mrs. Gravelin of St. Ours, an old lady said :

"The Duhamel horses were called Dutch. They were very handsome and fast pacers. I saw both the black and the gray stallion that he owned, and also a horse that Uncle Gravelin owned, which I understood to be Dutch."

Mr. Gravelin of St. Ours, born Aug. 23, I806, said :

"Duhamel's black horse was got by the Gascon LaRoque Horse and his gray one was got by the black. The Gascon LaRoque Horse was a Dutch horse; my uncle, Joseph Gravelin, owned him at one time, he was gray or roan, and about as old as I was. He trotted in the snow and if the road was good would pace. When I was four or five years old, mares came from everywhere to him. Duhamel's black horse was got by this roan horse of my uncle's, and I have often heard my uncle say that his horse came from a Dutch or English horse. This horse of my uncle, Gascon LaRoque horse, was about $15 \mathrm{I} / 4$ or $15 \mathrm{t} / 2$ hands high, un grand cheval. LaRoque bought him when a sucking colt of Vital Duprés of St. Ours, and sold him to my uncle, who kept him until he was seven years old, and sold him to go to the States. The Americans came and got all the good horses. He was built very different from the French horses. French horses made all to once, big belly. Dutch horses handsomer and finer. Duhamel's gray horse was three years younger than his sire, the black. This gray or roan horse owned by my uncle was heavier than your gray team [fifteen hands, nine hundred and fifty pounds each] and a little taller; was three or four years old when my uncle bought him. He was boss all the time he was here. I do not know the horse that got him. He was four or five years older than Duhamel's black. I do not remember any other roan horses at that time. They used to bring mares here from Vermont and trade them. The dam of the Duhamel Horse was a black pacer."

Mr. Duhamel, St. Ours, born I 829, said :

"My father was born in 1791 , married in 1819 , and died, $1848 . \mathrm{He}$ had a handsome black trotting stallion that he called Papillon and sold the year before he was married. I think this horse was connected with the Dansereau horse, but do not know how. An uncle of mine had a 
black and a gray stallion that paced very fast. This was later. A daughter of his lives four miles from here. Uncle's stallions were of the same blood as the Dansereaus."

Pierre Mandeville, born I 797, said:

"I was twenty-four or five years old when I remember the black horse of Duhamel. He was a fast pacer, un joli cheval. I knew Gascon LaRoque, but do not remember his horse. There were not many pacers when I was a boy, Baptiste Lebrun had a mare, and a man named Gravelin had a horse. I do not remember any fast pacers before Duhamel's except these. Gravelin's horse was a pacer, gray, and before the Duhamel horses. I was married when twenty-eight years old. Gravelin had his horse before I was married. He was larger than the Duhamel horses."

A gentleman of St. Ours, name not remembered, born, I8I6, said :

"Allaire bought the horse of Duhamel, about 60 years ago and sold him to Recollet of Sorel. He was from a horse owned by Gravelin. Dansereau bred a mare to this horse when Duhamel owned him. I do not know what he got. They bred a mare to him when one year old. The dam [of Duhamel Horse] was a small pacing Canadian mare. He had a gray horse younger."

Augustine Defeault, 82 years old of St. Ours, said :

"I knew the black Duhamel Horse, I have seen him. He was not large 5-2 black, a pacer, a very nice little horse, not a puller. There was also a gray horse, the black and the gray were brothers, their sire was the Gravelin Horse. I think Gravelin bought of Duprés when the horse was one year old. I knew the mother of the black and the gray, a nice mare, black both trotted and paced. I think Duhamel bought her about here. Duhamel lived on the farm next to me. I have lived here all my life. Louis Dansereau's black horse was a beauty, younger than the Duhamel Horse and better, I think. I do not know that Dansereau ever bred to Duhamel's stallions."

Polite Duhamel of St. Ours, said :

"Louis Dansereau raised a black stallion, son of my grandfather's black stallion, a short horse, black, trotted. I do not know anything about the mother's blood; don't know whether Dansereau raised more than one colt. Gravelin's horse was the father of my grandfather's black horse. What I say, I have been told by my father. Mr. Defeault told me that the Gravelin horse was by the Duprés Horse. I am sure that the Dansereau horse went to America."

We have written several times to Minneapolis, trying to get in touch with the son of M. Duprés that was thought to be living there, but did not succeed. Our bottom information then of the origin straight male line of the Dansereau breed of horses in Canada, from which Pilot and a very large number of the more celebrated fastest trotters and pacers in Canada came, is that Mr. Dansereau's first fast pacing stallion was by the Duhamel Horse, son of Allemande or Gravelin Horse, and that this Gravelin Horse was by the original Justin Morgan or a son. See Chapter XIV., pages 235-280 inclusive, Vol. I. American Morgan Horse 
and Register; and pages iv.-xi. inclusive, in Introduction, Vol. II. American Morgan Register; together with Introduction, pages ii.-xvi. of Vol. I. of this work.

From the earliest entrance of the original Justin Morgan Horse into northern Vermont in $179^{2}$, the horse was frequently called Dutch, and later his sons and descendants in male line were extensively advertised as Dutch both in Vermont and the Province of Quebec, where at that time, the fast Canadian pacer originated.

A number of these Advertisements we have quoted in the pages referred to. We add several more here :

Dutch Prince, said to be by Sherman Morgan, son of the original Justin Morgan. Advertised in the Danville (Vt.) North Star of April I9, I8I4, by W. W. Carpenter, to stand at Lyndon Centre, Kirby, and Waterford at $\$ 2$ to $\$ 4$. The advertisement says :

"Said horse is of as good blood and pedigree as any in the country, of good size, weil built, and is a dark chestnut color."

$\mathrm{He}$ is advertised again in the North Star of May, I827, by Joseph Pope, to stand at Wheelock, Danville, and Peacham, Vt. This advertisement reads :

"Dutch Prince was got by the noted Sherman Horse, and for size, elegance of proportion and goodness of Stock, is exceeded by none in this vicinity."

Mountain Traveler, by Sherman Morgan. Advertised in the Danville North Star, I818, as follows :

"The beautiful horse Mountain Traveler will stand at Capt. Fry's, Concord; Mr. Warner's store near Littleton; Mr. Park's store; Mr. Henry Stevens' tavern, Barnet; Mr. Works, Waterford; Capt. John Barney's tavern, St. Johnsbury Plain. Said horse is lately from the south-ward, half Dutch and half English; large size, well built, and of a beautiful bay color, and needs only to be seen to be admired."

St. Johnsbury, May 14, I8 8 .

And in same paper, 1820 , as follows :

"That noted half Dutch horse, Mountain Traveler, will stand, etc., at Barnet and St. Johnsbury at $\$ 2$ to $\$ 3$. Said horse is of a beautiful bay color, large size and well proportioned."

A son of John Barker informed us that this horse was by Sherman Morgan.

Dutch Morgan Trotter. Said to be by a son of Justin Morgan. Advertised, I830, by W. B. Chapin, Moultonborough, N. H., to be kept at Holderness Centre, Harlow, Moultonborough, Sandwich, South TamWorth, and Tamworth, N. H.

We have already quoted the advertisement of the sons of the original Justin Morgan, that of Weasel in the Danville North Star, May ro, I8Io :

"The Dutch horse Weasel four years old, will stand at the stable of the subscriber, one mile north of St. Johnsbury Plains, Vt. Terms one 
to three dollars. Said horse is $\mathbf{I}_{5}$ hands high, stout built, and got by the full-blooded Dutch horse that stood at St. Johnsbury last season. Richard W. FENTON."

The Hawkins' horse or Young Traveler. Advertised, I8I 7, at Danville and St. Johnsbury, Vt. :

"Young Traveler is descended from the old Dutch Goss horse ; and as he is generally known, a particular description is deemed unnecessary."

And in $1820-23$, the same horse at Stanstead, P. Q., described as the celebrated Dutch horse called the Hawkins' horse and formerly owned by Stephen Hawkins of St. Johnsbury.

Signed, John Johnson.

And again (son of the original Justin Morgan and sire of Black Hawk) in 1828 at Danville, Vt. :

"Notice for the information of those who may be gratified therewith, the noted and celebrated Dutch, Morgan or Sherman Horse (which is one and the same), will stand for the use of mares the ensuing season on St. Johnsbury Plain, on Friday and Saturday of each week, and the residue of the week at S. West's on Danville Green.

$$
\text { May 2, I } 828 \text {." }
$$

J. Buckminster.

And so, too, at L'Epiphanie a little below Montreal in the Province of Quebec it will be seen that Mr. Charles Archambault, a well known trainer and driver of that Province in referring to the Archambault Horse, bred by $\mathrm{T}$. Archambault, foaled about $\mathrm{I} 843$, and got by a horse that came from the States into Canada in the thirties, said:

"The Archambault Horse was a Morgan or Dutch horse called both ways and one of the prettiest horses that ever was. His sire was a Dutch or Morgan horse, imported from the States."

We would also here call attention to the letter of Mr. Barnard of Sherbrooke, to The New York Spirit of the Times in $\mathrm{r} 84 \mathrm{I}$, and which is published in the Preface of Vol. I., of this work, describing a breed of very handsomely built, fast, and active ponies, or not large horses, existing in the Province of Quebec and called Dutch. Mr. Barnard a remarkably intelligent horseman and sensible man, writes to make inquiries of The Spirit or its readers if they know of any similar breed anywhere else called Dutch. He says :

"There is a variety among the Canadian horses, of peculiar characteristics, low, heavy, short in the legs, with shoulder thick at the breast and thin at the withers, which are termed Dutch, but whence their origin is unknown. The ignorant habitants have a custom, too, of calling crossbred horses, which grow large, heavy and thick-meated (as all crosses with the Norman are apt to do), chevaux Allemande, Dutch horses, probably from their superficial resemblance to those solid chunks among them, first mentioned, and which appear clearly to be a variety distinct from the Norman.

"I hope that if any of your readers know of a Dutch breed, now or formerly in existence, of the fleet and active sort-not the lumbering and heavy--he will mention it in the 'Spirit.' Let no mistake be 
made, we don't wish to hear of a breed of coach or cart horses, but rather of swift and heavy ponies: the Morgan horse was but about I4 hands high."

And he closes the letter with this last remark, showing that involuntarily he sought the solution of his ignorance, in the Morgan horse, though not then familiar with his history, and apparently ignorant that the Morgan horse had been very commonly called Dutch.

It should be remembered that between the coming of the Morgan horse to Vermont in 1793 and the beginning and development of the fast Province of Quebec trotter and pacer, which Mr. Barnard expressly says were called Dutch, there was abundance of time. Indeed it was exactly that time that this breed appeared in the Province and was developed. Our information is decisive that before that, such a breed did not exist in the Province. This appears in the testimony of a number of the older witnesses that we interviewed, and will appear in the pages referred to.

Louis Duprés of Contre Cœur, born I 798, said : "There were no fast pacers here before the Dansereau horses."

M. Chapdelaine of St. Ours, born, I 809, said: "Duhamel had two horses a black and a gray; they were pacers. I saw pacers before but not so fast."

Madame Pierre Chapdelaine, born, I808, said: **** "I do not remember any other fast pacer. They had just commenced to race then and father had the best.".

Pierre Mandeville, born I797, said :

"There were not many pacers when I was a boy. Baptiste Lebrun had a mare, and a man named Gravelin had a horse. I do not remember any fast pacers before Duhamel's except that Gravelin's horse was a pacer and before the Duhamel horses."

Ermite St. Onge, Contre Cœur, born I8o6, said :

"I saw a nephew of Louis Dansereau. Louis Dansereau traded in Montreal a big farm horse for an old pacing mare. This mare had a black mare colt, and from this younger mare he raised twelve foals, nine of them stallions. The first fast pacers in this town were bred by Louis Dansereau. I was quite a boy when my uncle Dansereau got this black mare. I remember when drawing hay with my father, when I was a boy, seeing the colt of this American mare.

I remember Chicouagne breaking the colt that he bought of Louis Dansereau and afterwards sold to Joseph Dansereau [Pilot]. This colt was hard to drive and very swift. Joseph Dansereau took him to Montreal and sold him. He was black, about 15 hands, and I think was got by the Vassar Horse. Louis Dansereau afterwards raised another, black with two white feet behind, a little larger, and the fastest horse at Montreal or anywhere. He raced him at Verchères, St. Hyacinthe, Montreal, Sorel, and all about. I could not tell what his sire was, but think it was one of Dansereau's colts; he kept breeding to his own. I raised two colts from this horse, that I sold to a man at Three Rivers. I sold the 
mare colt for two hundred dollars, and understood that she was sold for two thousand dollars. She both trotted and paced. I was about forty when I raised these colts. I remember the Vassar Horse well when he was a colt. I was about twenty I think. I think I was only seven or eight when I first saw a colt of Louis Dansereau's American mare. I think the Vassar Horse was the first of the stallions raised by Dansereau from the black mare. I think the second was the one sold to Chicouagne, and by him to Joseph, sometimes called Ouillett Dansereau, a black horse that was quick, 'vite, vite, vite.' Duhamel of St. Ours (after his marriage) raised a colt from this Joseph Dansereau stallion that both paced and trotted, and that he kept quite a while. Duhamel afterwards left St. Ours. The Vassar Horse was the first fast pacer that I remember. I was married in 1832 , but was unmarried when Joseph Dansereau had the black horse. He sold him to an American for what he thought then a large price. I remember the Gravelin Horse, a fine large horse of mixed color. I think I was about twenty. Louis Dansereau had another after the Vassar Horse, that was called White Foot, that was larger than the Vassar Horse, and which he sold to Americans. Dansereau sold one to Fiset, one to LaBousset, one to Dessond, and one to Girard of Contre Cœur, now of L'Assomption."

In returning from one of our trips to Canada we came to the pretty hamlet of Freleighsburgh, composed of about equal parts of valleys and hills, with a sparkling and beautiful river winding through. It was after a long journey and our horses needed their dinner, if not rest. At the hotel we were told that Thomas Pickering, who lived on the hill, some five miles from the village, was excellent authority on all matters of history, as he had for many years spent much time in gathering historical information. The feeling was so strong among those of the citizens present that he should be seen that we hired a livery team and drove to Mr. Pickering's house. He gave us much valuable information, and among other things said :

"Father came here a little less than seventy years ago. I am sixtyfour. There were no pacers in the French country. The pacers from Canada came from the States to start with; Yankees used to cheat the Frenchmen in trading pacing mares. A man named King lived here many years ago, who used to work for Gov. Chittenden, on Onion River, Vermont. King lived to be nearly one hundred years old. $\mathrm{He}$ has told me many times about taking pacing mares into the French country and trading them to the French. There were no roads here then, only a blazed path through the woods to the French country. $\mathrm{He}$ used to go alone, taking half a dozen of these pacing mares at a time fastened together by head and tail. Once, he said, he went as far as Quebec. He had an extra memory and would tell every little particular about the trades. He came through Fairfield, and went through St. Cæsaire and St. Hyacinthe. Formerly there were only ponies in the French country. King used to tell, too, how Yankees would cheat the Frenchmen with pacing mares. No matter how old they were, they wanted them. King died twenty-five years ago or more. King came originally from New Jersey. He brought pacing mares into Canada as early as I 795." 
This important testimony of Mr. Pickering we found sustained in a book entitled, Travels through Canada and the United States in the Years I 806-7-8, by John Lambert, who says (Vol. I., page I28) :

"The cattle in Canada are rather diminutive, being mostly of the small Norman breed. If they have not degenerated in size by their emigration, they have certainly not improved. The horses are strong and swift, many of them handsome, but they are mere ponies compared with the English horse. There is a large breed about ninety miles below Quebec, which are generally brought up for heavy work. The first horse seen in Canada arrived in the ship Le Havre, July 16, I665. It appears that neither sheep nor horned cattle were in the Province long before that time. Their cows and oxen are small, lean and poor. The sheep are small and have but little fleece. Poultry are very good.

"The Americans from the States carry on a lucrative traffic with the Canadians for their horses. The latter are very fond of a horse which runs with a quick shuffling pace, and the Americans bring in with them a parcel of rickety animals which have that accomplishment. The Canadian willingly exchanges his fine little horse for the pacer and often gives a few pounds to boot. The Americans return with the Canadian horses to Boston, or New York, and there obtain thirty or forty pounds for each, according to their value, which in Canada rarely sell for more than ten or twelve pounds. The Canadians are reckoned very adroit at a bargain; but they sink in comparison with an American horse-dealer."

And again, while traveling in Vermont, he says :

'The Vermonters are clean traders and are seldom outwitted in a bargain; on the contrary, they have often displayed their dexterity as horse Jockeys in Canada, and exchange their weak and rickety pacer for the hardy little Canadian horses.'

From this it is evident that when he wrote, "The Americans from the States carry on a lucrative traffic with the Canadans,' etc., he referred to the Vermonters, and it should be remembered that at this time the land traffic between Lower Canada and the States was almost entirely across the Vermont line.

It thus appears that the Canadians had a passion for pacers, about the beginning of this century, which they gratified, not from any supplies of their own, but by means of those brought in from the States, especially from Vermont. These were generally pacing mares, and of course were frequently in foal to stallions of the locality whence they came. But it was precisely at this time that the Morgan horse began to flourish in Vermont, and it is a curious fact in this history that the Mr. King whose exploits in taking these mares into Canada each year has thus been handed down, lived at Williston, Vermont, where, in 1795 (the precise time when he was thus engaged) the Justin Morgan was advertised to stand.

GRAVES HORSE (BALTIMORE MORGAN) (3-32), dapple chestnut, 16 hands, I 400 pounds; foaled August, I 850 ; bred by Zenas H. Graves, Baltimore, Vt. ; got by Green Mountain Morgan : dam black, bred by 
Zenas H. Graves, got by the Roswell Earle Horse, a horse bred and owned by Roswell Earle of Chester, Vt., son of Young King William; 2d dam bought at Bridgewater, Vt., said to be by Gifford Morgan. Kept, I853, at Baltimore, Vt., and, I854, at Cavendish, Reading and Baltimore, Vt. Sold to Abel Lyman, West Randolph, Vt., I855; to parties in Michigan for $\$ 5400$. A very active and fine appearing horse, with high head and arching neck; kind and stock excellent. Z. H. Graves writes that seventeen of his colts were kept as stallions in the vicinity of Springfield. Received first premium at Vermont State Fair, 1855. (See The Morgan Horse and Register, Vol. I., p. 709.)

GRAVES HORSE (MOHAWK PRINCE) (I-8), dark chestnut, small star, one white hind foot, I5 hands, I025 pounds; foaled I868; bred by A. McDonnell, New Hampton, Chickasaw. County, Ia.; got by Mohawk Chief, son of Black Hawk: dam chestnut, bred by A. McDonnell, got by the Iverson Horse, son of Screwdriver, said to be Morgan; 2 d dam a gray roan, bred by a Mr. Burgess at Britt, Howard County, Ia., sold to Mr. McDonnell as a well-bred Morgan. Sold I868 to A. K. Graves, Chickasaw County, Ia., who kept him at Chickasaw until about I888; to William Wilson, Williamsburgh, Neb., whose property he died about 1898 . Information from J. F. Cagley, Warhua, Ia., who writes: "A fine appearing animal, action of the best, disposition good and one of the best stock getters that was ever in this county, fully 75 per cent of his colts going to the eastern market as drivers."

GRAVES HORSE (WILSON HORSE) ; said to be by a horse supposed to be Morgan that was kept one season at or near Charles City, Ia.; at a sevice fee of $\$ 25$. Owned by H. Wilson, Bradford, Ia., who is thought to have got him at Charles City, Ia. Went to Missouri where he was valued highly. This is evidently the same horse as the previous one.

GRAY ARCHY, gray; foaled I8I ; bred by Benjamin Phillips, Davidson County, Tenn.; got by Sir Archy, son of imported Diomed: dam said to be by imported Medley; $2 \mathrm{~d}$ dam by imported Jolly Roger; and $3 \mathrm{~d}$ dam by Meade's Celar.

GRAY BASHAW, 2 :30, gray; foaled I 88-; said to be by Corbin Bashaw : dam said to have three in the list. Information from Wm. Allen, Salina, Kan., who owned him Aug. 13, I892.

GRAY BAYARD (3-64), gray; foaled I885; bred by J. S. Dilworth, Mt. Union, O.; got by Bayard, son of Pilot Jr. : dam Brownie (grandam of Denver, said to be by Prince Edward, son of William Welch; and $\mathbf{2 d}$ dam Lady Lightfoot, by Abdallah Prince, son of Abdallah (Voorhees). Record $2: 243 / 4$. Sold to M. C. Tarr; to P. M. Smith, both of Wells- 
ville, O.; to Levi Foulk, Berlin Centre, O. Information from P. M. Smith.

Sire of Reversible, $2: 191 / 4$.

GRAY BILL. Untraced.

Sire of Kitty Gray, $2: 29 \frac{1}{4}$.

GRAY BLOODY BUTTOCKS, gray; foaled I 733 ; bred by Mr. Crofts; got by Bloody Buttocks : dam, Brown Fairwell, said to be by Grayhound; 2d dam by Makeless, son of Oglethorpe Arabian; 3d dam by Brimmer, son of the Yellow Turk; and 4 th dam by Place's White Turk.-General Stud Book, Vol. I., p. 44.

GRAY BROCKLESBY, gray; foaled 1738 ; bred by Mr. Crofts; got by Bloody Buttocks : dam Brocklesby, bred by Mr. Crofts, got by Grayhound; 2 d dam Brocklesby Betty, bred by Mr. Pelham, got by Curwen Bay Barb; 3d dam, Mr. Leedes' Hobby Mare, said to be by the Lister Turk.

GRAY CHARLEY, gray, I5 hands. Owned in Texas and sold when three, after the war, to Hannibal Jones, Holley Springs, Miss., who brought him to that place. A good square-built horse well shaped and carried his head well. A natural pacer and all his colts paced. Information from W. B. Brown, Holly Springs, Miss.

Mr. Cook, Holley Springs, in interview, said :

"Gray Charley was taken to Texas and brought back; he had more colts than any horse that ever stood in Marshal County, and all good ones. Shiloh was bred by Thomas Hancock of Wall Hill, Miss., who sold him when four years old to J. T. Eason of same place. He kept him two or three years and sold to Robert Latimore of Phyatira, Miss. who kept him about two years. He was then owned by Charles Harris, and W. F. Black of same place; Joe McCorma, Sanatobia; Parties at Coldwater, Miss. ; Smith \& Collyer, in Bowling Green. His dam was by Shoo Fly. Shiloh was a perfect Morgan, couldn't have made him prettier-round-hipped, heavy-muscled, close-coupled, fine head and neck, perfectly sound; not a drooping rump; very fast in his gaits, a fine pacer and good saddle horse. Shoo Fly was a pacer, a trotter and very fast; he had dropped rump and crooked hind legs.

"Shoo Fly was owned first by J. H. Still, Looxahoma, Miss., who sold him to Robert Day of the same place. He took him to Alamo, Ark, where he died about I 888 .

"The dam of Guy was sorrel, $15 \mathrm{I} / 2$ hands, owned first by J. Powell of Looxahoma, Miss.; he let J. K. Roach have her, and he A. Cathey of same place, whose property she died. I think Powell bred her."

GRAY CHESLEY (I-I6), gray, one white foot behind, $15 \frac{1}{4}$ hands, Iooo pounds; foaled 1860 ; bred by Charles F. Blake, Great Falls, N. H.; got by Allen Horse, son of Ethan Allen: dam gray, bred by Benjamin Moody, Ossipee, N. H., got by. Harpinus (Kidder Horse), son of old 
Harpinus; 2d dam gray, bred by John Blake, Ossipee, N. H., got by old Hunter. Pedigree from breeder.

GRAY CHILDERS, gray; bred by the Duke of Devonshire ; got by Childers : dam Miss Belvoir, bred by the Duke of Rutland, got by Gray Grantham, son of Brownlow Turk; $2 \mathrm{~d}$ dam, said to be by Pigot (or Paget) Turk (Mostyn's Bay Barb) ; 3d dam Betty Percival, bred by Mr. Pelham, got by Leedes' Arabian; 4th dam bred by Lord Darcy, got by Spanker.

GRAY COMET; foaled 18- ; said to be by Bowman's Comet.

Sire of Wallace, $2: 22 \frac{1}{4}$.

GRAY DAN (1-64), gray; foaled I871; bred by George Goodrich, South Newburg, Me.; got by Gideon, son of Hambletonian : dam said to be by Dirigo, son of Drew Horse. Sold to Robinson Bros., Newburg, Me. to Morrill and Gibbs, Bangor, Me.; to parties in Massachusetts.

Sire of 5 trotters $(2: 231 / 4) ; 3$ dams of 2 trotters, 1 pacer.

GRAY DAWN (3-I28), gray, I 6 hands, I Ioo pounds ; bred by James Kitchin, River John, N. S.; got by Uncle Sim, son of Privateer, by Gray Messenger (Hoagland's), which see : dam gray, said to be by Phil Sheridan, son of Columbus; $2 \mathrm{~d}$ dam thought to be by Royal George. Sold to James Gammon, River John, N. S. ; to Barney Flinn, Preston, N. S. ; to Harry McRoberts, Truro, N. S. Gelded when five, got but eight or nine colts. Died about I 897 . Information from Spurgeon Gammon, New Glascow, N. S., who writes :

"I am deeply interested in the strain from Uncle Sim. My father William Gammon bought him from C. H. Palmer, Port Chester, N. Y., winter of 1882 and brought him to River John, where he was kept until his death in 1893 , with the exception of a couple of seasons at Moneton and Baye Vista, N. B. He was a chestnut, about I5-I, IO25 pounds, very heavily muscled and got large sized horses. He got Gordon Sim, $2: 201 / 2$, and G. M. Ritcher, A. W. D. pacer, $2: 25$, Tom Trotter, $2: 28$, and quite a number of others under $2: 50$. Gray Dawn had a four-yearold mark of $2: 42$, afterwards trotted Moneton track in $2: 28$ to high wheels."

Sire of Abbie L., $2: 291 / 2$.

GRAY DIOMED, gray; foaled I 785 ; bred by, Sir C. Bunbury; got by Diomed, son of Florizel, by Herod: dam Gray Dorimant, bred by Sir C. Bunbury, got by Dorimant, son of Prophet; 2d dam Dizzy, bred by Duke of Ancaster, got by Blank, son of Godolphin Arabian; 3d dam Dizzy, bred by Duke of Ancaster, got by Driver, son of Wynn Arabian; $4^{\text {th }}$ dam said to be by Smiling Tom (Gallant's), bred at Hampton Court, got by Conyers' Arabian. Gray Diomed was sent to Russia, where he ran with success; afterwards several of his brothers were bought for that country.-General Stud Book, Vol. I., p. $25 I$. 
GRAY DIOMED, gray, I5 1/2 hands; foaled May, I 786 ; bred by Richard Brooke, England; got by Hart's imported Medley, son of Gimcrack : dam by Sloe, son of old Partner, by imported Traveler; $2 \mathrm{~d}$ dam by imported Vampire, son of Regulus ; 3d dam imported Calista, by Forester. Sold to Col. Tayloe, Richmond County, Va., I793, for $\$ 800$; to James Blick, I798, for \$2200; kept, I80o, at Perry's, Franklin County, N. C. Sold when old to Messrs. Battle and Hilliard, Edgecomb County, North Carolina, for $\$ 500$, whose property he died, I8o6.

Edgar.

GRAY DIOMED (BENTON'S), gray ; foaled I 846 ; bred by Horace Benton, North Middletown, Ky. ; got by Quicksilver, son of Cadet, by Johnson's Medley: dam said to be by a son of Stamboul, Arabian, but probably, of pacing blood. A saddle stallion 'that went all of the gaits. Advertised, 1855 , at stable of Horace Benton in Montgomery County, Ky., four miles east of North Middletown, as above, except dam, which is said to be by Roll's Quicksilver, son of Quicksilver, by imported Medley.

GRAY DUKE, gray ; foaled r 885 ; bred by T. M. Hosford, Lincoln, Neb. ; got by a son of Hambletonian : dam Nelly Gray, 2 :24, untraced.

Sire of Billy Russell, $2: 161 / 4$.

GRAY EAGLE, gray; foaled $\mathrm{r} 835$; said to be by Woodpecker, son of Bertrand: dam Ophelia, by Wild Medley, son of imported Medley; $2 \mathrm{~d}$ dam Ophelia, by Gray Diomed, son of imported Medley; 3d dam Primrose, by Apollo, son of imported Fearnaught; $4^{\text {th }}$ dam by Granby, son of Blank; $5^{\text {th }}$ dam by imported Figure; and 6 th dam by imported Othello.

GRAY EAGLE ( $\mathrm{r}-64$ ) ; bred by J. B. Russell, Russell's Corners, Wis. ; got by Mountain Eagle Jr., son of Mountain Eagle, by Young Planter : dam said to be by the Wood Horse, a Morgan horse brought to Baraboo, Wis., from Vermont by a Mr. Wood.

Sire of New Berlin Girl, $2: 291 / 2$, and winner of 10 recorded races.

GRAY EAGLE (3-32) said to be by Walker Morrill, son of Winthrop Morrill : dam Daisy, by Gray Morgan; 2d dam Minnie, by Glencoe (Finney's), son of Balie Peyton; 3 d dam Dolly, by Connecticut, son of Sam Patch; and $4^{\text {th }}$ dam Mary Peyton, by Balie Peyton. Owned by Levin Parker, Horntown, Va. A reliable trotter and superior stockgetter. See The Morgan Horse and Register, Vol. II., p. I52.

Sire of 2 trotters $\left(2: 27^{1 / 4}\right)$.

GRAY EAGLE, dappled gray, I5 $1 / 2$ hands, about rooo pounds; bred by Hiram Eddy, Huntington, Vt. ; got by Harris' Hamiltonian. Kept in Huntington, 6 or 7 years. Information from D. C. Barbour, Burlington, 
Vt., who says that this Hiram Eddy went to Stowe, Vt.; doesn't know whether he took the horse with him or not. This was before 1849 when informant was married.

GRAY EAGLE (I-I6), I6 hands, I30o pounds, bred at Brown's Station, Boone County, Mo., got by a black Morgan horse (thought to be a son of Black Hawk), owned by Chris Doyle and taken by him to California : dam a noted saddle mare brought to Brown's Station, Mo., by Mr. Brown. Sold to Mr. Little, Carthage, Mo.; to Mr. G. C. Wright, Magnolia Ave., St. Louis, Mo., who writes :

Joseph Battell, EsQ.,

St. Lours, Mo., Nov, I 2 , 1907 .

Dear Sir :-Your favor of $5^{\text {th }}$ duly received asking for pedigree of stallion, Gray Eagle, that I used to own, and should have answered sooner but I have been unable to find his pedigree up to date, but will soon. I have had so many stallions that it has slipped my memory exactly. I have it somewhere. I am looking for Chris Doyle, who took his sire to California a great many years ago. He was a great horse and could trot very fast in his day. Mr. Talmage never had any interest in him; I bought him from a Mr. Little of Carthage, Mo., who got him from the man who raised him at Brown's Station, Boone County, Mo.

I first saw him at Sarcoxie, Mo., he was being shown at fair there for first all-purpose stallions, and will say he was the best horse of that kind I ever saw, over 16 hands high; would weigh about 1300 pounds and as perfect a horse as I ever saw before or since ; could trot naturally fast but was never trained for speed. His colts were great big fine ones from common mares; some of them that fell into good hands, learned to trot fast. Gray Eagle's dam was a noted saddle mare brought to Brown's Station by Mr. Brown. A bay, his sire was a black Morgan horse, as I said was taken to California. Mr. Clement, if he could find Mr. Little of Carthage, would be able to give the desired information. I will look all of my papers through. I know I must have his pedigree somewhere, when I will send it to you and anything else I can do command me. I owned two other Morgan stallions, Col. Mullen, and Dan Nichols, by Venture, you can find their pedigree in Wallace's Stud Book, as they were both registered.

3869 Magnolia Ave., St. Louis, Mo.

Yours truly, G. C. WRIGHT.

GRAY EAGLE (GRAY JIM), $2: 3 \mathrm{I}$, and winner of 23 recorded races, gray, I6 hands; foaled 1855 ; bred by O. B. Gould, Franklin Furnace, O.; said to be by Gray Eagle, thoroughbred, son of Woodpecker: dam Kate Glencoe. See The Morgan Horse and Register, Vol. I., p. 878 .

GRAY EAGLE (BROOKS') ( $\mathrm{I}-8$ ), dapple gray, $153 / 4$ hands, said to be Morgan. Owned about 1860 by Mr. Brooks, Fortsville, N. Y., and is supposed to have gone from there to Lake George. R. F. Milligan, Saratoga Springs, writes :

"He had good legs and good feet, nice mane and tail; was very handsome and extremely stylish. I judge his character was very like 
that of old Justin Morgan, in that he was a great parade horse, appearing wonderfully well under the saddle. It was said he trotted very fast on the lake, which, I think, was Lake George. His colts were uniformly good horses, but the only one of note was Snow Flake or Nelly Taylor, who was from a small brown farm mare, said to be of Morgan blood."

See The Morgan Horse and Register, Vol. II., p. I52.

Sire of Snow Flake, $2: 30 \frac{1}{2}$, and winner of 12 recorded races.

GRAY EAGLE. Owned by Ed. Higbee, Mendon, Ill., in I86o.

GRAY EAGLE; foaled about I863; said to be by a horse of Morgan descent, owned by Frank Twitchell of Templeton, Mass. Owned by Warren Simonds, East Templeton, Mass.

GRAY EAGLE (CANADA). To learn about this horse we made a special trip to a French village some distance below Quebec, where we understood a son of the man who bred Gray Eagle lived. We found the son, who said that the dam was bought in Maine to be used in a lumber camp in the winter. She proved in foal and had this colt, which was sold to a prominent merchant in Quebec. He was afterwards owned for a while by W. I. Prendergast of Montreal, who at one time owned St. Lawrence.

M. Charlebois of Montreal, P. Q., in interview, September, r889, said :

"I knew Gray Eagle. He came from near Quebec, think he was a blood horse; think Huff of Quebec owned him; Huff is alive yet. Prendergast brought Gray Eagle in here, and owned him a year; he was a trotter."

Boston, Mass., May 22, I 890.

Dear Sir :-Your inquiry about Gray Eagle received. I knew of the stock of this horse many years before I owned any of his descendants, and was in a position to learn all that was known by parties who were familiar with him while alive. I have been unable to ascertain his pedigree, and can only say that a Montreal horse dealer, named Spaulding told me it was said that he was brought from Maine and called a Bush Messenger. This man is honest but is not a careful talker, and his evidence would not weigh much with me if I did not feel that he was not likely to have known about Bush Messenger, unless he has heard of him in this connection.

Canada Grey Eagle (I think the grey was always spelt with an e in his name) has a record of $2: 34$ at least, both at one and two miles. (That is, two miles in $5: 08)$. I believe he is the same horse that has a saddle record of $2: 26$ or $2: 263 / 4$, but I have been unable to substantiate this. He was a very nervous, high-strung horse and this temper was a characteristic of his get. They were so nervous in some instances as to shake like leaves when near the cars, yet they would stand right up to them. Some of his stock has been owned in Springfield, Mass. If you know any reliable and persistent horseman, resident of Montreal, I advise your enlisting him in your behalf. Mr. Prendergast, who formerly owned old St. Lawrence, may know something about him and you will find his address in one of the Wallace's Monthlies of the last two or three years, 
under the head of pedigree of old St. Lawrence. Dusty Miller and some other $2: 30$ horses are descended from Canada Gray Eagle. Gray Eagle must have been a very fast horse, for he repeated his record several times, and in every instance trotted on the poor, illy prepared tracks, then common to Lower Canada and his driver and appurtenances must have been anything but first class. The $2: 26 \mathrm{~T} / 2$ record, referred to, was taken on this side of the line. I own what I suppose to be a full sister of Daniel T. Campbell, registered as Bessie Campbell. Also the sister of his dam (Wenna) and her produce by Wedgewood and Viking. The dam mentioned, was called Belle Campbell. She was undoubtedly extremely fast and probably was never beaten. My Wenna was such another, but some seconds slower, no doubt. Arthur, record $2: 26 \mathrm{I} / 2$, is their full brother. He was faster than his record, I fully believe. To sum up, if you will turn to the Trotting Register (Wallace's), you will find under the head of Wenna, or Flight (from her by Wedgewood) all that I have been able to learn of this stock after years of patient and persistent inquiry. Wallace registers Wenna's grandam as "said to be by St. Lawrence." She was by St. Lawence. I found afterwards, from his former owner, Mr. Prendergast, that St. Lawrence was kept in that region for a $\$ 5$ fee, and sometimes for even less. He was about the cheapest stallion in reach of the farmers about there.

\section{Yours truly, Francis A. Foster}

Sire of Caravan's Gray Eagle (Dusty Miller), sire of Irene, $2: 201 / 2$, and winner of ro recorded races.

GRAY EAGLE (CARAVAN'S, DU'STY MILLER), 2 :36, gray, dark spot on shoulder, I 6 hands; foaled I 854 ; bred by James Roddy, Ferrins Point, Ontario, Can.; got by Canada Gray Eagle, brought from near Montreal, which see: dam (dam of Fenian Chief) chestnut, medium size, said to be by Sir Walter. Owned by Caravan, a miller in Philadelphia, who bred Irene, $2: 20 \mathrm{~T} / 2$.

W. H. Doble says :

"Gray Eagle had speed. I drove him a mile in $2: 26$ to wagon over Suffolk track in 1865 . I drove Irene when five years old in $2: 26$ and could have driven her in $2: 20$; afterwards drove her in $2: 191 / 4 . "$

Irene's dam was by Vandervere's Abdallah, son of Abdallah; 2 d dam a small bay mare, owned about $\mathbf{I} 844$ by John Hawley of Wayne County, Indiana, a Quaker, who sold her to Charles Burkett of same place. About I $S_{45}$ Burkett moved to Marlborough, N. J., where this mare was bred to Vandervere's Abdallah, son of old Abdallah. The foal was a filly named Minnie, and was the dam of Irene. See Dusty Miller, page $15^{8}$.

Sire of Irene, $2: 201 / 2$, and winner of Io recorded races.

GRAY EAGLE (CHENERY'S). Mr. Wallace says, Vol. I., American Trotting Register :

"Gray; foaled I85-; got by Gray Eagle, thoroughbred: dam by imported Trustee. Bred in Kentucky, and passed through many vicissitudes both as a runner and trotter, beating his competitors at both 
gaits; owned for a time in Ohio, now the property of Winthrop W. Chenery \& Co., Boston."

In Vol. II., Mr. Wallace says :

"The first that was known of this horse he was in the hands of William McKinney of Portsmouth, O., and represented by him to be by Bell Keye, and was called Bell Keye. After McKinney's death he became the property of Dr. A. B. Jones of Portsmouth, and he named him Gray Eagle. He was kept one or two seasons in the stud by O. B. Gould of Franklin Furnace, O., and was then put in training at Cincinnati and trotted two miles to wagon in $5: 09^{1} / 2$. He was purchased by W. W. Chenery \& Co., Boston; stood one or more seasons in Maine; now owned by S. S. Houghton, Boston, Mass." (Corrected from Vol. I.)

As we understand Mr. Gould, who was a very reputable man, always claimed this horse to be thoroughbred.

GRAY EAGLE (COMAN'S) (1-8), gray; foaled about I852; bred by Herman Coman, Luzerne, N. Y.; got by Black Hawk: dam gray, said to be by Burdick's Engineer, son of Engineer. Sold January, I857, to Dr. Coman, Buffalo, N. Y., who took him to Elkhorn, Wis., I 858 . Kept, 186 r, by E. P. Eaton; then by C. W. Phillips, Delevan, Wis., whose property he died, about $\mathrm{I} 868$. Harmon Coman writes :

"I kept him in the stud one year. His colts were all fine steppers. Lady Graham, one of his colts, could trot handy in $2: 42$ without any training."

See The Morgan Horse and Register, Vol. I., p. 530

Sire of McKesson's Gray Eagle, sire of 2 trotters $\left(2: 16^{3} / 4\right)$.

GRAY EAGLE (EARING'S, BLIND EAGLE) ( $\mathrm{x}-8)$, gray, I 5 I 2 hands, ı080 pounds; foaled I 849 ; bred by Samuel P. Nash, New Haven, Vt. ; got by Black Hawk : dam white, 950 to rooo pounds, bred by Col. D. P. Nash, New Haven, Vt., got by Alexander, a spotted horse, bought from a circus (see Vol. I.) ; 2 d dam bay, large, purchased of Gilman Bass, Bristol, Vt., and called English. Sold to Gifford \& Co., fall, I853, and in spring, 1854 , taken to Dodge County, Wis. ; then sold to H. B. Marsh, Horicon, Wis. ; to James Delaney, Fort Howard, Wis. ; to George Earing, Richmond, Ill., I867; to B. F. Stanton, Bassett Station, Wis., July, I869; to Michael McCahill, Woodstock, Ill., where he died, March, r875. A horse of fine proportions, and could trot in better than $2: 50$. See The Morgan Horse and Register, Vol. I., p. 492.

Sire of Carrie K., $2: 30$, St. Charles, $2: 26$; dams of Black Hawk McGregor, $2: 28$, Monte Christo, $2: 29$, Prince S., $2: 261 / 4$.

GRAY EAGLE (McKESSON'S, FERGUSON'S) (I-8), gray, I6 hands, I 200 pounds; foaled I 862 ; bred by Jonathan Potter, Lafayette, Wis.; got by Coman's Gray Eagle, son of Black Hawk: dam Lady Potter, bred by Jonathan Potter, got by Signal (Singleterry's Rattler) that.went to Califorria; 2d dam gray, I Ioo pounds, round barreled, with head 
and neck like a thoroughbred; brought about $\mathrm{I} 844$ to Wisconsin from the East, pedigree unknown. Sold to Charles Wales, Elkhorn, Ind. ; to Charles Dunlap, Elkhorn; to J. McKesson, Genoa Junction, Wis.; to G. W. Ferguson, Marshalltown, Ia.; to Charles Dunlap, Elkhorn, Wis., where he died in 1877 . G. W. Ferguson writes :

"Gray Eagle trotted in $2: 35$ while I owned him and after I sold him he trotted a "hard race and won it at Des Moines, Ia., in 2:27. His mares are great producers of speed."

Sire of Charley Ford, $2: 16^{3} / 4$, and winner of $3^{8}$ recorded races, also said to be sire of Charles W.; $2: 29 \frac{1}{2}$; I sire of I trotter, I pacer; 6 dams of 4 trotters, 2 pacers.

GRAY EAGLE (PIERCE'S) (I-8), dapple gray, I5 I/4 hands, I077 pounds ; bred by M. B. Wells, Canaan, Vt.; got be Dan Morrill, son of Morrill : dam dapple gray, about I 100 pounds, bred by Wm. B. Brown, Eaton, P. Q., got by Lard Horse, son of Post Boy (we suppose Doolittle's); 2d dam dapple gray, i Ioo pounds, bred by Henry Labaree, got by Black Prince, said to be a son of imported Negotiator, from a Morgan dam. Owned by William Tibbetts; M. B. Quimby, Canaan, Vt. ; Mr. Pierce, Hatley, P. Q.; then went to New York. Kept at Hereford, P. Q. ; Canaan, Vt., and vicinity; Stanstead and Barnston, P. Q. ; and at Stewartstown, N. H., I865-'66-'67.

Advertised in Stanstead (P. Q.) Journal, I879, by S. W. Pierce, Massawippi, at Coaticook, Barnston, Frelighsburg and Ayres Flat. Terms, $\$ 5$ to $\$ 8$. Best time, $2: 35$. Advertisement says: "Good disposition a noted trotter ; colts can be seen at Barnston, Hatley, etc."

See The Morgan Horse and Register, Vol. II., pp. 15 I-2.

GRAY EAGLE (YARBROUGH'S), milk white. Bought by Mr. Yarbrough, Waxahachie, Tex., from John Grover, who brought him from Nashville, Ten

Copy of letter from John Yarbrough :

Mr. Andrew Butcher,

Waxahachie, Tex., June 9, I904.

Dear Sir:-Yours of recent date received. The pedigree papers of the Gray Eagle stallion which my father owned have been lost or misplaced. He bought him from a young man who brought him here from Nashville, Tenn. He was a fine blooded horse, and a fine sire of saddle horses and harness horses, as well as general purpose horses. He had a record of $2: 32$ and also went all the saddle gaits. I remember the Mark Alexander horse, a chestnut. The old Gray Eagle horse was milk white in color. I would gladly send you his pedigree if I had it at hand.

Mr. Joseph Battell,

Yours very truly, John B. YarbROUGH.

IOWA PARK, Tex., July I6, I907.

Dear Sir :-After receiving the letter from Mr. Yarbrough about the horse, I met Mr. Dan Kelley at the Ennis Fair. He and his father before him were race horse men. He wanted to know how my young 
horse was bred. I told that his dam was by the Alexander horse, and that he was got by Yarbrough's old Gray Eagle horse. He said that he remembered the horse, but Gray Eagle was not the name of the Yarbrough horse, that it was Joe Goss; he was brought to Texas from Tennessee in the year $187 \mathrm{I}$ or ' 2 by a young man by the name of John Grover, and that Grover boarded at his father's (Kelley's) house for about two years, and kept the horse there prior to his selling him to Yarbrough; he was one of the best horses of his kind that he ever saw, had a record of $2: 32$ and was double gaited. And Kelley further stated that he did not remember the pedigree of the horse as his father had always handled running horses, and that he soon forgot the breeding of harness or saddle horses. He said that the horse might have been of the Gray Eagle stock, hence their giving him that name. My father has often spoke of seeing the horse's pedigree. He said old Mr. Yarbrough had it framed; no doubt when the old gentleman died years ago the pedigree was destroyed.

Last spring I took Lou Mather and Blondie Wilkes to Henrietta (in an adjoining county) to a stallion show. An old gentleman by the name of Ward told me that he had lived in Ellis County years ago, and that he remembered Grover and the horse he sold Yarbrough. He said that when Grover first brought the horse into the county, some one wrote back to Tennessee where he brought the horse from, and that they answered that the horse was a well-bred one and was deserving of a good patronage, and was just what Grover claimed him to be.

Very truly yours, A. D. Butcher.

GRAY GHOST (3-64), said to be by Bayard, son of Pilot Jr.

Sire of Philbert, $2: 161 / 4$.

GRAY HARRY, gray horse; foaled I 866 ; bred by Robert Teagarden, Brower, Ind.; got by old Tempest : dam said to be by old Rainbow. Record, $2: 26 \frac{1}{4}$.

Sire of Maud W., $2: 24 \frac{1}{4} ; 6$ pacers $\left(2: I_{5}\right)$; dam of 1 trotter.

GRAY HAWK (HARLOW HORSE) (I-8), dapple gray, I5 $5 / 2$ hands, I 200 pounds; foaled I 843 ; bred by Abner Harlow, Hartland, Vt. ; got by Morgan Tally Ho, son of Woodbury Morgan: dam gray, bred by David Carpenter, Randolph, Vt., got by a gray stallion owned at Barnard, Vt.; 2 d dam gray. Kept at Hartland, Woodstock and Pomfret, Vt. Sold to L. D. Harlow, son of breeder, who kept him at Brandon, I 850 , and sold that fall, for \$I 500 , to Messrs. Frink \& Walker, Chicago, Ill. They sold to a company in Chicago, composed of Messrs. Louis, Loomis, Butler and others; and they to a company at Clinton, Ind. Kept, 1854 or ' 55 , in Park County, Ind., and one season at Robinson, IIl. Received Ist premium at Windsor County (Vt.) Fair, and New York State Fair, I849. Linsley says: "Action fine and a sharp goer." See The Morgan Horse and Register, Vol. I., p. 677.

GRAY HAWK (JENNING'S) (I-8), gray, I5 I/4 hands, 1025 pounds; foaled 1851 ; bred by William Gibbs, Sudbury, Vt. ; got by Gray Hawk, 
son of Morgan Tally Ho: dam chestnut, said to be by Black Hawk. Taken to Mutual, O., by C. B. Jennings, and afterwards went to southern Illinois. C. B. Jennings writes :

" $\mathrm{He}$ was the fastest horse I ever sat behind; was never trained, but I have often paced him a quarter in 32 to 35 seconds, and fully believe if he had been tracked he could have pulled a wagon better than $2: 15$."

GRAY HAWK JR. (THOMSON HORSE) (3-32), gray; foaled I 849 ; bred by Calvin Tatman, Hartland, Vt.; got by Gray Hawk, son of Morgan Tally Ho: dam chestnut with stripe and gray hairs in coat, said to be by Thatcher Horse, a gray stallion, bred by Alonzo Thatcher, Pomfret, Vt., and got by Rice's Gray, a large gray horse owned by Benj. Rice, Royalton, Vt., breeding unknown; and $2 \mathrm{~d}$ dam chestnut, by Gifford Morgan. The Thatcher Horse was gelded at six. The Rice horse was also gelded young. Owned by A. W. Thomson, Woodstock, Vt. Taken from Vermont to LaSalle County, Ill., spring of 1856 , and died there.

GRAY HAWK MORGAN (I-I6), iron gray; foaled about I 855 ; bred by Samuel Strouse, Rockville, Ind.; got by Gray Hawk, son of Morgan Tally Ho: dam black, smooth built. Sold when two to Len. Hackney, Edinburgh, Ind. Died r 862 .

GRAY HAWK MORGAN. Mr. John Sampson, near Brazil, Ind., in interview May, I905, said :

"The first Morgan horse I knew was Gray Hawk Morgan. You bet he was a good horse. Not tall, but powerful built, and got over the ground as fast as any in those times- $1852-55$. I was running a threshing machine at the time down over those prairies, six or seven miles north of Terre Haute. He was kept there a season, owned in Chicago."

GRAY HAWK (WESTON'S), dapple gray, I6 hands; I300 pounds; foaled 1847 ; bred by Otis Foster, South Reading, Windsor County, Vt.; got by Rocky Mountain, a circus horse, white with dark stripe : dam Dolly, a mare of much power, dapple gray, bred by Benoni Buck, South Reading, Vt., got by a gray Trinkalow horse. Sold to Benjamin Weston, Plymouth, Vt., who sold to J. B. Weston, and he in the fall of I86 I to a man in Clarendon, Vt. He was taken soon after to Wisconsin. A horse of good appearance and disposition, with heavy shoulders and quite a trotter for his weight; stock good. Information from breeder. H. K. White, Clarendon, Vt., writes:

"Left more good colts than any horse in this vicinity. All horsemen in this vicinity speak well of him."

Otis Foster, the breeder of Gray Hawk, calls Rocky Mountain a wild horse, white with rather dark stripes; of the dam Mr. Foster says she was dapple gray. "I bought her of Benoni Buck, Esq." Of the third 
dam Mr. Foster says: "I think she came from Canada. Dolly, Gray Hawk's dam, was a powerful mare; when three years old the horse she was harnessed with refusing to draw, she took a load of 3000 pounds up a steep hill."

South Reading, Vt., August 10, i889.

Please, Sir, pardon my writing. My brother received a letter of inquiry last April concerning the pedigree of the horse called Gray Hawk. He has been thinking the matter over and found he was mistaken in the horse they had at Windsor being the sire of Gray Hawk's dam. That horse was the sire of the first colt that Gray Hawk's dam had, and he thinks the sire of Dolly (Gray Hawk's mother) must have been a horse that Benoni Buck, Esq: owned (my brother bought Dolly of the said Benoni Buck), and was called a Trinkelow horse, but what blood it was he does not know. I recollect that horse. He was gray, and I should think by the color might have been Dolly's father. We do not know of any way to ascertain any more about it. That Mr. Buck has a brother still living 9 I years and I I months old, but he cannot recollect anything about it, and all the others except my brother and myself, that then lived in this vicinity, are dead and gone. My brother is almost 82 and $\mathrm{I}$ am 76 .

I think my brother was mistaken one year in Dolly's age, when Mr. Buck drew lumber to Windsor. I am very sure she was four instead of three years.

I write this presuming that you recollect all about the other letter. When I write, my way is to write as to an acquaintance and not as to strangers. I was careless in not keeping your post office address better, but I think I recollect right.

Please excuse me. Very respectfully, MRS. A. A. PARKER.

For her Brother, Otis Foster.

Mr. White,

Bridgewater, Jan. 25, I889.

Dear Sir:-Yours of January i 9 is at hand. I will write you what I know about Mr. Weston's horse. I think he was got by a horse in the circus from a nice gray mare owned in Plymouth.

Mr. Weston is not living. He and his wife died in Chester. There is one son, I understand, living in Rockingham.

Gray Hawk's weight was I I 50 pounds and stood I6 hands. I think he bought him when quite young. He lived in Plymouth when he owned him.

Mr. Weston, I have been told, never published the horse's pedigree.

$$
\text { Yours, M. W. TAFT. }
$$

H. R. White,

Bartonsville, Feb. I3, r889.

Dear Sir :-Yours of $4^{\text {th }}$ inst. came duly to hand. I knew old Gray Hawk well and his proprietor, Mr. Joseph B. Weston, but really can give but faint idea of his pedigree. It was said about the time he first purchased him, that he was got by a wild horse that stood at Woodstock Green, and that his dam was a black mare of no great notoriety. How true all this is I never knew. But, on receipt of yours, I have made inquiry in regard to the matter of his youngest son, who says he was so young he remembers but little about it. He said, however, that his older brother, Joseph Page Weston, might give the desired information, but 
as I have been unable to see him will refer you to him, whose address is Rockingham.

Very truly yours, Maynard F. Burt.

North Clarendon, Vt., Jan. 7, i 889 .

Mr. Joseph Battell, Middlebury, Vt.,

Dear Sir :- In answer to your inquiries will say, I have filled out the blanks as far as I know and could learn.

In regard to Joseph Weston's Gray Hawk, the old gentleman, I have learned, is dead. Gray Hawk was bred in Windsor County, Reading, I think, and was owned and kept there a good many years. He was sold after he was twenty years old, and went West a hardy, rugged horse.

I will enclose a letter by which you may get some information regarding Young Champion.

If I could give you any further information I would gladly do so. Respectfully yours, H. R. WHITE.

Rockingham, Vt., April 8, I889.

Mr. Battell,

Dear Sir :-Yours at hand. Gray Hawk's dam was a Morgan mare, owned at that time by Otis Foster of Reading, Vt. The horse, when exhibited, was classed with the Bulrush Morgans. The blood of the sire I cannot tell. None of the old bills have been preserved. As it is, I do not see as I can give any information that will be of use to you.

$$
\text { Yours truly, J. P. WESTON. }
$$

Very probably sire of dam of Highland Gray, $2: 28$, which see.

GRAY HIGHLANDER, gray; foaled 1783 ; got by Bourdeaux : dam Teetotum, by Matchem ; 2 d dam Lady Bolingbroke, by Squirrel; 3 d dam Cypron, by Blaze; $4^{\text {th }}$ dam Selima, by Bethell's Arabian; $5^{\text {th }}$ dam by Merlin. Once owned by Col. Wilkinson, Bucks County, Penn., who describes him as being rather undersize, but "all horse," of great spirit, power and speed. His stock is of high repute in New Jersey.-American Turf Register, September, 1834.

A correspondent of the Horse Review, Chicago, July I, I902, writes, under heading, "A Story of Old Timers" :

"In my township, in the few years just before the civil war, there were at one time three stallions which had a state and almost national reputation. These were Robert Hitts' Keene Morgan, Joseph Cooper's Stockbridge Chief and Jesse P. Wilson's Dolphus all owners being farmers. These animals, of which I should like to give a short account, left a strong mark of improvement in this (Hamilton) and adjoining counties.

"About this time, in Butler County, the annual fairs of which made its name famous in the West for many years, a company organized of progressive farmers brought from New England, Gray Highlander and Victor; and Butler County farmers became distinguished for their fine drivers. Gray Highlander dated his ancestry into the latter part of the eighteenth Century, one of the line being Highlander, kept at Litchfield, Conn., who left a broad mark on the stock of the Nutmeg State. Our stock horses were mainly brought from New England, Pennsylvania, Kentucky, Tennessee and North Carolina. Among them came the Narragansett pacers, whose gait under the saddle was as easy as the rocking of a baby's cradle, and who seldom stumbled on roads thickly beset with 
stones, ruts and roots. I remember that our country doctor rode a horse that he said was got by Bulrush Morgan, one of the celebrated sons of the peerless Justin Morgan. I believe Bulrush was kept in Vermont, foaled in that State in 1813 , he died there aged thirty-five years. $\mathrm{He}$ was a fast trotter and of wonderful endurance.

"Alexander Neave of my township, brought from Kentucky Cassius M. Clay Jr. The Kentucky Clays became a recognized breed of horses, hardy, enduring and of bull-dog courage and tenacity on the race track. They would never quit until pulled off at dark, though trotting heats all an afternoon. Neave's Cassius M. Clay is often mentioned to this day in pedigrees of harness race horses. James Whalon's Perfection, as beautiful a horse as I ever saw, and Legget's Mambrino Star, a fine stock horse, were also of this township.

Jere M. Cochran."

GRAY HIGHLANDER; shown by E. R. Smith, Ky., very showy.

-Ohio Cultivator, 1854 .

GRAY HENRY ( $\mathrm{I}-32)$; said to be by Brown Henry, probably the horse of that name by Corbeau, son of Corbeau, Canadian.

Sire of 2 pacers $\left(2: 24^{3 / 4}\right)$.

\section{GRAY HORSE (CARL'S). See Florizel.}

GRAYHOUND; said to be by Chillaby : dam Slugey, a natural Barb Mare.

"The cover for this foal was in Barbary, after which both his sire and dam were purchased and brought into England by Mr. Marshall. $\mathrm{He}$ was got by Chillaby ; dam Slugey, a natural Barb Mare. Grayhound got the Duke of Wharton's Othello, about I 7 I 2, said to have beaten Chaunter easily in a trial, giving him a stone, but who falling lame ran only one match in public, against a bad horse; he also got Panton's Whitefoot a very good horse; Osmyn, a very fleet horse, and in good form for his size; the Duke of Wharton's Rake, a middling horse; Lord Halifax's Sampson, Goliah, and Favorite, pretty good I 2 stone Plate horses ; Desdemona, and other good mares; and several ordinary Plate horses, who ran in the North, where he was a common stallion and covered many of the best mares."-General Stud Book, Vol. I., page 390.

GRAYHOUND, Dapple gray; foaled 1793 ; said to be by the much famed horse Smiling Star. Advertised in Weathersfield and Windsor, Vt., I797.

GRAYHOUND, gray, about I6 hands, I050 pounds; foaled about I 852 ; bred by T. D. Chapman; foaled the property of Luther Stone, both of Charlotte, Vt. ; got by Black Hawk : dam gray (dam of Laura Williams, $2: 24^{\mathrm{T} / 2}$, Charley Mac, $2: 25$ and $2 \mathrm{~d}$ dam of Robert Lee, $2: 23 \frac{\mathrm{T} / 4}{4}$ ), bred by John Leonard, Orwell, Vt., got by North American (Bullock Horse). Sold to George Fowle, Alexandria, Va., I856; to Lloyd Minturn, New York city, $\mathbf{1} 858$. Kept, $\mathbf{I} 857$, at Alexandria, Va. ; that fall went to Long Island, in care of $\mathrm{Wm}$. Wheelan, who is said to have driven him a mile in $2: 30$, and two miles in $5: 14$. Kept, r858, at Vergennes, Vt. ; r859- 
6o, at Ferrisburgh and Charlotte, Vt.; fall of I86o went to Waterloo, N. Y., and remained there and at neighboring towns until his death in I872. R. R. Minturn, Shoreham, Vt., writes that Grayhound in his youth was a dark iron gray, very stylish and with good action. Received Ist premium at Vermont State Fair, I 858.

"A gray stallion was entered by L. Minturn in Class 2, Fair of Union Association, Great National Horse Show, Centreville Course ; 16 others were entered in this class." - Spirit of the Times, Nov. 6, 1858.

See The Morgan Horse and Register, Vol. I. p. 529.

Sire of dams of Ebony Spink, $2: 291 / 4$, Middlesex, $2: 24$, Ripton (?), $2: 26$, Robert Lee, $2: 23 \frac{1}{4}$. Second dams of Clara P., $2: 17$, Minnie B., $2: 291 / 4$.

GRAY JACK (1-8), $2: 28 \frac{1}{4}$, gray; foaled 1860 ; bred by Mr. Huntley, Lyme, Conn.; got by Carrier Horse (Young Gifford), son of Gifford Morgan. Sold to E. Packer Clark for M. Packer; to A. R. Lamb, Howard House, New York. Gelded young.

GRAY JACK (1-32), I5 hands, 975 pounds; foaled I866; bred by Elon Perry, Hoosick Falls, N. Y.; got by Young America, son of Fioagland's Gray Messenger: dam brown, bred by Henry Roggy, Hoosick, N. Y., got by Bellfounder, son of Morse Horse; 2 d dam black.

Sire of Alkathrepta, dam of Bay, $2: 24^{3 / 4}$.

GRAY JIM (ROONEY'S HAMILTONIAN) (I-8), gray; foaled I 859 ; said to be by Morgan Tally-Ho, son of Woodbury Morgan: dam by Harris' Hamiltonian. Sold to James Kellogg, and Samuel Rooney, both of Georgetown, Ia. Died i 879 .

Sire of 2 trotters $\left(2: 25 \frac{1}{4}\right)$; I dam of I trotter.

GRAYLIGHT (I-32), 2 :I61/2, gray, near hind foot white, I 6 hands, I I5o pounds; foaled I 882 ; bred by A. B. Darling, Ramseys, Bergen County, N. J. ; got by Starlight, son of Kentucky Prince : dam gray, bred by A. B. Darling, got by Strideaway, son of Black Hawk Telegraph; 2 d dam gray. Sold to Gen. Catlin, Brooklyn. Pedigree from E. F. Carpenter, Supt., Darlington Stock Farm, Ramseys, N. J. Gelded young.

GRAYLOCK ( $1-32$ ) said to be by Highland Gray, son of Darkey : dam Fanny Bromley, by Ed. Sherman son of Gen. Sherman; and $\mathbf{2 d}$ dam by North Horse. Pedigree from Jacob B. Perkins, Cleveland, O.

GRAYLOCK. See Nutpatch.

GRAY MAJOR (I-I6), said to be by Cutler's Comet, son of Herrick's Black Hawk.

GRAY MCCLELLAN (7-64), gray; foaled about 1867 ; bred by Seneca Daniels, Lakeville, Cal.; got by Gen. McClellan, son of North Star, by Bulrush Morgan : dam Nell, gray, bred in Ohio, raised in Wisconsin 
where she was purchased by James M. Learned and taken by him to California, said to be by Green Mountain Morgan. Sold to Wm. Bickler, Lakeville, Cal. Pedigree from breeder.

Sire of Blanche, $2: 25 \frac{1}{2} ;$ I dam of I trotter.

GRAY MAMBRINO, gray, I53/4 hands; foaled about 1 Soo ; bred by Benjamin C. Ridgway, Mount Holly, N. J., got by imported Messenger : dam said to be by Pulaski; $2 \mathrm{~d}$ dam by Wilkes; and $3 \mathrm{~d}$ dam by True Briton. Sold to R. I. Cooper; to W. M. Atkinson, Salem, N. J. It is thought that at one time he was called Foxhunter.

GRAY MEDLEY, dappled-gray, I5 hands; foaled I793; bred by Gov. Benjamin Williams, of Virginia; got by imported Medley : dam said to be by True Whig. Sold to R. D. Barry of Sumner County, Tenn., the latter part of 1799 , or early in I 800 .

"The first thoroughbred stallion ever kept in Tennessee was Gray Medley. He was foaled in I79r, bred by Gov. Benjamin Williams of Virginia, and was sold by him to Dr. R. D. Barry of Sumner County, Tenn. He reached the latter State the latter part of I 799, or early in I 800 . He was described as a beautiful dapple-gray of exquisite symmetry, and very remarkable power and constitution, rather undersize being scarcely 15 hands high, bit his speed, endurance, and excellent limbs made him decidedly an acquisition to the thoroughbred interests of the then new State. He made quite an impression upon the growing turf interests of the South and West, and among others that may proudly claim him in the ancestral line, was the celebrated 'Tonson' family.

"Madame Tonson was a grand-daughter of Gray Medley, and she produced the four famous sons, well known in their day as the 'Four Tennessee Brothers,' Monsieur Tonson, Sir Richard Tonson, Sir Henry Tonson and Champion all by General Andrew Jackson's distinguished horse, Pacolet. These four great sons were ample to have forever settled the fame of Madame Tonson, for they conquered the best horses of their time, in the hardest contests, at all distances. The pedigree of Madame Tonson, was alleged to be short, for she was by Top Gallant (the son of imported Diomed), from a daughter of Gray Medley, and she from an Oscar (imported) mare, and she from a daughter of imported Fearnaught, giving to Madame Tonson only three crosses, and her famous sons four. Sir Henry Tonson had all of the courage, strength and speed of the other three brothers; but he contracted a disease of the throat, that effected his mind and impaired his usefulness upon the turf at an early age. Heat races were the fashion then, none others were run scarcely, and he could not stand heats with his unsoundness. $\mathrm{He}$ was, however, too much for the elder brother, Sir Richard, in a dash at any distance, and proved this in the only contest they were ever engaged in, which occurred at Nashville, in the fall of 1828 . Sir Henry was owned by the Honorable Balie Pey.ton, then the young but rising statesman and turfman of that section. He was fond of the turf, but especially fond of his fine horse. Sir Henry inherited his color, a beautiful dappledgray, from the Medley or Gimcrack family, and the brothers evidently got their splendid, hard, flinty limbs with large flat bones, strong tendons of great substance and sound, good feet, from the same source. If the 
descendants of that wonderful little horse, Gimcrack, were distinguished above other horses in any particular quality, it was for the superiority of their feet and legs, and their unconquerable courage. They all lacked size, but were powerfully built, with short strong backs, immense muscular quarters, round well ribbed bodies, on short strong legs, with game racing-like heads, neck and ears. In countenance, they were intelligent ; in disposition, kind, with wonderful capacity to carry weight." - [Albion in the Spirit of the Times, 1877$]$.

GRAY MESSENGER, gray; bred by Wm. D. Phillips, Christiana, Del. ; sire not given: dam said to be by Gray Marquis. Advertised, 1819, in General Advertiser of Eastern Maryland, by William R. Stuart. "Stock equal to any for saddle, harness or heavy draft."

GRAY MESSENGER, gray, I6 $1 / 2$ hands, said to be by Cooper's Messenger of New Jersey, son of imported Messenger: and dam by Irish Gray.

GRAY MESSENGER; foaled I 8 - ; said to be by a Black Hawk horse and bred in Vermont.

Sire of Walter, $2: 29$.

GRAY MESSENGER (HOAGLAND'S) ( $\mathrm{I}-\delta$ ), gray; foaled about I $\delta 45$; said to have been bred near Niagara, Can.; and got by a son of Sherman Morgan. Taken, when four, by George Halsey, to Freehold, N. J. and sold to Sheriff Cox of Monmouth County; to Simeon D. Huagland, Gravesend, L. I., whose property he died. Mr. George G. Hopkins, New York, N. Y., former owner of Hopkins' Abdaliah, who knew this horse well, writes, July 30, I $\$ 94$ : "Hoagland's Gray Messenger was rather blocky, of Morgan build, with long well shaped head and neck, full square breast, good gaited, carrying head about straight."

S. D. Hoagland, Esq.,

Middleeury, Tit., March 5, i 886.

Dear Sir:- Will you please inform me of whom you bought your stallion Gray Messenger with history so far as you know before you had him, and much oblige.

Mr. J. Battell,

Truly yours, - Joseph Battell.

Gravesend, L. I., March 8, I 886 .

Dear Sir:-Yours of the $5^{\text {th }}$ inst. came duly to hand and contents noted. Would say in reply I got Gray Messenger from Sheriff Cox of Monmouth County, N. J. He was brought to New Jersey from the upper part of New York State; was brought here with the mare Tib Hinman and went to New Jersey about I 855 ; think a man by the name of Skinner brought him, but will not be positive. The first that I saw of him was on Long Island. The gray gelding Vermont I knew and always understood to be a Harris Hamiltonian; as to who bred him, I can give no information. Hoping this will prove satisfactory to you believe me.

$$
\text { Yours truly, S. D. Hoagland. }
$$

J. Remsen, Long Island in interview, I886, said : 
"Gray Messenger (Hoagland's) got the best stock in the country, every one of his trotters. See Uncle Sim Hoagland.

"I knew Jackson's Flying Cloud, had a colt from him. Stock good; my little horse from him could trot like a whirlwind. Flying Cloud took first premium at State Fair about I 855 . Henry's stock a good stock of horses, all trotters.

"I had Defiance from Eclipse. The Florors kept American Star at Hempstead; all trotters every one. Bay horse, good decent sized horse."

Mr. Joseph Battell,

JeRsey City, July 2I, I 894 .

Dear Sir :-In answer to your letter asking for information regarding "Hoagland's Gray Messenger," would say that from what I have been told, he was taken from Canada to Rochester and from there to Monmouth County, N. J., where Mr. S. D. Hoagland bought him aboit I 857 . He was gray, $15 \frac{1}{2}$ hands, good gaited, level headed, and quite speedy for that period, - had a record of $2: 44$ (I think) to wagon.

Respectfully, Geo.G. Hopkins.

Mr. George G. Horkins,

Bread Loaf Inn, Ripton, Vt., July 30, I894.

Dear Sir :- I am exceedingly obliged to you for a letter concerning Hoagland's Gray Messenger. Please describe the shape of this horse a

little more fully.

Ist.-Was he blocky built?

Ans.-Rather. I wrote you he was somewhat of a Morgan build.

2d.-Was he a handsome horse?

Ans.-No.

3d.-Did he have large or small head?

Ans.-Long head well shaped.

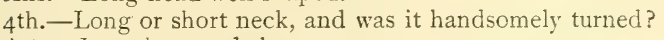

Ans.-Lengthy, good shape.

5 th.-Did he have a broad breast?

Ans.-Full, square breast.

6th.-Was his barrel round?

Ans.-Medium, would say good shaped body.

7th.-Was he well-ribbed back?

Ans.-Fairly.

8th.-Back long or short?

Ans.-Rather lengthy.

9th.--Mane and tail full or slim?

Ans.-Full.

roth.-Did he move handsomely and carry head well up?

Ans.-Good gaited-carried head about straight.

I leave room for answers to these questions and will be still further exceedingly obliged to you for answering the same and return. Also please inform me if you are the man who owned the horse known as Hopkins' Abdallah. If so give his description. State when, where and of whom you bought him and when and to whom you sold him and what finally became of him. My notes state that he was owned by George G. Hopkins of Green Point, R. I., and I see that this is your name.

Truly yours, JOSEPH BATTELL.

Sire of 2 trotters $(2: 261 / 2) ; 2$ sires of 2 trotters; I dam of I trotter. 
GRAY MESSENGER, said to be by the Morse Horse. We have received the following letter from Albert Longworth :

\section{JOSEPH BATTELL,}

McLean, Ill., April 28, I89i.

Dear Sir :-Yours of April 24 came duly to hand and in reply will say that "Gray Messenger" was by the Morse Horse. He was bought by a man by the name of Clarke through the agency of Hiram Woodruff, who was a personal friend of Mr. Clarke and who recommended Messenger. He said Messenger could lead any horse in the city of New York down the avenue for a ten-mile drive. Mr. Clarke brought him here over 30 years ago. He left many excellent colts in this neighborhood from the most common mares.

GRAY MESSENGER. See Young Stockbridge Chief.

GRAYMOMUS; said to be by Timoleon. Advertised with Col. Wright by Timoleon, and Bill Dearing by Cusp's Leviathan, by S. W. Moss, Oregon City, I86r, in the Oregon Farmer.

GRAY MORGAN (SAVIN'S); said to be by Calhoun Horse.

GRAY NORMAN (CASE'S NORMAN), gray, I 275 pounds; foaled I 855 ; bred by Daniel Case, Lockport, N. Y. ; got by Bathgate's Norman, son of the Morse Horse: dam gray. Owned by D. Fuller, LeRoy, N. Y., who sold about I 868 to a company, in Middlebury, Vt. He was kept the season of $\mathrm{I} 870$ at Richford, Vt., and in the spring of $\mathrm{r} 873$ was taken by E. C. Eells one of his owners to London, Ont., and kept there several years. Pedigree from breeder.

In an interview published in Middlebury Register, September 4, I $8 \&_{5}$, Mr. Darwin Rider of Middlebury, Vt., said :

"He was a large gray horse, I 7 hands high and could trot in about 2 :40. He was brought from Ohio by Mr. E. C. Eells, made two seasons here and was then taken to London, Ont. As I understand he was got by Alexander's Norman, son of the Morse Horse."

Addison House, Middlebury, Vt., April r6, i 886.

Editor Register :-In i 866 or '67, I bought Gray Norman at LeRoy, N. Y., of Dr. Fuller. E. C. Eells, D. Rider, C. Tinkham and N. E. Wheeler owned each one-fourth; price paid, \$I60o, called, I think, eleven years old, was kept by D. Rider at Middlebury until spring of I 873 , I think, making a season meantime, as I see by circular, at Richford, Vt., in 1870 . In the Spring of 1873 , he went to London, Ont., and made that season in hands of John Dulmage; next in hands of E. W. Eells; disposed of in 1875 , at London, since which I have never heard of him. Grand big horse, a trotter. I learn his mare foals breed speed.

Gray Morgan was a gray horse, I 7 hands, I 275 pounds; foaled probably in 1855 ; bred by Daniel Case, Lockport, N. Y.; got by Bathgate's Norman, son of the Morse Horse : dam a gray mare, breeding unknown; a better horse than Alexander's Norman, a sire of gentlemen's roadsters; speedy horse.

Yours truly, $\quad$ E. C. Eells. 
The Michigan Report of 1857 , says that the first premium on stallions three years old was awarded to Gray Norman.

GRAY PATHFINDER (9-128), gray, I53/4 hands, I050 pounds; foaled I 876 ; bred by Parker Hayner, Union City, Mich.; got by Buell's Pathfinder, son of Benedict's Pathfinder: dam gray, bred by James Pendill, Girard, Mich., got by Marshall Chief, son of Kilburn's Hero. Owned in Michigan.

Sire of Richard H., $2: 30$.

GRAY SQUIRREL; said to be by the full bred horse, Eolus: dam, Capt. Prior's noted running gray mare, Cade. Advertised at Lexington, Ky., I 806 .

GRAY STOCKING. Entered by J. B. Covington, Jacksonville, Ill., at the Illinois State Fair, I860.

GRAYSTONE (3-64), $2: 281 / 2$, iron-gray, I63/4 hands, I 250 pounds; foaled I 883 ; bred by H. H. Bowman, Osage, Mitchell County, Ia. ; got by Altitude, son of Almont : dam Lady Miller, gray, said to be by Creeper, son of Peck Horse, by Black Hawk; and $2 \mathrm{~d}$ dam by Bellfounder, son of Blucher, by Mambrino. Sold to Dr. Greenman, Cortland, N. Y. ; to Mr. Wickmire, Pedigree from breeder.

GRAYSTONE ( $1-64)$, bay, I533/4 hands, I Ioo pounds; foaled I 886 ; bred by J. C. McFerran, Louisville, Ky.; got by Nutwood, son of Belmont : dam Starling, bay, bred by Dr. A. S. Talbert, Lexington, Ky., got by George Wilkes, son of Hambletonian: 2d dam Jessie Pepper, brown, bred by R. P. Pepper, Frankfort, Ky., got by Mambrino Chief, son of Mambrino Paymaster; 3d dam said to be by Sidi Hamet; 4th dam by Diomed. Sold to M. L. Hare, Fisher's Switch, Ind., who sends pedigree.

Sire of II trotters $\left(2: 13 \frac{3}{4}\right)$, I 8 pacers $(2: 081 / 4) ;$ I dam of I trotter.

GREAT BRITAIN. A fine young dray horse from England, I 6 hands and very strong. Advertised as above in New York, 1762 .

GREAT DRAGON, I6 hands; foaled I 799 ; said to be of Chester Lion and Chester Ball breed. Advertised in Lancaster, Penn., I $\mathrm{So} 2$.

GREAT EASTERN (3-I28), 2:I8, bay, foaled I869; bred by George Hammil, Rome, N. Y.; got by Walkill Chief : dam bred by G. Hammil, got by Riley's Consternation ; $2 \mathrm{~d}$ dam bred by G. Hammil, got by Ferguson's Kentucky Hunter; 3d dam said to be by a son of Bajazet. Gelded young. Mr. Wallace writes :

"We present this week a picture of the mammoth trotter Great Eastern, $2: 19$, whose performances, during the past season, have stamped 
him as one of the most remarkable and speediest horses on the turf. This likeness is taken by a new process, and differs in size and execution from those we usually publish. The history of Great Eastern is not very long, but is quite full of action. His sire was Walkill Chief, foaled r 865 , by Hambletonian : dam Dolly Mills, by American Star. Walkill Chief was bred by Harrison Mills of Orange County, N. Y.; was the property of James IV. Hoyt, who sold him in I866, to E. Holmes of Cazenovia, N. Y. This gentleman owned him until, I 870 , when he sold him for $\$ 10,000$, to the Vermont Stock Company of Shelburne, Vt., in whose possession he died, June I4, I872, being only seven years old."-Spirit of the Times, Nor'. 2, 1876.

GREAT HEART ( I-64), brown; foaled I 888 ; bred by R. G. Stoner, Paris, Ky.; got by Mambrino Russell, son of Woodford Mambrino: dam Willie Wilkes, black, bred by John Stout, Midway, Ky., got by George Wilkes, son of Hambletonian; $2 \mathrm{~d}$ dam Sally Southworth, bay, bred by John Stout, Midway, Ky., got by Mambrino Patchen, son of Mambrino Chief; 3d dam Puss Prall, bay, bred by J. A. Prall, got by Mark Time, son of Berthune; $4^{\text {th }}$ dam said to be by Daniel Webster, son of Lance. Sold to A. C. Fisk, Coldwater, Mich.

Sire of Gale, $2: 19 \frac{1}{4} ; 4$ pacers $\left(2: 09 \frac{1}{4}\right)$.

GREAT HOPES (7-128), bay with star, snip on nose, hind foot white, i6 hands, I 300 pounds; foaled I 870 ; bred by Robert Steel, Cedar Park Stock Farm, Philadelphia, Penn.; got by Happy Medium, son of Hambletonian : dam Bess, bay, bred by Daniel A. Stuart, New Windsor, N. Y., got by Volunteer, son of Hambletonian; 2d dam Jenny, said to be by American Star; and $3 \mathrm{~d}$ dam Kittie Fisher, by a son of Messenger (Cole's). Pedigree from catalogue of breeder.

Sire of 2 trotters $\left(2: 26^{3} / 4\right)$.

GREAT STAKES (1-64), $2: 24^{1 / 2}$, bay; foaled $188_{7}$; bred by Z. E. Simmons, Lexington, Ky. ; got by Gerard, son of Beverly, by George Wilkes : dam Sweetmeat, chestnut, bred by Samuel Mitchell, Crawford, N. Y., got by Sweepstakes, son of Hambletonian; $2 \mathrm{~d}$ dam Gin, said to be by Rockafellow's Cassius M. Clay Jr. Sold to G. D. Bennett, Goldsboro, N. C., who sends pedigree; to John L. Roper, Norfolk, Va.

Sire of 5 trotters $\left(2: 19^{3 / 4}\right) ;$ Captain, $2: 16 \frac{1}{4}$.

GREAT TOM (3-32), bay, foaled I $8 \delta_{7}$; bred by G. D. Tyler, Union City, Mich.; got by Pathfinder (Buell's), son of Benedict's Pathfinder : dam Nelly Tyler, said to be by Magna Charta, son of Morgan Eagle ; 2 d dam Nell Rickard. Sold to Hub Knapp, Schoolcraft, Mich.; to B. C. Holly ; to J. IV. Carlisle; to Carlisle and Crook, Pueblo, Col.

Sire of 2 trotters $\left(2: 19 \frac{1}{2}\right), 2$ pacers $(2: 17) ; 2$ sires of 2 pacers; 2 dams of I trotter, $\mathbf{I}$ pacer.

GREAT WESTERN (5-64), chestnut; foaled I 880 ; bred by George W. 
Van Akin, Girard, Mich. ; got by Masterlode, son of Hambletonian : dam Nelly, bay, bred by G. W. Van Akin, Coldwater, Mich., got by Magna Charta, son of Morgan Eagle ; 2 d dam said to be by Thunderbolt. Sold to M. W. Thatcher, Coldwater, Mich.

Sire of 2 trotters $(2: 2 I)$; I sire of 3 trotters; I dam of I trotter.

GREELY HORSE. See Lion.

GREENBACK; foaled I86o; bred by Nathan Janes, Johnston County, Missouri; got by Patrick's Highlander, son of imported Highlander: dam said to be by Commerce; $2 \mathrm{~d}$ dam by Gohannah; $3 \mathrm{~d}$ dam by Bellair; and 4th dam by Hyder Ally. Owned at or near Green Ridge, Mo. Above pedigree is from posters of $\mathbf{I} 879$, and furnished by a correspondent of the Kentucky Stock Farm. Sold in I862 to James W. Martin, Otterville, Mo., for $\$ 400$.

Sire of dam of McDoel, $2: 15 \frac{1}{4}$.

GREENBACK (3-64), chestnut, I6 hands, I I 20 pounds; foaled I87I ; bred by William A. Hanson, Connorsville, Ind. ; got by Blue Bull : dam Flora Temple Jr., said to be by Tom Hal, son of Sorrel Tom. Sold to E. F. Drake, Fletcher, O., who sends pedigree; to W. M. Kear, Van Wert, O. ; to J. M. Romig, Brandon, Ia. Died, I9o2.

Sire of John M., $2: 27 \frac{1}{2}$, Fred Ager, $2: 24 \frac{1}{2} ; 3$ dams of 2 trotters, 3 pacers.

GREENBACK JR. (5-I28), bay, I6 $1 / 2$ hands, I 200 pounds; foaled 1877 or ' 78 ; bred by William T. Lamberton, Bentonville, Ind.; got by Greenback, son of Blue Bull : dam bay, bred by William T. Lamberton, got by Cloud Mambrino, son of Dan Underhill; $2 \mathrm{~d}$ dam bred by William Lamberton, got by a horse called Farmer, said to be a descendant of Stockholder. Owned in Montpelier, Ind., r89o.

GREENBACKS (I-I28), $2: 23 \mathrm{~T} / 4$, bay, with four white ankles, I 6 hands, I 40 pounds; foaled I 882 ; bred by R. S. Veech, Louisville, Ky. ; got by Princeps, son of Woodford Mambrino: dam Lorette, bay, bred by Charles H. Kerner, New York, N. Y., got by Hambletonian; 2 d dam Lady Walkill, bay, bred by Mr. Horton, Middletown, N. Y., got by C. M. Clay ; 3d dam said to be by Rockingham, son of imported Rockingham. Sold to A. I. Barber, Mason, Mich., who sends pedigree.

Sire of I trotters $\left(2: 15 \frac{1}{2}\right), 3$ pacers $\left(2: 19 \frac{1}{4}\right)$; I sire of I pacer; 4 dams of 3 trotters, I pacer.

GREEN BOY (I-64), $2: 273 / 4$, bay, black points, white stripe on right ankle, I $51 / 2$ hands, 960 pounds; foaled April I I, 1877 ; bred by Daniel Green, New Bedford, Mass.; got by John Green, son of Aberdeen, by Hambletonian : dam Eunice Green, bay, bred by Daniel Green, got by Hambletonian, son of Hambletonian, by Abdallah; 2d dam Lady Jupiter, bred by I. Van Sickels, Orange County, N. Y., got by Jupiter Abdallah, 
son of Jupiter; 3d dam Lady Van Sickle, bay, bred by Capt. Snyder, Sussex County, N. Y., got by Liberty, son of Lance; $4^{\text {th }}$ dam Capt. Snyder Mare, said to be by Abdallah. Owned by Clark C. Green, New Bedford, Mass. Pedigree from C. H. Peabody, V. S., Providence, R. I. Sire of 5 trotters $(2: 15) ;$ Harry C., $2: 181 \frac{1}{4}$.

GREENBUSH (I-I28), bay, I61/2 hands, I 275 pounds; foaled I879; bred by W. J. Neely, Ottawa, Ill.; got by Woodbury, son of Florida, by Hambletonian: dam Keepsake, bay, bred by W. J. Neely, got by Neely's Henry Clay, son of Strader's Cassius M. Clay Jr.; 2 d dam Cora Neely, bay, bred by Y. G. Murry, Racine, Wis., got by Richard's Bellfounder, son of Hungerford's Blucher; 3d dam Gourney Mare, bay, bred by a Mr. Gourney, Kenosha, Wis., got by Revolution, son of Sir Henry. Sold to O. D. Edmunds, Earlville, Ill., who sold to his brother in Minnesota. Kept in Ottawa and Paw Paw, Ill. Pedigree from breeder.

Sire of Greenbush Star, $2: 25 \frac{1}{2} ;$ I sire of $x$ trotter, 8 pacers.

GREENBUSH KING bay; foaled I $88_{3}$; bred by W. J. Neely, Ottawa, Ill.; got by Greenbush, son of Woodbury: dam Anna Belle, said to be by Byron, son of Royal George; and $2 \mathrm{~d}$ dam Mariah, by Wagner.

Sire of Hinda W., $2: 26 ; 8$ pacers ( $2: 10)$.

GREENBUSH STAR ( $\left.1-25^{6}\right), 2: 25 \frac{1}{2}$, bay, no marks, I $61 / 2$ hands, I 200 pounds ; foaled I 883 ; bred by W. J. Neely, Ottawa, LaSalle County, Ill. ; got by Greenbush, son of Woodbury, by Florida, son of Hambletonian : dam Mable, bay, bred by W. J. Neely, Ottawa, Ill., got by Byron, son of Field's Royal George; 2 d dam Kate O'Brien, bay, bred by R. A. Alexander, Woodburn Farm, Ky. ; got by imported Scythian ; 3d dam Young Clipper, said to be by Oliur ; and $4^{\text {th }}$ dam Clipper, by American Eclipse. Sold to Abert Cebell, Fort Atkinson, Wis. ; to K. B. Rutherford, Aurelia, Ia, Pedigree from breeder.

GREENFIELD, bay; foaled I872 ; bred by S. Baxter Black, Compassville, Penn.; got by Black's Hambletonian, son of Hambletonian: dam Rysdyk Maid, bay, bred by William M. Rysdyk, Chester, N. Y., got by Hambletonian; 2d dam Lady Van Buren, bay, bred by Milton Brown, Millerton, N. J., got by Bulrush (Young Zenith).

Sire of Grayfield, $2: 17 \frac{1}{2}$; I dam of I trotter.

GREEN ISLAND BLACK HAWK (I-I6), black, white hind feet, 15 $1 / 2$ hands, I 60 pounds; foaled I 860 ; bred by Abel Walker, Whiting, Vt.; got by Black Lion, son of Black Hawk: dam iron gray, bred by Abel Walker, got by the gray Walker Horse, foaled 1830 , son of Financeer, a dapple gray horse brought by Jerry Hammond from Poughkeepsie, N. Y., and said to be a Messenger. The dam of the old Walker Horse, 
M. B. Walker states, was bred at St. Johnsbury, Vt., and he thinks was Morgan. Taken by a Mr. Avery to Grand Isle County, Vt., and sold there. Mr. Walker writes :

Whiting, Vt., Dec. I 8, I885.

Editor Register :-Several months ago I received a blank from you in relation to the Morgan horses. I purposed to have filled it out and returned it. I was careless, mislaid it and have not been able to find it.

I own a stallion called Green Island Black Hawk. I presume there is not a better blooded horse in Vermont. $\mathrm{He}$ is $15 \mathrm{I} / 2$ hands high, weighs II60, is jet black, has white hind feet. He was got by Black Lion, owned by Mr. Pratt of Bridport, and he was by old Black Hawk. His dam was by the iron gray Walker Horse, owned by Amos E. Walker of Whiting, some twenty-five years ago, and he was by a Messenger horse. Several years ago I was at the Addison House, Middlebury. David Hill, the owner of Black Hawk, was conversing with a gentleman in relation to various distinguished horses. Mr. Hill made use of the following language: "The old iron gray Walker Horse, owned by Amos E. Walker, was the stock horse in Western Vermont."

I think I can safely say that as for nerve, bottom and endurance that the old Walker Horse took rank with the original Morgan horses.

If my horse had been trained he would have been one of the fast ones. Without any training he will trot a mile in $2: 40$.

$$
\text { Yours truly, Abel WALKer. }
$$

Letter from M. B. Walker.

Whiting, Vt., Dec. 28, ' 85 .

The old Walker Horse would be 56 years old next May. He has been dead 33 years. Nothing is certainly known of his breeding. $\mathrm{He}$ was got by a dapple gray horse that Jerry Hammond got in Poughkeepsie, N. Y., called Financier. Mr. Hammond called him a Messenger.

The present Walker Horse is 26 next spring; sire Black Lion, by Black Hawk; his dam by the old gray Walker Horse. Nothing is known of the blood of the dam of the old gray; she had the make of a Morgan mare; was bred at St. Johnsbury, where the old Justin Morgan was kept two years, and might be Morgan.

$$
\text { Yours, M. B. WALKER. }
$$

GREENLANDER (I-256), 2 :I5, black; foaled I882; bred by R. S. Veech, St. Mathews, Ky. ; got Princeps, son of Woodford Mambrino: dam Juno, foaled I 867 , bred by John Stewart, Boston, Mass., got by Hambletonian, son of Abdallah; $2 \mathrm{~d}$ dam Lady Morrison, a fast mare with a record of $2: 35$, pedigree not traced. Sold to Augustus Sharpe, Cherryvale, Kan. ; to W. R. McClintock, Essex, Ia.

Sire of 22 trotters $\left(2: 13^{3} / 4\right), 5$ pacers $(2: 173 / 4) ; 5$ sires of 13 trotters, 3 pacers.

GREENLANDER BOY $(3-64), 2: 2$ I 3/4, brown, I 6 hands, I I 50 pounds ; foaled 1887 ; bred by Augustus Sharpe, Shady Side Farm, Louisville, Ky., got by Greenlander, son of Princeps: dam Aurelia, bay, bred by Leland Stanford, Palo Alto, Cal., got by Electioneer, son of Hambletonian; 2d dam Aurora, $2: 27$, bred by Mr. Lamott, San Francisco, Cal., got by John Nelson, son of imported Trustee; 3d dam Lamott Mare. 
Sold to Scott Newman, Jr., Louisville, Ky. Pedigree from catalogue of breeder.

Sire of Fohn Durrett, $2: 14^{1 / 4}$.

GREENLEAF (3-128), bay; foaled I884; bred by J. W. Howard, Corry, Penn.; got by Jerome Eddy, son of Louis Napoleon: dam Nettie Pierce, chestnut, bred by M. Pierce, Rushville, N. Y., got by Andy Johnson, son of Henry Clay; 2d dam Blacky, said to be by Flying Cloud (Thompson's), son of Jackson's Flying Cloud.

GREENLEAF (I-16), 2 : I01/2, bay, with star and three white feet, 16 hands, I 000 pounds ; foaled I 886 ; bred by L. D. Mefford, Sadieville, Ky. ; got by Simmons, son of George Wilkes : dam bay, bred by L. D. Mefford, got by Jim Monroe; $2 \mathrm{~d}$ dam bred by William Anderson, got by Bald Stockings, son of Tom Hal ; 3 d dam bred by William Anderson, got by Bald Stockings, son of Tom Hal ; $4^{\text {th }}$ dam bred by William Anderson, got by Justin Morgan, kept near Lexington, Ky. Gelded young. Pedigree from W. H. Wilson, Cynthiana, Ky.

GREEN MOUNTAIN (I-4), black chestnut, I5 I/4 hands, II 25 pounds; foaled 1828 ; bred by William Bachop, Barnet, Vt., got by Sherman Morgan : dam thought to have been by the Dean Horse of Danville; $2 \mathrm{~d}$ dam black, brought from Canada and called English. Sold by breeder, I 834 , for $\$ 500$, to Messrs. Butler and Whitcher, who took him to Hampshire County, Massachusetts. Afterwards owned in Barnet for a number of years by a Mr. Harvey and later by George Wheeler, Danville, Vt., who, it is thought, took him West. He is described as a remarkably strong and hardy animal, not so high headed as some, but a very good traveler on the road and hard to tire out.

Nathan Bachop, Greensboro, Vt., born I802, said :

"Mr. Bachop of Barnet kept two Morgan horses called the Bachop horses; both chestnut. This was about I 828 . I worked for him; think he raised both of them. They were called the best blood and they were. Mares were brought to them from far and near."

Archibald Bachop, Newbury, Vt., in interview, I887, said :

"Our Green Mountain was sold to Butler and Whitcher of Haverhill, N. H. I was born in I8Io and married I844. Father died I84r. I was probably about 25 when the horse was sold. Sherman Morgan came to father's and made two or three seasons in his stable. Father had a black mare that came from Canada, called English blood. $\mathrm{He}$ raised from her another black one, got by the Dean Horse of Danville, a black, good-sized horse that was rather savage. I do not know his blood. The dam of the Green Mountain was one of these two mares and I rather think was the younger one. Father raised the same year from the other mare and also by Sherman Morgan a smallish black horse which he took to Boston when five years old and sold. This was the winter before we sold the other. Father lived then in Barnet. I think 
this last horse was kept a while in Massachusetts as a stallion. Burbank resembled our Green Mountain very much; about the same color and size. A Morgan horse owned in Cabot by Clark was quite a good horse; light chestnut, I5 hands, Iooo pounds; got by Sherman. He was kept at Barnet. The old Sherman was very hollow backed when at father's, a little too much that way, I think, but his stock were all right."

The following advertisement is copied from a local Massachusetts paper, name accidently omitted, of 1844 :

GREEN MOUNTAIN MORGAN.

A true son of the old Sherman Morgan will stand in Belchertown, Granby, South Hadley, Greenwich and Enfield.

(Signed) Jonathan S. Whitcher.

A certificate of William Archibald Bachop is annexed, stating that in the spring of $\mathrm{I}_{34}$ this horse was sold to Luther Butler and J. L. Whitcher. "A brown stud, foaled 1828 , dam a first-rate mare owned by Mr. Bachop, and got by a stud known by the name of old Sherman."

A certificate signed by sixteen in Vermont and New Hampshire says :

"We consider the Green Mountain Morgan one of the best we have ever seen of the Morgan race of horses. He drew first prize at the New Hampshire Fair last fall.

JASON Stockbridge, South Hadley."

GREEN MOUNTAIN (I-I6), said to be by Rough and Ready, owned by A. H. Blair, Georgia, Vt., son of Nimrod, owned by Joseph Smith, Berkshire, Vt. : and dam by Telescope. Taken West by Benjamin F. Sabin of Sycamore, Ill.

GREEN MOUNTAIN (3-32), I6 hands, I350 pounds; said to be by Green Mountain Morgan; and dam Morgan. A horse of this name was advertised at Columbus, O., by Blake \& Williams in the Ohio Cultivator, 1855 . A horse of this name, four years old or over, also took a premium at Illinois State Fair, 1857 .

In Porter's Spirit of The Times, June 26,1858 , under "Stock Horses in Ohio," is the following :

"** $*$ Zielley, mine host of the American hotel, gratifies the Morgan taste by keeping Green Mountain, by Hale's Green Mountain Morgan (of Royalton, Vt.) : dam Morgan. He is $\mathrm{I} 6$ hands high, $\mathrm{I} 350$ pounds, gets up in harness and turns about in pony style. His owner says he can drive him in $3: 30$ to a wagon."

GREEN MOUNTAIN. Awarded fifth premium on stallions at the New Hampshire State Fair, 1853. Owned by S. H. Edgerly, Manchester.

GREEN MOUNTAIN (CLARK'S) (I-I6), said to be by Green Mountain Black Hawk. Mr. L. L. Dorsey, Anchorage, Ky., writes as follows :

Mr. Joseph Battell,

Dear Sir :-Referring to enclosed, I beg to state that we sold Green Mountain Black Hawk to go to Columbia, Mo., about I869, and I saw 


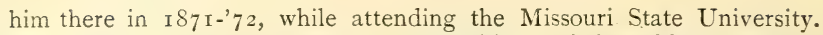
Mr. Clark may still be living at Columbia, and by addressing him, even if dead, your letter may fall into hands of some member of the family who would give you desired information. Sorry I cannot.

GREEN MOUNTAIN BANNER ( $\mathrm{I}-8$ ), brown with star, $15^{\mathrm{I} / 2}$ hands, Iooo pounds; foaled 1858 ; bred by Lewis Barlow, Brandon, Vt.; foaled the property of Harrison Knott, Pittsford, Vt. ; got by Black Banner, son of Black Hawk: dam dark dapple bay, 5 I/ $/ 4$ hands, half docked and acted like an old trotter; could speed in 2:50; a chunked mare built on Morgan type with head of unusual beauty and wide between the eyes, that was brought to Brandon, Vt., by two peddlers from Massachusetts, who claimed they got her on Long Island; claim not reliable; pedigree unknown. Of the mare Hiram S. Buttles, of Brandon, Vt., writes :

"In reply to your inquiry about those peddlers of long ago-one of them, a relative of mine, Wallace Buttles, has been dead twenty years or more, the other one, a Mr. Sargent, I never knew the address of. I think they swapped for the mare you speak of on the road somewhere, and don't believe they knew much about her pedigree."

Allen W. Thomson, Woodstock, Vt., writes in the Chicago National Live Stock Journal, Vol. X.

"About I 854 Mr. Buttles of Brandon, Vt., was informed by his nephew, Wallace Buttles of Massachusetts, that he had traded for a mare that had trotted on Long Island in $2: 32$ and was considered very valuable. She had a sore on one side near the withers. This W. Buttles traveled around mending clocks, etc., and a young man named Sargent traveled with him. Barlow of Brandon traded for the mare. She was dark bay with star, 15 hands, 900 pounds, mane and tail good, fine made and very resolute. Barlow bred her in 1856 to the Churchill Horse; she had in I 857 a bay filly with star called Queen of Vermont. Barlow bred her in 1857 to Black Banner and sold her to Harris Nott of Pittsford. In 1858 she had Green Mountain Banner, bay with star. Nott bred her in 1858 to Young Vermont by the Pease Horse, son of Black Hawk; she has Black Boy, black, that went to Pennsylvania and proved a valuable sire. Barlow sold Queen of Vermont when three years old to J. A. Bryant, Bethel, Vt., for $\$ 300 . "$

Sold to Hiram Bryant, Bethel, Vt.; to Lorenzo B. Bird, Stockbridge, Vt. Died at Fair Haven, Vt., 1874. See The Morgan Horse and Register, Vol. I., page 485 .

Sire of 2 trotters $(2: 2 \mathrm{I}) ; \mathrm{I}$ dam of I trotter.

GREEN MOUNTAIN BLACK HAWK (DORSEY'S, TOM, SORREL TOM) ( I-8), chestnut, white hind foot, $153 / 4$ hands, I I 50 pounds; foaled I 850 ; bred by Edward Wells, Bridport, Vt.; got by Sherman Black Hawk: dam chestnut, I050 pounds, foaled about I830, owned by Paris Fletcher, Bridport, Vt., who bought her, about I $84 \mathrm{I}$, of Jasper Fletcher, Woodstock, Vt., who had her of Galon Persons, said to be by Gifford Morgan. Sold to B. J. Myrick, Bridport, Vt., I85 I ; A. C. Fiske, Cold- 
water, Mich., I853; Smith \& Cripper; Elias Dorsey and John Burke, Louisville, Ky., about 1857 . Kept in Jefferson and Nelson Counties, Ky., a number of years. Afterwards owned by J. A. Reed \& Co., and P. H. Dorsey, Gillespie, Ill., and in Columbia, Mo. Died in Missouri about 1872 . A very valuable horse, combining, size beauty, style, action and speed. He was the winner of many premiums, including the threeyear-old purse at Addison County (Vt.), Fair, 1853, time 3: ro, sweepstakes premium at Michigan State Fair, 1854 , '55 ' 56 , ; ist premium for trotting stallions at United States Agricultural Fair, Louisville, Ky., I 857 ; speed ring premium at New Albany, Ind., time $2: 40$; also speed ring premium at Nelson County Fair, Ky., 1859, time $2: 40 \mathrm{r} / 2$, on one-third mile track; $\$ 250$ premium for best roadster stallion at Louisville, I860; $\$ 500$ premium for fastest trotting stallion at World's Horse Fair, Chicago, I862, and numerous others. Maj. I. L. Wharton, Springfield, Ky., writes: "He has left some of the best horses that have ever been in Kentucky."

The correspondent of the New York Spirit of The Times in November 29, I862, in an article upon "The Horse Stock of Michigan," says :

"Green Mountain Black Hawk is $\mathrm{I} 6$ hands high and weighs over a thousand pounds. Good form, unsurpassed in style and action."

Exhibited at the St. Louis, Mo., Agricultural Show, I 859.

B. J. Myrick, owner of sire, writes, dated, Bridport, Vt., March I4, I 886 .

\section{EDITOR REGISTER,}

The horse Green Mountain Black Hawk was got by Sherman Black Hawk in the year I 849. The dam was a very fine chestnut mare owned by Paris Fletcher. He claimed her to be a Morgan. He bought her over the mountain; I think he told me of his brother, Jasper, of Woodstock. She would weigh between ten and eleven hundred. Mr. Fletcher sold her to Edward Wells of Bridport, and he bred her to Sherman Black Hawk and raised the horse Green Mountain Black Hawk. I bought the colt when a yearling and sold him to Mr. Fisk of Coldwater, Mich., when he was three past. A. A. Fletcher may give you further information. Mr. Dorsey gave me Green Mountain Black's time as $2: 39$ in harness.

Mr. A. C. Fisk, Coldwater, Mich., also writes us that he bought this horse of Mr. Myrick of Vermont and sold him to E. Dorsey of Kentucky.

It would appear from the above that Green Mountain Black Hawk went from Vermont to Michigan in 1853 or ' 54 , and remained there as late as the fall of 1856 . He first appears in Kentucky in 1857 and was there in 1867 . Mr. Dorsey states that he afterwards went to Missouri, where he died about 1872 . He would seem to have been one of the best entire sons of Sherman Black Hawk.

DAM OF DORSEY'S GREEN MOUNTAIN BLACK HAWK.

Mr. B. J. Myrick states, in a letter published in the Register of April 2, last, that the dam of Green Mountain Black Hawk was a very fine 
chestnut mare owned by Paris Fletcher, who claimed her to be a Morgan; that he bought her (as Mr. Myrick thinks) of his brother, Jasper Fletcher of Woodstock, Vt.

Mr. Allen W. Thomson of Woodstock, in a recent letter, says :

"I went out Tuesday to South Woodstock to learn about the dam of Dorsey's Green Mountain Black Hawk. Jasper Fletcher lived some two miles from the south village, on the hill. There is a man there that knew all about the horses there in his day; they think he will not live long, and I thought it best to see him soon. He remembered Jasper Fletcher's having the mare and letting his brother have her; said she raised a very fine bay horse by the Ransom Horse (he by the Walker Horse) ; that Jasper Fletcher let his brother have her for $\$ 200$, considered a big price at that time. He could not tell where Jasper got the mare; said he did not have her more than two or three years; that she was a little balky. I saw two of Jasper's sons, George and Friend. They remembered her well, but could not tell where their father got her; thought Franklin Ladd might know, as he worked for their father at the time. I saw Mr. Ladd. He said Mr. Fletcher bought her off from a stage. They thought it was about $\mathbf{1} 84_{2}$ when he got her and she was ten or twelve years old at the time; that she showed Morgan blood strong. I have written to Mr. Fletcher's oldest son, who may know more about her."

Mr. Thomson adds :

"The dam of Green Mountain Black Hawk was foaled about I83o, and it looks as though she must have been by old Woodbury, or one of his sons, that is, by her age."

In a later letter Mr. Thomson encloses a letter to him from B. R. Fletcher, Jasper Fletcher's oldest son, as follows :

Mr. THOMSON, Northfield, Vt., April 22, 1886.

Sir :- I received a line from you, in regard to the old mare that father had. It is forty-five years last fall since he sold her. The last we heard from her she was in Coldwater. Father had her of Galon Persons, and he had her of a traveling man; don't know where she came from nor how old she was, not less than twelve or fifteen.
Yours truly,
B. R. Fletcher.

TROTTING STALLION STAKE IN KENTUCKY.

Messrs. R. A. Alexander, J. P. Gray, J. W. Brannan, S. B. Lewis and John Burke, five of the stock breeders of Kentucky, have entered into a trotting stallion stake of $\$ 200$ entrance, to come off in 1862 , for colts and fillies got in this year. The stallions are to be named before January $\mathrm{r}, \mathrm{I} 858$, and the race is to be run over the Association Course, Lexington, Ky., or any other course near that city to be agreed upon. The distance is to be mile heats, in harness, two or more to make a race. The entries thus far are as follows:
R. A. Alexander names the get of Pilot Jr.
J. P. Gray
J. W. Brannan
66
Mambrino Chief.
S. B. Lewis
John Burke
66
66
John Henry.
Ole Bull.
" " Green Mountain Black Hawk. 
The further subscriptions to this stake must be forwarded to Dr. E. L. Dudley, Lexington, with bond and approved security.-Spirit of The Times, Dec. 4, 1858 .

Sire of dam of Barkis, $2: 25 \frac{1}{2}$.

GREEN MOUNTAIN BLACK HAWK (3-32), bay, black legs, mane and tail, I $51 / 2$ hands, ro5o pounds; foaled 1855 ; the property of Dwight Cheney, Niles, Cayuga County, N. Y.; got by the Remmington Black Hawk, son of Black Hawk: dam said to be by Green Mountain Morgan. Has four times received the first premium at the show of Cayuga County Agricultural Society, and in the fall of ${ }_{1} 859$ the first premium at the Skaneateles Fair. Owned, 1860, by E. and W. S. Parker, Kelloggsville N. Y.-American Stock Journal, Vol. II., 1860.

GREEN MOUNTAIN BOY (I-I6). Awarded first premium at the New Hampshire State Fair, 1851, entered by C. Russell, Wilmot.

GREEN MOUNTAIN BOY (I-I6), black with one hind ankle white, I5 I/2 hands, 975 pounds ; foaled about 1850 ; bred by Ebenezer Bush, Shoreham, Vt. ; got by Prince Albert, son of Black Hawk: dam gray, a great roadster, bought by Mr. Bush of Orville Smith, said to be of Morgan and French blood. Sold to Oliver B. Smith, Shoreham, Vt., about I 85 I ; to W. L. Utley, Racine, Wis., about I 855 ; to some party at Niles, Mich., or vicinity, I865. W. L. Utley writes:

"Between the years 1855 and '6o, a number of stallions were brought from Vermont to this country, among them Green Mountain Boy and another horse from Addison County, chestnut, by Black Hawk, dam Puzzle Tail, Morgan, a very beautifully made horse of about Io50 pounds, but not as showy as Green Mountain Boy. He was kept here a few years and was taken to Ohio. A Mr. Waterman went to Vermont and brought in a Morgan stallion. Charles Wright brought from Vermont a number of mares and a number of stallions. There was another Black Hawk stallion by the Pratt Horse, Black Lion, and, in the western part of the county, two or three stallions by the North Horse (Sherman Black Hawk). From this influx of Vermont horses, Racine County has become celebrated for its beautiful and fast horses. Green Mountain Boy was the sire of Billy Utley, that trotted all one winter in Barnum's New York Hippodrome; also of Gov. Randell, $2: 38$, when four, that was sold at Chicago for a roadster, for $\$ 2700$, and many others that were fast in their day and fine. He trotted himself in $2: 38$ to I IOpound wooden-axle sulky. I am confident that with the track, training, and sulkies, horses get now, he would have trotted very fast. $\mathrm{He}$ was also one of the handsomest horses that ever lived."

See The Morgan Horse and Register, Vol. II., page ${ }_{5} 6$.

GREEN MOUNTAIN BOY (LITTLE BILLY, SUN PRAIRIE HORSE) (3-I6), chestnut with stripe in face, $14 \frac{1}{2}$ hands, 900 to Iooo pounds; foaled May 6, r850; bred by Joel Randall, Bridport, Vt. ; got by Black Hawk: dam bay, not over 900 pounds, Morgan-built, obtained by Joel 
Randall of Ethan Andrus, Cornwall, Vt., said to be by Gifford Morgan. Sold to John Ward, who took him, when four to Wisconsin, where he was owned by Moses Chase, Sun Prairie, and John T. Hidden, Lodi ; also, it is said, by Gilbert Dutcher, and in I87o, by Dr. Quincey, Evansville, Wis. Died August, 1876 .

C. A. Lewis, Caliope, Ia., writes :

"He took Ist premium at Wisconsin State Fair at Janesville, also at many county fairs. When 18 he was still king of the turf, beating all stallions that fall at the county fairs. Disposition quiet and gentle, quick, lively stepper, very honest, always keeping at his trot without a break; stock very fine. His time about $2: 40 . "$

See The Morgan Horse and Register, Vol. I., p. 498.

Sire of dams of Herod, $2: 241 / 2$, Reality, $2: 231 / 2$.

GREEN MOUNTAIN BOY (3-16), jet black, $15 \frac{1}{2}$ hands, I075 pounds; foaled Sept. 20, I 854 , in Northfield, Vt. ; said to be by Lawton Horse, son of Green Mountain Morgan : and dam by Randolph Morgan, son of Bulrush, by Justin Morgan. Sold to John Gregory, Northfield, Vt., who sold him for \$1 500 to Messrs. Ditch \& Drury, Waterloo, Monroe County, Ill., who owned him in I859. He was exhibited at the St. Louis Fair in $\mathbf{1} 858$, and awarded first premium in his class.-American Stock Journal, Vol. I., 1859 .

GREEN MOUNTAIN BOY Exhibited at State Fair, Madison, Wis., I 858 . Record 3 :05. Owned by E. Grover, Jr., Madison, Wis. Exhibited with Trotting Stallions four years and over at Wisconsin State Fair, I 860.

GREEN MOUNTAIN BOY; foaled about 1856 . Advertised for sale in the American Stock Journal, Vol. II., i 860 , as follows :

"Four year old stallion, Green Mountain Boy (for pedigree, see Vermont Stock Journal, March, 1857 ). He is as perfect and as pure-blooded Morgan as can be found Address, Daniel Kimball, Rutland, Vt.

GREEN MOUNTAIN BOY (I-64), $2: 281 / 4$, bay, $153 / 4$ hands, ro5o pounds; foaled I873; bred by Milton M. Miller, Brattleboro, Windham County, Vt.; got by Thomas Jefferson, son of Toronto Chief : dam bay said to be of St. Lawrence stock. Sold to William Dailey (Uncle Billy,) Hartford, Conn. ; to a Mr. Meyers of Baltimore, Md.; to Mr. Barker, Aberdeen, Md. Pedigree from breeder, who writes :

"I bought the dam of George F. Breed, 7x High St., Boston, in IS6I for \$I ooo. She was a 'big little mare'. I am confident could have trotted 20 miles in less than an hour and could show a $2: 30$ gait for a quarter.

GREEN MOUNTAIN BOY (GEN. SCOTT). See Gen. Scott, page 505 .

GREEN MOUNTAIN CHIEF (BOWEN HORSE, HUBBARD HORSF) 
(r-16), bay, with star and one hind foot white, 15 hands, ro5o pounds; foaled about I 852 ; bred by Mark Bowen, Bethel, or Royalton, Vt. ; got by Green Mountain Morgan: dam brought from New York State, untraced. Owned successively by Varsil Hubbard, Rochester, Vt.; Lewis Bates, Bethel, Vt.; Mr. Putnam, Barnard, Vt.; Warren Bean, West Randolph, Vt. Died about I874. Blocky built, strong and of good style, quite long bodied, and left many good colts. Could trot in about 3 :oo. Took ist premium at Windsor County (Vt.) Fair. Pedigree from V. M. Hubbard.

GREEN MOUNTAIN MORGAN (I-8), dark chestnut, low built and remarkably thick set from $I_{4} 1 / 2$ to 15 hands, IIoo pounds; bred by Nathaniel Whitcomb, Stockbridge, Vt. ; foaled abuut I $83_{2}$, the property of George Bundy, Bethel, Vt. ; got by Gifford Morgan : dam dark bay, a low, thick-set mare of rooo pounds, purchased in Nashua, N. H., where she is said to have worked on a canal, by Mr. Whitcomb, who traded her to J. Kendall, and he to G. Bundy, untraced. This mare is described by D. L. Putnam, former owner of Putnam Morgan, as rather heavy built, strong muscled and flat ribbed.

Allen W. Thomson of Woodstock describes her as a low thick-set mare that might have weighed rooo pounds.

A. W. Whitcomb, Bethel, Vt., writes:

"She was of light mouse color, yellowish on the belly and darker on the back."

Mr. E. K. Whitcomb of Elgin, Ill., is quite certain that this mare was of Morgan blood. From the locality where she was purchased it is very probable she may have been, but so far as we know, there is no tracing of her back of her purchase at Nashua. It will be seen from her color that she was in part "Casol." See Introduction, page xxv.

Green Mountain Morgan was sold by the breeder when four months old to Daniel Gay of Stockbridge, Vt. ; who sold him when four years old for seventy-five dollars to Hiram Twitchell, Bethel, Vt. ; and he the same year to John Woodbury, Bethel, Vt. Whilst owned by Mr. Woodbury, he was in charge of Daniel Cushing part of two seasons at Springfield, Vt. In I 842 , Silas Hale of South Royalston, Mass., bought him for seven hundred dollars and afterwards kept him at South Royalston, Mass., and at Brattleboro, Windsor, Townsend, Woodstock, Montpelier, Middlebury, Vergennes and Rutland, Vt., and at different places in New Hampshire. Mr. Hale sold him in 1850 to a stock company, in Washington County, Vt., for twenty-two hundred dollars. He was afterwards owned by John Martin, Marshfield, Vt., and died his property, at the stable of C. B. Martin, Oct. 4,1863 .

Mr. Linsley, from whom much of the above is taken, adds:

"Mr. Hale took him West in $\mathrm{r} 853$, and he received first premiums at several State Fairs in Kentucky, Ohio and Michigan, and in 1854 , he 
received the first premium at the Vermont State Fair at Brattleboro. $\mathrm{He}$ has also taken several other premiums. $\mathrm{He}$ is a horse of great muscular development and remarkably nervous, spirited action."

"Advertised by Silas Hale, I853, to be kept at stable of Mr. Cottrill, Montpelier, Vt., terms $\$ 25$. Advertised at Middlebury, Vt., May, I854.

OLD GREEN MOUNTAIN AND GOV. BANKS.

"Our neighbors in the Bay State have lately had an old-fashioned 'general training or muster' at Concord which attracted a great crowd of spectators. Everything and everybody was arrayed in holiday attire ; gay uniform, and glittering arms, flags, music, and a thousand attractive objects offered an infinite fund of materials for the letter writers; but these matters are a little 'out of our line' and we should not refer to them but that we wish to notice the appearance there of that renowned old veteran, Green Mountain.

"Quite a rivalry, it seems, sprang up among the field officers to secure the finest horses for the parade. Gov. Banks sent a special ambassador to the owners of Green Mountain, and after some negotiation the old horse was taken from his obscure retreat at Williamstown, Vt., and at the age of twenty-five (an age to which comparatively few horses ever attain), was taken a long distance to contend with a field of chosen studs in the trying and fatiguing evolutions of a military drill. We feared that age must have dimmed the fire of his eve, checked the full and vigorous pulsations of his blood, and tamed the unflinching courage and dauntless bearing which has never yet failed to arouse the enthusiastic applause of all beholders. But it seems we were mistaken. The staunch old veteran was the 'observed of all observers,' and it seemed to be the very general feeling that, instead of the horse being honored by bearing in the cavalcade the distinguished Governor of Massachusetts, His Excellency was rather honored in being allowed to bestride the finest parade horse in this country, which, it is said, Gen. Wool declared him to be.

"No wonder Vermonters are proud of the hero. He seems to us the embodiment of the ideal war horse of Job, that 'paweth in the valley, and rejoiceth in his strength.' Long may he live, and, when he goes the way of all horse-flesh, may he leave behind him a progeny that may continue to exhibit his distinguishing characteristics for many generations." -From the American Stock Joumal, Vol. I., 1859, page 296.

A correspondent of The New York Spirit of The Times, describing the State Fair at Saratoga, I 847 , says:

"On the grounds there was a very dark chestnut (almost black) stallion, called, I believe, Green Mountain Morgan. He was thirteen years old, and got by the old Gifford Morgan, also on the ground. There were also two other stallions exhibited, got by the same. The four bore a close family resemblance both in appearance and action. There is a difference in opinion in relation to these animals, but I willingly plead guilty to a great admiration for them. Such promptness and fire, with such perfect docility, I never saw united in any other species. Not one of them was over fifteen hands high-scarcely that-but when moving I never saw so much majesty embodied in horse flesh as was displayed by Green Mountain Morgan. His arched neck seemed 'clothed with thunder,' and his floating mane, his eye of fire, his red, distended nos- 
trils, his open mouth with the rigid tendons about it standing out in sharp relief, realized more perfectly to my mind the originals of those fiery and magnificent coursers - the Greek ideals of the war horse-to be found on the Elgin marbles, than I ever saw elsewhere. I called Charles Elliot, the painter, and had Green Mountain Morgan put to his paces for his inspection. Without a word from me he made precisely the criticism I have already done."

For further information of this noted horse see The Morgan Horse and Register, Vol. I., p. 221.

GREEN MOUNTAIN MORGAN. At the Michigan Fair, I $8_{5} \mathrm{I}$, the second premium for stallions was awarded to "Green Mountain Morgan," owned by John Parker, Kalamazoo.

GREEN MOUNTAIN MORGAN ; foaled I85o. Awarded first premium on speed at the New Hampshire State Fair, I854, entered by Layton Martin of Keene. See Keene Morgan probably the same horse.

GREEN MOUNTAIN MORGAN. In the records of the Ogle County Fair, Ill., I 854 , attention is called by J. H. Cartwright, Oregon, Ill., to "Green Mountain Morgan," lately brought from Vermont by Mr. Wetherbee. A horse of this name foaled 1857 , was exhibited at Wisconsin State Fair, I860.

GREEN MOUNTAIN MORGAN (3-I6), dark chestnut, small stripe in face, I 6 hands, I 300 pounds ; foaled Sept., I 862 ; said to be bred by Lyman L. Jourdon, Vermont, and got by Ethan Allen, son of Black Hawk: dam said to be by Ashuelot Morgan, son of Green Mountain Morgan; and $2 \mathrm{~d}$ dam by Morgan Emperor, son of Bulrush Morgan. Taken to Toronto, Can., by breeder who sold March 26, I866, to Edward Major of Toronto. Mr. Major kept him at Port Perry in the County of Ontario about eight seasons, then sold to $\mathrm{Wm}$. McKee, Port Hope, Ont., who had him two years, and sold to some party in Peterboro, where he remained three years and was sold to a man at Camelford, who owned him until about 1878 , when he was killed by lightning. Pedigree from breeder.

Sire of Honest Billy, $2: 29^{1 / 4}$, Bay Charley, $2: 23^{3 / 4}$.

GREEN MOUNTAIN MORGAN (DOW'S) (I-I6). Owned in Ohio and perhaps the horse of same name that went to Columbus $I 853$ and was advertised for sale 1856 and ' 57 by Blake and Williams.

TROTTING IN OHIO.

Porter's Spirit of The Times, Nov. 14, I857:

Columbus, Tuesday, Oct. 27.

A trotting match between Green Mountain (Morgan) and Black Hawk (Telegraph) for \$rooo a side came off this afternoon over the 
Capital Course and resulted in Green Mountain (Morgan) winning the race.

Sire of Sally $B ., 2: 23$.

\section{GREEN MOUNTAIN MORGAN (HINDS', MONTGOMERY'S GREEN}

MOUNTAIN) (3-32); bay, over I6 hands, I 200 pounds; foaled about I 860 ; bred by Francis M. Hinds, Hindsboro, Ill. ; got by Green Mountain Black Hawk, son of Sherman Black Hawk : dam Puss, foaled about I 856 , bred by Francis M. Hinds, got by General-Scott, son of Copperbottom; 2d dam Old Puss, chestnut, bred by Francis M. Hinds, got by Sportsman, thoroughbred; 3d dam bay, bred by Francis M. Hinds, got by Doublehead. A very strong, active horse. Sold to M. Lawson, Thomas Lawson, George Tiemans, Samuel Lippincott, Harvey Sain, Peter Hammer, and was kept in Coles and Douglass Counties, Illinois ; terms $\$ 7$ to $\$$ IO. Died I 889 . Pedigree from breeder.

Mr. John H. Halsey writes, July 24, I 896 , from Oakland, Ill., the following letter :

Mr. Joseph Battell,

Dear Sir :- In reply to yours of the I I th inst. I enclose pedigree of two mares. Green Mountain Morgan was Hinds' horse, not Hale's, as appears in some of the modern pedigrees.

Francis M. Hinds, who is still living, bred the bay mare Puss to Green Mountain Black Hawk in Kentucky at the Dorsey stables about the year I 860 , the produce was Green Mountain Morgan, a black horse. As a three-year-old he was captured by the Cavalry of the John Morgan raiders and rode in the raid across Indiana and Ohio in the War of the Rebellion. Francis M. Hinds followed the raiders from near Salem, Ind, to Eastern Ohio, at the crossing of the river, and recovered his horse.

Puss, his dam, foaled Monkey Rolla about 1880 , when she was twenty-four years old. Monkey Rolla was a great pacer and campaigned in the East.

Puss' dam was old Puss, by a thoroughbred. Francis M. Hinds brought Green Mountain Morgan here in the spring of 1865 . He was afterwards owned by Monmouth Lawson, Thomas Lawson, George Tiemons, Samuel Lippincott, Harvey Sain, Peter Hammer. Kept all these years in Coles and Douglas Counties, at a service fee of from $\$ 7$ to $\$ 10$, and died 1889 .

Green Mountain Morgan was the sire and grandsire of Black Belle. Her dam was a black mare bred by John Walling to Green Mountain Morgan. The dam of the black mare was a chestnut bred to Green Mountain Morgan by James Qe Sain.

John Dora, an extensive farmer and cattle feeder, bought Black Belle of John Walling, one of his tenants, when she was a yearling for $\$ 30$, and used her when she grew up as a cattle horse and business driver, when old and somewhat used up on the road he bred her to Dr. Herr.

She produced four foals by him, Pilot, a noted gelding in Chicago; Dora H., dam of Paris and others ; Cora, dam of Arguenaut and others ; and Dr. Herr, sire of Katy Flyer. Dr. Herr was never developed, but was ridden and driven; produced some good colts. Dam of Katy Flyer, 
Maud, the 22-year-old mare, was also got by Green Mountain Morgan as above. She has always been used as a farm, work and driving mare.

Horses were cheap and plentiful and John Dora was the largest cattle and mule feeder and farmer in this part of the country, and bred these horses for his own use as business horses. I was his live stock buyer and manager from 1883 until his death in I904, and I desire to perpetuate the blood of his horses, the Morgans, through Kate Flyer and her dam, Maud.

Sire of Black Belle, 3 d dam of fohn $M ., 2: 02 \frac{3}{4}$, A. J. Glick, $2: 10$; also sire of dam of Black Belle (3d dam of Fohn M.).

GREEN MOUNTAIN MORGAN (JIM) (I-I6), chestnut, with stripe on face, between 15 and 16 hands high, about 1200 pounds; bred by Hannan Fox, East Fairfield, Vt., and said to be Morgan. Sold to Mr. Conger ; to Mr. Dustin, Dickinson, N. Y. ; to A. D. Weller.

GREEN MOUNTAIN MORGAN (WIER'S) (3-I6), chestnut, III3 pounds; foaled 1846 ; said to be by Green Mountain Morgan: and dam by Morgan Cock of the Rock. Exhibited at National Exhibition of Horses, Springfield, Mass., I 853 , by F. A. Wier of Walpole, N. H., and spoken of as a Morgan horse of great beauty and fine action. Description and pedigree as above.

GREEN MOUNTAIN MORGAN JR. (I-I6), dark bay; foaled I 848 : dam Morgan mare raised in Vermont. Advertised, $\mathbf{I} 846$, in Greenfield Gazette, as above, by Charles Holman, Royalton, Mass. Advertised again in 1847 at Mansfield, N. H.

GREEN MOUNTAIN MORGAN JR. ( $\mathrm{I}-32)$, chestnut sorrel, I6 hands, I 000 pounds; said to be by Green Mountain Morgan Jr. Sold at Lexington for \$I $\$ 500$.

GREEN MOUNTAIN SHERMAN (I-8). Awarded first premium for best stallion at the Ogle County Fair, Illinois, I854. Entered by Mr. Wetherby.

GREEN MOUNTAIN TIGER (I-I6); foaled I855. Awarded third premium for best two-year-old at Iowa State Fair, 1857. Owned by D. R. Warfield of Muscatine County.

GREEN MOUNTAIN TRAVELER ( $\mathrm{I}-4)$. Advertised, I83I, in the Danville (Vt.) North Star by John Brown of Lyndon at Wheelock, Danville, St. Johnsbury and Lyndon, Vt. "Dark chestnut and as fine figure as can be produced in New England." Advertised, I 833 , under name of The Traveler at Danville, Cabot and Marshfield by D. P. Dana \& Co., and described as six years old and about $\mathrm{r}_{5}$ hands.

GREEN RIVER (I-32), $2: 22 \frac{1}{4}$, bay I 6 hands, I 200 pounds; foaled I 887 ; bred by Robert Dixon, Henderson, Ky. ; got by Princeps, son of Prin- 
ceps, by Woodford Mambrino: dam Maria, bay, bred by Robert Dixon, got by Marabout, son of Alexander's Abdallah; $2 \mathrm{~d}$ dam Nannie Dixon, black, bred by Geo. M. Priest, Henderson, Ky., got by Velox, son of Young Morrill; 3d dam Lura (thoroughbred), said to be by imported Consternation; and $4^{\text {th }}$ dam by Gray Eagle. Died IS92. Pedigree from breeder.

Sire of Lottie F., $2: 2 I_{1 / 2}$.

GREENSBURG ( I-64), bay ; foaled I 884 ; bred by M. J. Ridgway, LaPorte, Ind.; got by Lucas Broadhead, son of Harold : dam Maud Medium, bay, bred by Robert Steele, Philadelphia, Penn.; got by Happy Medium, son of Hambletonian; 2d dam Sophie, bred by Joseph Sill, Recklestown, N. J., got by California Patchen, son of George M. Patchen Jr.

Sire of Marion J., $2: 25 \frac{1}{4}$; I sire of $\mathbf{s}$ trotter.

GREENVILLE (3-5 12), brown; foaled I 888 ; bred by S. B. Madden, Mason, Mich.; got by Greenbacks, son of Princeps : dam Daisy, bay, bred by S. B. Madden, Mason, Mich. ; got by Trophy, son of Enchanter ; 2 d dam Flora, said to be by Censor, son of Washington Hambletonion; and 3d dam by Sir Henry. Pedigree from breeder.

Sire of Bessie Orr, $2: 161 / 4$.

GREENIVAY ( $1-64$ ), $2: 25$, brown; foaled I 888 ; bred by Augustus Sharpe, Louisville, Ky. ; got by Greenlander, son of Princeps, by Woodford Mambrino: dam Aurelia (dam of Greenlander Girl, $2: 14^{1} / 2$ ), bay, bred by Leland Stanford, Menlo Park, Cal, got by Electioneer; 2d dam Aurora, $2: 27$, chestnut, bred in California, said to be by John Nelson, by a son of imported Trustee; 3d dam Lamott Mare. Sold to W. H. Dillingham, Louisville, Ky., who sends pedigree; to G. W. Bicksler, St. Louis, Mo.

Sire of 2 pacers $\left(2: 19 \frac{1 / 4}{4}\right)$.

GREENWICH (I-256), bay; foaled I 882 ; bred by R. S. Veech, St. Matthews, Ky.; got by Princeps, son of Woodford Mambrino: dam Tinsel, bay, bred by Charles Backman, Stony Ford, N. Y., got by Messenger Duroc, son of Hambletonian; 2d dam Bess, bay, bred by Charles Backman, Orange County, N. Y., got by Hambletonian, son of Abdallah; 3d dam Jessie Sayre, brown, bred by Decatur J. Sayre, Orange County, N. Y., got by Henry Clay, son of Cassius M. Clay Jr.; 4th dam said to be by Liberty, son of Lance.

Sire of Prince Albert, $2: 2 \mathrm{I}^{1 / 4}$.

GREENIVOOD ( $1-25^{6}$ ), bay with star, $15 \frac{1}{2}$ hands, Iooo pounds at three years old ; foaled in I 886 ; bred by George Cummings, Boston, Mass.; got by Victor Patchen, son of Tom Patchen, by George M. Patchen : dam Rosetta, bay, bred by Sprague \& Akers, Kansas Stud Farm, Law- 
rence, Kan., got by Andrew Johnson, son of Mambrino Chief. Pedigree from the Oxford County Trotting Horse Breeders' Association catalogue sent by E. M. Thayer, South Paris, Me.

Sire of Fernwood, $2: 23 \frac{1}{4}$.

GREENWOOD; said to be by Elwood.

Sire of Lizzie Borden, 2:30.

GREENWOOD ( $1-32$ ), mahogany bay, I 6 hands, I 200 pounds; foaled about r 888 ; bred by A. J. Hough, Orwell, Vt.; got by Blackwood, son of Alexander's Norman : dam bay, bred by A. J. Hough, Orwell, got by Vermont Volunteer, son of Goldsmith's Volunteer; $2 \mathrm{~d}$ dam bay, bred by J. H. Thomas, Orwell, Vt., got by Young Columbus. Information from L. Clyde Barber, Sudbury, Vt.

GREGORIAN (3-128), $2: 293 / 4$, chestnut; foaled 1880 ; bred by Charles Backman, Stony Ford, N. Y. ; got by Prince George, son of Kentucky Prince, by Clark Chief : dam Beltina, chestnut, bred by Charles Backman, Stony Ford, N. Y., got by Mansfield, son of Messenger Duroc, by Hambletonian; 2d dam Beatrice, bay, bred by Charles Backman, got by Hambletonian; 3 d dam Lady Talmage (dam of Squire Talmage), chestnut, bred by James Clark, Wawayanda, Orange County, N. Y., got by American Star. Sold to W. H. Hill, Worcester, Mass.; to George D. Bennett, Goldsboro, N. C. ; to L. Banks Holt, Graham, N. C.

Sire of 2 trotters $\left(2: 19 \frac{1}{4}\right)$; Glencoe, $2: 17 \frac{1}{4}$.

GREGOR MCGREGOR (5-128), $2: 301 / 4$, bay with blaze, and white stockings behind, I 6 hands, II 75 pounds; foaled I 884 ; bred by John Dunning, Topeka, Kan.; got by Robert McGregor, son of Major Edsall : dam Kate Dunning, bay, bred at Topeka, Kan., said to be by Wetherland, son of Manhattan; and $2 \mathrm{~d}$ dam Sweet Laura, bay, by Volunteer, son of Hambletonian. Sold to John Foley, Topeka, Kan., to W. A. Randolph, Emporia, Kan., who sends pedigree. Died 1902.

Sire of Miss McLain, $2: 281 / 2$.

GRENADIER ( I-64), bay; foaled I 873 ; bred by R. S. Veech, Louisville, Ky. ; got by Princeps, son of Woodford Mambrino: dam Dawn, gray, bred at Woodburn Farm, Ky., got by Belmont, son of Alexander's Abdallah; 2 d dam Midnight, gray, bred by R. A. Alexander, Woodburn Farm, Ky., got by Pilot Jr. ; 3 d dam Twilight, said to be by Lexington ; and $4^{\text {th }}$ dam Daylight, by imported Glencoe. Sold to Conway Bros., Orange, Ind.; to Ray Warner, Cold Water, Mich.; to John Wood, Indianapolis, Ind.; to Sillick \& Berry, Quincy, Mich.; to George E. Adams, Pittsburg, Penn.; to J R. Rippey, Columbia, Mo.

Sire of Grandee, $2: 29 \frac{1}{2} ; 3$ dams of 2 trotters, 1 pacer.

GRENNAN (3-128), black; foaled I887; bred by G. \& C. P. Cecil, Dan- 
ville, Ky.; got by Gambetta Wilkes, son of George Wilkes : dam Grenade, bay, bred by R. S. Veech, St. Matthews, Ky., got by Princeps, son of Woodford Mambrino; 2 d dam Flora, brown, bred by Charles M. Reed, Erie, Penn., got by Volunteer, son of Hambletonian; 3d dam Flora Belle, bay, bred by Harrison Dills, Quincy, Ill., got by Stevens' Uwharie; $4^{\text {th }}$ dam Kit. Pedigree from catalogue of breeder.

Sire of May Lady, $2: 24 \frac{1}{4}$.

GREX (I-I 28 ), $2: 23 \frac{1}{4}$, black; foaled I 888 ; bred by G. \& C. P. Cecil, Danville, Ky.; got by Gambetta Wilkes, son of George Wilkes : dam Walie Sprague, black, bred by J. W. Wale, Garnettsville, Ky., got by Gov. Sprague ; $2 \mathrm{~d}$ dam Lida, said to be by Golddust, son of Vermont Morgan; 3d dam Blaze, by Booker's Boston; and $4^{\text {th }}$ dam thoroughbred Ailsie Scroggins, by Giles Scroggins. Pedigree from catalogue of breeder. Sold to H. A. Moyer, Syracuse, N. Y. ; to Joseph Marrian, Watertown, N. Y.

Sire of 2 pacers $(2: 201 / 4)$.

GRIFFARD, said to be by Lepine Horse.

Sire of Balmoral Boy, $2: 29 \frac{1}{2}$.

GRIFFIN (BARNARD) ( $1-256), 2: 29 \frac{1}{4}$, bay; foaled $\mathrm{r} 883$; bred by Charles Backman, Stony Ford, N. Y.; got by Messenger Duroc, son of Hambletonian: dam Gimp, bay, said to be by Princeps, son of Woodford Mambrino ; 2d dam Favorita, bred by O. P. Beard, Lexington, Ky., got by Alexander's Abdallah; 3 d dam said to be by Mambrino Chief; $4^{\text {th }}$ dam by Tom Crowder; and $5^{\text {th }}$ dam by Gray Eagle, thoroughbred.

Sire of W. R. C., $2: 18 \frac{3}{4}$, Lady Golddust, $2: 20$; I dam of I pacer.

GRIMALKIN, bay; foaled I 882 ; bred by R. S. Veech, St. Matthews, Ky. ; got by Princeps, son of Woodford Mambrino, by Mambrino Chief : dam Fallacy (dam of LeClede), said to be by George Wilkes; and 2d dam by Nonpariel, son of Long Island Black Hawk, by Andrew Jackson, son of Young Bashaw, by Grand Bashaw (Arabian),

Sire of 2 trotters $(2: I 61 / 4)$.

GRIS D'ARGENT. Advertised, I832, at St. Remey, at \$4; also Sir Solomon and Etalon Canadien at $\$ 4$; by Francois Fresue of Côte des Neiges.

GRISWOLD'S WILKES. Untraced.

Sire of Lady Travis, 2 : I6.

GROSJEAN ( $1-\mathrm{I}_{2} 8$ ), bav, star and snip, right hind ankle white, $151 / 2$ hands, I050 pounds; foaled May 25, I 883 ; bred by A. J. Alexander, Spring Station, Woodford County, Ky., got by Belmont, son of Alexander's Abdallah: dam Sue Dudley, bay, bred by R. A. Alexander, got by Edwin Forrest; 2d dam Madame Dudley, gray, bred in New Jersey, said to be 
by a Bashaw horse. Owned successively by A. J. Alexander, and H. S. Denny \& Bros., Ligonier, Penn., who send pedigree.

Sire of 3 trotters $\left(2: 2 I^{1} / 4\right), 2$ pacers $\left(2: 17 \frac{1}{4}\right)$.

GROSVENOR (I-I28), brown; foaled I878; bred by Jos. L. Woolfolk, Lexington, Ky. ; got by Administrator, son of Hambletonian : dam Sylva, bay, bred by Joseph L. Woolfolk, got by Edwin Forrest, son of Young Bay Kentucky Hunter ; 2 d dam Corinne, brown, bred by Jos. Woolfolk, got by Mambrino Chief, son of Mambrino Paymaster; 3 d dam Betty, bay, bred by David Castleman, Fayette County, Ky., got by Hunt's Commodore; 4th dam Bet Bounce. Sold to R. P. Pepper, South Elkhorn Stock Farm, Frankfort, Ky. ; to J. E. Day, Chicago, Ill., I881, by P. C. Kidd's combination sale at Lexington, Ky. Pedigree from breeder.

Sire of Lady Grosvenor, $2: 27$; I dam of I trotter.

GROUSE; bred by Gen. Callender Irving of Philadelphia; got by Eclipse : dam Erie, by Sir Solomon; 2d dam Grand Duchess (dam of Busiris). Advertised as above, I850, at James Atchison's, three miles from Lexington, Ky., on the old Maysville road, at place known as "Wright's Pond."

GROVER CLAY (1-256), $2: 23 \frac{1}{4}$, bay; foaled 1884 ; bred by W. W. Taylor, San Francisco, Cal. ; got by Electioneer : dam Maggie Norfolk, said to be by Norfolk, thoroughbred, son of Lexington; and $2 \mathrm{~d}$ dam Tilda Quill, by Billy Cheatham, son of Cracker, by Boston.

Sire of Clay S., $2: 13 \frac{3}{4}$.

GROVER CLEVELAND (I-32), $2: 183 / 4$, bred by Edwin Emery, West Poland, Me.; got by Redwood, son of Belmont: dam black, purchased when two years old by Mr. Emery of a Mr. Perkins, Oxford, Me., said to be by Sherwood (Black Joe), son of Tom Patchen; and $2 \mathrm{~d}$ dain by Winthrop Morrill. Gelded young.-Turf, Farm and Home, Auburn, $\mathrm{Me}$., 1893 .

G. SEE (1-256), bay horse ; foaled 1883 ; bred by Wm. N. Rue, Danville, Ky.; got by Onward, son of George Wilkes: dam Fanny Neale, bred by F. R. Neal, Washington County, Ky., got by Star Denmark ; 2 d dam Sally Neale (dam of Hambrino Belle, $2: 25 \frac{1}{2}$ ), said to be by Mambrino Chief; and $3 \mathrm{~d}$ dam by Terror. Sold to Cecil and Williams, Danville, Ky.

Sire of Kate Thomas, $2: 24 \frac{1}{2} ; 3$ pacers $\left(2: 13 \frac{3 / 4}{)}\right.$

GUADALQUIVER See Dignus (Guadalquiver).

GUALDO ; said to be by Sidney, son of Santa Claus. Sire of Fanny T., $2: 24 \frac{1}{4}$. 
GUARANTEE (I-16), bay, I53/4 hands, Iooo pounds; foaled 1871 ; bred by J. W. Sanborn, Cornish, Me.; got by Tom Patchen, son of George M. Patchen : dam Gorden Mare, bred by Dr. Bradley, Fryburg, Me., got by Tom Hegan, son of Hidden Horse ; 2 d dam bred by Dr. Bradley, got by Whalebone Morgan, son of Sherman Morgan ; $3 \mathrm{~d}$ dam bred by Dr. Bradley, got by Whalebone Rattler, son of Sherman Morgan ; $4^{\text {th }}$ dam said to be Messenger. Sold to S. W. Fowler, Freedom, N. H., who sends pedigree. Died 1896 .

Sire of 3 trotters $(2: 261 / 2)$.

GUARDSMAN, $2: 23 \frac{1}{2}$, brown; foaled 1885 ; bred by P. S. Talbert, Lexington, Ky.; got by Alcyone, son of George Wilkes: dam Que Vive, brown, bred by Ab. Allen, Lexington, Ky., got by Sentinel, son of Hambletonian; $2 \mathrm{~d}$ dam Missie, said to be by Brignoli, son of Mambrino Chief.

Sire of 5 trotters $\left(2: 14^{1 / 4}\right)$.

GUELPH (1-256), $2: 22^{1 / 2}$, brown, 16 hands, I300 pounds; foaled 1882 ; bred by R. S. Veech, St. Matthews, Ky. ; got by Princeps, son of Woodford Mambrino: dam Merry, bred by Charles Backman, Stony Ford, N. Y., got by Messenger Duroc, son of Hambletonian; 2d dam Bonnie Lassie, bay, bred by Charles Backman, got by Hambletonian; 3d dam said to be by Foxhunter. Owned successively by A. Sharpe, Louisville, Ky., Fred Seacord, Galesburg, Ill., who sends pedigree, and A. Turner \& Son, Red Oak, Ia.

Sire of 3 trotters $(2: 261 / 4), 2$ pacers $\left(2: 18 \frac{1}{2}\right) ;$ I dam of $I$ trotter.

GUIDE (1-32), brown, I6 $1 / 2$ hands; foaled 1871 ; bred by G. A. B. Shaw, St. Paul, Minn.; got by Swigert, son of Norman : dam Nelly, said to be by Richard's Bellfounder, son of Hungerford's Blucher, by Blucher, thoroughbred, son of Duroc; 2d dam Lady Mary, by Signal, son of Rob Roy, by Rob Roy; and 3d dam Kate, said to have been foaled I 834, and brought from Connecticut. Sold to Isaac Staples, Stillwater, Minn.

Sire of Zig, 2:25; I sire of 1 trotter; 17 dams of 15 trotters, 4 pacers.

GUIDE ( I-32), $2: 24^{\mathrm{T}} / 2$, seal brown, no marks, $15 \frac{1}{4}$ hands, 1047 pounds; foaled r 885 ; bred by A. T. Hatch, Suisun, Solan County, Cal.; got by Director, son of Dictator, by Hambletonian: dam Imogene, bay, bred by Judge Wilkins, Middletown, N. Y., got by Norwood, son of Hambletonian ; $2 \mathrm{~d}$ dam bred by Judge Wilkins, got by American Star ; $3 \mathrm{~d}$ dam said to be by Harry Clay, son of Cassius M. Clay Jr.; $4^{\text {th }}$ dam bought of D. B. Gowie, Middletown, N. Y., who bought of Judge Wilkins. Sold to Samuel Gamble for Daniel Cook, San Francisco; to A. T. Hatch. Pedigree from breeder.

Sire of 4 trotters $\left(2: 17 \frac{1}{2}\right)$. 
GUILFORD BOY (I-64), bay, I5 hands, 900 pounds; bred by Pingree Hoyt, Laconia, N. H. ; got by Dauntless, son of Hambletonian : dam said to be by Young Time, son of Kossuth.

Sire of Lucy K., $2: 261 / 4$, Cato, $2: 231 \frac{1}{2}$.

GUILFORD DUDLEY ( $1-128), 2: 30$, gray; foaled 1890 ; bred by Glenview Farm, Louisville, Ky.; got by Egotist, son of Electioneer : dam Belle Dudley (dam of Dodd Peet, 2 :I8), gray, bred at Woodburn Farm, Ky., got by Belmont, son of Alexander's Abdallah ; 2d dam Madam Dudley (grandam of Mambrino Dudley, $2: 193 / 4$ ), gray, bred in New Jersey, said to be by a Bashaw horse. Sold to S. Toomey, Canal Dover, O.

Sire of Annie Dudley, $2: 261 / 4$.

GUINDON HORSE, black, I5 hands, rooo pounds; bred in Canada. Owned by Mr. Guindon, Ferrisburgh, Vt., about I 830 , perhaps earlier. C. W. Atwood, Starksboro, Vt., who gave this information in 1888 , said:

"He was a Morgan made horse splendid looking, left the best of stock. Bidwell of Starksboro had a stallion by him."

See Magnum Bonum.

GULVALLIS (3-128), black, 15 t/2 hands, I 200 pounds ; foaled 1884 ; bred by Frank S. Barbour, Prospect, Ky.; got by Harry Wilkes, son of George Wilkes : dam Emma Barbour, brown, bred by Frank S. Barbour, got by St. Almo, son of Almont; 2 d dam Bessie, said to be by Getaway, son of Gossip Jones; 3d dam Ellen, by Valparaiso, son of imported Valparaiso ; and $4^{\text {th }}$ dam by Collector. Sold to J. K. Thomson, Earlham, Ia., who sends pedigree; to R. E. Holmes, Redfield, Ia.

Sire of Bessie Cecil, $2: 291 / 2$.

\section{GURNEY (SMITH'S). See Silliman Morgan.}

GURNSEY ( $\mathrm{I}-32$ ), bay with snip, I53/4 hands, II 75 pounds; foaled I887; bred by Robert Prewitt, Athens, Ky. ; got by Hector Wilkes (foaled in $\mathbf{I} 882$, and died in I888), son of George Wilkes: dam Young Secesh, said to be by Legal Tender Jr. (dam Blackbird, by Cameron Horse, son of Blackburns' Davy Crockett), son of Legal Tender; $2 \mathrm{~d}$ dam Secesh, by Blue Bull; and $3 \mathrm{~d}$ dam Nell, by Pocahontas Boy, son of Tom Rolfe. Sold to William Stranathan, Cumberland, O., who sends pedigree.

Sire of Elmer D., $2: 12^{3} / 4$.

GUSTO (3-1 28), brown; foaled 1888 ; bred by G. \& C. P. Cecil, Danville, Ky. ; got by Gambetta Wilkes, son of George Wilkes : dam Annie Patchen, bay, bred by A. G. Talbot \& G. \& C. P. Cecil, got by Mambrino Patchen; 2d dam Annie Wolford, said to be by Frank Wolford, son of Telegraph; $3^{\text {d dam }}$ by Len. Rogers; and 4 th dam by Marengo. Pedigee from catalogue of breeder.

Sire of 3 trotters $\left(2: 18 \frac{1}{4}\right), 6$ pacers $(2: 061 / 2): 2$ dams of 2 trotters. 
GUS VOLTZ (I-64), $2: 293 / 4$, bay, I6 hands, II 50 pounds; foaled I 887 ; bred by G. A. Voltz, Kenosha, Wis.; got by Phallas, son of Dictator : dam Grace Murray, seal brown, bred by Timothy Anglin, Lexington, Ky., got by George Wilkes, son of Hambletonian ; $2 \mathrm{~d}$ dam Betty Brown, bred by Timothy Anglin, got by Mambrino Patchen ; $3 \mathrm{~d}$ dam Pickles, said to be by Mambrino Chief; and $4^{\text {th }}$ dam by Gray Eagle. Sold to Barney Tracey ; to H. M. Fleurs; to G. A. Voltz, who sends pedigree.

Sire of Silvia Doll, $2: 20$.

GUY (1-128), $2: 063 / 4$, gray; foaled 1883 ; said to be by Shiloh, which see : and dam Maud, by Shoo Fly, which see.

Sire of 2 pacers $\left(2: 17^{1 / 4}\right)$.

GUY ALLEN (I-32), $2: 323 / 4$, black, 16 hands; foaled 1887 ; bred by $\mathrm{H}$. M. Littel, Macedon, N. Y.; got by St. Armand, son of Cuyler : dam Marplot, bay, bred by Dr. S. H. Chew, Lexington, Ky.; got by Almont son of Alexander's Abdallah; 2d dam Helen McGregor, bay, said to be by Rattler, son of Stockbridge Chief; 3 d dam by Brignoli, son of Mambrino Chief; and $4^{\text {th }}$ dam by Alexander's Pilot Jr. Sold to Fitch Bros., Hamilton, Can., who send pedigree.

Sire of Little Buck, $2: 191 / 4$.

GUY C. (I-64), $2: 14^{1 / 2}$, chestnut, I 6 hands; foaled I 886 ; bred by Chas. P. Ward, Aylsworth, Ind.; got by Bald Hornet, $2: 2 \mathrm{I}$ : dam Peggy (dam of Venture, $2: 09 \mathrm{I} / 2$ ), said to be by Haywood, son of Blackwood; 2d dam Lady, by Ward's Dexter; and 3d dam Fanny, by Lemon's Boston. Owned by B. H. Coffing, Covington, Ind.

GUY CORBITT ( $1-32$ ), bay ; foaled 1888 ; bred by Wm. Corbitt, San Mateo, Cal.; got by Guy Wilkes : dam Minnie Wilkes, bay, bred by L. J. Rose, Los Angeles, Cal., got by Sultan, son of The Moor; $2 \mathrm{~d}$ dam Kitty Wilkes, bay, bred by Wm. L. Simmons, Lexington, Ky.; got by George Wilkes, son of Hambletonian ; 3 d dam Snip Nose, bay, bred by Thomas Coons, Lexington, Ky., got by American Clay, son of Cassius M. Clay Jr.; 4th dam said to be by Bay Messenger (Downing's), son of Harpinus. Sold to Vincent C. Cromwell, Lexington, Ky. ; to Oliver Posey \& Son, Rushville, Ind.; to William Morrow \& Son, Nashville, Tenn.; to J. H. Kincaid, Athens, Ill.

Sire of 2 trotters $(2: 17 \%)$.

GUY DARRELL (3-128), bay; foaled 1884; bred by Ayres \& Russell, Duckers, Ky. ; got by Onward, son of George Wilkes : dam Fidget, brown, bred by R. P. Pepper, Frankfort, Ky., got by Almont, son of Alexander's Abdallah; 2 d dam Coquette, chestnut, bred by R. A. Alexander, Spring Station, Ky., got by Pilot Jr.; 3d dam Forty Cents, said to be by Wagner ;

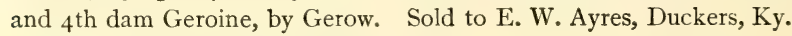

Sire of 2 trotters (2:25); Rejected Sid, $2: 22 \frac{1}{4}$. 
GUYDIRWOOD (I-32), bay; foaled I 893 ; bred by H. L. \& F. D. Stout, Dubuque, Ia.; got by Nutwood, son of Belmont: dam Essie, bay, bred by Wm. Corbit, Burlingame, Cal., got by Guy Wilkes, son of George Wilkes ; 2d dam Directress, black, bred by William Corbitt, San Mateo, Cal., got by Director, son of Dictator; 3 d dam Alice Clay, black, bred by R. P. Pepper, Frankfort, Ky. ; got by Almont, son of Alexander's Abdallah ; 4th dam Rosa Clay, brown, bred by Edward Oldham, Fayette County, Ky., got by American Clay, son of Cassius M. Clay Jr. Sold to Reed Fritz, Easton, Penn.; to Thomas Newman; to Wallace L. Hubbs, Phillipsburgh, N. J. ; to Charles E. Still, Kirksville, Mo.; to C. N. Petigrew, Seymour, Ia. ; to O. O. Littrell \& Co., Corydon, Ia.

Sire of Matanzas, $2: 21$.

GUY FAWCETT, $2: 3 \mathrm{I}$, chestnut, 15 I/2 hands, 1000 pounds; bred by R. G. Stoner, Paris, Bourbon County, Ky. ; got by Strathmore, son of Hambletonian : dam Virgie, bay, said to be by Alexander's Abdallah. Sold to R. G. West ; to Woodward \& Brasfield ; to James F. Carpenter; to H. W. Fawcett, New Albany, Ind., who sends pedigree Died I9oo.

Sire of Belle Orr, $2: \mathrm{II}^{1 / 4} / 4$

GUY K. ( $1-32$ ), gray; foaled I 883 ; bred by Mathew Dugan, Loveland, O. ; got by Guy Wilkes, son of George Wilkes : dam Lady K., bay, bred by Michael Cavanaugh, Cincinnati, O.; got by Gen. George H. Thomas, son of Mambrino Messenger; 2 d dam, Lady Crane, said to be by Fazoletta; and $3 \mathrm{~d}$ dam by Tom Crowder, son of Pilot.

Sire of 2 trotters $\left(2: 27 \frac{1}{2}\right)$; Dr. Haile, $2: \mathrm{II}^{1} \frac{1}{4}$; I sire of 3 pacers; I dam of I trotter.

GUY KOHL (3-I 28), bay, small star, right hind ankle white; foaled I 887 ; bred by William Corbitt, San Mateo, Cal.; got by Guy Wilkes, son of George Wilkes : dam Mamie Kohl, bay, bred by William Kohl, San Mateo, Cal., got by Steinway, son of Strathmore ; 2 d dam Lady Blanchard, gray, bred in California, said to be by Hambletonian (Whipple's), son of Guy Wilkes; and $3 \mathrm{~d}$ dam Lady Livingston, gray, bred in California, got by Gen. Taylor, son of Morse Horse. Sold to C. F. Clark, Boston, Mass. Pedigree from catalogue of breeder.

Sire of Genevieve, 2:181/4, Guy Kohl fr, $2: 23$.

GUY MILLER, bay with black points, 15 I/2 hands; foaled 1855 ; bred by Philander Banker, Goshen, N. Y. ; got by Hambletonian : dam bay, bred by Col. Wheeler, Florida, N. Y., got by Nanny's Bolivar. Sold to Mr. Guy Miller, when a weanling, who kept him till three years old, trotted him in a three-year-old race at Goshen, won it in three minutes and sold him for $\$ 500$, to R. H. Galloway, who traded him for the mare Princess, then in foal with Happy Medium. Went to California, I869, and died soon after. 
Above information from Mr. Guy Miller, Chester, N. Y., March, r, I907, who further writes:

Mr. Joseph BatTell:

I have filled out blank and will state further that I purchased the horse Guy Miller, of Philander Banker his breeder, as a weanling and sold him to R. F. Galloway on the Goshen track as a three-year-old the day after he had beaten a good field of three-year-olds, doing the mile in three minutes. It is also a fact that as a four-year-old this colt was matched against Robert Fillingham (Geo. Wilkes) for \$250 a side to trot mile heats on the Union Course, L. I., Felter paid forfeit and it was said that Fillingham showed so much speed that Felter did not wish to show it. It is my memory that Whipple's Hambletonian was bred by Elijah Coxe, Cornwall, N. Y., and got by Guy Miller while Galloway owned the latter. Guy Miller, Whipple's Hambletonian, and also his dam, were taken together to California. I think the dam of Whipple's Hambletonian went away in foal to Hambletonian and produce was a good horse, yet I seem to be unable to recall the horse. Guy Miller served no mares after his arrival in California.

He was a horse of splendid individuality, good head, clean long neck with open jowls, hair that indicated fine breeding, as to legs and feet, I knew of nothing better at the time. He was the first three-year-old to trot a mile in three minutes, which he did, whilst I owned him, at the Orange County Fair at Goshen, 1858 . Trotted in $2: 30$, in California soon after arrival.

Drift was bred by Gabriel Seeley, got by Hambletonian: dam by Saltram. I knew this mare. I know Gabriel Seely of Chester bred Drift, he also bred a full brother Almack, that Rysdyk purchased and started at Goshen with Wild Warrior as a four-year-old. Almack was about as good as his brother Drift.

I laid your inquiry aside when very busy, and did not imagine it would be so long; however, it is only a matter of months till I will have attained three score and ten years if I live, and with about ninety head of stock on my hands I have little time, yet it is a pleasure to give any information in my power. I am,

\section{Very truly yours, Guy MiLLer.}

"The first horse that Mr. Miller ever owned was the stallion Guy Miller, by Hambletonian: dam by Nanny's Bolivar. He purchased him as a weanling for $\$ I 35$, almost his years wages, kept him until three years old, trotted him in the three-year-old race at Goshen, won it in three minutes, and sold him for $\$ 500$, to R. F. Galloway, who drove him in the race. As a four-year-old the horse trotted at Middletown in $2: 45$. After that he trotted several races, and received forfeit from the Felter colt; now George Wilkes. In I $\$ 60, \mathrm{Mr}$. Galloway sold him to California parties for $\$ 3500$, and the noted trotting mare Princess, since owned by Mr. Bower. Princess had been bred to Hambletonian, but was not supposed to be in foal. She chanced to be, however, and dropped Happy Medium as the result. The horse Guy Miller afterwards went to California, where he died before he was tried in the stud."-Wallace's Monthly, Vol. I., p. 478 .

Sire of I sire of 3 trotters.

GUY MILLER JR. (SAYRE'S) (I-64), brown, I6 hands; foaled I 86 I ; bred by R. Sears, Goshen, N. Y.; got by Guy Miller, son of Hamble- 
tonian : dam Sharples' Abdallah, brown, foaled about 1850 , bred by Hall Vail, Kingsbridge, Penn., got by Abdallah; $2 \mathrm{~d}$ dam a mare raised in Otsego County, N. Y., and said to be by One-Eyed Kentucky Hunter. Sold to Daniel Sayre, and John R. Halstead, Unionville, N. Y.

Sire of 3 trotters $(2: 231 / 2)$; I sire of 3 trotters; I dam of I trotter.

GUYMOOR ( $1-32)$, bay, $153 / 4$ hands; foaled 1888 ; bred by William Corbitt, Burlingame, Cal.; got by Guy Wilkes, son of George Wilkes : dam Atalanta, brown, bred by L. J. Rose, Sunny Slope, Los Angeles, Cal., got by the Moor, son of Clay Pilot; 2 d dam Minnie-ha-ha, bay, bred by Geo. C. Stevens, Milwaukee, Wis., got by Bald Chief (Stevens'), son of Alexander's Bay Chief; 3 d dam Nettie Clay, said to be by Cassius M. Clay Jr. ; and 4th dam Col. Morgan's mare by Abdallah. Sold to Judson H. Clark, Elmira, N. Y.; to Macey Bros., Versailles, Ky., who sends pedigree ; to Lister Witherspoon, Versailles, Ky. ; to Johnson P. Weaver, Tremont City, Ohio.

Sire of Maid of the Mist, $2: 29 \frac{3}{4}$.

GUY PRINCETON ( $1-5 \mathrm{I} 2) \quad 2: 28 \frac{1}{4}$ ( $2: 29 \frac{1}{4}$ pacing), brown with star, white hind legs, $153 / 4$ hands, I 7 o pounds; foaled I 887 ; bred by B. T. Buford, Louisville, Ky., got by Princeton, son of Princeps : dam Wait-abit, dam of Harkaway, $2: 28 \frac{1}{4}$, which see. Sold to C. A. White, Danville, Ind., who sends pedigree from Kankakee, Ill., July r, I 89 I.

Sire of Jesse O., $2: 28 \frac{1}{4} ; 5$ pacers $\left(2: 09 \frac{1}{4}\right)$.

GUY SHERIDAN (3.64), bay, I5 1/2 hands, Io 80 pounds; foaled 1885 ; bred by Edward Pyle, Syracuse, Neb.; got by Charles Caffrey, son of Gen. Knox : dam bay, bred by Edward Pyle, then of Philadelphia, Penn., got by Yoeman, son of Toronto Chief ; $2 \mathrm{~d}$ dam bay said to be by Conklin's American Star. Pedigree from breeder.

GUY STRATAGEM (3-64), bay, 15 ז $/ 2$ hands; foaled 1885 ; bred by T. N. Braxtan, Paoli, Ind. ; got by Guy Faucett, son of Strathmore : dam Lucy, bay, bred by T. N. Braxton, got by Billy ; 2 d dam Fanny, chestnut, bred by T. N. Braxton, got by Green Mountain Morgan ; $3 \mathrm{~d}$ dam Morgan Belle, chestnut, bred by John Gregory of Vermont, got by Comet, son of Billy Root. Died about I 899 . Pedigree from breeder.

Sire of 2 pacers $\left(2: 16 \frac{1}{2}\right)$.

GUYTHURTON (I-16), bay with star, $15 \frac{1}{2}$ hands, rooo pounds; foaled I 888 ; bred by William Corbitt, San Mateo, Cal. ; got by Guy Wilkes, son of George Wilkes : dam Huntress, brown bred by William Corbitt, got by Arthurton, son of Hambletonian; 2d dam old Huntress, said to be by Skenandoah, son of Broken Leg Kentucky Hunter; 3d dam Susette, by Dave Hill (Easton's), son of Black Hawk. Sold to J. H. Osterhout, Troy, N. Y., who furnishes the above information. Died I 892 . Sire of Peter Clinch, $2: 24^{1} \frac{1}{4}$, Philadelphia Boy, 2:231/4. 
GUY WILKES (3-256), $2: 15 \frac{1}{4}$, bay, $15 \frac{1}{2}$, hands; foaled 1879 ; bred by William Dunn, Cincinnati, O.; got by George Wilkes, 2 :22 : dam Lady Bunker, chestnut, foaled 1873 (dam of El Mahdi, $2: 25 \mathrm{I} / 2$ ), bred by William Dunn, got by Herr's Mambrino Patchen; 2 d dam Lady Dunn (dam of Joe Bunker, $2: 19 \frac{T}{4}$ ), bred by Charles Roberts, Middletown, N. Y., got by Seeley's American Star, sold after the death of Chas. Roberts, to a Mr. McQuail and when four years old to F. J. Nodine, who sold to a Mr. Whitney and his executors, to William Dunn, whose property she died; 3d dam Capt. Roberts' mare, untraced. Sold before reaching maturity to Wm. Corbitt, San Mateo, near San Francisco, Cal.; to W. J. White, Rockport, O.-From Article in American Horse Breeder, February, 1902.

Sire of $7 \mathbf{r}$ trotters $\left(2: 07 \frac{3}{4}\right), 8$ pacers $\left(2: 08 \frac{1}{2}\right) ; 30$ sires of 103 trotters, 34 pacers; 18 dams of 24 trotters, 4 pacers.

G. W. HOWE $(\mathrm{I}-64), 2 \cdot 253 \frac{3}{4}, \mathrm{I} 53 / 4$ hands, I roo pounds ; foaled I $89 \mathrm{I}$; bred by H. D. McKinney, Janesville, Wis. ; got by King William L., son of William L., by George Wilkes : dam Envil, bay, bred by H. D. McKinney, got by Phallamont, son of Phallas, by Dictator ; 2 d dam Edmonia, bay, bred by Richard West, Greenville, Mich., got by Dictator, son of Hambletonian; 3 d dam Leah, bay, bred by D. Swigert, Woodford County, Ky., got by Woodford Mambrino, son of Mambrino Chief; 4th dam Maud, bay, bred by H. L. Broadwell, Harrison County, Ky., got by Alexander's Abdallah. Pedigree from breeder.

Sire of Gen. Howe, $2: 29 \frac{1}{4}$.

\section{GWIST HORSE, untraced.}

Sire of dam of Jenny, $2: 29 \frac{1}{4}$.

G. W. S. ( $\mathrm{x}-64), 2: 29^{\mathrm{T} / 2}$, bay; foaled $\mathrm{I} 893$; bred by G. W. Sherwood, Sheldon, Ia.; got by Woodford Wilkes, son of George Wilkes: dam Rosita, chestnut, bred by W. T. Withers, Lexington, Ky., got by Aberdeen, son of Hambletonian; 2d dam Etona, bay, bred by J. H. Chiles, Lexington, Ky., got by Almont, son of Abdallah; 3 d dam said to be by Edwin Forrest, son of Bay Kentucky Hunter; 4th dam by Black Highlander (Downing's), son of Crusader (Steele's). Pedigree from breeder. Sold to A. L. Lott, Ipswich, S. D. ; to B. B. Ward, Aberdeen, South Dakota; to C. H. Bristow, Bedford, Ia.

Sire of Lottheart, $2: 20^{3 / 4}$.

GYMNAST (3-32), chestnut; foaled I 888 ; bred by H. N. Smith, Fashion Stud Farm, Trenton, N. J. ; got by Rumor, son of Tattler: dam Gilda, chestnut, bred by Henry N. Smith, got by J. Gould, son of Hamiltonian; 2d dam Lady Dixon, said to be by Ethan Allen, son of Black Hawk; and $3 \mathrm{~d}$ dam by Abdallah, son of Mambrino. Sold to H. B. Van Cleve, Cleveland, O. 


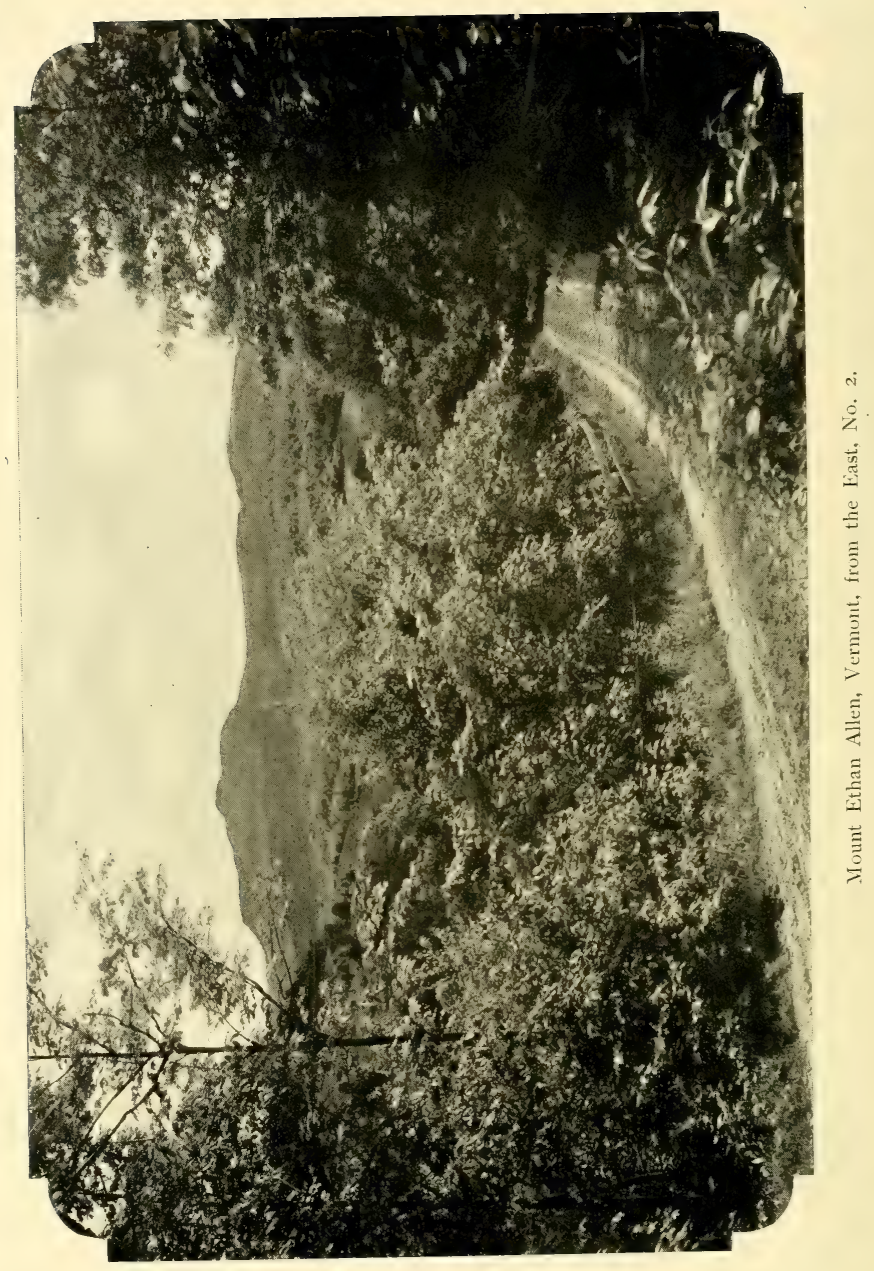






\section{BREEDERS AND OWNERS}

A BBOTT, BEN, I52.

A Abbott, Frank, 574 .

Abbott, William, I 96 .

Abernethy, Abraham F., 257.

Abicrombie, 429 .

Acinna, 126.

Adams, Dr., 96, 475 .

Adams, George, 240, 270,527 .

Adams, George E., 685.

Adams, James, I3 I.

Adams, John A., 194.

Adams, J. R., 95, 215.

Adams, Riley, 407.

Adams, R. M., 407.

Adams, William, 4r8.

Adams, W. W., 82 .

Addy, 350 .

Agnew, G. W., I 6 .

Agniel, George, 353 .

Aiken, C. L., 4I I.

Aiken, Isaac, 337 .

Akerman, Samuel, 263 .

Akers Stock Farm, 625 .

Albers, John, 437.

Alderman, Daniel, 53.

Alderman, W. P., 53 .

Aldrach, C. W., I43.

Aldrich, W. W., 3 .

Alexander, A. J., 6, 24, 30, 48, 59, 66, IO2, IO3, I 10, 140, I47, I64, I 79, 193, 205, 208, 2 10, 2 I I, 244, 247, 25 I, 345, 349, 35 I, $354,361,456,457,463,513$, $59^{2}, 598,686$.

Alexander, A. M., 42.

Alexander, Chas., 8o, 433.

Alexander, John K., 9.

Alexander, R. A., 6, 30, 48, 50, 54, 103, 106, 109, 1 24, I 79, 187,

I93, 205, 242, 349, 35 I, 354, $363,417,420,448,457,459$, $521,527,635,670,685,690$.

Alford, O. P., 6, 440 .

Allen, Ab., 688.

Allen, A. I., 623 .
Allen, Amory, 407.

Allen, Ezra, 462.

Allen, Gilbert, 407.

Allen, H. B. \& H. D., 79, 147.

Allen, J. H., 4I 5 .

Allen, Samuel, 377.

Allen, Vial, 378 .

Allen, William Russell, 2, 205, $25 \mathrm{r}$.

Allman, George T., I8I.

Alstrom, Charles A., 504.

Ames, Samuel, 538.

Ancaster, Duke of, I38, I39, 639, 650 .

Anderson, C. A., 594 .

Anderson, J. M., 68.

Anderson, Joseph, 30.

Anderson, Richard, 594.

Anderson, Robert, 356.

Anderson, Thomas, 2 I 6 .

Anderson, William, 350, 672.

Andrews, Charles, 2 I 3.

Andrews, D. C., 439.

Andrews, Nathan, 133.

Andrus, Ethan, 678 .

Anglin, T. C., roo.

Anglin, Timothy, 2 I I , 599, 640, 69 o.

Anglin, W. B., roo.

Ansley, B., 4I I.

Antisdale, Otis, 424.

Anway, L. B., 99.

Appleton Winona Breeding Association, 435 .

Appleyard, Captain, I 25.

Arandt, John J., 445.

Archambault, T., 644 .

Archambeau, A., 45.

Archer, A. C., 9.

Archer, George W., 445.

Archibald, Dr. O. W., 6 oo.

Armour, Sr., Wm., 500.

Armstrong, Capt., I 54.

Armstrong, Noah, 2.

Armstrong, Reuben, $37 \mathrm{I}$.

Armstrong, William \& James, 352.

Arnold, Fred, 68.

Art, A. Y., 454 . 
Arthur, 578 .

Arthur, Robert, 219.

Arthur, Wm. A. G., I 5 .

Ash Grove Farm, 588.

Ashe, R. P. \& W. L., 196.

Ashley, 30, 4 Io.

Ashley, A. B., 327.

Ashton, William, I73.

Aston, Sis R., 42 I.

Atherton, Charles, 295.

Atkins, Joel, 458.

Atkinson, W. D., 499.

Atkinson, W. M., 663.

Atwood, C. W., 689 .

Atwood, O. T., 40.

Augustin, C. B., 212.

Austin, 465, 578 .

Austin, B. A., I82.

Austin, Capt., 15 I.

Austin, Dr. P. A., 503.

Austin, Norman E., 50r.

Avery, 62, 67I.

Aycrigg, Gardner, 631.

Aycrigg, T. G., 63I.

Ayers, F. J., 629, 632.

Ayres, E. W., I62, 335, 690.

Ayres, H. D., 129.

Ayres, Herman D., I 5 .

Ayres \& Russell, 690.

RABBITT, WILLIAM B., I57.

B Babcock, A. C., 5, 625 .

Babcock, C. A., 344, 520, 616.

Babcock, F. G., 37 .

Babcock, Wm., 344 .

Babcock, Wm., \& Son, 542 .

Bach, James B., IO2.

Bachop, William, 672.

Backman, Charles, 2, 28, 39, 63, 79, 91, I18, I32, I95, 198, 204, 205, 2II, 354, 355, 521, 593, 597,6 г $3,684,685,686,688$.

Bacon, Capt. Edmund, I42.

Bacon, C. D., 243.

Bacon, F. G., 59 I.

Bacon, Harrison, 327.

Bacon, Maj. W. J., 347.

Badger, Bela, I49, 5 I 2 .

Bagby, J., I04.

Baggs, 163.

Bagley, John J., 62 I.

Bailey, I I 3 .

Bailey, Clark, 47 I.

Bailey, E. C., 485, 486.
Bailey, George L., I32.

Bailey, J. F., 3 .

Bailey, Smith, 583 .

Bailey, T., 613.

Bailey Brothers, 556 .

Baillie, Thomas, I36.

Bain, John, 526.

Baird, David, 4r8.

Baker, Chandler, I I I.

Baker, E. W., 333 .

Baker, Frank, 252.

Baker, J. V., I'2.

Baker, Richard, 194.

Baker, Willis, 499.

Baker Brothers, $5^{87}$.

Baker, Jr., Q. V., I 47.

Baker \& Harrıngton, I 9, 30.

Baker \& Hill, 505.

Baker \& Hobbs, 65.

Balch, 627.

Balch, H. F. \& F. K, I38.

Balch, L. C., 57 .

Balch, Wesley T., 252.

Balcom, W. H., 300.

Baldwin, 267.

Baldwin, Erastus, $35^{8}$.

Baldwin, W. G., I I 2, 269, 286.

Baldwin, W. W., 59, 44 I.

Balkman, Charles, 529 .

Ball, Maj. Wm., 394.

Ball, William, 506.

Ballard, $53^{8}$.

Ballard, John, 449.

Ballentine, John D., 640.

Bangor Furnace Co., $4 \mathrm{I}$.

Banker, Philander, 69I.

Banker, S. R., I 32.

Banks, Ed. R., I 82.

Banks, Geo. L., 462.

Banta, Will, 54 .

Banton, Wm. T., 9r.

Barber, A. I., 669.

Barber, P. S., 4I 5.

Barbour, Frank S., 689.

Barclay, 622.

Barclay, Richard, 489 .

Barden, John E., 606.

Bardwell, William, 239.

Bargs, Mrs. H., 406.

Barham, W. C., I44.

Barker, 4I r, 678.

Barker, A. W., 24.

Barker, C. L., 6 I 7 .

Barker, Dell, 2 Iо. 
Barker, Gen., 465.

Barker, George, 392.

Barker, H. C., 245.

Barker, H. L., 52 I.

Barker, H. S., 187.

Barker, K. C., I04.

Barlow, Dr., 2 I 7,52 I.

Barlow, Lewis, 674 .

Barnes, Aaron, 433.

Barnes, A. G., 72, 78, 4 I 6.

Barnes, C. O., 7 o.

Barnes, J. C., I 74 .

Barnes, W. H. L., 630.

Barnes, William, 523, 6r5.

Barnett, Charley, 177.

Barnett, George P., 521 .

Barnett, J. P., 389 .

Barnett, Moses, $52 \mathrm{I}$.

Barnhart, Maklon, I04.

Barnhart, Mrs. A. J., I37.

Barnhouse, Wm., 486.

Barnjum Bros., 570.

Barnum, A. W., I21.

Barres, Jake, 430.

Barrett, H. G., 6o3.

Barrington, Thomas, 64 .

Barrows, Abner, 492.

Barrows, Frank M., 52.

Barry, R. D., 663.

Barry, Smith, 4 I 6.

Barston, Dr., 5 I I.

Barstow, E. P., 379.

Bartholomew, N., $42 \mathrm{I}$.

Bartlett, S. M., 436.

Barton, Arthur C., I39.

Barton, H. E., 333 .

Barton, J., 37.

Barton, Joshua, 48.

Basch, Gen., 6r3.

Bascom, J. S., 8r.

Bashaw, M., 590.

Bashford, Allen, 248.

Bass, Gilman, 655 .

Bassett, E., 4I 7 .

Bassett, H. E., 445.

Bassford, E. P., 6 I 6.

Bastader, 2 I 7.

Batchelder, Nathaniel, 365 .

Batchelder, S. E., 392.

Bate, C., 6 I 7 .

Bate, J., 6r 7 .

Bates, B. E., I 2, 346.

Bates, Edwin, 446.

Bates, Ives G., I33.
Bates, Joseph F., I 7 .

Bates, Lewis, 679.

Bates, Moses G., 252.

Battell, Joseph, I 2, 55, 380, 475, 503 .

Battell, Wm., 6 ro.

Batten, John, 506.

Battle \& Hilliard, 65 I.

Baxter, 166.

Baxter, Edward, 44r.

Baxter, John S., 195.

Baxter, William, 444.

Baxter \& Gaines, 574 .

Bayles, John, 359.

Baylor, Col., 4, 394 .

Baylor, George, 603 .

Beach, Jay, 52.

Beach, Thomas N., 434 .

Beach, William, r 19.

Beaker, Henry, 527.

Beal, William, I65.

Bealey, Samuel, 406.

Beals, John, 7 .

Bean, J., I 59.

Bean, John, 538.

Bean, Warren, 679 .

Bear, Peter, I6I.

Beard, O. P., i го, 243, 620, 686.

Beard \& Bradley, 54 .

Beardsley \& Gilbert Bros., 544, 557.

Beattie, S. N., 54 I.

Beatty, R. H., 34I.

Beaupau, 428.

Beck, James, i io.

Beckwith, Ezekiel B., 43.

Beckwith, Oliver, $270,402$.

Bedell, John, I 53 .

Bedford, Duke of, I 24.

Bedford, Littleberry M., I64.

Bedford, L. M., I38.

Beecher, Jas. C., I 55 .

Beers, Dr. E. A., 537.

Beersall, Lewis, 169.

Belgian Horse Co., 594.

Bell, Charles F., 403 .

Bell, Clark, 5 oo.

Bell, Hilary, I 32 .

Bell, James, 444.

Bell, Joshua, 44r.

Bell, W. C., I 47 .

Bell \& Son, 444.

Bellinger, Dr., 6 oo.

Bellinger, M. D., 328.

Bellows, 2 r 8.

Bellows, John, 392. 
Bellows, Landlord, I 70.

Bels, A. H., 2.

Bement, George, 507, 509 .

Bemis, 252.

Bemis, H. V., 443.

Benedick, Alick, 485 .

Benedict, Charles, 257.

Benedict, George, 327.

Benjamin \& Sutherland, IO4, 523.

Bennett, Alvah, 27 I.

Bennett, Clark, 285 .

Bennett, Dexter, I I 9.

Bennett, Emily, 352 .

Bennett, George D., 668, 685 .

Bennett, J. W., I 27 .

Bennett, W. G., I 25.

Bennett, D. A., \& Eldridge, 490.

Bennett \& Myrick, 622.

Bennett \& Wells, 57 o.

Benson, Almon, 404.

Benson, Lorenzo, 430.

Benson, Mathew, I66.

Benton, A. L., 466, 622 .

Benton, Horace, $65 \mathrm{I}$.

Benton, John, I.

Berry, F. J., 6.

Berry, Frank, ror.

Berry, James R., 236, 239.

Berry, O. F., 42.

Berry, P. T., 54.

Berry, Samuel W., 2 I 7

Besset, E., 406.

Beswicks, George \& Hiram, 539.

Bethel, M., I 25.

Bettinger, John, 57 r.

Bevens, J. G., 432.

Bevens, Wm., 274.

Bickerstaff, J. O., I6r.

Bickler, Wm., $66_{3}$.

Bicksler, G. W., $68_{4}$.

Bidwell, B. J., 48 I, 484 .

Bigbee, H. C., 476.

Bigbee \& Christian, 475 .

Bigelow, 269.

Bigelow, A., 489 .

Biggs, E. R., 598.

Bihler, Wm., 474.

Billinger, E. T., 6r 9.

Billings, Frederick, 350, 590.

Billings, Joseph F., 370 .

Billmyer, Dr. E. T., 30, Io8.

Bimm, Ezra, 465 .

Bingham, J. M., 380.

Bingham, Judge, 368.
Bingham, S., 376 .

Bingham, Thomas, I 73 .

Birchard, E. A., 29.

Birch Grove Farm, 36.

Bird, Lorenzo B., 674 .

Biscoe, 475.

Biscoe, J., 57 .

Bish, 503 .

Bishop, Gabriel, 156.

Bishop, Joseph, 6 o.

Bishop, T. E., 197.

Bishop, Wm., 429.

Bissell, Capt. Elias, 377 .

Bissett \& Pallett, 397.

Bixby, H. E., 607 .

Bixby, H. H., 607.

Black, George N., I 24.

Black, S. Baxter, 67o.

Black, T. N., 603.

Black, W. F., 649.

Blackburn, 335 .

Blackmore, Oscar, 340.

Blair, A. H., 673 .

Blair, Charles R., 64 .

Blair, Robert, 225.

Blaisdell, Dr. N. O., 2 I.

Blaisdell, Watson, 499.

Blake, Charles, 566.

Blake, Charles F., 649.

Blake, George, 465 .

Blake, John, 650 .

Blake \& Goss, 335 .

Blake \& Williams, 673, 68r.

Blakemore, J. W., I 8 o.

Blanchard, G. B., I I 4, 2 I 5.

Blanchard, George E., 333 .

Bland, John, 83 .

Blank, Fred, 489 .

Bleugh, Henry D., 499.

Blewett, T. H., 36 .

Blewett, James T. \& T. H. W., I44.

Blick, James, $65 \mathrm{I}$.

Blodget, John A., 570.

Blodgett, Ephraim, 425 .

Blossom, $57 \mathrm{I}$.

Bly, 267 .

Boardman, Hiram, 5 I3.

Boggs, Joseph, 179 .

Bolard, Jacob, 95.

Bolton, 543 .

Bolton, John, 392.

Bond, J. B., $3^{80 .}$

Bonfield, 198.

Bonham, I I 2. 
Bonner, David, 73.

Bonner, Robert, 61, I84, I9 , I96.

Bonner, Wm., 29.

Bonnie, J. D., 52.

Bonta, W. D., 82, I3 1.

Booker, Jacob, 523 .

Boone, Thomas, 45 o.

Booth, A. L., I 48 .

Borah, J. V., 363 .

Borden, Spencer, 640.

Borders, J. K., I6I.

Borders, W. R., 624.

Bornhart, Jerome, 425 .

Borton, J. H., 389.

Bostwick, H. C., 246.

Boswell, H., 244.

Boswell, Hart, 79, r87.

Boswell, Joseph, I 6 .

Bosworth, John, 91.

Botts, John Minor, 477.

Boucher, A. W., 499.

Bouriceau, M., 2 I.

Bowen, Mark, 679.

Bowen, Geo. W., 6.

Bower, W. H., 523 .

Bowerman, Mike, 435.

Bowerman Bros., 24, 50, т24, 335 .

Bowers, Allen, I 74.

Bowers, Dr., 235.

Bowers, Josiah, 232.

Bowers Bros., 503 .

Bowman, H. H., 667.

Bowman, J. B., 55.

Bowman, John, 42.

Bowne, S. R., 403 .

Box, Frank, 430.

Boxwell, C. H., I45.

Boyce, P., I39.

Boyce, Rev. J. P., I48.

Boyce, S., 5 II.

Boyd, Dr., 32.

Boyd, John F., 58.

Boyd, J. S., го8.

Boyle, T. G., 570.

Bracacher, Dr., 475, 480.

Bracken, Dr. J. A., 489.

Bradford, Alyernon, Io8.

Bradhurst, William, 53 I.

Bradley, 389.

Bradley, C. T., 598.

Bradley, Dr., 688.

Bradley, Gen., I 70.

Bradley, James L., I46.

Bradley, John E., 529.
Bradley, J. W., 8ז.

Bradley, Richard, 524 .

Bradshaw, 599.

Bradshaw, John, 3 .

Bradt, B. H., 7 .

Bradt, Henry, I 8.

Bragg, Joel, 457.

Brainard, Lawrence, 31, 593.

Bralert, Ray, 8z.

Bramblet, Henry, 72.

Brand, Henry, 95.

Brandt, T. W., \& Son, 640.

Branshaw, John, 597.

Brant Bros., 335.

Brasfield, J., 95.

Brasfield \& Sevade, 2 I I.

Braxton, Col., 603.

Braxton, T. N., 693.

Bray, Theodore, 82 .

Breckenridge, John C., I62.

Breed, Ben, 259, 272.

Breed, C., 6r4.

Breed, Foster, 285.

Breed, George F., 678 .

Brehman, John, I 5 .

Brewster, J. E., $212,390$.

Brewster, John, 333.

Brewster, John W. A., I8I, 438, 529.

Bricker, John, 522 .

Brickes, John, 583 .

Bridge \& Helm, 578 .

Bridges, James, 2 I 9.

Briggs, Wm. S., 502 .

Bristow, C. H., 694.

Brittell, John, 30.

Broaddus, John, I 49.

Broadwell, H. L., 694.

Brockman \& Spencer, I 44.

Brockunier, C. W., 452.

Bronaugh, J. T., IO2.

Brooke, Richard, $65 \mathrm{I}$.

Brooking, A. V., 453.

Brookman, H. M., I $8 \mathrm{r}$.

Brooks, 652.

Brooks, A., 523.

Brooks, Bateman, 243, 250, 456.

Brooks, Charles, I 81,436 .

Brooks, D. M., I I9.

Brooks, Fletcher, I45.

Brooks, Mike, 503 .

Brooks, T. B., 456.

Brooks, T. L. \& J. I., $x_{4} 6$.

Broome, L. M., 6I 9.

Brown, 55, 477, 485, 498. 
Brown, A. J., 430.

Brown, B. B., 223.

Brown, Campbell, I4 I, 226.

Brown, C. C., 484.

Brown, C. J., 442.

Brown, C. L., 430.

Brown, Edwin, 176.

Brown, Fred, 336.

Brown, George, I 70.

Brown, Greenleaf C., 365 .

Brown, James, 526.

Brown, J. C., 353 .

Brown, J. C. \& S., 484 .

Brown, J. E., 210.

Brown, John, 69, 683.

Brown, John P., I5 I.

Brown, Joseph, io8.

Brown, L. E., $45 \mathrm{I}$.

Brown, Major, I 1 .

Brown, Milton, 670.

Brown, Peter J., 192.

Brown, Thos., 430.

Brown, Wm. B., 656 .

Brown, Wm. G., 37 .

Brown, W. T., 570.

Brown Bros., 458.

Brown, S. A., \& Co., 5, 52, 225, 226 , $522,571,635,637$.

Brown, Seavey \& Co., 499.

Brownell, Chauncey W., 328 .

Brownell, George E., 394.

Browning, J. W., I 85 .

Bruen \& Peasely, 193.

Brux, Mattie, 37.

Bryan, Jesse, 480.

Bryan, Joseph H., 223, 352, 621 .

Bryan, Jr., David, 234.

Bryan \& Castle, 427 .

Bryant, I I o.

Bryant, George E., I 1 o.

Bryant, Hiram, 674 .

Bryant, J. A., 674.

Bryant, William, 38 .

Bryson, W. B., 2 I 6.

Buchanan, John, I 77 .

Buchanan, S. R., 226.

Buck, Benoni, 658 .

Buck, Edward, 527 .

Buck, Elijah, 382 .

Buck, R. W., 586.

Buckland, Leonard, 535 .

Buckley, John, 530, 603.

Buckman, C. H. C., I 2 O.

Buckman \& Carragher, 524.
Buckminister, J., 644 .

Buel, George H., 505 .

Buel, W., 4 .

Buford, B. T., 693.

Buford, F. G., 93, 487.

Buford, General A., 2 I I.

Buford, G. H., 78,36 r.

Buford, John, 4 I 6.

Bullock, 270.

Bulkley, E. B., 59 .

Bump, H. V. \& A. D., I9.

Bunbury, Sir C., 650.

Bundy, George, 576, 679 .

Burbank, Ansel, rз 3 .

Burch, George W., 2, 66, 206.

Burchard, B., 4I.

Burdick, Nathan, 236.

Burge, 267.

Burgess, 648 .

Burgess, Jas., 506.

Burgess, M. E., 431.

Burgess, W. N., 98.

Burgett, W. C., I 45 .

Burgher, H. M., 486, 572 .

Burgin, Calvin, 79 .

Burgoyne, Gen., 538.

Burke, A. M., 345.

Burke, F. H., I68, 206.

Burke, Frank H., 248.

Burke, John, 675 .

Burkett, Charles, 654 .

Burnes, William, 59.

Burnett, J. S., 398.

Burnham, Nathan, I.

Burnham, O. K., 448.

Burns, 405 .

Burns, Washington, I 86.

Burr, Carl, 569 .

Burr, Smith, $227,232,235$.

Burroughs, B., 406.

Burrus, James M., 389 .

Burson, J. E., 584 .

Burtle, J. M., I 77 .

Burton, J. J., 357.

Burton \& Hathaway, 4I 2.

Burwell, H. C., 6I4.

Bush, 439.

Bush, C. A., 432.

Bush, Ebenezer, 677 .

Bush, Hiram, i 85 .

Bushe, Benjamin, 6 I 3 .

Bushong, 39.

Bussey, Esek, 5.

Buster, N. I., 7. 
Buswell, Gilman, 129.

Butler, Cephas, I39.

Butler, Chas., I 39.

Butler, Dr. Russ, 338.

Butler, James, 91, Ioo.

Butler, J. D. \& C., 346.

Butler, Luther, 673 .

Butler, S. H., I4 I.

Butler, Louis \& Loomis, 657 .

Butler \& Whitcher, 672.

Butt, A. B., $45^{8}$.

Buttels, L. D., 382 .

Butterworth, Job, I 77, 623 .

Buttles, Wallace, 674 .

Button, Alexander, 499.

Button, James, 34 .

Bye, Amos, 352.

Byerly \& Peck, 333 .

Bynum, Wade H., 525 .

Byrne, Philip, 97.

ABLE, GEORGE C., \& SONS, I93.

Cadwell, E. J., 523,

Cahill, 585 .

Cahill, Thomas, 244 .

Caldwell, H. L., 464.

Caldwell, J. C., 459.

Calkins, Harrison, 38 .

Calla, Wm., $35^{2}$.

Callaway, J. S., 4I 7 .

Callendine, Mrs. J. P., 68.

Callison, J. G., 37.

Calvert, Thomas C., $5 \mathrm{I}$.

Cameron, 238.

Cameron, David M., 239.

Camp, F. M., 432.

Campbell, Alexander, 389 .

Campbell, Capt., 137 .

Campbell, Col., 637 .

Campbell, D. S., 5 Io.

Campbell, George, 8r.

Campbell, M. C., 95, I41, 543.

Campbell, Robert S., 460.

Campbell, W. E., 203 .

Campbell, Jr., A. L., I4I.

Canniff, J. H., 5 I 9.

Cantell, Charles, 37 I.

Capen, 45.

Cardin, John, 450.

Carl, Coklin, 235 .

Carl, John, 394.

Carlisle, J. W., 668.

Carlisle \& Crook, 668.
Carman, Charles E., 524 .

Carman, Richard, 530.

Carmichael, J. H., 57 I.

Carmony \& Lackey, 39 .

Carnavan, Joseph, $15^{8 .}$

Carpenter, C., 63.

Carpenter, David, 657 .

Carpenter, Edwin F., 27.

Carpenter, W. W., I59, 643 .

Carpenter, W. W. \& G. P., 357.

Carr, Dabney, 190, 203, 563 .

Carr, David, rgo.

Carr, Jesse D., $212,336$.

Carroll, John, 66, 4 I 8.

Carson, Jack, 347.

Carsteman, John A., 633.

Carter, 9I.

Carter, Dr., 59.

Carter, Dr. C. S., 373.

Carter, Edward, 606.

Carter, James W., 95 .

Carter, John G., I 8.

Carter, John W., 95.

Carter, Martin, 94.

Cartwright, J. H., 68ז.

Carver, A. P., I68.

Cary Bros., 4I4.

Case, C. S., 29.

Case, Daniel, 666.

Case, F. B., 438.

Case, I. P., 628.

Case, Ira A., $5 \mathrm{I}$.

Case, Jerome I., I 78 .

Case, J. G., 226.

Case, J. I., 191, 623, 625 .

Case, Joseph, I 57.

Case, Nathan, $5 \mathrm{I}$.

Case, Peter J. \& Hoppock, Ely, 603.

Cash, Hiram F., 4.

Cash Bros., 539.

Cass, 37.

Cassady, Wear, 40.

Casserly, Eugene, 336.

Cassleman, C., 623 .

Casten, J. L., 6г 7 .

Castleman, David, 78, 687 .

Caswell, Chas, H., 500.

Cathey, A., 649.

Catlin, Gen., 662.

Caton, A. J., 599.

Caton, Arthur, I05.

Caton, Dr., I07.

Caton Stock Farm, 39, I 1 4, I I 5, I63, 599. 
Caurke, George, 527 .

Cavanaugh, Michael, 69r.

Cave Bros., 35.

Cavins, Thomas, 600.

Cebell, Albert, 670.

Cecil, C. P., 455 .

Cecil, G. \& C. P., го7, I I 7, г 20, г 79, $455,45^{*}, 457^{*}, 45^{*}, 465,474$, $570,586,594,63 \mathrm{I}, 636,685$, 686, 689 .

Cecil, Granville, 4I 5, 456, 457, 459, $471,636$.

Cecil, Granville, \& Williams, 593, 687 .

Chaffee, Oscar S., 2 I3.

Chamberlain, W. S., I 6 .

Chamberlin, George W., 337 .

Chamberlin, H. C., I94.

Chamberlin \& Gibbs, 4I2.

Chambers, W. T., I92.

Champney, Dr. Thomas, $4 \mathbf{1} 6$.

Chandler, Dr., 252.

Chandler, H. T., 420.

Chaney, G. A., 406.

Chapin, W. B, I59, 643 .

Chapman, 245.

Chapman, T. D., 66 т.

Chappee, Samuel, 425.

Chapter, Samuel, 522 .

Charlebois, 2 I.

Charlton, Lewis, $\mathbf{1 4 5}$.

Chase, O. S., 9 I.

Chase, Clement, 6ri.

Chase, D. L., 177 .

Chase, Frank, I 78 .

Chase, Moses, 678.

Chedel, 330.

Chenault, O. H., 223 .

Cheney, Dwight, 677 .

Cheney, Horace, 178 .

Cheney, P. A., 640.

Cheney \& Co., 4I3.

Cheney, Winthrop WV., \& Co., 655 .

Cheshire Improvement Co., 28.

Chesley, George E., I 57.

Chew, Dr. Samuel H., 465, 592, 690.

Chickester, Nathaniel, I5I.

Chicoine, Pierre, 439 .

Childs, Frank, r63.

Childs, Granville, 362 .

Childs, John A., 284 .

Chiles, J. H., 694.

Chiles, Richard, 190.
Chillson, 267.

Chilson, O. G., 427.

Chips, Frank, I 30.

Chom, Samuel, 22.

Chrisman, Judge G. L., 244.

Christian, 23, 475 .

Christopher, Daniel, I 73.

Christy, J. M., 7 .

Christy, Solomon, 424 .

Church, Hiram, 404 .

Church, L. L., 37 o.

Church, R. C., 433.

Church Bros., I37, 203.

Clagett, Thomas W., $58_{3}$.

Clancy, J. H., 498.

Clapp, A. W., 4I9.

Clark, I 26, 243, 666, 673 .

Clark, C. F., 69 I.

Clark, C. M., $47 \mathrm{I}$.

Clark, James, 349.

Clark, Judson H., 520.

Clark, E. Packer, 662.

Clark, Ephraim Fitch, I 72.

Clark, E. S., 36.

Clark, G., 327 .

Clark, George W., 38 .

Clark, J., 327.

Clark, James, 2 r6, 349, 685 .

Clark, J. C., го6.

Clark, John H., I 26.

Clark, John S., 50, 427.

Clark, Judson H., 95, 182, 2 13, 693 .

Clark, L. C., 526 .

Clark, Orlando, 357 .

Clark, P., 433.

Clark, Seymour, 425.

Clark, Walter, 49, I6o.

Clark, William, I3 I.

Clark, Wm. \& W. R., 6ro.

Clark Bros., 269.

Clawson, Garner, 436.

Clay, Capt. M. M., 513, 620.

Clay, James B., 4I6.

Clay, James E., 42, $5^{\text {I } 3 .}$

Clay, M. M., 6 I8.

Clay, Sidney, 420.

Claypool, M. S., 584 .

Clement, R. P., 4 I4.

Clement, S. E., 620.

Clements, Alday, 178 .

Cleveland, Capt. Josiah, 377 .

Cleveland, Duke of, r. 
Cleveland, Stephen, I 5 I .

Cleveland, Jr., I 5 I.

Cleveland, Jr., T. H., 353.

Clifton, 453.

Cline, J. L., 423.

Cline, John, \& Sons, 194, 196.

Clopper, Col. J. Y., 5 .

Clough, H. H., 446.

Clough \& Holcomb, 286.

Clow, Harmon, 405.

Coats, E. E., IO2.

Cobb, J. B., 59.

Cock, Townsend, I49, 150.

Cockle, 439.

Cockrill, M. S., 242.

Coffey, IV. S., I 48 .

Coffin, Thadeus, 201 .

Coffing, B. H., 690.

Coffman, John W., I I 3 .

Coham, H., 340.

Coke, 604.

Cokely, Peter, 434.

Colby, Lorenzo, 486.

Colby \& Taylor, I I 7 .

Cole, 43 I.

Cole, Charles E., 447.

Cole, F. S., I I 4 , 446.

Cole, James, $5 \mathrm{O} 2$.

Cole, O. M., 248.

Cole, Richard, 348 .

Cole, Samuel, I 7 o.

Cole, Stephen, 6i i.

Cole, William, I69.

Coleman, D. S., I 24.

Coleman, Ira H., I 75 .

Coleman, J. W., I 24 .

Coleman, J. Y., 68.

Coleman, William L., 339.

Coles, Gen., 153, 156.

Colhoun, John E., 73.

Collins, 404.

Collins, Dr. E. E., 434.

Collins, George W., 542 .

Colvin, John, \& Adams, 584 .

Colwell, C. R., 600.

Colwell, John, $\mathbf{1 4 9}$.

Colyer \& Co., 437.

Coman, Dr., 655.

Coman, Harmon, 655.

Combs, John S., 537, 538 .

Combs, Thomas H., 537, 538 .

Condon, John, 82.

Condon, Terry, 223.

Congdon, James, 83 .
Conger, 683 .

Conklin, Alexander, 142.

Conklin, E. K., 432.

Conklin, J. N., 598.

Conklin, Samuel, 2, 198.

Conley, John J., I 24 .

Conley, John N., I9.

Conley, John W., 95.

Conn, Gardner, 512.

Conn, J. R., 452.

Conn, P. B., I92.

Conn, R. W., 212.

Conn, R. W., \& Co., 390.

Connell, Dennis, 28.

Conover, Dr. A. V., 529.

Conway Bros., 685.

Cook, 424 .

Cook, Albert, 462 .

Cook, C. H., 265.

Cook, Daniel, 688.

Cook, Gustavus, 399.

Cook, J. A., I 83.

Cook, Jas. W., 206.

Cook, John M., 462.

Cook, Louis, 520 .

Cook, R. J., 520.

Cook, Seth, 58, 66.

Cook, Warner, 255.

Cook, Wm. H., Iо, I 2, 255, 332.

Cook, W. M., 602 .

Cook, W. P., \& Bros., I 66.

Cookston, Charles, 82 .

Cool, Lincoln, 409.

Coolage, J. G. W., 65 .

Cooledge, Ira, 573 .

Cooley, Justice, 393.

Coombs, W. L., 207.

Coons, Alexander, 58.

Coons, C. W., 242.

Coons, George, 349.

Coons, Thomas, 690.

Coons, Thomas L., 525 .

Cooper, 438.

Cooper, John H., 192.

Cooper, Jonas, 128.

Cooper, Jos. A., 82.

Cooper, Marmaduke, 240.

Cooper, R. I., 663 .

Cope, David, 57 I.

Cope, W. H. H., 572.

Copeland, H. F., 527 .

Copp, Isaac, 37 I.

Corbin, Capt. Warren, I63.

Corbin, John W., 57 I. 
Corbin, Royal, I 7o, 422.

Corbin, Jr., A., 400.

Corbit, 374 .

Corbitt, William, 196, 61 4, 635, 690. $691 *, 693 *, 694$.

Corcoran, W. W., I04.

Corev, George W., 399.

Corkey, 462.

Cornell, David, 332.

Corning, Erastus, 380 , 537 .

Corning, George C., 127 .

Cornwall, A. B., 415.

Corrigan, John, 127,513 .

Costill, Charles, 352 .

Cotherham, J. M., 372.

Cottman, Wm., 8r.

Cottrell, William, 9I, 543 .

Couch, Jackson, 406.

Country, A., I53.

Courtright, Ezra, 72.

Covington, J. B., 667 .

Cowham \& Rowan, 506.

Cox, L. J., 340, 537.

Cox, Sheriff, 664 .

Cox, T. J., I I I.

Coxe, Elijah, 692.

Coyner, Jchn A., 458.

Cozzens, L., 524 .

Crab, 475, 478 .

Crabb, H. W., 635 .

Crabtree, Cornelius, 2 I 6.

Craig, D. \& C. W., 37 .

Craig, E. H., 370.

Craig, J. C., 432.

Craig, Mrs. Nannie, I6o.

Craig, N., 37 •

Craig, S., 82。

Crain, C. L., $25 \mathrm{I}$.

Crain, James L., $25 \mathrm{r}$.

Cramer, A. H., 622.

Crampton, Charles, 499.

Crandall, J. O., I 82.

Crandall, S. E., 637.

Crandall Bros., 95.

Crandall \& Kern, 39.

Crane, Ed., 400.

Crane, Wm., I 87.

Crary, R. A., 473.

Crawford, William, 630.

Creagh, H. A., 6rg.

Creect, J. W., 250.

Cregg, Samuel, 590.

Creighton, C. H., 54 I.

Creighton, J. D., 57 o, 636 .
Cresen, 213.

Crew, Melvin, ro7.

Crittenden, C. S., 249.

Critz, Allen, 7.

Crocker, I 70, 239.

Croftie, William, 444.

Crofts, I, I39, 4I6, 590, 649*.

Crombie, Dr. J., 5 Io.

Cromwell, V. C., 49, 2 I 2.

Cromwell, Vincent, 79, I I3, 69 o.

Cromwell, Wm. V., 54 .

Crookham, Harry, 203.

Crooks, Oliver, 506.

Crosby, C. F., 394.

Crosby, Jacob, 39 .

Crosby, S., 348 .

Crosby, Seward, 397.

Croskey, Dr. Wm., 42 I.

Croskey, Harry, 66.

Cross, Chas., 570.

Cross, John, 570.

Cross, William, 570.

Crouch, J., 506.

Crouch, R. M., 500.

Crouch \& Grobmyer, 4, 63.

Crowell, A. J., I 79.

Crowell, John, I 7 .

Crowell, Sam., r 70.

Crowell \& Simpson, 436.

Crozer, John P., I 77.

Cruger, Henry W., I 74 .

Crughton, J. H., 24.

Cumberland, Duke of, I39, I68, I 74 .

Cumming, James R., 359, 5 I 4 .

Cummings, George, $68_{4}$.

Cummings, G. R., 355 .

Cummings, Manasseh, 557.

Cunningham, $4 \mathrm{I} 2$.

Cunningham, Frank, ro8.

Cunningham, H., 463 .

Cunningham, I. D., 94.

Cunningham, Pat., I 45.

Cunningham, Thomas, 434 .

Currier, Ephraim, $24 \mathrm{I}$.

Curry, I32.

Curry, B. F., I62.

Curry, Brook, 24, I $24,54 \mathrm{I}$.

Curry, J. F., 24 .

Curryer, J. C., 49.

Curtis, Geo. W., 372.

Curtis, L., 179.

Curtis, Wm., 362 .

Curtis, I. B., \& Sons, I6o. 
Cutter, Dr. William, 83, 90.

Cutts, H. T., 436 .

ADY, J. R., 434. Dahlman, 4 оr.

Dailey, William, 678 .

Dale, Jacob B., 6i I.

Dale, Owen, 572.

Daly, J. M., 50.

Daly, J. W., 4, 58.

Daly, Marcus, 2, 58 .

Daly, M. J., 602.

Dames, Wm., I 27.

Dana, Austin, 568.

Dana, A. W., I 56.

Dana, D. P., \& Co., 683.

Danakey, M. P., 592.

Danforth, A. G., 67, I48, 354 .

Danforth, A. M., 607 .

Danforth, Joe., 574 .

Dangerfield, Col., $5^{84}$.

Daniels, 50 .

Daniels, John, 407.

Daniels, R. W., 247.

Daniels, Seneca, 501, 662 .

Danley, Simpson, 622.

Dansereau, Joseph, 645 .

Dansereau, Louis, 20, $2 \mathrm{I}^{*}, 33,642$.

Dansereau, Ouillett, 646 .

Darbie, B. F., 79.

Dare, Charles B., 36.

Darling, A. B., $27,662$.

Darling, A. H., I9.

Darling, D. D., r91.

Darrell, John, 2 r8.

Dater, Phillip, 6.

Davenport, 409.

Davenport, A. H., 570.

Davenport, Samuel, 53.

Davidson, Alexander, 49, I 85 .

Davidson, John, 504 .

Davis, 529 .

Davis, A. C., 636 .

Davis, Barnes, I 86.

Davis, C. C., 629 .

Davis, Crit., 242.

Davis, D. C., 6I3.

Davis, Dr., 43.

Davis, Erwin, 249.

Davis, Fred L., 436.

Davis, George F., 5 I, II 3 .

Davis, G. L. \& A. C., 636.

Davis, I. D., I74, 573 .

Davis, L. A., 375 .
Davis, M. V. B., 409.

Davis, Peter, 505.

Davis, Price, 6 I 9.

Davis, Walter, 632.

Davoes, Harrison, 430.

Dawson, D. C., I64.

Day, Benjamin, 488.

Day, F. W., 8o.

Day, J. E., 687.

Day, J. W., 525 .

Day, Robert, 649.

Dayton, Lyman L., 9.

Dean, Dr. A. C., 403 .

Dean, George W, 5 oo.

Dean, Joseph B., 4 o.

Dean, Peter, 90.

Dean, Wm., 6I 4.

DeBleury, C. C. J., 5 I9.

Decker, John B., I6. 243 .

Decker, J. P., I32.

Decker, Wm., I8.

DeCraff, C. A., 594.

DeForest, 390.

DeGraff, C. A., 225.

DeGrout, 350.

DeGraw, H., I 82 .

Deinning, 44.

DeKalb Stock Farm, 6r 7 .

Delancy, Col., 377 .

Delancy, Silas, 4r.

Delancy, Warren, 90.

Deland, N. E., 72.

Delander, R. S., \& Co., I 46.

Delaney, James, 655 .

Delano, Ben., 267.

Delavan, William, $55^{8}$.

Delevan, 544, 568 .

Delong, Harmon, 52.

DeLong, Henry J., 328.

Delong, Jerry, 379.

DeNebirville, Charles, $\mathrm{I}_{42}$.

Denison, Geo., 504 .

Dennis, G. W., 400.

Dennis, H. M., 327 .

Denniston, George A., 390.

Denny, David, 158.

Denny, R. S., I 2 .

Denny Bros., 419, 687.

Denny \& Bush, 493.

Densmore, Gershom, 257.

Denton, E. P., 453.

Derby, Dr. W. C., 597 .

Derrell, John, $52 \mathrm{I}$.

Derrick, Daria, 395 . 
Derrick, David, 394, 395.

Derrick, Thomas, 4I 2 .

Derrick, Truman, 13, 394, 395, 6 1о.

DeSain, James, I06, I07.

Despeau, George, 434 .

Dessond, 646.

DeTurk, Isaac, r44.

Devonshire, Duke of 650.

Dewar, Pike, 5 o6.

Dewey, A., $37 \mathrm{r}$.

Dewey \& Stewart, 108, 181, 337, 438, 5 I2, 529 .

DeWitt, Henry, 60.

Dexter, S., 625 .

Deyo, Benjamin E., 505 .

Deyo, S. \& B. E., 505 .

Deysher, Abner S., 50 .

Dibble, H. M., 68.

Dickerson, J. N., 50.

Dickerson, Maj., I 75 .

Dickey, W. M., I63, 459.

Dickinson, Wm. C., 203 .

Dickson, J. M., IO4.

Dietmeyer, F. J., 345 .

Dietmeyer \& Skinner, 345.

Dietz, Fred, 97.

Diggs, D. C., 67.

Diggs, F. W., 67.

Dikerman, E. B., I8I.

Dilatush, John, I 8 .

Dillard, John, 36 r.

Dillingham, W. H., 684 .

Dillon, James, 425 .

Dillon, Patrick, 542.

Dills, Harrison, 459, 606, 686.

Dills, Noe., 620.

Dills, W. M., 630*.

Dilworth, J. S., 648.

Dilworth, Robert, 5 .

Dimmick, S., I 39 .

Dinion, John, 523 .

Dinsmore, Philip, I65.

Dixon, Dr., 329.

Dixon, Robert, 683 .

Dixon, Warren, 586 .

Doane, Sylvester, 68 .

Doane, Schuyler, 68, 270.

Dob'e, Budd, I37, 596.

Doble, W. H., 489.

Dobyns, I9.

Dodge, J. B., 409, 598.

Dodge, J. H., 68.

Dolan, John, I I I.

Dolan, P., I 13 .
Dolan \& Schlattern, 208.

Dole, Charles S., 382, 504 .

Dolly, Dr. F. C., 624 .

Dominick, George, ${ }_{5} 2$.

Donahey, M. P., 7 I.

Donaldson, 477 .

Donaldson, B., I43.

Donaldson, S., 5 I I.

Donegan, John, $47,440$.

Donelson, A. B., 94, 390, 606, 61 4 .

Dora, John, I06, 682 .

Dora, Mrs. R. C., 436.

Dore, Charles P., 520.

Dorsey, Elias, I39, 597, 675 .

Dorsey, Levi, 609.

Dorsey, L. I.., I25, I57, I61, I 77 $216,243,347,357,597,608$, 610, 61 7, 673 .

Dorsey, P. H., 675 .

Dorsey, Jr., L. L., 4I 7, 452.

Doswell, Thomas W., 347 .

Doud, George S., I 66.

Dougherty, George, 6I5.

Douglas, 638 .

Douglas, E. H., 226.

Douglas, St. Leger, I 74 .

Douglas, Stephen A., I I o.

Douglass, Wm., I 27 .

Douk, James, 8 o.

Dousman, H. L., 6 I 8.

Dover, Wayland, I го.

Dow, Neal, 32 .

Downer, 129.

Downing, 129.

Downing, Isaac, 598.

Downing, Marcus, $45^{8}$.

Doyle, Chris., 652.

Doyle, Peter, 352.

Drake, A., 284 .

Drake, C. P., 594.

Drake, Dr., I62.

Drake, E. F., 669.

Drake, Lauren C., 284 .

Draper, H. H., I 5.

Draper, James, $43^{8}$.

Drennan, P. L., I 29.

Drew, Hiram, I32.

Drew, John, 156.

Drew, Lemuel S., 607.

Drummond, John, 525 .

DuBois, A. L., 4I 5 .

Dubois, Cornelius, $\mathbf{1}_{52}$.

Dubois, James, 128.

DuBois, John E., I 77. 
Duckett, Isaac, 379 .

Ducy, S., 6 го.

Dudley, Frank W., I4I.

DuFort, M., I42.

DuFrein, M., I42.

Dugan, Mathew, 69r.

Duhme, F., 487.

Duhme, Jr., H., 443.

Duhnee, H. \& F., 572.

Duke, James K., Io6.

Duke, Thos. M., 443.

Duke of Ancaster, I38, I39, 639, 65 o.

Duke of Bedford, I 24.

Duke of Cleveland, $\mathbf{x}$.

Duke of Cumberland, I39, I68.

Duke of Devonshire, 1 24, 396, 650.

Duke of Gloucester, I 74 .

Duke of Grafton, 356 .

Duke of Hamilton, 375 .

Duke of Kingston, I 24.

Duke of Queensbury, 138 .

Duke of Rutland, 650.

Duke of Somerset, 125 .

Dule, W. C., 357.

Dulmage, John, 666.

Dume, Jefferson, 463 .

Dunbar, J. B., I 45.

Duncan, John, I I 3 .

Duncan, J. W., 73 .

Duncan, W. T., 525 .

Dunham, Gen., 599 .

Dunham Bros., 146.

Dunlap, Charles, 656 .

Dunlap, C. M., I47, 57 I.

Dunlap, J. C., 32 .

Dunlop, Dr. J. D., 4 .

Dunlop, H. C., 5I4.

Dunn, J. P., 97.

Dunn, M. P., 2 I 1.

Dunn, R. G., I96, 335 .

Dunn, Sewall, 2 I 5 .

Dunn, William, 40, 2 I 2, 694 .

Dunn, Wilson, $52 \mathrm{I}$.

Dunning, John, 685 .

Duprés, Vital, 640.

Durfee, C. A., 71, 62 I.

Durfee \& Hossington, 466.

Durfee \& Moody, 466.

Durgan, Dr., 557.

Durkee, Harrison, 71， 73， 142，445, 601.

Durkee, John, I29.

Durkee, Lieut., 377.

Durley, Dr. B. W., 599.
Durley, H. A., 599.

Duryea, P. H., 226.

Dusenberry \& King, 625 .

Dustin, 683 .

Dutcher, Gilbert, 678 .

Dutcher, Joshua, I 28.

Dutcher, J. B., \& Son, 378.

Dutton, 36r.

Dutton, A. P., 622.

Dutton, I. H., 622.

Dutton, Sir John, 363 .

DuVal, Clayborne, 376.

Duval, James, 335 .

Duvall, Joe., IO4.

Dwelley, M. S., 438.

Dwight, Dr., 403.

Dyett, T. \& J., II9.

Dyer, J., 499.

Dyer, L. W., 624 .

Dygert Bros., 4 .

FADS, 542 .

E Eagle, E. E., 597.

Earing, George, 655 .

Earle, John, 83 .

Earle, Roswell, 648.

Earl of Godolphin, 604.

Eason, J. T., 649.

Eastin, August, 226.

Eastman, A. R., 506.

Eastman, C., 68.

Eastman, Dorson, I64.

Eastman, Elijah, I64.

Eastman, Enoch, I64.

Eastman, Gus., 226.

Eaton, Eliab L., I65.

Eaton, E. P., 655.

Eaton, John, 432.

Eaton, M. C., 239.

Eddy, Hiram, $65 \mathrm{I}$.

Eddy, S. A., 527.

Eddy \& Wells, 395.

Edelin, Edward, 65.

Edgerly, S. H., 673.

Fdgerton, Ezra, 377.

Edmonston, Captain, I44.

Edmunds, Harrison, 462.

Edmunds, O. D., 670 .

Edmunds, S. H., 5 I 3 .

Edsall, Selah, 390.

Edson, Simeon H., I82.

Edstill, W. W., \& Co., 363.

Edwards, 397.

Edwards, Avery, 409. 
Edwards, Elisha, 462.

Edwards, J. H., I 85 .

Edwards, J. L., 537.

Edwards, William, 364.

Edwards \& White, 185.

Eells, E. C., 666.

Effner, George, 57 x.

Egan, James, 393.

Eldredge, E. A., 480, 483 .

Eldredge, J., 236.

Eldridge, C. S, 36 r.

Eldridge \& Bennett, D. A., 490.

Ellenwood, J. M., 527 .

Elliott, E., 6ri.

Elliott, Frank, 435 .

Elliott, John, I 26.

Ellis, C. B., 417.

Ellis, George, 2 I3.

Ellis, James, 242.

Ellis, Lewis, 340, 34 r.

Elliston, W. R., 226.

Ellsworth, 207.

Ellsworth, A. F., 603.

Ellsworth \& Herrick, 206.

Elmhurst Farm, 6 I6.

Elmore, A. E., 524 .

Elwood, Isaac, I 28.

Ely, Alexander, 474 .

Ely, C. D., 69.

Ely, George H., 215, 445 .

Ely, W. A., 4I, 243.

Embry, Jacob, 457.

Embry, J. W., $45 \mathrm{I}$.

Emerson, A. K., 338.

Emerson, Wm., 2 I 2.

Emerson, Wm. D., 434.

Emery, C. F., 432.

Emery, Edwin, 687 .

Emery, Samuel B., 2 I 7 .

Emory, Gen., I 86.

Engleman, J. H., 48, 457.

English, Joshua, 90.

English, William, I 6 .

Englishman \& Welch, 24.

Enos, Ethol H., 24 I.

Ensley, Robert, 405.

Eppes, Col. Francis, 382 .

Eppison, Isaac H., 586.

Erwin, 381 .

Essary, George, 527.

Estabrook, J. A., 207.

Estey, 25I.

Estill, W. W., 194.

Evans, Harry, I32.
Evans, Phil. E., I I 7 .

Evans, Silas, 462.

Everett, George, 640.

Everitt, Noah, 68.

Eversole, F. R., 82.

Everson, George, 345 .

Every, Edward, 572.

Ewalt, Joseph H., I 40.

Ewbank, J. W., I 44 .

Ewin, M., 620.

Ewing, S. C., 53.

Exall, Henry, 3, 38, 205.

Eycke, P. R., 3.

Eyckshimer, Sam., 424 .

Eyclesheimer, 5 Io.

Eyclesheimer, Chauncey, 507 .

Eyclesheimer, Stephen \& J. S. D., $507,510$.

Ezell, Brit, 43I.

EABIAN, 260. Fair, James C., 621 .

Fair, W. C., I 40.

Fairbanks, Frank, 600.

Fairbanks, Thomas, $47 \mathrm{I}$.

Fairchild, Smith, 352.

Fairfax, Lord, 353 .

Fairlawn Stock Farm, $58_{4}$.

Faison, Wm. I., 6r I.

Falconer, Robert, I54.

Fanning, A. J., 32.

Fanning, Talbert, 32 .

Farley, J. M., 328.

Farley, J. W., I62.

Farley, Robert, 22.

Farmer, Samuel, 404.

Farnham, A. R., 336.

Farnsworth, Wm., 359.

Farnum, John R., I 77, 430, 441.

Farr, E. S., 4I I.

Farr, Frederick, 2 I 5 .

Farrar, America, 450*.

Farrell, T. J., 79.

Farrell \& Godfrey, 427.

Farrelly, J. K., 244.

Farrington, Frank, 272.

Farrington, Nathaniel, $36 \mathrm{r}$.

Farwell, A. H., 225, 594 .

Fashion Stud Farm, I4 I, I48, 2 I6, 243,62 I.

Fasig, W. B., 346.

Fassett, Nathan, 24.

Fassett, Nathan C., I 76 .

Faulconer, E. P., 44r. 
Fawcett, H. W., 691.

Fayson, Wm. I., 394, 395.

Feagles, David R., I9I.

Feagles, Jacob R., 79.

Featheringill, J. D., 72.

Fell, A. G., 204.

Fellows, C. W., 373 .

Fellows, Fred, 445, 557 .

Felter, Harry, 543,

Felter, H. D., 563 .

Felter, Theron, $55^{8}$.

Felton, Frank, 27 I.

Fenton, 227.

Fenton, Richard W., I59.

Fenwick, 356 .

Ferguson, Bryant, 374.

Ferguson, Capt., $57 \mathrm{I}$.

Ferguson, Col. James, 373.

Ferguson, E. B., 4I.

Ferguson, E. N., 4I.

Ferguson, G. W., I87, 656 .

Ferguson, J. D., 33 I.

Ferguson, John S., 205, 446.

Ferguson, J. T., 36r.

Ferguson, J. W., 37 .

Ferguson, Mayor T. B., 373.

Ferrin, Charles, 373 .

Ferris, L. E., I6 6 .

Ferris, R. R., 78 .

Field, Charles, 453.

Field, W., 353, 375 .

Fields, John, 252.

Figg, Silas, 22.

Finch, Archy, i 9.

Finch, Chas., 286.

Finkle, H. G., 162.

Finnegan, P. A., 535 .

Finnegan \& Galaway, 432.

Fiset, 646 .

Fish, 445, 448.

Fish, Albert, 143 .

Fish, Andrew, 640.

Fish, Benjamin, 29.

Fish, Leonard, 573 .

Fish, Lionel G., 83 .

Fisher, 445.

Fisher, Adam, I05.

Fisher, George, $23,142$.

Fisk, A. C., $64,78,498,5$ I 2,523 , 6I 7, 668, 674.

Fiske, Josiah, 159 .

Fitch, G. A., 465 .

Fitch Bros., 690.

Fitzgerald, A. S., 443.
Fitzgerald, James W., 242.

Fitzgerald \& Kellogg, 195 .

Fitzhugh, Wm., 362.

Fitzsimmons, Robert, 38, 39 .

Fitzwater, Sr., George W., 500.

Fitzwilliam, Lord, $164^{*}$.

Flack, J. W., 6I6.

Flack \& Huffman, 597 .

Flagg, G., 422.

Flagg, Gershom, 347.

Flaherty, Richard, 370.

Flanders, Kimball, 355 .

Fleming, T. J., 447.

Fleming, Wm., 336, 4I 5 .

Fleming \& Rockhill Bros., 598.

Fletcher, Champion, 400.

Fletcher, D. C., 444.

Fletcher, Jasper, 674 .

Fletcher, Paris, 674.

Fletcher, Perry, 400.

Fleurs, H. M., 690.

Flinn, Barney, 650.

Flint, Jonas, 392.

Flood, 476.

Flood, Dr. P. H., 437.

Flood, W. S., 437.

Florea, A. W., I93.

Floyd, Gen., I 7 I, 233, 234.

Floyd, Henry, 6o7*.

Floyd, Ira E., 356.

Floyd, Richard, I 7 I.

Fogg, G. W., 599.

Foley, John, 685.

Fonda, J. I.., I 49.

Foot, Abram, 257.

Foot, Somers, 257 .

Foot, Whit., 476 .

Foote, I 26.

Foote, F. M., 375 .

Foote, S. A., 333 .

Foote, S. G., 3 I.

Foote Bros., I Io, 63 o.

Foote \& Bryant, i Io.

Forbes, Volney, 598.

Forbes \& McKay, 37 I.

Ford, B. W., I 23 .

Ford, F. G., 96.

Ford, James P., 448.

Ford, J. W., I 26.

Ford, O., 34I.

Ford, P. W., 36 .

Ford, W. R., I 77 .

Forman, T. O., 192.

Forsee, J. W., 4I9. 
Forsyth, N., 383 .

Foss, Hon. H. G., I4I.

Foster, A. K., 215 .

Foster, Col., 46.

Foster, Daniel, 407.

Foster, D. M., 9.

Foster, D. W., 2 r 5 .

Foster, George, 40.

Foster, L. G., 606.

Foster, L. T., I 6 .

Foster, Otis, 658.

Foster, Thomas, 522.

Foulk, Levi, 649.

Fowle, George, 66r.

Fowler, C. E., 345.

Fowler, George, 398.

Fowler, Wm., 487.

Fowler, S. W., 688.

Fox, D., 218.

Fox, Gen., I 8 I.

Fox, Hannan, 683 .

Fox, R. P., \& Son, I07.

Frampton, George W., 428.

France, W. C., 24, 71, 80, 248, 427.

Francis, Col., 240.

Francis, Luke, 90.

Franco, 249.

Franklin, Dr. Wm., 436.

Fraser, Alex, 244.

Fraser, Alexander, \& Welch, 356.

Frazer, Noah, 340.

Frazier, Daniel, 44I, 442.

Frazier, W. S., 640.

Frazier, W. W., Ir 8 .

Frederick, Lieut. Gen., 64 .

Freel, Edward, 345.

Freeman, George, 448.

Freeman, James G., 355 .

Freeman, S. E., 335 .

Freeman, T. C., 447.

Freeman, R. T., \& Son, I 44 .

French, Cyrus, 608.

French, George H., 507 .

French, H., 47.

French, J. M., 448.

French, S. M., $2 \mathrm{r}$.

Frew, D., 639 .

Frichette, 450.

Friel, Charles, Io2.

Frier \& Gibbs, 79.

Frink \& Walker, 657.

Fritts, H. K., I 8 .

Fritz, John, 474.

Fritz, Reed, 69r.
Fromm, Grand Bailiff, 64 .

Frost, E. E., 606.

Frost, James F., I96, 258 .

Frost, Jeremiah, 452.

Frost, John, 383 .

Frost, William, 584 .

Fuller, D., 666.

Fuller, Frank L., 352.

Fuller, L. N., 452.

Fullerton, Charles, 409.

Fullom, Alvin, 453.

Furgis, J. C., 38.

Furnam, 427.

CAFFNEY, DAVID, 629.

I Gage, Clint, 490, 497.

Gage, D. A., 594.

Gage, S. N., 390.

Gaines, Baxter M., I 74.

Gaines, D. H., 6r 2.

Gaines, E. P., 54.

Gaines, H., 82 .

Gaines, Ned, 446.

Galaway \& Finnegan, 432.

Galbreth, Dr. F. B., I $\&$ I.

Gale, Dr., 338.

Gale, Elisha, I 74 .

Galley, Wm., 462 .

Galloway, R. F., 692.

Galloway, R. H., 69 r.

Galloway, Robert, IO4.

Gamble, Samuel, 688.

Gammon, James, 650.

Gannon, D., 249.

Gano, S. F., I95, 47 I.

Gardiner, A. D., 2 Io.

Gardiner, L. S., I43.

Gardner, 33I.

Gardner, R. H., I95.

Gardner, William G., IO2.

Garforth, W., 9r.

Garnett, Edward, 2 I.

Garnett, E. G., 403.

Gates \& Prav, 389.

Gavers, Joseph, 529.

Gavin, Joseph, 40, 247, 345, 437 .

Gay, Daniel, 679 .

Gay, W., 340.

Gaylord, J. H., I.

Geers, E. F., 92.

Gelnix, F. K., 456.

Gentry, W. H., 98.

George, A. M., 578 .

George, Henry, 48. 
George, Thomas, I 84 .

George Stock Co., 498.

Gerald, F. S. ,597.

Gerighty, James, 213.

Gerow, Elias, 393.

Gette, C. H., 433 .

Getz, Wm. G., 207.

Gibbs, William, 657 .

Gibbs \& Chamberlain, 4I 2.

Gibbs \& Frier, 79.

Gibson, Capt., 586.

Gibson, J., I 39.

Gibson \& Edwards, 397.

Gifford, D. C., 583 .

Gifford, George, 526 .

Gifford, W. H., I6.

Gifford, Ziba, 573.

Gifford \& Co., 655 .

Gilbert, Dexter, 24 .

Gilbert, Edward, 544.

Gilbert, James, 544, 558, 559 .

Gilbert, John, 373 .

Gilbert Bros. \& Beardsley, 557.

Gilbirds, A. B., 584 .

Gilbirds, John F., $5^{84}$.

Giles, William, 157 .

Gill, John S., I 20, 457,636 .

Gill, M. H., 463 .

Gilman, Capt., 45.

Gilman, Daniel, 372.

Gilman, Dr., 505.

Gilman, H. H., 334 .

Gilman, John, 78 .

Gilmore, 589 .

Gilmour, Isaac, 525 .

Gilson, Yates \& Co., 586.

Giltner, H., 597 .

Girard, 646.

Gittings, Ivo., 385 .

Givens, Sam., I03.

Glass, V. K., I 23,593 .

Glathart, J. H., I 67.

Glazier, John, 292.

Glengary Stock Farm, 520 .

Glenn, G. G., 598.

Glenn, N. G., 597 .

Glenview Farm, 689.

Gloucester, Duke of, 174 .

Goddard, 46.

Goddard \& Herr, 446.

Gotfrey, D. B., 6o3.

Godfrey, S. H., 427.

Godfrey \& Farrel, 427.

Godolphin, Earl of, 604 .
Godolphin, Lord, 363 .

Goff, Dana, 404.

Goff, Sewell, 404.

Goff, S. T., 345 .

Goldman, A., I48.

Goldman, V. E., I48.

Goldsmith, Alden, I $12,148,163,248$, $454,464,6$ I6, 6і 7 .

Goode, Thomas, 87 .

Goodenough, R. A., 587, 588 .

Goodier, John, 622.

Goodloe, W. C., 59.

Goodman, Jeff., 6 I9.

Goodrich, G. A., I 94.

Goodrich, George, 459, 650.

Goodrich, H. C., 67.

Goodrich, John, I 86.

Goodrich \& Ireland, 242.

Goodwin, 619.

Goodwin, Joshua H., 530.

Goodwin, J. S., 503 .

Goodyear, John, I 58 .

Gordon, George, I9I.

Gordon, George B., 355 .

Gordon, John B., 355 .

Gorham, Horace, 407.

Gorham, L., 407.

Gorton, F. S., I Iо.

Goss \& Blake, 335 .

Goth, II. C., II 7 .

Gott, Pohattan, 7.

Gould, O. B., 652 , 655 .

Gourney, 670.

Gove, E. L., I96.

Gove, James, 637 .

Gove, John, 523 .

Government Morgan Horse Farm, 475.

Gowan, Alexander, 232.

Gowie, D. B., 688.

Gracy, Joseph, 590.

Grafton, Duke of 356 .

Graham, James A., I6 I, 2 I6.

Graham, John, 344,385 .

Graham, John R., I I 5 , I 24.

Grandey, Gen. George W., 334 .

Grand Seigneur of Arabia, 637 .

Granger, S. M., 489 .

Grant, N., 57 I.

Grant Bros., I 25.

Gratz, Benj., I 16 .

Gratz, M. B., I90, 523.

Gravelin, Joseph, 64I.

Graves, A. K., 648 . 
Graves, E. D., 403.

Graves, F. C., 360.

Graves, George W., 630.

Graves, Henry, 27.

Graves, James C., I91.

Graves, J. M., 38.

Graves, Joseph, 375 .

Graves, Leroy, 3 I.

Graves, R. N., 203.

Graves, Zenas H., 647.

Gray, J. W., 39, 4I.

Gray, L., 205.

Gray, R. P., 347.

Gray, W. H., 39.

Gray, Wm., 436.

Gray, John T., \& Co., 433.

Grear, Robert, 4I.

Green, I 53, 286, 350, 590.

Green, A. C., 368 .

Green, C. C., 529.

Green, Charles S., 6 ro.

Green, Clark C., 670.

Green, Daniel, 669.

Green, E. N., 425.

Green, G. H., I 26.

Green, J. A., 27, I48, I66, 592.

Green, John, 99.

Green, L. W., 48.

Green, Wm., 53.

Greene, Judge, I4I.

Greenleaf, William H., I29.

Greenman, Dr., 667.

Greenwell, John, 438 .

Greenwell, Stuart, $43^{8}$.

Greer, A. J., $5 \mathrm{I}$.

Gregory, John, 346, 678.

Gregg, I. H., I07.

Gregg, J. H., 4I 5 .

Gregory, G. D., 5 I 3 .

Greston, General, 47.

Greve, Herman, 6 I 6.

Greville, I25.

Gridley, Jared, 444.

Griffith, A., \& Hann, E. L., 457.

Grinnell, Wm., I9o.

Grinstead, James A., $44 \mathrm{I}$.

Grisewood, 590.

Griswold, J. C., 505 .

Griswold, S. P., I64.

Grobmyer, 4, 63 .

Groff, J. H., 156, 460.

Gross, 348.

Grosvenor, D. E., I 82 .

Grosvenor, Earl, I 40.
Grosvenor, Lord, 59 I.

Grover, E., 678.

Grover, John, 656.

Grundy, Thomas, 132.

Guild, Cyrus, 585 .

Guindon, 689.

Gurley, John P., 524.

Gurnee, Walter S., I 72.

Guy, F. C., 397.

Guy, Wm., 409.

HACKE, P. H., I 48.

H Hackett, Col., 575 .

Hackett, Isaac, 352.

Hackney, Len., 658.

Haddock, J. N., I9I.

Haden, E. V., I63.

Hadley, T. G., 370.

Hadlock, Kendall, 43.

Hagard \& Thompson, 637 .

Hagemier, Henry, 437.

Hagerman, Alf., 204.

Hagerman, John, 204.

Hagerman, L. B., 456.

Haggett, R. R., I3r.

Haggin, J. B., 58, I 67, 524, 526, 535 .

Haggins, Samuel, 105.

Haight, Daniel B., I46, I47, 6 I 6 .

Haight, Jacob N., I46, 420 .

Haight, J. N., 437.

Haight, Samuel, I 54 .

Hains, Frank, 618.

Hale, Frank, 433.

Hale, J. A., 436 .

Hale, Silas, 679.

Haley, Charles, 2 I 9.

Haley, H. E., 36.

Haley, Samuel, 2 I 9.

Halfpenny, Martin, 59 .

Hall, 36, 578 .

Hall, A. R., 49.

Hall, C., 6 г6.

Hall, Caleb, I 76 .

Hall, Charles S., 46.

Hall, F. A., 436.

Hall, George, I41, 526 .

Hall, George C., 635 .

Hall, Henry A., 240.

Hall, Henry N., $3^{80}$.

Hall, James H., $3 \mathbf{1}$.

Hall, J. H., 598.

Hall, John, 405.

Hall, Jonathan, I 5 I, 153 .

Hall, Joseph, 46, 530, 535, 536 . 
Hall, Otis, 183 .

Hall, P., I 8 I.

Hall, Richard B.

Hall, S. R., $33^{8}$.

Hall, Uriah, 488 .

Hall, V. C., 499.

Hall, William, 5 工.

Hall, William S., 70.

Hall, Jr., I. R., 394 .

Hallaway, S., 406.

Hallenbeck, Michael R., 379。

Halliday, Alonzo, 420.

Halliday, M., 407.

Halliday, S. S., 622.

Halsey, George, 664.

Halstead, John, 364, 693.

Hambrick, Jesse, 624 .

Hamilton, 578.

Hamilton, C. E., 6.

Hamilton, Dr. Thomas, 376.

Hamilton, Duke of, 375 .

Hamilton, E., 543.

Hamilton, Otis, 240, 270.

Hamilton, Wm., 333, 619.

Hamlin, C. J., 23, 24, 203,2 I 7, 246, $247,346,347,571,600,615$.

Hammel, John, 583 .

Hammett, B. \& L., I 6.

Hammett Stock Farm, 623.

Hammil, George, 667 .

Hammill \& Wicker, 266.

Hammond, Jerry, 670, 67 I.

Hammond, Thomas, 5 I 3 .

Hampton, Col. Wade, 2 I 6.

Hamsboro, H., I67.

Hance, Thomas, 2 I 4 .

Hancock, G. W., roo.

Hancock, Thomas, 649.

Hand, Paul, 476.

Hanes, Chas., 269.

Hanks, I., 7o.

Hanks, Philander, 284.

Hanley, Moses, 406.

Hammer, Peter, 682.

Hann, E. L., 457.

Hann, Robt., I 44 .

Hannah Bros., I $5 \mathrm{I}$.

Hannon, John, 57 .

Hansel, F. S., I07.

Hanson, Wm. A., 669.

Haram, J. H., 4I 7.

Harbison, Shelby T., 572.

Hardaway, Daniel, 24.

Harding, Col., I37.
Harding, J., 82, I3 I.

Hare, Jarmon, I 74 .

Hare, M. L., 3, 50, 667.

Haring, J. E., 60, 464.

Harker, Joseph, 9, 568 .

Harleston, I. C., 39 I.

Harlson, Fred, r99.

Harlow, Abner, 657.

Harlow, L. D., 657 .

Harnish, W. D., 204.

Harper, Enos, 7.

Harp, H. C., 363 .

Harp, James, 363 .

Harribel, 543 .

Harrington, Caleb, 239.

Harrington, E. M., IO5.

Harris, A. C., I 2, $24 \mathrm{I}$.

Harris, A. W. \& T. O., 599.

Harris, Charles, 4I4, 649.

Harris, Col., I69.

Harris, Edward, 8 I.

Harris, John, $24 \mathrm{I}$.

Harris, L., 528 .

Harris, L. B., 522.

Harris, Iuel, 97.

Harris, Nate, 485 .

Harris, Norvin T., I Io.

Harris, Samuel, I 18.

Harris, Squire, 383 .

Harris, Vernon, I67.

Harris, W. S., 78.

Harris, Jr., T. O., Io3, 45 o.

Harrison, F., 244.

Hart, James, I 75, 240.

Hart, J. W., 420.

Hart, R. G., 78.

Hart, R. K., Iо3.

Hart, Wm., 352 .

Hart, \& Talbot, Wm., I64.

Hartland, Leroy, 379.

Hartland Bros., 430.

Hartley, C. W., I8o.

Harvey, 672.

Harvey, D. F., 72.

Harvey, D. T., 502 .

Harvey, H. C., I05, I I 3 .

Harvey, Thomas, 260.

Harwood, Lyman, I5.

Haselton, Joe., 429.

Haskell, 5 то.

Haskin, I 83 .

Haskins, A., 40r.

Hasslee, A., 247.

Hastings, Apollus, 239. 
Hastings, Matthew, 436 .

Hatch, A. T., 688.

Hatch, Charles, 45.

Hatch, Harris, 635 .

Hatch, Joseph, 5 Io.

Hauldsworth, Thomas, 378 .

Haultz, Captain, 78.

Haurathly, James P., 95 .

Haven, D. W., $5+1$.

Havens, Thomas, $\mathbf{2} 20$.

Haws, A. J., 42.

Hawkins, C. D., 66, 614.

Hawkins, Ira, 78 .

Hawkins, Jonas, 63, 336 .

Hawkins, Jonathan, 61, 63, 73, 210 , $225,24 \mathrm{I}$.

Hawkins, Stephen, 644 .

Hawley, John, 654 .

Hay, Jonathan, 2 II.

Hayden, G. C., 4I3.

Haydon, W. B., 435 .

Hayes, Abiah, 433.

Hayes, Albert and Perry, 459.

Hayes, Daniel, I81, 207, 503, 583 .

Haves, Luther, 454.

Hayes, N., 6r 3 .

Hayford, Dea., 292.

Hayner, Parker, 667.

Hays, P., I 25.

Haywards, Henry, 42.

Hazard, S. B., 455.

Hazelrigg, William, 96.

Hazen, Chester, 29.

Hazzard, 156.

Head, Dr. J. M., 2, 528 .

Headley, C. WV., 435 .

Headley, G. W., 350.

Headley, H. P., I94.

Heagan, John, Ior.

Heald \& Loeber, 635.

Heard, Charles, 67.

Heard, Nathaniel, 376,378 .

Heath, Alden G., $35^{8}$.

Heath, A. S., 47.

Heath, Dr., 246.

Heath, Dr. Horatio W., 357 .

Heatherington, T., 512 .

Hedershot, I 26.

Hedding, 328 .

Hedge, 3 .

Heiltzheimer, Jacob, 40.

Heisey, G. H., 2 I I.

Helbe: E. J., 384.

Helm, Harvey, 48, I8 I.
Helm \& Bridges, 578 .

Helman, H. H., I97.

Hemenway, Asa, 91.

Heminway, Sidney S., 576 .

Heminway, Sylvanus, 474 .

Hendee, George W.. 594.

Henderson, B. H. \& M. H., 27.

Hendren, James M., 474.

Hendrickson, B. E., 529.

Hendrickson, Joseph, 529.

Hendrickson, Nathan, 535.

Hendrickson, Pierson, 224 .

Hendrickson, W. C., 206.

Hendricson, Wm., 336.

Henry, H. J., 337.

Henry, Mason, 459, $47 \mathrm{I}$.

Henry O. H., 583 .

Henry, W. J., 337.

Henwood, John S., r 80.

Hepburn, James, 177.

Hermitage Stud, 50, 450.

Herr, A. G., 42, I ro.

Herr, Dr. L., 9, 22, 80, 81, 107, I40, I $47,225,380,4 \mathrm{I} 7$,

Herr, E. D., 2 I 5, 418.

Herr \& Goddard, 446.

Herrick, 488.

Herrick \& Ellsworth, 207.

Hershey, B., 48, 59, 242, 487, 618 .

Herson, I. H., I68.

Hess, 94 .

Hess, Henry, 590.

Heth, Charles, $3 \mathrm{I}$.

Hetzheimer, Jacob, I 3 I.

Heustis, Daniel, 489.

Hewitt, A. M., 462.

Hibbard, 450.

Hibbard, Daniel B., I 7 .

Hibbard, Gen. lovell, 488.

Hicklyn, Walter, 6 го.

Hickok, Orin A., 204, 2 I 3.

Hicks, 6 I 3 .

Hicks, James, 525 .

Hicks, L. B., 385 .

Hicks, M. W., I07, 385, 394.

Hicks, Whitehead, 4I7.

Hicks, Wm. H., 15 .

Hidden, Geo., 434.

Hidden, John T., 678 .

Higbee Bros., 625 .

Higbee, Ed., 653 .

Higginbotham, William P., I 10.

Higgins, Judson, Iог.

Higgins, Nathaniel, I 57. 
Higgins, P., 37 .

Higginson, Col., 432.

Hight, Josiah, 356 .

Hightree, W., 346.

Hilderbrecht, George, 5 I4 .

Hill, 93.

Hill, Alexander, 6o, roz.

Hill, Capt., 137 .

Hill, David, 31, 381, 67 I.

Hill, D. Edgar, I43.

Hill, F. G., I97.

Hill, Hannan, 4ro.

Hill, M. F., ıо6.

Hill, Rich, 620 .

Hill, True, 366 .

Hill, W. H., 685 .

Hill, Whiteside, I 52.

Hill, William, I 8 , 593.

Hill \& Baker, 505.

Hiller, Aiken W., 4I 7 .

Hills, Jack.

Hilton, Wm. C.

Hinchman, John, 40.

Hinckley, E. J., 95.

Hinds, E. D., I 40.

Hinds, Francis M., 682.

Hinds, George.

Hines, J. B , 67.

Hinman, W. G., 59 .

Hisey, D. W., 40.

Hitchcock, Geo. C., 520,587 .

Hitchnell, 6 oo.

Hoagland, S. D., 345 .

Hoagland, Simeon D., 664 .

Hobbs, A. M., 23.

Hockaday, Ed., I 75 .

Hodge, Thomas, 226.

Hodgden, John S., 392.

Hodgens, T. D., I 82,602 .

Hodges, C. A., 529.

Hodgins, G. W. \& Son, 57 I.

Hodgkins, H. B., 635 .

Hodgson, Sam., 355 .

Hodson, R. R., 527 .

Hoe, 6r9.

Hoge, J. C., 6 r 6.

Hogue, Thomas, 4r 5 .

Holabird, Cassius, 329.

Holabird, C. B., 6 o.

Holabird \& Satterlee, 329.

Holbert, James, r91.

Holcolm, 286.

Holcomb, J. W., I29, 25 2, 333 .

Holcomb \& Roe, 252.
Holdridge, Billings, 4, 539.

Holenshead \& Son, 463 .

Holgate, Curtis, 193.

Holland, J. W., 33 I.

Holland, Nathan, 22.

Hollister, Willis, $4 \mathrm{r} 8$.

Holloway, Cephas, 506.

Holloway, J. C., 527.

Holly, B. C., 68, 397, 668.

Holman, Charles, 683.

Holme, John, 240.

Holmes, E., 668.

Holmes, R. E., 689.

Holmes, W. F., I62.

Holt, Banks L., 685.

Holton, John A., 340.

Holtshouser, Oliver, $43 \mathrm{I}$.

Holway, B. F., $212,336$.

Homer, George W., \& Co., $60_{3}$.

Homes, Col., 250.

Homes, Jonathan J., 375 .

Hood, C. L., 6 I 8.

Hook, Thomas, ro9, 463.

Hoomes, Col. John, 26, 83, 91, I49.

Hoover, A. J., 82.

Hope, Alix, 296.

Hopkins, 5 I 2 .

Hopkins, Chauncey, 167.

Hopkins, George G., 664 .

Hopkins, Mark, 360.

Hoppin, John, 499.

Hoppock, Ely, \& Case, Peter J., 603.

Hopson, Warren, 505 .

Hord, Wm., 624.

Horn, I 44 .

Hornby, Thomas, 378 .

Horne, Isaiah, 392.

Hornsby, Crabb \& Co., 4I 7 .

Hornsby, J. W., $62 \mathrm{x}$.

Horter, John, 500.

Horton, 669.

Hosford, T. M., 65 r.

Hoskins, Atwood B., I97.

Hostetler, Simon M., I46.

Hotaling, A. P., 197, 47 I.

Hotchkiss, 199.

Hough, A. J., 685.

Houghton, 6 I 7 .

Houghton, S. S., 44 I, 569, 655 .

Hourmedien, Samuel L., I I 2 .

House, O. C., 5 I 3 .

Houston, Geo., I40.

Houston, J. B., 79.

Howard, 132. 
Howard, I. V., 448.

Howard, John, $52 \mathrm{I}$.

Howard, J. W., 672.

Howard, Silas, $6 \mathbf{1} 2$.

Howe, Bela, 507 .

Howe, Dr., I4I.

Howe, Juba, 273.

Howe, Sol., 257 .

Howe, Phil., 247.

Howland, Gardner, бог.

Hoyt, James W., 489, 668.

Hoyt, Pingree, 689 .

Hoyt, T. J. \& A. F., 47.

Hoyton, T. B., I 53 .

Hubbard, John M., 626.

Hubbard, N., 382 .

Hubbard, Parker D., 357.

Hubbard, Varsil, 679.

Hubbs, Waliace L., 69 I.

Huckins, C. M., 486.

Hudson, John, 57.

Hudson, Price, 52 r.

Hudson, Theodore, 37 .

Huff, 653 .

Huffman \& Flack, 597.

Hugely, J. A., 49.

Hugely \& Robinson, 79.

Huges, D. B., 477.

Hughes, Dick, 476 .

Hughes, E. W., 475, 476.

Hughes, Jacob, 194 .

Hughes, John, 82 .

Hughes, Samuel, 49.

Hughes, Samuel C., I9r.

Hughes, Thomas, 242.

Hughs, William, 437 .

Hulett, M., 68.

Hulse, E. E., 6 I 6.

Hulse, Fred, 432 .

Hulton, Willton, \& Son, 47 I.

Hume, A. M., 55 .

Humphreys, Joshua, 349 .

Hunsden, Charles, 270.

Hunsdon, Wm. W., 490.

Hunt, A., 348.

Hunt, A. G., I32.

Hunt, C. A., 398 .

Hunt, G. Drummond, $45^{2}$.

Hunt, J. S., I 34.

Hunt, P. B., I48.

Hunt, Richard, 7 o.

Hunt, Stephen, 39 .

Hunt, Sr., G. Drummond, $24,25 *, 28$.

Hunt, Wm., \& Son, 57 o.
Hunt Bros., 2, 25, 28*, 35 I, 452.

Hunter, R. D., 345.

Hunter, William, 572.

Huntington, Hugh, 584 .

Huntington, Joel, 575 .

Huntley, 662.

Huntley, S. S., 38 .

Huntley \& Clark, 38, 58 .

Hurd, R. W., 434.

Hurlbut, Walter, 613.

Hurst, A., 36, 103, 455 .

Hurst, Bryan, I6o.

Hurst, Mrs. C. J., г6o.

Hussington \& Durfee, 466.

Hustin, Gen., 397.

Hutchinson, $5 \mathrm{I} 2$.

Hutchinson, John, 6 I 4.

Hutchinson, Wm., 330.

Huyler, John P., 464 .

Hyde, S. S., 28.

ICE, F. M., \& SON, 4I.

Ijams, W. P., $384,592$.

Ingersoll, Chas. W., 48I, 484 .

Ingersoll, M. H., 48 I.

Ingles, George, 445 .

Ingraham, George W., 50.

Ingraham, Richard, 522 .

Inus, John, 360 .

Ireland \& Goodridge, 242.

Irvine, W. M., 570 .

Irwin, Albert, I 57 .

Italian Government, $6{ }_{3} 6$.

Iverson, J. B., 8o.

Ives, Joseph, I 25.

JACKMAN, ROBERT, 592. Jackson, 578 .

Jackson, A., 602, 620 .

Jackson, Burwell, 23.

Jackson, Chas. R., 429.

Jackson, Gen., 64 .

Jackson, George, 590.

Jackson, Gus., 590.

Jackson, John, 258.

Jackson, Samuel J., 403 .

Jackson, Timothy T., I46, 401, 402, 420.

Jackson, T. T., 2 r.

Jackson, Washington, 428 .

Jackson, Jr., Thomas, $227,236$.

Jackson, Sr., Thomas, 127.

Jacobs, G. F., 527.

Jacobs, S., 599 . 
Jacobs Bros., 435 .

James, 622 .

James, George V., I 57 .

James, Henry, 242.

James, L. B., 500, 5 or.

James, Samuel, $3 \mathbf{I}$.

James, T., 396.

Janes, M. W., 474.

Janes, Nathan, 669.

Janes, W. P., I92.

Janvier, W. R., 98.

Jarvis, Dr. Leonard, 6i I.

Jarvis, J. H., \& Co., 57 o.

Jefferson, T. C., 83, 2 I I.

Jeffries, Daniel, 158.

Jeffries, James W., 586 .

Jenkins, Geo., 453 .

Jenkins, H. W. \& H. H., 453.

Jenks, 273 .

Jenne, John, 2 I 8, 52 I.

Jenness, Geo. N., 335 .

Jennings, A. C., $21,486$.

Jennings, C. B., 658.

Jesse, C. G., 2 I.

Jewell, T. P., 485 .

Jewett, Geo. M., I42, I43, 356, 623.

Jewett, H. C., 4 .

Jewett, Henry C., 247, 362, 375 .

Jewett, William E., 523 .

Jinks, Jerry, 285 .

Johnes, David, 428 .

Johnson, 23, 442.

Johnson, A., 536 .

Johnson, Ben., г6r.

Johnson, B. K., I 45 .

Johnson, Chas., 503 .

Johnson, Dick, 624 .

Johnson, Dudley, 4I.

Johnson, E. G., 389 .

Johnson, Elwood, 406.

Johnson, George, 255, 264.

Johnson, Hancock, 362 .

Johnson, H. N., $57 \mathrm{I}$.

Johnson, Howard, 5 I.

Johnson, James, I 20.

Johnson, J. M., $3^{80 .}$

Johnson, John, 644 .

Johnson, J. \& R. C., 502.

Johnson, Mark M., 5 I.

Johnson, Parmenius, I 3 I.

Johnson, Richard, I6 I, 599.

Johnson, W. R., 89.

Johnson, Jesse, \& Bro., 465.

Johnston, C. E., 462 .
Johnston, Chas., 363 .

Johnston, Dr. A. D., 400.

Johnston, H. W., 28.

Johnston, P. P., 35 I.

Johnston, Thomas, 462 .

Joiner, Nathaniel, 7 I, 54 I.

Jones, 232.

Jones, Caleb, I65.

Jones, D., 4 6 .

Jones, Daniel, 523 .

Jones, David W., I 22.

Jones, Dr. A. B., 655 .

Jones, G. H., 82.

Jones, Hannibal, 649.

Jones, Horace T., 566.

Jones, J., 475.

Jones, M. C., 4I 8.

Jones, Peter W., 435.

Jones, R. E., 504 .

Jones, Richard, 632 .

Jones, W. A., 208.

Jones, W. H., 446.

Jones, Caleb, \& Son, 446.

Jones or Underhill, 232.

Joslyn, Jarvis, 403.

Joslyn, L. D., 403.

Jourdan, Lyman L., 68I.

Judson, Elijah, 582 .

Jundt, John, 242.

Junkeith, 72 .

ALAMAZOO STOCK FARM,

K 504 .

Kanasby, Thomas, 507 .

Kane, James J., 224.

Kansas Stud Farm, 626.

Karns, J. S., 24 I.

Kase, D. L., 482, 557.

Kasson, 229.

Kaul, Andrew \& Shelby Co., 2 I I.

Kaul, A., \& Son, 2 I I.

Kay, Isaac, 536.

Kear, W. M., 669.

Kearney, J., 58.

Keates, James, 57.

Keedy, W. H., 409.

Keefe, W. P., I I3.

Keel, I8I.

Keith, 578 .

Keith, P. B., 588.

Keitley, John, 9.

Kellam, George, 486.

Kellam, G. M., 338 .

Kellam, Sabin, 338. 
Kelley, 376.

Kelley, Jack, 5 ro.

Kelley, John, 507.

Kelley, P. H., 38r.

Kelley, S. F., 436.

Kellogg, James, 662.

Kellogg, P. C., \& Co., 62 I.

Kellogg, Thomas, 569 .

Kellogg \& Fitzgerald, 95.

Kelly, Miles, 5 I.

Kelsey, H., I 49 .

Kelsey, John J., 504.

Kelsey, O. C., 435 .

Kendall, J., 679.

Kendall, Wm., 622 .

Kenedy, M. M., So.

Kennedy, Daniel, 6 I 6.

Kennedy, David, I 7 .

Kennedy, John M., I 7 .

Kennedy, John P., 3ॅ4.

Kennedy, M., I 7 .

Kennedy, Robert, 62.

Kennedy, S. E., 28.

Kenney, Joseph S., 480.

Kenney, Wm., 360.

Kenny, William M., 363 .

Kent, John, 432.

Kent \& Bailey, 556, 557.

Kenyon, George C., 447 .

Kern, A. L., 632.

Kern \& Crandall, 39.

Kerner, Charles H., $384,420,669$.

Kerr, S. D., 408.

Kerr, T. F., 207.

Kerr, W. H., r 78, 334, 335 .

Ketchum, D. C, 526 .

Keys, Samuel, 336.

Kibling, 5 8o.

Kibling, Fisher, 580.

Kibling, Richard, 469.

Kikbridge, Col. Joseph, 35 I.

Kidd, P. C., 687 .

Kidder, H. F., 59 .

Kidder, J. P., 483 .

Kilborn, Fred N., 40.

Kimball, 620.

Kimball, Charles W., I68.

Kimball, Daniel, 678 .

Kimball, Wm. C., 209.

Kincaid, J. H., 690.

King, 544, 646 .

King, Cyrus H., I 20.

King, D. S., 6o3.

King, Frank, 520.
King, G., I 75 .

King, John S., 544, 545, 558, 559.

King, L. D., r2o.

King, Moses, 500.

King, R. S., 520.

King, Rufus, 67 .

King, Thos. W., 500.

King, Wm., 439.

King \& Dusenberry, 625.

King of England, 637 .

Kingsley, J. F., 353.

Kingston, Duke of, I 24 .

Kinkead, F. P., 81, 179, 208, 354, $455,486,570$.

Kinkead, Geo. B., 503 .

Kinney, F. I., 430.

Kinney, L., $24 \mathrm{I}$.

Kinsman, Thomas, 2 ro.

Kipp, Elbert, 500.

Kirby, 347,584 .

Kirby, W. W., 40.

Kirk, B. P., I63.

Kirkman, John, 52, 615.

Kirkman, Thomas, 595 .

Kirtley, C., I 75.

Kirtley, Simeon, 349.

Kissam, I 22.

Kitchin, James, 650.

Kitson, U. W., 149.

Kittredge, B., 456.

Kitzmiller, A. A., 2 I I, 593.

Klein, John, \& Sons, I 32.

Kline, L. F., I6o.

Klotz, S. M., 419.

Knapp, Elwin, 6 г 7 .

Knapp, Hub., 668.

Kneebs, R. T., 2 I 4.

Knibbs, John, 622.

Knight, Daniel B., I 85 .

Knoble, Wm., 639 .

Knott, Harrison, 674 .

Knott, Rev., 402.

Knowlton, Len , 452 .

Kohl, William, 69r.

Kohlnier, Charles, 458.

Koon, C. M., 6r 4 .

Kortlander, A. H., 353 .

Kreigh, Philip, 596.

Kurtz, W. H., 503 .

I ABAREE, HENRY, 656 .

La Bousset, 646.

La Chambeau, Chas., 142.

Lackey, 447 . 
Lackey \& Carmony, 39 .

I ackman, Herman, 4 I.

Ladd, 402.

Ladd, J., 33r.

Ladd, James, 529.

La Forest, E., 7 o.

Lafton, Nicholas, 603 .

La Homidu, Bradick, 589 .

Lakin, Taylor, 4I.

Lamb, A. R., 662.

Lamb, I. H., I44.

Lamb, John H., 427.

Lamb \& Younger, 87.

Lambert, I. E., 447 .

Lamberton, William T., 669.

Lamott, 67 .

Lams, Russell, $\mathbf{1} 66$.

Lance, A. A., I05.

Lance, John, I05.

Lander, F. W., I33.

Landrigan, John, I9I.

Lane, Joshua, 422.

Lane, Robert, I 29.

Lanford, W. H., 4I.

Lang, Col. T. S., 393, 490, 493, 572 , 624 .

Lang, John, 335 .

Lang, Thomas, 446 .

Langhorm, Maurice, 392.

Langhlin, Chas. M., I42.

Langhlin, J. W., 503 .

Langley, A. W., 97.

Laper, Martin, 522.

Lapham, Oliver S., 489.

Lapham, Solon, 496 .

Larabie, S. E., I I 7, 186, 375, 38 o.

Large, A. N., 6 I4.

Larkin, K., 498.

La Roque, Gascon, 640, 642 .

Larrabee, John S., 498.

Larrabee, Judge, 28 r.

Larrow, Albert, io.

Larson, G. E., 573 .

Lasser, Joseph, 194 .

Lathrop, Ariel, 378.

Lathrop, Herbert, 4, 362.

Lathrop, Paul, 362.

Latimore, Robert, 649.

Latta Bros., I 8o.

Lattimer, Samuel, 377 .

Lauer, E. G. J., I62.

Lauer \& Madeau, I62.

Laurin, Cyrille, 465 .

Lawrence, D., 60.
Lawrence, E. J., Io6.

Lawrence, George, ro7.

Lawrence, Leonard, I 7 I, 232.

Lawrence, Peter, I 72.

Lawson, 23.

Lawson, M., 682.

Lawson, Thomas, 682 .

Laytham, James, 115.

Leadbeater, I37.

Learn, Randall, 6ז 3 .

Learned, James M., 64, 5 о I.

Leavitt, Sheldon, 568 .

Lee, D. B., 190.

Lee, E. W., 4t́s 5 .

Lee, Geo. F., 465.

Lee, George W., 596.

Lee, G. W. \& J. A., 4I 5, 57 O.

Lee, John, 148.

Lee, J. W., I 48.

Lee, Phillip Ludwell, 26.

Lee, R. I., 374.

Leech, Ed., 460 .

Leekley Bros., 623.

Leffert, I 70.

Lefferts, John, I 54, I 7 I.

Leffingwell, J. W., 393.

Leffler, Jacob, 4r3, 4r4.

Leggatt, Charles, 454 .

Leggett, B. F., I 83 .

Leland, Frederick, 252, 296, 504 .

Lemark, John W., 36 .

Lenz, Nicholas, 39 .

Lenz, Peter, 39 .

Leonard, Aaron, 626.

Leonard, Andrew G., 2 I 5 .

Leonard, Fred H., 5 .

Leonard, George, 372 .

Leonard, Howard, 5, 626 .

Leonard, Jacob, 407.

Leonard, John, 661.

Leslie, Dr. J., 8 o.

Lester, Moses, I 73.

Letcher, W. R., I 9 I.

Letourneau, Peter, ro6.

Levitt, George, 162.

Lewis, Alec, 232, 234.

Lewis, Captain Joseph, 544 .

Lewis, E., $42 \mathrm{I}$.

Lewis, E. B., 2 I 2.

Lewis, Elder James, r33.

Lewis, Enoch, IO3, 244.

Lewis, John, 600.

Lewis, J. S., 544, 557, 558, 568.

Lewis, M. J., 500. 
Lewis, Thomas, 572.

Lewis, William H., 28.

Leys, John, 418.

Lillard, E. T., 3.

Lilley \& Sisson, 373 .

Lillis, John, 62 I.

Lincoln, David, 4I 2.

Lincoln, Oscar, 527.

Line, John, 63 .

Linell, W. B., 363 .

Lineman, J. C., 198.

Linsey, S. B., 243.

Linsley, Charles, 636*.

Linson, Benjamin, 7 .

Linton, Hugh, 2 I 6.

Liphr, W. J., 4I 7 .

Lippincott, Joseph K., 389.

Lippincott, Samuel, 682.

Lisle, C. A., 24 I.

Lisle, T. K., \& Co., 106.

Littel, H. M., 690.

Little, 652.

Little, Chas., I 7 I, 233.

Littlefield, Joseph, Io2.

Litton, Labon, 507.

Littrell, O. O., \& Co., 69r.

Livermore, 407.

Livermore, L. D., 407.

Livingston, Walter, 174 .

Lloyd, George, M., I 54, I 7 I.

Lloyd, John L., 9 I.

Lloyd, L. C., I61.

Locke, D. R., 597.

Lockwood, Howard, 626.

Loeber, Fred W., 635 .

Logan, G. C., 50.

Logan, Robert, 44I.

Logsden, Joe., I 66.

Logsdoin, Jesse, 62 .

Long, E. \& D., I 7 I.

Long, Edward, i 7 ז.

Long, E. T., I8r.

Long, James, 345 .

Long, Lem'l, 500.

Long, N. D., I 7 I.

I.ongenecker, W. M., I.

Longstreet, Dr., 530.

Longworth, Nicholas, 55 .

Look, Samuel J., 599.

Loomer, Edward, 7 I, I42, 57 I.

Loomis, Frank, 249.

Loomis, George W. W., I88, 424.

Lord, 584 .

Lord, B. B. \& C. J., I3r.
Lott, A. L., 694.

Louis, Loomis \& Butler, 657 .

Lovatt, Thomas B., 82 .

Love, J. F., 419.

Lovel, H. L., 502.

Lovell, Capt., 377 .

Lovejoy, S. B., 487.

Lowe, Frank, 429.

Lowe, George, 7 .

Lowe, John, 489.

Lowell, Charles, I04.

Lowell, F. P., I I 8, 356 .

Lowrey, H. H., 589 .

Lucas, Rev. Joseph D., 34.

Lucas, Steve, 96.

Lucket, William, rog.

Ludlow, Ephraim, 24I.

Ludlow, Geo. H., 463.

Ludwig, Elmer, 100.

Lull, $22 \mathrm{x}$.

Luse, Nathan B., 463.

Lutes, Samuel, 28, 355 .

Luxton, Major, 55 .

Lyle, John A., I62.

Lyle, W. J., 22, 421, 624 .

Lyman, Abel, 648 .

Lynch, David, 570.

Lyon, A. G., 594 .

Lyon, Allen, 438.

M ABBETT, JAMES, 420.

N Mac, 425.

Mace, Dan., 160, 252, 260, 374, 502, 587 .

Macey Bros., 207, 693 .

Macey, Ward, 480.

Mack, David, \& J. Mixter, II I.

Mackey, O. T., 5 o.

Madara, James W., 584.

Madden, J. E., I $24,192$.

Madden, John, 50.

Madden, S. B., 684.

Madora, J. W., 474.

Mahone, R. D., roo, 2 I I, 599.

Mahoney, Thomas, 102.

Major, Edward, 68I.

Mallery, John, 598.

Mallory, Daniel, I 75.

Maloney, George, 389.

Manchester, Robert, 33 I.

Mancy, Isaac, 407 .

Mangin, Henry, 245.

Mann, 432, 537, 538.

Mann, N. B., 30, 328, 47 I. 
Manners, Lord W., 632.

Mansell, 39 .

Mapes, T. F., 142.

Marble, O. E., 592.

Marbold, H. J., 633.

Marder, John, I 79, I96.

Marine, Wesley, 444.

Markentin, C. B., 356 .

Marks, William, I97.

Marks, Wm. D., 5 I 4 .

Marquis of Rockingham, 605 .

Marrian, Joseph, 686.

Marriman, Harry, 424.

Marrett, T. B., I62.

Marsh, D. W., I47.

Marsh, H. B., 655 .

Marshall, 378 .

Marshall, Benjamin, 34 .

Marston, Jere, 8.

Marston, Theodore, 8.

Martense, 53 .

Martin, 444.

Martin, G. F., 57.

Martin, Harry H., I 29.

Martin, I. M., 592.

Martin, James W., 669.

Martin, Joe D., 440.

Martin, John, 440, 679.

Martin, Jno. D., 529.

Martin, J. W., 52, 195.

Martin, Layton, 68I.

Martin, N. W., 195.

Martin, W. C., I93.

Marvel, D. K., 408.

Mashinger, George, 70.

Mason, 359, 368, 483 .

Mason, Gen., 64.

Mason, I. S., 208.

Mason, J. C., 403.

Mason, Munro J., 484.

Masser, Isaac, I 5 I.

Masters, T. B., 328.

Mastick, S. F., 389 .

Mather, 489.

Matheson, F. O., 363.

Mathews, Freeman T., 152.

Mathews, Hammond, 27.

Mathews, W. B., 400.

Mathieson, R. B., 503.

Matlock, S. W., 526 *.

Matlock, Thomas, 526 .

Matterson, 4I 7 .

Mausy, Gen., 374.

Maxwell, Steve, 80.
May, John, 598.

May, Dr. Wm., 569*.

Mayberry, L. H., 430.

Mayerall Bros., I 19.

Mayhew, H. A., 336.

Maynard, E., 397.

Maynard, J. E., 252.

Mayne, Clifton E., 64 .

McAdams, Jr., Wilson, 35 .

McAlister, D. A., 43r.

McAllister, J. E., 2 I0*.

McAlister, W. H., 3.

McCahill, Michael, 655 .

McCall, A. C., 375 .

McCann, A. Smith, I I3, 592.

McCann, D. S., 24.

McCann, George H., 584.

McCarthy, 373 .

McCarthy, D., 64.

McCarty, C. C., 8I.

McCarty, Dan., 63.

McCauley, John, 536.

McClaine, Wm., 443.

McClintock, W. R., 67 I.

McColough, 44I.

McConnell, C. H., 95.

McConnell, R. Y., I44.

McCorket, J. G. R., 82 .

McCorma, Joe, 649 .

McCormack, Marshall, $35 \mathrm{I}$.

McCormick Live Stock Co., 197.

McCaslin, R. R., 622.

McClintock, Alex., 6 I6.

McClintock, J. B., 474.

McConchie Bros., 58.

McCoy, B. N., 6 15 .

McCracken, J. G., 31, 609.

McCracken, William, 35, ro5.

McCray, 480.

McCrea, Jr., A. L., 348.

McCrea, R., 536.

McCrory, 232.

McCummings, 460.

McCurdy, E. S., 352.

McDaniel, D., 429.

McDaniel, F. M., 127.

McDaniels, Springer, 49.

McDonald, Charles A., 39.

McDonald, J. A., 197.

McDonald, James, 32 .

McDonald, M. A., I92.

McDonald, M. M., 524 .

McDonald, R. T., 205.

McDonnell, A., 97, 648. 
McDowell, A., 390.

McDowell, H. C., 73, 356.

McDowell, H. C., \& Son, 8r.

McElnance, J., I53.

McElroy, George, 6 го.

McElroy, Whit., I43.

McElwain, J. A., I92.

McElwain, J. S., 67.

McElwin, David, 6ro.

McFadden, Thomas, 576 .

McFarland, John S., 486.

McFerran, J. B., 2 I 2.

McFerran, J. C., 91, I40, I47, I70, $24 \mathrm{r}, 244,336,36 \mathrm{r}, 380,390$, $456,600,621,632 \%, 667$.

McFerran, J. C., \& Co., I 15.

McFerran, J. C., \& Son, 599.

McGarry, J. S., 4I3.

McGee, R., 359.

McGhee, Thos., 623 .

McGraw, Frank, 6i 7 .

McGraw, John, 6.

McGrunder, J. H., 132.

McHaffie, M. F., 435 .

McHaffie, M. F., \& Son, 419.

McHatton, James A., I I 4 .

McIntyre \& Dikeman, $\mathbf{I} 8 \mathbf{r}$.

McKay, Angus M., 37 .

McKay \& Forbes, 37 I.

McKee, James, 6 o.

McKee, Joseph, 42 .

McKee, S. E., 42.

McKee, Wm., 68I.

McKee \& Trainor, 570.

McKenney, H. D., 97.

MicKennin, Alex., 527 .

McKenzie, J. A., 37 o.

McKesson, J., 656.

McKeuber, Andrew, 2 I 2.

McKinna, A. J., 639.

McKinney, H. D., I40, 694.

McKinney, Horace, 1 or.

McKinney, William, 655.

McKinnon, W. D., $47 \mathrm{I}$.

McLarren, J. C., I Iо.

McLaughlin, 409.

McLaughlin, Andy, 37 I.

McLaughlin, Charles, 23 .

McLeod, Murdock, 527 *.

McMillan, Samuel, 630.

McMonagle, Hugh, 4I I, 487 .

McNally, I., 597.

McNeal, John, 9 r.

McNeil, B. H., 14 I.
McNeil, Malcolm, 359.

McNeil, W. A., 260.

McNitt, James, $34 \mathrm{I}$.

McNulty, 539.

McPherson, Gen., 73 .

McQuail, 694.

McQueen, Peter, 639.

McRoberts, Harry, 650

McSee, James, 390.

McSweny, Andrew, 623.

McVain, 537,538 .

McVittie, Alex., 360.

McWhinney, C. A., 593.

McWorter, Wm., I 7 .

Meacham, Isaac, 346.

Meachem, John, I 75 .

Mead, F. G., 359.

Mead, Josiah, 30.

Mead, Stephen, I 45.

Meade, Gerieral, 382 .

Meade, Judge, 90.

Mealey, Timothy, 39 .

Mears, W. B., 586.

Meeker, Jacob, 482 .

Mefford, L. D., 672.

Mefford, Thomas, I 3 o.

Megibben, Thomas J., I 78 , I 79

Melvin, E. B., 249.

Mendenhall, Martin, 98 .

Mendon, George Klose, 527.

Mercer, J. W., 204.

Merrell, J. B., 456.

Merriam, John, 269.

Merrifield, C. J., 52 .

Merrill, Walter, 196.

Merriman, 6r 2 .

Merriman, Harry, 424.

Mershon, James T., 5 .

Messenger, F., 59, 446.

Messner, D. A., 19.

Meyer, E. H., 457.

Meyer, E. J., 593 .

Meyers, 678 .

Meyers, G. W., Iоз.

Mickail, Josh., 4I 5 .

Middaugh, T. J., 523 .

Middle ton, Joel, 535 .

Middletown, J. R., 45 I.

Midway, W. B., I 79 .

Miles, James, I 32.

Millard, Mrs. M. E., 52.

Miller, I 26, I 80.

Miller, Abraham, $35 \mathrm{r}$.

Miller, Albert, 639. 
Miller, C. P., 445 .

Miller, Dudley, $55^{8}$.

Miller, E. H., 206.

Miller, Emery, 159.

Miller, Glen, 598.

Miller, Guy, 27, 45 r, 69 r.

Miller, James, 225, 362, 613.

Miller, J. J., I04.

Miller, John E., 445.

Miller, Milton M., 678.

Miller, Wesley A., I 48.

Miller, Willard A., 52 .

Miller, Jr., E. H., 445.

Miller \& Sibley, 204, 205, 352, 6 I 6.

Millett, E. B., 356 .

Millett, I. M., 356 .

Milliman, Charles, $34 \mathrm{I}$.

Mills, E. S., 337 .

Mills, Harrison, 437, 668.

Mills, James M., 355, 420, 448.

Mills, John F., I 4 I.

Millspaugh, Chauncey, 437.

Milner, Isaac, I 4 I.

Minchin, John, I43.

Minchison, J. D., 7 I.

Miner, Charles, 462 .

Minor, Eli B., 524 .

Minter, William, 335.

Minturn, Lloyd, 66I.

Minty, A. M., $43^{8}$.

Mitchell, Benjamin H., 90.

Mitchell, C. I. B., 440.

Mitchell, C. W., 526 .

Mitchell, Cyrus, I9.

Mitchell, D. D., 337 .

Mitchell, Harry B., 440.

Mitchell, Jesse, 388.

Mitchell, John L., 623.

Mitchell, Joseph, 385 .

Mitchell, S. A., 443.

Mitchell, Samuel, 668.

Mitchell, W. W., 639 .

Mitchell Bros., 430.

Mix, John, 4I.

Mixter, J., I I 1 .

Mizner, Mrs. Louisa, 8I.

Moak, 426.

Mock, Clay, 382 .

Mogier, D. C., I62.

Monahan, John, 40I.

Monical, John W., I05.

Monroe, V. C., 3 .

Monroe, Salisbury \& Cunningham, 95.

Montague, E. D., I I 4 .
Montague, James, 5 I3.

Montague, T. J., 5 o.

Montgomery, Dr. Harry, 447.

Montgomery, Henry M., 29.

Montgomery, R. R., 40.

Montgomery, Wm., 38 .

Moody, 33 .

Moody, Benjamin, 649.

Moody, George, I63, 622 *.

Moody, Harry, 156.

Moody, J. W., 35 .

Moody, Melvin, 622 .

Moody, Mrs. M. L., I 25 .

Moody, Wm. H., 346.

Moody \& Durfee, 466.

Moon, R. H., 4 ro.

Moore, A. H., 95.

Moore, Arthur, 452.

Moore, B. J., 6 I 6.

Moore, Geo. Nick., 475.

Moore, Riley, 144.

Moore, Sir John, 391, 450.

Moore, T. E., 73, 4I 5, 462, 584 .

Moore, W. W., I 2, 587 .

Morehead \& Knowles, I43.

Moots, D. S., I 93.

Moreland, Thomas Hornby, 378 .

Moremen, Alanson, 452.

Moremen, Willis, 45 I.

Morey, L. B., 42, I 8 I, 45 s.

Morgan, Charles, 337 .

Morgan, E. D., 520,573 .

Morgan, George E., 61 5 .

Morgan, Joseph C., $633^{*}$.

Morgan, Justin, 66, 377 .

Morgan, Robert, 269.

Morgan, Thomas, 269.

Morin, W. A., 623 .

Morrell, James S., 225.

Morrell, Samuel, 168.

Morrill \& Gibbs, 650 .

Morris, L. D., 357.

Morris, Robert, I 72.

Morris, W. O., ro6.

Morrison, George H., I 12.

Morrison, J. C., 333.

Morrison \& Overall, 363 .

Morrow, 204.

Morrow, J. L., 420.

Morrow, J. W., 635 .

Morrow, William, \& Son, 690.

Morse, Abner, I 30.

Morse, Dr. W. C., I 9.

Morse, E. D., 629. 
Morse, F., 243.

Morse, Frank, 2 I 3.

Morse, L. M., 63.

Morse, Jr., Frank, 2 I 3.

Moston, Ed., 328.

Morton, Wm., I33.

Mosby, Wade, 149.

Moser, Leo, 244, 607.

Mosher, E. W., 346.

Mosher, John F., I 9 .

Mosher, Stephen, I 19.

Mosman, IOI.

Moss, S. W., 666.

Mott, A., 62 I.

Mott, Benjamin, ז83.

Mott, Edward, I 83 .

Mott, J. A., 472.

Mott, Joseph M., I 83 .

Moulton, 390.

Moulton, A. W., 166.

Moulton, Charles, 6r I.

Moulton Bros., 589.

Mount, Joseph, 535 .

Mower, Maj., 632.

Moyer, H. A., 21 2, 452, 686.

Mudgett, Andrew, I I.

Muir, Mrs. Kate L., 177.

Muir, T. B., 382 .

Muir, Thomas, $3^{8} 3$.

Muir, Wm., 79.

Mullins, 405 .

Mungeon, Jerry.

Munroe, C. M., I 53.

Munro, I. H., 61 3 .

Munson, 377 .

Munson, H. B., 582 .

Murphy, Felix, I03.

Murphy, Martin, 98 .

Murphy, P. M., 464 .

Murray, Byron, 273.

Murray, H. R., 5 I.

Murray, M., 407 .

Murray, Morris, 615.

Murray, William, 66.

Murray, David, \& Sons, 185.

Murry, Y. G., 670.

Murry Bros., 409.

Mustain, T. C., 66.

Myatt, 436 .

Myers, Edward, 173.

Myers, Robert N., ${ }_{2} 28$.

Myers \& Wagner, 474.

Myrick, B. J., 674, 675 .

Myrick, D., 259 .
Myrick, Elias S., 498.

Myrick \& Bennett, 622 .

NAPIN, ELIAS, 32. Nash, Col. D. P., 655.

Nash, Samuel P., 655 .

Naylor, W., 542.

Neal, F. R., 687.

Neal, J. H., 9 I.

Neal, J. W., 456.

Neale, B. H., 363 .

Neale, Frank, 593 .

Neale, J. B., I I5.

Nearing, Zephaniah, 258.

Needham, W. B., I.

Needham, Wm., 427 .

Neely, W. J., 331, 670*.

Nelson, 352.

Nelson, C. H., 78.

Nelson, Morton, 436 .

Nelson, Orville, 239.

Nelson, Thomas, 373.

Nesmet, I 77 .

Nettleton, T. B., I03.

Neville, James S., I05.

New, Robert, 57 I.

Newhall, A. T., I 25.

Newland, Henry, 236.

Newland \& Pumyea, 636.

Newman, C., 3 I.

Newman, Carson, I I 4 .

Newman, John, 420, 562 .

Newman, Thomas, $60 \mathrm{I}$.

Newman, Jr., Scott, 672.

Newton, Anderson, I 86.

Newton, Harris, 496.

Newton, H. E., 57 I.

Newton, I. W., I63.

Newton, J. C., 58.

Newton, J. E., 380.

Newton, J. V., 523 .

Newton, Owen, 4I 4.

Newton, Sir M., 207.

Nickel, Philip, 506.

Nickenson, Abijah, $27 \mathrm{I}$.

Nichols, Charles, 438 .

Nichols, G. W., 384 .

Nichols, Pliny, 599 .

Nichols, T. J. \& F., $3^{82 \text {. }}$

Nicholson, Lewis, 173 .

Nicoll, K. D., 60.

Nihlein Bros., 606.

Nims, David, 247.

Nims, D. B., 600. 
Nipton, H. H., 7 .

Noble, 370.

Noble, A., I 26.

Noble, Augustus, 15 .

Noble, H. D., I 26.

Noble, L. P., 389.

Nock, G. D., I6r.

Nodine, F. J., 694.

Nolan, Charles, 3, 454.

Norcross, E. L., $37 \mathrm{I}$.

Northrup, Nazro, 259.

Norris, Dr. W. S., 542.

Norris, F. D., $163,248$.

Norton, Chas., 183 .

Norton, Elihu, 5 ro.

Norton, J. P., 523.

Norton, William R., 523 .

Norwood, E. M., I6z.

Nottingham, Lebin W., 6r 8 .

Nuttal, J. F., 360.

Nuttall, L. W., \& Son, 36o.

Nutter, David, 243.

Nutter, Mrs. William, 96.

Nye, A. B., I 43.

Nye, Henry W., 407.

Nye, Ira M., 445.

AKES, LEVI, I 27.

Oakwood Stock Farm, 53 .

Oatman, A. T., 454.

Oberlin, 427.

Odel, Ben, 238.

Offensend, O., 332.

Offutt, A. Louis, 96.

Offutt, S. S., 448.

Ogilvie, R. B., 38 .

Ogle, Benjamin, $8 \mathrm{r}$.

Oglebay, James H., 94.

O'Hara, Charles, 340.

O'Kelley, Capt. or Col. Dennis, I68.

O'Kelley, Philip, I 68.

Oldham, Edward, 69 I.

Olds, $59^{8 .}$

Oliver, D., I 7 o.

Oliver, J. B., 78 .

Oliver, T. T., 480 .

Oliver \& McDuffie, 98.

Olmstead, Henry, 4I 2.

Olney, George W., 6r 3 .

Onderdonk, Jacob, 153 .

Orcutt, A., I 59.

Ormsbee, 285 .

Orr, James, 402.

Osbaldeston, I66, 207.
Osborne, Dennis, $54^{2}$.

Osgood, F. H., I 24 .

Osman, 43.

Osterhout, J. H., 693.

Ossory, Lord, I 25.

Otis, 573,625 .

Otis, Geo. D., 570.

Ouimette, F., 369 .

Overall \& Morrison, 363 .

Overpeck, Lee, 445 .

Overton, John, 32, 336.

Overton, May, 32 .

Owen, 36o.

Owen, George W., 537.

Owen, Thos., 177.

Owenby, 62 .

Owens, C. S., 5 .

PABST, Jr., FRED, 362.

Packard, Charles F., 196.

Packard, J. D., 598.

Packenham, Gen., 229.

Packer, Geo. W., 393.

Paddock, E. J., 49.

Paddock, James, 43.

Page, 9o.

Page, B. M., 42 I.

Page, Col., 465.

Page, J. W., I 75.

Page, N. J., $42 \mathrm{r}$.

Page, Wilfred, 207.

Paine, A. B., 145 .

Paine, Lyman H., 258.

Palmer, Caleb O., 602.

Palmer, C. H., 650.

Palmer, Charles, 90.

Palmer, F. S., 573.

Palmer, Geo., 2, 537, 538.

Palmer, H. J., 599.

Palmer, Ira F., 602.

Palmer, J., $45 \mathrm{I}$.

Palmer, John, 38.

Palmeter, D. C., I 24, I 76.

Palo Alto Stock Farm, 63 .

Pancoast, A. C., I I 0.

Pangborn, 352.

Pantlin, Boyde, 373 .

Panton, I39.

Parish, Dabney, 35 .

Parker, 48I.

Parker, B. D., 639.

Parker, E. H., 5 Io.

Parker, E. \& W. S., 677 .

Parker, George, I I 3 . 
Parker, George W., 526.

Parker, Howard, 66, 206.

Parker, James, 425.

Parker, John, 68I.

Parker, Levin, $65 \mathrm{I}$.

Parker, W. C., 606.

Parker, William \& A. S., I68.

Parker \& Otis, 573.

Parkhurst, J. W., 438.

Parks, J. B., I 83 .

Parks, W. A., I 29.

Parks, W. M., 568.

Parks, W. W., 568.

Park, T. W., 43I, 489.

Park \& Schmulback, 6 I 6.

Parlin, S. W., 83.

Parmele, J. W., 433.

Parrish, J. G., 336.

Parrot, George, 506.

Parry, D. S., 216.

Parsons, H. R., 36.

Parsons, J. I., I68.

Partridge, Orrin, 334 .

Patchen, George M., 556.

Patten, W. L., 504.

Patterson, Hugh, 2 I 2.

Patterson, Jr., Rody, 192.

Patton, Dr., I 9.

Patton \& Tribby, I9.

Paul, Alba, 45 $\mathrm{x}$.

Paul, L. G., 45 I.

Paul, Nelson, 239.

Paul, Samuel, 330.

Paul, T. M., 385 .

Payne, r 44, 373.

Payne, B. H., 446.

Payne, Horace, 328.

Payne, William, 375 .

Peabody, C. H., 670.

Peake, Ben, rog.

Peak, M. N., 384 .

Pearson, 4 6 .

Peart, E. C., 68.

Pease, N. B., I36, 500.

Pease, Simeon, I 33 .

Peate, Mark, I33.

Peck, 331, 333, 536.

Peck, A., 2.

Peck, T. W., 6 3 .

Peck, L. W., 420.

Peck, N. D. \& J. W., I.

Pelham, 416, 590, 649, 650.

Pelton, Lysander, $3 \mathbf{I}$.

Pelton, Thomas, 165.
Prendergast, 535 .

Pendill, James, 667 .

Pendleton, Joseph, 428.

Pengelly \& Ellenger, 195 .

Pennington, Sir John, 125 .

Penny, B. M., 69.

Penny, F. H., 69.

Penny, S. H., 69.

Pepper, L. P., I 24.

Pepper, R.P., 43, 47, 48, 49, I03, I32, I44, I63, I79, I93, 204, 226, $242,248,372,373,4 \mathrm{I} 4,420$, $42 \mathrm{I}, 45.5,458,465,635,667$, $687,690,691$.

Pepper, R. P., \& Son, 2, 537, 57 I.

Perkins, 687.

Perkins, C. E., 203.

Perkins, C. M. D., 445 .

Perkins, Daniel, 37 I.

Perkins, Dr. John, 637.

Perkins, J. D., 4I 7 .

Perkins, L. G., 572 .

Perkins, M. D., 578 .

Perkins, Samuel R., 367 .

Perkins, W. J., 79.

Perrin, Benjamin, 6 1 I.

Perrin, A. S., \& Co., 6 I I.

Perry, 409.

Perry, Alanson, Io6.

Perry, Dr., I 73.

Perry, E. N., 499.

Perry, John, 5 I.

Perry, Samuel, 24.

Perry, William S., I 5 .

Persons, Galon, 674.

Peters, A. G., I05.

Peterson, A. B., Io9.

Peterson, Henry, I 66.

Petigrew, C. N., 69 I.

Pettingill, Howard, I64.

Peyton, Balie, 663 .

Phelon, E. M., I 85.

Phelps, C. H., 203.

Phelps, Chas. H., 433.

Phelps, H. W., 53 .

Phelps, Seth P., 359.

Phelps, W. C., 62 I.

Phillips, 489.

Phillips, Benjamin, 648 .

Phillips, Clark, 545, 556, $55^{8}$.

Phillips, C. S., 66, 609.

Phillips, C. W., 655 .

Phillips, E. V., 556.

Phillips, Joshua, 560. 
Phillips, S. C., 44ז.

Phillips, Wm. D., 664.

Phillips, Wm. I., I 28.

Phinney, Col., 422.

Pickard, O. W., 636 .

Pickering, C. E., 48, 456, 459.

Pickering, Elisha, $4 \mathbf{1} 7$.

Pickering, Jacob H., 503 .

Pickering, Thomas, 646 .

Pickett, John, 543.

Pickhard, Wm., 25 I, 603.

Pidd, Thomas, 4I 5 .

Pierce, 656.

Pierce, Amos, 570.

Pierce, M., 672.

Pierce, S. W., 656.

Pierce, Waldo T., 37 I.

Pierson, Fred, 445.

Pierson, J. R., I04.

Pinchin, 266.

Pinchin, O. P., 24.

Piper, C. H., 49.

Pitkin, Thomas W., 377.

Pittman, C. I., I 8r.

Pittman, Dr. C., 22.

Pitts, Wm. R., 484.

Plank, F. M., 405.

Plant, I. C., 245 .

Platt, Geo., $45 \mathrm{I}$.

Pluis, John, 598.

Plumley, Fred, 296.

Poland, Ellery, I96.

Polhemus, 273.

Polk, W. \& V. L., 226, 458*.

Polk Bros., 8.

Pollock, T., $215,242$.

Pomeroy, L., I 9.

Pond, C. M., 448, 464.

Pond, Everett, 295.

Pope, Harden, 606.

Pope, Joseph, I59, 643.

Popham, I 2 I.

Porter, Alexander, 605.

Porter, John, I 2.

Porter, John W., 223, 260.

Porter, M. H., 149.

Porter, Nathan, 526 .

Porter, William T., 244.

Porter, Alexander, 5 I 2.

Portress, Col., 383 .

Posey, Oliver, \& Son, 690.

Post, A. B., 393.

Post, Frank, I 76 .

Post, William W., 164 .
Potter, 208, 327.

Potter, George, 424, 426.

Potter, Henry, 169.

Potter, John, 240. 426.

Potter, Jonathan, 655 .

Potter, Warren, I 76, 429.

Pounds, M. A., 4 I.

Powder, W. A., 457.

Powel, John, I 54.

Powell, Ed. L., 402.

Powell, Garrett, I04, 624.

Powell, J., 649.

Powell Bros., 4, 50, 66, 143, 2 I 6, 226, 241, 6I4, 6I5, 6 I6.

Powers, Everard, 528 .

Powers, Samuel, 452.

Prairie Dell Farm, 599.

Prall, J. A., I6o, I43, 668.

Pratt, 269, 67r.

Pratt, A. G., 7 .

Pratt, C. A., 506.

Pratt, Chester, $3 \mathrm{I}$.

Pratt, E. R., 3i, I 56.

Pratt, Jonah, I 8.

Pratt, Lorenzo, 338.

Pratt Bros., 247.

Pray \& Gates, 389 .

Preadmore, George, 398.

Preble, P. S., 7I., 54 I.

Prendergast, 46 .

Prendergast, C. F., I 25.

Prendergrast, Martin, 572.

Prendergrast, W. I., 653 .

Prescott, 179.

Prescott, J. H., I 48.

Prescott, N. M., 498.

Pressnall, B. B., \& Son, 4 I.

Preston, Otis, 196.

Prewitt, Robert, IO2, I24, 459, 487, 689.

Price, 22.

Price, Dr., 390.

Price, D. W., 4.

Priest, George M., 684.

Prince, Benjamin, 53.

Pringle, Asa M., 637.

Prior, Capt., 667.

Prior, Jno., I6r.

Proctor, Adin, 606.

Prussia, Azariah, 635 .

Pryor, Philip, 429.

Pugh Bros., 35.

Pullen, James, 2 I 9.

Pullen, Sullivan, 2 I 9. 
Pumphrey, H. R., 247.

Putnam, 679.

Putnam, Curtis, 577.

Putnam, D. L., 679.

Pyle, Edward, 2 I, 540, 693.

Pynchen, Joseph, 606.

Q

UEEN, TIP, 224.

Queensbury, Duke of, $13^{8}$.

Quimby, David, Iог*.

Quimby, M. B., 656 .

Quintin, D. Scott, I 24 .

RACOLET, J. B., 372.

R Radcliff, C. S., 6r6.

Ragsdale, I44.

Railey Bros., 8o, 572.

Railey, Logan, 51, 80*.

Rainey, George, I44.

Ralston, James D., 598.

Ramsey, Capt., I39.

Ramsey, D. M., rog.

Randall, 432.

Randall, Joel, 677.

Randall, L. J., 446.

Randall, N. A., 587 .

Randall, R., 632.

Randall, S. M., 400*.

Randenbush, G. W., 459 .

Randolph, Peyton, 440.

Randolph, W. A., 685.

Randolph, Wesley, 618.

Rankin, 360.

Rathburn, H. R., 4I 8.

Rayburn, Frank, 630*.

Ray, Col. George, 577 .

Ray, John P., 556.

Ray, Landon, 24.

Rayley, Charles, 34I.

Raymond, L. O., 9.

Raymond, W. H., 47, 79, г 6.

Read, Charles M., 39 .

Redd, John S., 43o.

Redmon, G. W., 600.

Redmond, Charles, I 85 .

Redmond, C. W., I 56 .

Redmond, John, 156 .

Reed, A. J., 203.

Reed, Charles M., 686.

Reed, Dr., 366.

Reed, Dr. Alexander, 4I3.

Reed, D. W., 572.

Reed, George H., 8o.

Reed, J. A. \& Co., 675 .
Reed, P. \& A., 359.

Reeder, D., 3 I.

Reeves, Frank, 528.

Regan, Joseph, 535 .

Reid, A. V., 570.

Relf, C. P., 537.

Remer, George N., 50.

Reno, John, 485,

Rex, C. S., I 37 .

Reynolds, Dr. L. B., 526 .

Reynolds, H. J., 3 .

Reynolds, James, Io3.

Reynolds, Jules, ${ }_{5} 6$.

Reynolds, S., 47.

Rhea, G., I 53 .

Rhodes, A. J., 509 .

Rhodes, Dana, I04.

Rice, Andrew H., I67.

Rice, Arthur, 4 I 4.

Rice, A. T., Io6.

Rice, Benj., 658.

Rice, Dr. B. S., 624*.

Rice, E. S., 55.

Rice, W. F., 624.

Rich, John T., 260.

Richards, A. K., I 80.

Richards, Keen, 446.

Richards, L. A., 203.

Richards, Nelson, 10.

Richards, Richard, I, 3, 29*, 127*, I $49,345^{*}, 6$ I 7,632 .

Richardson, F. D., 4I.

Richardson, F. J., 243.

Richardson, J. B., $637^{*}$.

Richardson, Josiah, 576 .

Richardson, Mark, 418.

Richmond, 272.

Richmond, Capt. Eber, 44, 574 .

Richmond, George P., 37 .

Richmond, J., 6 г 7.

Richmond, Milton Garr, 458.

Ricords, Lemuel, ro8.

Riddle, 2 I 5 .

Rider, O. A., $43^{8}$.

Rider, D., 666.

Ridgeley, Gov., 173 .

Ridgway, Benjamin C., $66_{3}$.

Ridgway, M. J., 684.

Riford, O. \& S., I 76.

Riley, E. A., I59.

Riley, Frank, 489.

Riley, John, $3^{8}$.

Ripham, Martin, 598.

Rippey, J. R., I97, 685. 
Risdon, L. B., 5 I4.

Rising, Rufus, 252.

Rising, Zeno, 270.

Risk, R. C., 4I9.

Rivenburg, W., \& Son, 375 .

Roach, J. K., 649.

Roach, John, 526 *

Robb, Samuel, 61 2 *.

Robbins, E. W., I 86 .

Robbins, J. E., 592.

Roberts, 2 I 8, 607.

Roberts, Charles, 694 .

Roberts, C. L., 431.

Roberts, J. D., 525 .

Roberts, Jim, 485 .

Roberts, J. M., 43 I.

Roberts, J. S., 499.

Roberts, W. M., 36 .

Robertson, Walter E., 639.

Robeson, Andrew, 40I.

Robinson, 6or.

Robinson, Charles, 63, 337, 466.

Robinson, David, I64.

Robinson, E. D., I65.

Robinson, George M., 407 .

Robinson, George N., 500.

Robinson, Jean, 499.

Robinson, J. W., 80.

Robinson, Robert, 2 I 3.

Robinson, S., 153 .

Robinson, W. H., I93, 456.

Robinson, William, 161, 5 13.

Robinson, W. T., 504 .

Robinson Bros., 650.

Robinson \& Hugely, 79.

Rockefeller, John D., 224.

Rockefeller, Philip, 6r 2.

Rockhill Bros. \& Fleming, 598.

Rockingham, Marquis of, 605 .

Rockwell, George, 236 .

Rockwell, George \& Cameron, 238, 239.

Rockwell, Jeremy, 239.

Rockwood, 498.

Roddy, James, I56, 373, 654 .

Rodes, Levi S., 514 .

Rodes, Levi T., 5 I9.

Rodes, Sr., 514 .

Roe, 505 .

Roe, Geo. R., 462.

Roe, Nathaniel, 393 .

Roe, William, 374 .

Roger, 394.

Rogers, Bill, 359.
Rogers, Dio, 2 I 2.

Rogers, E., 328.

Rogers, Lewis, 505 .

Rogers, N ewell, 527 .

Rogers, Richard, 505 .

Rogers, Samuel D., I 75 .

Rolland, L. H., \& Co., 328.

Romig, J. M., 669.

Rooney, A. B., I40.

Rooney, Samuel, 662 .

Roosevelt, James, 60г.

Roper, John L., 668.

Rose, Alec, 232.

Rose, Brewster, 235.

Rose, John, 226.

Rose, L. J., 52, 58, 205, 2 I I*, 4I 2 *, $61_{5}, 636 *, 690,693$.

Rose, N. R., 505.

Rose, Jr., L. J., 53.

Roseberry, H. M., 623 .

Roseman, William, 406.

Ross, Dave, 427.

Ross, James, 226.

Ross, Welcome C., 425 .

Rowan, George, 506.

Rowe, Col. G., 395.

Rowe, E. L., 465.

Rowland, James, 350.

Rowland, Wm., $44^{8}$.

Rowlands, David, 94 .

Rowley, Sidney, 453.

Rubb \& Brown, 57 .

Rudd, Theron, 397.

Ruddock, E. C., 393.

Ruddock, Louisa D., 393.

Rue, L. E., 457.

Rue, William M., 457.

Rue, William N., 687.

Rule, Charles, 444.

Rule, W. T., 444.

Rumsey, J. F., 5.

Rundal, Frank, 522 .

Rupert, J., 362.

Rupert, L. S., 354.

Ruppert, Jacob, 394 .

Russell, 94.

Russell, C., 677 .

Russell, Col. H. S., I 78, 252, 365, 6r9.

Russell, Dr. W. P., 407.

Russell, Edmund W., 403.

Russell, George, 2 I 1.

Russell, George K., 195.

Russell, H. L., 192. 
Russell, Holton, 349.

Russell, H. S., 38, I47.

Russell, J. B., 65I.

Russell, John H., 349.

Russell, Oliver, 29.

Russell, S. R., 433.

Russell, Thurston, 443.

Russell, W. C., I8 8 .

Russell, Wm. J., 407

Russell \& Kohler, 4I3.

Rust, D. E., 420.

Ruste, Martin, 598.

Rutherford, K. B., 67 o.

Ruth, Thomas H., \& W. H.

Rutland, Duke of, 650 .

Rutter, Wm., 462 .

Ryan, Patrick, 48 o.

Ryder, Ebenezer, 487.

Ryland, 232.

Rynders, Capt., 6ro.

Rysdyk, William M., I 18, 195, 670.

SABIN, BENJAMIN F., 673.

$\checkmark$ Sabin, Henry S., I.

Sabre, J. B., 332.

Sackett, Col., 247.

Sackett, George, 607.

Sage, Ulysses, I 54 .

Sagersor, Noah, 194.

Sain, Harvey, 682.

St. Albans, John, 369.

St. Clair \& Curry, 24.

St. Germaine, M., 369.

St. John, 224 .

St. John, Jim, I 55 .

St. John, M. G., 393.

St. Quintin, Sir W., I39.

Salisbury, 94 .

Salisbury, M., 42, I 10.

Salisbury, Monroe, 28, 91, 97, 1 18, 572.

Salisbury, Monroe, \& Cunningham, 95.

Sample, W. H., I 87.

Sampson, Reuben, 284 .

Sampson, Stephen, 586.

Samson, Curley, 474.

Sanborn, J. W., 688.

Sanborn, W. A., 6 I 6 .

Sands, 169.

Sands, M. M., 38 I.

Sauer, A. P., I48.

Sandford, Captain, ror.

Sanford, Ira, 23.

Sargent, 674 .
Sargent, Geo. B., 7 r.

Satterlee \& Halabird, 329.

Saunders, Dr., I33.

Saunders, Wm. H., 69.

Saunderson, Ed. J., I 8 I.

Savage, Herbert, I I I.

Savage, M. N., I9.

Savage, Walter, 47 I.

Savidge, Thomas, 541 .

Sawtelle, Ely G., 62 I.

Sawyer, 6o9.

Sawyer, Caleb D., 404.

Sawyer, Charles N., 434.

Sawyer, John A., 260.

Saxon, Robert, 436.

Saxton, 607.

Sayles, 557 .

Sayles, Hiram, 535 .

Sayles, Leander, 429.

Sayre, Daniel, 693.

Sayre, Decatur J., 684.

Scales, Y. D., 67.

Scanlon, James, 531 .

Schanck, D., 375 .

Schenck, John, 2 I, 372.

Schenck, Peter, $3^{8} 3$.

Schermerhorn \& Banks, I 82.

Scherzer, E., 454.

Schlatter \& Dolan, 20 .

Schmulback \& Park, 206, 6 I6.

Schofield, H., 35 r.

Schuarte, 24.

Schultz, Fred B., 196.

Schweitzer, Theodore, 632 .

Scobey, Taylor \& Farr, 369.

Scott, Col. Wm. C., 477 .

Scott, Cleveland, 204.

Scott, Edward, 466.

Scott, Elmore, 620.

Scott, G. W., 2 I 7 .

Scott, John, 397.

Scott, J. R., I62.

Scott, W. W., 430.

Scott Bros., 9I.

Scrobey, John W., I4I.

Scully, Patrick, 7, I8.

Scutt, A. B., I 20.

Scutt, A. P., I 20.

Seacord, Fred, 58, 688.

Seaman, C. C., 83 .

Sears, I6, 619.

Sears, John, 454.

Sears, R., 692.

Sears, William E., I 7 . 
Seaver, Ebenezer, 4II.

Seavey, J. L., Ioz.

Secord, Bill, 154 .

Sedgewick, Allen D., I I9.

Seeley, Americus, ro8.

Seeley, Augustus, 587 .

Seeley, Henry, 487.

Seeley, I. C., I63.

Seeley, Jesse T., I67.

Seeley, Jonas, 592.

Seeley, Morris, 425 .

Seely, Nathaniel, 48r.

Seenun, Gov. Thomas, 373 .

Seibel, Emil, 94.

Seidert, K. F., 432.

Selden, Col. M., 87 .

Sellers, W. H., 448.

Sellick, I65.

Seney, George I., 53.

Sentor, Sam. M., I 59 .

Sepon, John P., 569.

Sessions, H. C., 504, 5 I3.

Setzer, Jr., H., 203.

Sevaney, A. F., 7.

Seward, I. A., 504.

Sexton, Geo. G., 504 .

Seymour, C. H., 207.

Seymour, Epaphro, I 52.

Seyster \& Fesler, 598.

Shackelford, J. A., 8I.

Shackelford, J. T., 8r.

Shaeffer, Dr. A. H., 72.

Shaggs, E. M., 53 .

Sharp, William, 4I.

Sharpe, Augustus, I6 1, 206, 67 I*, 684 .

Sharpe, Gov., 378.

Sharples, Charles L., I 29, I48.

Shattuck, Chandler, 427.

Shattuck, F. K., 504.

Shaw, G. A. B., 688.

Shaw, G. J., 242, $520,573$.

Shaw, J., 328 .

Shaw, Jacob N., I I I.

Shaw, John, 407.

Shaw, T. J., 9.

Shaw, Howard, 625.

Shaw, Wm., 626 .

Shawhan, D. P., 36o.

Shawhan, Joseph J., 360.

Shear, 529.

Shearing, Matt G., 509.

Sheeley, James, I I9.

Sheely, E., 67.

Sheeran, J. B., 6r 5 .
Sheffer, W. H., I 94.

Shelby Co. \& Kaul, Andrew, 2 I I.

Shelby, Sir John, 169.

Shelden, J. Q. A., I 75.

Sheldon, C. M., 432 .

Sheldon, V., 400.

Sheldon, Wm., 2 ro.

Shenkel, Rudolph, 420.

Shepard, 8o.

Shepard, H. C., IO7, 4I 5.

Sheperd, Charles, I 99.

Sheperd, John, 598.

Sheppard, I. N., 106, I 78, 357 .

Shera, James, 593.

Sherlock, Bacon \& Titus, 2 1 8.

Sherman, A., I 5.

Sherman, E. D., Iо3.

Sherman, Edmond, I82, 505.

Sherman, E. R., I 82 .

Sherman, George, $54 \mathrm{I}$.

Sherman, J. A., I I 2, $207,244$.

Sherman, John, I82, 6 Io.

Sherwood, A., 95.

Sherwood, George W., 597.

Sherwood, G. W., 694 .

Shilton, Hiram, 523.

Shippee, L. U., 64, 79, гоo, 203.

Shirk, E. H., 526 .

Shoemaker, Isaac, 503.

Shoop, D. K., I 79.

Showalter, A. C., 248.

Shropshire, Ben., I9o.

Shropshire, Joseph, 349 .

Shuff, 340.

Shults, John H., 95.

Shultz, E. L., 246.

Shluy, I 26.

Shy, James, I 54 .

Sibley \& Miller, 204, 205, 352, 6 I6.

Sickles, Isaiah, 530.

Sikes, Hiram, I64.

Silgar, J. W., 389 .

Sill, Joseph, 684 .

Sillick \& Berry, 685 .

Simard, I 28.

Simmons, 568 .

Simmons, Eph., 252.

Simmons, L. E., 16o.

Simmons, W. L., 1 9, 4 г, 7 1, г 26, г6о, I $95,247,454,46_{3}, 54 \mathrm{I}, 56_{3}$, 571,690 .

Simmons, W. L., \& Z. E., 452 .

Simmons, Z. E., 6, 335, 374, 525, 668.

Simmons Bros., 525 . 
Simmons \& Snyder, 627.

Simms, Willis, 72.

Simon, Louis C., 443.

Simonds, Warren, 653 .

Simons, C. M., 480 .

Simonson, William, 25 I.

Simpson, 353,436 .

Simpson, J. W., 630.

Simpson, V., I03.

Simpson, Wm., 205, 630.

Simpson \& Crowell, 436.

Singerly, Wm. W., 382 .

Sisson, W., 427.

Sisson \& Lilley, 373.

Skannal, J. A., 363 .

Skinner, 664 .

Skinner, C. H., \& M., 224.

Skinner, Silas, $\mathbf{5} 2$.

Skinner, Truman, 79.

Skinner, W. N., Io6.

Skinner \& Dietmeyer, 345 .

Skipwith, Payton, 376.

Slattery, Patrick, 97, I I 8.

Slatton, John S., 430.

Slatton, Mat, 430.

Slaughter, F. M., 2 I 8, 597 .

Slaughter, Marion, 7 .

Sleeper, 397.

Slicer, P. M., 22.

Slocum, Lot D., I 45.

Small, Dr. C. P., 602 .

Small, Ezekiel, 462 .

Small, James, I 32 .

Small, W. E., 507.

Smally, Dr. L. F., 405.

Smead, J. D., 505.

Smiley, G. W., \& M. J., I 75 .

Smith, 99, 414, 622.

Smith, Allen, $28 \mathrm{r}, 285$.

Smith, Brainard T., 7 I.

Smith, C. P., 573.

Smith, Dr., Io8.

Smith, E. A., I67.

Smith, E. D., 80.

Smith, E. H., 444.

Smith, E. J., 54I.

Smith, Elizur, 36, 66, 195, 196, 2 14, 345,606 .

Smith, Enoch, 270.

Smith, Geo., I4I.

Smith, Geo. C., 69.

Smith, H. F., 219.

Smith, Henry N., I48, I 77, 243, 359, $36 \mathrm{I}, 384,420,490,5 \mathrm{I} 4,694$.
Smith, Isaac C., 7 I, 6I 7 .

Smith, John, 372.

Smith, John J., 504.

Smith, Joseph, 673 .

Smith, J. G., 47.

Smith, J. R., 38.

Smith, J. R., \& C. J., I4I. 446.

Smith, J. T., 372.

Smith, Leonard L., I 23.

Smith, Linn., IO3.

Smith, Luther, 83 .

Smith, Maj., 44r.

Smith, M. H., 599.

Smith, M., \& A. G., I42.

Smith, N. E., 402.

Smith, Newton, ó8.

Smith, O., 45 I.

Smith, Orson, 370.

Smith, Orville, 677 .

Smith, P. M., 648.

Smith, Robert, 506.

Smith, Robert H., 334 .

Smith, Samuel M., 332 .

Smith, T., 536.

Smith, Thomas, $372,542,543$.

Smith, T. L., 97.

Smith, T. T., 589.

Smith, W. A., 44I.

Smith, Walter, 370.

Smith, W. B., I I 7, 5 I 3, 588 .

Smith, W. H. E., I 4 I.

Smith, Wilbur F., 504.

Smith, W. J., I I9.

Smith, Worthy, 22.

Smith \& Collyer, 649.

Smith \& Cripper, 675 .

Smith \& Marders, 178.

Smith \& McCullough, 632 .

Smith, Wilcox \& Horton, 198.

Snider, T. C., 207.

Snoddy, Geo., 443 .

Snoddy, Will A., 443.

Snow, 47.

Snow, David, 1 2, 223, 260.

Snow, W., 4I 2.

Snyder, 627 .

Snyder, Capt., 67 o.

Snyder, E., $25 \mathrm{I}$.

Snyder, E. A., 204.

Snyder, G. W., \& Co., 348 .

Snyder, Porter A., 6I 7 .

Snyder, T. J., 2 I 4.

Sogers, John, $25 \mathrm{I}$.

Solace, Calvin, 5 I 2. 
Sollace, H. M., 5 I.

Somerindyke, 375 .

Somerset, Duke of, I 25.

Soper, Martin, 522.

Sotheron, 207.

Southard, D., I 6 .

Southard, James, $3^{81}$.

Southard, R. W., I 6 .

Southerland, Rolly, $\mathbf{9 6} 6$.

Spain, J. S., 454.

Span \& Stoddard, 500.

Sparks, 473.

Spaulding, 59r.

Speckels, A. B., 63.

Speight, Capt., 569.

Spencer, 144.

Spencer Bros., 463.

Spier, William E., 50.

Spottswood, Al., 54 I.

Sprague, Col. Amasa, 252, 334, 624 .

Sprague, Gov., 629.

Sprague, W. M., 40I.

Sprague \& Akers, 331, 333, 335, 626, 684.

Spreaker, S., I 8 I.

Spriggs, T., 618.

Spurr, R. J., Iog.

Squires, Dr. L. A., 430.

Stackhouse, James, 194 .

Stagg, E. L., 9.

Stambaugh, 522 .

Stambaugh, H. H., 6I 3 .

Standish, Sir Francis, I6o.

Stanford, Charles, 50, 83, 248.

Stanford, Leland, 3, 36, 50, I I 6, i 1 8, I 19, I 24, I 25, I93, 195, I96*, I97, 198, 202*, $203,204^{*}, 205^{*}$, 206*, 207, 2 I 2, 2 I 5, 248, 336, $355,362,445,464,466,471$, $520,595,615,618,629,67$, 684 .

Stanford, Senator, 63, 579 .

Stanhope, R. H., 54 I.

Stanhope, Wm., 335.

Stanhope, Wm. F., I9I

Stanley, E. A., 409.

Stanley \& Co., I 75 .

Stanton, Benjamin, 6.

Stanton, B. F., 655 .

Staples, Isaac, 688.

Stark, A. T., 587 .

Starr, George, 4I.

Starr, H. J., I I I.

Stausburg, Samuel, 6r 9.
Steadman, S. N., 636 .

Stearns, 466.

Stearns, Frank, 467, 579, 58o.

Stearns, John, 90.

Stearns, Melvin, 579.

Stearns \& Vickery, 469.

Steel, Robert, I 19.

Steele, Andrew, 24I.

Steele, Capt., 338.

Steele, James S., 6 I 7 .

Steele, Robert, 208，215，243，248, 668,684 .

Steele, Thomas, 79, 6 I 6.

Steele, W. E., I62.

Steen, R., I63.

Steiner, John, 443.

Steinhoff, James, 594 .

Stephens, A. L., 209.

Stephenson, Judge John, 54 .

Sterling, Lord, 538 .

Stevens, Ambrose, 154.

Stevens, Charles D., \& Russel, 422.

Stevens, C. M., 473.

Stevens, Daniel, 357 .

Stevens, E., I 54.

Stevens, Frank, 460.

Stevens, Frank E., 44I.

Stevens, Fred, 154 .

Stevens, Geo., 458.

Stevens, George C., I09, 205, 693.

Stevens, George F., I 78, 462 .

Stevens, G. S., I 43 .

Stevens, H. B., 370.

Stevens, W. H., 448.

Stevens Bros., 486.

Stevenson, Robert H., 599.

Stevenson \& Thompson, 333.

Steward, W. H., 63.

Stewart, A. C., 606.

Stewart, J. G., 446.

Stewart, John, I6I, 67 I.

Stewart, John T., 4I9.

Stewart, Lyman, 573, 576 .

Stewart, W. T., $42 \mathrm{I}$.

Stewart \& Dewey, 108, 181, 337, 438, $512,529$.

Stickles, A. H., I 6.

Stiles, John W., 4 I.

Still, Charles E., 69 I.

Still, J. H., 649 .

Stillwell, W. E., 507 .

Stinchfield, Sewal, I I I.

Stinson, R. C., 52 I.

Stipp, Isaac, 474 . 
Stockwell, S., I64.

Stofer, Richard, 542.

Stone, D. E., 146.

Stone, Harmon, 539 .

Stone, W. E., 67.

Stoner, R. G., 58, 161, 363, 44 ז, 632, 668, $69 \mathrm{r}$.

Stony Ford Stock Farm, 593.

Stores, John, 576 .

Storms, 639 .

Storrs, Jehiel, 138 .

Storrs, John, 576 .

Story, J. T., 345 .

Stout, Charles, 389.

Stout, H. L., \& F. D., 38, I37, I40, I97, $211,361,600,691$.

Stout, John, I43, I6o, 5 I 1, 615, 668.

Stout, Mrs. S. L., I6o.

Stout, Wm., 4I.

Stowell, Hollis G., 4I I.

Strader, R. S., 50, 81, ro6, 640.

Straiter, William, $38_{3}$.

Stranathan, William, 689.

Strand, J. S., I 82.

Stratton, C., \& R. A., 52 I.

Strayer, Sam., 5 O3.

Streator, S. R., 4I8.

Stribling, A. B., I 40.

Strickland, Dr., 2 I 3 .

Strickland, Sir W., 125.

Strong, H. P., I09, 45 I.

Strong, Joseph, I 86.

Strouse, Samuel, $65^{8}$.

Stuart, Daniel A., 668.

Stuart, Wm. R., 664.

Stubbs, S. W., I 75 .

Studdert, George J., 6 r 9.

Studer, A. M., 40, 148.

Studwick, Dr. Wm., 7 o.

Sturges, M. E., 19.

Styles, C. H., 207.

Styles, J., \& G. W., 486.

Sublett, S. B., 67.

Summers, Patrick, I8o.

Summers, W. P., 67.

Sutherland, A. H., I64.

Sutherland, E. G., I 82 .

Sutherland, Mrs. W. D., I 82 .

Sutherland \& Benjamin, 197, 523.

Suttles, Tom., 372.

Sutton, W. M., 445 •

Swade, 2 I I.

Swain, Dr., ro8.

Swaine, W. P., 445.
Swan, Amos, 376 .

Swan, George B., 524 .

Swan, John, 220.

Swann, Col., 64 .

Swazey, M., 4 .

Sweet, Geo., 195.

Sweet, S. H., 6 I 6.

Sweet \& Lusk, 2 I 2.

Swift, Dean, $3^{8}$.

Swigert, 4I 7.

Swigert, D., 5 r , 53, 82, 103, 694 .

Swigert, W., 42.

Switzer, Frank, 27.

Swinburn, Dr. John, 72.

Sydleman, J. W., IO2.

Sydner, T. J., 4I 9.

Sydner, Tom L., 542.

Synder Bros., 335 .

TABER, S. G., 636. Taft, 26I.

Taggart, David M., 358.

Talbert, A. S., 39, I47, I63.

Talbert, Dr. A. S., 197, 2 I I, 632, 667

Talbert, P. S., 688.

Talberts, James T., 72.

Talbot, A. G., 689 .

Talbot, William \& Hart, I 64.

Talbott, A. R, 37 .

Talbott, James T., I 29.

Talbott, J. T., 474.

Tallman, Darius, 626 .

Tallman, Wm., 628 .

Talmage, D., 534 .

Tanner, James, 20.

Tapp, $\mathbf{1} 45$.

Tappan, John, 227.

Tarleton, William, I8o.

Tarlton, Jere, 6 I 6.

Tarlton, Wm., 529.

Tarr, M. C., 648.

Tarreltson, W. C., 20.

Tasker, Col. Benjamin, 8I.

Tatman, Calvin, 658 .

Tattersall, I 74 .

Tayloe, Col., 89, 65 I.

Tayloe, John, 453 .

Taylor, I 2 I.

Taylor, A. H., 393* , 464, 526 .

Taylor, C. F., 594 .

Taylor, Col. John, 382 .

Taylor, Elnathan, 225.

Taylor, George, 4I4.

Taylor, H. M. H., I 7 . 
Taylor, J. C., II 3 .

Taylor, J. F., IO2, IO3.

Taylor, J. W., 635 .

Taylor, M. P. William, 137 .

Taylor, O. H., 49.

Taylor, R. J., roo.

Taylor, Robert, $\mathbf{1 6 2}$.

Taylor, S. McKean, 27.

Taylor, T. B., 600.

Taylor, W. H., I42.

Taylor, W. W., 687 .

Taylor Bros., 47 I.

Taylor Stock Farm, 30.

Teacle, 5 Io.

Teacle, E. W., 507.

Teagarden, Robert, 657 .

Tedham, 58o.

Tedham, Alfred, 467 .

Templeman, E. R., 592.

Templeton, Wm., 443.

Tenney, C. H., 196.

Terhune, T. J., 500.

Terrell, R. B., 457.

Terry, Addison, 538 .

Terwilliger, John, $38 \mathrm{r}$.

Thatcher, Alonzo, 658 .

Thatcher, M. W., 669 .

Thatcher, Jr., Benj., 638 .

Thayer, Charles H.; 124.

Thayer, J., 124.

Thayer, O. B., $45^{2}$.

Thayer Bros., 30.

Thomas, B., 638.

Thomas, D. L., 180 .

Thomas, D. W., I 10, 212,382 .

Thomas, G. M., I 92.

Thomas, James, Io9.

Thomas, J. H., 42, 685 .

Thomas, John, $5^{8} 3$.

Thomas, Keller, I05.

Thomas, Presley, 5 I 2.

Thomas, S. O., 4I4.

Thomas, W., 43I.

Thomas, Claude, \& Bro., I 78.

Thomson, A. W., 658 .

Thomson, J. K., 689.

Thomson, W. H., 489.

Thompkins, Gilbert, 195 .

Thompson, Ior, 333 .

Thompson, Caleb, 383 .

Thompson, Col., 46.

Thompson, H. D., \& R. C., 2 I4.

Thompson, John, 336, 522 .

Thompson, J. W., I I I.
Thompson, L. H., I 9 I.

Thompson, N., 557,562 .

Thompson, Philo, 346 .

Thompson, R. T., 82 .

Thompson, T. G., 505 .

Thompson, Thomas, 138 .

Thompson, Tom, I 5 I.

Thompson \& Haggard, 637.

Thomson, Allen W., 35 o.

Thorington, 286.

Thorne, Edward, 620 .

Thorne, Edwin, I 10, I64, I84, 632 .

Thorne, Oakleigh, 79.

Thornton, 502, 638 .

Thornton, Anthony, 391, 591.

Thornton, Berley, 362 .

Thornton, H. I., 636 .

Tichenor, R. M., 497.

Tichenor, Samuel, 490, 496.

Tichenor, S. S., 497.

Tickenor, Caleb, 568 .

Tickenor, Jonas, 464 .

Tickenor, Rollin M., 490.

Tiemans, George, 682.

Tierney, J. \& T. M., I40.

Tiffany, George O., 572 .

Tilden, Joel, 376 .

Tilton, Gen. W. S., 594 .

Tindall, Ben, 158 .

Tinkham, Asa, 338 .

Tinkham, C., 666.

Tinsley, T. T., 356, 385, 394 .

Tittley Bros., 405 .

Titus, Herhon, 598.

Titus, L. H., 58, 91 , I67.

Titus, Timothy, 2 I 6 .

Tobey, Dr., 22.

Tockridge, W. M., 428.

Todd, W. F., I 77 .

Todd, Wm., 30 .

Todd, William or Samuel, 397.

Todhunter, R., 388.

Todhunter, R. P., I 78, 192, 446.

Toler, H. G., 524.

Tolger, F. A., I05.

Toll \& Rardin, 6.

Tollman, Darius, 328 .

Tomlenson, Beers, 285 .

Tone, Richard, 53 I.

Tone, Thomas, 531.

Toomey, Michael P., I 27 .

Toomey, S., 689.

Topliff, Russell, 573 .

Tougas, L. T., $44 \mathrm{I}$. 
Tounsend, 472.

Tourtelotte, Martin, I 78 .

Tourtellotte, W. H., I 29.

Towner, I. C., 4I 7 .

Townsend, Peter, 374 .

Townsend, Zadock, 5 I r.

Tracey, Barney, 690.

Tracey, L. B., 28.

Tracy, Thomas, 36 .

Trafton, C. C., I 4 I.

Trainor \& McKee, 570.

Traphagen, Wm. C., 36 I.

Travis, E. J., 244.

Treacy, B. J., 49, 82, 102, 145, 183, 348,363 .

Treadway, W. B., 2 I 4.

Treadwell, James, 6i 8.

Tresslar, E. M., I05.

Tribon, N. M., 502 .

Tripp, D. N., IO4.

Troutman, J. C., 132 .

Truax, Peter, 2.

Tucker, Dr. James, 6r 8.

Tucker, John H., I 19.

Tuft, Capt., 158.

Tulle, 296.

Turner, A. C., I 26.

Turner, J. W., 242.

Turner, N. B., 2, 432, 528 .

Turner, Thomas, 214, 419, 542 .

Turner, Thomas E., 447.

Turner, Wm., I 26.

Turner, W. N., 36 .

Turner, A. \& Son, 688.

Turrill, Royal, 420.

Tuthill, William J., I48, I63, 248 .

Twadale, J. B., 573 .

Tweed, Wm. M., 639.

Twitchell, Frank, 653 .

Twitchell, Hiram, 679 .

Twitchell, Lucius, 407.

Twitchell, S. F., 603.

Twitchell, S., 398.

Twitchell, S. L., 407.

Twogood, D. C., 450, 599

Twombly, Jack, I 28.

Twombly, Louis, 47.

Twyman, J. C., I94.

Tyler, G. DeVitt, 35 .

Tyler, G. D., 668.

Tyler, R., I 38 .

Tyson, Jesse, I45.

Tyson, Silas, 430 .
ULERY, ELY, 444.

Ulery, John, I6o.

Underhill, 232.

Underhill, Willett, 18 I.

Underwood, J. H., 65.

Updergraff, Dr. J. T. \& D. B., 406.

Upham, Gen. D. P., 55 .

Upson, 6 I 5 .

Urmston, W. D., 417.

Utley, I eander, 442 .

Utley, William, 33 I, 393.

Utley, W. L., 677 .

\section{VAIL, HALL, 693.}

Vail, John, 232, 235 .

Vail, W. T., г го.

Valensin, G., 356, 362, 394 .

Van Akin, W., 434, 669.

Van Blarcom, J. C., 624.

Van Buren, Clarence, I 85 .

Van Buskirk, Morris, 507.

Van Campen, Jr., Geo., 225.

Vance, Morgan, 52, 6I5.

Vance, William, 456 .

Van Cleve, H. B., 694 .

Van DeBogart, Wolcott, 539.

Vanderbilt, C., 126.

Vandervoort, Peter, 344.

Vandeveer, J. C., 379 .

Van Dorn, Moses T., 355.

VanDuzer, W. H., 437 .

Van Dyke, Thomas, 242.

Van Kleeck, Montfort, Io.

Van Mater, John, I 27.

Van Mater, Joseph H., 383 .

Vanmeter, Joseph, 570 .

Van Ranst, C. W., 83, 350, 38 r.

Van Sickels, I., 669.

Van Sickles, 328 .

Van Sken, G. W., 5 .

Van Swearenger, Thomas, 205.

Van Wyck, John J., 385 .

Varbonceur, 519.

Vasey Bros., 70.

Vaughan, A. J., 346.

Vaughan, William, 384 .

Vaughn, E. D., 15.

Vaughn, Ed., 238.

Vealie, Charles, 19.

Veech, R. S., 42, 94, I10, 242, 250, $427,45^{2}, 454,459^{*}, 613,632$, $669,671,684,685,686 * 688$.

Veitch, W. P., 500.

Vermont Horse Stock Co., 6o3. 
Vernon, Richard, 83 .

Verty, John, 489.

Vervecke, Victor, 594 .

Vest, Dr. E., I 19.

Vick, Joseph, 333 .

Vickers, S. P., 4I 7 .

Vickery, Joseph, 579 .

Viley, John M., I02,

Viley, Warren, $25 \mathrm{I}$.

Village Farm, 92.

Vimont, Jeff., I 32.

Vinal, Spencer J., 220.

Vincent, 2 I 8.

Vincent, Reuben, 154 .

Vincent, Thomas, 36r.

Vinsen, Dr., $15 \mathrm{I}$.

Vinton, N., 159.

Vogel, George, r9 1 .

Vogel, W. H. \& E., I 66.

Voglesong, J. W., I66.

Vogt, Charles A., 375, 592:

Voltz, G. A., 690.

Voorhees, John, 5 I 2.

Vrooman, H. B., I 74 .

WADDELL, A. M., I47, 606.

Waddy, Frederick, 22.

Waddy, Wm. D., 6r9.

Wade, H. P., 6г 2 .

Wadell, G. A., 8o.

Wadhams, Abraham, 269.

Wadsworth, Col. William W., 556 .

Wadsworth, E. S., I 78, 603 .

Wadsworth, James, 40, 4I6, 559.

Wait, 43 .

Wait, J., $54 \mathrm{I}$.

Wale, J. W., 686.

Wales, Charles, 656.

Walhunter \& Painter, W., 429.

Walker, 488, 575 .

Walker, Abel, 670,67 I.

Walker, Amos, 379.

Walker, A. S., I 8.

Walker, Cyrenus, 539.

Walker, James, 41, 619, 639.

Walker, James T., 247 .

Walker, J. H., 28, 191, 593.

Walker, Johnson, 632 .

Walker, Milton, 107.

Walker Bros., 5 .

Walker \& Frink, 657 .

Wallace, A. T., 374 .

Wallace, Caleb, 223.

Wallace, Frank, 182.
Wallace, R., 2 I 8.

Wallace, R. B., 5 I 3.

Wallace, S. B., $25 \mathrm{I}$.

Wallace, W. S., 385, 420.

Wallace Bros., 6 oo.

Wallace \& Muir, 169.

Walling, John, I06, 682 .

Walling, Joseph, 95.

Walter, John C., I46.

Waltermire, Walter, 530.

Walton, Capt. Tim, 528 .

Walton, E. C., I67.

Walton, I. D., 252.

Walton, W. D., 363 .

Waltz, A. S., 525 .

Ward, B. B., 6́94.

Ward, Chas. P., 690.

Ward, Dr., I 8.

Ward, George V., 399.

Ward, H. L., 428.

Ward, John, 678.

Ward, Junius R., 399.

Wardsworth, Roger, 603.

Wardwell, Isaac, I20.

Ware, G. W., 2.

Ware, J. T., $54 \mathrm{r}$.

Warfield, Charles L., 207.

Warfield, D. R., 683.

Warfield, Frank, 48, 59.

Warlock \& Megibben, 4I 7 .

Warmock, 349.

IVarner, Alfred, I43.

Warner, F. D., $57 \mathrm{I}$.

Warner, Frank E., 28.

Warner, Ray, 685.

Warner, T., 407.

IVarren, A. K., 5 I 3 .

Warren, Clauson, 5 .

Warren, Henry, $5^{87}$.

Warren \& Wood, 364, 452.

Wasson, D. Edgar, 8 o.

Waterman, 677 .

Water's Stock Farm, I46, 623 .

Wathen, Jr., John B., 465 .

Watkins, David, 638 .

Watson, Allen, 537.

Watson, D., 78.

Watson, Edward H., 65.

Watson, Frank, I40.

Watson \& Jefferson, 83 .

Wattles, S. L., I68.

Watts, W. C., 600 .

Weatherhead, Daniel, 229, 236.

Weathers, E. P., I 77. 
Weaver, Johnson P., 693.

Webb, George W., 28.

Webb, Isaac, I95.

Webb, L. M., 438 .

Webber, William, 375 .

Webster, 260.

Webster, Catlin, 204.

Webster, D. C., 345 .

Webster, Joseph, 216 .

Weed, George, 255.

Weeks, George L., 58 .

Weeks, James, I2 I.

Weeks, Thos. J., 502 .

Weese, Wm. T., 6 oo.

Weir, F. A., 42, 48o, 575, 577, 683 .

Weir, James, 166 .

Weithoff, Frank A., 527.

Welch, Mike, 598.

Welch \& Delevan, 544 .

Welch \& Dunn, 24 .

Welch \& Englishman, 24 .

Weller, A. D., 683.

Wellis, J. H., 464.

Wells, Chas. H., 526.

Wells, C. J., I54.

Wells, Edward, 674.

Wells, M. B., 656 .

Wells, S. C., 80, I 6 .

Wells \& Eddy, 395.

Welsh, A., 54r.

Welsh, Alexander \& Fraser, 356.

Welty, John C., I 59 .

Wentworth, A., 585 .

Wescott, Hamilton, $\mathbf{5}$.

West, Henry, I 84 .

West, Judge, 593 .

West, Mrs., I 54 .

West, R., 50, I80, I9I, 440, 520.

West, R. G., 69r.

West, Richard, $36,49,79,80,95, \mathbf{1} 48$, I78, 192, 193, 194, 215, 242, $353,384,45^{8}, 47$ I , 6I6, 691, 694 .

West, Col. R., \& Clay, Capt. M. M., 6 i 8.

Westerman, L. H., 3, 6 .

Weston, Benjamin, 658 .

Weston, J. B., 658.

Wetherbee, 68I.

Wetherbee, F. M., 620*.

Wetherby, $68_{3}$.

Wetherby, Seth, 4 oo.

Wetherell, J. N., 375 .

Whalen, John, I3 $\mathrm{I}$.
Whalen, Joseph, 373 .

Whaley, Robert, 425, 562 .

Whaley, Sr., 425.

Wheaten, Dr. J. L., 374 .

Wheatley, Nathaniel, 488 .

Wheeden, W., I04.

Wheelan, Wm., 66г.

Wheeler, C. D. \& H. H., 4r8.

Wheeler, Charles, 393.

Wheeler, Col., 69r.

Wheeler, E. G., 390.

Wheeler, George, 672.

Wheeler, G. F., 145, 525 .

Wheeler, John, 328 .

Wheeler, N. E., 666.

Wheeler, R. J., 543 .

Wheeler, S. H., I9r.

Wheelock, A. A., 15.

Wheelock, J. W., 6r3.

Wheldon \& Fuller, 447.

Whipple, A., 2 I 6, 572 .

Whipple, Ambro, 454.

Whipple, S. B., 35, 197.

Whipple, Stephen B., 204.

Whitacre, E. C., I Iо.

Whitcher, J. L., 673.

Whitcher, Jonathan S., 673 .

Whitcomb, ro8.

Whitcomb, Albert, 209.

Whitcomb, B. D., 37 I.

Whitcomb, George G., 6r9.

Whitcomb, Jim, 575 .

Whitcomb, Nathaniel, 679 .

Whitcomb, A. S., \& Wilson, Thomas, 537.

White, 185,538 .

White, C. A., 693.

White, Chastain, 125 .

White, Dr. D. C., 48 r.

White, Frank, 392.

White, Franklin, 332 .

White, J. A., I 27.

White, J. H., 392.

White, N. J., 3 I。

White, O. L. R., 505.

White, Samuel F., 9I.

White, W. A., I 82 .

White, W. J., 694.

Whitefield, Thomas, I I r.

Whiteman, James T., 526 .

Whitenall, H. G., 6 5 .

Whithers, W. T., 52 .

Whiting, E. P., 37 .

Whitman, Sam, 377 . 
Whitney, 447, 694 .

Whitney, A. L., 35 .

Whitney, A. P., 35 .

Whitney, C. P., ro6.

Whitney, T. W., 6I 7 .

Whitson \& Tappen, John, 227.

Whitstone, John, 403.

Whittemore, Joseph, 404.

Whitten, Wm., 457 .

Whitworth, G. K. \& J. L., 198.

Whyland, A. E., I95.

Wicker, 259.

Wicker, Benager, 270 .

Wicker, Charles, 270.

Wicker, Gustavus, $270,402$.

Wicker, G. \& C., 505 .

Wickersham, J. H., 67 .

Wickmire, 667 .

Wicks, Edward, 40.

Wier, F. A., 573, 683 .

Wiggin, Z. J., 639.

Wiggins, J., 159.

Wilbur, John, I96.

Wilcox, E. N., 246.

Wilcox, H. \& S., 198.

Wilcox, J. W., 43 .

Wilcox, T. C., 4 I9.

Wilder, Chas., 46.

Wildes, A. F., 53 .

Wildman, I68.

Wiley, 390.

Wiley, George A., 447.

Wilkins, John B., 78 .

Wilkins, Judge, 688.

Wilkins, Perry, 401.

Wilkinson, Col., 660.

Wilkinson, James B., 96.

Wilkinson, J. O., 26.

Willard, 208.

Willard, A. H., 434 .

Williams, I6o, 373, 500, 604 .

Williams, A. F., 400.

Williams, Alfred, $3 \mathrm{x}$.

Williams, B. T., 437.

Williams, C. W., I 37, 393 .

Williams, F. W., 622 .

Williams, Gov. Benjamin, 663 .

Williams, Hugh, $\mathbf{x}$.

Williams, Jack, 239, $3^{8}$ I, 6 го.

Williams, J. E., 52, 522 .

Williams, J. H., 636 .

Williams, Judge Wm. D., I6o.

Williams, Minor B., 399.

Williams, Robert, 640.
Williams, W. H., 2 r.

Williams \& Blake, 673.

Williams \& Cecil, 593 .

Williams \& Hopkins, 156.

Williamson, B. P., 436.

Williamson, W. H., I 24.

Williamson, W. M., 99.

Willing, 207.

Willing, George, 540.

Willis, Dr. W. H., 334 .

Willis, H. S., 6.

Willis, J. D., I80, 344, 6 I4.

Willis, Jesse H., I 13 .

Willis, John, I 75 .

Willitt, J., I 75, 635 .

Willoughby, Dr., 635 .

Wilmarth, Jonathan, 380.

Wilmer, Pere, 440.

IVilson, I 74 .

Wilson, Andrew, I I 8, 203.

Wilson, B. F., 4I3.

Wilson, B. J., Io6.

Wilson, Capt. J. P., I I I.

Wilson, Dr., 2 I.

Wilson, G. A., 522 .

Wilson, George, 435 .

Wilson, H., 648.

Wilson, Isaac, 26.

Wilson, James, 5, 39, 208, 379, 593 .

Wilson. J. L., I I 4, 486.

Wilson, John, 592.

Wilson, John B., 536 .

Wilson, L. Bank, 79.

Wilson, Thomas, I 19.

Wilson, W. H., 37, 48, I29, I49, 4 I 5 , $474,593,62 \mathrm{x}$.

Wilson, William, 648 .

Wilson, W. S., 340.

Wilson, Wm. C., 94 .

Wilson, Thomas, \& Whitcomb, A. S., 537.

Winch Bros., 527.

Winchester, William, I 77 .

Windram, A. W., 6 r 4 .

Winegar, E. J., I96, 378 .

Wing, Wm. F., $57 \mathrm{r}$.

Wingate, H. P., 37 I.

Winne, John, 525 .

Winn, Wm., I 74 .

Winona, Appleton, 435.

Winship, A. I. \& Amos, 458.

Winthrop, John, 38 .

Wise, A. S., 6 I 3 .

Wise, K. D., 2 I8, 597 . 
Wiseman, Newton, $3^{85}$.

Wiser, J. P., 536.

Witcher \& Butler, 672.

Withers, Wm. T., 38, 52, 105, II5, I48, I61, I62, 243, 332, 352, $353,363,421,636,694$.

Witherspoon, Lester, 161, 599, 693 .

Wivel, Col., 38 r.

Wolf, 6r 2 .

Wolf, Jr., John S., 475.

Womack, S. R., 216.

Wood, Fatty, 574.

Wood, Gabriel, 226.

Wood, James, 58 o.

Wood, John, 69, 603, 685 .

Wood, Joseph, I 52 .

Wood Nathan, 379 .

Wood, Samuel, 600.

Wood, Stephen, 466, 579, 5 So.

Wood, William C., 600.

Wood, W. R., 43 o.

Wood \& Warren, 452.

Woodburn Farm, i45, 61 7, 685, 689.

Woodbury, I 52 .

Woodbury, Arthur L., 335 .

Woodbury, John, 679 .

Woodbury, Peter, 488.

Woodford, Dr., 137 .

Woodhull, 606.

Woodman, E. R., 573.

Woodruff, Hannibal, I 76 .

Woodruff, Hiram, 199, 628.

Woodruff, H. S., 4r 4 .

Woodruff, Wm., 502 .

Woods, A. F., 59 .

Woodside, John R., 27.

Woodward, Abram, 522.

Woodward, S. B., 332.

Woodward \& Brasfield, 69r.

Woodward \& Sturtevant, 488.

Woodworth, Dr. James, 576.

Woolcott, Sam, 447.

Woolfolk, Jos. L., 687 .

Woolford, J. E., 156.

Woolnough, C. I., 363 .

Worden, Jesse, 625 .

Worth, Lemuel, 94 .

Worthington, C. T. \& H., 456.

Worthington, John, 345 .
Worthing, W. W., 504 .

Wren, John, 62.

Wrenn, W., I6r.

Wright, Austin A., r30, 428, 523 .

Wright, B. S., 365, 37 I, 512, 619.

Wright, C. B., 260.

Wright, Charles, 677 .

Wright, C. T., 632 .

Wright, Ezra, 2 I 7.

Wright, F. H., 66.

Wright, G. C., 642 .

Wright, Ira S., 407.

Wright, S. B., I 44 .

Wright, Andrew, \& Son, 285.

Wyck, Z. B., 385 .

Wyckoff, Garret, 436.

Wygout, Michael, I52.

Wylie, W. R., I63.

Wyman, Sam, 576 .

Wynn, Sir W. W., 391.

Wynn, William, 454.

Wyrill, Sir M., 605 .

\section{YALE, HARVEY, 422, 505.} Yaney, John, 639.

Yarbrough, 656.

Yeager, J. T., 22.

Yeager, Lee T., 22.

Yeiser, Dr., I 1 7, 1 20, 636*.

Yeiser, Dr. Henry, I 17.

Yeiser, J. J., 636.

Yeoman, Elial, 485.

Yeomans, J. D., I 13 .

Yerick, H. E., 592.

Yerkes, Andrew, 83 .

Yetter, Andy, 8o.

Yoell, J. H., 94.

Young, A., 459.

Young, Abram, 167.

Young, D., 47.

Young, Ephraim, 541.

Young, Thomas, I 83 .

Younger \& Lamb, 87 .

7 EIGLER, M., 48o. Zielley, 673 .

Zielley, John F., r 74 .

Zoller, ro8. 


\title{
INDEX TO INTRODUCTION-VOL. I.
}

\author{
(A. S. R.)
}

Accepted Pedigrees Criticised.-J. G. Spaulding, . . lxix Age and Endurance of Old Time Trotters.-Cyrus Lukens, in the Western Horseman, . . . . . . clxxiv Alexander, A. J., Death of.-The Horse Review, . . c ccviii American Star (Seeley's), . . . . xvii, lxxvii, lxxxi, cxx American Trotter.-American Turf Register, . . . . $\mathrm{xxx}$ An Irishman's Wit, . . . . . . . . c cc Bare-Foot Horses.-Turf, Farm and Home,. . . . cxcv Barnard, G., Sherbrooke, Que., Letters of, . vii, ix, xxiii, xxviii Beauty and Style in Trotters.-The Horse Review, . . Ixxxvi Best Age to Breed.-American Horse Breeder, . . . . cxi Big Barns, Objections to.-Aurelius, in The American Trotter, cxcvii Black Hawks in Maine.-American Stock Fournal, . . cxli Blaze, son of Childers, . . . . . . . . . xcvii, cv Blood Basis Essential to Permanent Success in Breeding.-Middlebury (Vt.) Register, . . . . . 1 lxxv

Bonner, Robert, Horses owned by ; on Shoeing, clxxii-clxxiv, cxciii Breed for a Type.-Fas. D. Ladd, in Dunton's Spirit of the Turf, cxlix Breeding, . . . . . . . xlii, cxxxvi Breeding, the Question of.-The Horse Reviez, . . 1xxxiii Breeding Trotters.-American Cultivator, . . . 1xi-lxiii Breeding Trotters._C. F. Hamlin, . . . . . cxliii Broad Tires, . . . . . . . . . cxcix Brodhead, L., Letters from, . . lv, lxvi, cxxxii Brood Mares._Middlebury (Vt.) Register, . . . . lii Canada, The Horses of (G. Barnard) - Spirit of The Times, xxiii-xxx Canada, Travels through, by John Lambert, . . . xxix Canadian Cross.-The Spirit of the Times, . . . xxii Canadian Horses. - The Horse of America (By Frank Forester, 1857), . . . . . . . . xxxiv-xli

Care of the New Born Foal.-W. L. Williams, V.S., . clxxxiii Chittenden, Hon. L. E., Letter from, . . . . cxxxvii Colden, Cadwallader R., Death of.-Spirit of the Times, . xli 
Color in Horses.-Turf, Field and Farm, . . . . . 1v Concerning Trotters.-Breeder and Sportsman, . . . cxv Copperbottom, History of, Curious Compilation.-Field and Farm, . . . . clxxy Don't Inter-Breed the Gaits.-The Horse Revicw, . . Ixxxiv Driver, Son of Shales, . . . . . . . cvii Early Importation of Horses to the United States from Province of Quebec,

Earliest Importation of Horses to America, . . . clxvi

Edmunds, Hon. George F., Letter from, . . . . . c clxi

Enchantress, dam of Harold, . . . . . . liv

English Breed of Trotting Horses, . . . . . c c

Engineer, . . . . . . . . . liv

Famous War Horse, . . . . . . . . . clvii

Fashion Stud Farm.-The Horse Revicw, . . . . xcii

Feeding Working Horses.-Country Gentleman, . . clxxviii

Fireaway (Jenkinson's), . . . . . . . cvii

Fondness of Horses for Sweets.-Newark Sunday Call, . clxxxi

Four of the Saddle Gaits.-Randall's Horse Register, . clxxvi

Frank Forester (Henry William Herbert), . xxxiv-xli, cxxxix

Freleighsburgh, Que., . . . . . . . xxviii

French Tiger, . . . . . . . . . xiv

Government Morgans, The, . . . . . . clx

Hackney Horse, Modern Type of.-English Hackncy Stud Book,

Had to Harrow.-Westem Sportsman,

Half a Million for Forty Horses Solely for Pleasure.-

American Horse Brecder,

Hambletonian, Maternal Line of,

Hamiltonian (Bishop's),

Hamlin, C. J., Letter from,

Harold, Breeding of,

Hatch, G. M., Letter of. - American Horse Breeder,

Have Mercy on the Horses.-Breeder and Sportsman,

Highland Gray, Dam of.-Middlebury Register,

ciii-cxi

ccii

Historical,

Horse, Description of.-Shakcspeare,

Horse of America, The--Fohn H. Wallace,

Horse Race Down South Fifty Years Ago.-G. B. Robcrtson, Horse Reason or Instinct.-Breeder and Sportsman, .

Horses, Earliest Importation of, to America, . . . clxvi

clxxii

liii

lxxiv

cxliii

liv

clix

clxxvii

lxxiii

$\mathrm{xviii}$

cxxxvii

xcvi-c

clxii

$\mathrm{ccv}$ 
Horses in Early America.-F. W. Ingham, . . . clxiv Horses in Maine, . . . . . . . . xlviii

Horses of the United States and Canada, by Baron Faverot

De Kerbrech, Quotations from, . . . . . . cxlii

Horses on Snow Shoes.-Randall's Horse Register, . . cxcviii

Howard, Sanford.-Remarks on the Horse, . . xlii-xlviii

How the Trotter Should be Bred and Reared.-L. Brodhead,

Importations of Horses to Virginia, New York, Massachu-

setts and Canada, . . . . . . . clxix-clxx

In-Breeding.-Middlebury Register, . . . . . . . . lii

Indian Pony, The, . . . . . . . . $\mathrm{xxxv}$

Immortality for Animals._Our Dumb Animals, . . ccvi

Jarvis, Consul, Death of.-American Stock Foumal, . . . . xli

Jewell Mares, by Gill's Vermont-G. \& C. P. Cecil, . cliv

Ladd, James D., Letters from, . . . . . . 1xx, cxlix

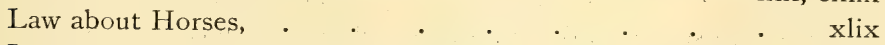

Letter from the Founder of Fashion Stud Farm.-Ameri-

can Horse Breeder, . . . . . . . . . . . .

Little Britain, . . . . . . . . . . . liv

Lukens, Cyrus - Trotting Horse Breeders' Interests, . . . clxx

Mares and Stallions, Care of.-L. H. Granger in Breeders'

Gazette, . . . . . . . . .

Marshland Shales, . . . . . . . . . $\mathrm{cx}$

Maryland Horses.-Spirit of the Times, . . . . . xxii

McCoy, Dr., Concerning Hambletonian.-The Horse Review, cxvii

Memory of Horses.-Western Horscman, . . . . ccv

Miscellaneous, . . . . . . . . . clxii

Morgan Cross, The-Breeder and Sportsman, . . . clii

Morgan Stallions, Advertisements of, as Dutch, . . . . v, vi

Morgan Horse, The Original Importation of, into Vermont, ii

Morgan Horse, Introduction of, into Province of Quebec, ii

Morgan Horse.-Fas. D. Ladd, in Dunton's Spirit of the

Turf, . . . . . . . . . $1 \mathrm{xx}$

Morgan Horse, The, . . . . . . . . cxxxvii-clxi

Morgan Horse, The-S. W. Parlin, . . . . . clvi

Morgan Horses, Early Distribution of, . . . . . . $\mathrm{ii}-\mathrm{x}$

Morgan Household.-Alban Wye, in New York Sportsman, cxlv

Morgan Mares, Pedigree of.-Herbert Brainerd, in American

Horse Breeder, . . . . . . . . clii

Mrs. Caudle.-Cyrus Lukcns, . . . . . . . cxxxi 
Narragansett Pacer, The.-Henry William Herbert (Frank Forester), .

Necessity for a Trotting Type.-Clark's Horse Revicw,

xxxvi

$\mathrm{lxx}$

$\mathrm{xxi}$

$\mathrm{xciv}$

xcri

xxii

cxcvi

liii

One-Eye, .

$\mathrm{xxviii- \textrm {xxx }}$

Pacers Introduced into Quebec,

Palo-Alto, Successful Experiments at.-Turf, Ficld and

Farm,

lvi-lxi

Parlin, S. W., Article on the Morgan Horsc, . . clvi-clix

Pedigrees, Erroneous, Corrected, . . . . . liii-lv

Pretender, Celebrated Horse, . . . . . . c cvii

Proposition to Trotting Amateurs.-Spirit of the Timcs, . xxiii

Quebec, Horses of, Early Importation of, to the United States, ii-x

Remarks on the Horse by Sanford Howard, 1856, . . xlii

Rhode Island Horses. - Newport Mercury, . . . . xviii

Rommel, George M., U. S. Bureau of Animal Industry, Regarding the American Carriage Horse-Breeder and

Sportsman,

cxxxiii

St. Clair, .

xvii

Sampson, son of Blaze, . . . . . . . . . . xcviii

Saving the Work Horses.-The Weckly Horse World, . clxxxviii

Seizing the Family Mule.-Toronto World, . . . ccix

Shakespeare (From Venus and Adonis), . . . cxxxvii

Shales, . . . . . . . . . . c cvi

Sherbrooke, Que., . . . . . . . . . . . $\quad$. $\quad$ xii

Silvertail, . . . . . . . . . . liii

Single Brood Mare Owner.-The Western Horseman, . cxxx

Size in Breeding.-Brcedcr and Sportsman, San Francisco, . cxiv

Skinner, Hon. J. S., Letter upon Horses, . . . . . . $\quad$ xxx

Smith, Henry N., Letter from, . . . . . .

Stanford, Senator, on Horse Breeding, . . . . $1 \mathrm{xv}$

Tennessee Pedigrees.-Turf, Ficld and Farm, . . . 1xiii

The Blotter Absorbed Him.-The Western Horseman, . cci

To Judge a Horse.-By Xenophon, . . . . . cxxxv

Training and Educating.-Turf, Farm and Home, . . cciii

Trotting Contest, A.-Spirit of the Times, . . . . xxii

Trotting Horses, English Breed of, . . . . . c c 
Trotting Horse Breeders' Interests._Cyrus Lukcns in The Western Horseman, . . . . . . . clxx

Trotting Horse, The-American Turf Rigistir and Sporting Magazine, . . . . . . . . xviii

Useful Cub, . . . . . . . . . cvii

Vermont and Canada horses, striking resemblance between referred to by numerous witnesses, . . . . $\mathrm{ii}-\mathrm{x}$

Vermont Draught Horse,-Frank Forester, . . . . cxxxix

Wallace, John H., . . . . . . . . xcvi

Watering Horses in Hot Weather-Horse World, . . clxxx

Where it Comes From, Pacing Gait.-The Horse Revicw, . Ixxix

Why Trotting Bred Colts Pace.-The Horse Reirew, . I Ixxxv Woodburn Farm.-The Horse Revicw, . . . xciii Young Champion, . $\quad . \quad$. $\quad . \quad$. $\quad . \quad . \quad . \quad$ liv 


\title{
INDEX TO INTRODUCTION-VOL. II.
}

\author{
(A. S. R.)
}

Advertisements from Connecticut Journal, cclxxi

American Boy by Sea Gull,

cxiv

American Stage Coach,

ccxxii

Americus,

$\mathrm{xxxix}$

Arabian Ranger,

cvii

Aristotle,

lxix

Badger,

lxxxix

Bald Galloway,

Barbadoes,

lxxv, xci

Barrows, Dr. Albert, Interview with-"

Basto,

xxvii

clxxiv

Bay Barb (Curwen's), . . . . . . . lxxxiv

Bay Bolton, . . . . . . . . . 1xxxiv

Bay Figure, . . . . . . . . clxxxviii

Beautiful Bay (True Briton), . . . . . . ccxcix

Bedford, imported I796, . . . . . . . . Ixxi

Bellfounder, . . . . . . . . . . . ccxxviii

Bellfounder, imported I822, . . . . . . . cxi

Bерро, . . . . . . . . . xcvii

Blaze, son of Childers, . . . . . . . . $\mathrm{cv}$

Bloody Buttocks, . . . . . . . . 1xvii

Bogus (Ellis'), . . . . . . . . . . xcvii

Bold Phoenix, . . . . . . . . clxx

Boston Weekly News Letters, established I 704, Historical

Quotations from 1633-1765, . . . . ccxix, ccxxiii

Breeding Interests in Maine, . . . . . . cxxvi

Brimmer, . . . . . . . . lxvii, xc

Brown Highlander, imported I797, . . . . . cix

Bulle Rock, imported into Virginia I730, . . . 1xv

Bulrock, . . . . . . . $\mathrm{cccv}$

Bulrush Morgan, . . . . . . . . cxxiii

Buzzard, imported to Virginia about $\mathrm{I} 804$, . . . Ixxix 
Byerly Turk,

lxvii, lxxiv, xci

Cade, by Godolphin Arabian,

$\mathrm{xC}$

Cade, by Cade, son of Godolphin Arabian, imported I 762, lxxxix Cardinal Puff,

lxxxix

Cardinal Woolsey,

Careless, .

cxxxiv, clix

Casol Horses, .

lxxxv

Cattle, Description of,

$\mathrm{xxv}$

Champlain Agricultural Fairs at Vergennes (Vermont), Account of,

cclx

Chickasaw Horse, The,

Cock of the Rock,

Columbus,

Commentaries of Peru,

Connecticut, Early History of,

Connecticut, Early Horse Advertisements,

Conqueror,

Cooper, J. Fenimore, Quotations from,

Copperbottom,

Crab, imported 1745 ,

Creeper, .

Curwen Bay Barb,

Dabster, imported I 74I,

Dare Devil, imported I 795 ,

Dariel (Lady Wonder),

Darley Arabian,

Defiance,

De Lancey, Edward F., Letter from,

De Lancey Residence, Description of,

Denmark (Gaines'),

. cxcvii

lviii

cxci, cciv

- xxxvi

xlvi

cclvii

cclxii

$\operatorname{ccxxxi}$

cxiii

xiii, xxxi, ccxlvii

- lxv, lxxxiv

Denning Allen,

- ccxxvii

Dey of Algiers,

lxxv

lxv

lxxi

$\mathrm{xl}$

1xiv, lxxxv

clxiii

xciii

xcvi

ci

xii

Dick Bogus,

Diomed, History of,

Diomede, imported I 798 ,

Dodsworth,

Don Quixote, .

Dora J. (brood mare),

Dove, imported I76I,

Drew Horse,

Driver,

cix, ccxxiv

- clxxxv

lxxii

lxxii

lxvii, xc

cxcriii

$\mathrm{xl}$

lxxxviii

cxxiv

cccv 
Driver, by Imported Driver,

cxcix

Duroc Messenger,

Dutch Morgan Trotter,

cciv

Dutch Weasel,

cxlii

Early Addison (Vermont), Horses,

clxviii

Early Maine Trotters.-Noted Maine Horses,

ccvi

Early Trotters,

cxxvii

Eastman, Dorson,

cexxviii

Eaton Horse,

Eclipse Fagdown,

xxvi

Edwin Forest,

cxxiv

clexxviii

Engineer,

Engineer (Burdick's),

Engineer by Sampson, . . . . . . . . cvi

Eureka (Butler's), . . . . . . . . . xvi

European, . . . . . . . . . xcriii

Expedition, imported I80I, . . . . . . cxir

Fanny Jenks,

Fearnaught, foaled I755, . . . . . . lxviii

Fearnaught, sons of,

Figure, imported 1765 ,

First Consul,

Flimnap,

Flora Temple,

Flora Temple, dam of,

Flora Temple.-Spirit of the Times

Flying Childers (Childer's),

Fox,

Free and Easy,

lxix

Ixxxviii

cciii

lxxxix

xxxii

xxxiv

xxxiii

lxxvi, lxxxy

lxxvii, lxxxiv

ccxci

French Charley,

xxxvi

ccxliii

Galloways,

xii

General Gates,

cxxiii

General Knox,

Genet,

Gifford Morgan,

clxxxix

cxlvi

Godolphin Arabian,

lxiv, lxxy, xci

ccxlv

Gov. Bowie, Interview with,

$\mathrm{cx}$

Grand Bashaw,

Grayhound,

Green Mountain Morgan,

lxvii, xc clxxxii 
Government Morgan Horse Farm.-Chicago Horseman and

Gurney,

Spirit of the Timcs,

Hampton Court Childers,

Harpinus,

Harrison Chief,

xi

$\mathrm{xxviii}$

Hartford Courant, Advertisements from, i $767-1799$,

Hedgeford,

Henry Dundas,

Hero,

Hiatogas, The,

Hickory, foaled I 804 ,

Highlander,

History of Maine by James Sullivan, Quotations from,

Horse Breeding in the River Platte States,

Horses, Early Importation of, to Canada,

Horses, Early Importation of, to Massachusetts,

Horses, Early Importation of, to Virginia,

Horses of America, The,

Horses imported into Connecticut,

Horses imported into Maryland,

Horses imported into Massachusetts,

Horses imported into New Jersey,

Horses imported into New York,

Horses imported into Pennsylvania,

Horses imported into Rhode Island,

Horses imported into South Carolina,

lxxxy

ccxxxii

$\mathrm{xV}$

cclxxiv

. ci

clxxxii

cxxxvii

ccxlvii

lxxx

cccxiii

cxx

lx

lxi

lxi

xliii

crii

$\operatorname{lxx} \mathrm{x}$

cix

cxiv

$\mathrm{xc}$

ci

cxiii

lxxxix

Horses in New England, Description of, . . . . cclxi

Horses in Chili,

lii

Horses of General Washington,

lix

Horses of Peru,

xlviii

Horses of the River Platte States._Sidncy, . . . . xlviii

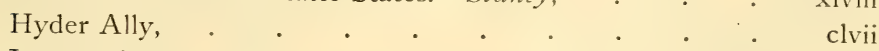

Importations of Horses to South America from U. S., . liv

Indian Pony, The.-by Lieut.-Col. Dodge, . . . $\mathrm{lv}_{\mathrm{v}}$

Irish Gray,

clxxxy

Janus, by Imported Janus,

cxc

Janus, imported about 1752 ,

lxvi

Jigg,

lxvii

Jolly Roger, imported about I 748 ,

lxvi

Justin Morgan Horse,

ccviii 
Kentucky Hunters, Family of, .

xcviii

King Philip,

cccx, ccxxxii

King William, imported I796,

cviii

Keokuk,

cxcv

Lady Sutton,

$\mathrm{xl}$

cclxx

La Prisque,

Lath,

Leeboo,

Leedes Arabian, foaled I655,

clxxii

Lexington (Cabell's)

Leonidas,

Leopard, .

Liberty,

Llamas, The,

Loomis, Son of G. W. W.,

Mac,

Macaroni,

Magnum Bonum,

Maine, Early History of, .

Maine Horses, Advertisements of,

Ixxiv

$\mathrm{xV}$

Makeless,

Mambrino, by Engincer,

Man's Debt to the Horse.-Our Dumb Animals,

Markham Arabian,

Massachusetts, Early History of,

McCarthy, Dr., Interview with,

Medley, imported 1784 ,

Merrimack Intelligencer,

clxxxvi

cclxxviii, cclxxix

cxciii

xliii

$\mathrm{xxxi}$

$\mathrm{xxxv}, \mathrm{cxxv}$

clvii

cxciii

cxix

cxxv

lxvii

cvii

xli

lxiv

ccxi

xxix

$\mathrm{lxx}$

ccxxvii

cxxiii

Merry Tom, imported Previous to 1767 , . . . . Ixx

Messenger, imported I788, . . . . . . cii

Messenger (Witherell's), . . . . . . cxxii

Monkey, imported I 747, . . . . . . . Ixv

Moore, John, Interview with, . . . . . xxix

Morgan Bulrush, . . . . , . . . clxxiv

Morgan Caesar, . $\quad . \quad$. $\quad . \quad$. . . . cxxiii

Morgan Tiger, . $\quad . \quad$. . . . . cciii

Morrill Horse, . . . . . . . . clxxv

Mountain Traveler, . . . . . . . . clxx, clxxii

Napoleon Morgan, . . . . . . . . cxciii

Narragansett Pacer, . $\quad . \quad$. $\quad . \quad$. . . ccl 
Narragansett Stallions, Advertisements of, cclii

Narragansetts, The, .

cxiii

Native American Woods Horse,

New England and Other Horses,

cclxxvi

New Hampshire, Early History of,

ccxxxvi

New Hampshire Horses, Advertisements of,

cxxix

Othello,

cxxx, cxlvi

Othello, Dam of,

lxxxi

Pacing Horses,

lxxxii

$\mathrm{ccl}$

Partner

lxvii

Partner (Croft's),

$\mathrm{xc}$

Peacock,

$\mathrm{clv}$

Pedigree Manufacturing,

xviii

Phoenix,

Phoenix, by Wildair,

Plymouth Colony Records,

ccxxvii

cclxxxviii

Ponies in Maryland,

Post Boy,

$\operatorname{ccxx}$

lx

Purcheas, Samuel, Works of,

cxci

Queen Mab,

xlvii

Ranger, .

lxxxii

Ranger, by Arabian Ranger,

Red Bird,

Red Oak,

cclxv, cclxxx, cclxxxi
.$\quad$ cccvii

cxxxii

Rhode Island, Early History of,

xiv

Rhode Island Records, Quotations from,

ccxxxiii

Ripton,

ccxxxix

xxxix

Robinson Family, Rhode Island,

ccliii

Robinson, Rowland D., letters from, . . . . . ccliv

Royal Morgan,

Rutland Coneyskins,

cxxiii

Sampson, Son of Blaze,

lxxxvi

Sea Gull,

Shadow, imported 1767 ,

Shark, imported i 786 ,

Sherman Morgan,

Sir Charles,

$\mathrm{cV}$

cxiv

lxix

lxxi

Sir Edward, by Don Quixote,

Six-penny Horses,

Smiling Ball,

clxxxi

$\mathrm{xxx}$

Soldier,

ccxc, ccxci

clxxvi 
Spanish Horses, . . . . . . . . . xliv Spanker, . . . . . . . . . . $\quad$ xci

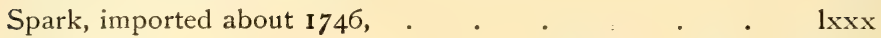
Sportsman, . . . . . cclxxviii, cclxxxi, cclxxxiii State Fair at Middlebury (Vermont), I85 I, Account of, . cxciv Steady, . . . . . . . . . . $\mathrm{xc}$ Sweeper, . $\quad . \quad . \quad . \quad . \quad . \quad . \quad . \quad . \quad$ cli Tacony, . . . . . . . . . . $\mathrm{xxxV}$ Telescope, . . . . . . clxvii, clxxxiii, clxxxiv Thoroughbred, The, . . . . . . . . 1xiii Thoroughbred Racers descended from Diomed, . . 1xxix Tom Bogus, xcvii, cclxiii Tom Breed of Horses in Maryland, . . . . ccxlv, ccxlvi Tom Foot, - ccxlvii Traveling in New England in Early Times, . . ccxxxviii Traveler (Morton's), imported I 754 , True Briton (Beautiful Bay), lxvi True Briton, by Othello, Trustee, by Catton, imported I 828 , Urilius,

Vermont, Early History of,

Vermont Horses, Advertisements of, Virgil, Quotation from,

Weasel,

Welch, Samuel, Interview with, Whip, imported about I 80 I,

Whirligig, imported I 773 ,

White Turk (Place's),

Wildair,

Wildair, by Kildeer,

Wildair, Get of,

Wildair, imported I 764 ,

Wild Arab,

Wildeer,

Wild Napoleon,

Wild Ranger,

Wildeer (Wildair, Church Horse), lxviii, xcii, xciii, cclxiii 1xxxvi cxiv clxxxiv cxlvii cxlix, ccx lxiii clv xxxii $\operatorname{lxxx}$ ci Wilder, Gen. J. T., Interview with, cclxxxi, cclxxxiv, xxxiv Winthrop, John, Journal of, $\mathrm{XXV}$ Winthrop Messenger, ccxvii cxxi Winthrop Messenger, Sons of, cxxii 
Witherell's Messenger, . . . . . . . cxxii

Worcester Gazette, . . . . . . . . $\operatorname{ccxxx}$

Worcester Spy, Quotations from, I784,.1834, . . . ccxxiii

Wright, Silas, Sketch of, . . . . . . . $\quad$ xvii

Yankee Boy, . . . . . . . . . . . ccii

Yellow Bird, imported, . . . . . . . . . $\quad$ xxvi

Young Boldair . . . . . clii, clxxxv, clxxxix

Young Dey of Algiers, . . . . . . cxcviii, cc, cci

Young Elephant, . . . . . . . . cxxxix

Young Figure, $\quad . \quad$. $\quad . \quad$. $\quad . \quad$. $\quad . \quad$. cclxxxiii

Young Highlander, . . . . . . . . . cclxix

Young Magnum Bonum, . . . . . . clxxxviii

Young Messenger, . . . . . . . . cxcii

Young Morgan, . . . . . . . clxxiv, clxxix

Young Morgan (Woodbury Morgan), . . . . cxxxiii

Young Nimrod, . $\quad . \quad$. $\quad . \quad$. $\quad . \quad$. . clxxxvii

Young Quicksilver, . . . . . . . . . . ccxxviii

Young Ranger, . . . clii, clvii, clxxxv, cclxxx, ccxc

Young Ranger, by Young Wildair, . . . . . clxxxix

Young Soldier, . . . . . clxvii, clxxvii, clxxxi

Young Traveler, . . . . . . . . . . lxxxiii

Young Wildair, . . . . . . cclxxviii, cclxxix

Zilcaadi, . . . . . . . . . . . c c 



\section{THE MORGAN HORSE AND REGISTER, . VOLS. I. \& II. BY JOSEPH BATTELL}

Eleven hundred and seven hundred pages respectively. Bound in three fourths leather and handsomely illustrated. Price of Vol. I. $\$ 5.00$, Vol. II. $\$ 3.35$, or $\$ 8.00$ for both Volumes, express or postage prepaid.

The Morgan Horse and Register, Vol. III., is ready for the printers.

It will contain in alphabetical order all horses recorded in previous volumes referring to Vol. and page where recorded, ratings and number of each and all horses registered since Vol. II. A very valuable volume.

\section{CRITICISMS AND REVIEWS.}

VOL. I. of Battell's Morgan Horse and Register has at last been issued. It is a volume of more than a thousand pages, and no more beautiful press work has ever been seen. The volume shows a vast amount of research aud personal investigation. It contains a great deal which has never before been published, and will probably lead to endless discussion. *** The portraits of Denning Allen, the Fearnaughts, Lord Clinton and others are gems of art and beauty.

But pictures do not make books, and Mr. Battell's Register is one of the most valuable of recent acquisitions to equine literature, one that should be in the library of every horseman and every student of the breeding problem. No one before has attempted a work of such magnitude, nor has endeavored to get at the evidence on which is based the many beliefs as to the ancestry of many famous ones, and while it may surprise some to find in the first volume the claim that Seely's American Star and old Pacing Pilot are direct descendants of Justin Morgan, it must be admitted the evidence given is quite as conclusive as that upon which is based the claim that their ancestry is in other lines.- [Clark's Horse Review.

The Morgan Horse and Register is the latest and one of the most valua'jle contributions to horse literature that we have had the pleasure of examining. * * *

It has generally been conceded by those who have studied the subject carefully that the family of horses founded by Justin Morgan has never been equalled as roa?sters and for general purposes where animals of heavy weight were not required. * * *

The most surprising pedigree in the work is that of Seely's American Star. It 


\section{APPENDIX}

has long been claimed by those who have investigated the matter carefully that he could not have been by Stockholm's American Star, which appeared as his sire in the earlier volumes of Wallace's Trotting Register. Probably Mr. Battell spent more time and money carefully investigating this pedigree and collecting facts in regard to it, than any other in the work, and he has been amply rewarded. After giving the facts fully upon which he bases the pedigree, Mr. Battell gives the breeding of this renowned brood-mare sire as follows:

\section{AMERICAN STAR (SEELY'S).}

Chestnut or sorrel, with star, hind feet white, $15 \frac{1}{2}$ hands, I050 pounds; foaled I 837 ; bred by Henry H. Berry, Pompton Plains, N. J.; got by Coburn's American Star, son of Cock of the Rock, by Sherman Morgan: dam bay, stripe in face, about I6 hands, a used-up stage mare purchased in New York city by Mr. Berry at a small price to work in team, breeding entirely unknown.

The chapters on Justin Morgan and Seely's American Star are alone worth twice the cost of the book. There is also a very interesting chapter on Pilot, sire of Pilot Jr. Mr. Battell traced this horse through all the hands he passed until he located him in Montreal, and there is little doubt that he traced him from that point to his breeder. We are giad to learn from the author that the work is selling rapidly.[American Horse Breeder.

Lexington, Mass.

Joseph Battell, EsQ.,

My Dear Sir:-Your valued favor is received; also Vol. I. of the Morgan Horse and Register. As the book was received this morning, I have had little time to read it. It is very handsome and I was particularly pleased with the chapters on the Stars, Pilot, the pacers and the breeding of the original Morgan. I do not see but your claim is admirably sustained.

Very truly yours,

Edward S. Payson.

No publication upon the horse of recent years has awakened so great a public interest as this volume bearing the authorship of Mr. Battell of Vermont.-[Mirror and Farmer, Manchester, N. H.

We have received from Mr. Joseph Battell of Middlebury, Vt., the first Volume of his new work, The Morgan Horse and Register. It is, mechanically, a very fine job: fine paper, elegant binding and illustrations many of them half-tones from photographs, and on fine plate paper, all go to make it an ornament, in the book line, fit for the parlor table. It contains rooo pages. Whatever adds to the sum of human knowledge in any special line is invaluable and to the specialist indispensable, and Mr. Battell's book should contain within its covers very much that is not only new but important. * * * Probably no man living, in a whole lifetime, ever traveled the distance in pursuit of information, wrote the letters, or spent the hours in historical research that the author of this work has done in the last ten 


\section{CRITICISMS AND REVIEWS}

years, and the result is embodied in this volume. $* * *$ Truly " Truth lies at the bottom of the well, and Mr. Battell has gone deeper after it, stayed under longer, and come to the surface with more facts in his grasp than any other writer on the subject. It is a great work, and we have had no time as yet to master its contents, but as time occurs shall refer to it again and again. *** J. W. Thompson, author of Maine Bred Horses.

Mr. Joseph Battell,

\section{The Horseman, Chicago, Ill.}

My Dear Sir:-The complimentary copy of The Morgan Horse and Register which you are good enough to send me came safely to hand. It is by long odds the most complete and comprehensive work of the kind ever issued, and all the friends and breeders of the Morgan horse owe you a life-long debt of gratitude for your painstaking labor in the field of your choice. It is not only of special value to Morgan horse breeders, but to all others engaged in the light harness horse industry. The illustrations serve a very good purpose and the makeup of the book renders it an ornament to any library. I will give it careful public review at the first chance. Meantime, with best wishes, I am

$$
\text { Yours sincerely, E. C. WALKER. "Veritas." }
$$

The following in the New York Herald is from Mr. Gurney C. Gue, Secretary and Treasurer of the American Hackney Horse Society:

" Joseph Battell, of Middlebury, Vt., has just published the second volume of the Morgan Horse and Register, a combined history and stud book of the Morgan family of horses. In all the field of horse literature probably no work has ever been published by private enterprise involving so much labor and expense as the loyal Vermont horseman has lavished on these volumes. In them are preserved not only the pedigrees of the Morgans of note but detailed descriptions and histories as well, together with scores of portraits equally interesting and valuable to horsemen. Mr. Battell's researches into the horse history of America have extended over a period of more than twenty years. Besides a very large correspondence during that time; he has visited personally nearly every State in the Union and has made repeated excursions to Canada, Mexico and the Pacific coast in quest of information about the descendants of Justin Morgan, as well as all other families which have contributed in the development of the American roadster." 


\title{
AMERICAN STALLION REGISTER
}

\author{
IN SIX VOLUMES
}

BY JOSEPH BATTELL.

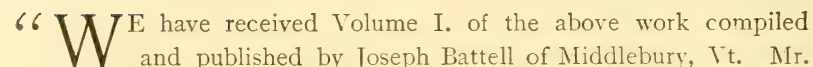
Batteli has probably spent more time and more of his own money, and has traveled a greater number of miles in search of information relating to the origin and breeding of the light-harness horses of America, than all the other authors who have ever written upon this subject. $\mathrm{He}$ is an ardent admirer of the Morgan family of horses, and the author of the very interesting standard work, "The Morgan Horse and Register.'

"Volume I. of the American Stallion Register is a well-bound book that contains 890 pages of matter relating to pedigrees, etc., exclusive of more than 200 pages of interesting historical and miscellaneous introductory matter, and also contains many fine illustrations mostly of noted horses. The names of the stallions whose pedigrees are given are arranged in alphabetical order. This volume contains all stallions with names beginning with $\mathrm{A}, \mathrm{B}$ and $\mathrm{C}$. From a hasty examination of the work we believe it to be both interesting and valuable to all breeders of light-harness stock and students of the breeding problem. Many of the pedigrees are different than given in Wallace's American Trotting Register, but Mr. Battell gives his authority for the change and publishes many letters concerning the horses, that he has received from parties who had owned or known the animals. Volume II. is nearly ready for the press."-S. II. Parlin in American Horse Breeder, April 27, 1909. 


\section{APPENDIX}

[From The Iforse Review, Chicago, May 11, 1909].

We are in receipt, from the publishers, the American Publishing Company, of Middlebury, Vt., of Volume I. of the American Stallion Register, a very handsome book of nearly 900 large and elegantly printed pages, which the sub-title describes as including-

"All stallions prominent in the breeding of the American roadster, trotter and pacer, from the earliest records to 1902. And this includes nearly all imported English thoroughbreds, and their more distinguished get, together with many the English stallions from which they are descended; all sires of $2: 30$ trotters or $2: 25$ racers; also the rating of Morgan blood in all of these stallions so far as known. Compiled from original sources, with many pedigrees, hitherto incorrectly recorded, corrected (in all cases the evidence upon which this is done being given), and many more pedigrees extended."

The author, as these statements will lead those familiar with pedigrees to apprehend, is Mr. Joseph Battell, of Middlebury, Vt., the author of that very valuable work, "The Morgan Horse and Register," which is one of those most indispensable in the Review's library. Mr. Battell is widely known, and has been for a long term of years, one of the most indefatigable tracers of trotting and pacing pedigrees in America. Like the "Morgan Horse and Register," the present work has been published by Mr. Battell at his own expense and is another monument to his devotion and endeavors. Its magnitude can be appreciated best when it is stated that although the portion of the volume devoted to the list of stallions registered extends, with the "Additions and Corrections," to over Soo pages, it covers only the first three letters of the alphabet. From this it may be estimated that at least three more volumes of similar size will be necessary to complete the work; of which we learn that volume II., is now nearing completion.

Light-Harness horse breeders owe Mr. Battell a heavy debt of gratitude for the enormous amount of time and money that he has expended in labors of which they are the chief beneficiaries, and we hope that they are sensible of it. We, in particular, take pleasure in expressing a lively sense of our own gratitude to him. We cannot say that we endorse all the versions of disputed pedigrees that he has accepted as correct and so registered; of many of them we have considerable doubt 


\section{CRITICISMS AND REVIEWS}

while others we disagree in entirely. But this does not affect our opinion that in his pages will still be found a mass of facts of great importance that are nowhere else accessible-which alone confers a very high, and in some ways extraordinary, value upon them.

Typographically the "American Stallion Register" is superb, as it is also as a piece of mechanical book-making, offering thereby a great contrast to the official "American Trotting Register," which in these respects, leaves much to be desired. Aside from the registration department, Volume I. contains over 200 pages of miscellaneous and historical articles, reprinted from various publications which the compiler has selected as being of value for preservation in permanent form ; while there are profuse illustrations of noted stallions and landscape views of localities notable in breeding annals.

We tender our thanks to Mr. Battell for the volume and our compliments upon its publication, and trust that nothing may prevent the appearance of the succeeding ones in due time.

\section{Hon. Joseph Battell,}

Preston, Minn., May i3, i9o9.

Dear Sir :-Volume I. of the American Stallion Register, to a truth seeker in pedigrees, is as important as Supreme Court decisions to a lawyer. No other record presents the evidence which you have gathered concerning doubtful pedigrees. Other compilers have presented conclusions, merely, with rarely any evidence and that invariably favorable to one side. To submit the whole case and allow the public to judge, whether your conclusions are in accord with the evidence or not, is a course which should have been the rule for others as well as yourself.

The Wallaceian versions of many pedigrees are now found to have been based upon his predjudices, surmises and desires without any tangible evidence to support them. In fact the evidence in some instances presented to him, destroyed the versions he doggedly adhered to.

No horseman's library is complete without your Stallion Register and no student of breeding can hope to know the truth without reference to it.

Yours truly, M. T. Grattan.

[From Breeder and Sportsman, San Francisco, Cal.]

MR. JOSEPH BATTELL, author of the Morgan Horse and Register, has sent us Volume I. of his latest publication, the American Stal- 


\section{APPENDIX}

lon Register, printed by the American Publishing Company of Middlebury, Vt. It is a beautifully printed and illustrated book of nearly rooo pages, the frontispiece being a half-tone reproduction of ex-President Roosevelt mounted on a charger that is leaping a fence. Volume II. of this work is largely in plate and will soon be issued. The work is one that has cost Mr. Battell a vast amount of labor and money, and it will be of great value to all who are interested in horse pedigrees. Volume I. contains the names of horses arranged alphabetically from A. to $C$. inclusive. The entire work will consist of six volumes and the price is $\$ 5$ per volume.

The first Volume of "American Stallion Register" has just come to hand. It is a beautiful book, bound in the most substantial and approved manner, and printed in good clear type.

There are 65 illustrations. Many of these are of noted horses, others are of the localities from which these horses come, and are beautifully executed. The Introduction consisting of over 200 pages, opens with a chapter tracing the horses bred in the Province of Quebec during the first half of the nineteenth century, and which entered in a remarkable degree into the breeding of the early American trotters and pacers. It is shown that the foundation of this stock was the original Morgan horse, imported into northern Vermont adjoining the Province of Quebec, in 1792 . Several of his sons were taken to Canada and from this stock crossed with other American and Canadian blood came the large numbers of very fast trotters and pacers, which were imported into the middle, western and southern states, especially Maryland, Kentucky, Indiana and Missouri, included among the first of which were, Copperbottom, Pilot, Tom Hal, Davy Crocket, and many others. Following this chapter the Introduction is divided into Historical, Breeding, The Morgan Horse and Miscellaneous, and includes letters from quite a number of the more prominent early turf writers, Hon. J. S. Skinner, author of the Turf Register, I829-43; Sanford Howard editor of American Cultivator; John H. Wallace, founder of the American Trotting Register; James D. Ladd; Cyrus Lukens and the very prominent breeders, Senator Stanford, Lucas Brodhead (manager of the great Woodburn farm owned by R. A. Alexander and later A. J. Alexander), Henry N. Smith, C. J. Hamlin and others. In the Introduction are also two very 


\section{CRITICISMS AND REVIEWS}

interesting articles on "The Norfolk Trotter" and "The Modern Type of the Hackney Horse" from the English Hackney Stud Book.

Anyone carefully studying the first two hunderd pages would get a liberal education in horse lorc and much that is new to the best posted horsemen in our country. The balance of the book is taken up with the Register proper when the name, date and place of birth, description and breeder when known are given, followed by short history of turf and stud career with the number of their get in the list and number of producing sires and dams. The illustrations of noted horses are very fine and include Justin Morgan, Black Hawk, Ethan Allen, Fearnaught, Alexander's Abdallah, Goldsmith's Maid, Almont, Arion, Flora Temple, Blue Bull, Brown Hal, Cresceus, Columbus and many others.

This volume only covers the three first letters of the alphabet, hence, only horses whose names begin with these letters are inserted. If the succeeding volumes are as interesting and complete as this, the work will when finished, be the most valuable work of the kind published in this country, and should be in every library, private and public, in the land. We understand there are to be six volumes in all and that they will be issued as speedily as possible. The price is five dollars per volume, postage or express prepaid.-Charles A. Chapman, the well known correstondent of sezeral turf journals, in Middlebury (It.) Register, May 7, Igog.

Hon. Joseph Battell, Middlebury, Vt.

LAWreNce, KAx., May 24, I909.

Dear Sir:- I am in receipt of a copy of the ist Volume of your American Stallion Register, and thank you very much, both for the book and the compliment. From what examination I have been able to give it, the work impresses me as incomparably superior to any that has preceded it in the same line. I have no doubt but that it will prove popular with horse breeders generally, and with horse lovers as well.

DEAR Mr. BATTELl,

$$
\text { Very truly yours, O. E. LEARNARD. }
$$

New York City, May 2i, igog.

I am in receipt of your new book, and beg to thank you for it. Of course I have not examined it thoroughly, but can see at a glance that it involves a vast amount of work and will prove exceedingly valuable for reference. Wishing you success with it $\mathrm{I}$ am with best regards.

$$
\text { Yours truly, Hamilton Busby. }
$$




\section{APPENDIX}

Mr. Joseph Battell,

Connersville, Ind., June 2, 1909 .

Dear Sir :- I received my copy of the American Stallion Register, Vol. I., and I consider I got value received the first evening I studied it.

I had spent $\$ 5$ worth of time and expense in trying to trace the breeding of the Ben Snatcher horses which stood in Morgan County and in my own home town Plainfield, Hendricks County. Your Book told me just what I wanted to know about the Ben Snatchers.

I also wanted to know about the Copperbottoms, and was very much interested in reading about old Copperbottom. I have shod a great many roan Copperbottoms.

I prize the Stallion Register very much and I want to congratulate you on the wide open manner in which you have treated the information you have received. I do not blame you for being predjudiced in favor of the Morgan Horse, but it is a good thing to show the world your information, rather than your opinions. The book represents a large amount of careful work and I appreciate it. With best wishes I am,

Respectfully, JoHN T. WILKIN.

Hon. Joseph Battell,

Orwell, Vt., June 7, I909.

My Dear Sir:-I hope you will not interpret this rather untimely acknowledgment of your very kind favor of Vol. I., of American Stallion Register as an indication that it was not fully appreciated, for it certainly was and it reflects great credit upon your untiring perseverance in compiling it. It should be in every library where there is any interest or love for that most noble of all animals-the Horse. Again thanking you,

I am truly,

H. T. CutTs.

"Joseph Battell, of Middlebury, Vt., who gave to the United States the farm on which the government's Morgan horse breeding stud is located, has put the horsemen of the country under new obligation to him by bringing out the first of a series of large volumes entitled the 'American Stallion Register,' in which he has put on record in permanent form the pedigree, descriptions and histories of several thousand horses that figure in the formation of the breed of trotters. Recognizing the fact that the American horse, like the American people, is of composite origin and ancestry, Mr. Battell has taken in important stallions of all breeds, whether thoroughbred runners, Morgans, Norfolk trotters, Arabs or animals of mixed breeding, and instead of following the barren style of the ordinary stud book he has incorporated a mass of interesting and invaluable information gleaned from early periodicals and from personal correspondence with breeders and owners during a long lifetime of unselfish effort in the interest of the American horse. Much of the matter is not to be found elsewhere, and the work in an important contribution to the horse history of the country."-Gurney C. Gue, Secretary and Treasurer of the American Hackney Horse Society, in the Nezo York Herald. 








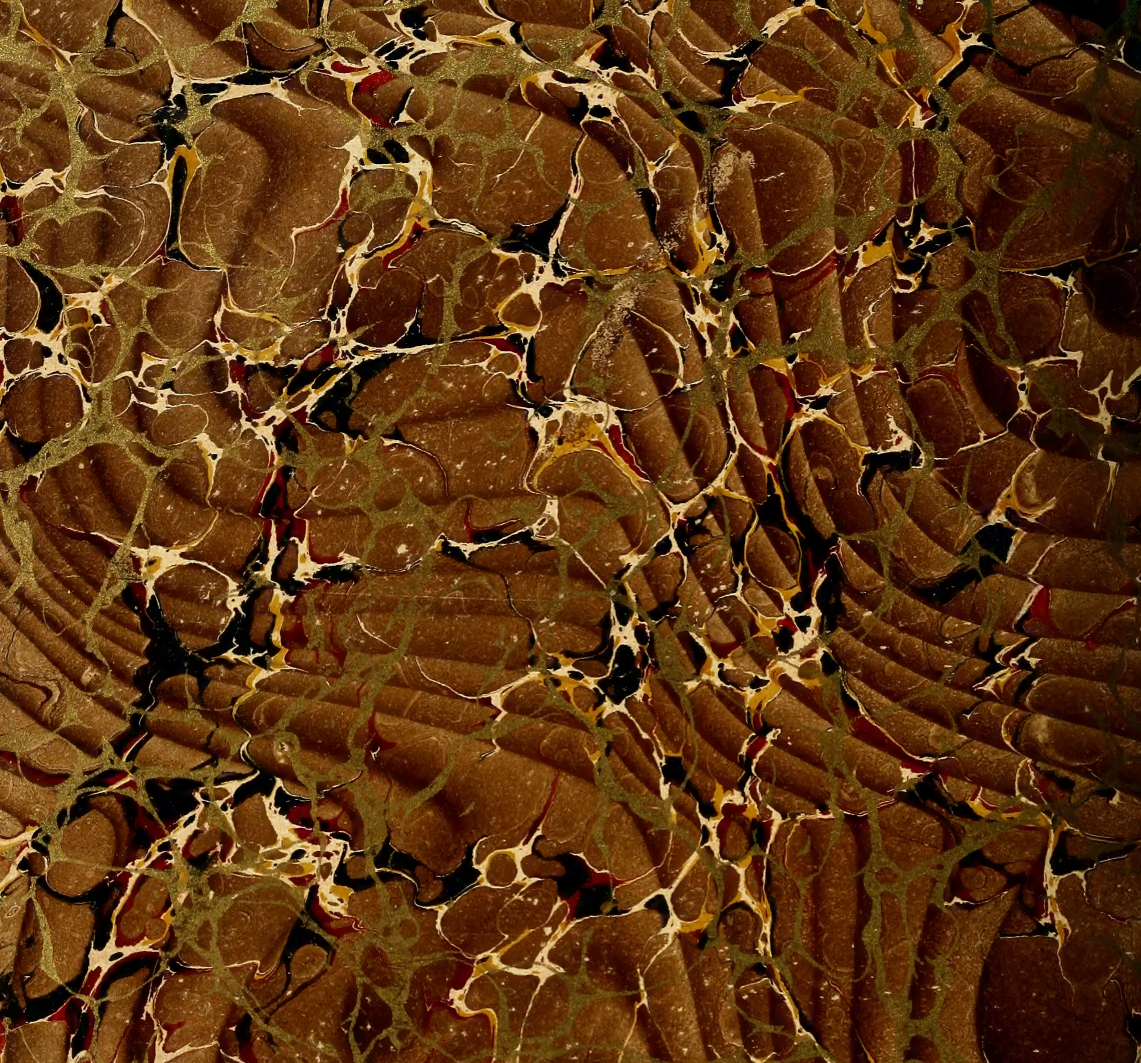

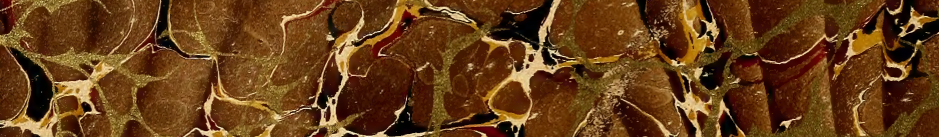 ve the a 3$)^{m}=$}

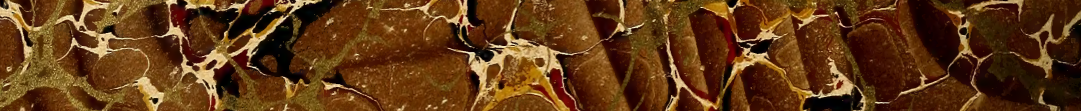

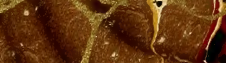

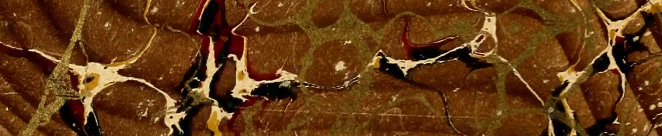




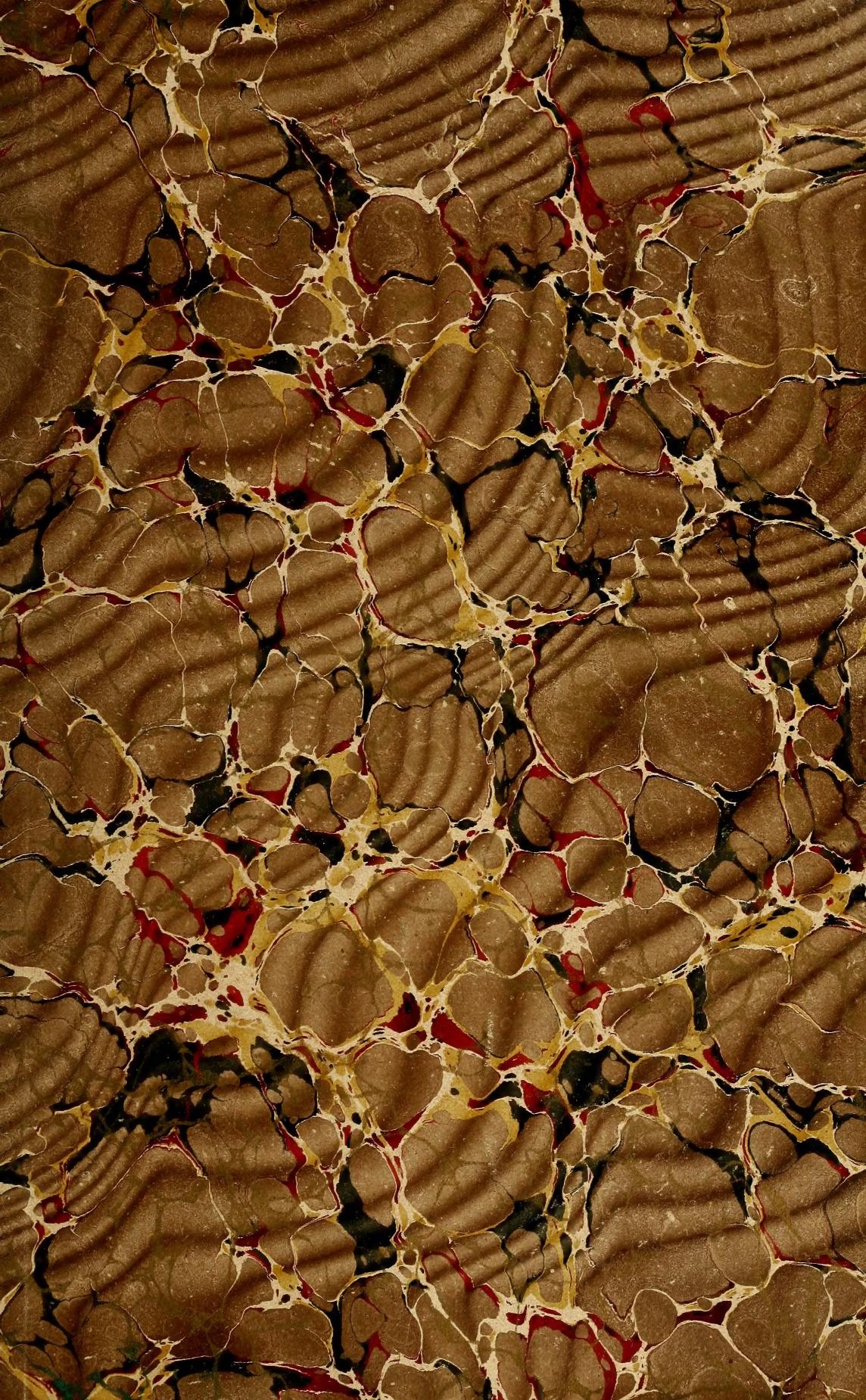


